

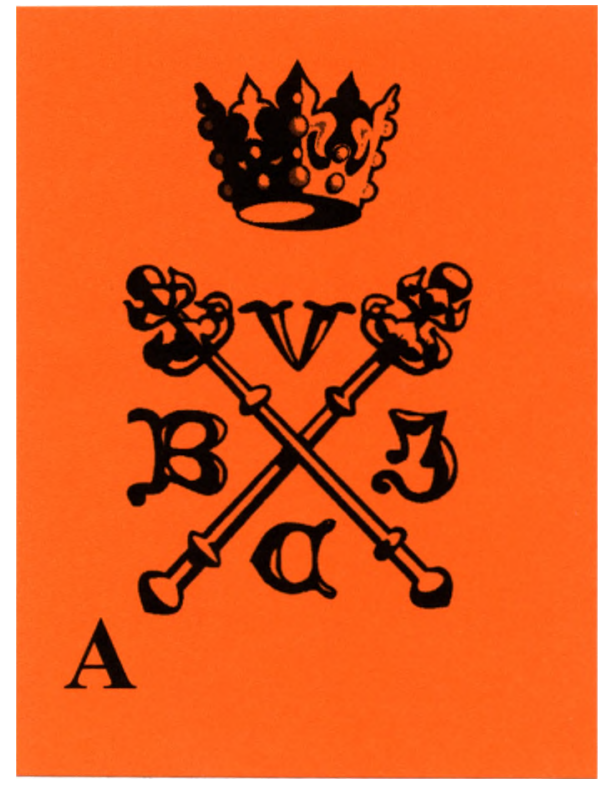






\section{Gramatyka opisowa klasycznej łaciny w ujęciu strukturalnym}


Elisabettae, uxori amantissimae et magistrae sermonis Latini optimae 


\section{HUBERT WolANIN}

\section{Gramatyka opisowa klasycznej łaciny w ujęciu strukturalnym}

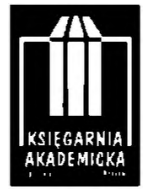

Kraków 
Copyright by Hubert Wolanin, 2012

\section{Recenzenci}

Prof. dr hab. Michal Bednarski

Dr hab. Wojciech Sowa

Opracowanie redakcyjne

Kinga Paraskiewicz, Mateusz Kijewski

Projekt okładki

Igor Stanislawski

Pracę wykonano w ramach projektu badawczego nr N N104 190634, zrealizowanego przez Polskie Towarzystwo Filologiczne i finansowanego przez Ministerstwo Nauki i Szkolnictwa Wyższego w latach 2008-2011

Publikacja dofinansowana została ze środków Ministerstwa Nauki i Szkolnictwa Wyższego na działalność upowszechniającą naukę, z dotacji na działalność statutową Wydziału Filologicznego Uniwersytetu Jagiellońskiego przez Instytut Filologii Klasycznej UJ oraz Polskie Towarzystwo Filologiczne

ISBN 978-83-7638-214-2 (wersja papierowa)

ISBN 978-83-7638-603-4 (e-book)

\section{KSIĘGARNIA AKADEMICKA}

ul. św. Anny 6, 31-008 Kraków

tel./faks: 124312743,124211387

e-mail: akademicka@akademicka.pl

Księgarnia internetowa:

www.akademicka.pl 


\section{Spis treści}

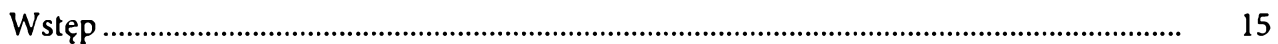

Wprowadzenie ................................................................................................................... 17

1. Założenia ogólne ............................................................................................... 17

2. Źródła wiedzy o gramatyce języka łacińskiego ......................................................... 17

3. Język a gramatyka: pojęcie gramatyki ...................................................................... 19

4. Wybrana literatura .................................................................................................... 20

\section{FONOLOGIA I FONETYKA}

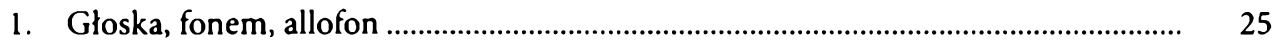

2. Łaciński konsonantyzm .................................................................................... 28

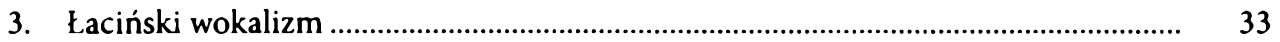

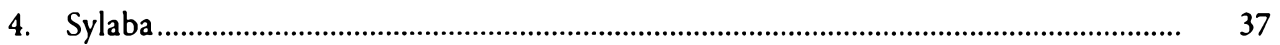

4.1. Struktura sylaby ..........................................................................................

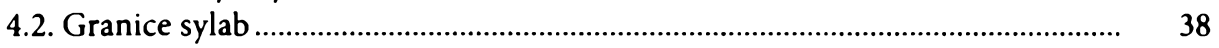

4.3. Cechy prozodyczne.......................................................................................... 38

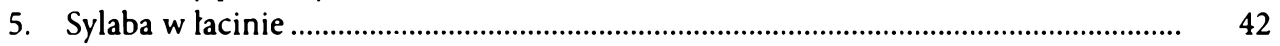

5.1. Granice sylab: sylaby otwarte i sylaby zamknięte.................................................. 42

5.2. Iloczas sylab: sylaby krótkie (lekkie) i sylaby długie (ciężkie) ............................. 46

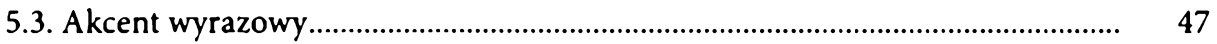

6. Uwagi szczegółowe na temat lacińskiego konsonantyzmu ........................................ 55

6.1. Obstruenty zwarte ........................................................................................... 55

6.2. Problem aspiracji obstruentów zwartych ............................................................ 62

6.3. Obstruenty szczelinowe (spiranty) ......................................................................... 64

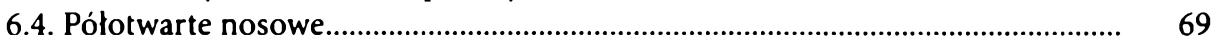

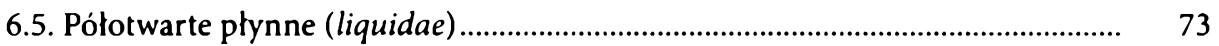

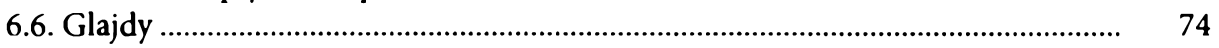

7. Uwagi szczegółowe na temat lacińskiego wokalizmu ................................................ $\quad 80$

7.1. Samogłoski.................................................................................................... 80

7.2. Dyftongi ............................................................................................................ 85

7.3. Przebudowa łacińskiego wokalizmu w okresie Cesarstwa ................................... 91

8. Wybrana literatura ................................................................................................... 94

\section{MORFOLOGIA}

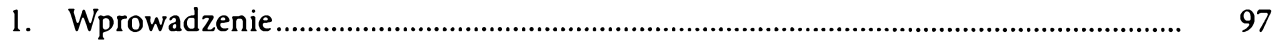

1.1. Morfem, morf, allomorf....................................................................................... 97

1.2. Dystrybucyjna klasyfikacja morfemów ……………………………………......... 98 
1.3. Funkcjonalna klasyfikacja morfemów ............................................................ 98

1.4. Wyraz tekstowy, wyraz gramatyczny, wyraz słownikowy (leksem) ................... 100

1.5. Struktura morfologiczna wyrazów lacińskich ..................................................... 103

1.6. Wybrana literatura ........................................................................................ 104

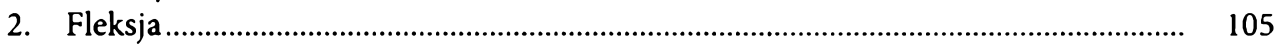

2.1. Flektem, forma tekstowa, forma fleksyjna....................................................... 105

2.2. Budowa form fleksyjnych: temat fleksyjny, flektyw, końcówka fleksyjna .......... 106

2.3. Formalny i funkcjonalny paradygmat fleksyjny ................................................. 108

2.4. Typologia kategorii fleksyjnych ....................................................................... 110

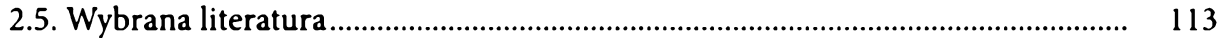

3. Funkcjonalna klasyfikacja leksemów: części mowy ................................................... 114

3.1. Kryteria klasyfikacji........................................................................................... 114

3.2. Leksemy autosyntagmatyczne: czasowniki, przymiotniki, rzeczowniki, przysłówki.................................................................................................... 115

3.3. Prymarna i sekundarna dystrybucja składniowa leksemów................................ 118

3.4. Leksemy nieautosyntagmatyczne: przyimki, spójniki, partykuły ..................... 120

3.5. Status gramatyczny zaimków i liczebników .................................................... 123

3.6. Schemat ogólnej klasyfikacji łacińskich leksemów .............................................. 124

3.7. Wybrana literatura ............................................................................................ 124

4. Paradygmatyka fleksyjna rzeczowników i przymiotników ........................................ 125

4.1. Kategorie imienne i ich wykładniki ................................................................ 125

4.2. Ogólne właściwości łacińskiej paradygmatyki deklinacyjnej ............................ 127

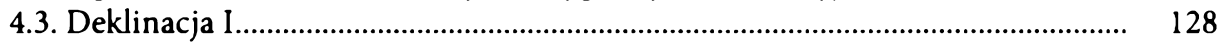

4.4. Deklinacja II ………………….......................................................................... 130

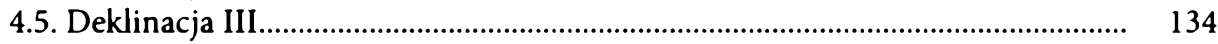

4.6. Deklinacja IV ................................................................................................ 141

4.7. Deklinacja V .................................................................................................. 143

4.8. Rzeczowniki pochodzenia greckiego …………................................................. 144

4.9. Wybrana literatura ................................................................................................. 145

5. Paradygmatyka fleksyjna zaimków........................................................................ 146

5.1. Ogólne właściwości paradygmatyki zaimkowej .................................................. 146

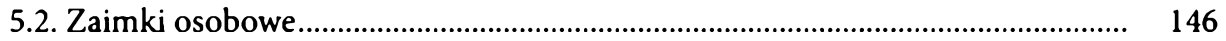

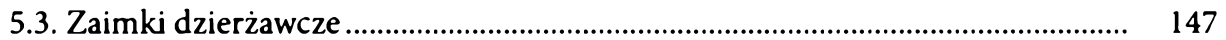

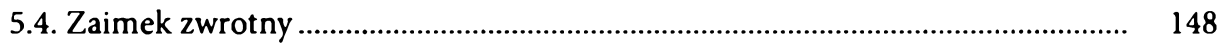

5.5. Zaimki wskazujące.............................................................................................. 149

5.6. Zaimki określające ........................................................................................... 150

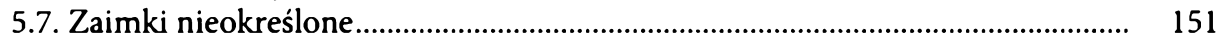

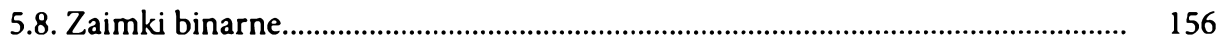

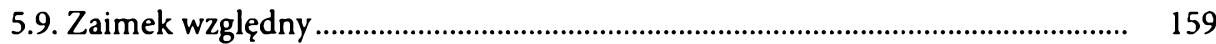

5.10. Zaimki pytajne ................................................................................................. 159

5.11. Zaimki przeczące .............................................................................................. 160

5.12. Przymiotniki zaimkowe ......................................................................... 161

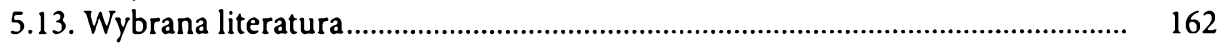

6. Paragygmatyka fleksyjna czasowników .................................................................. 163

6.1. Werbalne kategorie fleksyjne: ich wartości i typy wykładników........................ 163

6.2. Wykładniki derywacyjne ....................................................................................... 164

6.2.1. Temat praesentis ................................................................................... 165 
6.2.2. Temat perfecti.

6.2.3. Temat participium perfecti ……................................................................. 167

6.3. Wykładniki końcówkowe

6.4. Wykładniki sufiksalne.

6.4.1. Wykładnik indicativi praesentis

6.4.2. Wykładniki indicativi futuri primi.

6.4.3. Wykładniki indicativi imperfecti

6.4.4. Wykładniki indicativi perfecti.

6.4.5. Wykladniki indicativi plusquamperfecti.

6.4.6. Wykładniki indicativi futuri exacti (secundi) ......................................... 176

6.4.7. Wykładniki coniunctivi praesentis

6.4.8. Wykladniki coniunctivi imperfecti

6.4.9. Wykładniki coniunctivi perfecti.

6.4.10. Wykładniki coniunctivi plusquamperfecti.

6.4.11. Wykladniki imperativi

6.4.12. Wykładniki participii praesentis activi

6.4.13. Wykładnik participii perfecti passivi.

6.4.14. Wykładnik participii futuri activi

6.4.15. Wykładniki participii futuri passivi

6.4.16. Wykładniki infinitivi praesentis activi.

6.4.17. Wykładniki infinitivi praesentis passivi

6.4.18. Wykładnik infinitivi perfecti activi

6.4.19. Wykladnik infinitivi perfecti passivi

6.4.20. Wykładnik infinitivi futuri activi

186

6.4.21. Wykładnik infinitivi futuri passivi

6.4.22. Wykładniki gerundii

6.4.23. Wykładniki supini

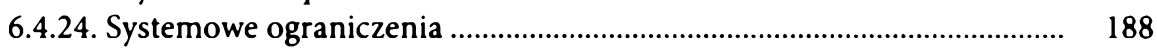

6.5. Wybrana literatura

7. Charakterystyka funkcjonalna rzeczowników.

7.1. Rzeczowniki jako klasa leksemów

7.2. Osoba (persona)

7.3. Rodzaj (genus)

7.4. Liczba (numerus)

7.5. Przypadek (casus)

7.5.1. Charakterystyka funkcjonalna wartości kategorii przypadka rzeczownika - wprowadzenie

\subsubsection{Nominativus}

7.5.2.1. Rzeczownik w nominatiwie jako podmiot

7.5.2.2. Rzeczownik $w$ nominatiwie jako orzecznik

7.5.2.3. Rzeczownik $w$ nominatiwie jako adresatyw

7.5.2.4. Rzeczownik $w$ nominatiwie jako składnik wypowiedzeń niezdaniowych

7.5.3.2. Rzeczownik $w$ genetiwie jako dopełnienie (dalsze) 
7.5.3.4. Rzeczownik w genetiwie jako funkcjonalny odpowiednik orzecznika

7.5.3.5. Rzeczownik w genetiwie jako okolicznik ..................................... 217

7.5.4. Dativus

7.5.4.1. Rzeczownik w datiwie jako dopełnienie dalsze

221

7.5.4.2. Rzeczownik $w$ datiwie jako orzecznik

7.5.4.3. Rzeczownik $w$ datiwie jako funkcjonalny odpowiednik orzecznika

7.5.4.4. Rzeczownik $w$ datiwie jako uzupełnienie orzecznikowe

7.5.4.5. Rzeczownik $w$ datiwie jako okolicznik

7.5.4.6. Rzeczownik $w$ datiwie jako przydawka

228

7.5.4.7. Rzeczownik w datiwie jako operator tekstowy .............................. 230

7.5.5. Accusativus

230

7.5.5.1. Rzeczownik $w$ akuzatiwie jako dopełnienie bliższe

230

7.5.5.2. Rzeczownik $w$ akuzatiwie jako dopełnienie dalsze

7.5.5.3. Rzeczownik $w$ akuzatiwie jako funkcjonalny odpowiednik podmiotu

7.5.5.4. Rzeczownik w akuzatiwie jako orzecznik

7.5.5.5. Rzeczownik w akuzatiwie jako funkcjonalny odpowiednik orzecznika

7.5.5.6. Rzeczownik $w$ akuzatiwie jako uzupełnienie orzecznikowe

7.5.5.7. Rzeczownik w akuzatiwie jako okolicznik

7.5.5.8. Rzeczownik $w$ akuzatiwie jako przydawka

7.5.5.9. Rzeczownik $w$ akuzatiwie jako składnik wypowiedzeń niezdaniowych

7.5.5.10. Rzeczownik w akuzatiwie jako operator tekstowy ...................... 244

7.5.6.1. Rzeczownik w ablatiwie jako okolicznik

7.5.6.2. Rzeczownik $w$ ablatiwie jako dopelnienie dalsze

7.5.6.3. Rzeczownik $w$ ablatiwie jako przydawka

7.5.6.4. Rzeczownik w ablatiwie jako orzecznik.

7.5.6.5. Rzeczownik w ablatiwie jako funkcjonalny odpowiednik podmiotu

7.5.6.6. Rzeczownik w ablatiwie jako funkcjonalny odpowiednik orzecznika.

7.5.6.7. Rzeczownik w ablatiwie jako operator tekstowy ........................... 265

\subsubsection{Vocativus}

\subsection{Wybrana literatura}

8. Charakterystyka funkcjonalna przymiotników ....................................................... 268

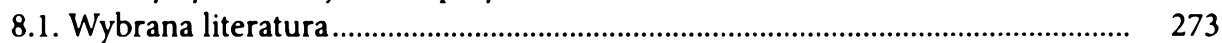

9. Charakterystyka funkcjonalna przysłówków .............................................................. 274

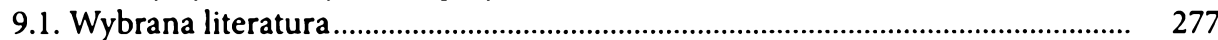

10. Charakterystyka funkcjonalna zaimków ............................................................. 278

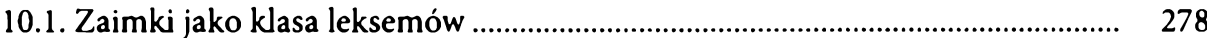

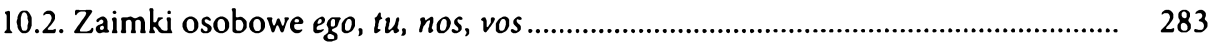

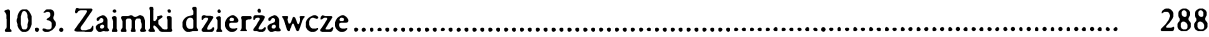

10.3.1. Zaimki dzierżawczo-osobowe meus, tuus, noster, vester ........................ 288 
10.3.2. Zaimek dzierżawczo-zwrotny suus

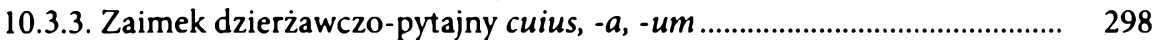

10.4. Zaimek zwrotny se

299

10.5. Zaimki wskazujące: hic, haec, hoc; iste, ista, istud; ille, illa, illud ....................... 305

10.6. Zaimki określające

312

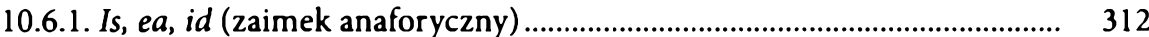

10.6.2. Idem, eadem, idem (zaimek identyfikujący)........................................... 321

10.6.3. Ipse, ipsa, ipsum (zaimek izolujący / intensyfikujący)............................. 328

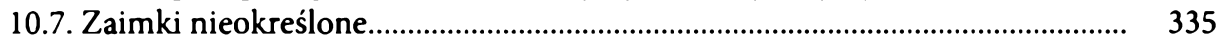

10.7.1. Quis, quid ............................................................................................. 336

10.7.2. Quisquam, quicquam; ullus, ulla, ullum ........................................... 338

10.7.3. Aliquis, aliquid .................................................................................... 345

10.7.4. Quidam, quiddam ……................................................................... 350

10.7.5. Quispiam, quidpiam............................................................................. 353

10.7.6. Quivis, quidvis; quilibet, quidlibet......................................................... 355

10.7.7. Quisquis, quidquid; quicumque, quaecumque, quodcumque ............... 356

10.7.8. Quisque, quidque; unusquisque, unumquidque ...................................... 358

10.8. Zaimki binarne .......................................................................................... 364

10.8.1. Uterque, utraque, utrumque; ambo, ambae, ambo.................................. 365

10.8.2. Neuter, neutra, neutrum ........................................................................ 366

10.8.3. Uter, utra, utrum; alteruter, alterutra, alterutrum; utervis, utravis, utrumvis; uterlibet, utralibet, utrumlibet ................................................. 367

10.8.4. Utercumque, utracumque, utrumcumque............................................... 368

10.8.5. Alter, altera, alterum, (alius, alia, aliud) ............................................... 368

10.9. Zaimek względny qui, quae, quod ...................................................................... 374

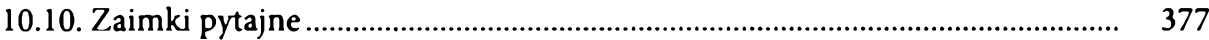

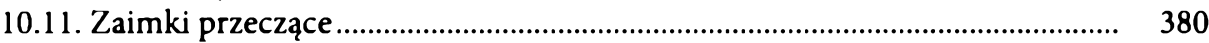

10.12. Wybrana literatura........................................................................................... 382

11. Charakterystyka funkcjonalna liczebników ………..................................................

11.1. Liczebniki jako klasa leksemów........................................................................ 383

11.2. Liczebniki główne (nomina numeralia cardinalia) ............................................ 384

11.2.1. Charakterystyka gramatyczna liczebników głównych ............................ 384

11.2.1.1. Liczebniki mille i milia ............................................................. 386

11.2.2. Struktura semantyczna i syntaktyczna wyrażeń liczebnikowych ........... 389

11.2.2.1. Struktura semantyczna i syntaktyczna wyrażeń

liczebnikowych $z$ liczebnikiem milia ............................................ 392

11.2.3. Ogólne zestawienie liczebników głównych i podstawowych schematów tworzenia złożonych liczebników głównych.......................... 398

11.2.4. Pradygmaty formalne liczebników: unus, duo, tres, milia ....................... 400

11.3. Liczebniki porządkowe (nomina numeralia ordinalia) ..................................... 400

11.3.1. Ogólne zestawienie liczebników porządkowych i podstawowych schematów tworzenia złożonych liczebników porządkowych................ 404

11.4. Liczebniki podziałowe (nomina numeralia distributiva).................................. 405

11.4.1. Ogólne zestawienie liczebników podziałowych i podstawowych schematów tworzenia złożonych liczebników podziałowych ................. 409

11.5. Liczebniki wielorakie (nomina numeralia multiplicativa)................................. 409

11.6. Liczebniki frekwentatywne / przysłówkowe (adverbia numeralia).................. 410 
11.6.1. Ogólne zestawienie liczebników frekwentatywnych i podstawowych schematów tworzenia złożonych liczebników frekwentatywnych

11.7. Wybrana literatura.

12. Charakterystyka funkcjonalna czasowników............................................................ 413

12.1. Czasowniki jako klasa leksemów................................................................... 413

12.2. Czas (tempus) - tzw. consecutio temporum ......................................................... 413

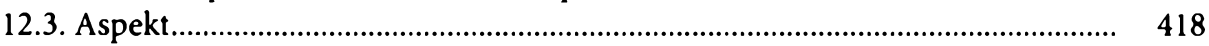

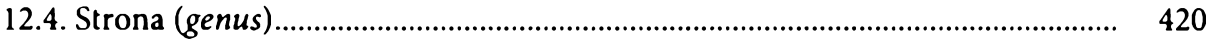

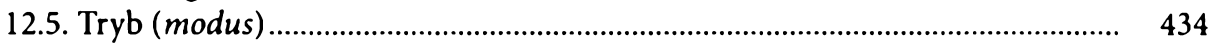

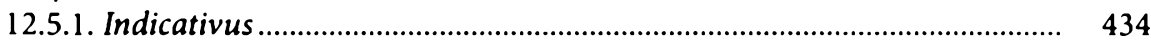

12.5.2. Imperativus .......................................................................... 436

12.5.3. Coniunctivus ......................................................................................... 438

12.5.3.1. Koniuktiwus jako wykładnik nacechowanej modalności intencjonalnej

12.5.3.1.1. Modalność imperatywna ...................................................... 438

12.5.3.1.2. Modalność dezyderatywna ................................................ 439

12.5.3.2. Koniuktiwus jako wykładnik nacechowanej modalności epistemicznej.

12.5.3.3. Koniuktiwus jako wykładnik nacechowanej modalności deontycznej

12.5.3.4. Koniuktiwus jako wykładnik podrzędności składniowej zdań składowych w ramach zdań złożonych

12.6. Osoba (persona)

12.7. Liczba (numerus) ...................................................................................... 449

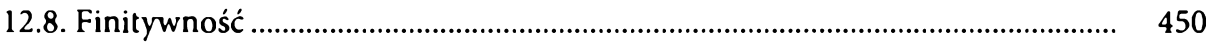

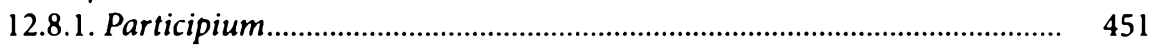

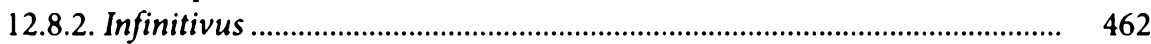

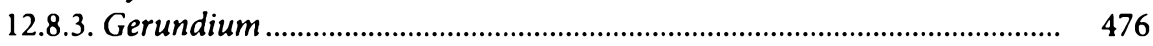

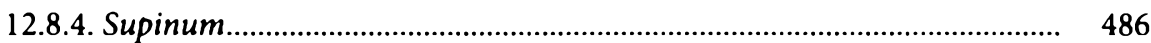

12.9. Wybrana literatura ........................................................................................... 490

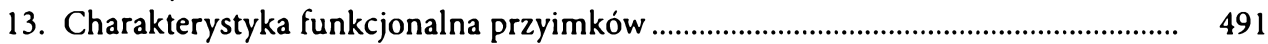

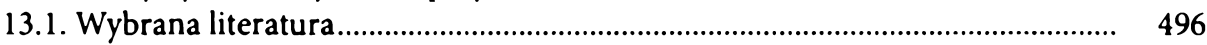

14. Charakterystyka funkcjonalna spójników ............................................................. 497

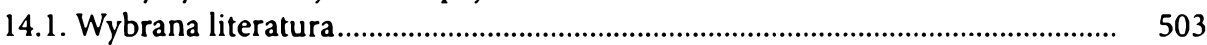

15. Charakterystyka funkcjonalna partykuł ............................................................... 504

15.1. Wybrana literatura............................................................................................... 507

\section{SKŁADNIA}

1. Ogólna typologia składniowa wypowiedzeń

2. Wypowiedzenia niezdaniowe niezależne składniowo (równoważniki zdań niezależne składniowo)

3. Zdanie 
3.1.1.3. Modalność logiczna (deontyczna, dynamiczna) ......................... 520

3.1.2. Modalność w lacinie ................................................................................. 521

3.1.2.1. Modalność intencjonalna ....................................................... 521

3.1.2.2. Modalność epistemiczna............................................................ 524

3.1.2.2.1. Partykułowe operatory modalne................................... 524

3.1.2.2.2. Coniunctivus .................................................................. 526

3.1.2.2.3. Nominativus cum infinitivo......................................... 527

3.1.2.2.4. Czasowniki modalne .................................................. 540

3.1.2.2.5. Inne wyrażenia czasownikowe .................................... 541

3.1.2.2.6. Futurum ............................................................... 542

3.1.2.2.7. Interrogatywa............................................................. 542

3.1.2.3. Modalność logiczna (deontyczna, dynamiczna) ......................... 542

3.1.2.3.1. Czasowniki i wyrażenia modalne .................................. 543

3.1.2.3.2. Coniunctivus ................................................................ 545

3.1.2.3.3. Konstrukcje partycypialne .......................................... 546

3.1.2.3.3.1. Participium futuri passivi........................... 546

3.1.2.3.3.2. Participium futuri activi........................... 548

3.1.2.3.4. Nominativus cum infinitivo........................................... 549

3.1.2.3.5. Imperatywa i dezyderatywa ........................................ 550

3.1.2.4. Współwystępowanie modalności ................................................ 551

3.1.2.5. Status składniowy leksykalnych wykładników modalności ........ 553

3.1.2.5.1. Partykuły ...................................................................... 554

3.1.2.5.2. Zaimki .................................................................... 554

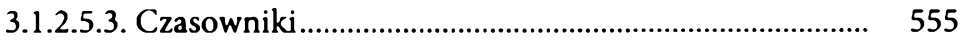

3.1.3. Wybrana literatura ............................................................................... 564

3.2. Składniki zdania ....................................................................................... 564

3.2.1. Ogólna typologia składników zdania ....................................................... 564

3.2.2. Człony syntaktyczne (części zdania) ........................................................ 565

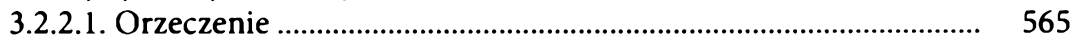

3.2.2.1.1. Orzeczenie proste......................................................... 566

3.2.2.1.2. Orzeczenie złożone ....................................................... 566

3.2.2.2. Uzupełnienie orzecznikowe (komplement orzecznikowy) ........ 570

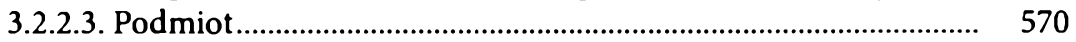

3.2.2.4. Przydawka .............................................................................. 572

3.2.2.4.1. Przydawka apozycyjna ............................................... 575

3.2.2.4.2. Przydawka orzecznikowa (praedicativum) .................. 577

3.2.2.5. Dopełnienie .............................................................................. 578

3.2.2.6. Okolicznik............................................................................... 582

3.2.3. Konektory ….................................................................................... 585

3.2.3.1. Konektory parataktyczne (współrzędne)...................................... 585

3.2.3.2. Konektory hipotaktyczne (podrzędne) ......................................... 592

3.2.3.3. Konektory jako wskaźniki relacji semantycznych, lączących człony syntaktyczne pozostające $w$ stosunku nadrzędno-podrzędnym........................................................... 597

3.2.4. Operatory tekstowe ........................................................................................ 598

3.2.4.1. Operatory nawiązania międzywypowiedzeniowego (spójności retorycznej) 
3.2.4.2. Operatory modalne

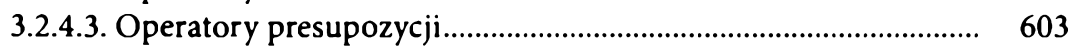

3.2.4.4. Operatory kwantyfikacji i negacji.................................................. 606

3.2.4.5. Operatory emotywne (ekspresywne i impresywne).................... 607

3.2.5. Wyrażenia adresatywne........................................................................ 608

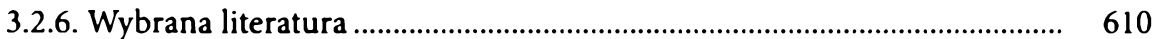

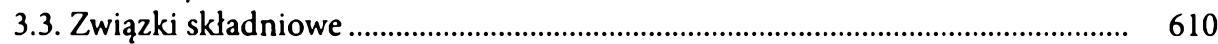

3.3.1. Związek kongruencji (zgody) .................................................................. 610

3.3.1.1. Związek kongruencji atrybutywnej (związek atrybucji) ............. 611

3.3.1.2. Związek kongruencji predykatywnej (związek predykacji) ........ 621

3.3.2. Związek rekcji (rządu) ................................................................................... 625

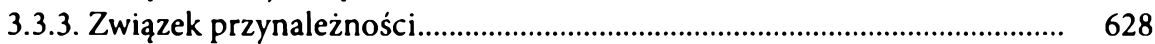

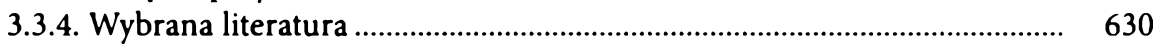

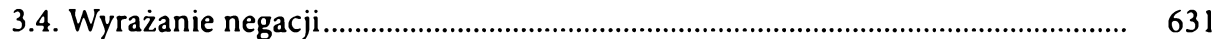

3.4.1. Wybrana literatura ............................................................................ 638

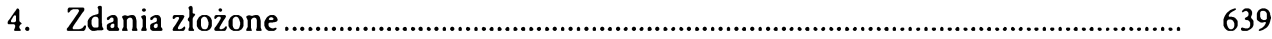

4.1. Kryteria klasyfikacji i typologia zdań złożonych............................................. 640

4.2. Zdania złożone współrzędnie ............................................................................ 641

4.3. Zdania złożone podrzędnie ............................................................................. 644

4.3.1. Kryteria klasyfikacji i typologia zdań podrzędnych w ramach zdań złożonych podrzędnie ............................................................................. 645

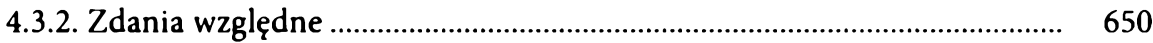

4.3.2.1. Wprowadzenie............................................................................ 650

4.3.2.2. Zdania z zaimkiem względnym o charakterze rzeczownikowym i przysłówkowym

4.3.2.2.1. Zdania $\mathrm{z}$ rzeczownikowym korelatem zaimka względnego.

4.3.2.2.2. Zdania z zaimkowym korelatem zaimka względnego.

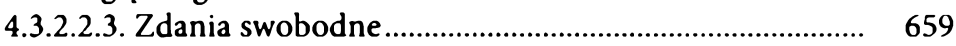

4.3.2.2.4. Zdania rozwijające ...................................................... 661

4.3.2.3. Zdania z zaimkiem względnym o charakterze przymiotnikowym

4.3.2.3.1. Zdania z zaimkiem qui, quae, quod użytym przydawkowo

4.3.2.3.2. Zdania z zaimkami qualis, quantus, quot.................... 665

4.3.2.4. Semantyczne funkcje zdań względnych.......................................... 667

4.3.2.4.1. Zdania względne restryktywne .................................. 667

4.3.2.4.2. Zdania względne nierestryktywne ................................ 671

4.3.2.4.3. Zdania względne predykatywne

(względno-okolicznikowe).

4.3.2.5. Syntaktyczne funkcje zdań względnych

4.3.2.5.1. Zdania z zaimkiem względnym użytym

rzeczownikowo.

4.3.2.5.2. Zdania z zaimkiem względnym użytym

przymiotnikowo (przydawkowo).

4.3.2.5.3. Zdania z zaimkami qualis, quantus, quot. 
4.3.2.5.4. Zdania z przysłówkowymi zaimkami względnymi ..... 681

4.3.2.6. Tryb orzeczenia w zdaniach względnych...................................... $\quad 682$

4.3.2.7. Uwagi na temat wybranych cech składniowych zdań

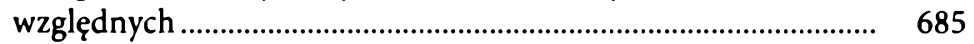

4.3.2.8. Tzw. „połączenie względne”............................................................ 691

4.3.3. Zdania spójnikowe................................................................................... 693

4.3.3.1. Zdania podmiotowe ................................................................... $\quad 694$

4.3.3.2. Zdania przydawkowe.................................................................. 701

4.3.3.3. Zdania dopełnieniowe................................................................ 706

4.3.3.4. Zdania orzecznikowe.................................................................. 717

4.3.3.5. Zdania okolicznikowe ................................................................. 718

4.3.3.5.1. Zdania okolicznikowe celu .......................................... 718

4.3.3.5.2. Zdania okolicznikowe skutku......................................... 724

4.3.3.5.3. Zdania okolicznikowe przyczyny.................................. $\quad 729$

4.3.3.5.4. Zdania okolicznikowe czasu ......................................... 741

4.3.3.5.5. Zdania okolicznikowe przyzwolenia ........................... 755

4.3.3.5.6. Zdania okolicznikowe warunku.................................... 761

4.3.3.5.7. Zdania okolicznikowe porównania .............................. 773

4.3.4. Zdania asyndetyczne ............................................................................ 774

4.3.5. Równoważniki zdań podrzędnych........................................................ 779

4.3.5.1. Accusativus cum infinitivo.......................................................... 779

4.3.5.2. Ablativus absolutus....................................................................... 787

4.3.6. Wybrana literatura ……………............................................................ 791

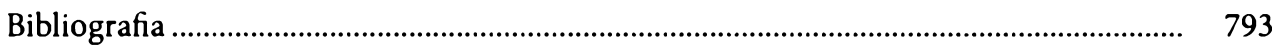

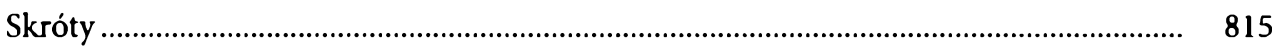





\section{Wstęp}

Książka ta powstała z poczucia obowiązku wobec studentów filologii klasycznej, dla których jako nauczyciel akademicki przez wiele lat prowadziłem zajęcia $\mathrm{z}$ gramatyki opisowej języka łacińskiego. Zajęciom tym nieustannie brakowało odpowiedniego podręcznika akademickiego, mogącego stanowić dla nich elementarną bazę metodologiczną i egzemplifikacyjną, w szczególności zaś takiego, który - przynajmniej w jakimś stopniu - uwzględniałby dorobek dwudziestowiecznej lingwistyki w zakresie podstawowego aparatu pojęciowo-terminologicznego gramatyki. Zawstydzony tą sytuacją podjąłem (karkołomną) próbę przygotowania książki, która u progu dwudziestego pierwszego wieku stworzyłaby studentom filologii szansę na wyrwanie się z zaklętego kręgu dziewiętnastowiecznej gramatyki. Nie do końca zdawałem sobie przy tym sprawę $\mathrm{z}$ trudności, które czekają kogoś, kto próbuje mierzyć się z takim zadaniem, zwłaszcza $w$ pojedynkę. Również $z$ uwagi na limitowany czas realizacji projektu badawczego oraz ograniczoną objętość książki nie wszystkie założenia udało się zrealizować $\mathrm{w}$ pełni. Pewne zagadnienia tylko zarysowano lub opracowano ogólnie, inne zupełnie pominięto, jak np. słowotwórstwo. Być może za jakiś czas uda się powrócić do tego projektu, uzupełniając braki i dokonując niezbędnych korekt. Pozostaje mieć nadzieję, że mimo wszystkich niedociągnięć zawarty w tym opracowaniu strukturalistyczny opis systemu gramatycznego łaciny, jako alternatywa dla dotychczasowej praktyki nauczania uniwersyteckiego, spotka się z zainteresowaniem i pomoże lepiej przybliżyć język starożytnych Rzymian zarówno adeptom filologii klasycznej, zwłaszcza tym o zainteresowaniach językoznawczych, jak i lingwistom różnych specjalności, wśród których znajomość tego języka staje się coraz mniej powszechna.

Do powstania tej książki przyczyniło się wiele osób, którym winien jestem wdzięczność. W pierwszej kolejności wymienić muszę Studentów Katedry, a później Instytutu Filologii Klasycznej Uniwersytetu Jagiellońskiego, a także Studentów Katedry Filologii Klasycznej Uniwersytetu Śląskiego, z którymi miałem wielką przyjemność odbywać przez wiele lat zajęcia z gramatyki opisowej języka łacińskiego. To oni najpierw namawiali mnie do napisania tego podręcznika, a potem długo na niego czekali. Oni też wywarli znaczny wpływ na jego kształt poprzez swoje uwagi, komentarze i dyskusje. W początkowym okresie każdego kursu, trochę nieufni wobec nieco innego sposobu rozmawiania o gramatyce, wykazywali sporą rezerwę 
wobec konieczności opanowania nowych dla nich terminów i pojęć, pod koniec zdawali się jednak dostrzegać walory proponowanej metodologii, żywiąc przy tym od początku przekonanie, że sposób prezentowania gramatyki łacińskiej w dostępnych dla nich podręcznikach trudno uznać za w pełni satysfakcjonujący. To utwierdziło mnie w przekonaniu, że warto podjąć próbę opracowania wykładu zarówno pełniejszego, jak i metodologicznie alternatywnego w stosunku do dotychczasowych. Podziękowania kieruję także do P.T. Członków Zespołu Języka Łacińskiego Jagiellońskiego Centrum Językowego UJ, którzy z zainteresowaniem i przychylnością odnieśli się do rozwiązań metodologicznych, jakie miałem zaszczyt Im przedstawić podczas przeprowadzonego na zaproszenie Kierownika zespołu, dr. hab. Marka Hermanna, seminarium pt. Gramatyka łacinska $i$ jej nauczanie w perspektywie językoznawstwa strukturalnego i funkcjonalnego. Dziękuję dr. hab. Antoniemu Bobrowskiemu i dr. hab. Rafałowi Rosołowi za udostępnione mi materiały zarówno w formie drukowanej, jak i elektronicznej. Dziękuję Pani mgr Dominice Maliszewskiej-Filip i Panu mgr. Markowi Szerszeniowi, kustoszom biblioteki Instytutu Filologii Klasycznej UJ, za umożliwienie mi korzystania ze zbiorów bibliotecznych na preferencyjnych warunkach. Dziękuję P.T. Władzom Polskiego Towarzystwa Filologicznego, które przyjęło funkcję gospodarza projektu mającego na celu przygotowanie koncepcji i zrealizowanie badań niezbędnych dla powstania tego opracowania. Dziękuję Pani dr hab. Dorocie Szumskiej, prodziekan Wydziału Filologicznego UJ, za życzliwe wsparcie, które umożliwiło sfinansowanie publikacji książki. Dziękuję Pani dr hab. Kindze Paraskiewicz za opiekę, jaką otoczyła tekst tej książki jako jej redaktor. Szczególne podziękowania składam Panu Adamowi Lejczakowi, prezesowi wydawnictwa Księgarnia Akademicka, za wszystko, co zrobił, aby książka ta mogła się ukazać. A właściwie za wszystko to, czego nie zrobił, choć mógł.

Wszystkim P.T. Czytelnikom będę wdzięczny za wszelkie uwagi i komentarze dotyczące zawartości książki.

Hubert Wolanin hubert.wolanin@uj.edu.pl 


\section{Wprowadzenie}

\section{ZAŁOŻENIA OGÓLNE}

Celem niniejszego opracowania było sporządzenie opisu systemu gramatycznego klasycznej laciny $\mathrm{w}$ aspekcie synchronicznym, $\mathrm{z}$ wykorzystaniem aparatu pojęciowo-terminologicznego i założeń metodologicznych współczesnego językoznawstwa strukturalistycznego. Zgodnie z powszechnym rozumieniem określenia „klasyczna łacina" przedmiotem opisu jest głównie gramatyka języka pisanego rzymskich warstw wykształconych, który znalazł odzwierciedlenie w zachowanych tekstach literackich pochodzących z okresu od I w. przed Chr. do II w. po Chr., w mniejszym zakresie także z okresu nieco wcześniejszego (III-II w. przed Chr.) i późniejszego (III-V w. po Chr.). Tak zakreślone ramy czasowe siłą rzeczy implikują uwzględnienie również aspektu diachronicznego, jednak ze względu na znany konserwatyzm starożytnej łaciny literackiej możliwe jest ograniczenie się $\mathrm{w}$ tym zakresie do zasygnalizowania określonych tendencji rozwojowych, ujawniających się głównie w sferze fonetyki i fonologi języka mówionego, zwłaszcza potocznego.

\section{2. ŹRÓDŁA WIEDZY O GRAMATYCE JĘZYKA ŁACIŃSKIEGO}

Podstawowym źródłem wiedzy o gramatyce klasycznej łaciny są zachowane starożytne teksty literackie, które doszły do naszych czasów głównie drogą średniowiecznej tradycji rękopiśmiennej. Szczęśliwie zachowała się do naszych czasów znaczna część spuścizny pisarskiej takich poetów łacińskich jak Wergiliusz, Owidiusz, Lukrecjusz, Katullus czy Horacy, a także takich prozaików jak Cyceron, Salustiusz, Cezar, Liwiusz czy Seneka. Teksty te przekazują informacje przede wszystkim o pisanej odmianie łacińskiego języka oficjalnego, literackiego, jednak charakter niektórych utworów pozwala także na poznanie pewnych właściwości języka mniej formalnego, potocznego czy mówionego. W tym kontekście wskazać można np. na dzieła komediowe (np. Plauta), listy (np. Cycerona), powieści (np. Petroniusza) czy pozbawione ambicji literackich piśmiennictwo fachowe $\mathrm{z}$ różnych dziedzin (np. Witruwiusza). Naszą wiedzę o gramatyce łacińskiej uzupełniają ponadto zabytki epigraficzne, a także zachowane starożytne traktaty gramatyczne (np. Warrona, Pryscjana) oraz utwory o charakterze 
eseistycznym (np. Geliusza) czy dydaktycznym (np. Kwintyliana), w których przedmiotem autorskich refleksji są m.in. różne kwestie językowe. Znana na ogół (w większym lub mniejszym przybliżeniu) datacja zachowanych tekstów pozwala również na zidentyfikowanie określonych tendencji rozwojowych, którym podlegały określone elementy gramatyki starożytnej łaciny.

Dzięki wskazanym wyżej źródłom możliwe jest dość kompletne zrekonstruowanie i opisanie systemu gramatycznego klasycznej łaciny, chociaż poziom szczegółowości, z jaką można tego opisu dokonać, jest różny w odniesieniu do poszczególnych podsystemów. Posiadamy wystarczająco wiele danych, aby móc stosunkowo dokładnie poznać łacińską morfologię i składnię - przynajmniej w odniesieniu do literackiej odmiany tego języka. Pojawiające się w tym zakresie niedostatki opisu wynikają nie tyle $\mathrm{z}$ braku dostatecznych danych źródłowych, ile raczej z trudności w ustaleniu granic między normą a błędem językowym, a w przypadku systemu składniowego dodatkowo z braku w pełni satysfakcjonującego modelu tego opisu. Mniej szczegółowo i dokładnie możemy opisać system fonologiczny starożytnej łaciny, choć i w tym względzie dość znaczną ilość faktów jesteśmy w stanie ustalić $z$ dużą dozą prawdopodobieństwa. Podstawowym czynnikiem, który to umożliwia, jest system pisma, czyli alfabet łaciński. Ok. VII w. przed Chr. zapożyczony on został przez Rzymian od Greków, najprawdopodobniej od mieszkanców miasta Cumae w Kampanii, kolonii założonej przez Greków z Chalkis na Eubei. Dodajmy, że ta lokalna odmiana pisma, będąca jedną z zachodniogreckich wersji alfabetu, różniła się nieco od odmiany wschodnio-jońskiej (milezyjskiej), która później, tj. od roku 403 przed Chr., stała się oficjalnym pismem państwa ateńskiego i podstawą klasycznego alfabetu greckiego. Na sposób zaadaptowania przez Rzymian tego kumańskiego alfabetu wpłynął także sposób posługiwania się nim przez Etrusków, którzy przyswoili go sobie nieco wcześniej, a ich kultura silnie wówczas oddziaływała na kształtującą się dopiero cywilizację rzymską. Kilkanaście stuleci później alfabet łaciński został wykorzystany do zapisu powstałych na bazie łaciny języków romańskich (i nie tylko) z zachowaniem - w znacznym stopniu - wartości fonetycznych poszczególnych liter, ustalonych wcześniej dla zapisu głosek łacińskich. Alfabet ten przyjęty też został do notacji języka polskiego, co znacznie ułatwia nam identyfikację brzmienia poszczególnych głosek w zapisach wyrazów lacińskich. Nie znaczy to jednak, że relacja między stroną graficzną a fonetyczną wyrazów, jaka ustaliła się w różnych językach nowożytnych, dokładnie odpowiada tej, która funkcjonowała w klasycznej łacinie. Co więcej, w ramach samej starożytnej tradycji przekazu tekstów pisanych stosunek między stosowaną konwencją ortograficzną a rzeczywistym brzmieniem wyrazów z pewnością nie był jednoznaczny ani jednolity. Różnice między pisownią a wymową musiały się ujawniać, zwłaszcza gdy uwzględni się aspekt chronologiczny, geograficzny oraz odmienne rejestry językowe (łacina archaiczna / klasyczna, język oficjalny / potoczny, stołeczny / prowincjonalny itd.). W tym względzie wiele szczegółów dotyczących artykulacji różnych głosek oraz ich ciągów w obrębie wyrazów pozostaje nieznanych. Dysponujemy jednak źródłami, które rzucają trochę światła na tę kwestię. Są nimi uwagi starożytnych gramatyków i innych autorów na temat wymowy 
różnych wyrazów, odnajdywane w antycznych tekstach etymologie czy gry słowne oparte na brzmieniu wyrazów, zapożyczenia łacińskie i zapisy lacińskich wyrazów w innych językach (głównie w grece), sposób kontynuacji łacińskich słów w językach romańskich, poświadczone inskrypcyjnie różne warianty ortograficzne łacińskich wyrazów (zwłaszcza nieformalne naścienne graffiti zapisujące słowa "fonetycznie", $z$ pogwałceniem zasad oficjalnej ortografii), wreszcie schematy metryczne i wewnętrzna struktura języka łacińskiego. Dodajmy, że niezależnie od szczegółowości naszej aktualnej wiedzy o fonetyce starożytnej łaciny w poszczególnych krajach, także w Polsce, funkcjonują określone, historycznie ukształtowane konwencje wymowy tego języka, które w różnym stopniu odpowiadają tej wiedzy, a ich kształt znacząco determinowany jest przez właściwości rodzimych systemów fonologicznych. Obecnie wyraźnie zarysowuje się tendencja do maksymalnego zbliżania tych konwencji do stanu fonetycznego, który na drodze naukowych analiz rekonstruowany jest dla okresu starożytnego.

\section{JEZYK A GRAMATYKA: POJĘCIE GRAMATYKI}

Język jest podstawowym narzędziem komunikacji między ludźmi w obrębie określonej społeczności. Narzędzie to stanowione jest przez system konwencjonalnych znaków, prymarnie dźwiękowych (wytwarzanych przez aparat głosowy człowieka), a wtórnie pisanych (graficznych). Fundamentalną cechą języka jest jego otwartość, czyli właściwość polegająca na tym, że za pośrednictwem skończonej liczby znaków elementarnych może być generowana nieskończona ilość znaków (komunikatów) złożonych.

Znak językowy cechuje się podstawową opozycją formy i funkcji. W odniesieniu do formy znaku stosuje się m.in. takie określenia jak plan wyrażania, strona oznaczająca znaku, significans, natomiast funkcja znaku określana jest jako plan treści, strona oznaczana, significatum. Ze wspomnianej wyżej cechy otwartości języka wynika, że zarówno forma znaków językowych, jak i ich treść, złożone są z określonych jednostek elementarnych, z kolei status języka jako systemu, a nie prostego zbioru znaków, implikuje istnienie konkretnych reguł, które pozwalają na łączenie owych jednostek planu wyrażania i jednostek planu treści w większe struktury.

Istnienie nakładających się na siebie opozycji: forma - funkcja oraz jednostka struktura, a także różny stopień złożoności znaku (komunikatu) językowego, pozwalają na wyodrębnienie trzech płaszczyzn organizacji języka. Pierwsza z nich, płaszczyna fonologiczna, dotyczy wyłącznie formy znaków językowych. Jej podstawowymi jednostkami są fonemy (głoski), a podstawowymi strukturami sylaby. Fonemy (głoski) są jednostkami funkcjonalnymi, ale ich funkcja nie ma charakteru znakowego, lecz dystynktywny, tzn. sprowadza się do rozróżniania (identyfikacji) jednostek znaczących (znaków językowych), których formalny wykładnik (stronę oznaczającą) stanowią. Dwie pozostałe płaszczyzny obejmują elementy, które oprócz charakterystyki formalnej cechują się także właśnie określoną funkcją znakową. Płaszczyzny te 
są zhierarchizowane względem siebie, a podstawę różnicy między nimi stanowi stopień złożoności funkcji znakowej ich podstawowych jednostek funkcjonalnych oraz zróżnicowanie sposobu łączenia się tych jednostek w struktury. Płaszczyzną hierarchicznie niższą jest płaszczyzna morfologiczna, której podstawowymi jednostkami są morfemy, czyli elementarne jednostki znakowe (np. rdzenie wyrazowe, sufiksy, końcówki), zaś podstawowymi strukturami wyrazy. Z kolei płaszczyzną wyższą jest płaszczyzna składniowa (syntaktyczna), której podstawowymi jednostkami są człony syntaktyczne (części) zdania, a podstawową strukturą zdanie (wypowiedzenie); płaszczyzna ta obejmuje zatem ponadelementarne jednostki i struktury formalno-funkcyjne języka.

Ogólny schemat organizacyjny języka można zatem przedstawić w następujący sposób:

jednostki

(system)

fonemy

morfemy

części zdania

(człony syntaktyczne) struktury

(tekst)

sylaby

wyrazy

zdania

(wypowiedzenia)

Szczegółowa charakterystyka tego właśnie systemu organizacyjnego języka stanowi przedmiot jego gramatyki opisowej, która w związku $z$ tym obejmuje 3 podstawowe działy: fonologię, morfologię i składnię.

\section{WYBRANA LITERATURA}

Wszystkie wyszczególnione pozycje bibliograficzne odsyłają do pełnego wykazu bibliografii, zamieszczonego na końcu książki.

Podręczniki do gramatyki łacińskiej lub jej działów:

Baños Baños (2009), Bassols de Climent (1992), Beltrán (1999), Clackson (2011), Greenough, Kittredge, Howard, D'Ooge (1903 (1983)), Hammond (1976), Juret (1926), Leumann 1963 (1977), Menge (2000), Morani (2000), Oniga (2004), Palmer (1954), Pinkster (1990), Rubenbauer, Hofmann, Heine (1975), Rubio (1983), Samolewicz, Sołtysik (2000), Scherer (1975), Serbat (1975), Sommer (1914), Sommer, Pfister (1977), Stolz, Schmalz, Leumann, Hofmann (1928), Traina, Bertotti (1965-1969), Traina, Bernardi Perini (1971- 
-1972), Traina, Pasqualini (1985), Wielewski (1964), Wikarjak (1978), Woodcock (1959), Zawadzki (2003)

\section{Podręczniki do gramatyki polskiej:}

Grzegorczykowa, Laskowski, Wróbel (1984 (1998, 1999)), Grzegorczykowa (1998), Nagórko (1996, 2010), Saloni, Swidziński (1998), Topolińska (1984), Wróbel $(1995,2001)$

\section{Opracowania metodologiczne:}

Andreoni Fontecedro (1986), Calboli (1968, 1983b), Della Casa (1975), Dönnges, Happ (1977), Favarin (1979, 2000), Górska (1999), Happ (1976, 1979), Oniga (1991, 1996), Pinkster (1985a), Proverbio (1979b), Ros (2001), Steinthal (1979) 


FONOLOGIA I FONETYKA 


\section{1. \\ Głoska, fonem, allofon}

Podstawowymi jednostkami funkcjonalnymi płaszczyzny fonologicznej są fonemy. Wykorzystywane $w$ gramatyce pojęcie fonemu ma charakter abstrakcyjny i pozostaje w określonym związku z pojęciem głoski, które odnosi się do realnej (artykułowanej) jednostki planu wyrażania. Otóż głoska jest zjawiskiem (bytem) fizycznym, który może być określony jako realna, elementarna (niepodzielna liniowo) jednostka dźwiękowej formy wypowiedzenia, stanowiąca zespół wszystkich współwystępujących cech artykulacyjnych i akustycznych (fonetycznych). Na ów zespół współwystępujących cech fonetycznych składają się m.in. takie cechy jak: czas trwania artykulacji głoski, wysokość wyartykułowanego dźwięku, jego natężenie (głośność), miejsce jego artykulacji (w obrębie aparatu głosowego), sposób artykulacji (np. z udziałem drgań wiązadeł głosowych lub bez ich udziału) itp. Nie wszystkie jednak cechy fonetyczne charakteryzujące głoski są wykorzystywane przez system językowy do różnicowania (identyfikacji) znaków. Np. w języku polskim takie cechy głosek jak czas trwania artykulacji czy wysokość dźwięku nie służą rozróżnianiu wyrazów, w związku $\mathrm{z}$ czym są pomijane $w$ opisie systemu gramatycznego. Opis ten uwzględnia natomiast te cechy, które takiemu rozróżnieniu służą. W języku polskim taką cechą jest m.in. miejsce artykulacji, ponieważ np. wargowa artykulacja głoski [p] pozwala odróżnić wyraz pora od wyrazu kora, którego pierwsza głoska, czyli [k], cechuje się artykulacją tylnojęzykową. W związku z tym gramatyka częściej niż pojęciem głoski posługuje się pojęciem fonemu, rozumianym jako abstrakcyjna, elementarna jednostka funkcjonalna planu wyrażania, stanowiąca zespół współwystępujących cech wyłącznie istotnych (relewantnych) z punktu widzenia funkcji dystynktywnej, czyli funkcji rozróżniania znaczących elementów językowych. Ponieważ cechy te jednocześnie stanowią podstawę różnicy (opozycji) między samymi fonemami, nazywa się je również cechami dystynktywnymi. Można zatem stwierdzić, że fonem to wybór określonych cech głoski, tych mianowicie, które mają charakter dystynktywny. Tym samym każdy fonem fizycznie realizowany jest przez odpowiadającą mu głoskę (lub zbiór głosek), a $z$ drugiej strony każda głoska stanowi fizyczną reprezentację określonego fonemu. Fizycznie nie da się bowiem wyartykułować cech wyłącznie dystynktywnych, z pominięciem innych, niedystynktywnych, takich jak np. czas trwania artykulacji czy 
wysokość dźwięku, które nie są cechami konstytutywnymi fonemu, np. polskiego /a/, ale są jednymi z cech fonetycznych (fizycznych parametrów) głoski, np. [a].

Dla ścisłości wykładu stosuje się konwencję polegającą na: zapisie fonemów z użyciem ukośników, np. /b/; zapisie (wartości fonetycznej) głosek z użyciem nawiasów kwadratowych, np. [b]; oraz na użyciu kursywy dla zapisu liter, czyli konwencji ortograficznej przyjętej (przez Rzymian) dla notacji poszczególnych fonemów w wyrazach, a więc np. $b$ (jak w wyrazie bonus).

Jak wspomniano wyżej, właściwością konstytuujących fonemy cech dystynktywnych jest to, że są one wykorzystywane przez system językowy do różnicowania znaków (wyrazów). Dowodem na dystynktywny charakter określonej cechy jest istnienie w języku dwóch znaków (wyrazów) różniących się formalnie wyłącznie w zakresie tej jednej cechy jednego ze swych fonemów. Parę złożoną z tego rodzaju znaków (wyrazów) określa się terminem pary minimalnej. Przykładowo istnienie w języku łacińskim pary wyrazów: tum 'wtedy' : dum 'dopóki' dowodzi dystynktywności cechy dźwięczności w obrębie systemu łacińskich spółgłosek, zaś istnienie pary wyrazów tum 'wtedy' : cum 'gdy' wskazuje na dystynktywność cechy miejsca artykulacji w ramach tegoż systemu.

Każdemu fonemowi, rozumianemu jako zespół określonych cech dystynktywnych, można przypisać jeden lub kilka wariantów realizacyjnych w postaci jednej lub kilku reprezentujących ów fonem głosek. W przypadku, gdy jeden fonem może być reprezentowany (realizowany) przez więcej niż jedną głoskę, mówimy o zjawisku allofonii, a głoski reprezentujące dany (ten sam) fonem nazywane są allofonami danego fonemu. Zróżnicowanie sposobu realizacji fonemu, skutkujące zaistnieniem allofonii, może wynikać $\mathrm{z}$ oddziaływania określonego kontekstu fonologicznego. Np. $\mathrm{w}$ języku polskim fonem $/ \mathrm{n} / \mathrm{w}$ neutralnych kontekstach realizowany jest jako spółgłoska półotwarta przedniojęzykowo-zębowa, jak np. w wyrazie noc, natomiast przed spółgłoską tylnojęzykową / $\mathrm{k} / \mathrm{lub} / \mathrm{g} /$ fonem ten reprezentowany jest przez spółgłoskę półotwartą tylnojęzykową [n] (podobną do ostatniej spółgłoski np. w ang. wating), jak np. w wyrazie bank [bank] czy bingo [bingo]. W takim przypadku mówimy o allofonach pozycyjnych (inaczej: kombinatorycznych) danego fonemu, pozostających względem siebie w dystrybucji komplementarnej (uzupełniającej), czyli występujących w kontekstach rozłącznych (wzajemnie się wykluczających). Tak więc uznamy, że w języku polskim [n] i [n] są pozycyjnymi allofonami fonemu /n/; albo inaczej: fonem $/ \mathrm{n} /$ jest reprezentowany przez dwa allofony pozycyjne: [n] i [n].

Jednak allofonia jest determinowana nie tylko oddziaływaniem określonego kontekstu fonologicznego, lecz może także wynikać $z$ istnienia określonej normy językowej (stylistycznej lub regionalnej), dopuszczającej wariantywność realizacji danego fonemu. Np. w języku polskim fonem /un/, oprócz powszechnej artykulacji dwuwargowej [ł], może przybierać również realizację przedniojęzykowo-dziąsłową, tzw. „aktorską" („sceniczną") lub „kresową", np. w nagłosie ${ }^{1}$ wyrazu łatwy. Poza tym wariantywna realizacja określonego fonemu może być także skutkiem odziaływania 
właściwości języka osobniczego, czyli może być indywidualną, akceptowaną cechą wymowy osoby mówiącej, jak np. tylnojęzykowe (,języczkowe”) [R], będące allofonem /r/ słyszalnym w wymowie takich postaci polskiego życia publicznego, jak np. premier Donald Tusk. Tego rodzaju niezależne od kontekstu fonologicznego allofony nazywane są allofonami fakultatywnymi.

Wspólną cechą allofonów danego fonemu, zarówno pozycyjnych jak i fakultatywnych, jest to, że istniejące między nimi różnice fonetyczne są nierelewantne (nieistotne) fonologicznie, tzn nie służą różnicowaniu znaków. $Z$ jednej bowiem strony nie istnieje para minimalna złożona $z$ wyrazów typu *[bank] : [bank], z drugiej zaś opozycja ciągów artykulacyjnych [rada] : [Rada] nie reprezentuje dwu różnych znaków (wyrazów).

Ze względu na cechę dystynktywną otwartości artykulacyjnej fonemy tworzą dwa podsystemy:

a. wokaliczny (samogłoskowy), który złożony jest $\mathrm{z}$ fonemów o artykulacji relatywnie bardziej otwartej (tzn. w trakcie ich wymawiania w żadnym miejscu kanału głosowego nie następuje zwarcie ani znaczniejsze zwężenie narządów artykulacyjnych); fonemy te pełnią funkcję zgłoskotwórczą;

b. konsonantyczny (spółgłoskowy), który złożony jest $\mathrm{z}$ fonemów o artykulacji relatywnie bardziej zamkniętej (tzn. w trakcie ich wymawiania następuje w miejscu artykulacji zwarcie lub znaczne zwężenie narządów mowy); fonemy te nie pełnią funkcji zgłoskotwórczej.

Do systemu wokalicznego, oprócz samogłosek, należą również dyftongi (dwugłoski), tj. fonemy zgłoskotwórcze o artykulacji ciągłej, ze zmiennym przebiegiem akustycznym. Nagłos dyftongu, czyli początkowy etap jego artykulacji, jest odmienny od jego wygłosu, czyli końcowej fazy artykulacji. Dyftong, którego nagłos ma charakter samogłoskowy, a wygłos jest zbieżny $z$ artykulacją glajdu (zob. niżej), a więc np. /ai/ [aj], / $\mathrm{e}^{\mathrm{u} /}$ [eł], nazywany jest dyftongiem zstępującym, natomiast dyftong o odwrotnej strukturze - dyftongiem wstępującym. 


\section{2. \\ Łaciński konsonantyzm}

Cechami dystynktywnymi łacińskiego systemu konsonantycznego (spółgłoskowego) są:

1. dźwięczność (bezdźwięczność), czyli obecność (lub nieobecność) tzw. tonu krtaniowiowego $\mathrm{w}$ głosce, wywołanego drganiami wiązadeł głosowych w trakcie jej artykulacji; w oparciu o tę cechę wyróżnia się spółgłoski:

- dźwięczne: /b/,/d/,/g/,/gu/,/m/,/n/,/r/, /l/, /ux/, /in/

- bezdźwięczne: $/ \mathrm{p} /, / \mathrm{t} /, / \mathrm{k} /, / \mathrm{k} /, / \mathrm{f} /, / \mathrm{s} /, / \mathrm{h} /$

2. miejsce artykulacji, czyli obszar maksymalnego zbliżenia (zwężenia lub zwarcia) narządów mowy w obrębie kanału głosowego w trakcie artykulacji głoski; w oparciu o tę cechę wyróżnia się spółgłoski:

- dwuwargowe (bilabialne): /p/,/b/, /m/, /un/

- wargowo-zębową (labiodentalną): /f/

$\rightarrow$ przedniojęzykowe zębowe (dentalne): /t/,/d/,/n/

$\rightarrow$ przedniojęzykowe dziąsłowe (alweolarne):/r/, /l/, /s/

- środkowojęzykową podniebienną (palatalną): /i /

$\rightarrow$ tylnojęzykowe (welarne): / / /, /g/

- tylnojęzykowe labialne (labiowelarne): / $\mathrm{k}^{\mathrm{u}} / \mathrm{/g} /$

- krtaniową (glottalną): /h/

3. sposób wykonywania ruchów artykulacyjnych, czyli sposób wytwarzania (źródło) dźwięku spółgłoski; w oparciu o tę cechę wyróżnia się:

$\rightarrow$ obstruenty zwarte: /p/,/b/,/t/,/d/,/k/,/g/,/ku/,/gu/

$\rightarrow$ obstruenty szczelinowe (spiranty): /f/, /s/, /h/

- półotwarte nosowe: $/ \mathrm{m} /, / \mathrm{n} /$

- półotwartą boczną: /l/

$\rightarrow$ półotwartą drżącą: /r/

$\rightarrow$ glajdy:/un/, /i / $/$.

Obstruenty to spółgłoski, które artykułowane są przy najmniejszym stopniu otwarcia narządów mowy. Obstruenty zwarte (mutae), zwane też zwarto-wybuchowymi, cechują się wystąpieniem momentu całkowitej blokady przepływu powietrza przez kanał głosowy wskutek pełnego zwarcia narządów mowy w określonym miej- 
scu jamy gardłowo-ustnej, a następnie gwałtownym uwolnieniem powietrza stłoczonego za tak powstałą przegrodą, będącym efektem następującego później nagłego rozwarcia narządów mowy. $Z$ kolei obstruenty szczelinowe, inaczej spiranty, artykułowane są bez zwarcia, ale przy znacznym zbliżeniu narządów mowy; w miejscu artykulacji tworzą one wąską szczelinę, a przepływający przez nią strumień powietrza daje efekt charakterystycznego dla tych spółgłosek szumu.

Spółgłoski półotwarte, zwane też sonorantami lub spółgłoskami sonornymi, cechują się artykulacją dźwięczną, realizowaną ze zwarciem narządów mowy w jednym miejscu i równoczesnym ich rozwarciem w innym, wskutek czego nie następuje blokada przepływu strumienia powietrza przez kanał głosowy. Półotwarte nosowe charakteryzują się swobodnym przepływem powietrza przez otwartą jamę nosową przy jednoczesnym zwarciu dwuwargowym $(/ \mathrm{m} /)$ lub przedniojęzykowo-zębowym $(/ \mathrm{n} /)$ w jamie ustnej. Półotwarta boczna (lateralna) /l/ artykułowana jest ze zwarciem przedniej części języka z dziąsłami (lub górnymi zębami) i z równoczesnym obniżeniem środkowej części języka, dzięki czemu powietrze swobodnie przepływa przy jego bocznych krawędziach i wydostaje się na zewnątrz przez usta. Artykulacja spółgłoski półotwartej drżącej (wibracyjnej) /r/ polega na wprawieniu w drgania czubka języka stykającego się z dziąsłami; wskutek następujących szybko po sobie naprzemiennych faz styku i rozwarcia strumień tłoczonego z płuc powietrza, wywołujący drgania języka, uchodzi swobodnie (w fazach rozwarcia) przez jamę ustną. Półotwarta boczna i drżąca, a więc $/ \mathrm{l} / \mathrm{i} / \mathrm{r} /$, w opozycji do nosowych, czyli $/ \mathrm{m} / \mathrm{i} / \mathrm{n} /$, zwane są spółgłoskami płynnymi (liquidae).

Glajdy, czyli /un/ [1] oraz /i/ [j], to spółgłoski, których cechy artykulacyjne i akustyczne są charakterystyczne dla samogłosek (tj. /u/ oraz /i/), jednak nie pełnią one funkcji zgłoskotwórczej; z tego względu klasyfikowane też są jako spółgłoskowe warianty sonantów, czyli fonemów łączących funkcjonalne właściwości samogłosek i spółgłosek. Cechuje je artykulacja dźwięczna i względnie swobodny przepływ strumienia powietrza przez kanał głosowy, jednak stopień zwężenia narządów mowy jest nieco większy niż przy artykulacji samogłoskowej. Ponadto w porównaniu z samogłoskami wykazują mniejszą intensywność dźwięku i krótszy czas jego trwania. Niekiedy zwane są głoskami ześlizgowymi lub półsamogłoskami.

Uwzględniając wyżej wskazane cechy dystynktywne, laciński system spółgłoskowy można przedstawić za pomocą następującej tabeli: 


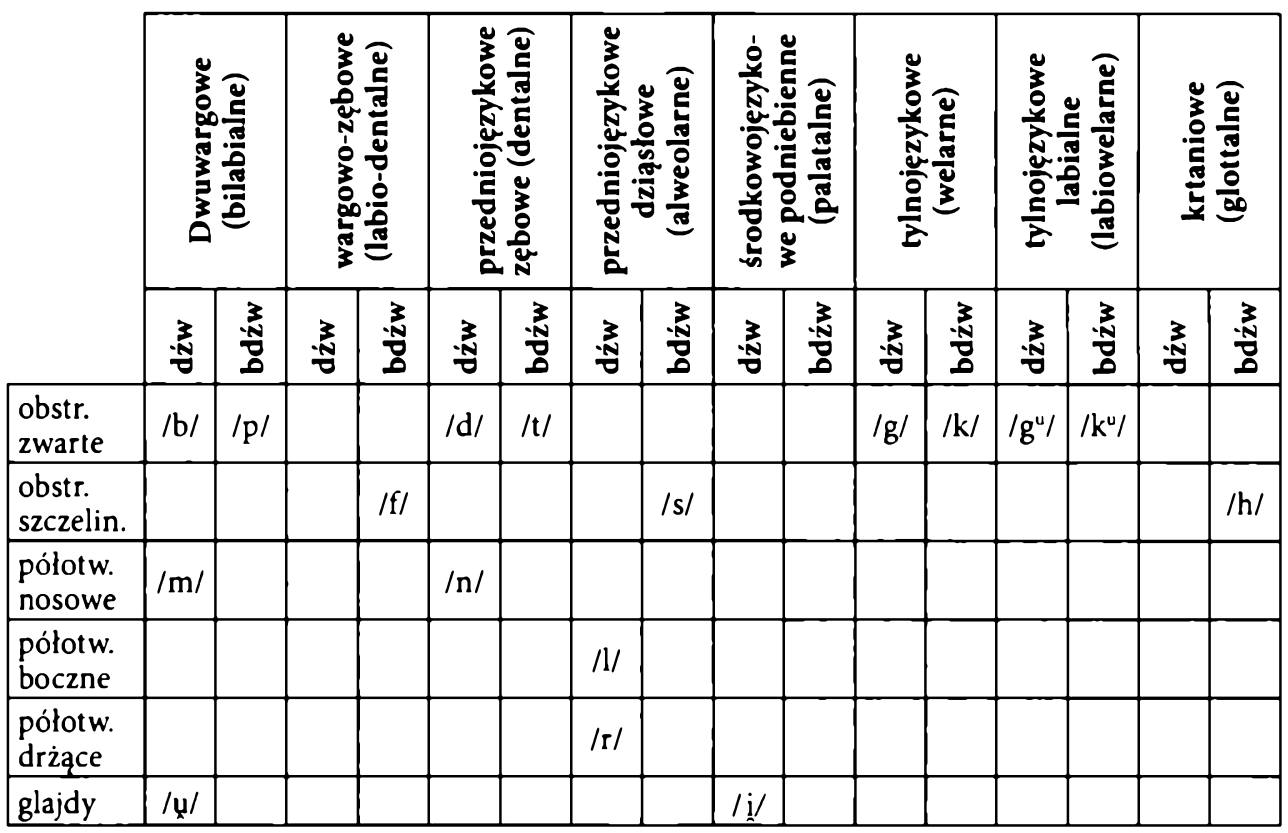

Czwartą cechą dystynktywną łacińskiego systemu konsonantycznego jest iloczas, czyli czas trwania artykulacji głoski; w oparciu o tę cechę wyróżnia się spółgłoski krótkie i długie. Tradycyjnie mówi się tu o spółgłoskach pojedynczych i podwojonych (geminatach); faktycznie jednak, w przypadku tzw. "geminat", mamy do czynienia z jednym tylko zwarciem (zwężeniem) narządów mowy i jednym rozwarciem, czyli nie mamy do czynienia z powtarzaniem danej spółgłoski, lecz z przedłużeniem czasu artykulacji $w$ fazie zwarcia lub zwężenia narządów artykulacyjnych (tj. $w$ fazie tzw. napięcia mięśniowego). Długie spółgłoski posiada również np. język włoski, $\mathrm{z}$ których część odziedziczył bezpośrednio z łaciny, np.: carro $(\leftarrow$ łac. carrum), anno $(\leftarrow$ łac. annum), a inne są wynikiem rozwoju fonetycznego tego języka, np. cattivo $(\leftarrow$ lac. captivum).

Dystynktywności tej cechy w łacinie dowodzi istnienie takich minimalnych par wyrazowych, jak np.:

- sumus 'jesteśmy' : summus 'najwyższy'

- anus 'staruszka' : annus 'rok'

- carus 'drogi' : carrus 'wóz'

- colis 'troszczysz się' : collis 'wzgórze'

- ager 'pole' : agger 'wał'

- operiri 'być przykrytym' : opperiri 'oczekiwać'

- adit 'podchodzi' : addit 'dodaje.'

W bezpośredniej opozycji fonologicznej co do cechy iloczasu pozostawały względem siebie wszystkie spółgłoski $\mathbf{z}$ wyjątkiem /ú /, /h/ i labiowelarnych, przy czym niektóre długie występowały tylko na granicy międzymorfemowej (np. affero $\leftarrow$ ad-fero). 
Opozycja iloczasu spółgłosek ulegała neutralizacji w nagłosie i wygłosie wyrazowym (czyli na początku i na końcu wyrazu), gdzie występowały tylko krótkie (por. mellis, melle ale mel) ${ }^{2}$. Dystrybucja długich spółgłosek była ponadto ograniczona do pozycji interwokalicznej, z wyjątkiem zwartych i /ff/, które mogły pojawić się także przed płynnymi (opprimo, agglutino, affrango, affligo), oraz /ss/, które mogło wystąpić również przed glajdem /ú / (assuesco).

Pisownia podwójnych liter na oznaczenie długich spółgłosek, a więc pisownia typu fuisse, annus, terra itp., została zapoczątkowana po koniec III w. przed Chr., jednak stała się normą dopiero ok. roku 100 przed Chr. Jeszcze w inskrypcji z roku 186 przed Chr. (Senatus Consultum de Bacchanalibus) spotykamy pisownię ESENT (klas. essent), HABUISE (klas. habuisse) itp. Podobnie we wcześniejszych inskrypcjach do zapisu długich spółgłosek stosowana jest powszechnie pisownia pojedynczych liter, np. ILE (klas. ille 'ów'). W epoce augustowskiej próbowano (bez większego powodzenia) wprowadzić specjalny znak nad literą, tzw. sicilicum, dla oznaczenia długości notowanej nią spółgłoski, np. OŚA (klas. ossa 'kości').

Trzeba też pamiętać, że długa spółgłoska, będąca wynikiem zmian asymilacyjnych zachodzących na granicy między przedrostkiem a rdzeniem wyrazu, mogła być również zapisywana w sposób odzwierciedlający morfologiczną odrębność prefiksu, a więc za pośrednictwem tzw. grafii morfofonemicznej (analogicznej), jak np.: obfero [offero], subministro [sumministro], adsequor [assek ${ }^{u}$ or], adgredior [aggredior] itp. Za tym, że zapis taki rzeczywiście mógł notować długie spółgłoski, które pojawiały się w tych miejscach zwłaszcza w potocznej wymowie ludzi mniej wykształconych, przemawia uformowanie się równoległego, wariantywnego zapisu typu: offero, sumministro, assequor itp. Nie bez znaczenia w tym względzie są także świadectwa gramatyków ${ }^{3}$. Pozostaje kwestią otwartą, czy, a jeśli tak, to do jakiego stopnia tej asymilacyjnej tendencji opierała się wymowa ludzi wykształconych ${ }^{4}$.

' Najdłużej zachowało się w wygłosie wyrazowym długie / kk/ w wyrazie hoc, który w epoce klasycznej zapisywany był $z$ użyciem jednej litery $c$, ale w wierszu, także przed samogloskowym nagłosem kolejnego wyrazu, zajmował pozycję przeznaczoną dla długiej (ciężkiej) sylaby (zob. niżej), chociaż zawierał krótką samogłoskę; por. np. Hor., Serm. I, 2, 54: hoc amat et laudat: 'matronam nullam ego tango'.

'Np. Long., Orthogr. 62, 4-9: siquis in his quaerat vocibus, quae incipiunt a littera t, merito indifferenter scribuntur attinet attentus et adtinet adtentus, quoniam utralibet littera scripta eundem auribus sonum reddunt; nec minus ea quae a g littera incipiunt variant huius praepositionis [i.e. ad-] enuntiationem, nam interdum elisa d littera g geminatur, ut aggerat. Nieco dalej (ibid. 16-18) gramatyk czyni jednak następujące zastrzeżenie co do sekwencji -dl-: est etiam ubi transeat $d$ in $l$, si ab hac eadem littera vox sequens incipiat, ut est alligere, nec semper tamen, quoniam dicimus adluere et adloqui et adlabi.

$\checkmark$ Jeżeli przyjmiemy, że utrzymywanie się standardu grafii analogicznej może świadczyć o zachowaniu w tym kręgu użytkowników łaciny odrębności artykulacyjnej obu fonemów na granicy morfemów, to prawdopodobne wydaje się jednak częściowe oddziaływanie asymilacyjne, sprowadzające się do ubezdźwięcznienia zwartych /b/ i /d/ przed bezdźwięcznymi (obfero [opfero], adpono [atpono] itd.). 
Szczególną pozycję $\mathrm{w}$ łacińskim podsystemie konsonantycznym zajmuje spirant $/ \mathrm{h} /$, który cechował się bardzo słabą artykulacją, wskutek czego, już od epoki archaicznej poczynając, wykazywał silną tendencję do redukcji i zaniku, a w okresie klasycznym i późniejszym praktycznie przestał być wymawiany w potocznym języku mówionym. W języku kulturalnym był sztucznie podtrzymywany w wymowie (głównie $w$ nagłosie wyrazowym) i piśmie, jednak jego słaba, marginalna pozycja w ramach systemu sprawiła, że jako element sylaby nie wykazywał cech charakterystycznych dla statusu autonomicznej łacińskiej spółgłoski (zob. niżej). 


\section{3. \\ Łaciński wokalizm}

Cechami dystynktywnymi łacińskiego systemu wokalicznego (samogłoskowego) są:

1. miejsce artykulacji; w oparciu o tę cechę wyróżnia się samogłoski:

$\rightarrow$ przednie: /i/, /ì/, /e/, /ē/

$\rightarrow$ środkowe: $/ \mathrm{a} /, / \bar{a} /$

$\rightarrow$ tylne: $/ \mathrm{u} /, / \overline{\mathrm{u}} /, / \mathrm{o} /, / \bar{o} /$

2. apertura, czyli stopień rozwarcia narządów mowy (położenie żuchwy i masy języka $w$ stosunku do podniebienia, tj. ich uniesienie lub opuszczenie $w$ trakcie artykulacji, współdecydujące wraz z miejscem artykulacji o barwie samogłoski); w oparciu o tę cechę wyróżnia się samogłoski:

- wysokie (wąskie, przymknięte): /i/, /ì/,/u/, /ū/

- średnie: /e/, /ē/, /o/, /ō/

- niskie (szerokie, otwarte): /a/, /ā/

3. iloczas, czyli czas trwania wokalizacji (artykulacji) samogłoski; w oparciu o tę cechę wyodrębnia się samogłoski:

$\rightarrow$ długie: /ì/, /èl, /àl, /ü/, /ō/

- krótkie: /i/, /e/, /a/, /u/, /o/

Łaciński system samogłoskowy można zatem zobrazować następującą tabelą:

\begin{tabular}{|l|c|c|c|c|c|c|}
\cline { 2 - 7 } \multicolumn{1}{c|}{} & \multicolumn{2}{c|}{ przednie } & \multicolumn{2}{c|}{ środkowe } & \multicolumn{2}{c|}{ tylne } \\
\cline { 2 - 7 } \multicolumn{1}{c|}{} & krótkie & dlugie & krótkie & długie & krótkie & dlugie \\
\hline wysokie & $/ \mathrm{i} /$ & $/ \mathrm{i} /$ & & & $/ \mathrm{u} /$ & $/ \mathrm{u} /$ \\
\hline średnie & $/ \mathrm{e} /$ & $/ \overline{\mathrm{e}} /$ & & & $/ \mathrm{o} /$ & $/ \overline{\mathrm{o}} /$ \\
\hline niskie & & & $/ \mathrm{a} /$ & $/ \bar{a} /$ & & \\
\hline
\end{tabular}

Dystrybucja ww. samogłosek w obrębie wyrazu nie była ograniczona: każda z nich mogła wystąpić zarówno w nagłosie, jak i w śródgłosie oraz wygłosie wyrazu.

W ograniczonym zakresie system ten uzupełniały samogłoski nazalizowane (nosowe), które były mniej stabilnymi jego elementami. Ich obecność w systemie była wynikiem oddziaływania tendencji do nazalizacji samogłosek, która zaznaczyła się w dwóch kontekstach fonologicznych. Jednym $z$ nich była pozycja przed sekwencją 
/n/ + szczelinowa /s/ lub /f/; w tym kontekście /n/ zanikało, pozostawiając refleks w postaci nazalizacji i (kompensacyjnego) wzdłużenia poprzedzającej samogłoski, jak np. w wyrazach: mensis [mẽ:sis], confero [kō:ferō], inferus [ï:ferus]. Drugim kontekstem było położenie przed wygłosowym (= końcowym)/-m/, które także zanikało (lub osłabiało się), nazalizując poprzedzającą samogłoskę, najprawdopodobniej bez jej wzdłużania, jak np. w wyrazach: dominam [dominā], dominum [dominū], florem [florẽ], olim [olī]. Nazalizacja samogłosek we wskazanych wyżej kontekstach pojawiła się już w okresie archaicznym, jednak później w języku potocznym zaczęła zanikać, natomiast w języku kulturalnym, pod wpływem nauczania szkolnego, być może pojawiła się tendencja do pełniejszej artykulacji spółgłosek nosowych, tj. /n/ i /m/. Prawdopodobnie jednak artykulacja taka, przynajmniej w odniesieniu do wygłosowego /-m/, nie stała się powszechnie praktykowaną normą, na co zdaje się wskazywać status wygłosowych -am, -um, -em w poezji, identyczny ze statusem wygłosu samogłoskowego, podlegającego elizji przed samogłoskowym nagłosem kolejnego wyrazus

Samogłoski wysokie, czyli /i/ oraz/u/, stanowią samogłoskowe warianty sonantów, których spółgłoskowymi realizacjami są glajdy /i / oraz /ụ/.

Samogłoski krótkie (z wyjątkiem /a/) cechowały się artykulacją bardziej otwartą niż ich odpowiedniki długie, które były bardziej przymknięte. Różnica stopnia otwartości (apertury) samogłosek o tej samej barwie, towarzysząca ich podstawowej opozycji iloczasowej (długa/krótka), nie miała jednak charakteru autonomicznej cechy dystynktywnej, gdyż np. obok /o/ krótkiego i bardziej otwartego niż /ō/ długie nie istniało w systemie /o/ krótkie i zarazem (tak samo jak /ō/) przymknięte, a obok /ō/ długiego i przymkniętego nie istniało /ō/ długie i bardziej otwarte. Różnica ta była zatem właściwością subfonologiczną (nadwyżkową, nierelewantną), skorelowaną z cechą dystynktywną iloczasu. Jednak w okresie późnej starożytności, po zaniku iloczasu jako cechy dystynktywnej łacińskich samogłosek, różnica ta odegrała fundamentalną rolę w procesie kształtowania się systemów wokalicznych języków romańskich.

Taki sam status cechy subfonologicznej miała różnica skorelowana z cechą miejsca artykulacji, polegająca na labializacji (zaokrągleniu) samogłosek tylnych /u/, /ü/, /o/, /o/, w przeciwieństwie do samogłosek przednich, które nie wykazywały zaokrąglenia. Labializacja polega na wysunięciu wprzód i zaokrągleniu warg w trakcie artykulacji głoski (jak np. przy wymawianiu /ü/ w niem. über czy Glück).

W starożytności nie ustaliła się żadna konwencja ortograficzna odróżniania w pisowni samogłosek nazalizowanych od nienazalizowanych. Podobnie nie wytworzono żadnej konwencji rozróżniania samogłosek długich i krótkich, chociaż w tym zakresie usiłowano wprowadzić pewne normy. Np. Akcjusz dla zapisu długich samogłosek postulowal stosowanie podwojonych liter, np. PAASTORES, LEEGE itp. ${ }^{6}$, przy czym

' Więcej na ten temat zob. niżej w uwagach szczegółowych dotyczących spółgłosek półotwartych nosowych.

' Por. Scaur., Orthogr. 18, 12-13: Accius geminatis vocalibus scribi natura longas syllabas voluit. Inskrypcyjne poświadczenia ortografii tego rodzaju pochodzą głównie z lat 135-75 przed Chr.; dłużej notowano w ten sposób długie /ū/, zwłaszcza w formach fleksyjnych rzeczowników IV deklinacji, np. EXERCITVVS. 
w związku z tym, że ok. połowy II w. przed Chr. dawny dyftong / $e^{i} /$, zapisywany dygrafem EI/ei, zmonoftongizował się do pojedynczej długiej samogłoski /i/, dla jej notacji Akcjusz proponował wprowadzenie "historycznej" ortografii, a więc pisownię typu TERENTEINVS ${ }^{7}$. Z kolei z początkiem I w. przed Chr. dla zapisu długiego /i/ pojawia się konwencja stosowania tzw. I longa, czyli znaku litery I wyższego od pozostałych liter, np. CIVES ROMANI. Wreszcie pod koniec okresu republikańskiego litery notujące długie samogłoski zaczęto opatrywać tzw. apeksem, przypominającym znak akutu, np. PRIVATÁ IMPENSÁ COMPARÁVI. Ostatecznie jednak żadna $\mathrm{z}$ tych propozycji nie przyjęła się w sposób powszechny ${ }^{8}$. Również współcześnie w zapisie łacińskich wyrazów i tekstów na ogół nie odróżnia się ortograficznie samogłosek długich od krótkich; gdy jednak z jakichś względów zachodzi taka potrzeba, dla oznaczenia długości samogłoski stosuje się diakryt w postaci poziomej kreski nad literą, np. /ā/, lub znak dwukropka stawiany po literze, np. /a:/.

Należy jednak zaznaczyć, że mimo wspomnianego braku stałej normy stosowane okazjonalnie przez Rzymian wyróżniki ortograficzne stanowią dla nas jedno $\mathrm{z}$ istotnych źródeł informacji o iloczasie samogłosek w poszczególnych łacińskich wyrazach i formach wyrazowych. Wiedzę na ten temat czerpiemy także ze sposobu użycia poszczególnych wyrazów w poezji łacińskiej, ze stwierdzeń zawartych w pismach gramatyków rzymskich i innych dziełach literackich, z greckich transkrypcji łacińskich wyrazów, jak również z ustaleń gramatyki historycznej, dotyczących indoeuropejskiego pochodzenia łacińskich fonemów, ich tendencji rozwojowych w toku ewolucji języka, a także ich kontynuantów w językach romańskich. I właśnie dzięki ustaleniom poczynionym na gruncie gramatyki historycznej wiemy także, że określone procesy zmian, które nastąpiły w toku ewolucji łaciny, zdeterminowały wartość iloczasu samogłosek w określonych kontekstach fonologicznych, wskutek czego w łacinie klasycznej krótki iloczas wykazują samogłoski:

1. zajmujące $\mathbf{w}$ wyrazie pozycję przed inną samogłoską, np. w: habeo (wobec habère), audio (wobec audire) ${ }^{10}$;

2. znajdujące się $\mathbf{w}$ ostatniej sylabie wyrazu kończącego się pojedynczą spółgłoską inną niż/-s/, np.: laudat (wobec laudās, laudāre), amor (wobec amōris)"

Por. Marius Victorinus, Ars grammatica 1,4 (GL VI, 8, 11-14): Accius [...] cum longa syllaba scribenda esset, duas vocales ponebat, praeterquam quae in ' $i$ ' litteram incideret: hanc per ' $e$ ' et 'i' scribebat. Dodajmy, że podejmowane też były próby wprowadzenia podobnej „historycznej” ortografii dla zapisu długiego / $\overline{\mathrm{u}} / \mathrm{w} z$ wiązku z wcześniejszą monoftongizacją dyftongu /ou/ $\rightarrow / \overline{\mathrm{u}} /$, a więc wprowadzenia pisowni typu COVRAVERVNT.

* Więcej szczegółów na temat (ewolucji) ortografii łacińskiej zob. Strzelecki (1947).

y Znane nam schematy metryczne łacińskiej poezji składały się z sekwencji pozycji przeznaczonych dla sylab o odpowiednim (krótkim lub długim) iloczasie, który w określonych sytuacjach (tj. w przypadku sylab otwartych) determinowany był właśnie iloczasem samogłosek stanowiących ich ośrodki (zob. niżej).

1" Zasada ta ujmowana bywa w lacińską formułę: vocalis ante vocalem brevis est (corripitur).

"Samogłoski znajdujące się przed końcowym /-s/ mogą mieć iloczas zarówno krótki (np.: hortus, legis), jak i długi (np.: hortōs, legēs); podobnie niezdeterminowany jest iloczas samogłosek, po których nie występuje już żadna spółgłoska: por. np.: tabula (nom. sg.), tabulä (abl. sg.). 
Dodajmy, że dystynktywności cechy iloczasu łacińskich samogłosek dowodzi m.in. istnienie takich minimalnych par wyrazowych jak, np.:

- latus 'bok' : lātus 'szeroki'

$\rightarrow$ levis 'lekki' : lèvis 'gładki'

- liber 'książka' : liber 'wolny'

- uti 'aby': ùti 'używać'

$\rightarrow$ populus 'lud' : pōpulus 'topola'.

Tradycyjnie wśród elementów współtworzących łaciński system wokaliczny wymienia się także dyftongi: $/ \mathrm{a}^{\mathrm{i} /}, / \mathrm{a}^{\psi} /, / \mathrm{o}^{\mathrm{i}} /, / \mathrm{o}^{\psi} /, / \mathrm{e}^{\mathrm{i} /}$ oraz $/ \mathrm{e}^{\mathrm{\psi}} /$. Fonologiczny (strukturalny) status tych elementów jest jednak dyskusyjny, tzn. wątpliwości budzi to, czy stanowią one pojedyncze fonemy (a więc właściwe, fonologiczne dyftongi), czy też raczej należy je uznać za struktury bifonematyczne, złożone $z$ samogłoski i spółgłoskowego glajdu. Zagadnienie to, pozostające w związku ze strukturą łacińskiej sylaby, omówione zostanie nieco szerzej $\mathrm{w}$ dalszej części ( $\mathrm{tj}$. w uwagach szczegółowych nt. łacińskiego konsonantyzmu i wokalizmu - zob. niżej). W tym miejscu zaznaczymy jedynie, że fonemy (lub struktury) te wraz $z$ upływem czasu podlegały rozmaitym indywidualnym zmianom, $w$ związku $z$ czym sposób ich obecności $w$ lacinie jest zróżnicowany i zdeterminowany diachronicznie. 


\section{4. \\ Sylaba}

\subsection{STRUKTURA SYLABY}

Podstawową strukturą płaszczyzny fonologicznej, złożoną z fonemów, jest sylaba (zgłoska). Sylaba to odcinek ciągu fonicznego stanowiący jedność akustyczną, który potencjalnie może być samodzielną fonetycznie wypowiedzią. Konstytutywnym (obligatoryjnym) składnikiem sylaby jest element (fonem) cechujący się dźwięcznością i względnie dużą otwartością artykulacyjną, pozwalającą na realizowanie cech prozodycznych, tj. iloczasu, akcentu i intonacji. Element ten, zwany zgłoskotwórczym, tworzy ośrodek (szczyt) sylaby. Składnikami fakultatywnymi sylaby są elementy artykulacyjnie węższe, które tworzą marginalia (stoki) sylaby. Elementem zgłoskotwórczym jest najczęściej samogłoska lub dyftong (V - 'vocalis'), natomiast marginalia sylaby tworzą spółgłoski lub grupy spółgłosek (C - 'consonantes'), które zajmują pozycję nagłosu i wygłosu sylaby. Dodajmy, że terminem „nagłos” generalnie określa się początek (początkową część) jakiejkolwiek struktury realizowanej jako ciąg fonologiczny (a więc np. początek sylaby, morfemu, wyrazu), terminem "wygłos" koniec (końcową część) tej struktury, a terminem „śródgłos” jej część środkową, znajdującą się między nagłosem a wygłosem. Nagłosowa spółgłoska sylaby (lub nagłosowa grupa spółgłosek) to tzw. następ, zaś wygłosowa spółgłoska (lub grupa spółgłosek) to tzw. zestęp sylaby. Status spółgłoskowego nagłosu i spółgłoskowego wygłosu sylaby nie jest jednakowy: nagłos ma pozycję mocniejszą a wygłos słabszą. Przejawia się to $\mathrm{w}$ tym, że nagłosowe spółgłoski fonetycznie cechują się większą intensywnością (donośnością) niż wygłosowe, które przez to są mniej stabilne i bardziej podatne na procesy fonologicznych zmian, takich jak np. asymilacja, osłabienie (lenicja) czy zanik. Konsekwencją tego jest obserwowalna historycznie tendencja do redukcji (eliminacji) spółgłosek wygłosowych sylaby ${ }^{12}$. W niektórych opracowaniach opisuje się w związku z tym sylabę jako strukturę dwudzielną, która składa się z następu oraz rymu obejmującego ośrodek i zestęp.

12 Por. np.: lac. arch. *isdem $\rightarrow$ klas. idem, arch. * sedparo $\rightarrow$ klas. separo. Więcej na temat realizacji tej tendencji w lacinie zob. Porzio Gernia (1976). 
Sylaba o strukturze V lub CV, czyli sylaba pozbawiona spółgłoskowego wygłosu (zakończona wygłosowym elementem wokalicznym), nazywana jest otwartą, zaś sylaba o strukturze VC lub CVC, czyli zakończona na spółgłoskę lub grupę spółgłosek, jest sylabą zamkniętą.

\subsection{GRANICE SYLAB}

W różnych językach koniec wygłosu jednej sylaby i początek nagłosu kolejnej, czyli granica między sąsiadującymi sylabami w obrębie wyrazu ${ }^{13}$, może przebiegać w różnych miejscach, w zależności od cech systemu fonologicznego danego języka, a zwłaszcza w zależności od jego cech fonotaktycznych, czyli reguł dystrybucji fonemów w obrębie złożonych $\mathrm{z}$ nich struktur ${ }^{14}$. Generalnie granice sylab determinowane są przez dwie podstawowe zasady mówiące, iż:

1. strukturalne właściwości nagłosu i wygłosu wyrazowego, czyli typologia i kolejność występowania fonemów mogących pojawić się po pauzie wyrazowej i przed nią, determinują strukturalne właściwości nagłosu i wygłosu sylabicznego wewnątrz wyrazu ${ }^{15}$.

2. $\quad$ uwagi na właściwości fonetyczne sylaby (mocniejsza pozycja nagłosu, słabsza wygłosu), skutkujące historyczną tendencją do redukowania sylab zamkniętych $^{16}$, podział wyrazu na sylaby uwzględnia postulat maksymalizacji liczby sylab otwartych.

\subsection{CECHY PROZODYCZNE}

Sylaba jest podstawą realizacji cech prozodycznych języka, takich jak iloczas, akcent i intonacja, czyli cech fonicznych o charakterze ponadsegmentalnym, będących atrybutami nie pojedynczych fonemów, lecz większych struktur (odcinków wypowiedzi) z nich złożonych. Cechy te zwane też są prozodemami lub fonemami suprasegmentalnymi. W różnych językach poszczególne cechy prozodyczne mają różny status: mogą być cechami fonicznymi relewantnymi (fonologicznymi), tzn. pełniącymi istotne

13 Dodajmy, że ilokroć mówimy w tym rozdziale o wyrazie, mamy na myśli tzw. wyraz fonologiczny, który może być (i najczęściej jest) tożsamy z tekstową reprezentacją określonej jednostki leksykalnej (słownikowej), ale może też być strukturą poszerzoną o enklityki lub proklityki.

it Czyli wzajemnej lączliwości fonemów w ramach tych struktur i ograniczeń w tym względzie.

15 Tzn. fonemy (samogłoski, spółgłoski lub kombinacje spółglosek) określonej klasy, które mogą wystąpić $w$ nagłosie wyrazowym (czyli po pauzie), mogą również tworzyć nagłos sylaby (wewnątrz wyrazu), zaś fonemy, które mogą wystąpić w wygłosie wyrazowym (czyli przed pauzą), mogą również stanowić wygłos sylaby (wewnątrz wyrazu).

is Tendencją zgodną z podstawową zasadą regulującą zachowanie językowe, tj. zasadą ekonomizacji (minimalizacji) wysiłku: wyraz o strukturze sylabicznej $C V+C V+C V \ldots z$ pewnością wymaga mniejszego wysilku artykulacyjnego niż wyraz o strukturze CVC + CVC + CVC... 
funkcje komunikacyjne, takie jak funkcja dystynktywna (różnicowanie znaków) lub delimitacyjna (sygnalizowanie granic między wyrazami czy morfemami), albo mogą być cechami nierelewantnymi (niefonologicznymi), czyli niepełniącymi istotnych komunikacyjnie funkcji. W zależności od rangi, jaką mają cechy prozodyczne w systemie fonologicznym języka, charakteryzuje się stopień prozodyczności poszczególnych języków, określając je np. jako skrajnie prozodyczne lub skrajnie nieprozodyczne, umiarkowanie prozodyczne (jak np. klasyczna łacina ${ }^{17}$ ) lub umiarkowanie nieprozodyczne (jak np. język polski ${ }^{18}$ ). Same zaś cechy prozodyczne (prozodemy) mają charakter międzysylabowy (intersylabiczny) i/lub wewnątrzsylabowy (intrasylabiczny). W pierwszym przypadku cechy prozodyczne ujawniane są poprzez kontrast zachodzący między sylabą (będącą nośnikiem określonej cechy prozodycznej) jako całością, a sylabami sąsiednimi (pozostałymi) w ramach wyrazu, w tym drugim zaś poprzez kontrast istniejący między częściami sylaby realizującej daną cechę prozodyczną.

Dodajmy, że w łacinie cechy prozodyczne, a zwłaszcza iloczas sylaby, odgrywały szczególnie istotną rolę $\mathrm{w}$ klasycznej wersyfikacji; tego rodzaju zastosowanie środków prozodycznych ma charakter wtórny, jednak $z$ uwagi na ograniczenia poznawcze wynikające ze statusu łaciny jako języka martwego stanowi ono dla nas istotne źródło informacji na temat łacińskiej prozodii.

Iloczas sylaby to cecha foniczna opierająca się na opozycji: sylaba krótka / sylaba długa. Podstawą opozycji jest czas trwania artykulacji sylaby. W językach, w których iloczas sylab jest prozodyczną cechą fonologicznie relewantną, może on - np. determinując intonację czy miejsce padania lub charakter akcentu wyrazowego - uczestniczyć $\mathrm{w}$ pełnieniu funkcji dystynktywnej lub delimitacyjnej. Jeśli najmniejszym (niepodzielnym) nośnikiem cech prozodycznych jest sylaba jako całość, mówimy o tzw. językach sylabicznych, w których iloczas sylaby jest zawsze tożsamy $z$ iloczasem jej wokalicznego ośrodka. Jeżeli natomiast nośnikiem cech prozodycznych jest część sylaby długiej, odpowiadająca iloczasowi sylaby krótkiej, czyli tzw. mora, mówimy o językach morowych. W językach morowych jedna część sylaby długiej (jedna mora) może być nośnikiem intonacji wznoszącej, druga opadającej, jak np. przy akcentuacji cyrkumfleksowej w klasycznej grece, albo też nośnikiem wartości iloczasu sylaby może być zarówno część sylaby stanowiąca jej samogłoskowy ośrodek, jak i część stanowiąca spółgłoskowy zestęp, jak np. w klasycznej łacinie. Iloczas może mieć charakter międzysylabiczny, realizując się poprzez opozycję między sylabami krótkimi i długimi, lub wewnątrzsylabowy, ujawniając się np. poprzez kontrast między czasem trwania artykulacji samogłoskowego ośrodka i spółgłoskowego wygłosu sylaby. Dodajmy, że od iloczasu sylaby, będącego cechą prozodyczną, należy odróżnić iloczas samogłosek i spółgłosek, będący cechą dystynktywną fonemów.

Akcent to cecha foniczna sylaby, opierająca się na opozycji: sylaba akcentowana / sylaba nieakcentowana. Ulokowanie (miejsce padania) akcentu w obrębie wyrazów

17 W lacinie fonologiczny charakter ma iloczas, determinujący miejsce padania akcentu, oraz akcent, pełniący funkcję delimitacyjną - zob. niżej.

is W języku polskim fonologiczny charakter ma jedynie akcent pełniący funkcję delimitacyjną. 
danego języka może być stałe (zdeterminowane) w stosunku do granicy wyrazu lub swobodne (niezdeterminowane). W pierwszym przypadku akcent pełni funkcję delimitacyjną, polegającą na sygnalizowaniu granic (czyli początku lub końca) wyrazów; por. pol. kócha nadarémnie / kochána darémnie, gdzie sylaba akcentowana sygnalizuje koniec wyrazu po następującej po niej sylabie ${ }^{19}$. W przypadku akcentu swobodnego jego funkcja ogranicza się do identyfikowania liczby wyrazów w ciągu wypowiedzeniowym (tzw. funkcja kulminatywna), jednak dodatkowo może on też pełnić funkcję dystynktywną (por. ros. múka 'męka' i muká 'mąka', gr. Tó i Touós 'ucięty').

Podstawą przeciwstawienia sylaby akcentowanej sylabom niekacentowanym (czyli podstawą uwydatnienia sylaby akcentowanej) może być:

1. siła głosu, czyli wymówienie sylaby akcentowanej głośniej (z większym natężeniem dźwięku, z większą energią artykulacyjną i akustyczną); ten rodzaj akcentu to tzw. akcent dynamiczny (ekspiratoryczny), charakterystyczny m.in. dla języka polskiego;

2. ton głosu, czyli wyróżnienie sylaby akcentowanej (lub jej określonej części) wysokością dźwięku; ten rodzaj akcentu to tzw. akcent toniczny (melodyczny, muzyczny); ze względu na sposób realizowania akcentu tonicznego wyróżnić jeszcze można akcent monotoniczny, w którym sylaba akcentowana artykułowana jest jednolitym, wyższym w stosunku do pozostałych sylab tonem, oraz akcent politoniczny, cechujący się zróżnicowanymi i opozycyjnymi względem siebie przebiegami linii melodycznej sylab akcentowanych; ten ostatni typ akcentu spotykamy m.in. w starożytnej grece, gdzie - w przypadku sylab długich - akcent (= podwyższenie tonu) może padać albo na nagłos (pierwszą morę) sylaby akcentowanej, która wskutek tego w pierwszej fazie artykulacji ma intonację wznoszącą a w drugiej opadającą ${ }^{20}$, albo na wygłos (drugą morę) sylaby akcentowanej, która wskutek tego ma intonację wznoszącą w drugiej fazie artykulacji ${ }^{21}$.

Wyłącznie międzysylabiczny charakter ma zazwyczaj akcent dynamiczny, opierający się na prostej opozycji sylab akcentowanych i nieakcentowanych, natomiast akcent politoniczny, polegający na przeciwstawieniu sylabom nieakcentowanym akcentowanych sylab zróżnicowanych w nagłosie i wygłosie co do wysokości tonu, ma także charakter wewnątrzsylabowy.

Intonacja to cecha foniczna polegająca na zróżnicowaniu względnej wysokości tonu w obrębie sylaby lub wyrazu. Cecha ta może pełnić dystynktywną funkcję różnicowania wyrazów (w tzw. językach tonalnych, często spotykanych w Afryce i Azji) lub stanowić podstawę realizacji akcentu tonicznego (jak np. w języku starogreckim).

${ }_{14}$ Ten rodzaj akcentu, padającego na sylabę przedostatnią, zwany jest akcentem paroksytonicznym. Miejsce padania stalego akcentu może być jednak ulokowane również inaczej w stosunku do granic wyrazu: akcent padający na pier wszą sylabę wyrazu, jak np. w języku czeskim, zwany jest akcentem inicjalnym, padający na ostatnią, jak we francuskim, oksytonicznym, zaś padający na sylabę trzecią od końca wyrazu, jak w macedońskim, akcentem proparoksytonicznym.

2" Jest to tzw. akcent cyrkumfleksowy.

${ }_{21}$ Ten typ akcentu to tzw. akcent akutowy. 
Przebieg melodyczny (kontur intonacyjny) wyrazów może być także wskaźnikiem ich funkcji pragmatycznych, który pozwala na zidentyfikowanie wyrazów jako wypowiedzenia oznajmujące, rozkazujące, pytajne, wykrzyknieniowe itp. W zależności od sposobu realizacji intonacji może ona mieć charaker inter- lub intrasylabiczny. 


\section{5. \\ Sylaba w łacinie}

\subsection{GRANICE SYLAB: SYLABY OTWARTE I SYLABY ZAMKNIĘTE}

Reguły fonotaktyczne języka łacińskiego nie narzucają żadnych ograniczeń w zakresie samogłoskowego nagłosu i wygłosu wyrazowego, tzn. wyrazy, i tym samym sylaby, mogą zaczynać się i kończyć na każdą samogłoskę. Spółgłoskowy nagłos wyrazowy może tworzyć pojedyncza dowolna spółgłoska (z wyjątkiem / $\mathrm{g} /$ /), np.: pater, domus, quartus, facio, salus, mater, nox, rex, locus, vates, iacet, lub grupa spółgłosek o strukturze:

1. zwarta lub /f/ + płynna ${ }^{22}$, np.: tristis, clamo, brevis, gloria, frigor, flecto;

2. /s/ + zwarta bezdźwięczna lub /u/, np.: stare, species, scando, squalor, suadeo;

3. /s/ + zwarta bezdźwięczna + płynna, np.: scribo, strangulo, splendor, stlembus.

Spółgłoskowy wygłos wyrazowy może tworzyć pojedyncza spółgłoska, tj. obstruent zwarty, np.: amat, istud, illoc, szczelinowa /s/, np. animus, patres lub sonorant ${ }^{23}$, np.: solum, nomen, pater, animal, albo grupa spółgłoskowa o strukturze:

1. sonorant + bezdźwięczny obstruent, np.: amant, pars, hunc;

2. bezdźwięczna zwarta $+/ \mathrm{s} /$, np.: felix, daps;

3. $/ \mathrm{s} /+/ \mathrm{t} /$, np.: est, factust (= factum est);

4. sonorant + bezdźwięczna zwarta $+/ \mathrm{s} /$, np.: falx, urbs [urps].

Biorąc pod uwagę powyższe reguły fonotaktyczne dotyczące łacińskiego nagłosu wyrazowego oraz wspomniane wcześniej zasady podziału wyrazu na sylaby należałoby stwierdzić, iż także $w$ środgłosie wyrazu nagłos sylaby mogą tworzyć zarówno grupy spółgłoskowe o strukturze zwarta lub /f/ + płynna, jak i grupy z /s/ w pierwszej pozycji. Implikuje to sylabizację zarówno typu sa.crum, re.flec.to, jak i typu pe.stis, de.scri.bo. Jednak specyfika łacińskich cech prozodycznych (tj. iloczasu i związane-

22 Oprócz /tl-/ i /dl-/. Na temat nagłosu notowanego literami gn-, jak np. w: Gnaeus, gnosco, gnarus, gnatus, który najprawdopodobniej - poprzez stadium /nn-/ - w epoce klasyczej ulegl uproszczeniu do /n-/ (także przy zachowaniu tradycyjnej pisowni), zob. Stephens (1978), (1980).

2.3 Ewentualnie również glajd, jeśli traktujemy dyftong ae jako strukturę bifonematyczną (tj. /a/ + /i/ $/$ ), czyli jeśli przyjmiemy fonetyczny tylko, a nie fonologiczny charakter lacińskich dyftongów (zob. niżej część dot. dyftongów). 
go z nim akcentu wyrazowego - zob. niżej), których sylaba jest nośnikiem, wskazuje na możliwość tworzenia nagłosu sylabicznego jedynie przez grupę spółgłoskową o strukturze zwarta lub /f/ + płynna (czyli sa.crum, re.flec.to) ${ }^{24}$, wykluczając równocześnie możliwość nagłosu sylabicznego stanowionego przez grupę z /s/ w pierwszej pozycji ${ }^{25}$, co implikuje przebieg granicy międzysylabowej $w$ obrębie tej grupy i sylabizację typu pes.tis, des.cri.bo ${ }^{26}$.

Łacińskie reguły fonotaktyczne nie pozwalają $z$ kolei na wystąpienie $w$ nagłosie i wygłosie wyrazowym spółgłosek długich (geminat), które mogą jednak pojawić się w śródgłosie międzysamogłoskowym; por. np.: mellis, melle ale mel (a nie *mell) ${ }^{27}$. Należy w związku z tym przyjąć, że jeśli w wyrazie między samogłoskami znajduje się długa spółgłoska, granica między sylabami przebiega w środku jej artykulacji (w połowie czasu trwania fazy napięcia mięśniowego). Tym samym sylaba oddzielona od kolejnej sylaby długą spółgłoską jest sylabą zamkniętą, jak np. pierwsze sylaby w wyrazach: mellis, annus, carrus itp.

Ostatecznie więc zasady podziału łacińskiego wyrazu na sylaby ująć można w następujący sposób:

1. pojedyncza spółgłoska oddzielająca w obrębie wyrazu dwie samogłoski należy do nagłosu sylaby następującej; tym samym sylaba poprzedzająca jest wtedy sylabą otwartą, np.: le.ge.re, ta.bu.la, ma.re, ca.ve.re;

24 Chodzi o to, że tylko przed grupą o tej strukturze przedostatnia sylaba zawierająca krótką samogłoskę zachowuje krótki iloczas i nie jest w związku z tym akcentowana, jak np. w vólucres, péragro; akcent w tych wyrazach pada na trzecią sylabę od końca, co implikuje sylabizację vo.lu. cres, pe.ra.gro (zob. niżej). O tworzeniu nagłosu sylabicznego przez grupę: /f/ + płynna, czyli o sylabizacji typu: re.flec.to, świadczy sposób użycia wyrazów zawierających tę grupę w klasycznej poezji: jeśli sylaba poprzedzajaca tę grupę zawiera krótką samogłoskę, zajmuje w wierszu pozycje przeznaczoną dla krótkiej sylaby; por. np. Verg., Aen. 11, 622: clamorem tollunt et mollia colla reflectunt.

25 Wskazuje na to sposób akcentowania wyrazów typu agréstis, w których przedostatnia sylaba, chociaż zawiera krótką samogłoskę, jest akcentowana, co świadczy o jej długim iloczasie i implikuje sylabizację a.gres.tis (a nie a.gre.stis). Również w poezji przedostatnia sylaba wyrazów typu agrestis zajmuje pozycje przeznaczone w schematach metrycznych dla sylab długich; zob. np. Verg., Aen. 3, 34; 5, 40; 7, 111. Na wyjątkowy status/s/ w ramach grup spółgłoskowych zwraca uwagę m.in. Pulgram (1974: 80-81), podkreślając tendencję niektórych języków do eliminacji tego fonemu z pozycji pierwszego elementu nagłosowej grupy spółgłoskowej wyrazu (spica $\rightarrow$ espica $\rightarrow$ hiszp. espiga (sylabizacja: es.pi.ga)); możemy dodać, że od II-III w. po Chr. pojawiają się łacińskie inkskrypcyjne warianty graficzne typu iscola $(=s c(h)$ ola), espiritum (= spiritum), ispatha (= spatha). Z kolei Cser (1999) postuluje, by /s/ występującemu w nagłosie wyrazowym przed zwartą (stare, stridor), w wygłosie wyrazowym po zwartej (daps, urbs) oraz w śródgłosie między zwartymi (depstum), przypisać status /s/ pozasylabicznego („extrasyllabic/s/”), traktując ten fonem jako należący do wyrazu, ale nienależący do żadnej z jego sylab.

26 Dodatkowym wskaźnikiem w tym względzie może być ortografia niektórych inskrypcji odnotowujących podział wyrazów na sylaby, gdzie z jednej strony znajdujemy zapisy typu PA.TRI, PV.BLICIA, z drugiej zaś CAE.LAES.TI.

2i Zob. Benedetti (1996) na temat wariancji: -V:C-/-VCC- pojawiającej się okazjonalnie w ramach tych samych jednostek leksykalnych, np. litera/littera. 
2. jeżeli między samogłoskami znajduje się grupa dwóch spółgłosek, złożona ze spółgłoski zwartej oraz płynnej /r/ lub /l/ (tzw. muta cum liquida), albo z /f/ oraz płynnej / $/ \mathrm{l} /$ lub /l/, grupa ta $\mathrm{w}$ całości należy do (nagłosu) sylaby następującej, wskutek czego sylaba poprzedzająca pozostanie sylabą otwartą, np.: pa.tris, lu.crum, ne.gle.go, du.plex, re.fre.no, re.flec.to;

3. jeżeli między samogłoskami znajduje się grupa dwóch spółgłosek, złożona ze spółgłosek innych niż wymienione wyżej, wówczas pierwsza $z$ nich należy do (wygłosu) sylaby poprzedzającej, która tym samym będzie sylabą zamkniętą, druga zaś do (nagłosu) sylaby następującej, np.: lec.tus, mun.dus, cer.tus, som.nus, cel.sus, ag.men, hos.pes, res.pon.det ${ }^{28}$;

4. jeżeli między samogłoskami znajduje się grupa złożona z trzech lub czterech spółgłosek, granica dzieląca ją na część wygłosową (poprzedzającej sylaby) i część nagłosową (sylaby następującej) przebiega w jej obrębie w sposób uwzględniający strukturalne właściwości wygłosu i nagłosu wyrazowego oraz wspomniane wyżej ograniczenie dotyczące nieakceptowalności nagłosu sylabicznego stanowionego przez grupę z /s/ w pierwszej pozycji, np.: mem.brum, emp.tus, ins.tar, mons.trum;

5. jeśli między samogłoskami znajduje się długa spółgłoska (geminata), granica między sylabami przebiega w środku jej artykulacji, czyniąc sylabę poprzedzającą zamkniętą, np.: an.nus, pas.sus, mel.lis.

Schemat podziału wyrazu na sylaby:

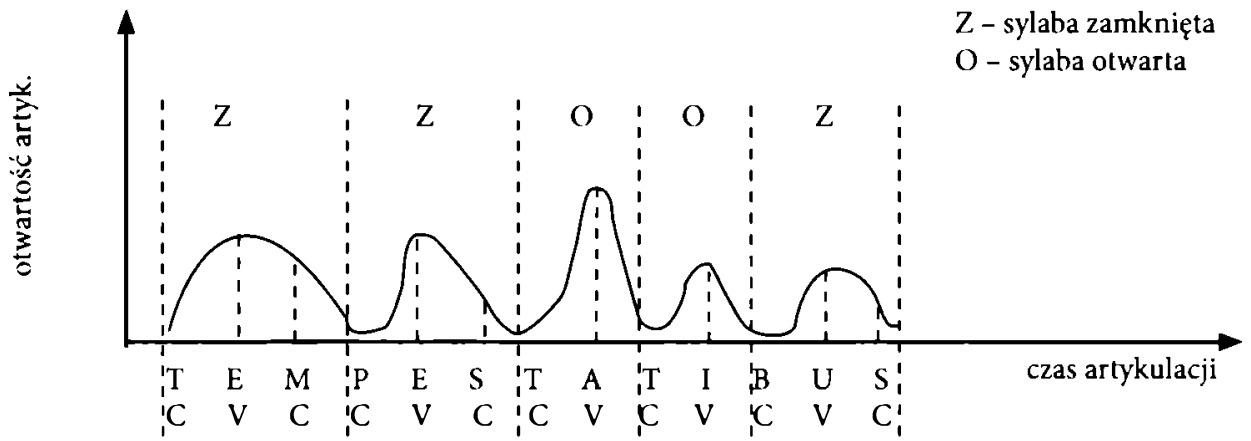

Jeżeli uwzględni się wspomniane wyżej ograniczenie dotyczące niedopuszczalności tworzenia nagłosu sylabicznego przez sekwencję /s/ + zwarta ${ }^{29}$, ogólny schemat sylaby determinowany przez łacińskie reguły fonotaktyczne przewidywał będzie więc wystąpienie maksymalnie jednego obstruentu i jednego sonorantu lub glajdu $w$ jej

${ }^{24}$ Spirant /h/, z uwagi na jego właściwości artykulacyjne i marginalną (zanikową) pozycję w systemie (zob. niżej), nie konstytuuje ( $w$ połączeniu $z$ inną spółgłoską) grupy spółgłoskowej; pierwsze sylaby takich wyrazów jak np. perhibeo czy abhinc zachowują więc status sylab otwartych.

${ }^{29}$ Tzn. jeśli pominie się /s/ występujące w nagłosie wyrazowym przed zwartą. 
nagłosie (następie) oraz jednego sonorantu lub glajdu ${ }^{30} \mathrm{i}$ jednego obstruentu $\mathrm{w}$ wygłosie (zestępie) $)^{31}$. Schemat ten ${ }^{32}$ ilustrują poniższe przykłady:

$(s)$
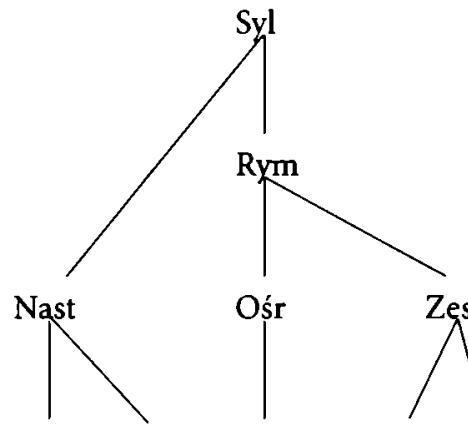

obs son/gl sam son/gl obs

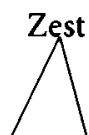

son/gl obs obs
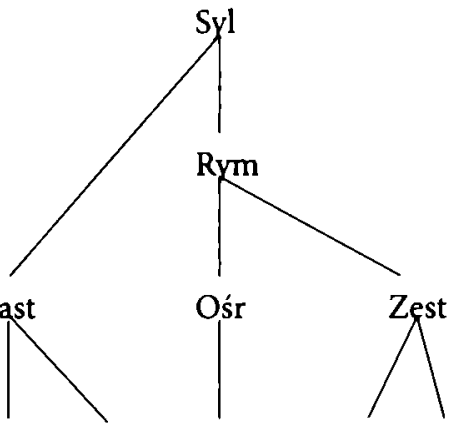

son/gl obs

(s)

\begin{tabular}{|c|c|c|c|c|c|c|c|c|c|}
\hline & $\mathrm{m}$ & a & & & & $\mathbf{r}$ & e & & \\
\hline \multirow[t]{3}{*}{$s$} & $u$ & $a$ & & & & $\underline{x}$ & $\mathbf{i}$ & & $\mathrm{s}$ \\
\hline & 1 & $\mathrm{a}$ & & & & ب. & a & $\mathbf{n}$ & $t$ \\
\hline & $\underline{\mathrm{i}}$ & $\mathbf{u}$ & & & b & & e & & $\mathrm{t}$ \\
\hline $\mathrm{P}$ & & e & & $s$ & $t$ & & $\mathrm{i}$ & & $\mathbf{s}$ \\
\hline \multirow[t]{2}{*}{$\mathrm{P}$} & & $\mathbf{a}$ & & & $\mathrm{t}$ & $\mathbf{r}$ & $\mathrm{i}$ & & $\mathrm{s}$ \\
\hline & 1 & $\mathbf{u}$ & & & $\mathrm{k}$ & r & $\mathrm{u}$ & $\mathrm{m}$ & \\
\hline \multirow[t]{3}{*}{$\mathrm{d}$} & & $\mathbf{u}$ & & & $\mathrm{P}$ & l & $e$ & & $\mathrm{k}$ \\
\hline & 1 & e & & $\mathrm{k}$ & $\mathrm{t}$ & & $\mathrm{u}$ & & $\mathrm{s}$ \\
\hline & $\mathrm{m}$ & $\mathbf{u}$ & $\mathrm{n}$ & & $\mathrm{d}$ & & u & & $s$ \\
\hline \multirow[t]{7}{*}{$\mathrm{k}$} & & $\mathrm{e}$ & 1 & & $s$ & & $\mathrm{u}$ & & $s$ \\
\hline & $\mathrm{m}$ & e & $\mathrm{m}$ & & b & $\mathbf{r}$ & u & $\mathrm{m}$ & \\
\hline & & e & $\mathrm{m}$ & $\mathrm{P}$ & $\mathrm{t}$ & & u & & $s$ \\
\hline & & $\mathrm{i}$ & $\mathrm{n}$ & $\mathbf{s}$ & $\mathrm{t}$ & & a & $r$ & \\
\hline & $\mathrm{m}$ & 0 & $\mathrm{n}$ & $s$ & $\mathrm{t}$ & $r$ & $\mathrm{u}$ & $\mathrm{m}$ & \\
\hline & & & & & & & $\mathrm{u}$ & $\mathrm{r}$ & $\mathrm{b}$ \\
\hline & & & & & & $\mathrm{p}$ & a & & $\mathrm{k}$ \\
\hline $\mathrm{t}$ & $r$ & $\mathrm{i}$ & & & & $\mathrm{d}$ & o & $\mathbf{r}$ & \\
\hline $\mathrm{P}$ & & $\mathbf{a}$ & & & $\mathbf{s}$ & $\mathbf{s}$ & $\mathrm{u}$ & & $\mathbf{s}$ \\
\hline
\end{tabular}

31 Miejsce dla glajdu w zestępie sylaby wynika $z$ symetrii zestępu względem następu, gdzie ewidentnie się pojawia (por.: suavis [sụa.ụis], vita [ụi.ta]), zaś wypełnienie tego miejsca wiąże się z przyjęciem bifonematycznej interpretacji lacińskich dyftongów (zob. niżej część dot. dyftongów).

${ }^{31}$ Dodajmy, że do reguły tej nie stosuje się wyjątkowy dla laciny wygłos -st (obecny tylko w est (i formach pochodnych) oraz spójniku ast), a także wyglos: (sonorant + ) zwarta $+/ \mathrm{s} /$ (jak np. w urbs, pax), który pojawia się głównie w pozycji przed pauzą (tj. na końcu wyrazu), rzadziej (jako wygłos sylaby) w śródglosie wyrazu (sextus, depstum; wygłos -st - nigdy).

${ }^{32}$ Cf. Cser (1999). 
Powyższe zasady podziału wyrazów na sylaby były respektowane także $w$ lacińskiej poezji, gdzie iloczas sylab (zob. niżej) wypełniających pozycje wyznaczane przez schematy metryczne w pewnym stopniu uzależniony był od iloczasu ośrodkowych samogłosek, a w pewnym również od granic sylab (czyli od ich otwartości bądź zamknięcia). Jednak $w$ wierszu daktylicznym mogły się również pojawiać sylaby metrycznie zamknięte (= długie), choć fonologiczne otwarte (= krótkie). Chodzi o sylaby $\mathrm{z}$ krótką samogłoską w ośrodku, po której następowała grupa spółgłoskowa o strukturze: zwarta + płynna (muta cum liquida), jak np. środkowe sylaby w wyrazach integrum, volucres. Jak wskazaliśmy wyżej, sylaby tego typu są fonologicznie (prozodycznie) otwarte (krótkie), bowiem następująca po samogłosce grupa spółgłoskowa tworzy w całości nagłos kolejnej sylaby, jednak w wierszu daktylicznym sylaby tego rodzaju mogły (choć nie musiały) wypełniać miejsce przeznaczone w schemacie metrycznym dla sylaby długiej, co implikuje (niefonologiczną) sylabizację typu in.teg.rum, vo.luc.res ${ }^{33}$.

\subsection{ILOCZAS SYLAB: SYLABY KRÓTKIE (LEKKIE) I SYLABY DŁUGIE (CIĘŻKIE)}

Realizowana przez sylaby prozodyczna cecha iloczasu stanowi podstawę relewantnej w łacinie opozycji sylab długich i krótkich. Ze względu na fakt, że iloczas jest również fonologiczną cechą dystynktywną łacińskich fonemów, stanowiącą podstawę ich podziału na długie i krótkie, dla terminologicznego odróżnienia prozodycznych cech sylab od fonologicznych cech głosek zamiast określenia "sylaba długa" stosuje się również termin "sylaba ciężka", a zamiast określenia "sylaba krótka" termin "sylaba lekka" ${ }^{34}$. Funkcją iloczasu sylab w łacinie jest identyfikacja miejsca padania akcentu wyrazowego. Co do swej fizycznej istoty jest on parametrem określającym czas trwania artykulacji sylaby, który zależy od dwu czynników: iloczasu samogłoski stanowiącej ośrodek sylaby oraz charakterystyki wygłosu sylaby (czyli jej otwartości bądź zamknięcia). Wzajemne relacje między tymi czynnikami pozwalają na zdefiniowanie wartości iloczasu łacińskich sylab w następujący sposób:

A. sylaba jest długa (ciężka), jeśli spełniony jest jeden lub oba $z$ następujących warunków:

1. jej ośrodkiem jest samogłoska długa (bez względu na to, czy jest sylabą zamknię-

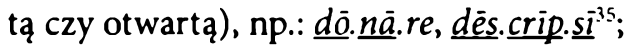

${ }^{33}$ Por. np. Lucretius, 4, 1222: quae patribus patres tradunt a strirpe profecta, gdzie pierwsza sylaba wyrazu patribus zajmuje pozycję sylaby krótkiej, a wyrazu patres sylaby długiej.

${ }^{34}$ Zob. np. Allen (1965), Pulgram (1974), Cser (1999), gdzie używa się odpowiednio terminów "heavy / light syllable(s)".

3 Sylaby długie (ciężkie) w załączonych przykładach wyróżnione zostały podkreśleniem. 
2. jest sylabą zamkniętą (bez względu na to, czy iloczas samogłoski stanowiącej jej ośrodek jest długi czy krótki ${ }^{36}$ ), np.: dês.cen.de.re, doc.tus:

B. sylaba jest krótka (lekka), jeśli równocześnie spełnione są dwa warunki:

1. jest sylabą otwartą;

2. jej ośrodkiem jest krótka samogłoska, np.: le.ge.re, ta.bu.la.

Można zatem stwierdzić, że iloczas sylaby determinowany jest strukturą jej wygłosu: sylaby kończące się długą samogłoską lub spółgłoską są długie (ciężkie), zaś sylaby kończące się krótką samogłoską są krótkie (lekkie).

Ponieważ nośnikiem wartości iloczasu sylaby może być zarówno jej samogłoskowy ośrodek, jak i spółgłoskowy zestęp w jej wygłosie, zaliczamy łacinę do języków morowych. W związku z tym elementarną funkcjonalną jednostką prozodyczną, związaną z iloczasem sylab, jest $w$ łacinie tzw. mora, odpowiadająca umownemu czasowi artykulacji sylaby krótkiej (lekkiej). Zasady regulujące miejsce padania akcentu wyrazowego (czyli jego oddalenie od końca wyrazu - zob. niżej), a także sposób realizowania określonych schematów metrycznych w poezji (tj. możliwość wypełnienia tej samej pozycji przez sylabę ciężką lub dwie sylaby lekkie), pozwalają na stwierdzenie, że mora odpowiada też połowie umownego czasu artykulacji sylaby długiej. Zatem sylaby krótkie (lekkie) to sylaby, których wartość iloczasu jest równa jednej morze, zaś sylaby długie (ciężkie) to sylaby, których wartość iloczasu jest równa dwóm morom.

\subsection{AKCENT WYRAZOWY}

Akcent $w$ języku lacińskim pełni funkcję delimitacyjną, polegającą na sygnalizowaniu końca wyrazu. Jego ulokowanie $w$ wyrazie jest stałe i związane właśnie z końcem wyrazu oraz iloczasem sylab: pada on mianowicie na sylabę zawierającą przedostatnią morę przed ostatnią sylabą. Inaczej mówiąc, pada on w miejscu po-

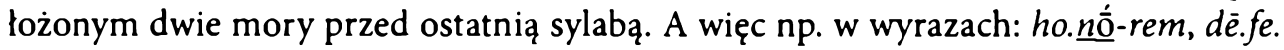
rún-tur akcent pada na sylaby przedostatnie, ponieważ są one długie (dwumorowe), a więc - oprócz ostatniej - zawierają także przedostatnią morę, licząc od ostatniej sylaby. W wyrazie dé.fé.ri-mus przedostatnia sylaba (-ri-) jest krótka (jednomorowa), w związku z czym zawiera tylko ostatnią morę, licząc od ostatniej sylaby; mora przedostatnia znajduje się zatem w sylabie poprzedzającej, czyli trzeciej od końca (-fe-), na którą $\mathrm{w}$ związku $\mathrm{z}$ tym pada akcent. W praktyce akcent pada zatem na sy-

${ }^{16}$ Tradycyjnie sylaba zamknięta, której ośrodkiem jest krótka samogłoska (jak np. obie sylaby $w$ wyrazie doc.tus), nazywana bywa sylabą długą "z pozycji”, co stanowi kalkę łacińskiego określenia positione lub positu ( $\mathrm{w}$ opozycji do określenia naturä identyfikującego sylabę $\mathrm{z}$ długą samogłoską w ośrodku), a to $z$ kolei jest tłumaczeniem terminu używanego przez gramatyków greckich, tj. terminu $\theta \epsilon ́ \sigma \epsilon l$, który może oznaczać 'ze względu na położenie' lub 'przez konwencję'

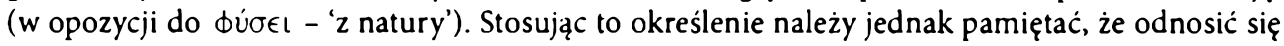
ono może wyłącznie do iloczasu sylaby, nigdy zaś do iloczasu samogłoski (tzn. nie istnieje coś takiego jak „samogłoska długa z pozycji”"). Odrębny pogląd w tej sprawie prezentuje Pulgram (1974). 
labę przedostatnią, jeśli jest ona długa, lub na sylabę trzecią od końca wyrazu, jeśli sylaba przedostatnia jest krótka. W wyrazach dwusylabowych akcent $\mathrm{z}$ konieczności pada, oczywiście, na sylabę pierwszą (czyli przedostatnią), bez względu na jej iloczas. Porównanie miejsca padania akcentu w takich wyrazach jak np. ho.nṓ-rem i dè.fe.rún-tur dowodzi morowego charakteru języka łacińskiego (tzn. dowodzi, że nie tylko samogłoskowy ośrodek, ale i spółgłoskowy zestęp sylaby może być nośnikiem iloczasu), natomiast porównanie miejsca padania akcentu w takich wyrazach jak dè.fe.rún-tur i dè.fé.ri-mus dowodzi, że wartość iloczasu długiej sylaby jest równa sumie iloczasów dwóch krótkich sylab (czyli jest równa dwóm morom) ${ }^{37}$.

Odnosząc się wyżej do problematyki granic sylab zaznaczyliśmy, że znajdująca się między dwiema samogłoskami grupa spółgłoskowa złożona ze zwartej i płynnej (muta cum liquida), chociaż w poezji daktylicznej mogła być dzielona pomiędzy dwie sąsiadujące sylaby (np.: vo.luc.res, pe.rag.ro), fonologicznie (prozodycznie) należała w całości do nagłosu kolejnej sylaby (np.: vo.lu.cres, pe.ra.gro) ${ }^{38}$. Jeśli znajdująca się przed tą grupą sylaba była sylabą przedostatnią w wyrazie, a jej ośrodkiem była krótka samogłoska (jak ma to właśnie miejsce w przytoczonych przykładach), to konsekwencją tego było również akcentowanie trzeciej sylaby od końca (a więc vólucres, péragro $)^{39}$.

Jeśli do wyrazu przyłączane były enklityczne spójniki lub partykuły (-que, -ve, -ne, -ce), miejsce padania akcentu dostosowywało się do końcowej granicy całości zestroju akcentowego, a więc np.: populúsque, vidésne, trepidántve itp. Problematyczny jest sposób akcentowania form wyrazowych, w których przed enklityką znajdowała się krótka (lekka) sylaba, jak np.: Musaque, liminaque, bonaque, utraque, pleraque. Zgodnie $\mathrm{z}$ ogólnymi regułami akcent powinien $\mathrm{w}$ nich padać na sylaby trzecie od końca, a więc: Músaque, liminaque, bónaque, útraque, pléraque, jednak gramatycy starożytni

"Chodzi o to, że gdyby wartość iloczasu długiej sylaby odpowiadala np. trzem morom, wówczas akcent $w$ wyrazie deferimus musialby padać na czwartą sylabę od końca, bowiem nie tylko druga, ale i trzecia sylaba od końca jest w nim krótka.

${ }^{36}$ Podobnie jak do nagłosu kolejnej sylaby należała grupa złożona z /f/ i płynnej.

${ }^{34} \mathrm{O}$ tym, że tak właśnie było, świadczą komentarze gramatyków do wierszy, w których wyrazy tego rodzaju umieszczone były na końcu heksametru, gdzie oczekiwana była zgodność (co do miejsca ulokowania) metrycznej tezy (iktusu) i akcentu wyrazowego, zaś schemat metryczny wymagał przedostaniej sylaby długiej, a więc determinował podział sylabiczny o postaci vo.luc.res, pe.rag.ro. Np. Kwintylian mówił w takim przypadku o zmianie (miejsca) akcentu i akcentowaniu środkowej sylaby, co sugeruje, że „zwykłym" miejscem padania akcentu w takich wyrazach była właśnie sylaba trzecia od końca; równocześnie zalecal, aby wymawiając te wyrazy poza wierszem, nie odstępować od przyjętego zwyczaju (Quint., Inst. 1, 5, 28-29: Evenit ut metri quoque condicio mutet accentum: 'pecudes pictaque volucres', nam 'volucres' media acuta legam [...]. Separata vero haec a praecepto nostro non recedent). $Z$ kolei Serwiusz, odnosząc się do umieszczonego $w$ tej samej pozycji wyrazu peragro, jednoznacznie potwierdza zachowanie jego akcentu na trzeciej sylabie od końca, podkreślając, że wystąpienie sekwencji muta cum liquida wspiera jedynie metrum i nie ma konsekwencji dla miejsca padania akcentu wyrazowego (Serv., Aen. 1, 384: [...] Libyae deserta peragro'] 'peragro' 'per' habet accentum [...]; muta enim et liquida quotiens ponuntur metrum iuvant, non accentum). 
zasadę akcentowania przedostatniej sylaby uogólniali na wszystkie formy występujące $\mathrm{z}$ enklitykami ${ }^{40}$. W związku $\mathrm{z}$ tym niektórzy badacze mówią $\mathrm{o}$ istnieniu specyficznej reguły akcentowania enklityk (zawsze na przedostatniej sylabie, bez względu na jej iloczas), której odmienność (od ogólnych reguł) miałaby stanowić wyraz świadomości aglutynacyjnego charakteru zestrojów enklitycznych, tj. świadomości semantycznej autonomii obu ich składowych elementów ${ }^{41}$. Nie można też wykluczyć, że formy typu: bonaque, utraque, pleraque akcentowane były na sylabie przedostatniej (a więc bonáque, utráque, pleráque) pod wpływem analogii do bonúsque, utérque, plerúsque. Do enklityk akcentowanych na przedostatniej sylabie zaliczali starożytni gramatycy również itaque (= et ita), które jednak odróżniali od "spójnikowego" itaque 'zatem', 'przeto', akcentowanego na sylabie trzeciej od końca ${ }^{42}$. Dzisiaj trudno, oczywiście, rozstrzygnąć, czy w świadomości Rzymian itaque w ogóle funcjonowało jako enklityka, czy też raczej odbierane było jako jeden, niepodzielny wyraz; bliskość, a właściwie nierozdzielność znaczeniowa obu potencjalnie odrębnych form nie pozwala również na wyciąganie wniosków w oparciu o analizę kontekstów.

W pewnej grupie wyrazów akcentowanych na sylabie przedostatniej z przyczyn fonetycznych nastąpił zanik ostatniej, poakcentowej sylaby. Ponieważ zanik ten dokonał się już po okresie stabilizacji miejsca padania akcentu, w formach tego typu akcent zachował się, wraz z długim iloczasem samogłoski, na sylabie akcentowanej pierwotnie ${ }^{43}$, która tym samym stała się ostatnią sylabą wyrazu. Z taką właśnie sytuacją mamy do czynienia $w$ wyrazach, które $\mathrm{w}$ połączeniu $\mathrm{z}$ enklitykami -ce $\mathrm{i}$-ne akcentowane były na przedostatniej sylabie, a następnie utraciły ostatnią sylabę wskutek apokopy wygłosowej samogłoski /-e/ w enklitykach. Nie zmieniły jednak miejsca położenia akcentu, który w związku z tym znalazł się $\mathrm{w}$ sylabie ostatniej, np.: illic $(\leftarrow$ illice), adhúc $(\leftarrow$ adhúce $)$, posthác $(\leftarrow$ postháce $)$, egón $(\leftarrow$ egóne $)$, tantón $(\leftarrow$ tantóne $)$, audin ( $\leftarrow$ audisne) itp. Akcent na ostatniej sylabie wskutek apokopy wygłosowego /-e/ posiadały także imperatywne formy derywatów przedrostkowych utworzonych na bazie dico i duco, czyli np.: addíc ( $\leftarrow$ addice), addúc $(\leftarrow$ addúce). Podobnie akcentowana była ostatnia sylaba $w$ mianownikowych formach rzeczowników, w których nastąpiła synkopa tematycznej samogłoski $/-\mathrm{i}-/$, jak np. w nostrás $(\leftarrow$ nostráts $\leftarrow$ nostrátis) ${ }^{44}$, oraz w czasownikowych formach perfektywnych 3. os., powstałych po zaniku interwokalicznego glajdu /u / w sufiksie i kontrakcji samogłosek, jak np.: $\mathrm{w}$ audit

411 Por. np. Serv., Aen. 10, 668: minores particulae, ut 'que, ne, ve, ce', quotiens iunguntur aliis partibus, ante se accentum faciunt, qualislibet sit syllaba quae praecedit, sive brevis sive longa, ut 'musaque, huiusve, illucce, tantone'; zob. też Mart. Cap., Nupt. 3, 272.

41 Zob. Bernardi Perini (1970: 38-43).

42. Por. np. Serv., Donat. (GL IV, 427, 13-16): 'Itaque' pars orationis quaeritur utrum correpta media an producta dici debeat. Scire debemus quoniam tunc corripitur media, cum una pars fuerit orationis; tunc vero producitur, cum duae; Pseudo-Priscianus, De accentibus liber (GL III, 521): 'itáque', quando adverbium; quando vero coniunctio,' ítaque' dicimus.

4. Por. Serv., Aen. 10, 668: constat mutilatas partes orationis accentum in eodem loco habere, in quo etiam integrae habuerunt.

14 A także w: primás, optimás, Arpinás, Crotoniás, Maecenás, Quiris, Samnís itp. 
$(\leftarrow \text { audivit })^{45}$, obit $(\leftarrow \text { obivit })^{46}$, perit $(\leftarrow \text { perivit })^{47}$, redit $(\leftarrow \text { redivit })^{48}$ itp. Niezgodnie $\mathrm{z}$ ogólnymi regułami akcentowane były też formy wokatiwu liczby pojedynczej imion własnych II deklinacji o temacie zakończonym na /-i-/ z poprzedzającą krótką (lekką) sylabą. Przykładem może być imię Valerius ${ }^{49}$, którego wokatiwus miał postać Valeri i ze względu na krótkość sylaby -le-powinien być akcentowany na sylabie trzeciej od końca, a więc Váleri; jednak przez analogię do pozostałych form fleksyjnych, w których jako akcentowana trzecia od końca występowała sylaba -le- (Valérius, Valério, Valérium), również w wokatiwie zachowała ona akcent, stąd Valéri ${ }^{50}$.

Z kolei większość przyimków stanowiła proklityki tworzące zestrój akcentowy $\mathrm{z}$ wyrazem następującym, a więc np.: in úrbe, ab amico. Proklityczny charakter miały również pierwsze elementy złożeń powstałych przez połączenie tematów czasownikowych (cale(o), are (o), assue(sco), commone(o), made(o), mansue(sco), tepe(o)) oraz form czasowników facio lub fio, a więc calefacio/calefio, arefacio, assuefacio, commonefacio, madefacio, mansuefacio, tepefacio, a także satisfacio. Według Pryscjana ${ }^{51} \mathbf{w}$ formach tego rodzaju akcent nie przesuwał się poza drugi człon złożenia stanowiony przez formy czasowników fio lub facio i padał w związku z tym również na sylaby ostatnie złożenia oraz przedostatnie krótkie (lekkie), np.: calefis, calefít, calefácis, calefácit.

Co do charakteru, akcent łaciński najprawdopodobniej opierał się na sile głosu, a więc był akcentem dynamicznym (ekspiratorycznym). Na taki właśnie, tj. dynamiczny charakter akcentu łacińskiego wskazuje kilka przesłanek. Jedną z nich jest obserwowalne w łacinie osłabienie lub zanik samogłosek w sylabach poakcentowych, co stanowi typową konsekwencję funkcjonowania akcentu tego rodzaju. Formy typu: pergo $\left(\leftarrow{ }^{*}\right.$ perrego), aetas $\left(\leftarrow{ }^{*}\right.$ aevotas $)$, conficio $\left(\leftarrow{ }^{*} \text { confacio }\right)^{52}$ sugerują istnienie inicjalnego akcentu ekspiratorycznego w okresie przedliterackim, natomiast pojawienie się form imperatywnych typu dic (obok wcześniejszego dice $e^{53}$ ), wspomniane wyżej formy $\mathrm{z}$ akcentem na ostatniej sylabie typu illic ( $\leftarrow$ illice), oboczność form typu: ma-

${ }^{45}$ Obok tego, po zaniku glajdu możliwe też było zachowanie obu samogłosek /i/, z których pierwsza ulegała skróceniu (vocalis ante vocalem) a akcent przechodził na sylabę trzecią od końca, a więc np. áudiit; zob. jednak Serv., Aen. 1, 451, który formy tego rodzaju uznaje za wyłącznie poetyckie: sed hoc (scil. leniit) in metro, ubi necessitas cogit.

t6 Zob. Lucretius 3, 1042.

17 Ibid. 4, 771.

18 Ibid. 3, 502; zob. też Prisc., Inst. gram. 4, $21-22$ (GL II, 128-130); 7, 19 (GL II, 302).

14 Inny przykład to imię Vergilius.

5) Por. Gell., Noc. Att. 13, 26, 2: Si quis nunc, Valerium appellans, in casu vocandi [...] acuerit primam, non aberit quin rideatur.

${ }^{5}$ Prisc., Inst. gram. 8, 35 (G.L II, 402): Si vero 'facio' verbo vel 'fio' integris manentibus aliud verbum infinitum ante ea componatur, non solum significationes et coniugationes integras eis servamus, sed etiam accentus, ut 'calefácio, calefácis, calefácit', 'tepefácio, tepefácis, tepefácit', in secunda enim et tertia persona paenultimas acuimus, quamvis sunt breves. Similiter 'calefio, calefis, calefit', 'tepefio, tepefis, tepefit' finales servant accentus in secunda et tertia persona, quos habent in simplicibus.

52 Wiecej na ten temat zob. Janson (1977).

s3 Zob. np.: Acc., Praetext. 12; Naev., Trag. 60; Pl., Bacch. 716; Capt. 359; Merc. 159; Mil. 256; Stich. 696; Quint., Inst. 1, 6, 21. 
nipulus/maniplus, calidus/caldus czy figurujące w Appendix Probi napomnienia w rodzaju: oculus non oclus, frigida non fricda, orbis non orbs wskazują na dynamiczny charakter akcentu po związaniu go $z$ końcem wyrazu i iloczasem sylab, czyli w epoce klasycznej i późniejszej. Z dynamicznym charakterem akcentu wydaje się być związane także zjawisko skracania iloczasu ostatniej sylaby w wyrazach o budowie jambicznej, czyli w wyrazach dwusylabowych z pierwszą akcentowaną sylabą krótką i drugą sylabą długą, np.: égō, cítō, bénē itp. ${ }^{54}$ Impulsem dla tego procesu była zapewne nienaturalność akcentowania krótkiej sylaby przed następującą sylabą długą ( $w$ wyrazach dłuższych krótka sylaba była akcentowana jedynie przed kolejną również krótką, jak np. w deférimus, dócilis), a jego mechanizm mógł opierać się właśnie na charakterystycznym dla akcentu ekspiratorycznego osłabianiu sylaby poakcentowej. Najwyraźniej jednak za dynamicznym charakterem łacińskiego akcentu przemawiają różnice dzielące go od tonicznego akcentu w klasycznej grece, którego charakter i ulokowanie w wyrazie zależały nie od iloczasu sylaby, a jedynie od iloczasu elementów zgłoskotwórczych (samogłosek i dyftongów), mogących być jego nośnikami; por.

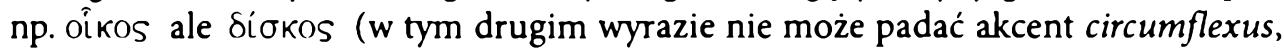
mimo że sylaba akcentowana jest również długa; zawiera jednak krótką samogłoskę); oíkos ale oïkou (w pierwszej formie pada akcent circumflexus, mimo że ostatnia sylaba jest również długa; zawiera jednak krótką samogłoskę); ả $\theta \rho \omega \pi 0 S$ ale àv $\theta \rho \omega ́ \pi 0 v$ (w pierwszej formie akcent acutus pada na trzecią sylabę od końca, mimo że ostatnia sylaba jest także (jak w à $v \rho \omega \dot{\pi}$ (jou) długa; zawiera jednak krótką samogłoskę itd.). Poza tym akcent $w$ języku greckim miał charakter swobodny i dystynktywny, natomiast $\mathrm{w}$ łacinie akcent jest co do miejsca padania stały i nie pełni funkcji dystynktywnej (zob. niżej). Wreszcie nie ma wystraczających przesłanek wskazujących na zróżnicowanie charakteru akcentu ${ }^{55}$ łacińskich sylab długich w zależności od pozycji, jaką zajmuje $w$ nich druga mora przed ostatnią sylabą, tzn. nie ma podstaw, by sądzić, że akcent np. w wyrazie honórem miał inny charakter niż akcent np. w wyrazie démere, mimo że $w$ tym pierwszym druga mora przed ostatnią sylabą znajduje się w nagłosie sylaby akcentowanej, zaś w tym drugim w wygłosie sylaby akcentowanej. Pozwala to na wyciągnięcie wniosku, że intonacja sylabiczna w łacinie nie miała charakteru fonologicznego.

Wyrażane są jednak również poglądy o tonicznym charakterze łacińskiego akcentu. Opierają się one głównie na świadectwach starożytnych autorów, w tym przede wszystkim na fragmencie $\mathrm{z}$ tekstu Kwintyliana, który mówi o zróżnicowanym charakterze łacińskiej akcentuacji:

In omni voce acuta intra numerum trium syllabarum continetur, sive eae sunt in verbo solae sive ultimae, et in iis aut proxima extremae aut ab illa tertia. Trium porro de quibus loquor media longa aut acuta aut flexa erit, eodem loco brevis utique gravem habebit sonum ideoque positam ante se, id est ab ultima tertiam, acuet. Est autem

it Więcej na temat uwarunkowań (syntaktycznych, semantycznych, leksykalnych) tego procesu zob. Stephens (1986), Mańczak (1968), Allen (1973:181).

s Chodzi o zróżnicowanie typu: akcent cyrkumfleksowy vs akcent akutowy. 
in omni voce utique acuta, sed numquam plus una nec umquam ultima, ideoque in disyllabis prior. Praeterea numquam in eadem flexa et acuta [quoniam est in flexa et acut $^{56}{ }^{5}$, itaque neutra cludet vocem Latinam. Ea vero, quae sunt syllabae unius, erunt acuta aut flexa, ne sit aliqua vox sine acuta. (Quint., Inst. 1, 5, 30-31) - „W każdym wyrazie zgłoska $z$ akcentem wysokim znajduje się $w$ obrębie trzech zgłosek już to jedynych, już też ostatnich w danym wyrazie, a wśród tych znowu jest to albo zgłoska przedostatnia, albo trzecia od końca. $Z$ tych zaś trzech, o których mówię, zgłoska środkowa, jeżeli jest długa, może otrzymać akcent wysoki lub łamany; jeżeli jednak w tym właśnie miejscu jest zgłoska krótka, to będzie ona mieć oczywiście akcent niski, a wtedy akcent wysoki otrzyma zgłoska poprzednia, tzn. trzecia od końca wyrazu. W każdym wyrazie musi być zgłoska $\mathrm{z}$ akcentem wysokim, ale nie może ich być więcej, niż jedna w jednym wyrazie i nigdy nie może nią być ostatnia; a zatem w wyrazach dwuzgłoskowych - pierwsza. Poza tym nigdy w tym samym wyrazie nie ma zgłoski $\mathrm{z}$ akcentem łamanym obok zgłoski $\mathrm{z}$ akcentem wysokim [ponieważ $\mathrm{w}$ zgłosce łamanej zawiera się również wysoka - HW], czyli że żadna z takich zgłosek nie kończy wyrazu łacińskiego. Wyrazy jednozgłoskowe, rzecz jasna, będą mieć akcent lamany albo wysoki, zgodnie $\mathrm{z}$ regułą, że w każdym wyrazie jest akcent wysoki" ${ }^{5}$.

W tekście Kwintyliana wyróżniona zatem zostaje syllaba acuta (mająca akcent „wysoki" - ostry, rosnący?) oraz syllaba flexa (mająca akcent „łamany” - rosnąco-opadający?), przy czym określenie syllaba acuta używane jest również w szerszym znaczeniu sylaby akcentowanej jako takiej (por. z jednej strony: est autem in omni voce utique acuta; $[. .$.$] ne sit aliqua vox sine acuta; z$ drugiej zaś: numquam in eadem (scil. voce) flexa et acuta (scil. syllba); wiąże się to zapewne z tą okolicznością, że akcent, jakim miałaby się cechować syllaba flexa, byłby również w (pierwszej) części rosnący. Oprócz tego wyróżniona została jeszcze sylaba, która gravem habebit sonum; w oparciu o kontekst ${ }^{58}$ należałoby ją utożsamić raczej $\mathrm{z}$ sylabą atoniczną w pozycji poakcentowej niż z sylabą akcentowaną. Jednak wyjąwszy to, co konotują same terminy acuta, flexa, gravis, z przytoczonego tekstu nie dowiadujemy się niczego o istocie poszczególnych typów akcentu, właściwych sylabom określanym tymi terminami, a przede wszystkim niczego o dystrybucji tych akcentów. Poza tym, że sylaba trzecia od końca jest acuta, jeśli przedostatnia jest krótka, dowiadujemy się jedynie, że sylaba, która jest jedyną sylabą wyrazu, oraz sylaba przedostatnia, jeśli jest sylabą długą, mogą być albo acutae, albo flexae; nie wiemy jednak kiedy (w jakich wyrazach) owa jedyna sylaba w wyrazie lub przedostatnia długa jest acuta, a kiedy flexa. Czy zależy to od iloczasu samogłoski? Trudno bowiem wyobrazić sobie akcent cyrkumfleksowy padający na długą (zamkniętą) sylabę z krótką samogłoską

56 Według wydania w Loeb Classical Library (Butler). W niektórych kodeksach słowa te są pomijane lub pojawia się $w$ tym miejscu niejasne sformułowanie qui in eadem flexa et acuta, usuwane przez część wydawców (Radermacher, Teubner) lub opatrywne filologicznym krzyżem z komentarzem mówiącym o prawdopodobnie mylnym powtórzeniu wyrazów (Winterbottom, Oxford).

5خ Kwintylian, Ksztalcenie mówcy, tłum. M. Brożek, Biblioteka Narodowa, seria II, Wroclaw 1951.

in Zob. też ibid., 22. 
w ośrodku. Zaskakująco milczą na ten temat łacińskie źródła ${ }^{59}$, co stanowi uderzającą różnicę $\mathrm{w}$ porównaniu $\mathrm{z}$ greką, gdzie nie mamy w zasadzie żadnej wątpliwości co do tego, który wyraz cechował się akcentem akutowym, a który cyrkumfleksowym. W tym kontekście warto zwrócić uwagę na fakt, że zastosowana nomenklatura stanowi prostą kalkę terminologii greckiej (acuta $=\dot{o} \xi \epsilon \hat{\imath} a$, gravis $=\beta a \rho \in \hat{\imath} a$, (circum) flexa $=\pi \epsilon \rho ı \sigma \pi \omega \mu \epsilon ́ \nu \eta)$, podobnie zresztą jak sam termin accentus $(=\pi \rho 0 \sigma \omega \delta i ́ a)$. Mając na uwadze ogólną zależność rzymskiej teorii gramatycznej od greckiej możemy przypuszczać, że i w tym przypadku mamy do czynienia z prostą próbą adaptacji greckiego aparatu terminologicznego do opisu łacińskiego systemu akcentuacyjnego, mimo różnic dzielących w tym zakresie oba języki, a przy tym sposób użycia terminu gravis wzmacnia podejrzenie o brak należytego rozróżnienia między akcentem a intonacją wyrazową. Warto też odnotować, że mamy także świadectwa gramatyków stwierdzających, że sylaba akcentowana brzmiała w łacinie głośniej (plus sonat), i odwołujących się do natężenia dźwięku (nisus vocis), jak np. wypowiedź Maurusa Serwiusza Honoratusa: Accentus in ea syllaba est, quae plus sonat. Quam rem deprehendimus, si fingamus nos aliquem longe positum clamare. Invenimus enim naturali ratione illam syllabam plus sonare, quae retinet accentum, atque usque eodem nisum vocis ascendere (Commentarius in Artem Donati, GL IV, 426, 16-21). Swiadectwa te pochodzą co prawda z późnego okresu, tj. ok. 400 r. po Chr., prawdopodobnie jednak oparte są na źródłach wcześniejszych.

Mimo podnoszonych wątpliwości niektórzy badacze, jak wspomniano, dopuszczają możliwość istnienia w łacinie akcentu melodycznego, który miałby funkcjonować od początku epoki literackiej (III w. przed Chr.) ${ }^{60}$. W pierwszych stuleciach Cesarstwa (II w. po Chr.) miałby on stopniowo przekształcać się w akcent dynamiczny, głównie wskutek oddziaływania przedlatyńskich substratów językowych na rozległych terenach rzymskich prowincji. Byłby to pierwszy symptom procesu rozpadania się łacińskiej wspólnoty językowej, który ostatecznie doprowadził do powstania na bazie łaciny odrębnych języków romańskich, z których wszystkie cechowały się akcentem dynamicznym. Ze zmianą tą mógłby też mieć związek zanik iloczasu samogłosek jako cechy dystynktywnej, który zastąpiony został w tej funkcji opozycją apertury (zob. niżej).

$5 y$ Przywołać możemy w tym miejscu np. dwa passusy z Cyceronowego Oratora, także zbyt ogólne, by na ich podstawie wyciągać jakieś zasadnicze wnioski: (Cic., Orat. 57-58): Mira est enim quaedam natura vocis, cuius quidem e tribus omnino sonis, inflexo acuto gravi, tanta sit et tam suavis varietas perfecta in cantibus. Est autem etiam in dicendo quidam cantus obscurior, non hic e Phrygia et Caria rhetorum epilogus paene canticum, sed ille quem significat Demosthenes et Aeschines [...]. Ipsa enim natura, quasi modularetur hominum orationem, in omni verbo posuit acutam vocem nec una plus nec a postrema syllaba citra tertiam. (Ibidem, 173): omnium longitudinum et brevitatum in sonis sicut acutarum graviumque vocum iudicium ipsa natura in auribus nostris collcavit. Jak widać, w pierwszym z przytoczonych ustępów Cyceron mówi o retorach greckich i może mieć na myśli raczej grekę niż łacinę; w drugim wyrażenia acutae voces / graves voces mogą po prostu oznaczać, odpowiednio, sylaby akcentowane i sylaby nieakcentowane.

61) Więcej na temat sporu o charakter akcentu zob. Bernardi Perini (1970: 1-14); tam też wskazówki bibliograficzne. 
Niezależnie jednak od przyjętego stanowiska $\mathrm{w}$ kwestii charakteru lacińskiego akcentu należy podkreślić, że ani akcent, ani iloczas sylaby nie pełniły $\mathrm{w}$ łacinie funkcji dystynktywnej. Funkcję dystynktywną pełnił natomiast iloczas jako cecha fonologiczna głosek. Ponieważ w przyjętej przez nas konwencji artykulacyjnej nie uwzględnia się na ogół iloczasu samogłosek, pomocniczo jako wskaźnik pozwalający na rozróżnianie form wyrazowych traktowany bywa akcent (skorelowany $z$ iloczasem sylab, a przez to pośrednio i z iloczasem samogłosek), który jest uwzględniany przez naszą konwencję artykulacyjną. W tym względzie można się powołać np. na pary wyrazów typu: ducéris (2. os. sg. ind. fut. pass. 'będziesz prowadzony') i dúceris (2. os. sg. ind. praes. pass. 'jesteś prowadzony'). Należy jednak pamiętać, że w rzeczywistości odmienność pozycji (względem końca wyrazu) sylab akcentowanych w obu tych formach fleksyjnych (tzn. fakt, że w jednej z nich akcent pada na trzecią sylabę od końca, a w drugiej na drugą) nie jest systemowym (gramatycznym) środkiem formalnym różnicującym te wyrazy, lecz jedynie ubocznym skutkiem, wynikającym ze zróżnicowania iloczasu samogłosek /ê/ i /e/ w każdej z tych form, i tym samym zróżnicowania cech prozodycznych sylab, w których samogłoski te występują. Innymi słowy, formy te różnią się od siebie przede wszystkim tym, że w jednej z nich występuje długie /ê/, a w drugiej krótkie /e/, natomiast postrzegana przez nas odmienność sposobu ich akcentowania jest jedynie konsekwencją tej różnicy. 


\section{6. \\ Uwagi szczegółowe na temat łacińskiego konsonantyzmu}

\subsection{OBSTRUENTY ZWARTE}

Klasa obstruentów zwartych obejmowała w klasycznej łacinie 8 fonemów, a mianowicie: $/ \mathrm{p} /, / \mathrm{b} /, / \mathrm{t} /, / \mathrm{d} /, / \mathrm{k} /, / \mathrm{g} /, / \mathrm{k}^{\mathrm{u}} / \mathrm{i} / \mathrm{g} /$. Funkcjonująca w ramach tej klasy opozycja dźwięczności / bezdźwięczności ulegała neutralizacji w pozycji wygłosowej wyrazu, gdzie występowały wyłącznie bezdźwięczne (w pewnych wyrazach, ze względów historycznych, zapisywane tak jak dźwięczne, np. aliquod ${ }^{61}$ ). W wygłosie wyrazowym zanikała także opozycja labialności funkcjonująca wśród tylnojęzykowych; w położeniu tym pojawiały się wyłącznie zwarte nielabializowane (por.: neque ale nec, atque ale $a c)$.

Fonem /p/ [p], a więc obstruent zwarty dwuwargowy (bilabialny) bezdźwięczny, wymawiany był jak np. pierwsza spółgłoska w pol. wyrazie prawo czy pałac. Notowany był zwykle literą $P / p$, jak np. w pax, populus itp., jednak przed spółgłoskami /t/ $\mathrm{i} / \mathrm{s} /$ zapisywany też bywał literą $B / b$. Miało to miejsce w sytuacji, gdy spółgłoska ta była efektem kontekstowego ubezdźwięcznienia $/ b /$, a użycie litery $B / b$ motywowane było zachowaniem ortograficznej analogii $w$ ramach fleksji lub słowotwórstwa; stąd np. standardowa pisownia trabs [traps], czyli analogicznie do trabis, trabi itd; plebs [pleps], analogicznie do plebis, plebi itd.; urbs [urps], analogicznie do urbis, urbi itd.; obtineo [optineo], analogicznie do obicio, obnoxio itp; absumo [apsumo], analogicznie do abeo, abrado itp.

O tym, że we wskazanych wyżej kontekstach litera $b$ notuje rzeczywiście fonem /p/, świadczą:

1. liczne inskrypcje z niestandardową pisownią typu PLEPS, OPSIDES, OPTINE$B I T, A P S O L V E R E, \mathrm{z}$ drugiej zaś strony okazjonalnie poświadczona pisownia typu SCRIBTVRA;

") O bezdźwięczności spółgłosek zwartych w tym położeniu świadczą ortograficzne pomyłki widoczne na inskrypcjach, jak np. ALIQUOD w miejsce ALIQUOT 'kilka' (Monumentum Ancyranum 2, 25). 
2. stwierdzenia gramatyków, komentujące różnice między pisownią a wymową, np.: (o wyrazie obtinuit): Secundam enim b litteram ratio poscit, aures magis audiunt $p$ (Quint., Inst. 1, 7, 7); (o pisowni abs): de qua scriptione illud quaeritur, utrum per $p$ an per $b$ et $s$ debeat scribi [...]; qui originem verborum propriam respiciunt, per $b$ scribunt (Velius Longus, De orthographia 61, 5-9 (= GL VII, 62).

Fonem /b/ [b], czyli obstruent zwarty dwuwargowy (bilabialny) dźwięczny, wymawiany był jak np. pierwsza spółgłoska w pol. wyrazie brat czy baron. Zapisywany był literą $B / b$, jak np. w: bonus, ruber itp. W epoce poklasycznej, od I w. po Chr. poczynając, w potocznym języku fonem ten wykazywał tendencję do uszczelinowienia (spirantyzacji), czyli przekształcania się w dźwięczną dwuwargową spółgłoskę szczelinową lub uderzeniową, podobną do hiszpańskiej spółgłoski interwokalicznej zapisywanej literą $b, \mathrm{np}$. w wyrazach lobo, haba. Swiadczy o tym grafia niektórych nieformalnych inskrypcji, gdzie zapisywany był przy użyciu litery $u(=v$ w naszej konwencji ortograficznej) notującej glajd /un/, który w pierwszych wiekach po Chr. również podległ procesowi podobnego uszczelinowienia (zob. niżej); stąd zapisy typu sivi (= sibi), devere (= debere) itp..$^{62}$

Fonem / $\mathrm{t}$ [ $\mathrm{t}$, czyli obstruent zwarty przedniojęzykowy zębowy (dentalny) bezdźwięczny, wymawiany był jak np. pierwsza spółgłoska w pol. wyrazie tama czy tron. Zapisywany był literą $T / t$, jak np. w: tenuis, mutat, amat itp. W języku potocznym istniała zapewne dość silna tendencja do osłabiania jego artykulacji w pozycji wygłosowej po samogłosce, o czym świadczą liczne zabytki epigraficzne ( $z$ różnych okresów) pomijające zapis /t/ w tej pozycji, jak np. archaiczna inskrypcja ${ }^{63}$ notująca $D E D E$ (= dedit) czy jedno z graffiti na murze pompejańskim ${ }^{64}$ (79 r. po Chr.), gdzie czytamy: Quisquis ama valia peria qui nosci amare (= klas. Quisquis amat valeat, pereat qui nescit amare - „Każdy, kto kocha, niech ma się dobrze, niech zginie, kto kochać nie potrafi"). Brak również kontynuantów / t/ w tym kontekście fonetycznym w większości języków romańskich (por. np. wł. (lui/lei) ama). Ok. III w. po Chr. fonem /t/ przed antywokalicznym /i/ (wtedy już w potocznej mowie uspógłoskowionym w tej pozycji do /i/ [j]) uległ asybilacji do zwarto-szczelinowego [ts], czego dowodzi inskrypcyjna grafia typu VINCENTZVS (= Vincentius - III w. po Chr.), TERENSVS (= Terentius), a później także liczne pomyłki na zabytkach epigraficznych (i w manuskryptach) polegające na zapisie -ci- ${ }^{65} \mathrm{w}$ miejsce $-t i-$, jak np.: terciae (=tertiae), definiciones (= definitiones) itp. Zmianę tę dokumentuje także brzmienie odpowiednich kontynuantów form łacińskich w językach romańskich, np.: wł. forza, hiszp. fuerza, franc. force $(\leftarrow \text { łac. fortia - neutr. pl. pojmowane jako nom. fem. sg. })^{66}$.

${ }^{62}$ Por. też Appendix Probi: baculus non vaculus; tolerabilis non toleravilis.

${ }^{63}$ Corpus Inscriptionum Latinarum $1^{2}, 47$.

it Corpus Inscriptionum Latinarum IV, 1173.

${ }^{n 5}$ Fonem $/ \mathrm{k} / \mathrm{w}$ tej pozycji uległ podobnej asybilacji; zob. niżej.

th Najprawdopodobniej zmiana ta jednak nie zachodziła w sytuacji, gdy /t/ poprzedzone było /s/ (a więc np. w formach typu hostia), oraz gdy po sekwencji /-ti-/ następowało /i/, a więc np. w formach typu otii (gen. sg. od otium), gdzie kontrakcja dwóch samogloskowych /i/ nie dopuściła do asybilacji /t/. O całkowitym braku asybilacji /t/ we wcześniejszym okresie świadczą greckie 
Fonem /d/ [d], czyli obstruent zwarty przedniojęzykowy zębowy (dentalny) dźwięczny, wymawiany był jak np. pierwsza spółgłoska w pol. wyrazie dama czy dom. Zapisywany był literą $D / d$, jak np. w damno, modus itp. Występując (rzadko) w pozycji wygłosu wyrazowego, zwykle w formach jednosylabowych mocno związanych artykulacyjnie $\mathrm{z}$ wyrazami następującymi, wykazywał $\mathrm{w}$ języku potocznym tendencję do ubezdźwięcznienia; świadczą o tym inskrypcyjne (głównie pompejańskie) warianty ortograficzne typu: at quem (= ad quem), at porta (=ad portam), quot scripsi (= quod scripsi), quit ego (= quid ego), set intra (= sed intra), aput forum (= apud forum), aput exercitum (= apud exercitum).

Fonem $/ \mathrm{k} / \mathrm{k}$ ], czyli obstruent zwarty tylnojęzykowy (welarny) bezdźwięczny, wymawiany był jak np. pierwsza spółgłoska w pol. wyrazie kaprys czy krawat. W okresie klasycznym zapisywany był literą $C / c$, jak np. w: columna, cresco, lac, a jeśli występował przed szczelinowym $/ \mathrm{s} /$, sekwencja obu tych spółgłosek, tj. $/ \mathrm{k} /+$ $/ \mathrm{s} /$, zapisywana była ligaturą $X / x$, jak np. w: pax, existo, relaxare itp. Fonem ten występował również przed samogłoskami przednimi i dyftongami, a więc np. w: centum [kentum], celer [keler], percipio [perkipio] itp. O tym, że taka właśnie była artykulacja także $\mathrm{w}$ kontekście przed samogłoskami przednimi, świadczy kilka przesłanek:

1. grecka transkrypcja odnośnych wyrazów łacińskich, np.: $\kappa \dot{v} \sigma \omega \rho=$ łac. censor, Kıке́ $\rho \omega \nu=$ łac. Cicero, кí

2. brzmienie wczesnych (I-IV w. po Chr.) zapożyczeń celtyckich i germańskich z łaciny, np.: goc. kaisar 'cesarz' z lac. Caesar (por. niem. Kaiser); por też niem. Keller 'piwnica' ( $\leftarrow$ łac. cellarium), Kiste 'skrzynia' $(\leftarrow$ łac. cista);

3. poświadczona na inskrypcjach z okresu republikańskiego grafia: DEKEM[BRIS], MARKELLINO;

4. istnienie wariantów ortograficznych typu: pulcher/pulcer, Gracchi/Gracci (zob. niżej: problem aspiracji spółgłosek zwartych);

5. brzmienie kontynuantów łacińskich wyrazów w niektórych izolowanych dialektach romańskich, np. sard. kentu ( $\mathrm{z}$ łac. centum).

Ok. IV-V w. po Chr. dokonała się palatalizacja (zmiękczenie) i asybilacja (uszczelinowienie) wymowy tego fonemu przed samogłoskami przednimi /e/oraz $/ \mathrm{i} /{ }^{68}$, stąd jego palatalna, szczelinowa lub zwarto-szczelinowa artykulacja w romańskich kontynuantach takich wyrazów jak np. centum (por.: wł. cento, franc. cent, hiszp. ciento ${ }^{69}$. Przyjęta w Polsce tradycyjna konwencja wymowy łaciny uwzględnia tę późną zmianę (centum [tsentum]), należy jednak pamiętać, że nie ma żadnych śladów takiej artykulacji przed IV w. po Chr., w związku z czym odnoszenie jej do łaciny kla-

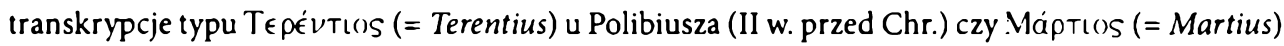
u Dionizjusza z Halikarnasu (I w. przed Chr.).

6i Por. też lacińską transkrypcję greckiego wyrazu kıӨápa jako cithara.

ak Także przed /i/ uspólgłoskowionym do /i/ [j] w pozycji przedsamogloskowej, jak np. w tercia.

ay Por także pochodzącą z VI w. po Chr. grecką transkrypcję lacińskiego toponimu:

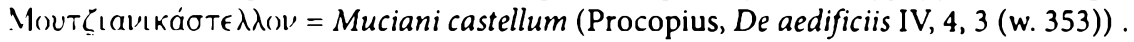


sycznej jest anachronizmem. Być może jednak w klasycznej łacinie fonem $/ \mathrm{k} /$ nie był artykułowany identycznie we wszystkich kontekstach fonologicznych, na co zdaje się wskazywać sposób jego zapisu na archaicznych inskrypcjach, gdzie przed samogłoskami przednimi /e/ oraz /i/ przeważnie zapisywany był literą $C^{0}$ (np.: FECED, LOCI), przed spółgłoskami i samogłoską /a/ literą $K^{\prime \prime}$ (np.: LIKTOR, KAPIAT), natomiast przed /o/ i /u/ literą $Q^{72}$ (np.: QOMES, QVROIS). Świadczyć to może o tym, że fonem ten reprezentowany był przez trzy różne pozycyjne allofony. Ponieważ jednak różnice $w$ sposobie artykulacji tej spółgłoski nie miały charakteru fonologicznego (dystynktywnego), nie istniała obiektywna potrzeba ich odzwierciedlania w piśmie, w związku z czym sukcesywnie uogólniona została notacja tego fonemu za pośrednictwem litery $C / c$ we wszystkich kontekstach. Użycie litery $K / k$ ograniczone zostało do kilku abrewiatur (KAL[ENDAE], K[AESO]), zaś literę Q/q zaczęto stosować wyłącznie w składzie dygrafu $Q V / q u$ zapisującego spółgłoskę labiowelarną $/ \mathrm{k}^{\mathrm{u}}$. Dodajmy, że rozpowszechnienie się użycia litery $\mathrm{C} / \mathrm{c}$ i praktyczne wyeliminowanie z pisowni litery $K / k$ świadczy także o tym, że literą $C / c$ zapisywany był ten sam fonem niezależnie od kontekstu: gdyby np. w nagłosie wyrazu columna wymawiana była inna spółgłoska niż np. w nagłosie wyrazu centum, nie uznano by litery $K / k$ za zbędną.

Fonem /g/ [g], czyli obstruent zwarty tylnojęzykowy (welarny) dźwięczny, wymawiany był jak np. pierwsza spółgłoska w pol. wyrazie gra czy gospoda. W okresie archaicznym zapisywany był literą $C / c$, np.: VIRCO [ưirgo], ECO [ego], a więc literą stanowiącą także jeden z pozycyjnych wariantów (obok $K / k$ i $Q / q$ ) zapisu spółgłoski bezdźwięcznej /k/. Oznacza to, że początkowo tylnojęzykowe spółgłoski /g/ i / k/ nie były rozróżniane w zapisie, co najprawdopodobniej było wynikiem oddziaływania praktyki stosowanej przez Etrusków, w których języku opozycja dźwięcznych i bezdźwięcznych nie była istotna, w związku z czym do zapisu tylnojęzykowych zamiennie mogli stosować przejęte z greki litery $\Gamma, K \mathrm{i}$. W Wacinie jednak opozycja dźwięczności jest jedną z kluczowych cech dystynktywnych (por. np. crus 'goleñ' : grus 'żuraw'), dlatego od ok. III w. przed Chr. dźwięczność spółgłoski tylnojęzykowej zaczęto zaznaczać diakrytem w postaci poziomej kreski dodanej do litery $C$, co dało początek literze $G^{73}$. Dawna pisownia (bez diakrytu) ograniczona została do dwu abrewiatur męskich imion, tj. C. (= Gaius) i CN. (= Gnaeus).

Około roku 500 po Chr. fonem /g/ uległ palatalizacji i asybilacji przed /e/ oraz /i/, co znalazło odzwierciedlenie w językach romańskich (por. np.: wł. generoso [dżeneroso], pagina [padżina] itp.). $Z$ kolei przed przedniojęzykowym nosowym /n/ nastąpiła nazalizacja /g/ i pojawienie się allofonu pozycyjnego, tj. półotwartego tylno-

") Litera ta stanowi kontynuant przejętej $z$ alfabetu greckiego litery "gamma" $(\Gamma)$.

7 Odpowiada ona greckiej literze „kappa” $(K)$.

12 Odpowiednik greckiej litery „koppa” (ð).

'3 Literę tę wprowadzić miał do alfabetu Spuriusz Karwiliusz, wyzwoleniec Spuriusza Karwiliusza Maksymusa Rugi, konsula z roku 234 przed Chr.; zob. Scaur., Orthogr. 15, 7-16. 
językowego nosowego [n] ${ }^{74}$, jak np. w: magnus [mannus], dignus [dinnus], regnum [rennum] itp. ${ }^{75}$ Przemawia za tym kilka przesłanek:

1. istnienie $w$ łacinie ogólnej tendencji do nazalizacji zwartych przed /n/; por. np.: gr. üாvos vs. łac. somnus, poświadczona inskrypcyjnie forma AMNEGAVIT (= abnegavit);

2. ortografia niektórych inskrypcji, np.: INGNES (= ignes), INGNOMINIAE (= ignominiae), SINGNIFER (= signifer), DINGNISSIME (= klas. dignissime), $\operatorname{SINNU}\left(=\right.$ signum $^{76}$;

3. uproszczenie zapisu struktur morfologicznych typu: in + gnosco $\rightarrow$ ignosco; con + gnatus $\rightarrow$ cognatus, in + gnarus $\rightarrow$ ignarus, które można objaśnić jako odzwierciedlenie efektu asymilacji [n] do [n], a następnie kontrakcji obu nosowych [n] $+[\mathrm{n}]$ $\rightarrow[n]$, wskutek czego wystarczało już użycie jednej tylko litery (tj. $g$ ) do zapisu [n] będącego rezultatem kontrakcji;

4. zwężenie krótkiej samogłoski /e/ do /i/ przed -gn- (np.: dignus $\leftarrow$ decet, lignum $\leftarrow$ lego), które jest charakterystyczne właśnie dla pozycji przed [n] (por. np.: gr. T'́ $\gamma \gamma \omega$ [tengō] = łac. tinguo [ting $\left.{ }^{\mathrm{u} o ̄}\right]$ ).

Rozwój w językach romańskich grupy spółgłoskowej zapisywanej w łacinie -gnzdaje się jednak wskazywać na zwartą raczej niż półotwartą, nosową artykulację spółgłoski /g/ przed/n/, co może wynikać z tego, iż w okresie poklasycznym szkoły wprowadziły w tym kontekście właśnie zwartą, "ortograficzną" wymowę, która najpierw utrwaliła się wśród kręgów wykształconych, a następnie nabrała bardziej powszechnego charakteru. Tę późną, „ortograficzną” wymowę zdają się też potwierdzać niektóre świadectwa epigraficzne $z$ anaptyktyczną (wtrąconą) samogłoską, np. DIGI$N A$ (= digna). Nagłosowe gn-, jak np. w Gnaeus, gnatus, gnosco, w epoce klasycznej najprawdopodobniej uległo uproszczeniu do $n-[n]$, o czym świadczy rozpowszechnienie się wariantów ortograficznych typu: natus, nosco itp. Częściowe zachowanie dawnej grafii $g n$ - tłumaczyć można zapewne prestiżem tradycji (Gnaeus) oraz zachowaniem analogii wobec form złożonych (cognatus, cognosco), z czym być może wiązało się także wspomniane wyżej późniejsze przywrócenie zwartej, „ortograficznej” wymowy /g/ w tym kontekście ${ }^{i \top}$.

Fonem $/ \mathrm{k}^{\mathrm{u}} /\left[\mathrm{k}^{\mathrm{u}}\right]$, czyli obstruent zwarty tylnojęzykowy labialny (labiowelarny) bezdźwięczny, nie posiada bezpośredniego odpowiednika w języku polskim; wymawiany był ze zwarciem welarnym jak głoska $[\mathrm{k}], \mathrm{z}$ równoczesnym wysunięciem ku przodowi i zaokrągleniem warg jak przy wymawianiu [un]. W lacinie klasycznej

it Wymawianego jak ang. -ing np. w wyrazie sleeping [sli:pin], czy - n-np. w pol. bank [bank].

is Najprawdopodobniej $w$ okresie archaicznym artykulacja taka miała miejsce także $w$ nagłosie wyrazowym zapisywanym gn-, jak np. w Gnaeus czy gnatus. W epoce klasycznej nagłos ten prawdopodobnie uprościł się do /n-/; więcej na ten temat zob. Stephens $(1978,1980)$.

in Zob. niżej uwagi dotyczące fonemu /n/ przed spółgłoskami tylnojęzykowymi, gdzie mowa jest o tym, że w takich wyrazach, jak np. uncus czy ingens, litera n notuje właśnie [n]. Można przypuszczać, że n częściej niż g notowało [n] i latwiej było kojarzone z tą artykulacją, dlatego okazjonalnie pojawiało się także w zapisach typu ingnominiae.

"Por. Maur., Litt. 894: ' $g$ ' tamen sonabit illic, quando 'Gnaeum' enuntio. 
notowany był za pośrednictwem dygrafu $Q V / q u$. O tym, że najprawdopodobniej dygraf ten nie zpisywał sekwencji dwóch fonemów, tj. zwartej / $\mathrm{k}$ i glajdu /u/, lecz właśnie pojedynczy fonem labiowelarny $/ \mathrm{k}^{\mathrm{\omega}} /$, który cechował się nieco inną artykulacją niż welarne / $/ \mathrm{k}$ zapisywane literą $C / c$, świadczy kilka przesłanek:

1. Gramatycy starożytni uznawali element labialny (un) za integralną część (pojedynczej) głoski zapisywanej z użyciem litery $Q / q$ i mówili o jej wymowie z zaokrąglonymi lub wyciągniętymi ku przodowi wargami ${ }^{78}$.

2. Pomijając nieliczne wyjątki, sylaba zawierająca krótką samogłoskę, oddzielona od następnej sylaby przez element fonologiczny zapisywany jako -qu-, jest w lacinie zawsze sylabą krótką (lekką) ${ }^{79}$, a więc pozostaje sylabą otwartą, jak np. pierwsza sylaba w wyrazie equi 'konie', która w wierszu zawsze zajmuje pozycję sylaby krótkiej. Wskazuje to, że zapis qu notuje pojedynczą głoskę, a nie sekwencję dwóch spółgłosek $/ \mathrm{k} /+/ \mathrm{u} /$. Trudno też przyjąć, że ewentualna sekwencja spółgłosek $/ \mathrm{k} /+$ /ứ/, zapisywana przez qu, mogłaby mieć status grupy nagłosowej sylaby (a więc status analogiczny do sekwencji muta cum liquida), jako że w łacinie we wszystkich przypadkach połączenie spółgłoski zwartej $z$ /ụ/ sprawia, że poprzedzająca je sylaba jest zamknięta, i tym samym długa (ciężka), jak np. w advenio [adụenio], gdzie pierwsza sylaba, mimo że zawiera krótką samogłoskę, jest długa; poza tym glajd /ụ/ w językach romańskich we wszystkich kontekstach przekształcił się w wargowo-zębową spółgłoskę szczelinową (por. wł. volare, avvenire), natomiast element labialny notowany przez qu zmianie tej nie podległ (por. wł. quando, quinto itp. $)^{80}$.

3. Przeciwko traktowaniu elementu zapisywanego qu jako bifonematycznej (dwufonemowej) sekwencji / $\mathrm{k} / \mathrm{l}$ / $/$ przemawiają także reguły fonotaktyczne dotyczące dystrybucji /úk. Chodzi o to, że fonem ten nie wchodzi nigdy w skład grup złożonych $\mathrm{z}$ trzech spółgłosek, w związku czym sekwencje zapisywane squ (jak np. $\mathrm{w}$ squalor, quisque), rqu (jak w torqueo) czy nqu (jak w relinquo) przy interpretacji bifonematycznej qu musiałyby zostać uznane za wyjątki. Poza tym nagłosowe trójelementowe grupy konsonantyczne składają się zawsze $z$ /s/, zwartej i płynnej (jak np. w strepitus), w związku z czym w nagłosowym squ- (jak np. w squalor), traktowanym jako sekwencja trzech fonemów, ostatni element (tj. /un/) stanowiłby odpowiednik płynnej, a tymczasem możliwość tworzenia grupy /sụ/ (jak np. w suavis), wobec niedopuszczalności grupy złożonej z /s/ i płynnej (a więc np. /sr/ lub /sl/), wskazuje na przynależność /ụ/ do innej klasy dystrybucyjnej niż płynne, co także utrudnia włączenie squ- w schemat struktury łacińskich trójspółgłoskowych grup konsonantycznych ${ }^{81}$.

${ }^{74}$ Por. np. Pompeius (GL V, 104): [in qu, $u$ ] pars est litterae praecedentis; zob. też Scaur., Orthogr. 15, 19-16,2; Marius Victorinus, Ars grammatica (GL VI, 34).

${ }_{7 y}$ Wyjątkiem jest np. u Lukrecjusza pierwsza sylaba w wyrazie aqua (De rerum natura 6, 552; ibid. 868,1072$)$ i w wyrazie liquidus $(1,349 ; 3,427 ; 4,1259)$.

"No Na temat zob. też Long., Orthogr. 58,19-59,8.

*I Cf. Marotta (1982: 1194-1195). 
4. Fonem $/ \mathrm{m} /$ przed elementem zapisywanym jako -qu- pozostaje bez zmian, jak $\mathrm{np}$. w quamquam, quicumque, numquam, podczas gdy przed / $\mathrm{k}$ / (zapisywanym literą $c$ ) fonem ten ulega asymilacji co do miejsca artykulacji i reprezentowany jest przez tylnojęzykowy allofon [n] zapisywany literą $n^{82}$, np.: tum $+c(e) \rightarrow$ tunc [tunk], am(bo) + ceps $\rightarrow$ anceps [ankeps]; może to sugerować, że - w przeciwieństwie do fonemu $/ \mathrm{k} /(c)$ - immanentną cechą wymowy $/ \mathrm{k}^{\mathrm{u}} /(q u)$ była labializacja, która pozwalała na zachowanie labialnej artykulacji poprzedzającego fonemu $/ \mathrm{m} /$ (jak w numquam itp. $)^{83}$.

5. Element fonologiczny zapisywany $w$ łacinie jako - $q u$ - historycznie niemal zawsze wywodzi się z pojedynczego, labiowelarnego fonemu indoeuropejskiego, który w innych językach tej rodziny reprezentowany jest również przez pojedynczy fonem, np.: łac. quod = skr. kad, osk. pud; łac. quis, quid = gr. Tls, TL.

$\mathrm{W}$ późnej poezji (od V w. po Chr.) sylaba z krótką samogłoską przed -qu-coraz częściej zajmuje pozycję sylaby długiej (ciężkiej), co może świadczyć o tendencji do artykułowania $/ \mathrm{k}^{\mathrm{u}} /$ jako struktury bifonematycznej (dwugłoskowej). Również stosowana $\mathrm{w}$ Polsce konwencja wymowy łaciny przewiduje artykulację -qu-jako grupy spółgłoskowej, analogicznej do nagłosowych grup w takich wyrazach jak np. pol. kwaśny czy kwitnąć. Należy jednak zaznaczyć, iż za tym, że wymowa taka nie była praktykowana w starożytności, przemawiają nie tylko przytoczone wyżej argumenty, ale i greckie transkrypcje odnośnych wyrazów łacińskich na zabytkach epigraficznych z okresu klasycznego (augustowskiego), a więc np.: KOrA lub KOA (= QUA), czy KYINTI $\Lambda I O \Sigma$ (= QUINTILIUS); warto też dodać, że bezdźwięczny spirant wargowo-zębowy notowany był w łacinie literą $F / f$ (jak np. w facere), a jego dźwięczny odpowiednik (taki, jak np. pierwsza spółgłoska w pol. walka) w systemie fonologicznym klasycznej łaciny w ogóle nie istniał.

Fonem $/ \mathrm{g}^{\mathrm{u} /}\left[\mathrm{g}^{\mathrm{\psi}}\right]$, czyli obstruent zwarty labiowelarny dźwięczny notowany dygrafem $G V / g u$, to również pojedyncza głoska, choć trudniej to wykazać, gdyż pojawia się ona w lacinie tylko po /n/ [n], jak np. w: lingua, sanguis itp., co powoduje, że nie występuje nigdy w nagłosie wyrazu, a poprzedzająca ją sylaba jest zawsze ciężka. Jednak ponieważ wszystkie pozostałe spółgłoski zwarte występują w parach dźwięczna : bezdźwięczna (/p/ : /b/,/t/ : /d/ itp.), można uznać, że i / $/ \mathrm{k}^{\mathrm{u}}$ miało $\mathrm{w}$ tym systemie swój dźwięczny odpowiednik, właśnie w postaci /g\%. Dodatkową przesłankę stanowić może sposób zapisu tego fonemu (tj. posługiwanie się dygrafem gu), który znajduje paralelę $w$ dygraficznym zapisie qu notującym bezdźwięczny odpowiednik tej głoski, a więc $/ \mathrm{k}^{\mathrm{u}}$. Pewnej argumentacji przemawiającej przeciwko interpretowaniu gu jako zapisu sekwencji dwufonemowej (tj. /g/ + /un/), a dokładniej ngu jako zapisu sekwencji trójfonemowej, dostarczyć mogą przywołane już wyżej (w odniesieniu do

k2 Zob. niżej uwagi dot. fonemu /n/.

*3. Argument ten nieco osłabiają poświadczenia o istnieniu wariantów ortograficznych typu quanquam (zob. Prisc. Inst. gram. 1,38, 17-19) oraz możliwość interpretacji standardowej pisowni typu quamquam, quicumque jako efektu oddziaływania analogii względem quam, cum itd. Na ten temat zob. też Allen (1965: 16-20). 
$/ \mathrm{k}^{\mathrm{u}} /$ ) reguły fonotaktyczne, mówiące o nieuczestnictwie /un/ w składzie trójelementowych grup spółgłoskowych. Na dodatek w grupach tych rozpoczynających się od /n/ zwarta jest zawsze bezdźwięczna (cancri, ventri), w związku z czym istnienie pary minimalnej linquas (con. praes. czasownika linquo) : linguas (acc. pl. rzeczownika lingua) stanowiłoby wyjątek od prawdopodobnej neutralizacji opozycji dźwięczności w tym kontekście ${ }^{84}$. Jak się wydaje, fonem /gu/ artykułowany był jak głoska [g] z zaokrągleniem warg jak przy wymowie [u्n].

Obie spółgłoski labiowelarne $/ \mathrm{k}^{\mathrm{u}} / \mathrm{i} / \mathrm{g}^{\mathrm{u}} /$ przed samogłoskami tylnymi $/ \mathrm{u} / \mathrm{i} / \mathrm{o} /$ na skutek procesu dysymilacji prawdopodobnie traciły komponent labialny, który absorbowany był przez następujące po nich labializowane samogłoski, tzn.: $/ \mathrm{k}^{\mathrm{u}} \mathrm{u} / \rightarrow$ $/ \mathrm{ku} /, / \mathrm{k}^{\mathrm{u}} \mathrm{o} / \rightarrow / \mathrm{ko} /, \mathrm{g}^{\mathrm{u}} \mathrm{u} / \rightarrow / \mathrm{gu} /, / \mathrm{g}^{\mathrm{u}} \mathrm{o} / \rightarrow / \mathrm{go} /$. Zdają się na to wskazywać przypadki użycia litery $c \mathrm{w}$ odnośnych kontekstach, a także wypowiedzi gramatyków starożytnych ${ }^{85}$. Owa tendencja do utraty labialności ma archaiczny rodowód (por.: secundus $\leftarrow$ *sequondus, cottidie $\leftarrow$ arch. quottidie, cum $\leftarrow$ arch. quom, cuius obok quis), często jednak rzeczywistą wymowę zaciemnia oficjalna ortografia uwzględniająca reguły analogii w ramach fleksji, a więc np.: pisownia equus [ekus] pod wpływem equi [ek ${ }^{\mathrm{u}} \mathrm{i}$, pisownia unguunt [ungunt] pod wpływem unguit [ung ${ }^{\mathrm{u} i t]}$ itd. $Z$ drugiej strony nie można wykluczyć także analogii w wymowie, a więc np. [ek $\left.{ }^{u} u s\right]$ pod wpływem [ek ${ }^{\mathrm{i}} \mathrm{i}$. Niemniej jednak $\mathrm{w}$ okresie klasycznym i późniejszym delabializacja ta była zapewne cechą charakterystyczną języka potocznego, o czym świadczy ortografia odpowiednich wyrazów na naściennych inskrypcjach pompejańskich, np.: comodo (= quomodo) czy hiperpoprawne quoservis (= conservis), oboczność form typu antiquus/anticus (por. wł. antico), a także napomnienia w Appendix Probi: equs non ecus, coqus non cocus, vacua non vaqua, aqua non acqua ${ }^{86}$, coquens non cocens, coqui non coci, exequiae non execiae. Co więcej, poświadczone $\mathrm{w}$ tym ostatnim źródle formy cocens [kokens] i coci [koki], w których można się dopatrzeć oddziaływania analogii względem coquus/cocus [kokus], a przede wszystkim forma execiae, świadczą o postępującym procesie uniezależniania się delabializacji $/ \mathrm{k} /$ od fonetycznego kontekstu stanowionego przez następującą samogłoskę /u/ lub /o/.

\subsection{PROBLEM ASPIRACJI OBSTRUENTÓW ZWARTYCH}

W łacinie nie istniała fonologiczna opozycja spółgłosek zwartych nieaspirowanych (nieprzydechowych) i aspirowanych (przydechowych), w przeciwieństwie do greki, gdzie wśród bezdźwięcznych, obok szeregu nieaspirowanych /p/,/t/, /k/ (notowanych odpowiednio literami $\pi, T, \kappa)$, istniał również szereg aspirowanych $/ \mathrm{p}^{\mathrm{h}} /$,

k4 Cf. Marotta (1982: 1195).

${ }^{* 5}$ Por. np. Long., Orthogr. 59, 3-4: auribus quidem sufficiebat ut 'equus' per unum ' $u$ ' scriberetur, ratio tamen duo exigit.

"6 Forma vaqua ma charakter hiperpoprawny, natomiast zapis acqua jest swoistą ortograficzną hybrydą. 
$/ \mathrm{t}^{\mathrm{h}} /, / \mathrm{k}^{\mathrm{h}} /$ (notowanych odpowiednio literami $\phi, \theta, \chi$ ). Łacińskie spółgłoski zwarte, w tym bezdźwięczne, generalnie artykułowane były w sposób nieaspirowany, czego dowodzi grecka transkrypcja wyrazów łacińskich, w której łacińskie spółgłoski zwar-

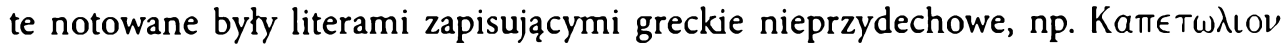
(= Capitolium). Jednak inny fakt świadczyć może o tym, że łacińskie zwarte bezdźwięczne w nagłosie wyrazu, zwłaszcza przed samogłoską, wymawiane były z lekkim przydechem (mniejszym jednak niż greckie $/ \mathrm{p}^{\mathrm{h}} /, / \mathrm{t}^{\mathrm{h}} /, / \mathrm{k}^{\mathrm{h}} /$ ). Chodzi mianowicie o to, że w niektórych wczesnych łacińskich zapożyczeniach $z$ greki greckie bezdźwięczne nieprzydechowe w nagłosie wyrazów znajdują odpowiedniki w postaci dźwięcznych, np.: guberno $\leftarrow \kappa u \beta \epsilon ́ \rho \nu \omega$, buxus $\leftarrow \pi u ́ \xi o s$ itp. ${ }^{87}$ Może to sugerować, iż łaciński zwarty bezdźwięczny nagłos wyrazowy cechował się lekką apiracją i dlatego, aby oddać grecki nagłos zwarty nieaspirowany, uciekano się do dźwięcznej, która nigdy nie była wymawiana $\mathrm{z}$ przydechem.

$\mathrm{Z}$ kolei greckie zwarte aspirowane (czyli $/ \mathrm{p}^{\mathrm{h}} /, / \mathrm{t}^{\mathrm{h}} /, / \mathrm{k}^{\mathrm{h}} /$, zapisywane odpowiednio literami $\phi, \theta, \chi)$ początkowo transkrybowane były w łacinie wyłącznie za pośrednictwem liter $P, T$ i $C$, a więc np.: PILEMO (= gr. $\Phi(\lambda \hat{\eta} \mu \mathrm{ov})$, CORINTO (= Kópı $v \theta o s$ ), ANTIOCO (= AvTíoXOS), i parę wczesnych pożyczek przetrwało w takiej formie, np.:

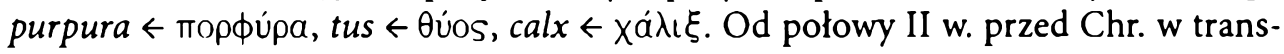
krypcji tych fonemów zaczynają być stosowane dygrafy $p h$, th, ch, a więc pojawiają się inskrypcyjne zapisy typu: PHILIPPUS, CORINTHUS, CHORUS. Jest to zapewne efekt wzrostu świadomości co do fonetycznej odrębności greki, który zaznaczył się w środowisku rzymskich warstw wykształconych, a zwłaszcza w kręgach rozwijającego się filhellenizmu. Można przypuszczać, że świadomość ta przejawiła się zarówno $\mathrm{w}$ tendencji do wierniejszego odtwarzania brzmienia greckich spółgłosek aspirowanych $\mathrm{w}$ mowie, jak i w posługiwaniu się dygrafami przy ich zapisie. Jednak wkrótce, już od końca II w. przed Chr. poczynając, dygrafy pojawiają się również w notacji niektórych rdzennie lacińskich wyrazów, a także zapożyczeń, których formy wyjściowe nie zawierały spółgłosek aspirowanych, np.: pulcher, lachrima, sepulchrum, triumphus. Zjawisko to, sugerujące wprowadzenie w tych (i innych) wyrazach spółgłosek przydechowych, stanowi, jak się wydaje, refleks rozpowszechnienia się mody na naśladownictwo greckiego sposobu wymowy oraz języka warstw wykształconych $^{88}$, chociaż niektóre spośród tych innowacji przyjęły się także w języku literac$\mathrm{kim}^{89}$. Zapewne nie bez znaczenia w tym względzie pozostał również wspomniany wcześniej fakt naturalnej tendencji do aspiracji łacińskich spółgłosek w określonych kontekstach, ujawniającej się prawdopodobnie $\mathrm{z}$ różnym natężeniem $\mathrm{w}$ różnych

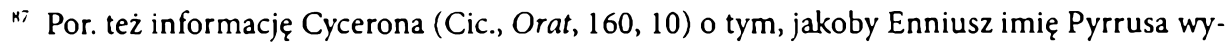
mawiać miał „Burrus”.

${ }^{\text {k8 }}$ Por. Quint., Inst. 1, 5, 20: Diu [...] servatum ne consonantibus adspirarent, ut in 'Graccis' et 'triumpis'. Erupit brevi tempore nimius usus, ut 'choronae', 'chenturiones', 'praechones' adhuc quibusdam inscriptionibus maneant. Zob. też Gell., Noc. Att. 2, 3, 3.

*y Wiemy np., że Cyceron (Cic., Orat., 160) akceptował formy pulcher, triumphus, Cethegus, Carthago, ale odrzucał takie jak sepulchrum, chorona, lachrima. 
regionach i w różnych grupach społecznych. Niefonologiczny charakter tej aspiracji nie wymagał stosowania specjalnej grafii, ale skoro już raz dygrafy pojawiły się w łacińskiej pisowni (dla wierniejszego zapisu brzmienia greckich wyrazów), zakres ich używania szybko uległ rozszerzeniu. Należy przy tym zaznaczyć, że notowane nimi głoski łacińskie do końca starożytności zachowały charakter spółgłosek zwartych przydechowych, a ich uszczelinowienie odpowiednio do /f/, / $\theta / \mathrm{i} / \mathrm{h} /$ nastąpiło dopiero u progu średniowiecza.

\subsection{OBSTRUENTY SZCZELINOWE (SPIRANTY)}

Grupa obstruentów szczelinowych obejmowała 3 fonemy: /f/, /s/ i /h/, z których wszystkie artykułowane były bezdźwięcznie.

Fonem /f/ [f], czyli spirant wargowo-zębowy (labiodentalny), artykułowany był jak np. pierwsza spółgłoska w pol. wyrazach fasola, fraszka czy środkowa spółgłoska w wyrazie sufit. Taką właśnie wargowo-zębową wymowę tego fonemu potwierdzają świadectwa gramatyków starożytnych ${ }^{90}$. Zapisywany był literą $F / f^{91}$, jak np. w: facere, frater, defendere, rufus. Jego dystrybucja ograniczona była do nagłosu i śródgłosu wyrazowego; nie występował w wygłosie wyrazowym.

Fonem /s/ [s], czyli spirant przedniojęzykowy dziąsłowy (alweolarny), wymawiany był jak np. pierwsza spółgłoska w pol. wyrazach sanie, sen, sport czy środkowa spółgłoska w wyrazach basen, deser. Zapisywany był literą $S / s$, jak np. w: solus, stare, casus. Jeżeli poprzedzony był spółgłoską $/ \mathrm{k} /$, sekwencja obu fonemów $(/ \mathrm{k} / \mathrm{l} / \mathrm{s} /)$ zapisywana była ligaturą $X / x$, jak np. w: dixi, exaudio, nox itp. Występował w nagłosie, śródgłosie i wygłosie wyrazu, przy czym długie /ss/ pojawiało się wyłącznie w pozycji interwokalicznej po krótkiej samogłosce, jak np. w missus (wobec misi), oraz wyjątkowo przed glajdem /un/, jak np. w assuetus ${ }^{92}$.

We wczesnej łacinie wygłosowe /s/ poprzedzone krótką samogłoską wykazywało tendencję do osłabiania się, czego wyrazem jest pomijanie go w zapisie widoczne na wielu archaicznych inskrypcjach (np. CORNELIO = klas. Cornelius). Od początku II w. przed Chr. /s/ w tej pozycji jest już konsekwentnie notowane, jednak we wcze-

"Np. Marius Victorinus, Ars grammatica (GL VI, 34): F litteram imum labrum superis imprimentes dentibus [...] leni spiramine proferemus.

${ }^{91}$ Litera ta stanowi kontynuant przejętej z alfabetu greckiego litery „digamma”, która zapisywała tam spirant labiodentalny dźwięczny /v/, artykułowany jak np. pierwsza spółgłoska w pol. wyrazach woda, walka, wentyl. Dlatego na najstarszych inskrypcjach laciński bezdźwięczny fonem /f/ zapisywany był za pomocą dygrafu $F H$, tzn. dla zaznaczenia bezdźwięcznego charakteru zapisywanej spółgłoski posługiwano się dodatkowo literą $H$ jako swoistym znakiem sygnalizującym ubezdźwięcznienie; por. np. FHE : FHAKED (= klas. fecit) w napisie na słynnej Fibula Praenestina z ok. 600 r. przed Chr. Z czasem, ponieważ nie istniał w łacinie dźwięczny odpowiednik /f/, czyli $/ \mathrm{v} /$, i tym samym nie istniało niebezpieczeństwo błędnego odczytania wartości fonologicznej litery $F$, zaniechano dopisywania do niej $H$.

${ }^{2}$ Por. np. Ov., Ib., 10. 
snej poezji sylaba, do której należy, przed nagłosową pojedynczą spółgłoską kolejnego wyrazu zajmuje niekiedy pozycję sylaby lekkiej (a więc traktowana jest jak sylaba otwarta) ${ }^{93}$. Według Cycerona tego rodzaju redukcja wygłosowego /s/, przed spółgłoskowym nagłosem kolejnego wyrazu, uchodziła niegdyś za przejaw językowego wyrafinowania (politius), natomiast w czasach jemu współczesnych trąciła pewnym nieokrzesaniem (subrusticum) ${ }^{94}$.

W okresie przedliterackim /s/ w pozycji interwokalicznej (międzysamogłoskowej) na krótko udźwięczniło się do /z/, a następnie szybko uległo rotacyzmowi, prze$\mathrm{kształcając} \mathrm{się} \mathrm{w} / \mathrm{r} /$ zapisywane literą $R / r\left(\mathrm{np}\right.$. arch. honoses $\rightarrow \mathrm{klas}$. honores $\left.{ }^{95}\right)$. Proces ten zakończył się ok. połowy IV w. przed $\mathrm{Chr} .{ }^{96}$ Istniejące w późniejszej łacinie /s/ interwokaliczne pochodzi najczęściej albo z dawniejszego długiego /ss/, które skróciło się po długiej samogłosce lub dyftongu (np. cāssus $\rightarrow$ cãsus, divīssio $\rightarrow$ divisio, caussa $\rightarrow$ causa, religiōssus $\rightarrow$ religiōsus) $)^{97}$, albo $\mathrm{z}$ dawniejszego /s/ nagłosowego, które zachowało się bez zmian w złożeniach na granicy morfemów, umożliwiając $\mathrm{w}$ ten sposób identyfikację struktury słowotwórczej formacji (np.: de $+\operatorname{sino} \rightarrow$ desino, $n i+$ $s i \rightarrow$ nisi), albo też pozostało bez zmian $\mathrm{w}$ zapożyczeniach $\mathrm{z}$ innych języków, jak np. w pochodzących z greki wyrazach basis czy Musa ${ }^{98}$.

Należy podkreślić, że występujące w lacinie klasycznej /s/ międzysamogłoskowe nie wykazywało tendencji do udźwięczniania i zachowało swój bezdźwięczny charakter do końca starożytności ${ }^{99}$. Dźwięczne /z/ Rzymianie artykułowali wyłącznie wymawiając zawierające je greckie wyrazy, a do jego zapisu używali litery $Z / z$.

${ }^{43}$ Zob. np. Enn., Ann., 280; Lucilius 7, 293; Lucretius 2, 53; Catull. 116, 8.

94 Cf. Cic., Orat. 161: Quin etiam, quod iam subrusticum videtur, olim autem politius, eorum verborum, quorum eaedem erant postremae duae litterae quae sunt in 'optumus', postremam litteram detrahebant, nisi vocalis insequebatur. Ita non erat ea offensio in versibus quam nunc fugiunt poetae novi. Sic enim loquebamur: „Qui est omnibu princeps”, non „omnibus princeps, et: „Vita illa dignu locoque", non "dignus".

45. W rzeczownikach i przymiotnikach, których formy nom. sg. i przypadków zależnych zawierały w ostatniej sylabie tematu samogłoskę o tej samej barwie, doszło do analogicznego przekształcenia w/r/ także wyglosowego /s/ w nom. sg., jak np. w: honor, honoris (w przeciwieństwie do genus, generis); zmiana ta nie objęła jednak formacji jednosylabowych typu: flos, floris.

${ }^{46}$ Cicero przekazuje informację (Fam. 9, 21, 2), że Lucius Papirius Crassus, cenzor z roku 338, jako pierwszy z rodziny przestał być nazywany Papisius (primum Papisius est vocari desitus).

4i Skrócenie to prawdopodobnie nastąpiło w drugiej połowie I w. przed Chr., na co wskazują dane inskrypcyjne, które od tego czasu poczynając coraz częściej w wyżej wymienionych kontekstach przekazują zapis pojedynczej litery s. Z kolei Kwintylian stwierdza (Quint., Inst. 1, 7, 20), że jeszcze w czasach Cycerona i Wergiliusza powszechna była pisownia podwójnego ss, a rękopisy obu tych wielkich autorów miałyby wskazywać, że oni sami także pisownię tę praktykowali. Do końca starożytności utrzymało się długie /ss/ po samogłoskach krótkich, jak np. w possum, cessi, missus itp.

"Pewne znaczenie miala zapewne także obecność / $\mathrm{r} / \mathrm{w}$ nagłosie kolejnej sylaby, wpływająca na zachowanie /s/ ze względu na dysymilację, jak np. w Caesarem, miserum. Więcej na temat rotacyzmu zob. Safarewicz (1932), Baldi (1994).

yy Świadczą o tym chociażby greckie transkrypcie, w których w miejscu lacińskiego s pojawia się zawsze $\sigma$, nigdy $\zeta$, jak np. w haīa $\rho$ (= łac. Caesar). Dodajmy, że na bezdźwięczność tego 
Pojawiła się ona w łacińskim alfabecie ok. I w. przed Chr. i używana była do transkrypcji greckiej litery "dzeta” (Z/z), która w tym czasie zapisywała już właśnie dźwięczny

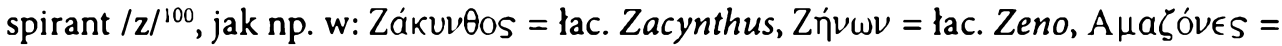
lac. Amazones ${ }^{101}$. Okazjonalnie litera $Z / z$ (obok $S / s$ ) stosowana również była do transkrypcji greckiej „sigmy” $(\Sigma / \sigma)$, jeśli ta zapisywała /z/ pochodzące $\mathrm{z}$ udźwięcznienia /s/ przed spółgłoskami dźwięcznymi, jak np. w: $\sigma \mu a ́ p a \gamma \delta o s=$ lac. zmaragdos (obok smaragdos), ă $\sigma \beta \in \sigma \tau O S=$ lac. azbestos (obok asbestos), $\Lambda \in \sigma \beta i a=$ lac. Lezbia (obok Lesbia). Dodajmy, że pisownia ta była krytykowana przez gramatyków, ale rozpowszechniona w inskrypcjach ${ }^{102}$.

Fonem /h/ [h] był spirantem krtaniowym (glottalnym), wymawianym jak np. pierwsza głoska w pol. wyrazach hałas, hetman, hodowca czy środkowa głoska w wyrazach moher, juhas. Zapisywany był literą $H / h$, jak np. w wyrazach: habeo, heres, veho, nihil. Geneza tego fonemu, jego właściwości artykulacyjne oraz dystrybucja w obrębie leksyki sprawiły, że pozycja, jaką zajmował w ramach łacińskiego systemu fonologicznego, była marginalna.

Jego genezę wiąże się przede wszystkim $\mathrm{z}$ rozwojem odziedziczonej ze wspólnoty praindoeuropejskiej zwartej spółgłoski aspirowanej $/ \mathrm{g}^{\mathrm{h}} /$, która $\mathrm{w}$ łacinie $\mathrm{w}$ nagłosie wyrazowym przed samogłoską uległa przekształceniu w słaby spirant krtaniowy /h/; stąd obecność tego fonemu w takich wyrazach, jak np.: habere, heres, hortus, hostis. $\mathrm{W}$ pozycji śródgłosowej praindoeuropejskie $/ \mathrm{g}^{\mathrm{h}} /$ prawdopodobnie przekształciło się $\mathrm{w} / \mathrm{g} /{ }^{103}$, co oznacza, że poza pierwotnie nagłosowym nie istniało $\mathrm{w}$ łacinie $/ \mathrm{h} / \mathrm{wywo}$ dzące się bezpośrednio ze wspólnoty indoeuropejskiej. Śródgłosowe /h/ występowało więc w tym języku jedynie jako pierwsza głoska drugiego członu w wyrazach słowotwórczo złożonych, takich jak np.: co-hors, ni-hil ( ${ }^{*}$ ne-hilum), per-hibeo, de-hinc, a także w bardzo niewielkiej liczbie leksemów (veho, traho, mihi) stanowiących prawdopodobnie zapożyczenia $\mathrm{z}$ innych dialektów italskich. Poza tym nagłosowe przedsamogłoskowe /h-/ było notowane w pewnej grupie wyrazów obcego, najczęściej greckiego pochodzenia (haeresis, hebdomada, hilarus, hora, histrio), grupie wyrazów o funkcji ekspresywnej (heu(s), hem, hinnio, hio) oraz wyrazów o nieznanej bądź niepewnej etymologii (haereo, harena, haruspex, harundo, haud, hebes, herba, hircus,

fonemu w sąsiedztwie spółgłosek wskazuje z kolei ubezdźwięcznienie poprzedzających ją zwartych, jak np. w scripsi (wobec scribo).

(1(k) Ze względu na pochodzenie tego spirantu z wcześniejszego [dz] lub [zd] (zachowanego jeszcze w poezji Homera) cechował się on, przynajmniej w pozycji interwokalicznej, długim iloczasem ([zz]) sprawiając, że poprzedzająca sylaba z krótką samogłoską była sylabą zamkniętą i tym samym długą (ciężką); por też np. Probus (GL IV, 256): $z$ [...] quoniam duplex est, facit positione longam.

1'II Wcześniej dla potrzeb transkrypcji tej litery (i zapisu notowanego nią dźwięcznego /z/)

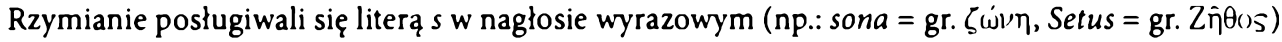
oraz geminatą $s s w$ śródgłosie (np.: massa $=$ gr. $\mu a ́ \zeta a$, malacisso $=\mu a \lambda a \kappa i \zeta \omega)$.

1112 Więcej na temat statusu spółgłoski /s/ w' obrębie łacińskiego systemu fonologicznego, jej właściwości fonotaktycznych i tendencji rozwojowych, zob. Porzio Gernia (1973).

103 Jak np. w: figulus, ego, tragula. 
honor). W wygłosie po samogłosce pojawiało się tylko w wykrzyknieniach typu $a h$, eh. Niska frekwencja tego fonemu skutkująca jego niewielką efektywnością funkcjonalną, a także jego mała wyrazistość fonetyczna i artykulacyjna usytuowały go na peryferii łacińskiego systemu konsonantycznego. Słabo z nim zintegrowany, cechował się niestabilnością, która przejawiła się wyraźną tendencją do redukcji i zaniku, widoczną od epoki archaicznej poczynając. Powołać się w tym względzie można na leksemy typu: nemo ( ${ }^{*}$ ne-hemo), debeo $\left(\leftarrow^{*}\right.$ de-hibeo $\leftarrow^{*}$ de-habeo), które dowodzą, iz interwokaliczne /-h-/ miało w epoce przedliterackiej artykulację na tyle słabą, że nie zapobiegło kontrakcji otaczających je samogłosek. $Z$ kolei formy typu diribeo $(\leftarrow$ dis-habeo) wskazują, że /h/ występujące po /s/ nie stanowiło przeszkody dla procesu rotacyzmu (tj. przekształcenia się/s/ w/r/ - zob. wyżej), któremu podlegało /s/ w pozycji interwokalicznej. W odniesieniu do wczesnej epoki literackiej wskazówek dostarczają badania metryczne, z których wynika, że w komediach Plauta i Terencjusza formy cohibeo, prohibeo wymawiane były trójsylabowo, antehac dwusylabowo a dehinc jednosylabowo ${ }^{104}$. Gdy chodzi o wyrazy $z$ nagłosowym przedsamogłoskowym /h-/, to przeprowadzone analizy wskazują, że w tekstach Plauta funkcjonowały one analogicznie do wyrazów $z$ nagłosem wokalicznym, tzn. dopuszczały elizję wygłosowej samogłoski wyrazu poprzedzającego, a potwierdzone przypadki tolerowania (nie elidowania) wygłosowej samogłoski (przed sekwencją /h-/ + samogłoska w nagłosie kolejnego wyrazu) wynikać mogą z szeregu różnych przyczyn o charakterze metryczno-syntaktycznym i nie stanowią jednoznacznego dowodu na mocny, spółgłoskowy status nagłosowego /h/, które w epoce plautyńskiej najprawdopodobniej nie było już artykułowane lub zostało ograniczone do słabego przydechu ${ }^{105}$.

Ok. połowy II w. przed Chr. w inteligenckich kręgach filhellenów pojawiła się tendencja do przywrócenia / $\mathrm{h} / \mathrm{w}$ mowie i piśmie, inspirowana zapewne funkcjonowaniem aspiracji w grece, która w tym środowisku cieszyła się dużym prestiżem ${ }^{106}$. Właściwe stosowanie /h/ stało się wówczas jednym $\mathrm{z}$ wyznaczników wysokiej kultury i atrybutem języka ludzi wykształconych ${ }^{107}$. W nauczaniu szkolnym poprawna wymowa i pisownia tej głoski były podtrzymywane do końca starożytności ${ }^{108}$, jednak w żywym języku mówionym, zwłaszcza warstw słabiej wykształconych, prawdopo-

III Cf. Porzio-Gernia (1974: 59); tam też szczególowa analiza statusu /h/ w lacinie.

${ }^{115}$ Ibid. 73-85; por. też Quint., Inst. 1, 5, 20: Parcissime ea (scil. adspiratione) veteres usi etiam in vocalibus, cum 'aedos' 'ircos'que dicebant.

l'k Por. Gell., Noc. Att. 2, 3, 1-4: 'H' litteram, sive illam spiritum magis quam litteram dici oportet, inserebant eam veteres nostri plerisque vocibus verborum firmandis roborandisque, ut sonus earum esset viridior vegetiorque; atque id videntur fecisse studio et exemplo lingune Atticae. [...] Sic 'ahenum', sic 'vehemens', sic 'incohare', sic 'helluari', sic 'halucinari', sic 'honera', sic 'honestum' dixerunt. In his enim verbis omnibus litterae seu spiritus istius nulla ratio visa est, nisi ut firmitas et vigor vocis quasi quibusdam nervis additis intenderetur.

1117 Por. np. słowa gramatyka Nigidiusa Figulusa, przytoczone przez Aulusa Geliusza (Noc. Att. 13, 6, 3): rusticus fit sermo, si adspires perperam.

IIM Zob. np. slowa św. Augustyna (Confessiones 1, 18), który wspominając swoje szkolne lata stwierdza, że było mniejszym grzechem nienawidzić człowieka, lamiąc prawa boskie, niż wymówić słowo homo bez aspiracji, lamiąc reguły gramatyczne; por. też Appendix Probi: adhuc non aduc. 
dobnie już w I w. po Chr. fonem ten przestał być artykułowany. Swiadczą o tym liczne inskrypcje $\mathrm{z}$ tego okresu, w szczególności te nieformalne, jak np. graffiti na murach pompejańskich, w których z jednej strony spotykamy zapisy typu: Oratia (= Horatia), ic (= hic), abeto (= habeto), omo (= homo), odzwierciedlające ówczesne realia fonetyczne potocznej łaciny, $\mathrm{z}$ drugiej zaś grafię w rodzaju hire (= ire), holim (= olim), havet (= avet), będącą efektem niedostatków w przyswojeniu szkolnych reguł ortograficznych bądź też nieudolnego naśladownictwa języka kulturalnego, co skutkowało nadużywaniem /h/ i popadaniem w manierę wyśmianą w znanej pieśni Katullusa ${ }^{109}$.

Jednak mimo wspomnianego wysiłku elit zmierzającego do zachowania $/ \mathrm{h} /$ w wymowie i piśmie klasyczna poezja łacińska nadal odzwierciedla naturalnie słaby status tej spółgłoski, ciążący ku jej zanikowi: jeśli w wierszu /h/ znajdowało się w nagłosie wyrazu przed samogłoską, wygłosowa samogłoska poprzedzającego wyrazu ulegała elizji (jak przed nagłosem samogłoskowym) ${ }^{110}$, natomiast wygłosowa sylaba zakończona na jedną spółgłoskę i zawierająca krótką samogłoskę pozostawała sylabą krótką (lekką) ${ }^{111}$; podobnie w obrębie jednego wyrazu lekką pozostawała (niewygłosowa) sylaba $\mathrm{z}$ krótką samogłoską, po której następowała jedna spółgłoska $+/ \mathrm{h} /{ }^{112}$, a wyrazy typu dehinc mogły być używane jako struktury jednosylabowe $z$ wtórnym dyftongiem ${ }^{113}$. Sztuczności owego procesu restytucji /h/ w języku elit dowodzą wreszcie niekończące się dyskusje gramatyków nad zasadnością bądź niezasadnością wymowy i zapisu tej głoski w określonych wyrazach. Doprowadziły one do tego, że powstały i zyskały status normy warianty ortograficzne zarówno pomijające zapis umotywowanego etymologicznie /h/, jak np.: anser (zamiast "hanser), er (zamiast *her), jak i warianty $\mathrm{z} h$ nieuzasadnionym etymologicznie, jak np.: humerus, humor, humidus. $\mathrm{Z}$ drugiej zaś strony naturalna tendencja do niewymawiania /h/, zwłaszcza interwokalicznego, była na tyle silna, że w okresie Cesarstwa za poprawne uznane zostały przez gramatyków takie formy, jak np. vemens (= vehemens) czy prendere (= prehendere $)^{114}$; co więcej: formy $\mathrm{z}$ zachowanym /h/ interwokalicznym już przez Kwintyliana postrzegane były jako pozostałość owej wykpionej przez Katullusa maniery nadużywania aspiracji ${ }^{115}$. Wydaje się w związku z tym, że w języku kulturalnym nagłosowe / $\mathrm{h} /$ było sztucznie podtrzymywane $\mathrm{w}$ wymowie, natomiast $\mathrm{w}$ śródgłosie wyrazowym litera $h$ funkcjonowała jedynie jako znak hiatu (jak np. w ahenus, traho, veho) lub jako znak markujący początek kolejnego morfemu leksykalnego w obrębie złożenia (jak np. w abhinc, adhuc, adhibeo, exhaurire). Wyrazem tendencji do zaniku

${ }^{119}$ Catull. 84; por. też licznie poświadczoną w materiale inskrypcyjnym wariancję ortograficzną typu: haedus/edus, hasta/asta, hortus/ortus, harena/arena, harundo/arundo, hircus/ircus, hostia/ostia, hora/ora, haruspex/aruspex itp.

111 Por. np. Verg., Aen. 3, 426: prim(a) hominis facies et pulchro pectore virgo.

III Ibid. 6, 589: ibat ovans, divumque sibi poscebat honorem.

112 Ibid. 8, 324: aurea quae perhibent illo sub rege fuere / saecula.

11. Ibid. 1, 131: Eurum ad se Zephyrumque vocat, dehinc talia fatur.

114 Por też akceptowalną oboczność form typu nihil/nil, mihi/mi.

115 Por. Quint., Inst. 1, 5, 21: Inde durat ad nos usque 'vehementer' et 'comprehendere' et 'mihi'. Por. też Long., Orthogr. 68, 16-17: prendo enim dicimus, non prehendo. 
/h/ w żywej, mówionej łacinie jest także nieobecność tego fonemu w językach romańskich, gdzie jedynie w grafii utrzymało się tzw. „nieme h".

\subsection{PÓŁOTWARTE NOSOWE}

Do grupy tej należały 2 fonemy półotwarte, $\mathrm{tj}$. $/ \mathrm{n} / \mathrm{i} / \mathrm{m} /$, realizowane jako spółgłoski dźwięczne. Występowały w nagłosie (nox, mater), śródgłosie (pono, homo) i wygłosie (pecten, odium) wyrazu.

Fonem /n/ [n], czyli półotwarty nosowy dentalny ${ }^{116}$, artykułowany był jak np. pierwsza głoska w pol. wyrazach noc, narada czy nektar. Zapisywany był literą $N / n$, jak np. w wyrazach: nox, cantare, bonus, nomen. Jednak przed spółgłoskami tylnojęzykowymi / $/ \mathrm{i} / \mathrm{g} /$ oraz tylnojęzykowymi labialnym $/ \mathrm{k}^{\mathrm{u}} / \mathrm{i} / \mathrm{g}^{\mathrm{u}} /$ fonem ten realizowany był $\mathrm{w}$ postaci allofonu półotwartego nosowego tylnojęzykowego [n] ${ }^{117}$, jak np. w: uncus [unkus], tango [tango], relinquo [relink ${ }^{\mathrm{u}}$ ], lingua [ling ${ }^{\mathrm{u}}$ ] itp. Prawdopodobnie allofon ten artykułowany był także $w$ wyrażeniach przyimkowych złożonych z przyimka in oraz rzeczownika rozpoczynającego się od spółgłoski tylnojęzykowej, a więc w wyrażeniach typu in causa [incausa]. Za tym, że we wskazanych wyżej kontekstach fonem $/ \mathrm{n} /$ reprezentowany był właśnie przez allofon [n], oprócz względów czysto fonetycznych, przemawiają także wyraźne świadectwa starożytnych gramatyków:

1. Warron ${ }^{118}$ (cytowany przez Pryscjana ${ }^{119}$ ) mówi o "głosce wspólnej dla greki i łaciny", powołując się na wyrazy, w których Grecy zapisywali podwójne $g^{120}$, a Rzymianie $n$ i $g-z$ wyjątkiem Akcjusza (II w. przed Chr.), który także miał postulować wprowadzenie greckiej konwencji ortograficznej z użyciem podwójnego $g$, a więc pisownię aggulus, aggens, agguilla, iggerunt, agcora, agceps ${ }^{121}$ itp.;

2. Według relacji Geliusza ${ }^{122}$ Publiusz Nigidiusz Figulus (I w. przed Chr.) w swych Zapiskach gramatycznych (Commentarii grammatici) twierdził, iż w takich wy-

116 Por. Mart. Cap., Nup. 3, 261: N lingua dentibus appulsa conlidit. Nie można jednak wykluczyć także dziąsłowej (alweolarnej) artykulacji tego fonemu, polegającej na zwarciu przedniej części języka z górnymi dziąsłami (a nie zębami).

117 Wymawianego jak ang. -ing np. w wyrazie sleeping [sli:pin] czy - $n$ - np. w pol. bank [bank].

114 Varro, Fragmenta grammatica 3, 3-7: vox communis est Graecis et Latinis, ut his verbis aggulus aggens agguilla iggerunt. In eiusmodi Graeci et Accius noster bina g scribunt, alii $n$ et $g$, quod in hoc veritatem videre facile non est. Similiter agceps agcora.

114 Inst. gram. 1,39, 17-21.

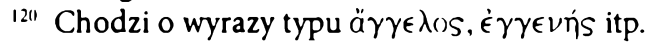

121 Ten ostatni przykład dowodzi przy okazji, że wyraz ten wymawiany był [ankeps], a więc świadczy o tylnojęzykowej artykulacji ([k]) fonemu zapisanego literą $c ; w$ innej sytuacji, tj. przy wymowie przedniojęzykowej (jak np. w pol. lancet), trudno sobie wyobrazić postulat zamiany litery $n$ na $g$ dla zapisu poprzedzającej spółgłoski tylnojęzykowej nosowej [n], analogicznie do pozostalych przykładów.

12: Gell., Noc. Att. 19, 14, 7: Inter litteram $n$ et $g$ est alia vis, ut in nomine anguis et angari et ancorae et increpat et incurrit et ingenuus. In omnibus his non verum $n$, sed adulterinum ponitur. Nam n non esse lingua iudicio est; nam si ea littera esset, lingua palatum tangeret. 
razach jak anguis, ancorae, increpat, ingenuus nie występuje "prawdziwe" $n$, lecz „pozorne” ( non verum n, sed adulterinum), ponieważ jeśli byłoby tam „prawdziwe" $n$, język dotykałby podniebienia w trakcie jego wymawiania.

$\mathrm{Z}$ kolei przed szczelinowymi /s/ i /f/ już $w$ archaicznej łacinie fonem /n/ tracił swój spółgłoskowy charakter, pozostawiając refleks w postaci nazalizacji (artykulacji nosowej) i kompensacyjnego (zastępczego) wzdłużenia poprzedzającej samogłoski, jak np. w wyrazie consol ${ }^{123}$ [kõ:sol], confero [kō:fero], censor [kē:sor] ${ }^{124}$. Ponieważ nie wytworzyła się żadna konwencja ortograficzna notowania tej nosowości, na archaicznych inskrypcjach, obok zapisu typu: CONSOL, CENSOR, CONSENTIONT ${ }^{25}$, CONFECI, INFEROS często spotykamy grafię: COSOL ${ }^{126}, C E S O R, C O S E N T I O N T$, COFECI, IFEROS. Później w mowie potocznej nosowość zaniknęła i według przekazów nawet Cyceron takie słowa jak: forensia, Megalensia, hortensia, miał wymawiać [foresia], [Megalesia], [hortesia] ${ }^{127}$. Na fakt zaniku artykulacji nosowej w łacinie potocznej wskazują też greckie transkrypcje ${ }^{128}$ oraz romańskie kontynuanty określonych wyrazów, np.: wł. sposa (klas. łac. sponsa 'narzeczona'), mese (klas. łac. mensis 'miesiąc'), isola (klas. łac. insula 'wyspa')129. Jednak $w$ oficjalnej ortografii notacja $n$ w tej pozycji częściowo przetrwała, a częściowo została zrestytuowana, $z$ jednej strony zapewne dla zachowania analogii w ramach fleksji (np. w: amans pod wpływem amantis, amantes itd., w tonsus pod wpływem tondeo), z drugiej zaś wskutek świadomości budowy słowotwórczej określonych wyrazów (np.: con-stare, in-super). Zapisywana tą literą spółgłoska powróciła też (z pozostawieniem wzdłużonego iloczasu poprzedzających samogłosek ${ }^{130}$ ) do wymowy ludzi wykształconych, stając się tym samym jednym $z$ wyróżników języka kulturalnego. Nieudolne naśladownictwo tego języka prowadziło $z$ kolei do szeregu pomyłek, o czym świadczą znajdowane na pompejańskich graffiti warianty graficzne typu: formonsa, pariens (= paries), a także uwagi gramatyków, przestrzegających np. przed formami typu: occansio, Herculens ${ }^{13 !}$.

12. Klas. consul.

124 Samogłoski te wymawiane były podobnie jak polskie samogłoski nosowe np. w wyrazach wąs czy kęs. W zastosowanej transkrypcji fonetycznej wyrazów lacińskich diakryt nad zapisującą samogłoskę literą symbolizuje nosowość, a dwukropek po literze długi iloczas.

125 Klas. consentiunt.

126 Stąd używany nawet w okresie klasycznym skrót cos.

127 Long., Orthogr. 79, 1-2: Cicero, qui foresia et Megalesia et hortesia sine n littera libenter dicebat. Por. też Quint., Inst. 1, 7, 29: 'consules' exempta n littera legimus.

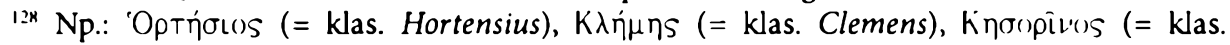
Censorinus).

$12 y$ Por. też Appendix Probi: ansa non asa; mensa non mesa.

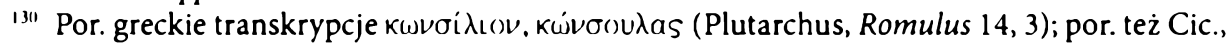
Orat. 159: indoctus dicimus brevi prima littera, insanus producta, inhumanus brevi, infelix longa et, ne multis, quibus in verbis eae primae litterae sunt quae in sapiente atque felice, 'in' producte dicitur, in ceteris omnibus breviter; podobnie Gellius (2, 17; 4,17), Diomedes (GL I, 433), Servius (GL IV, 442).

${ }^{13}$ Cf. Appendix Probi; por. też np.: Flavius Caper (II w. po Chr.), De orthographia 95, 8-9 (= GL VII, 95): omnia adverbia numeri sine $n$ scribenda sunt, ut milies, centies, decies; quotiens, totiens per $n$ scribenda sunt. 
Należy dodać, że /n/ zrestytuowane przed /f/ prawdopodobnie realizowane było w postaci allofonu wymawianego $\mathrm{z}$ zetknięciem dolnej wargi i górnych zębów, $\mathrm{tj}$. w postaci allofonu zasymilowanego pod względem miejsca artykulacji do następującego po nim spirantu wargowo-zębowego; przemawia za tym pisownia typu COMFLVONT (= klas. confluunt) czy IM FRONTE (= klas. in fronte), poświadczona na niektórych inskrypcjach z czasów republikańskich, dowodząca wargowej artykulacji tego fonemu.

Pewne przesłanki sugerują też, iż w języku potocznym /n/ cechowało się słabą artykulacją w pozycji przed spółgłoskami zwartymi; na inskrypcjach pompejańskich wielokrotnie pojawia się pisownia pomijająca notację tego fonemu w tym kontekście, np.: ligis (= lingis), nuc (= nunc), quodam (= quondam), metula (= mentula), Froto (=Fronto).

Fonem $/ \mathrm{m} /[\mathrm{m}]$, czyli półotwarty nosowy dwuwargowy, wymawiany był jak np. pierwsza spółgłoska w pol. wyrazach matka, mowa, mróz itp. Zapisywany był literą $\mathrm{M} / \mathrm{m}$, jak np. w wyrazach: motus, Roma, ambulare itp. Fonem $/ \mathrm{m} /$, pojawiający się przed spółgłoskami wargowymi w wyniku zmian asymilacyjnych $/ \mathrm{n} / \rightarrow / \mathrm{m} /$, mógł także być zapisywany literą $N / n$, jak np. w wyrazach: inpellere, inbellis itp., które częściej notowane były $\mathrm{z}$ użyciem zapisu impellere, imbellis itp., a także $\mathrm{w}$ wyrażeniach przyimkowych typu: in pace, in balneum, in muro, na co wskazują zachowane inskrypcje z pisownią im pace, im balneum, im muro.

W wygłosie wyrazu po samogłosce, a więc w formach typu fabulam, hortum, fortem itp., fonem ten ulegał osłabieniu, które (przynajmniej w języku potocznym) było bliskie redukcji tego fonemu do nazalizacji poprzedzającej samogłoski. Potwierdza to kilka argumentów:

1. W archaicznych inskrypcjach $/ \mathrm{m} / \mathrm{w}$ tej pozycji często pomijane jest w zapisie, jak np. na nagrobku Korneliusza Lucjusza Scypiona Barbatusa z I poł. III w. przed Chr., gdzie czytamy m.in.: TAVRASIA CISAVNA SAMNIO CEPIT (= klas. Taurasiam, Cisaunam, Samnium cepit);

2. W wierszu samogłoska, po której następuje wygłosowe $/ \mathrm{m} /$, ulega elizji przed nagłosową samogłoską kolejnego wyrazu, czyli ma taki sam status jak wszystkie wygłosowe samogłoski w tym kontekście, np. Exegi monument(um) aere perennius (Hor., Carm. 3, 30, 1). Podobny, samogłoskowy status ma połączenie samogłoska + wygłosowe /m/ w warunkach, w których następuje afereza, czego potwierdzeniem są formy typu factust (= factum est $)^{132}$;

3. Gramatycy starożytni podkreślają odmienność brzmienia spółgłoski $/ \mathrm{m} / \mathrm{w}$ tej pozycji, w szczególności przed samogłoskowym nagłosem kolejnego wyrazu, jej osłabienie (etiam si scribitur, tamen parum exprimitur [...], adeo, ut paene cuiusdam novae litterae sonum reddat; neque enim eximitur, sed obscuratur ${ }^{133}$ ) albo całkowity zanik ( $m$ terminat nec tamen in enuntiatione apparet ${ }^{134}$ );

132 Zob. np. Pl., Capt. 806, Amph. 615, Pseud. 185, Trin. 43.

13. Quint., Inst. 9, 4, 40.

1.4 Long., Orthogr. 54, 5-6. 
4. Brak śladów wygłosowego $/ \mathrm{m} /$ po samogłosce $w$ językach romańskich ${ }^{135}$; por. np.: wł. muro, hiszp. muro, franc. mur, które pochodzą z lac. murum.

Problematyczna jest kwestia ewentualnego kompensacyjnego wzdłużenia samogłoski unosowionej po zaniku wygłosowego $/-\mathrm{m} /$. Niektórzy uczeni opowiadają się za tego rodzaju wzdłużeniem, argumentując, iż sylaba, do której ona należy, jest w wierszu długa (ciężka) przed pojedynczą spółgłoską w następnym wyrazie, jak np. w Italia $(m)$ fato profugus Laviniaque venit / litora ${ }^{136}$. Powołują się także na wyliczenia wskazujące, że odsetek elizji tego rodzaju sylab (przed długimi i krótkim sylabami) w klasycznej poezji jest znacznie niższy niż odsetek elizji krótkich wygłosowych samogłosek, i tylko nieco wyższy niż odsetek elizji długich wygłosowych samogłosek i dyftongów ${ }^{137}$. $\mathrm{Z}$ drugiej jednak strony inni badacze podkreślają, że nie odnotowano żadnego przypadku, w którym ewentualna długość samogłoski przed wygłosowym /-m/ byłaby na inskrypcjach sygnalizowana zapisem podwojonej litery czy apeksem, a $w$ wierszach, $w$ których sylaby $z$ wygłosowym /-m/ nie są elidowane, powodując hiatus, mają one zwykle wartość krótkiej sylaby. Poza tym końcówka drugiej deklinacji -um pochodzi z wcześniejszego -om (podobnie jak - us z -os), a zmiana $o \rightarrow u$ obejmowała wyłącznie krótkie samogłoski. Zwraca się również uwagę na fakt, iż proces redukcji wygłosowego $/-\mathrm{m} /$ prawdopodobnie nie następował w wyrazach, które były silnie związane (składniowo $\mathrm{i}$ intonacyjnie) $\mathrm{z}$ wyrazem następnym, zaczynającym się na spółgłoskę. Zdają się na to wskazywać niektóre zapisy inskrypcyjne, których grafia sugeruje zajście procesu asymilacyjnego na granicy międzywyrazowej, jak np. tan durum (= klas. tam durum), a podobne wnioski nasuwają także stwierdzenia gramatyków ${ }^{138}$. W takich przypadkach /-m/ nabierałoby więc charakteru śródgłosowego i mogłoby być realizowane jako $[\mathrm{m}]$ przed spółgłoskami wargowymi i labiowelarnymi (np. [bonumpatrē] = bonum patrem), jako [n] przed spółgłoskami zębowymi (np. [istandomũ] = istam domum) oraz jako [n] przed welarnymi (np. [nostranclassē] = nostram clasem). Być może więc również przed silniejszą pauzą fonem ten nie był całkowicie redukowany, lecz jedynie osłabiany do dwuwargowej spółgłoski szczelinowej lub uderzeniowej (podobnej np. do śródgłosowej spółgłoski w hiszp. lobo) ${ }^{139}$, która odpowiedzialna była za długość sylaby przed jednospółgłoskowym nagłosem kolejnego wyrazu, a równocześnie - $\mathrm{z}$ uwagi na słabą artykulację - nie powstrzy-

$135 \mathrm{Z}$ wyjątkiem niektórych wyrazów jednosylabowych, np. wł. con ( $\leftarrow$ lac. cum), franc. rien $(\leftarrow$ łac. rem), hiszp. quien ( $\leftarrow$ lac. quem), co wskazywałoby, że w procesie nazalizacji samogłoski najpierw następowało osłabienie wygłosowego zwarcia, tj. przejście $/ \mathrm{m} / \mathrm{do} / \mathrm{n} /$, a następnie redukcja $/ \mathrm{n} /$ do rezonansu nosowego jako cechy poprzedzającej samogłoski.

136 Verg., Aen. 1, 2.

137 Cf. Allen (1965: 130-131); zob. też Sturtevant (1940: 151).

${ }^{134} \mathrm{~Np}$. Weliusza Longusa, którego wypowiedż (De orthographia 78, 18-21) wskazuje na upodobnienie wygłosowego $/-\mathrm{m} /$ do $/ \mathrm{n} / \mathrm{w}$ ramach wyrażenia etiam nunc: nam et non numquam plenius per $n$ quam per $m$ enuntiatur, ut cum dico 'etiam nunc', quamvis per $m$ scribam, nescio quo modo tamen exprimere non possum.

${ }_{134}$ Odpowiadałoby to przywołanym wyżej opisom starożytnych gramatyków, charakteryzujacych tę głoskę jako peregrina littera czy też paene cuiusdam novae litterae sonus. 
mywała elizji poprzedzającej samogłoski przed nagłosem samogłoskowym ${ }^{140}$. W tym kontekście należy jednak zaznaczyć, że zmianie prowadzącej w potocznej mowie do podobnego rezultatu uległa w pierwszych wiekach po Chr. także spółgłoska /b/ (zob. wyżej) oraz glajd /úl (zob. niżej), co w nieformalnej grafii skutkowało częstymi pomyłkami typu sivi (= sibi) czy Berus (= Verus), natomiast nie obserwuje się podobych pomyłek w notacji wygłosowego /-m/.

W II w. przed Chr. ustaliła się oficjalna konwencja ortograficzna przewidująca zapisywanie wygłosowego $/ \mathrm{m} /$ przy użyciu litery $M / m$, czemu towarzyszyło zapewne szkolne zalecanie pełniejszej artykulacji tego fonemu. Jednak w języku potocznym, zwłaszcza używanym przez warstwy mniej wykształcone, zalecenia te raczej nie znalazły większego odzewu, o czym świadczą nieformalne inskrypcje często pomijające zapis tej spółgłoski, jak np.: commendo tibi Iulia Faustilla, Marii filia (klas.: commendo tibi Iuliam Faustillam, Marii filiam) ${ }^{141}$, a także wskazówki zawarte w Appendix Probi: olim non oli; pridem non pride; idem non ide.

\subsection{PÓŁOTWARTE PŁYNNE (LIQUIDAE)}

Do grupy tej należą dwa foneny półotwarte przedniojęzykowe dziąsłowe, tj. /r/ i /l/, realizowane jako spółgłoski dźwięczne. Mogły wystąpić na początku (radius, lenis), w środku (durus, calor) i na końcu wyrazu (mater, semel). Termin "płynne" stanowi thumaczenie łacińskiego wyrazu liquidae, a ten $\mathrm{z}$ kolei greckiego úpaai. Gramatycy greccy określali nim spółgłoski, które - występując po spółgłoskach zwartych - powodowały, że poprzedzająca je sylaba zawierająca krótką samogłoskę miała "płynny” iloczas, tzn. mogła być długa lub krótka (ciężka lub lekka), jak np. pierwsza sylaba w wyrazie matpós. W łacinie właściwością tą cechują się właśnie spółgłoski $/ \mathrm{r} / \mathrm{i} / / \mathrm{l} /$, i do nich ogranicza się stosowanie tego terminu, natomiast $\mathrm{w}$ grece grupa ta obejmowała także $/ \mathrm{m} / \mathrm{i} / \mathrm{n} /$.

Fonem /r/ [r], czyli półotwarty drżący, wymawiany był jak np. pierwsza spółgłoska w pol. wyrazach robot, radość czy retusz. Zapisywany był literą $R / r$, jak np. w: ratio, porto czy mater. O tym, że miał artykulację drżącą (wibrującą) świadczą zarówno sugestywne wypowiedzi starożytnych autorów, porównujących jego brzmienie do warczenia psa (littera canina) ${ }^{142}$, jak i bardziej techniczne, a zarazem precyzyjne opisy gramatyków ${ }^{143}$. W okresie archaicznym, tj. przed połową II w. przed Chr., spółgłoska ta mogła mieć artykulację uderzeniową, na co zdają się wskazywać niektóre inskrypcje notujące $R \mathrm{w}$ miejsce $D$ (np. ARVORSVM $\leftarrow A D V O R S V M$ ), natomiast jeszcze wcześniej, tj. przed połową IV w. przed Chr., mogła mieć wymowę szczelinową, o czym może świadczyć dokonany do tego czasu proces rotacyzmu, czyli

\footnotetext{
141) Cf. Fink (1969); zob też Campanile (1973).

141 Defixionum tabellae (A. Audollent, Paris 1904), nr 228 (Karthago, II w. po Chr.).

142 Zob. Lucilius, Saturae (frgm.) 9, 377; Persius, Saturae 1, 109.

14. Np. Maur., Litt. 238: vibrat tremulis ictibus aridum sonorem.
} 
przekształcenia się interwokalicznego /s/ $\mathrm{w} / \mathrm{r} /$ (poprzez pośrednie stadium /z/). Z kolei w I w. przed Chr. pojawia się notacja rh-i -rrh- (np. rhetor, Pyrrhus), sta-

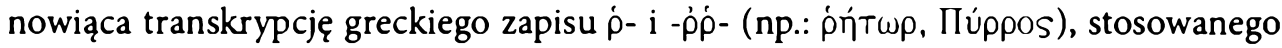
w odniesieniu do bezdźwięcznego [r]. Trudno jednak orzec, w jakim stopniu transkrypcji tej towarzyszyło naśladownictwo greckiej wymowy tego zpisu.

Fonem /1/, czyli półotwarty boczny, wymawiany był jak np. pierwsza spółgłoska w pol. wyrazach lato, lekarstwo czy luneta. Zapisywany był literą $L / l$, jak np. w: lac, columna, cultus, sal. Być może jednak fonem ten realizowany był poprzez dwa nieco różniące się między sobą pozycyjne allofony: jeden z nich to tzw. „jasne l”, które artykułowane było przed samogłoskami (przednimi) i odpowiadało polskiemu standardowemu [l], natomiast drugi $z$ allofonów to tzw. „ciemne l”, które wymawiane było przed spółgłoskami (i samogłoskami nieprzednimi) oraz w pozycji wygłosowej, a więc np. w consultum, sol. Artykulacja „ciemnego l” wiąże się z opuszczeniem grzbietu języka i podniesieniem jego tylnej części, co generuje efekt w postaci pogłębionego rezonansu, jak np. przy wymowie ang. milk lub hill czy pol. „kresowego” [1]. Na istnienie tego rodzaju allofonii wskazują uwagi gramatyków, określających brzmienie „jasnego l" terminem sonus exilis, a "ciemnego" sonus plenus (lub pinguis $)^{144}$; sygnalizować ją też mogą pewne zmiany samogłoskowe, np.: velim ale vultis $\leftarrow$ veltis (pod wpływem związanego $\mathrm{z}$,ciemnym l" rezonansu podobnego do tylnych samogłosek / u/ i /o//145.

\subsection{GLAJDY}

System fonologiczny klasycznej łaciny obejmował dwa glajdy, tj. /i / [j] oraz / [ł]. Stanowiły one konsonantyczne warianty sonantów, których wokalicznymi wariantami były samogłoski /i/ oraz /u/. Spółgłoskowa realizacja sonantów wymagała sąsiedztwa samogłoski, jednak sąsiedztwo to nie determinowało jeszcze tej realizacji, jako że w kontekście tym sonanty mogły również występować w wariancie samogłoskowym. Pomijając dyftongi (zob. niżej), jedynie pozycja interwokaliczna wiązała się $\mathrm{z}$ obligatoryjnie spółgłoskową realizacją sonantów, natomiast $\mathrm{w}$ położeniu między spółgłoską a samogłoską oraz w przypadku bezpośredniego sąsiedztwa dwóch sonantów, o spółgłoskowym bądź samogłoskowym statusie sonantu decydowały względy historyczne, tj. przynależność do określonego (historycznego) elementu morfologicznego (pierwiastka, sufiksu, końcówki) oraz pozycja zajmowana w jego ramach.

${ }_{144}$ Cf. Plinius Secundus, Dubius sermo (frgm.) 8, 1-6 (= GL II(1) 29 (Prisc., Inst. gram. 1,38, 8-12)), gdzie Pliniusz jako mające plenum sonum kwalifikuje także l znajdujące się po spółgłosce należącej do tej samej sylaby (jak np. w flavus, clarus), za mające sonum exilem uznaje przede wszystkim l zajmujące drugą pozycję w geminacie (np. w ille, Metellus), natomiast l znajdującemu się $\mathrm{w}$ pozostałych pozycjach przypisuje sonum medium (jak np. w lectum, lectus).

145 Por. też pojawiające się w późnej łacinie warianty ortograficzne wokalizujące „ciemne l”, np. cauculus (= calculus), Aubia (= Albia). 
Poza tym status sonantu (spółgłoskowy/samogłoskowy) mógł podlegać wahaniom, a także ulegać zmianon w toku historycznego rozwoju łaciny.

Glajd /i/ [j] to spółgłoskowy alternant sonantu, którego zgłoskotwórczym alternantem jest samogłoska/i/ [i]. Cechował się artykulacją środkowojęzykową podniebienną, czyli palatalną, jak np. pierwsza głoska w pol. wyrazach jutro, jodła czy środkowa głoska w wyrazach kajak, przejazd. W łacinie zapisywany był literą $I / i$, jak np. w: iubeo [jubeo], iam [jam], a więc tak samo jak samogłoskowa realizacja tego sonantu, np. w dico [dīkō]; literę $J / j$ wprowadzono dla notacji spółgłoskowego /i / [j] dopiero w czasach nowożytnych.

Pomijając dyftongi (zob. niżej), spółgłoskowe /i/ [j] występowało $\mathrm{w}$ łacinie na ogół w nagłosie wyrazu przed samogłoską ${ }^{146}, \mathrm{np}$. w: iacet, iubeo, oraz w śródgłosie wyrazu w pozycji interwokalicznej (tzn. między samogłoskami), np. w: peior, cu-

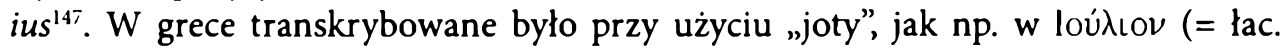
Iulium). Nagłosowe /i্// zachowywało swój spółgłoskowy status także w derywatach przedrostkowych, a więc gdy znalazło się w śródgłosie wyrazu na granicy między elementami słowotwórczymi; mogło wtedy występować po spółgłosce kończącej przedrostek, jak np. w adiecit [adjēkit], coniungo [konjungō]. W innych kontekstach sonant ten zwykle realizowany był jako samogłoska, a więc $w$ nagłosie przed spółgłoską i w wygłosie po spółgłosce, jak np. w ibi [ibi], w śródgłosie między spółgłoskami, jak np. w pictor [piktor], a także między spółgłoską a samogłoską, jak np. w trójsylabowych: capio [kapiō], faciunt [fakiunt] itp., przy czym w tej ostatniej pozycji w łacinie potocznej wykazywał tendencję do konsonantyzacji (tj. uspółgłoskowienia do /i/ [j]), która została sfonologizowana w łacinie późnej. Artykulacyjne podobieństwo spółgłoskowego [j] i samogłoskowego [i], czyli podobieństwo obu wariantów realizacyjnych tego samego sonantu, przy wspomnianej tendencji do konsonantyzacji /i/ w pozycji prewokalicznej bywało czasem wykorzystywane także w klasycznej poezji: np. u Horacego, w Serm. II, 8, 21 w imieniu Varius litera $i$ ma wartość samogłoski, zaś w imieniu Servilius drugie $i$ notuje spółgłoskę [j]; podobnie w kilku innych jeszcze wyrazach użytych w poezji tego autora litera $i$ zapisuje spółgłoskowe /i / w pozycji między spółgłoską a samogłoską, np. w consilinum (Carm. III, 4, 41), principium (Carm. III, 6, 6), Nasidieni (Serm. II, 8, 1), vindemiator (Serm. I, 7, 30). Z kolei (etymologicznie) samogłoskowe /i/, jak np. w ire, zachowywało swój samogłoskowy status również w sytuacji, gdy w ramach jakiejś formy gramatycznej znalazło się w pozycji nagłosowej przed samogłoską, jak np. w iens [iens].

W odróżnieniu od nagłosu wyrazowego (np. w: iugum, iubeo, iam itp.), w śródgłosie interwokalicznym glajd ten niemal zawsze miał wartość długiej (podwójnej) spółgłoski, jak np. w aio [ajjo], maior [majjor], peior [pejjor], Troia [trojja] itp. Za postulowaniem takiej właśnie artykulacji przemawia kilka argumentów:

14t Przy określaniu pozycji glajdów termin „samogłoska” obejmuje również zwokalizowane sonanty, a więc samogloskowe /u/ oraz /i/.

147 Jednak w poezji litera i mogła notować samogłoskę w takich wyrazach jak Gaius [gaius] czy Achaia [akhaia]. 
1. zachowały się inskrypcyjne poświadczenia notacji interwokalicznego /i/ z użyciem podwójnej litery I, np.: POMPEIIANVS, CVIIVS, EIIUS, MAIIOREM;

2. o długiej artykulacji tego fonemu wyraźnie piszą gramatycy starożytni ${ }^{148}$;

3. poprzedzająca sylaba jest zawsze długa (ciężka), nawet jeśli zawiera krótką samogłoskę (jak np. w maior, peior), co również poświadczają gramatycy starożytni ${ }^{149}$; 4. fonem ten często jest wynikiem rozwoju sekwencji dwu fonemów (np. maior $\leftarrow^{*}$ magios), a jego romańskie kontynuanty także mają status długich spółgłosek (np. lac. peiorem $\rightarrow$ wł. peggiore).

Mimo iż interwokaliczne /í/ było długie, zapisywano je pojedynczą literą $i$, co wynikało zapewne $\mathrm{z}$ faktu, iż nie istniała dystynktywna opozycja długiego i krótkiego /i / interwokalicznego ${ }^{150}$, w związku z czym stosowanie podwojonej litery byłoby zbyteczne (redundantne). Jedyny wyjątek w tym zakresie stanowią wyrazy złożone, utworzone przez dodanie przedrostka do podstawy rozpoczynającej się od nagłosowego (a więc krótkiego) /i/l. Chodzi o takie formacje jak: biiugus (bi- + iugus), quadriiugus (quadri- + iugus), w których sylaby bi- oraz -ri-, zawierające krótką samogłoskę, pozostają krótkie (lekkie), co dowodzi, że następujące po nich spółgłoskowe /i/ zachowało krótki iloczas. Być może podobny wniosek odnieść należy także do formacji typu: dïiudico, träiectus, èiaculo, prōiectus itp., przy czym jednoznaczna interpretacja nie jest $w$ tym przypadku możliwa $z$ uwagi na fakt, iz $w$ tych wyrazach poprzedzająca /í/ sylaba zawiera długą samogłoskę, wskutek czego sylaba ta eo ipso jest sylabą długą (ciężką).

Tendencja do unikania pisowni podwójnego ii zaznacza się w starożytnej konwencji ortograficznej także w przypadku wyrazów, w których spółgłoskowe /i/ sąsiaduje z samogłoskowym /i/. Egzemplifikacją może być zapis takich wyrazów jak np.: abicio, adicio, conicio, inicio, obicio, subicio, w których pierwsza sylaba jest długa (ciężka), mimo że jej ośrodkiem jest krótka samogłoska ${ }^{15 !}$. Dowodzi to, iż litera $i$ znajdująca się tam po przedrostkach notuje nie tylko samogłoskowe /i/, ale i poprzedzające je spółgłoskowe $/ \underline{i} /{ }^{152}$, które jest odpowiedzialne za zamknięcie (i tym

${ }^{1+k}$ Np. Prisc., Inst. gram. 1,18: et ' $i$ ' quidem [...] pro duplici accipitur consonante [...] quando in medio dictionis ab eo incipit syllaba post vocalem ante se positam subsequente quoque vocali in eadem syllaba, ut 'maius', 'peius', 'eius', in quo loco antiqui solebant geminare eandem 'i' litteram et 'maiius', 'peiius', 'eiius' scribere. Por. też Quint., Inst. 1, 4, 11: Sciat etiam Ciceroni placuisse 'aiio' Maiiam'que geminata ' $i$ ' scribere; Long. Orthogr. 54, 16-17: Cicero [...] qui et 'Aiiacem' et 'Maiiam' per duo 'i' scribenda existimavit.

isy Np. Maur., Litt. 618-621: ' $i$ ' media cum conlocatur hinc et hinc vocalium, 'Troia' sive 'Maia' dicas, 'peior' aut 'ieiunium', nominum primas videmus esse vocales breves, ' $i$ ' tamen sola sequente duplum habere temporis.

15.1 Krótkie /i / interwokaliczne uległo w łacinie zanikowi jeszcze w epoce przedliterackiej, doprowadzając do kontrakcji samogłosek, np.: "treies $\rightarrow{ }^{*}$ trees $\rightarrow$ trēs (por. skr. trayas, gr. T $\rho \in \hat{i} s$ ). Długość interwokalicznego /ii/ była więc $w$ istocie cechą redundantną.

${ }_{151}$ Te same (pierwsze) sylaby w takich wyrazach jak np.: abeo, adeo, ineo, obeo, subeo są krótkie (lekkie).

152 Dodatkowym argumentem $\mathrm{w}$ tej kwestii jest tutaj fakt pochodności formacji typu adicio $\mathrm{z}$ ad- + iacio, z czym wiąże się regularne ścieśnienie krótkiego /a/ (w iacio) do krótkiego /i/ po tym, 
samym długość) pierwszych sylab. Zapisy tych wyrazów notują zatem czterosylabowe ciągi fonetyczne [adjikiō], [abjikiō], [konjikiō] itd. Jeszcze bardziej wyrazisty pod tym względem przykład stanowi zapis czterosylabowego wyrazu reicio, w którym litera $i$ notuje samogłoskowe /i/ oraz poprzedzające je spółgłoskowe długie /i// [j]] odpowiedzialne za długość przedrostkowej sylaby $r^{-{ }^{153}}$ zawierającej krótką samogłoskę ${ }^{154}$; zapis ten notuje zatem ciąg fonetyczny o postaci [rejjikiö] ${ }^{155}$. Z drugiej jednak strony musiało się zdarzać, że dochodziło $\mathrm{w}$ wymowie do kontrakcji obu wariantów realizacyjnych tego sonantu, co prowadziło do dyftongizacji poprzedzającej samogłoski, jak świadczy o tym np. okazjonalne użycie w poezji formy reice jako wyrazu dwusylabowego ${ }^{156}$.

Glajd /un/ [1] to spółgloskowy alternant sonantu, którego samogłoskowym wariantem jest /u/. Cechował się on artykulacją dwuwargową (bilabialną), jak np. pierwsza głoska w pol. wyrazach lawka, lopata czy środkowa głoska w wyrazach pałac, pełen. W łacinie zapisywany był literą $V / u$, jak np. w wyrazach: VADO/uado [ưāō], LAVO/lauo [laūō], a więc tak samo jak samogłoskowa realizacja tego sonantu, np. w wyrazach: VNDA/unda [unda], DVCO/duco [dūkō] ${ }^{157}$. Wprowadzenie rozróżnienia ortograficznego i stosowanie litery $V / v$ dla zapisu spółgłoskowego wariantu tego sonantu ${ }^{158}$ (VADO/vado, LAVO/lavo), oraz litery U/u dla zapisu jego alternantu samogłoskowego (UNDA/unda, DUCO/duco), ma rodowód dopiero nowożytny (renesansowy). $Z$ uwagi na zakorzenioną w naszym kraju (i nie tylko) tradycję posługiwania się tym ortograficznym rozróżnieniem także w zapisach tekstów starożytnych, konwencja ta stosowana jest również w niniejszym opracowaniu. Poza dyftongami (zob. niżej), glajd /ü/ występował najczęściej w nagłosie wyrazu przed samogłoską, jak np. w: venio [ueniō], victoria [ưiktōria], między samogłoskami, jak np. w: cavere [kaụēre], levis [leưiis], oraz między spółgłoską a samogłoską, jak np. w: silva [siluna],

gdy po dodaniu przedrostka znalazło się w sylabie śródgłosowej. Zob. też na ten temat Gell., Noc. Att. 4, 17.

153 Zob. np. Verg., Aen. 10, 473: sic ait, atque oculos Rutulorum reicit arvis.

is $\mathrm{W}$ takich wyrazach jak np. recipio, reduco, repono itp., przedrostkowa sylaba re- jest krótka (lekka); por. np. Verg., Aen. 3, 231: instruimus mensas arisque reponimus ignem.

155 Por. też Long. Orthogr. 54, 20-21: incipit per tria ' $i$ ' scribi coiiicit.

156 Por. Verg., Ecl. 3, 96: Tityre, pascentis a flumine reice capellas; ale id., Georg. 3, 389: reice, ne maculis infuscet vellera pullis.

157 Cesarz Klaudiusz usiłowal dokonać reformy lacińskiej ortografii, polegającej na wprowadzeniu do alfabetu „odwróconej digammy" (tj. odwóconej litery $F$ ), która miała zapisywać spółgloskowe /ụ/, w odróżnieniu od samogłoskowego /u/, notowanego dotychczasową literą $V / u$. Na inskrypcjach $z$ okresu jego panowania odnajdywane są zapisy $z$ użyciem tej litery, jednak wkrótce po śmierci cesarza litera ta zniknęla z materiału inskrypcyjnego. Podobnie nieudane były jego próby wprowadzenia litery zwanej „antysigmą", mającej być odpowiednikiem greckiego $\Psi$ i służyć do zapisu zbitki spółgłoskowej [ps], a także „przepołowionego H”, prawdopodobnie jako odpowiednika greckiego $\Upsilon$ $\$ z zapisach lacińskich zapożyczeń z greki. Zob. Suet., Claud. 41; Prisc., Inst.gram. 1,20; 1,42; Long., Orthogr. $75,17-76,8$.

15* Z wyjątkiem pozycji po /s/, gdzie do jego zapisu stosowana jest litera $U / u$, jak np. w: seusco, suavis. 
suesco [sūēskō]; w tej ostatniej pozycji częściej jednak występowało samogłoskowe /u/, jak np. w: belua [bēlua], monuit [monuit], suere [suere]. W przeciwieństwie do /i /, międzysamogłoskowe /un/ nie wykazuje wzdłużonego iloczasu.

Za dwuwargową artykulacją tego fonemu przemawia kilka argumentów:

1. stosowanie do jego zapisu tej samej litery, która używana była przez Rzymian do notacji samogłoskowego /u/;

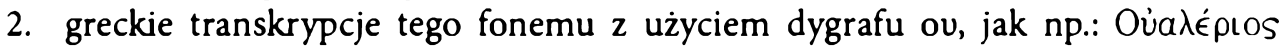

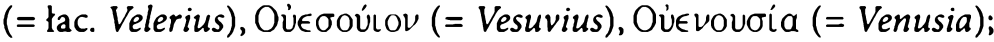

3. spotykane okazjonalnie w poezji przypadki zrównywania go z samogłoskowym /u/ poprzez użycie np. słowa silva jako wyrazu trójsylabowego [silua] ${ }^{159}$;

4. wypowiedzi gramatyków starożytnych, wskazujące na wysuwanie warg ku przodowi podczas wymawiania tej gloski ${ }^{160}$;

5. istnienie słowotwórczych powiązań między parami takich wyrazów, jak caveo : cautus $^{161}$, lavo : lautus, novus : nuntius ${ }^{162}$, brevis : bruma.

Dopiero w I w. po Chr. zaczynają pojawiać się w zabytkach epigraficznych przypadki mieszania spółgłoskowego /un/ z /b/, co może świadczyć o analogicznym jak w przypadku /b/ (zob. wyżej) uszczelinowieniu wymowy tego fonemu, czyli przekształceniu go w dźwięczną dwuwargową spółgłoskę szczelinową (uderzeniową?). Dowodzą tego inskrypcyjne warianty ortograficzne typu VIBA (= viva), pompejańskie graffiti z zapisami: baliat (= valeat), Berus (= Verus), greckie transkrypcje w ro-

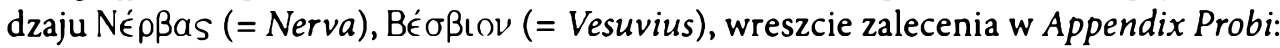
alveus non albeus (a $\mathrm{z}$ drugiej strony: plebes non plevis; tabes non tavis). W kolejnym etapie wymowa dwuwargowa przeszła w wargowo-zębową, podobną do wymowy np. pierwszej głoski w pol. wyrazach waza, wesele czy środkowej głoski w wyrazach kawat, powóz. Ten kierunek ewolucji widoczny jest również $w$ większości romańskich kontynuantów tego fonemu, jednak nie ma żadnych śladów jego szczelinowej, wargowo-zębowej wymowy w okresie klasycznym.

Przed samogłoskowym /u/ i /o/ spółgłoskowe /un/ wykazywało w śródgłosie tendencję do zaniku. Tendencja ta uaktywniała się w różnych okresach historycznego rozwoju łaciny. Jej efektem jest m.in. przekształcenie się archaicznych form deivos, Gnaivos w klasyczne deus, Gnaeus, natomiast w późniejszym okresie świadczą o niej okazjonalnie spotykane na inskrypcjach (począwszy od końca okresu republikańskiego) warianty ortograficzne typu: AEVM (= aevum), VIVS (= vivus), SERVS

15y Hor., Carm. 1, 23, 4; Epod. 13, 2. Z drugiej strony spotyka się użycie słów typu genua, belua jako wyrazów dwusylabowych (zwłaszcza w okresie Cesarstwa), co równieź świadczy o fonetycznym podobieństwie samogłoskowego /u/ i spółgłoskowego /u/. Por. też zastosowanie przez Horacego słowa pituita jako wyrazu trójsylabowego (a więc [pitụita]) w Serm. 2, 2, 76 i Epist. 1, 1, 108.

160 Zob. np. Gell., Noc. Att. 10, 4, 4. Por. też starożytne etymologie, wywodzące np. auris od avere (Varro, Lling. 6, 83) czy pituita od petit vitam (Quint., Inst. 1, 6, 37).

161 Por. też podobieństwo brzmienia okrzyku handlarza sprzedającego przywiezione $z$ Kaunus figi Cauneas! do wyrażenia cave ne eas, które miałoby być zesłanym przez bogów (a wydrwionym przez Cycerona) ostrzeżeniem dla Krassusa wyruszającego na Wschód (Cic., Div. 2, 84).

${ }_{162} \mathrm{Z}$ wielokrotnie poświadczoną inskrypcyjną grafią NOVNTIVS. 
(= servus), uwagi w Appendix Probi typu: avus non aus, flavus non flaus, rivus non rius, pavor non paor, a takíe niektóre formy romańskie, jak np.: wł. rio $(\leftarrow$ łac. ri $(v) u)$, paura $(\leftarrow$ lac. pa(v)ore). Jednak $\mathrm{w}$ wielu przypadkach notacja (i prawdopodobnie również wymowa) spółgłoskowego / $\mathbf{u} / \mathrm{w}$ tym kontekście została zachowana wskutek oddziaływania analogii względem innych form fleksyjnych $w$ ramach paradygmatu (a więc np.: aevum przez analogię do aevi, aevis) ${ }^{163}$. Tendencja do pomijania w wymowie dotyczyła także spółgłoskowego /ư⿱ / w pozycji między dwiema samogłoskami o tej samej barwie, czego rezultatem są np. formy latrina $(\leftarrow$ lavatrina $)$, ditis $(\leftarrow$ divitis, gen. sg. od dives), a także formacje perfektywne typu: audii ( $\leftarrow$ audivi), audisti $(\leftarrow$ audivisti) itp. Z kolei „przejściowy” glajd /un/ pojawiał się prawdopodobnie przy zbiegu samogłoski $/ \mathrm{u} / \mathrm{z}$ inną samogłoską, jak np. w: ruina [ruụina], victualia [ưiktuunalia]. Zwykle nie był on zapisywany ${ }^{164}$, jednak o jego istnieniu świadczą z jednej strony odpowiednie romańskie kontynuanty (por.: wł. rovina, vettovaglia), z drugiej zaś ortografia niektórych pompejańskich inskrypcji notujących ów glajd, np. poueri (= pueri).

$\mathrm{W}$ formach cui i huic realizowany samogłoskowo sonant $/ \mathrm{u} / \mathrm{z}$ następującym sonantem palatalnym utworzył fonetyczny dyftong, o czym świadczy fakt, że formy te w klasycznej poezji używane były w miejscu przeznaczonym dla jednej długiej (ciężkiej) sylaby ${ }^{165}$.

Ze względu na wspomniany wcześniej fakt zależności rozwoju sonantów od czynników natury historycznej w klasycznej łacinie współwystępują obok siebie takie pary wyrazów jak: silva i belua, volvit i voluit, invitus i minuit, suescere $i$ suere, gdzie $w$ identycznych kontekstach fonetycznych sonant bilabialny realizowany jest w jednym przypadku spółgłoskowo, w drugim samogłoskowo. To samo dotyczy sonantu palatalnego $w$ takich parach wyrazowych jak np.: adiecit i capietur, coniungo i puniuntur, iecit i iens ${ }^{166}$.

16.3 Wyjątek w tym zakresie stanowi forma boum (gen. pl. od bos, bovis 'wół'), która zyskała status normy.

In Por. też np. zapis iuenis (= iuvenis) na jednej z pompejańskich inskrypcji.

165 Samogłoskowości /u/ w tych formach dowodzi z jednej strony dopuszczalność elizji przed huic, $\mathrm{z}$ drugiej zaś krótkość (czyli otwartość) sylaby -li- w formie alicui. Dodajmy jednak, że w łacinie „srebrnej” formy te zaczęły być traktowane jako struktury dwuzgłoskowe, z obiema sylabami krótkimi (lekkimi).

${ }^{166}$ Por. też Quint., Inst. 1, 4, 10: Atque etiam in ipsis vocalibus grammatici est videre, an aliquas pro consonantibus usus acceperit, quia 'iam' sicut 'etiam' scribitur, et 'uos' cut 'tuos'. 


\section{7. \\ Uwagi szczegółowe na temat łacińskiego wokalizmu}

\subsection{SAMOGŁOSKI}

Jak wspomniano już wcześniej, Rzymianie nie wypracowali żadnej ogólnie akceptowanej konwencji ortograficznej, pozwalającej na rozróżnienie w piśmie samogłosek krótkich i długich. Odrębne znaki graficzne (litery) identyfikowały w związku z tym samogłoski różniące się między sobą jedynie dwiema pozostałymi cechami dystynktywnymi, czyli tymi, które decydowały o ich barwie. Tak więc litera $I / i$ zapisywała samogłoski wysokie przednie/i/ oraz/i/, litera $V / u$ samogłoski wysokie tylne /u/ i / $/ \overline{\mathrm{u}} /{ }^{16 \bar{\tau}}$, litera E/e samogłoski średnie przednie /e/ i /ē/, litera O/o samogłoski średnie tylne /o/ i /ō/, litera $A /$ a samogłoski niskie środkowe /a/ i /à/. Polska konwencja ortograficzna posługuje się tymi literami do zapisu rodzimych samogłosek o tej samej barwie, które wskutek tego stały się elementami polskiej konwencji artykulacyjnej także samogłosek łacińskich. Jednak nasz system wokaliczny nie tylko nie uwzględnia iloczasu jako jednej z cech dystynktywnych, ale i pod innymi względami nie przystaje do wokalizmu łacińskiego, którego poszczególne elementy nie znajdują dokładnych odpowiedników w języku polskim. Dlatego bliżej może on zostać scharakteryzowany jedynie w sposób opisowy.

I tak, jedną z cech różniących polski i łaciński system samogłoskowy jest zasygnalizowany już wyżej fakt, iż podstawowej opozycji iloczasowej samogłosek wysokich i średnich towarzyszyła subfonologiczna różnica stopnia apertury, która polegała na

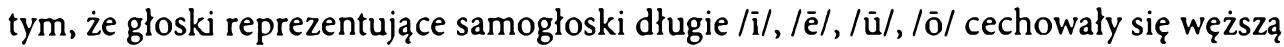
(bardziej ścieśnioną) artykulacją niż głoski reprezentujące ich odpowiedniki krótkie. Zróżnicowanie to nie dotyczyło samogłosek niskich, tj. długiego /ā/ i krótkiego /a/, których reprezentacje różniły się między sobą jedynie pod względem iloczasu.

16i Jak już zaznaczono wcześniej, litera ta zapisywała również spółgłoskowy wariant tego sonatu, czyli /ú/, jednak ze względu na zakorzenioną w naszym kraju tradycję różnicownia zapisu samogłoskowego i spółgłoskowego, również i w tym opracowaniu samogłoskowe /u/ i /ū/ zapisywane jest literą $U / u$. 
Uwzględniając tę właściwość, relacje, w jakich pozostawały względem siebie głoski reprezentujące samogłoski klasycznej łaciny, można ująć w następujący diagram, którego oś horyzontalna wyznacza miejsce artykulacji poszczególnych głosek, zaś oś wertykalna ich aperturę:

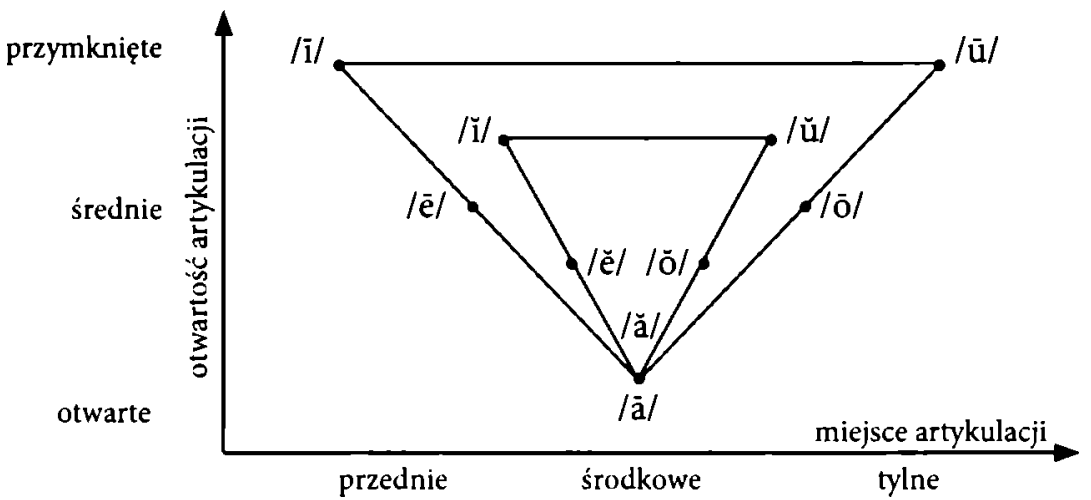

Powyższy diagram wskazuje, że krótkie samogłoski /i/ oraz/u/, z uwagi na ich szerszą wymowę, były artykulacyjnie bliższe długim /ē/ i /ō/ niż /ì/ i / $/ \bar{u} /$, podobnie jak długie /è/ i /ō/, ze względu na węższą artykulację, były bliższe /i/ oraz/u/ niż krótkim /e/ i /o/. Stan ten potwierdza kilka przesłanek:

1. wypowiedzi gramatyków, $z$ jednej strony akcentujące różnice między długimi i krótkimi samogłoskami o tej samej barwie (/i/ oraz/o//168, $\mathrm{z}$ drugiej zaś wskazujące na bliskość np. długiego /ē/ i (krótkiego) /i/ ${ }^{169}$;

2. widoczna w epigrafice (zwłaszcza późnej) tendencja do używania litery e dla zapisu krótkiego /i/ oraz litery $i$ dla długiego /ê/, np.: trebibus (= tribibus), menus (= minus), sene $(=\text { sine })^{170}$, filix $\left(=\right.$ fëlix), rignum $(=$ rëgnum $)$, minsis $(=\text { mènsis })^{171}$, a także litery $o$ dla zapisu krótkiego /u/ oraz litery $u$ do zapisu długiego /ö/, np.: colomnas (= columnas), nomero (= numero), sob $(=s u b)^{172}$, octubris (= octöbris), punere (= pōnere), matrunae (= matrōnae $)^{173}$;

3. greckie transkrypcje lacińskiego krótkiego /i/ za pośrednictwem litery $\epsilon$, co

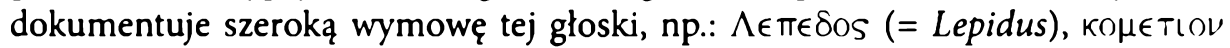
(= comitium), $\Delta o \mu \epsilon \operatorname{TlOS}$ (= Domitius), $T \in \beta \in \rho \operatorname{os}$ (= Tiberius);

16* Por. np. Long., Orthogr. 49, 16-19: i vero littera interdum exilis est, interdum pinguis, ut in eo, quod est 'prodit', 'vincit', 'condit' exilius volo sonare; in eo vero quod significatur 'prodire', 'vincire', 'condire' usque piguescit. Zob. też Maur., Litt 130-134.

$16 y$ Por. Pompeius relacjonujący stwierdzenie Terentianusa Maurusa (GL V, 102): Quotienscumque e longam volumus proferri, vicina sit ad i litteram.

${ }_{170} \mathrm{Nb}$. już w isnkrypacjach pompejańskich odnajdujemy zapisy: pravessimus, domene, mulierebus, munerebus.

1 i1 Por. też Appendix Probi: vates non vatis; fames non famis; vulpes non vulpis.

ii Por. też ibid.: columna non colomna; puella non poella

17 Por. też ibid.: sobrius non suber. 
4. romańskie kontynuanty, w których łacińskie krótkie /i/ i długie /è/ często mają jednakowy odpowiednik, jak np. /e/ we włoskim; por.: degno $\leftarrow$ dignus, fedele $\leftarrow$ fidelis, secco $\leftarrow$ siccus, felice $\leftarrow$ félix, segreto $\leftarrow$ sécrētus, vero $\leftarrow$ vèrum (podczas gdy długie /i// ma inny odpowiednik: libertá $\leftarrow$ libertas, rito $\leftarrow$ ritus, vivo $\leftarrow$ vivus).

Krótkie samogłoski wysokie i średnie, a w szczególności przednie (tj. /i/ oraz/e/), w sąsiedztwie /r/ przejawiały tendencję do artykulacji bardziej otwartej (szerokiej) niż w innych kontekstach fonetycznych. Refleksem tego jest - ukształtowany jeszcze w epoce przedklasycznej - stan stosunków międzywyrazowych w ramach słowotwórstwa i fleksji, ukazujący właśnie szerszą artykulację samogłoskową przed /r/; por. np. regularne zwężenie się w sylabie środkowej samogłoski /a/ do /i/ ( ${ }^{*}$ re-facio $\rightarrow$ reficio), ale przed /r/ tylko do /e/ ( ${ }^{*}$ re-pario $\rightarrow$ reperio); por. też rozszerzenie artykulacji /i/ do /e/ przed /r/, np.: cinis ale cineris, cinerem; legis, legit, legimus ale legere, legeris. Można jednak sądzić, że tendencja do bardziej otwartej wymowy samogłosek w sąsiedztwie /r/ trwała także w epoce klasycznej i późniejszej, o czym świadczą formy w rodzaju: herundo (= hirundo), passar (= passer), carcar (= carcer), ansar (= anser), novarca (= noverca), poświadczone inskrypcyjnie bądź w Appendix Probi.

Z kolei przed samogłoskami krótkie /e/ wykazywało tendencję do artykulacji bardziej zamkniętej, zbliżonej do [i]. Właściwość ta prawdopodobie także była charakterystyczna dla całego okresu rozwoju starożytnej łaciny, jako że z jednej strony Velius Longus w II w. po Chr. przypisywał ją "ludziom dawnych czasów" ${ }^{174}, \mathrm{z}$ drugiej zaś jej obecność w późniejszym okresie potwierdzają inskrypcyjne (pompejańskie) formy typu: alia (= alea), casium (= caseum), mia (= mea), balnia (= balnea), abias (= habeas), iamus (= eamus), peria (= pereat $)^{175}$, greckie transkrypcje o postaci à $\rho$ ı

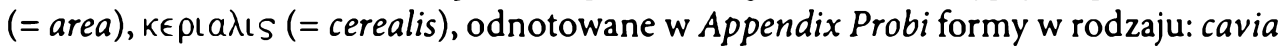
(= cavea), lancia (= lancea), vinia (= vinea), paliarium (= palearium), calcius (= calceus) ${ }^{176}$, wreszcie formy romańskie, jak np. wł. dio, hiszp. dios ( $\leftarrow$ lac. deus). Być może węższą artykulację przed samogłoskami miało także krótkie /i/, które w tej pozycji często notowane jest przez tzw. I longa, jak np.: prIusquam, dles, plus.

Sekwencja następujących bezpośrednio po sobie (lub rozdzielonych $/ \mathrm{h} /$ ) samogłosek o tej samej barwie była w potocznej wymowie najprawdopodobniej skracana do pojedynczej długiej samogłoski. Sugerują to poświadczone w inskrypcjach (głównie pompejańskich) warianty ortograficzne $\mathrm{z}$ jedną literą $\mathrm{w}$ miejscu sekwencji samogłosek, jak np.: prendere (= prehendere), cors (= cohors), lignari, librari, pomari (= lignarii etc. - nom. pl.), socis, iudicis, Fabis (= sociis, etc. - dat./abl. pl.), mortus (= mortuus), ingenus (= ingenuus).

Krótkie /u/ w łacinie klasycznej często stanowi kontynuację wcześniejszego krótkiego /o/, które w okresie archaicznym w wielu pozycjach zwęziło się właśnie do

1it Long., Orthogr. 77, 12-13: mium [...] per i antiquis relinquamus.

17s Wymowę tę potwierdzają takíe pochodzące $\mathrm{z}$ inskrypcji pompejańskich przykłady pisowni odwrotnej (hiperpoprawnej), np.: Iuleas (= Iulias), propiteos (= propitios), moreor (= morior), pateor (= patior).

176 Por. też zamieszczone tam napomnienia odnośnie do form hiperpoprawnych: ostium non osteum; alium non aleum; lilium non lileum. 
krótkiego /u/. Np. w ciągu III stulecia przed Chr. proces ten objął sylaby wygłosowe, prowadząc do przekształceń typu Luciom $\rightarrow$ Lucium. Jednak w kontekście po /u/, /ux/,

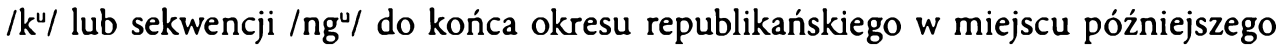
$V / u$ na inskrypcjach notowana jest litera $O / o$; znajdujemy tam zatem formy typu: VOLGVS, AVONCVLVS, PERSPICVOS, EQVOS ${ }^{177}$. Nie mamy pewności, czy grafia ta odpowiada faktycznej wymowie tych wyrazów w dwóch ostatnich wiekach republiki, czy też zachowanie litery O/o wynika raczej z tendencji do unikania zapisu dwóch kolejno po sobie następujących liter $V / u$, który mógłby sugerować notację długiego samogłoskowego $/ \overline{\mathrm{u}} /$. W każdym razie od okresu augustowskiego formy tego rodzaju $w$ oficjalnej epigrafice konsekwentnie są już zapisywane $z$ użyciem litery $V / u$, a więc przyjmują postać ortograficzną VVLGVS, AVVNCVLVS, PERSPICVVS, EQVVS itp. ${ }^{178}$

$\mathrm{Z}$ kolei w okresie archaicznym samogłoska /u/ wymawiana i zapisywana była także $w$ wyrazach pochodzenia greckiego, których oryginały zawierały przednie zaokrąglone /ü/ notowane literą „y psylon" $(\Upsilon / v)$, np.: bursa $(=\beta u ́ p \sigma \eta)^{179}$, inskr. Sibulla $\left(=\sum ı \beta u ́ \lambda \lambda \eta\right)$, crupta $(=\kappa \rho u ́ \pi \tau \eta){ }^{180}$. W I stuleciu przed Chr. w języku literackim zaczęto samogloskę tę zapisywać przejętą z greckiego alfabetu literą $Y / y, z$ czym wiązała się zapewne bardziej zbliżona do oryginału, czyli bardziej przednia jej wymowa ${ }^{181}$. Greckie zapożyczenia zyskują zatem pisownię typu: nympha, symbolus, mysterium, satyrus itp. ${ }^{182}$ Od ok. II/III w. po Chr. greckie /ü/ zaczęło przechodzić w/i/, w związku z czym w późniejszej łacinie pojawiają się greckie zapożyczenia transkrybujące greckie $Y / u$ za pomocą litery $I / i$, np. girus ${ }^{183}$ (= jûpos). Ponieważ wymowa /ü/ i pisownia $Y / y$ były jednym z wyróżników łaciny kulturalnej, nie zabrakło „kulturalnych inaczej”, którzy wstawiali (i wymawiali) $Y / y \mathrm{w}$ miejscu rodzimego łacińskiegu /u/, a później również /i/, o czym świadczą uwagi gramatyków ${ }^{184}$ i napomnienia w Appendix Probi ${ }^{185}$.

17 Dwie ostatnie formy oczywiście również reprezentują nominativus singularis.

1; Jednak jeszcze pod koniec I w. po Chr. Kwintylian wspomina swoich nauczycieli posługujących się grafią - VO- w tych kontekstach i zaznacza, że ani tradycyjny, ani nowszy (tj. - $V V$-) zapis nie ooddaje wiernie emitowanych w odnośnych wyrazach dźwięków: Nostri praeceptores 'seruum' 'ceruum'que ' $u$ ' et 'o' litteris scripserunt, quia subiecta sibi vocalis in unum sonum coalescere et confindi nequiret; nunc ' $u$ ' gemina scribuntur ea ratione quam reddidi: neutro sane modo vox quam sentimus efficitur (Inst. 1, 7,26). Jak zasygnalizowaliśmy wyżej, w łacinie potocznej w śródgłosie wyrazowym spólgloskowe /u/ przed samogłoskowym /u/ wykazywało tendencję do zaniku, co wynika z zapisów typu SERVS, AEVM, odnajdywanych na nieformalnych inskrypcjach.

i,y Por. wł. borsa, franc. bourse.

ıxi Por. wł. grotta. Por. też Cic., Orat. 160, 10: Burrum semper Ennius, numquam Pyrrhum.

ıx। A więc/ü/, podobnie jak np. w niem. über.

1*2 Por. Scaur., Orthogr. 25, 13-16: Y litteram supervacuam Latino sermoni putaverunt, quomiam pro illa $V$ cederet. Sed cum quaedam in nostrum sermonem Graeca nomina admissa sint, in quibus evidenter sonus huius litterae exprimitur, ut 'hyperbaton' et hymnus et hyacinthus et similia, in eisdem hac littera necessario utimur.

1*3 Appendix Probi; por. też wł. giro.

ins Por. np. Cap., Orthogr. 105, 17-18: Y litteram nulla vox nostra adsciscit, ideo insultabis 'gylam' dicentibus; Charisius, Artis grammaticae libri V (Barwick: I, 132, 4-5 = GL I, 103): Gulam [...] per u scribemus, non per $y$.

ins Np.: crista non crysta. 
W wyrazach rdzennie łacińskich natomiast, w śródgłosowych sylabach otwartych, przed spółgłoskami wargowymi $/ \mathrm{m} /, / \mathrm{f} /, / \mathrm{p} /, / \mathrm{b} /$ notowana była $\mathrm{w}$ okresie archaicznym krótka samogłoska /u/, która w późniejszym okresie (tj. od końca II w. przed Chr.) zaczęła być zapisywana literą $i$, np.: optumus ( $\rightarrow$ optimus), maxumus ( $\rightarrow$ maximus) pontufex ( $\rightarrow$ pontifex), manufestus ( $\rightarrow$ manifestus), manupretium ( $\rightarrow$ manipretium), manubiae ( $\rightarrow$ manibiae) itp. Samogłoska ta na ogół stanowiła kontynuant innej wcześniejszej samogłoski, osłabionej w pozycji poakcentowej, i - jak się wydaje - miała artykulację bardziej przednią niż „zwykłe”, odziedziczone /u/, co spowodowało jej późniejsze przesunięcie w kierunku /i/. W I w. przed Chr. za sprawą Cezara ustaliła się oficjalna norma zapisywania jej literą $I / i^{186}$, a jej wcześniejsza wymowa, zbliżona do /u/, uznana została przez Cycerona za prowincjonalizm (rusticanum) ${ }^{187}$. Jednak świadectwa gramatyków każą przypuszczać, że do pełnej identyfikacji tej samogłoski $z$ /i/ nie doszło ${ }^{188}$ i jakaś odmienność jej wymowy, przynajmniej w pewnych rejestrach czy środowiskach językowych, pozostała ${ }^{189}$. Wzmianki o jej brzmieniu pośrednim między /i/i / u/sugerują, że od „zwykłego” /i/ mogła się różnić zaokrągleniem ${ }^{190}$, którego /i/ było generalnie w łacinie pozbawione, jednak $\mathrm{w}$ pozycji po spółgłoskowym $/ \mathrm{u} / \mathrm{i}$ labiowelarnym $/ \mathrm{k} /$, a więc np. w wyrazach vir, video czy quis, prawdopodobnie pojawiała się zokrąglona wymowa $/ \mathrm{i} /{ }^{191}$, którą gramatycy interpretowali właśnie jako upodobnienie do $/ \mathrm{u} /{ }^{192}$. Tak więc samogłoska, która występowała w środkowej sylabie np. takiego wyrazu jak pontifex, była zapewne zbliżona w wymowie do krótkiego $/ \ddot{\mathrm{u}} /{ }^{193}$, chociaż nigdy w grece nie transkrybowano jej $z$ użyciem litery $Y / U^{194}$ - prawdopodobnie dlatego, że notowana nią głoska grecka, zarówno krótka jak i długa, była zaokrągloną samogłoską przednią, ale bardziej zamkniętą niż lacińskie samogłoski krótkie ${ }^{195}$, w tym i postulowane zaokrąglone /i/ ${ }^{196}$.

IH6 Por. Quint., Inst. 1, 7, 21: Iam 'optimus' 'maximus' ut mediam i litteram, quae veteribus u fuerat, acciperent C. primum Caesaris inscriptione traditur factum; Cassiodorus (GL VII, 150): 'lacrumae' an 'lacrimae', 'maxumus' an 'maximus', et siqua similia sunt, quo modo scribi debeant, quaesitum est. Terentius Varro tradidit Caesarem per ' $i$ ' eius modi verba solitum esse enuntiare et scribere: inde propter auctoritatem tanti viri conuetudinem factam.

1k7 Zob. Long., Orthogr. 49, 21.

I** Chociaż w językach romańskich nie ma ona odrębnych od „zwykłego”/i/ kontynuantów.

IHy Por. np. Quint., Inst. 1, 4, 8: medius est quidam u et $i<i>$ litterae sonus; non enim sic 'optimum' dicimus ut 'opimum'; Long., Orthogr. 50, 3-5: nos vero postquam exilitas sermonis delectare coepit, usque i littera castigavimus illam (scil. u litterae) pinguitudinem, non tamen, ut plene $i$ litteram enuntiaremus.

140) Czyli labializacją, będącą wynikiem asymilacji do następującej wargowej spółgłoski.

191 Swiadczą o tym (inskrypcyjne) transkrypcje lacińskiego qui $\mathrm{w}$ grece za pośrednictwem

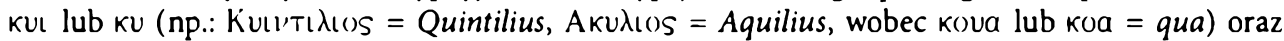
transkrypcje greckiego ku za pośrednictwem lacińskiego qui (np. Quinici = Kuvıкoí, Quiriace = Kupıакท́); por. też Appendix Probi: vir non vyr; virgo non vyrgo.

192 Por. Long., Orthogr. 75, 15-17: fit ut saepe aliud scribamus, aliud enuntiemus, ut supra locutus sum de viro et virtute, ubi i scribitur et paene $u$ enuntiatur.

193. Takiego, jak np. w niem. Glück czy fünf.

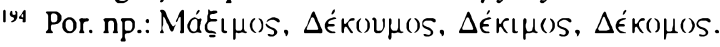

195 Zob. Allen (1965: 59).

$196 \mathrm{Z}$ tego samego względu nie była też zapisywana literą $Y / y$ - aż do późnego okresu, kiedy zaczęto mylnie używać tej litery zamiast $i$ w rdzennie łacińskich wyrazach wskutek nieudolnego 
Należy jeszcze zaznaczyć, że w toku wypowiadania ciągów wyrazowych (zdań, wyrażeń, fraz itd.) wymowa wygłosowych fonemów wokalicznych ${ }^{197}$ mogła być modyfikowana, jeśli występowały one przed wokalicznym nagłosem ${ }^{198}$ kolejnego wyrazu. Krótkie samogłoski, a także fonemy wokaliczne niebędące wykładnikami funkcji gramatycznych lub występujące $w$ wyrazach współtworzących $z$ kolejnymi utarte zwroty czy wyrażenia, prawdopodobnie były wtedy redukowane, co prowadziło do powstania ciągów artykulacyjnych wymawianych jak jeden wyraz, np. w monstr(um) horrendum [monstr(h)orrendũ], cert(e) aspexit [kertaspeksit] itp. Długie wygłosowe samogłoski i dyftongi mogły natomiast ulegać kontrakcji z nagłosowymi samogłoskami i dyftongami wyrazów następujących ${ }^{199}$, zaś samogłoski /ī/ oraz / $\mathbf{u} /$ osłabiać się do spółgłoskowych /i / i /un/, jak np. w odi et amo [odjetamo].

W wygłosowych sylabach zamkniętych długie samogłoski zachowały się tylko przed /-s/, jak np. w: ornās (wobec ornat), habēs (wobec habet) itp.

$\mathrm{Na}$ temat samogłosek nosowych (nazalizowanych) zob. wyżej w części dotyczącej łacińskiego wokalizmu oraz w uwagach szczegółowych dotyczących spółgłosek $\mathrm{ln} / \mathrm{i} / \mathrm{m} /$.

\subsection{DYFTONGI}

Do dyftongów współtworzących łaciński wokalizm zalicza się tradycyjnie $/ \mathrm{a}^{\mathrm{i}}$, $/ \mathrm{a}^{\mathrm{w}} /, / \mathrm{o}^{\mathrm{i}} /, / \mathrm{o}^{\mathrm{u}} /, / \mathrm{e}^{\mathrm{i}} /$ oraz $/ \mathrm{e}^{\mathrm{u}} /$.

Dyftong / $\mathrm{a}^{\mathrm{i} /}$ wymawiany był podobnie jak następująca po naglosowej spółgłosce część takich polskich wyrazów jak np. maj czy raj. Pierwotnie zapisywany był dygrafem AI/ai, jak np. w AIDILIS (na inskrypcji nagrobkowej Scypiona Barbatusa z pierwszej połowy III w. przed Chr.). Na początku II w. przed Chr. pojawia się pisownia $A E / a e^{200}$, która świadczy o lekkim rozszerzeniu artykulacji wyglosu dyftongu, czyli o jego przekształceniu się $\mathrm{w} / \mathrm{a}^{\mathrm{e}}$. Niemniej przez cały okres klasycznej starożytności element zapisywany jako ae zachował $w$ łacinie kulturalnej status fonetycznego dyftongu, za czym przemawia kilka argumentów:

1. greckie transkrypcje lacińskiego ae zawsze $\mathrm{z}$ użyciem dygrafu al, jak np. w Kaı́í $\lambda \iota s$ (= Caecilius) ${ }^{201}$;

naśladownictwa języka literackiego, w którym posługiwano się literą $Y / y w$ transkrypcji greckiego Y/u (notującego już w tym czasie /i/). Zob. wyżej.

$197 \mathrm{~W}$ tym również nazalizowanych samogłosek zapisywanych standardowo -um, -am, -em.

19N W tym takie aspirowanym, a więc zapisywanym he-, ho-, ha- itp.

199 Argumentem przemawiającym za takim procesem, a równocześnie ilustracją rezultatów, do których on prowadzil, mogą być wyrazy utworzone w epoce przedliterackiej na drodze prefiksacji wynikłej z przyłączenia przyimków, np.: dégo $(\leftarrow$ dé-ago $)$, prōmo $(\leftarrow$ prō-emo), praetor $(\leftarrow$ prae-itor).

${ }^{2(1)} \mathrm{Na}$ znanej inskrypcji Senatus Consultum de Bacchanalibus z roku 186 przed Chr. obok tradycyjnej notacji $A I Q V O M, T A B E L A I, D A T A I$ pojawia się też już zapis $A E D E M$.

201 Zob. np. App., Ib. 322, 351, 440; Ill. 33. 
2. zapożyczenia germańskie zachowujące brzmienie dyftongu, jak np. goc. kaisar (IV w. po Chr.);

3. świadectwa gramatyków łacińskich, potwierdzające wymowę dyftongiczną, jak np. Terencjusza Skaurusa, który równocześnie podkreśla brzmienie wygłosowego elementu zbliżone do $/ \mathrm{e}^{202}$, czy Pryscjana, który deklaruje obecność $w$ łacinie

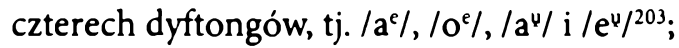

4. aliteracje występujące $w$ utartych formułach urzędowych, np. w formule identyfikującej urzędników sprawujących pieczę nad mennicą: triumviri auro argento aere flando feriundo ${ }^{204}$, oraz $\mathrm{w}$ poezji, np. lumine sic tremulo terra et caua caerula candent ${ }^{205}$ (Enn., Trag. 250 (Melanippa)).

Końcówka -ae obecna w paradygmacie liczby pojedynczej I deklinacji, $\mathrm{z}$ uwagi na jej pochodzenie od dwusylabowego /āi/, w poezji bywała okazjonalnie zapisywana - ai i artykułowana dwusylabowo, na co zwrócił uwagę m.in. Kwintylian ${ }^{206}$ i Pry$\operatorname{scjan}^{207}$ (a wyśmiał Marcjalis ${ }^{208}$ ).

$\mathrm{Na}$ wiejskiej prowincji wcześnie pojawiła się tendencja do monoftongizacji dyftongu $/ \mathrm{a}^{\mathrm{e}} /{ }^{209} \mathrm{i}$ wymawiania w jego miejscu pojedynczej długiej samogłoski /ę/ o artykulacji szerszej (bardziej otwartej) niż istniejące w systemie /è/; dowodzą tego niektóre $\mathrm{z}$ pompejańskich graffiti, na których pojawia się z jednej strony grafia $\mathrm{z} e \mathrm{w}$ miejscu dyftongu, np.: egrotes, Emilio, eris (= aeris), z drugiej zaś grafia $\mathrm{z}$ ae w miejscu krótkiego (a więc artykulacyjnie bardziej otwartego) /e/, np.: advaentu, Numaerio, Saecundae, Venaeria, vicinae (voc. masc.). Łaciński sermo urbanus charakteryzował się zachowaniem wymowy dwugłoskowej, jednak wspomniana tendencja do monoftongizacji sprawiła, że dygraf ae (obok pojedynczej litery $e$ ) zaczął być wykorzystywany także do notacji greckiego otwartego /ę/ (zapisywanego literą $\mathrm{H} / \eta$ ) w łacińskich za-

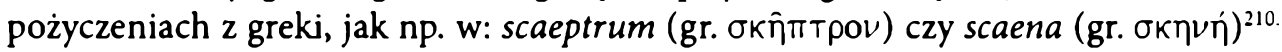
W okresie późnego Cesarstwa tendencja do monoftongizacji zintensyfikowała się

202 Scaur., Orthogr. 16, 6-10: 'a' igitur littera praeposita est ' $u$ ' et 'e' litteris, 'ae' 'au' [...] et apud antiquos ' $i$ ' littera pro ea scribebatur [...], ut 'pictai vestis' et 'aulai medio' pro 'pictae' et 'aulae'; sed magis in illis 'e' novissima sonat.

${ }_{2113}$ Prisc., Inst. gram. 1, 50 13-14: Sunt igitur diphthongi, quibus nunc utimur, quattuor, diphthongi autem dicuntur, quod binos phthongos, hoc est voces, comprehendunt.

204 A więc: [aurō argentō aerē]; wąskie /ē/ występujące w końcówce dat. sg. wyrazu aere reprezentuje pośredni etap rozwoju dyftongu /ei/, który ostatecznie zmonoftongizował się do /i/ (zob. niżej). Co do posługiwania się aliteracjami w tego typu formułach por. np. triumviri agris adiudicandis adsignandis.

2015 A więc: [kaụa kaerula kandent].

2116 Quint., Inst. 1, 7, 18-19.

217 Prisc., Inst. gram. 1, 50, 15-20: ae, quando a poetis per diaeresin profertur, secundum Graecos per a et i scribitur, ut 'aulai', 'pictai' pro 'aulae' et 'pictae'. Vergilius in III: „Aulai medio libabant pocula Bacchi", idem in VIIII: "Dives equum, dives pictai vestis et auri”.

${ }^{211}$ Mart., Epigr. 9, 90, 5.

201 Już w Il w. przed Chr. Lucyliusz przestrzegał: Cecilius pretor ne rusticus fiat - zob. Varro, Ling. 7, 96; por. też ibid. 5, 97: in Latio rure edus: qui in urbe, ut in multis, $A$ addito, aedus.

${ }^{210}$ Ibid. 7, 96. 
i rozpowszechniła na wszystkie rejestry językowe, prowadząc do wyparcia tego dyftongu z systemu i wprowadzenia w jego miejsce nowej długiej samogłoski /ę/; o jej szerszej artykulacji niż /ē/ dotychczas istniejące, oprócz przywołanych wyżej zapisów $\mathrm{z}$ użyciem dygrafu ae w miejsce krótkiego /e/, świadczą także jej romańskie kontynuanty, zbieżne z krótkim /e/, a nie wcześniejszym /ē/ (zob. niżej).

Dyftong /a $/{ }^{4}$ zapisywany był dygrafem AV/au i wymawiany podobnie jak np. pierwsza sylaba w pol. wyrazach auto, audyt czy aula. W grece transkrybowany był $\mathrm{z}$ użyciem liter au, ao lub aou. Najdłużej spośród wszystkich dyftongów opierał się monoftongizacji i dopiero na gruncie indywidualnego rozwoju (niektórych) języków romańskich nastąpiła jego monoftongizacja do /ō/. Jednak w umbryjskim i innych językach italskich wokół Lacjum dość wcześnie nastąpiło przekształcenie się /a $/ \mathrm{w} / \bar{o} /$, a zmiana ta w pewnym zakresie szybko przedostała się także do języka Rzymu jako prowincjonalizm ${ }^{21}$. Pojawiły się w związku z tym w łacinie rustycyzmy typu: òlla (obok aulla), cōlis (obok caulis), cōda (obok cauda), plōstrum (obok plaustrum), przy czym pewne formy wyrazowe $\mathrm{z} / \overline{\mathrm{o}} / \leftarrow / \mathrm{a}^{\mathrm{u}} /$, takie jak np.: lōtus $(\leftarrow$ lautus $)$, pōllulum $(\leftarrow$ paullulum) czy óricula ( $\leftarrow$ auricula), przeniknęły także do (mniej formalnego) języka miejskiego ludzi wykształconych ${ }^{212}$. Z drugiej strony pojawiły się "hiperurbanizmy", jak np.: caudex $(\leftarrow$ cōdex), austium $(\leftarrow \overline{o s t i u m})$ czy plaudere (które nb. niemal całkowicie wyparło pierwotne plōdere). Z kolei w nagłosie wyrazu, jeśli kolejna sylaba zawierała /u/, notuje się tendencję do redukcji /a $/$ do /a/, o czym świadczy występowanie form typu Agustus ${ }^{213}$ czy ascultare ${ }^{214}$.

Dyftong /o'/ artykułowany był w sposób zbliżony np. do pierwszej sylaby w pol. wyrazach ojciec, ojczyzna, jednak podległ podobnemu jak w przypadku dyftongu /a $/$ procesowi lekkiego rozszerzenia wygłosu, przyjmując $w$ rezultacie postać $/ 0^{e} /$ Zapisywany był dygrafem $O E / o e$, przy czym zachował się w stosunkowo niewielu łacińskich wyrazach, jako że w większości przypadków pierwotny dyftong /oi/ wcześnie, tj. na przełomie III i II w. przed Chr., zmonoftongizował się do długiego /ū/, jak $\mathrm{np}$. w wyrazach: unum, plurimi, które wywodzą się z wcześniejszych oino, ploirume, zapisanych jeszcze $\mathrm{w}$ tej postaci na inskrypcji nagrobnej Lucjusza Scypiona (syna Barbatusa) $z$ drugiej połowy III w. przed Chr. Do epoki klasycznej przetrwał w takich wyrazach jak np.: oboedio, amoenus, proelium, foedus, coepi, poena (obok równoleglego punire), moenia (obok murus). Występuje także w greckich pożyczkach, stanowiąc

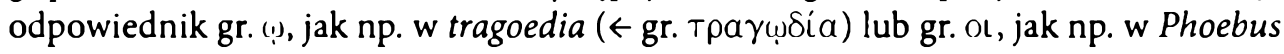
$\left(\leftarrow\right.$ gr. $\Phi_{O} \hat{\imath} \beta(s)$. W późnej łacinie zmonoftongizował się do długiego /ē/215.

21 Por. np. Pompeius Festus, De verborum significatione, 182, 46-48: 'Orata' genus piscis appellatur a colore auri, quod rustici 'orum' dicebant, ut 'auriculas' 'oriculas'.

21: Zob. np. Cic., Fam. 12, 12, 2; Q. fr. 2, 14, 4.

$213 \mathrm{~W}$ inskrypcjach, począwszy od zabytków pompejańskich; por. też np. wł. agosto, franc. aost.

214 Por. Cap., Verb. dub. 108, 6: ausculta, non asculta.

21 Pierwsze przykłady pisowni $e$ (zamiast oe) spotykamy jednak już na zabytkach pompejańskich, np.: amenus, citharedus, Phebus. 
Dyftong $/ 0^{\%}$, zapisywany dygrafem $\mathrm{OV} / \mathrm{ou}$ i wymawiany podobnie jak np. pierwsza sylaba w pol. wyrazie ołtarz, pod koniec IIl w. przed Chr. także przekształcił się w długie /ü/, a archaiczną grafię okazjonalnie spotyka się na starych inskrypcjach, np.: IOVS (= klas. ius), COVRAVERVNT (= klas. curaverunt). W epoce klasycznej dyftong ten pojawia się jedynie wtórnie jako efekt kontrakcji w przypadku jednosylabowej wymowy wyrazu prout, na co zdaje się wskazywać sposób, w jaki wyraz ten mógł być używany w poezji ${ }^{216}$.

Dyftong /e $\mathrm{i} /$, zapisywany dygrafem EI/ei i wymawiany jak np. następująca po nagłosowej spółgłosce część pol. wyrazu lej, funkcjonował w łacinie archaicznej, o czym świadczą zabytki inskrypcyjne pochodzące z okresu do połowy III w. przed Chr., które notują m.in. takie formy jak np.: VIRTVTEI (dat. sg. = klas. virtuti), FOIDERATEI (nom. pl. = klas. foederati), DEIVOS (= klas. divus). Ok. połowy trzeciego stulecia dyftong ten przekształcił się w pojedynczą długą samogłoskę zapisywaną literą E/e, np.: PLOIRUME (nom. pl. = klas. plurimi), DIOVE (dat. sg. = klas. Iovi) ${ }^{217}$. Samogłoska ta zapewne artykułowana była nieco inaczej niż współistniejące w systemie długie /è/, takie jak np. w légatus czy cēlo, bowiem w późniejszym rozwoju, tj. ok. połowy kolejnego stulecia, utożsamiła się nie $\mathrm{z} / \mathrm{e} /, \operatorname{lecz} \mathrm{z} / \overline{\mathbf{l}} /$ i zaczęła być notowana literą $I / i^{218}$; prawdopodobnie więc miała wymowę węższą niż „zwykłe” /ēl, czyli pośrednią między /ē/ i /ì/. W okresie klasycznym dyftong /e $\mathrm{i} /$ pojawił się wtórnie jako efekt możliwej (tj. sugerowanej przez łacińską wersyfikację) kontrakcji /e/ i /i/ w takich formach jak np.: deinde ${ }^{219}$, de(h)inc ${ }^{220}$, aureis ${ }^{221}$ oraz w końcówkach gen. i dat. sg. rzeczowników V deklinacji, jak np. w rei.

Dyftong /e $/$ był zapisywany przy użyciu dygrafu EV/eu i artykułowany jak np. pierwsza sylaba wyrazu Europa. Jeszcze w epoce przedliterackiej zmonoftongizował się do /ü/; zachował się jedynie w spójnikach neu, seu, partykule wykrzyknikowej heu(s), a także w pożyczkach greckich typu: Euboea, Prometheus.

Jak wynika z powyższego przeglądu, łacińskie dyftongi stanowią niejednorodną i zróżnicowaną diachronicznie grupę. $Z$ punktu widzenia synchronicznego, znaczącą rolę $w$ strukturze systemu fonologicznego klasycznej łaciny odgrywały jedynie $/ a^{i} /$

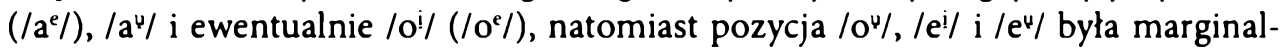

216 Por. Hor., Serm. 2, 6, 66-68: vernasque procacis / pasco libatis dapibus; prout cuique libido est / siccat inaequalis calices conviva.

217 Chociaż nadal stosowane były także zapisy z zastosowaniem dygrafu EI (np.: CEIVIS, DEICERENT, VIREI), a nawet pojawiły się mylne użycia dygrafu EI/ei w wyrazach, w których samogłoska /è/ nie kontynuowała wcześniejszego dyftongu, np. DECREIVIT.

${ }_{21 *}$ To spowodowało z kolei mylne użycia dygrafu EI w wyrazach zawierających /i/ niepochodzące z dyftongu, jak np.: AUDEIRE, COGENDEI (gen. sg.).

${ }_{21 y}$ Por. Ov., Met. 9, 142-144: flendoque dolorem / diffudit miseranda suum. Mox deinde quid autem / flemus?'.

2210 Por. Verg., Aen. 1, 131: Eurum ad se Zephyrumque vocat, dehinc talia fatur.

221 Por. ibid. 1, 725-727: fit strepitus tectis vocemque per ampla volutant / atria; dependent lychni laquearibus aureis / incensi. 
na $^{222}$. Kontrowersje wzbudza status łacińskich dyftongów, tzn. rozstrzygnięcie, czy stanowią one pojedyncze fonemy, a więc fonologiczne dyftongi, czy też są to jedynie dyftongi fonetyczne, czyli sekwencje dwufonemowe złożone $z$ samogłoski i glajdu. Aby struktura wokaliczna (zgłoskotwórcza) o zmiennym przebiegu akustycznym mogła być uznana za fonologiczny dyftong ( $\mathrm{tj}$. pojedynczy fonem), powinna stanowić funkcjonalny ekwiwalent (długiej) samogłoski, czyli podlegać tym samym co samogłoska regułom fonologicznym i fonotaktycznym. Z punktu widzenia omawianej wcześniej problematyki dotyczącej sylaby fonologiczny (strukturalny) status artykulacji dyftongicznych określany jest przez ich pozycję w obrębie struktury sylaby, determinowaną przez reguły fonotaktyczne. W tym względzie ekwiwalencja dyftongu w stosunku do samogłosek oznacza przynależność obu jego elementów składowych (tj. nagłosowej samogłoski i wygłosowego glajdu) do ośrodka sylaby. Tymczasem analiza łacińskich sylab zawierających dyftongi, przeprowadzona pod tym właśnie kątem, wskazuje na istnienie ważnego ograniczenia fonotaktycznego różniącego je od pojedynczych samogłosek, a polegającego na braku łączliwości z tautosylabiczny$\mathrm{mi}$ ( $\mathrm{tj}$. należącymi do tej samej sylaby) sonorantami wygłosowymi. Chodzi o to, że dyftongi mogą występować jedynie przed tautosylabicznymi obstruentami, jak np. w: auc.tus, aes.tus, faus.tus, natomiast nie istnieją w łacinie sylaby typu: .paen., .caul., poer(s). itp. ${ }^{223}$ Zarysowany wcześniej ${ }^{224}$ ogólny schemat struktury sylaby łacińskiej, przewidujący w jej wygłosie miejsce na sonorant lub glajd, obstruent albo sekwencję fonemów tych klas, lokuje zatem glajd zamykający dyftong w pozycji zestępu (a nie ośrodka) sylaby. Taka strukturyzacja sylab zawierających dyftong czyni je też w pełni paralelnymi względem struktury sylab z pojedynczą sylabą w ośrodku; ilustują to poniżse przykłady:

222 Zob. też Benedetti (1996) na temat alternatywnej linii rozwojowej dyfongów przed bezdźwięcznymi spółgloskami zwartymi, prowadzącej do powstania krótkiej samogłoski i wzdłużenia spółgloski, np.: "meito $\rightarrow$ mitto, *Dioupater $\rightarrow$ luppiter.

${ }^{223} \mathrm{~W}$ przeciwieństwie do sylab zawierających pojedynczą samogłoskę, jak np. w cen.sor, tur.ba, som.nus, ins.tar. Oprócz nich strukturę tego typu prezentują jedynie sylaby $z$ marginalnym w lacinie, wtórnym dyftongiem /ei/, który mógł pojawić się przy jednosylabowej artykulacji wyrazów deinde i de(h)inc. Dodajmy, że w wyrazach typu: poena, laurus czy paenitet sonorant występujący po dyftongu nie ma charakteru tautosylabicznego (por.: /poị.na/, /laụ.rus/, /pai.ni.tet/).

224 Zob. wyżej, rozdzial 5.1.: Sylaba w lacinie. Granice sylab: sylaby otwarte i sylaby zamknięte. 
(s)

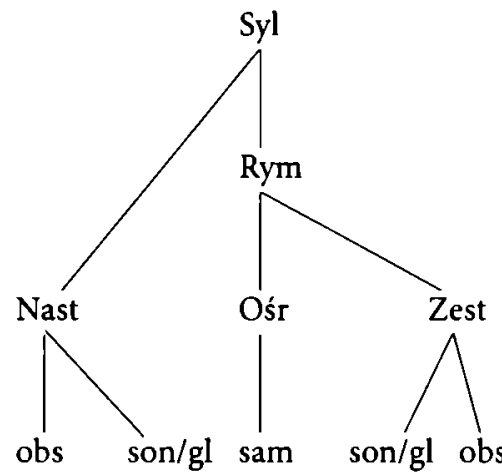

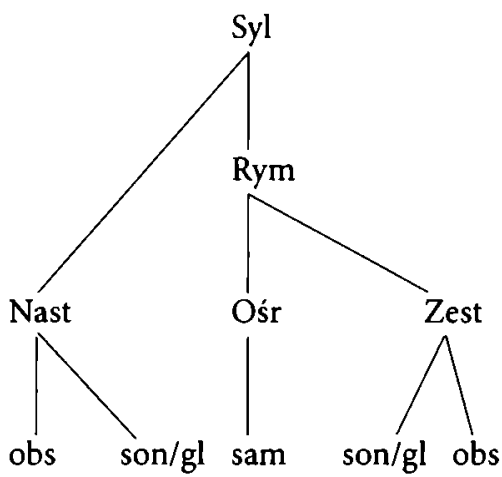

t

u

$\mathrm{u}$

s

S

f

p $\quad 1 \quad$ a

k

$\mathrm{p}$

प $s$
S

a

a

a u

U 5

I

$\mathrm{t}$

d

n a

g

g

$\mathrm{t}$

f

r u

u

$\mathbf{O}$
S

r $\mathbf{m}$

a $\quad$ S

S

a

a

a

i

$\begin{array}{rrrr} & \text { e } & \text { r } & \\ \text { r } & \text { a } & & \\ \text { a } & & s \\ & \text { a } & \text { i } & \text { k }\end{array}$

Paralela ta implikuje tym samym przypisanie łacińskim dyftongom statusu struktur bifonematycznych, złożonych z samogłoski i glajdu ${ }^{225}$, a więc statusu dyftongu fonetycznego, a nie fonologicznego.

Status ten potwierdza również resylabizacja (tj. przesunięcie do innej sylaby) wygłosowego glajdu dyftongów, ujawniająca się w sytuacji, gdy ( $w$ formach wyrazowych pokrewnych) zajmuje on pozycję przedsamogłoskową (prewokaliczną); sytuację tę ilustrują np. pary wyrazów: lautus : lavare, cautus : cavere. Glajd w pozycji prewokalicznej jest zawsze w takich przypadkach resylabizowany do nagłosu kolejnej sylaby,

225 Zmiana pisowni $a i \rightarrow$ ae i oi $\rightarrow$ oe oznaczać może, że glajd/ì/ reprezentowany był przez bardziej otwarty allofon w pozycji postwokalicznej i bardziej zamknięty w pozycji pre- $i$ interwokalicznej. 
a więc /la.ūā.re/ (wobec /laụ.tus/), /ka.ụē.re/ (wobec/kaun.tus/), czyli analogicznie jak $\mathrm{np}$. / k/ w ramach pary facere : factus (tj. /fa.ke.re/ wobec/fak.tus/). To również wskazuje na fakt, że wygłosowy glajd w dyftongu zajmuje pozycję zestępu sylaby (a nie ośrodka), bowiem nie spotyka się w łacinie resylabizacji do nagłosu z ośrodka sylaby. Gdy idzie o dyftong $a e^{226}$, to w pozycji przedsamogłoskowej występuje on jedynie $\mathrm{w}$ formacjach $\mathrm{z}$ przedrostkiem prae-, a więc $\mathrm{w}$ formacjach typu praealtus, oraz $\mathrm{w}$ imieniu własnym Gnaeus. W wyrazach tych wygłosowy glajd dyftongu był resylabizowany do nagłosu kolejnej sylaby (a więc np. /pra. ial.tus/) w okresie archaicznym, o czym świadczy krótki iloczas pierwszej sylaby tych wyrazów (u Plauta w 10 przypadkach na 11). W okresie klasycznym sylaby tego typu charakteryzują się długim iloczasem, co jednak niekoniecznie musi oznaczać sylabizację typu /prai.al.tus/ (i status fonologicznego dyftongu), lecz może pozostawać w związku z zasygnalizowaną wyżejej (redundantną) długością interwokalicznego /i/ w epoce klasycznej (a więc [prajjaltus], analogicznie do [majjor], [ejjus] itp. $)^{228}$.

\subsection{PRZEBUDOWA ŁACIŃSKIEGO WOKALIZMU W OKRESIE CESARSTWA}

Ok. II-III w. po Chr. rozpoczął się proces przebudowy łacińskiego systemu wokalicznego, którego efektem było zastąpienie opozycji iloczasowych opozycjami opartymi na stopniu apertury. Jak zaznaczyliśmy już wcześniej, również $w$ ramach systemu iloczasowego różnica stopnia apertury towarzyszyła, jako cecha subfonologiczna, samogłoskom wysokim i średnim. Przejawiało się to w tym, że samogłoski długie miały artykulacje węższą niż ich krótkie odpowiedniki, wskutek czego krótkie /i/ i /u/ były pod względem otwartości bliższe długim /ê/i /ō/ niż/ì/ i /ū/. Monoftongizacja dyftongu ae doprowadziła $\mathrm{z}$ kolei do powstania nowej długiej samogłoski /ę/, która była artykulacyjnie szersza od dotychczas istniejącego w sytemie $/ e \bar{l} /$, a więc pod względem apertury odpowiadała krótkiemu /e/. Proces zbliżania krótkich /i/ i /u/ do długich /ē/ i /ō/ postępował, prowadząc ku rozszerzeniu ich artykulacji odpowiednio do /ẹ/ i /ọ/, węższych od pierwotnych krótkich /e/ i /o/. Pojawiły się w związku z tym cztery podstawowe stopnie apertury:

1. najwęższy, na którym znalazły się długie $/ \overline{\mathrm{i}} /$ oraz $/ \overline{\mathrm{u}} /$;

2. szerszy, reprezentowany przez krótkie $/ \mathrm{e} /(\leftarrow / \mathrm{i} /) \mathrm{i} / \mathrm{o} /(\leftarrow / \mathrm{u} /)$ oraz długie /ē/ i /ō/;

3. jeszcze szerszy, $z$ dawnymi krótkimi /e/ i /o/ oraz nową długą /ę/, powstałą w wyniku monoftongizacji dyftongu $a e$;

4. najszerszy, $\mathrm{z} / \mathrm{a} / \mathrm{i} / \mathrm{a} /$.

226 Dyftong oe nie występuje $w$ lacinie $w$ pozycji prewokalicznej.

22: Tj. w części dotyczącej glajdów.

22* Powyższa argumentacja dotycząca niefonologicznego charakteru lacińskich dyftongów przedstawiona została za Cser (1999); tam też zob. dodatkowe argumenty związane m.in. $z$ alternacjami wokalicznymi. 
System ten ująć można zatem w następujący schemat:

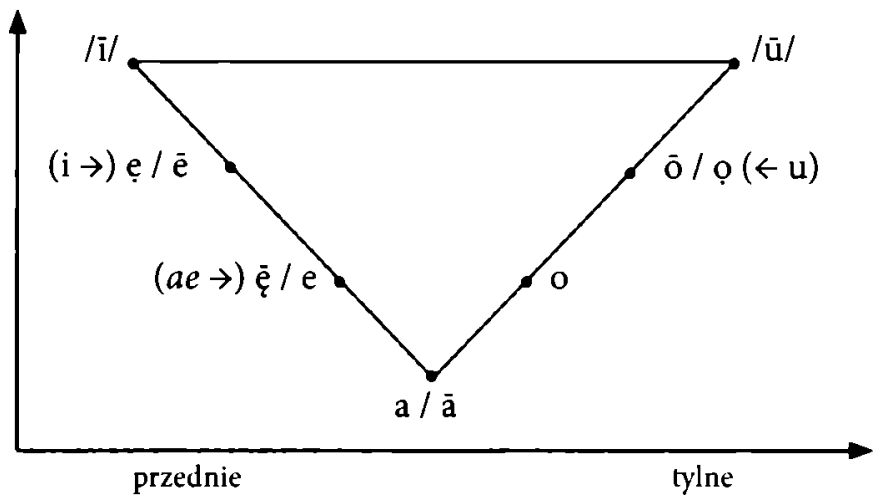

Wobec słabnącej opozycji iloczasowej najpierw nastąpiła fuzja (tj. zlanie się, ujednolicenie) łacińskiego krótkiego /a/ i długiego /ā/ do jednego romańskiego /a/, a następnie, po stronie samogłosek przednich, fuzja wąskiego /ẹ/ (pochodzącego z krótkiego /i/) i długiego /ē/ do romańskiego wąskiego/ẹ/, oraz szerokiego /ę/ (powstałego z ae) i krótkiego /e/ do romańskiego szerokiego (otwartego) /ę/, a po stronie samogłosek tylnych fuzja wąskiego /ọ/ (pochodzącego z krótkiego /u/) i długiego /ō/ do romańskiego wąskiego /ọ/; krótkie /o/ stanęło w opozycji do tego ostatniego jako romańskie szerokie (otwarte) /Q/. Potwierdzeniem tego procesu są odrębne kontynuanty $/ \bar{i} /, / \overline{\mathrm{u}} / \mathrm{i} / \mathrm{o} /$ oraz wspólne (identyczne) kontynuanty w językach romańskich tych fonemów, które podległy fuzji. Należy jednak zaznaczyć, że w toku ewolucji każdego $\mathrm{z}$ języków romańskich kontynuanty te ulegały kolejnym indywidualnym zmianom, zależnym od wielu różnych czynników kontekstowych (m.in. pozycji względem akcentu (początku / końca wyrazu), otwartości / zamknięcia sylaby, kontekstu spółgłoskowego itp.). W stosunkowo najmniej zmienionym stanie zachowały się w sylabach akcentowanych otwartych; ich odpowiedniości względem samogłosek łacińskich $w$ tym położeniu ilustruje poniższe zestawienie.

$/ \mathrm{i} / \quad \rightarrow$ romańskie $/ \mathrm{i} /: \quad$ lac. filum $\rightarrow$ wł. filo, hiszp. hilo, franc. fil

$/ \overline{\mathrm{u}} / \quad \rightarrow \quad$ romańskie $/ \mathrm{u} /: \quad$ łac. mūrum $\rightarrow$ wł. muro, hiszp. muro, franc. mur

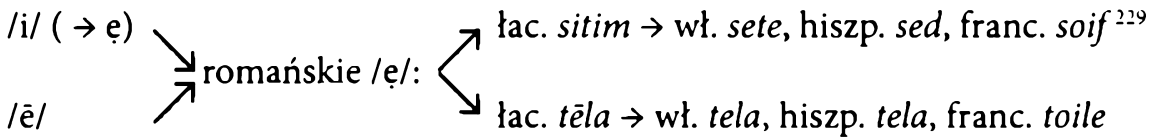

${ }_{22 y}$ We francuskim romańskie /ẹ/ przekształciło się w ei, a następnie w oi [ựa]. 


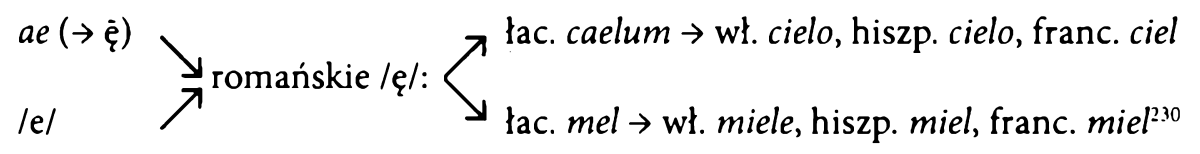

lu/ $(\rightarrow \mathrm{o})$
$/ \mathrm{o} /$$\searrow_{\text {romańskie } / \mathrm{o} /: \coprod_{\text {łac. hōra } \rightarrow \text { wł. ora, hiszp. hora, franc. heure }}}$

/o/ $\rightarrow$ romańskie /Q /: $\quad$ lac. novum $\rightarrow$ wł. nuovo, hiszp. nuevo, starofranc. nuef

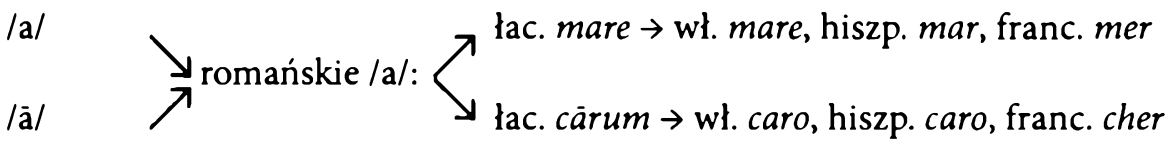

Należy przy tym pamiętać, że wyżej opisane zmiany nie dokonywały się równocześnie ani równomiernie na terenie całego Imperium Romanum; pewnych regionów, zwłaszcza bardziej peryferyjnych czy izolowanych (np. Sardynii, Korsyki, Dacji czy niektórych obszarów południa Italii) zmiany te w ogóle nie objęły. Przedstawiony wyżej zarys rozwoju łacińskich fonemów wokalicznych ma charakter znacznie uproszczony i schematyczny, natomiast bardziej szczegółowy opis ewolucji łaciny w drugiej połowie pierwszego tysiąclecia po Chr. jest już zadaniem językoznawstwa romańskiego i nie wchodzi w zakres tematyki niniejszego opracowania.

23) Szerokie romańskie /ę/, podobnie jak szerokie /Q/ $(\leftarrow / 0 /)$, podległo procesowi tzw. dyftongizacji romańskiej. 


\section{8. \\ Wybrana literatura}

Allen (1965), Bednarski (1981), Benedetti (1996), Janson (1979), Kelly (1967), Marouzeau (1955), Safarewicz (1937, 1953, 1966, 1986), Sturtevant (1940), Traina (1957), Väänänen (1963), Ward (1962).

Konsonantyzm:

Baldi (1994), Hamp (1959), Giannini, Marotta (1989), Marotta (1982), Porzio Gernia (1973, 1974), Safarewicz $(1932,1962)$.

Wokalizm i prozodia:

Allen (1973), Bernardi Perini (1970), Campanile (1973), Cser (1999), Cygan (1996 ), Franceschi (1976), Janson (1977), Panfilov (1977), Porzio Gernia (1976), Pulgram (1974, 1975), Spence (1965), Stephens (1986).

Alfabet i ortografia:

Bernardi Perini (1983), Cristofani (1978), Della Casa (1974), Strzelecki (1938, 1947, 1949, 1950, 1958), Traina (1957). 
MORFOLOGIA 



\section{1. \\ Wprowadzenie}

\subsection{MORFEM, MORF, ALLOMORF}

Elementarnymi jednostkami funkcjonalnymi płaszczyzny morfologicznej języka są morfemy. Podobnie jak fonem, również morfem jest terminem identyfikującym pojęcie abstrakcyjne. Oznacza on abstrakcyjną, elementarną jednostkę systemu językowego, której przypisana jest określona funkcja semantyczna (znaczeniowa) lub/i syntaktyczna (składniowa). Jednostka ta zefiniowana jest poprzez sieć opozycji funkcjonalnych i formalnych, $w$ jakie wchodzi ona $z$ innymi analogicznymi jednostkami funkcjonalnymi języka.

Każdemu morfemowi odpowiada $\mathrm{w}$ planie wyrażania określony jedno- lub wieloelementowy zbiór wykładników formalnych (reprezentacji fonologicznych), zwanych morfami. Tym samym morf to najmniejsza dająca się wydzielić w tekście jednostka językowa mająca funkcję semantyczną lub/i syntaktyczną, reprezentowana przez ciąg fonemów i odpowiadająca jednemu i tylko jednemu morfemowi. Jeśli dwie tego typu jednostki różnią się pod względem formy lub funkcji, to jednostki te są dwoma różnymi morfami.

Morfy różniące się między sobą pod względem formy, ale nie pod względem funkcji, czyli morfy odpowiadające jednemu morfemowi (stanowiące jego dwie różne reprezentacje fonologiczne), to allomorfy danego morfemu. Za takie uznać można morfy spełniające trzy następujące warunki:

- pozostają w stosunku do siebie w dystrybucji uzupełniającej (komplementarnej);

- posiadają identyczną fukcję;

- występujące między nimi różnice fonologiczne dadzą się wyjaśnić przy pomocy reguł morfonologicznych danego języka (tzn. reguł objaśniających fonologiczne uwarunkowania występujących alternacji).

Np. allomorfami tego samego morfemu są (wyróżnione pogrubieniem): pol. bazar-u / bazarz-e, pies-ø / ps-a, las-ø / leś-ny, w piątek / we wtorek; łac. mel-ø / mell-is, cor-ø / cord-is, ager-ø / agr-i, ama-b-o / ama-bi-s / ama-be-ris, a me / ab amico, in-duco / im-pello. 
Morfy, które posiadają identyczną formę (tę samą strukturę fonologiczną), ale cechują się różną funkcją i tym samym odpowiadają różnym morfemom, to morfy homofoniczne, np.: pol. pal-ø 'słup' / pal-ę, prosz-e / lamp-ę; łac. vēr-e 'wiosną' / vēr-um 'prawda', vol-o 'lecę' / vol-o 'chcę', am-ö 'kocham' / amic-ō 'przyjacielowi'.

Istnieją także morfemy zerowe (oznaczane symbolem ø), czyli takie, których reprezentację stanowi morf zerowy (tzw. zero fonologiczne). O morfemie zerowym mówimy wtedy, gdy zero fonologiczne pozostaje $w$ relacji $z$ morfami niezerowymi, wchodząc $z$ nimi $w$ opozycje funkcjonalne, np. końcowe zero fonologiczne $w$ pol. wyrazie $\dot{z} 0 n-\theta$, stojące w opozycji do niezerowych morfów w wyrazach: $\dot{z} o n-y, \dot{z} o n-\ell$, żon-ach, żon-ami. Por. też łac. orator- $\emptyset \mathrm{w}$ opozycji do orator-is, orator-em, orator-um; $a m a-ø-t$ w opozycji do ama-ba-t, ama-bi-t, ama-re-t.

\subsection{DYSTRYBUCYJNA KLASYFIKACJA MORFEMÓW}

Dystrybucyjna klasyfikacja morfemów uwzględnia ich autonomię tekstową oraz konteksty, w jakich występują w ramach (współ)tworzonych przez nie struktur wyrazowych. Według tej klasyfikacji wyróżnia się:

1. morfemy swobodne, tj. morfemy, których reprezentacje fonologiczne (morfy) są równe wyrazom tekstowym, np.: pol. dziś, tam; łac. ibi, ab, ter;

2. morfemy związane, tj. morfemy, których reprezentacje fonologiczne nie stanowią wyrazów tekstowych, lecz ich części, np.: pol. prze-pis-a-ć; łac. hort-ul-us.

Wśród morfemów związanych wyróżnia się:

2.a. morfemy rdzenne, tj. morfemy konstytutywne form gramatycznych, np. pol. roz-syl-a-ć; lac. laud-a-nt, con-duc-o;

2.b. morfemy nierdzenne, inaczej afiksy, czyli morfemy współtworzące wraz z morfemem rdzennym formy gramatyczne.

Morfemy nierdzenne (afiksy) dzielą się z kolei na:

2.b.1. prefiksy, czyli morfemy znajdujące się w prepozycji do rdzenia, np.: pol. roz-syt-a-ć, tac. con-duc-o;

2.b.2. sufiksy, czyli morfemy zajmujące pozycję po rdzeniu, np.: pol. pis-a-ć, lac. laud-a-re, laud-a-ba-m;

2.b.3. postfiksy, czyli morfemy znajdujące się po końcówkach fleksyjnych, np.: pol. kogo-kolwiek, łac. cui-que;

2.b.4. interfiksy, czyli morfemy znajdujące się pomiędzy morfemami rdzennymi w wyrazach słowotwórczo złożonych, np.: pol. wod-o-ciag, łac. omn-i-pot-ent-es.

\subsection{FUNKCJONALNA KLASYFIKACJA MORFEMÓW}

Funkcjonalna klasyfikacja morfemów uwzględnia rodzaj pełnionej przez morfemy funkcji oraz stopień ich kategorialności, czyli regularności formalno-funkcyjnej. W ramach tej klasyfikacji wyróżnia się: 
1. morfemy leksykalne, czyli morfemy będące wykładnikami znaczenia leksykalnego (słownikowego); cechuje je niekategorialna (jednostkowa, indywidualna) funkcja semantyczna, tj. brak regularności formalno-funkcyjnej; morfemami leksykalnymi są jedynie morfemy rdzenne, np.: pol. szkol-n-y, pis-a-ć; łac. hort-ul-us, laud-a-nt;

2. morfemy gramatyczne, czyli morfemy będące wykładnikami funkcji gramatycznych; cechuje je kategorialna (systemowa) funkcja semantyczna i/lub syntaktyczna, a więc określony poziom regularności formalno-funkcyjnej.

Morfemy gramatyczne dzielą się z kolei na:

2.a. morfemy słowotwórcze (derywacyjne), czyli morfemy o funkcji wykładników pochodności słowotwórczej; cechuje je niższy (niż morfemy fleksyjne) poziom regularności formalno-funkcyjnej (kategorialności); stanowią je prefiksy słowotwórcze (np. con-duc-o), sufiksy słowotwórcze (np. bell-ic-us, laud-a-re) i postfiksy słowotwórcze (np. quem-que);

2.b. morfemy fleksyjne, czyli morfemy o funkcji wykładników wartości określonych kategorii fleksyjnych (np. przypadka, liczby, czasu, osoby itp.); cechuje je najwyzszy poziom regularności formalno-funkcyjnej i są obligatoryjne dla określonych klas wyrazów, którym przysługują dane kategorie fleksyjne; stanowią je sufiksy fleksyjne (np. laud-a-re, laud-a-ba-nt) i końcówki fleksyjne (laud-a-ba-nt, bell-ic-us).

Cechą charakterystyczną morfemów fleksyjnych jest synkretyzm, czyli kumulacja funkcji. Oznacza to, że dany morfem fleksyjny nie jest wykładnikiem jednej tylko kategorii fleksyjnej, lecz większej ich liczby. Np. morfem reprezentowany przez morf -isse- w wyrazie laudavissent jest wykładnikiem zarówno trybu jak i czasu (coniunctivi plusquamperfecti), zaś morfem (reprezentowany przez morf) -em w wyrazie oratorem wyraża zarówno przypadek jak i liczbę (accusativus singularis).

Końcówki fleksyjne to morfemy (sufiksy) fleksyjne, będące synkretycznymi (skumulowanymi) wykładnikami wartości fleksyjnych kategorii przypadka i liczby (są to tzw. końcówki deklinacyjne) lub osoby, liczby i strony (tzw. końcówki koniugacyjne).

Kategoria fleksyjna to podstawa dwu- lub wielowartościowej systemowej opozycji funkcjonalnej między określonymi klasami wyrazów gramatycznych, opozycji wyrażanej za pośrednictwem skategorializowanych, obligatoryjnych dla tych klas wyrazów gramatycznych wykładników morfologicznych (tj. właśnie sufiksów i koncówek fleksyjnych). Sieć opozycji, na których opiera się dana kategoria, wyznacza zbiór jej wartości. Przykładowo fleksyjna kategoria osoby jest podstawą opozycji funkcjonalnej między klasami wyrazów reprezentowanymi przez takie formy jak np.: amo, amas, amat; opozycja w ramach tej kategorii wyrażana jest za pośrednictwem skategorializowanych wykładników morfologicznych, tj. końcówek fleksyjnych: $-o$, $-s,-t$. W oparciu o tę kategorię oponują względem siebie trzy elementy, co wyznacza zbiór trzech wartości tej kategorii: 1. osoba, 2. osoba, 3. osoba.

Szerszym pojęciem niż kategoria fleksyjna jest pojęcie kategorii morfologicznej, która również wyznaczona jest w oparciu o kryterium formalno-funkcyjne o charakterze morfologicznym, ale która oprócz kategorii fleksyjnych, np. osoby, obejmuje 
również mniej regularne kategorie o charakterze słowotwórczym, np. deminutivum (por. np. hort-ul-us wobec hort-ø-us).

Pojęciem najszerszym jest pojęcie kategorii gramatycznej, czyli kategori funkcjonalnej wyznaczonej zarówno w oparciu o kryterium morfologiczne (np. osoba lub deminutivum), jak i składniowe (np. okolicznik).

\subsection{WYRAZ TEKSTOWY, WYRAZ GRAMATYCZNY, WYRAZ SŁOWNIKOWY (LEKSEM)}

Podstawową strukturą złożoną $\mathrm{z}$ morfemów jest wyraz. Z uwagi na wieloznaczność określenia „wyraz" konieczne jest pewne uściślenie znaczenia, w jakim używa się go jako terminu gramatycznego. Wyodrębnia się zatem kilka pojęć desygnowanych terminem „wyraz" wraz z dodatkowymi określnikami.

Wyraz tekstowy to jednostka funkcjonalna, będąca przedmiotem reguł linearyzacji (segmentacji) tekstu; jest to najmniejszy segment tekstu (ciąg morfemów reprezentowanych przez odpowiadające im morfy), spełniający co najmniej jeden z poniższych warunków:

1. może wystąpić jako samodzielne wypowiedzenie, np.: łac. cras, pol. jutro (np. w odpowiedzi na pytanie: Kiedy zrobimy zakupy?);

2. wykazuje zmienność (odwracalność) pozycji syntagmatycznej w stosunku do innych segmentów wypowiedzi; np. w ramach ciągu templum clarum, zarówno element templum jak i clarum mogą być uznane za odrębne wyrazy tekstowe ze względu na wzajemną odwracalność ich pozycji syntagmatycznej, tj. akceptowalność struktury clarum templum. Z kolei w ramach ciągu templum żaden jego segment nie może być uznany za odrębny wyraz tekstowy $z$ uwagi na nieakceptowalność struktur typu *lumtemp itp.;

3. jest segmentem ciągłym (liniowo niepodzielnym), tzn. nie dopuszcza możliwości wtrącenia w jego obręb dodatkowego elementu będącego wyrazem tekstowym; np. w obręb ciągu morfemów templum nie jest możliwe wtrącenie jakiegokolwiek dodatkowego elementu, co świadczy o tym, że ciąg ten stanowi jeden wyraz tekstowy - w przeciwieństwie do np. ciągu templum clarum, który dopuszcza taką możliwość (np. templum visitavit clarum), co dowodzi, iż konstytuowany jest przez dwa wyrazy tekstowe;

4. jest elementem ciągu, którego drugi element jest wyrazem tekstowym i stanowi funkcjonalny odpowiednik elementów tworzących z pierwszym ciąg podzielny liniowo, np. apud w ramach ciągu apud me, gdzie me jest wyrazem tekstowym (por. vocavit me / me vocavit) i stanowi funkcjonalny odpowiednik elementów typu patrem, które $\mathrm{z}$ apud tworzą ciąg podzielny liniowo, np. apud meum patrem;

5. otwiera tylko jedno miejsce dla morfemów fleksyjnych, np.: armiger, armigeri, armigero itd.; ciąg typu: respublica, reipublicae, rempublicam itp. konstytuować zatem będzie dwa wyrazy tekstowe, lecz jeden wyraz ortograficzny ( $t j$. ciąg liter ograniczony dwoma odstępami). 
Wyrazy tekstowe, lub ciągi wyrazów tekstowych, stanowią fonologiczne (tekstowe) reprezentacje wyrazów gramatycznych.

Wyraz gramatyczny to elementarna, abstrakcyjna jednostka funkcjonalna planu treści, ukonstytuowana przez określoną funkcję leksykalną (słownikową, znaczeniową) oraz gramatyczną. Przez funkcję gramatyczną rozumie się zbiór współwystępujących ( $\mathrm{z}$ daną funkcją leksykalną) wartości kategorii fleksyjnych, a w przypadku wyrazów niepodlegających fleksji właściwą im funkcję (pozycję) składniową. Fonologiczne reprezentacje wyrazów gramatycznych stanowione są przez pojedyncze wyrazy tekstowe lub wieloelementowe ciągi wyrazów tekstowych.

Wyrazy gramatyczne reprezentowane przez pojedyncze wyrazy tekstowe to tzw. syntetyczne wyrazy gramatyczne (syntetyczne formy gramatyczne), jak np. wyraz gramatyczny: ALTUS acc. sg. fem., reprezentowany przez pojedynczy wyraz tekstowy altam.

Wyrazy gramatyczne reprezentowane przez ponadjednoelementowe ciągi wyrazów tekstowych to tzw. analityczne (peryfrastyczne) wyrazy gramatyczne, jak np. wyraz gramatyczny: LAUDARE ind. perf. pass. 3. sg. masc., reprezentowany przez dwuelementowy ciąg wyrazów tekstowych laudatus est.

Należy jednak pamiętać, że $z$ analitycznym wyrazem gramatycznym mamy do czynienia wtedy i tylko wtedy, gdy dany ciąg wyrazów tekstowych wypełnia miejsce w systemie gramatycznym, otwierane przez sieć regularnych opozycji fleksyjnych, np.:

$\rightarrow$ laudo - laudor

$\rightarrow$ laudavi - laudatus sum,

gdzie ciąg wyrazów tekstowych laudatus sum wypełnia przy jednostce słownikowej LAUDARE miejsce, otwierane dla czasowników (przechodnich) przez kategorię fleksyjną strony przy wszystkich wartościach kategorii czasu.

Różne wyrazy gramatyczne, reprezentowane przez ten sam wyraz tekstowy (ten sam ciąg wyrazów tekstowych), to wyrazy gramatyczne hominimiczne; por. np.:

- stała matematyczna / stała temperatura / dziewczyna stała przed domem;

- dam ci odpowiedź jutro / jest wiele dam $w$ naszym towarzystwie;

- ksiqżki leża na półce / okładki ksiażki są kolorowe;

- multi flores in horto sunt / multos flores in horto habeo / tu flores militari virtute;

- dedit librum puero / hic homo notus mihi est a puero;

- oratio consulis brevis erat / suae plus quam communi saluti consulis.

$\mathrm{Z}$ kolei dwa różne wyrazy tekstowe reprezentować mogą jeden wyraz gramatyczny, stanowiąc:

1. warianty fakultatywne danego wyrazu gramatycznego, np.:

- laudaverunt/laudavere, reprezentujące wyraz gramatyczny: LAUDARE ind. perf. act. 3. pl:;

- caperis/capere, reprezentujące wyraz gramatyczny: CAPERE ind. praes. pass. 2. sg.; 
$\rightarrow$ hostes/hostis, reprezentujące wyraz gramatyczny: HOSTIS acc. pl.

2. warianty pozycyjne danego wyrazu gramatycznego, np.:

- deis/deabus, reprezentujące wyraz gramatyczny: DEA dat. pl.;

3. warianty funkcjonalne danego wyrazu gramatycznego, np.:

- vestri/vestrum, reprezentujące wyraz gramatyczny: VOS gen. pl.

Wyraz słownikowy, inaczej leksem, to abstrakcyjna jednostka systemu słownikowego (leksykalnego), której odpowiada pewien ściśle wyznaczony zbiór wyrazów (form) gramatycznych, reprezentowanych w tekście przez określony zbiór wyrazów (lub ciągów wyrazów) tekstowych.

Kryterium wyznaczania zbioru wyrazów (form) gramatycznych, odpowiadających danemu leksemowi, stanowi istnienie (bezpośredniej lub pośredniej) opozycji fleksyjnej między tymi wyrazami jako jedynej różnicy formalno-funkcyjnej między nimi. Opozycja fleksyjna zaś to relacja między dwoma wyrazami gramatycznymi polegająca na tym, że jedyną różnicą między nimi jest różnica wynikająca $z$ wyrażania różnych wartości w zakresie tylko jednej kategorii fleksyjnej (bezpośrednia opozycja fleksyjna) lub kilku różnych kategorii fleksyjnych (pośrednia opozycja fleksyjna).

Np. wyrazy gramatyczne reprezentowane przez wyrazy tekstowe: hortus i hortos należą do zbioru wyrazów gramatycznych odpowiadających temu samemu leksemowi (= reprezentują ten sam leksem), ponieważ różnica formalno-funkcyjna występująca między nimi da się w całości sprowadzić do wyrażania różnych wartości w zakresie fleksyjnej kategorii przypadka i liczby (nom. sg. : acc. pl.); wyrazy te stoją zatem względem siebie w pośredniej opozycji fleksyjnej.

Natomiast wyrazy gramatyczne reprezentowane przez wyrazy tekstowe: hortus i hortulos nie należą do zbioru wyrazów gramatycznych odpowiadających temu samemu leksemowi (= nie reprezentują tego samego leksemu), ponieważ różnica formalno-funkcyjna występująca między nimi nie da się w całości sprowadzić do wyrażania różnych wartości w zakresie określonych kategorii fleksyjnych (tj. przypadka i liczby); poza opozycją fleksyjną pozostaje różnica wynikająca $z$ deminutywnego znaczenia morfemu -ul-w hortulus, w związku z czym przyjmiemy, że wyrazy te reprezentują dwa różne leksemy.

Konwencjonalnie dany leksem oznacza się zapisem dużymi literami umownie wybranego reprezentującego go wyrazu gramatycznego, np. DOMINUS, co oznacza, że nie chodzi o ten konkretnie wyraz gramatyczny (nom. sg.), ale o jednostkę słownikową oznaczającą 'pana', czyli o zbiór wszystkich wyrazów gramatycznych reprezentujących tę jednostkę leksykalną. W nawiązaniu do wyżej przywołanych przykładów możemy więc odnotować, że wyrazy gramatyczne hortus i hortos reprezentują ten sam leksem HORTUS, natomiast wyraz gramatyczny hortulos reprezentuje leksem HORTULUS.

Składnik znaczeniowy wspólny dla wszystkich wyrazów (form) gramatycznych odpowiadających danemu leksemowi stanowi znaczenie leksykalne tych wyrazów, natomiast zbiór przysługujących im wartości kategorii fleksyjnych stanowi ich znaczenie gramatyczne (funkcję gramatyczną). 
Leksem, któremu odpowiada wieloelementowy zbiór wyrazów (form) gramatycznych, jest leksemem odmiennym, jak np. HORTUS czy SCRIBERE, natomiast leksem, któremu odpowiada jednoelementowy zbiór wyrazów gramatycznych, jest leksemem nieodmiennym, jak np. BENE lub IBI. Za nieodmienne uznawane bywają również leksemy, którym odpowiada zbiór wyłącznie homonimicznych wyrazów gramatycznych, jak np. DECEM albo ALIQUOT.

Szczególny jest w łacinie status leksemu ESSE 'być.' Wyrazy tekstowe, które reprezentują odpowiadające mu wyrazy gramatyczne, jak np. w zdaniu: Deus est „Bóg istnieje" czy Cicero orator erat „Cyceron był mówcą", mogą także być składnikami ciągów wyrazów tekstowych reprezentujących analityczne wyrazy gramatyczne odpowiadające innym leksemom, jak np. w zdaniu: Hostis victus est „Wróg został pokonany", gdzie est jest składnikiem ciągu reprezentującego jeden z (analitycznych) wyrazów gramatycznych leksemu VINCERE, a mianowicie VINCERE ind. perf. pass. 3. sg. masc.

\subsection{STRUKTURA MORFOLOGICZNA WYRAZÓW ŁACIŃSKICH}

Mówiąc poniżej o strukturze morfologicznej wyrazów łacińskich, mamy na myśli wyrazy tekstowe reprezentujące odpowiednie wyrazy gramatyczne poszczególnych leksemów. Dla ekonomii zapisu w tym właśnie znaczeniu używany bywa termin wyraz, podobnie jak termin morfem stosowany jest (dla uproszczenia) w znaczeniu reprezentującego go morfu.

Struktura morfologiczna wyrazów łacińskich zależy od kilku czynników. Jednym z nich jest ich złożoność bądź niezłożoność słowotwórcza. W zależności od tego czynnika wyrazy niezłożone słowotwórczo zawierać będą tylko jeden (morf reprezentujący) morfem leksykalny, jak np.: reg-al-is, laud-a-ba-mus, zaś wyrazy złożone więcej niż jeden, np.: omn-i-pot-ent-es, sign- $i$-fer- $i$.

Innym czynnikiem jest odmienność lub nieodmienność leksemu.

Wyrazy reprezentujące leksemy nieodmienne złożone będą wyłącznie $z$ morfemów leksykalnych, np.: heri, ubi-vis, lub z morfemów leksykalnych i morfemów

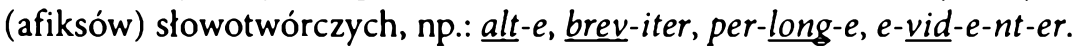

$\mathrm{Z}$ kolei wyrazy reprezentujące leksemy odmienne zawierać będą morfemy leksykalne, słowotwórcze i fleksyjne, jak np. wyraz custod-i-re-t, gdzie:

- custod- to morfem leksykalny (rdzenny), będący wykładnikiem funkcji leksykalnej (znaczenia słownikowego);

- $-i$ - to morfem (sufiks) slowotwórczy, derywujący czasownikowy temat praesentis (por. np. rzeczownik custo(d)-ø-s, custod-ø-is);

- -re-to morfem (sufiks) fleksyjny, będący skumulowanym wykładnikiem wartości kategorii czasu i trybu (por. custod-i-a-t, custod-i-e-t, custod-i-eba-t, custud-i-ø-t);

- $t$ to sufiks fleksyjny (końcówka fleksyjna), będący skumulowanym wykładnikiem wartości kategorii osoby, liczby i strony (por. custod-i-re-m, custud-i-re-s; custod-i-re-nt; custod-i-re-tur). 
Elementem struktury morfologicznej niektórych formacji fleksyjnych są morfemy zerowe, tj. morfemy, których formalną reprezentacją jest fonologiczne zero, jak np. w wyrazie laud-a-ø-tis, gdzie fleksyjny morfem zerowy (-ø-) jest wykładnikiem wartości kategorii trybu (indicativi) i czasu (praesentis); por. np. formy: laud-a-ba-tis, laud-a-bi-tis, laud-a-re-tis, laud-ø-e-tis, w których odpowiednio morfemy -ba-, -bi-, -re-, -e- stanowią funkcjonalne odpowiedniki morfemu -ø-, wyrażając pozostałe, przewidywane przez system kombinacje wartości obu tych kategorii fleksyjnych, a więc odpowiednio wartości indicativi imperfecti, indicativi futuri, coniunctivi imperfecti i coniunctivi praesentis.

Podobnie $\mathrm{z}$ morfemem zerowym spotykać się możemy $\mathrm{w}$ formach deklinacyjnych, jak np. w: urb-ø-s, urb-ø-em, gdzie morfem słowotwórczy reprezentowany jest przez morf zerowy (por. urb-an-us, urb-an-um itd.), czy np. w anim-al-ø, gdzie przez morf zerowy wyrażany jest morfem fleksyjny będący wykładnikiem wartości przypadka i liczby, tj. nominatiwu singularis (por. anim-al-is, anim-al-i, anim-al-ibus itd.).

Niektóre morfemy fleksyjne reprezentowane są $w$ poszczególnych wyrazach gramatycznych przez różne allomorfy. Np. morfem (sufiks) będący wykładnikiem indicativi futuri $\mathrm{w}$ czasownikowych formacjach I i II koniugacji reprezentowany jest przez 4 różne allomorfy, tj.: $-b-/-b \check{e}-/ \mid-b \check{u}-/-b \check{i}$, determinowane kontekstem fonologicznym:

- $b$ - przed samogłoską, jak np. w laud-a-b-o;

- -bé-przed /-r/, jak np. w laud-a-bée-ris;

$\rightarrow$-bŭ-przed /-n/, jak np. w laud-a-bŭ-nt;

- $-b \check{i}$ - w pozostałych kontekstach fonologicznych, jak np. w: laud-a-bi-s, laud-a-bimus, laud-a-bi-tur itd.

\subsection{WYBRANA LITERATURA}

Bubenik (1999), Bybee (1985), Grzegorczykowa, Laskowski, Wróbel (1999, s. 33- 51, 65-78) 


\section{2. \\ Fleksja}

\subsection{FLEKTEM, FORMA TEKSTOWA, FORMA FLEKSYJNA}

W opisie systemu fleksyjnego wyraz gramatyczny odpowiadający leksemowi odmiennemu określany jest terminem flektem. Przez pojęcie flektemu należy zatem rozumieć abstrakcyjną jednostkę językową, obejmującą - przy danym znaczeniu leksykalnym - określony zbiór współwystępujących wartości kategorii fleksyjnych, np. DEA: dativus pluralis, gdzie zapis „DEA” identyfikuje znaczenie leksykalne, a zapis: "dativus singularis" identyfikuje zbiór wartości kategorii fleksyjnych.

Wyraz tekstowy (ciąg wyrazów tekstowych), reprezentujący określony flektem lub flektemy, nosi nazwę formy tekstowej; np. deis to forma tekstowa reprezentująca flektem DEA: dativus pluralis oraz flektem DEA: ablativus pluralis.

$\mathrm{Z}$ uwagi na różnorodność (złożoność) relacji zachodzących między flektemami a reprezentującymi je formami tekstowymi dla opisu systemu fleksyjnego konieczne jest jeszcze wyodrębnienie pojęcia formy fleksyjnej, rozumianej jako jednostka funkcjonalna języka stanowiąca połączenie określonego flektemu i określonej formy tekstowej reprezentującej ten flektem. W związku z tym różnymi formami fleksyjnymi będą zarówno jednostki reprezentujące różne flektemy (także za pośrednictwem tych samych form tekstowych, np. deis (dat. pl.) i deis (abl. pl.)), jak i jednostki realizowane poprzez różne formy tekstowe (także te odnoszące się do tego samego flektemu, np. deis (dat. sg.) i deabus (dat. sg.)).

Wzajemne relacje między pojęciem flektemu, formy tekstowej i formy fleksyjnej można zatem zegzemplifikować następującym zestawieniem:

- deis (dat. pl.) : dearum (gen. pl.) - dwa różne flektemy, dwie różne formy tekstowe, dwie różne formy fleksyjne;

- deis (dat. pl.) : deis (abl. pl.) - dwa różne flektemy, ta sama forma tekstowa, dwie różne formy fleksyjne;

- deis (dat. pl.) : deabus (dat. pl.) - ten sam flektem, dwie różne formy tekstowe, dwie różne formy fleksyjne.

Dwie formy fleksyjne odnoszące się do tego samego flektemu za pośrednictwem $\mathrm{d} w u$ różnych form tekstowych (np. deis (dat. pl.) i deabus (dat. pl.)) to formy fleksyjne oboczne (warianty tekstowe). 
Dwie formy fleksyjne odnoszące się do dwu różnych flektemów za pośrednictwem tej samej formy tekstowej (np. deis (dat. pl.) i deis (abl. pl.)) to formy fleksyjne homonimiczne (synkretyczne).

\subsection{BUDOWA FORM FLEKSYJNYCH: TEMAT FLEKSYJNY, FLEKTYW, KOŃCOOWKA FLEKSYJNA}

Forma fleksyjna reprezentowana przez pojedynczy wyraz tekstowy, np. dominus, to syntetyczna forma fleksyjna, natomiast forma fleksyjna reprezentowana przez ponadjednoelementowy ciąg wyrazów tekstowych, np. laudatus est, to analityczna (peryfrastyczna, opisowa) forma fleksyjna.

Każda forma fleksyjna ma budowę dwudzielną: składa się z morfemu (lub ciągu morfemów) będącego wykładnikiem znaczenia leksykalnego (słownikowego) danej formy fleksyjnej oraz z morfemu (lub ciągu morfemów) stanowiącego wykładnik jej funkcji gramatycznej (znaczenia gramatycznego). Część formy fleksyjnej obejmująca wykładnik znaczenia leksykalnego to temat fleksyjny danej formy, natomiast część zawierająca wykładnik funkcji gramatycznej to flektyw.

Wykładnik funkcji gramatycznej, czyli flektyw, może być morfologicznie prosty, jak np. w domin||us lub morfologicznie złożony, jak np. w lauda||ba-nt, gdzie symbolem \| oznaczono granicę między tematem fleksyjnym a flektywem. W analitycznych formach fleksyjnych część flektywu stanowi wyraz tekstowy różny od wyrazu tekstowego zawierającego temat fleksyjny (wykładnik znaczenia leksykalnego) danej formy; np. w odniesieniu do formy laudat ||us est temat fleksyjny to laudat-, a flektyw to - us est.

Flekyw może składać się z:

1. jednego sufiksu fleksyjnego, który jest końcówką fleksyjną, np. domin\|us;

2. jednego sufiksu fleksyjnego, który nie jest końcówką fleksyjną, np. lauda||re (inf.);

3. sufiksu fleksyjnego niebędącego końcówką i sufiksu będącego końcówką fleksyjną, np. lauda||ba-nt, lauda||nt-em; w takim przypadku, oddzielając od fomy fleksyjnej samą końcówkę otrzymujemy wtórny temat fleksyjny, np.: laudaba|nt, laudant|em.

W przypadku analitycznych form fleksyjnych flektyw stanowi różną kombinację morfemów sufiksalnych (końcówkowych i niekońcówkowych) oraz rdzennych, np.: laudat ||us es-t, laudat |um es-se; morfem rdzenny współtworzący flektyw, a więc w podanych przykładach morfem es-, traci wtedy swoją funkcję leksykalną i staje się (współ)wykładnikiem określonej funkcji gramatycznej.

Końcówki fleksyjne różne formalnie, lecz tożsame funkcjonalnie, to końcówki fleksyjne izofunkcyjne, jak np. końcówki -ae, -i, -is, będące wykładnikami genetiwu singularis $\mathrm{w}$ imiennych formach fleksyjnych reprezentujących leksemy należące do różnych klas paradygmatycznych (deklinacji), a więc np. w rzeczownikowych formach fleksyjnych: tabul-ae, domin-i, honor-is. 
Końcówki fleksyjne izofunkcyjne dopuszczalne przez formy fleksyjne reprezentujące ten sam leksem (flektem) to końcówki izofunkcyjne równoległe (oboczne), jak np. końcówki występujące w parach stanowionych przez formy: de-is / de-abus, laudav-erunt / laudav-ere.

Z kolei końcówki fleksyjne tożsame formalnie, lecz różne funkcjonalne, to końcówki fleksyjne homonimiczne, jak np. końcówki w formach fleksyjnych tabul-ae (gen. sg.) i tabul-ae (nom. pl.); stanowią one zatem przeciwieństwo (odwrotność) końcówek izofunkcyjnych.

Temat fleksyjny może podlegać formalnej alternacji. Prowadzi to do powstania różnego typu alternantów (formalnych wariantów) tematu fleksyjnego. Wśród nich wyróżnia się:

1 Morfonologiczne alternanty (warianty) tematu fleksyjnego, które charakteryzują się tym, że zachodzące między nimi różnice w strukturze fonologicznej sprowadzają się do alternacji morfonologicznych, tj. do różnic motywowanych odmiennymi kontekstami fonologicznymi, w których alternanty te się pojawiają. $\mathrm{Z}$ morfonologicznymi alternantami tematu fleksyjnego mamy do czynienia np. w formach fleksyjnych reprezentujących leksem REX 'król', gdzie alternant tematu ze spółgłoską bezdźwięczną / $\mathrm{k} /$ na jego końcu pojawia się $\mathrm{w}$ kontekście następującej po nim bezdźwięcznej spółgłoski /s/, a więc np. w nominatiwie singularis rek-s (tradycyjna ortografia: rex), natomiast alternant ze spółgloską dźwięczną /g/ występuje we wszystkich pozostałych (tj. przedsamogłoskowych) kontekstach fonologicznych, a więc np. w formach: reg-is, reg-em, reg-ibus itd. Podobnie w formach fleksyjnych reprezentujących leksem MEL 'miód' przed pauzą (czyli przed morfemem zerowym) pojawia się alternant tematu z krótką ostatnią spółgłoską, a więc mel- 0 , natomiast w pozostałych kontekstach fonologicznych występuje alternant tematu ze spółgłoską długą, a więc np.: mell-is, mell-i, mell-e.

2. Morfologiczne alternanty (warianty) tematu fleksyjnego, które cechują się tym, że zachodzące między nimi różnice $w$ strukturze fonologicznej nie są zależne od kontekstu fonologicznego. Alternanty te wykazują się jednak dwiema innymi właściwościami. Pierwsza polega na tym, że w wielu przypadkach są one w pewnym stopniu skategorializowane, regularne, co oznacza, że różnice fonologiczne występujące między nimi są charakterystyczne nie tylko dla pojedynczych leksemów, lecz dla określonych ich klas. Drugą właściwością jest to, że poszczególne alternanty, oprócz wyrażania funkcji leksykalnej, współwyrażają (wraz z innymi wykładnikami morfologicznymi) określone funkcje gramatyczne, tj. stanowią indeksy określonych kategorii gramatycznych. Np. alternanty tematyczne lauda- / laudav-, występujące $\mathrm{w}$ formach fleksyjnych czasownikowego leksemu LAUDARE 'chwalic' i stanowiące $w$ nich (odpowiednio) tzw. temat praesentis i temat perfecti, z jednej strony należą do określonego formalnego typu paradygmatycznego (współtworzonego przez tematy form fleksyjnych takich leksemów jak np.: AMARE, VOCARE, SALUTARE itp.), z drugiej strony są wykładnikami niedokonaności/dokonaności w ramach gramatycznej kategorii aspektu. Alternanty te stanowią zatem, podobnie jak sufiksy czy końcówki fleksyjne, jeden 
z morfologicznych środków sygnalizowania określonych treści gramatycznych. Należy dodać, że alternanty morfologiczne mogą mieć również swoje alternanty morfonologiczne, jak np. laudä-(s) / laudä-(t) / laud-(o). Specyficznym typem alternantów morfologicznych są alternanty supletywne. O morfologicznych supletywnych alternantach tematu fleksyjnego mówimy wtedy, gdy formalne (fonologiczne) różnice między nimi są bardzo duże i różnice te nie są kategorialne (regularne, powtarzalne), jak np. ferr-(o) / tul-(i).

3 Fakultatywne (równoległe, oboczne) alternanty tematu fleksyjnego, jak np. ed- I es- (występujące np. w formach edere / esse 'jeść) czy amav- / ama- (występujące $\mathrm{np}$. w formach amavisti / amasti 'pokochałes').

\subsection{FORMALNY I FUNKCJONALNY PARADYGMAT FLEKSYJNY}

Opis paradygmatyki fleksyjnej danego leksemu zakłada z jednej strony określenie zasobu przysługujących mu (wartości) kategorii fleksyjnych i związków zachodzących między ich wykładnikami, a więc określenie zespołu przysługujących mu flektemów, zdrugiej zaś ustalenie zespołu form fleksyjnych reprezentujących te flektemy. Zespół flektemów przysługujących danemu leksemowi to paradygmat funkcjonalny tego leksemu, zaś zespół form fleksyjnych reprezentujących te flektemy to jego paradygmat formalny.

W ramach paradygmatyki fleksyjnej, jako elementu gramatyki opisowej, ustala się określone wzory paradygmatów funkcjonalnych i formalnych oraz identyfikuje się klasy leksemów, których paradygmaty wzorom tym podlegają.

Struktura paradygmatu funkcjonalnego leksemu zdeterminowana jest przez zestaw kategorii fleksyjnych przysługujących temu leksemowi oraz zestaw możliwych wartości każdej z tych kategorii. To z kolei zdeterminowane jest przez klasę funkcjonalną (część mowy), do jakiej dany leksem należy. Leksemy należące do tej samej klasy funkcjonalnej (części mowy) mogą się jednak różnić pod względem struktury paradygmatu funkcjonalnego. Jedne $\mathrm{z}$ nich mogą się bowiem charakteryzować pełnym paradygmatem funkcjonalnym, inne paradygmatem funkcjonalnym niepełnym, zredukowanym ze względu na jakąś kategorię fleksyjną.

Pełny paradygmat funkcjonalny leksemu wyznaczony jest przez wszystkie możliwe wartości wszystkich kategorii morfologicznych, które przysługują leksemom należącym do danej klasy funkcjonalnej (części mowy). Innymi słowy, pełny paradygmat funkcjonalny to maksymalny dla danej klasy funkcjonalnej (części mowy) zbiór flektemów określonego leksemu. Np. zupełny paradygmat funkcjonalny posiada leksem AMICUS 'przyjaciel', ponieważ może on przybierać wszystkie wartości kategorii przypadka i liczby, które przysługują leksemom należącym do klasy rzeczowników; podobnie np. leksem SCRIBERE 'pisać', ponieważ może on przyjmować wszystkie wartości kategorii, osoby, liczby, czasu, strony, trybu i finitywności, przysługujące leksemom należącym do klasy czasowników.

Paradygmat funkcjonalny niepełny, zredukowany ze względu na jakąś kategorię fleksyjną występuje wtedy, gdy zespół wartości jakiejś (lub jakichś) kategorii flek- 
syjnej jest dla danego leksemu ograniczony, np. paradygmat funkcjonalny leksemu TENEBRAE 'ciemnośc' jest niezupełny (zredukowany) ze względu na kategorię liczby, ponieważ leksem ten nie może przyjmować wartości singularis; podobnie paradygmat funkcjonalny leksemu FLORERE 'kwitnąć' jest niezupełny (zredukowany) ze względu na kategorię strony, ponieważ nie może on przyjmować wartości passivum.

Kształt paradygmatu formalnego leksemu jest zdeterminowany przez strukturę paradygmatu funkcjonalnego danego leksemu, a w dalszej kolejności przez zestaw morfemów fleksyjnych przybieranych przez odpowiadające danemu leksemowi formy fleksyjne oraz przez ewentualną alternację ich tematu fleksyjnego.

Paradygmat formalny leksemu może mieć charakter defektywny w zakresie jakiejś kategorii fleksyjnej, co polega na tym, że nie pozwala on na morfologiczną identyfikację wartości którejś z kategorii fleksyjnych przysługujących temu leksemowi. Ten typ paradygmatu występuje wtedy, gdy formy fleksyjne reprezentujące dany leksem pozbawione są formalnych (morfologicznych) wykładników określonej kategorii fleksyjnej, czyli gdy wszystkie wartości tej kategorii wyrażane są przez formy fleksyjne homonimiczne.

Np. defektywnym pod względem kategorii przypadka jest paradygmat formalny liczebnikowego leksemu TRIGINTA 'trzydzieści'. Leksem ten należy do klasy liczebników głównych, które charakteryzują się tym, że reprezentujące je formy fleksyjne, użyte w wyrażeniach zdaniowych, pełnią funkcję przymiotnikowych przydawek łączących się z określanym (nadrzędnym) rzeczownikiem związkiem zgody (kongruencji atrybutywnej) $)^{1}$, jak np. formy reprezentujące liczbnik TRECENTI 'trzysta' w wyrażeniach: venerunt trecenti pueri, auditus est clamor trecentorum puerorum, profuit trecentis pueris, vidit trecentos pueros, narravit de trecentis pueris. Analogiczną pozycję przydawki atrybutywnej w wyżej wskazanych wyrażeniach zajmują także formy fleksyjne reprezentujące liczebnik TRIGINTA, a więc: venerunt triginta pueri, auditus est clamor triginta puerorum, profuit triginta pueris, vidit triginta pueros, narravit de triginta pueris. Oznacza to, że paradygmat funkcjonalny leksemu TRIGINTA jest w zakresie kategorii przypadka pełny (tzn. leksem ten, poprzez reprezentujące go formy fleksyjne, może przyjmować wszystkie wartości tej kategorii), ale jego paradygmat formalny jest pod tym względem defektywny, tzn. jest on pozbawiony formalnych wykładników tej kategorii, identyfikujących morfologicznie jej poszczególne wartości, i w rezultacie jest on złożony wyłącznie $z$ form fleksyjnych homonimicznych. Dodajmy, że również w odniesieniu do kategorii rodzaju gramatycznego paradygmat funkcjonalny liczebnika TRIGINTA jest pełny, natomiast jego paradygmat formalny defektywny; por. triginta pueri, triginta puellae, triginta oppida (wobec trecenti pueri, trecentae puellae, trecenta oppida).

Paradygmat formalny złożony wyłącznie $\mathrm{z}$ form fleksyjnych homonimicznych to zerowy paradygmat formalny leksemu. Taki właśnie zerowy paradygmat formalny charakteryzuje leksem TRIGINTA ze względu na defektywność jego paradygmatu formalnego w zakresie kategoii przypadka i rodzaju oraz niepełność jego paradygmatu 
funkcjonalnego w zakresie kategorii liczby (jest on bowiem leksemem należącym do klasy pluralia tantum, a więc reprezentujące go formy fleksyjne nie mogą przyjmować wartości singularis - por. nieakceptowalność wyrażeń typu *triginta puer).

Paradygmat fleksyjny ukonstytuowany m.in. przez kategorię fleksyjną czasu i strony to paradygmat koniugacyjny; fleksja oparta o paradygmat koniugacyjny to koniugacja.

Paradygmat fleksyjny ukonstytuowany m.in. przez kategorię fleksyjną przypadka to paradygmat deklinacyjny; fleksja oparta o paradygmat deklinacyjny to deklinacja.

\subsection{TYPOLOGIA KATEGORII FLEKSYJNYCH}

Status kategorii fleksyjnych wyznaczają takie parametry jak rodzaj spełnianej przez nie funkcji, składniowe uwarunkowanie ich funkcjonowania w strukturze wypowiedzenia, a także sposób, w jaki przysługują one poszczególnym klasom leksemów. Parametry te stanowią kryteria semantycznej, syntaktycznej i morfologicznej klasyfikacji kategorii fleksyjnych.

W ramach klasyfikacji semantycznej wyróżnia się:

1. kategorie nominatywne, czyli pełniące funkcję semantyczną (znaczeniową), mające odniesienie do rzeczywistości pozajęzykowej, jak np. liczba rzeczowników, informująca o liczebności (tj. jedno- lub wieloelementowości) zbioru obiektów desygnowanych przez rzeczowniki, czy czas czasowników, informujący o ulokowaniu w czasie fizycznym (pozajęzykowym) desygnowanych przez czasowniki zdarzeń;

2. kategorie tekstowe (nienominatywne, semantycznie puste), pozbawione funkcji znaczeniowej i służące sygnalizowaniu relacji treściowych oraz związków składniowych zachodzących między elementami wypowiedzenia, jak np. strona czasownika, będąca indeksem składniowego uporządkowania konotowanych przez czasownik wyrażeń argumentowych ${ }^{2}$, czy kategoria rodzaju przymiotnika, będąca współwykładnikiem związku zgody z nadrzędnym składniowo rzeczownikiem.

Należy przy tym pamiętać, że pewne kategorie fleksyjne, uwzględniane przez dane klasy leksemów, mogą mieć zróżnicowaną charakterystykę funkcjonalną, w zależności od użycia tekstowego. Np. kategoria liczby rzeczownika może równocześnie pełnić funkcję nominatywną (informowania o jedno- lub wieloelementowości zbioru jego desygnatów) i funkcję tekstową (np. sygnalizowania związku składniowego z czasownikowym orzeczeniem), jak np. w zdaniach: Pies szczeka $w$ mieszkaniu sqsiada i Psy szczekaja w mieszkaniu sąsiada. Jednak może również pełnić funkcję wyłącznie tekstową, np. w przypadku niereferencjalnego użycia rzeczownika, tj. użycia niemającego odniesienia do konkretnego elementu rzeczywistości pozajęzykowej, a więc np. w tożsamych znaczeniowo zdaniach: Pies jest ssakiem i Psy sq ssakami. 
W ramach klasyfikacji syntaktycznej wyróżnia się:

1. kategorie syntaktycznie niezależne / zależne (niedeterminowane / determinowane); 2. kategorie syntaktycznie determinujące / niedeterminujące.

Kategorie syntaktycznie niezależne (niedeterminowane) cechują się tym, że ich wartości w ramach wyrażenia zdaniowego nie są wyznaczane przez żadne inne elementy wypowiedzenia, jak np. liczba rzeczownika, natomiast wartości kategorii syntaktycznie zależnych (determinowanych) wyznaczane są przez określone składniki otoczenia składniowego, jak np. liczba przymiotnika, której wartość (liczba pojedyncza / mnoga) determinowana jest przez wartość kategorii liczby syntaktycznie nadrzędnego rzeczownika.

Z kolei o kategoriach determinujących mówimy wtedy, gdy wyznaczają one wartości kategorii fleksyjnych w składnikach syntaktycznie zależnych, jak np. przypadek rzeczownika, determinujący wartość kategorii przypadka w składniowo zależnym przymiotniku. Kategorie niedeterminujące nie wpływają na charakterystykę fleksyjną innych członów składniowych, jak np. liczba przymiotnika.

Tak kategorie determinujące jak i niedeterminujące mogą być zarazem syntaktycznie zależne lub niezależne. Np. kategorią determinującą i zarazem syntaktycznie zależną jest kategoria przypadka rzeczownika (determinująca przypadek przymiotnika i zależna syntaktycznie od czasownika), kategorią determinującą i syntaktycznie niezależną jest np. liczba rzeczownika (determinująca liczbę przymiotnika), kategorią niedeterminującą i syntaktycznie zależną jest np. rodzaj przymiotnika (syntaktycznie zależny od rodzaju rzeczownika), kategorią niedeterminującą, syntaktycznie niezależną jest np. czas czasownika.

Kategorie fleksyjne syntaktycznie determinujące, przysługujące leksemom określonej klasy, mają zawsze swój odpowiednik w postaci kategorii syntaktycznie determinowanych (zależnych), przysługujących leksemom innej klasy, z którymi te pierwsze wchodzą $w$ bezpośrednie związki składniowe. Kategorie związane takim stosunkiem nazywane są sprzężonymi kategoriami fleksyjnymi. Tego rodzaju sprzężonymi kategoriami fleksyjnymi są np. rodzaj rzeczowników i rodzaj przymiotników.

W ramach klasyfikacji morfologicznej wyróżnia się:

1. kategorie o charakterze fleksyjnym (sensu stricto), cechujące się tym, że leksemy, którym one przysługują, mogą (za pośrednictwem reprezentujących je form fleksyjnych) przybierać różne wartości tych kategorii (odmieniać się w ramach tych kategorii), jak np. przypadek rzeczownika czy osoba czasownika;

2. kategorie o charakterze klasyfikującym (inaczej: selektywnym), które przysługują leksemom w taki sposób, iż wszystkie reprezentujące je formy fleksyjne mogą przyjmować tylko jedną wartość tych kategorii, nie tworząc tym samym bezpośrednich opozycji morfologicznych w ich ramach. Innymi słowy dany leksem nie odmienia się według tej kategorii, lecz jako całość scharakteryzowany jest przez jedną wartość tej kategorii, jak np. rodzaj rzeczownika.

Mamy jednak do czynienia również z przypadkami, w których morfologiczny status kategorii fleksyjnych, przysługujących formom fleksyjnym reprezentującym 
dany leksem, uzależniony jest od wartości, jakie formy te wyrażają w ramach innej kategorii fleksyjnej. Np. kategoria strony form fleksyjnych, reprezentujących leksemy czasownikowe należące do klasy tzw. verba deponentia, ma charakter selektywny w odniesieniu do wszystkich form osobowych, a więc w odniesieniu do form, które $w$ ramach kategorii finitywności reprezentują wartość verbum finitum. Formy te mogą bowiem przyjmować wylącznie wartość passivum, stanowiąc tym samym passiva tantum. Natomiast w odniesieniu do form nieosobowych czasowników tej klasy, a więc $\mathrm{w}$ odniesieniu do form reprezentujących wartość verbum infinitum $\mathrm{w}$ ramach kategorii finitywności, kategoria strony ma charakter fleksyjny, bowiem w skład paradygmatu fleksyjnego czasowników klasy verba deponentia wchodzą np. zarówno aktywne, jak i pasywne patricipia (np.: sequens, secuturus / secutus, sequendus).

Ponadto spotkać się możemy ze szczególnym przypadkiem selektywności kategorii morfologicznej polegającym na tym, iż wyrażana przez daną formę fleksyjną wartość tej kategorii uzależniona jest od wartości, jaką forma ta nacechowana jest w ramach innej kategorii fleksyjnej; np. wartość kategorii strony osobowych form czasowników należących do klasy tzw. verba semideponentia uzależniona jest od wartości, jakimi formy te nacechowane są w ramach kategorii czasu, tzn. w praesens, imperfectum i futurum primum przyjmują one wyłącznie wartość activum (np.: gaudeo, gaudebam, gaudebo), natomiast w perfectum, plusquamperfectum i futurum exactum wyłącznie wartość passivum (np.: gavisus sum, gavisus eram, gavisus ero). Wyłączność przyjmowania bądź jednej, bądź drugiej wartości kategorii strony przy danej wartości kategorii czasu sprawia, iż w ramach kategorii strony osobowe formy reprezentujące verba semideponentia nie wchodzą z sobą w bezpośrednie opozycje morfologiczne, co pozwala na stwierdzenie, iż sposób, w jaki uwzględniają one tę kategorię, ma charakter selektywny.

Widać więc, że typologiczny status poszczególnych kategorii fleksyjnych jest niejednolity i uzależniony od różnych czynników. Z jednej strony pewne parametry, wyznaczające status określonej kategorii w ramach jednej klasyfikacji, mogą determinować status tej kategorii $w$ ramach innej klasyfikacji, np. morfologicznie klasyfikujący charakter jakiejś kategorii (np. kategorii rodzaju rzeczowników) determinuje równocześnie jej status składniowy jako kategorii syntaktycznie niezależnej (rodzaj rzeczowników nie jest bowiem uzależniony od żadnego składnika ich otoczenia składniowego). Z drugiej strony status danej kategorii może być zróżnicowany i uzależniony od klasy funkcjonalnej leksemów, którym przysługuje. Np. kategoria rodzaju gramatycznego jest dla rzeczowników kategorią klasyfikującą, syntaktycznie niezależną i determinującą, dla przymiotników zaś kategorią fleksyjną, syntaktycznie zależną i niedeterminującą. Co więcej, nawet w ramach danej części mowy określona kategoria może mieć odmienny status w odniesieniu do leksemów należących do różnych podklas funkcjonalnych. Np. kategoria liczby jest dla rzeczowników kategorią o charakterze fleksyjnym, jednak dla podklasy rzeczowników pluralia tantum jest kategorią klasyfikującą (selektywną). Leksemy należące do tej podklasy będą zatem miały paradygmat funkcjonalny niepełny (zredukowany) ze względu na tę katego- 
rię. Podobnie kategoria strony, która dla łacińskich leksemów czasownikowych jest kategorią o charakterze fleksyjnym, dla czasowników z grupy tzw. verba deponentia (czyli passiva tantum) będzie miała (w obrębie form osobowych) charakter kategorii klasyfikującej. $\mathrm{Z}$ tego rodzaju odmiennością morfologicznego statusu kategorii w odniesieniu do różnych podklas leksemów należących do tej samej części mowy wiązać się może także odmienność ich charakterystyki funkcjonalnej; np. klasyfikujący charakter kategorii liczby rzeczowników należących do podklasy pluralia tantum implikuje jej wyłącznie tekstową (nienominatywną) funkcję (por. niemożność identyfikacji liczebności zbioru elementów desygnowanych przez rzeczowniki pluralia tantum w wyrażeniach: Nożyczki leża na stole czy Hostis consuli insidias paravit „Wróg przygotował zasadzkę/zasadzki na konsula”).

Status kategorii fleksyjnej modyfikować może także konkretne użycie tekstowe leksemu, któremu dana kategoria przysługuje. Wyżej wskazano już na przykład modyfikacji statusu funkcjonalnego kategorii liczby rzeczownika (tj. redukcji funkcji nominatywnej), mającej miejsce w przypadku niereferencjalnego użycia tego rzeczownika (Pies jest ssakiem / Psy sa ssakami). W tym kontekście powołać się również możemy na czas i tryb czasownika, które są kategoriami syntaktycznie niezależnymi (niedeterminowanymi), jednak w przypadku użycia tych kategorii $w$ ich sekundarnych funkcjach, tj. jako wykładnków - odpowiednio - czasu względnego i podrzędności składniowej zdania, stają się kategoriami syntaktycznie zależnymi (determinowanymi); tego rodzaju użycie tych kategorii w łacinie znane jest jako tzw. consecutio temporum.

\subsection{WYBRANA LITERATURA}

Grzegorczykowa, Laskowski, Wróbel (1999, s. 125-150) 


\section{3. \\ Funkcjonalna klasyfikacja leksemów: \\ części mowy}

\subsection{KRYTERIA KLASYFIKACJI}

Tworzące zasób słownikowy języka leksemy nie stanowią jednolitej grupy. Różnią się między sobą cechami semantycznymi, a także właściwościami morfologicznymi (fleksyjnymi) i składniowymi reprezentujących je w tekście wyrazów gramatycznych. $\mathrm{Z}$ uwagi na różnice i podobieństwa występujące w tym zakresie dzieli się leksemy na najbardziej ogólne klasy funkcjonalne, zwane częściami mowy. Mimo wielowiekowej tradycji dokonywania tego rodzaju podziału klasyfikacja zasobu leksykalnego na części mowy jest jednym $z$ najbardziej trudnych zagadnień w lingwistyce, które - jak dotąd - nie znalazło jednego, powszechnie akceptowalnego rozwiązania. Podstawowy problem stanowi kwestia kryterium klasyfikacyjnego, którego zastosowanie powinno dawać homogeniczny, rozłączny podział całego słownictwa na jednoznacznie identyfikowalne klasy wyrazów o wspólnych, istotnych cechach gramatycznych. Istniejące opracowania gramatyki łacińskiej kryterium podziału wyrazów na części mowy zwykle w ogóle nie wskazują, a przyjęta w nich tradycyjnie ustalona systematyka ma charakter zdecydowanie heterogeniczny.

Dla przeprowadzenia podziału całości zasobu leksykalnego języka na klasy funkcjonalne (części mowy) posłużyć można się kryterium semantycznym, morfologicznym lub syntaktycznym. Przyjęcie kryterium semantycznego (znaczeniowego) rodzi oczywiste trudności związane przede wszystkim z brakiem jego dostatecznej ostrości czy precyzji. Wyodrębniając poszczególne części mowy na podstawie cech znaczeniowych leksemów (nazwy rzeczy, cech, czynności itd.), trudno byłoby bowiem uzasadnić, dlaczego np. takie wyrazy jak jasny, jasność i jaśnieć należą do trzech różnych klas (części mowy), zaś takie jak stól, biel i bieg do tej samej; to samo dotyczy, mutatis mudandis, leksyki łacińskiej (por. np. fervidus, fervor, ferveo). Kryterium morfologiczne, odwołujące się do cech fleksyjnych leksemów, jest znacznie bardziej obiektywne i precyzyjne; pozwala na przejrzystą klasyfikację części mowy podlegających fleksji, jednak jego mankamentem jest to, że wszystkie wyrazy nieodmienne lokuje w jednej 
klasie, nie dając możliwości rozróżnienia między np. przysłówkami a przyimkami, spójnikami czy partykułami. Wydaje się w związku z tym, że najlepszym kryterium pozwalającym na przeprowadzenie systematyki łacińskich części mowy w oparciu o jednolitą procedurę formalną, która daje podział na klasy relewantne gramatycznie, a równocześnie $w$ miarę możliwości uwzględnia istniejącą $w$ tym zakresie tradycję, jest kryterium syntaktyczne. Podstawą klasyfikacji będzie zatem status składniowy prymarnie przypisany leksemom w strukturze wypowiedzenia (zdania). Z uwagi na określoną korelację między właściwościami syntaktycznymi leksemów a ich cechami znaczeniowymi i fleksyjnymi kryterium semantyczne i morfologiczne uwzględnione zostanie jako dodatkowa, pomocnicza podstawa klasyfikacji.

$\mathrm{Z}$ tak zdefiniowanym kryterium podziału wyrazów na części mowy wiąże się $\mathrm{z}$ jednej strony kwestia określonej teorii syntaktycznej, w ramach której klasyfikacja jest dokonywana, $\mathrm{z}$ drugiej zaś kwestia fundamentalnego dla strukturalizmu pojęcia hierarchii, implikującego prymarną i sekundarną dystrybucję składniową leksemów, czyli rozróżnienie prymarnej (podstawowej) funkcji składniowej pełnionej przez leksemy i funkcji sekundarnych (wtórnych, pobocznych). Przyjęty w niniejszym opracowaniu model opisu struktury skladniowej wypowiedzenia (zdania) zakłada rozróżnienie między składnikami wypowiedzenia należącymi do struktury syntaktycznej (tj. tworzącymi tzw. warstwę przedmiotową wypowiedzenia, stanowiącą kreację rzeczywistości pozajęzykowej $\mathrm{w}$ nim przedstawionej) i składnikami nienależącymi do tej struktury ( $\mathrm{tj}$. tworzącymi tzw. warstwę strategii nadawczo-odbiorczej wypowiedzenia). Składnikami należącymi do struktury syntaktycznej są człony syntaktyczne (inaczej człony składniowe, tradycyjnie zwane też częściami zdania) oraz konektory, natomiast składniki nienależące do struktury syntaktycznej wypowiedzenia to operatory tekstowe i adresatywy. $Z$ rozróżnieniem tym związany jest podstawowy podział klas funkcjonalnych leksemów na autosyntagmatyczne, czyli takie, które prymarnie pełnią $w$ wypowiedzeniu (poprzez reprezentujące je wyrazy gramatyczne) funkcję członu syntaktycznego, oraz nieautosyntagmatyczne, czyli takie, które prymarnie nie pełnią funkcji członu syntaktycznego.

\subsection{LEKSEMY AUTOSYNTAGMATYCZNE: CZASOWNIKI, PRZYMIOTNIKI, RZECZOWNIKI, PRZYSŁÓWKI}

Cechą charakterystyczną członów syntaktycznych jest to, że wchodzą one z sobą w określone relacje semantyczne (znaczeniowe) oraz relacje formalne o charakterze nadrzędno-podrzędnym zwane związkami składniowymi (syntaktycznymi). Relacje semantyczne opierają się na opozycji: człon określany / człon określający (określnik), co oznacza, że jeden z członów desygnuje (wyraża) jakiś obiekt, drugi zaś desygnuje cechę (właściwość) przypisywaną temu obiektowi w wypowiedzi. Z punktu widzenia składniowego człon określany jest syntaktycznie nadrzędny, człon określający (określnik) jest syntaktycznie podrzędny. Sposób desygnacji przez określnik cechy przypisywanej desygnatowi członu określanego nie jest jednak jednolity. 
Może on polegać na tym, że przypisywaną desygnatowi członu określanego cechę określnik ujmuje $\mathrm{w}$ tzw. ramy czasowo-modalne, ujawniając równocześnie status desygnatu członu określanego $w$ ramach sytuacji aktu mowy (porozumiewania się, komunikowania). Ujęcie cechy w ramy czasowo-modalne oznacza, że cechę tę określnik obligatoryjnie charakteryzuje temporalnie (por.: Consul dolet / dolebat / dolebit „Konsul cierpi / cierpiał / będzie cierpiał”) oraz nadaje jej określoną perspektywę modalną, tj. ukazuje ją jako stan faktyczny lub niefaktyczny, czyli np. potencjalny, prawdopodobny, hipotetyczny, nierealny, postulatywny itp. (por.: Consul dolet / doleat / doleret / doleto „Konsul cierpi / mógłby cierpieć / cierpiałby / niech cierpi”). $\mathrm{Z}$ kolei ujawnienie statusu desygnatu członu określanego w ramach aktu mowy polega na identyfikacji pozycji tego desygnatu jako nadawcy komunikatu (autora wypowiedzenia), adresata lub obiektu niebędącego uczestnikiem aktu porozumiewania się (por.: (ego) doleo / (tu) doles / (consul) dolet). Ten sposób desygnowania cechy przypisywanej w wypowiedzeniu obiektowi (desygnatowi członu określanego) nazwiemy terminem predykacja, zaś samą cechę desygnowaną w taki sposób terminem predykat lub treść predykatywna. Człon syntaktyczny, będący wykładnikiem predykatu, to orzeczenie (określnik predykatywny), które jest członem głównym (konstytutywnym) wypowiedzenia mającego status zdania. Człon syntaktyczny, stanowiący w stosunku do orzeczenia człon określany, to gramatyczny podmiot zdania. Podmiot wchodzi z orzeczeniem w związek formalny (syntaktyczny), w którym zajmuje pozycję członu nadrzędnego, zaś orzeczenie członu podrzędnego (zależnego).

Cecha przypisywana przez określnik desygnatowi członu określanego może być jednak pozbawiona ram czasowo-modalnych oraz indeksu statusu desygnatu członu określanego, np. consul fortis 'konsul dzielny' (por. ego fortis / tu fortis). Ten sposób desygnowania cechy nazwiemy terminem atrybucja, zaś samą cechę desygnowaną w taki sposób terminem atrybut lub treść atrybutywna. Człon syntaktyczny, będący wykładnikiem atrybutu, to przydawka (określnik atrybutywny). Przydawka wraz z członem styntaktycznym stanowiącym człon przez nią określany tworzy strukturę składniową zwaną grupą imienną (nominalną). W ramach tej grupy człon określany stanowi jej człon główny (nadrzędny), natomiast określnik (przydawka) stanowi jej człon zależny (podrzędny).

Treściom predykatywnym i atrybutywnym mogą być z kolei również przypisywane pewne cechy przez określniki drugiego stopnia, np.: Consul dolet valde „Konsul cierpi bardzo", consul fortis valde "konsul dzielny bardzo". Określniki te dodatkowo charakteryzują (precyzują) więc same predykaty i atrybuty, a nie bezpośrednio desygnat podmiotu czy członu głównego grupy imiennej. Wykładniki predykatów i atrybutów (czyli orzeczenia i przydawki) stają się wtedy członami określanymi względem określników drugiego stopnia i wchodzą z nimi w związek formalny (składniowy), w którym zajmują pozycję członów nadrzędnych.

Klasa leksemów, które poprzez reprezentujące je wyrazy gramatyczne pełnią prymarnie funkcję członu konstytutywnego wyrażenia zdaniowego, czyli zajmują pozycję składniową orzeczenia zdania, to czasowniki. Semantycznie stanowią one człon określający, będący wykładnikiem treści predykatywnej orzekanej w zdaniu o desy- 
gnacie członu określanego, którym jest podmiot zdania. Morfologicznie czasowniki scharakteryzowane są przez fleksyjne kategorie: liczby, osoby, czasu, trybu, strony i finitywności. Kategoria liczby i osoby służy im do realizacji składniowego (formalnego) związku z członem określanym (podmiotem). Związek ten ma charakter kongruencji (zgody) opartej na tych właśnie kategoriach. W jego ramach człon określany (podmiot) determinuje (akomoduje) wyrażaną przez człon określający (orzeczenie) wartość kategorii liczby (por.: Consul dolet / Consules dolent) oraz osoby (por.: Ego doleo / Tu doles / Consul dolet). Ten rodzaj związku składniowego to związek kongruencji predykatywnej (związek predykacji), w którym podmiot jest członem nadrzędnym (determinującym, akomodującym) a orzeczenie członem podrzędnym (determinowanym, akomodowanym). $Z$ kolei kategoria czasu i trybu pozwala czasownikowi na ujęcie desygnowanych treści predykatywnych w ramy czasowo-modalne, kategoria strony informuje o statusie desygnatu podmiotu jako argumentu implikowanego przez predykat, którego wykładnikiem jest dany czasownik ${ }^{3}$, zaś kategoria finitywności umożliwia czasownikom przyjęcie sekundarnych (wtórnych, dodatkowych) funkcji składniowych w ramach sekundarnej dystrybucji składniowej4.

Leksemy reprezentowane przez wyrazy gramatyczne, które prymarnie zajmują pozycję członu zależnego (podrzędnego) grupy imiennej, czyli przydawki, to przymiotniki. Semantycznie stanowią one człon określający, będący wykładnikiem treści atrybutywnych przypisywanych w wypowiedzeniu desygnatowi członu określanego. Morfologicznie charakteryzują się one fleksyjną kategorią liczby, przypadka i rodzaju, które są wskaźnikami związku składniowego łączącego je, jako człony zależne grupy imiennej, z członem głównym (nadrzędnym) grupy. Związek ten również ma charakter kongruencji (zgody); w jego ramach człon główny grupy determinuje (akomoduje) wartość kategorii liczby wyrażaną przez zajmujący pozycję członu zależnego przymiotnik (por. consul fortis / consules fortes), wartość kategorii rodzaju (por. consul bonus / mater bona / iter bonum) oraz przypadka (por. consul fortis / consulis fortis / consuli forti / consulem fortem / consule forti). Ten rodzaj związku składniowego to związek kongruencji atrybutywnej (związek atrybucji), a stanowiona przez przymiotnik przydawka przyjmuje w nim status członu determinowanego (akomodowanego).

Klasa leksemów reprezentowana przez wyrazy gramatyczne, które prymarnie przyjmują status członu nadrzędnego (determinującego, akomodującego) w ramach związku predykacji i atrybucji, to rzeczowniki. Semantycznie charakteryzowane są tym, iż stanowiąc nazwy obiektów (rzeczy, zjawisk, pojęć abstrakcyjnych), pełnią funkcję członu określanego wobec określników predykatywnych i atrybutywnych. Morfologicznie cechują się fleksyjną kategorią liczby i przypadka oraz kategorią osoby i rodzaju o charakterze klasyfikującym (selektywnym). Fleksyjna kategoria liczby pozwala rzeczownikom na kwantyfikację numeryczną zbioru ich desygnatów, a także służy im do realizacji składni kongruencji zarówno w związku predykacji, jak i atrybucji; klasyfikująca kategoria osoby, której wartość ujawniana jest przez człon pod- 
rzędny (orzeczenie) w ramach związku predykacji, identyfikuje dodatkowo status desygnowanego przez rzeczownik obiektu w ramach aktu mowy. Z kolei klasyfikująca kategoria rodzaju stanowi - obok kategorii liczby i przypadka - wskaźnik związku kongruencji atrybutywnej, a jej wartość ujawniana jest przez człon podrzędny tego związku. Fleksyjna kategoria przypadka, oprócz sygnalizowania związku atrybucji, pełni funkcję wykładnika pozycji syntaktycznej zajmowanej przez rzeczownik w strukturze składniowej wypowiedzenia. Prymarną pozycją składniową zajmowaną przez rzeczowniki jest pozycja gramatycznego podmiotu, w której stanowi on człon nadrzędny zarówno związku predykacji, jak i atrybucji.

Leksemy reprezentowane przez wyrazy gramatyczne, które prymarnie stanowią człon syntaktyczny zależny od czasownikowego orzeczenia lub przymiotnikowej przydawki, to przysłówki. Stanowiony przez nie człon składniowy nosi nazwę okolicznika. Z punktu widzenia semantycznego przysłówki desygnują cechy przypisywane $\mathrm{w}$ wypowiedzeniu predykatom lub atrybutom, w związku z czym zajmują pozycję członu określającego względem wykładników treści predykatywnych lub atrybutywnych. Morfologicznie charakteryzują się brakiem przysługujących im kategorii fleksyjnych, co sprawia, że związek składniowy, który łączy stanowiony przez nie człon syntaktyczny (okolicznik) z członem nadrzędnym (orzeczeniem lub przydawką), cechuje się brakiem determinacji (akomodacji). Tego rodzaju związek nazywamy związkiem przynależności. Tym samym możemy określić przysłówki jako klasę leksemów, które prymarnie pełnią funkcję składniową okolicznika, stanowiąc człon podrzędny w ramach związku przynależności.

Leksemy należące do wskazanych wyżej klas (części mowy), czyli rzeczowniki, czasowniki, przymiotniki i przysłówki, z uwagi na to, że poprzez reprezentujące je wyrazy gramatyczne pełnią prymarnie funkcje członów syntaktycznych (części zdania), nazywane są leksemami autosyntagmatycznymi.

\subsection{PRYMARNA I SEKUNDARNA DYSTRYBUCJA SKŁADNIOWA LEKSEMÓW}

Funkcje składniowe, z którymi powyżej związane zostały poszczególne klasy leksemów, określone zostały jako prymarne, ponieważ wynikają one z ogólnych właściwości semantycznych i morfologicznych tych leksemów, predysponujących je do pełnienia owych funkcji. Tym samym pełnienie w wypowiedzeniu tych funkcji, tj. przez rzeczowniki funkcji podmiotu, przez czasowniki funkcji orzeczenia, przez przymiotniki funkcji przydawki i przez przysłówki funkcji okolicznika, to tzw. prymarna dystrybucja składniowa leksemów należących do wyżej wymienionych klas.

Jednak nawet pobieżna obserwacja języka dowodzi, że nie we wszystkich wypowiedzeniach (zdaniach) rzeczowniki pełnią wyłącznie funkcję podmiotu, czasowniki orzeczenia, przymiotniki przydawki, a przysłówki okolicznika. Wynika to ze zjawiska hierarchii funkcji, które umożliwia leksemom pełnienie - poprzez reprezentujące je wyrazy gramatyczne - nie tylko prymarnych dla nich, ale i sekundarnych funkcji 
składniowych, tzn. takich, które są funkcjami prymarnymi dla innych klas leksemów. Np. w zdaniu: Hostes victi fugerunt „Pokonani wrogowie uciekli” wyraz gramatyczny reprezentujący czasownikowy leksem VINCERE, czyli victi, nie zajmuje pozycji orzeczenia, lecz przydawki: nie zawiera bowiem w sobie indeksu wartości kategorii osoby członu określanego, czyli hostes, i tym samym nie jest $\mathrm{z}$ nim związany związkiem predykacji; jest z nim natomiast związany charakterystycznym dla przydawki związkiem atrybucji, opartym na kategorii liczby, rodzaju i przypadka. W zdaniu: Milites pugnabant magna virtute "Żołnierze walczyli $\mathrm{z}$ wielkim męstwem" wyraz gramatyczny reprezentujący rzeczownikowy leksem VIRTUS, czyli virtute, nie zajmuje pozycji podmiotu, lecz pozycję okolicznika: nie stanowi bowiem członu nadrzędnego względem określnika predykatywnego (orzeczenia), tj. pugnabant, lecz człon względem niego podrzędny. Podobnie w zdaniu: Domus est patris „Dom jest (= należy do) ojca” wyraz gramatyczny reprezentujący rzeczownikowy leksem PATER, czyli patris, nie zajmuje pozycji podmiotu, lecz jest częścią złożonego orzeczenia (tzw. orzecznikiem), stanowiąc wykładnik podstawowej treści predykatywnej, która jest charakteryzowana temporalnie i modalnie przez drugi element tego orzeczenia (tzw. łącznik, czyli est), ujawniający także (poprzez wyrażaną wartość kategorii osoby) status desygnatu członu określanego (podmiotu) w ramach aktu mowy. Tego rodzaju fakt pełnienia przez leksemy funkcji składniowych innych niż ich funkcja prymarna określany jest jako sekundarna dystrybucja składniowa. Dystrybucję tę $w$ wielu przypadkach również umożliwiają leksemom ich cechy morfologiczne, jak np. przysługująca rzeczownikom kategoria przypadka czy uwzględniana przez czasowniki kategoria finitywności.

Z sekundarną dystrybucją składniową rzeczowników wiąże się także pozycja składniowa dopełnienia, czyli członu syntaktycznego podrzędnego względem części zdania stanowionej przez czasownik lub przymiotnik (rzadko przysłówek), zarówno w ramach ich prymarnej, jak i sekundarnej dystrybucji składniowej. Zajmując tę pozycję, rzeczownik desygnuje obiekt implikowany przez semantykę (znaczenie, treść) swojego nadrzędnika. Np. znaczenie czasownika LAUDARE 'chwalić, stanowiące treść predykatywną przypisywaną desygnatowi podmiotu w zdaniu: Magister laudavit "Nauczyciel pochwalił”, implikuje wyrażenie określonego obiektu (np. discipulum "ucznia"), warunkującego zaistnienie sytuacji będącej treścią predykacji; desygnujący ten obiekt rzeczownik zajmie właśnie pozycję składniową dopełnienia (w tym przypadku wobec czasownikowego orzeczenia), a więc np. Magister laudavit discipulum "Nauczyciel pochwalił ucznia". Wyrażenie tego rodzaju obiektu implikuje również np. znaczenie przymiotnika SIMILIS 'podobny', użytego jako wykładnik treści atrybutywnej przypisywanej desygnatowi członu nadrzędnego w grupie imiennej filius similis "syn podobny"; rzeczownik desygnujący ów obiekt także będzie pełnił składniową funkcję dopełnienia (w tym przypadku dopełnienia przydawki), a więc np. filius similis patri „syn podobny do ojca”. Okolicznik, który także jest członem zależnym od określnika o treści predykatywnej lub atrybutywnej, różni się od dopełnienia tym, że jego desygnat nie jest implikowany (wymagany) przez semantykę składniowego nadrzędnika (por. np. kompletność znaczeniową wypowiedzenia: Consul dolebat „Konsul cierpiał” czy consul fortis „konsul dzielny”); dopełnienie natomiast 
cechuje się wyższym poziomem obligatoryjności (por. niekompletność znaczeniową wypowiedzeń: Magister laudavit „Nauczyciel pochwalił” lub filius similis „syn podobny"), a także znacznym stopniem zdeterminowania swej formalnej postaci (laudavit + SUBST acc., similis + SUBST dat). Z uwagi na te właściwości związek składniowy, który łączy dopełnienie z członem nadrzędnym, określany jest terminem rekcja (składnia rządu). W wielu wypadkach rozróżnienie między dopełnieniem a okolicznikiem jest jednak problematyczne ze względu na częstą niejednoznaczność statusu (obligatoryjny / fakultatywnie przyłączany) i formalnej postaci (por. similis patri / patris) uzupełnień postulowanych bądź dopuszczanych przez ich nadrzędniki.

\subsection{LEKSEMY NIEAUTOSYNTAGMATYCZNE: PRZYIMKI, SPÓJNIKI, PARTYKUŁY}

Wśród leksemów nieautosyntagmatycznych wskazać można takie, które w strukturze wypowiedzenia same nie stanowią członu składniowego, ale wchodzą w jego skład. Dotyczy to w szczególności członów syntaktycznych konstytuowanych przez rzeczowniki w ramach ich sekundarnej dystrybucji składniowej. Np. w zdaniu: Milites pugnabant sine metu "Żołnierze walczyli bez strachu” w skład okolicznika sine metu, oprócz wyrazu gramatycznego reprezentującego rzeczownikowy leksem METUS, który jest konstytutywnym elementem tego członu, wchodzi także wyraz sine. Wyraz ten morfologicznie nie uwzględnia żadnej kategorii fleksyjnej, natomiast semantycznie precyzuje relacje znaczeniowe, w jakich współtworzony przez niego (wraz z metu) człon syntaktyczny (okolicznik) pozostaje względem członu nadrzędnego (por. pugnabant sine metu / cum metu / prae metu). Klasa tego rodzaju leksemów, które prymarnie nie stanowią samodzielnie członów syntaktycznych, a jedynie współtworzą je wraz z leksemami zdolnymi ( $w$ innych kontekstach) do samodzielnego stanowienia członów syntaktycznych, to przyimki. Leksemy nieautosyntagmatyczne, które wraz z leksemami autosyntagmatycznymi współtworzą ( $w$ określonych kontekstach) człony syntaktyczne, to leksemy synsyntagmatyczne. A zatem przyimki można zdefiniować jako klasę leksemów nieautosyntagmatycznych (synsyntagmatycznych), które wraz leksemami autosyntagmatycznymi (rzeczownikami) współtworzą zależne składniowo człony syntaktyczne, zajmując w nich pozycję elementu niekonstytutywnego (akcesorycznego). Semantycznie uściślają one relację znaczeniową, jaka łączy współtworzony przez nie człon syntaktyczny z członem nadrzędnym, natomiast morfologicznie cechują się nieuwzględnianiem żadnych kategorii fleksyjnych. Są zatem leksemami nieodmiennymi, reprezentowanymi przez wyłącznie jednoelementowe zbiory wyrazów gramatycznych, jednak istnieje korelacja między poszczególnymi konkretnymi leksemami przyimkowymi, a wartościami kategorii przypadka przybieranymi przez rzeczownikowe wyrazy gramatyczne, które współtworzą wraz $\mathrm{z}$ nimi dane człony syntaktyczne. $\mathrm{W}$ odniesieniu do pewnych przyimków korelacja ta ma charakter jednoznaczny (np. AB + SUBST abl.), w odniesieniu do innych uzależniona jest od relacji semantycznych, łączących dany człon syntaktyczny z członem 
nadrzędnym (np. IN + SUBST acc. / abl.; por.: Milites veniunt in urbem "Żołnierze przybywają do miasta" / Milites pugnant in iurbe "Żołnierze walczą w mieście").

Inną klasę leksemów nieautosyntagmatycznych tworzą takie, które w wypowiedzeniu stanowią prymarnie składniki zdania należące do jego struktury syntaktycznej, ale niebędące członami syntaktycznymi. Składniki te to konektory, które są wskaźnikami (indeksami) relacji intersyntagmatycznych, czyli relacji syntaktyczno-semantycznych zachodzących między członami syntaktycznymi połączonymi związkiem szeregowym, oraz relacji syntaktycznych lub syntaktyczno-semantycznych zachodzących między zdaniami składowymi zdania złożonego. Np. w zdaniu: Boni et fortes milites ceciderunt in pugna "Dobrzy i dzielni żołnierze zginęli w bitwie" element et stanowi konektor będący wskaźnikiem semantycznej relacji łączności między dwiema przydawkami stojącymi względem siebie w relacji szeregowej, czyli przydawkami współrzędnymi (niezależnymi) syntaktycznie względem siebie i zależnymi składniowo od tego samego członu nadrzędnego (milites). W zdaniu: Coque cenam aut abi in malum cruciatum "Gotuj kolację albo odejdź do diabła" składnik aut stanowi konektor będący indeksem relacji współrzędno-rozłącznej między dwoma zdaniami składowymi tworzącymi zdanie złożone. W zdaniu: Caesar effecit, ut omnes gentes inter se certarent „Cezar sprawił, że wszystkie ludy ze sobą walczyły” element $u t$ stanowi konektor będący wskaźnikiem zależności (podrzędności) składniowej jednego ze zdań składowych względem drugiego w ramach zdania złożonego; w zdaniu: Senatus triumphum ei decrevit, quia terribilem hostem vicerat "Senat przyznał mu prawo do odbycia tryumfu, ponieważ pokonał strasznego wroga" składnik quia stanowi konektor będący indeksem relacji podrzędno-przyczynowej, w jakiej pozostaje jedno ze zdań składowych względem drugiego w obrębie zdania złożonego. Klasa leksemów, które prymarnie przyjmują w wypowiedzeniu funkcję konektorów (wykładników zespolenia), to spójniki. Spójniki będą zatem miały status klasy leksemów nieautosyntagmatycznych intersyntagmatycznych, których cechą dystynktywną jest prymarna funkcja konektora w strukturze składniowej wypowiedzenia (zdania). Morfologicznie spójniki nie podlegają żadnym kategoriom fleksyjnym, zaś znaczeniowo są wykładnikami relacji semantyczno-syntaktycznych, łączących zdaniowe i niezdaniowe (połączone szeregowo) składniki wyrażenia zdaniowego.

Jeszcze inną klasą leksemów nieautosyntagmatycznych są leksemy asyntagmatyczne. Prymarnie stanowią one składniki wypowiedzenia nienależące do jego struktury syntaktycznej, czyli niebędące członami syntaktycznymi ani konektorami. Składniki te to operatory tekstowe, które nie tworzą tzw. warstwy przedmiotowej wypowiedzenia (tj. nie kreują elementów pozajęzykowego świata przedstawionego w danym wypowiedzeniu), lecz służą autorowi komunikatu do realizacji określonych strategii nadawczo-odbiorczych. W ramach tych strategii osiągane mogą być różne cele, $\mathrm{z}$ czym związany jest podział operatorów na kilka różnych klas funkcjonalnyh. Jedną z takich klas stanowią np. operatory nawiązania międzypowiedzeniowego, jak np.: igitur, itaque, enim, nam, ergo, praeterea ('a zatem,' 'przeto,' 'wobec tego', 'bowiem', 'z kolei', 'ponadto', 'poza tym', 'w dodatku'), których funkcją jest nadanie komunikatowi spójności retorycznej $\mathrm{w}$ ramach wypowiedzi obejmującej więcej niż jedno 
zdanie. Inną klasę reprezentują operatory presupozycji, jak np.: etiam, demum, solum, modo, praecipue ('jeszcze, 'również, 'nawet', 'dopiero', 'wreszcie', 'zaledwie', 'zwłaszcza'), poprzez które nadawca komunikatu odwołuje się do niewyrażonych wprost okoliczności, znanych odbiorcy lub stanowiących kontekst danego wypowiedzenia. Do jeszcze innej grupy należą operatory modalne, wyrażające ustosunkowanie (postawę) nadawcy komunikatu względem stanu rzeczy (zdarzenia) przedstawionego w komunikacie za pośrednictwem elementów tworzących jego strukturę syntaktyczną, tzn. poprzez zastosowanie tego rodzaju operatorów nadawca może zasygnalizować, że stan ten uważa za pewny, prawdopodobny, wątpliwy, możliwy, oczywisty, pożądąny, oczekiwany, nakazany, zakazany, nieistniejący itp. (certe, plane, sane, potius, fortasse, forsitan, utinam, ne - 'z pewnością', 'zapewne', 'oczywiście', 'raczej,' 'może', 'oby (nie)', 'niech (nie)'), lub też może wyrazić swoją niewiedzę co do danego stanu rzeczy (utrum?, an? 'czy?'). Kolejną grupę tworzą operatory kwantyfikujące, jak np.: prope, paene, fere, vix, omnino, quasi ('prawie,' 'niemal', 'ledwo,' 'zupełnie', 'całkiem,' 'w ogóle') i przeczące, jak non, haud ('nie'). Wreszcie operatory emotywne (o, eheu, heus, hem, ei, eia - 'o', 'ach', 'och', 'aha', 'hej') służą wyrażeniu emocji nadawcy komunikatu. Klasa leksemów, które prymarnie pełnią funkcję operatorów tekstowych, to partykuły. Nie uwzględniają one żadnych kategorii fleksyjnych, a ich charakterystyka semantyczna jest zróżnicowana.

Leksemy nieautosyntagmatyczne, podobnie jak autosyntagmatyczne, również charakteryzują się hierarchizacją funkcji, w związku z czym sekundarnie, tj. w ramach sekundarnej dystrybucji składniowej, pełnić mogą w strukturze wypowiedzenia funkcje inne niż ich funkcja prymarna; por. np.: Odi et amo „Kocham i nienawidzę" (et = konektor) / Audiatur et altera pars „Niech będzie wysłuchana i druga strona" (et = operator presupozycji; nie jest konektorem, ponieważ nie jest indeksem żadnej ralacji zachodzącej między składnikami zdania); Copias prope castra collocavit "Rozmieścił wojsko obok obozu" ( prope = wyraz synsyntagmatyczny, współtworzący wraz z castra okolicznik) / prope victor "niemal zwycięzca" (prope = operator kwantyfikujący) / conviva clamatus prope - „współbiesiadnik przywołany z pobliża” (prope $=$ okolicznik). Jak widać, zróżnicowanie funkcjonalne (przynajmniej niektórych) leksemów tego typu wykracza nie tylko poza granice dzielące różne klasy i odmiany leksemów nieautosyntagmatycznych, ale i granice pomiędzy leksemami autosyntagmatycznymi i nieautosyntagmatycznymi. Rodzić to może trudności z identyfikacją funkcji prymarnej dla danego leksemu, i tym samym z przypisaniem go do określonej klasy funkcjonalnej (części mowy - cf. prope). Trudności te pogłębia jeszcze brak powszechnie akceptowalnej wśród badaczy procedury i metodologii klasyfikacyjnej.

Dodajmy, że niektóre spośród funkcji realizowanych przez partykuły zajmujące w wypowiedzeniu pozycje operatorów tekstowych mogą być realizowane także przez leksemy autosyntagmatyczne $w$ ramach stanowionych przez nie członów syntaktycznych. Dotyczy to w szczególności sygnalizowania modalności, z którym, jak zostało to już wspomniane wyżej, mamy do czynienia obligatoryjnie w ramach każdego orzeczenia, czy to prostego (por. Consul gaudet / gaudeat „Konsul cieszy się / niech się cieszy”), czy złożonego (por. Consul videtur gaudere „Konsul chyba cieszy się”). Od 
zgramatykalizowanych wykładników modalności powyższego typu operatory modalne różnią się jednak tym, że nie są wbudowane w samą strukturę orzeczenia, tzn. nie stanowią jego części i po ich usunięciu orzeczenie nie ulega dezintegracji (por. akceptowalność form typu consul fortasse gaudet "konsul być może cieszy się" i consul gaudet „konsul cieszy się,, wobec nieakceptowalności wyrażenia *consul gaudere).

\subsection{STATUS GRAMATYCZNY ZAIMKÓW I LICZEBNIKÓW}

Wśród wyodrębnianych tradycyjnie klas leksemów (części mowy) wymienia się jeszcze zaimki i liczebniki. Łatwo jednak zauważyć, że leksemy zaliczane do tych klas nie są definiowalne w oparciu o żadną wspólną cechę gramatyczną, tj. składniową czy morfologiczną. Wystarczy zestawić np. takie zaimki, jak ego, tuus i ibi, aby stwierdzić, że nie wykazują one żadnych cech gramatycznych, które byłyby wspólne im wszystkim, a równocześnie odmienne od właściwości leksemów należących do pozostałych części mowy. To, co je łączy, to nie gramatyka, lecz raczej sposób realizowania funkcji semantycznej, polegający na wskazywaniu (a nie symbolizowaniu), anaforze czy kwantyfikacji. Jest to więc część mowy wyodrębniona w oparciu o inne, niegramatyczne kryterium. Pod względem gramatycznym zaś część zaimków, np.: ego, quisquam, nemo, spełnia główne kryteria definicyjne rzeczowników, zajmując w strukturze składniowej zdania pozycje przeznaczone dla leksemów tej właśnie klasy. Inne zaimki, jak np. meus, ille, ullus, wykazują składniowe i morfologiczne cechy przymiotników. Wreszcie jeszcze inne, jak np. ibi, numquam, aliter, charakteryzują się właściwościami przysłówkowymi, nie uwzględniając żadnych kategorii fleksyjnych i pełniąc w wypowiedzeniu funkcje składniowe okoliczników. Należy więc uznać zaimki za część mowy, która wyodrębniana jest ze względu na sposób oznaczania, natomiast pod względem gramatycznym stanowi zbiór leksemów wewnętrznie niejednolity. Biorąc pod uwagę właściwości gramatyczne, część zaimków uznamy za podzbiór leksemów rzeczownikowych, część za podzbiór leksemów przymiotnikowych, jeszcze inną część za podzbiór leksemów przysłówkowych.

Podobnie niejednorodna gramatycznie jest klasa wyrazów nazywana tradycyjnie liczebnikami, w obrębie której wyodrębnia się semantyczne podklasy liczebników głównych, porządkowych, podziałowych, wielorakich i wielokrotnych. Większość leksemów zaliczanych do liczebników wykazuje syntaktyczne i morfologiczne właściwości przymiotników; dotyczy to liczebników głównych (por. Vidi trecentos milites „Zobaczylem trzystu żołnierzy”), porządkowych (por.: vicesimus tertius annus „dwudziesty trzeci rok"), podziałowych (por. Animal habet quinos digitos in prioribus pedibus „Zwierzę ma po pięć palców na przednich lapach") i wielorakich (por. Locum duplici muro muniverunt "Miejsce otoczyli podwójnym murem"). Jedynie liczebnik główny milia "tysiące” ma status rzeczownika plurale tantum rodzaju nijakiego (por.: Vidi tria milia militum „Zobaczyłem trzy tysiące żołnierzy”), a liczebniki wielokrotne status przysłówków (por.: Cum hoste quinquies dimicavit "Z wrogiem starł się pięciokrotnie"). Pod względem gramatycznym liczebniki wielokrotne stanowić zatem będą semantyczny podzbiór 
przysłówków, liczebnik milia jednoelementowy podzbiór leksemów rzeczownikowych, zaś wszystkie pozostałe liczbniki podzbiór leksemów przymiotnikowych.

$\mathrm{Z}$ uwagi na to, że zaimki i liczebniki wykazują gramatyczne (składniowe) właściwości rzeczowników, przymiotników bądź zaimków, zaliczane są do leksemów autosyntagmatycznych.

\subsection{SCHEMAT OGÓLNEJ KLASYFIKACJI ŁACIŃSKICH LEKSEMÓW}

Ogólną klasyfikację lacińskich leksemów można zatem ująć w następujący schemat:

\section{LEKSEMY}

AUTOSYNTAGMATYCZNE

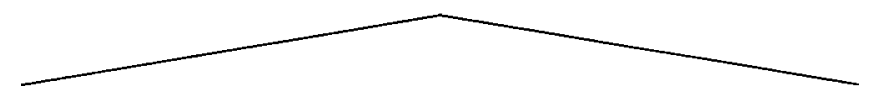

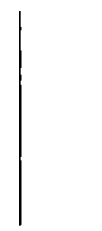

RZECZOWNIKI

(w tym rzeczownikowy

podzbiór zaimków

i liczebników)

CZASOWNIKI

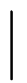

PRZYMIOTNIKI

(w tym przymiotnikowy

podzbiór zaimków i liczebników)<smiles>C=C</smiles>

PRZYSŁÓWKI

(w tym przysłówkowy

podzbiór zaimków i liczebników)
NIEAUTOSYNTAGMATYCZNE

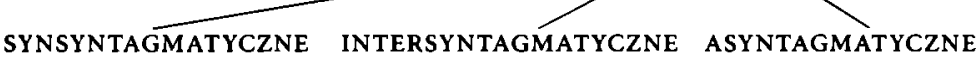

PRZYIMKI

SPÓJNIKI

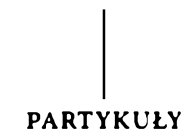




\section{4. \\ Paradygmatyka fleksyjna rzeczowników \\ i przymiotników}

\subsection{KATEGORIE IMIENNE I ICH WYKŁADNIKI}

Fleksja łacińskich rzeczowników i przymiotników oparta jest na kategoriach:

1. przypadka (casus) o wartościach:

- nominativus (nom.) - mianownik

- genetivus (gen.) - dopełniacz

- dativus (dat.) - celownik

- accusativus (acc.) - biernik

$\rightarrow$ ablativus (abl.) - narzędnik

- vocativus (voc.) - wołacz

2. liczby (numerus) o wartościach:

- singularis (sg.) - liczba pojedyncza

$\rightarrow$ pluralis ( $p l$.) - liczba mnoga

3. rodzaju (genus) o wartościach:

- masculinum (masc.) - rodzaj męski

$\rightarrow$ femininum (fem.) - rodzaj żeński

$\rightarrow$ neutrum (neutr.) - rodzaj nijaki.

Dla wyrażania wartości poszczególnych kategorii fleksyjnych rzeczowników i przymiotników łaciński system deklinacyjny dysponuje wykładnikami formalnymi o charakterze końcówkowym. Końcówki te stanowią skumulowane (synkretyczne) wykładniki wartości tych kategorii, w związku z czym deklinacyjne formy fleksyjne mają charakter syntetyczny, a ich flektyw jest morfologicznie prosty. Z kolei temat fleksyjny w wielu przypadkach podlega formalnym alternacjom.

Oprócz kumulacji funkcji łaciński system końcówek deklinacyjnych cechuje się izofunkcyjnością, która pozwala na wyodrębnienie pięciu wzorów paradygmatów formalnych, zwanych deklinacjami. Izofunkcyjność ta stanowi dziedzictwo prze- 
szłości, związana jest bowiem z wcześniejszym (historycznym) zróżnicowaniem zakończeń tematów leksemów podlegających deklinacji. Otóż pierwotnie niektóre rzeczowniki i przymiotniki miały temat zakończony na samogłoskę/a/, inne na samogłoskę /o/, jeszcze inne na spółgłoskę albo sonant /ei/ (/i/) lub /ou/ (/u/). Te formalne (fonologiczne) różnice w zakończeniu tematów skutkowały formalnym zróżnicowaniem przyłączanych przez nie końcówek fleksyjnych, tzn. tematy zakończone na /a/ przyłączały inne końcówki niż tematy zakończone na /o/ czy na spółgłoskę itd. W ten sposób doszło do ukształtowania się kilku różnych wzorów paradygmatu formalnego (kilku różnych deklinacji). W toku dalszego rozwoju języka doszło do szeregu zmian fonetycznych na granicy między tematem a końcówką fleksyjną (np. kontrakcje, wzdłużenia, zanik czy asymilacje samogłosek), które doprowadziły do ukształtowania się w klasycznej łacinie odmiennych stosunków morfologicznych w obrębie wyrazu, w tym m.in. do przesunięcia granic morfemów.

Np. tzw. I deklinacja łacińska obejmuje leksemy, których temat historycznie kończył się na samogłoskę /a/. Porównanie form fleksyjnych reprezentujących poszczególne flektemy tych leksemów, np.:

- tabulä < z dawn. ${ }^{*}$ tabulä-ø (nom. sg.),

$\rightarrow$ tabulās < z dawn. "tabulä-ns (acc. pl.),

- tabulis < z dawn. *tabulä-is (dat./abl. pl.)

prowadzi do uznania za końcówki fleksyjne elementów: -ā, -ās, -īs, zaś za temat fleksyjny ciągu: tabul-. Widać zatem, że dawne zakończenie tematu - $\bar{a}$ w niektórych formach fleksyjnych nie jest w ogóle widoczne, a tam gdzie się zachowało, przyjęło status (elementu) końcówki.

W paradygmatach leksemów II deklinacji dawne zakończenie tematu -ō- w stanie niezmienionym nie zachowało się w żadnej formie fleksyjnej, a jego przekształcone kontynuanty w poszczególnych formach fleksyjnych również trzeba - z punktu widzenia gramatyki opisowej klasycznej łaciny - uznać za elementy końcówek, np.:

$\rightarrow$ discipul-us < $\mathbf{z}$ dawn. ${ }^{*}$ discipulŏ-s (nom. sg.),

$\rightarrow$ discipul- $i<\mathrm{z}$ dawn. ${ }^{*}$ discipulŏ- $i$ (nom. pl.),

$\rightarrow$ discipul-ōs < z dawn. *discipulö-ns (acc. pl.).

A zatem zakończenie tematu, które historycznie leży u podstaw zróżnicowania wzorów paradygmatów formalnych, z punktu widzenia gramatyki opisowej klasycznej łaciny nie może stanowić kryterium przynależności leksemu do danej deklinacji, bowiem tematy zakończone np. na -ul-znajdują się zarówno w pierwszej deklinacji (np. tabul-a), jak i w drugiej (np. discipul-us), a także trzeciej (np. consul, consul-is). $\mathrm{Z}$ drugiej zaś strony w pierwszej deklinacji, oprócz leksemów o tematach zakończonych na -ul-, znajdują się leksemy o tematach zakończonych praktycznie na wszystkie inne fonemy; por. np.: ros- $a$, domin- $a$, terr- $a$, lup- $a$, und- $a$, de- $a$, victori-a itd.; podobnie w pozostałych deklinacjach.

Dlatego kryterium przynależnośći leksemu do określonego wzoru paradygmatu formalnego stanowi z punktu widzenia opisowego formalny kształt końcówki gen. $s g$. przybieranej przez ten leksem. I tak według wzoru paradygmatu formalnego I deklinacji kształtują swój paradygmat formalny leksemy przybierające w gen. sg. koń- 
cówkę - ae, według wzoru II deklinacji leksemy przybierające końcówkę -i, według wzoru III deklinacji leksemy przybierające końcówkę -is, według wzoru IV deklinacji leksemy przybierające końcówkę - ùs oraz według wzoru V deklinacji leksemy przybierające końcówkę -ei.

W odniesieniu do rzeczowników końcówki fleksyjne stanowią skumulowane wykładniki wartości kategorii liczby i przypadka. Kategorie rodzaju i osoby, ze względu na ich klasyfikujący (selektywny) charakter dla rzeczowników, nie są sygnalizowane przez końcówki fleksyjne. Określone wartości kategorii rodzaju i osoby przynależą leksemom rzeczownikowym jako takim i nie posiadają formalnych wykładników w reprezentujących je formach fleksyjnych, lecz są morfologicznie sygnalizowane (wyrażane) na płaszczyźnie składniowej przez określone człony syntaktyczne zależne składniowo od rzeczowników, tj. przydawkę przymiotnikową (rodzaj) oraz orzeczenie (osoba), por. np.: mater bona, pater bonus, iter bonum, mater dixit.

$\mathrm{W}$ odniesieniu do przymiotników, końcówki fleksyjne stanowią skumulowane wykładniki wartości kategorii liczby, przypadka i rodzaju. Poszerzony (o kategorię rodzaju) zakres kumulacji funkcji końcówek przymiotnika wynika $z$ tzw. mocji, tj. możliwości przyłączania przez temat przymiotnikowy, przy tej samej wartości kategorii liczby i przypadka, odmiennych wykładników (końcówek) dla różnych wartości kategorii rodzaju, np.: nom. sg. masc. long-ūs, nom. sg. fem. long-ă, nom. sg. neutr. long-ŭm. W wielu jednak wypadkach końcówki deklinacyjne przymiotników są homonimiczne ze względu na kategorię rodzaju, już to w zakresie wszystkich trzech jej wartości, np. masc./fem./neutr. dat. sg. brev-i, już to w zakresie co najmniej dwu wartości, np. masc./fem. acc. sg. brev-ëm. Kategoria osoby jest dla przymiotników kategorią neutralną, tzn. przymiotniki nie uwzględniają morfologicznie tej kategorii, por.: (ego) bonǔs, (tu) bonǔs, (discipulus) bonūs.

A zatem pełny paradygmat funkcjonalny leksemu rzeczownikowego, oparty na kategorii liczby ( 2 wartości) i przypadka (6 wartości), będzie się składał z 12 flektemów. Pełny paradygmat funkcjonalny leksemu przymiotnikowego, oparty na kategorii liczby ( 2 wartości), przypadka (6 wartości) i rodzaju (3 wartości), będzie się składał z 36 flektemów.

\subsection{OGÓLNE WŁAŚCIWOŚCI ŁACIŃSKIEJ PARADYGMATYKI DEKLINACYJNEJ}

1. W obrębie wszystkich wzorów paradygmatów formalnych (w obrębie wszystkich deklinacji) występuje homonimia końcówek:

$\rightarrow$ dat. pl. i abl. pl. wszystkich rodzajów,

$\rightarrow$ nom., acc. i voc. neutr. obu liczb,

- nom. i voc. obu liczb i wszystkich rodzajów - z wyjątkiem liczby pojedynczej leksemów II deklinacji mających w nom. sg. końcówkę -ǔs.

2. Istnieje niewielka grupa rzeczowników i przymiotników o zerowym paradygmacie formalnym, a więc rzeczowników i przymiotników nieodmiennych. Są to: 
- rzeczowniki: fas 'to, co dozwolone', nefas 'bezbożność, niegodziwość, necesse 'koniecznośc'l; rzeczowniki te nacechowane są wartością neutrum singulare (tantum); por. np. magnum nefas 'wielka niegodziwość';

- przymiotniki: frugi 'uczciwy, rzetelny', nequam 'bezwartościowy, nikczemny', potis/pote 'mający moc, będący w stanie'.

3. Kilka rzeczowników ma zredukowany paradygmat pod względem kategorii przypadka (i liczby). Należą do nich:

- rzeczownik (spons) spontis (fem.) '(wolna) wola', tworzący wyłącznie formy genetiwu (spontis) i ablatiwu (sponte) liczby pojedynczej;

- rzeczownik venus (masc.) 'sprzedaż, którego paradygmat ograniczony jest do form akuzatiwu (venum) i datiwu (veno / venui) liczby pojedynczej;

- rzeczownik vis (fem.) 'siła', który ma słabo poświadczone formy genetiwu i datiwu liczby pojedynczej, przy pełnym paradygmacie przypadkowym $w$ liczbie mnogiej.

\subsection{DEKLINACJA I}

Deklinacja ta obejmuje rzeczowniki i przymiotniki, których temat historycznie zakończony był na -āa-/-à - .

Końcówki deklinacyjne:

$\begin{array}{lll} & \text { sg. } & \text { pl., } \\ \text { nom. } & -\bar{a} & -a e, \\ \text { gen. } & -a e & -\bar{a} r u ̈ m(-\overline{u m}), \\ \text { dat. } & -a e & -\bar{i} s, \\ \text { acc. } & -\bar{a} m & -\bar{a} s, \\ \text { abl. } & -\bar{a} & -\bar{i} s, \\ \text { voc. } & -\bar{a} & -a e .\end{array}$

Końcówki te przyłączają tematy rzeczownikowe i przymiotnikowe.

Tematy przymiotnikowe przyjmują je dla wyrażenia (wraz z poszczególnymi wartościami kategorii liczby i przypadka) wartości femininum kategorii rodzaju. Łączliwość z tymi końcówkami cechuje te tematy przymiotnikowe, które dla wyrażenia wartości masculinum i neutrum przyłączają końcówki deklinacji II. A zatem cechą charakterystyczną tej grupy przymiotników jest to, iż pełny wzór ich paradygmatu formalnego ukonstytuowany jest przez końcówki fleksyjne I i II deklinacji.

1 Wyraz ten występuje wyłącznie $w$ funkcji orzecznika, stąd może być także traktowany jako przymiotnik o zerowym paradygmacie formalnym; jedynie u Lukrecjusza $(6,815)$ pojawia się forma necessis, która ma tam status rzeczownika w genetiwie. Podobnymi właściwościami cechuje się również używana orzecznikowo forma necessum/necessus, chociaż, znów u Lukrecjusza $(3,962)$, spotykamy formę necessis o statusie rzeczownika $w$ datiwie pluralis. 
Przykładowe paradygmaty:

\begin{tabular}{|c|c|c|c|c|c|}
\hline \multicolumn{3}{|c|}{ rzeczownik regina, -ae 'królowa' } & \multicolumn{3}{|c|}{$\begin{array}{l}\text { przymiotnik wyrażający } \\
\text { rodzaj zeński alta, ae 'wysoka' }\end{array}$} \\
\hline & singularis & pluralis & & singularis & pluralis \\
\hline $\begin{array}{l}\text { nom. } \\
\text { gen. } \\
\text { dat. } \\
\text { acc. } \\
\text { abl. } \\
\text { voc. }\end{array}$ & $\begin{array}{l}\text { regin-à } \\
\text { regin-ae } \\
\text { regin-ae } \\
\text { regin-ăm } \\
\text { regin-ā } \\
\text { regin-ā }\end{array}$ & $\begin{array}{l}\text { regin-ae } \\
\text { regin-ärǔm } \\
\text { regin-ìs } \\
\text { regin-ās } \\
\text { regin-is } \\
\text { regin-ae }\end{array}$ & $\begin{array}{l}\text { nom. } \\
\text { gen. } \\
\text { dat. } \\
\text { acc. } \\
\text { abl. } \\
\text { voc. }\end{array}$ & $\begin{array}{l}\text { alt-à } \\
\text { alt-ae } \\
\text { alt-ae } \\
\text { alt-ăm } \\
\text { alt-à } \\
\text { alt-à }\end{array}$ & $\begin{array}{l}\text { alt-ae } \\
\text { alt-ãrǔm } \\
\text { alt-ìs } \\
\text { alt-ās } \\
\text { alt-is } \\
\text { alt-ae }\end{array}$ \\
\hline
\end{tabular}

\section{Uwagi:}

Końcówki -ăm i -ärŭm (-ŭm) zawierają etymologicznie krótkie samogłoski; zob. jednak uwagi dot. wygłosowego/-m/ (wyżej, s. 71-73).

Stara końcówka gen. sg. -ās zachowała się w klasycznej łacinie tylko przy rzeczowniku familia, gdy był on używany w zwrocie: pater / mater familias 'ojciec / matka rodziny'.

Rzeczowniki wielosylabowe, $w$ tym $w$ szczególności złożenia $z$ drugim członem o postaci -cola, -gena (np.: agricola, terrigena), a także nazwy miar i ludów (np.: drachma, Dardanida), obok regularnej końcówki gen. pl. o postaci -ärŭm, mogą także przyłączać końcówkę skróconą (oboczną) o postaci -üm; tak więc formy gen. pl. tych leksemów mogą mieć postać: agricolärüm lub agricolüm, terrigenārüm lub terrigenüm, drachmärüm lub drachmüm, Dardanidärüm lub Dardanidüm.

Rzeczowniki o desygnatach osobowych płci żeńskiej, które posiadają w II deklinacji powiązane $\mathrm{z}$ nimi słowotwórczo odpowiedniki desygnujące osoby płci męskiej (np.: dea : deus, filia : filius, domina : dominus, serva : servus, amica : amicus itp.) mogą $\mathrm{w}$ dat. i $a b l$. pl., dla uniknięcia homonimii ze swoimi odpowiednikami z II deklinacji, zamiast końcówki -is przyłączać końcówkę -ābǔs, np.: deābŭs, amicābŭs, zwłaszcza gdy używane są w wyrażeniach wspólnie z tymi odpowiednikami, np.: deis deäbüsque itp.

Rzeczowniki, będące nazwami miast i mniejszych wysp sg. tantum dla wyrażenia funkcji lokatywnej przybierają końcówkę -ae, np.: Romae ('w Rzymie'), Capuae ('w Kapui') itp.

Większość rzeczowników tworzących formy fleksyjne według wzoru I deklinacji nacechowana jest rodzajem żeńskim. Rodzaj męski ma jednak większość rzeczowników desygnujących osoby płci męskiej, np.: agricola, nauta, poeta, scriba, incola, collega, auriga i in., w tym także imiona własne, jak np.: Catilina, Agrippa.

Rodzaj żeński zachowują jednak: operae, -arum ('robotnicy') oraz vigiliae, -arum ('strażnicy'), a także nazwy rzek: Allia (lewy dopływ Tybru) oraz Albula (stara nazwa Tybru).

Do klasy pluralia tantum należą zarówno niektóre rzeczowniki pospolite, jak np.: divitiae, -arum; insidiae, -arum; tenebrae, -arum; nuptiae, -arum, jak i własne, np.: Athenae, -arum; Cannae, -arum; Cumae, -arum; Thebae, -arum; Syracusae, -arum. 
Niektóre rzeczowniki cechują się zróżnicowaniem funkcji semantycznej w zależności od wartości kategorii liczby, np.:

- sg. copia 'obfitość'

$\rightarrow$ sg. littera 'litera'

- sg. vigilia 'czuwanie'

- sg. opera 'praca, dzieło' pl. copiae 'środki utrzymania; wojsko',

pl. litterae 'litery; list; literatura',

pl. vigiliae 'strażnicy',

pl. operae 'prace, dzieła; robotnicy'.

\subsection{DEKLINACJA II}

Deklinacja ta obejmuje rzeczowniki i przymiotniki, których temat historycznie zakończony był na -ö.

Końcówki deklinacyjne:

sg. pl.,

\begin{tabular}{|c|c|c|}
\hline nom. & $-\check{u} s,-\emptyset,-\check{u} m$ & $-\bar{i},-\check{a}$ \\
\hline gen. & $-i$ & -ōrŭm (-ǔm), \\
\hline dat. & $-\bar{o}$ & $-i s$ \\
\hline acc. & $-\check{u} m$ & $-\bar{o} s,-\bar{a}$, \\
\hline$l$. & $-\bar{O}$ & $-\bar{i} s$ \\
\hline voc. & $-\check{e},-\emptyset,-\check{u} m$ & $-\bar{i},-\check{a}$. \\
\hline
\end{tabular}

Końcówki te przyłączają tematy rzeczownikowe i przymiotnikowe.

Tematy przymiotnikowe przyjmują je dla wyrażenia (wraz z poszczególnymi wartościami kategorii liczby i przypadka) wartości masculinum i neutrum kategorii rodzaju. Łączliwość z tymi końcówkami cechuje te tematy przymiotnikowe, które dla wyrażenia wartości femininum przyłączają końcówki I deklinacji. A zatem cechą charakterystyczną tej grupy przymiotników jest to, iż pełny wzór ich paradygmatu formalnego ukonstytuowany jest przez końcówki fleksyjne I i II deklinacji.

Końcówkę nom. sg. -ŭm przyjmują rzeczowniki i przymiotniki w rodzaju nijakim.

Końcówki nom. sg. -ŭs i -ø przyjmują rzeczowniki i przymiotniki w rodzaju męskim. Dystrybucja obu tych końcówek ukształtowana została w wyniku procesów fonologicznych, jakie dokonały się w lacinie przedliterackiej. Z punktu widzenia opisowego nie jest możliwe zdefiniowanie reguł tej dystrybucji, tym samym łączliwość danego tematu $\mathrm{z}$ jedną lub drugą końcówką nom. sg. stanowi właściwość o charakterze leksykalnym, a nie gramatycznym. Można jedynie stwierdzić, że końcówkę przyłącza wyłącznie część tematów rzeczownikowych i przymiotnikowych zakończonych na -èr oraz rzeczownik vir, viri ('mężczyzna') wraz z utworzonymi na jego podstawie złożeniami (triumvir, decemvir itp.).

Część rzeczowników i przymiotników, przyjmujących w nom. sg. (masc.) końcówkę - $\oslash$ cechuje się alternacją w obrębie tematu, polegającą na zaniku samogłoski /è/ poprzedzającej /-r/ w zakończeniu tematu we wszystkich formach fleksyjnych 
z wyjątkiem nom. i voc. sg. (masc.). Alternacja ta również jest wynikiem określonych procesów fonologicznych zaszłych w przeszłości i warunki jej występowania nie są definiowalne w kategoriach synchronicznych (opisowych) łaciny klasycznej.

W voc. sg. końcówkę -ē przyjmują te rzeczowniki i przymiotniki w rodzaju męskim, które w nom. sg. przyłączają końcówkę - ǔs; końcówkę - ŭm przyjmują rzeczowniki i przymiotniki w rodzaju nijakim, zaś końcówkę -ø rzeczowniki i przymiotniki, które w nom. sg. przyjmują homofoniczną końcówkę -ø.

W nom., acc. i voc. pl. homonimiczne końcówki o postaci -à przyjmują rzeczowniki i przymiotniki w rodzaju nijakim.

Przykładowe paradygmaty rzeczowników:

\begin{tabular}{|c|c|c|c|c|c|}
\hline & \multicolumn{2}{|c|}{$\begin{array}{c}\text { rzeczownik rodzaju męskiego } \\
\text { z końcówką -ùs w nom. sg.: } \\
\text { dominus, - } i \text { 'pan' }\end{array}$} & \multicolumn{3}{|c|}{$\begin{array}{c}\text { rzeczownik rodzaju nijakiego } \\
\text { z końcówką -ùm w nom. sg.: } \\
\text { bellum, - } i \text { 'wojna' }\end{array}$} \\
\hline & singularis & pluralis & & singularis & pluralis \\
\hline $\begin{array}{l}\text { nom. } \\
\text { gen. } \\
\text { dat. } \\
\text { acc. } \\
\text { abl. } \\
\text { voc. }\end{array}$ & $\begin{array}{l}\text { domin-ǔs } \\
\text { domin-ĩ } \\
\text { domin-ō } \\
\text { domin-ŭm } \\
\text { domin-ō } \\
\text { domin-è } \\
\end{array}$ & $\begin{array}{l}\text { domin-ì } \\
\text { domin-ōrŭm } \\
\text { domin-îs } \\
\text { domin-ōs } \\
\text { domin- is } \\
\text { domin-i }\end{array}$ & $\begin{array}{l}\text { nom. } \\
\text { gen. } \\
\text { dat. } \\
\text { acc. } \\
\text { abl. } \\
\text { voc. }\end{array}$ & $\begin{array}{l}\text { bell-ǔm } \\
\text { bell-ĩ } \\
\text { bell-ō } \\
\text { bell-ūm } \\
\text { bell-ō } \\
\text { bell-ǔm }\end{array}$ & $\begin{array}{l}\text { bell-à } \\
\text { bell-örŭm } \\
\text { bell-is } \\
\text { bell- à } \\
\text { bell-is } \\
\text { bell-ă } \\
\end{array}$ \\
\hline
\end{tabular}

\begin{tabular}{|c|c|c|c|c|c|}
\hline & \multicolumn{2}{|c|}{$\begin{array}{c}\text { rzeczownik rodzaju męskiego } \\
\text { z końcówką - } \oplus \text { w nom. sg. } \\
\text { bez alternacji w obrębie tematu: } \\
\text { puer, - } i \text { 'chłopiec' }\end{array}$} & \multicolumn{3}{|c|}{$\begin{array}{l}\text { rzeczownik rodzaju męskiego } \\
\text { z końcówką -ø w nom. sg. } \\
\text { z alternacją w obrębie tematu: } \\
\text { magister, -tri 'nauczyciel' }\end{array}$} \\
\hline & singularis & pluralis & & singularis & pluralis \\
\hline $\begin{array}{l}\text { nom. } \\
\text { gen. } \\
\text { dat. } \\
\text { acc. } \\
\text { abl. } \\
\text { voc. }\end{array}$ & $\begin{array}{l}\text { puer } \\
\text { puer-ī } \\
\text { puer-ō } \\
\text { puer-ùm } \\
\text { puer-ō } \\
\text { puer }\end{array}$ & $\begin{array}{l}\text { puer-ì } \\
\text { puer-ōrǔm } \\
\text { puer-ís } \\
\text { puer-ōs } \\
\text { puer-ìs } \\
\text { puer-ì }\end{array}$ & $\begin{array}{l}\text { nom. } \\
\text { gen. } \\
\text { dat. } \\
\text { acc. } \\
\text { abl. } \\
\text { voc. }\end{array}$ & \begin{tabular}{|l|} 
magister \\
magistr-ī \\
magistr-ō \\
magistr-ŭm \\
magistr-ō \\
magister
\end{tabular} & $\begin{array}{l}\text { magistr-i } \\
\text { magistr-ōrŭm } \\
\text { magistr-īs } \\
\text { magistr-ōs } \\
\text { magistr-îs } \\
\text { magistr-i }\end{array}$ \\
\hline
\end{tabular}


Przykładowe paradygmaty przymiotników wyrażających rodzaj męski i nijaki:

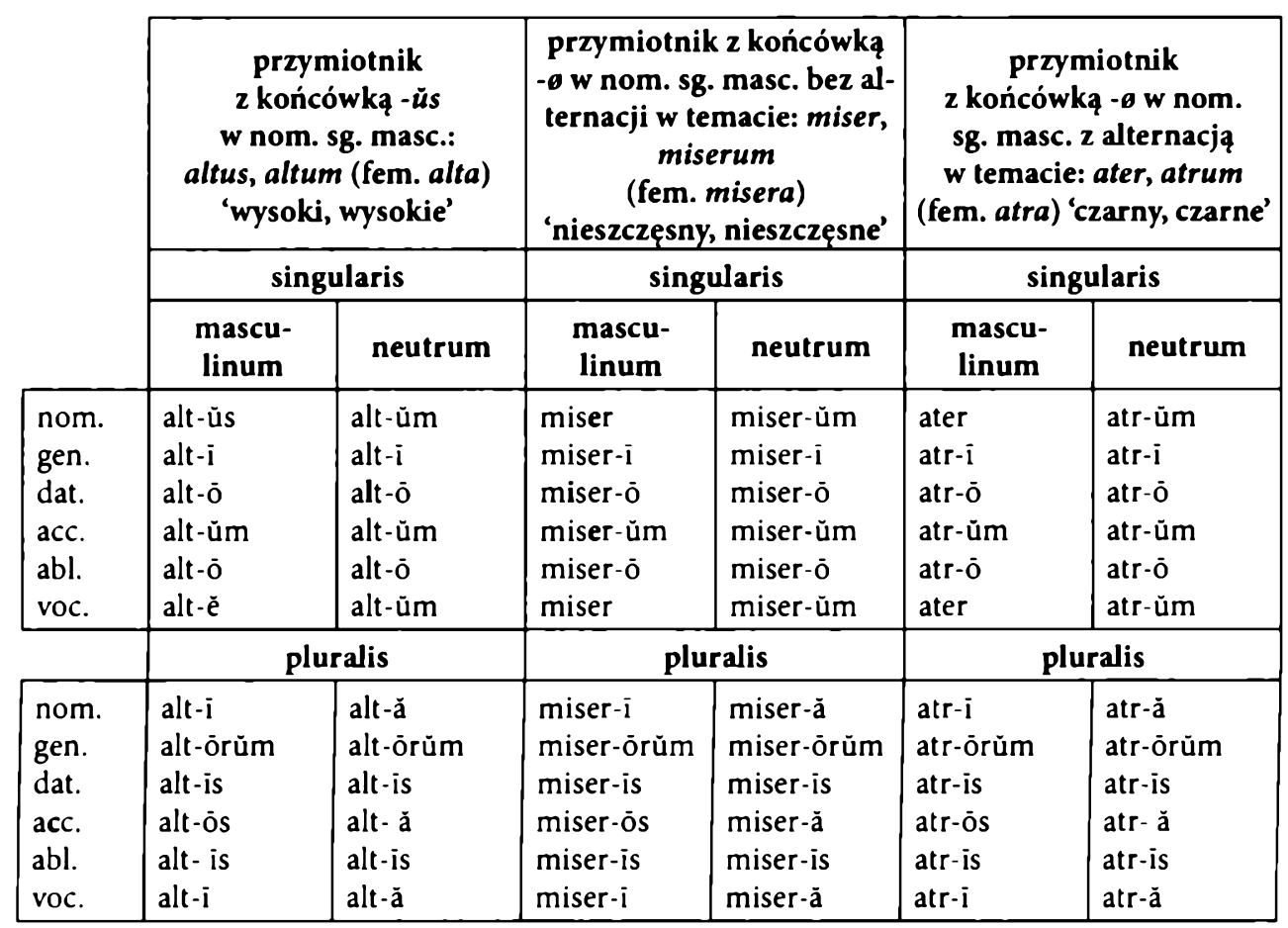

\section{Uwagi:}

Końcówki -ŭm i -ōrŭm (-ŭm) zawierają etymologicznie krótkie samogłoski; zob. jednak uwagi dot. wygłosowego /m/ (wyżej, s. 71-73)

Rzeczownik filiŭs oraz imiona własne o temacie zakończonym na samogłoskowe /-ĩ-/ (Publiǔs, Corneliuus, Hortensius, itp.) w voc. sg. cechują się alternacją tematu, polegającą na wzdłużeniu wygłosowej samogłoski tematu do /-i/; do alternantu tego przyłączana jest końcówka -ø, stąd formy voc. o postaci: fili, Publi, Corneli, Valeri, itp. ${ }^{2}$ Do reguły tej nie stosują się imiona własne pochodzenia greckiego, np.: Dariŭs, voc. Dariě. ${ }^{3}$ Najprawdopodobniej wskutek częstego używania w połączeniu z voc. fili, podobną formę voc. sg. przyjął zaimek meus, tj. mi (fili) 'mój (synu)'.

W rzeczownikowych i przymiotnikowych tematach zakończonych na spółgłoskowe długie /î/ (plebeius, Pompeius itp.) fonem ten nie jest notowany przed końcówkami zaczynającymi się od samogłoskowego /ì/; stąd pisownia z jedną literą "i", np.: gen. sg. plebei, Pompei, dat. abl. pl. plebeis, ale z zachowaniem akcentu na przedostat-

2 Ponieważ wygłosowe długie /-i/ w tych formach jest wynikiem kontrakcji krótkiej samogłoski kończącej pierwotnie temat z krótką samogłoską końcówki, akcent zachowal się na drugiej sylabie od końca (czyli na trzeciej od końca przed kontrakcją), nawet jeśli była ona krótka, a więc np. Valéri! 'Waleriuszu!'.

${ }^{3}$ Imię pochodzenia perskiego, przejęte przez lacinę z greki. 
niej sylabie. Czasem (zwłaszcza we wcześniejszej łacinie) konwencja ta obejmowała także leksemy o tematach zakończonych na krótkie samogłoskowe /i//, np.: gen. Corneli, fili czy dat./abl. pl. filis ${ }^{4}$ (od Corneliŭs, filiŭs), również z zachowaniem miejsca akcentu, uwzględniającego obecność samogłoskowego / / / w zakończeniu tematus. Tego rodzaju konwencje ortograficzne nie dotyczą jednak form nom. pl. (zob. wyżej, uwagi dot. dyftongu /ej/, który pierwotnie stanowił końcówkę tego przypadka).

Rzeczownik dèŭs w nom. voc. dat. $i$ abl. pl., oprócz form regularnych (nom./voc. pl. dèi, dat./abl. pl. dēìs), posiada w swym paradygmacie formalnym formy oboczne, utworzone na bazie alternantów tematycznych o postaci $d i$ - oraz $d$-, a więc nom./voc. pl. dī, dì, dat./abl. pl. dīis, dìs. Ponadto w voc. sg. występują oboczne formy o postaci dèùs i dìvĕ. Homonimiczną z nom. sg. formę voc. sg. posiada także rzeczownik agnus. Również od rzeczownika populus nie tworzy się formy wokatywnej, lecz w jej funkcji zwykle występuje forma nominatiwu.

W paradygmatach formalnych niektórych leksemów rzeczownikowych, w gen. pl., oprócz form regularnych z końcówką -ōrüm, mogą także wystąpić formy oboczne $\mathbf{z}$ końcówką skróconą (oboczną) o postaci -ŭm. Dotyczy to głównie nazw monet i miar (denarius, sestertius, nummus, talentum, modius), nazw własnych greckiego pochodzenia (Danai, Achivi), wyrazów o temacie zakończonym na /r/ (inferus, posterus, triumvir, faber, liberi), wyrazów długich, wielosylabowych (np. consnguineus), a wyjątkowo także innych, wśród nich rzeczowników deus i socius. Tak więc wyrazy te, oprócz regularnych form gen. pl.: denariōrüm, Danaōrüm, inferōrüm, consanguineōrŭm, deorum, sociorum, itp., posiadają także formy oboczne: denariŭm, Danaŭm, inferŭm, consanguineŭm, deum, socium itp.

Paradygmat formalny rzeczownika locus, - $i$ 'miejsce' w liczbie mnogiej, obok regularnych form rodzaju męskiego: locī, locōrūm itd., współtworzą także formy rodzaju nijakiego: locă, locōrŭm itd.; tym samym leksem ten posiada paradygmat formalny i funkcjonalny rozszerzony w stosunku do pozostałych leksemów rzeczownikowych. Formy rodzaju męskiego używane są zwykle $w$ odniesieniu do miejsc $w$ tekstach, cytatów, wypowiedzi (por. loci communes), formy rodzaju nijakiego w odniesieniu do miejsc topograficznych.

Rzeczowniki będące nazwami miast i mniejszych wysp sg. tantum dla wyrażenia funkcji lokatywnej przybierają końcówkę $-i$, np.: Corinthi ('w Koryncie'), Saguntī ('w Saguncie'), Deli ('na Delos') itp. Również niektóre rzeczowniki pospolite przybierają tę końcówkę, jeśli użyte zostają w funcji lokatywnej, np.: humi ('na ziemi'), belli ('na wojnie').

Rzeczowniki przybierające w nom. sg. końcówkę -ǔs są rodzaju męskiego. Rodzaj żeński mają jednak rzeczowniki: humüs ('ziemia'), alvŭs ('brzuch'), colǔs ('kądziel') oraz liczne pożyczki greckie, jak np.: dialectǔs, paragraphŭs, atomŭs, crystallŭs i in. Z kolei rodzaj nijaki mają rzeczowniki: virŭs ('trucizna'), vulgŭs ('tłum') oraz pelägŭs ('morze'); w voc. i acc. rzeczowniki te przybierają końcówki homofoniczne z nom.

4 Zamiast ustalonej (później) jako norma grafii: Cornelii, filii, filiis.

Zob. na ten temat Bernardi Perini (1970: 43-45). 
Do klasy pluralia tantum należą zarówno niektóre rzeczowniki pospolite, jak np.: fasti, -örūm 'kalendarz', liberi, -örŭm 'dzieci', exta, -ōrŭm 'wnętrzności', arma, -örŭm 'broń, jak i własne, np.: Argi, -ōrŭm 'Argos', Delphi, -ōrüm 'Delfy'.

Niektóre rzeczowniki cechują się zróżnicowaniem funkcji semantycznej w zależności od wartości kategorii liczby, np.:

- sg. auxilium 'pomoc'

- sg. castrum 'twierdza, zamek'

- sg. impedimuntum 'przeszkoda'

- sg. rostrum 'dziób okrętu'

- sg. comitium 'miejsce zgromadzenia'

$\rightarrow$ sg. ludus 'zabawa; szkoła' pl. auxilia 'wojska posiłkowe',

pl. castra 'twierdze, zamki; obóz wojskowy',

pl. impedimenta 'tabor wojskowy',

pl. rostra 'dzioby okrętów; mównica',

pl. comitia 'zgromadzenie ludowe',

pl. ludi 'igrzyska'.

\subsection{DEKLINACJA III}

Deklinacja ta obejmuje rzeczowniki i przymiotniki, których temat historycznie zakończony był na spółgłoskę, np.: $d u x$, ducis; nomen, nominis, lub na sonant (ei/i, ou/u), np.: fortis, -e; civis, -is; pars, partis; sus, suis. To zróżnicowanie historycznych zakończeń tematów (wraz z późniejszymi zmianami fonologicznymi i zmianami powstałymi $w$ oparciu o działanie prawa analogii) odpowiedzialne jest za istnienie trzech różnych typów formalnych tego wzoru paradygmatu, tzw. typu spółgłoskowego, samogłoskowego i mieszanego.

Końcówki deklinacyjne:

sg.

nom.

gen.

dat.

acc. $\quad-\check{e} m,-i m,-\check{e},-\emptyset,-s$

abl. $\quad-\ddot{e},-\bar{l}$

voc. $\quad-i \bar{s},-\bar{e} s,-\check{e},-s,-\emptyset$ pl.,

$-\bar{e} s,-\bar{a},-i \ddot{a}$,

-üm, -iüm,

-ibŭs,

-ès (-is), $-\ddot{a},-i \ddot{a}$,

$-\ddot{i b u ̆ s,}$

$-\bar{e} s,-\bar{a},-i \grave{a}$.

Końcówki te przyłączają tematy rzeczownikowe i przymiotnikowe.

Końcówki -ēm, -imm i -ŭm (-iŭm) zawierają etymologicznie krótkie samogłoski; zob. jednak uwagi dot. wygłosowego $/ \mathrm{m} /$ (wyżej, s. 71-73)

Końcówki: nom. voc. sg. -è, acc. sg. -è, -o, nom. acc. voc. pl. -ä, -iä nacechowane są rodzajem nijakim (przyłączają je wyłącznie rzeczowniki i przymiotniki w rodzaju nijakim). Końcówka acc. sg. -s przyłączana jest wyłącznie przez część przymiotników dla wyrażenia wartości neutrum kategorii rodzaju, np. princep-s.

Końcówki: nom. voc. sg. -iss, -ès, acc. sg. -èm, -im, nom. voc. pl. -ēs, acc. pl. -ēs, (-iss) nacechowane są rodzajem męskim lub żeńskim (przyjmują je wyłącznie rzeczowniki i przymiotniki w rodzaju męskim lub żeńskim - nigdy nijakim). 
Pozostałe końcówki nie są scharakteryzowane co do kategorii rodzaju.

Dystrybucja poszczególnych końcówek nom. sg. w odniesieniu do różnych tematów rzeczownikowych i przymiotnikowych tej deklinacji ukształtowana została historycznie i nie podlega regułom definiowalnym w kategoriach opisowych dla łaciny klasycznej; z punktu widzenia opisowego stanowi zatem właściwość o charakterze leksykalnym.

Spośród przymiotników jedne w nom. sg. przyjmują trzy różne niehomonimiczne końcówki dla wyrażenia poszczególnych wartości kategorii rodzaju, np.: celer-ø (masc.), celer-is (fem.), celer-è (neutr.), inne przybierają końcówki homonimiczne dla wyrażenia rodzaju męskiego i żeńskiego, np.: brev-iss (masc., fem.), brev-ë (neutr.), jeszcze inne przybierają końcówki homonimiczne dla wszystkich trzech wartości kategorii rodzaju, np. pauper-ø (masc., fem., neutr.). Wzór paradygmatu przymiotników III deklinacji ukonstytuowany jest $w$ całości przez końcówki fleksyjne tej deklinacji.

Dystrybucja końcówek izofunkcyjnych ze względu na kategorie liczby i przypadka uwzględnia następujące reguły:

I. Końcówki: abl. sg. -è, gen. pl. -ŭm, (nom. acc. voc. pl. neutr. -ă) konstytuują tzw. typ spółgłoskowy III deklinacji i współwystępują w paradygmatach formalnych takich leksemów jak:

1. imparisyllaba ( $\mathrm{tj}$. leksemy mające $\mathrm{w}$ formie gen. sg. więcej sylab niż $\mathrm{w}$ formie nom. $s g)$, których temat w gen. sg. zakończony jest na nie więcej niż jedną spółgłoskę; dotyczy to:

a. wszystkich leksemów rzeczownikowych spełniających to kryterium (z wyjątkiem wymienionych w pkt. II.3.b.), np.: rex, reg-is; corpus, corpor- $i s^{6}$;

b. wszystkich formacji komparatiwu przymiotników, np.: altior, -ius; altior-iss;

c. przymiotników (w stopniu równym), przyłączających w nom. sg. homonimiczne końcówki dla wszystkich wartości kategorii rodzaju ( $\mathrm{z}$ wyjątkiem przymiotników wymienionych w pkt. II.1.), np.: vetus, -teris; dives, -vitis; pauper, -eris; princeps, -cipis; particeps, -cipis; compos, -otis; superstes, -titis ${ }^{7}$;

2. imparisyllaba, których temat zakończony jest na samogłoskę -u-, np.: sus, suis; grus, gruis;

3. następujące parisyllaba: mater, -tris; pater, -tris; frater, -tris; iuvenis, -is; senex, -nis; vates, -is; canis, -is (tzw. "rodzina z psem"), a także accipiter, -tris; panis, -is.

II. Końcówki: abl. sg. -ī, gen. pl. -iŭm, (nom. acc. voc. pl. neutr. -iă) konstytuują tzw. typ samogłoskowy III deklinacji i współwystępują w paradygmatach formalnych takich leksemów jak:

' Jednak gen. pl. z końcówką -iūm mogą mieć rzeczowniki o temacie zakończonym na -ās/-ät- oraz -is-/-ìt-, np.: Arpinās, Arpinātis; Samnis, Samnitis; civitās, civitâtis, a także rzeczowniki jednosylabowe, np.: dos, dotis; fraus, fraudis; lis, litis; mus, muris; nix, nivis i in.

Abl. sg. z końców'ką -i mają jednak zwykle: (im)memor, -is; inops, -pis; supplex, -licis; vigil, -is; $\mathbf{z}$ nich jednak tylko vetus, -eris ma nom. acc. voc. pl. neutr. z końcówką -ä (vetera) zaś wszystkie pozostałe z końcówką -iă (np. vigilia). 
1. przymiotniki w stopniu równym, przy czym spośród przyłączających w nom. sg. końcówki homonimiczne tylko te, których temat w gen. sg. zakończony jest na -c-, -rt- lub -nt-, a przyłączane w nom. sg. homonimiczne końcówki mają postać -s, a więc np.: felix, -icis; audax, -acis; iners, -rtis; ingens -ntis itp.;

2. zadiektywizowane participia praesentis activi;

3. rzeczowniki rodzaju nijakiego, które:

a. w nom. sg. przyłączają końcówkę -è, np.: mar-è, ret-é;

b. w nom. sg. przyłączają końcówkę -ø, a temat mają zakończony na -al-/-äl-lub -ar-/-är-, np.: animal-ø, animäl-is; exemplar-ø, exemplär-is;

4. równozgłoskowe nazwy miast i rzek z końcówką -is $\mathrm{w}$ nom. sg., które $\mathrm{w}$ acc. sg. przyłączają końcówkę -imm, np.: Neapol-is (acc. sg. Neapol-im), Tiber-is (acc. sg. Tiber-im);

5. kilka równozgłoskowych rzeczowników pospolitych rodzaju żeńskiego z końcówką -is w nom. sg., które w acc. sg. również przyłączają końcówkę -im; są to m.in. rzeczowniki: sit-is, turr-is, pupp-is, secur-is, tuss-is;

6. rzeczownik vis (acc. sg. vim, abl. sg. vï, gen. pl. viriüm).

III. Końcówki: abl. sg. -ë, gen. pl. -iŭm, (nom. acc. voc. pl. neut. -iă) konstytuują tzw. typ mieszany III deklinacji i współwystępują w paradygmatach formalnych takich leksemów jak:

1. rzeczownikowe imparisyllaba, których temat w gen. sg. zakończony jest co najmniej dwiema spółgloskami, np.: pars, part-is; dens, dent-is ${ }^{8}$;

2. rzeczownikowe parisyllaba przyłączające w nom. sg. końcówkę -is lub -ēs (z wyjątkiem wymienionych w pkt. I.3. i II.4.-5.), np.: civ-is, nub-ès;

3. niezadiektywizowane participia praesentis activi.

Oboczną (równoległą) do -ès końcówkę acc. pl. -iss mogą przyłączać wszystkie rzeczowniki i przymiotniki rodzaju męskiego i żeńskiego samogłoskowego i mieszanego typu wzoru paradygmatu formalnego. W paradygmatach formalnych tych leksemów wystąpią zatem $\mathrm{w}$ acc. pl. formy fleksyjne oboczne, np.:

$\rightarrow$ fort-ēs/fort-is;

- turr-ès/turr-is;

$\rightarrow$ part-ès/part-ìs;

- civ-ès/civ-is.

Dystrybucja pozostałych końcówek, izofunkcyjnych ze względu na kategorię liczby i przypadka, uwzględnia wartość kategorii rodzaju oraz respektuje zasadę homonimii końcówek nom. i voc., a w przypadku neutrów homonimię końcówek nom. acc. i voc., odpowiednio w liczbie pojedynczej i mnogiej.

" Rzeczownik parens, -ntis może mieć także w gen. pl. -ŭm; z kolei rzeczownik rodzaju nijakiego cor, -rdis w nom. acc. i voc. pl. ma końcówkę -a (corda). 
Przykładowe paradygmaty rzeczowników i przymiotnika typu spółgłoskowego:

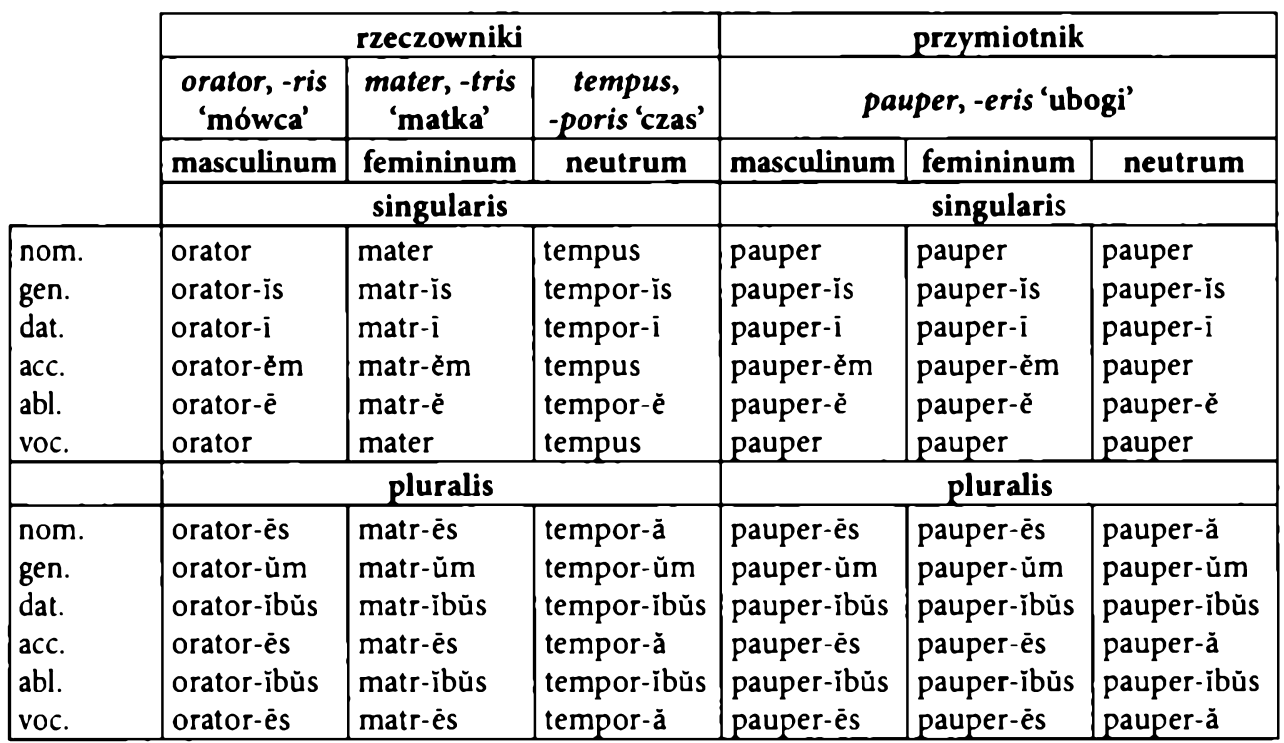

Przykładowe paradygmaty rzeczowników i przymiotnika typu samogłoskowego:

\begin{tabular}{|c|c|c|c|c|c|}
\hline & \multicolumn{2}{|c|}{ rzeczowniki } & \multicolumn{3}{|c|}{ przymiotnik } \\
\hline & \multirow{2}{*}{$\begin{array}{c}\text { turris, -is } \\
\text { 'wieza' } \\
\text { femininum }\end{array}$} & \multirow{2}{*}{$\begin{array}{c}\text { mare, -ris } \\
\text { 'morze' } \\
\text { neutrum }\end{array}$} & \multicolumn{3}{|c|}{ brevis, -e 'krótki, -ka, -kie' } \\
\hline & & & masculinum & femininum & neutrum \\
\hline & \multicolumn{2}{|c|}{ singularis } & \multicolumn{3}{|c|}{ singularis } \\
\hline $\begin{array}{l}\text { nom. } \\
\text { gen. } \\
\text { dat. } \\
\text { acc. } \\
\text { abl. } \\
\text { voc. }\end{array}$ & $\begin{array}{l}\text { turr-is } \\
\text { turr-is } \\
\text { turr-ì } \\
\text { turr-im } \\
\text { turr-i } \\
\text { turr-is }\end{array}$ & $\begin{array}{l}\text { mar-è } \\
\text { mar-ìs } \\
\text { mar-ì } \\
\text { mar-è } \\
\text { mar-ì } \\
\text { mar-è }\end{array}$ & $\begin{array}{l}\text { brev-is } \\
\text { brev-is } \\
\text { brev-i } \\
\text { brev-èm } \\
\text { brev-i } \\
\text { brev-is }\end{array}$ & $\begin{array}{l}\text { brev-is } \\
\text { brev-is } \\
\text { brev-ì } \\
\text { brev-èm } \\
\text { brev-i } \\
\text { brev-is }\end{array}$ & $\begin{array}{l}\text { brev-è } \\
\text { brev-ìs } \\
\text { brev-ì } \\
\text { brev-è } \\
\text { brev-ì } \\
\text { brev-è }\end{array}$ \\
\hline & \multicolumn{2}{|c|}{ pluralis } & \multicolumn{3}{|c|}{ pluralis } \\
\hline $\begin{array}{l}\text { nom. } \\
\text { gen. } \\
\text { dat. } \\
\text { acc. } \\
\text { abl. } \\
\text { voc. }\end{array}$ & $\begin{array}{l}\text { turr-ēs } \\
\text { turr-iūm } \\
\text { turr-ībǔs } \\
\text { turr-ēs (-is) } \\
\text { turr-ïbŭs } \\
\text { turr-ēs } \\
\end{array}$ & $\begin{array}{l}\text { mar-iă } \\
\text { mar-iŭm } \\
\text { mar-ībŭs } \\
\text { mar-ià } \\
\text { mar-ỉbŭs } \\
\text { mar-iă } \\
\end{array}$ & $\begin{array}{l}\text { brev-ēs } \\
\text { brev-iŭm } \\
\text { brev-ïbŭs } \\
\text { brev-ēs (-īs) } \\
\text { brev-ibŭs } \\
\text { brev-ēs }\end{array}$ & $\begin{array}{l}\text { brev-ēs } \\
\text { brev-iŭm } \\
\text { brev-ïbǔs } \\
\text { brev-ēs (-is) } \\
\text { brev-ïbŭs } \\
\text { brev-ēs }\end{array}$ & $\begin{array}{l}\text { brev-iă } \\
\text { brev-iŭm } \\
\text { brev-ibǔs } \\
\text { brev-ià } \\
\text { brev-íbǔs } \\
\text { brev-ià }\end{array}$ \\
\hline
\end{tabular}


Przykładowe paradygmaty rzeczowników i participium praesentis activi typu mieszanego:

\begin{tabular}{|c|c|c|c|c|c|}
\hline & \multicolumn{2}{|c|}{ rzeczowniki } & \multirow{2}{*}{\multicolumn{3}{|c|}{$\begin{array}{l}\text { participium praesentis activi } \\
\text { videns, -ntis 'widzący' }\end{array}$}} \\
\hline & \multirow{2}{*}{$\begin{array}{c}\text { mons, -ntis } \\
\text { 'góra' } \\
\text { masculinum }\end{array}$} & \multirow{2}{*}{$\begin{array}{c}\text { classis, }- \text { is } \\
\text { 'flota' } \\
\text { femininum }\end{array}$} & & & \\
\hline & & & masculinum & femininum & neutrum \\
\hline & \multicolumn{2}{|c|}{ singularis } & \multicolumn{3}{|c|}{ singularis } \\
\hline \multirow[t]{2}{*}{$\begin{array}{l}\text { nom. } \\
\text { gen. } \\
\text { dat. } \\
\text { acc. } \\
\text { abl. } \\
\text { voc. }\end{array}$} & $\begin{array}{l}\text { mon-s } \\
\text { mont-ìs } \\
\text { mont-ì } \\
\text { mont-èm } \\
\text { mont-è } \\
\text { mon-s } \\
\end{array}$ & $\begin{array}{l}\text { class-ĩs } \\
\text { class-ĩs } \\
\text { class-ì } \\
\text { class-èm } \\
\text { class-è } \\
\text { class- ìs } \\
\end{array}$ & $\begin{array}{l}\text { viden-s } \\
\text { vident-ìs } \\
\text { vident-i } \\
\text { vident-èm } \\
\text { vident-è } \\
\text { viden-s } \\
\end{array}$ & $\begin{array}{l}\text { viden-s } \\
\text { vident-ìs } \\
\text { vident-ì } \\
\text { vident-èm } \\
\text { vident-è } \\
\text { viden-s } \\
\end{array}$ & $\begin{array}{l}\text { viden-s } \\
\text { vident-ìs } \\
\text { vident-i } \\
\text { viden-s } \\
\text { vident-è } \\
\text { viden-s } \\
\end{array}$ \\
\hline & \multicolumn{2}{|c|}{ pluralis } & \multicolumn{3}{|c|}{ pluralis } \\
\hline $\begin{array}{l}\text { nom. } \\
\text { gen. } \\
\text { dat. } \\
\text { acc. } \\
\text { abl. } \\
\text { voc. }\end{array}$ & $\begin{array}{l}\text { mont-ēs } \\
\text { mont-iŭm } \\
\text { mont-îbūs } \\
\text { mont-ès (-is) } \\
\text { mont-ïbŭs } \\
\text { mont-ēs }\end{array}$ & $\begin{array}{l}\text { class-ēs } \\
\text { class-īŭm } \\
\text { class-ïbŭs } \\
\text { class-ēs (-îs) } \\
\text { class-ïbŭs } \\
\text { class-ēs }\end{array}$ & $\begin{array}{l}\text { vident-ēs } \\
\text { vident-iŭm } \\
\text { vident-ïbūs } \\
\text { vident-ēs (-îs) } \\
\text { vident-ïbǔs } \\
\text { vident-ès }\end{array}$ & $\begin{array}{l}\text { vident-ēs } \\
\text { vident-iŭm } \\
\text { vident-ïbŭs } \\
\text { vident-ēs (-îs) } \\
\text { vident-ïbŭs } \\
\text { vident-ēs }\end{array}$ & $\begin{array}{l}\text { vident-īă } \\
\text { vident-ǐŭm } \\
\text { vident-ībǔs } \\
\text { vident-īă } \\
\text { vident-íbǔs } \\
\text { vident-īà }\end{array}$ \\
\hline
\end{tabular}

Charakterystyczną cechą paradygmatów formalnych leksemów należących do deklinacji III jest pojawiająca się w wielu wypadkach alternacja formalna w obrębie tematu. W ramach tej alternacji alternant nom. / voc. sg. (w przypadku neutrów nom. /acc. /voc. sg.) przeciwstawia się alternantowi tematycznemu wszystkich pozostałych form fleksyjnych, np.: homo-/homin-, pater-/patr-, corpus-/corpor-, nomen-/nomin-, itp. Alternacja ta dotyczy zarówno elementów wokalicznych (samogłosek) jak i konsonantycznych (spółgłosek). Jej geneza ma charakter zróżnicowany. W jednych przypadkach stanowi ona wynik zachowania odziedziczonych ze wspólnoty indoeuropejskiej, nieumotywowanych fonetycznie alternacji o charakterze morfologicznym, w innych wynik określonych procesów fonetycznych, zaszłych już w toku samodzielnego rozwoju łaciny.

I. Alternacje wynikające z zachowania odziedziczonych ze wspólnoty indoeuropejskiej alternacji o charakterze morfologicznym mogły przyjmować następujące formy:

1. apofonia wokaliczna (przegłos) o postaci: stopień pełny - $e$ - / stopień pełny - osufiksu:

$\rightarrow$ genuss (dawn. genos) / gener-is,

$\rightarrow$ vetus (dawn. vetos) / veter $r$-is,

2. apofonia wokaliczna (przegłos) o postaci: stopień pełny -e-/ stopień redukcji sufiksu:

$\rightarrow$ pater/patr-is,

$\rightarrow$ fraterlfratr-is, 
3. heterokliza, wynikająca $\mathrm{z}$ wymiany (oboczności) alternujacych ze sobą sufiksów $-r-1-n-$ :

- iter/iten-is (poźniej: itin-is, jeszcze później, per analogiam do postaci nom. sg.: itineris);

- iecur/iecin-is (później, per analogiam do postaci nom. sg.: iecinor-is, iecor-is);

$\rightarrow$ femurlfemin-is (później, per analogiam do postaci nom. sg.: femor-is).

Alternacje te nie były umotywowane fonetycznie, lecz miały charakter morfologiczny (tzn. pełniły funkcję morfologiczną), stanowiąc wraz z końcówkami fleksyjnymi formalny współwykładnik kategorii przypadka.

II. Aternacje wynikające $\mathrm{z}$ procesów fonetycznych zaszłych $\mathrm{w}$ toku rozwoju historycznego łaciny mogły prowadzić do następujących zmian:

1. Zwężenie artykulacji krótkich samogłosek wskutek zmiany (w ramach fleksji) któregoś z takich czynników jak:

a. relatywna pozycja w obrębie wyrazu (nagłos, wygłos, śródgłos);

b. relatywna pozycja względem akcentu (pozycja przedakcentowa, akcentowa, poakcentowa);

c. stopień otwartości otwartości sylaby, w której się znajdują (sylaba otwarta, sylaba zamknięta):

artifëx, artifïcis; capüt, capitis; nomën, nominis.

2. Rozszerzenie artykulacji krótkich samogłosek przed /r/: corpuss, corporis; cinis, cineris.

3. Skrócenie samogłoski w wygłosie zamkniętym inną spółgłoską niż /s/: oratōr, oratōris; animăl, animālis.

4. Przekształcenie się/s/ w/r/ (tzw. rotacyzm) w pozycji interwokalicznej (międzysamogłoskowej): mos, moris; funus, funeris, corpus, corporis.

Ponieważ istniały w łacinie także wyrazy zakończone w nom. sg. na „właściwe” (tj. niepochodzące $\mathrm{z}$ rotacyzmu) - $r$, np.: amator, genitor, itp., to analogicznie w paradygmatach niektórych leksemów o temacie zakończonym na /-s/ pojawiło się /r/ zamiast /s/ również $\mathrm{w}$ nom. sg., chociaż nie ma tam warunków fonetycznych do zajścia rotacyzmu; stało się tak głównie w przypadku wyrazów mających w nom. sg. więcej niż jedną sylabę wskutek tendencji do ujednolicenia (wyrównania) tematu w ramach paradygmatu: honor, honoris (por. honestus); arbor , arboris (por. arbustus).

5. Zanik wygłosowego $/ \mathrm{n} /$ po długiej samogłosce, np.: homō $(n)$, hominis; leō(n), leōnis.

6. Skrócenie długich spógłosek (tzw. uproszczenie geminat) w wygłosie wyrazu: $\mathrm{np.:}$ as $(s)$, assis; mel(l), mellis.

7. Ubezdźwięcznienie /g/przed końcówkowym /s/, np.: rex (z reg-s), regis.

8. Zanik wygłosowych spółgłosek /t/ i /d/ po innych spółgłoskach (uproszczenie wygłosowych grup spółgłoskowych), np.: lac (t), lactis; cor $(d)$, cord-is.

9. Zanik /n/ i zwartych zębowych /t/, /d/ przed wygłosowym /s/ pochodzącym $\mathrm{z}$ końcówki, np.: sangui $(n) s$, sanguinis; $\operatorname{virtu}(t) s$, virtutis; palu $(d) s$, paludis. 
Pewne problemy może rodzić kwestia podziału na temat i końcówkę niektórych formacji nom. sg. zakończonych na /-s/, takich jak np.: virtus, pes, miles. Ze względu na to, że z punktu widzenia opisowego $w$ deklinacji tej z jednej strony trzeba przyjąć istnienie zróżnicowanych alternacji tematycznych, $z$ drugiej zaś istnienie dla nom. sg. takich końcówek jak -s i - $\emptyset$ (por. np.: pax, pacis; orator, oratoris), formy typu: virtus, pes, miles itp. teoretycznie podzielić można na temat i końcówkę dwojako:

1. virtus- $\emptyset$, virtut-is

pes- $\emptyset$, ped-is

miles- $\emptyset$, milit-is

wyodrębniając altenanty tematyczne odpowiednio: virtus-/virtut-, pes-/ped-, miles-/milit-.

2. virtu-s, virtut-is

pe-s, ped-is

mile-s, milit-is

wyodrębniając alternanty tematyczne odpowiednio: virtu-/virtut-, pe-/ped-, mile-/milit-.

Historycznie formy nom. sg. tych wyrazów ukształtowały się w ten sposób, że zwarty zębowy wygłos tematu (/-t/, /-d/) pierwotnie zasymilował (upodobnił) się do historycznej końcówki nom. sg. /-s/, co dało podwójne (długie)/-ss/, a następnie to podwójne (długie) /-ss/ uprościło (skróciło) się do pojedynczego (krótkiego) /-s/:

$\rightarrow{ }^{*}$ virtut-s $\rightarrow$ *virtus-s $\rightarrow$ virtus,

- *ped-s $\rightarrow$ *pes-s $\rightarrow$ pes.

A zatem w końcowym /-s/, znajdującym się w tych formach w klasycznej łacinie, zawiera się zarówno historyczne zakończenie tematu $(/-t /, /-d /)$, jak i historyczna końcówka (/-s/) - w przeciwieństwie do formacji rodzaju nijakiego typu genus, corpus, w których końcowe /-s/ stanowi (ulegające rotacyzmowi w pozostałych formach) zakończenie tematu przyłączającego końcówkę -ø (corpus-ø, corpor-is).

W niniejszym opracowaniu przyjęto konwencję traktowania każdego wygłosowego /-s/ po samogłosce w nom. sg. jako zakończenie tematu, jeśli dany leksem cechuje się alternacją tematyczną. Tym samym alternant $\mathrm{z} /$-s/ ma charakter alternantu morfonologicznego, tj. pojawiającego się przed końcówką -ø.

Uwagi:

Rzeczownik bos, bovis 'wół' w gen. pl. ma formę boum, w dat. abl. pl. bobus lub bubus.

Imię Iuppiter ma fleksję supletywną: Iuppiter, Iovis, Iovi, Iovem, Iove, Iuppiter.

Rzeczownik requies, requietis 'spokój' obok regularnych form acc. i abl. sg.: requietem, requiete może także tworzyć formy ze skróconym tematem: requiem, requie.

Rzeczownik vas, vasis (neutr.) 'naczynie' w pl. przyjmuje końcówki II deklinacji, a więc: vasa, vasorum, vasis.

Rzeczownik ignis, -is 'ogień' w pewnych zwrotach w abl. sg. przyjmuje końcówkę $-i$, np.: ferro ignique 'ogniem i mieczem', aqua et igni interdicere 'wykluczyć ze wspólnoty ognia i wody' (= skazać na banicję). 
Rzeczowniki należące do klasy pluralia tantum to m.in.: cervices, -um 'kark', fides, -ium 'lutnia', moenia, -ium 'mury', viscera, -um 'wnętrzności'.

Niektóre rzeczowniki cechują się zróżnicowaniem funkcji semantycznej w zależności od wartości kategorii liczby, np.:

- sg. aedis, -is 'świątynia'

pl. aedes, -ium 'świątynie; dom mieszkalny';

- sg. finis, -is 'koniec, granica'

pl. fines, -ium 'kraj, obszar';

- sg. pars, -rtis 'część'

- sg. ops, -pis 'pomoc'

pl. partes, -ium 'części; rola aktorska; partia polityczna'; pl. opes, -um 'bogactwo, majątek'.

Rzeczowniki będące nazwami miast i mniejszych wysp dla wyrażenia funkcji lokatywnej przybierają końcówkę równą abl., np. Karthagine ('w Kartaginie').

Poszczególne wartości kategorii rodzaju rzeczowników III deklinacji nie są związane z określonymi końcówkami nom. sg.; tym samym rodzaj gramatyczny rzeczowników tej deklinacji nie jest determinowany ich cechami fleksyjnymi, pozostając cechą leskykalną.

\subsection{DEKLINACJA IV}

Deklinacja ta obejmuje rzeczowniki, których temat historycznie zakończony był na sonant /-u/. Rzeczowniki te historycznie tworzyły formy fleksyjne według wzoru III deklinacji (por. greka). Wytworzenie odrębnego wzoru paradygmatu dla wszystkich rzeczowników tej grupy (z wyjątkiem rzeczowników sus 'wieprz' i grus 'żuraw') stanowi innowację łacińską.

Końcówki deklinacyjne:

sg. pl.,

\begin{tabular}{|c|c|c|}
\hline nom. & $-\bar{u} s,-\bar{u}$ & $-\bar{u} s,-\bar{u} a \grave{a}$ \\
\hline & $-\overline{u s}$ & -ŭŭm (-ǔm), \\
\hline t. & $-\bar{u} \bar{i},-\bar{u}$ & -ibŭs/-übūs, \\
\hline & $\begin{array}{l}-\bar{u} m,-\bar{u}- \\
-\bar{u}\end{array}$ & $\begin{array}{l}\bar{u} s,-\check{u} \bar{a}, \\
-\grave{b} b \check{u} s /-\check{u} b \check{u} s,\end{array}$ \\
\hline voc. & $-\breve{u} s,-\bar{u}$ & $-\bar{u} s,-\bar{u} \bar{a}$. \\
\hline
\end{tabular}

Końcówki -ŭm i -ŭŭm (-ŭm) zawierają etymologicznie krótkie samogłoski; zob. jednak uwagi dot. wygłosowego /m/ (wyżej, s. 71-73).

Końcówki: nom., acc., voc. i dat. sg. -ū oraz nom., acc. i voc. pl. -ŭă przyjmują rzeczowniki rodzaju nijakiego.

Końcówki alternatywne w stosunku do nich przyjmują rzeczowniki rodzaju męskiego oraz kilka rzeczowników rodzaju żeńskiego, którymi są: domus, manus, porticus, tribus, nurus, socrus, anus, quercus, acus, a także plurale tantum Idus, -uum.

Końcówka nom., acc. i voc. sg. -ū rzeczowników rodzaju nijakiego może wystąpić także z krótkim iloczasem, tj. - $\check{u}$.

Końcówki dat. i abl. pl. -übǔs przyjmują rzeczowniki: artus, -us 'człon', arcus, -us 'łuk', partus, -us 'poród', tribus, -us 'dzielnica', lacus, -us 'jezioro', quercus, -us 'dąb' i specus, -us 'jaskinia'. 
Rzeczowniki: portus, -us 'port' i veru, -us 'ostrze' w dat. i abl. pl. mogą przyjmować zarówno końcówkę -ĭbŭs, jak i -ŭbǔs; dla tych leksemów będą to zatem końcówki równoległe.

W gen. pl., obok końcówki -ŭŭm, rzeczowniki tej deklinacji mogą również przyjmować równoległą (lecz rzadziej występującą) końcówkę -ŭm, np.: man-ŭm 'rąk', pass-ǔm 'kroków' itp.

Przykładowe paradygmaty rzeczowników

\begin{tabular}{|c|c|c|c|}
\hline & exercitus, -us 'wojsko' & arcus, -us 'luk' & genu, -us 'kolano' \\
\hline & masculinum & masculinum & neutrum \\
\hline & singularis & singularis & singularis \\
\hline $\begin{array}{l}\text { nom. } \\
\text { gen. } \\
\text { dat. } \\
\text { acc. } \\
\text { abl. } \\
\text { voc. }\end{array}$ & $\begin{array}{l}\text { exercit-ǔs } \\
\text { exercit-ūs } \\
\text { exercit-ǔì } \\
\text { exercit-ŭm } \\
\text { exercit-ū } \\
\text { exercit-ǔs }\end{array}$ & $\begin{array}{l}\operatorname{arc-ùs} \\
\operatorname{arc}-u ̄ s \\
\operatorname{arc-ūì~} \\
\operatorname{arc-ŭm} \\
\operatorname{arc-ū~} \\
\operatorname{arc-ùs}\end{array}$ & $\begin{array}{l}\text { gen-ù } \\
\text { gen ùs } \\
\text { gen-ū } \\
\text { gen-ū } \\
\text { gen-ū } \\
\text { gen-ù }\end{array}$ \\
\hline & pluralis & pluralis & pluralis \\
\hline $\begin{array}{l}\text { nom. } \\
\text { gen. } \\
\text { dat. } \\
\text { acc. } \\
\text { abl. } \\
\text { voc. }\end{array}$ & $\begin{array}{l}\text { exercit-ūs } \\
\text { exercit-ŭŭm (-ŭm) } \\
\text { exercit-ībūs } \\
\text { exercit-ūs } \\
\text { exercit-ībūs } \\
\text { exercit-ūs }\end{array}$ & $\begin{array}{l}\text { arc-ūs } \\
\operatorname{arc-ŭŭm~(-ŭm)~} \\
\text { arc-ŭbŭs } \\
\text { arc-ūs } \\
\text { arc-ŭbŭs } \\
\text { arc-ūs }\end{array}$ & $\begin{array}{l}\text { gen-ǔă } \\
\text { gen-ǔŭm (-ǔm) } \\
\text { gen-ibŭs } \\
\text { gen-ŭă } \\
\text { gen-íbŭs } \\
\text { gen-ǔă }\end{array}$ \\
\hline
\end{tabular}

Ze względu na identyczność brzmienia końcówki nom. sg. -ǔs w tej deklinacji z końcówką nom. sg. II deklinacji, zdarzają się przypadki mieszania obu tych wzorów paradygmatu. Zazwyczaj ogranicza się to do używania w gen. sg. znacznej liczby leksemów IV deklinacji, obok końcówki -ūs, także końcówki II deklinacji -i, np.: apectus i aspecti, colus i coli, cupressus i cupressi, pinus i pini, senatus i senati, exercitus i exerciti, portus i porti itp. W niektórych wypadkach pomieszanie to sięga jednak również innych przypadków, np. (u Wergiliusza) nom. pl. lauri. Najbardziej charakterystycznym przykładem tego mieszania jest paradygmat formalny leksemu domus 'dom', który historycznie należy do II deklinacji:

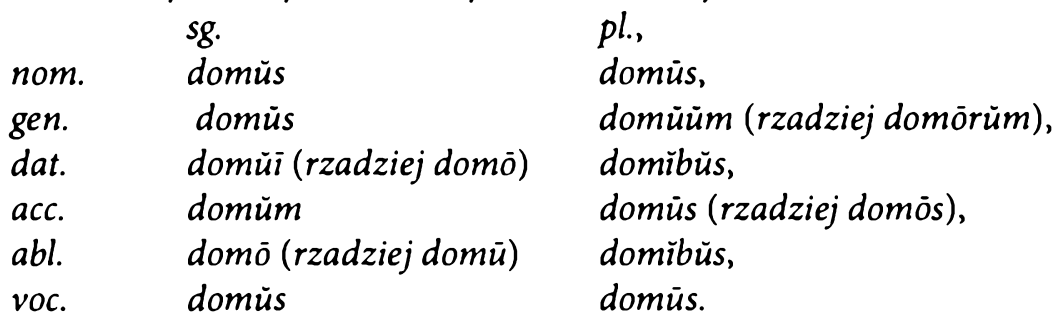

Formy: domi używa się zwykle w funkcji lokatywnej 'w domu', podobnie jak: domum 'do domu', domo ' $\mathrm{z}$ domu'. 


\subsection{DEKLINACJA V}

Deklinacja ta również stanowi innowację łacińską. Należy do niej niewielka grupa rzeczowników, których temat historycznie zakończony był na -ei (np. res) lub -eu (np. dies) i które również należały do III deklinacji (por. greka).

Końcówki deklinacyjne:

$\begin{array}{lll} & s g . & \text { pl., } \\ \text { nom. } & -\bar{e} s & -\bar{e} s, \\ \text { gen. } & -\bar{e} \bar{i},-\bar{e} \bar{i} & -\overline{e r} u m, \\ \text { dat. } & -\bar{e} \bar{l},-\bar{e} \bar{i} & -\bar{e} b u \bar{s}, \\ \text { acc. } & -\bar{e} m & -\bar{e} s, \\ \text { abl. } & -\bar{e} & -\bar{e} b u ̈ s, \\ \text { voc. } & -\bar{e} s & -\bar{e} s .\end{array}$

Końcówki -èm i -ērŭm zawierają etymologicznie krótkie samogłoski; zob. jednak uwagi dot. wygłosowego /m/ (wyżej, s. 71-73)

Końcówki gen. i dat. sg. -ēē przyłączają najczęściej rzeczowniki, których temat zakończony jest na samogłoskę, np.: (od diēs) diēī, (od faciēs) faciēî. Końcówkę gen. i dat. sg. -ēi przyłączają najczęściej rzeczowniki, których temat zakończony jest na spółgłoskę, np.: (od rēs) rēî, (od spēs) spēi.

Przykładowe paradygmaty rzeczowników:

\begin{tabular}{|c|c|c|c|c|c|}
\hline & \multicolumn{2}{|c|}{ rzeczownik dies, -ei 'dzień' } & \multicolumn{3}{|c|}{ rzeczownik res, -ei 'rzecz' } \\
\hline & singularis & pluralis & & singularis & pluralis \\
\hline nom. & di-ēs & di-ēs & nom. & r-ès & r-ès \\
\hline gen. & di-èì & di-ērŭm & gen. & r-ěì & r-ërŭm \\
\hline dat. & di-ēè & di-ēbŭs & dat. & r-ēi & r-èbŭs \\
\hline acc. & di-èm & di-ès & acc. & r-èm & r-ès \\
\hline abl. & di-è & di-ēbǔs & abl. & $r-\bar{e}$ & r-èbŭs \\
\hline voc. & di-ès & di-ēs & voc. & r-ēs & $\mathrm{r}$-ēs \\
\hline
\end{tabular}

Pełny paradygmat formalny i funkcjonalny, ukształtowany według tego wzoru, posiadają właściwie tylko dwa leksemy: res i dies. Pozostałe (np.: luxuries, canities, materies, mollities i in.) stanowią singularia tantum. Jedynie acies, effigies, spes i species tworzą jeszcze formy nom., acc. i voc. pl. Liczne spośród nich posiadają swoje odpowiedniki w deklinacji I (luxuria, materia, mollitia i in.).

Wszystkie rzeczowniki tej deklinacji mają rodzaj żeński, z wyjątkiem dies i meridies, które mają rodzaj męski. Jednak dies ma również rodzaj żeński, jeśli:

- oznacza konkretny termin, datę, np. Dies statuta ad profectionem venit „Nadszedł dzień wyznaczony do wymarszu";

- wyraża ogólne pojęcie czasu, np. Diem perexiguam alicui dare „Wyznaczyć komuś bardzo krótki okres czasu". 


\subsection{RZECZOWNIKI POCHODZENIA GRECKIEGO}

Rzeczowniki pochodzenia greckiego (pospolite i nazwy własne) asymilowane były do wzorów paradygmatów łacińskich I, II i III deklinacji; w epoce augustowskiej silna była jednak tendencja do zachowywania greckich końcówek. W efekcie rzeczowniki należące do różnych greckich typów fleksyjnych cechują się $w$ łacinie pewnymi swoistymi cechami odmiany, polegającymi $z$ jednej strony na zachowaniu pewnych końcówek greckich, $\mathrm{z}$ drugiej zaś na braku pełnej stabilizacji w ramach jednego paradygmatu łacińskiego (jednej deklinacji), co doprowadziło z kolei do występowania różnych form obocznych.

Deklinacja I

nom. Eurydic-ēe

gen. Eurydic-ēs (-ae)

dat. Eurydic-ae

acc. Eurydic-èn (-am)

abl. Eurydic-ēe $(-a)$

voc. Eurydic- $\bar{e}(-a)$ nom. Aenē-ās

gen. Aenè-ae

dat. Aenē-ae

acc. Aenè-än (-am)

abl. Aenē-à

voc. Aenè- $\bar{a}$ nom. Orest-ēs, gen. Orest-ae (-is) $(-i)$, dat. Orest-ae $(-i)$, acc. Orest-èn (-em), $a b l$. Orest $-\bar{e}(-\bar{a})$, voc. Orest $-\bar{e}(-a)$.

Według powyższych paradygmatow odmieniają się również odpowiednio inne rzeczowniki, np.: według Eurydice także Danāē, Niobe; według Orestes także Anchises, Perses $\mathrm{i}$ in. Niektóre rzeczowniki uległy pełnej latynizacji, np. Hecuba.

Deklinacja II

nom. Promethē-ŭs (-theus) Del-ŭs (-ŏs)

Epir-üm (-ös)

gen. Promethē-i (-ŏs)

Del-ī

Del-ō

Epir-ī

$\operatorname{Ili-ŭm(-ön),}$

dat. Promethè $-\bar{o}(-\bar{\imath})$

acc. Promethẽ $-\check{u} m(-\check{a})$

abl. Promethè-o

Del-ŭm (-ōn)

Epir-ō

Ili $\bar{i}-\bar{i}$,

voc. Promethè- $\bar{u}(-t h e u)$

Del-ö

Epir-üm (-ön)

Ilī-ō,

Del-ë

Epir-ō

Ilì-ūm (-ön),

Ilì-ō,

Epir-üm (-ös)

Ilì-ŭm (-ön).

Według powyższych paradygmatow odmieniają się również odpowiednio inne rzeczowniki, np.: według Prometheus takze Orpheus, Peleus, Idomeneus, Theseus, według Delus/Delos także Pharus/Pharos i in.

Rzeczowniki tworzące liczbę mnogą przyłączają końcówki łacińskie, przy czym w gen. pl. może wystąpić także końcówka grecka -ōn. Dotyczy to zwłaszcza tytułów dzieł literackich podawanych w genetiwie zależnym od (domyślnego) libri, np.: Georgicōn, Bucolicōn, Satiricōn (libri) „(księgi) Georgików, Bukolików, Satyryków”.

Deklinacja III

nom. Socrät-ès

gen. Socrăt-is $(-\bar{\imath})$

dat. Socrăt-i
Hectŏr

Hectör-is

Hectör-i
Didō

Didūs (-donis)

Didō (-doni)
Paris, Parìd-òs, Parìd-ī, 


\begin{tabular}{|c|c|c|c|}
\hline c. Socrăt-ĕm (-ēn) & Hectŏr-ëm $(-\check{a})$ & Didō (-don) (-donem) & Parin \\
\hline abl. Socrät-ē & Hectōr-ē & Didō (-done) & Parid- \\
\hline voc. Socrät-ès $(-\bar{e})$ & Hectör & Dido & Par-i, \\
\hline $\begin{array}{l}\text { nom. poès-ìs } \\
\text { gen. poès-is }\end{array}$ & $\begin{array}{l}\text { sg. nom. poëmă } \\
\text { gen. poëmät-iss }\end{array}$ & \multirow{3}{*}{\multicolumn{2}{|c|}{ 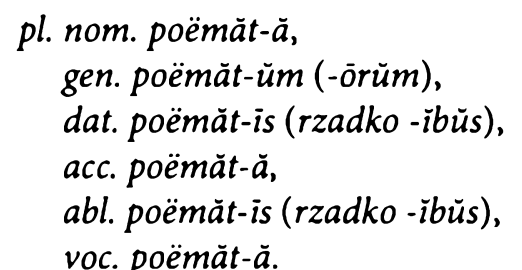 }} \\
\hline $\begin{array}{l}\text { dat. poès-ì } \\
\text { acc. poès-in }\end{array}$ & $\begin{array}{l}\text { dat. poëmăt-i } \\
\text { acc poëmă }\end{array}$ & & \\
\hline $\begin{array}{l}\text { bl. poès-i } i \\
\text { c. poès-is }\end{array}$ & $\begin{array}{l}\text { abl. poëmăt-è } \\
\text { voc. poëmă }\end{array}$ & & \\
\hline
\end{tabular}

Według powyższych paradygmatow odmieniają się również odpowiednio inne rzeczowniki, np.: według Socrates także Aristides, Achilles, Hercules; według Dido również Calypso, Clio, Sappho; według poema także drama, epigramma i in. Niektóre imiona własne, np. Achilles, Hercules, mogą także odmieniać się według II deklinacji (gen. sg. Achilli, Herculi).

W gen. pl. może wystąpić także końcówka grecka -ōn. Dotyczy to zwłaszcza tytułów dzieł literackich podawanych w genetiwie zależnym od (domyślnego) libri, np. Metamorphoseōn (libri) „(księgi) Metamorfoz”. W acc. pl. rzeczowników rodzaju męskiego i żeńskiego, obok końcówki -es, często wystęuje również końcówka -as, np. Cyclopes/Cyclopas.

Reczowniki: aër, aëris 'powietrze', aether, aetheris 'eter', w gen. sg., obok regularnej końcówki -ǐs, mogą też przybierać (grecką) końcówkę -õs, a więc: aëris lub aëros, aetheris lub aetheros; w acc. sg. mają grecką końcówkę -ă: aëra, aethera. Również inne rzeczowniki mogą $\mathrm{w}$ gen. sg. przybierać końcówki -is lub -os, a w acc. sg. -em lub - $a$, np.: crater, gen. sg. cratēris/cratēros, acc. sg. cratërem/cratēra.

Imiona własne o temacie zakończonym na -as/-ant-, np.: Atlas, Atlantis, mają voc. sg. bez wygłosowego $-s, \mathrm{tj}$. Atla.

Imiona własne, mające $\mathrm{w}$ nom. sg. końcówkę -is, np. Charybdis, mają voc. sg. bez wygłosowego $-\mathrm{s}$, tj.: Charybdi.

Imię Oedipus, Oedipodis w acc. sg. ma formę: Oedipum.

\subsection{WYBRANA LITERATURA}

Bakkum (1994), Beltrán (1999, s. 43-92), Brosman (2001), Buzássyová (2005), Dickey (2000a, 2000b), Dressler (2002), González (1999, 2000-2001, 2002), Greenough, Kittredge, Howard, D'Ooge (1903 (1983), s. 16-54), Janson (1971), Kircher-Durand (1996), Lazzeroni (1997-1999), Marchese (1979), Morani (1985-1986), Porzio Gernia (1986), Wikarjak (1978, s. 16-30) 


\section{5. \\ Paradygmatyka fleksyjna zaimków}

\subsection{OGÓLNE WŁAŚCIWOŚCI PARADYGMATYKI ZAIMKOWEJ}

Paradygmaty formalne zaimków odbiegają nieco od wzorów paradygmatów rzeczownikowo-przymiotnikowych. Niektóre z zaimków jako jednostki leksykalne wykazują brak nacechowania pod względem kategorii rodzaju (i liczby), inne charakteryzują się podwójnym, tj. rzeczownikowym i przymiotnikowym, paradygmatem, a w ramach tego pierwszego zróżnicowaniem postaci stojących w opozycji formalno-funkcyjnej związanej z osobowością/nieosobowością desygnatu. Ponadto paradygmaty zaimkowe często charakteryzują się fuzyjnością ( $\mathrm{tj}$. brakiem wyraźnej granicy między tematem a koncówką), supletywizmem i postfiksacją. Osobliwością wielu z nich jest końcówka gen. sg. -ius, która nie współtworzy żadnego z paradygmatów rzeczownikowo-przymiotnikowych.

\subsection{ZAIMKI OSOBOWE}

Zaimki osobowe mają gramatyczny status rzeczowników. Jako jednostki leksykalne wykazują brak nacechowania pod względem kategorii rodzaju, jednak reprezentujące je wyrazy gramatyczne mogą kontekstowo przyjmować wartość masculinum bądź femininum, ujawnianą przez ich przymiotnikowe (przydawkowe) podrzędniki. Podstawą wewnętrznego podziału zaimków osobowych jest reprezentowana przez nie wartość klasyfikującej kategorii osoby (stąd wyodrębnienie zaimków 1. os. i zaimków 2. os.), a także wartość kategorii liczby z uwagi na eliptyczny (a nie matematyczny - zob. niżej 10.2.) charakter liczby mnogiej wyrazów tej klasy i formalną ich odrębność względem form singularis (stąd wyodrębnienie zaimków (1. i 2. os.) liczby pojedynczej oraz zaimków (1. i 2. os.) liczby mnogiej). W związku z tym gramatyczna kategoria liczby ma dla zaimków osobowych również status kategorii klasyfikującej (selektywnej); są to więc (odpowiednio) singularia bądź pluralia tantum. Kategoria przypadka zachowuje jednak w odniesieniu do nich charakter fleksyjny. Na system zaimków osobowych składają się zatem w lacinie cztery jednostki leksykalne, a mianowicie: 
- ego 'ja' - 1. os. sg.

$\rightarrow$ tu 'ty' - 2. os. sg.

$\rightarrow$ nos 'my' - 1. os. pl.

$\rightarrow$ vos 'wy' - 2. os. pl.

W związku z tym, co napisano wyżej, paradygmaty formalne tych leksemów składają się tylko $\mathrm{z}$ form fleksyjnych zróżnicowanych formalnie w ramach kategorii przypadka i homofonicznych w ramach kategorii rodzaju. Znajdujemy w nich jednak również wariancję form fleksyjnych reprezentujących te same flektemy. Dodatkowo paradygmaty te cechuje supletywizm i silna fuzyjność (brak ostrej granicy między tematem a końcówką). Przedstawia je poniższa tabela:

\begin{tabular}{|c|c|c|c|c|}
\hline & $\begin{array}{l}\text { 1. os. sg. masc./ } \\
\text { fem. }\end{array}$ & $\begin{array}{c}\text { 2. os. sg. } \\
\text { masc./fem. }\end{array}$ & $\begin{array}{c}\text { 1. os. pl. } \\
\text { masc./fem. }\end{array}$ & $\begin{array}{c}\text { 2. os. pl. } \\
\text { masc./fem. }\end{array}$ \\
\hline $\begin{array}{l}\text { nom./voc. } \\
\text { gen. } \\
\text { dat. } \\
\text { acc. } \\
\text { abl. }\end{array}$ & $\begin{array}{l}\text { ěgō/ěgǒ } \\
\text { měi } \\
\text { mìhi/mìhì/mi } \\
\text { mē } \\
\text { mē }\end{array}$ & $\begin{array}{l}\text { tū } \\
\text { tŭi } \\
\text { tĭbìitibibi } \\
\text { tẽ } \\
\text { tē }\end{array}$ & $\begin{array}{l}\text { nōs } \\
\text { nostrī/nostrŭm } \\
\text { nōbis } \\
\text { nōs } \\
\text { nōbis }\end{array}$ & $\begin{array}{l}\text { vōs } \\
\text { vestrī/vestrŭm } \\
\text { vōbīs } \\
\text { vōs } \\
\text { vōbīs }\end{array}$ \\
\hline
\end{tabular}

Wariancja form genetiwu zaimków 1. i 2. os. pl. (nostrï/nostrŭm, vestrï/vestrüm) obciążona jest funkcjonalnie (zob. niżej 10.2.). Alternacja występująca w ramach innych flektemów ma charakter wyłącznie formalny; tym samym alternanty te stanowią formy fleksyjne oboczne.

Formy ablatiwu wszystkich zaimków mogą z przyimkiem cum tworzyć jeden wyraz tekstowy występując $\mathrm{w}$ prepozycji do przyimka (mecum, tecum, nobiscum, vobiscum).

Poszczególne formy fleksyjne zaimków osobowych mogą też przyjmować postać wzmocnioną (emfatyczną); wzmocnienie to może dokonać się poprzez przyłączenie

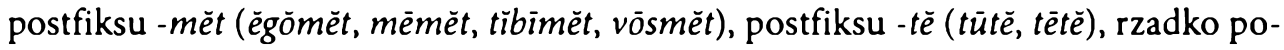
przez reduplikację (mēmē).

\subsection{ZAIMKI DZIERŻAWCZE}

Zaimki dzierżawcze mają gramatyczny status przymiotników, których formy rodzaju męskiego i nijakiego podlegają fleksji według wzoru paradygmatu formalnego II deklinacji rzeczownikowo-przymiotnikowej (zob. wyżej 4.4.), natomiast formy rodzaju żeńskiego według wzoru paradygmatu I deklinacji (zob. wyżej 4.3.). Zaimki te tworzą system, na który składają się:

1. Zaimki dzierżawczo-osobowe:

- meus, mea, meum 'mój, moja, moje', sygnalizujący związek desygnatu swego rzeczownikowego nadrzędnika z osobą nadawcy komunikatu; 
- tuus, tua, tuum 'twój, twoja, twoje', sygnalizujący związek desygnatu swego rzeczownikowego nadrzędnika z osobą odbiorcy komunikatu;

- noster, nostra, nostrum 'nasz, nasza, nasze', sygnalizujący związek desygnatu swego rzeczownikowego nadrzędnika ze zbiorem osób, do którego należy nadawca komunikatu albo nadawca i odbiorca;

- vester, vestra, vestrum 'wasz, wasza, wasze', sygnalizujący związek desygnatu swego rzeczownikowego nadrzędnika ze zbiorem osób, do którego należy odbiorca komunikatu (bez nadawcy).

2. Zaimek dzierżawczo-zwrotny:

suus, sua, suum 'swój, swoja, swoje; jego, jej; ich', sygnalizujący związek swego rzeczownikowego nadrzędnika z osobą inną niż nadawca i odbiorca komunikatu, albo z grupą osób, do której nie należy ani nadawca, ani odbiorca.

3. Zaimek dzierżawczo-pytajny:

cuius, cuia, cuium 'czyj, czyja, czyje', sygnalizujący niewiedzę nadawcy co do związku desygnatu jego rzeczownikowego nadrzędnika $z$ uczestnikami aktu mowy lub innymi osobami.

Paradygmat formalny zaimka noster, -ra, -rum cechuje się alternancją tematyczną noster-/nostr-, przy czym alternant noster- występuje tylko w nom. / voc. sg. masc. (przed końcówką zerową).

Paradygmat formalny zaimka vester, -ra, -rum cechuje się alternancją tematyczną vester-/vestr-, przy czym alternant vester- występuje tylko w nom. / voc. sg. masc. (przed końcówką zerową).

Alternacja tematyczna występuje także w paradygmacie formalnym zaimka meus, $-a,-u m$, który w voc. sg. masc. przyjmuje postać mi.

Formy abl. sg. zaimków meus, tuus i suus mogą wystąpić w postaci wzmocnionej (emfatycznej) z przyłączonym postfiksem -ptẽ (meōptè, meāptē; tuōptè, tuāptē; suōptè, suāptē).

\subsection{ZAIMEK ZWROTNY}

Zaimek zwrotny ma gramatyczny status rzeczownika. Charakteryzuje się koreferencją $z$ wyrażeniem rzeczownikowym nacechowanym wartością 3. os., pełniącym funkcję gramatycznego podmiotu zdania, w związku z czym jego paradygnat funkcjonalny (i tym samym formalny) pozbawiony jest $w$ ramach kategorii przypadka wartości nominativus. Poza tym leksem ten jest nienacechowany co do kategorii liczby i rodzaju, jednak reprezentujące go wyrazy gramatyczne mogą (kontekstowo) przyjmować każdą $\mathrm{z}$ wartości obu tych kategorii, podlegając $w$ tym względzie funkcjonalnej akomodacji do wyrażenia podmiotowego, ujawnianej przez ich przymiotnikowe (przydawkowe) podrzędniki. Paradygmat formalny tego leksemu składa się zatem $\mathrm{z}$ form fleksyjnych zróżnicowanych formalnie $\mathrm{w}$ ramach kategorii przypadka i homofonicznych $w$ ramach kategorii liczby i rodzaju: 


\begin{tabular}{|l|l|}
\hline & \multicolumn{1}{|c|}{ sg./pl. } \\
& masc./fem./neutr. \\
\hline nom. & - \\
gen. & sǔi \\
dat. & sỉbi \\
acc. & sẽ \\
abl. & sē \\
\hline
\end{tabular}

$\mathrm{Z}$ przyimkiem cum forma ablatiwu tworzy jeden wyraz tekstowy, występując w prepozycji do przyimka (secum).

Wzmocnione (emfatyczne) formy tego zaimka tworzone są w odniesieniu do akuzatiwu i ablatiwu poprzez reduplikację (sēsē), a w odniesieniu do datiwu poprzez dodanie postfiksu -mět (sibimèt).

\subsection{ZAIMKI WSKAZUJĄCE}

Zaimki wskazujące, inaczej deiktyczne, mają gramatyczny status przymiotników, choć często pełnią również funkcje rzeczownikowe. Identyfikują bądź charakteryzują swe desygnaty lub desygnaty swych rzeczownikowych nadrzędników, określając relacje (prymarnie przestrzenne, sekundarnie czasowe, emocjonalne i in.), w jakich pozostają one $\mathrm{w}$ stosunku do uczestników aktu mowy. $\mathrm{W}$ łacinie zaimki te tworzą system złożony $\mathrm{z}$ trzech leksemów, $\mathrm{z}$ których każdy wyraża inny typ tych relacji:

- hic, haec, hoc - 'ten, ta, to' (o czymś bliskim nadawcy);

- iste, ista, istud - 'ten, ta to' (o czymś bliskim odbiorcy);

- ille, illa, illud - 'tamten, tamta, tamto' (o czymś odległym od nadawcy i odbiorcy).

Paradygmaty formalne tych zaimków różnią się od paradygmatów rzeczownikowo-przymiotnikowych; przedstawia je poniższa tabela:

\begin{tabular}{|c|c|c|c|c|c|c|c|c|c|}
\hline & \multicolumn{3}{|c|}{ hic, haec, hoc } & \multicolumn{3}{|c|}{ iste, ista, istud } & \multicolumn{3}{|c|}{ ille, illa, illud } \\
\hline & \multicolumn{3}{|c|}{ singularis } & \multicolumn{3}{|c|}{ singularis } & \multicolumn{3}{|c|}{ singularis } \\
\hline & masc. & fem. & neutr. & masc. & fem. & neutr. & masc. & fem. & neutr. \\
\hline \multirow[t]{3}{*}{$\begin{array}{l}\text { nom. } \\
\text { gen. } \\
\text { dat. } \\
\text { acc. } \\
\text { abl. }\end{array}$} & $\begin{array}{l}\text { hìc } \\
\text { huiǔs } \\
\text { huīc } \\
\text { hunc } \\
\text { hōc } \\
\end{array}$ & $\begin{array}{l}\text { haec } \\
\text { huiǔs } \\
\text { huīc } \\
\text { hanc } \\
\text { hāc } \\
\end{array}$ & $\begin{array}{l}\text { hŏc } \\
\text { huiǔs } \\
\text { huīc } \\
\text { hơc } \\
\text { hòc }\end{array}$ & $\begin{array}{l}\text { istẽ } \\
\text { istiūs } \\
\text { istī } \\
\text { istǔm } \\
\text { istō } \\
\end{array}$ & \begin{tabular}{|l} 
istă \\
istiūs \\
istī \\
istăm \\
istā \\
\end{tabular} & \begin{tabular}{|l} 
istūd \\
istiūs \\
istī \\
istūd \\
istō \\
\end{tabular} & \begin{tabular}{|l} 
illè \\
illiūs \\
illì \\
illùm \\
illō \\
\end{tabular} & \begin{tabular}{|l|} 
illă \\
illiūs \\
illì \\
illăm \\
illā \\
\end{tabular} & $\begin{array}{l}\text { illǔd } \\
\text { illiǔs } \\
\text { illī } \\
\text { illǔd } \\
\text { illō } \\
\end{array}$ \\
\hline & \multicolumn{3}{|c|}{ pluralis } & \multicolumn{3}{|c|}{ pluralis } & \multicolumn{3}{|c|}{ pluralis } \\
\hline & masc. & fem. & neutr. & masc. & fem. & neutr. & masc. & fem. & neutr. \\
\hline $\begin{array}{l}\text { nom. } \\
\text { gen. } \\
\text { dat. } \\
\text { acc. } \\
\text { abl. }\end{array}$ & \begin{tabular}{|l} 
hì \\
hōrǔm \\
hìs \\
hōs \\
hìs \\
\end{tabular} & \begin{tabular}{|l} 
hae \\
hārǔm \\
hīs \\
hās \\
hiss \\
\end{tabular} & \begin{tabular}{|l} 
haec \\
hōrǔm \\
hìs \\
haec \\
his \\
\end{tabular} & \begin{tabular}{|l|} 
istī \\
istōrŭm \\
istīs \\
istōs \\
istīs \\
\end{tabular} & \begin{tabular}{|l} 
istae \\
istārŭm \\
istīs \\
istās \\
istīs \\
\end{tabular} & \begin{tabular}{|l|} 
istā \\
istōrǔm \\
istīs \\
istă \\
istis \\
\end{tabular} & \begin{tabular}{|l} 
illī \\
illōrǔm \\
illīs \\
illōs \\
illīs \\
\end{tabular} & \begin{tabular}{|l} 
illae \\
illārǔm \\
illis \\
illās \\
illìs \\
\end{tabular} & \begin{tabular}{|l} 
illă \\
illōrǔm \\
illis \\
illă \\
illis \\
\end{tabular} \\
\hline
\end{tabular}


Formy hōc, hāc, huīc zachowały długość samogłosek, ponieważ następująca po nich wygłosowa spółgłoska - c stanowi zredukowaną (wskutek apokopy) postać dawnej partykuły wzmacniającej ce, która uległa aglutynacji z formą zaimkową (höc-ce; por. pol. tenże). Widoczna jest ona także w formach haec, hunc, hanc, a także hic i höc $(\leftarrow$ hŏcc $\leftarrow$ hŏcce $\leftarrow$ hŏdce $)$. W przypadku tych dwóch ostatnich refleksem historycznej obecności grupy spółgłoskowej w ich strukturze fonologicznej jest możliwość zajmowania przez nie miejsc przeznaczonych w schematach metrycznych dla sylab ciężkich (długich) ${ }^{1}$. W pełnej postaci partykuła ta współtworzyć może emfatyczne formy gen. sg. i dat. / abl. pl. zaimka hic, haec, hoc (huiusce, hisce), gdzie zyskuje status postfiksu. Widoczna jest również $w$ innych formach wyrazowych, np.: ecce, tunc, nunc, illic, sic. Okazjonalnie (zwłaszcza w tekstach Plauta) współtworzy też emfatyczne formy pozostałych zaimków wskazujących, najczęściej acc. sing. masc. i fem. (istunc, istanc, illunc, illanc).

\subsection{ZAIMKI OKREŚLAJĄCE}

Terminem tym tradyjnie określa się trzy zaimki zwierające historycznie ten sam pierwiastek:

- zaimek anaforyczny is, ea, id - 'ten / on, ta / ona, to / ono;

- zaimek identyfikujący idem, eadem, idem - 'ten sam, ta sama, to samo;

- zaimek intensyfikujący ipse, ipsa, ipsum - 'sam, sama, samo'.

Zaimki te mają gramatyczny status przymiotników, często jednak wypełniają pozycje rzeczownikowe. Ich paradygmaty formalne przedstawiają poniższe tabele:

\begin{tabular}{|c|c|c|c|c|c|c|}
\hline & \multicolumn{3}{|c|}{ is, ea, id } & \multicolumn{3}{|c|}{ ipse, ipsa, ipsum } \\
\hline & \multicolumn{3}{|c|}{ singularis } & \multicolumn{3}{|c|}{ singularis } \\
\hline & masc. & fem. & neutr. & masc. & fem. & neutr. \\
\hline \multirow[t]{3}{*}{$\begin{array}{l}\text { nom. } \\
\text { gen. } \\
\text { dat. } \\
\text { acc. } \\
\text { abl. } \\
\end{array}$} & \begin{tabular}{|l} 
ìs \\
eiǔs \\
eĩ/ei \\
eǔm \\
eō \\
\end{tabular} & \begin{tabular}{|l} 
eă \\
eiūs \\
eĩei \\
eăm \\
eã \\
\end{tabular} & \begin{tabular}{|l} 
id \\
eiūs \\
eì/ei \\
idd \\
eō \\
\end{tabular} & \begin{tabular}{|l} 
ipsẽ \\
ipsīũs \\
ipsī \\
ipsūm \\
ipsō \\
\end{tabular} & $\begin{array}{l}\text { ipsă } \\
\text { ipsīūs } \\
\text { ipsī } \\
\text { ipsăm } \\
\text { ipsā } \\
\end{array}$ & \begin{tabular}{|l|} 
ipsūm \\
ipsiuǔs \\
ipsī \\
ipsǔm \\
ipsō \\
\end{tabular} \\
\hline & \multicolumn{3}{|c|}{ pluralis } & \multicolumn{3}{|c|}{ pluralis } \\
\hline & masc. & fem. & neutr. & masc. & fem. & neutr. \\
\hline $\begin{array}{l}\text { nom. } \\
\text { gen. } \\
\text { dat. } \\
\text { acc. } \\
\text { abl. }\end{array}$ & $\begin{array}{l}\text { eī/iī/ì } \\
\text { eōrŭm } \\
\text { eīs/iìs/îs } \\
\text { eōs } \\
\text { eìs/iìs/îs }\end{array}$ & $\begin{array}{l}\text { eae } \\
\text { eārūm } \\
\text { eĩs/iīs/îs } \\
\text { eās } \\
\text { eĩs/iīs/îs }\end{array}$ & \begin{tabular}{|l} 
eă \\
eōrŭm \\
eīs/iìs/îs \\
eă \\
eīs/iīs/îs
\end{tabular} & $\begin{array}{l}\text { ipsī } \\
\text { ipsōrūm } \\
\text { ipsīs } \\
\text { ipsōs } \\
\text { ipsīs }\end{array}$ & $\begin{array}{l}\text { ipsae } \\
\text { ipsārūm } \\
\text { ipsīs } \\
\text { ipsās } \\
\text { ipsīs }\end{array}$ & $\begin{array}{l}\text { ipsă } \\
\text { ipsōrūm } \\
\text { ipsis } \\
\text { ipsă } \\
\text { ipsīs }\end{array}$ \\
\hline
\end{tabular}




\begin{tabular}{|c|c|c|c|}
\hline & \multicolumn{3}{|c|}{ idem, eadem, idem } \\
\hline & \multicolumn{3}{|c|}{ singularis } \\
\hline & masc. & fem. & neutr. \\
\hline \multirow[t]{3}{*}{$\begin{array}{l}\text { nom. } \\
\text { gen. } \\
\text { dat. } \\
\text { acc. } \\
\text { abl. }\end{array}$} & $\begin{array}{l}\text { idem } \\
\text { eiusdem } \\
\text { eidem } \\
\text { eundem } \\
\text { eōdem }\end{array}$ & $\begin{array}{l}\text { eàdem } \\
\text { eiusdem } \\
\text { eìdem } \\
\text { eandem } \\
\text { eādem }\end{array}$ & $\begin{array}{l}\text { idem } \\
\text { eiusdem } \\
\text { eidem } \\
\text { ìdem } \\
\text { eōdem }\end{array}$ \\
\hline & \multicolumn{3}{|c|}{ pluralis } \\
\hline & masc. & fem. & neutr. \\
\hline $\begin{array}{l}\text { nom. } \\
\text { gen. } \\
\text { dat. } \\
\text { acc. } \\
\text { abl. }\end{array}$ & $\begin{array}{l}\text { eīdem/iìdem /īdem } \\
\text { eōrundem } \\
\text { eisdem/iīsdem/īsdem } \\
\text { eōsdem } \\
\text { eissdem/iīsdem/īsdem }\end{array}$ & $\begin{array}{l}\text { eaedem } \\
\text { eārundem } \\
\text { eisdem/iīsdem/isdem } \\
\text { eāsdem } \\
\text { eīsdem/iissdem/isdem }\end{array}$ & $\begin{array}{l}\text { eădem } \\
\text { eōrundem } \\
\text { eìsdem/iīsdem/īsdem } \\
\text { eădem } \\
\text { eisdem/iissdem/isdem }\end{array}$ \\
\hline
\end{tabular}

Oprócz zaimka is, ea, id anaforyczny charakter mają także inne jeszcze zaimki przymiotnikowe, które cechują się jednak regularnymi paradygmatami rzeczownikowo-przymiotnikowymi deklinacji III, jak np. talis, tale 'taki, taka, takie', lub deklinacji I i II, jak np. tantus, tanta, tantum 'tak wielki/wielka/wielkie'. Wyjątek stanowi przymiotnikowy zaimek tot 'tylu, tyle', którego paradygmat funkcjonalny jest ograniczony pod względem kategorii liczby (jest to plurale tantum), a paradygmat formalny defektywny pod względem kategorii przypadka i rodzaju, w związku z czym charakteryzuje się on zerowym paradygmatem formalnym (tzn. wszystkie reprezentujące go formy fleksyjne są homofoniczne).

\subsection{ZAIMKI NIEOKREŚLONE}

Zaimki nieokreślone tworzą w lacinie rozbudowany system. W strukturze składniowej wypowiedzenia mogą pełnić zarówno funkcje rzeczownikowe, jak i przymiotnikowe (przydawkowe), przy czym część z nich wykazuje pewne zróżnicowanie postaci określonych form fleksyjnych (głównie nominatiwu i akuzatiwu liczby pojedynczej) w zależności od ich rzeczownikowego bądź przymiotnikowego (przydawkowego) użycia. Przyjmuje się w związku $\mathrm{z}$ tym istnienie rzeczownikowego i przymiotnikowego paradygmatu tych zaimków lub też ich dwu postaci: rzeczownikowej i przymiotnikowej. W ramach obu paradygmatów zaimki te cechują się fleksyjnym charakterem kategorii przypadka. Ich postać przymiotnikowa uwzględnia fleksyjnie także kategorię liczby i rodzaju, natomiast paradygmat rzeczownikowy tych zaimków ograniczony jest do singularis i obejmuje dwa warianty formalno-funkcyjne (stojące w opozycji funkcjonalnej ze względu na osobowość/nieosobowość ich desygnatu), z których jeden generalnie nacechowany jest rodzajem męskim, drugi nijakim. Często jednak również przymiotnikowe formy ulegają kontekstowej substantywizacji, wypełniając $w$ zdaniu pozycje rzeczownikowe. 
Pod względem słowotwórczym wyróżnić można zaimki synchronicznie niemotywowane (niepochodne), oraz zaimki motywowane (pochodne). Do tych pierwszych zaliczają się dwa zaimki:

1. quis, quid - 'ktoś, coś' (postać rzeczownikowa) qui, quae/qua, quod - 'jakiś, jakaś, jakieś' (postać przymiotnikowa) którego temat stanowi również bazę zaimka względnego i pytajnego

2. ullus, ulla, ullum - 'jakiś/żaden, jakaś/żadna, jakieś/żadne' który posiada tylko paradygmat przymiotnikowy, ale - jak wszystkie przymiotniki i inne przymiotnikowe zaimki - może podlegać kontekstowej substantywizacji.

Paradygmaty tych zaimków przedstawiają poniższe tabele:

\begin{tabular}{|c|c|c|c|c|c|c|c|c|}
\hline & \multicolumn{2}{|c|}{$\begin{array}{c}\text { quis, quid } \\
\text { (parad. rzeczownikowy) }\end{array}$} & \multicolumn{3}{|c|}{$\begin{array}{c}\text { qui, quae/qua, quod } \\
\text { (parad. przymiotnikowy) }\end{array}$} & \multicolumn{3}{|c|}{$\begin{array}{c}\text { ullus, ulla, ullum } \\
\text { (parad. przymiotnikowy) }\end{array}$} \\
\hline & \multicolumn{2}{|c|}{ singularis } & \multicolumn{3}{|c|}{ singularis } & \multicolumn{3}{|c|}{ singularis } \\
\hline & masc. & neutr. & masc. & fem. & neutr. & masc. & fem. & neutr. \\
\hline \multirow[t]{4}{*}{$\begin{array}{l}\text { nom. } \\
\text { gen. } \\
\text { dat. } \\
\text { acc. } \\
\text { abl. }\end{array}$} & $\begin{array}{l}\text { quìs } \\
\text { cuiǔs } \\
\text { cuî/cui } \\
\text { quěm } \\
\text { quō }\end{array}$ & $\begin{array}{l}\text { quĩd } \\
\text { cuiǔs } \\
\text { cuì/cui } \\
\text { quīd } \\
\text { quō }\end{array}$ & $\begin{array}{l}\text { quī } \\
\text { cuiǔs } \\
\text { cuì/cui } \\
\text { quěm } \\
\text { quō }\end{array}$ & $\begin{array}{l}\text { quae/quă } \\
\text { cuiǔs } \\
\text { cuī/cui } \\
\text { quăm } \\
\text { quā }\end{array}$ & $\begin{array}{l}\text { quǒd } \\
\text { cuiǔs } \\
\text { cui/cui } \\
\text { quōd } \\
\text { quō }\end{array}$ & $\begin{array}{l}\text { ullús } \\
\text { ulliŭs } \\
\text { ulli } \\
\text { ullŭm } \\
\text { ullō }\end{array}$ & $\begin{array}{l}\text { ullă } \\
\text { ulliūs } \\
\text { ullī } \\
\text { ullăm } \\
\text { ullä }\end{array}$ & $\begin{array}{l}\text { ullǔm } \\
\text { ulliǔs } \\
\text { ullī } \\
\text { ullŭm } \\
\text { ullō }\end{array}$ \\
\hline & & & \multicolumn{3}{|c|}{ pluralis } & \multicolumn{3}{|c|}{ pluralis } \\
\hline & & & masc. & fem. & neutr. & masc. & fem. & neutr. \\
\hline & & $\begin{array}{l}\text { nom. } \\
\text { gen. } \\
\text { dat. } \\
\text { acc. } \\
\text { abl }\end{array}$ & $\begin{array}{l}\text { quĩ } \\
\text { quōrǔm } \\
\text { quíbŭs } \\
\text { quōs } \\
\text { quỉbǔs }\end{array}$ & $\begin{array}{l}\text { quae } \\
\text { quãrǔm } \\
\text { quïbǔs } \\
\text { quās } \\
\text { quỉbǔs }\end{array}$ & $\begin{array}{l}\text { quă/quae } \\
\text { quórŭm } \\
\text { quibuuss } \\
\text { quă/quae } \\
\text { quíbŭs }\end{array}$ & $\begin{array}{l}\text { ullì } \\
\text { ullōrŭm } \\
\text { ullis } \\
\text { ullōs } \\
\text { ullis }\end{array}$ & $\begin{array}{l}\text { ullae } \\
\text { ullārŭm } \\
\text { ullìs } \\
\text { ullās } \\
\text { ullìs }\end{array}$ & $\begin{array}{l}\text { ullă } \\
\text { ullōrŭm } \\
\text { ullìs } \\
\text { ullà } \\
\text { ulliss }\end{array}$ \\
\hline
\end{tabular}

W odniesieniu do pierwszego $\mathrm{z}$ nich należy dodać, że istnieją nieliczne poświadczenia formy dat./abl. pl. tego zaimka o postaci quis (zamiast quibŭs).

Budowa pozostałych zaimków nieokreślonych jest słowotwórczo motywowana. W większości utworzone one zostały na drodze prefiksacji lub postfiksacji podstawy słowotwórczej, stanowionej przez wskazany wyżej niepochodny zaimek quis, quid; qui, quaelqua, quod. 
Na drodze prefiksacji utworzony został zaimek:

- aliquis, aliquid - 'ktoś, coś' (postać rzeczownikowa);

- aliqui/aliquis, aliqua, aliquod - 'jakiś, jakaś, jakieś' (postać przymiotnikowa).

Jego paradygmat formalny przedstawia poniższa tabela:

\begin{tabular}{|c|c|c|c|c|c|}
\hline & \multirow{2}{*}{\multicolumn{2}{|c|}{$\begin{array}{c}\text { aliquis, aliquid } \\
\text { (parad. rzeczownikowy) } \\
\text { singularis } \\
\end{array}$}} & \multicolumn{3}{|c|}{$\begin{array}{c}\text { aliqui/aliquis, aliqua, aliquod } \\
\text { (parad. przymiotnikowy) }\end{array}$} \\
\hline & & & \multicolumn{3}{|c|}{ singularis } \\
\hline & masc. & neutr. & masc. & fem. & neutr. \\
\hline \multirow[t]{4}{*}{$\begin{array}{l}\text { nom. } \\
\text { gen. } \\
\text { dat. } \\
\text { acc. } \\
\text { abl. }\end{array}$} & \begin{tabular}{|l} 
alìquĩs \\
alícuiūs \\
alīcuĩ \\
alìquèm \\
alìquō
\end{tabular} & $\begin{array}{l}\text { aliquiid } \\
\text { alicuiūs } \\
\text { alicuí } \\
\text { aliquiid } \\
\text { aliquō }\end{array}$ & $\begin{array}{l}\text { aliquii/aliquīs } \\
\text { alícuiǔs } \\
\text { alícuī } \\
\text { alìquěm } \\
\text { aliquō }\end{array}$ & \begin{tabular}{|l} 
alìquă \\
alìcuiǔs \\
alìcuĩ \\
aliqquăm \\
aliquā
\end{tabular} & 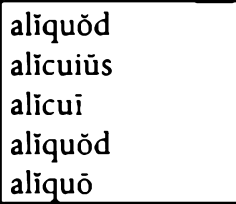 \\
\hline & & & \multicolumn{3}{|c|}{ pluralis } \\
\hline & & & masc. & fem. & neutr. \\
\hline & & $\begin{array}{l}\text { nom. } \\
\text { gen. } \\
\text { dat. } \\
\text { acc. } \\
\text { abl. }\end{array}$ & $\begin{array}{l}\text { aliqqui } \\
\text { aliquoórŭm } \\
\text { aliquibŭs/aliquis } \\
\text { aliquōs } \\
\text { aliquibŭs/aliquiss }\end{array}$ & 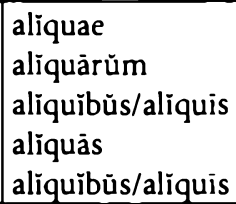 & 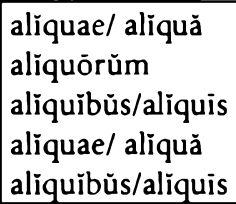 \\
\hline
\end{tabular}

W nom. sg. fem. rzadko pojawia się również forma aliquae.

$Z$ kolei poprzez postfiksację powstały następujące zaimki o paradygmacie rzeczownikowym i przymiotnikowym:

- quidam, quiddam - 'ktoś, coś';

- quidam, quaedam, quoddam - 'jakiś, jakaś, jakieś;

- quispiam, quidpiam - 'ktoś, coś;

- quispiam, quaepiam, quodpiam - ‘jakiś, jakaś, jakieś’;

- quivis, quidvis - 'ktokolwiek, cokolwiek';

- quivis, quaevis, quodvis - 'jakikolwiek, jakakolwiek, jakiekolwiek’;

- quilibet, quidlibet - 'ktokolwiek, cokolwiek';

- quilibet, quaelibet, quodlibet - 'jakikolwiek, jakakolwiek, jakiekolwiek';

- quisque, quidque - 'każdy, każda rzecz';

- quisque, quaeque, quodque - 'każdy, każda, każda'.

Analogiczną budowę wykazuje również mający tylko paradygmat rzeczownikowy' zaimek

$2 \mathrm{Z}$ form przymiotnikowych poświadczony jest tylko raz acc. sg. fem. quamquam (Sen., Lucil. $108,24)$. 
- quisquam, quicquam/quidquam - 'ktoś/nikt, coś/nic' oraz mający tylko przymiotnikowy paradygmat zaimek

- quicumque, quaecumque, quodcumque - 'jakikolwiek, jakakolwiek, jakiekolwiek'.

Paradygmaty tych zaimków ilustruje poniższa tabela na przykładzie leksemu quisque. Różnica między paradygmatem tego zaimka a paradygmatami pozostałych zaimków tej grupy dotyczy przede wszystkim (niedmiennego) postfiksu, tzn. w miejce postfiksu -que występować będą (odpowiednio) postfiksy-dam, -piam, -vis, -libet, -cumque. Poza tym zaimki te wykazują względem siebie zróżnicowanie co do sygmatyczności/asygmatyczności formy nom. sg. masc., tzn. jedne z nich (w obu paradygmatach) tworzą ją sygmatycznie (quisque, quispiam, quisquam), inne asygmatycznie (quidam, quivis, quilibet, quicumque); różnica ta uwidoczniona jest w powyższym zapisie tych zaimków.

\begin{tabular}{|c|c|c|c|c|c|}
\hline & \multicolumn{2}{|c|}{$\begin{array}{c}\text { quisque, quidque } \\
\text { (parad. rzeczownikowy) }\end{array}$} & \multicolumn{3}{|c|}{$\begin{array}{l}\text { quisque, quaequae, quodque } \\
\text { (parad. przymiotnikowy) }\end{array}$} \\
\hline & \multicolumn{2}{|c|}{ singularis } & \multicolumn{3}{|c|}{ singularis } \\
\hline & masc. & neutr. & masc. & fem. & neutr. \\
\hline \multirow[t]{4}{*}{$\begin{array}{l}\text { nom. } \\
\text { gen. } \\
\text { dat. } \\
\text { acc. } \\
\text { abl. } \\
\end{array}$} & \begin{tabular}{|l} 
quisque \\
cuiusque \\
cuíque/cuique \\
quemque \\
quōque \\
\end{tabular} & $\begin{array}{l}\text { quidque } \\
\text { cuiusque } \\
\text { cuique/cuique } \\
\text { quidque } \\
\text { quöque }\end{array}$ & $\begin{array}{l}\text { quisque } \\
\text { cuiusque } \\
\text { cuique/cuique } \\
\text { quemque } \\
\text { quóque }\end{array}$ & $\begin{array}{l}\text { quaeque/quaque } \\
\text { cuiusque } \\
\text { cuique/cuique } \\
\text { quamque } \\
\text { quāque } \\
\end{array}$ & $\begin{array}{l}\text { quodque } \\
\text { cuiusque } \\
\text { cuique/cuique } \\
\text { quodque } \\
\text { quōque } \\
\end{array}$ \\
\hline & & & \multicolumn{3}{|c|}{ pluralis } \\
\hline & & & masc. & fem. & neutr. \\
\hline & & $\begin{array}{l}\text { nom. } \\
\text { gen. } \\
\text { dat. } \\
\text { acc. } \\
\text { abl }\end{array}$ & $\begin{array}{l}\text { quique } \\
\text { quōrumque } \\
\text { quibusque } \\
\text { quosque } \\
\text { quibusque }\end{array}$ & $\begin{array}{l}\text { quaeque } \\
\text { quārumque } \\
\text { quibusque } \\
\text { quasque } \\
\text { quibusque }\end{array}$ & $\begin{array}{l}\text { quāque/quaeque } \\
\text { quōrumque } \\
\text { quibusque } \\
\text { quăque/quaeque } \\
\text { quibusque }\end{array}$ \\
\hline
\end{tabular}

W dat. / abl. pl. część poprzedzająca postfiks niektórych spośród tych zaimków może mieć postać quis- (zamiast quibus-).

W paradygmacie zaimka quidam /m/ poprzedzające /d/ w acc. sg. i gen. pl. asymiluje się (pod względem miejsca artykulacji) do /n/, co doprowadziło do powstania form acc. sg. quendam, quandam oraz gen. pl. quorundam, quarundam.

Postfiks -libet może także przybrać postać -lubet.

Zaimek quivis występuje w nietypowej formie gen. sg. cuivis w ramach wyrażenia cuivis modi 'wszelkiego rodzaju'.

Połączeniem liczebnika unus i zaimka quisque jest zaimek

- unusquisque, unumquidque

- unusquisque, unaquaequae, unumquodque 
o znaczeniu 'każdy jeden, każda jedna, każde jedno'. W zasadzie są to dwa wyrazy tekstowe, często pisane rozdzielnie (unus quisque), dlatego nawet przy pisowni łącznej (unusquisque) otwierane sa dwa miejsca dla morfemów fleksyjnych.

\begin{tabular}{|c|c|c|c|c|c|}
\hline & \multirow{2}{*}{\multicolumn{2}{|c|}{$\begin{array}{c}\text { unusquisque, unumquidque } \\
\text { (parad. rzeczownikowy) }\end{array}$}} & \multicolumn{3}{|c|}{$\begin{array}{l}\text { unusquisque, unaquaeque, unumquodque } \\
\text { (parad. przymiotnikowy) }\end{array}$} \\
\hline & & & \multicolumn{3}{|c|}{ singularis } \\
\hline & masc. & neutr. & masc. & fem. & neutr. \\
\hline \multirow[t]{4}{*}{$\begin{array}{l}\text { nom. } \\
\text { gen. } \\
\text { dat. } \\
\text { acc. } \\
\text { abl } \\
\end{array}$} & $\begin{array}{l}\text { unusquisque } \\
\text { uniuscuiusque } \\
\text { unicuique } \\
\text { unumquemque } \\
\text { unoquōque }\end{array}$ & $\begin{array}{l}\text { unumquidque } \\
\text { uniuscuiusque } \\
\text { unicuique } \\
\text { unumquidque } \\
\text { unoquōque }\end{array}$ & $\begin{array}{l}\text { unusquisque } \\
\text { uniuscuiusque } \\
\text { unicuique } \\
\text { unumquemque } \\
\text { unoquōque }\end{array}$ & $\begin{array}{l}\text { unaquaeque } \\
\text { uniuscuiusque } \\
\text { unicuique } \\
\text { unamquamque } \\
\text { unaquãque }\end{array}$ & $\begin{array}{l}\text { unumquodque } \\
\text { uniuscuiusque } \\
\text { unicuique } \\
\text { unumquodque } \\
\text { unoquōque }\end{array}$ \\
\hline & & & \multicolumn{3}{|c|}{ pluralis } \\
\hline & & & masc. & fem. & neutr. \\
\hline & & $\begin{array}{l}\text { nom. } \\
\text { gen. } \\
\text { dat. } \\
\text { acc. } \\
\text { abl }\end{array}$ & $\begin{array}{l}\text { uniquique } \\
\text { unorumquō- } \\
\text { rumque } \\
\text { unisquibusque } \\
\text { unosquosque } \\
\text { unisquibusque }\end{array}$ & $\begin{array}{l}\text { unaequaeque } \\
\text { unarumquā- } \\
\text { rumque } \\
\text { unisquibusque } \\
\text { unasquasque } \\
\text { unisquibusque }\end{array}$ & $\begin{array}{l}\text { unaquăeque } \\
\text { unorumquō- } \\
\text { rumque } \\
\text { unisquibusque } \\
\text { unaquàeque } \\
\text { unisquibusque }\end{array}$ \\
\hline
\end{tabular}

\section{Zaimek}

- quisquis, quidquid 'ktokolwiek, cokolwiek';

- quisquis, (quaequae), quodquod 'jakikolwiek, (jakakolwiek), jakiekolwiek' utworzony został na drodze reduplikacji podstawy słowotwórczej. Regularnie używane były jednak tylko formy nom. sg. masc. quisquis i nom. / acc. sg. neutr. quidquid. W liczbie pojedynczej poświadczone są też formy acc. masc. quemquem, nom. / acc. neutr. quodquod oraz abl. quoquo i quaqua. Brak poświadczeń dla form w datiwie, a w genetiwie spotykana jest jedynie nietypowa dla tego przypadka postać w ramach wyrażenia cuicui modi 'jakiegokolwiek rodzaju'. Dla liczby mnogiej poświadczone są jedynie formy nom. / acc. neutr. quaequae oraz acc. masc. quosquos.

$\mathrm{Na}$ drodze postfiksacji utworzone też zostały nieokreślone zaimki przymiotnikowe:

- qualislibet, qualelibet 'jakikolwiek, jakakolwiek, jakiekolwiek'

- qualiscumque, qualecumque 'jakikolwiek, jakakolwiek, jakiekolwiek'

- quantuslibet, quantalibet, quantumlibet 'jakkolwiek wielki/wielka/wielkie'

- quantusvis, quantavis, quantumvis 'jakkolwiek wielki/wielka/wielkie'

- quantuscumque, quantacumque, quantumcumque 'jakkolwiek wielki/wielka/wielkie.'

Ich podstawą słowotwórczą są jednak przymiotnikowe zaimki cechujące się regularnym paradygmatem rzeczownikowo-przymiotnikowym deklinacji III (qualis, -e) lub deklinacji I i II (quantus, - $a,-u m$ ), do których dołączony został (nieodmienny) postfiks (-libet, -cumque lub -vis). Przykładowe schematy paradygmatów zaimków 
tego typu przedstawia poniższa tabela, przy czym nie wszystkie konkretne formy fleksyjne są poświadczone w zachowanych tekstach:

\begin{tabular}{|c|c|c|c|c|c|c|}
\hline & \multicolumn{3}{|c|}{ qualiscumque, qualecumque } & \multicolumn{3}{|c|}{ quantusvis, quantavis, quantumvis } \\
\hline & \multicolumn{3}{|c|}{ singularis } & \multicolumn{3}{|c|}{ singularis } \\
\hline & masc. & fem. & neutr. & masc. & fem. & neutr. \\
\hline \multirow[t]{3}{*}{$\begin{array}{l}\text { nom. } \\
\text { gen. } \\
\text { dat. } \\
\text { acc. } \\
\text { abl. } \\
\end{array}$} & $\begin{array}{l}\text { qualiscumque } \\
\text { qualiscumque } \\
\text { qualicumque } \\
\text { qualemcumque } \\
\text { qualicumque }\end{array}$ & $\begin{array}{l}\text { qualiscumque } \\
\text { qualiscumque } \\
\text { qualicumque } \\
\text { qualemcumque } \\
\text { qualicumque } \\
\end{array}$ & $\begin{array}{l}\text { qualecumque } \\
\text { qualiscumque } \\
\text { qualicumque } \\
\text { qualecumque } \\
\text { qualicumque }\end{array}$ & $\begin{array}{l}\text { quantusvis } \\
\text { quantivis } \\
\text { quantovis } \\
\text { quantumvis } \\
\text { quantovis } \\
\end{array}$ & $\begin{array}{l}\text { quantavis } \\
\text { quantaevis } \\
\text { quantaevis } \\
\text { quantamvis } \\
\text { quantavis } \\
\end{array}$ & $\begin{array}{l}\text { quantumvis } \\
\text { quantivis } \\
\text { quantovis } \\
\text { quantumvis } \\
\text { quantovis } \\
\end{array}$ \\
\hline & \multicolumn{3}{|c|}{ pluralis } & \multicolumn{3}{|c|}{ pluralis } \\
\hline & masc. & fem. & neutr. & masc. & fem. & neutr. \\
\hline $\begin{array}{l}\text { nom. } \\
\text { gen. } \\
\text { dat. } \\
\text { acc. } \\
\text { abl. }\end{array}$ & $\begin{array}{l}\text { qualescumque } \\
\text { qualiumcumque } \\
\text { qualibuscumque } \\
\text { qualescumque } \\
\text { qualibuscumque }\end{array}$ & $\begin{array}{l}\text { qualescumque } \\
\text { qualiumcumque } \\
\text { qualibuscumque } \\
\text { qualescumque } \\
\text { qualibuscumque }\end{array}$ & $\begin{array}{l}\text { qualiacumque } \\
\text { qualiumcumque } \\
\text { qualibuscumque } \\
\text { qualiacumque } \\
\text { qualibuscumque }\end{array}$ & $\begin{array}{l}\text { quantivis } \\
\text { quantorumvis } \\
\text { quantisvis } \\
\text { quantosvis } \\
\text { quantisvis } \\
\end{array}$ & $\begin{array}{l}\text { quantaevis } \\
\text { quantarumvis } \\
\text { quantisvis } \\
\text { quantasvis } \\
\text { quantisvis }\end{array}$ & $\begin{array}{l}\text { quantavis } \\
\text { quantorumvis } \\
\text { quantisvis } \\
\text { quantavis } \\
\text { quantisvis } \\
\end{array}$ \\
\hline
\end{tabular}

Do zaimków nieokreślonych zalicza się również przymiotnikowy zaimek aliquot 'kilka, kilku', którego paradygmat formalny jest defektywny pod względem kategorii rodzaju i przypadka, co przy ograniczonym paradygmacie funkcjonalnym w zakresie kategorii liczby (plurale tantum) daje w efekcie paradygmat formalny zerowy (tzn. zbiór wyłącznie homofonicznych form fleksyjnych reprezentujących poszczególne flektemy).

\subsection{ZAIMKI BINARNE}

Zaimki binarne, chociaż często pełnią w zdaniu funkcje rzeczownikowe, cechują się przymiotnikowym paradygmatem fleksyjnym. Do zaimków tej klasy należą:

- alter, altera, alterum 'drugi / jeden $\mathrm{z}$ dwóch';

- uter, utra, utrum 'jeden albo drugi';

- neuter, neutra, neutrum 'żaden z dwóch';

- alteruter, alterutra, alterutrum 'jeden $\mathrm{z}$ dwóch';

- uterque, utraque, utrumque 'jeden i drugi';

- utervis, utravis, utrumvis 'którykolwiek z dwóch';

- uterlibet, utralibet, utrumlibet 'którykolwiek z dwóch';

- utercumque, utracumque, utrumcumque 'którykolwiek $z$ dwóch'

Zaimki te tworzą formy fleksyjne rodzaju męskiego i nijakiego według wzoru paradygmatu rzeczownikowo-przymiotnikowego deklinacji II, a formy fleksyjne rodzaju żeńskiego według wzoru deklinacji I, przy czym w formach gen. sg. wszystkich 
trzech rodzajów przyłączana jest taka sama (charakterystyczna dla zaimków) końcówka -ius, a w formach dat. sg. końcówka - $i$. W odniesieniu do zaimka alter sporadycznie odnotowywana jest forma dat. sg. masc. altero, nieco częściej forma dat. sg. fem. alterae ${ }^{3}$.

Zaimek uter, utra, utrum stanowi podstawę słowotwórczą zaimków neuter i alteruter, które utworzone zostały na drodze prefiksacji, oraz zaimków uterque, utervis, uterlibet, utercumque, które utworzone zostały na drodze postfiksacji, przy czym alternant tematyczny uter- występuje tylko w formach nom. sg. masc., natomiast wszystkie pozostałe formy fleksyjne współtworzy alternant utr-.

Formy liczby mnogiej tych zaimków odnoszą się głównie do pojęć zbiorowych, np. ,jedni i drudzy”, „ani jedni, ani drudzy”, albo stanowią określniki rzeczowników należących do klasy pluralia tantum. Z uwagi na specyfikę znaczenia formy fleksyjne reprezentujące pewne flektemy nie są jednak poświadczone w zachowanych tekstach, a paradygmaty niektórych zaimków ograniczone są tylko do liczby pojedynczej.

$\mathrm{W}$ poniższych tabelach przedstawiony został paradygmat formalny zaimka alter oraz przykładowe paradygmaty zaimków utworzonych na bazie zaimka uter poprzez prefiksację (neuter) i postfiksację (uterque, uterlibet):

\begin{tabular}{|c|c|c|c|c|c|c|}
\hline & \multicolumn{3}{|c|}{ alter, altera, alterum } & \multicolumn{3}{|c|}{ neuter, neutra, neutrum } \\
\hline & \multicolumn{3}{|c|}{ singularis } & \multicolumn{3}{|c|}{ singularis } \\
\hline & masc. & fem. & neutr. & masc. & fem. & neutr. \\
\hline \multirow[t]{3}{*}{$\begin{array}{l}\text { nom. } \\
\text { gen. } \\
\text { dat. } \\
\text { acc. } \\
\text { abl. }\end{array}$} & \begin{tabular}{|l} 
altēr \\
alteriǔs \\
altērī \\
altērǔm \\
altērō \\
\end{tabular} & \begin{tabular}{|l|} 
altèrà \\
alteriūs \\
altěrī \\
altěrām \\
altērā \\
\end{tabular} & $\begin{array}{l}\text { altěrǔm } \\
\text { alteriūs } \\
\text { altěrī } \\
\text { altěrǔm } \\
\text { altěrō }\end{array}$ & $\begin{array}{l}\text { neŭtěr } \\
\text { neǔtriǔs } \\
\text { neǔtrī } \\
\text { neǔtrǔm } \\
\text { neǔtrō }\end{array}$ & $\begin{array}{l}\text { neŭtrà } \\
\text { neŭtrīŭs } \\
\text { neǔtrì } \\
\text { neǔtrām } \\
\text { neǔtrā }\end{array}$ & $\begin{array}{l}\text { neǔtrŭm } \\
\text { neǔtriùs } \\
\text { neǔtrī } \\
\text { neǔtrǔm } \\
\text { neǔtrō }\end{array}$ \\
\hline & \multicolumn{3}{|c|}{ pluralis } & \multicolumn{3}{|c|}{ pluralis } \\
\hline & masc. & fem. & neutr. & masc. & fem. & neutr. \\
\hline $\begin{array}{l}\text { nom. } \\
\text { gen. } \\
\text { dat. } \\
\text { acc. } \\
\text { abl. }\end{array}$ & \begin{tabular}{|l} 
altērī \\
alterōrŭm \\
altēriss \\
altěrōs \\
altēris
\end{tabular} & $\begin{array}{l}\text { altērae } \\
\text { alterārūm } \\
\text { altērīs } \\
\text { altērās } \\
\text { altēriss }\end{array}$ & \begin{tabular}{|l} 
alterà \\
alterōrǔm \\
altērīs \\
altēră \\
altērìs
\end{tabular} & $\begin{array}{l}\text { neǔtrī } \\
\text { neŭtrōrŭm } \\
\text { neŭtrīs } \\
\text { neǔtrōs } \\
\text { neǔtris }\end{array}$ & \begin{tabular}{|l} 
neŭtrae \\
neŭtrārŭm \\
neǔtrīs \\
neŭtrās \\
neǔtrīs
\end{tabular} & $\begin{array}{l}\text { neǔtrà } \\
\text { neǔtrōrŭm } \\
\text { neǔtris } \\
\text { neǔtră } \\
\text { neǔtris }\end{array}$ \\
\hline
\end{tabular}




\begin{tabular}{|c|c|c|c|c|c|c|}
\hline & \multicolumn{3}{|c|}{ utergue, utraque, utrumque } & \multicolumn{3}{|c|}{ uterlibet, utralibet, utrumlibet } \\
\hline & \multicolumn{3}{|c|}{ singularis } & \multicolumn{3}{|c|}{ singularis } \\
\hline & masc. & fem. & neutr. & masc. & fem. & neutr. \\
\hline \multirow[t]{3}{*}{$\begin{array}{l}\text { nom. } \\
\text { gen. } \\
\text { dat. } \\
\text { acc. } \\
\text { abl. }\end{array}$} & $\begin{array}{l}\text { uterque } \\
\text { utriusque } \\
\text { utrique } \\
\text { utrumque } \\
\text { utrōque }\end{array}$ & $\begin{array}{l}\text { utrăque } \\
\text { utriusque } \\
\text { utrique } \\
\text { utramque } \\
\text { utrāque } \\
\end{array}$ & $\begin{array}{l}\text { utrumque } \\
\text { utriusque } \\
\text { utrique } \\
\text { utrumque } \\
\text { utrōque } \\
\end{array}$ & $\begin{array}{l}\text { uterlibet } \\
\text { utriuslïbet } \\
\text { utrilibet } \\
\text { utrumlibet } \\
\text { utrölibet }\end{array}$ & $\begin{array}{l}\text { uträlibet } \\
\text { utriuslïbet } \\
\text { utrilibet } \\
\text { utramlibet } \\
\text { uträlibet }\end{array}$ & $\begin{array}{l}\text { utrumlibet } \\
\text { utriuslibet } \\
\text { utrilibet } \\
\text { utrumlibet } \\
\text { utrōlibet }\end{array}$ \\
\hline & \multicolumn{3}{|c|}{ pluralis } & & & \\
\hline & masc. & fem. & neutr. & & & \\
\hline $\begin{array}{l}\text { nom. } \\
\text { gen. } \\
\text { dat. } \\
\text { acc. } \\
\text { abl. }\end{array}$ & $\begin{array}{l}\text { utrīque } \\
\text { utrōrumque } \\
\text { utrīsque } \\
\text { utrōsque } \\
\text { utrīsque }\end{array}$ & $\begin{array}{l}\text { utraeque } \\
\text { utrārumque } \\
\text { utrīsque } \\
\text { utrāsque } \\
\text { utrīsque }\end{array}$ & $\begin{array}{l}\text { utrăque } \\
\text { utrōrumque } \\
\text { utrīsque } \\
\text { utrăque } \\
\text { utrīsque }\end{array}$ & & & \\
\hline
\end{tabular}

Do grupy tej zalicza się też zaimek ambo, ambae, ambo 'oba(j), obie, oba', którego przymiotnikowy paradygmat, konserwujący elementy historycznej liczby podwójnej, ograniczony jest do pluralis:

\begin{tabular}{|c|c|c|c|}
\hline & \multicolumn{3}{|c|}{ ambo, ambae, ambo } \\
\hline & \multicolumn{3}{|c|}{ pluralis } \\
\hline & masc. & fem. & neutr. \\
\hline $\begin{array}{l}\text { Nom. } \\
\text { Gen. } \\
\text { Dat. } \\
\text { Acc. } \\
\text { Abl. }\end{array}$ & $\begin{array}{l}\text { ambō } \\
\text { ambōrum } \\
\text { ambōbǔs } \\
\text { ambōs/ambō } \\
\text { ambōbŭs }\end{array}$ & $\begin{array}{l}\text { ambae } \\
\text { ambārum } \\
\text { ambābǔs } \\
\text { ambās } \\
\text { ambābŭs }\end{array}$ & $\begin{array}{l}\text { ambō } \\
\text { ambōrum } \\
\text { ambōbūs } \\
\text { ambō } \\
\text { ambōbǔs }\end{array}$ \\
\hline
\end{tabular}




\subsection{ZAIMEK WZGLĘDNY}

Podstawowym zaimkiem względnym jest w lacinie zaimek qui, quae, quod 'który, która, które'. Ma on gramatyczny status przymiotnika, choć często używany jest również w funkcjach rzeczownikowych. Jego paradygmat formalny przedstawia poniższa tabela:

\begin{tabular}{|c|c|c|c|c|c|c|}
\hline & \multicolumn{6}{|c|}{ qui, quae, quod } \\
\hline & \multicolumn{3}{|c|}{ singularis } & \multicolumn{3}{|c|}{ pluralis } \\
\hline & masc. & fem. & neutr. & masc. & fem. & neutr. \\
\hline $\begin{array}{l}\text { nom. } \\
\text { gen. } \\
\text { dat. } \\
\text { acc. } \\
\text { abl. }\end{array}$ & $\begin{array}{l}\text { quĩ } \\
\text { cuiǔs } \\
\text { cuì/cui } \\
\text { quěm } \\
\text { quó }\end{array}$ & $\begin{array}{l}\text { quae } \\
\text { cuiūs } \\
\text { cuì/cui } \\
\text { quăm } \\
\text { quā }\end{array}$ & $\begin{array}{l}\text { quǒd } \\
\text { cuiǔs } \\
\text { cuī/cui } \\
\text { quǒd } \\
\text { quō }\end{array}$ & $\begin{array}{l}\text { quĩ } \\
\text { quōrǔm } \\
\text { quībŭs } \\
\text { quōs } \\
\text { quỉbŭs } \\
\end{array}$ & $\begin{array}{l}\text { quae } \\
\text { quārŭm } \\
\text { quībǔs } \\
\text { quās } \\
\text { quỉbǔs }\end{array}$ & $\begin{array}{l}\text { quae } \\
\text { quōrŭm } \\
\text { quỉbŭs } \\
\text { quae } \\
\text { quibŭs }\end{array}$ \\
\hline
\end{tabular}

Okazjonalnie formy dat. / abl. pl. przyjmują postać quis. Formy abl. sg. i abl. pl. mogą z przyimkiem cum tworzyć jeden wyraz tekstowy, występując w prepozycji względem przyimka (quōcum, quācum, quibuscum, w pl. także quīcum).

\subsection{ZAIMKI PYTAJNE}

Podstawowymi zaimkami pytajnymi w łacinie są zaimki quis? quid? 'kto? co?' oraz qui? quae? quod? 'jaki? jaka? jakie?' Zbudowane są na bazie tego samego rdzenia zaimkowego (względno-nieokreślonego-pytajnego) i cechują się (odpowiednio) paradygmatem rzeczownikowym i przymiotnikowym:

\begin{tabular}{|c|c|c|c|c|c|c|}
\hline & \multicolumn{3}{|c|}{$\begin{array}{c}\text { quis? quid? } \\
\text { (parad. rzeczownikowy) }\end{array}$} & \multicolumn{3}{|c|}{$\begin{array}{c}\text { qui? quae? quod? } \\
\text { (parad. przymiotnikowy) }\end{array}$} \\
\hline & \multicolumn{3}{|c|}{ singularis } & \multicolumn{3}{|c|}{ singularis } \\
\hline & masc. & ne & utr. & masc. & fem. & neutr. \\
\hline \multirow[t]{4}{*}{$\begin{array}{l}\text { nom. } \\
\text { gen. } \\
\text { dat. } \\
\text { acc. } \\
\text { abl. }\end{array}$} & $\begin{array}{l}\text { quīs } \\
\text { cuiūs } \\
\text { cuĩ/cui } \\
\text { quèm } \\
\text { quō }\end{array}$ & $\begin{array}{l}\text { quīd } \\
\text { cuiǔs } \\
\text { cuì/cui } \\
\text { quīd } \\
\text { quō }\end{array}$ & & $\begin{array}{l}\text { quī } \\
\text { cuiūs } \\
\text { cuī/cui } \\
\text { quèm } \\
\text { quō }\end{array}$ & $\begin{array}{l}\text { quae } \\
\text { cuiǔs } \\
\text { cuĩ/cui } \\
\text { quăm } \\
\text { quā }\end{array}$ & $\begin{array}{l}\text { quōd } \\
\text { cuiǔs } \\
\text { cuĩ/cui } \\
\text { quōd } \\
\text { quō }\end{array}$ \\
\hline & & & & \multicolumn{3}{|c|}{ pluralis } \\
\hline & & & & masc. & fem. & neutr. \\
\hline & & & $\begin{array}{l}\text { nom. } \\
\text { gen. } \\
\text { dat. } \\
\text { acc. } \\
\text { abl. }\end{array}$ & $\begin{array}{l}\text { quī } \\
\text { quōrǔm } \\
\text { quībǔs } \\
\text { quōs } \\
\text { quībǔs }\end{array}$ & $\begin{array}{l}\text { quae } \\
\text { quārǔm } \\
\text { quībŭs } \\
\text { quās } \\
\text { quībŭs }\end{array}$ & $\begin{array}{l}\text { quae } \\
\text { quōrŭm } \\
\text { quĭbŭs } \\
\text { quae } \\
\text { quibŭs }\end{array}$ \\
\hline
\end{tabular}


Paradygmat zaimka uter? utra? utrum? 'który, -a, -e z dwóch?' ma charakter przymiotnikowy:

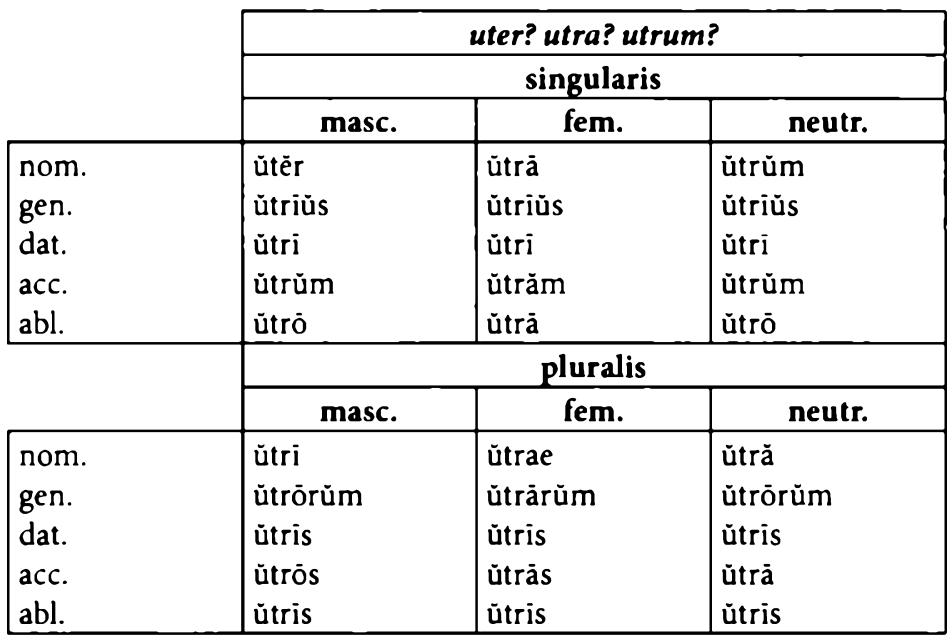

Inne zaimki pytajne (pomijając przysłówkowe) mają charakter przymiotnikowy i cechują się regularnymi paradygmatami rzeczownikowo-przymiotnikowymi deklinacji III, jak np. qualis? quale? 'jaki? jaka? jakie? (co do jakości, charakteru)', lub deklinacji I i II, jak np. quantus? quanta? quantum? 'jak wielki, -a, -ie?'. Przymiotnikowy zaimek quot? 'ile? ilu?' z uwagi na ograniczoność paradygmatu funkcjonalnego pod względem kategorii liczby (plurale tantum) i defektywność paradygmatu formalnego w zakresie kategorii przypadka i rodzaju posiada zerowy paradygmat formalny, tzn. wszystkie reprezentujące go formy fleksyjne są homonimiczne (stanowione przez te same formy tekstowe).

\subsection{ZAIMKI PRZECZĄCE}

Rzeczownikowym zaimkiem przeczącym jest zaimek nemo 'nikt', odnoszący się do desygnatów osobowych i nacechowany rodzajem męskim, oraz zaimek nihil (nil) 'nic', odnoszący się do desygnatów nieosobowych i nacechowany rodzajem nijakim. Oba te zaimki charakteryzują się ograniczonym paradygmatem funkcjonalnym pod względem kategorii liczby, stanowiąc singularia tantum. Przymiotnikowym zaimkiem przeczącym jest zaimek nullus, nulla, nullum 'żaden, żadna, żadne'.

Paradygmat funkcjonalny zaimka nihil ograniczony jest ponadto pod względem kategorii przypadka do dwóch wartości, tj. nom. i acc., które $\mathrm{z}$ uwagi na systemowy synkretyzm form rodzaju nijakiego reprezentowane są przez tę samą formę tekstową nihil (lub nil, która jest wynikiem zaniku słabego interwokalicznego $/ \mathrm{h} / \mathrm{i}$ kontrakcji samogłosek). Funkcjonalnymi odpowiednikami (nieaktualizowanych) form fleksyjnych, odnoszących się do flektemów nieuwzględnianych w paradygmacie tego za- 
imka, są syntagmy imienne oparte na związku atrybucji, złożone $\mathrm{z}$ form fleksyjnych (w gen., dat. $i$ abl.) reprezentujących rzeczownik res 'rzecz' i przymiotnikowy zaimek przeczący nullus, $-a,-u m$.

Spośród form fleksyjnych składających się na paradygmat formalny zaimka nemo tekstowe poświadczenie formy genetiwu (neminis) ograniczone jest w zasadzie tylko do kilku wystąpień w tekstach archaicznych ${ }^{4} ;$ zwykle stosowany jest jej funkcjonalny odpowiednik $\mathrm{w}$ postaci substantywizowanej formy zaimka nullus ( $\mathrm{tj}$. nullius). Poświadczenie formy ablatiwu (nemine) jest nieco lepsze ${ }^{5}$, ale i ona często zastępowana bywa odpowiednią formą zaimka nullus (tj. nullo).

Pełne paradygmaty zaimków przeczących przedstawia poniższa tabela:

\begin{tabular}{|c|c|c|c|c|c|}
\hline & nemo & nihil & \multicolumn{3}{|c|}{ nullus, nulla, nullum } \\
\hline & \multicolumn{2}{|c|}{ singularis } & \multicolumn{3}{|c|}{ singularis } \\
\hline & masc. & neutr. & masc. & fem. & neutr. \\
\hline \multirow[t]{4}{*}{$\begin{array}{l}\text { nom. } \\
\text { gen. } \\
\text { dat. } \\
\text { acc. } \\
\text { abl. }\end{array}$} & $\begin{array}{l}\text { nēmō } \\
\text { nēminìs (nulliūs) } \\
\text { nēmìnī } \\
\text { nēminèm } \\
\text { nēminnè (nullō) }\end{array}$ & 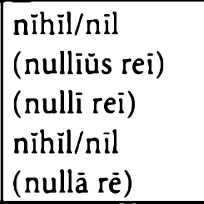 & \begin{tabular}{|l|} 
nullŭs \\
nullīùs \\
nullī \\
nullŭm \\
nullō \\
\end{tabular} & \begin{tabular}{|l|} 
nullă \\
nulliǔs \\
nullì \\
nullăm \\
nullā \\
\end{tabular} & $\begin{array}{l}\text { nullǔm } \\
\text { nullīùs } \\
\text { nullī } \\
\text { nullūm } \\
\text { nullō } \\
\end{array}$ \\
\hline & & & \multicolumn{3}{|c|}{ pluralis } \\
\hline & & & masc. & fem. & neutr. \\
\hline & & $\begin{array}{l}\text { nom. } \\
\text { gen. } \\
\text { dat. } \\
\text { acc. } \\
\text { abl. }\end{array}$ & $\begin{array}{l}\text { nullì } \\
\text { nullōrǔm } \\
\text { nullīs } \\
\text { nullōs } \\
\text { nullis } \\
\end{array}$ & $\begin{array}{l}\text { nullae } \\
\text { nullārǔm } \\
\text { nullīs } \\
\text { nullās } \\
\text { nullis }\end{array}$ & $\begin{array}{l}\text { nullă } \\
\text { nullōrǔm } \\
\text { nulliss } \\
\text { nullă } \\
\text { nulliss }\end{array}$ \\
\hline
\end{tabular}

Przeczący charakter ma również zaimek binarny neuter, neutra, neutrum 'żaden / żadna / żadne z dwóch', o którym mowa wyżej (zob. 5.8.)

\subsection{PRZYMIOTNIKI ZAIMKOWE}

Przymiotnikami zaimkowymi określa się głównie leksemy:

- totus, tota, totum - 'cały, cała, całe';

- solus, sola, solum - 'sam, sama, samo'.

Ich paradygmaty formalne generalnie ukształtowane są według wzoru deklinacji I (dla form rodzaju żeńskiego) oraz deklinacji II (dla form rodzaju męskiego i nija-

5 Rhet. Her. 4, 7; Pl., Cist. 87; Mil. 1062; Suet., Aug. 45, 4; 95, 1; Tib. 12, 2; 17, 1; 73, 2; Cal. 46, 1; Ner., 47, 3; Vit. 17, 1; Tit. 7, 3; Tac., Hist. 2, 47; Ann. 16, 27. 
kiego), jednak we wszystkich wariantach rodzajowych genetiwu liczby pojedynczej przyjmują zwykle zaimkową końcówkę -ius (totius, solius ${ }^{6}$ ), a we wszystkich wariantach rodzajowych datiwu liczby pojedynczej końcówkę - $i\left(\right.$ tot $^{i}$, soli $\left.{ }^{8}\right)$.

Do grupy przymiotników zaimkowych zalicza się również leksem

- alius, alia, aliud - 'inny, inna, inne'

$\mathrm{z}$ uwagi na fakt, iz $\mathrm{w}$ miejsce form genetiwu i datiwu liczby pojedynczej tego zaimka stosowane są często ich funkcjonalne odpowiedniki w postaci form gen. sg. i dat. sg. zaimka binarnego alter, a więc alterius i alteri. Poświadczone jest jednak także użycie form gen. sg. fem. aliae ${ }^{9}$, gen. sg. neutr. alii ${ }^{10}$, gen. sg. masc. alius ${ }^{11}$, dat. sg. fem. aliae ${ }^{12}$, dat. sg. masc. alii ${ }^{13}$, dat. sg. masc. alio ${ }^{14}$.

\subsection{WYBRANA LITERATURA}

Beltrán (1999, s. 99-120), Greenough, Kittredge, Howard, D’Ooge (1903 (1983), s. 63-71), Wikarjak (1978, s. 38-42)

6 Poświadczona jest jednak również forma gen. sg. masc. soli (Ter., Heaut. 129).

7 Poświadczona jest jednak również forma dat. sg. masc. i neutr. toto (Prop., Eleg. 3, 11, 57; Apul., Met. 10, 28).

" Poświadczona jest jednak również forma dat. sg. fem. solae (Pl., Mil. 356, 1019; Ter., Eun. 1004).

${ }^{4}$ Cic., Div. 2, 30.

11) Varr., Ling. 9, 67.

1 Gel., Noc. Att. 17, 5, 14.

12 Pl., Mil. 802.

${ }^{13}$ Rhet. Her. 2, 6; Sall., Cat. 52, 1.

14 Rhet. Her. 2, 19. 


\section{6. \\ Paragygmatyka fleksyjna czasowników}

\subsection{WERBALNE KATEGORIE FLEKSYJNE: ICH WARTOŚCI I TYPY WYKŁADNIKÓW}

Fleksja łacińskich czasowników oparta jest na kategoriach:

1. osoby (persona) o wartościach:

- pierwsza osoba (1. os.),

$\rightarrow$ druga osoba (2. os.),

$\rightarrow$ trzecia osoba (3. os.).

2. liczby (numerus) o wartościach:

$\rightarrow$ singularis (sg.) - liczba pojedyncza,

- pluralis (pl.) - liczba mnoga.

3. czasu (tempus) o wartościach:

$\rightarrow$ praesens (praes.) - czas teraźniejszy,

- imperfectum (impf.) - czas przeszły niedokonany,

- perfectum (perf.) - czas przeszły dokonany,

- futurum (fut.) / futurum primum (fut. I) - czas przyszły,

- plusquamperfectum (plpf.) - czas przeszły względny uprzedni,

$\rightarrow$ futurum exactum (fut. II) - czas przyszły względny uprzedni.

4. trybu (modus) o wartościach:

- indicativus (ind.) - tryb oznajmujący,

- coniunctivus (con.) - tryb przypuszczający,

- imperativus (imper.) - tryb rozkazujący.

5. strony (genus) o wartościach:

$\rightarrow$ activum (act.) - strona czynna,

- passivum (pass.) - strona bierna. 
6. finitywności o wartościach:

- verbum finitum - forma osobowa (finitywna),

- verbum infinitum - forma nieosobowa (niefinitywna),

- infinitivus (inf.) - bezokolicznik,

- participium (part.) - imiesłów,

- gerundium (ger.) - rzeczownik odsłowny,

- supinum (sup.) - okolicznik odsłowny.

W ograniczonym zakresie czasowniki łacińskie uwzględniają także kategorię aspektu, której formalnym wykładnikiem jest alternant tematyczny czasownika, mający status raczej derywacyjny, niż fleksyjny.

Dla wyrażania (wartości) poszczególnych kategorii morfologicznych czasownika łaciński system koniugacyjny dysponuje wykładnikami o charakterze:

1. derywacyjnym,

2. końcówkowym,

3. sufiksalnym.

Wszytkie te rodzaje morfologicznych wykładników charakteryzują się określonymi właściwościami dystrybucyjnymi (morfotaktycznymi).

\subsection{WYKŁADNIKI DERYWACYJNE}

Wykładnikami o charakterze derywacyjnym są morfologiczne alternanty tematyczne leksemów czasownikowych, w jakich ukazują się ich morfemy rdzenne (pierwiastki). Łaciński system koniugacyjny opiera się na trzech historycznie ukształtowanych tematach, w których występuje (lub może występować) każdy leksem czasownikowy. Są to mianowicie: tzw. temat praesentis, temat perfecti i temat participii perfecti (supini). W obrębie każdego $\mathrm{z}$ tych tematów obserwuje się znaczne zróżnicowanie formalne, bowiem historycznie tematy te utworzone zostały przy użyciu różnych formantów o charakterze zarówno sufiksalnym jak i apofonicznym. Cechują się one w związku z tym niższym poziomem formalnej regularności. Podobnie niski jest też poziom regularności, gdy chodzi o dystrybucję (wzajemną zależność) formalnych typów poszczególnych tematów przy danym leksemie czasownikowym, tzn. formalny typ jednego tematu danego leksemu nie determinuje formalnej postaci obu jego pozostałych tematów. Mamy zatem do czynienia ze względną niezależnością formalnych typów poszczególnych tematów w obrębie leksemu. W przypadku niektórych leksemów notujemy również brak któregoś (lub którychś) z tematów (por. np.: aio, inquam, fio; odi, memini, coepi) oraz zjawisko supletywizmu (np.: fero, tuli, latum). Można więc uznać, że formalna postać poszczególnych tematów czasownikowych, jak również samo ich istnienie $\mathrm{w}$ odniesieniu do danego leksemu, stanowi właściwość o charakterze raczej leksykalnym (derywacyjnym, słowotwórczym) niż fleksyjnym.

W klasycznej łacinie alternant tematyczny zwykle jest wykładnikiem niedokonanej (temat praesentis) lub dokonanej (temat (participii) perfecti) wartości kategorii 
aspektu poszczególnych formacji morfologicznych. W przypadku wyrażania czasu względnego przez dane formacje sygnalizuje nieuprzedniość (temat praesentis) lub uprzedniość (temat (participii) perfecti). Ponadto temat participii perfecti związany jest $\mathbf{z w y k l e ~} \mathbf{z}$ formacjami sygnalizującymi nacechowaną diatezę, a zatem jego istnienie bądź nieistnienie $w$ odniesieniu do danego leksemu zależne jest często od struktury semantycznej (argumentowej) tego leksemu.

\subsubsection{Temat praesentis}

Charakterystyczne dla łaciny zróżnicowanie formalne tematu praesentis, a konkretnie zróżnicowanie jego zakończenia, ma wpływ na właściwości morfotaktyczne tego tematu. $\mathrm{Z}$ tego względu łacińskie leksemy czasownikowe dzielą się na cztery podstawowe klasy (koniugacje), reprezentujące cztery różne wzory paradygmatów formalnych w zakresie formacji tworzonych na bazie tego tematu.

Pierwszą klasę (pierwszą koniugację) tworzą czasowniki, których temat praesentis zakończony jest na samogłoskę /ā/, np.: amā-, laudā- itp. Określony wpływ na tę samogłoskę wywiera kontekst fonetyczny w jakim się ona znajduje:

1. w sylabie zamkniętej inną spółgłoską niż/s/lub grupą/-ns/ulega ona skróceniu do /ă/, jak np. w: amă-t, amä-ntür;

2. jeśli znajduje się przed inną samogłoską, ulega zanikowi, jak np. wam-ō.

Tym samym pierwszą koniugację stanowią czasowniki, których temat praesentis w poszczególnych formacjach gramatycznych (tworzonych na bazie tego tematu) pojawia się $w$ trzech wariantach formalnych (alternantach morfonologicznych), tj. $z$ samogłoską /ā/, /ă/ lub bez tej samogłoski na końcu, a więc np.: amä-/amä-/am-.

Drugą koniugację tworzą czasowniki, których temat praesentis zakończony jest na samogłoskę /ë/, np.: vidè-, habē-itp. Na samogłoskę tę również określony wpływ wywiera kontekst fonetyczny: jeśli mianowicie znajduje się ona przed inną samogłoską lub w sylabie zamkniętej inną spółgłoską niż /s/ lub grupą /ns/, ulega skróceniu do /ël, jak np. w: vidè-ö, vidè-t, vidè-ntür; nigdy jednak nie ulega ona zanikowi. $\mathrm{W}$ związku z tym wzór paradygmatu formalnego drugiej koniugacji reprezentują czasowniki, których temat praesentis (w poszczególnych formacjach tworzonych na jego bazie) pojawia się $w$ dwóch wariantach formalnych (alternantach morfonologicznych), tj. z zakończeniem na /ē/lub /èl, a więc np. vidè-/vidè-.

Trzecią koniugację tworzą czasowniki dwojakiego rodzaju:

a. mające temat praesentis zakończony na krótką samogłoskę, która:

1. przed inną samogłoską ulega zanikowi, jak np. w leg-ö;

2. w wygłosie wyrazu oraz przed /r/ ma postać/ěl, jak np. w: legè, legëeris;

3. przed /n/ ma postać/ŭ/, jak np. w legü-nt;

4. w pozostałych kontekstach fonetycznych ma postać /ĩ/, jak np. w: legï-t, leği-müs; 
b. mające temat praesentis zakończony na samogłoskę /ǐl/ (np.: capi-, fací-), która:

1. przed samogłoską /i/ ulega zanikowi, jak np. w cap-i;

2. w wygłosie wyrazu oraz przed /r/ przyjmuje postać/ël, jak np. w: capè, capè-rĭs;

3. $\mathrm{przed} / \mathrm{n} /$ ulega rozszerzeniu o/ü/, jak np. w capiü-nt;

4. w pozostałych kontekstach fonetycznych pozostaje bez zmian, jak np. w: capi-o, capi-mus 1-4.

A zatem według wzoru paradygmatu formalnego trzeciej koniugacji tworzą poszczególne formacje leksemy, których temat praesentis pojawia się:

a. w czterech wariantach formalnych (alternantach morfonologicznych), tj. z / / i/, $\mathrm{z} / \mathrm{e} /, \mathrm{z}$ /ŭ/ oraz bez samogłoski na końcu, a więc np.: legi-/legë-/legü-/leg-;

b. w czterech wariantach formalnych (alternantach morfonologicznych), tj. z / / $/$ $\mathrm{z} / \mathrm{e} /, \mathrm{z} / \mathrm{iŭ} /$ oraz bez samogłoski na końcu, a więc np.: capi-/capè-/capiü-/cap-.

Tematy czasowników: fêrrè, vēllè, nōllè i mällè, należących również do trzeciej koniugacji typu a., charakteryzują się w pewnych formacjach fleksyjnych specyficznymi właściwościami morfotaktycznymi. Ponadto:

- temat czasownika ferrrě cechuje się brakiem kończącej go samogłoski w większej liczbie kontekstów fonetycznych niż wskazane w pkt. al.;

- czasownik vëllĕ, oprócz wariantu tematycznego vĕl-, posiada jeszcze warianty: vŏl( $\check{u})-, v \check{u} l-, v \bar{i}-$;

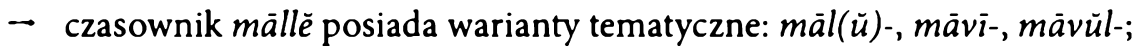

- czasownik nöllè, o temacie nōl(ü)-, pewnych formacji tworzonych od tematu praesentis nie posiada, uzupełniając je supletywnie.

Nie wszystkie formy tworzone od tematu praesentis są poświadczone dla czasowników: fio, aio, inquam. Czasownik édo niektóre formy może mieć utworzone również od tematu o postaci ěs-.

Czwartą koniugację tworzą czasowniki, których temat praesentis zakończony jest na samogłoskę /i/, np.: puni-, muni- itp. Samogłoska ta przed inną samogłoską oraz w sylabie zamkniętej inną spółgłoską niż/s/ ulega skróceniu do /i//, jak np. w: puni-ō, puni-t, zaś przed $/ \mathrm{n} /$ temat ulega rozszerzeniu o/ŭ/, jak np. w puniŭ-nt. A zatem według wzoru paradygmatu czwartej koniugacji tworzone są formacje morfologiczne czasowników, których temat praesentis pojawia się w trzech wariantach formalnych (alternantach morfonologicznych), tj. z samogłoską /i/, /ì/ lub /iŭ/ na końcu, a więc np.: puni-/puni-/puniü-.

Temat czasownika irè, należącego również do czwartej koniugacji, charakteryzuje się w pewnych formacjach fleksyjnych specyficznymi właściwościami morfotaktycznymi. Temat ten cechuje się także większą liczbą wariantów formalnych, które mają postać: $\check{e}_{-}, \bar{e} \breve{u}-, i_{-}, \bar{i}$-. Podobnymi właściwościami cechują się tematy czasowników quirē i nequirè, używanych tylko w niektórych formach. 
Poza podziałem na cztery koniugacje znajduje się czasownik esse, którego temat

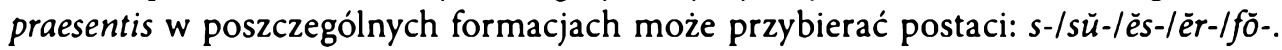
Te same postaci tematu praesentis występują również $\mathrm{w}$ formacjach słowotwórczo złożonych z tym czasownikiem.

\subsubsection{Temat perfecti}

Temat perfecti, podobnie jak temat praesentis, cechuje się również formalną niejednolitością $w$ odniesieniu do poszczególnych leksemów, w tym także formalnym zróżnicowaniem zakończenia; por. np.: laudav-, monu-, mans-, stet-, pepul-itp. Jednak zróżnicowanie to nie wpływa na właściwości morfotaktyczne tego tematu (tj. na jego łączliwość z sufiksami i końcówkami fleksyjnymi) i dlatego brak zróżnicowania wzorów paradygmatów formalnych (podziału na koniugacje) formacji tworzonych na jego bazie. Na zakończenie tego tematu nie ma również wpływu zróżnicowanie kontekstu fonetycznego w poszczególnych formacjach. Jednak przy niektórych leksemach temat ten może wystąpić $\mathrm{w}$ dwu obocznych wariantach, np. (desino) desi-/ desiv-.

\subsubsection{Temat participium perfecti}

Temat participium perfecti tworzony jest także w sposób niejednolity dla poszczególnych leksemów. Temat ten zakończony może być na spółgłoskę /t/, jak np.: laudat-, lect-, lub na spółgłoskę /s/, jak np.: claus-, sess-. Formalny kształt zakończenia nie ma jednak wpływu na właściwości morfotaktyczne tego tematu. Podobnie nie oddziaływuje na zakończenie tego tematu kontekst fonetyczny, w jakim się ono znajduje w ramach poszczególnych formacji tworzonych na bazie tego tematu.

\subsection{WYKŁADNIKI KOŃCÓWKOWE}

Czasownikowe końcówki fleksyjne stanowią obligatoryjne dla formacji finitywnych skumulowane wykładniki (wartości) kategorii osoby, liczby i strony oraz współwykładniki kategorii trybu i czasu.

Końcówki indicativi/coniunctivi (z wyjątkiem indicativi perfecti activi):

\begin{tabular}{|c|l|l|l|}
\hline \multicolumn{4}{|c|}{ końcówki ind./con. (z wyjątkiem ind. perf. act.) } \\
\hline liczba & \multicolumn{1}{|c|}{ os. } & \multicolumn{1}{c|}{ activi } & \multicolumn{1}{c|}{ passivi } \\
\hline \multirow{4}{*}{$s g}$. & 1. & $-\overline{0},-\mathrm{m}$ & $-\mathrm{ŏr},-\mathrm{r}$ \\
\cline { 2 - 5 } & 2. & $-\mathrm{s}$ & - rìs/-rě \\
\cline { 2 - 4 } & 3. & $-\mathrm{t}$ & - tŭr \\
\hline
\end{tabular}




\begin{tabular}{|l|l|l|l|}
\hline \multicolumn{4}{|c|}{ końcówki ind./con. (z wyjątkiem ind. perf. act.) } \\
\hline liczba & \multicolumn{1}{|c|}{ os. } & \multicolumn{1}{|c|}{ activi } & \multicolumn{1}{c|}{ passivi } \\
\hline \multirow{4}{*}{$p l}$. & 1. & - mŭs & -mŭr \\
\cline { 2 - 5 } & 2. & - tĩs & - -mini \\
\cline { 2 - 5 } & 3. & - nt & -ntŭr \\
\hline
\end{tabular}

Końcówki indicativi perfecti activi:

\begin{tabular}{|c|c|c|}
\hline \multicolumn{3}{|r|}{ końcówki ind. perf. act. } \\
\hline liczba & os. & \\
\hline \multirow{3}{*}{ sg. } & 1. & $-\mathbf{i}$ \\
\hline & 2. & $\begin{array}{l}\text {-isti (-stī) } \\
\end{array}$ \\
\hline & 3. & -it \\
\hline \multirow{3}{*}{ pl. } & 1. & -ímǔs \\
\hline & 2. & -istīs (-stīs) \\
\hline & 3. & -êrŭnt (poet. także -ěrŭnt), -ērě (poet. także -ěrè) \\
\hline
\end{tabular}

Końcówki imperativi:

\begin{tabular}{|c|c|c|c|c|}
\hline \multicolumn{5}{|c|}{ końcówki imperativi } \\
\hline czas & liczba & os. & activi & passivi \\
\hline \multirow{2}{*}{ praes. } & sg. & 2. & -0 & -rẽ \\
\hline & pl. & 2. & - tè & $-\min i$ \\
\hline \multirow{4}{*}{ futuri } & \multirow[t]{2}{*}{ sg. } & 2. & - tō & -tōr \\
\hline & & 3. & - tō & -tơr \\
\hline & \multirow[t]{2}{*}{ pl. } & 2. & -tōtè & - \\
\hline & & 3. & -ntō & -ntŏr \\
\hline
\end{tabular}

Końcówki indicativi / coniunctivi passivi sg. 2. os. (-rĭs/-rē) oraz końcówki indicativi perfecti activi pl. 3. os. (-èrünt/-èrē, poet.: -èrünt/-ërē) są końcówkami izofunkcyjnymi równoległymi (obocznymi). Końcówki indicativi perfecti activi 2. os. sg. -sti i pl. -stīs mają status końcówek równoległych (obocznych) względem (odpowiednio) -isti i -istis tylko dla pewnych klas leksemów. Pozostałe końcówki izofunkcyjne, tj. końcówki indicativi / coniunctivi sg. 1 . os. act. $(-\bar{o},-m)$ i pass. $(-o ̄ r,-r)$, mają charakter komplementarny, a ich dystrybucja uwzględnia przynależność leksemów czasownikowych do określonych klas formalnych oraz typ formacji fleksyjnych tworzonych $\mathrm{z}$ ich udziałem.

Niektóre formacje niefinitywne posiadają końcówki deklinacyjne, będące skumulowanymi wykładnikami wartości kategorii przypadka, liczby i rodzaju. Końcówki te nie różnią się od końcówek określonych klas przymiotników. 


\subsection{WYKŁADNIKI SUFIKSALNE}

Sufiksy czasownikowe stanowią skumulowane (współ)wykładniki (wartości) kategorii trybu, czasu i finitywności. Są one obligatoryjnymi elementami wszystkich czasownikowych formacji morfologicznych.

\subsubsection{Wykładnik indicativi praesentis}

Wykładnikiem tych wartości jest sufiks -ø- dołączany do tematu praesentis czasownika.

W 1. os. sg. dołączane są końcówki: act. -ō, pass. -ŏr.

Przykładowe paradygmaty czasowników:

\begin{tabular}{|c|c|c|c|c|c|}
\hline & $\begin{array}{c}\text { koniugacja I } \\
\text { amō, -äré } \\
\text { 'kochać' } \\
\end{array}$ & $\begin{array}{c}\text { koniugacja II } \\
\text { vidēō, -ēré } \\
\text { 'widzieć' } \\
\end{array}$ & $\begin{array}{c}\text { koniugacja III a } \\
\text { legō, -èré } \\
\text { 'zbierać, 'czytać' } \\
\end{array}$ & $\begin{array}{c}\text { koniugacja III b } \\
\text { capiō, -èré } \\
\text { 'chwytać' }\end{array}$ & $\begin{array}{c}\text { koniugacja IV } \\
\text { punīo, -irè } \\
\text { 'karać' } \\
\end{array}$ \\
\hline & activum & activum & activum & activum & activum \\
\hline \multirow[t]{2}{*}{$\begin{array}{c}\text { sg. } 1 . \\
2 . \\
3 . \\
\text { pl. } 1 . \\
2 . \\
3 . \\
\end{array}$} & $\begin{array}{l}\text { am-ō } \\
\text { amà-s } \\
\text { amà-t } \\
\text { amā-mūs } \\
\text { amà-tís } \\
\text { amă-nt }\end{array}$ & $\begin{array}{l}\text { vidè-ō } \\
\text { vidè-s } \\
\text { vidè-t } \\
\text { vidē-mūs } \\
\text { vidē-tìs } \\
\text { vidè-nt } \\
\end{array}$ & $\begin{array}{l}\text { leg-ō } \\
\text { legì-s } \\
\text { legì-t } \\
\text { legì-mùs } \\
\text { legì-tìs } \\
\text { legǔ-nt }\end{array}$ & $\begin{array}{l}\text { capì-ō } \\
\text { capì-s } \\
\text { capì-t } \\
\text { capì-mǔs } \\
\text { capì-tĩs } \\
\text { capĭŭ-nt } \\
\end{array}$ & $\begin{array}{l}\text { punì-ō } \\
\text { punī-s } \\
\text { punì-t } \\
\text { punì-mǔs } \\
\text { punì-tìs } \\
\text { punìù-nt }\end{array}$ \\
\hline & passivum & passivum & passivum & passivum & passivum \\
\hline $\begin{array}{c}\text { sg. } 1 . \\
2 . \\
3 . \\
\text { pl. } 1 . \\
2 . \\
3 .\end{array}$ & $\begin{array}{l}\text { am-ŏr } \\
\text { amā-rìs (-rè) } \\
\text { amā-tŭr } \\
\text { amā-mūr } \\
\text { amà-mìnī } \\
\text { amà-ntŭr }\end{array}$ & $\begin{array}{l}\text { vidē-ŏr } \\
\text { vidē-rĭs (-rē) } \\
\text { vidē-tŭr } \\
\text { vidē-mŭr } \\
\text { vidē-mìnī } \\
\text { vidè-ntǔr }\end{array}$ & $\begin{array}{l}\text { leg-ŏr } \\
\text { legě-rǐs (-rẽ) } \\
\text { legi-tǔr } \\
\text { legi-mŭr } \\
\text { legi-minini } \\
\text { legǔ-ntǔr }\end{array}$ & 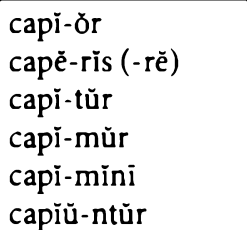 & $\begin{array}{l}\text { punì-ör } \\
\text { puni-rìs (-rě) } \\
\text { puni-tŭr } \\
\text { puni-mūr } \\
\text { puni-mìnì } \\
\text { punīŭ-ntŭr }\end{array}$ \\
\hline
\end{tabular}

Czasownik èssē 'być' w 1. os. sg. przybiera końcówkę - $m$; przed końcówkami rozpoczynającymi się od /m/ lub /n/ występuje wariant tematyczny sŭ-, przed innymi és-; w 2. os. sg. końcówka osobowa ujednoliciła się z wygłosem tematu.

W złożeniach czasownik esse występuje zawsze $\mathrm{w}$ drugiej pozycji ${ }^{1}$. Jeżeli pierwsza część złożenia kończy się na bezdźwięczną zębową /t/, zębowa ta przed wariantem tematycznym sŭ- asymiluje się do /s/, powodując powstanie długiego /ss/, jak np. w possum (wobec potes). W przypadku dźwięcznej zębowej/d/spotyka się ortografię zarówno uwzględniającą asymilację (np. assum wobec adest), jak i zachowującą odrębność notacji zębowej (adsum). Jeżeli pierwsza część złożenia kończy się na samo-

I Omawiane tu formacje tradyjnie określa się terminem złożenia (z esse), mimo iż morfem poprzedzający temat czasownikowy ma raczej charakter prefiksu. 
głoskę, przed wariantem tematycznym ěs- może pojawić się epentetyczna spógłoska /d/, jak np. w prodest (wobec prosum) lub też na granicy morfemów może pojawić się hiat, jak np. w deest (1. os. sg. desum).

Paradygmat czasownika esse i przykładowe paradygmaty czasowników złożonych z esse:

\begin{tabular}{|c|c|c|c|c|c|c|}
\hline & sum, esse & $\begin{array}{c}\text { absum, } \\
\text { abesse }\end{array}$ & $\begin{array}{c}\text { adsum, } \\
\text { adesse }\end{array}$ & $\begin{array}{l}\text { possum, } \\
\text { posse }\end{array}$ & $\begin{array}{c}\text { desum, } \\
\text { deesse }\end{array}$ & $\begin{array}{l}\text { prosum, } \\
\text { prodesse }\end{array}$ \\
\hline sg. 1. & sŭ-m & absŭ-m & $\begin{array}{l}\text { adsŭ-m } \\
\text { (assǔ-m) }\end{array}$ & possŭ-m & desŭ-m & prosū-m \\
\hline 2. & ès & aběs & aděs & potěs & deěs & prodès \\
\hline 3. & ès-t & aběs-t & aděs-t & potěs-t & deěs-t & proděs-t \\
\hline pl. 1. & & absu-mus & $\begin{array}{l}\text { adsu-mus } \\
\text { (assŭ-mŭs) }\end{array}$ & & & prosu-mus \\
\hline 2. & ès-tís & aběs-tĭs & aděs-tīs & potěs-tīs & deěs-tīs & proděs-tīs \\
\hline 3. & sŭ-nt & absǔ-nt & $\begin{array}{l}\text { adsǔ-nt } \\
\text { (assǔ-nt) }\end{array}$ & possǔ-nt & desŭ-nt & prosú-nt \\
\hline
\end{tabular}

Czasownik trzeciej koniugacji fërrē jedynie przed końcówkami rozpoczynający$\mathrm{mi} \operatorname{się~od~} / \mathrm{m} / \mathrm{i} / \mathrm{n} /$ posiada temat zakończony na odpowiednią samogłoskę ( $\mathrm{tj}$. /ǐl lub $/ \check{u} /$ ); w pozostałych przypadkach temat pozbawiony jest wygłosowej samogłoski.

Czasownik trzeciej koniugacji vëllë (activum tantum) posiada warianty tematyczne: vŏl- (1. os. sg.), vī- (2. os. sg.), vŭl- (3. os. sg., 2. os. pl.), vŏlŭ- (1. i 3. os. pl.).

Czasownik trzeciej koniugacji nōllè (activum tantum) posiada tylko formy 1. os. sg. (temat: $n \bar{o} l$-) oraz l. i 3. os. pl. (temat: nōlü-). Pozostałe formy uzupełniane są supletywnie formami czasownika velle z negacją non.

Czasownik trzeciej koniugacji mällè (activum tantum) posiada warianty tematyczne: mäl- (1. os. sg.), mālü- (1. i 3. os. pl.), māvi- (2. os. sg.), māvŭl- (3. os. sg. i 2. os. pl.).

Czasownik czwartej koniugacji irě posiada warianty tematyczne: $\check{e}-(1$ os. sg.), $\check{e} \check{u}$ - (3. os. pl.), $i$ - (w pozostałych formach; w pass. tylko 3. os. sg.).

Wszystkie te czasowniki w l. os. sg. act. przybierają końcówkę -ō, pass. -ōr.

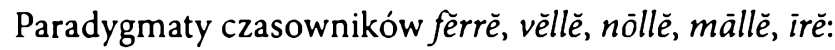

\begin{tabular}{|c|c|c|c|c|c|c|c|}
\hline & \multicolumn{2}{|c|}{$\begin{array}{c}\text { fērō, fērrē } \\
\text { 'nieść, nosić' }\end{array}$} & \multirow{2}{*}{ 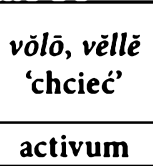 } & \multirow{2}{*}{$\begin{array}{c}\text { nōlō, nōllè } \\
\text { 'nie } \\
\text { chcieć' } \\
\text { activum }\end{array}$} & \multirow{2}{*}{$\begin{array}{c}\text { mälō, } \\
\text { māllé } \\
\text { 'woleć' } \\
\text { activum }\end{array}$} & \multicolumn{2}{|c|}{ 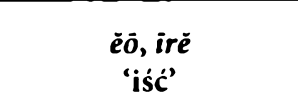 } \\
\hline & activum & passivum & & & & activum & passivum \\
\hline $\begin{array}{r}\text { sg. } 1 . \\
2 . \\
3 . \\
\text { pl. } 1 . \\
2 . \\
3 .\end{array}$ & $\begin{array}{l}\text { fèr-ō } \\
\text { fĕr-s } \\
\text { fër-t } \\
\text { fĕrì-mŭs } \\
\text { fër-tìs } \\
\text { fërŭ-nt }\end{array}$ & 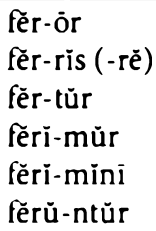 & $\begin{array}{l}\text { vŏl-ō } \\
\text { vī-s } \\
\text { vŭl-t } \\
\text { vŏlǔ-mǔs } \\
\text { vǔl-tís } \\
\text { vŏlǔ-nt }\end{array}$ & $\begin{array}{l}\text { nōl-ō } \\
\text { non vì-s } \\
\text { non vŭl-t } \\
\text { nōlú-mǔs } \\
\text { non vǔl-tīs } \\
\text { nōlǔ-nt }\end{array}$ & $\begin{array}{l}\text { māl-ō } \\
\text { māvi-s } \\
\text { māvūl-t } \\
\text { mālú-mǔs } \\
\text { māvǔl-tīs } \\
\text { mālǔ-nt }\end{array}$ & 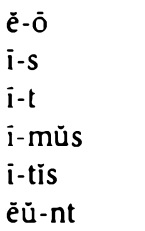 & î-tǔr \\
\hline
\end{tabular}




\subsubsection{Wykładniki indicativi futuri primi}

Stanowią je odpowiednie sufiksy dodawane do tematu praesentis czasownika według następujących zasad:

1. Dla czasowników należących do koniugacji I i II jest to sufiks ukazujący się w czterech wariantach formalnych: $-b \bar{e}-/-b \bar{i}-/-b \bar{u}-/-b-$, w zależności od kontekstu fonetycznego, tj. w zależności od następującego po nim fonemu:

- $-b$-przed samogłoską;

- -bé- $\operatorname{przed} / \mathrm{r} /$;

$\rightarrow \quad-b \check{u}$ - $\operatorname{przed} / \mathrm{n} /$;

- $-b i$ - w pozostałych kontekstach fonetycznych.

W 1. os. sg. dołączane są końcówki: act. -ō, pass. -ör.

2. Dla czasowników należących do koniugacji III i IV są to sufiksy:

- w 1. os. sg. sufiks -ä-;

- w pozostałych formach sufiks - $-\bar{e}-$, który w sylabie zamkniętej inną spółgłoską niz /s/ ulega skróceniu do -ë-;

W 1. os. sg. dołączane są końcówki: act. - $m$, pass. -r.

Przykładowe paradygmaty czasowników:

\begin{tabular}{|c|c|c|c|c|c|}
\hline & $\begin{array}{c}\text { koniugacja I } \\
a m \bar{o},-\bar{a} r \bar{e}\end{array}$ & $\begin{array}{c}\text { koniugacja II } \\
\text { vidēō, -ēré }\end{array}$ & $\begin{array}{c}\text { koniug. IIl a } \\
\text { legō,-ëré }\end{array}$ & $\begin{array}{c}\text { koniuga- } \\
\text { cja III b } \\
\text { capiō, -èré }\end{array}$ & $\begin{array}{c}\text { koniugacja IV } \\
\text { punīō, -iré }\end{array}$ \\
\hline & activum & activum & activum & activum & activum \\
\hline \multirow[t]{2}{*}{$\begin{array}{r}\text { sg. } 1 . \\
2 . \\
3 . \\
\text { pl. } 1 . \\
2 . \\
3 .\end{array}$} & $\begin{array}{l}\text { amā-b-ō } \\
\text { amà-bì-s } \\
\text { amā-bì-t } \\
\text { amā-bì-mǔs } \\
\text { amā-bi-tīs } \\
\text { amā-bù-nt } \\
\end{array}$ & $\begin{array}{l}\text { vidē-b-ō } \\
\text { vidè-bì-s } \\
\text { vidē-bì-t } \\
\text { vidē-bì-mùs } \\
\text { vidē-bì-tís } \\
\text { vidē-bù-nt }\end{array}$ & $\begin{array}{l}\text { leg-ă-m } \\
\text { leg-è-s } \\
\text { leg-è-t } \\
\text { leg-è-mǔs } \\
\text { leg-è-tís } \\
\text { leg-è-nt }\end{array}$ & $\begin{array}{l}\text { capì-à-m } \\
\text { capì-è-s } \\
\text { capì-è-t } \\
\text { capi-è-mùs } \\
\text { capì-è-tìs } \\
\text { capì-è-nt } \\
\end{array}$ & $\begin{array}{l}\text { punì-ă-m } \\
\text { punì-ē-s } \\
\text { punì-è-t } \\
\text { punì-ē-mùs } \\
\text { punì-è-tìs } \\
\text { punì-è-nt }\end{array}$ \\
\hline & passivum & passivum & passivum & passivum & passivum \\
\hline $\begin{array}{r}\text { sg. } 1 . \\
2 . \\
3 . \\
\text { pl. } 1 . \\
2 . \\
3 .\end{array}$ & 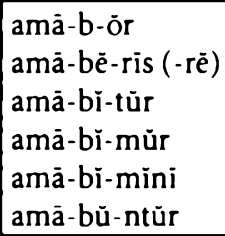 & 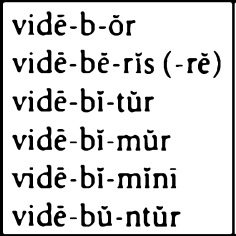 & $\begin{array}{l}\text { leg-à-r } \\
\text { leg-ē-rís (-rẽ) } \\
\text { leg-ē-tŭr } \\
\text { leg-ē-mǔr } \\
\text { leg-è-minni } \\
\text { leg-è-ntùr }\end{array}$ & $\begin{array}{l}\text { capì-à-r } \\
\text { capì-ē-rìs (-rē) } \\
\text { capì-ē-tŭr } \\
\text { capì-ē-mŭr } \\
\text { capì-ē-mìnì } \\
\text { capì-ē-ntŭr }\end{array}$ & 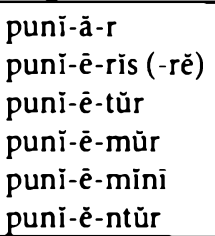 \\
\hline
\end{tabular}

Dla czasownika ěssĕ sufiks ma postać -ø- w 1. os. sg., - -u- w 3. os. pl. , - - - w pozostałych formach; temat występuje w wariancie èr-; w 1. os. sg. przyłączana jest końcówka -ō. W czasownikach złożonych $z$ esse, jeśli pierwsza część złożenia kończy się na samogłoskę, przed tematem (-ër-) może pojawić się epentetyczna spógłoska /d/, jak np. w prodero, lub też na granicy morfemów może pojawić się hiat, jak np. w deero. 
Paradygmat czasownika esse i przykładowe paradygmaty czasowników złożonych $z$ esse:

\begin{tabular}{|c|c|c|c|c|c|c|}
\hline & sum, esse & $\begin{array}{c}\text { absum, } \\
\text { abesse }\end{array}$ & $\begin{array}{c}\text { adsum, } \\
\text { adesse }\end{array}$ & $\begin{array}{c}\text { possum, } \\
\text { posse }\end{array}$ & $\begin{array}{c}\text { desum, } \\
\text { deesse }\end{array}$ & $\begin{array}{l}\text { prosum, } \\
\text { prodesse }\end{array}$ \\
\hline $\begin{array}{r}\text { sg. } 1 . \\
2 . \\
3 . \\
\text { pl. } 1 . \\
2 . \\
3 .\end{array}$ & \begin{tabular}{|l} 
ĕr-ō \\
èr-ì-s \\
èr-ì-t \\
èr-ì-mŭs \\
èr-ì-tīs \\
ĕr-ŭ-nt
\end{tabular} & $\begin{array}{l}\text { abēr-ō } \\
\text { abĕr-ì-s } \\
\text { aběr-ì-t } \\
\text { abĕr-ì-mŭs } \\
\text { abĕr-ì-tìs } \\
\text { aběr-ŭ-nt }\end{array}$ & 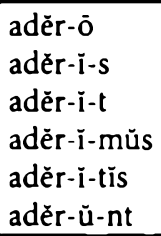 & 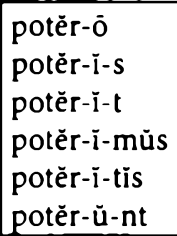 & 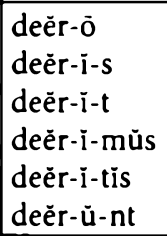 & $\begin{array}{l}\text { proděr-ō } \\
\text { proděr-ì-s } \\
\text { proděr-ì-t } \\
\text { proděr-ì-mūs } \\
\text { proděr-ì-tīs } \\
\text { proděr-ŭ-nt }\end{array}$ \\
\hline
\end{tabular}

Czasowniki III koniugacji: vēllè, nōllè, mällè mają tematy uogólnione w wariantach: vŏl-, nōl-, māl-.

Czasownik IV koniugacji irě tworzy futurum primum tak, jak czasowniki I i II koniugacji, występując $w$ wariancie tematycznym $i$-.

Paradygmaty czasowników fërrē, vēllè, nōllè, mällě, irě:

\begin{tabular}{|c|c|c|c|c|c|c|c|}
\hline & \multicolumn{2}{|c|}{ fërō, fërrë } & \multirow{2}{*}{$\begin{array}{l}\text { vŏlō, véllē } \\
\text { activum }\end{array}$} & \multirow{2}{*}{$\frac{\text { nōlō, nōllè }}{\text { activum }}$} & \multirow{2}{*}{$\begin{array}{c}\text { mälō, } \\
\text { mällé } \\
\text { activum }\end{array}$} & \multicolumn{2}{|c|}{$\check{e} \overline{\boldsymbol{o}}$, îré } \\
\hline & activum & passivum & & & & activum & pass. \\
\hline \begin{tabular}{|c|}
$s g .1$. \\
2. \\
3. \\
pl. 1. \\
2. \\
3.
\end{tabular} & $\begin{array}{l}\text { fër-à-m } \\
\text { fĕr-ē-s } \\
\text { fĕr-è-t } \\
\text { fĕr-ēe-mús } \\
\text { fër-è-tīs } \\
\text { fër-è-nt }\end{array}$ & 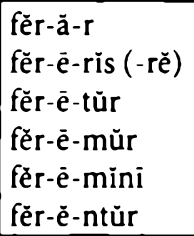 & $\begin{array}{l}\text { vŏl-ă-m } \\
\text { vŏl-ē-s } \\
\text { vŏl-è-t } \\
\text { vŏl-ē-mŭs } \\
\text { vŏl-è-tís } \\
\text { vŏl-è-nt }\end{array}$ & \begin{tabular}{|l|} 
nōl-à-m \\
nōl-ē-s \\
nōl-è-t \\
nōl-ē-mŭs \\
nōl-è-tîs \\
nōl-è-nt \\
\end{tabular} & $\begin{array}{l}\text { māl-à-m } \\
\text { māl-è-s } \\
\text { māl-è-t } \\
\text { māl-ēe-mǔs } \\
\text { māl-è-tīs } \\
\text { māl-è-nt }\end{array}$ & $\begin{array}{l}\text { ì-b-ō } \\
\text { i-bì-s } \\
\text { i-bì-t } \\
\text { i-bì-mŭs } \\
\text { i-bù-tìs } \\
\text { i-bŭ-nt }\end{array}$ & í-bì-tŭr \\
\hline
\end{tabular}

\subsubsection{Wykładniki indicativi imperfecti}

Stanowią je odpowiednie sufiksy dodawane do tematu praesentis czasownika według następujących zasad:

1. Dla czasowników I i II koniugacji jest to sufiks - $b \bar{a}$-; samogłoska tego sufiksu ulega skróceniu do /ă/, jeśli znajduje się w sylabie zamkniętej inną spógłoską niż $/ \mathrm{s} /$.

2. Dla czasowników III i IV koniugacji jest to sufiks -ēbā-; w sufiksie tym samogłoska /ā/ ulega skróceniu do /ă/, jeśli znajdzie się ona w sylabie zamkniętej inną spółgłoską niż /s/.

W 1. os. sg. dołączane są końcówki: act. - m, pass. -r. 
Przykładowe paradygmaty czasowników:

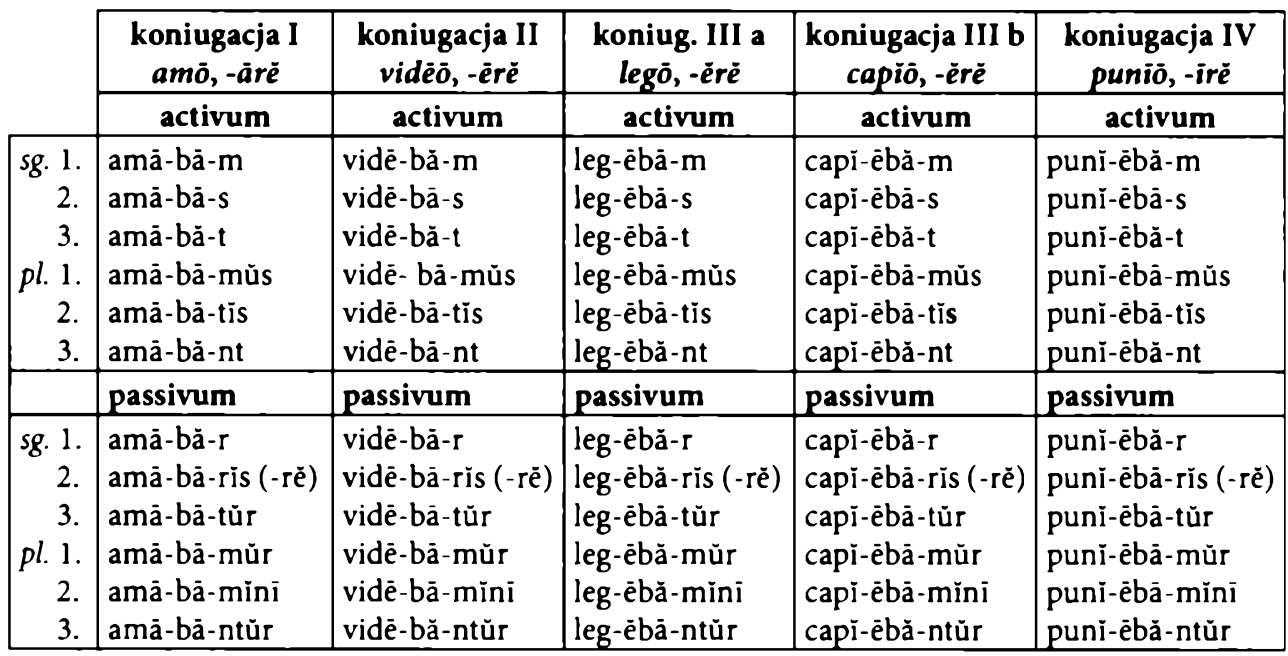

Dla czasownika éssẽ sufiks ma postać - $\bar{a}$ - i ulega skróceniu do - $-\bar{a}-$, jeśli znajduje się w sylabie zamkniętej inną spółgłoską niż /s/; temat występuje w wariancie ěr-; w l. os. sg. przyłączana jest końcówka $-m$. W czasownikach złożonych $z$ esse, jeśli pierwsza część złożenia kończy się na samogłoskę, przed tematem (-ër-) może pojawić się epentetyczna spógłoska /d/, jak np. w proderăt, lub też na granicy morfemów może pojawić się hiat, jak np. w deerăt.

Paradygmat czasownika esse i przykładowe paradygmaty czasowników złożonych $\mathrm{z}$ esse:

\begin{tabular}{|c|c|c|c|c|c|c|}
\hline & sum, esse & $\begin{array}{c}\text { absum, } \\
\text { abesse }\end{array}$ & $\begin{array}{c}\text { adsum, } \\
\text { adesse }\end{array}$ & $\begin{array}{c}\text { possum, } \\
\text { posse }\end{array}$ & $\begin{array}{c}\text { desum, } \\
\text { deesse }\end{array}$ & $\begin{array}{l}\text { prosum, } \\
\text { prodesse }\end{array}$ \\
\hline sg. 1. & èr-à-m & abèr-à-m & adēr-à-m & potèr-ă-m & deěr-ā-m & prodēr-à-m \\
\hline 2. & èr-à-s & abèr-à-s & adēr-ā-s & potèr-à-s & deěr-ā-s & prodèr-à-s \\
\hline 3. & èr-à-t & abèr-à-t & adēr-à-t & potēr-à-t & deěr-ă-t & proděr-à-t \\
\hline pl. 1. & èr-à-mŭs & aběr-ā-mūs & aděr-ā-mǔs & potěr-ā-mǔs & deěr-ā-mŭs & proděr-à-mǔs \\
\hline 2. & èr-ā-tìs & abèr-ā-ť̃s & adèr-ā-tìs & potèr-ā-tìs & deěr-ā-tīs & prodèr-ā-tìs \\
\hline 3. & èr-à-nt & aběr-à-nt & adèr-ă-nt & potěr-à-nt & deěr-ă-nt & proděr-ā-nt \\
\hline
\end{tabular}

Czasowniki III koniugacji: vèllè, nōllè, māllè mają tematy uogólnione w wariantach: vōl-, nōl-, mäl-.

Czasownik IV koniugacji irě tworzy indicativus imperfecti tak, jak czasowniki I i II koniugacji, występując w wariancie tematycznym $i$-. 
Paradygmaty czasowników fêrrěe, vĕllĕ, nōllĕ, mällĕ, irě:

\begin{tabular}{|c|c|c|c|c|c|c|c|}
\hline & \multicolumn{2}{|c|}{ fērō, ferrrē } & \multirow{2}{*}{\begin{tabular}{|c|} 
vōlō, vèllē \\
activum
\end{tabular}} & \multirow{2}{*}{$\frac{\text { nōlō, nōllè }}{\text { activum }}$} & \multirow{2}{*}{$\begin{array}{c}\text { māló, } \\
\text { màllé } \\
\text { activum }\end{array}$} & \multicolumn{2}{|c|}{$\check{e} \bar{e} \overline{0}$, ir } \\
\hline & activum & passivum & & & & activum & pass. \\
\hline sg. 1. & fẽr-ēbă-m & fĕr-ēbă-r & vŏl-ēbă-m & nōl-ēbă-m & māl-ēbă-m & i-bă-m & \\
\hline 2. & fẽr-ēbā-s & fèr-ēbà-rīs (-rě) & vǒl-ēbā-s & nōl-ēbā-s & māl-ēbā-s & i-bā-s & \\
\hline 3. & fêr-ēbă-t & fèr-ēbā-tǔr & vŏl-ēbă-t & nōl-ēbă-t & māl-ēbă-t & i-bả-t & i-bā-tŭr \\
\hline pl. 1. & fẽr-ēbā- & fĕr-ēbā-mūr & vǒl-ēbā- & nōl-èbā- & māl-ēbà- & i-bā-mǔs & \\
\hline & mŭs & & 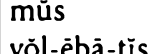 & $\begin{array}{l}\text { mŭs } \\
\text { nōl-ēbā-tīs }\end{array}$ & $\begin{array}{l}\text { mǔs } \\
\text { māl-ēbā-ťss }\end{array}$ & & \\
\hline $\begin{array}{l}2 . \\
3 .\end{array}$ & $\begin{array}{l}\text { lër-ēbā-tīs } \\
\text { fẽr-ëbä-nt }\end{array}$ & $\begin{array}{l}\text { fêr-ēbā-minnì } \\
\text { fër-ēbă-ntūr }\end{array}$ & $\begin{array}{l}\text { vŏl-ēbā-tís } \\
\text { vŏl-ēbă-nt }\end{array}$ & $\begin{array}{l}\text { nōl-ēbả-tīs } \\
\text { nōl-ēbă-nt }\end{array}$ & $\begin{array}{l}\text { māl-ēbā-tìs } \\
\text { māl-ēbă-nt }\end{array}$ & $\begin{array}{l}\text { î-bā-tìs } \\
\text { i-bă-nt }\end{array}$ & \\
\hline
\end{tabular}

\subsubsection{Wykładniki indicativi perfecti}

1. W activum wykładnikiem tym jest sufiks - $\bullet$ - dołączany do tematu perfecti; tematy zakończone na $-v$ mogą $\mathrm{w} 2$. os. sg. i 2 . os. pl. przyłączać uproszczone końców$\mathrm{ki}, \mathrm{tj}$. odpowiednio: -stī i -stīs; temat jest wtedy pozbawiony ostatniej spółgłoski, tj. /v/, np.: ama-stì (obok amav-istī), ama-stiss (obok amav-istis).

Przykładowe paradygmaty czasowników:

\begin{tabular}{|c|c|c|c|}
\hline & $\ddot{a} \boldsymbol{m} \bar{o},-\bar{a} r \grave{e},-\bar{a} v \bar{i},-\bar{a} t u ̈ m$ & mittō, -ërè, misì, missūm & fêrō, fêrrè, tülì, lätūm \\
\hline sg. 1. & àmāv-i & mis-ì & tŭl-ì \\
\hline 2. & ămāv-ìstī (ămā-stī) & mìs-ìstì & tǔl-ìsti \\
\hline 3. & ămāv-ît & mis-it & tūl-ît \\
\hline pl. 1. & ămảv-ìmŭs & mìs-ĭmǔs & tūl-ìmūs \\
\hline 2. & ămāv-isstis (āmā-stīs) & miss-ĩstīs & tŭl-ìstìs \\
\hline 3. & ămāv-èrǔnt (-èrē) & mis-èrǔnt (-ērě) & tǔl-èrǔnt (-ērè) \\
\hline
\end{tabular}

2. W passivum wykładnik ma charakter złożony. Wartość ta realizowana jest bowiem przez formacje analityczne składające się z form participium perfecti danego leksemu czasownikowego oraz form indicativi praesentis czasownika esse ( $w$ funkcji czasownika posiłkowego). Temat fleksyjny czasownika posiłkowego jest wykładnikiem wartości kategorii trybu i czasu, natomiast jego końcówki fleksyjne są wykładnikami wartości kategorii osoby, oraz - wraz z końcówkami participium - współwykładnikami kategorii liczby; temat participium perfecti jest wykładnikiem funkcji leksykalnej, sufiks (zerowy) pasywności, zaś końcówki fleksyjne są współwykładnikami kategorii liczby oraz wykładnikami kategorii rodzaju i przypadka. Z tego względu formacja ta uwzględnia także wymogi związku atrybucji; kategoria przypadka ma charakter klasyfikujący (nominativus tantum). 
Przykładowe paradygmaty czasowników:

\begin{tabular}{|c|c|c|c|}
\hline & $\ddot{a} m \bar{m},-\bar{a} r \grave{e},-\bar{a} v \bar{i},-\bar{a} t u ̈ m$ & mittō, -èré, misi, missüm & fẽrō, fêrrè, tüli, lätūm \\
\hline sg. 1. & ămāt-ŭs, -ă, -ŭm sŭm & mìss-ŭs, -ă, -ŭm sŭm & lāt-ŭs, -ă, -ŭm sŭm \\
\hline 2. & àmāt-ǔs, -ă, -ǔm ès & miss-ǔs, -ă, -ŭm ěs & lāt-ǔs, -ă, -ǔm ěs \\
\hline 3. & àmāt-ǔs, -à, -ùm ěst & miss-ǔs, -ă, -ŭm ěst & lāt-ǔs, -à, -ǔm ěst \\
\hline pl. 1. & àmāt-î, -ae, -à sủmǔs & miss-ī, -ae, -à sǔmǔs & lāt-ì, -ae, -à sǔmǔs \\
\hline 2. & àmāt-ì, -ae, -ă èstĩs & miss-ì, -ae, -ă èstīs & lāt-ì, -ae, -à èstīs \\
\hline 3. & àmāt-ì, -ae, -ă sŭnt & miss-ì, -ae, -ă sŭnt & lāt-ì, -ae, -ă sŭnt \\
\hline
\end{tabular}

\subsubsection{Wykładniki indicativi plusquamperfecti}

1. W activum wykładnikiem jest sufiks -èrā-, którego samogłoska /ā/ ulega skróceniu do /ă/, jeśli znajduje się w sylabie zamkniętej spółgłoską inną niż /s/; sufiks ten dołączany jest do tematu perfecti czasownika; jeśli temat zakończony jest na $-v$, sufiks może przyjąć formę skróconą o postaci -rā-, która dołączana jest do tematu pozbawionego kończącego go - $v$ (np. ama-rā-, obok amav-èrā-).

W 1. os. sg. dołączana jest końcówka - $m$.

Przykładowe paradygmaty czasowników:

\begin{tabular}{|c|c|c|c|}
\hline & $\ddot{a} m \bar{o},-\bar{a} r \check{e},-\bar{a} v \bar{i},-\bar{a} t u ̈ m$ & mîttō, -èrè, misisi, missǔm & férō, fêrrè, tùlì, lätùm \\
\hline sg. 1. & ămāv-èră-m (ămā-ră-m) & mis-èră-m & tŭl-èră-m \\
\hline 2. & àmāv-èrā-s (ămā-rā-s) & mìs-èrā-s & tūl-èrā-s \\
\hline 3. & ămāv-èră-t (ămā-ră-t) & mis-èră-t & tūl-èră-t \\
\hline pl. 1. & ămāv-èrā-mǔs (ămā-rā-mǔs) & mìs-èrā-mǔs & tŭl-èrā-mūs \\
\hline 2. & àmāv-ěrā-tís (ămā-rā-tīs) & mis-èrā-tìs & tǔl-èrā-tìs \\
\hline 3. & àmāv-ěră-nt (ămā-ră-nt) & mis-èră-nt & tŭl-ěră-nt \\
\hline
\end{tabular}

2. W passivum wykładnik ma charakter złożony. Wartość ta realizowana jest bowiem przez formacje analityczne składające się z form participium perfecti danego leksemu czasownikowego oraz form indicativi imperfecti czasownika esse (w funkcji czasownika posiłkowego). Temat fleksyjny czasownika posiłkowego jest wykładnikiem wartości kategorii trybu i czasu, natomiast jego końcówki fleksyjne są wykładnikami wartości kategorii osoby, oraz - wraz z końcówkami participium - współwykładnikami kategorii liczby. Temat participium perfecti jest wykładnikjem funkcji leksykalnej, sufiks (zerowy) pasywności, zaś końcówki fleksyjne są współwykładnikami kategorii liczby oraz wykładnikami kategorii rodzaju i przypadka. $Z$ tego względu formacja ta uwzględnia także wymogi związku atrybucji; kategoria przypadka ma charakter klasyfikujący (nominativus tantum). 
Przykładowe paradygmaty czasowników:

\begin{tabular}{|c|c|c|c|}
\hline & $\ddot{a} m \bar{o},-\bar{a} r \dot{e},-\bar{a} v \bar{i},-\bar{a} t \bar{u} m$ & mittō, -ëré, misì, missüm & fêrō, fêrrè, tüli, lätūm \\
\hline sg. 1. & ămāt-ǔs, -ă, -ŭm ěrăm & mìss-ǔs, -ă, -ŭm ěrăm & lāt-ŭs, -ă, -ŭm ěrăm \\
\hline 2. & àmāt-ǔs, -ă, -ùm ěrās & mīss-ǔs, -ă, -ŭm ěrās & lāt-ǔs, -ă, -ŭm èrās \\
\hline 3. & ămāt-ǔs, -à, -ǔm èrăt & mìss-ǔs, -à, -ǔm ěrăt & lāt-ǔs, -à, -ŭm èrăt \\
\hline pl. 1. & àmāt-ī, -ae, -à èrāmūs & mìss-î, -ae, -à èrāmūs & lāt-ī, -ae, -ă èrāmūs \\
\hline 2. & àmāt-ī, -ae, -à èrātīs & mìss-ī, -ae, -ā êrātīs & lāt-ì, -ae, -à èrātìs \\
\hline 3. & àmāt-ī, -ae, -à èrănt & mìss-î, -ae, -à èrănt & lāt-î, -ae, -à èrănt \\
\hline
\end{tabular}

\subsubsection{Wykładniki indicativi futuri exacti (secundi)}

1. W activum wykładnikiem jest sufiks -ërĭ-, którego samogłoska /ǐl ulega zanikowi, jeśli znajduje się przed inną samogłoską. Sufiks ten dołączany jest do tematu perfecti czasownika. W 1. os. sg. dołączana jest końcówka -ō.

Przykładowe paradygmaty czasowników:

\begin{tabular}{|c|c|c|c|}
\hline & $\ddot{a} m \bar{o},-\bar{a} r \bar{e},-\bar{a} v \bar{i},-\bar{a} t u ̄ m$ & mittō, -èrè, misīi, missūm & fërō, fêrrè, tülì, lätūm \\
\hline sg. 1. & ămāv-ěr-ō & mis-èr-ō & tūl-èr-ō \\
\hline 2. & ămāv-èrì-s & mis-èrì-s & tŭl-èrī-s \\
\hline 3. & ămāv-ěrì-t & mìs-ěrī-t & tŭl-ěrì-t \\
\hline pl. 1. & ămāv-ērì-mǔs & mis-èrì-mŭs & tŭl-ěrì-mūs \\
\hline 2. & ămāv-èrī-tīs & mis-ěrì-tīs & tǔl-èrì-tīs \\
\hline 3. & ămāv-èrĭ-nt & mìs-ěrì-nt & tŭl-ěrī-nt \\
\hline
\end{tabular}

2. W passivum wykładnik ma charakter złożony. Wartość ta realizowana jest bowiem przez formacje analityczne składające się $\mathrm{z}$ form participium perfecti danego leksemu czasownikowego oraz form indicativi futuri primi czasownika esse ( $w$ funkcji czasownika posiłkowego). Temat fleksyjny czasownika posiłkowego jest wykładnikiem wartości kategorii trybu i czasu, natomiast jego końcówki fleksyjne są wykładnikami wartości kategorii osoby, oraz - wraz z końcówkami participium - współwykładnikami kategorii liczby. Temat participium perfecti jest wykładnikiem funkcji leksykalnej, sufiks (zerowy) pasywności, zaś końcówki fleksyjne są współwykładnikami kategorii liczby oraz wykładnikami kategorii rodzaju i przypadka. $Z$ tego względu formacja ta uwzględnia także wymogi związku atrybucji. Kategoria przypadka ma charakter klasyfikujący (nominativus tantum). 
Przykładowe paradygmaty czasowników:

\begin{tabular}{|c|c|c|c|}
\hline & $\check{a} m \bar{o},-\bar{a} r \bar{e},-\bar{a} v \bar{i},-\bar{a} t u ̄ m$ & mittō, -ěrè̃, misi, missūm & férō, fêrrě, tùlī, lātūm \\
\hline sg. 1. & ămāt-ǔs, -ă, -ŭm ěrō & mìss-ǔs, -à, -ŭm èrō & lāt-ǔs, -à, -ǔm ērō \\
\hline 2. & ămāt-ǔs, -ă, -ǔm èrīs & misss-ǔs, -ă, -ǔm ěrìs & lāt-ǔs, -ă, -ŭm èrǐs \\
\hline 3. & àmāt-ǔs, -à, -ǔm èrīt & mìss-ǔs, -ă, -ǔm èrìt & lāt-ǔs, -ā, -ǔm ěrìt \\
\hline pl. 1. & àmāt-ì, -ae, -à èrìmǔs & mìss-ī, -ae, -à èrìmǔs & lāt-ì, -ae, -ă ěrìmǔs \\
\hline 2. & àmāt-ī, -ae, -ā èrītīs & mìss-ì, -ae, -à èrītīs & lāt-î, -ae, -à èrītǐs \\
\hline 3. & ămāt-ī, -ae, -à èrǔnt & mìss-ì, -ae, -à èrūnt & lāt-ì, -ae, -à èrǔnt \\
\hline
\end{tabular}

\subsubsection{Wykładniki coniunctivi praesentis}

1. Dla czasowników I koniugacji wykładnikiem tym jest sufiks -e-e, który ulega skróceniu do -é-, jeśli znajduje się w sylabie zamkniętej inną spółgłoską niż /s/.

2. Dla czasowników koniugacji II-IV wykładnikiem jest sufiks $-\bar{a}-$, który ulega skróceniu do -ä-, jeśli znajduje się w sylabie zamkniętej inną spółgłoską niż /s/. Sufiksy te dołączane są do tematu praesentis. W 1. os. sg. przyłączana jest końcówka act. - $m$, pass. $-r$.

Przykładowe paradygmaty czasowników:

\begin{tabular}{|c|c|c|c|c|c|}
\hline & $\begin{array}{c}\text { koniugacja I } \\
\text { amōo, -äré }\end{array}$ & $\begin{array}{c}\text { koniugacja II } \\
\text { vidēō, -ērè }\end{array}$ & $\begin{array}{c}\text { koniug. III a } \\
\text { legõo,-ēré }\end{array}$ & $\begin{array}{c}\text { koniuga- } \\
\text { cja III b } \\
\text { capiō, -èrè }\end{array}$ & $\begin{array}{c}\text { koniugacja IV } \\
\text { puniō, -iré }\end{array}$ \\
\hline & activum & activum & activum & activum & activum \\
\hline \multirow[t]{2}{*}{\begin{tabular}{|c|} 
sg. 1. \\
2. \\
3. \\
pl. 1. \\
2. \\
3. \\
\end{tabular}} & 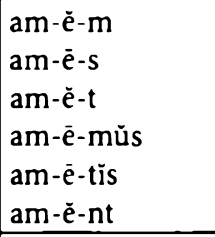 & $\begin{array}{l}\text { vidè-à-m } \\
\text { vidè-à-s } \\
\text { vidè-ă-t } \\
\text { vidè-à-mǔs } \\
\text { vidè-à-tís } \\
\text { vidè-à-nt } \\
\end{array}$ & $\begin{array}{l}\text { leg-à-m } \\
\text { leg-ā-s } \\
\text { leg-ă-t } \\
\text { leg-ā-mǔs } \\
\text { leg-ā-tĩs } \\
\text { leg-ă-nt } \\
\end{array}$ & $\begin{array}{l}\text { capì-à-m } \\
\text { capì-à-s } \\
\text { capì-à-t } \\
\text { capì-à-mǔs } \\
\text { capi-à-tìs } \\
\text { capì-ă-nt } \\
\end{array}$ & $\begin{array}{l}\text { punì-ă-m } \\
\text { punì-ā-s } \\
\text { punì-ă-t } \\
\text { punì-à-mǔs } \\
\text { punì-ā-tĭs } \\
\text { punì-ă-nt } \\
\end{array}$ \\
\hline & passivum & passivum & passivum & passivum & passivum \\
\hline \begin{tabular}{|c|} 
sg. 1. \\
2. \\
3. \\
pl. 1. \\
2. \\
3.
\end{tabular} & 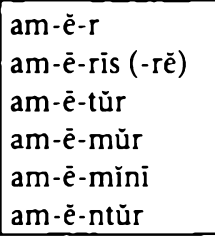 & 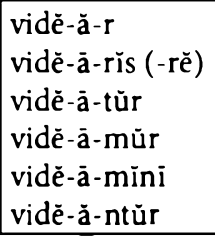 & $\begin{array}{l}\text { leg-à-r } \\
\text { leg-ā-rìs (-rẽ) } \\
\text { leg-ā-tǔr } \\
\text { leg-à-mŭr } \\
\text { leg-à-minni } \\
\text { leg-à-ntǔr }\end{array}$ & $\begin{array}{l}\text { capì-à-r } \\
\text { capì-à-rìs (-rẽ) } \\
\text { capì-ā-tǔr } \\
\text { capì-ā-mŭr } \\
\text { capì-à-mìnì } \\
\text { capì-ă-ntǔr }\end{array}$ & 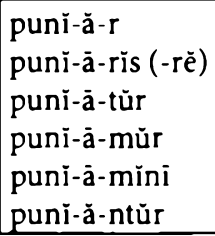 \\
\hline
\end{tabular}

Dla czasownika esse wykładnikiem jest sufiks -i-, którego samogłoska ulega skróceniu do /î/, jeśli znajduje się w sylabie zamkniętej inną spółgłoską niż /s/. Sufiks ten dołączany jest do tematu praesentis, który przyjmuje uogólnioną postać s-. W 1 . os. $s g$. dodawana jest końcówka $-m$. W czasownikach złożonych $z$ esse, jeśli pierwsza część złożenia kończy się na bezdźwięczną zębową /t/, zębowa ta asymiluje się do /s/, 
powodując powstanie długiego /ss/, jak np. w possim (wobec potes). W przypadku dźwięcznej zębowej /d/ spotyka się ortografię zarówno uwzględniającą asymilację (np. assit wobec adest), jak i zachowującą odrębność notacji zębowej (adsit).

Paradygmat czasownika esse i przykładowe paradygmaty czasowników złożonych z esse:

\begin{tabular}{|c|c|c|c|c|c|c|}
\hline & sum, esse & $\begin{array}{c}\text { absum, } \\
\text { abesse }\end{array}$ & adsum, adesse & $\begin{array}{c}\text { possum, } \\
\text { posse }\end{array}$ & $\begin{array}{l}\text { desum, } \\
\text { deesse }\end{array}$ & $\begin{array}{l}\text { prosum, } \\
\text { prodesse }\end{array}$ \\
\hline sg. 1. & $s-i-m$ & abs-i-m & ads-i-m (ass-ì-m) & poss-i-m & des-i-m & pros-i-m \\
\hline 2. & $s-\bar{i}-s$ & abs-ī-s & ads-ī-s (ass-ī-s) & poss-ī-s & des-î-s & pros-i-s \\
\hline 3. & $s-\bar{i}-\mathrm{t}$ & abs-î-t & ads $-\bar{i}-t($ ass $-\grave{i}-t)$ & poss $-\mathrm{i}-\mathrm{t}$ & des-î-t & pros-î-t \\
\hline pl. 1. & $s$-î-mǔs & abs-i-mŭs & ads-i-mǔs (ass-ī-mǔs) & poss-î-mŭs & des-i-mŭs & pros-i-mŭs \\
\hline 2. & $s$-ì-tìs & abs-î-tīs & ads-i-tīs (ass-i-tīs) & poss-i-tīs & des-î-tīs & pros-i-tìs \\
\hline 3. & $s-\bar{i}-n t$ & abs-ì-nt & ads-î-nt (ass-ì-nt) & poss-i-nt & des-i-nt & pros-i-nt \\
\hline
\end{tabular}

Czasownik ferre przybiera wykładniki właściwe czasownikom koniugacji III.

Dla czasowników vèllè, nōllè, mällè sufiks ma postać -ī-. Jego samogłoska ulega skróceniu do /îl, jeśli znajduje się w sylabie zamkniętej inną spółgłoską niż /s/. Tematy praesentis czasowników występują $\mathrm{w}$ wariantach odpowiednio: vēl-, nōl-, māl-. W 1. os. sg. przystępuje końcówka -m.

Czasownik irě przybiera wykładniki właściwe czasownikom IV koniugacji. Występuje w uogólnionym wariancie tematu praesentis $\check{e}$-. W 1. os. sg. łączy się z końcówką - $m$.

Paradygmaty czasowników: fẽrrē, vēllè, nōllè, mällè, irě:

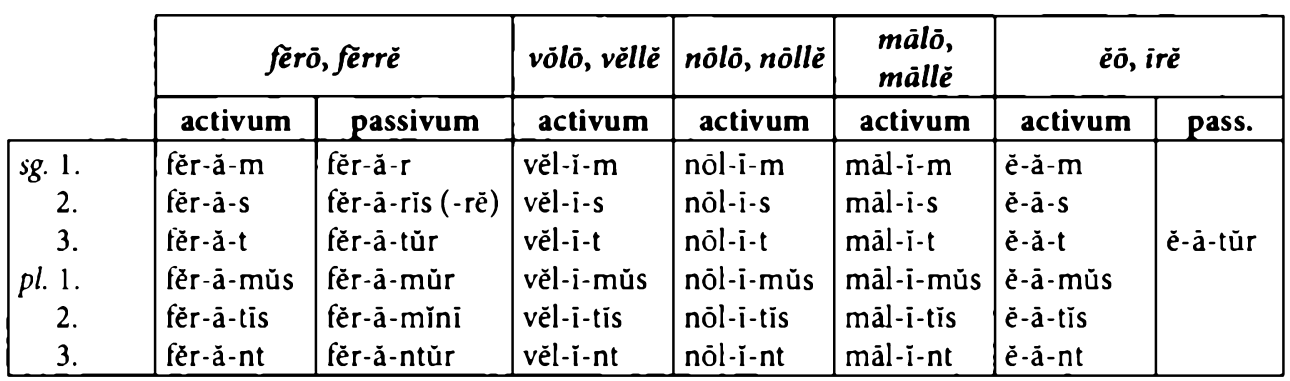

\subsubsection{Wykładniki coniunctivi imperfecti}

Wykładnikiem tych wartości jest sufiks -rē-, którego samogłoska ulega skróceniu do /ěl, jeśli znajduje się w sylabie zamkniętej spółgłoską inną niż /s/.

Sufiks ten dołączany jest do tematu praesentis.

W l. os. sg. przyłączana jest końcówka act. -m, pass. -r. 
Przykładowe paradygmaty czasowników:

\begin{tabular}{|c|c|c|c|c|c|}
\hline & $\begin{array}{c}\text { koniugacja I } \\
a m o \overline{,},-\bar{a} r \bar{e}\end{array}$ & $\begin{array}{c}\text { koniugacja II } \\
\text { vidēō, -ēéré }\end{array}$ & $\begin{array}{c}\text { koniug. III a } \\
\text { legō, -èré }\end{array}$ & \begin{tabular}{|c|} 
koniugacja III b \\
capiō, -èré
\end{tabular} & $\begin{array}{c}\text { koniugacja IV } \\
\text { punīō,-iré }\end{array}$ \\
\hline & activum & activum & activum & activum & activum \\
\hline \multirow[t]{2}{*}{$\begin{aligned} & g . 1 . \\
& 2 . \\
& 3 . \\
& \text { pl. } 1 . \\
& 2 . \\
& 3 .\end{aligned}$} & $\begin{array}{l}\text { amā-rē-m } \\
\text { amā-rē-s } \\
\text { amā-rè-t } \\
\text { amā-rē-mŭs } \\
\text { amā-rē-tīs } \\
\text { amā-rè-nt } \\
\end{array}$ & $\begin{array}{l}\text { vidē-rè-m } \\
\text { vidē-rē-s } \\
\text { vidē-rè-t } \\
\text { vidē-rē-mǔs } \\
\text { vidē-rē-tīs } \\
\text { vidē-rè -nt }\end{array}$ & 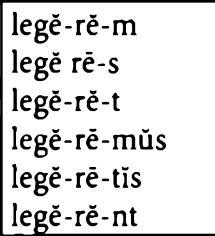 & $\begin{array}{l}\text { capè-rè-m } \\
\text { capè rē-s } \\
\text { capè-rè-t } \\
\text { capè-rè-mŭs } \\
\text { capè-rè-tīs } \\
\text { capè-rè-nt }\end{array}$ & $\begin{array}{l}\text { punī-rè-m } \\
\text { puni-rē-s } \\
\text { puni-rè-t } \\
\text { puni-rē-mùs } \\
\text { puni-rē-tīs } \\
\text { puni-rè-nt }\end{array}$ \\
\hline & passivum & passivum & passivum & passivum & passivum \\
\hline $\begin{array}{r}\text { sg. } 1 . \\
2 . \\
3 . \\
\text { pl. } 1 . \\
2 . \\
3 .\end{array}$ & $\begin{array}{l}\text { amā-rè-r } \\
\text { amā-rē-rǐs (-rě) } \\
\text { amā-rē-tǔr } \\
\text { amā-rē-mŭr } \\
\text { amā-rē-mīnì } \\
\text { amā-rè-ntŭr }\end{array}$ & 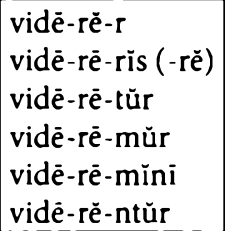 & $\begin{array}{l}\text { legè-rè-r } \\
\text { legè-rē-rìs (-rè) } \\
\text { legè-rē-tŭr } \\
\text { legè-rē-mŭr } \\
\text { legè-rē-mìnì } \\
\text { legè-rè-ntŭr }\end{array}$ & $\begin{array}{l}\text { capè-rè-r } \\
\text { capè-rē-rīs (-rě) } \\
\text { capè-rē-tŭr } \\
\text { capè-rē-mŭr } \\
\text { capè-rē-minì } \\
\text { capè-rè-ntŭr }\end{array}$ & $\begin{array}{l}\text { puni-rè-r } \\
\text { puni-rē-rīs (-rē) } \\
\text { puni-rē-tŭr } \\
\text { puni-rē-mūr } \\
\text { puni-rē-mìnì } \\
\text { puni-rē-ntŭr }\end{array}$ \\
\hline
\end{tabular}

Czasownik ěssě, przybierając sufiks -rē- (-rě-), ma uogólniony wariant tematyczny o postaci fŏ-. Równoległą i powszechniej stosowaną (zwłaszcza w złożeniach) formacją jest jednak forma $z$ uogólnionym tematem ěs- i sufiksem -sē-, w którym samogłoska ulega skróceniu do /ěl, jeśli znajduje się w sylabie zamkniętej spółgłoską inną niż /s/. W czasownikach złożonych z esse, jeśli pierwsza część złożenia kończy się na samogłoskę, przed tematem (-ěs-) może pojawić się epentetyczna spógłoska /d/, jak np. w prodesset, lub też na granicy morfemów może pojawić się hiat, jak np. w deesset. W formach leksemu posse temat czasownika ma ujednoliconą postać $s-$, wskutek czego poprzedzająca zębowa /t/ uległa asymilacji, a następnie zanikowi przed /s-se-/.

W l.os. sg. przyłączana jest końcówka -m.

Paradygmat czasownika esse i przykładowe paradygmaty czasowników złożonych z esse:

\begin{tabular}{|c|c|c|c|c|c|c|}
\hline & sum esse & $\begin{array}{c}\text { absum, } \\
\text { abesse }\end{array}$ & $\begin{array}{c}\text { adsum, } \\
\text { adesse }\end{array}$ & $\begin{array}{l}\text { possum, } \\
\text { posse }\end{array}$ & $\begin{array}{c}\text { desum, } \\
\text { deesse }\end{array}$ & $\begin{array}{l}\text { prosum, } \\
\text { prodesse }\end{array}$ \\
\hline sg. 1. & $\begin{array}{l}\text { ès-sě-m } \\
\text { (fŏ-rĕ-m) }\end{array}$ & aběs-sě-m & aděs-sě-m & pos-sè-m & deěs-sě-m & proděs-sè-m \\
\hline 2. & $\begin{array}{l}\text { ès-sē-s } \\
\text { (fŏ-rē-s) }\end{array}$ & aběs-sē-s & adēs-sē-s & pos-sē-s & deěs-sē-s & prodēs-sē-s \\
\hline 3. & $\begin{array}{l}\text { ès-sẽ-t } \\
(\text { fō-rĕ-t) }\end{array}$ & abēs-sè-t & adès-sēe-t & pos-sè-t & deěs-sē-t & prodès-sè-t \\
\hline pl. 1. & $\begin{array}{l}\text { ès-sē-mǔs } \\
\text { (fö-ré-mŭs) }\end{array}$ & aběs-sē-mūs & adēs-sē-mǔs & pos-sē-mŭs & deěs-sē-mǔs & proděs-sē-mǔs \\
\hline 2. & $\begin{array}{l}\text { ès-sē-tĭs } \\
\text { (fŏ-rē-tís) }\end{array}$ & aběs-sēe-tĭs & adēs-sēe-tìs & pos-sē-tìs & deěs-sē-tĭs & prodès-sē-līs \\
\hline 3. & $\begin{array}{l}\text { ès-sè-nt } \\
\text { (fŏ-rĕ-nt) }\end{array}$ & aběs-sè-nt & adès-sè-nt & pos-sè-nt & deěs-sě-nt & prodēs-sè-nt \\
\hline
\end{tabular}


Czasowniki fërrě i irĕ przybierają sufiks -rēe-, natomiast czasowniki vĕllè, nōllè i mällè sufiks -lēe-. Samogłoska tych sufiksów ulega skróceniu do /ěl, jeśli znajduje się w sylabie zamkniętej spółgłoską inną niż /s/. Czasownikowe tematy praesentis ujednolicone są w wariantach odpowiednio: fër-, i-, vël-, nōl-, mäl-.

$\mathrm{W}$ l. os. sg. przyłączana jest końcówka activi -m, passivi -r.

Paradygmaty czasowników: fẽrrè, vēllè, nōllē, mällè, ìrē:

\begin{tabular}{|c|c|c|c|c|c|c|c|}
\hline & \multicolumn{2}{|c|}{ fêrō, fêrreè } & \multirow{2}{*}{\begin{tabular}{|c|} 
vōlō, véllē \\
activum
\end{tabular}} & \multirow{2}{*}{$\frac{\text { nōlō, nōllēe }}{\text { activum }}$} & \multirow{2}{*}{$\begin{array}{c}\text { mālō, } \\
\text { māllè }\end{array}$} & \multicolumn{2}{|c|}{$\check{e} \bar{e} \overline{,}$ îré } \\
\hline & activum & passivum & & & & activum & passivum \\
\hline $\begin{array}{r}\text { sg. } 1 . \\
2 . \\
3 . \\
\text { pl. } 1 . \\
2 . \\
3 .\end{array}$ & 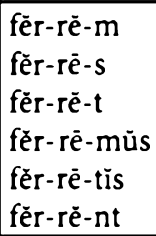 & 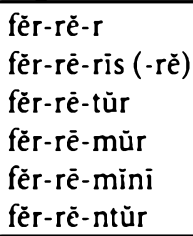 & $\begin{array}{l}\text { vèl-lè-m } \\
\text { vẽl-lè-s } \\
\text { vēl-lè-t } \\
\text { vēl-lè-mùs } \\
\text { vēl-lè-tìs } \\
\text { vēl-lè-nt }\end{array}$ & $\begin{array}{l}\text { nōl-lè-m } \\
\text { nōl-lè-s } \\
\text { nōl-lè-t } \\
\text { nōl-lē-mús } \\
\text { nōl-lēetis } \\
\text { nōl-lè-nt }\end{array}$ & $\begin{array}{l}\text { māl-lè-m } \\
\text { māl-lē-s } \\
\text { māl-lè-t } \\
\text { māl-lē-mūs } \\
\text { māl-lē-tìs } \\
\text { māl-lè-nt }\end{array}$ & $\begin{array}{l}\text { i-rè-m } \\
\text { i-rē-s } \\
\text { i-rè-t } \\
\text { i-rē-mùs } \\
\text { i-rē-tìs } \\
\text { i-rè-nt }\end{array}$ & i-rē-tǔr \\
\hline
\end{tabular}

\subsubsection{Wykładniki coniunctivi perfecti}

1. W activum wykładnikiem jest sufiks -èri-. Sufiks ten dołączany jest do tematu perfecti czasownika. Jeśli temat zakończony jest na $-v$, sufiks może przyjąć formę skróconą -ri-, która dołączana jest do tematu pozbawionego kończącej go spółgłoski, np. ama-ri- (obok amav-èri-).

W 1. os. sg. dołączana jest końcówka - $m$.

Przykładowe paradygmaty czasowników:

\begin{tabular}{|c|c|c|c|}
\hline & $\ddot{a} \dot{m} \bar{o},-\bar{a} r \grave{e},-\bar{a} v \bar{i},-\bar{a} t u ̄ m$ & mittō, -èrēe, misī, misssūm & férō, fêrrè, tülì, lätūm \\
\hline sg. 1. & àmāv-ěrì-m (āmā-rī-m) & mis-ěrì-m & tǔl-èrì-m \\
\hline 2. & ămāv-ěrì-s (ămā-rì-s) & mis-èrì-s & tŭl-èrì-s \\
\hline 3. & àmāv-èrì-t (ămā-rì-t) & mis-èrì-t & tǔl-ěrī-t \\
\hline pl. 1. & àmāv-ěrì-mǔs (ămā-rì-mūs) & mìs-ěrì-mŭs & tūl-èrî-mǔs \\
\hline 2. & àmāv-èrī-tìs (àmả-rī-tīs) & mis-ěrì-tīs & tǔl-ěrī-tìs \\
\hline 3. & àmāv-èrì-nt (àmā-rì-nt) & mis-èrì-nt & tül-èrì-nt \\
\hline
\end{tabular}

2. W passivum wykładnik ma charakter złożony. Wartość ta realizowana jest bowiem przez formacje analityczne składające się $\mathbf{z}$ form participium perfecti danego leksemu czasownikowego oraz form coniunctivi praesentis czasownika esse (w funkcji czasownika posiłkowego). Temat fleksyjny czasownika posiłkowego jest wykładnikiem wartości kategorii trybu i czasu, natomiast jego końcówki fleksyjne są wykładnikami wartości kategorii osoby, oraz - wraz z końcówkami participium - współwykładnikami kategorii liczby. Temat participium perfecti jest wykładnikiem funkcji leksykalnej, sufiks (zerowy) pasywności, zaś końców- 
ki fleksyjne są współwykładnikami kategorii liczby oraz wykładnikami kategorii rodzaju i przypadka. $Z$ tego względu formacja ta uwzględnia także wymogi związku atrybucji. Kategoria przypadka ma charakter klasyfikujący (nominativus tantum).

Przykładowe paradygmaty czasowników:

\begin{tabular}{|c|c|c|c|}
\hline & $\ddot{a} \boldsymbol{m} \bar{o},-\bar{a} r \bar{e},-\bar{a} v \bar{i},-\bar{a} t u ̈ m$ & mittō, -ërě, misī, missǔm & fẽrō, fêrrē, tülì, lätüm \\
\hline sg. 1. & àmāt-ŭs, -ă, -ŭm sìm & mǐss-ŭs, -ă, -ŭm sìm & lāt-ŭs, -ă, -ǔm sìm \\
\hline 2. & ămāt-ǔs, -ă, -ŭm siss & misss-ǔs, -ă, -ŭm sìs & lāt-ǔs, -à, -ŭm sīs \\
\hline 3. & ămāt-ǔs, -ă, -ŭm sĭt & mìss-ǔs, -ă, -ŭm sĭt & lāt-ūs, -ă, -ŭm sīt \\
\hline pl. 1. & ămāt-ì, -ae, -ă sīmǔs & mĭss-ī, -ae, -ă sīmŭs & lāt-ì, -ae, -ă sīmǔs \\
\hline 2. & àmāt-ì, -ae, -ã sìtĩs & misss-ì, -ae, -à sitīs & làt-ì, -ae, -ă sītīs \\
\hline 3. & àmāt-î, -ae, -à sinnt & misss-i, -ae, -ă sint & làt-ì, -ae, -à sìnt \\
\hline
\end{tabular}

\subsubsection{Wykładniki coniunctivi plusquamperfecti}

1. W activum wykładnikiem jest sufiks -ǐssēe-, którego samogłoska /è/ ulega skróceniu do /ě/, jeśli znajduje się w sylabie zamkniętej spółgłoską inną niż /s/. Sufiks ten dołączany jest do tematu perfecti czasownika. Jeśli temat zakończony jest na $-v$, sufiks może przyjąć formę skróconą -ssē- (-ssě-), która dołączana jest do tematu pozbawionego kończącej go spółgłoski, np. ama-ssē- (obok amav-issē-).

W 1. os. sg. dołączana jest końcówka - $m$.

Przykładowe paradygmaty czasowników:

\begin{tabular}{|c|c|c|c|}
\hline & $\ddot{a} m \bar{o},-\bar{a} r \grave{e},-\bar{a} v \bar{i},-\bar{a} t u ̈ m$ & mittō, -èrè, misì, missüm & férō, fêrrè, tüli, lätūm \\
\hline sg. 1. & àmāv-ĩssè-m (āmā-ssē-m) & mis-ĩssě-m & tŭl-ĩssě-m \\
\hline 2. & ămāv-īssē-s (ămā-ssē-s) & mis-ìssēe-s & tŭl-ĩssēe-s \\
\hline 3. & ămāv-ìssè-t (àmā-ssē-t) & mis-ìssè-t & tūl-īssè-t \\
\hline pl. 1. & ămāv-ìssē-mǔs (ămā-ssē-mǔs) & mis-ìssē-mǔs & tūl-īssē-mǔs \\
\hline 2. & ămāv-ĩssē-tīs (ămā-ssēe-tīs) & mis-īssē-tīs & tŭl-īssē-tĩs \\
\hline 3. & ămāv-ìssě-nt (ămā-ssě-nt) & mīs-ìssè-nt & tŭl-ìssè-nt \\
\hline
\end{tabular}

2. W passivum wykładnik ma charakter złożony. Wartość ta realizowana jest bowiem przez formacje analityczne składające się z participium perfecti danego leksemu czasownikowego oraz form coniunctivi imperfecti czasownika esse ( $w$ funkcji czasownika posiłkowego). Temat fleksyjny czasownika posiłkowego jest wykładnikiem wartości kategorii trybu i czasu, natomiast jego końcówki fleksyjne są wykładnikami wartości kategorii osoby, oraz - wraz z końcówkami participium - współwykładnikami kategorii liczby. Temat participium perfecti jest wykładnikiem funkcji leksykalnej, sufiks (zerowy) pasywności, zaś końcówki fleksyjne są współwykładnikami kategorii liczby oraz wykładnikami kategorii rodzaju i przy- 
padka. Z tego względu formacja ta uwzględnia także wymogi związku atrybucji. Kategoria przypadka ma charakter klasyfikujący (nominativus tantum).

Przykładowe paradygmaty czasowników:

\begin{tabular}{|c|c|c|c|}
\hline & ămō, -ärě, $-\bar{a} v \bar{i},-\bar{a} t u ̄ m$ & mittō, -èrè̃, misi, missǔm & fẽrō, fêrrè, tùli, lätùm \\
\hline sg. 1. & ămāt-ǔs, -ă, -ǔm ěssěm & mìss-ǔs, -ă, -ŭm èssěm & lāt-ǔs, -ă, -ǔm èssěm \\
\hline 2. & ămāt-ǔs, -ă, -ǔm ěssēs & mìss-ǔs, -ă, -ŭm ěssēs & lāt-ŭs, -ă, -ŭm èssēs \\
\hline 3. & ămāt-ǔs, -ă, -ŭm ěssēt & mìss-ǔs, -ă, -ǔm ěssět & lāt-ǔs, -ă, -ǔm èssět \\
\hline pl. 1. & ămāt-ì, -ae, -ă ěssēmǔs & mìss-î, -ae, -ă èssēmǔs & lāt-ì, -ae, -à èssēmǔs \\
\hline 2. & ămāt-ì, -ae, -à ěssētīs & mìss-ī, -ae, -ă èssētīs & lāt-ì, -ae, -à èssètĩs \\
\hline 3. & ămāt-ì, -ae, -ă èssěnt & mìss-ī, -ae, -ă ěssěnt & lāt-ì, -ae, -à ěssěnt \\
\hline
\end{tabular}

\subsubsection{Wykładniki imperativi}

Wykładnikiem imperativi jest $\mathrm{z}$ jednej strony sufiks - $\emptyset$ - dodany do tematu praesentis, z drugiej zaś określone końcówki (odrębne od końcówek indicativi / coniunctivi), które oprócz stanowienia współwykładników tej wartości kategorii trybu, są także wykładnikami określonych wartości kategorii czasu, strony, liczby i osoby.

Przykładowe paradygmaty czasowników w imperatiwie:

\begin{tabular}{|c|c|c|c|c|c|c|c|}
\hline & & & $\begin{array}{l}\text { koniug. I } \\
a m \bar{o},-\bar{a} r \bar{e}\end{array}$ & $\begin{array}{l}\text { koniug. II } \\
\text { vidéō, -ērēe }\end{array}$ & $\begin{array}{c}\text { koniug. III a } \\
\text { legō, -ēré }\end{array}$ & $\begin{array}{c}\text { koniug. III b } \\
\text { capiō, -èrè }\end{array}$ & $\begin{array}{l}\text { koniug. IV } \\
\text { puniō, -iré }\end{array}$ \\
\hline \multirow{2}{*}{ praes. } & act. & $\begin{array}{l}\text { sg. } 2 \\
\text { pl. } 2 .\end{array}$ & $\begin{array}{l}\text { amā } \\
\text { amā-tè }\end{array}$ & $\begin{array}{l}\text { vidē } \\
\text { vidē-tè }\end{array}$ & $\begin{array}{l}\text { legè } \\
\text { legí-tè }\end{array}$ & $\begin{array}{l}\text { capè } \\
\text { capí-tè }\end{array}$ & $\begin{array}{l}\text { punī } \\
\text { puni-tè }\end{array}$ \\
\hline & pass. & $\begin{array}{l}\text { sg. } 2 \\
\text { pl. } 2 .\end{array}$ & $\begin{array}{l}\text { amā-rè } \\
\text { amà-mìnì }\end{array}$ & $\begin{array}{l}\text { vidè-rè } \\
\text { vidē-minni }\end{array}$ & $\begin{array}{l}\text { legè-rẽ } \\
\text { legì-minì }\end{array}$ & $\begin{array}{l}\text { capè-rè } \\
\text { capi-minini }\end{array}$ & $\begin{array}{l}\text { punì-rè } \\
\text { puni-minìi }\end{array}$ \\
\hline \multirow[t]{2}{*}{ fut. } & act. & $\begin{array}{r}\text { sg. } 2 . \\
3 . \\
\text { pl. } 2 \\
3 .\end{array}$ & $\begin{array}{l}\text { amā-tō } \\
\text { amā-tō } \\
\text { amā-tōtè } \\
\text { amà-ntō }\end{array}$ & $\begin{array}{l}\text { vidē-tō } \\
\text { vidē-tō } \\
\text { vidē-tōtē } \\
\text { vidē-ntō }\end{array}$ & $\begin{array}{l}\text { legì-tō } \\
\text { legí-tō } \\
\text { legí-tōtè } \\
\text { legù-ntō }\end{array}$ & $\begin{array}{l}\text { capì-tō } \\
\text { capi-tōo } \\
\text { capi-tōtě } \\
\text { capiù-ntō }\end{array}$ & $\begin{array}{l}\text { puni-tō } \\
\text { puni-tō } \\
\text { puni-tōtě } \\
\text { puniùu-ntō }\end{array}$ \\
\hline & pass. & $\begin{aligned} \text { sg. } 2 . \\
3 . \\
\text { pl. } 3 .\end{aligned}$ & $\begin{array}{l}\text { amā-tǒr } \\
\text { amā-tǒr } \\
\text { amā-ntǒr }\end{array}$ & $\begin{array}{l}\text { vidē-tơr } \\
\text { vidē-tǒr } \\
\text { vidē-ntōr }\end{array}$ & $\begin{array}{l}\text { legì-tŏr } \\
\text { legì-tŏr } \\
\text { legù-ntōr }\end{array}$ & $\begin{array}{l}\text { capì-tŏr } \\
\text { capi-tǒr } \\
\text { capiūu-ntǒr }\end{array}$ & $\begin{array}{l}\text { puni-tǒr } \\
\text { puni-tǒr } \\
\text { puniǔ-ntŏr }\end{array}$ \\
\hline
\end{tabular}

Czasownik ěssě ma uogólniony temat ěs-, z wyjątkiem 3. os. pl. futuri, gdzie występuje temat $s \breve{u}$-.

Od czasowników vēllě i mällè nie są używane formy imperatiwu. Czasownik nōllẽ ma uogólniony temat nōli-, $\mathrm{z}$ wyjątkiem 3. os. pl. futuri, gdzie występuje temat nōlü-.

Czasownik irě ma uogólniony temat $\bar{i}-, \mathrm{z}$ wyjątkiem 3. os. pl. futuri, gdzie występuje temat $\bar{e} \bar{u}$-. 
Temat czasowników: dicěrě, ducērě, facěrē, fërrě w 2. os. sg. praesentis activi pozbawiony jest wygłosowej samogłoski (oprócz facērě także wtedy, jeśli czasowniki te stanowią podstawę złożeń). Temat czasownika fêrrě pozbawiony jest tej samogłoski także w pozostałych formach, $\mathrm{z}$ wyjątkiem 2. os. pl. praesentis passivi (férĭ-) oraz 3. os. pl. futuri activi i passivi (ferrü-).

\subsubsection{Wykładniki participii praesentis activi}

1. Dla czasowników koniugacji I i II wykładnikiem jest sufiks - nt-, w nominatiwie singularis sufiks - ns-.

2. Dla czasowników koniugacji III i IV wykładnikiem jest sufiks -ënt-, w nominatiwie singularis sufiks -èns-.

Sufiksy te dołączane są do tematu praesentis. Przyłączają one końcówki deklinacyjne III deklinacji (typ mieszany); w nominatiwie singularis końcówką jest -ø; końcówki deklinacyjne są skumulowanymi wykładnikami (wartości) kategorii przypadka, liczby i rodzaju, współtworząc paradygmat o charakterze przymiotnikowym.

Formy participium praesentis activi przykładowych czasowników:

\begin{tabular}{|c|c|c|c|c|c|}
\hline & $\begin{array}{l}\text { koniug. I } \\
a m \bar{o},-\bar{a} r e ́\end{array}$ & $\begin{array}{l}\text { koniug. II } \\
\text { vidēōó, -éré }\end{array}$ & $\begin{array}{c}\text { koniug. III a } \\
\text { legōo, -èré }\end{array}$ & $\begin{array}{c}\text { koniug. III b } \\
\text { capiō, -èré }\end{array}$ & $\begin{array}{l}\text { koniug. IV } \\
\text { puniō, -iré }\end{array}$ \\
\hline $\begin{array}{l}\text { nom. sg. } \\
\text { gen. sg. }\end{array}$ & $\begin{array}{l}\text { amā-ns } \\
\text { amă-nt-ìs }\end{array}$ & $\begin{array}{l}\text { vidē-ns } \\
\text { vidè-nt-iss }\end{array}$ & $\begin{array}{l}\text { leg-ēns } \\
\text { leg-ènt-ĩs }\end{array}$ & $\begin{array}{l}\text { capì-ēns } \\
\text { capì-ěnt-ìs }\end{array}$ & $\begin{array}{l}\text { punì-ēns } \\
\text { punì-ènt-ìs }\end{array}$ \\
\hline
\end{tabular}

Od czasownika èssē tworzone są formy tego participium tylko w niektórych formacjach złożonych z tym czasownikiem. Temat występuje wówczas w wariancie $s$-, zaś sufiksy są identyczne jak dla czasowników koniugacji III i IV.

Czasowniki vēllè, nōllè, mällè mają uogólniony temat vōl-, nōl-, mäl-.

Czasownik irē w nom. sg. ma temat $i$ - oraz sufiks -èns-; w pozostałych formach występuje temat ěŭ- oraz sufiks - nt-.

\subsubsection{Wykładnik participii perfecti passivi}

Wykładnikiem tego participium jest sufiks - $\oslash$ - dodany do tematu participii perfecti. Przyłączane są końcówki deklinacyjne I deklinacji dla rodzaju żeńskiego oraz II deklinacji dla rodzaju męskiego i nijakiego. W nominatiwie singularis masculini końcówką jest -ūs. Końcówki deklinacyjne są skumulowanymi wykładnikami (wartości) kategorii przypadka, liczby i rodzaju, współtworząc paradygmat o charakterze przymiotnikowym. 
Formy participium perfecti passivi przykładowych czasowników:

\begin{tabular}{|c|c|c|c|}
\hline & $\ddot{a} m \bar{o},-\bar{a} r \grave{e},-\bar{a} v \bar{i},-\bar{a} t u ̄ m$ & mittō, -èrè, misi, missǔm & fêrō, fêrrè, tùli, lätūm \\
\hline $\begin{array}{l}\text { sg. nom. } \\
\text { gen. }\end{array}$ & $\begin{array}{l}\text { ămāt-ǔs, -à, -ŭm } \\
\text { ămāt-i, -ae, -i }\end{array}$ & $\begin{array}{l}\text { mìss-ǔs, -ă, -ŭm } \\
\text { misss-i, -ae, -i }\end{array}$ & $\begin{array}{l}\text { lät-ŭs, -ă, -ŭm } \\
\text { lāt-ì, -ae, -í }\end{array}$ \\
\hline pl. nom. & ămāt-ì, -ae, -à & miss-ì, -ae, -à & làt-ì, -ae, -à \\
\hline
\end{tabular}

\subsubsection{Wykładnik participii futuri activi}

Wykładnikiem tej formacji jest sufiks -ür-dodany do tematu participii perfecti. Przyłączane są końcówki deklinacyjne I deklinacji dla rodzaju żeńskiego oraz II deklinacji dla rodzaju męskiego i nijakiego. W nominatiwie singularis masculini końcówką jest -ùs. Końcówki deklinacyjne są skumulowanymi wykładnikami (wartości) kategorii przypadka, liczby i rodzaju, współtworząc paradygmat o charakterze przymiotnikowym.

Formy participium futuri activi przykładowych czasowników:

\begin{tabular}{|c|c|c|c|}
\hline & $\ddot{a} \boldsymbol{m} \bar{o},-\bar{a} r \bar{e},-\bar{a} v \bar{\imath},-\bar{a} t u ̈ m$ & mittō, -èrè, misi, missūm & fêrō, fêrrè, tülī, lātūm \\
\hline $\begin{array}{l}\text { sg. nom. } \\
\text { gen. }\end{array}$ & $\begin{array}{l}\text { àmāt-ūr-ǔs, -à, -ūm } \\
\text { àmāt-ūr-ì, -ae, -i }\end{array}$ & $\begin{array}{l}\text { mìss-ūr-ùs, -à, -ùm } \\
\text { mìss-ūr-i, -ae, -ì }\end{array}$ & $\begin{array}{l}\text { lāt-ūr-ùs, -à, -ùm } \\
\text { làt-ūr-ì, -ae, -ì }\end{array}$ \\
\hline pl. nom. & àmāt-ūr-ī, -ae, -à & miss-ūr-ì, -ae, -à & làt-ùr-ì, -ae, -à \\
\hline
\end{tabular}

W przypadku niektórych leksemów sufiks -ūr- dołączany jest do nieco inaczej niż temat participii perfecti - ukształtowanej części przedprzyrostkowej:

- morior - temat part. perf.: mortu-(us) - part. fut. act.: morit-ūr-(us),

- nascor - temat part. perf:: nat-(us) - part. fut. act.: nascit-ūr-(us),

- orior - temat part. perf.: ort-(us) - part. fut. act.: orit-ūr-(us),

- pario - temat part. perf.: part-(us) - part. fut. act.: parit-ür-(us).

W przypadku czasownika èssě część przedprzyrostkowa ma postać fŭt-(fut-ur-us).

\subsubsection{Wykładniki participii futuri passivi}

1. Dla czasowników koniugacji I i II wykładnikiem jest sufiks -nd-.

2. Dla czasowników koniugacji III i IV wykładnikiem jest sufiks -ënd-; archaiczna postać: -ünd-.

Sufiksy te dodawane są do tematu praesentis. Przyłączane są końcówki deklinacyjne I deklinacji dla rodzaju żeńskiego oraz II deklinacji dla rodzaju męskiego i nijakiego: w nominatiwie singularis masculini końcówką jest - ǔs. Końcówki deklinacyjne są skumulowanymi wykładnikami (wartości) kategorii przypadka, liczby i rodzaju, współtworząc paradygmat o charakterze przymiotnikowym. 
Formy participium futuri passivi przykładowych czasowników:

\begin{tabular}{|c|c|c|c|c|c|}
\hline sg. & $\begin{array}{l}\text { koniug. I } \\
a m \bar{o},-\bar{a} r \bar{e}\end{array}$ & $\begin{array}{l}\text { koniug. II } \\
\text { vidēōo, -èré }\end{array}$ & $\begin{array}{c}\text { koniug. III a } \\
\text { legó, -èré }\end{array}$ & $\begin{array}{c}\text { koniug. III b } \\
\text { capiō, -ërēe }\end{array}$ & $\begin{array}{l}\text { koniug. IV } \\
\text { puniō, -iré }\end{array}$ \\
\hline $\begin{array}{l}\text { nom. } \\
\text { gen. }\end{array}$ & $\begin{array}{l}\text { amă-nd-ŭs, -ãa, -ŭm } \\
\text { amă-nd-î, -ae, -i }\end{array}$ & $\begin{array}{l}\text { vidè-nd-ŭs, -ă, -ŭm } \\
\text { vidè-nd-ì, -ae, -ì }\end{array}$ & \begin{tabular}{|l} 
leg-ēnd-ŭs, -à, -ŭm \\
leg-ēnd-ĩ, -ae, -ĩ
\end{tabular} & $\begin{array}{l}\text { capi-ènd-ūs, -à, -ūm } \\
\text { capi-ènd-ī, -ae, -ī }\end{array}$ & $\begin{array}{l}\text { punì-ènd-ǔs, -ă, -ŭm } \\
\text { punì-ěnd-ĩ, -ae, -i }\end{array}$ \\
\hline
\end{tabular}

\subsubsection{Wykładniki infinitivi praesentis activi}

Wykładnikiem tej formacji jest sufiks -ré dodany do tematu praesentis.

Formy infinitivi praesentis activi przykładowych czasowników:

\begin{tabular}{|c|c|c|c|c|}
\hline $\begin{array}{l}\text { koniug. I } \\
a m \bar{o},-\bar{a} r \bar{e}\end{array}$ & $\begin{array}{l}\text { koniug. II } \\
\text { vidéōo,-èré }\end{array}$ & $\begin{array}{c}\text { koniug. III a } \\
\text { legō, -éré }\end{array}$ & $\begin{array}{c}\text { koniug. III b } \\
\text { capiō, -ëré }\end{array}$ & $\begin{array}{l}\text { koniug. IV } \\
\text { puniō, -iré }\end{array}$ \\
\hline amā-rẽ & vidē-rè & legè-rè & capë-rè & punì-rè \\
\hline
\end{tabular}

Czasownik irē przybiera wariant tematyczny $i-$, czasownik fêrrē wariant fêr-.

Dla czasownika ěssě sufiks ma postać -sĕ; dołączany jest do wariantu tematycznego ěs-.

Dla czasowników: vèllè, nöllē i mällè sufiks ma postać -lë; dołączany jest do tematu odpowiednio: vĕl-, nöl-, mäl-.

\subsubsection{Wykładniki infinitivi praesentis passivi}

1. Dla czasowników koniugacji I, II i IV wykładnikiem jest sufiks - rī (postać archaiczna: -riěr).

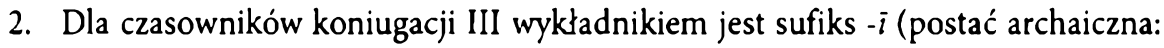
-ierr).

Sufiksy te dodawane są do tematu praesentis.

Formy infinitivi praesentis passivi przykładowych czasowników:

\begin{tabular}{|c|c|c|c|c|}
\hline $\begin{array}{l}\text { koniug. I } \\
a m o \overline{,}-\bar{a} r \bar{e}\end{array}$ & $\begin{array}{l}\text { koniug. II } \\
\text { vidēōo,-éré }\end{array}$ & $\begin{array}{c}\text { koniug. III a } \\
\text { legō, -ëré }\end{array}$ & $\begin{array}{c}\text { koniug. III b } \\
\text { capiō, -éré }\end{array}$ & $\begin{array}{l}\text { koniug. IV } \\
\text { puniōo, -irë }\end{array}$ \\
\hline amā-rî & vidè-rí & leg-ì (leg-ièr) & cap-ì (cap-ièr) & puni-rì \\
\hline
\end{tabular}

Czasownik fërrē przyjmuje sufiks -rī, dodany do tematu fër-. 


\subsubsection{Wykładnik infinitivi perfecti activi}

Wykładnikiem jest sufiks -issě dodany do tematu perfecti. Jeśli temat zakończony jest na $-v$, sufiks może przyjąć formę skróconą -ssē, która dołączana jest do tematu pozbawionego kończącej go spółgłoski, np. ama-ssẽ (obok amav-issē).

Formy infinitivi perfecti activi przykładowych czasowników:

\begin{tabular}{|c|c|c|}
\hline 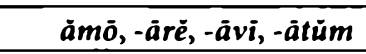 & mittō, -èrè, misi, missŭm & férō, fêrrè, tŭli, lätŭm \\
\hline ămāv-íssẽ (ămā-ssē) & mis-isssē & tŭl-īssè \\
\hline
\end{tabular}

\subsubsection{Wykładnik infinitivi perfecti passivi}

Wykładnik tych wartości ma charakter złożony, bowiem reprezentujące je formacje mają charakter analityczny i składają się $\mathrm{z}$ form participium perfecti danego leksemu czasownikowego oraz form infinitiwu praesentis (activi) czasownika posiłkowego esse. Czasownik posiłkowy jest wykładnikiem wartości infinitivus $\mathrm{w}$ ramach kategorii finitywności. Temat participium perfecti jest wykładnikiem funkcji leksykalnej, sufiks (zerowy) participium jest wykładnikiem kategorii strony i czasu, zaś jego końcówki fleksyjne są skumulowanymi wykładnikami kategorii liczby, rodzaju i przypadka. $Z$ tego względu formacja ta uwzględnia także wymogi składniowego związku atrybucji. Kategoria przypadka ograniczona jest do wartości nominativus i accusativus.

Formy infinitivi perfecti passivi przykładowych czasowników:

\begin{tabular}{|c|c|c|c|}
\hline & $\ddot{a} m \bar{o},-\bar{a} r \bar{e},-\bar{a} v \bar{i},-\bar{a} t u ̈ m$ & mittō, -èré, misi, missŭm & fêrō, fêrrè, tülī, lātüm \\
\hline $\begin{array}{l}\text { sg. nom. } \\
\text { acc. } \\
\text { pl. nom. } \\
\text { acc. }\end{array}$ & 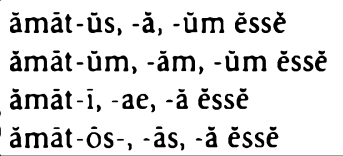 & 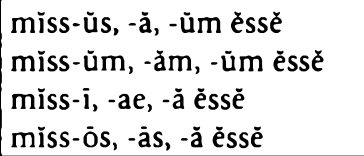 & 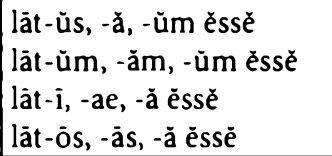 \\
\hline
\end{tabular}

\subsubsection{Wykładnik infinitivi futuri activi}

Wykładnik tych wartości ma charakter złożony, bowiem reprezentujące je formacje mają charakter analityczny i składają się z form participium futuri activi danego leksemu czasownikowego oraz infinitiwu praesentis (activi) czasownika posiłkowego esse. Czasownik posiłkowy jest wykładnikiem wartości infinitivus w ramach kategorii finitywności. Temat participium jest wykładnikiem funkcji leksykalnej, sufiks (-ür-) participium jest wykładnikiem kategorii strony i czasu, zaś jego końcówki fleksyjne są skumulowanymi wykładnikami kategorii liczby, rodzaju i przypadka. Z tego wzglę- 
du formacja ta uwzględnia także wymogi składniowego związku atrybucji. Kategoria przypadka ograniczona jest do wartości nominativus i accusativus.

Czasownik ěssě ma jeszcze równoległą syntetyczną formę o postaci förě o zerowym paradygmacie formalnym.

Formy infinitivi futuri activi przykładowych czasowników:

\begin{tabular}{|c|c|c|c|}
\hline & 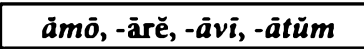 & mìttō, -ërè, mìsi, misssŭm & fêrō, fêrrè, tŭli, lätūm \\
\hline $\begin{array}{l}\text { sg. nom. } \\
\text { acc. } \\
\text { pl. nom. } \\
\text { acc. }\end{array}$ & 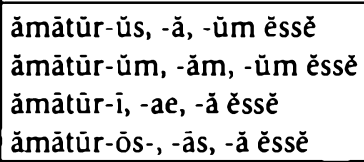 & 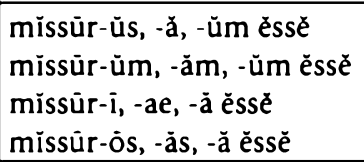 & 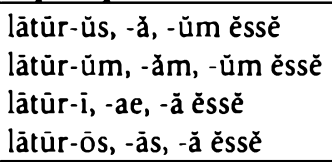 \\
\hline
\end{tabular}

\subsubsection{Wykładnik infinitivi futuri passivi}

Wykładnik tych wartości ma charakter złożony, bowiem reprezentujące je formacje mają charakter analityczny i składają się z formy złożonej z tematu participii perfecti danego leksemu czasownikowego i sufiksu -üm, oraz z formy îri.

Formy infinitivi futuri passivi przykładowych czasowników:

\begin{tabular}{|c|c|c|}
\hline$\check{a} \boldsymbol{m} \bar{o},-\bar{a} r \bar{e},-\bar{a} v \bar{i},-\bar{a} t u ̈ m$ & mittō, -èrè, misi, müssŭm & fêrō, ferrrè, tŭli, lätŭm \\
\hline àmàt-ūm ìri & mìss-ŭm ìrī & lät-ūm irì \\
\hline
\end{tabular}

\subsubsection{Wykładniki gerundii}

1. Dla czasowników koniugacji I i II wykładnikiem jest sufiks - nd-.

2. Dla czasowników koniugacji III i IV wykładnikiem jest sufiks -ënd- (archaiczna postać: - ŭnd-).

Sufiksy te dołączane są do tematu praesentis i wykazują łączliwość z końcówkami II deklinacji, będącymi wykładnikami kategorii przypadka, która ograniczona jest do wartości: genetivus, dativus, accusativus (wyłącznie w połączeniu z przyimkami) i ablativus, oraz kategorii liczby, która ograniczona jest do wartości singularis.

Czasownik irě przybiera wariant tematyczny $\check{e}$ - oraz sufiks -ünd-. 
Formy gerundii przykładowych czasowników:

\begin{tabular}{|c|c|c|c|c|c|}
\hline & $\begin{array}{l}\text { koniug. I } \\
a m \bar{o},-\bar{a} r \tilde{e}\end{array}$ & $\begin{array}{l}\text { koniug. II } \\
\text { vidéōo, -éré }\end{array}$ & $\begin{array}{c}\text { koniug. III a } \\
\text { legō, -èré }\end{array}$ & $\begin{array}{c}\text { koniug. III b } \\
\text { capiō, -èré }\end{array}$ & $\begin{array}{l}\text { koniug. IV } \\
\text { puniōo, -iré }\end{array}$ \\
\hline $\begin{array}{l}\text { gen. } \\
\text { dat. } \\
\text { acc. } \\
\text { abl. }\end{array}$ & $\begin{array}{l}\text { amă-nd-ì } \\
\text { amă-nd-ò } \\
\text { (ad) amă-nd-ŭm } \\
\text { amă-nd-ò }\end{array}$ & $\begin{array}{l}\text { vidè-nd-ì } \\
\text { vidè-nd- ō } \\
\text { (ad) vidè-nd-ŭm } \\
\text { vidè-nd- ò }\end{array}$ & \begin{tabular}{|l|} 
leg-ènd-ì \\
leg-ènd- ò \\
(ad) leg-ènd-ǔm \\
leg-ènd- ò
\end{tabular} & $\begin{array}{l}\text { capì-ènd-ì } \\
\text { capì-ènd-ō } \\
\text { (ad) capi-ènd-ūm } \\
\text { capì-ènd-ö }\end{array}$ & $\begin{array}{l}\text { puni-ènd-ì } \\
\text { puni-ènd- ò } \\
\text { (ad) puni-ènd-ūm } \\
\text { puni-ènd-ò }\end{array}$ \\
\hline
\end{tabular}

\subsubsection{Wykładniki supini}

Dla poszczególnych funkcji semantyczno-syntaktycznych wykładnikami tej formacji są sufiksy:

1. - ùm - dla funkcji okolicznika celu przy czasowniku,

2. $-\bar{u}$ - dla funkcji okolicznika względu przy przymiotniku.

Sufiksy te dołączane są do tematu participii perfecti czasownika.

Formy supini przykładowych czasowników:

\begin{tabular}{|c|c|c|}
\hline$\ddot{a} m \bar{o},-\bar{a} r \bar{e},-\bar{a} v \bar{i},-a \bar{t} u \bar{m}$ & mittō, -èrēe, misī, missūm & fẽrō, fêrrě, tüli, lätüm \\
\hline $\begin{array}{l}\text { àmāt-ùm } \\
\text { àmāt-ù }\end{array}$ & $\begin{array}{l}\text { misss-ŭm } \\
\text { misss-ù }\end{array}$ & $\begin{array}{l}\text { lāt -ŭm } \\
\text { lāt -ù }\end{array}$ \\
\hline
\end{tabular}

\subsubsection{Systemowe ograniczenia}

Leksemy czasownikowe należące do klasy activa tantum nie mają form o wartości passivum w ramach kategorii strony. Leksemy sygnalizujące wyłącznie diatezę nacechowaną niepodmiotową nie mają ponadto żadnych form o wartości pluralis ( $w$ ramach kategorii liczby) oraz 1. i 2. osoby (w ramach kategorii osoby).

Leksemy należące do klasy passiva tantum (czyli tzw. verba deponentia) nie posiadają form osobowych o wartości activum w ramach kategorii strony. Spośród form nieosobowych posiadają $w$ swym paradygmacie formalnym:

- infinitiwy: praesentis passivi, perfecti passivi, futuri activi;

- participia: praesentis activi, perfecti passivi, futuri activi, przechodnie także futuri passivi;

$\rightarrow$ gerundium i supinum.

Tzw. verba semideponentia nie posiadają w swym paradygmacie żadnych form osobowych o wartości passivum tworzonych na bazie tematu praesentis (chyba że sygnalizują diatezę niepodmiotową) oraz żadnych form tworzonych na bazie tematu perfecti. Spośród form nieosobowych w skład ich paradygmatu wchodzą te same formacje, które współtworzą paradygmat czasowników klasy verba deponentia, $\mathrm{z}$ wyjąt- 
kiem infinitiwu praesentis passivi. W jego miejsce w paradygmacie tych czasowników znajduje się infinitivus praesentis activi.

Czasownik revertor nie ma żadnych form osobowych o wartości activi tworzonych na bazie tematu praesentis oraz $\mathrm{w}$ ogóle żadnych form tworzonych na bazie tematu participii perfecti.

Czasownik oriōr, orīi, ortus sum tworzy ind. praes., con. impf. oraz imperat. praes. według koniugacji III.

\subsection{WYBRANA LITERATURA}

Beltrán (1999, s. 129-194), Dressler (2002), Greenough, Kittredge, Howard, D’Ooge (1903 (1983), s. 72-125), Mańczak (1995), Matthews (972), Wikarjak (1978, s. 43-94) 


\section{7. \\ Charakterystyka funkcjonalna rzeczowników}

\subsection{RZECZOWNIKI JAKO KLASA LEKSEMÓW}

Rzeczowniki to klasa leksemów reprezentowana przez wyrazy gramatyczne, których prymarną funkcją składniową jest funkcja podmiotu, czyli członu nadrzędnego (akomodującego) w ramach związku składniowego predykacji i atrybucji. Jako nazwy obiektów (rzeczy, zjawisk, pojęć abstrakcyjnych) prymarnie zajmują one pozycję członu określanego wobec określników predykatywnych i atrybutywnych. Sekundarnie mogą pełnić funkcję przydawki, dopełnienia lub okolicznika, i tym samym zajmować pozycję członu zależnego grupy imiennej i werbalnej, związanego z członem nadrzędnym związkiem kongruencji, rekcji lub przynależności. Oprócz tego mogą zajmować pozycję orzecznika, funkcjonalnego odpowiednika podmiotu lub orzecznika (w ramach równoważników zdań znanych jako accusativus cum infinitivo oraz ablativus absolutus), a poza strukturą syntaktyczną zdania rzeczowniki pełnić mogą także funkcję adresatywu. $\mathrm{Z}$ wyjątkiem orzeczenia wszystkie człony składniowe zależne od składników zdań stanowionych przez rzeczowniki mają status przydawek. Pod względem morfologicznym rzeczownikom przysługuje kategoria osoby, rodzaju, liczby i przypadka.

\subsection{OSOBA (PERSONA)}

Gramatyczna kategoria osoby ma w lacinie trzy wartości, identyfikowane umownie jako l. osoba, 2. osoba i 3. osoba. Osoba rzeczownika jest kategorią morfologiczną syntaktycznie niezależną o charakterze klasyfikującym (selektywnym) i funkcji nominatywnej, polegającej na identyfikacji statusu desygnatu rzeczownika w obrębie sytuacji aktu mowy: 1. osoba identyfikuje desygnat rzeczownika $z$ nadawcą komunikatu lub grupą, do której należy nadawca lub nadawca i odbiorca komunikatu; 2. osoba identyfikuje desygnat rzeczownika $z$ odbiorcą lub grupą, do której należy odbiorca, ale nie należy nadawca komunikatu; 3 . osoba identyfikuje desygnat rzeczownika z obiektem lub grupą obiektów, z których żaden nie jest uczestnikiem aktu językowego 
porozumiewania się. Indeks wartości selektywnej kategorii osoby rzeczownika tkwi w czasowniku pełniącym w strukturze składniowej zdania funkcję członu syntaktycznie podrzędnego, związanego $z$ członem nadrzędnym stanowionym przez rzeczownik związkiem kongruencji predykatywnej. Oznacza to, że wartość kategorii osoby rzeczownika identyfikowana jest jedynie przez czasownikowe orzeczenie $\mathbf{w}$ odniesieniu do rzeczownika pełniącego funkcję gramatycznego podmiotu. Wykładnikiem wartości kategorii osoby rzeczownika jest czasownikowa końcówka osobowa (por.: ego dic-o, tu dici-s, puer dici-t). Tym samym kategoria osoby rzeczownika pełni także funkcję wewnątrztekstową, stanowiąc (obok kategorii liczby) formalną podstawę syntaktycznego związku predykacji; w ramach tego związku jest kategorią determinującą wartość fleksyjnej kategorii osoby czasownika.

Ze względu na swój klasyfikujący (selektywny) charakter kategoria osoby dzieli zbiór leksemów rzeczownikowych na trzy podklasy: do podklasy rzeczowników w pierwszej osobie należą rzeczownikowe zaimki ego 'ja' i nos 'my', do podklasy rzeczowników w drugiej osobie należą rzeczownikowe zaimki tu 'ty' i vos 'wy', natomiast wszystkie pozostałe leksemy rzeczownikowe należą do podklasy rzeczowników w trzeciej osobie, a więc np. is 'on', consul 'konsul' itp.

\subsection{RODZAJ (GENUS)}

Kategoria rodzaju ma w języku łacińskim trzy wartości: masculinum (masc.) rodzaj męski, femininum (fem.) - rodzaj żeński i neutrum (neut.) - rodzaj nijaki. Dla rzeczowników rodzaj jest kategorią syntaktycznie niezależną, klasyfikującą (selektywną), która dzieli leksemy rzeczownikowe na trzy podklasy: rzeczowniki rodzaju męskiego (masculina), rzeczowniki rodzaju żenskiego (feminina) i rzeczowniki rodzaju nijakiego (neutra). Rodzaj rzeczownika determinuje wartość fleksyjnej kategorii rodzaju przymiotnika, który w strukturze składniowej wypowiedzenia realizuje funkcję przydawki względem członu syntaktycznego stanowionego przez rzeczownik. Końcówka fleksyjna przymiotnika, będąca wykładnikiem tej wartości, jest tym samym indeksem wartości kategorii rodzaju nadrzędnego składniowo rzeczownika, która ujawniana jest w ramach związku kongruencji atrybutywnej (por. pater bonus, mater bona, iter bonum). Rodzaj rzeczownika jest zatem wyznaczony przez występujące między poszczególnymi rzeczownikami różnice $w$ łączliwości syntaktycznej z określonymi zbiorami form fleksyjnych przymiotników. Podział rzeczowników na klasy rodzajowe to więc podział ze względu na ich łączliwość z formami fleksyjnymi przymiotników. Takie ujęcie istoty kategorii rodzaju rzeczowników wynika także z jej funkcji, która ma charakter przede wszystkim tekstowy (syntaktaktyczny) i polega na sygnalizowaniu (opartych na kongruencji atrybutywnej) związków syntaktycznych między składnikami wypowiedzenia tworzącymi grupę imienną.

Tej podstawowej funkcji towarzyszyć może także funkcja nominatywna (semantyczna), polegająca na wskazywaniu na rodzaj naturalny, czyli płeć desygnatu rzeczownika (masculinum/femininum), lub brak nacechowania desygnatu co do płci 
(neutrum); por. np. masculina typu: pater 'ojciec', filius 'syn', vir 'mężczyna', maritus 'mąż'; feminina typu: mater 'matka', filia 'córka', femina 'kobieta', marita 'żona'; neutra typu: tempus 'czas', cor 'serce', gelu 'lód', templum 'świątynia'. Mamy też do czynienia z parami homonimicznych rzeczowników, zróżnicowanych co do wartości kategorii rodzaju w zależności od płci desygnatu, np.: comes (masc.) 'towarzysz' / comes (fem.) 'towarzyszka'; coniunx (masc.) 'małżonek' / coniunx (fem.) 'małżonka', bos (masc.) 'wół' / bos (fem.) 'krowa'. Nie ma jednak pełnej odpowiedniości między rodzajem gramatycznym rzeczownika a płcią bądź też brakiem płci jego desygnatu. $Z$ jednej strony bardzo wiele rzeczowników rodzaju męskiego lub żeńskiego desygnuje obiekty (pojęcia) nienacechowane pod względem płci (por. np. masculina typu: amor 'miłość, mons 'góra', fructus 'owoc'; feminina typu: invidia 'zawiść', magnitudo 'wielkość, sitis 'pragnienie'), z drugiej zaś strony istnieją rzeczowniki, które przy danej (jednej) wartości kategorii rodzaju desygnują istoty zarówno płci męskiej, jak i żeńskiej (np.: canis (masc.) 'pies/suka', aquila (fem.) 'orzeł/orlica'). Można więc co najwyżej mówić o pewnej korelacji między wartością kategorii rodzaju gramatycznego rzeczowników a płcią ich desygnatów.

$\mathrm{Z}$ różnych względów można też mówić o korelacji gramatycznego rodzaju męskiego rzeczowników z obiektami stanowiącymi desygnaty nazw:

- miesięcy, np. December (frigidus) '(zimny) grudzień',

- wiatrów, np. Aquilo (rapidus) '(gwałtowny) Akwilon',

- rzek, np. Tiberis (flavus) '(bladożółty) Tybr',

- ludów, np. Persae (antiqui) '(starożytni) Persowie',

a także o korelacji rodzaju żeńskiego rzeczowników i obiektów stanowiących desygnaty nazw:

- drzew, np. populus (alta) '(wysoka) topola',

- krajów, np. Aegyptus (fructuosa) '(żyzny) Egipt',

- miast, np. Corinthus (opulenta) '(bogaty) Korynt',

- wysp, np. Cyprus (magna) '(wielki) Cypr'.

\subsection{LICZBA (NUMERUS)}

Gramatyczna kategoria liczby ma w języku łacińskim dwie wartości: liczba pojedyncza, tj. (numerus) singularis, oraz liczba mnoga, czyli (numerus) pluralis. Liczba rzeczowników jest kategorią morfologiczną syntaktycznie niezależną, determinującą, o charakterze fleksyjnym. Obligatoryjną funkcją kategorii liczby rzeczowników jest funkcja tekstowa (syntaktyczna), polegająca na sygnalizowaniu opartych na kongruencji (predykatywnej i atrybutywnej) związków syntaktycznych między składnikami wypowiedzenia. Najczęściej jednak funkcji tej towarzyszy także funkcja nominatywna (semantyczna), której istotą jest informowanie o jednostkowym lub niejednostkowym (wieloelementowym) charakterze desygnatu liczebnika. W ramach realizacji tego rodzaju funkcji, zwanej kwantyfikacją numeryczną, wartość singularis sygnalizuje jednoelementowość, zaś wartość pluralis wieloelementowość zbioru stanowionego 
przez desygnat rzeczownika, np.: Navis Caesari tradita est „Okręt przekazany został Cezarowi” / Naves Caesari traditae sunt "Okręty zostały przekazane Cezarowi”.

Niektóre spośród łacińskich leksemów rzeczownikowych cechują się ograniczonym (zredukowanym) paradygmatem funkcjonalnym w zakresie kategorii liczby, która w odniesieniu do nich ma charakter klasyfikujący (selektywny). Istnieją w związku $\mathrm{z}$ tym pluralia tantum, jak np.: nuptiae, -arum 'zaślubiny', fasti, -orum 'kalendarz', moenia, -ium 'mury', czy singularia tantum, jak np.: canities, -ei 'siwizna', humanitas, -atis 'człowieczeństwo'.

Nominatywna funkcja kategorii liczby rzeczowników, polegająca na kwantyfikacji numerycznej desygnatu, nie zawsze jest realizowana. Funkcja ta ulega neutralizacji w odniesieniu do leksemów, dla których liczba ma charakter klasyfikujący (por. np. nuptiae = 'ślub' lub 'śluby'). $\mathrm{W}$ takich przypadkach kwantyfikacja dokonywana jest za pośrednictwem odrębnych, przydawkowych określników kwantyfikujących, np.: unae nuptiae 'jeden ślub', nonnullae (aliquot) nuptiae 'kilka ślubów'. Warunkiem aktualizacji nominatywnej funkcji kategorii liczby rzeczowników jest także policzalny (tzn. ograniczony w przestrzeni lub czasie) charakter ich desygnatów, a także referencjalne (tj. mające odniesienie do konkretnych obiektów w rzeczywistości pozajęzykowej) użycie danego rzeczownika; por. tożsamość znaczeniową zdań: Homo homini lupus est i Homines hominibus lupi sunt „Człowiek jest dla człowieka wilkiem”/ „Ludzie są dla ludzi wilkami”, w których mamy do czynienia z niereferencjalnym (generycznym) użyciem rzeczowników HOMO i LUPUS (tzn. takim, w którym rzeczowniki te nie odnoszą się do żadnego konkretnego człowieka czy wilka), w przeciwieństwie do zróżnicowania znaczeniowego zdań: Heri venit ad me quidam homo i Heri venerunt ad me quidam homines "Wczoraj przyszedł do mnie jakiś człowiek” / „Wczoraj przyszli do mnie jacyś ludzie", w których rzeczownik HOMO cechuje się użyciem referencyjnym (tzn. mającym odniesienie do konkretnych obiektów świata pozajęzykowego).

Oprócz wskazanej wyżej kwantyfikacji numerycznej, która określana bywa terminem pluralis matematyczny, spotykamy się również $z$ odmiennym wariantem funkcjonalnym liczby mnogiej, charakteryzującym (lub mogącym charakteryzować) niektóre leksemy rzeczownikowe. Jest to tzw. pluralis eliptyczny, który nie wskazuje na multiplikację obiektu stanowiącego desygnat rzeczownika $w$ singularis', lecz sygnalizuje zbiorowość różnych obiektów wyznaczoną przez ich związek z jednym, wyróżnionym elementem zbioru. Tego rodzaju charakterystyką funkcjonalną cechuje się np. zaimek osobowy nos, którego desygnatem jest zbiór osób wykazujących związek z nadawcą komunikatu². Podobną charakterystyką cechować się może również zaimek vos (jeśli obejmuje szerszą grupę niż bezpośredni adresaci wypowiedzi), a także takie określenia jak np. Castores ${ }^{3}$, które desygnuje nie "mnogość Kastorów", lecz braci: Kastora i Polluksa.

Np. milites $=$ miles + miles + miles...

2 A więc nos to nie ego + ego + ego..., lecz ego + alii.

${ }^{3}$ Cf. Apul., Met. 10, 31; Plin., Nat. hist. 7, 86; 35, 27; Serv., Georg. 1, 58; 3, 89; por. też pol. pl. 
Ze szczególnym sposobem funkcjonowania kategorii liczby mamy do czynienia w przypadku nacechowanego stylistycznie użycia zaimka nos w odniesieniu do jednej tylko osoby, tj. nadawcy komunikatu; w zależności od kontekstu mówimy wtedy o tzw. pluralis maiestaticus lub pluralis modestiae (por. np.: Neque nos te fruimur et tu nobis cares „Nie mogę cieszyć się twoją obecnością, a i ty odczuwasz mój brak” (Cic., Att. 2, 1, 4)).

Jeśli rzeczownik, który w liczbie pojedynczej desygnuje obiekt o charakterze zbiorowym, zajmuje w zdaniu pozycję podmiotu, zależne od niego czasownikowe orzeczenie może wystapić w pluralis, dostosowując się w ten sposób nie do formalnej, lecz semantycznej charakterystyki członu akomodującego; por. np. Pars [militum], cum substitissent, ab hoste circumventi sunt "Część [żołnierzy], po tym jak przystanęła, otoczona została przez wroga" (Liv., 32, 15, 5). Tego rodzaju rodzaju relacja między podmiotem a orzeczeniem, stosunkowo rzadka w lacinie, znana jest jako tzw. constructio ad sensum.

\subsection{PRZYPADEK (CASUS)}

Kategoria przypadka ma w łacinie 6 wartości: nominativus (nom.) - mianownik, genetivus (gen.) - dopełniacz, dativus (dat.) - celownik, accusativus (acc.) - biernik, ablativus (abl.) - narzędnik i vocativus (voc.) - wołacz. Przypadek rzeczowników jest kategorią morfologiczną o charakterze fleksyjnym, syntaktycznie zależną i determinującą wartość kategorii przypadka składniowo zależnych przymiotników. Podstawową funkcją kategorii przypadka rzeczownika jest sygnalizowanie pozycji syntaktycznej wyrazu gramatycznego reprezentującego leksem rzeczownikowy. Elementarną opozycją funkcjonalną $\mathrm{w}$ ramach tej kategorii jest więc przeciwstawienie nominatiwu (casus rectus), jako przypadka przede wszystkim podmiotu gramatycznego, przypadkom zależnym (casus obliqui), które związane są z sekundarnymi funkcjami syntaktycznymi rzeczownika (dopełnienia, przydawki, okolicznika, orzecznika). Specyficzny jest status wokatiwu jako sygnału użycia leksemu rzeczownikowego $\mathrm{w}$ impresywnej funkcji apelu. W strukturze składniowej zdania zajmuje on pozycję adresatywu, stanowiącego dodatkowy składnik zdania lub konstytutywny człon samodzielnej jednostki wypowiedzeniowej, tj. wyrażenia adresatywnego. Ta funkcjonalna swoistość wołacza sprawia, że jest to jedyna forma fleksyjna rzeczownika niewchodząca $w$ związki syntaktyczne $z$ innymi elementami wypowiedzenia zdaniowego; wchodzi ona $w$ związki składniowe jedynie $z$ elementami wyrażenia adresatywnego, które współstanowi.

Sekundarnie kategoria przypadka rzeczownika może mieć również charakter nominatywny (semantyczny). Wiąże się to z przyjmowaniem przez rzeczownik dodatkowego nacechowania semantycznego $w$ ramach pełnionych przez niego sekundarnych funkcji składniowych, głównie okolicznikowych, których istotą jest sygnalizowanie realacji przestrzennych i czasowych, instrumentalnych itp., często z udziałem odpowiedniego przyimka. Aktualizacja tego dodatkowego nacechowania 
znaczeniowego stoi u podstaw tradycyjnego podziału poszczególnych wartości kategorii przypadka na tzw. przypadki gramatyczne, czyli determinujące funkcje syntaktyczne, którym rzadko towarzyszy dodatkowe nacechowanie semantyczne, oraz tzw. przypadki konkretne, czyli determinujące funkcje syntaktyczne, z którymi często związane jest dodatkowe nacechowanie semantyczne rzeczownika. Do tzw. przypadków gramatycznych zalicza się zwykle nominativus, accusativus i genetivus, do przypadków konkretnych ablativus i dativus. Należy jednak zaznaczyć, klasyfikacja ta ma charakter umowny, bowiem w wielu wypadkach użyciu przypadka gramatycznego może towarzyszyć dodatkowe nacechowanie znaczeniowe (np. Eo Romam „Udaję się do Rzymu" - nacechowanie semantyczne kierunku), z kolei zastosowanie przypadka zaliczanego do konkretnych może być takiego nacechowania pozbawione (np. Abundo ingenio „Mam pod dostatkiem talentu”).

\subsubsection{Charakterystyka funkcjonalna wartości kategorii przypadka rzeczownika - wprowadzenie}

Dokonana poniżej funkcjonalna charakterystyka poszczególnych wartości kategorii przypadka przeprowadzona została przede wszystkim w oparciu o kryterium syntaktyczne, tzn. obejmuje ona w pierwszym rzędzie wskazanie funkcji składniowych, których pełnienie związane jest z przyjęciem tych wartości przez rzeczowniki. Kryterium składniowemu podporządkowane zostało kryterium semantyczne, czyli charakterystyka funkcji znaczeniowej rzeczowników w poszczególnych przypadkach; w wielu wypadkach uwzględnia ona tradycyjne określniki typu: genetivus qualitatis, dativus finalis itp. Spośród funkcji realizowanych przez rzeczowniki w połączeniu $\mathrm{z}$ określonymi przyimkami uwzględnione zostały zasadniczo te, których realizacja możliwa jest również bez użycia przyimka.

Funkcje składniowe pełnione przez rzeczowniki w różnych przypadkach określane są terminami identyfikującymi zajmowane przez nie pozycje składniowe czy też stanowione przez nie człony syntaktyczne, a więc terminami: podmiot, przydawka, dopełnienie, okolicznik, orzecznik, adresatyw. Poniżej zamieszczony więc został krótki opis pojęć stojących za tymi terminami; pojęcia te przedstawione zostały także w rozdziale poświęconym składni.

Podmiot to człon syntaktyczny cechujący się brakiem zależności składniowej od jakiegokolwiek innego składnika wypowiedzenia oraz nadrzędnością składniową w ramach związku głównego zdania, czyli w ramach związku predykacji, łączącego go $z$ orzeczeniem; podmiot może być zatem zdefiniowany jako niepodrzędna składniowo część zdania, stanowiąca człon nadrzędny w ramach związku predykacji $\mathrm{z}$ orzeczeniem.

Funkcja podmiotu jest prymarną funkcją składniową rzeczowników. Wszystkie pozostałe wymienione niżej funkcje syntaktyczne wynikają z sekundarnej dystrybucji składniowej rzeczowników. 
Funkcjonalny odpowiednik podmiotu to nadrzędny składniowo element równoważników zdań podrzędnych, określanych terminami accusativus cum infinitivo oraz ablativus absolutus. Element ten stanowi człon nadrzędny (akomodujący) w ramach syntaktycznego związku atrybucji, który łączy go $z$ funkcjonalnym odpowiednikiem orzeczenia, realizowanym przez czasownik $\mathrm{w}$ infinitiwie (accusativus cum infinitivo) lub participium (ablativus absolutus).

Orzecznik to składnik orzeczenia współtworzonego wraz z osobową lub osobową i nieosobową formą czasownika, będący podstawowym wykładnikiem wyrażanej przez to orzeczenie treści predykatywnej.

Funkcjonalny odpowiednik orzecznika to składnik funkcjonalnego odpowiednika orzeczenia, współtworzonego wraz z (wyłącznie) nieosobową formą czasownika $\mathrm{w}$ ramach równoważnika zdania (głównie o postaci accusativus cum infinitivo lub ablativus absolutus), stanowiący główny wykładnik wyrażanych przez ten człon syntaktyczny treści predykatywnych.

Uzupełnienie orzecznikowe (komplement orzecznikowy) to składnik członu syntaktycznego innego niż funkcjonalny odpowiednik orzeczenia, współtworzonego wraz z (wyłącznie) nieosobową formą czasownika, będący głównym wykładnikiem wyrażanych przez ten człon treści przedmiotowych.

Adresatyw to składnik zdania leżący poza jego strukturą syntaktyczną. Stanowiony jest głównie przez rzeczownik w wokatiwie, który pełni funkcję apelu i służy realizacji określonej strategii nadawczo-odbiorczej autora wypowiedzenia. Nie jest zależny składniowo od żadnego członu syntaktycznego zdania, lecz sam może stanowić podstawę wyrażenia adresatywnego o postaci grupy imiennej (lub zdania przydawkowego), w którym zajmuje pozycję członu nadrzędnego.

Pozycje składniowe przydawki, dopełnienia i okolicznika zdeterminowane są ich zależnością składniową od innych członów syntaktycznych wypowiedzenia oraz przynależnością ich syntaktycznych nadrzędników do określonych klas leksemów (części mowy), a w przypadku dopełnienia i okolicznika również właściwościami semantycznymi leksemów należących do tych klas.

I tak przydawka to człon syntaktyczny, który jest podrzędny składniowo względem każdej części zdania stanowionej przez rzeczownik (lub jego funkcjonalny odpowiednik zaimkowy, przymiotnikowy lub imiesłowowy); prymarnie przydawka jest zatem członem podrzędnym względem podmiotu, uwzględniając jednak sekundarną dystrybucję składniową rzeczownika, może stanowić człon podrzędny względem rzeczownikowego dopełnienia, okolicznika, orzecznika, adresatywu, innej rzeczownikowej przydawki, a także funkcjonalnego odpowiednika podmiotu lub orzecznika. Ze swoim syntaktycznym nadrzędnikiem przydawka powiązana jest związkiem zgody (kongruencji atrybutywnej), przynależności lub rekcji.

Dopełnienie to część zdania podrzędna składniowo względem członu syntaktycznego stanowionego przez czasownik, przymiotnik lub przysłówek, desygnująca obiekt implikowany przez semantykę (znaczenie, treść) swojego nadrzędnika. Prymarnie dopełnienie jest więc członem podrzędnym względem czasownikowego orzeczenia, przymiotnikowej przydawki lub przysłówkowego okolicznika; jednak 
jeśli uwzględnić sekundarną dystrybucję składniową czasowników, przymiotników i przysłówków, dopełnienie może stanowić człon podrzędny względem innych członów syntaktycznych, np. bezokolicznikowego podmiotu, wyrażonej przez gerundium lub participium przydawki, wyrażonego przez supinum okolicznika, funkcjonalnego odpowiednika orzeczenia w ramach składni accusativus cum infinitivo lub ablativus absolutus, wyrażonego przez substantywizowany przymiotnik podmiotu lub dopełnienia itd. Wśród dopełnień konotowanych przez pewną klasę czasowników (tj. przez tzw. czasowniki przechodnie) wyodrębnia się dopełnienie bliższe, które - w odróżnieniu od dopełnienia dalszego - charakteryzuje się tym, że w przypadku zmiany diatezy zdaniowej na bierną jego desygnat może zostać ujawniony przez mianownikowy podmiot. Implikowaniu przez semantykę czasownika, przymiotnika lub przysłówka określonego obiektu towarzyszy znaczny poziom zdeterminowania desygnującego ten obiekt rzeczownika (czyli dopełnienia) co do wartości kategorii przypadka; związek łączący dopełnienie z jego składniowym nadrzędnikiem jest zatem związkiem rekcji.

Okolicznik to człon składniowy, który od dopełnienia różni się jedynie tym, że jego desygnat nie jest implikowany przez semantykę jego składniowego nadrzędnika. Okolicznik nie jest zatem przez człon nadrzędny konotowany (wymagany), a jedynie fakultatywnie przyłączany, wskutek czego związek, który łączy go z członem nadrzędnym, to związek przynależności. Podobnie jak dopełnienie, okolicznik jest więc członem zależnym prymarnie od czasownikowego orzeczenia, przymiotnikowej przydawki lub przysłówkowego okolicznika. Jeśli uwzględnić jednak sekundarną dystrybucję składniową czasowników, przymiotników i przysłówków, okolicznik może stanowić człon podrzędny względem innych członów syntaktycznych, np. bezokolicznikowego podmiotu, wyrażonej przez gerundium lub participium przydawki, funkcjonalnego odpowiednika orzeczenia w ramach składni accusativus cum infinitivo lub ablativus absolutus, wyrażonego przez substantywizowany przymiotnik podmiotu lub dopełnienia itd.

W poniższym opisie funkcji składniowych i semantycznych, które pełnione są przez rzeczowniki w poszczególnych przypadkach, pominięta została funkcja przydawki apozycyjnej, jako że nie jest ona związana z żadną konkretną wartością kategorii przypadka, tzn. może ona być realizowana przez rzeczowniki we wszystkich przypadkach. Funkcję tę scharakteryzowano bliżej przy opisie przydawki w części poświęconej składni.

\subsubsection{Nominativus}

\subsubsection{Rzeczownik w nominatiwie jako podmiot}

Nominativus związany jest przede wszystkim z realizacją prymarnej dla rzeczowników funkcji składniowej, tj. funkcji gramatycznego podmiotu. Realizując tę 
funkcję rzeczownik w nominatiwie stanowi człon określany, nadrzędny $w$ ramach związku predykacji $z$ orzeczeniem oraz $w$ ramach związku atrybucji, rekcji lub przynależności z przydawką:

Milites [...] hostium phalangem perfregerunt. (Caes., Gall.1, 25, 2)

„Żolnierze przelamali nieprzyjacielską falangę".

Hunc $[\ldots]$ lubido maxuma invaserat rei publicae capiundae. (Sall., Cat 5, 6)

„Jego ogarnęla ogromna żądza opanowania rzeczpospolitej”.

Domus patris longe a foro aberat. (Cic., Cael. 18)

„Dom ojca znajdowal się daleko od forum”.

Illa mihi placebat oratio de convenientia consensuque naturae (Cic., Nat. 3, 28)

„Podobala mi się ta przemowa o zgodności i harmonii w naturze".

Należy zaznaczyć, że odpowiednikiem łacińskiego podmiotu w nominatiwie nie zawsze jest w polskim przekładzie mianownikowy podmiot; por. np.:

Deficit enim non voluntas sed spes. (Cic., Att. 7, 21, 1)

„Brakuje bowiem nie woli, lecz nadziei”.

Trecenti $[\ldots]$ captivi ad portas nocte venerunt. (Sen., Controv. 5, 7, 1)

„Trzystu jeńców przybyło nocą do bram".

\subsubsection{Rzeczownik w nominatiwie jako orzecznik}

Funkcja orzecznikowa realizowana jest przez rzeczowniki w powiązaniu z określoną klasą czasowników, które współkonstytuują wraz z nimi orzeczenie; czasowniki te występują w formie osobowej, wyrażając obligatoryjną dla związku predykacji wartość kategorii osoby (i liczby) oraz umożliwiając ujęcie wyrażanej wspólnie treści predykatywnej w ramy czasowo-modalne. Tego rodzaju użycie mianownikowego orzecznika (obok mianownikowego podmiotu) określane jest tradycyjnie terminem nominativus duplex:

Erucius Clarus [...] bis consul fuit. (Gell., Noct. Att. 13, 18, 2)

„Erucjusz Klarus dwukrotnie był konsulem”.

Haec quidem vita mors est. (Cic., Tusc. 1, 75)

"Tego rodzaju życie jest śmiercią".

Ego huic causae patronus exstiti. (Cic., S. Rosc. 5)

„Ja zglosilem się jako obrońca w tej sprawie".

Vercingetorix rex ab suis appelatus est. (Caes., Gall. 7, 4, 5)

„Wercyngetoryks zostal obwolany królem przez swoich (ludzi)”.

Consules creati (sunt) L. Valerius M. Horatius. (Liv., 3, 55, 1)

„Konsulami zostali wybrani Lucjusz Waleriusz i Marek Horacjusz”. 
Q. Rubrius Varro a senatu hostis [...] iudicatus est. (Cic., Brut. 168)

„Kwintus Rubrius Warron zostal przez senat uznany za wroga”.

Przy wyrażaniu bardziej złożonych treści czasowo-modalnych orzeczenie współtworzyć mogą (wraz z rzeczownikiem $w$ nominatiwie) dwie formy czasownikowe. Jedną z nich jest zwykle bezokolicznik, a drugą osobowa forma czasowników modalnych, fazowych lub stanowych typu: potest, vult, cupit, incipit, solet, albo forma pasywna typu videtur, dicitur, traditur, habetur itd., wyrażająca nacechowaną modalność w ramach struktury zwanej tradycyjnie nominativus cum infinitivo:

Socrates $[\ldots]$ parens philosophiae iure dici potest. (Cic., Fin. 1, 2)

„Sokrates słusznie może zostać nazwany ojcem filozofii”.

Tanagraea quaedam meretrix fuisse dicitur. (Cic., Dom. 111)

„Pewna Tanagrea podobno była kurtyzaną".

\subsubsection{Rzeczownik $w$ nominatiwie jako adresatyw}

Do realizacji tej funkcji stosowany jest głównie rzeczownik w wokatiwie, jednak z uwagi na morfologiczną bliskość nominatiwu i wokatiwu okazjonalnie, zwłaszcza w języku potocznym oraz rytualnym, również rzeczownik w nominatiwie może pełnić impresywną funkcję apelu (por. pol.: Janek, zamknij drzwi!):

$O$ vir fortis atque amicus! (Ter., Phorm. 324)

„O dzielny człowieku i przyjacielu!”.

Agedum, pontifex publicus populi Romani, praei verba, quibus me pro legionibus devove$a m !$ (Liv., 8, 9)

„Dalej więc, publiczny kapłanie narodu rzymskiego, wypowiadaj slowa, przez których powtórzenie mam się poświęcić za legiony".

\subsubsection{Rzeczownik w nominatiwie jako składnik wypowiedzeń niezdaniowych}

Formy mianownikowe stanowić też mogą konstytutywny człon wypowiedzi niezdaniowych o charakterze wykrzyknień lub zawiadomień. Towarzyszą im wtedy zwykle partykuły: $o$, en, ecce (w podobnej funkcji mogą być użyte również formy w akuzatiwie - zob. niżej):

O conservandus civis cum tam pio iustoque foedere! (Cic., Phil. 13, 37)

(iron.) „Co za obywatel godzien tego, by go strzec wraz z jego tak zbożnym i sprawiedliwym przymierzem!" 
En - inquit - fidus coniugis mei comes, en venator egregius, en carus maritus. (Apul., Met.. 8, 12)

„Oto - powiada - wierny towarzysz mego męża, oto wyborny myśliwy, oto ukochany malżonek".

Sed ecce in manibus vir et praestantissimo ingenio et flagranti studio et doctus a puero $C$. Gracchus. (Cic., Brut. 125)

„Lecz oto przed nami czlowiek o wybitnych zdolnościach, ogarniçty płomienną pasją, kształcony od dziecka, Gajusz Grakchus".

\subsubsection{Genetivus}

\subsubsection{Rzeczownik w genetiwie jako przydawka}

Funkcja przydawki (dopełniaczowej) jest podstawową funkcją składniową rzeczownika $w$ genetiwie, tzn. rzeczownik $w$ formie genetiwu systemowo zajmuje pozycję członu zależnego grupy imiennej. Składniowym nadrzędnikiem przydawki jest człon syntaktyczny stanowiony przez rzeczownik (lub leksem innej klasy zajmujący sekundarnie nadrzędną pozycję $w$ obrębie grupy imiennej). W ramach prymarnej dystrybucji składniowej rzeczowników członem tym jest zatem podmiot, w ramach dystrybucji sekundarnej każdy inny człon składniowy, tj. funkcjonalny odpowiednik podmiotu, dopełnienie, okolicznik, przydawka, adresatyw, orzecznik lub jego funkcjonalny odpowiednik.

Semantyczne relacje łączące przydawkę dopełniaczową z członem określanym są bardzo zróżnicowane, a przy tym często trudne do uchwycenia, zdefiniowania i tym samym do ujęcia $w$ ramach jednolitej klasyfikacji, która obejmowałaby wszystkie użycia i zakreślała ostre granice między nimi. W niektórych przypadkach relacje te wynikają z implikacji ze strony semantyki członu określanego (intellegentia legis 'znajomość prawa'), w innych przypadkach implikacji takiej brak (flumina lactis 'rzeki mleka'), co skutkuje zróżnicowaniem syntaktycznego statusu tych relacji (rekcja przynależność). Generalnie można stwierdzić jedynie, że u ich podstaw leży ogólna łączność lub też szeroko pojęta przynależność. Bardziej szczegółowe identyfikowanie i definiowanie stosunków znaczeniowych zachodzących między przydawką dopełniaczową a członem określanym zaowocowało całym szeregiem różnych klasyfikacji, z których żadna nie wydaje się w pełni satysfakcjonująca. Mając na uwadze fakt, iż wyczerpująca specyfikacja i charakterystyka tych stosunków należy raczej do zadań semantyki niż gramatyki, ograniczymy się do wskazania na najbardziej podstawowe ich typy. Odnotujemy zatem, że przez rzeczownikową przydawkę dopełniaczową może być wyrażany:

1. Posiadacz obiektu nazwanego przez człon określany; jest to tzw. genetivus possessivus: 
Naves hostium promunturium superarunt. (Ps.- Caes., Bell. Afr. 63, 4)

„Okręty wrogów opłynęly przylądek”.

Domus patris longe a foro aberat. (Cic., Cael. 18)

„Dom ojca znajdował się daleko od forum”.

In Allobrogum fines [...] exercitum duxit. (Caes., Gall., 1, 10)

"Do kraju Allobrogów poprowadził wojsko".

Do tej kategorii tradycyjnie klasyfikowane są także przydawki dopełniaczowe stanowiące człony złożonych nazw miast, obiektów architektonicznych itp., identyfikujące ich mieszkańców, założycieli, patronów, np.: Lutetia Parisorum 'Paryż' (Caes., Gall. 6, 3, 4), Augusta Taurinorum 'Turyn' (Tac., Hist. 2, 66), horti Pompei 'ogrody Pompejusza' (Cic., Phil. 2, 109), a także przydawki stanowione przez nazwy bóstw, określające poświęcone im świątynie, gwiazdy itp., np.: stella Veneris 'gwiazda Wenery' (= planeta Wenus), templum Martis 'świątynia Marsa'; w odniesieniu do tego rodzaju przydawek określających świątynie czasem spotyka się elipsę członu określanego, np. Ubi ad Dianae veneris... „Gdy dojdziesz do (świątyni) Diany..." (Ter., Adelph. 582).)

2. Osoba pozostająca $w$ określonej relacji (rodzinnej lub społecznej) w stosunku do osoby, której (rodzinny lub społeczny) status albo imię ujawnia człon określany; ten rodzaj przydawki również bywa określany terminem genetivus possessivus:

Avus Lentuli [...] armatus Gracchum est persecutus. (Cic., Catil. 4, 13)

„Dziad Lentulusa zbrojnie ścigal Grakcha”.

Euclionis filiam laudant. (Pl., Aul. 476)

"Córkę Eukliona chwalą".

Is adulescentis illius est avonculus. (Pl., Aul., 35)

„On jest wujem tego mlodzieńca”.

Credo ego illum [...] adiise huius nutricem virginis. (Pl., Aul. 815)

„Sądzę, że on podszedł do niani tej dziewczyny”.

Hasdrubal Hamilcaris ad Lapides Atros castra habebat. (Liv., 26, 17, 4)

„Hazdrubal (syn) Hamilkara miał obóz w pobliżu (miejsca zwanego) Lapides Atri”.

Mater Corneliae Gracchorum. (Val. Max., Facta et dicta memorabilia 6, 7, 1)

"Matka Kornelii (matki) Grakchów".

Equidem Sosia Amphitruonis sum. (Pl., Amph. 411)

„Jestem Sozjasz (sluga) Amfitriona”.

3. Obiekt, do którego należy lub którego element stanowi desygnat członu określanego:

Sarmenta in cornibus iuvencorum deligata incendit. (Nep., Hann. 5, 2)

„Zapala galązki przywiązane do rogów bydląt”. 
Truncis arborum [...] abscisis (Caes., Gall., 7, 73)

"Po ścięciu pni drzew".

Est mihi tecum $[\ldots]$ certamen $[\ldots]$ pro urbis muris. (Cic., Nat. 3, 94)

„Walczę z tobą o mury miasta".

4. Obiekt, którego atrybut (cechę, właściwość) stanowi desygnat członu określanego:

Navium figura [...] permoti barbari constiterunt. (Caes., Gall., 4, 25)

„Zaskoczeni kszlałtem okrętów barbarzyńcy przystanęli”.

Lux solis aut lunae aut cuiuslibet sideris (Sen., Nat. 1, 2, 2)

„Swiatło słońca, albo księżyca albo jakielkolwiek gwiazdy”.

[...] sicut [...] maiorum eius amplitudo postulabat. (Cic., Catil. 4, 9)

„zgodnie z tym, czego wymagała świetność jego przodków”.

Si $[\ldots]$ plus valuerit quam $[\ldots]$ rei publicae dignitas [...] (Cic., Catil. 4, 20)

"gdyby okazał się silniejszy niż godność państwa [...]".

Id [...] imperii severitas et res publica postulabat. (Cic., Catil., 2, 3)

„Tego wymagala powaga urzędu i racja stanu”.

5. Osobowy lub nieosobowy sprawca działania (czynu, stytuacji, aktu, stanu itp.), desygnowanego przez człon określany, którym jest często rzeczownik powiązany słowotwórczo z czasownikiem; genetiwus rzeczownika użyty w tej funkcji określany jest tradycyjnie terminem genetivus subiectivus:

Risus populi (factus est). (Cic., Verr., 2, 4, 27)

"Rozległ się śmiech ludu".

Igitur de Catilinae coniuratione [...] paucis absolvam. (Sall., Cat. 4, 3)

"A zatem o spisku Katyliny pokrótce opowiem".

Statuistis etiam intra muros Antonii scelus [...] versari. (Cic., Phil. 3, 13)

"Oświadczyliście, że nawet w murach (miasta) zbrodnia Antoniusza panoszy się".

Oratio consulum animum meum erexit. (Cic., Phil. 5,1 )

„Przemówienia konsulów podniosły mnie na duchu”.

Exponit [...] auditas esse voces, quae pericula belli nuntiarent. (Cic., Div. 1, 99).

„Opowiada, że dało się słyszeć głosy, które zapowiadały niebezpieczeństwa wojny”.

Usque ad solis occasum pugnabatur. (Caes., Gall. 3, 15)

„Walczono aż do zachodu slońca”.

Wariantem tego rodzaju przydawki jest tzw. genetivus auctoris, czyli przydawka identyfikująca autora jakiegoś dzieła, np. carmina Horatii 'pieśni Horacego', liber Ciceronis 'księga Cycerona', proverbium Graecorum 'powiedzenie Greków'. 
6. Obiekt desygnowanego przez człon określany działania (czynu, postawy, uczucia itp.), ujętego abstrakcyjnie lub przypisanego jakiejś osobie lub rzeczy; jest to tzw. genetivus obiectivus:

$A b$ isdem (cohortibus sunt) factae caedes sagittariorum ac funditorum. (Caes., Civ. 3, 94) „Przez te same kohorty dokonane zostały rzezie luczników i procarzy”.

Tantum te cepisse odium regni videbatur, ut [...] (Cic., Phil. 2, 91)

„Wydawało się, że ogarnęła cię tak wielka nienawiść do wladzy królewskiej, że [...]”.

[...] dum spes pacis erit. (Cic., Att. 7, 17, 4)

„dopóki będzie nadzieja na pokój”"

[...] omnes [...], qui in hac civitate intellegentiam iuris habuerunt. (Cic., Phil. 9, 10)

„wszyscy, którzy w tym państwie posiedli znajomość prawa”.

Catonem veteres inimicitiae Caesaris incitant. (Caes., Civ. 1, 4)

„Katona rozjątrza zadawniona wrogość do Cezara”.

[...] ultor sceleris illius, propugnator senatus, defensor vestrae voluntatis, patronus publici consensus. (Cic., Mil. 39)

„mściciel owej zbrodni, obrońca senatu, sojusznik waszych zamiarów, patron publicznej zgody".

[...] qui autem rei publicae sit hostis [...] (Cic., Catil. 4, 10)

„kto zaś bylby wrogiem państwa [...]”.

Sed ne hoc quidem infirmae memoriae remedium est. (Quint., Inst. 11, 2, 49)

„Lecz nawet to nie jest lekarstwem na słabą pamięć".

7. Specyfikacja, eksplikacja bądź identyfikacja obiektu (pojęcia) nazwanego przez człon określany; przydawki wyrażające tego rodzaju bliskie sobie relacje określane są różnymi terminami: genetivus explicativus, epexeticus, synonymus, definitivus, a także genetivus specificationis, inhaerentiae, identitatis. W wielu przypadkach implikowane przez nie relacje odpowiadają stosunkom wyrażanym przez apozycję, np.: urbs Romae 'miasto Rzym' = urbs Roma ${ }^{4}$, stosunkom wyrażanym przez metajęzykowy zabieg $\mathrm{w}$ postaci wyrażenia cudzysłowowego, np. nomen amicitiae 'słowo przyjaźn' = nomen „amicitia", czy też stosunkom dającym się wyrazić poprzez sformułowania typu: „polegający na (czymś)”, „sprowadzający się do (czegoś)”, „będący (czymś)”, „w postaci (czegoś)”, np. poena mortis - „kara śmierci" = kara polegająca na (sprowadzająca się do / w postaci) śmierci':

+ We wcześniejszej literaturze oraz w pismach Cycerona i Cezara grupy złożone z rzeczownika pospolitego i geograficznej nazwy własnej mają wyłącznie strukturę apozycyjną, a więc właśnie urbs Roma. Struktury złożone z tego typu wyrazów z przydawką dopelniaczową typu urbs Romae pojawiają się, obok grup apozycyjnych, w dziełach Wergiliusza, Katullusa i twórców późniejszych.

"Por. Cic., Verr. 2, 5, 54: Quid, si hoc verbo non esses usus „libenter"?; id., Planc. 75: Nam istius verbi "quousque" haec poterat esse invidia.

" Stosunki te wyrazić można także poprzez peryfrazę z użyciem wyrażeń o znaczeniu: „a mianowicie", "to jest", np. poena mortis = poena, nempe (id est) mors. 
Antenor [...] urbem Patavi [...] locavit. (Verg., Aen. 1, 247)

"Antenor miasto Padwa założył".

Flos purpureus rosae. (Hor., Carm. 3, 15, 15)

„Purpurowy kwiat róży”.

Dico [...] Epicurum [...] non intellegere [...], quid sonet haec vox voluptatis. (Cic. Fin., $2,6)$

"Twierdzę, że Epikur nie rozumie, co znaczy owo słowo rozkosz".

Mercedem tanta virtus [...] laudis gloriaeque desiderat. (Cic., Phil.5, 35)

„Tak wielkie męstwo domaga się zapłaty (w postaci) sławy i chwaly”.

Cur decernit honorem sepulturae? (Cic., Phil. 9, 14)

„Dlaczego opowiada się za przyznaniem zaszczytu (publicznego) pogrzebu?”

8. Pojęcie charakteryzujące jakościowo obiekt desygnowany przez człon określany; stanowi zawsze element złożonego określnika, którego drugim komponentem jest zależny składniowo przymiotnik. Przydawka używana w tej funkcji znaczeniowej znana jest jako tzw. genetivus qualitatis ${ }^{7}$ :

L. Tarquinius [...] fratrem habuerat Arruntem Tarquinium, iuvenem mitis ingenii. (Liv., $1,46,4)$

„Lucjusz Tarkwiniusz miał brata Arrunta Tarkwiniusza, młodzieńca o lagodnym usposobieniu".

C. Volusenus, [...] vir et consilii magni et virtutis, ad Galbam adcurrit. (Caes., Gall. 3, 5) „Gajusz Wolusenus, człowiek zarówno o wielkiej rozwadze, jak i o (wielkim) męstwie, podbiega do Galby".

Darius $[\ldots]$ classem quingentarum navium comparavit. (Nep., Milt. 4, 1)

„Dariusz wystawil flotę pięciuset okrętów".

Aristides [...] exilio decem annorum multatus est. (Nep., Arist. 1, 3)

"Arystydes został ukarany wygnaniem dziesięciu lat (dziesięcioletnim)".

Rem [...] magnam complexus sum et plurimi otii. (Cic., Att., 4, 16, 2)

„Podjąłem rzecz wielką i (wymagającą) wiele wolnego czasu”.

9. Klasa (zbiór, rodzaj) obiektów, charakteryzująca pod względem przynależności desygnat członu określanego, który stanowi wyróżniony element (podzbiór, część) tej klasy. Członem określanym jest na ogół substantywizowany przymiotnik (często w komparatiwie lub superlatiwie), liczebnik lub (rzeczownikowy) zaimek; tego rodzaju przydawka to tzw. genetivus partitivus:

Paucae $[\ldots]$ bestiarum $[\ldots]$ stragem edebant. (Liv., 30, 33, 14)

„Nieliczne spośród bestii czynity spustoszenie”. 
Neque dux Romanus ultum iit [...], quamquam multi tribunorum praefectorumque [...] cecidissent. (Tac., Ann., 4, 73)

„Wódz rzymski nie wyruszył na odwet, chociaż wielu z trybunów i prefektów poległo".

Pars hominum vitiis gaudet. (Hor., Serm. 2, 7,6)

"Część ludzi cieszy się ze swoich wad".

Maior Neronum proelium commisit. (Hor., Carm. 4, 14, 14)

„Starszy z Neronów stoczył bitwę".

Maximus regum $[\ldots]$ luxus $[\ldots]$ agitabat. (Flor., Epit. 1, 24)

„Największy $\mathbf{z}$ królów prowadzil zbytkowane życie".

Scipio Laelium Masinissamque cum [...] expeditis militum [...] mittit. (Liv., 30, 9)

„Scypion wysyła Leliusza i Masynissę wraz z lekkozbrojnymi żołnierzami (dosł. lekkozbrojnymi spośród żołnierzy)".

Haud dubium erat quin cum Aequis alter consulum bellum gereret. (Liv., 3, 4, 2)

"Nie było wątpliwości, że z Ekwami drugi z konsulów prowadzi wojnę".

Quidam militum iuxta rogum interfecere se. (Tac., Hist. 2, 49)

„Niektórzy spośród żołnierzy przy stosie popełnili samobójstwo".

Jako genetivus partitivus (lub quantitatis) kwalifikowana jest także przydawka, której nadrzędnik desygnuje pojęcie o charakterze kwantytatywnym:

Erit profecto inter horum laudes aliquid loci nostrae gloriae. (Cic., Catil. 4, 21)

„Wśród ich chwalebnych dokonań znajdzie się zapewne trochę miejsca i dla moich zasług”.

Parum praesidii in legibus erat. (Tac., Ann., 1, 58)

„Prawa zapewniały (zbyt) mało ochrony”.

Aliquid temporis tui sume etiam tibi. (Sen., Dial. 10, 18, 1)

„Nieco twojego czasu przeznacz także dla siebie”.

Podobnie za odmianę genetivus partitivus uznaje się przydawkę, której nadrzędnikiem jest zaimkowa forma id, identyfikująca kontekstowo (anaforycznie lub kataforycznie) treść aktualizującą (konkretyzującą) znaczenie owej dopełniaczowej przydawki lub stanowiącą bliższą charakterystykę jej desygnatu. W rezultacie więc to właśnie zaimek, mimo składniowej nadrzędności, pełni rolę określnika dopełniaczowej przydawki:

Advertere quosdam cultu externo in sedibus senatorum; et quinam forent rogitantes [...] audiverant earum gentium legatis id honoris datum, quae virtute et amicitia Romana praecellerent. (Tac., Ann. 13, 54)

„Zauważyli kilku ludzi w cudzoziemskich strojach na siedzeniach dla senatorów; dopytując się, co to za jedni, uslyszeli, że zaszczyt ten przyznano posłom tych ludów, które wyróżniają się męstwem i przyjaźnią wobec Rzymu".

Postquam ad id loci legati venerunt [...] (Sall., Cat. 45, 3)

„Po tym jak do tego miejsca przyszli posłowie [...]". 
Id temporis ego adulescens Romae sectabar eum discendi gratia. (Gell., Noc. Att. 13, 18, 3) „W tym czasie jako młodzieniec podążałem za nim w Rzymie, by się (od niego) uczyć”.

Etsi nobis, qui id aetatis sumus, evigilatum fere est. (Cic., Rep. 3, 41)

„Chociaż my, którzy jesteśmy w tym wieku, raczej już nie zachowujemy stałej czujności”.

Ad id ventum inopiae est, ut lora detractasque scutis pelles [...] mandere conarentur. (Liv., 23, 19)

„Doszło do takiego niedostatku, że (ludzie) próbowali przeżuwać rzemienie i zdarte z tarcz skóry".

Romanorum nemo id auctoritatis aderat, ut promissa eius magni penderentur. (Tac., Ann. 12, 18)

„Wśród Rzymian nie było nikogo o takim autorytecie, by jego obietnice mogly mieć jakieś większe znaczenie".

Ze specyficznym użyciem tej przydawki mamy do czynienia w przypadku, gdy nadrzędnik sygnalizuje nieistnienie lub niemożność identyfikacji - w obrębie danej klasy - obiektu, któremu przypisywane są $w$ wypowiedzeniu określone właściwości, oraz gdy wskazuje się na jego tożsamość $\mathrm{z}$ całą klasą:

Elephanto beluarum nulla prudentior (est). (Cic., Nat. 1, 97)

„Żadne ze zwierząt nie jest inteligentniejsze od słonia”.

Quis hominum (te) patietur passim cupidines [...] disseminantem? (Apul., Met. 5, 31)

„Kto $\mathbf{z}$ ludzi ścierpi ciebie, rozbudzającego wszędzie namiętności?”

[...] cum Spurinna diceret timendum esse, ne et consilium et vita deficeret, earum enim rerum utramque a corde proficisci. (Cic., Div., 1, 119)

"gdy Spurinna mówil, że trzeba się obawiać, by nie zabrakło (mu) zarówno rozwagi, jak i życia, albowiem obydwie spośród tych rzeczy pochodzą z serca".

10. Rodzaj substancji (materii, obiektów), który konstytuuje desygnat członu określanego; ten rodzaj przydawki również określany bywa terminem genetivus partitivus, lub też stosowane są do niego takie określenia jak genetivus materiae, copiae, quantitatis:

Flumina $[\ldots]$ lactis $[\ldots]$ ibant. (Ov., Met., 1, 111)

„Rzeki mleka płynęly".

Non quaero unde quadraginta amphoras mellis habueris. (Cic., Verr., 2, 2, 183)

„Nie dociekam, skąd miałeś czterdzieści amfor miodu”.

Scutorum incendi $[\ldots]$ acervos. (Verg., Aen. 8, 562)

"Podpaliłem stosy tarcz".

Boii et Tulingi [...] agmen hostium claudebant. (Caes., Gall., 1, 25)

"Bojowie i Tulingowie zamykali oddzial nieprzyjaciól".

Quanta multitudo hominum convenerit ad hoc iudicium, vides. (Cic., S. Rosc. 11)

„Widzisz, jak wielki tłum ludzi zebral się na tę rozprawę". 
Mihi talentum argenti adnumeravit. (Pl., Asin. 500)

„Wyptacil mi telent srebra”.

11. Treść charakteryzująca desygnat członu określanego z perspektywy związanych z nim okoliczności miejsca, czasu, przyczyny, celu itp.:

Omnia superioris noctis consilia ad me perlata esse sentiunt. (Cic., Catil. 2, 6)

„Widzą, że wszystkie plany z poprzedniej nocy zostały mi doniesione”.

Moderationem vero clementiamque [...] in victoria belli civilis admirabilem exhibuit. (Suet., Iul. 75)

„Wykazal godny podziwu umiar i lagodność w chwili zwycięstwa w wojnie domowej”.

Intellegit mortem [...] laborum ac miseriarum quietem. (Cic., Catil. 4,7 )

„Uważa śmierć za odpoczynek po trudach i udrękach”.

Ita torpentes gelu in castra rediere, ut vix laetitiam victoriae sentirent. (Liv., 21, 56)

„Do obozu wrócili tak skostniali z zimna, że ledwie odczuwali radość z powodu zwycięstwa”.

Quod ego sic administrabo, $[\ldots]$ ut $[\ldots]$ ne improbus quidem quisquam $[\ldots]$ poenam sui sceleris sufferat. (Cic., Catil. 2, 28)

„Tak calą rzeczą pokieruję, by nawet żaden lajdak nie poniósł kary za swą zbrodnię (= z powodu swej zbrodni)".

Video $[\ldots]$ quis sibi has urbanas insidias caedis atque incendiorum depoposcerit. (Cic., Catil. 2, 6)

„Wiem, kto zażądal dla siebie możliwości urządzania w mieście zasadzek dla (szerzenia) rzezi i pożogi".

\subsubsection{Rzeczownik w genetiwie jako dopełnienie (dalsze)}

Rzeczowniki w genetiwie pełnią funkcję dopełnienia dalszego przede wszystkim względem orzeczeń (lub innych członów syntaktycznych) stanowionych przez czasowniki należące do kilku klas semantycznych. Klasy te tworzą:

1. Czasowniki, których znaczenie odnosi się do sfery pamiętania, przypominania, wspominania, zapominania itp., a więc czasowniki: memini, recordor, reminiscor, obliviscor, admoneo, commoneo, commonefacio; wyrażone w genetiwie dopełnienia desygnują osobę lub rzecz, która jest pamiętana, przypominana (sobie lub komuś), wspominana bądź zapominana. Genetiwus będący formalnym wyróżnikiem wykładników tych dopełnienień znany jest jako tzw. genetivus memoriae (vel oblivionis):

Faciam, ut huius loci dieique meique semper memineris. (Ter., Eun. 801)

„Sprawię, że na zawsze zapamiętasz to miejsce i (ten) dzień, i mnie”.

Meminerint (adulescentes) verecundiae. (Cic., Off. 1, 122)

„Niech (mlodzieńcy) pamiętają o (zachowywaniu) powściągliwości”. 
Flagitiorum suorum recordabitur. (Cic., Pis. 13)

"Będzie sobie przypominal swe niegodziwe czyny".

Oprócz dopełnienia w genetiwie, przy czasownikach memini i recordor wystąpić może także dopełnienie $\mathrm{w}$ akuzatiwie oraz $\mathrm{w}$ ablatiwie $\mathrm{z}$ przyimkiem de:

Cinnam memini, Sullam vidi. (Cic., Phil. 5, 17)

„Pamiętam Cynnę, widziałem Sullę".

Omnia meminit Siron Epicuri dogmata. (Cic., Acad., 2, 106)

„Siron pamięta wszystkie doktryny Epikura”.

Recordamini, Quirites, omnis civilis dissensiones. (Cic., Catil. 3, 24)

„Przypomnijcie sobie, Kwiryci, wszystkie wewnętrzne spory”.

De palla memento! (Pl., Asin. 939)

„Pamiętaj o plaszczu!"

De Herode et Mettio meminero. (Cic., Att. 15, 27, 3)

"Będę pamiętał o Herodzie i Metiuszu".

De te recordor. (Cic., Scaur. 49)

"Pamiętam o tobie".

Reminisceretur et veteris incommodi populi Romani et pristinae virtutis Helvetiorum. (Caes., Gall. 1, 13)

„Niech sobie przypomni o dawnej klęsce narodu rzymskiego i o prastarej dzielności Helwetów".

[...] tamquam equus reminiscitur viae, cum ad initium eius admotus est. (Sen., Lucil. $124,16)$

„lak jak koń przypomina sobie drogę, kiedy został przyprowadzony do jej początku”.

Obliviscere caedis atque incendiorum. (Cic., Catil. 1,6)

"Zapomnij o rzezi i pożogach".

Nec tamen Epicuri licet oblivisci. (Cic., Fin. 5, 3).

„Jednak nie można zapominać o Epikurze”.

Czasowniki reminiscor i obliviscor również mogą mieć dopełnienia $\mathrm{w}$ akuzatiwie:

Dulcis moriens reminiscitur Argos. (Verg., Aen. 10, 782)

„Umierając, przypomina sobie slodkie Argos".

Duras $[\ldots]$ reminiscere noctes. (Stat., Silv. $1,2,37$ )

„Przypomnij sobie przykre noce”.

Hinc iam obliviscere Graios. (Verg., Aen. 2, 148)

"Odıąd zapomij już o Grekach".

Totam causam oblitus est. (Cic., Brut. 217)

„Zapomnial całą sprawę (= zupełnie zapomnial, o co chodzi w tej sprawie)". 
Oblitus sum omnia. (Pl., Bacch. 790)

"Wszystko zapomniałem".

(Catilina) admonebat alium egestatis, alium cupiditatis suae, compluris periculi aut ignominiae. (Sall., Cat. 21).

"(Katylina) jednemu przypominał nędzę, innemu jego pożądliwość, wielu niebezpieczeństwo albo zniewage".

Mearum me [...] miseriarum commones. (Pl., Rud., 743)

„Przypominasz mi o moich nieszczęśsiach”.

Nunc clementiae, nunc mansuetudinis maiorum, nunc utilitatis publicae commonefacit. (Gell., Noc. Att. 6, 3, 53).

„Przywoluje na pamięć już to lagodność, już to laskawość (naszych) przodków, już to interes publiczny".

Czasowniki admoneo, commoneo, commonefacio o znaczeniu 'przypominać (komuś) o czymś' otwierają miejsce dla dopełnienia w akuzatiwie wyrażającego osobę, której się przypomina, natomiast dopełnienie wyrażające przypominaną rzecz może wystąpić nie tylko w genetiwie, ale również akuzatiwie, jeśli wyrażone jest zaimkiem lub substantywizowanym przymiotnikiem $\mathrm{w}$ rodzaju nijakim albo $\mathrm{w}$ ablatiwie $\mathrm{z}$ przyimkiem de:

Illud me admones. (Cic., Att. 9, 9, 2)

"O tym mi przypominasz".

Hoc unum commonefaciam. (Sen., Lucil. 21, 11)

„To jedno przypomnę".

Te admoneo de syngrapha Sittiana. (Cic., Fam. 7, 4, 5)

„Przypominam ci o kontrakcie Sittiusza”.

Dopełnienie w genetiwie może również pojawić przy wyrażeniu in mentem (alicui) venire - 'przychodzić (komuś) na myśl'; konstytuujący je czasownik występuje wtedy wyłącznie w 3. os. sg. i nie otwiera miejsca dla mianownikowego podmiotu:

Venit mihi in mentem Marci Catonis. (Cic., Verr. 2, 5, 180)

„Przychodzi mi na myśl Marek Katon”.

Non minus saepe ei venit in mentem potestatis quam aequitatis tuae. (Cic., Quinct. 6) „Nie mniej często przychodzi mu na myśl twoja władza, jak twoja sprawiedliwość”.

Non dubito quin $[\ldots]$ nunc $[. .$.$] tuorum tibi scelerum veniat in mentem. (Cic., Verr. 2,$ $1,47)$

„Nie wạtpię, że teraz przychodzą ci na myśl twoje zbrodnie".

Jeśli w ramach tego wyrażenia przychodzący na myśl obiekt desygnuje zaimek lub substantywizowany przymiotnik w rodzaju nijakim, zajmuje pozycję mianownikowego podmiotu: 
Minus enim stultus est is, cui nihil in mentem venit, quam ille, qui quod stulte alteri venit in mentem comprobat. (Cic., Cluent. 84)

„Mniej głupi jest bowiem ten, któremu nic nie przychodzi na myśl, niż ten, który aprobuje to, co glupiego przychodzi na myśl drugiemu".

Non nulla mihi in mentem veniunt. (Cic., Att. 9, 7c, 1)

„Wiele rzeczy przychodzi mi na myśl”.

Należy dodać, że przy wyżej wymienionych czasownikach w miejsce dopełnień mogą występować także podrzędne zdania dopełnieniowe lub ich równoważniki (accusarivus cum infinitivo):

Recordatus est, quid sibi [...] accidisset. (Cic., Q. fr. 2, 2, 1 )

„Wspomniał, co mu się zdarzyło".

$\mathrm{Te}[\ldots]$ commonent fortissimum tibi patrem $[\ldots]$ fuisse. (Cic., Verr. 1, 1, 52)

„Przypominają ci, że miałeś bardzo dzielnego ojca”.

2. Czasowniki mające znaczenie oskarżania, obwiniania (o coś), pozywania do sądu, skazywania (za coś), uwalniania od oskarżenia (o coś), a więc np. czasowniki: accuso, incuso, insimulo, arguo, convinco, (reum) facio, arcesso, postulo, damno, condemno, abolvo, libero; konotowane przez nie dopełnienie w genetiwie identyfikuje zarzut lub winę i określane jest terminem genetivus criminis:

(Miltiades) accusatus [...] est proditionis. (Nep., Milt. 7)

"(Miltiades) zostal oskarżony o zdradę".

(Fannius) C. Verrem insimulat avaritiae et audaciae. (Cic., Verr. 2, 1, 128)

„(Fanniusz) zarzuca Gajuszowi Werresowi chciwość i bezczelność".

Nicomedes $[\ldots]$ furti $[\ldots]$ damnatus est. (Cic., Flacc. 43)

„Nikomedes zostal skazany za kradzież".

(Tiberius) Fannium Caepionem [...] reum maiestatis apud iudices fecit et condemnavit. (Suet., Tib. 8, 1)

„(Tyberiusz) Fanniusza Cepiona oskarżył przed sądem o obrazę majestatu i doprowadzil do skazania".

Praetorem Bithyniae quaestor ipsius $[\ldots]$ maiestatis postulavit. (Tac., Ann. 1, 74)

„Pretora Bitynii jego wlasny kwestor pozwał o obrazę majestatu”.

Absolutus (est) Cestius Proculus repetundarum, Cretensibus accusantibus. (Tac., Ann. 13, 30)

„Uwolniony został od zarzutu (dokonania) zdzierstw Cestiusz Prokulus, którego oskarżali Kreteńczycy".

W miejsce dopełnienia w genetiwie czasowniki te przyjmować mogą także dopełnienia wyrażone rzeczownikiem $\mathrm{w}$ ablatiwie $\mathrm{z}$ przyimkiem de lub $\mathrm{w}$ akuzatiwie $z$ przyimkiem ob. Jeśli stanowione są przez rzeczowniki o znaczeniu ogólnym, generycznym, jak np. crimen, scelus, mogą wystąpić w ablatiwie: 
Lex vetat eum, qui de pecuniis repetundis damnatus sit, in contione orationem habere. (Rhet. Her. 1, 20)

„Prawo zabrania przemawiania na zgromadzeniu ludowym temu, kto zostal skazany za zdzierstwa finansowe".

Damnatus (est) isdem consulibus Vipsanius Laenas ob Sardiniam avare habitam. (Tac., Ann. 13, 30)

„Za tych samych konsulów Wipsaniusz Lenas został skazany za zachlaność w zarządzaniu Sardynią".

Przy czasownikach oznaczających skazywanie, karanie lub uwalnianie od kary, np.: damno, condemno, multo, absolvo, libero, mogą wystąpić także dopełnienienia w genetiwie, wyrażające w sposób ogólny (nie konkretny) wymiar kary. Wyjątkiem jest kara śmierci, która także może być wyrażona w ten sposób:

Cupio octupli damnari Apronium. (Cic., Verr. 2, 3, 28).

„Chcę, żeby Aproniusz zostal ukarany grzywną ośmiokrotnie większą".

(Socratis) responso iudices sic exarserunt, ut capitis hominem innocentissimum condamnarent. (Cic., De orat. 1, 233)

„Odpowiedzią (Sokratesa) sędziowic tak się oburzyli, że najbardziej niewinnego człowieka skazali na śmierć".

3. Czasowniki wyrażające uczucia przykrości, niezadowolenia, irytacji, odrazy ( $p i$ get), wstydu, żalu (pudet, paenitet), zniechęcenia, wstrętu (taedet), litości, żalu, współczucia (miseret), czyli tzw. verba affectuum. Orzeczenia stanowione przez te czasowniki występują zwykle w 3. os. sg. i implikują niepodmiotową składnię zdania, otwierając miejsce dla dopełnienia wyrażającego przedmiot uczucia w genetiwie oraz dla dopełnienia wyrażającego osobę doznającą uczucia $\mathrm{w}$ akuzatiwie: Me civitatis morum piget taedetque. (Sall., Iug. 4, 9)

„Złoszczą mnie i brzydzą obyczaje społeczeństwa”.

[...] si scias, quam me pudeat nequitiae tuae, cuius te ipsum non pudet. (Cic., Phil. 2, 76) "gdybyś wiedzial, jak bardzo wstyd mi za twoją niegodziwość, której ty sam się nie wstydzisz"

Eos, qui secus, quam decuit, vixerunt, peccatorum suorum [...] maxume paenitet. (Cic., Div. 1, 64)

„Ci, klórzy żyli inaczej niż przystalo, najbardziej żałują swoich grzechów”.

Neque me militum neque vos ducis paenituit. (Tac., Agr. 33, 3)

"Ani ja nie wstydzilem się za żolnierzy, ani wy za wodza".

Nec te telluris amatae [...] miseret? (Stat., Theb. 7, 157)

„Nie żal ci ukochanej ziemi?”

"Przy pudet dopełnienie w genetiwie wyrażać może także osobę, przed którą lub wobec której odczuwa się wstyd: Id mihi vehementer dolet et me tui pudet "Bardzo mnie to boli i wstyd mi przed tobą" (Ter., Adelph. 682). 
$\mathrm{W}$ formach perfektywnych czasowniki te ( $\mathrm{z}$ wyjątkiem paenitet) mogą wystąpić także w passivum:

Apollinem tam humilis victoriae puditum est. (Apul., Flor. 3, 46)

"Apollinowi wstyd było tak haniebnego zwycięstwa".

Me rei publicae maxime miseritum est. (Scip. Afr. min., Orat. fr. 30, 10)

„Najbardziej żal mi bylo rzeczpospolitej”.

Ita me ibi male convivi sermonisque taesumst. (Pl., Most. 316)

„Tak bardzo zmierziła mnie tam ta uczta i rozmowa”.

Czasownik miserere może wystąpić w stronie biernej także $w$ formach nieperfektywnych. Formy pasywne tego czasownika najczęściej implikują jednak podmiotową składnię zdania, z zachowaniem dopełnienia wyrażającego przedmiot uczucia w genetiwie:

Si mortuorum aliquis miseretur, et non natorum misereatur. (Sen., Dial. 6, 19, 5)

"Jeśli ktoś lituje się nad zmarłymi, to niech lituje się i nad nie narodzonymi”.

Patris tui misereor. (Sen., Controv. 2, 3, 9)

„Żal mi twojego ojca".

Saepe miseritus sum generis humani. (Sen., Lucil. 108, 13)

"Często litowałem się nad rodzajem ludzkim".

Miseremini indigne caesorum iuvenum. (Apul., Met. 3, 8)

"Zlitujcie się nad niewinnie pomordowanymi mlodzieńcami".

Przy większości spośród wyżej wskazanych czasowników przedmiot uczucia może być także wyrażony w składni podmiotowej przez pełniący funkcję podmiotu zaimek lub substantywizowany przymiotnik rodzaju nijakiego w mianowniku, a także przez bezokolicznik, zdanie podrzędne lub jego równoważnik (accusarivus cum infinitivo), wypełniające miejsce podmiotu:

Neque id me sane paenitet. (Gell., Noc. Att. 13, 2, 4)

"I nie czuję żalu (nie ubolewam) z tego powodu".

Non te haec pudent? (Ter., Adelph. 754)

„Nie wstydzisz się tych rzeczy?”

Semper metuet, quem saeva pudebunt. (Lucan., Bell. Civ. 8, 495)

"Zawsze będzie się bal ten, kogo będą zawstydzać srogie czyny".

Illum tu lauda et imitare, quem non piget mori, cum iuvet vivere. (Sen., Lucil. 54, 7) jemność".

„Chwal i naśladuj tego, komu nie jest przykro umierać, chociaż i życie sprawia przy-

Neque me paenitet vixisse. (Cic., Sen. 84)

„I nie żaluje, że żyłem". 
An paenitet vos, quod salvum atque incolumem exercitum $[\ldots]$ traduxerim? (Caes., Civ. 2, 32, 12)

"Czy bolejecie nad tym, że cało i zdrowo wojsko (przez morze) przeprawiłem?"

Cum sene non puduit talem dormire puellam. (Prop., Eleg. 2, 18b, 17)

„Nie było czymś wstydliwym, że taka dziewczyna sypia ze starcem".

Wyjątkowo w archaicznej łacinie w tej funkcji pojawić się może także rzeczownik:

Me quidem haec condicio nunc non paenitet. (Pl., Stich. 51)

„Mnie ten obecny stan nie sprawia przykrości”.

Miejsce dla dopełnienia dalszego w genetiwie otwiera także pewna liczba czasowników, które nie tworzą zwartej grupy semantycznej. Przy niektórych czasownikach dopełnienie $w$ genetiwie stanowi alternatywną postać dopełnienia, które może być wyrażone także $w$ innym przypadku, najczęściej w ablatiwie, np.:

Convivium vicinorum cotidie compleo. (Cic., Sen. 46)

"Codziennie wypełniam ucztę sąsiadami" (= zapraszam sąsiadów na ucztę).

Implentur veteris Bacchi pinguisque ferinae. (Verg., Aen. 1, 215)

"Opychają się starym winem i tłustą dziczyzną".

Dum custodis eges. (Hor., Serm. 1, 4, 118)

„Dopóki potrzebujesz opiekuna”.

(Hannibal) cum [...] alienarum opum indigeret, numquam destiterit animo bellare cum Romanis. (Nep., Hann. 1, 3)

„(Hannibal) nawet wtedy, gdy potrzebowal pomocy innych, ani na moment nie przestal duchem walczyć z Rzymianami".

Desine mollium tandem querellarum. (Hor., Carm. 2, 9, 18)

„Porzuć wreszcie niemçskie lamenty”.

[...] postquam [...] Lysander classis hostium est potitus [...] (Nep., Lys. 1, 4)

„po tym jak Lizander zawładnąl flotą nieprzyjaciól [...]".

Neque huius sis veritus feminae primariae. (Ter., Phorm. 971)

„I nie okazaleś szacunku tej znakomitej kobiecie”.

Neque $[. .$.$] sepositi ciceris nec [\ldots]$ invidit avenae. (Hor., Serm. 2, 6, 84)

„Nie żałuje ani odłożonego na zapas grochu, ani owsa”.

Poza tym dopełnienie w genetiwie występuje także przy wielu przymiotnikach pełniących funkcję przydawki lub (równoważnika) orzecznika bądź przy substantywizowanych przymiotnikach zajmujących inne pozycje składniowe, np.:

Cetthegus, qui paulo ante $[\ldots]$ dixisset se semper bonorum ferramentorum studiosum fuisse [...]. (Cic., Catil. 3, 10)

„Cetegus, który nieco wcześniej powiedzial, że zawsze byl rozmiłowany w dobrej broni [...]". 
Q. Scaevola [...] peritissimus iuris [...] est habitus. (Cic., Brut. 212)

„Kwintus Scewola był uważany za bardzo bieglego w prawie".

Fuere item ea tempestate, qui crederent $M$. Licinium Crassum non ignarum eius consilii fuisse. (Sall., Cat. 17, 7)

„Byli również w tym czasie tacy, którzy wierzyli, że Marek Licyniusz Krassus nie był nieświadomy tego planu".

Erat in oppido multitudo insolens belli diuturnitate otii. (Caes., Gall. 2, 36)

„Przebywało w mieście mnóstwo ludzi odwykłych od wojny wskutek dlugotrwalego pokoju”.

Ausus es $[\ldots]$ clivum Capitolinum dicere me consule plenum servorum armatorum fuisse. (Cic., Phil. 2, 16)

„Miałeś czelność twierdzić, że za mojego konsulatu droga prowadząca na Kapitol pełna była uzbrojonych niewolników".

$\mathrm{Z}$ dopełnieniem $\mathrm{w}$ genetiwie mamy do czynienia również przy zadiektywizowanych participiach praesentis, mających charakter przymiotników denotujących pewną stałą właściwość (skłonność, dyspozycję):

Erat Iugurtha [...] appetens gloriae militaris. (Sall., Iug. 7, 1)

„Jugurta byt żądny chwały wojennej”.

Aliquis [...] legum, officii, rei publicae, sociorum atque amicorum neglegentior. (Cic., Verr. 2, 3, 143)

„Ktoś mniej dbający o prawa, obowiązki, państwo, towarzyszy i przyjaciól”.

Nemo erat adeo tardus aut fugiens laboris, ut [... ]. (Caes., Civ. 1, 69)

„Nikt nie był do tego stopnia tępy albo nieskory do wysitku, aby [...]".

Niezadiektywizowane participia, zachowujące znaczenie czasownikowe, otwierają zwykle miejsce dla dopełnienia w przypadku determinowanym rekcją odpowiadających im form osobowych; por. np.: Cum gladiis non in regnum appetentem, sed in regnantem impetum fecerunt. „Rzucili się z mieczami nie na człowieka sięgającego po władzę królewską, lecz na już panującego" (Cic., Phil. 2, 114).

Rzeczownikowe dopełnienia w genetiwie (stanowione głównie przez formy takich rzeczowników jak animus czy mens) występują także przy pewnych przymiotnikach, tworząc z nimi sfrazeologizowane wyrażenia odnoszące się do stanów psychicznych, np.: aeger animi 'przygnębiony', sanus mentis 'zdrowy na umyśle' itp.

\subsubsection{Rzeczownik w genetiwie jako orzecznik}

Rzeczownik w genetiwie pełni funkcję orzecznika przede wszystkim przy formach czasownika esse, desygnując:

1. Osoby, którym przypisywane jest posiadanie lub autorstwo desygnatu podmiotu (genetivus possessivus/auctoris): 
Praeter Capitolium atque arcem omnia haec hostium erant. (Liv., 6, 40, 17)

"Oprócz Kapitolu i zamku wszystko to należało do nieprzyjaciód".

Hic versus Plauti non est, hic est. (Cic., Fam. 9, 16, 4)

„Ten wers nie jest Paluta, a ten jest”.

2. Obiekty (osobowe i nieosobowe), którym desygnat podmiotu przypisywany jest jako im szczególnie właściwy, stosowny, przynależny, odpowiedni; pozycję podmiotu (lub jego funkcjonalnego odpowiednika) często wypełnia wtedy bezokolicznik lub zdanie podrzędne:

Non minus est imperatoris consilio superare quam gladio. (Caes., Civ. 1, 72)

„W nie mniejszym stopniu przynależy wodzowi zuyciężać dzięki rozwadze, jak dzięki mieczowi".

Cuiusvis hominis est errare, nullius nisi insipientis perseverare in errore. (Cic., Phil. $12,5)$

"Cechą każdego czlowieka jest błądzić, ale cechą wylącznie glupca jest trwać w blędzie".

Temeritas [...] est florentis aetatis, prudentia senescentis. (Cic., Sen. 20)

„Lekkomyślność jest cechą mlodego wieku, rozwaga wieku dojrzałego".

3. Obiekty (pojęcia, właściwości) charakteryzujące jakościowo desygnat podmiotu; orzecznikowi tego rodzaju obligatoryjnie towarzyszy przydawka przymiotnikowa, związana $z$ nim związkiem atrybucji; ten typ orzecznika określany jest także terminem genetivus qualitatis:

Res erat multae operae. (Caes., Gall. 5, 11)

„Rzecz wymagala wielkiego wysilku”.

Huius enim classis mille et ducentarum navium longarum fuit. (Nep., Them. 2, 4)

„Jego flota liczyła bowiem tysiąc dwieście okrętów wojennych”.

Występując $w$ genetiwie, funkcję orzecznika pełnią także pewne rzeczowniki oznaczające przedmioty małej wartości, np.: pilus 'włos', naucum 'łupina orzecha', as 'as' (= grosz, drobna moneta), floccus 'pęczek wełnianego włosia', a także nihilum 'nic'. Współtworzą one orzeczenia wyrażające niskie wartościowanie, lekceważenie kogoś lub czegoś - w połączeniu z czasownikami: facere, habere, ducere, putare, aestimare, pendere - lub bycie nisko wartościowanym, lekceważonym - w połączeniu $\mathrm{z}$ czasownikami esse, fieri, constare, valere. Orzeczenia te są charakterystyczne dla języka potocznego i często towarzyszy im przeczenie (por. pol. „nie wart funta kłaków”). Przy tych samych czasownikach mogą także wystąpić w charakterze orzeczników substantywizowane przymiotniki lub zaimki w genetiwie, np.: magni, maximi, plurimi, parvi, pluris, minoris, tanti, quanti, tantidem itp., stanowiąc współwykładnik orzeczenia oznaczającego wartościowanie zarówno niskie, jak i wysokie, ale wyrażone w terminach ogólnych ('oceniać wysoko / nisko / niżej', 'mieć duże / małe znaczenie / 
wartość / cenę, 'kosztować tyle samo / tyle, ile...' itp. ${ }^{10}$. Występujące w ramach takich orzeczeń orzeczniki w genetiwie określane są terminem genetivus pretii:

Rumores [...] senum severiorum omnes unius aestimemus assis. (Catull. 5, 2-3)

„Całą gadaninę zbyt surowych starców uznajmy za niewartą zlamanego szeląga".

Nemo Iovem pili facit. (Petron., Sat. 44, 17)

„Dla Jowisza nikt nie ma nawet za grosz poszanowania”.

Non habeo [...] nauci Marsum augurem, non vicanos haruspices, non de circo astrologos. (Cic., Div. 1, 132)

„Żadnej wartości nie ma dla mnie marsyjski augur, ani wiejscy haruspikowie, ani cyrkowi astrolodzy".

Invidere omnes mihi, mordere clanculum, ego non flocci pendere. (Ter., Eun. 410-411)

„Wszyscy mi zazdroszczą, po kryjomu dogryzaja, a ja mam to za nic".

Merito vostro amo vos, quia me colitis et magni facitis. (Pl., Cist. 21-22)

"Kocham was, bo na to zasłużyliście, ponieważ mnie szanujecie i wysoko cenicie".

Non ego illud parvi aestimo, milites, quod nemo est vestrum, cuius non ante oculos ipse saepe militare aliquod ediderim facinus. (Liv., 21, 43)

„Nie ma dla mnie malego znaczenia to, żotnierze, że nie ma wśród was nikogo, przed którego obliczem osobiście nie dokonywalbym po wielokroć jakichś czynów wymagających żolnierskiej dzielności".

Ecquid [...] tibi videtur [...] senex ille Caecilianus minoris facere Eutychum, filium rusticum, quam illum alterum, Chaerestratum? (Cic., S. Rosc. 46)

„Czy wydaje ci się, że ów starzec z komedii Cecyliusza mniej ceni Eutychusa, syna mieszkającego na wsi, niż tego drugiego, Cherestratusa?"

Frumentum tanti fuit, quanti iste aestimavit. (Cic., Verr. 2, 3, 194)

„Zboże mialo taką cenę, na jaką on je oszacowal”.

Tecta $[\ldots \mid$ ambulatiuncula addenda est; quam ut tantam faciamus, quantam in Tusculano fecimus, prope dimidio minoris constabit isto loco. (Cic., Att. 13, 29, 1)

„Trzeba dodać mały portyk; gdyby byt takiej wielkości jak ten, który zbudowaliśmy w Tusculum, kosztować będzie niemal o polowę mniej w tamtym miejscu."

Ponadto do tej klasy zaliczyć można także występujące w genetiwie orzeczniki w ramach wyrażeń lucri / compendii facere (aliquid) 'wykorzystać coś dla osiągnięcia zysku', 'osiągnąć zysk (z czegoś)':

Nocturni [...], qui volebant pallium lucri facere, flagitabant, uti apud se utraque deponerentur. (Petron., Sat. 15, 2)

„Nocni stróże, którzy chcieli zarobić na plaszczu, domagali się, aby obie rzeczy zostały u nich zlożone w depozycie".

1" $\mathrm{Z}$ tą grupą orzeczników wiąże się inny charakter przeczenia niż w wyżej wymienionych orzeczeniach wyrażających niskie wartościowanie za pośrednictwem orzeczników o konkretnym znaczeniu - por. podane niżej przykłady. 


\subsubsection{Rzeczownik $w$ genetiwie jako funkcjonalny odpowiednik orzecznika}

Zajęcie przez rzeczowniki $w$ genetiwe pozycji funkcjonalnego odpowiednika orzecznika związane jest $\mathrm{z}$ sekundarną dystrybucją składniową czasowników, $\mathrm{z}$ którymi współtworzyć mogą (jako orzeczniki) wskazane wyżej orzeczenia. Wyrażone $\mathrm{w}$ genetiwie funkcjonalne odpowiedniki orzeczników cechują się w związku $\mathrm{z}$ tym takimi samymi właściwościami semantycznymi, jak wyrażane $\mathrm{w}$ genetiwie orzeczniki. Różnią się zaś od nich tym, że stanowią podstawowe wykładniki treści predykatywnej w ramach funkcjonalnych odpowiedników orzeczeń współtworzonych $\mathrm{z}$ formami nieosobowymi czasowników (tj. z bezokolicznikami), głównie w ramach równoważników zdań o postaci accusativus cum infinitivo:

Praesidibus [...] rescripsit boni pastoris esse tondere pecus, non deglubere. (Suet., Tib. 32) „Zarządcom (prowincji) odpisal, że dobremu pasterzowi przystoi strzyc owce, a nie obdzierać (je) ze skóry".

(Philodamus) negavit moris esse Graecorum, ut in convivio virorum accumberent mulieres. (Cic., Verr., 2, 1, 66)

„(Filodamus) stwierdzil, że nie jest właściwe dla obyczaju greckiego, aby podczas uczty dla mężczyzn zajmowały miejsce przy stole (także) kobiety".

z elizją czasownika esse:

Eum [...] magni animi, magnae inter Gallos auctoritatis (esse) cognoverat. (Caes., Gall. $5,6)$

„Wcześniej dowiedzial się, że on cechuje sį̨ wielką odwagą i wielkim uznaniem wśród Gallów".

Video te nihili pendere prae Philolache omnis homines. (Pl., Most. 245)

„Widzę, że wobec Filolachesa wszystkich (innych) ludzi zupełnie lekceważysz".

Scio enim eius ordinis auctoritatem semper apud te magni fuisse. (Cic., Fam. 13, 72, 2)

„Wiem bowiem, że autorytet tego stanu zawsze miał u ciebie wielką wartość".

\subsubsection{Rzeczownik w genetiwie jako okolicznik}

Pozycję okolicznika rzeczowniki w genetiwie zajmują:

1. Przy czasowniku interest w znaczeniu '(coś dla kogoś / czegoś) jest ważne, liczy się, ma znaczenie'; wyrażony w genetiwie okolicznik identyfikuje osobę lub rzecz (sprawę), dla której coś jest ważne. Formy osobowe czasownika interest ograniczone są wtedy do 3. os. sg., a miejsce podmiotu wypełnia wylącznie mianownikowy zaimek w rodzaju nijakim, infinitivus, zdanie podrzędne lub jego równoważnik (accusativus cum infinitivo):

Theodori quidem nihil interest, humine an sublime putescat. (Cic., Tusc. 1, 102)

„Dla Teodora w ogóle nie jest ważne, czy będzie gnił w ziemi, czy w powietrzu (odpowiedź filozofa na slowa króla grożącego mu ukrzyżowaniem)". 
Non interfuit occidentium, quid diceret. (Tac., Hist. 1, 41)

„Dla zabójców nie mialo znaczenia, co mówił".

Ostendam alio loco quantum salutis communis intersit duos consules in re publica Kalendis Ianuariis esse. (Cic., Mur. 4)

„W innym miejscu wykażę, jak wielkie znaczenie dla powszechnego bezpieczeństwa ma to, żeby dwóch konsulów pierwszego stycznia objęło w państwie urząd".

Legati adiecerunt [...] cum ceterorum id interesse, tum praecipue Rhodiorum. (Liv., 42, $46,4)$

„Posłowie dodali, że o ile jest to ważne dla (wszystkich) pozostałych, o tyle najbardziej dla Rodyjczyków".

Si nihil [...] interest regis, peto, ut, dum dico, vinculis liberer. (Curt., Hist. Al. Magn. 7, 1, 18)

„Jeśli królowi nie sprawia to różnicy proszę, aby na czas, gdy będę mówił, uwolniono mnie z kajdan".

W tym kontekście okolicznik odpowiadający wyżej wymienionemu rzeczownikowi w genetiwie, nie odnoszący się do osoby, może zostać wyrażony także $\mathrm{w}$ inny sposób, m.in. przez rzeczownik $\mathrm{w}$ akuzatiwie $\mathrm{z}$ przyimkiem ad:

Ad honorem nostrum interest quam primum ad urbem me venire. (Cic., Fam. 16, 1, 1) „Jest ważne dla mojego honoru, abym jak najszybciej dotarł do miasta”.

Z kolei jeśli odnosi się on do osób za pośrednictwem zaimków, przyjmuje postać zaimka dzierżawczego w abl. sg. fem., a więc wyraża się poprzez formy: mea, tua, nostra, vestra, sua:

Video enim quid mea intersit, quid utriusque nostrum. (Cic., Fam. 7, 23, 4)

„Widzę bowiem, co jest ważne dla mnie, (i) co dla każdego z nas dwojga”.

Nostra interest scire ea, quae eventura sunt. (Cic., Div. 2, 105)

"Zależy nam na tym, by wiedzieć, co się wydarzy".

Malui facere, quod meus familiaris tanti sua interesse arbitraretur. (Cic., Fam. 13, 10, 1) „Wolałem uczynić to, o czym mój przyjaciel sądzil, iż jest dla niego bardzo ważne”.

2. Przy czasownikach oznaczających kupowanie, sprzedawanie, wynajmowanie, licytowanie itp. Przy tego rodzaju nadrzędnikach może wystąpić okolicznik w postaci genetiwu substantywizowanych przymiotników: magni, parvi, minoris, pluris itp. lub zaimków: tanti, quanti, tantidem itp. identyfikujących ogólnie ujętą cenę obiektu lub wartość transakcji, o których mowa w wypowiedzeniu. Semantycznie okolicznik ten to genetivus pretii:

Multo minoris vendidit non modo quam tu, sed etiam quam qui antet te vendiderunt. (Cic., Verr. 2, 3, 43)

„Sprzedał o wiele taniej nie tylko niż ty, ale także niż ci, którzy przed tobą sprzedawali”. 
Emit homo cupidus et locuples tanti, quanti Pythius voluit. (Cic., Off. 3, 59)

„Ogarnięty gorącym pragnieniem i bogaty czlowiek kupuje za taką cenę, jakiej chcial Pytiusz".

M. Minucio [...] et A. Sempronio consulibus magna vis frumenti ex Sicilia advecta, agitatumque in senatu quanti plebi daretur. (Liv., 2, 34)

„Za konsulatu Marka Minucjusza i Aulusa Semproniusza przywieziono z Sycylii wielką ilość zboża i debatowano w senacie, po jakiej cenie sprzedawać je ludowi".

Okoliczniki o postaci substantywizowanych przymiotników w genetiwie (magni, permagni, parvi) mogą także wystąpić przy czasownikach interest $i$ refert, cechujących się znaczeniem i właściwościami składniowymi określonymi wyżej w pkt. 1. Okoliczniki te wartościują wtedy treść predykatywną wyrażaną przez składniowy nadrzędnik, w związku z czym również mogą być uznane za odmianę genetivus pretii ${ }^{11}$ :

Caesar [...] magni interesse arbitrabatur quam primum oppido potiri. (Caes., Civ. 1, 21)

„Ceazar uważal, że jest bardzo ważne, aby jak najszybciej zawładnął miastem”.

Tribuni plebis permagni interest qui sint. (Cic., Planc. 13)

„Ogromne ma znaczenie (= liczy się bardzo wysoko), jacy są trybuni ludowi".

Animi magni refert quali in corpore locati sint, multa enim e corpore existunt, quae acuent mentem, multa, quae obtundant. (Cic., Tusc. 1, 80)

„Jest bardzo ważne, $w$ jakim ciele dusze są ulokowane, bowiem $z$ ciala pochodzi wiele rzeczy, które czynią umysł bystrym, i wiele, które go przytępiają".

In eo parvi refert, quid veri sit. (Liv., 8,18 )

„W tej sprawie małe ma znaczenie (= nisko się liczy), co jest prawdą".

3. Przy przymiotnikach (w stopniu wyższym i najwyższym) oraz liczebnikach pełniących funkcję orzecznika lub przydawki, a także przy (innych) okolicznikach. Semantycznie należą one do typu genetivus partitivus:

Ventorum frigidissimi sunt quos a septentrione diximus spirare. (Plin., Nat. hist. 2, 126)

"Spośród wiatrów najzimniejsze są te, o których powiedzieliśmy, że wieją z pólnocy".

Omnium oratorum [...] acutissimum iudico [...] Q. Sertorium (Cic., Brut. 180)

„Za najbardziej przenikliwego spośród wszystkich mówców uważam Sertoriusza".

[...] ut vir doctissimus fecit Plato atque idem gravissimus philosophorum. (Cic., Leg. $2,14)$

„jak uczynil Platon, czlowiek najbardziej uczony i zarazem najwybitniejszy z filozofów”. Haec mihi Stertinius, sapientum octavus, [...] arma dedit. (Hor., Serm. 2, 3, 296)

„Tę oręż dał mi Stertiniusz, ósmy z mędrców".

11 W tych kontekstach podobne treści mogą być także wyrażane przez przysłówki (magnopere, magis, minime, maxime itp.) lub zaimki (nihil, multum, minimum itp.). 
Ubinam gentium sumus? (Cic., Catil. 1, 9)

„Gdzie spośród narodów jesteśmy? (= wśród jakiego narodu żyjemy?)”

4. W innych kontekstach, jeśli rzeczownikami tymi są nazwy miast lub mniejszych wysp $^{12}$ należące do paradygmatu fleksyjnego I lub II deklinacji liczby pojedynczej, a także niektóre inne rzeczowniki (humus, vicinia, animus, mens) używane jako określniki miejsc. Tego rodzaju lokatywny okolicznik stanowi refleks tego, iż w języku praindoeuropejskim, z którego łacina się wywodzi, istniał osobny przypadek służący wyrażaniu okoliczników miejsca, tzw. locativus. W łacinie jego odrębność zaznacza się jedynie szczątkowo w takich formacjach jak: domi (rzadziej domui), ruri, Carthagini, natomiast w odniesieniu do innych leksemów jego formalny kształt odpowiada albo właśnie genetiwowi, albo ablatiwowi (zob. niżej: 7.5.6.1.0.)

Cum (Nero) magni aestimaret cantare etiam Romae, Neroneum agona ante praestitutam diem revocavit. (Suet., Ner. 21 )

„Ponieważ (Neron) bardzo sobie cenił występy pieśniarskie również w Rzymie, ogłosił rozpoczęcie kolejnych igrzysk Neronowych przed wyznaczonym terminem".

Repperit [...] Pompeium remanere Brundisii cum cohortibus viginti. (Caes., Civ. 1, 25)

„Dowiedział się, że Pompejusz pozostał w Brundyzjum z dwudziestoma kohortami”.

Destinaverat [...] Sami Polycratis regiam restituere, Mileti Didymeum peragere. (Suet., Cal. 21)

„Postanowil na Samos odbudować palac Polykratesa, w Milecie ukończyć przybytek Apollina Didymejskiego".

Tiberium quoque Rhodi agentem coluerat. (Tac., Ann. 3, 48)

„Z szacunkiem odnosił się także do Tyberiusza bawiącego na Rodos”.

Me capillos eius, qui [...] desecti humi iacebant, clanculo praecipit auferre. (Apul., Met. $3,16)$

„Nakazuje mi potajemnie przynieść jego włosy, które ścięte leżały na ziemi”.

Proximae viciniae habitat. (Pl., Bacch. 205-206)

"Mieszka w najbliższym sąsiedztwie".

Animi pendere soleo, cum semel quid orsus traducor alio. (Cic., Leg. 1, 9)

„Zwykle niepokoję się w duszy, kiedy raz coś zacząwszy zmuszony jestem przejść do czegoś innego".

Desipiebam mentis, cum illa scripta mittebam tibi. (Pl., Epid. 138)

"Byłem chory na umysle, gdy wysylatem ci te listy". 


\subsubsection{Dafivus}

\subsubsection{Rzeczownik $w$ datiwie jako dopełnienie dalsze}

Dopełnienie dalsze jest podstawową funkcją składniową rzeczowników w datiwie. Funkcja ta wynika z właściwości znaczeniowych określonych klas czasowników, przymiotników i niewielkiej grupy przysłówków, które implikują ujawnienie obiektów mających ogólny status celu, adresata, recypienta czy punktu odniesienia desygnowanych przez te klasy leksemów czynności, działań, zdarzeń, postaw, uczuć, cech, właściwości itp., np.: prodesse (alicui) 'pomagać' (komuś), similis (alicui (rei)) 'podobny' (do kogoś (czegoś)). Prymarnie członami nadrzędnymi dla celownikowych dopełnień dalszych są więc czasownikowe orzeczenia, przymiotnikowe przydawki i przysłówkowe okoliczniki, ale sekundarnie mogą być nimi także np.: bezokolicznikowe podmioty, imiesłowowe przydawki, funkcjonalne odpowiedniki orzeczenia $\mathrm{w}$ infinitiwie lub participum ( $\mathrm{w}$ ramach accusativus cum infinitivo lub ablativus $a b$ solutus) czy przymiotnikowe orzeczniki. Z członami nadrzędnymi łączy dopełnienia dalsze związek rekcji.

Celownikowe dopełnienia dalsze konotowane przez czasownikowe człony nadrzędne mogą być jedynymi dopełnieniami tych członów lub też mogą występować równolegle obok innych, które wyrażane są najczęściej w akuzatiwie i mają status dopełnienia bliższego. Strukturalna różnica między tymi dopełnieniami, czyli różnica między dopełnieniem dalszym a bliższym, sprowadza się do tego, że po zmianie diatezy zdaniowej na bierną desygnat dopełnienia bliższego ujawniany jest przez mianownikowy podmiot, np.: Natura hominibus brevem vitam dedit („Natura ludziom dała krótkie życie”) $\rightarrow$ A natura hominibus brevis vita data est ("Przez naturę ludziom dane zostało krótkie życie"), natomiast desygnat dopełnienia dalszego przy danym członie czasownikowym nie jest ujawniany przez mianownikowy podmiot, ponieważ w przypadku zmiany diatezy jego wykładnik zachowuje ten sam status dopełnieniowego członu zależnego $\mathrm{w}$ datiwie, np.: Natura hominibus brevem vitam dedit ( $\mathrm{Na}$ tura ludziom dała krótkie życie”) $\rightarrow$ A natura hominibus brevis vita data est („Przez naturę ludziom dane zostało krótkie życie"), lub też nadanie zdaniu diatezy biernej w ogóle nie jest możliwe, np.: Ancilla prodest dominae („Służąca pomaga pani”).

Tradycyjnie leksemy czasownikowe, które otwierają miejsce dla dopełnienia blizszego (i tym samym dopuszczają bierną diatezę zdaniową), nazywane są przechodnimi, natomiast te, które miejsca takiego nie otwierają, nazywane są nieprzechodnimi. Dopełnienia dalsze konotowane zatem mogą być zarówno przez czasowniki przechodnie, jak i nieprzechodnie. Należy jednak zaznaczyć, że przechodniość, a także liczba, status i forma dopełnień, w wielu przypadkach nie są jednoznacznie przypisane danej czasownikowej jednostce leksykalnej jako takiej, lecz zdeterminowane są przez różne znaczenia (treści predykatywne), które może ona wyrażać. Oznacza to, że ten sam leksem czasownikowy, w zależności od wyrażanego $\mathrm{w}$ danym użyciu znaczenia, może $\mathrm{w}$ jednym przypadku cechować się przechodniością, $w$ innym nie- 
przechodnością; podobnie w jednym znaczeniu (kontekście) może otwierać miejsce dla dopełnienia $w$ datiwie, $w$ innym dla dopełnienia $w$ innym przypadku, $w$ jeszcze innym może nie konotować żadnego dopełnienia; por. np.: Parti civium consulunt „Troszczą się o część obywateli” (Cic., Off. 1, 85); Me de Antonio consulis „Pytasz mnie o opinię w sprawie Antoniusza" (Cic., Brut. 2, 4); Consulam hanc rem amicos "Poradzę się w tej sprawie przyjaciół" (Pl., Men. 700); In commune non consulunt "Nie naradzają się wspólnie" (Tac., Agr. 12); Pro memoria mei nec consulat quisquam „Niech nikt dla uwiecznienia mej pamięci nie stara się o uchwałę senatu” (Tac., Dial. 13) ${ }^{13}$. Poza tym, nawet jeśli różne użycia danego nadrzędnika (czasownikowego lub przymiotnikowego) nie wiążą się z wyraźnym zróżnicowaniem znaczeniowym, konotowane przez niego dopełnienie może przybierać różne postaci formalne; por. np: Quantum natura hominis pecudibus [...] antecedat „Jak bardzo natura człowieka góruje nad bydlętami" (Cic., Off. 1, 105) wobec: Scientia atque usu nauticarum rerum reliquos antecedunt „Wiedzą i doświadczeniem w zakresie żeglarstwa górują nad pozostałymi" (Caes., Gall. 3, 8) 14 . Podobnie: Amator similis est oppidi hostilis „Amant podobny jest do wrogiej twierdzy" (Pl., Truc. 170) wobec: Quid illi simile bello fuit? "Co było podobnego do tamtej wojny?" (Caes., Gall. 7, 77) ${ }^{15}$.

Składniowe konteksty dla dopełnień dalszych w datiwie mogą zatem stanowić:

1. Czasownikowe człony syntaktyczne, głównie orzeczenia, mające charakter:

$\rightarrow$ przechodni:

Facile omnes, cum valemus, recta consilia aegrotis damus. (Ter., Andr. 309)

"Łatwo w'szyscy, gdy jesteśmy zdrowi, dajemy dobre rady chorym".

Auxilium promittet Achaia Troiae. (Ov., Met. 13, 325)

"Grecja obieca Troi pomoc".

Imperium navium legato populi Romani ademisti, Syracusano tradidisti. (Cic., Verr. 5 , 137)

„Dowództwo nad fotą odebraleś legatowi ludu rzymskiego, powierzyleś Syrakuzańczykowi".

Cretensibus obsides imperavit. (Cic., Manil. 35)

„Kreteńczykom nakazal (dać) zakładników”.

Dextra pars (classis) attribuitur Massiliensibus, sinistra Nisidio. (Caes., Civ. 2, 4)

„Prawe skrzydlo (floty) przydzielone zostaje Massylijczykom, lewe Nasydiuszowi”.

- nieprzechodni:

Equo ne credite, Teucri. (Verg., Aen. 2, 48)

${ }_{13}$ Pod tym względem por. też wlaściwości składniowe takich czasowników' jak np.: caveo, metuo, timeo, prospicio, provideo, tempero, dono, credo, concedo.

14 Por. też np.: adulor, aemulor, despero, medeor.

is Por. też np.: aptus, utilis, par, comis, proprius, necessarius, communis, aequalis. 
„Nie wierzcie (trojańskiemu) koniowi, Teukrowie”.

Patribus conscriptis [...] parui. (Cic., Sull. 21)

„Senatorom bylem posluszny".

Huic Caesar legioni indulserat praecipue et [...] confidebat maxime. (Caes., Gall. 1, 40)

„Temu legionowi Cezar szczególnie sprzyjał i najbardziej ufał”.

(Vercingetorigem) Arverni [...] obsecrant, ut suis fortunis consulat. (Caes., Gall. 7, 8)

„Arwernowie zaklinają (Wercyngetoryksa), aby zatroszczył się o ich dobytek”.

Sp. Tarpeius Romanae praeerat arci. (Liv., 1, 11,6)

„Spuriusz Tarpejusz stal na czele rzymskiego zamku”.

Non modum non invidetur illi aetati (scil. iuvevtuti), verum etiam favetur. (Cic., Off. $2,45)$

„Nie tylko nie odczuwa się zazdrości w stosunku do (ludzi) tego (tj. mlodzieńczego) wieku, lecz wręcz okazuje się życzliwość".

W ramach sekundarnej dystrybucji składniowej czasowników, zarówno przechodnich jak i nieprzechodnich, składniowymi kontekstami dla rzeczownikowych dopełnień $w$ datiwie mogą również być wyrażone $w$ infinitiwie podmioty, dopełnienia, orzeczniki i funkcjonalne odpowiedniki orzeczeń (w ramach accusativus cum infinitivo), a także wyrażone w participium przydawki i funkcjonalne odpowiedniki orzeczeń ( $w$ ramach ablativus absolutus):

Pulchrum est benefacere rei publicae. (Sall., Cat. 3, 1)

„Czymś pięknym jest wyświadczać przysługi państwu”.

Ea stultitiast facinus magnum timido cordi credere. (Pl., Pseud. 576)

„Glupotą jest powierzyć wielki czyn bojaźliwemu sercu".

Rex [...] clamare coepit candelabrum [...] se in illo conventu civium Romanorum dare donare dicare consecrare Iovi Optimo Maximo. (Cic., Verr. 4, 67)

„Król zaczął wolać, że na tym zgromadzeniu obywateli rzymskich kandelabr daje, ofiaruje, przeznacza i poświęca Jowiszowi Najlepszemu Największemu".

(Psyche) virginitati suae $[\ldots]$ metuens et pavet et horrescit. (Apul., Met. 5, 4)

"(Psyche) obawiając się o swe dziewictwo trwoży się i drży ze strachu".

M. Valerius consul $[\ldots]$ provincia exercituque mandato $L$. Cincio praetori $[\ldots]$ senatum extemplo habuit. (Liv., 27, 5)

„Konsul Marek Waleriusz, powierzywszy zarząd prowincji i wojsko pretorowi Lucjuszowi Cyncjuszowi, bezzwłocznie zwołal posiedzenie senatu".

2. Przymiotnikowe człony syntaktyczne, głównie przydawki:

Caesar $[. .$.$] castris idoneum locum delegit. (Caes., Gall. 1, 49)$

„Cezar wybrał dogodne dla obozu miejsce".

Auctores fuisse [...] Icilios accipio ex familia infestissima patribus tres in eum annum tribunos plebis creatos. (Liv., 4, 54) 
„Jak się dowiaduję, Icyliusze byli sprawcami tego, że z rodziny bardzo wrogiej patrycjuszom wybrano na ten rok trzech trybunów ludowych".

W ramach sekundarnej dystrybucji składniowej przymiotników również np. przymiotnikowe orzeczniki lub funkcjonalne równoważniki orzeczników:

Gratum multitudini spectaculum fuit. (Liv., 2, 7)

„Widok byl mity dla tlumu”.

Non erat Othonis mollis et corpori similis animus. (Tac., Hist. 1, 22)

„Dusza Othona nie była zniewieściala i podobna ciału”.

Ait $[\ldots]$ se dictatorem $L$. Quinctium facturum; ibi animum parem tantae potestati esse. (Liv., 4, 13)

„Powiada, że uczyni dyktatorem Lucjusza Kwinkcjusza; w nim bowiem tkwi duch dorównujący tak wielkiej wladzy".

3. Przysłówkowe okoliczniki lub inne człony syntaktyczne, stanowione przez przysłówki:

Cum igitur hoc sit extremum, congruenter naturae convenienterque vivere, necessario sequitur omnes sapientes semper feliciter $[. .$.$] vivere. (Cic., Fin. 3, 26)$

„Skoro zatem to jest celem ostatecznym, a mianowicie życie zgodnie $\mathbf{z}$ naturą i stosownie do niej, to nieuchronnie wynika z tego, że wszyscy mędrcy żyją szczęśliwie".

\subsubsection{Rzeczownik w datiwie jako orzecznik}

Rzeczowniki w datiwie mogą także pełnić funkcję orzecznika, stanowiąc podstawowy wykładnik treści predykatywnej wyrażanej przez orzeczenie. Łącznikami współtworzącymi wraz z nimi orzeczenia są najczęściej formy czasownika esse, a także formy innych czasowników, które pozbawione są wtedy swego podstawowego (słownikowego) znaczenia predykatywnego.

Wyróżnić można dwa zasadnicze warianty semantyczne rzeczownikowych orzeczników w datiwie:

1. Dativus possessivus, który wraz z łącznikiem w postaci form czasownika esse współtworzy orzeczenie wyrażające przynależność desygnatu podmiotu do desygnatu orzecznika:

Non semper idem floribus est honor vernis. (Hor., Carm. 2, 11, 9-10)

„Wiosenne kwiaty nie zawsze mają ten sam wdzięk”.

Est igitur homini cum deo similitudo. (Cic., Leg. 1, 25)

„Jest zatem czlowiekowi przynależne podobieństwo do boga”.

Adde quod Romanis ad manum domi supplementum esset. (Liv., 9, 19)

"Do tego Rzymianie mieliby w ojczyźnie pod ręką rezerwy wojskowe”. 
Ei morbo nomen est avaritia. (Cic., Tusc. 4, 24)

„Choroba ta ma na imię chciwość".

2. Dativus finalis, który wraz z łącznikiem $\mathrm{w}$ postaci form czasowników esse, fieri oraz czasowników przechodnich: dare, tribuere, vertere, habere, ducere itp. współtworzy orzeczenia wyrażające status przypisywany w zdaniu desygnatowi podmiotu lub dopełnienia:

Luxuria et ignavia $[\ldots]$ rei publicae [...] cladi sunt. (Sall., Iug. 85, 43)

„Zbytek i lenistwo stają się klęską dla rzeczypospolitej”.

Una erat magno usui res praeparata ab nostris, falces praeacutae insertae adfixaeque longuriis. (Caes., Gall. 3, 14)

„Jedna rzecz przygotowana przez naszych okazała się bardzo użyteczna (dosł.: była ku wielkiemu pożytkowi), a mianowicie dobrze wyostrzone sierpy, nasadzone i przymocowane do żerdzi".

M. Petronius [...] suis saluti fuit. (Caes., Gall. 7, 50)

"Marek Petroniusz był ratunkiem dla jego żolnierzy".

Ad vos confugi, patres conscripi, quibus [...] cogor prius oneri quam usui esse. (Sall., Iug. $14,5)$

„Do was ucieklem, sentorowie, dla których zmuszony jestem stać się wcześniej ciężarem niż pomoca".

Tu id in me reprehendis, quod Q. Metello laudi datum est? (Cic., Planc. 89)

"Ganisz we mnie to, co Kwintusowi Metellusowi poczytano za chwalę?"

Idne alteri crimini dabis, quod [...] tu ipse fecisti? (Cic., Caecin. 31)

"Czy drugiemu uczynisz przedmiotem oskarżenia to, czego sam się dopuścileś?"

Tu nunc tibi id laudi duci(s), quod tum fecisti inopia? (Ter., Adelph. 104-105)

"Ty teraz poczytujesz sobie za chwalę to, co wtedy robileś (wyłącznie) z ubóstwa?"

\subsubsection{Rzeczownik $w$ datiwie jako funkcjonalny odpowiednik orzecznika}

Z uwagi na sekundarną dystrybucję składniową czasowników rzeczowniki w datiwie mogą także zajmować pozycje funkcjonalnych odpowiedników orzecznika, stanowiąc podstawowe wykładniki treści predykatywnej w ramach funkcjonalnych odpowiedników orzeczeń współtworzonych z czasownikowymi formami nieosobowymi.

[...] quam rem tibi certo scio gaudio esse. (Sall., Iug. 9, 2).

„wiem na pewno, że ta rzecz sprawia ci radość (dost.: jest dla ciebie radością)".

Te intelleges summam laudem Sexto Roscio vitio et culpae dedisse. (Cic., S. Rosc. 84)

„Zrozumiesz, że przedmiot najwyżzzej chwały poczytałeś Sekstusowi Roscjuszowi za wadę i przewinienie". 


\subsubsection{Rzeczownik $w$ datiwie jako uzupełnienie orzecznikowe}

Mogą również stanowić uzupełnienia (komplementy) orzecznikowe $\mathrm{w}$ ramach współtworzonych z nieosobowymi formami czasownikowymi członów syntaktycznych innych niż funkcjonalne odpowiedniki orzeczeń, stanowiąc główne wykładniki wyrażanych przez te człony treści przedmiotowych, np.:

Habere $[. .$.$] quaestui rem publicam non modo turpe est, sed sceleratum etiam et nefa-$ rium. (Cic., Off. 2, 77)

„Traktowanie państwa jako obiektu zysku (= wyzyskiwanie państwa) jest czymś nie tylko odrażającym, ale także zbrodniczym i niegodziwym".

\subsubsection{Rzeczownik w datiwie jako okolicznik}

Wyrażone w datiwie okoliczniki są określnikami członów syntaktycznych (współ) stanowionych przez czasowniki lub przymiotniki, użyte zarówno w ramach ich prymarnej, jak i sekundarnej dystrybucji składniowej. Okoliczniki te mogą wyrażać:

1. Cel działań wyrażonych przez nadrzędny człon czasownikowy lub przeznaczenie obiektów będących przedmiotem tych działań; tę funkcję również określa się terminem dativus finalis:

P. Crassus [...] tertiam aciem laborantibus nostris subsidio misit. (Caes., Gall. 1, 52)

„Publiusz Krassus trzeci szyk przysłał na pomoc naszym (żołnierzom), będącym w trudnym położeniu".

Castra $[\ldots]$ vobis hostium urbemque praedae do. (Liv., 7, 16)

"Obóz nieprzyjacielski i miasto daję wam na lup".

Pittacus [...], cum Mytilenaei multa milia ingerum ei agri muneri darent [...], inquit [...]. (Nep., Thras.4)

„Pittakos, kiedy mieszkańcy Mityleny dawali mu w podarunku wiele tysięcy jugerów ziemi, powiedział: [...]".

2. Obiekt objęty oddziaływaniem wyrażanej przez nadrzędnik czynności (sytuacji, postawy, cechy); ze względu na charakter tego oddziaływania okolicznik ten określa się jako tzw. dativus commodi ('korzyści') lub incommodi ('szkody'). Często jest on wyrażany przez rzeczownikowe zaimki:

Hicine vir patriae natus usquam nisi in patria morietur? (Cic., Mil., 105)

„Czy ten człowiek, zrodzony dla ojczyzny, umrze $w$ jakimkolwiek innym miejscu niż w ojczyźnie?"

Non vitae sed scholae discimus. (Sen., Lucil. 106, 12)

"Uczymy się nie dla życia, ale dla szkoły".

Neque enim solum nobis divites esse volumus, sed liberis, propinquis, amicis maximeque rei publicae. (Cic., Off. 3,63) 
„Nie chcemy być bogaci tylko dla siebie, ale i dla dzieci, krewnych, przyjaciól, a najbardziej dla państwa".

[...] Scipiones, qui iter Poenis vel corporibus suis obstruere voluerunt. (Cic., Sen. 75)

„Scypionowie, którzy chcieli Punijczykom zagrodzić drogę (do Rzymu) choćby wlasnymi cialami".

Alteri vivas oportet, si vis tibi vivere. (Sen., Lucil. 48, 2)

„Trzeba, abyś żyl dla drugiego, jeśli chcesz żyć dla siebie”.

3. Punkt odniesienia dla treści wyrażanych przez nadrzędnik albo obiekt stanowiący perspektywę, z której treści te są wyrażane; jest to tzw. dativus relativus. Podobnie jak w poprzednim wypadku, w funkcji tej często używane są rzeczownikowe zaimki, a także substantywizowane imiesłowy:

Quae est ista servitus tam claro homini tamque nobili? (Cic., Parad. 41)

"Czym jest ta niewola dla tak slawnego czlowieka i tak szlachetnego?"

Maiorum gloria posteris quasi lumen est. (Sall., Iug. 85, 23)

„Slawa przodków jest dla potomnych jakby świattem”.

Is finis populationibus fuit. (Liv., 2, 30)

"To okazalo się koncem dla grabieży (= położyło kres grabieżom)".

Plato [...] mihi unus instar est centum milium. (Cic., Brut. 191)

„Dla mnie jeden Platon jest równy stu tysiącom (innych)".

Caesar Gomphos pervenit, quod est oppidum primum Thessaliae venientibus ab Epiro. (Caes., Civ. 3, 80)

„Cezar przybył do Gomf, które są pierwszym miastem Tessalii dla idących z Epiru”.

Vere aestimanti Aetolicum magis ad Thermopylas bellum quam regium fuit. (Liv., 37, 58)

„Dla kogoś, kto ocenia rzeczy zgodnie z prawdą, wojna pod Termopilami była bardziej wojną z Etolami niż z królem".

4. Sprawcę działania wyrażonego przez nadrzędnik w wypowiedzeniu o diatezie biernej. Poza sytuacjami, w których nadrzędnik (współ)stanowiony jest przez formy participium futuri passivi (gerundivum) czasowników, okoliczniki tego typu $\mathrm{w}$ datiwie są stosunkowo rzadkie, gdyż najczęściej przyjmują formę rzeczownika w ablatiwie z przyimkiem $a b$ (zob. niżej: 7.5.6.1. pkt 4)

Caesari omnia uno tempore erant agenda. (Caes., Gall. 2, 20)

"Cezar musial wszystkie rzeczy robić w jednym czasie".

Ita mihi res tota provisa atque praecauta est, ut [...]. (Cic., Verr. 4, 91)

"Cała rzecz tak została przeze mnie przewidziana i zabezpieczona, że [...]".

Sic dissimillimis bestiolis communiter cibus quaeritur. (Cic., Nat. 2,123)

„W ten sposób zupelnie niepodobne do siebie zwierzęta wspólnie zabiegają o pożywienie".

Aelia Paetina e familia Tuberonum Narcisso fovebatur. (Tac., Ann. 12, 1) 
"Elia Petyna z rodziny Tuberonów była popierana przez Narcyza”.

Infert se $[. .$.$] per medios miscetque viris neque cernitur ulli. (Verg., Aen. 1, 439-440)$

"Wkracza pomiędzy ludzi, mieszając się z nimi, a przez nikogo nie zostaje zauważony".

Puella $[\ldots]$ amata nobis quantum amabitur nulla. (Catull.8, 4-5)

„Dziewczyna kochana przeze mnie tak, jak nie będzie kochana żadna inna”.

5. Osobowy obiekt stanowiący ośrodek perspektywy modalnej, z której ukazana jest treść predykatywna:

Nihil citra Capuam tutum esse omnibus videtur. (Caes., Civ. 1, 14)

„Wszystkim się wydaje, że nie ma niczego bezpiecznego po tej stronie Kapui”.

Festinandum ceteris videbatur. (Tac., Hist. 1, 33)

„Pozostałym (osobom) wydawalo się (= Pozostali uznali), że należy się spieszyć”.

A. Cornelio [...] imperatum, si ita consuli videretur, ut legiones in Aetoliam traiectas M. Acilio traderet. (Liv., 37, 2)

„Aulus Korneliusz otrzymal polecenie, aby - jeśli konsul uzna to za wlaściwe - przerzucił legiony do Etolii i przekazał je Maniuszowi Acyliuszowi".

Cur mortem malum tibi videri dicis? (Cic., Tusc. 1, 25)

„Dlaczego twierdzisz, że śmierć wydaje się tobie złem?”

T. Torquatus [...] numquid tibi videtur de voluptatibus suis cogitavisse? (Cic., Fin. 1, 24)

"Czy doprawdy wydaje ci się, że Tytus Torkwatus myślal o swoich wlasnych przyjemnościach?"

6. Miejsce, ku któremu skierowany jest ruch będący treścią nadrzędnika. Tego rodzaju okolicznik w datiwie jest stosunkowo rzadki i w zasadzie ograniczony do tekstów poetyckich, jako że zwykle tego typu treść wyrażana jest przez rzeczownik w akuzatiwie (często z przyimkami $a d$, in - zob. niżej: 7.5.5.7. pkt 1):

It clamor caelo. (Verg., Aen. 5, 451)

"Krzyk idzie ku niebu".

\subsubsection{Rzeczownik w datiwie jako przydawka}

Wyrażone $\mathrm{w}$ datiwie przydawki są podrzędne składniowo względem członów syntaktycznych stanowionych przez rzeczowniki, zarówno w ramach ich prymarnej, jak i sekundarnej dystrybucji składniowej. Z członami tymi powiązane są zazwyczaj związkiem przynależności. Relacje semantyczne zachodzące między celownikowymi przydawkami a ich syntaktycznymi nadrzędnikami są zróżnicowane. W przypadku niektórych rzeczowników odczasownikowych w pozycji członu nadrzędnego przydawki te implikowane są przez semantykę motywującego rzeczownik czasownika (np. obtemperatio legibus 'podporządkowanie się prawom'), co powoduje, że związek łączący oba człony składniowe nabiera charakteru związku rekcji: 
Dies colloquio dictus est ex eo die quintus. (Caes., Gall. 1, 42)

„Jako dzień dla obycia rozmowy wyznaczony zostal piąty dzień od tego (dnia)”.

Receptui signum [...] audire non possumus. (Cic., Phil. 13, 15)

„Sygnalu do odwrotu nie możemy usłyszeć”.

Quid enim gladiatoribus clamores innumerabilium civium? (Cic., Phil. 1, 36)

„Co bowiem (znaczą) okrzyki niezliczonych obywateli skierowane do (= na cześć) gladiatorów?"

Cum autem audirem meos $[\ldots]$ inimicos $[. .$.$] huic accusationi esse fautores [. .$.$] . Cic.,$ Planc. 1)

„Skoro zaś usłyszałem, że moi wrogowie są zwolennikami tego oskarżenia [...]".

Quod neque insidiae consuli procedebant [... ]. (Sall., Cat. 32)

„Ponieważ ani zasadzki na konsula nie udawały się [...]".

Iustitia est obtemperatio scriptis legibus institutisque populorum. (Cic., Leg. 1, 42)

„Sprawiedliwość to podporządkowanie się spisanym ustawom i zarządzeniom (poszczególnych) ludów".

(Saliis) tunicae pictae insigne dedit et super tunicam aeneum corpori tegumen. (Liv., $1,20)$

„(Saliom) dał oznakę godności w postaci wyszywanej tuniki, a na tunice spiżową osłonę dla piersi (scil. pancerz)".

Postquam illos videt $[\ldots]$ miseriis suis remedium mortem exspectare, $[\ldots]$ inquit $[\ldots]$. (Sall., Cat. 40)

„Po tym, jak zobaczyl, że śmierci oczekują jako lekarstwa na swoje nieszczęścia, powiada $[\ldots] "$.

Specyficzny jest status celownikowej przydawki wyrażającej imię lub przydomek, która zależna jest od rzeczowników typu: nomen, cognomen, praenomen itp. Występuje ona w zwrotach wyrażających posiadanie lub nadawanie imienia, obok wyrażonego $w$ datiwie orzecznika lub dopełnienia dalszego, identyfikującego nosiciela imienia. Ze względu na relacje znaczeniowe, w jakich pozostaje ze swym składniowym nadrzędnikiem, przydawka ta może zostać określona terminem dativus explicativus:

Puero $[\ldots]$ ab inopia Egerio indutum nomen. (Liv., 1, 34)

"Chlopcu 2 powodu ubóstwa nadano imię Egeriusz".

L. Tarquinius regnare occepit, cui Superbo cognomen facta indiderunt. (Liv., 1, 49)

„Rozpocząl panowanie Lucjusz Tarkwiniusz, któremu dokonane przez niego czyny przysporzyły przydomek Pysznego".

Quinctilius praetor cum filio, cui Marco praenomen erat, $[\ldots]$ ad equites pergit. (Liv., 30, 18)

„Pretor Kwinktyliusz z synem, który mial na imię Marek, podążył w stronę konnicy”.

Masinissa [...] in amicitiam receptus a P. Scipione, cui postea Africano cognomen ex virtute fuit, multa et praeclara rei militaris facinora fecerat. (Sall., Iug. 5) 
„Masynissa, przyjęty w poczet przyjaciól przez Publiusza Scypiona, który później z powodu

zasług nosil przydomek Afrykańskiego, dokonal wielu przeslawnych czynów wojennych".

Należy jednak zaznaczyć, że w analogicznych kontekstach przydawka tego rodzaju może także zostać wyrażona rzeczownikiem w genetiwie (genetivus explicativus):

Q. Metellus praetor, cui $[\ldots]$ Macedonici nomen indutum erat $[\ldots]$. (Velleius Paterculus, Historia Romana 1, 11)

„Pretor Kwintus Metellus, któremu nadane zostało imię Macedończyka”.

Może także mieć charakter przydawki apozycyjnej i pozostawać z nadrzędnikiem w związku zgody (najczęściej występuje wtedy w nominatiwie lub akuzatiwie):

Ei morbo nomen est avaritia. (Cic., Tusc. 4, 24)

„Choroba ta ma na imię chciwość".

\subsubsection{Rzeczownik $w$ datiwie jako operator tekstowy}

Z datiwem związana jest funkcja operatora tekstowego o charakterze emotywnym, ekspresyjno-impresywnym. Funkcja ta, tradyjnie określana terminem dativus ethicus, charakterystyczna jest dla potocznego języka mówionego i realizowana jest przede wszystkim przez rzeczownikowe zaimki (osobowe):

At tibi repente paucis post diebus [...] venit ad me Caninius. (Cic., Fam. 9, 2)

"A tu ci nagle po paru dniach przychodzi do mnie Kaniniusz".

Eccum hic tibi. (Ter., Heaut. 829)

„Oto ci jestem tutaj”.

Tu mihi $[\ldots]$ istius audaciam defendis? (Cic., Verr. 3, 213)

„Ty mi tu bronisz zuchwalstwa tego lajdaka?"

Quid mihi Celsus agit? (Hor., Epist. 13, 15)

„Co mi tam porabia Celsus?"

\subsubsection{Accusativus}

\subsubsection{Rzeczownik w akuzatiwie jako dopełnienie bliższe}

Funkcja dopełnienia bliższego jest podstawową funkcją składniową rzeczowników w akuzatiwie. Pod względem semantycznym funkcja ta związana jest $\mathrm{z}$ desygnowaniem obiektu (innego niż desygnat podmiotu) warunkującego zaistnienie sytuacji (czynności) oznaczanej przez czasownikowy nadrzędnik. Formalną cechą dopełnienia bliższego, odróżniającą je od dopełnienia dalszego, jest możliwość ujawnienia 
jego desygnatu przez mianownikowy podmiot po nadaniu zdaniu (wyrażeniu) diatezy biernej, np. Puer legit librum "Chłopiec czyta książkę" $\rightarrow$ Liber legitur a puero „Książka jest czytana przez chłopca”. Składniowymi nadrzędnikami dla dopełnień bliższych w akuzatiwie będą zatem człony sntaktatyczne stanowione przez tzw. czasowniki przechodnie, czyli takie, które we wszystkich lub niektórych swoich znaczeniach dopuszczają zmianę diatezy z czynnej na bierną ${ }^{16}$. Jeśli weźmiemy pod uwagę prymarną i sekundarną dystrybucję składniową czasowników, członami tymi będą w pierwszym rzędzie orzeczenia, a w dalszej kolejności wszystkie inne części zdania stanowione przez czasownikowe formy bezokolicznikowe, imiesłowowe, gerundialne oraz supinum:

Mecum posuisti moenia Troiae. (Ov., Met. 12, 587)

„Wraz ze mną zbudowaleś mury Troi”.

Legatos [...] Romam [...] mittunt ducentes paucos in speciem captivos perfugasque et fugitivos, quo impetrabilior pax esset. (Liv., 30, 16)

„Wysyłają do Rzymu posłów, przyprowadzając dla pozoru kilku jeńców oraz zbiegów wolnych i niewolników, aby przez to uzyskanie pokoju było latwiejsze".

Ego illum exercitum [...] magno opere contemno. (Cic., Catil. 2, 5)

„Ja z całej duszy gardzę tym wojskiem".

Quodsi curam fugimus, virtus fugienda est. (Cic., Lael. 47)

"Jeśli bowiem unikamy troski, w sposób konieczny unikamy też cnoty".

Legati Aurunci senatum adeunt. (Liv., 2, 26)

„Posłowie Aurunków przybywają do senatu".

Civem bonum ludit. (Cic., Fam. 8, 9, 1)

„Gra (scil. udaje) dobrego obywatela”.

Humanius est deridere vitam quam deplorare. (Sen., Dial. 9, 15)

„Bardziej po ludzku jest pośmiać się z życia, niż lamentować nad nim”.

Efferor studio patres vestros [...] videndi. (Cic., Sen. 83)

„Jestem przejęty pragnieniem zobaczenia waszych ojców”.

Haedui $[\ldots]$ legatos ad Caesarem mittunt rogatum auxilium. (Caes., Gall. 1, 11)

"Eduowie wysyłają do Cezara posłów, aby prosić o pomoc".

W przeciwieństwie do języka polskiego zaprzeczenie czasownikowego nadrzędnika nie zmienia formy gramatycznej (przypadka) dopełnienia:

Ego quidem neque umquam uxorem habui neque habeo. (Pl., Men. 399)

„) a ani nigdy nie miałem żony, ani nie mam”.

${ }^{16}$ Bardzo liczne czasowniki w części swoich użyć (znaczeń) mają charakter przechodni, ot wierając miejsce dla dopełnienia bliższego (np. Fugi nuptias (Ter., Andr. 766) „Uniknąłem małżeństwa”; por.: Mors fugitur (Cic., Leg. 1, 31) „Smierć jest unikana”), natomiast w' części mają charakter nieprzechodni (Cura fugit - Ov., Ars 1, 238) „Troska znika"). 
Populus Romanus [...] non amat profusas epulas. (Cic., Mur. 76) „Lud rzymski nie lubi zbytkownych uczt”.

Miejsce dla dopełnienia bliższego w akuzatiwie otwierają także niektóre czasowniki należące do klasy verba deponentia. Wprawdzie formy osobowe tych czasowników nie dopuszczają diatezy biernej, jednak diatezę taką sygnalizują formy ich participium futuri passivi (gerundivum), a nadrzędnik tych form ujawnia wtedy obiekt odpowiadający desygnatowi biernikowego dopełnienia przy formach osobowych; por. np.: Me ut scribam aliquid hortaris (Cic., Att. 2, 12, 3) „Zachęcasz mnie, abym coś napisał”; Sed ego nec rogandus sum nec hortandus (Plin., Epist. 3, 15, 2) „Lecz ja nie muszę być ani proszony, ani zachęcany". Pozwala to na przypisanie również tego rodzaju czasownikom przechodniego charakteru i na uznanie towarzyszących im dopełnień $w$ akuzatiwie za dopełnienia bliższe:

Aequo animo belli patitur iniurias. (Cic., Phil. 12,9)

„Ze spokojem znosi nieszczęścia wojny”.

Senex iuvenem amplexus $[\ldots]$ aiebat $[\ldots]$. (Liv., 1, 26)

„Starzec, objąwszy mlodzieńca, mówil [...]".

Reliquas copias Helvetiorum ut consequi posset, pontem in Arari faciendum curat. (Caes., Gall. 1, 13)

"Aby mógt ścigać pozostałe oddzialy Helwetów, zadbał o zbudowanie mostu na rzece Arar".

(Themistocles) maritimos praedones consectando mare tutum reddidit. (Nep., Them. 2)

"(Temistokles) ścigając morskich korsarzy przywrócił bezpieczeństwo na morzu”.

Ambiorix $[\ldots]$ Nervios $[\ldots]$ hortatur ne $[. .$.$] ulciscendi Romanos pro iis quas acceperint$ iniuriis occasionem dimittant. (Caes., Gall. 5, 38).

„Ambioryks zachęca Nerwiów, aby nie przepuścili okazji do zemszczenia się na Rzymianach za doznane krzywdy".

Pewne klasy czasowników w określonym znaczeniu otwierają miejsce zarówno dla biernikowego dopełnienia bliższego, jak i dla innej formy rzeczownikowej (lub przymiotnikowej) w akuzatiwie, pełniącej funkcję:

\section{Orzecznika:}

Eius modi coniunctionem tectorum oppidum vel urbem appellaverunt. (Cic., Rep. 1, 47)

"Tego rodzaju skupisko domów nazwali grodem lub miastem"

Ego P. Clodium arbitrabar perniciosum civem. (Cic., Phil. 8, 16)

„Ja uważałem Publiusza Klodiusza za obywatela szkodliwego (dla państwa)".

O fortunate [...] adulescens, qui tuae virtutis Homerum praeconem inveneris. (Cic., Arch. 24)

„O szczęśliwy młodzieńcze, który znalazłeś Homera jako piewç̨ twego męstwa".

17 Por.: (Vercingetorix) rex ab suis appellatur. (Caes., Gall. 8, 4) „(Wercyngetoryks) przez swoich ludzi obwołany zostaje królem". 
(Consul) dictatorem [...] T. Manlium Torquatum ex auctoritate senatus dixit. (Liv., 7, 26) „Na mocy uchwaly senatu (konsul) mianowal dyktatorem Tytusa Manliusza Torkwatusa".

Tum illic autem Lemnius propinquam uxorem duxit. (Pl., Cist. 173-174)

"Wtedy zaś tenże Lemnijczyk pojął zạ żonę krewną".

Eodem tempore Ambarri [...] Ceasarem certiorem faciunt sese [...] non facile ab oppidis vim hostium prohibere. (Caes., Gall. 1, 11)

„W tym samym czasie Ambarrowie powiadamiają Cezara, że z trudem odpierają od miast napór nieprzyjaciół".

Iste (scil. Verres) [...] omnis eas tabulas abstulit, parietes [...] nudos ac deformatos reliquit. (Cic., Verr. 4, 122)

„Ten zaś (scil. Werres) wszystkie te obrazy zabrał, ściany pozostawił nagie i oszpecone”.

2. Dopełnienia dalszego:

(Catilina) iuventutem [...] mala facinora edocebat. (Sall., Cat. 16)

"(Katylina) uczył młodzież złych uczynków"'."

Ut celem patrem [...] tua flagitia, aut damna aut desidiabula? (Pl., Bacch. 375-376)

„Miałbym ukrywać przed ojcem twoje lajdactwa, rozrzutność albo próżniactwoo?"1y.

Tiberius $[\ldots]$ L. Pisonem sententiam rogat. (Tac., Ann. 3, 68)

"Tyberiusz zapytal o zdanie Lucjusza Pizona"z".

W odniesieniu do niektórych czasowników, np.: posco, reposco, flagito (aliquem aliquid $)^{21}$, zarówno jedno, jak i drugie $\mathrm{z}$ konotowanych przez nie dopełnień $\mathrm{w}$ akuzatiwie może zajmować pozycję dopełnienia bliższego; świadczy o tym możliwość nadania konstytuowanym przez te czasowniki zdaniom diatezy biernej o dwojakiej strukturze; por. np.:

C. Terentius $[\ldots]$ claves portarum cum magistratus poposcisset [...]. (Liv., 27, 24)

„Gdy Gajusz Terencjusz zażądal od urzędników kluczy do bram [...]”.

wobec:

I" Por.: Vir impiger et sub Hannibale magistro omnes belli artes edoctus. (Liv., 25, 40) „Człowiek energiczny i pod okiem Hannibala wyuczony wszelkiego wojennego rzemiosła".

${ }_{1 y}$ Por.: Id Alcibiades diutius celari non potuit. (Nep., Alc. 5) „To nie mogło być dłużej ukrywane przed Alkibiadesem". W zdaniach konstytuowanych przez formy tego czasownika dopełnienie dalsze może też być wyrażone przez rzeczownik w ablatiwie z przyimkiem de, np.: Deiotarus [...] de insidiis celare te noluit? (Cic., Deiot. 18) „Deiotarus nie chciał ukryć przed tobą zasadzek?”. W zdaniach z diatezą bierną dopełnienie dalsze wyrażane jest $\mathbf{w}$ ten sposób zawsze, jeśli jego wykładnikiem nie jest zaimek, np.: Non est [...] de illo veneno celata mater (Cic., Cluent. 189) „Nie zatajono tej trucizny przed matką".

20 Por.: D. Iunius Silanus primus sententiam rogatus (Sall., Cat. 50) „Decymus Junius Silanus pierwszy zapytany o zdanie". Przy tym czasowniku dopełnienie dalsze również może być wyrażone przez rzeczownik w ablatiwie z przyimkiem de, np.: Iam de istoc rogare omitte (Pl., Pers. 642) „Przestań już pytać o to".

2 Możliwa jest również rekcja: aliquid ab aliquo. 
Segetes alimentaque debita dives poscebatur humus. (Ov., Met. 1, 147-138)

„Żądano od żyznej ziemi plonów i potrzebnych pokarmów”.

oraz:

Poscebatur argentum. (Cic., Verr. 4, 31)

„Żądano sreber stolowych”.

Miejsce dla dopełnienia bliższego i dalszego $\mathrm{w}$ akuzatiwie otwierają również pewne czasowniki z przedrostkami tra(ns)-, circum- i ad-, których znaczenie związane jest (wprost lub przenośnie) z ruchem, np.:

Caesar certior factus est tres iam partes copiarum Helvetios id flumen traduxisse. (Caes., Gall. 1, 12)

„Ceazar zostal powiadomiony, że Helweci już trzy czwarte swych oddzialów przeprawili przez tę rzekę"2?.

Caesar Germanos levis armaturae equitumque partem flumen traicit. (Caes., Civ. 1, 83) "Cezar lekkozbrojnych Germanów i część konnicy przerzuca przez rzekę".

Quos (scil. Roucillum et Aecum) Pompeius (...) omnia sua praesidia circumduxit. (Caes., Civ. 3, 61)

„Ich (scil. Rucillusa i Ekusa) Pompejusz oprowadzil po wszystkich swoich umocnionych placówkach".

(Petreius) idem iusiurandum adigit Afranium. (Caes., Civ. 1, 76)

„(Petrejusz) do tej samej przysięgi przymusil Afraniusza”.

\subsubsection{Rzeczownik $w$ akuzatiwie jako dopełnienie dalsze}

Dopełnienie dalsze w akuzatiwie konotowane może być przez człony syntaktyczne stanowione przez:

1. Czasowniki o znaczeniu przechodnim (por. wyżej):

(Catilina) iuventutem [...] mala facinora edocebat. (Sall., Catil. 16) „Katylina uczyl mlodzież zlych uczynków”.

Ut celem patrem [...] tua flagitia, aut damna aut desidiabula? (Pl., Bacch. 375-376) „Mialbym ukrywać przed ojcem twoje lajdactwa, rozrzutność albo próżniactwo?”

Tiberius $[\ldots]$ L. Pisonem sententiam rogat. (Tac., Ann. 3, 68)

„Tyberiusz zapytał o zdanie Lucjusza Pizona”.

Caesar Germanos levis armaturae equitumque partem flumen traicit. (Caes., Civ. 1, 83) „Cezar lekkozbrojnych Germanów i część konnicy przerzuca przez rzekę".

22 Por.: ne maior multitudo Germanorum Rhenum traducatur (Caes., Gall. 1, 31) „aby większa masa Germanów nie przeprawiała się przez Ren". 
Quos (scil. Roucillum et Aecum) Pompeius [...] omnia sua praesidia circumduxit. (Caes., Civ. 3, 61)

„Ich (tj. Rucillusa i Ekusa) Pompejusz oprowadził po wszystkich swoich umocnionych placówkach".

(Petreius) idem iusiurandum adigit Afranium. (Caes., Civ. 1, 76)

"(Petrejusz) do tej samej przysięgi przymusił Afraniusza”.

2. Czasowniki o znaczeniu nieprzechodnim:

- Czasowniki: decet 'przystoi (komuś)', dedecet 'nie przystoi (komuś)', fugit, fallit, praeterit 'uchodzi (czyjejś uwagi)'; w znaczeniach tych występują one wyłącznie w 3. os. i otwierają miejsce dla rzeczownikowych (lub zaimkowych) form w nominatiwie, bezokoliczników, zdań podrzędnych lub ich równoważników (accusativus cum infinitivo), wypełniających pozycję podmiotu:

Non decet regem ${ }^{23}$ saeva nec inexorabilis ira. (Sen., Clem. 1, 5, 6)

"Nic przystoi królowi srogi i nieubłagany gniew".

Oratorem [...] irasci minime decet, simulare non dedecet. (Cic., Tusc. 4, 55)

„Mówcy zupełnie nie przystoi gniewać się, ale udawać gniew nie przynosi ujmy”.

Quae res Caesarem non fefellerat. (Ps.-Caes., Bell. Afr. 75)

„Ta rzecz nie uszła uwagi Cezara”.

Non me fallebat, Hannibal, adventus tui spe Carthaginienses [...] praesentem indutiarum fidem [...] turbasse. (Liv., 30, 32)

„Nie uchodziło mojej uwagi, Hannibalu, że z powodu nadziei na twoje przybycie Kartagińczycy zaklócili obecny rozejm".

Neque [...] haec Dionysium fugiebant. (Nep., Di. 2, 1)

"I nie uchodzity te rzeczy uwagi Dionizjusza".

Neque vero id Caesarem fugiebat tanto [...] detrimento perterritum exercitum sustinere non posse. (Caes., Civ. 1, 71)

„I nie uszlo to uwagi Cezara, że wojsko przerażone tak wielką klęską nie może stawiać oporu."

Nec te praeterit utique quanto iam tempore delitescentem ancillam nequiverim repperire. (Apul., Met. 6, 7)

„I z pewnością nie uchodzi twojej uwagi, od jak długiego już czasu nie mog̨̧ odnaleźć ukrywającej się niewolnicy".

- Czasowniki wyrażające uczucia: przykrości, niezadowolenia, irytacji, odrazy ( $p i$ get), wstydu, żalu (pudet, paenitet), zniechęcenia, wstrętu (taedet), litości, żalu, współczucia (miseret), czyli tzw. verba affectuum; orzeczenia stanowione przez te czasowniki występują zwykle w 3. os. sg. i implikują niepodmiotową składnię zdania $z$ dopełnieniem wyrażającym przedmiot uczucia $w$ genetiwie oraz

${ }^{23} \mathrm{~W}$ tym kontekście dopełnienie może być wyrażone także przez rzeczownik $\mathrm{w}$ datiwie: Istuc facinus [...] nostro generi non decet (Pl., Amph. 820) „Ten czyn nie przystoi naszemu rodowi”. 
z dopełnieniem wyrażającym osobę doznającą uczucia w akuzatiwie; ze względu na osobowy charakter desygnatu wykładnikiem dopełnienia w akuzatiwie często jest rzeczownikowy (zwłaszcza osobowy) zaimek:

Cum populum iudicii sui paeniteret, multae novem partis detraxit. (Nep., Timoth. 4)

„Ponieważ lud żałował swego wyroku, dziewięć dziesiątych sumy nalożonej (przez niego) grzywny anulowal".

Miserebat non poenae magis homines quam sceleris, quo poenam meriti essent. (Liv., 2, 5) „Ludziom bylo żal nie tyle z powodu kary, co ze względu na zbrodnię, za którą na karę zaslużyli".

Taedebat populum omnium magistratuum eius anni. (Liv., 9, 7)

„Lud czul niechęć do wszystkich urzędników tego roku".

Me civitatis morum piget taedetque. (Sall., Iug. 4, 9)

„Zloszczą mnie i brzydzą obyczaje spoleczeństwa”.

[...] si scias, quam me pudeat nequitiae tuae, cuius te ipsum non pudet. (Cic., Phil. 2, 76) „gdybyś wiedzial, jak bardzo wstyd mi za twoją niegodziwość, której ty sam się nie wstydzisz"24.

Większość spośród wyżej wskazanych czasowników może również implikować składnię podmiotową, $z$ wypełniającym miejsce podmiotu i wyrażającym przedmiot uczucia zaimkiem lub substantywizowanym przymiotnikiem rodzaju nijakiego, bezokolicznikiem, zdaniem podrzędnym lub jego równoważnikiem ( sativus cum infinitivo), a wyjątkowo (w archaicznej łacinie) także rzeczownikiem:

Nonne pudet physicos haec dicere? (Cic., Div. 2, 33)

"Czy nie wstyd filozofom przyrody glosić takie rzeczy?”

Paenituit iurasse patrem. (Ov., Met. 2, 49)

„Ojciec pożałowal, że zlożył przysięgę".

Non te haec pudent? (Ter., Adelph. 754)

"Czy ty nie wstydzisz się tych rzeczy?"

Semper metuet, quem saeva pudebunt. (Lucan., Bell. Civ. 8, 495)

„Zawsze będzie się bal ten, kogo będą zawstydzać srogie czyny”.

An paenitet vos, quod salvum atque incolumem exercitum [...] traduxerim? (Caes., Civ. 2, 32,12 )

"Czy wy bolejecie nad tym, że calo i zdrowo wojsko (przez morze) przeprawilem?"

Me quidem haec condicio nunc non paenitet. (Pl., Stich. 51)

„Mnie ten obecny stan nie sprawia przykrości”.

${ }^{24}$ Przy pudet dopełnienie $w$ genetiwie wyrażać może także osobę, przed którą lub wobec której odczuwa się wstyd: Id mihi vehementer dolet et me tui pudet „Bardzo mnie to boli i wstyd mi przed tobą" (Ter., Adelph. 682). 
$\mathrm{W}$ formach perfektywnych czasowniki te ( $\mathrm{z}$ wyjątkiem paenitet) mogą wystąpić takie w passivum:

Apollinem tam humilis victoriae puditum est. (Apul., Flor. 3, 46)

"Apollinowi wstyd było tak haniebnego zwycięstwa”.

Me rei publicae maxime miseritum est. (Scip. Afr. min., Orat. fr. 30, 10)

„Najbardziej żal mi było rzeczpospolitej”.

Ita me ibi male convivi sermonisque taesumst. (Pl., Most. 316)

„Tak bardzo zmierziła mnie tamta uczta i rozmowa”.

Czasownik miserere może wystąpić $w$ stronie biernej także $w$ formach nieperfektywnych. Formy pasywne tego czasownika najczęściej implikują jednak podmiotową składnię zdania, w której wykładnik osoby doznającej uczucia wyrażony jest $\mathrm{w}$ nominatiwie i zajmuje pozycję podmiotu:

Si mortuorum aliquis miseretur, et non natorum misereatur. (Sen., Dial. 6, 19, 5)

„Jeśli ktoś lituje się nad zmarłymi, to niech lituje się i nad nienarodzonymi”.

\subsubsection{Rzeczownik $w$ akuzatiwie jako funkcjonalny odpowiednik podmiotu}

Pozycja funkcjonalnego odpowiednika podmiotu zajmowana jest przez rzeczowniki $w$ akuzatiwie $w$ ramach równoważnika zdania podrzędnego, najczęściej dopełnieniowego lub podmiotowego, znanego pod nazwą accusativus cum infinitivo. Jako funkcjonalny odpowiednik podmiotu rzeczownik w akuzatiwie związany jest związkiem atrybucji (kongruencji atrybutywnej) $\mathrm{z}$ funkcjonalnym odpowiednikiem orzeczenia, stanowionym przez bezokolicznikową formę czasownika:

Nomen Attici perire Ciceronis epistulae non sinunt. (Sen., Lucil. 21, 4)

„Listy Cycerona nie pozwalają, by imię Attyka zaginęło (w niepamięci)”.

Ibi haud multa verba facta, cum Macedones quodcumque senatus censuisset, id regem facturum esse dicerent. (Liv., 33, 24)

„Tam padło niewiele słów, ponieważ Macedończycy oświadczyli, że król wszystko zrobi, cokolwiek senat postanowi".

Constat $[\ldots]$ ad salutem civium civitatumque incolumitatem $[\ldots]$ inventas esse leges. (Cic., Leg. 2, 11)

"Jest wiadomym, że prawa zostały wynalezione dla dobra obywateli i pomyślności pańsıw".

(Clodius) dictitabat palam consulatum Miloni eripi non posse, vitam posse. (Cic., Mil. 26)

„(Klodiusz) nieustannie powtarzał wobec wszystkich, że konsulat nie może być odebrany Milonowi, ale życie może".

Omnibus $[. .$.$] expedit salvam esse rem publicam. (Cic., Phil. 13, 16)$

„Jest w interesie wszystkich, żeby państwo było bezpieczne ( $w$ dobrej kondycji)”. 


\subsubsection{Rzeczownik w akuzatiwie jako orzecznik}

Miejsce dla biernikowego orzecznika otwiera pewna klasa czasowników cechujących się znaczeniem przechodnim, a więc konotujących - obok orzecznika - także dopełnienie bliższe w akuzatiwie (por. wyżej):

Eius modi coniunctionem tectorum oppidum vel urbem appellaverunt. (Cic., Rep. 1, 47) "Tego rodzaju skupisko domów nazwali grodem lub miastem".

Ego P. Clodium arbitrabar perniciosum civem. (Cic., Phil. 8, 16)

„Ja uważalem Publiusza Klodiusza za obywatela szkodliwego (dla państwa)".

O fortunate [...] adulescens, qui tuae virtutis Homerum praeconem inveneris. (Cic., Arch. 24)

„O szczęśliwy mlodzieńcze, który znalazłeś Homera jako piewcę twego męstwa”.

(Consul) dictatorem [...] T. Manlium Torquatum ex auctoritate senatus dixit. (Liv., 7, 26)

„Na mocy uchwaly senatu konsul mianowal dyktatorem Tytusa Manliusza Torkwatusa”.

Tum illic autem Lemnius propinquam uxorem duxit. (PI., Cist. 173-174)

„Wtedy zaś tenże Lemnijczyk pojąl za żonę krewną".

Rzeczownikowy orzecznik w akuzatiwie może być również konotowany przez czasowniki nieprzechodnie (np. esse, fieri) w ramach orzeczeń, które - obok form osobowych - współkonstytuowane są przez ich formy nieosobowe (bezokoliczniki):

Inpune quae lubet facere, id est regem esse. (Sall., Iug. 31, 26)

„Czynić bezkarnie wszystko, czego się tylko zapragnie, to jest (= oznacza) być królem".

\subsubsection{Rzeczownik $w$ akuzatiwie jako funkcjonalny odpowiednik orzecznika}

Funkcjonalne odpowiedniki orzecznika, reprezentowane przez rzeczowniki w akuzatiwie, konotowane mogą być przez czasowniki przechodnie i nieprzechodnie w ramach ich sekundarnej dystrybucji składniowej. Stanowią wykładnik głównej treści predykatywnej $w$ ramach funkcjonalnego odpowiednika orzeczenia, współtworzonego $\mathrm{z}$ formami nieosobowymi czasowników $\mathrm{w}$ równoważnikach zdań typu accusativus cum infinitivo:

Scimus L. Acilium apud patres nostros appellatum esse sapientem. (Cic., Lael. 6)

"Wiemy, że Lucjusz Acyliusz przez naszych przodków zwany był mędrcem”.

Video [...] te me arbitrari hominem idoneum, quem senecta aetate ludos facias. (Pl., Aul. 252-253)

„Widzę, że ty uważasz mnie za czlowieka odpowiedniego do tego, by z powodu podeszlego wieku robić z niego glupca".

Ego illos meorum laborum atque incommodorum participes esse nolui. (Cic., Prov. 44)

„Ja nie chciałem, żeby oni byli uczestnikami moich trosk i kłopotów”. 


\subsubsection{Rzeczownik $w$ akuzatiwie jako uzupełnienie orzecznikowe}

W funkcji uzupełnień orzecznikowych występują rzeczowniki w akuzatiwie, stanowiąc składniki członów syntaktycznych współtworzonych z nieosobowymi formami czasowników, innych jednak niż funkcjonalne odpowiedniki orzeczeń, np. stanowiąc składniki członów podmiotowych:

Nimia'st miseria nimis pulchrum esse hominem. (Pl., Mil. 68)

„Wielki to (jest) kłopot być zbyt pięknym czlowiekiem”.

Satis est non esse mendacem. (Cic., De orat. 2, 51)

„Wystarczy nie być klamcą".

\subsubsection{Rzeczownik w akuzatiwie jako okolicznik}

Wyrażone w akuzatiwie okoliczniki zależne są składniowo od czasownikowych i przymiotnikowych członów syntaktycznych. Pod względem semantycznym okoliczniki te wyrażają:

1. Kierunek lub przestrzenny cel działania (procesu, ruchu) desygnowanego przez człon nadrzędny. Tego rodzaju okolicznik znany jest jako tzw. accusativus directivus (vel directionis), a jego wykładnikami są nazwy miast i (małych) wysp, a także rzeczowniki domus i rus:

Tabulae testamenti unae per legatos eius Romam erant adlatae. (Caes., Civ. 3, 108)

„Jeden egzemplarz testamentu przez jego postów zostal zawieziony do Rzymu”.

Dionysius [...], cum fanum Proserpinae Locris expilavisset, navigabat Syracusas. (Cic., Nat. 3, 83)

„Dionizjusz, po tym jak ograbil świątynię Prozerpiny w Lokrach, plynął do Syrakuz".

Claudius [...] Ilvam insulam et ab Ilva Corsicam, a Corsica in Sardiniam traiecit. (Liv., 30, 39)

„Klaudiusz przeprawił się na wyspę Elbę, a z Elby na Korsykę, z Korsyki na Sardynię".

Me a portu praemisit domum, ut haec nuntiem uxori suae. (Pl., Amph. 195)

"Mnie z portu wystal naprzód do domu, abym zaniósł te wieści jego żonie”.

Hoc proelio trans Rhenum nuntiato Suebi [...] domum reverti coeperunt. (Caes., Gall. $1,54)$

„Gdy wieści o tej bitwie dotarły za Ren, Swebowie zaczęli powracać do domu (= do ojczyzny)".

Quoniam a viro ad me rus advenit nuntius rus non iturum [...]. (Pl., Merc. 667-668)

„Ponieważ przyszła do mnie na wieś od męża wiadomość, że on na wieś nie przybędzie $[\ldots] "$.

Namque erit alius (scil. discipulus) historiae magis idoneus, alius compositus ad carmen, alius utilis studio iuris, ut nonnulli rus fortasse mittendi. (Quint., Inst. 2, 8, 7) 
„Bowiem jeden (uczeń) będzie się bardziej nadawał do nauki historii, inny będzie zdatny do poezji, jeszcze inny do nauki prawa, zaś niektórych trzeba będzie może odesłać na wieś".

Jeśli jego wykładnikami są inne rzeczowniki, okolicznik ten współtworzony jest zwykle przez przyimki in lub ad. Pierwszy z nich wskazuje najczęściej na działanie (ruch) zmierzające do wnętrza obiektu desygnowanego przez rzeczownik, drugi na działanie zmierzające $w$ kierunku (lub proces skierowany w stronę) tego obiektu:

C. Cestio M. Servilio consulibus nobiles Parthi in urbem venere ignaro rege Artabano. (Tac., Ann. 6, 31)

„Za konsulatu Gajusza Cestiusza i Marka Serwiliusza dostojnicy partyjscy przybyli do miasta (= do Rzymu) bez wiedzy króla Artabanusa".

Classis Punica [...] cum praeda omnis generis in Africam redit. (Liv., 27, 6)

„Flota punicka z wszelkiego rodzaju zdobyczą odpłynęła z powrotem do Afryki”.

Quidam ex his [...] nocte ad Nervios pervenerunt. (Caes., Gall. 2, 17)

"Niektórzy z nich nocą przedostali się do Nerwiów".

Manus ad caelum et sidera tollit. (Ov., Met. 2, 487)

„Ręce wznosi do nieba i gwiazd".

Deus ad homines venit, immo quod est propius, in homines venit. (Sen., Lucil. 73, 16)

„Bóg przychodzi do ludzi, a nawet, ściślej mówiąc, wstępuje w ludzi”.

2. Wymiar odległości lub dystansu dzielącego obiekty ${ }^{25}$ :

Zama quinque dierum iter a Carthagine abest. (Liv., 30, 29)

„Zama jest oddalona od Kartaginy o drogę pięciu dni (= o pięć dni marszu)".

Duae primum trabes in solo aeque longae distantes inter se pedes quattuor conlocantur. (Caes., Civ. 2, 10)

„Najpierw układane są na ziemi dwie jednakowej długości belki, oddalone od siebie na cztery stopy".

Milia passum tria ab eorum castris castra ponit. (Caes., Gall. 1, 22)

"O trzy tysiące kroków od ich obozu zakłada (swój) obóz".

3. Wymiar rozciągłości w przestrzeni:

Ante oppidum planities circiter milia passuum tria in longitudinem patebat. (Caes., Gall. $7,69)$

„Przed miastem rozciągała się równina na okolo trzy tysiące kroków dluga”.

Milites [...] aggerem latum pedes trecentos triginta, altum pedes octoginta exstruxerunt. (Caes., Gall. 7, 24)

„Żołnierze zbudowali wał oblężniczy długi na trzysta trzydzieści stóp, wysoki na osiemdziesiąt stóp".

25. Tego typu treści, podobnie jak te zdefiniowane w dwóch kolejnych punktach (tj. 3. i 4.), mogą być wyrażane również przez okoliczniki mające postać rzeczowników w ablatiwie (zob. niżej: 7.5.6.1. pkt 13, 14). 
Progressus milia passuum sex equites convenit. (Caes., Civ. 2, 39)

„Postąpiwszy naprzód sześć tysięcy kroków napotkal jeźdźców”.

In omni vita sua quemque a recta conscientia traversum unguem non oportet discedere. (Cic., Att. 13, 20, 4)

„W całym swym życiu nikt nie powinien nawet na szerokość paznokcia odstępować od prawego sumienia".

4. Wymiar rozciągłości w czasie:

Nemo [...] est tam senex, qui se annum non putet posse vivere. (Cic., Sen. 24)

„Nikt nie jest na tyle stary, by nie uważać, że może jeszcze pożyć (przez) rok”.

Carneades [...] vixit nonaginta annos. (Cic., Lucull. 16)

„Karneades żył dziewięćdziesiąt lat”.

Masinissa [...] P. Scipioni occurrit et deinde adsidue dies noctesque infestus aderat. (Liv., $25,34)$

„Masynissa Publiuszowi Scypionowi zastąpił drogę, a potem nieustannie dniami i nocami siedzial mu pod bokiem gotów do walki".

De lucro prope iam quadriennium vivimus. (Cic., Fam. 9, 17, 1)

„Z laski losu żyjemy już prawie cztery lata (od czterech lat)”.

Do tej grupy zaliczyć należy także okolicznik stanowiony przez formę annos (ew. annum, menses, dies), który przy formach perfektywnych czasownika nascor identyfikuje (wraz z liczebnikową przydawką) wiek osoby, np. Natus erat decem annos "Miał dziesięć lat" (= żył (istniał) od dziesięciu lat); quinque annos et duos menses nata "mająca pięć lat i dwa miesiące" (= żyjąca od pięciu lat i dwóch miesięcy):

Hortensius [...] undeviginti annos natus erat eo tempore. (Cic., Brut. 229)

„Hortensjusz mial wówczas dziewiętnaście lat".

Ea, si vivit, annos nata'st sedecim. (Ter., Eun. 526)

„Ona, jeśli żyje, ma szesnaście lat”.

D. Iunio Q. Haterio consulibus sedecim annos natus Nero Octaviam, Caesaris filiam, in matrimonium accepit. (Tac., Ann. 12, 58)

„Za konsulatu Decymusa Juniusza i Kwintusa Hateriusza mający szesnaście lat Neron otrzymal za żonę Oktawię, córkę Cezara".

Pater meus [...] Hamilcar puerulo me, utpote non amplius novem annos nato, in Hispaniam imperator proficiscens Karthagine Iovi Optimo Maximo hostias immolavit. (Nep., Hann. 2)

„Ojciec mój Hamilkar, kiedy byłem bardzo małym chłopcem, bo mającym nie więcej niż dziewięć lat, wyruszając jako wódz z Kartaginy do Hiszpanii, złożył ofiary Jowiszowi Największemu Najlepszemu".

5. Sferę, w obrębie której aktualna jest treść wyrażana przez składniowy nadrzędnik. Tego rodzaju rzeczownikowy okolicznik $w$ bierniku występuje szczególnie często w poezji i nazywany bywa akuzatiwem względu lub określany terminem accusativus respectus albo accusativus Graecus: 
Caedit $[\ldots]$ nigrantes terga iuvencos. (Verg., Aen. 5, 96-97)

"Zabija w ofierze byczki o czarnych grzbietach (dost. byczki czarne co do grzbietów)".

Tres praemia primi accipient flavaque caput nectentur oliva. (Verg., Aen. 5, 308-309)

„Trzej pierwsi otrzymają nagrody, a ich glowa zostanie uwieńczona złocistym wieńcem $z$ oliwki (dosł.: zostaną uwieńczeni co do glowy)".

Aeneas $[. .$.$] os umerosque deo similis. (Verg., Aen., 1, 588-589)$

„Eneasz $\mathbf{z}$ twarzy i ramion podobny do boga”.

Poza poezją okolicznik tego typu wyrażany jest najczęściej zaimkiem lub przymiotnikiem:

Ego illud adsentior Theophrasto. (Cic., De orat. 3, 184)

"Co do lego zgadzam się z Teofrastem".

Regnum, cetera egregium, ab una parte haud satis prosperum fuerat. (Liv., 1, 32)

„Panowanie, co do pozostałych rzeczy świetne, pod jednym względem nie dość udane było".

Quid tibi obsto? (Cic., S. Rosc. 145)

„W czym ci przeszkadzam?”

6. Zakres lub stopień, w jakim aktualna jest treść wyrażana przez składniowy nadrzędnik. Ten typ okolicznika określany jest jako tzw. accusativus limitationis, przy czym termin ten stosowany też bywa w odniesieniu do (niektórych) wyszczególnionych wyżej okoliczników względu (accusativus respectus). Pomijając tę grupę okoliczników, accusativus limitationis ograniczony jest w zasadzie do formy partem określonej przydawką magnam (maximam):

Stoici cum de animi perturbationibus disputant, magnam partem in his partiendis et definiendis occupati sunt. (Cic., Tusc. 4,9)

„Stoicy rozprawiając o niepokojach duszy, w dużej mierze zajęci są ich klasyfikowaniem i definiowaniem".

Suebi $[\ldots]$ maximam partem lacte atque pecore vivunt. (Caes., Gall. 4,1 )

„Swebowie w przeważającej mierze żywią się mlekiem i mięsem udomowionego bydla”.

\subsubsection{Rzeczownik w akuzatiwie jako przydawka}

Przydawki wyrażone $w$ bierniku są rzadkie. Reprezentowane są głównie przez nazwy miast lub rzeczownik domus, a ich nadrzędnikami są człony syntaktyczne stanowione przede wszystkim przez rzeczowniki związane $z$ ruchem, $w$ tym rzeczownikowe deverbativa utworzone od czasowników powiązanych znaczeniowo z oznaczaniem ruchu:

Neque ante consulis Romam adventum nec postquam is rediit. (Liv., 22, 61)

"Ani przed przybyciem konsula do Rzymu, ani po tym, gdy przybył". 
Nocturnus introitus Zmyrnam. (Cic., Phil. 11, 5)

„Nocne wkroczenie do Smyrny".

Eius iter Brundisium. (Cic., Phil. 5, 22)

"Jego podróż do Brundyzjum".

Domum reditionis spe sublata. (Caes., Gall. 1, 5)

„Odjąwszy sobie nadzieję na powrót do domu”.

Specyficzną przydawką biernikową jest wyrażenie id genus 'tego rodzaju':

Libri post mortem eius editi [...] pleni sunt id genus rerum. (Gell., Noc. Att. 13, 10, 2)

„Księgi wydane po jego śmierci pełne są rzeczy tego rodzaju”.

Scis me antea orationes aut aliquid id genus solitum scribere. (Cic., Att. 13, 12, 3)

„Wiesz, że poprzednio pisalem przeważnie mowy albo coś tego rodzaju”.

\subsubsection{Rzeczownik $w$ akuzatiwie jako składnik wypowiedzeń niezdaniowych}

Rzeczowniki w akuzatiwie stanowić też mogą konstytutywny człon wypowiedzi niezdaniowych o charakterze wykrzyknień (tzw. accusativus exclamationis) lub zawiadomień. Towarzyszą im wtedy często partykuły: $o$, heu, em, en, ecce, pro, per lub enklityczna partykuła -ne dodana do określającego rzeczownik zaimka hic, haec, hoc:

Nugas! (Pl., Most. 1087)

"(Co za) bzdury!"

Huncine hominem, hancine impudentiam, iudices, hanc audaciam! (Cic., Verr. 2, 5, 62)

„Co za czlowiek, co za bezwstyd, sędziowie, co za zuchwałość!"

Hoccin(e) saeclum! (Ter., Adelph. 304)

"Co za czasy!"

O condicionem miseram [...] conservandae rei publicae! (Cic., Catil. 2, 14)

"O nieszczęsna dolo państwa, które trzeba ratować!"

O miseras hominum mentes, o pectora caeca! (Lucretius 2, 14)

„O nieszczęsne ludzkie umysły, o zaślepione serca!"

O stultum hominem, dixerit quispiam, et repugnantem utilitati suae! (Cic., Off. 3, 100)

„Co za glupi człowiek - ktoś mógtby powiedzieć - i działający wbrew swemu pożytkowi!"

Heu me infelicem! (Ter., Hec. 282)

"O ja nieszczęsny!"

Em tibi pateram! (Pl., Amph. 778)

„Oto twój kielich!"

En quattuor aras! (Verg., Ecl. 5, 65)

"Oto cztery oftarze!"

Ecce me. (Pl., Cist. 283)

„Oto ja (jestem)". 


\subsubsection{Rzeczownik w akuzatiwie jako operator tekstowy}

W obrębie zdania formy biernikowe współtworzyć mogą (wraz z określonymi przyimkami) emotywne operatory tekstowe o postaci utartych zawołań czy zaklęć:

Quis, pro deum fidem, ita conparatus [...] fortissimum virum non vicerit? (Liv., 44, 38) „Któż, na litość boską, tak przygotowany nie pokonałby nawet najdzielniejszego czlowieka?”

Est mihi iucunda [...] vestra erga me voluntas, sed eam per deos immortalis deponite atque $[. .$.$] de vobis ac de vstris liberis cogitate. (Cic., Catil. 4,1$ )

„Miła jest mi wasza życzliwość dla mnie, lecz, na bogów nieśmiertelnych, poniechajcie jej i pomyślcie o sobie i swoich dzieciach".

\subsubsection{Ablativus}

\subsubsection{Rzeczownik w ablatiwie jako okolicznik}

Funkcja okolicznikowa jest najbardziej typowa dla ablatiwu, chociaż rzeczowniki w tym przypadku często pełnią także inne funkcje składniowe. Semantyka zarówno okoliczników, jak i innych członów syntaktycznych stanowionych przez rzeczowniki w ablatiwie, jest pochodną synkretycznego charakteru tego przypadka w łacinie, który pod względem funkcjonalnym kontynuuje trzy różne przypadki indoeuropejskie: 1) indoeuropejski ablativus (= separativus) wskazujący na punkt wyjścia czynności i procesów desygnowanych w wypowiedzeniu; 2) indoeuropejski instrumentalis wyrażający okoliczności o charakterze narzędnikowo-socjatywnym; 3) indoeuropejski locativus sytuujący wyrażane przez wypowiedzenie treści w czasie i przestrzeni. Ze względu na konkretny charakter stosunków wyrażanych przez ten przypadek zarówno okolicznikom, jak i innym członom składniowym konstytuowanym przez rzeczowniki w ablatiwie, często towarzyszą przyimki, które precyzują lub uwypuklają rodzaj relacji semantycznej łączącej te człony $z$ ich składniowymi nadrzędnikami. Jednak semantyka nadrzędników nie zawsze pozwala na jednoznaczną klasyfikację składniową zależnych od nich członów syntaktycznych, tzn. w wielu przypadkach bardzo płynna jest granica między konotacją (wymaganiem) przez ów nadrzędnik ablatywnego uzupełnienia, a jego fakultatywnym przyłączaniem, w związku z czym często problematyczne staje się określenie, czy uzupełnienie to ma status okolicznika czy dopełnienia. Składniowymi nadrzędnikami dla wyrażonych w ablatiwie okoliczników są człony syntaktyczne konstytuowane przez czasowniki, przymiotniki i (rzadko) przysłówki, a status desygnowanych przez nie treści może być określony jako:

1. Punkt wyjścia czynności, procesu lub zdarzenia, o których mowa w wypowiedzeniu. Okolicznik wyrażający tego rodzaju treść określany jest jako tzw. ablativus separativus (lub separationis) i często współtworzony jest przez przyimki ex, de, ab: 
Hostis Antonius iudicatus Italia cesserat. (Nep., Att. 9)

"Antoniusz uznany za wroga ustąpił z Italii".

Nuntius ei domo venit ephororum missu. (Nep., Ages. 4)

„Przybył do niego z ojczystego kraju posel na polecenie eforów".

Te cognomen non solum Athenis deportasse, sed humanitatem et prudentiam intellego. (Cic., Sen. 1)

„Wiem, że nie tylko przydomek przywiozłeś sobie z Aten, lecz także szlachetność obyczajów i roztropność".

Sapientia $[. .$.$] est una, quae maestitiam pellat ex animis. (Cic., Fin. 1, 43)$

„Mądrość jest jedyną rzeczą, która może przegnać $\mathbf{z}$ dusz smutek”.

Ei ferrum e manibus extorsimus. (Cic., Catil. 2, 2)

„Miecz wydarliśmy mu z rąk”.

Ut ait Homerus 'ex eius lingua melle dulcior fluebat oratio'. (Cic., Sen. 31)

„Jak powiada Homer 'z jego ust (dost: języka) plynęła mowa słodsza od miodu”."

Aliquot homines de caelo tacti exanimatique fuerant. (Liv., 22, 36)

„Kilku ludzi zostało uderzonych z nieba (scil. piorunem) i zabitych".

Perseum filium cum modica manu circummisit, ut a superioribus locis urbem adgrederetur. (Liv., 40, 22)

„Syna Perseusa $z$ niewielkim oddzialem posyła okrężną drogą, aby ten zaatakowal miasto $\mathbf{z}$ wyżej położonego terenu".

2. Punkt odniesienia dla desygnowanego $w$ wypowiedzeniu stosunku separacji, oddalenia, oddzielenia itp. Składnikiem tego okolicznika, zwanego również ablativus separativus (separationis), jest często przyimek $a b$ :

Volturcius [...] gladio se a multitudine defendit. (Sall., Cat. 45)

„Wolturcjusz mieczem broni się przed thumem".

Vacat $[\ldots]$ animus molestia liber ad inspectum universi. (Sen., Lucil. 92, 6)

"Umyst wolny od zmartwień jest otwarty na poznawanie świata".

Postero die procul a castris hostes in collibus constiterunt. (Caes., Gall. 5, 17)

"Następnego dnia wrogowie zajęli stanowiska na wzgórzach, daleko od (naszego) obozu".

3. Pochodzenie osoby (obiektu) lub źródło procesu (stanu, sytuacji), o których mowa w wypowiedzeniu. Pod względem znaczeniowym okolicznik ten identyfikowany jest terminem ablativus originis i współtworzony może być przez przyimki $a b, e x,($ rzadko) de:

Atrei filii, qui Pelope natus fuit. (Cic., Nat. 3, 53)

„Synowie Atreusza, który zrodzony został z Pelopsa”.

Amitae meae Iuliae maternum genus ab regibus ortum [...] est. (Suet., Iul. 6)

„Ród mojej ciotki Julii po kądzieli wywodzi się królów”. 
Neque enim (Caunus) est de tigride natus. (Ov., Met. 9, 613)

"Nie jest przecież (Kaunus) zrodzony z tygrysicy".

Rhenus [...] oritur ex Lepontiis, qui Alpes incolunt. (Caes., Gall. 4, 10)

„Ren bierze swój początek (= wypływa) z kraju Leponcjów, którzy zamieszkują Alpy”.

Quoniam pares virtutes sunt, recta facta, quando a virtutibus proficiscuntur, paria debent esse. (Cic., Parad. 22)

„Ponieważ cnoty są sobie równe, to również dobre uczynki, jeśli wywodzą się $\mathbf{z}$ cnót, powinny być sobie równe".

Deum adgnoscis ex operibus eius. (Cic., Tusc. 1, 70)

„Boga poznajesz z jego dziel”.

Venisse eas salvas audivi ex nauta, qui illas vexerat. (Ter., Phorm. 575-576)

„O tym, że przybyły cale i zdrowe, usłyszalem od żeglarza, który je przywiózł”.

Accipe nunc Danaum insidias et crimine ab uno disce omnis. (Verg., Aen. 2, 65-66)

„Poznaj teraz zasadzkę Danaów i z jednego ich wystẹpku zdobądź wiedzę o nich wszysıkich”.

4. Sprawca czynności lub czynnik sprawczy sytuacji albo zdarzenia, o których mowa w wypowiedzeniu. Okolicznik ten zwykle występuje przy czasownikach w passivum, sygnalizujących nacechowaną (bierną) diatezę zdaniową; stosuje się do niego nazwę ablativus agentis vel rei efficientis, a jeśli jego desygnat ma charakter ożywiony (bądź personifikowany), współtworzony jest zawsze przez przyimek $a b$ :

Populus [...] inopia urgebatur. (Sall., Iug. 41)

"Lud był nękany przez niedostatek".

Quorum ille (scil. Vercingetotix) precibus permotus castra ex Biturigibus movet in Arvernos versus. (Caes., Gall. 7, 8)

„Poruszony ich prośbami (scil. Wercyngetoryks), zabiera wojsko z kraju Biturygów i rusza ku ziemiom Arwernów".

Deinde a militibus adducitur ad eum adulta virgo. (Liv., 26, 50)

„Następnie przez żołnierzy przyprowadzona zostaje do niego dorosła panna”.

Sophocles [...] a filiis in iudicium vocatus est. (Cic., Sen. 22)

„Sofokles przez synów został pozwany do sądu".

(Caesar) ab exploratoribus certior factus est Ariovisti copias a nostris milia passuum quattuor et viginti abesse. (Caes., Gall. 1, 41)

"(Cezar) został powiadomiony przez zwiadowców, że oddziały Ariowista znajdują się w odleglości dwudziestu czterech tysięcy kroków od naszych".

Ad Mithridaticum bellum missus a senat $u[. .$.$] opinionem vicit omnium, quae de virtute$ eius erat. (Cic., Lucull. 1)

„Wysłany przez senat na wojnę z Mitrydatesem, przewyższyl panujące powszechnie przekonanie o jego męstwie". 
Qui appetitus [...] non satis a ratione retinentur, ii sine dubio finem et modum transeunt. (Cic., Off. 1, 102)

„Popędy, które nie są wystarczająco trzymane w ryzach przez rozum, niewątpliwie przekraczają granice i właściwą miarę".

5. Obiekt stanowiący punkt odniesienia dla treści atrybutywnej, predykatywnej bądź okolicznikowej ujętej w aspekcie porównawczym (względnym) i wyrażanej przez przymiotnik lub przysłówek w stopniu wyższym. Przy tego rodzaju okoliczniku obiekt będący punktem wyjścia porównania (czyli obiekt porówywany z czymś) desygnowany jest przez bezpośredni nadrzędnik członu (współ)stanowionego przez przymiotnik w komparatiwie lub przez czasownik określony przysłówkiem w komparatiwie. Okolicznik ten realizowany jest często także przez rzeczownikowe lub substantywizowane zaimki i znany jest jako tzw. ablativus comparativus (lub comparationis):

Exegi monumentum aere perennius. (Hor., Carm. 3, 30, 1)

"Wzniosłem pomnik trwalszy od spiżu".

Gemini $[\ldots]$ fratres $[\ldots]$ nive candidioribus ambo vectabantur equis. (Ov., Met. 8, 372-374)

„Obaj bracia bliźniacy (scil. Kastor i Polluks) jechali na koniach bielszych od śniegu”.

Quis me est fortunatior, qui ex improviso filiam inveni meam? (Pl., Rud. 1191-1192)

„Któż jest szczęśliwszy ode mnie, który niespodziewanie odnalazł swą córkę?”

Nihil est otiosa senectute iucundius. (Cic., Sen. 49)

„Nic nie jest milsze od pozbawionej przymusowych zajęć starości".

Cur olivum sanguine viperino cautius vitat? (Hor., Carm. 1, 8, 8-10)

„Dlaczego oliwy wystrzega się baczniej niż krwi żmii (= żmijego jadu)?"

Quo modo autem, si naturalis esset ira, $[. .$.$] alius alio magis iracundus esset? (Cic., Tusc.$ $4,79)$

„W jaki sposób zatem, jeśli gniew byłby rzeczą naturalną, jeden (człowick) mógłby być bardziej sklonny do gniewu od drugiego?"

In eo enim solo est ratio, qua nihil potest esse praestantius. (Cic., Nat. 2, 16)

„W nim bowiem (scil.w czlowieku) jako jedynym jest rozum, od którego nic nie może być znakomitszego".

Okolicznik ten realizowany też bywa przez występujące $w$ ablatiwie rzeczowniki lub substantywizowane przymiotniki, które stanowią semantyczne odpowiedniki okolicznikowych zdań porównawczych:

De meis in vos meritis praedicaturus non sum, quae sunt adhuc et mea voluntate et vestra exspectatione leviora. (Caes., Civ. 2, 32)

„Nie mam zamiaru rozpowiadać o moich względem was zasługach, które wciąż są skromniejsze niżbym chciał i niż wy oczekiwalibyście". 
Cum [...] mihi de Q. Hortensii morte esset adlatum, opinione omnium maiorem animo accepi dolorem. (Cic., Brut. 1)

„Gdy doniesiono mi o śmierci Kwintusa Hortensjusza, odczułem w duszy ból większy niż wszyscy mogliby sądzić".

Serius spe omnium Romam venit. (Liv., 26, 26)

„Przybył do Rzymu później niż wszyscy się spodziewali”.

Latius opinione disseminatum est hoc malum. (Cic., Catil. 4, 6)

"Owo zło ropowszechnilo się szerzej niż się sądzi”.

Neque enim verendum est [...] ne plus aequo quid in amicitiam congeratur. (Cic., Lael. 58)

„Nie powinniśmy się bowiem lękać, że (przez nas) zostanie wniesione do przyjaźni coś więcej niż wymaga tego sprawiedliwość".

Fluvius Arnus per eos dies solito magis inundaverat. (Liv., 22, 2)

„Rzeka Arnus (= Arno) w tych dniach wylała bardziej niż (wylewała) zwykle”.

W podobnych kontekstach analogiczną treść wyrażać mogą także okoliczniki stanowione przez przyimek quam i rzeczownik w tym samym przypadku, co rzeczownik desygnujący obiekt porównywany do czegoś:

Tu eruditior quam Piso ea contemnis quae illi idiotae praeclara duxerunt. (Cic., Pis. 62)

„Ty lepiej wyksztalcony niz Pizon $[\ldots \mid$ pogardzasz tym, co ci ignoranci uznali za wspaniałe rzeczy”.

Meum semper iuducium fuit omnia nostros [...] invenisse sapientius quam Graecos. (Cic., Tusc. 1, 1)

„Zawsze żywiłem przekonanie, że nasi rodacy we wszystkim wykazali się większą mądrością niż Grecy".

Omnibus rebus ornatum hominem [...], non nullis rebus inferiorem quam te aedilem factum esse miraris? (Cic., Planc. 30)

„Czy dziwisz się, że zostal ustanowiony edylem człowiek wyposażony we wszelkie zalety, mający niższą pozycję niż ty tylko pod niektórymi względami?"

Profectus cum exercitu ab urbe exspectatione hominum maiore quam spe cum Faliscis et $\mathrm{Ca}$ penatibus signa confert. (Liv., 5, 19)

„Wyruszywszy z wojkkiem z miasta, powodowany nie tyle nadzieją, ile oczekiwaniem ludzi (dosl. przy oczekiwaniu ludzi większym niż nadzieja), stoczyl bitwę z Faliskami i Kapenatami".

Jeśli przymiotnik i jego nadrzędnik występują w genetiwie lub datiwie, w miejsce okolicznika wyrażonego rzeczownikiem w ablatiwie lub rzeczownikiem z przyimkiem quam stosowane jest zdanie okolicznikowe porównania:

Haec certe tam miserabilis ac supplex legatio etiam insolentioris, quam illa fuit, legationis satis magnum piaculum esset. (Liv., 45, 23)

„Z pewnością to godne współczucia i korne poselstwo mogłoby być wystarczającym akıem pokuty za poselstwo nawet zuchwalsze niż (było) tamto".

Tibi multo maiori, quam Africanus fuit, me non multo minorem quam Laelium facile in amicitia adiunctum esse patiare. (Cic., Fam. 5, 7, 3) 
"Latwo zgodziłbyś się, żebym ja, trochę mniej znaczny od Leliusza, przez ciebie, o wiele znakomitszego niż (byl) Afrykańczyk, zostal przyjęty w poczel przyjaciól".

Jeśli żaden $z$ wyrazów desygnujących zestawiane w porównywaniu obiekty nie jest bezpośrednim nadrzędnikiem przymiotnika, wówczas okolicznik desygnujący obiekt, $z$ którym inny jest porównywany, wyrażany jest za pośrednictwem przyimka quam i rzeczownika w przypadku determinowanym jego pozycją składniową:

(Pars orationis) quae contionibus accomodatior est quam iudiciis. (Cic., Cluent. 2)

„(Część przemówienia), która stosowniejsza jest do publicznych zgromadzeń niż posiedzeń sądowych".

Misericordia dignior quam contumelia. (Cic., Pis. 32)

„Bardziej godny litości niż obelgi”.

Senex est meliore condicione quam adulescens. (Cic., Sen. 68)

„Starzec jest w lepszym położeniu niż młodzieniec”.

Ille Metelli vitam negat beatiorem quam Reguli. (Cic., Fin. 5, 88)

„Zaprzecza on, by życie Metellusa było szczęśliwsze niż Regulusa”.

6. Materia lub substancja, która w kontekście znaczenia nadrzędnika przyjmuje status tworzywa. Okolicznik ten, w skład którego często wchodzi przyimek ex lub de, występuje przy nielicznej grupie czasowników typu: facere, efficere, fieri itp. i określany bywa terminem ablativus materiae:

Democritum [...] levibus et rotundis corpusculis efficientem animum concursu quodam fortuito omittamus. (Cic., Tusc. 1, 22)

„Pomińmy Demokryta, który tworzył duszę z lekkich i okrągłych cząstek poprzez ich przypadkowe polączenie".

Ponte navibus effecto tramissoque exercitu primus Ornospades [...] in castra venit. (Tac., Ann. 6, 37)

„Po zbudowaniu z okrętów mostu (scil. pontonowego) i przeprawieniu wojska pierwszy przybył do obozu Ornospades".

(Naves) factae [...] subito ex umida materia non eundem usum celeritatis habuerant. (Caes., Civ. 1, 58)

"(Okręty) zbudowane w pośpiechu $\mathbf{z}$ mokrego materiału (scil. $\mathrm{z}$ mokrego drewna) nie miały tej samej przydatności wynikającej z szybkości".

Haec sunt penetralia magni amnis, in his residens facto de cautibus antro undis iura dabat. (Ov., Met. 575-576)

„Oto wnętrze siedziby wielkiego boga rzeki; tu przebywając, z jaskini utworzonej ze skal wydawał rozkazy falom".

Tribus hastis iugum fit. (Liv., 3, 28)

„Jarzmo robi się $\mathbf{z}$ trzech włóczni".

Quid hoc homine faciatis? (Cic., Verr. 2, 1, 42)

"Co zrobicie z tym człowiekiem? (dosł.: Co zrobicie z tego czlowieka?)" 
Quid Tulliola mea fiet? (Cic., Fam. 14, 4, 3)

„Co stanie się z moją Tuliolą? (dosł.: Co powstanie z mojej Tulioli?)"

7. Przyczyna zdarzenia (sytuacji, stanu), o którym mowa w wypowiedzeniu, stąd okolicznik ten nazywany jest ablativus causae. Może być współtworzony przez przyimki: ex, ab, de, prae:

Sunt in culpa, qui officia deserunt mollitia animi. (Cic., Fin. 1, 33)

„Ponoszą winę ci, którzy zaniedbują obowiązki $z$ powodu slabości ducha”.

Quidam morbo aliquo et sensus stupore suavitatem cibi non sentiunt. (Cic., Phil. 2, 115)

„Niektórzy z powodu jakiejś choroby i otępienia zmysłów nie czują słodyczy potraw”.

Ita torpentes gelu in castra rediere, ut vix laetitiam victoriae sentirent. (Liv., 21, 56)

„Do obozu wrócili tak skostniali z zimna, że ledwie odczuwali radość z powodu zwycięstwa”.

Cum Tarquinius ex vulnere aeger fuisse et vivere falso diceretur, ille (scil. Servius) $[\ldots]$ non commisit se patribus, sed [...] populum de se ipse consuluit. (Cic., Rep. 2, 38)

„Ponieważ falszywie sądzono, że Tarkwiniusz zachorował od ran, ale żyje, (Serwiusz) nie zwrócił się do senatu, lecz sam zapytał lud o zdanie co do jego osoby ( $t$ j. co do jego ewentualnej sukcesji)".

Demetrius [...] captus bello in custodia [...] periit a morbo. (Nep., Reg. 3)

„Demetriusz pojmany na wojnie umart w więzieniu na skutek choroby".

De tuis divitiis intolerantissime gloriaris. (Cic., Vatin. 29)

„Z powodu twoich bogactw chełpisz się w sposób najbardziej nieznośny".

Neque miser me commovere possum prae formidine. (Pl., Amph. 337)

„I, nieszczęsny, nawet ruszyć się nie mogę ze strachu”.

Słowo: causa 'przyczyna, powód', również jest wyrażane w tym kontekście w ablatiwie (a więc: causā ' $z$ powodu') i określane jest przydawką przymiotnikową (najczęściej zaimkową), np. eā causā, qua de causa 'z tego powodu', lub rzeczownikową w genetiwie (genetivus explicativus), najczęściej w prepozycji, np. virtutis causā ' $\mathrm{z}$ powodu męstwa (= z powodu, którym jest męstwo)'. W tym drugim przypadku, tj. w połączeniu $\mathrm{z}$ rzeczownikiem $\mathrm{w}$ genetiwie, ablatywna forma causā funkcjonalnie bliska jest przyimkowi; oprócz causā, w analogicznej funkcji używana jest także forma gratiā:

Saepe de luxuria atque avaritia nostrorum civium questus sum multosque mortalis ea causa advorsos habeo. (Sall., Cat. 52, 7)

"Często żaliłem się na zbytek i chciwość naszych obywateli i wielu ludzi mam z tego powodu przeciwko sobie".

Qua de causa Helvetii quoque reliquos Gallos virtute praecedunt. (Caes., Gall. 1, 1)

„Z tego powodu również Helwetowie przewyższają pozostałych Gallów dzielnością”.

Tertio anno virtutis causa mihi T. Quinctius Flaminius decumum ordinem hastatum adsignavit. (Liv., 42, 34) 
„W trzecim roku $\mathbf{z}$ powodu męstwa Tytus Kwincjusz Flaminiusz przydzielił mi dziesiąty oddział włóczników".

Redditura est tuam (filiam) tibi et ea gratia domo profecta est. (Pl., Cist. 762)

"Ma zamiar oddać ci twoją córkę i z tego powodu wyszla z domu”.

In ea coniuratione fuit $Q$. Curius, [...] quem censores senatu probri gratia moverant. (Sall., Cat. 23)

„W spisku tym uczestniczył Kwintus Kuriusz, którego cenzorowie z powodu zdemoralizowania usunęli $z$ senatu".

Należy jednak pamiętać, że wskazane wyżej wyrażenia z causa i gratia desygnować mogą także innego rodzaju okoliczności, mające charakter celu bądź względu:

Eo sex cohortes praesidii causa ex provincia misit. (Caes., Civ. 2, 18)

„Tam wyslał z prowincji sześć kohort dla ochrony”.

Syro ignoscas volo quae mea causa fecit. (Ter., Heaut. 1066-1067)

"Chcę, żebyś wybaczył Syrusowi to, co uczynił przez wzgląd na mnie (dla mego dobra)".

Legati $[\ldots]$ pollicentur se et frumentum et quaecumque res eis suppeteret communis salutis gratia subministraturos. (Ps.-Caesar, Bell. Afr. 33)

„Posłowie obiecują, że dla wspólnego bezpieczeństwa dostarczą zboża i wszystkiego tego, czego mają pod dostatkiem".

8. Narzędzie lub środek, za pośrednictwem którego realizowane jest działanie desygnowane przez nadrzędnik; jest to tzw. ablativus intrumentalis (instrumenti):

Saepissimae curam et angorem animi mei sermone et consilio levasti tuo. (Cic., Att. 1, $18,1)$

"Często zatroskanie i niepokój mej duszy lagodzileś swoją rozmową (ze mną) i radą".

Multae [...] istarum arborum mea manu sunt satae. (Cic., Sen. 59)

"Wiele z tych drzew zasadzonych zostało moją ręką".

Eminus fundis, sagittis reliquisque telis pugnabatur. (Caes., Civ. 1, 26)

"Walczono na odległość za pomocą proc, strzal i innych pocisków".

Prodigiis atque portentis di immortales nobis futura praedicunt. (Cic., Phil. 4, 10)

„Za pośrednictwem cudownych znaków i wróżb bogowie nieśmiertelni przepowiadają nam przyszłość".

Caesar, quo facilius equitatum Pompeianum ad Dyrrachium contineret, aditus duos [...] magnis operibus praemunivit. (Caes., Civ. 3, 58)

„Cezar, aby latwiej mógł zamknąć konnicę Pompejusza pod Dyrrachium, dwa dojścia obwarowuje silnymi umocnieniami".

Galli $[. .$.$] spatia omnis temporis non numero dierum, sed noctium finiunt. (Caes., Gall.$ $6,18)$

„Gallowie w'szekie odcinki czasu określają (definiują) nie liczbą dni, lecz nocy". 
Eo Misagenes Numida venit cum mille equitibus, pari peditum numero, ad hoc elephantis duobus et viginti. (Liv., 42, 62)

„Tam przybył Numida Misagenes $\mathbf{z}$ tysiącem jeźdźców, taką samą liczbą piechoty, a do tego $\mathbf{z}$ dwudziestoma dwoma sloniami".

Secunda vigilia magno cum strepitu ac tumultu castris egressi (sunt). (Caes., Gall. 2, 11)

"O drugiej straży nocnej wyszli z obozu wśród ogromnego zgiełku i zamieszania".

Summa igitur et perfecta gloria constat ex tribus his: si diligit multitudo, si fidem habet, si cum admiratione quadam honore dignos putat. (Cic., Off. 2, 31)

„Najwyższa i doskonała sława sprowadza się zatem do tych trzech rzeczy: że ogół ludzi sprzyja nam, że nam ufa, i że przy pewnym dla nas podziwie uważa nas za godnych wszelkiego zaszczytu".

11. Cena lub wartość obiektu albo transakcji, przy nadrzędnikach oznaczających kupowanie, sprzedawanie, wynajmowanie, szacowanie, licytowanie, a także posiadanie wartości, kosztowanie itp. Okolicznik ten znany jest jako tzw. ablativus pretii. W przeciwieństwie do występujących w podobnych kontekstach okoliczników wyrażanych w genetiwie (tzw. genetivus pretii zob. wyżej: 7.5.3.5. pkt 2), okoliczniki te (scil. w ablatiwie) desygnują konkretne (handlowe) ceny i wartości. Mogą jednak także wyrażać pojęcia ogólniejsze za pośrednictwem substantywizowanych przymiotników (magno, parvo itp.) lub też oznaczać cenę (wartość) w sensie metaforycznym:

Vicinis me quibusdam duobus servis fratribus undecim denariis vendidit. (Apul., Met. $10,13)$

„Jakimś dwu braciom, niewolnikom z sąsiedztwa, sprzedał mnie za jedenaście denarów”.

Aristotelem quoque traditum libros pauculos Speusippi philosophi [...] emisse talentis Atticis tribus. (Gell., Noc. Att. 3, 17, 3).

„Przekazano, że również Arystoteles kupił tylko kilka książek filozofa Speuzyppa za trzy talenty attyckie".

Gallinae Africanae [...] veneunt propter penuriam magno. (Varro, Rust. $3,9,18$ )

„Perliczki, ze względu na ich niedostatek, sprzedawane są po wysokich cenach”.

Conduxit in Palatio non magno domum. (Cic., Cael. 18)

"Wynajął za niewielkie pieniądze dom na Palatynie".

Emit morte immortalitatem. (Quint., Inst. 9, 3, 71)

„Kupił nieśmiertelność za cenę śmierci”.

Vendidit [...] auro patriam. (Verg., Aen. 6, 621)

„Zaprzedał ojczyznę za złoto".

Indignantes milites Caesar $[\ldots]$ edocet quanto detrimento et quot virorum fortium morte necesse sit constare victoriam. (Caes., Gall. 7, 19)

„Pelnych oburzenia żołnierzy Cezar poucza, jak wielkimi stratami i śmiercią ilu dzielnych ludzi musiałoby być okupione zwycięstwo". 
12. Wzgląd lub zakres, w jakim aktualna jest treść desygnowana przez składniowy nadrzędnik. $Z$ uwagi na swe cechy semantyczne okolicznik ten określany jest terminami ablativus limitationis lub ablativus respectus:

(Peripatetici Academicique) re consentientes vocabulis differebant. (Cic., Fin. 4, 5)

„(Perypatetycy i akademicy), zgadzający się z sobą co do treści, różnili się co do słów (terminologii)".

Et statura fuit humili et corpore exiguo et claudus altero pede. (Nep., Ages. 8)

"Był niskiego wzrostu, drobnej postury i kulawy (utykający) na jedną nogę".

Helvetii $[. .$.$] reliquos Gallos virtute praecedunt. (Caes., Gall. 1, 1)$

„Helwetowie przewyższają pozostałych Gallów dzielnością".

Lacedaemonius [...] Agesilaus nomine, non potestate rex fuit. (Nep., Reg. 1)

"Lacedemończyk Agesilaos był królem tylko $z$ imienia ( $\mathrm{z}$ nazwy), nie $\mathbf{z}$ wladzy”.

Sunt quidam aut ita lingua haesitantes aut ita voce obsoni $[\ldots]$, ut $[\ldots]$ in oratorum numerum venire non possint. (Cic., De orat. 1, 115)

„Są jednak niektórzy tak zacinający się w mowie lub tak odstręczający co do swego glosu, iż do grona mówców wejść nie mogą".

Omnes maiores natu ex oppido egressi manus ad Caesarem tendere $[\ldots]$ coeperunt. (Caes., Gall. 2, 13)

„Wszyscy starsi wiekiem wyszedłszy z miasta zaczęli wyciągać ręce do Cezara”.

13. Wymiar zróżnicowania bądź oddalenia w czasie lub przestrzeni, orzekanego przez składniowy nadrzędnik o implikowanych przezeń obiektach:

Qua ex parte est Hibernia insula, dimidio minor ut existimatur quam Britannia. (Caes., Gall. 5, 13)

„Z tej strony leży wyspa Hibernia (scil. Irlandia), o polowę mniejsza - jak się sądzi - od Brytanii".

Ex aethere igitur innumerabiles flammae siderum existunt, quorum est princeps sol $[\ldots]$ multis partibus maior atque amplior quam terra universa. (Cic., Nat. 2, 92)

„Z eteru powstają zatem niezliczone plomienie ciał niebieskich, z których najważniejsze jest stońce, wiele razy większe i wspanialsze niż cała ziemia".

Tum (stabant) Cyrtiorum et Elymaeorum [...] auxilia, et sedecim elephanti modico intervallo distantes. (Liv., 37, 40)

„Dalej stały cyrtyjskie i elimajskie wojska positkowe oraz szesnaście słoni oddalonych o niewielki dystans".

Adit $[\ldots]$ Epidaurum [...] inclutam Aesculapi nobili templo, quod quinque milibus passuum ab urbe distans $[\ldots]$ donis dives erat. (Liv., 45, 28)

„Odwiedza Epidauros slawne ze wspaniakej świątyni Eskulapa, która odlegla byla o pięć tysięcy kroków od miasta i obfitowala w dary (wotywne)".

Vidimus paucis post mensibus [...] exercitum [...] spoliatum. (Cic., Verr. 2, 3, 177)

„Kilka miesięcy później zobaczyliśmy rozbrojone wojsko”. 
Annis fere quingentis decem post Romam conditam Livius fabulam dedit. (Cic., Tusc. 1, 3) „Około pięćset dziesięć lat po zalożeniu Rzymu Liwiusz (Andronik) wystawil sztukę teatralną".

Saeculis multis ante gymnasia inventa sunt, quam in eis philosophi garrire coeperunt. (Cic., De orat. 2, 21)

„Gimnazja zostały założone wiele wieków wcześniej niż filozofowie zaczęli w nich trajkotać”.

14. Wymiar rozciągłości (w czasie lub przestrzeni) obiektów, zjawisk, zdarzeń, sytuacji, o których mowa w wypowiedzeniu:

Per Arduennam silvam, quae est totius Galliae maxima [...] milibusque amplius quingentis in longitudinem patet, L. Minucium Basilum [...] praemittit. (Caes., Gall. 6, 29)

„Przez Las Ardueński, który jest największy w calej Galii i na dlugość rozciąga się na ponad pięćset tysięcy (kroków), wyprawia przodem Lucjusza Minucjusza Bazylusa".

Pericles [...] quadraginta annis praefuit Athenis. (Cic., De orat. 3, 138)

„Perykles przez czterdzieści lat przewodzil Atenom".

Ea quae Saturni stella dicitur [...] triginta fere annis cursum suum conficit. (Cic., Nat. 2,52)

„Gwiazda zwana Saturnem przebywa swą drogę (= drogę swej orbity) w ciągu niemal trzydziestu lat".

Hoc cum esset modo pugnatum continenter horis quinque nostri [...] gladiis destrictis impetum $[. .$.$] in cohortis faciunt. (Caes., Civ. 1, 46)$

„Gdy w ten sposób walczono już bez ustanku przez pięć godzin, nasi, dobywszy mieczy, przypuścili atak na kohorty".

Ariovistus his omnibus diebus exercitum castris continuit. (Caes., Gall. 1, 48)

"Ariowist przez wszystkie te dni trzymal wojsko w obozie".

Hanc (urbem) hoc biennio consul evertes. (Cic., Rep. 6, 11)

"(Miasto) to w ciągu najbliższych dwóch lat zrównasz z ziemią, będąc konsulem".

15. Miejsce w przestrzeni lub obszar, gdzie lokowane są obiekty, zdarzenia, sytuacje itp., o których mowa w wypowiedzeniu. Okolicznik tego typu znany jest jako tzw. ablativus loci. Wyrażany jest bez użycia przyimka, jeśli jest nim nazwa miasta (lub małej wyspy) stanowiona przez rzeczownik należący do paradygmatu fleksyjnego III deklinacji lub przez rzeczownik w liczbie mnogiej (niezależnie od przynależności do paradygmatu fleksyjnego). W pozostałych przypadkach najczęściej współtworzony jest przez rzeczownik w ablatiwie i przyimek in:

Certius aliquanto, quae Carthagine acta essent, ab rege scierant quam ab ipsis Carthaginiensibus. (Liv., 41, 22)

„Tego, co wydarzyło się w Kartaginie, dowiedzieli się ze znacznie większą pewnością od króla niż od samych Kartagińczyków".

(Timoleon) cum primum potuit, imperium deposuit ac privatus Syracusis, quod reliquum vitae fuit, vixit. (Nep., Timol. 3) 
„(Timoleon) przy pierwszej okazji złożył władzę i resztę życia spędzil w Syrakuzach jako zwykly obywatel".

Magoni [...] nuntiatum ab Carthagine est iubere senatum ut classem, quam Gadibus haberet, in Italiam traiceret. (Liv., 28, 36)

„Magonowi doniesiono z Kartaginy, że (tamtejszy) senat nakazuje, aby flotę, która ma w Kadyksie, przerzucil do Italii".

(Vitellius) pueritiam primamque adulescentiam Capreis egit. (Suet., Vit. 3)

„(Witeliusz) dzieciństwo i wczesną mlodość spędzil na Kapri”.

Themistoclem illum, summum Athenis virum, dixisse aiunt [...]. (Cic., Arch. 20)

"Mówią, że słynny Temistokles, najpotężniejszy człowiek w Atenach, powiedział [...]".

Castra sunt in Italia contra populum Romanum in Etruriae faucibus conclocata. (Cic., Catil. 1, 5)

„W Italii przeciwko narodowi rzymskiemu rozlokowano obóz wojskowy w wąwozach Etrurii".

Actum de imperio Marcelli in circo Flaminio est ingenti concursu plebis et omnium ordinum. (Liv., 27, 21)

„Sprawa przywództwa wojskowego Marcellusa rozegrała się w Cyrku Flaminiusza przy wielkim zbiegowisku plebsu i wszystkich stanów".

Suspicati hostes huc nostros esse venturos noctu in silvis delituerant. (Caes., Gall. 4, 32)

„Wrogowie domyślając się, że nasi tutaj przyjdą, nocą ukryli się w lasach”.

Bez przyimka okolicznik ten tworzyć mogą także rzeczowniki inne niż nazwy miast (przede wszystkim takie, jak locus, pars itp.), zwłaszcza gdy są określane przydawkami lub gdy desygnują obszary (przestrzenie), w obrębie których zachodzą desygnowane przez człon nadrzędny zdarzenia (sytuacje). Dużą swobodą w pomijaniu przyimka cechuje się szczególnie język poezji:

Ceasar [...] locis certis horrea constituit. (Caes., Civ. 3, 42)

"Cezar nakazal zbudować $\mathbf{w}$ określonych miejscach spichlerze”.

Carcer $[\ldots]$ media urbe $[\ldots]$ aedificatur. (Liv., 1,33 )

„W środku miasta zbudowane zostaje więzienie".

Dilectum habuit tota provincia. (Caes., Civ. 2, 18)

„Przeprowadzil pobór do wojska w calej prowincji”.

Usipetes et Tenctheri $[\ldots]$ multis locis Germaniae triennium vagati ad Rhenum pervenerunt. (Caes., Gall. 4, 4)

„Uzypetowie i Tenkterowie, po tym jak przez trzy lata tulali sie po wielu rejonach Germanii, dotarli nad Ren".

Ibam forte via sacra [...]. (Hor., Serm. 1, 9, 1)

„Szedlem raz ulicą świętą [...]".

Tum litore curvo exstruimus [...] toros. (Verg., Aen. 3, 223-224)

"Wtedy na zakrzywionym wybrzeżu urządzamy loża". 
16. Mniej lub bardziej szeroko pojęty moment $w$ czasie, charakteryzujący treść desygnowaną przez składniowy nadrzędnik; ten typ okolicznika znany jest jako tzw. ablativus temporis. Niektóre rzeczowniki, które znaczeniowo nie odnoszą się wprost do czasu, lecz kontekstowo mogą implikować okoliczność czasową, występują zwykle z przyimkiem in, jeśli nie są określone przydawką:

Erat Crastinus evocatus in exercitu Ceasaris, qui superiore anno [...] primum pilum in legione decima duxerat. (Caes., Civ. 3, 91)

„Był w armii Cezara powołany (przez niego) Krastinus, który w poprzednim roku dowodził pierwszą centurią dziesiątego legionu".

A Brundisio Dyrrachium [...] hieme transmisit. (Suet., Iul. 58)

„Z Brundyzjum do Dyrrachium przeprawił się zimą".

Eadem nocte accidit, ut esset luna plena. (Caes., Gall. 4, 29)

"Tej samej nocy zdarzyło się, że nastała pełnia księżyca".

Natus erat Agricola [...] idibus Iuniiis. (Tac., Agr. 44)

"Agrykola urodzil się w idy czerwcowe (= 13 czerwca)".

Volusenus perspectis regionibus omnibus [...] quinto die ad Ceasarem revertitur. (Caes., Gall. 4, 21)

„Woluzenus, dokonawszy przeglądu wszystkich rejonów, piątego dnia powraca do Cezara”.

Decemviri $[\ldots]$ renuntiaverunt ieiunium instituendum Cereri esse, et id quinto quoque anno servandum. (Liv., 36, 37)

„Decemwirowie oznajmili, że należy ustanowić dzień postu na cześć Cerery i zachowywać go co cztery lata (dosł. każdego piątego roku)".

Proavus Augusti secundo Punico bello stipendia in Sicilia tribunus militum fecit. (Suet., Aug. 2)

„Pradziad Augusta w czasie drugiej wojny punickiej odbywał służbę na Sycylii jako trybun wojskowy".

Noster populus in pace $[\ldots]$ magistratibus minatur, recusat, appellat, provocat, in bello sic paret ut regi. (Cic., Rep. 1, 63)

„Nasz naród w czasie pokoju urzędnikom grozi, sprzeciwia się, pozywa przed trybunaty, odwołuje się od decyzji, lecz w czasie wojny tak im jest posłuszny jak królowi".

Summa senectute [...] M. Cato legem suadens in Galbam multa dixit. (Cic., Brut. 89)

„W czasie swej późnej starości Marek Katon, doradzając przyjęcie ustawy, wygłosił długą mowę oskarżycielską przeciwko Galbie".

Beatum, cui etiam in senectute contigerit, ut sapientiam verasque opiniones assequi possit! (Cic., Fin. 5, 58)

„Szczęśliwy, któremu przynajmniej w okresie starości jest dane to, że może osiągnąć mądrość i słuszność poglądów". 


\subsubsection{Rzeczownik $w$ ablatiwie jako dopełnienie dalsze}

Dopełnienia dalsze wyrażone rzeczownikami w ablatiwie konotowane są przez czasownikowe i przymiotnikowe człony nadrzędne, których znaczeniem najczęściej jest:

1. Sytuacja (relacja, postawa, czynność) powstrzymywania, pozbawiania, oddzielania, różnicowania, a także braku, niedostatku, potrzeby itp. Ze względu na właściwości znaczeniowe tego typu nadrzędników konotowane przez nie dopełnienia określane są również terminem ablativus separativus (lub separationis), a ich elementem może być przyimek $a b$ :

Qui si reliquis flagitiis et sceleribus abstinere potuisset, tamen unum ob hoc factum dignum illum omni poena putarem. (Cic., Phil. 13, 17)

"Nawet gdyby mógl powstrzymać się od pozostalych niegodziwości i zbrodni, to jednak z powodu tego jednego czynu uznałbym, że zasługuje na wszelką karę".

Non metuis viros fortis egregiosque cives, quod a corpore tuo prohibentur armis. (Cic., Phil. 2, 116)

"Nie obawiasz się dzielnych mężów i zacnych obywateli, ponieważ przy pomocy broni są oni trzymani z dala od twego ciala (twej osoby)".

Caesar dixit $[. .$.$] duces a pace abhorruisse. (Caes., Civ. 1, 85)$

"Cezar odpowiedzial, że wodzowie wzbraniali się przed pokojem”.

Epaminondas $[\ldots]$ perfecit, $[\ldots]$ ut auxilio sociorum Lacedaemonii privarentur. (Nep., Epam. 6)

„Epaminondas sprawil, że Lacedemończycy zostali pozbawieni pomocy sprzymierzeńców”.

Multae [...] civitates ab Afranio desciscunt. (Caes., Civ. 1, 60)

„Liczne plemiona odstępują od Afraniusza”.

Graviter et severe voluptatem secrevit a bono. (Cic., Fin. 2, 24)

„Poważnie i zdecydowanie oddzielił rozkosz od dobra”.

Cupiditas $[\ldots]$ et inanis alacritas $[.$.$] non multum differunt ab amentia. (Cic., Tusc.$ $4,36)$

„Pożądliwość i czcza wesolość niewiele różnią się od glupoty”.

Priores eius orationes non carent vitiis. (Tac., Dial. 22)

„Wcześniejsze jego mowy nie są wolne od błędów”.

Complures dies frumento milites caruerint. (Caes., Gall. 7, 17)

„Przez wiele dni żolnierze odczuwali brak zboża”.

Cleantes [...] sapientem consolatur, qui consolatione non eget. (Cic., Tusc. 3, 77)

„Kleantes pociesza człowieka mądrego, który pocieszenia nie potrzebuje”.

2. Czynność związana z napełnianiem, zaopatrywaniem, wyposażaniem, obdarowywaniem itp., a także stan związany z pełnią, obfitością, nasyceniem, dostat- 
kiem itp. Konotowane przez te nadrzędniki dopełnienia znane są jako tzw. ablativus copiae:

Boni assiduique domini $[\ldots]$ villa $[\ldots]$ abundat porco, haedo, agno, gallina, lacte, caseo, melle. (Cic., Sen. 56)

„Dom dobrego i gorliwego gospodarza obfituje w wieprze, kozy, jagnięta, kury, mleko, ser, miód".

Cruore scaena abundavit. (Suet., Cal. 57)

"Scena spłynęla krwią".

Malum est avaritia: multos enim magnis incommodis affecit pecuniae cupiditas. (Cic., Inv. 1, 95)

„Chciwość jest zlem: wielu bowiem ludziom żądza pieniądza przysporzyła wielkich kłopotów".

Liber, qui est de summo bono, refertus est et verbis et sententiis talibus. (Cic., Tusc. 3, 42) „Książka, która dotyczy najwyższego dobra, wypełniona jest i slowami i myślami tego rodzaju".

P. Africanus [...], vir omnibus bonis artibus atque omni virtute praeditus, $P$. Sulpicio Galo $[\ldots]$ id $[\ldots]$ probro dedit, quod tunicis uteretur manus totas operientibus. (Gell., Noc. Att. 6, 12, 4)

„Publius Africanus [...], czlowiek obdarzony wszystkimi zacnymi talentami i wszelkimi przymiotami moralnymi, Publiuszowi Sulpiciuszowi Galusowi poczytał za powód do wstydu to, że nosił tuniki przykrywające całe ręce".

Librisque inspectis cum plena religione civitas esset, senatui placuit dictatorem feriarum constituendarum causa dici. (Liv., 7, 28)

"I gdy po zajrzeniu do ksiąg (sybillińskich) miasto przepetnione było zabobonnym przerażeniem, senat uznal za wlaściwe mianować dyktatora dla zorganizowania świąt przeblagalnych".

3. Oskarżanie, obwinianie (o coś), pozywanie do sądu, skazywanie (za coś), uwalnianie, bronienie od oskarżenia (o coś); konotowane przez tę klasę nadrzędników dopełnienia dalsze, identyfikujące oskarżenie lub winę, stanowione są zarówno przez rzeczowniki w genetiwie (zob. wyżej - genetivus criminis: 7.5.3.2. pkt 2), jak i przez rzeczowniki w ablatiwie z przyimkiem de. Bez przyimka dopełnienia te tworzą rzeczowniki o znaczeniu ogólnym (np. scelus, crimen), którym towarzyszyć mogą wyrażone $\mathrm{w}$ genetiwie określniki precyzujące charakter oskarżenia. Występujące $w$ ablatiwie dopełnienia tego typu znane są jako tzw. ablativus criminis:

Hunc de vi accusandum putas? (Cic., Sest. 90)

„Uważasz, że on powinien zostać oskarżony o przemoc?"

Lex vetat eum, qui de pecuniis repetundis damnatus sit, in contione orationem habere. (Rhet. Her. 1, 20)

„Prawo zabrania przemawiania na zgromadzeniu ludowym temu, kto został skazany za zdzierstwa finansowe". 
Sententia iudicum de ambitu condemnatos restituit. (Suet., Iul. 41)

„Skazanych wyrokiem sądowym za nadużycia wyborcze przywrócil do dawnej godności”.

Accusatus hoc crimine iudicumque absolutus sententiis [...] occisus est ab Thebanis apud Hiliartum. (Nep., Lys. 3)

„Oskarżony o to przestępstwo i uniewinniony wrokiem sędziów został zabity przez Tebańczyków pod Hiliartos".

An commotae crimine mentis absolves hominem? (Hor., Serm. 2, 3, 278-279)

„Czy uwolnisz człowieka od zarzutu szaleństwa?”

Przy nadrzędnikach oznaczających skazywanie, karanie lub uwalnianie od kary mogą wystąpić także dopełnienienia w ablatiwie desygnujące karę, wyrażając jej konkretny rodzaj lub wymiar ${ }^{26}$ :

Vitia [...] hominum atque fraudes damnis, ignominiis, vinclis, verberibus, exsiliis, morte multantur. (Cic., De orat. 1, 194)

„Występki i oszustwa ludzi karane są grzywnami, napiętnowaniem, więzieniem, chlostą, wygnaniem, śmiercią".

(Cimon) testarum suffragiis [...] decem annorum exilio multatus est. (Nep., Cim. 3)

"Glosami sądu skorupkowego (Kimon) skazany został na dziesięcioletnie wygnanie".

Frusinates tertia parte agri damnati (sunt). (Liv., 10, 1)

„Mieszkańcy miasta Frusino ukarani zostali odebraniem trzeciej części ziemi”.

Interdictum ne capite domnatos propinqui lugerent. (Suet., Tib. 61)

„Krewnym zabroniono oplakiwania skazanych na śmierć”.

Rodzaj kary może być jednak także wyrażony przez dopełnienia stanowione przez wyrażenia przyimkowe typu: ad metalla, ad mortem itp.:

Multos honesti ordinis $[. .$.$] ad metalla et munitiones viarum aut ad bestias condemnavit. (Suet.,$ Cal. 27)

„Wielu obywateli znakomitego stanu skazal na pracę w kopalniach kruszcu i przy naprawie dróg lub na pożarcie przez dzikie zwierzęta".

4. Inna czynność (sytuacja, właściwość) implikująca istnienie materialnego lub niematerialnego obiektu warunkującego jej zaistnienie. Często wyrażający ów obiekt rzeczownik $w$ ablatiwie konstytuuje dopełnienie wraz z określonym przyimkiem. Często też przy danych nadrzędnikach istnieją inne, alternatywne (w stosunku do rzeczownika w ablatiwie) sposoby wyrażenia dopełnienia:

Domum habuit in colle Quirinali, $[\ldots]$ cuius amoenitas non aedificio, sed silva constabat. (Nep., Att. 13)

„Na wzgórzu kwirynalskim miał dom, którego urok opierał się nie na budynku, lecz parku”.

Graecis utimur verbis ubi nostra desunt. (Quint., Inst. $1,5,58$ )

„Posługujemy się greckimi slowami wszędzie tam, gdzie brakuje naszych”. 
Is maxime divitiis fruitur, qui minime divitiis indeget. (Sen., Lucil. 14, 17)

„Ten najbardziej korzysta $\mathbf{z}$ bogactw, kto najmniej ich pożąda".

Est (in Sparta) genus quoddam hominum, quod Hilotae vocatur, quorum magna multitudo agros Lacedaemoniorum colit servorumque munere fungitur. (Nep., Paus. 3)

„Jest (w Sparcie) pewna klasa ludzi zwanych Helotami, których wielka liczba uprawia ziemię Lacedemończyków oraz pełni rolę niewolników".

Principes in annos singulos gentibus [...] quantum et quo loco visum est agri adtribuunt atque anno post alio transire cogunt $[\ldots]$ ne adsidua consuetudine capti studium belli gerendi agri cultura commutent. (Caes., Gall. 6, 22)

„Naczelnicy plemienni co roku przydzielają poszczególnym rodom ziemię w uznanym przez siebie miejscu i wielkości, a po roku zmuszają ich do przejścia gdzie indziej, aby wskutek upodobania sobie osiadłego trybu życia nie zamienili zapału do prowadzenia wojny na zamilowanie do rolnictwa".

Quis enim non modo liber, sed etiam servus libertate dignus fuit, cui nostra salus cara non esset? (Cic., Leg. 3, 25)

„Jakiż znalazl się bowiem czlowiek, nie tylko wolny, ale nawet niewolnik godny wolności, któremu nie leżałoby na sercu moje ocalenie?"

Maior [...] pars eorum victus in lacte, caseo, carne consistit. (Caes., Gall. 6, 22)

"Glówna część ich pożywienia sklada się z mleka, sera i mięsa”.

De eorum fide constantiaque dubitatis? (Caes., Gall. 7, 77)

„Czy wątpicie w ich wierność i stałość?”

\subsubsection{Rzeczownik $w$ ablatiwie jako przydawka}

Specyficzny dla rzeczownika w ablatiwie jest typ przydawki oparty na związku przynależności, charakteryzujący jakościowo desygnat rzeczownikowego nadrzędnika; jest to tzw. ablativus qualitatis. Podobnie jak genetivus qualitatis (zob. wyżej: 7.5.3.1. pkt 8), stanowi on element określnika złożonego, którego drugim składnikiem jest zależny od niego składniowo przymiotnik, powiązany związkiem kongruencji atrybutywnej:

L. Cotta, homo summo ingenio summaque prudentia [...] supplicationem decrevit. (Cic., Phil. 2, 13)

„Lucjusz Kotta, czlowiek o wybitnym intelekcie i wielkiej mądrości, zarządzil modły dziękczynne".

Ad mensam eximia forma pueros delectos iussit consistere. (Cic., Tusc. 5, 61)

„Rozkazal, aby przy stole stanęli wybrani chlopcy o wyjątkowej urodzie”.

Erat inter Labienum atque hostem difficili transitu flumen ripisque praeruptis. (Caes., Gall. 6, 7)

„Między Labienusem a nieprzyjacielem znajdowala się rzeka o trudnej przeprawie (= trudna do przeprawy) i urwistych brzegach". 
(Datames) Thuyn, hominem maximi corporis terribilique facie [...], optima veste texit. (Nep., Dat. 3)

„(Datames) Tuysa, człowieka o wielkim wzroście i strasznym wyglądzie, okrył wspaniałą szatą".

Poza tym rzeczowniki mogą być określane przez proste przydawki ablatywne (z przyimkami lub bez przyimków), których funkcje semantyczne odpowiadają zwykle wyszczególnionym wyżej funkcjom okolicznikowym lub dopełnieniowym; można zatem wśród nich wyróżnić:

1. Ablativus separativus (separationis):

Tantam spem attulerat exploratae victoriae tua praeclara Mutina eruptio. (Cic., Fam. 11, $14,1)$

„Tak wielką nadzieję na pewne zwycięstwo przyniósł twój sławny wypad z Mutiny”.

Auctore Icilio Numitorioque secessio ab decemviris facta est. (Liv., 3, 51)

„Za sprawą Icyliusza i Numitoriusza nastąpilo odejście (żołnierzy) od decemwirów (= bunt przeciw decemwirom)".

E physicis $[\ldots]$ veri a falso distinctio traditur. (Cic., Fin. 1, 64)

„Z nauki o przyrodzie płynie umiejęıność odróżnienia prawdy od falszu”.

2. Ablativus originis:

Duobus his unius diei proeliis Caesar desideravit [...] C. Felginatem Placentia, A. Granium Puteolis, M. Sacrativirum Capua. (Caes., Civ. 3, 71)

„W obu tych bitwach stoczonych jednego dnia Cezar stracil Gajusza Fleginatę z Placencji, Aulusa Graniusza z Puteolów, Marka Sakratywirusa z Kapui".

Mittitur ad eos [...] Q. Iunius ex Hispania quidam. (Caes., Gall. 5, 27)

„Wysyłany jest do nich niejaki Kwintus Juniusz (pochodzący) z Hiszpanii”.

3. Ablativus materiae:

Porta adversa ingens solidoque adamante columnae. (Verg., Aen. 6, 552)

"Z przodu wielka brama i kolumny $\mathbf{z}$ twardego diamentu (adamantu)".

Vidistis simulacrum Cereris e marmore. (Cic., Verr. 2, 4, 109)

"Zobaczyliście posąg Cerery z marmuru”.

Templum de marmore ponam. (Verg., Georg. 3, 13)

„Zbuduję światynię $\mathbf{z}$ marmuru”.

4. Ablativus instrumenti / causae:

Exercitus nostri interitus ferro, fame, frigore, pestilentia. (Cic., Pis. 40)

„Zaglada naszego wojska od miecza, z powodu glodu, zimna, zarazy”.

5. Ablativus limitationis / respectus:

Sunt enim quidam homines non re sed nomine. (Cic., Off. 1, 105) 
"Niektórzy są bowiem ludźmi nie co do istoty, lecz tylko z nazwy".

Mardonius [...], natione Medus, [...] haud ita magna manu Graeciae fugatus est. (Nep., Paus. 1)

„Mardomiusz, z pochodzenia Med, rozgromiony zostal przez niezbyt wielki oddzial grecki”.

6. Ablativus loci:

Palaestra et tot locis sessiones gymnasiorum et Graecorum disputationum memoriam quodam modo commovent. (Cic., De orat. 2, 20)

„Palestra i lawki w tylu miejscach w pewien sposób przywodzą na pamięć gimnazja i toczone w nich przez Greków dysputy".

Num igitur utiliorem tibi hunc Triarium putas esse posse quam si tua sint Puteolis granaria? (Cic., Fin. 2, 84)

„Czy zatem uważasz, że ten Triariusz może ci przysporzyć więcej pożytku niż gdyby twoją wlasnością stały się spichlerze w Puteolach?"

7. Ablativus temporis:

Me $[\ldots]$ delectant $[\ldots]$ et refrigeratio aestate et vicissim aut sol aut ignis hibernus. (Cic., Sen. 46)

„Sprawia mi przyjemność zarówno chlód w lecie, jak i dla odmiany zimowe slońce lub ognisko".

\subsubsection{Rzeczownik w ablatiwie jako orzecznik}

Rzeczowniki w ablatiwie pełnią funkcję orzecznika w ramach orzeczeń współtworzonych $z$ formami osobowymi czasownika esse lub (rzadziej) habere. Orzecznikom tego typu obligatoryjnie towarzyszy zależna od nich składniowo przydawka przymiotnikowa, związana związkiem kongruencji atrybutywnej. Semantycznie orzeczniki te klasyfikowane są tradycyjnie jako ablativus qualitatis:

Gladiatores [...] animo meliore sunt quam pars patriciorum. (Cic., Catil. 2, 26)

„Gladiatorzy cechują się większą odwagą niż część patrycjuszy”.

(Caesar) fuisse traditur excelsa statura, colore candido, teretibus membris, ore paulo pleniore, nigris vegetisque oculis. (Suet., Iul. 45)

„(Cezar) podobno był wysokiego wzrostu, mial bladą cerę, zaokrąglone członki, twarz nieco zbyt pełną, czarne i bystre oczy".

Quam fuit inbecillus $P$. Africani filius [...], quam tenui aut nulla potius valetudine! (Cic., Sen. 35)

„Jakże słaby fizycznie był syn Publiusza Afrykańskiego, jak delikatnego - albo raczej w ogóle bez żadnego - zdrowia!" 
Britanni $[\ldots]$ capillo $[\ldots]$ sunt promisso atque omni parte corporis rasa praeter caput et labrum superius. (Caes., Gall. 5, 14)

„Brytowie mają długie włosy, a wszystkie pozostałe części ciała wygolone, z wyjątkiem glowy i górnej wargi".

[...] praeter Haeduos et Remos, quos praecipuo semper honore Caesar habuit. (Caes., Gall. 5, 54)

„oprócz Eduów i Remów, których Cezar miał zawsze w szczególnym poważaniu".

\subsubsection{Rzeczownik $w$ ablatiwie jako funkcjonalny odpowiednik podmiotu}

Pozycję funkcjonalnego odpowiednika podmiotu rzeczowniki w ablatiwie zajmują w ramach równoważników zdań okolicznikowych, zwanych ablativus absolutus. Powiązane są składniowym związkiem kongruencji atrybutywnej $\mathrm{z}$ funkcjonalnymi odpowiednikami orzeczenia, realizowanymi przez czasownikowe formy imiesłowowowe (participia) w ablatiwie, lub $\mathrm{z}$ funkcjonalnymi odpowiednikami orzeczników, realizowanymi przez formy rzeczownikowe lub przymiotnikowe $\mathrm{w}$ ablatiwie:

Q. Titurius et $L$. Cotta legati, qui in Menapiorum fines legiones duxerant, omnibus eorum agris vastatis, frumentis succisis, aedificiis incensis [...] ad Caesarem se receperunt. (Caes., Gall. 4, 28)

„Legaci Kwintus Tyturiusz i Lucjusz Kotta, którzy poprowadzili legiony do kraju Menapiów, po tym, gdy wszystkie ziemie Menapiów zostały już spustoszone, zboże wyżęte a budynki spalone, powrócili do Cezara".

(Claudius) historiam in adulescentia hortante T. Livio, Sulpicio vero Flavo etiam adiuvante, scribere adgressus est. (Suet., Claud. 41)

„(Klaudiusz) przystapił do pisania swego dzieła historycznego już w młodości, gdy Tytus Liwiusz go zachęcal, a Sulpicjusz Flawus nawet pomagal".

Patres conscripti, qui Hannibale vivo numquam se sine insidiis futuros existimarent, legatos in Bithyniam miserunt. (Nep., Hann. 12)

„Senatorowie, którzy uważali, że dopóki Hannibal jest żywy, nigdy nie będą wolni od jego knowań, wyprawili posłów do Bitynii".

\subsubsection{Rzeczownik w ablatiwie jako funkcjonalny odpowiednik orzecznika}

Pozycję funkcjonalnego odpowiednika orzecznika rzeczowniki w ablatiwie zajmują zasadniczo w dwóch kontekstach składniowych. Jednym z nich jest równoważnik zdania okolicznikowego o postaci ablativus absolutus:

Bellum Gallicum [...] C. Caesare imperatore gestum est. (Cic., Prov. 32)

„Wojna z Gallami stoczona została pod dowództwem Gajusza Cezara (dosł.: gdy Gajusz Cezar byl dowódcą)". 
Quod $[\ldots]$ quasi deo teste promiseris, id tenendum est. (Cic., Off. 3, 104)

„Co przyrzekłeś jakby wobec boga jako świadka (dosł.: gdy bóg byl świadkiem), tego należy dotrzymać".

Athenienses $[\ldots]$ totam eam rem [...] auctore Aristide repudiaverunt. (Cic., Off. 3, 49)

„Ateńczycy calą tę rzecz za namową Arystydesa odrzucili (dosł.: ponieważ Arystydes był tego zwolennikiem)".

Omnia summa consecutus es virtute duce, comite fortuna. (Cic., Fam. 10, 3, 2)

„Do wszystkich najwyższych godności doszedłeś, mając męstwo za przewodnika i szczęście za towarzysza (dosł.: gdy męstwo było (twoim) przewodnikiem i szczęście towarzyszem)".

Drugim, rzadszym kontekstem jest rówoważnik zdania o postaci accusativus cum infinitivo. W jego ramach rzeczownik w ablatiwie zająć może pozycję funkcjonalnego odpowiednika orzecznika, współtworząc - wraz z bezokolicznikową formą czasownika esse - funkcjonalny odpowiednik orzeczenia. Rzeczownikowi w tej pozycji obligatoryjnie towarzyszy przydawka przymiotnikowa, a desygnowana przez niego treść predykatywna identyfikowana jest jako tzw. ablativus qualitatis:

Me forti animo esse oportere censebas. (Cic., Brut. 330)

„Uznaleś, że trzeba, abym był silnego ducha”.

\subsubsection{Rzeczownik w ablatiwie jako operator tekstowy}

Wyrażone w ablatiwie rzeczowniki typu sententia, opinio itp. mogą stanowić konstytutywny człon operatora tekstowego identyfikującego ośrodek perspektywy modalnej, z której ukazana jest treść składająca się na warstwę przedmiotową wypowiedzi. Zależnym składniowo składnikiem takiego operatora jest przydawka, najczęściej w postaci zaimka dzierżawczego. Tradycyjnie wyrażenia tego typu klasyfikowane są jako ablativus limitationis:

Nam id mea quidem opinione [...] satis non est. (Quint., Inst. 1, pr. 18)

„Bowiem to, przynajmniej w mojej opinii nie jest wystarczające".

Tibi par mea sententia nemo umquam fuit. (Cic., De orat. 1, 122)

„Moim zdaniem nigdy nie bylo nikogo równego tobie”.

\subsubsection{Vocativus}

Rzeczownik w wokatiwie służy realizacji określonej strategii nadawczo-odbiorczej autora wypowiedzenia, pełniąc impresywną funkcję apelu. $Z$ punktu widzenia składniowego ma status adresatywu, który może być konstytutywnym elementem wyrażenia adresatywnego o strukturze grupy imiennej i/lub zdania przydawkowego, gdzie zajmuje pozycję członu nadrzędnego (determinującego). Adresatyw lub wy- 
rażenie adresatywne może być samodzielną jednostką wypowiedzeniową albo (częściej) stanowić składnik szerszej struktury zdaniowej, niezwiązany syntaktycznie z jej pozostałymi elementami (członami syntaktycznymi). Użyciu rzeczownika w wokatiwie często towarzyszą określone partykuły pełniące funkcję operatorów emotywnych:

O mi Aeschine, o mi germane! (Ter., Adelph. 268-269)

„O mój Eschinie, o mój bracie!"

Heus, Staphyla, prodi atque ostium aperi! (Pl., Aul. 350)

„Hej, Stafilo, chodź i otwórz drzwi!”

Quid fles, cucule? (Pl., Pseud. 96)

"Cóż płaczesz, gluptaku?"

Quo usque tandem abutere, Catilina, patientia nostra? (Cic., Catil. 1, 1)

„Doprawdy jak długo jeszcze, Katylino, będziesz nadużywał naszej cierpliwości?”

Video, patres conscripti, in me omnium vestrum ora atque oculos esse conversos. (Cic., Catil. 4,1$)$

„Widzę, senatorowie, że na mnie zwrócone są twarze i oczy was wszystkich”.

O vita misero longa, felici brevis! (Sen., Controv. 7, 3, 8)

„O życie, dla nieszczęsnika długie, dla szczęśliwca krótkie!"

O fons Bandusiae, splendidior vitro, dulci digne mero non sine floribus, cras donaberis haedo. (Hor., Carm. 3, 13, 1-3)

„O źródlo banduzyjskie, bardziej lśniące niż szklo, godne słodkiego wina i kwiatów, jutro otrzymasz w darze koziołka".

W analogicznej funkcji adresatywnej stosowane są także substantywizowane (tj. niebędące podrzędnymi składniowo elementami grupy imiennej) formy imiesłowowe i przymiotnikowe w wokatiwie. Dotyczy to zwłaszcza poezji:

Quo moriture ruis maioraque viribus audes? (Verg., Aen. 10, 811)

"Dokąd, zatraceńcze, gnasz, porywając się na rzeczy ponad sily?"

Anchisa generate, deum certissima proles, Cocyti stagna alta vides Stygiamque paludem. (Verg., Aen. 6, 322-323)

„Synu Anchizesa, niewątpliwy potomku bogów, patrzysz na glębokie rozlewiska Kocytu i stygijskie bagna".

Tum Cocles: 'Tiberine pater', inquit, 'te sancte precor, haec arma et hunc militem propitio flumine accipias'. (Liv., 2, 10)

„Wtedy Kokles: 'Ojcze Tyberynie', rzecze, 'blagam cię, święty, ugość laskawie w swym życzliwym nurcie ten oręż i tego żołnierza".'

Ze względu na charakterystyczny dla większości leksemów rzeczownikowych brak rozróżnienia formalnego między wokatiwem a nominatiwem, notuje się użycie form mianownikowych $w$ miejsce wokatiwu (zob. wyżej: 7.5.2.3.). Niekiedy formy 
mianownikowe pojawiają równolegle obok form wokatywnych w ramach jednego wypowiedzenia:

$\mathrm{Da}$, meus ocellus, mea rosa, mi anime, mea voluptas, Leonida, argentum mihi. ( $\mathrm{Pl}$., Asin. 664-665)

„Moje oczko, ma różo, moja duszo, ma rozkoszy, Leonidasie, daj mi to srebro".

'Audi', inquit, 'Iuppiter, audi, pater patrate populi Albani; audi tu, populus Albanus'. (Liv., 1, 24)

„S'luchaj,' powiada, 'Jowiszu!; słuchaj, mianowany przedstawicielu narodu albańskiego!; Sluchaj ty, narodzie albański!".

\subsection{WYBRANA LITERATURA}

Bonelli (1983), Cabrillana (2001, 2002, 2005), Calboli (1996, 2005b), Dressler (1979), García-Hernández (1994), Górska (2004), Kaczmarkowski (1985), Lavency (1979), Luraghi (1989), Murru (1977), Önnerfors (2002), Panhuis (1978), Proverbio (1998), Serbat (1996), Torrego (1991) 


\section{8. \\ Charakterystyka funkcjonalna przymiotników}

Przymiotniki to klasa leksemów reprezentowana przez wyrazy gramatyczne, których prymarną funkcją składniową jest funkcja przydawki, czyli członu podrzędnego (akomodowanego) w ramach grupy imiennej. Jako nazwy cech przymiotniki zajmują w grupie imiennej pozycję członu określającego, związanego z członem określanym związkiem kongruencji atrybutywnej.

Wyrazy gramatyczne, reprezentujące leksemy przymiotnikowe, scharakteryzowane są przez fleksyjną kategorię liczby o wartościach singularis i pluralis, rodzaju o wartościach: masculinum, femininum, neutrum oraz przypadka o wartościach: nominativus, genetivus, dativus, accusativus, ablativus, vocativus. Wszystkie te kategorie mają w odniesieniu do przymiotników jednakowy status: pod względem morfologicznym są to kategorie o charakterze fleksyjnym (tzn. każdy przymiotnik może przyjmować każdą z wartości tych kategorii), pod względem synataktycznym są kategoriami składniowo zależnymi (determinowanymi) i niedeterminującymi, zaś pod względem funkcjonalnym są kategoriami o charakterze tekstowym (tzn. składniowym, nienominatywnym, semantycznie pustym).

W ramach wypowiedzenia wartości kategorii liczby, rodzaju i przypadka przymiotnika determinowane są przez wartości, które w odniesieniu do tych kategorii wyrażane są przez nadrzędny składniowo rzeczownik; dlatego kategorie liczby, rodzaju i przypadka rzeczowników i przymiotników są kategoriami fleksyjnymi sprzężonymi.

Funkcją kategorii liczby, rodzaju i przypadka przymiotnika jest sygnalizowanie zależności składniowej przymiotnika od nadrzędnego rzeczownika w ramach grupy imiennej, a więc sygnalizowanie związków (powiązań) składniowych zachodzących w strukturze wypowiedzenia. Rodzaj związku składniowego opartego na kategorii liczby, rodzaju i przypadku to właśnie związek kongruencji atrybutywnej ${ }^{1}$. W jego ramach szczególny jest status kategorii rodzaju przymiotnika, który jest indeksem wartości kategorii rodzaju nadrzędnego rzeczownika, dla którego rodzaj jest kategorią selektywną (klasyfikującą, niefleksyjną), pozbawioną morfologicznego wykładnika.

1 Więcej na temat związku kongruencji atrybutywnej i jego szczególnych wlasciwościach zob. niżej, Skladnia 3.3.1.1. 
Właściwości semantyczne i morfologiczne przymiotników decydują o tym, że prymarną funkcją składniową tej klasy leksemów jest funkcja przydawki związanej z nadrzędnym członem rzeczownikowym związkiem kongruencji atrybutywnej. Przymiotniki realizują tę funkcję w odniesieniu do rzeczowników pełniących zarówno ich prymarną funkcję podmiotu, jak i ich funkcje sekundarne, tj. funkcję dopełnienia, okolicznika, orzecznika, przydawki, adresatywu itd.:

Domi militiaeque boni mores colebantur. (Sall., Cat. 9)

„W czasie pokoju i w czasie wojny pielęgnowane były dobre obyczaje".

Caesar $[\ldots]$ castris idoneum locum delegit. (Caes., Gall. 1, 49)

„Cezar uybral dogodne dla obozu miejsce".

Quae est ista servitus tam claro homini tamque nobili? (Cic., Parad. 41)

"Czym jest ta niewola dla tak slawnego człowieka i tak szlachetnego?"

Ego P. Clodium arbitrabar perniciosum civem. (Cic., Phil. 8, 16)

„Ja uważalem Publiusza Klodiusza za obywatela szkodliwego (dla państwa)".

L. Tarquinius fratrem habuerat Arruntem Tarquinium, iuvenem mitis ingenii. (Liv., 1, $46,4)$

„Lucjusz Tarkwiniusz mial brata Arrunta Tarkwiniusza, mlodzieńca o lagodnym usposobieniu".

O fons Bandusiae, splendidior vitro, dulci digne mero non sine floribus, cras donaberis haedo. (Hor., Carm. 3, 13, 1-3)

„O źródło banduzyjskie, bardziej lśniące niż szkło, godne słodkiego wina i kwiatów, jutro otrzymasz w darze koziołka".

Sekundarnie przymiotniki pełnić mogą funkcję:

a. Orzecznika:

Quoniam pares virtutes sunt, recta facta, quando a virtutibus proficiscuntur, paria debent esse. (Cic., Parad. 22)

„Ponieważ cnoty są sobie równe, to również dobre uczynki, jeśli wywodzą się z cnót, powinny być sobie równe".

(Themistocles) maritimos praedones consectando mare tutum reddidit. (Nep., Them. 2)

"(Temistokles), ścigając morskich korsarzy, na powrót uczynił morze bezpiecznym".

b. Funkcjonalnego odpowiednika orzecznika:

Omnibus $[. .$.$] expedit salvam esse rem publicam. (Cic., Phil. 13, 16)$

"Jest w interesie wszystkich, żeby państwo było bezpieczne".

Negas fortem esse quemquam posse, qui dolorem malum putet. (Cic., Fin. 4, 53)

„Twierdzisz, że nikt nie może być dzielny, kıo uznaje cierpienie za zło".

Patres conscripti, qui Hannibale vivo numquam se sine insidiis futuros existimarent, legatos in Bithyniam miserunt. (Nep., Hann. 12)

„Senatorowie, którzy uważali, że dopóki Hannibal żyje (dosl. jest żywy), nigdy nie będą wolni od jego knowań, wyprawili posłów do Bitynii". 
Relinquebatur una per Sequanos via, qua Sequanis invitis propter angustias ire non poterant. (Caes., Gall. 1, 9)

„Pozostawała jedna droga przez kraj Sekwanów, którą - ze względu na jej ciasnotę - nie mogli iść, gdyby Sekwanowie byli temu niechętni (= wbrew woli Sekwanów)".

c. Uzupełnienia (komplementu) orzecznikowgo:

Contentum [...] suis rebus esse maximae sunt certissimaeque divitiae. (Cic., Parad. 51) „Być zadowolonym z tego, co się ma, jest największym i najpewniejszym bogactwem".

(Atticus) idoneum tempus ratus studiis obsequendi suis Athenas se contulit. (Nep., Att. 2) "(Attyk), uznawszy czas za dogodny do zajęcia się swoimi studiami, wyjechal do Aten”.

Człony syntaktyczne zależne od składników zdań (współ)stanowionych przez przymiotniki generalnie mają status okoliczników:

(Tiberius) satis firmus [...] adversus pecuniam. (Tac., Ann. 3, 18)

"(Tyberiusz) dość niewzruszony (odporny) wobec pokus majątkowych".

Cechy semantyczne niektórych przymiotników implikować mogą jednak uzupełnienia, których status odpowiada dopełnieniom:

Fuere item ea tempestate, qui crederent $M$. Licinium Crassum non ignarum eius consilii fuisse. (Sall., Cat. 17, 7)

„Byli również w tym czasie tacy, którzy wierzyli, że Marek Licyniusz Krassus nie był nieświadomy tego planu".

Non erat Othonis mollis et corpori similis animus. (Tac., Hist. 1, 22)

„Dusza Othona nie była zniewieściala i podobna çiału”.

Przymiotniki podlegać mogą kontekstowo ujawnianej substantywizacji (urzeczownikowieniu), czego przejawem jest przyjęcie rzeczownikowych cech morfologicznych, semantycznych i składniowych.

Rzeczownikową cechą morfologiczną, charakteryzującą substantywizowane przymiotniki, jest selektywny (klasyfikujący) charakter gramatycznej kategorii rodzaju, co oznacza, że cechują się one albo wyłącznie rodzajem męskim, albo wyłącznie żeńskim, albo wyłącznie nijakim. Tym samym substantywizowane rzeczowniki, fundowane na tym samym przymiotniku, lecz różniące się wartością kategorii rodzaju, należy uznać za dwie odrębne jednostki leksykalne, np.: amicus, -i $(m)$ 'przyjaciel', amica, -ae (f) 'przyjaciółka' ( $\leftarrow$ amicus, $-a,-u m$ 'przyjacielski, przyjazny').

Semantyczną cechą substantywizowanych przymiotników jest desygnowanie obiektów (osób, rzeczy, zjawisk, pojęć), których właściwości pozostają w związku z oznaczanym przez fundujący przymiotnik atrybutem. Desygnatami substantywizowanych przymiotników w rodzaju męskim, które często występują w liczbie mnogiej, są zwykle mężczyźni lub generalnie ludzie o określonych cechach, np.: boni 'dobrzy (ludzie)', maiores 'przodkowie', barbari 'obcy, cudzoziemcy', Romani 'Rzymianie', vicinus 'sąsiad', propinquus 'krewny', aequalis 'rówieśnik' itp. Desygnatami substantywizowanych przymiotników w rodzaju żeńskim są przeważnie kobiety, np.: Sabinae 'Sabinki', vicina 'sąsiadka', propinqua 'krewna', amica 'przyjaciółka' itp. Desygnatami 
substantywizowanych przymiotników $\mathbf{w}$ rodzaju nijakim są uogólnione lub kontekstowo identyfikowalne rzeczy (fakty, zjawiska itp.) cechujące się właściwościami nazywanymi przez fundujący przymiotnik lub abstrakcyjne pojęcia będące rezultatem nominacji tych właściwości, np.: honestum 'coś, co jest moralnie dobre, szlachetny czyn / cnota, prawość', malum 'coś złego, nieszczęście, niepowodzenie, zły uczynek / zło.' W niektórych przypadkach substantywizacja przymiotnika jest wynikiem elipsy określonego rzeczownika jako członu nadrzędnego, co wiąże się z silną konkretyzacją znaczenia substantywizowanego przymiotnika, determinowaną semantyką elidowanego rzeczownika, np.: Ianuarius (mensis) 'styczeń', regia (domus) 'pałac królewski', hiberna (castra) 'wojskowy obóz zimowy'.

Syntaktyczną cechą substantywizowanych przymiotników jest przyjęcie rzeczownikowych cech składniowych, czego konsekwencją jest możliwość pełnienia funkcji składniowych, które wynikają zarówno z prymarnej, jak i sekundarnej dystrybucji składniowej rzeczowników. Urzeczownikowione przymiotniki mogą zatem zajmować pozycję np.:

a. Podmiotu:

Vestra $[\ldots]$ interest ne imperatorem pessimi faciant. (Tac., Hist. 1, 30)

„W waszym interesie jest zapobiec temu, aby cesarza nie wybierali najgorsi".

Improbi autem et avari $[\ldots]$ non modo non copiosi ac divites, sed etiam inopes et pauperes existimandi sunt. (Cic., Parad. 52)

„Z kolei niegodziwi i chciwi nie tylko nie powinni być uważani za bogatych czy majętnych, lecz wręcz za biednych i ubogich".

b. Orzecznika:

Malum mihi videtur esse mors. (Cic., Tusc. 1, 9)

„Wydaje mi się, że śmierć jest zlem”.

Varium et mutabile semper femina (est). (Verg., Aen. 4, 569-570)

"Kobieta jest zawsze czymś niestalym i zmiennym".

c. Dopełnienia:

M. Antonius [...] in eo libro quem unum reliquit, disertos ait se vidisse multos, eloquentem omnino neminem. (Cic., Orat. 18)

„Marek Antoniusz w jedynej księdze, jaką pozostawil, mówi, że widzial wielu wygadanych, ale wymownego zgoła nikogo".

Et facere et pati fortia Romanum est. (Liv., 2, 12)

„Zarówno dokonywać potężnych rzeczy, jak i (takie rzeczy) znosić, jest czymś, co cechuje Rzymian".

d. Okolicznika:

O vita misero longa, felici brevis! (Sen., Controv. $7,3,8$ )

„() życie, dla nieszczęśnika dlugie, dla szczęśliwca krótkie!" 
Medio diei $[\ldots]$ Nero egreditur ad cohortem. (Tac., Ann. 12,69)

„W środku dnia (= w południe) Neron wychodzi i zbliża się do kohorty”.

e. Funkcjonalnego odpowiednika podmiotu:

Possum igitur $[. .$.$] suscensere dicenti non omnis bonos esse beatos? (Cic., Tusc. 5, 25)$ „Czyż mogę zatem oburzać się na kogoś mówiącego, że nie wszyscy dobrzy są szczęśliwi?”

f. Funkcjonalnego odpowiednika orzecznika:

Deinde concludebas summum malum esse dolorem, summum bonum voluptatem. (Cic., Fin. 2, 63)

„Następnie wyciągałeś wniosek, że największym zlem jest cierpienie, największym dobrem rozkosz".

Pewne funkcje semantyczno-syntaktyczne są szczególnie charakterystyczne dla substantywizowanych przymiotników (i zaimków) określonej grupy znaczeniowej, jak np. wyrażony w genetiwie orzecznik lub okolicznik wyrażający w sposób ogólny wartościowanie lub cenę (tzw. genentivus pretii - zob. wyżej: 7.5.3.3.; 7.5.3.5.):

Merito vostro amo vos, quia me colitis et magni facitis. (Pl., Cist. 21-22)

„Kocham was, bo na to zasłużyliście, ponieważ mnie szanujecie i wysoko cenicie”.

Istud quidem quod polliceris aequi bonique facio. (Apul., Met. 1, 5)

„To, co obiecujesz, cenię sobie (= doceniam, oceniam jako sluszne i dobre)”.

Multo minoris vendidit non modo quam tu, sed etiam quam qui antet te vendiderunt. (Cic., Verr. 2, 3, 43)

„Sprzedal o wiele taniej nie tylko niż ty, ale także niż ci, którzy przed tobą sprzedawali”.

Tribuni plebis permagni interest qui sint. (Cic., Planc. 13)

„Ogromne ma znaczenie, jacy są trybuni ludowi".

In eo parvi refert, quid veri sit. (Liv., 8, 18)

„W tej sprawie male ma znaczenie, co jest prawdą".

Określnikami (członami podrzędnymi) substantywizowanych przymiotników mogą być przymiotnikowe lub rzeczownikowe przydawki, np.:

M. Antonius $[\ldots]$ in eo libro quem unum reliquit, disertos ait se vidisse multos, eloquentem omnino neminem. (Cic., Orat. 18)

„Marek Antoniusz w jedynej księdze, jaką pozostawil, mówi, że widzial wielu wygadanych, ale wymownego zgola nikogo".

Medio diei [...] Nero egreditur ad cohortem. (Tac., Ann. 12, 69)

„W środku dnia (= w poludnie) Neron wychodzi i zbliża się do kohorty".

Jednak określnikami tymi mogą być także przysłówkowe okoliczniki:

Bassus [...] eo animo vultuque finem suum spectat quo alienum spectare nimis securi putares. (Sen., Lucil. 30, 3) 
„Bassus oczekuje własnego końca $\mathrm{z}$ takim spokojem ducha i oblicza, z jakim oczekiwanie cudzego kresu uznałbyś za wlaściwe dla kogoś nazbyt zobojętnialego".

Multo minoris vendidit non modo quam tu, sed etiam quam qui antet te vendiderunt. (Cic., Verr. 2, 3, 43)

„Sprzedał 0 wiele taniej nie tylko niż ty, ale takíe niż ci, którzy przed tobą sprzedawali”.

\subsection{WYBRANA LITERATURA}

Arias Abellán (1996), Cuzzolin (2011), Heberlein (1995), Kircher-Durand (1996), Pinkster (1983b) 


\section{9. \\ Charakterystyka funkcjonalna przysłówków}

Przysłówki' to klasa leksemów reprezentowana przez wyrazy gramatyczne, które nie są scharakteryzowane przez żadne kategorie fleksyjne, a ich prymarną funkcją składniową jest funkcja okolicznika, czyli członu syntaktycznego zależnego od składnika zdania stanowionego przez czasownik, przymiotnik lub (inny) przysłówek. W odróżnieniu od dopełnienia okolicznik nie jest przez składniowy nadrzędnik konotowany (wymagany, implikowany), a jedynie fakultatywnie przyłączany. Rodzaj składniowej zależności łączącej okolicznik z członem nadrzędnym określany jest terminem związek przynależności:

Nostri fotriter impetum eorum tulerunt celeriterque ad suos quisque ordines redit. (Caes., Civ. 3, 37)

„Nasi dzielnie wytrzymali ich atak i każdy szybko wrócil do swoich szeregów”.

Se putant satis magnam adeptos esse dicendi gloriam. (Cic., Brut. 92)

Uważają, że osiągnęli dostatecznie wielką stawę oratorską".

Maiores nostri longe aliter et de illo et de ceteris talibus viris existimabant. (Cic., S. Rosc. 50)

„Przodkowie nasi zdecydowanie inaczej myśleli i o nim i o pozostatych takich ludziach".

W ramach sekundarnej dystrybucji składniowej wyrazy gramatyczne, które reprezentują leksemy przysłówkowe, mogą zajmować także inne pozycje składniowe, $\mathrm{np}$. orzecznika lub funkcjonalnego odpowiednika orzecznika:

Haec commemoro, quae sunt palam. (Cic., Pis. 11)

„Wspominam te rzeczy, które są powszechnie znane”.

Alia probabilia, contra alia dicimus. (Cic., Off. 2, 7)

„Jedne rzeczy nazywamy prawdopodobnymi, inne nazywamy przeciwnie (tj. nieprawdopodobnymi)".

' Pod względem cech gramatycznych do klasy tej należą również przysłówkowe zaimki i przysłówkowe liczebniki. 
Cum quaereretur ab illo quo tanta diligentia artis spectaret ad paucissimos adventurae, 'satis sunt' inquit 'mihi pauci, satis est unus'. (Sen., Lucil. 7, 11)

„Gdy był pytany, do czego zmierza oddając się tak gorliwie sztuce, która dotrze do bardzo nielicznych, odrzekł: 'wystarczają mi nieliczni, wystarcza jeden'".

Socrates mihi videtur $[\ldots]$ primus a rebus occultis et ab ipsa natura involutis [...] avocavisse philosophiam, $[\ldots]$ ut $[\ldots]$ caelestia $[\ldots]$ procul esse a nostra cognitione censeret. (Cic., Acad. 1, 15)

„Wydaje mi się, że Sokrates jako pierwszy odwiódł filozofię od spraw ukrytych i zaciemnionych przez samą naturę, uznając, że zjawiska na niebie są z dala od (= poza zasięgiem) naszego poznania".

Mogą również być określnikami rzeczowników, przyjmując tym samym funkcję przydawek:

Non tu nunc hominum mores vides? (Pl., Pers. 385)

„Nie dostrzegasz obyczajów dzisiejszych ludzi?”

Eri semper lenitas verebar quorsum evaderet. (Ter., Andr. 175-176)

„Obawiałem się, do czego zmierza (czym się skończy) ta nieustanna lagodność mego pana”.

L. Paulum, bis consulem, domitorem Graeciae, omnium oculi conspicere [...] avent. (Liv., $45,39)$

„Oczy wszystkich pragną zobaczyć Lucjusza Paulusa, dwukrotnie konsula, pogromcę Grecji".

Quid mihi $[\ldots]$ erat $[\ldots]$ hinc abitio quidve in navem inscensio? (Pl., Rud. 502-503)

„Na cóż mi był wyjazd stąd, na cóż wejście na okręt?"

Przysłówki, które pod względem znaczeniowym mają charakter kwantyfikatorów ilościowych, mogą ulegać substantywizacji i zajmować rzeczownikowe pozycje składniowe, a więc np. pozycję podmiotu czy dopełnienia:

Messala, [...] si iam satis aetatis ac roboris haberet, ipse pro Sex. Roscio diceret. (Cic., S. Rosc. 149)

„Messala, gdyby mial już dość (= wystarczającą ilość) lat i sil, sam przemawiałby w obronie Sekstusa Roscjusza".

Nimis enim insidiarum ad capiundas auris adhiberi videtur, si $[\ldots]$ in dicendo numeri ab oratore quaeruntur. (Cic., Orat. 170)

„Wydaje się bowiem, że stosowanych jest zbyt wiele (= nadmiar) pulapek mających usidlić uszy, jeśli przemawiając mówca zabiega o efekty rytmiczne".

Pewne przysłówki mogą sekundarnie przyjmować funkcje przyimkowe, a więc funkcje, które właściwe są dla leksemów synsyntagmatycznych:

Cum iam prope castra venisset, vi morbi oppressus vitam amiserit. (Cic., Phil. 9, 15)

„Gdy już podszedł blisko obozu, zlożony atakiem choroby, umarl”.

${ }^{2}$ Tego rodzaju użycie przysłówka może być zapewne interpretowane jako grecyzm. 
Cum quaereretur ab illo quo tanta diligentia artis spectaret ad paucissimos adventurae, 'satis sunt' inquit 'mihi pauci, satis est unus'. (Sen., Lucil. 7, 11)

„Gdy był pytany, do czego zmierza oddając się tak gorliwie sztuce, która dotrze do bardzo nielicznych, odrzekl: 'wystarczają mi nieliczni, wystarcza jeden"'.

Socrates mihi videtur $[\ldots]$ primus a rebus occultis et ab ipsa natura involutis $[\ldots]$ avocavisse philosophiam, $[\ldots]$ ut $[\ldots]$ caelestia $[\ldots]$ procul esse a nostra cognitione censeret. (Cic., Acad. 1, 15)

„Wydaje mi się, że Sokrates jako pierwszy odwiódł filozofię od spraw ukrytych i zaciemnionych przez samą naturę, uznając, że zjawiska na niebie są z dala od (= poza zasięgiem) naszego poznania".

Mogą również być określnikami rzeczowników, przyjmując tym samym funkcję przydawek:

Non tu nunc hominum mores vides? (Pl., Pers. 385)

„Nie dostrzegasz obyczajów dzisiejszych ludzi?"

Eri semper lenitas verebar quorsum evaderet. (Ter., Andr. 175-176)

„Obawiałem się, do czego zmierza (czym się skończy) ta nieustanna lagodność mego pana”.

L. Paulum, bis consulem, domitorem Graeciae, omnium oculi conspicere [...] avent. (Liv., 45,39 )

„Oczy wszystkich pragną zobaczyć Lucjusza Paulusa, dwukrotnie konsula, pogromcę Grecji".

Quid mihi $[\ldots]$ erat $[\ldots]$ hinc abitio quidve in navem inscensio? (PI., Rud. 502-503)

„Na cóż mi byl wyjazd stąd, na cóż wejście na okręt?"

Przysłówki, które pod względem znaczeniowym mają charakter kwantyfikatorów ilościowych, mogą ulegać substantywizacji i zajmować rzeczownikowe pozycje składniowe, a więc np. pozycję podmiotu czy dopełnienia:

Messala, [...] si iam satis aetatis ac roboris haberet, ipse pro Sex. Roscio diceret. (Cic., S. Rosc. 149)

„Messala, gdyby miał już dość (= wystarczającą ilość) lat i sil, sam przemawialby w obronie Sekstusa Roscjusza".

Nimis enim insidiarum ad capiundas auris adhiberi videtur, si $[\ldots]$ in dicendo numeri ab oratore quaeruntur. (Cic., Orat. 170)

„Wydaje się bowiem, że stosowanych jest zbyt wiele (= nadmiar) pułapek mających usidlić uszy, jeśli przemawiając mówca zabiega o efekty rytmiczne".

Pewne przysłówki mogą sekundarnie przyjmować funkcje przyimkowe, a więc funkcje, które właściwe są dla leksemów synsyntagmatycznych:

Cum iam prope castra venisset, vi morbi oppressus vitam amiserit. (Cic., Phil. 9, 15)

„Gdy już podszedł blisko obozu, złożony alakiem choroby, umarl”.

${ }^{2}$ Tego rodzaju użycie przysłówka może być zapewne interpretowane jako grecyzm. 
Wobec: Etenim prope est spelunca quaedam conversa ad aquilonem infinita altitudine. (Cic., Verr. 2, 4, 197)

„W pobliżu znajduje się bowiem jakaś pieczara zwrócona na pólnoc, nieskończenie glęboka”.

Labienus [...] cum XXV cohortibus magnoque equitatu contra hostem proficiscitur. (Caes., Gall. 6, 7)

„Labienus z dwudziestoma pięcioma kohortami i wielką ilością konnicy rusza przeciw nieprzyjacielowi".

Wobec: Nec vincere possis flumina, si contra quam rapit unda nates. (Ov., Ars 2, 181-182) „I nie móglbyś pokonać rzeki, jeśli płynąłbyś przeciwnie (= w przeciwnym kierunku), niż porywa fala (nurt)".

Haec $[\ldots]$ te palam laudaveram. (Hor., Epod. 11, 19)

„Pochwalikem to przed tobą".

Wobec: De deditione omnes iam palam loquebantur. (Caes., Civ. 2, 36)

„Wszyscy już otwarcie mówili o kapitulacji”.

Poza tym leksemy przysłówkowe (lub tradycyjnie klasyfikowane jako przysłówkowe) mogą też funkcjonować jako operatory tekstowe:

a. Nawiązania międzywypowiedzeniowego:

Ser. Tullius regnavit annos quattuor et quadraginta ita, ut bono etiam moderatoque succedenti regi difficilis aemulatio esset; ceterum id quoque ad gloriam accessit, quod cum illo simul $[\ldots]$ regna occiderunt. (Liv., 1,48 )

„Serwiusz Tulliusz panował przez czterdzieści cztery lata w taki sposób, że nawet dobremu i powściągliwenu następcy trudno byloby mu dorównać; poza tym do jego chwaly przyczyniło się również to, że wraz z nim zakończyły się rządy królewskie".

b. Presupozycji:

Tum demum Liscus oratione Caesaris adductus, quod antea tacuerat, proponit. (Caes., Gall. 1, 17)

„Wtedy dopiero Liskus, pod wptywem przemówienia Cezara, wyjawia to, co wcześniej przemilczał".

c. Kwantyfikacji:

Accepi ab Aristocrito tris epistulas, quas ego lacrimis prope delevi. (Cic., Fam. 14, 3, 1)

"Otrzymałem od Arystokryta trzy listy, które łzami niemal zmazałem”.

Człony składniowo zależne od przysłówków mają zasadniczo status okoliczników i stanowione są przez inne przysłówki, rzeczowniki lub połączenia rzeczowników z przyimkami (wyrażenia przyimkowe):

Satis diu vixit. (Sen., Dial. 6, 24, 1)

"Żył dostatecznie dlugo". 
Maiores nostri longe aliter et de illo et de ceteris talibus viris existimabant. (Cic., S. Rosc. 50)

„Przodkowie nasi zdecydowanię inaczej myśleli i o nim, i o pozostałych takich ludziach”.

Qui decimae legionis aquilam ferebat, obtestatus deos ut ea res legioni feliciter eveniret, 'desilite' inquit 'commilitones'. (Caes., Gall. 4, 25)

„Chorąży niosący orła dziesiątego legionu, wezwawszy bogów, aby ta rzecz wypadła szczęśliwie dla legionu, zawołał: 'skaczcie, towarzysze broni!"'

Procul ab aqua et natura iniquo loco castra ponunt. (Caes., Civ. 1, 81)

„Daleko od wody i w niedogodnym z natury miejscu zakładają obóz".

Niektóre przysłówki implikują jednak uzupełnienia, których status odpowiadać może dopełnieniu:

Cum igitur hoc sit extremum, congruenter naturae convenienterque vivere, necessario sequitur omnes sapientes semper feliciter $[\ldots]$ vivere. (Cic., Fin. 3, 26)

„Skoro zatem to jest celcm ostatecznym, a mianowicie życie zgodnie z natura i stosownie do niej, to nieuchronnie wynika z tego, że wszyscy mędrcy żyją szczęśliwie".

Dotyczy to również przysłówków o znaczeniu kwantyfikatorów ilościowych, używanych rzeczownikowo lub zajmujących pozycję orzecznikową:

Messala, [...] si iam satis aetatis ac roboris haberet, ipse pro Sex. Roscio diceret. (Cic., S. Rosc. 149)

„Messala, gdyby miał już dość (= wystarczającą ilość) lat i sill, sam przemawiałby w obronie Sekstusa Roscjusza".

Nimis enim insidiarum ad capiundas auris adhiberi videtur, si $[\ldots]$ in dicendo numeri ab oratore quaeruntur. (Cic., Orat. 170)

„Wydaje się bowiem, że stosowanych jest zbyt wiele (= nadmiar) pułapek mających usidlić uszy, jeśli przemawiając, mówca zabiega o efekty rytmiczne".

Urbi quoque Romae ingens praebitus terror, magis in re subita quam quod ad arcendam vim parum virium esset. (Liv., 3, 8)

„Również na Rzym padł wielki strach, raczej wskutek nagłości wydarzenia, niż żeby było zbyt malo (= niedostatek) sił do powstrzymania ataku".

\subsection{WYBRANA LITERATURA}

Cabrillana (2011a), Luraghi (2010), Ricca (2010) 


\section{0. \\ Charakterystyka funkcjonalna zaimków}

\subsection{ZAIMKI JAKO KLASA LEKSEMÓW}

Zaimki to klasa leksemów, której tradycyjnie przypisuje się status osobnej części mowy. Klasa ta wyróżniona jednak może być wyłącznie na podstawie zupełnie innych kryteriów niż rzeczowniki, przymiotniki, przysłówki czy czasowniki. W przeciwieństwie do nich, zaimki nie są definiowalne w oparciu o żadne cechy gramatyczne, a więc syntaktyczne czy morfologiczne, gdyż pod tym względem stanowią one zbiór wewnętrznie niejednolity. Wystarczy porównać takie leksemy tradycyjnie zaliczane do tej klasy, jak np.: ego, nihil, ille, noster, inde, ubi, by się przekonać, że wykazują one skrajnie odmienne cechy składniowe i morfologiczne.

Jak osobna klasa leksemów (część mowy) zaimki nie są więc wyodrębniane na podstawie cech gramatycznych, lecz w oparciu o sposób realizacji ich funkcji znakowej. W przeciwieństwie do pozostałych leksemów autosyntagmatycznych zaimki nie symbolizują bowiem żadnych przypisanych im konkretnych klas obiektów dających się wyznaczyć w oparciu o charakteryzujące je obiektywne cechy immanentne, lecz desygnują w oparciu o inne techniki oznaczania, co pozwala im na pełnienie różnych funkcji. Funkcje te mogą polegać na:

a. Wskazywaniu, czyli odsyłaniu do określonego obiektu (referenta) poprzez określenie jego stosunku do odpowiednich punktów odniesienia w konsytuacji lub w kontekście. Podstawowymi punktami odniesienia w konsytuacji są osobowe, czasowe lub przestrzenne parametry aktu komunikacji, a więc osoba nadawcy lub odbiorcy wypowiedzi, a także czas i miejsce wytworzenia komunikatu. W oparciu o te punkty odniesienia realizują swą funkcję znakową zaimki o charakterze deiktycznym, a więc zaimki osobowe (ego, tu, nos, vos) i wskazujące (hic, ille, iste, huc, istic, illac, nunc). Z kolei kontekstowymi punktami odniesienia są desygnaty innych składników wyrażenia, do których odsyłają zaimki o charakterze anaforycznym ${ }^{1}$

1 Czyli zaimki odsyłające do (znaczenia) jednego z wyrazów występujących wcześniej w tekście. Np. w zdaniu: Zobaczylem pod poczta Tomka, ale on mnie nie zauważyl zaimek on pełni funkcję anaforyczną, odsyłając do (znaczenia) wyrazu Tomka, który jest w tym przypadku wyrazem 
i kataforycznym², a więc np. tzw. zaimki określające (is, idem, item, tum, ibi, totiens), zaimek zwrotny (se) czy względny (qui).

b. Kwantyfikacji, czyli przypisaniu określonego statusu obiektom, co ma miejsce w przypadku zaimków nieokreślonych (aliquis, quidam, quilibet, utervis, ubicumque) czy przeczących (nemo, nullus, numquam).

c. Realizacji określonych celów pragmatycznych, np. sygnalizowaniu prośby o identyfikację obiektu lub cechy; dotyczy to zaimków pytajnych, a więc np.: quid?, uter?, ubi?.

d. Realizacji określonych strategii nadawczo-odbiorczych, a więc np. suponowaniu określonych treści, jak np. w przypadku zaimka ipse 'nawet'.

Z uwzględnieniem kryteriów gramatycznych (tj. morfologicznych i składniowych) zaimki dzielą się na rzeczowne, przymiotne i przysłowne. Podział ten wynika z odpowiedniości zachodzących między morfologiczno-syntaktycznymi właściwościami poszczególnych zaimków i właściwościami morfologiczno-syntaktycznymi rzeczowników, przymiotników i przysłówków. Pod względem gramatycznym ogół zaimków rozpada się więc na trzy odrębne klasy: 1) klasę zaimków rzeczownych, którą można uznać za podzbiór leksemów rzeczownikowych, 2) klasę zaimków przymiotnych, którą można uznać za podzbiór leksemów przymiotnikowych, 3) klasę zaimków przysłownych, którą można uznać za podzbiór leksemów przysłówkowych. Przy zachowaniu tradycyjnego podziału znaczeniowego zaimków (tj. podziału na zaimki osobowe, dzierżawcze, nieokreślone itd.) ich przynależność do poszczególnych klas (podzbiorów) gramatycznych może być ujęta następująco:

a. W klasie zaimków rzeczownych, czyli stanowiących podzbiór leksemów rzeczownikowych, znajdują się zaimki:

1. osobowe: ego, tu, nos, vos;

2. zwrotny: se;

3. nieokreślone: quisquam, quidquam; aliquis, aliquid; quidam, quiddam; quispiam, quidpiam; quis, quid; quivis, quidvis; quilibet, quidlibet; quisquis, quidquid; quicumque, quidcumque; quisque, quidque; unusquisque, unumquidque;

4. pytajne: quis?, quid?;

5. przeczące: nemo, nihil;

anaforyzowanym, zwanym też poprzednikiem (antecedensem) relacji anaforycznej. Można więc powiedzieć, że zaimki anaforyczne odsyłają wstecz po linii tekstu, w związku z czym mamy do czynienia $z$ anaforą.

2 Czyli zaimki odsyłające do (znaczenia) jednego z wyrazów występujących później w tekście. Np. w zdaniu: Biorac pod uwage jej dotychczasowe zachowanie, trzeba przyznać, ze dzisiaj Zosia była nadzwyczaj uprzejma zaimek jej pełni funkcję kataforyczną odsyłając do (znaczenia) wyrazu Zosia, który jest w tym przypadku wyrazem kataforyzowanym. Można zatem powiedzieć, że zaimki kataforyczne odsyłają wprzód po linii tekstu, w związku z czym mamy do czynienia $z$ kataforą (antycypacją). 
b. W klasie zaimków przymiotnych, czyli stanowiących podzbiór leksemów przymiotnikowych, znajdują się zaimki:

1. dzierżawcze: meus, - $a$, um; tuus, - $a$, -um; noster, -tra, -trum; vester, -tra, -trum;

2. dzierżawczy zwrotny: suus, $-a,-u m$;

3. wskazujące: hic, haec, hoc; iste, ista, istud; ille, illa, illud;

4. określające: is, ea, id; idem, eadem, idem; ipse, ipsa, ipsum; talis, -e; tantus, -a, -um; tot;

5. nieokreślone: ullus, -a, -um; aliqui, aliqua, aliquod; aliquot; quidam, quaedam, quoddam; quispiam, quaepiam, quodpiam; qui, quae (qua), quod; quivis, quaevis, quodvis; quilibet, quaelibet, quodlibet; quisquis, quaequae, quodquod; quicumque, quaecumque; quodcumque; quisque, quaeque, quodque; unusquisque, unaquaeque, unumquodque; alius, - $a$, -um; alter, -era, -erum; uterque, utraque, utrumque; uterlibet, utralibet, utrumlibet; utervis, utravis, utrumvis; utercumque, utracumque, utrumcumque; qualislibet, qualisvis, qualiscumque, quantuslibet, quantusvis, quantuscumqe;

6. względny: qui, quae, quod;

7. pytajne: qui?, quae?, quod?; uter?, utra?, utrum?; qualis?, -e?; quantus?, -a?, -um?; quot?;

8. przeczące: nullus, - $a,-$ um; neuter, -tra,-trum.

c. W klasie zaimków przysłownych, czyli stanowiących podzbiór leksemów przysłówkowych, znajdują się zaimki:

1. wskazujące: hic, istic, illic, huc, istuc, illuc, hinc, istinc, illinc, hac, istac, illac;

2. określające: ibi, eo, eodem, inde, ea, tantum, nunc, tum, tunc, totiens, tam, ita, sic;

3. nieokreślone: alicubi, aliquo, alicunde, aliqua, aliquando, aliquotiens, aliquantum, ubivis, ubilibet, ubicumque, ubiubi, quovis, quolibet, quocumque, quoquo, undevis, undelibet, undecumque, undeunde, quavis, qualibet, quacumque, quaqua, quantumlibet, quantumvis, quantumcumque, quandolibet, quandovis, quandocumque, quotienslibet, quotiensvis, quotienscumque, undique, ubique, utrimque, utroque, aliter, alibi, alias, usquam, uspiam;

4. pytajne: ubi?, quo?, qua?, utro?, unde?, quando?, quotiens?, quantum?;

5. przeczące: numquam, nusquam.

Zaimki rzeczowne pełnią funkcje składniowe realizowane przez rzeczowniki, zarówno w ramach ich prymarnej, jak i sekundarnej dystrybucji składniowej. Mogą więc zajmować zarówno pozycję podmiotu (np. Vos estis fugae meae causa „Wy jesteście przyczyną mojej ucieczki”), jak i dopełnienia (np. Mitte mihi aliquem „Przyślij mi kogoś”), przydawki dopełniaczowej (np. Cuiusvis animum potes movere „Możesz poruszyć serce każdego") czy okolicznika (Apud te cenavit „U ciebie jadł obiad”). Generalnie posiadają również identyczne jak rzeczowniki właściwości morfologiczne: przysługuje im fleksyjna kategoria liczby i przypadka oraz kategoria rodzaju i osoby o charakterze klasyfikującym (selektywnym). Niektóre grupy zaimków rzeczownikowych cechują się jednak pewnymi szczególnymi właściwościami morfologicznymi: 
1. Dość liczne spośród nich występują w dwu wariantywnych postaciach, przeciwstawiających się sobie ze wględu na osobowość/nieosobowość desygnatu oraz związaną z desygnatem wartość gramatycznej kategorii rodzaju (masc./neut.), np.: nemo/nihil, quis/quid, aliquis/aliquid, quisque/quidque itp.

2. Niektóre zaimki (podobnie zresztą jak ich polskie odpowiedniki) są niescharakteryzowane co do pewnych kategorii fleksyjnych. Np. zaimki osobowe (ego, tu, nos, vos) są niescharakteryzowane co do kategorii rodzaju, tzn. mogą one przybierać zarówno rodzaj męski, jak i żeński (por.: Ego laudatus sum „Ja zostałem pochwalony" / Ego laudata sum „Ja zostałam pochwalona”); zaimek zwrotny (se) jest niescharakteryzowany zarówno co do kategorii rodzaju (por.: Se ipsum laudavit "Pochwalił siebie samego" / Se ipsam laudavit „Pochwaliła siebie samą"), jak i co do kategorii liczby (Se ipsos laudaverunt „Pochwalili siebie samych”).

3. Jeszcze inne zaimki cechują się niepełnym paradygmatem funkcjonalnym. Np. zaimki przeczące nemo, nihil oraz pytajne quis?, quid? są singularia tantum, natomiast zaimek zwrotny se nie przyjmuje wartości nominativus w ramach kategorii przypadka.

Zaimki przymiotne zajmują przymiotnikowe pozycje składniowe, a więc pełnią funkcję przydawek pozostających z rzeczownikowym członem nadrzędnym w związku kongruencji atrybutywnej, opartym na kategorii liczby, rodzaju i przypadku, np.: Nemini meus adventus labori fuit "Mój przyjazd nikomu nie przysporzył kłopotu”; Potuisti populari hanc terram, quae te genuit atque aluit? „Potrafiłeś pustoszyć tę ziemię, która cię zrodziła i żywiła?”; Portus satis amplus quantaevis classi videtur „Port wydaje się dostatecznie obszerny dla jakkolwiek wielkiej floty”; Disputationem habitam non quasi narrantes exponimus, sed eisdem fere verbis, ut disputatum est „Przeprowadzoną rozmowę przedstawię nie tak, jak gdybym opowiadał, lecz niemal tymi samymi słowami, jakimi dysputowano". Zaimki te posiadają również takie same jak przymiotniki cechy morfologiczne, tzn. podlegają fleksji w ramach kategorii liczby, rodzaju i przypadka. Jednak zaimki quot, tot i aliquot charakteryzują się ograniczonym paradygmatem funkcjonalnym pod względem kategorii liczby, przyjmując jedynie wartość pluralis (są to więc pluralia tantum).

Niektóre zaimki przymiotne często podlegają substantywizacji, wypełniając rzeczownikowe pozycje składniowe; por. np.: Quid is fecit? (Ter., Phorm. 124) „Cóż on takiego zrobił?” (obok: Is homo semper me delectavit (Cic., Q. fr. 3, 1, 22) „Ten człowiek zawsze mnie urzekat"); Video [...] esse hic in senatu quosdam, qui tecum una fuerunt (Cic., Catil. 1, 8) „Widzę, że są tu w senacie pewni ludzie, którzy byli razem z tobą" (obok: Adiutores quosdam consilii sui nanctus [...] exercitum a Pelusio clam Alexandriam evocavit (Caes., Civ. 3, 108) „Znalazłszy jakichś zwolenników swego zamysłu, ściągnął potajemnie wojsko z Peluzjum do Aleksandrii"). Podstawowym kryterium odróżniającym zaimki przymiotne od rzeczownych pozostaje więc fleksyjny charakter kategorii rodzaju zaimków przymiotnych (wobec klasyfikującego charakteru kategorii rodzaju zaimków rzeczownych). W odniesieniu do niektórych zaimków (zwłaszcza nieokreślonych) ze zróżnicowaniem ich użycia składniowego 
(tj. użycie w pozycjach przymiotnikowych vs. użycie w pozycjach rzeczownikowych) związane jest zróżnicowanie ich postaci, np.: aliqui, aliqua, aliquod (postać przymiotnikowa) / aliquis, aliquid (postać rzeczownikowa).

Zaimki rzeczowne i przymiotne charakteryzują się pewnymi szczególnymi właściwościami paradygmatyki formalnej. Do właściwości tych należy m.in.:

1. często pojawiające się znaczne zróżnicowanie formalnej postaci tematu fleksyjnego; zróżnicowanie to może być wynikiem fuzji, czyli ściślejszego zespolenia morfemów składających się na formę fleksyjną, które przejawia się w różnego rodzaju zmianach fonologicznych i w konsekwencji prowadzi do zatarcia granicy między tematem a końcówką (por. np.: mei / mihi / me, qui / cuius, hic / huius / hos); zróżnicowanie to może być także efektem supletywizmu, czyli łączenia w paradygmacie jednego leksemu tematów całkowicie odmiennych pod względem formalnym (por. np.: ego / mei, nemo / nullius);

2. występująca w paradygmatach wielu zaimków (zwłaszcza nieokreślonych) postfiksacja, czyli dodanie morfemu (postfiksu) po końcówce fleksyjnej (por. np.: cuiquam / quemquam, cuique / quemque, cuivis / quemvis, cuilibet / quemlibet);

3. odrębność pewnych końcówek w stosunku do formalnych paradygmatów rzeczownikowo-przymiotnikowych; dotyczy to w szczególności końcówki gen. sg. (cuius, eius, nullius itp.), a także końcówek występujących w niektórych innych formach fleksyjnych różnych zaimków (np. acc. sg. me, te; nom. pl. neutr. quae, haec $\mathrm{i}$ in.);

4. defektywność paradygmatu formalnego w zakresie kategorii przypadka i rodzaju, dotycząca trzech zaimków przymiotnych: quot, tot i aliquot; z uwagi na fakt, iż paradygmat funkcjonalny tych zaimków jest zredukowany pod względem kategorii liczby (są to mianowicie pluralia tantum), ich paradygmat formalny jest w efekcie zerowy.

Zaimki przysłowne pełnią w wypowiedzeniu funkcje składniowe, które są funkcjami charakterystycznymi dla przysłówków, a więc przede wszystkim funkcje okolicznikowe, np.: Caelum certe patet: ibimus illac (Ov., Met. 8, 186) „Niebo bez wątpienia stoi otworem: pójdziemy tamtędy"; Domi illius aliquotiens fuisti (Cic., Cael. 58) „W jego domu kilkakrotnie przebywałeś"; Hi di non sunt, quia nusquam coluntur (Cic., Nat. 3, 45) „Oni nie są bogami, ponieważ nigdzie nie oddaje im się boskiej czci". Podobnie jak przysłówki, zaimki przysłowne nie uwzględniają też żadnych kategorii fleksyjnych.

Przedstawiona niżej charakterystyka funkcjonalna zaimków przeprowadzona została w oparciu o ich tradycyjny podział uwzględniający kryteria semantyczne. 


\subsection{ZAIMKI OSOBOWE EGO, TU, NOS, VOS}

Zaimki osobowe: ego 'ja', tu 'ty', nos 'my', vos 'wy' mają status zaimków rzeczownych o charakterze deiktycznym (wskazującym). Pełnią funkcję referencyjną, odsyłając do określonych osób poprzez wskazanie pozycji, jakie osoby te zajmują (czy też ról, które pełnią) $w$ ramach aktu mowy. Zaimek ego odsyła do osoby nadawcy komunikatu (osoby wypowiadającej tekst). Zaimek tu odsyła do osoby odbiorcy komunikatu (adresata tekstu). Zaimek nos odsyła do zbioru osób, wśród których jest nadawca komunikatu (lub nadawca i odbiorca), a zaimek vos do zbioru osób będących odbiorcami albo wśród których jest odbiorca lub odbiorcy komunikatu (bez nadawcy).

Zaimki ego i nos nacechowane są wartością l. osoby, a zaimki tu i vos wartością 2. osoby w ramach gramatycznej kategorii osoby. Wartości te ujawniane są fleksyjnie przez osobowe formy czasownikowych orzeczeń w stosunku do ww. zaimków zajmujących pozycję podmiotu; por. np.: Hoc modo res gesta est, ut ego dico (Pl., Rud. 1072) "Tak się rzecz miała, jak ja mówię" wobec: Est, hercle, ita, ut tu dicis (Pl., Curc. 50) - „Jest, na Herkulesa, tak, jak ty mówisz"; podobnie: Pro his nos habemus luxuriam atque avaritiam (Sall., Cat. 52) "Zamiast tych (zalet) my mamy zbytek i chciwośc”" wobec: Potestatem omnem vos habetis, ut statuatis, utrum [...] (Cic., Mil. 4) „Wy macie wszelką władzę, by zdecydować, czy [...]”. Ów selektywny (klasyfikujący) charakter kategorii osoby leży też u podstaw tradycyjnej nomenklatury, zgodnie z którą ego i nos określane są jako zaimki 1. osoby, a tu i vos jako zaimki 2. osoby.

$\mathrm{Z}$ kolei zaimki ego i tu stoją w opozycji względem zaimków nos i vos w ramach kategorii liczby, reprezentując - odpowiednio - wartości: singularis (liczba pojedyncza) i pluralis (liczba mnoga). Opozycja ta ma charakter semantyczny, co oznacza, że wartość singularis sygnalizuje jednostkowy (jednoelementowy), a wartość pluralis niejednostkowy (wieloelementowy) charakter desygnatu danego zaimka. Wieloelementowość desygnatu, sygnalizowana przez pluralis zaimków nos i vos, nie stanowi jednak prostej multyplikacji desygnatu ich odpowiedników w singularis (czyli ego i $t u$ ), bowiem np. zbiór desygnowany przez zaimek nos nie jest (a przynajmniej nie musi być) stanowiony przez zbiór nadawców komunikatu, lecz przez zbiór osób, do których nadawca należy; innymi słowy desygnatu zaimka nos nie można ująć jako ego + ego + ego +..., lecz raczej jako ego + alii. To samo - mutatis mutandis - można powiedzieć o relacji znaczeniowej zachodzącej między vos i tu. Desygnatami zaimków nos i vos nie są więc zbiory złożone $z$ desygnatów zaimków będących ich odpowiednikami w liczbie pojedynczej, lecz raczej zbiory, w których desygnaty zaimków w liczbie pojedynczej są elementami wyróżnionymi (tj. elementami, wokół których zbiory te są skoncentrowane). Pluralis desygnujący tego rodzaju zbiorowość nazywany bywa pluralis eliptycznym, w przeciwieństwie do pluralis matematycznego, desygnującego zbiorowość złożoną z elementów będących desygnatami wyrazu w singularis (np. arbores $=$ arbor + arbor + arbor $+\ldots$... Identyfikacja elementów wchodzących w zakres zbiorów desygnowanych przez zaimki nos i vos (czyli referencja tych zaimków) ustalana jest każdorazowo przez kontekst lub konsytuację. Z uwagi na specyfikę 
relacji semantycznych, łączących zaimki osobowe $w$ liczbie pojedynczej z zaimkami w liczbie mnogiej, a także ze względu na supletywizm cechujący ich relacje formalne, reprezentujące te zaimki wyrazy gramatyczne można uznać nie za formy fleksyjne jednego leksemu, lecz za reprezentacje dwu odrębnych leksemów; innymi słowy: ego i nos (podobnie jak tu i vos) to nie tyle dwie formy fleksyjne tego samego zaimka, lecz dwa odrębne zaimki, $\mathrm{z}$ których jeden to singulare tantum, a drugi plurale tantum.

Zaimek 1. osoby w liczbie mnogiej, czyli nos, może także odsyłać wyłącznie do osoby nadawcy komunikatu, a nie do zbioru osób związanych z nadawcą. Takie użycie form tego zaimka, umotywowane istnieniem określonej konwencji stylistycznej, zwane jest pluralis modestiae i spotykane jest często np. w listach czy mowach Cycerona; por. np.: Signa, quae nobis curasti, ea sunt ad Caietam exposita. Nos ea non vidimus; neque enim exeundi Roma potestas nobis fuit. (Cic., Att. 1, 3, 2) „Posągi, które dla mnie kupiłeś, wyładowane zostały w pobliżu Kajety. Ja ich (jeszcze) nie widziałem; i w ogóle nie była mi dana możliwość wyjazdu z Rzymu".

W zakresie kategorii rodzaju zaimki osobowe mogą przyjmować zarówno wartość masculinum, jak i femininum; por. np.: Ego vos ambos credere hoc mihi vehementer velim (Ter., Eun. 1069) „Bardzo chciałbym, żebyście wy obaj wierzyli mi co do tego" wobec: Rogitavi ego vos [...] ambas (Pl., Truc. 777) „)a przepytałem was obie”. Fakt ten pozwala na przypisanie zaimkom osobowym braku scharakteryzowania pod względem tej kategorii bądź też na postulowanie istnienia hominimicznych form zaimków rodzaju męskiego i żeńskiego.

Fleksyjna kategoria przypadka pozwala zaimkom osobowym na zajmowanie różnych pozycji składniowych, które otwierane są dla wyrażeń rzeczownikowych, jak np. pozycji:

1. dopełnienia bliższego: Senatus te consentiens cum populo Romano consalutat patrem patriae (Suet., Aug. 58) „Senat, jednomyślnie z ludem rzymskim, pozdrawia cię jako ojca ojczyzny";

2. dopełnienia dalszego: Quis nobis credet, cui nos? (Cic., Verr. 2, 1, 127) „Kto nam uwierzy, komu my (uwierzymy)?";

3. okolicznika: Quis me est fortunatior, qui ex improviso filiam inveni meam? (Pl., Rud. 1191-1192) „Któż jest szczęśliwszy ode mnie, który niespodziewanie odnalazł swą córkę?".

Pozycja otwierana dla mianownikowego podmiotu często pozostaje przez zaimki osobowe niewypełniona. Elipsa zaimków w tym kontekście jest możliwa dzięki temu, iż są one ewokowane przez formy (tj. końcówki osobowe) czasownikowych orzeczeń:

Veni, vidi, vici. (Sen., Suas., 2, 22)

"Przyszedłem, zobaczyłem, zwyciężyłem”

Quanta multitudo hominum convenerit ad hoc iudicium, vides. (Cic., S. Rosc. 11)

„Widzisz, jak wielki tłum ludzi zebrał sį̣ na tę rozprawę".

Propter virtutem [...] iure laudamur. (Cic., Nat. 3, 87)

„Za cnotę słusznie jesteśmy chwaleni”. 
Dialecticam inventam esse dicitis veri et falsi quasi disceptatricem et iudicem. (Cic., Lucull. 91)

„Mówicie, że dialektyka została wynaleziona jako jakby rozjemczyni i rozsądzicielka prawdy i fałszu".

Jeśli pozycja ta jest wypełniana, czyli jeśli zaimki osobowe $w$ funkcji mianownikowego podmiotu są wyrażane $\mathrm{w}$ strukturze powierzchniowej zdania, to dzieje się to najczęściej, gdy:

1. Spoczywa na nich nacisk (emfaza) - zwłaszcza przy przeciwstawieniach oraz kiedy określane są przydawkami:

Tu me amas, ego te amo. (Pl., Most. 305)

„Ty mnie kochasz, ja kocham ciebie".

Equidem me Caesaris militem dici volui, vos me imperatoris nomine appellavistis. (Caes., Civ. 2, 32)

„Co do mnie, to chciałem być jedynie nazywany żołnierzem Cezara, wy natomiast nadaliście mi tytul imperatora".

Non deest rei publicae consilium neque auctoritas huius ordinis: nos, nos, dico aperte, consules desumus. (Cic., Catil. 1, 3)

„Nie brak Rzeczypospolitej rozwagi ani auterytetu tego (scil. senatorskiego) stanu: my, powiadam otwarcie, my konsulowie zawodzimy".

Hanc (aquilam) ego - inquit - et vivus multos per annos magna diligentia defendi et nunc moriens eadem fide Caesari restituo. (Caes., Civ. 3, 64)

„Tego (orla) - powiada - ja i będąc przy życiu z wielką troską przez wiele lat chronilem, i teraz umierając z taką samą wiernością zwracam Cezarowi".

2. Następuje wyliczenie dwu lub kilku podmiotów lub kiedy od zaimka uzależnione jest zdanie względne:

Ego et Maximus meus biduum iam beatissimum agimus. (Sen., Lucil. 87, 2)

„Ja i mój Maksymus już dwa dni bardzo przyjemnie spędzamy".

$T u$, qui deos putas humana neglegere, nonne animadvertis ex tot tabulis pictis, quam multi votis vim tempestatis effugerint? (Cic., Nat. 3,89)

„Ty, który uważasz, że bogowie nie dbają o sprawy ludzkie, czy nie dostrzegasz na podstawie tak licznych obrazów, jak wielu ludzi dzięki złożonym bogom ślubom ocalało z gwałtownych nawalnic?"

Zaimki 1. i 2. osoby liczby mnogiej (czyli nos i vos) w genetiwie reprezentowane są przez dwie różne formy tekstowe; są to - odpowiednio - nostri i nostrum oraz vestri i vestrum. Dystrybucja tych form opiera się na kryterium semantycznym. Formy nostrum i vestrum wyrażają treści o charakterze partytywnym ('z / spośród nas', ' $\mathrm{z}$ / spośród was'); występują także w zwrotach omnium nostrum ('nas wszystkich') oraz omnium vestrum ('was wszystkich'):

Quis enim nostrum similitudines negat esse, cum eae plurimis in rebus appareant. (Cic., Lucull. 54) 
„Bowiem klóż z nas przeczy, że istnieją podobieństwa, skoro ujawniają się one w bardzo licznych rzeczach".

Alii vestrum anseres sunt, qui tantum modo clamant, nocere non possunt, alii canes, qui et latrare et mordere possunt. (Cic., S. Rosc. 57)

„Jedni $\mathbf{z}$ was są gęsiami, klóre tylko gęgają, ale szkodzić nie mogą, drudzy zaś psami, które potrafią i szczekać, i gryźć".

Nunc te patria, quae communis est parens omnium nostrum, odit ac metuit. (Cic., Catil. $1,17)$

„Teraz ojczyzna, które jest rodzicielką nas wszystkich, nienawidzi cię i boi się ciebie”.

Video, patres conscripti, in me omnium vestrum ora atque oculos esse conversos. (Cic., Catil 4,1$)$

„Widzę, senatorowic, że na mnic zwrócone są twarze i oczy was wszystkich”.

Pozostałe funkcje znaczeniowe genetiwu tych zaimków realizowane są zwykle za pośrednictwem form tekstowych o postaci nostri i vestri:

Nostri melior pars animus est. (Sen., Nat. 1, prooem.14)

"Lepszą częścią nas jest dusza”.

Memoria nostri durabit, si vita meruimus. (Plin., Epist. 9, 19, 6)

„Pamięć o nas będzie trwała, jeśli swoim życiem zasłużyliśmy na nią”.

(Antonius) ita enim se recipiebat ardens odio vestri [...], ut nihil nisi de pernicie populi Romani cogitaret. (Cic., Phil. 4, 4)

"(Antoniusz) bowiem wracal tak rozpalony nienawiścią do was, że o niczym innym nie myślal, jak tylko o zagładzie narodu rzymskiego".

Habetis ducem memorem vestri, oblitum sui. (Cic., Catil. 4, 19)

„Macie przywódcę pamiętającego o was i zapominającego o sobie".

Przyimek cum występujący $z$ ablatywnymi formami zaimków osobowych sytuowany jest w postpozycji do tych zaimków i współtworzy $z$ nimi jeden wyraz tekstowy (tj. mecum, tecum, nobiscum, vobiscum):

Ego autem primum velim vos $[\ldots]$ servare mecum pacem. (Liv., 31, 18)

"A ja przede wszystkim chciałbym, byście zachowali pokój ze mną".

Ad Ciceronem venio, cui eadem pugna cum aequalibus suis fuit, quae mihi vobiscum est. (Tac., Dial. 22)

„Przechodzę do Cycerona, który ze swymi współczesnymi toczył taką samą walkę, jaką ja $z$ wami prowadzę".

Formy przypadków zależnych zaimków osobowych stosowane są również dla sygnalizowania referencjalnej tożsamości (koreferencji) ${ }^{3}$ z zaimkiem osobowym użytym podmiotowo lub niewyrażonym powierzchniowo, lecz ewokowanym przez

${ }^{3}$ Czyli zjawiska polegającego na odnoszeniu się dwóch (lub więcej) wyrazów do tego samego obiektu. Np. w zdaniu: Tym postepkiem Zosia bardzo sobie zaszkodzila wyrazy Zosia i sobie odno- 
formę (tj. końcówkę osobową) czasownika. W języku polskim wymagane jest wtedy użycie zaimka zwrotnego, natomiast stosowane w tej funkcji łacińskie zaimki osobowe znajdują się w dystrybucji komplementarnej (czyli uzupełniającej) w stosunku do zaimka zwrotnego (se), który sygnalizuje koreferencję $\mathrm{z}$ wyrażeniem innym niż zaimek osobowy:

His ego tuis scriptis me consolor. (Cic., Att. 9, 10, 10)

"Tymi twoimi listami ja się pocieszam".

Multa mecum ipse reputavi. (Cic., $P$. red. in sen. 32)

„Wiele spraw sam z sobą rozważyłem”.

Absconde te in otio, sed et ipsum otium absconde. (Sen., Lucil. 68, 1)

„Ukryj się w odosobnieniu, lecz równocześnie ukryj i samo to odosobnienie”.

Quicquid discis, tibi discis. (Petron., Sat. 46)

"Czegokolwiek się uczysz, uczysz się dla siebie".

Monent, ut quanto superiores simus, tanto nos geramus summissius. (Cic., Off. 1, 90)

"Napominają, abyśmy zachowywali się tym skromniej, im bardziej górujemy nad innymi".

De vobis ac de vestris liberis cogitate. (Cic., Catil. 4,1 )

„Pomyślcie o sobie i o swoich dzieciach".

Łacina nie dysponuje zaimkiem osobowym trzeciej osoby. Funkcję referencyjną w stosunku do osoby niebędącej nadawcą ani odbiorcą komunikatu, a także w stosunku do zbioru osób, wśród których nie ma nadawcy ani odbiorcy komunikatu, realizują inne zaimki o charakterze deiktycznym i anaforycznym, przede wszystkim zaimek anaforyczny is oraz zaimki wskazujące hic, ille, iste:

Mercator quidam fuit Syracusis senex; ei sunt nati filii gemini duo. (Pl., Men. 17-18)

„Był w Syrakuzach pewien stary kupiec; jemu urodzili się dwaj synowie bliźnięta”.

Te Syracusis natum esse dixisti: et hic natust ibi. (Pl., Men. 1097)

„Mówileś, żeś urodził się w Syrakuzach: i ten oto również urodził się tam!"

Ille mi par esse deo videtur [...], qui sedens adversus identidem te spectat et audit. (Catull. 51, 1-4)

„Wydaje mi się, że jest on równy bogom, on, który siedząc wciąż naprzeciwko, patrzy na ciebie i slucha cię".

Nunc intellego, si iste [...] in Manliana castra pervenerit, neminem tam stultum fore, qui non videat coniurationem esse factam. (Cic., Catil. 1, 30)

„Teraz wiem, że jeśli ten tutaj (scil. Katylina) uda się do obozu Manliusza, nikt nie będzie na tyle zaślepiony, by nie widzieć, że został zawiązany spisek".

O odrębności tych zaimków w stosunku do zaimków osobowych (1. i 2. os.) świadczą zarówno ich cechy morfologiczne (tj. fleksyjny charakter kategorii rodzaju),

szą się do tej samej osoby; można więc powiedzieć, że wyrazy te są referencjalnie tożsame, albo że łączy je stosunek koreferencji. 
jak i składniowe (tj. możliwość pełnienia funkcji przydawki przymiotnikowej, np. Is homo semper me delectavit (Cic., Q. fr. 3, 1, 22) „Ten człowiek zawsze mnie urzekał”), oraz semantyczne (np. możliwość desygnowania referentów nieosobowych: Quae sit natura boni summumque quid eius? (Hor., Serm. 2, 6, 76) „Jaka jest natura dobra i co jest jego szczytem?").

\subsection{ZAIMKI DZIERŻAWCZE}

Zaimki dzierżawcze mają gramatyczny status przymiotników, a zatem zajmują $\mathrm{w}$ wyrażeniu pozycję przydawki związnej $\mathrm{z}$ rzeczownikowym nadrzędnikiem związkiem kongruencji (zgody) atrybutywnej, opartej na kategorii liczby, rodzaju i przypadka. Pod względem semantycznym należy wśród zaimków dzierżawczych wyodrębnić zaimki dzierżawczo-osobowe, zaimek dzierżawczo-zwrotny oraz zaimek dzierżawczo-pytajny.

\subsubsection{Zaimki dzierżawczo-osobowe meus, tuus, noster, vester}

Zaimki dzierżawczo-osobowe: meus, - $a$, -um 'mój, moja, -je', tuus, -a, um 'twój, twoja, -e', noster, -tra, -trum 'nasz, -a, -e', vester, -tra, -trum 'wasz, -a, -e', sygnalizują związek desygnatu ich rzeczownikowego nadrzędnika $z$ osobą nadawcy (meus) lub odbiorcy (tuus) komunikatu albo ze zbiorem osób, do którego należy nadawca ${ }^{4}$ (noster) lub odbiorca ${ }^{5}$ (vester) komunikatu. Wbrew nazwie związek ten nie sprowadza się jednak wyłącznie do stosunku przynależności czy posiadania (jak np. w wyrażeniu: domus mea 'mój dom' = 'dom, który należy do mnie', 'dom, który ja posiadam'), lecz obejmuje także relacje o innym charakterze, które identyfikowalne są w oparciu o kontekst (por. np.: adventus meus 'moje przybycie' = 'fakt, iż ja przybyłem'). Z kolei co do osób lub zbiorów osób, z którymi związek jest przez zaimki dzierżawczo-osobowe sygnalizowany, to nie różnią się one od tych, do których odsyłają skorelowane $\mathrm{z}$ nimi zaimki osobowe, a więc meus $\leftrightarrow$ ego, tuus $\leftrightarrow$ tu, noster $\leftrightarrow$ nos, vester $\leftrightarrow$ vos. Można więc stwierdzić, iż pod tym względem zaimki dzierżawczo-osobowe stanowią syntaktyczne (adnominalne) warianty odpowiednich zaimków osobowych:

Quis est, qui conplet aures meas, tantus et tam dulcis sonus? (Cic., Rep. 6, 18)

"Co to za donośny i tak miły dźwięk, który napełnia moje uszy?"

Quandoque enim fatalis et meus dies veniet. (Tac., Dial. 13)

„Kiedyś bowiem nadejdzie także i mój dzień przeznaczenia”.

Hanc tibi Naso tuus mittit, Rufine, salutem. (Ov., Pont. 1, 3, 1)

„To pozdrowienie, Rufinie, przesyla ci twój Naso".

4 Lub nadawca i odbiorca.

5 Bez nadawcy. 
Loco aequo, tempore tuo pugnasti? (Liv., 38,45 )

"Czy bitwę stoczyłeś w odpowiednim miejscu, w korzystnym dla ciebie momencie?"

Pecora [...] natura prona atque ventro oboedientia finxit, sed nostra omnis vis in animo et corpore sita est. (Sall., Cat. 1)

„Bydlęta natura stworzyła pochylonymi ku ziemi i uleglymi potrzebom brzucha, natomiast cała nasza moc tkwi w duchu i w ciele".

Id [...] nostris moribus nefas habetur. (Nep., Pr. 4)

„Wedle naszej (scil. rzymskiej) obyczajowości uchodzi to za czyn bezbożny".

Terram vestram ceterorumque Gallorum ingressi sunt duces imperatoresque Romani. (Tac., Hist. 4, 73)

„Na ziemię waszą i pozostałych Gallów wkroczyli rzymscy wodzowie i imperatorzy”.

Supplicia et contumelias vestras disciplinam appellat. (Tac., Hist. 1, 37)

„Kary i zniewagi wasze (= których zaznaliście) nazywa dyscypliną (wojskową)".

Zaimek noster, -tra, -trum może także sygnalizować związek desygnatu rzeczownikowego nadrzędnika $z$ samym tylko nadawcą komunikatu (a nie grupą nadawcy), czyli może być używany w miejsce zaimka meus, $-a,-u m$. Tego rodzaju użycie, podobnie jak stosowanie zaimka nos w miejsce ego (zob. wyżej), wynika $\mathrm{z}$ istnienia określonej konwencji stylistycznej (modestiae causa):

Nemo annalis nostros cum scriptura eorum contenderit, qui veteres populi Romani res composuere. (Tac., Ann. 4, 32)

„Niech nikt nie porównuje moich roczników z pismami tych, którzy opisali dawne dzieje narodu rzymskiego".

Erit profecto inter horum laudes aliquid loci nostrae gloriae. (Cic., Catil. 4, 21)

"Między chwalebnymi czynami tych ludzi znajdzie się zapewne nieco miejsca i dla mojej chlubnej działalności".

Rescripsi ad omnia tua; nunc nostra accipe. (Cic., Att. 15, 29, 2)

"Odpisalem na wszystkie twoje sprawy, teraz poznaj moje".

Łacińskie zaimki dzierżawczo-osobowe stosowane są także wtedy, gdy osoba (lub grupa osób), do której odsyłają, jest tożsama $z$ osobą wskazywaną w zdaniu przez zajmujący pozycję podmiotu zaimek osobowy, wyrażony powierzchniowo lub ewokowany przez formę (tj. końcówkę osobową) czasownikowego orzeczenia; w języku polskim w tym kontekście używany jest zwykle zaimek dzierżawczo-zwrotny (swój, $-a,-e$ ), natomiast dystrybucja łacińskiego zaimka dzierżawczo-zwrotnego (suus, -a, -um) kontekstu tego nie obejmuje:

Ego meum seape corpus et vitam obieci armis inimicorum tuorum. (Cic., Mil. 100) "Ja wielokrotnie swoje ciało i życie naraziłem na ataki twoich nieprzyjaciól".

Meum officium facio. (Ter., Adelph. 593)

„Spełniam swój obowiązek”. 
An tu, probissima puella, parentes tuos intervisere properas? (Apul., Met. 6, 30)

„Czy ty może, zacna panienieczko, spieszysz odwiedzić swoich rodziców?"

Unum hoc proelium superest; quo confecto et ille suam dignitatem et nos nostram libertatem recuperabimus. (Caes., Civ. 3, 91)

„Ta jedna bitwa nam pozostala; po jej stoczeniu on odzyska swą cześć, a my swoją wolność".

De vobis ac de vestris liberis cogitate. (Cic., Catil. 4,1 )

"Pomyślcie o sobie i o swoich dzieciach".

W ramach sekundarnej dystrybucji składniowej zaimki dzierżawczo-osobowe, podobnie jak wszystkie (inne) przymiotniki, mogą pełnić funkcję orzecznika:

Nuda recede Venus: non est tuus iste libellus. (Mart., Epigr. 8, 1, 3)

„Ustąp, naga Wenero: ta książeczka nie jest twoja”.

Amnes magni magnarumque gentium termini usque ad ostium a fonte vestri sunt. (Sen., Lucil. 89, 20)

„Wielkie rzeki rozgraniczające potężne narody są wasze od źródła aż po ujście”.

Potest enim idem meum esse et tuum. (Sen., Benef. 7, 4, 6)

„Może bowiem ta sama rzecz być moja i twoja”.

Quem agrum nunc praetereuntes vestrum esse dicitis et quem $[\ldots]$ externi homines vestrum esse audiunt, is, cum erit divisus, neque erit vester neque vester esse dicetur. (Cic., Leg. Agr. 2, 81)

„Teren, o którym, przejeżdżając, mówicie teraz, że jest wasz, i o którym cudzoziemcy słyszą, że jest wasz, kiedy zostanie podzielony, ani już nie będzie wasz, ani za wasz nie będzie uchodzil".

lub funkcjonalnego odpowiednika orzecznika:

Eum (fundum) ego ex iure Quiritium meum esse aio. (Cic., Mur. 26)

"Stwierdzam, że ten (grunt) na mocy prawa Kwirytów jest mój".

Tu illam scibas non tuam esse. (Pl., Aul. 754)

„Ty wiedzialeś, że ona nie jest twoja”.

Quem agrum nunc praetereuntes vestrum esse dicitis et quem $[\ldots]$ externi homines vestrum esse audiunt, is, cum erit divisus, neque erit vester neque vester esse dicetur. (Cic., Leg. Agr. 2, 81)

„Teren, o którym, przejeżdżając, mówicie teraz, że jest wasz, i o którym cudzoziemcy słyszą, że jest wasz, kiedy zostanie podzielony, ani już nie będzie wasz, ani za wasz nie będzie uchodzil".

Zaimki dzierżawczo-osobowe mogą również podlegać kontekstowej substantywizacji (urzeczownikowieniu), czego przejawem jest przyjęcie rzeczownikowych cech morfologicznych, syntaktycznych i semantycznych. W rodzaju męskim i żeńskim zaimki te desygnują wówczas odnoszące się do (grupy) nadawcy lub odbiorcy obiekty osobowe (pan/pani, kochanek/kochanka, członkowie rodziny, domownicy, przyjaciele, towarzysze, zwolennicy, rodacy, żołnierze, wspólnicy itp.), natomiast 
w rodzaju nijakim desygnują pojęcia bądź obiekty nieosobowe (własność, majątek, posiadłość, napisany tekst, obowiązek, zadanie, cecha, właściwość itp.):

Me invito abduxit meam. (Ter., Adelph. 197)

„Wbrew mej woli uprowadził moją dziewczynę".

Subolfacio, quia nobis epulum daturus est Mammea, binos denarios mihi et meis. (Petron., Sat. 45, 10)

„Czuję, że Mammea zamierza wydać nam ucztę, po dwa denary na glowę dla mnie i dla moich kompanów".

Adsum auxilio, Amphitruo, tibi et tuis. (Pl., Amph. 1131)

„Przychodzę z pomocą, Amfitrionie, tobie i twoim bliskim”.

Aegram esse simulant mulierem; nostra ilico it visere ad eam. (Ter., Hec. 188-189)

"Udają, że dziewczyna jest chora; nasza pani natychmiast idzie do niej w odwiedziny".

Nostri celeriter arma ceperunt. (Caes., Gall. 3, 28)

„Nasi (zołnierze) błyskawicznie chwycili za broń”.

Meum semper iuducium fuit omnia nostros [...] invenisse sapientius quam Graecos. (Cic., Tusc. 1, 1)

„Zawsze żywiłem przekonanie, że nasi rodacy we wszystkim wykazali się większą mądrością niż Grecy".

Similia dici possunt de explicatione naturae, qua et hi utuntur et vestri. (Cic., Fin. 4, 11) „Podobne sądy można wypowiedzieć o badaniu przyrody, którym zajmują się i tamci (scil. perypatetycy) i wasi (scil. stoicy)".

Omnia mea mecum sunt: iustitia, virtus, prudentia. (Sen., Lucil. 9, 19)

„Wszystko, co do mnie należy (scil. cała moja własność), jesı ze mną: sprawiedliwość, męstwo, roztropność".

Ni tua custodis, avidus iam haec auferet heres. (Hor., Serm. 2, 3, 151)

„Jeśli nie strzeżesz swego mienia, to chciwy spadkobierca wnet ci je zabierze".

Cum tua lego, te audire [...] videor. (Cic., Q. fr. 1, 1, 45)

"Gdy czytam to, co napisałeś, zdaje mi się, że cię styszę".

Nil gustabit de meo. (PI., Pers. 473)

„Niczego nie zje na mój koszt".

Superest pro sanguine merces, quam monstrare meum est. (Lucan., Bell. Civ. 7, 738-739)

"Za rozlaną krew pozostaje zapłata, której wskazanie jest moim zadaniem”.

Non est tuum de re publica bene mereri. (Cic., Phil. 2, 36)

"Nie jest czymśs wlaściwym tobie dobrze przyslużyć się państwu”.

Quod $[. .$.$] illi vevientes in castra interfeci sunt, vestrum est, [\ldots]$ non nostrum. (Liv., $39,36)$

„To, że oni, idąc do obozu, zostali zabici, waszą jest zasługą, nie naszą (= wy to spowodowaliście, nie my)". 


\subsubsection{Zaimek dzierżawczo-zwrotny suus}

Zaimek dzierżawczo-zwrotny suus, - $a$, um 'swój, swoja, swoje' generalnie sygnalizuje związek desygnatu swego nadrzędnikowego rzeczownika $z$ desygnatem podmiotu zdania ${ }^{6}$, o ile podmiotem tym nie jest zaimek osobowy, wyrażony powierzchniowo lub ewokowany przez formę (końcówkę) czasownikowego orzeczenia; innymi słowy: o ile podmiot nie jest nacechowany wartością 1. lub 2. osoby, gdyż wówczas związek ten wyrażają odpowiednie zaimki dzierżawczo-osobowe (zob. wyżej: 10.3.1.):

Caesar suas copias in proximum collem subducit. (Caes., Gall. 1, 22)

"Cezar podprowadza swoje oddzialy pod najbliższe wzgórze".

Philosophi etiam in eis libellis, quos de contemnenda gloria scribunt, nomen suum inscribunt. (Cic., Arch. 26)

„Filozofowie nawet $w$ tych księgach, które piszą o pogardzie dla sławy, umieszczają swoje imię na stronie tytulowej".

Canuleius pro legibus suis et adversus consules [...] disseruit. (Liv., 4, 3)

„Kanulejusz przemówil w obronie swoich wniosków prawnych, a przeciw konsulom”.

Mulier aliquot dierum abstinentia sicca passa est frangi pertinaciam suam. (Petron., Sat. 111, 13)

„Kobieta, wycieńczona kilkudniową glodówką, pozwoliła przełamać swój upór".

Ita ille imprudens ipse suus fuit accusator. (Nep., Lys. 4)

„W ten sposób, nierozważny, stal się on swoim wlasnym oskarżycielem (= oskarżycielem samego siebie)".

Również w zdaniu składniowo podrzędnym zaimek ten sygnalizuje związek desygnatu swego rzeczownikowego nadrzędnika $z$ desygnatem podmiotu zdania, $\mathrm{w}$ którym się znajduje, a więc $\mathrm{z}$ desygnatem podmiotu zdania podrzędnego (także wtedy, gdy jego pozycja pozostaje niewypełniona, a więc gdy mamy do czynienia $\mathrm{z}$ tzw. podmiotem domyślnym):

Caesar $[\ldots]$ noluit eum locum [...] vacare, ne propter bonitatem agrorum Germani $[\ldots]$ suis finibus in Helvetiorum fines transirent. (Caes., Gall. 1, 28)

„Cezar nie chcial, by miejsce to stalo pustką, z obawy przed tym, żeby Germanie, z powodu urodzajności (tamtejszych) ziem, nie przeszli ze swego teryterium do kraju Helwetów".

(Verres) rogat et orat Dolabellam, ut de sua provincia decedat, ad Neronem proficiscatur. (Cic., Verr. 2, 1, 72)

"(Werres) prosi i zaklina Dolabellę, aby ze swej prowincji wyjechak i udal się do Nerona".

Sed qui ab eo (scil. Pompeio) missi erant [...] liberius cum militibus regis conloqui coeperunt eosque hortari, ut suum officium Pompeio praestarent neve eius fortunam despicerent. (Caes., Civ. 3, 103)

' Dotyczy to, oczywiście, sytuacji, w których rzeczownikowym nadrzędnikiem tego zaimka nie jest sam podmiot zdania. 
„Lecz wysłannicy (Pompejusza) zaczęli swobodniej rozmawiać z żołnierzami króla i nakłaniać ich, aby wypełnili swoje zobowiązanie wobec Pompejusza i nie okazywali pogardy dla jego losu".

(Antiochus) Ptolemaei legatis [...] petentibus [...], ut suum munus tueretur [...], respondit non aliter neque classem revocaturum neque exercitum reducturum nisi sibi et tota Cypro et Pelusio agro [...] cederetur. (Liv., 45, 11)

"(Antioch) postom Ptolemeusza proszącym, aby mial na względzie swoją powiność, odpowiedział, że ani floty nie odwoła, ani wojska nie wycofa, jeśli nie ustąpi mu się z całego Cypru i Peluzjonu".

Dotyczy to także równoważników (funkcjonalnych odpowiedników) zdań podrzędnych. Znajdujący się $w$ ich obrębie zaimek dzierżawczo-zwrotny sygnalizuje wówczas związek desygnatu swego rzeczownikowego nadrzędnika $z$ desygnatem funkcjonalnego odpowiednika podmiotu:

Caesar [...] Helvetios, Tulingos, Latobrigos in fines suos [...] reverti iussit. (Caes., Gall. $1,28)$

"Cezar rozkazal, aby Helwetowie, Tulingowie i Latobrygowie powrócili do swoich krajów".

Jednak zaimek ten sygnalizować może także związek z innymi obiektami (osobami) niż desygnat podmiotu zdania, w którym się znajduje (czyli innymi niż desygnat podmiotu „własnego" zdania), a identyfikacja tych obiektów następuje wyłącznie w oparciu o kontekst. Poniżej ukazany został w ogólnym zarysie ów dodatkowy, sekundarny zakres referencji tego zaimka.

1. Zaimek dzierżawczo-zwrotny znajdujący się w zdaniu podrzędnym (lub równoważniku zdania podrzędnego) może sygnalizować związek desygnatu swego rzeczownikowego nadrzędnika $z$ desygnatem podmiotu zdania nadrzędnego - jeśli zdanie podrzędne cechuje się tzw. „wewnętrzną zależnością", tzn. jeśli jego treść wyraża słowa, myśli, uczucia, intencje itp. przypisywane desygnatowi podmiotu zdania nadrzędnego:

Quem (scil. Vercingetorigem) perterriti omnes Arverni circumsistunt atque obsecrant, ut suis fortunis consulat. (Caes., Gall. 7, 8)

"Arwernowie, wszyscy zdjęci strachem, otaczają i błagają (Wercyngetoryksa), aby zatroszczyl się o ich dobytek".

Palinurus est aput inferos petens ab Aenea, ut suum corpus requirendum et sepeliendum curet. (Gell., Noc. Att. 10, 16, 2)

„Palinurus znajduje się $w$ krainie zmarłych, prosząc Eneasza, aby zatroszczyl się o odnalezienie i pogrzebanie jego ciała".

(Quartilla) miratur, quis deus iuvenes tam urbanos in suam regionem detulerit. (Petron., Sat. 16, 4)

"(Kwartylla) zastanawia się, jakiż to bóg sprowadzil w jej strony tak kulturalnych młodzieńców". 
Albam, unde ipsi (scil. Romani) oriundi erant, a fundamentis proruerunt, ne stirpis, ne memoria originum suarum exstaret. (Liv., 26, 13)

„Albę, skąd sami się wywodzą (scil. Rzymianie), zrównali z ziemią, aby nie pozostała pamięć o ich pochodzeniu i początkach".

Zdarza się jednak, że zaimek ten odsyła do podmiotu zdania nadrzędnego, chociaż zdanie podrzędne, w którym się znajduje, nie spełnia kryteriów "wewnętrznej zależności"'. Dotyczy to głównie zdań przydawkowych (względnych) lub przyczynowych, ukazujących wyrażaną treść z perspektywy desygnatu podmiotu zdania nadrzędnego:

Poetus [...] omnis libros, quos frater suus reliquisset, mihi donavit. (Cic., Att. 2, 1, 12)

„Petus podarowal mi wszystkie książki, które pozostawil jego brat".

Eunones [...] adlevat supplicem (Mithridatem) laudatque, quod [...] suam dextram petendae veniae delegerit. (Tac., Ann. 12, 19)

„Eunones podnosi upokorzonego (Mitrydatesa) i chwali z tego powodu, że jego prawicę wybrat, aby wyprosić sobie laskę".

2. Zaimek dzierżawczo-zwrotny może odsyłać do desygnatu innego wyrazu niż podmiot zdania (własnego lub nadrzędnego), jeśli:

a. desygnatem tym jest obiekt osobowy stanowiący tzw. podmiot logiczny czy psychologiczny, a więc obiekt będący punktem odniesienia dla orzekanej w wypowiedzeniu treści, bądź też ośrodkiem perspektywy, z której treść ta jest ukazywana:

Plerumque omnibus Gallis prae magnitudine corporum suorum brevitas nostra contemptui est. (Caes., Gall. 2, 30)

„Generalnie u wszystkich Gallów, ze względu na wielką posturę ich ciał, nasz niski wzrost wzbudza pogardę."

Si parebunt his legibus, nihil erit iis Urbe, nihil domo sua dulcius. (Cic., Leg. 3, 19)

„Jeśli posłuchają tych praw, nic od Rzymu, nic od ich domu nie będzie im milsze".

Rerum suarum quas possent ferendarum secum dominis ius fiebat. (Liv., 32, 13)

„Wlaścicielom przyslugiwało prawo zabrania z sobą ich rzeczy, (tych) które mogli (unieść)".

Haec ego non dicerem, $[\ldots]$ si [...] Caesarem benefici sui paeniteret. (Cic., Lig. 29) ${ }^{8}$

„Nie mówilbym tego, gdyby Cezar żalowal swego dobrodziejstwa”.

b. desygnatem tym jest jest obiekt osobowy niescharakteryzowany, wyrażony zaimkiem uogólniającym dystrybutywnym:

7 W związku z czym oczekiwane byłoby w tym kontekście użycie zaimka anaforycznego is w genetiwie (zob. niżej).

" Dodajmy, że w przeciwieństwie do trzech poprzednich przykładów, w zdaniu tym - z uwagi na specyficzne właściwości składniowe czasownikowego orzeczenia (paeniteret) - nie jest możliwe wystąpienie mianownikowego podmiotu. 
Cum autem suo cuique iudicio sit utendum, difficile factu est me id sentire quod tu velis. (Cic., Nat. 3, 1)

„Jako że każdy powinien posługiwać się swoim osądem, trudno sprawić, żebym mial taki pogląd, jakiego ty oczekujesz".

Camillus $[\ldots]$ vidit intentos [...] opifices suo quemque operi. (Liv., 26, 25) „Kamillus zobaczył rzemieślników, każdego zajętego swoją pracą".

(Numa) simulat sibi cum dea Egeria congressus nocturnos esse; eius se monitu [...] sacerdotes suos cuique deorum praeficere. (Liv., 1, 19)

"(Numa) udaje, że odbywa nocne spotkania $z$ boginią Egerią (i że) za jej radą każdemu z bogów wyznacza jego kapłanów".

c. zaimek ma charakter emfatyczny ('swój własny', 'właśnie swój'):

Hunc (scil. Hannibalem) sui cives e civitate eiecerunt. (Cic., Sest. 142)

„Jego własni obywatele wygnali go (scil. Hannibala) z państwa”.

Suus rex reginae placet. (Pl., Stich. 133)

„(Każdej) królowej podoba się jej własny król (proverb. = Każda pliszka swój ogon chwali)”.

Suis flammis delete Fidenas. (Liv., 4, 33)

„Spalcie Fideny ich własnym ogniem".

Incolebant urbem eam (scil. Toronem) profugi ab Thebis Phthioticis; urbe sua capta a Philippo [...], sedem iis Aetoli eam dederant. (Liv., 28, 7)

„Miasto to (scil. Tronion) zamieszkiwali uchodźcy z Teb Ftiotydzkich; gdy ich własne miasto (scil. Teby) zostało zdobyte przez Filipa, Etolowie przydzielili im tę właśnie siedzibę".

d. zaimek wyraża relację ścisłej przynależności (silnego powiązania) desygnatu swego rzeczownikowego nadrzędnika do desygnatu innego (niż podmiot) składnika zdania:

Antonianae scaphae [...] quadriremem cum remigibus defensoribusque suis ceperunt. (Caes., Civ. 3, 24)

„Lodzie Antoniusza przechwyciły czterorzędowiec z wraz z jego wioślarzami i obrońcami”.

Ponite ante oculos vobis Rullum [...] cum suis formosis finitoribus auctionantem. (Cic., Leg. Agr. 2, 53)

„Wyobraźcie sobie Rullusa $\mathbf{z}$ jego urodziwymi mierniczymi, prowadzącego sprzedaż na aukcji".

Unika się jednak stosowania tego zaimka, jeśli miałby on sygnalizować wyżej wymienione relacje $w$ odniesieniu do desygnatów składników zdania, które pozostają względem siebie $w$ stosunku szeregowym. $W$ takim kontekście używany jest raczej zaimek anaforyczny is ( $w$ genetiwie):

Nam qui per tot annos Hieronem filiumque eius Gelonem [...] vidissent [...]. (Liv., 24, 5)

„Bowiem ci, którzy przez tyle lat oglądali Hierona i jego syna Gelona [...]”.

Dotyczy to również podmiotowych składników zdania; dlatego: 
Litaviccus cum suis clientibus [...] Gergoviam perfugit. (Caes., Gall. 7, 40)

„Litawikkus ze swoimi klientami zbiegl do Gergowii".

ale:

Interfectus est [...] M. Fulvius consularis eiusque duo adulescentuli filii. (Cic., Phil. 8, 14) „Został zabity byly konsul Marek Fulwiusz i jego dwaj mlodzi synowie”.

3. Zaimek dzierżawczo-zwrotny może również odsyłać do obiektu osobowego niescharakteryzowanego, uogólnionego, który nie jest wyrażony przez żaden konkretny wyraz:

Valetudo sustentatur notitia sui corporis. (Cic., Off. 2, 86)

„Zdrowie można podtrzymać dzięki znajomości swego ciala".

Contentum [...] suis rebus esse maximae sunt certissimaeque divitiae. (Cic., Parad. 51)

„Bycie zadowolonym ze swego majątku jest największym i najpewniejszym bogactwem”.

Levius [...] vaniusque profecto est sua decreta et consulta tollere quam aliorum. (Liv., 3, 21)

„Doprawdy czymś bardziej niepoważnym i głupim jest lekceważyć wlasne zarządzenia i uchwaly niż cudze".

4. Zaimek dzierżawczo-zwrotny, którego nadrzędnik zależny jest od imiesłowu, może odsyłać:

a. do osoby desygnowanej przez ten imiesłów bądź przez wyraz przez niego określany:

Hunc (scil. Mitridatem) in [...] fuga Tigranes, rex Armenius, excepit diffidentemque rebus suis confirmavit. (Cic., Man. 23)

„Jego (scil. Mitrydatesa) Tigranes, król Armenii, przyjąl i wątpiącego w swe powodzenie umocnil na duchu".

(Erictho) viventis animas et adhuc sua membra regentis infodit busto. (Lucan., Bell. Civ. $6,529)$

"Czarownica (Erychto) żywe dusze i jeszcze wladające swymi czlonkami grzebie w grobie".

b. do osoby desygnowanej przez podmiot zdania:

Hannibal $[. .$.$] mille passus ab urbe castra locat, cum Gracchus magis verecundia [\ldots]$ deserendi socios implorantes fidem suam [...], quam satis fidens exercitui. (Liv., 23, 36)

„Hannibal w odległości tysiąca kroków od miasta rozbił obóz, jako że Grakchus pozostal na miejscu, bardziej jednak z poczucia wstydu przed opuszczeniem sprzymierzeńców rozpaczliwie apelujących do jego lojalności, niż ufając dostatecznie wojsku".

5. Zróżnicowana jest referencja tego zaimka, gdy:

a. podlega on adiektywizacji (uprzymiotnikowieniu), przybierając dodatkowe, przymiotnikowe znaczenie, np.: (dla kogoś) 'stosowny', 'odpowiedni', 'właściwy', 'dogodny', 'naturalny', 'korzystny', 'pomyślny', 'indywidualny', własny' itp.: 
Ibi (Hannibal) non bello aperto sed suis artibus, fraude et insidiis, est prope circumventus. (Liv., 21, 34)

„Tam (Hannibal) omal nie zostal osaczony, ale nie w otwartej walce, lecz poprzez zastosowanie jemu wlaściwych zabiegów: oszustwa i zasadzki".

De quibus singulis dicam suo loco. (Cic., Div. 2, 16)

„O poszczególnych tych rzeczach powiem we właściwym (dla nich) miejscu”.

Volscis levatis metu suum rediit ingenium: rursus occultum parant bellum [...], legatos quoque ad sollicitandum Latium passim dimittunt. (Liv., 2, 22)

„Do Wolsków uwolnionych od strachu powraca wlaściwa im skłonność: znowu szykują się po cichu do wojny, w różne strony rozsyłają także posłów, aby podburzyć Lacjum".

Ap. Claudius [...] vento aestuque suo Locros traiecit. (Liv., 23, 41)

„Appiusz Klaudius przy pomyślnym (dla siebie) wietrze i stanie morza przeprawił się do Lokrów".

Ferunt sua flamina classem. (Verg., Aen. 5, 832)

„Niosą flotę pomyślne (dla niej) wiatry”.

Ignoranti, quem portum petat, nullus suus ventus est. (Sen., Lucil. 71, 3)

„Dla kogoś kto nie wie, do jakiego portu zmierza, nie ma pomyślnego (dla niego) wiatru”.

b. podlega on substantywizacji (urzeczownikowieniu), przybierając rzeczownikowe cechy składniowe, morfologiczne i semantyczne; w rodzaju męskim i żeńskim zaimek ten desygnuje wówczas obiekty osobowe: (czyjś) 'małżonek/-ka', 'kochanek/-ka', 'narzeczony/-a'; (przynależni komuś) 'podwładni', 'żołnierze', 'stronnicy', 'zwolennicy', 'przyjaciele', 'krewni,' 'bliscy' itp. W rodzaju nijakim desygnuje obiekty nieosobowe: (czyjeś) 'mienie,' 'dobra', 'własność,' 'majątek'; 'interesy', 'sprawy', 'poglądy', 'pisma' itp.:

Pompeius [...] naviculam parvulam conscendit cum paucis suis. (Caes., Civ. 3, 104)

„Pompejusz wsiada na mały stateczek z kilkoma swymi ludżmi”.

(Tiberius) felicem Priamum vocabat, quod superstes omnium suorum extitisset. (Suet., Tib. 62)

"(Tyberiusz) nazywal Priama szczęśliwcem z tego powodu, że przeżył on (scil. Priam) wszystkich swych najbliższych".

(Antonius) illam suam suas res sibi habere iussit. (Cic., Phil. 2, 69)

"(Antoniusz) rozkazał, żeby ta jego (scil. Antoniusza) kochanka zabrała z sobą swe rzeczy".

Epicurum $[. .$.$] et Metrodorum non fere praeter suos quisquam in manus sumit. (Cic.,$ Tusc. 2, 8)

„Epikura i Metrodorosa niemal nikt nie bierze do ręki, oprócz ich zwolenników”.

Haedui cum se suaque ab iis defendere non possent, legatos ad Ceasarem mittunt rogatum auxilium. (Caes., Gall. 1, 11)

„Ponieważ Eduowie nie byli w stanie obronić przed nimi siebie i swego dobytku, wystali do Cezara posłów z prośbą o pomoc". 
Caesar $[\ldots]$ docebat $[\ldots]$ populi Romani hanc esse consuetudinem, ut socios atque amicos non modo sui nihil deperdere, sed gratia, dignitate, honore auctiores velit esse. (Caes., Gall. 1, 43)

„Cezar przekonywal, że naród rzymski ma w swoim zwyczaju to, iż pragnie, aby sprzymierzeńcy i przyjaciele nie tylko niczego ze swego majątku nie utracili, ale aby powiększali swe wpływy, godności i cześć".

Bructeros sua urentis $[\ldots]$ L. Stertinius $[\ldots]$ fudit. (Tac., Ann. 1, 60)

„Brukterów palących swoje włości rozgromił Lucjusz Stertyniusz”.

Vita hominum sine cupiditate agebatur, sua quoique satis placebant. (Sall., Cat. 2)

"Życie ludzi upływalo bez chciwości; każdemu wystarczało swoje (= to, co jego)".

c. stosowany jest predykatywnie, tj. zajmuje pozycję orzecznika lub jego funkcjonalnego odpowiednika:

Diodorus [...] quoque suus est de summoque bono dissentiens dici vere Peripateticus non potest. (Cic., Fin. 5, 14)

„Diodor także jest sobie tylko wlaściwy (= samodzielny w poglądach) i ponieważ ma odmienne zdanie na temat najwyższego dobra, nie byłoby słusznym nazywanie go perypatetykiem".

Quorum cohortes militum [...] Iuba conspicatus, suam esse praedicans praedam, magnam partem eorum interfici iussit. (Caes., Civ. 2, 44)

„Zobaczywszy kohorty tych żołnierzy [...] Juba, oświadczając, że lup jest jego, wielką ich część kazal zabić".

(elipt.) Quae est eius (scil. animi) natura? Propria, puto, et sua. (Cic., Tusc. 1, 70)

„Jaki jest jej (scil. duszy) charakter? Szczególny, sądzę, i jej tylko właściwy”.

\subsubsection{Zaimek dzierżawczo-pytajny cuius, -a, -um}

Zaimek dzierżawczo-pytajny sygnalizuje niewiedzę autora komunikatu co do związku desygnatu rzeczownikowego nadrzędnika z uczestnikami aktu mowy lub innymi osobami. Przymiotnikowy zaimek dzierżawczo-pytajny cuius, - $a$, -um 'czyj, -a, -e’ używany był w lacinie stosunkowo rzadko, głównie w literaturze archaicznej:

Cuiam vocem ego audio? (Pl., Curc. 229)

"Czyj glos słyszę?"

Quoium puerum hic adposisti? (Ter., Andr. 763)

"Czyje dziecko tu podłożyłaś?"

Dic mihi, Damoeta, cuium pecus? an Meliboei? (Verg., Ecl. 3, 1)

„Powiedz mi, Dametasie, czyja to trzoda? Czy Melibeusza?"

Poza pytajną, zaimek ten realizować mógł także funkcję względną (anaforyczną):

Is Helenam avexit, cuia causa nunc facio obsidium Ilio. (PI., Bacch. 948)

"On uprowadzil Helenę, z której powodu teraz czynię oblężenie Ilium". 
Znacznie częściej funkcję zaimka dzierżawczo-pytajnego realizuje w łacinie zaimek pytajny (quis?, quid?) w genetiwie, tj. cuius?

\subsection{ZAIMEK ZWROTNY SE}

Zaimek zwrotny se ma charakter rzeczownikowy. Pełni funkcję anaforyczną, cechując się koreferencją $\mathrm{z}$ wyrażeniem rzeczownikowym zajmującym pozycję podmiotu zdania' ${ }^{9}$ Oznacza to, że sygnalizuje on referencjalną tożsamość swego desygnatu z desygnatem podmiotu. Dystrybucja tego zaimka podlega jednak ograniczeniu polegającemu na tym, iż obejmuje ona koreferencję z podmiotem nacechowanym wyłącznie wartością 3 . osoby. Koreferencję z podmiotem nacechowanym wartością 1. lub 2. osoby wyrażają natomiast odpowiednie zaimki osobowe (zob. wyżej):

Trepidus ad haec Vitelius pauca purgandi sui causa respondit. (Tac., Hist. 3, 70)

„Przerażony Witeliusz w paru słowach na to odpowiedzial dla usprawiedliwienia siebie".

(Sapiens) solus scit sibi vivere. (Sen., Lucil. 55, 4)

„Tylko (mędrzec) potrafì żyć dla siebie".

(Verres) vocat ad se Syracusanos. (Cic., Verr. 2, 2, 48)

"(Werres) przyzywa do siebie Syrakuzańczyków".

W genetiwie zaimek zwrotny może wyrażać funkcje dzierżawcze, sygnalizując związek desygnatu swego nadrzędnika $\mathrm{z}$ desygnatem podmiotu:

Montes summa sui parte procera nemora et antiqua habent. (Plin., Epist. 5, 6, 7)

„Wzgórza w ich najwyższej partii porośnięte są wysokimi i bardzo starymi lasami”.

Również w zdaniach podrzędnych wyrażana przez ten zaimek koreferencja dotyczy (domyślnego) podmiotu zdania, w którym zaimek się znajduje. Analogicznie zasada ta funkcjonuje $w$ ramach równoważników zdań podrzędnych, gdzie zaimek wyraża koreferencję $\mathrm{z}$ funkcjonalnym odpowiednikiem podmiotu:

Socrates $[\ldots]$ suasisse fertur discipulis suis, crebro ut semet in speculo contemplarentur. (Apul., Apol. 15)

„Sokrates podobno doradzal swym uczniom, aby często oglądali siebie (przypatrywali się sobie) w lustrze".

Ne tum quidem te respicies et cogitabis sibi quemque natum esse et suis voluntatibus? (Cic., Fin. 2, 79)

„Czy nie spojrzysz wtedy na siebie i nie pomyślisz, że każdy urodził się dla siebie i swoich przyjemności?"

${ }^{y}$ Rówmież w przypadku, gdy pozycja ta, ze względu na ekonomię wypowiedzi, pozostaje $w$ danym zdaniu niewypełniona, a więc w przypadku tzw. podmiotu domyślnego, identyfikowalnego na podstawie szerszego kontekstu. 
Non possum existimare plus quemquam a se ipso quam me a te amari. (Cic., Fam. 15, $21,3)$

„Nie mogę uważać, by kıoś był bardziej kochany przez siebie samego, niż ja jestem przez ciebie".

(Antonius) illam suam suas res sibi habere iussit. (Cic., Phil. 2, 69)

"(Antoniusz) rozkazal, żeby ta jego (scil. Antoniusza) kochanka zabrala z sobą swe rzeczy".

Z uwagi na koreferencję z podmiotem paradygmat funkcjonalny tego zaimka jest ograniczony w zakresie kategorii przypadka, tzn. nie obejmuje on wartości nominativus. Przyjmując wszystkie pozostałe wartości tej kategorii, zaimek zwrotny zajmuje wyłącznie sekundarne dla rzeczownika ( $t j$. niepodmiotowe) pozycje składniowe. Występując $w$ ablatiwie $z$ przyimkiem cum sytuuje się w postpozycji i współtworzy $\mathrm{z}$ nim jeden wyraz tekstowy, tj. secum:

Gnatho [...] ducit secum una virginem. (Ter., Eun. 228-229)

"Gnaton prowadzi z sobą dziewczynę".

Omnia sternet abducetque secum vetustas. (Sen., Dial. 6, 26, 6)

"Wszystko zniszczy i zabierze z sobą upływ czasu".

Quam multos scriptores rerum suarum magnus ille Alexander secum habuisse dicitur! (Cic., Arch. 24)

„Jakże wielu kronikarzy swych dokonań miał podobno przy sobie ów wielki Aleksander!"

Zaimek zwrotny se nie jest nacechowany pod względem kategorii liczby i rodzaju. Może wyrażać koreferencję z rzeczownikowym podmiotem nacechowanym każdą $\mathrm{z}$ wartości tych kategorii, podlegając w tym zakresie (funkcjonalnej) akomodacji ujawnianej przez jego składniowe podrzędniki, które uwzględniają te kategorie w sposób fleksyjny, a więc np.:

Pompeianus miles fratrem suum, dein cognito facinore se ipsum interfecit. (Tac., Hist. 3, 51) „Żołnierz pompejański zabił swego brata, a potem, gdy rozpoznal swą zbrodniç, siebie samego".

Res publica [...] se ipsam sibi restitutam putabit. (Cic., Phil. 13, 9)

„Rzeczpospolita uzna siebie samą za przywróconą sobie”.

Apud maiores tanta religionis vis fuit, ut quidam imperatores etiam se ipsos dis immortalibus $[. .$.$] pro re publica devoverent. (Cic., Nat. 2, 10)$

„Wśród przodków tak wielka była siła religii, że niektórzy wodzowie nawet siebie samych ofiarowywali bogom niesmiertelnym dla obrony państwa".

Zaimek zwrotny, podobnie jak zaimek dzierżawczo-zwrotny (zob. wyżej), sygnalizować może także koreferencję $\mathbf{z}$ wyrazami innymi niż te, które pełnią funkcję podmiotu w zdaniu zawierającym tenże zaimek. Identyfikacja tych wyrazów determinowana jest kontekstem, poniżej zaś przedstawiono w zarysie możliwy zakres owej dodatkowej, sekundarnej referencji tego zaimka. 
1. Znajdując się $\mathbf{w}$ zdaniu podrzędnym (lub równoważniku zdania podrzędnego), zaimek zwrotny może wyrażać koreferencję z wyrazem zajmującym pozycję podmiotu w zdaniu składniowo nadrzędnym - jeśli zdanie podrzędne cechuje się tzw. „wewnętrzną zależnością", tzn. jeśli jego treść wyraża słowa, myśli, uczucia, intencje itp. przypisywane desygnatowi podmiotu zdania nadrzędnego:

Ubii autem, qui uni ex Transrhenanis ad Ceasarem legatos miserant [...], magnopere orabant, ut sibi auxilium ferret. (Caes., Gall. 4, 16)

„Ubiowie, którzy jako jedyni spośród plemion zareńskich wcześniej wyprawili do Cezara postów, usilnie go prosili, by przyszedł im z pomocą".

Quos cum [...] Ariovistus conspexisset [...], conclamavit quid ad se venirent. (Caes., Gall. $1,47)$

„Gdy Ariowist ich spostrzegl, zawolal, po cóż do niego przychodzą".

(Cicero) effecerat, ut Q. Curius [...] consilia Catilinae sibi proderet. (Sall., Cat. 26)

„(Cyceron) sprawil, że Kwintus Kuriusz zdradzal mu plany Katyliny”.

Dictator $[\ldots]$ equites $[\ldots]$ silvis se accultare iubet neque inde ante movere quam ab se acceperint signum. (Liv., 7, 14)

„Dyktator nakazuje, aby jeźdźcy ukryli się w lasach i nie ruszali się stamtąd wcześniej, aż otrzymają od niego znak".

(Brutus) pollicetur enim se provinciam Galliam retenturum in senatus populusque Romani potestate. (Cic., Phil. 3, 8)

„(Brutus) obiecuje bowiem, że utrzyma on prowincję Galię we władzy senatu i narodu rzymskiego".

Ariovistus [...] respondit [...] non sese Gallis, sed Gallos sibi bellum intulisse. (Caes., Gall. 1, 44)

„Ariowist odpowiedzial, że to nie on Gallom, lecz Gallowie jemu wypowiedzieli wojnę".

Ariovistus respondit [...] neminem secum sine sua pernicie contendisse. (Caes., Gall. 1, 36)

"Ariowist odpowiedział że nikt z nim (scil. Ariowistem) nie walczyl bez wlasnej zguby".

Zdarza się jednak, że zaimek ten wyraża koreferencję z podmiotem zdania nadrzędnego, chociaż zdanie podrzędne, w którym się znajduje, nie spełnia kryteriów wewnętrznej zależności"10. Dotyczy to głównie zdań przydawkowych (względnych) lub przyczynowych, ukazujących wyrażaną treść z perspektywy desygnatu podmiotu zdania nadrzędnego:

Metellus [...] iis urbibus, quae ad se defecerant [...], praesidia inponit. (Sall., Iug. 61)

"Metellus w tych miastach, które przeszły na jego stronę, umieszcza garnizony".

Qui fit, Maecenas, ut nemo, quam sibi sortem seu ratio dederit seu fors obiecerit, illa contentus vivat? (Hor., Serm. 1, 1, 1-3)

„Jak to się dzieje, Mecenasie, że nikt nie jest zadowolony z losu, który już to dał mu rozumny wybór, już to narzucil przypadek".

$10 \mathrm{~W}$ związku z czym oczekiwane byłoby w tym kontekście użycie zaimka anaforycznego is (zob. niżej). 
Decima legio per tribunos militum ei (scil. Caesari) gratias egit, quod de se optimum iudicium fecisset. (Caes., Gall. 1, 41)

„Dziesiąty legion za pośrednictwem trybunów wojskowych złożył podziękowanie Cezarowi, ponieważ (w opinii dzisiątego legionu Cezar) wyrazil o nim (scil. o dzisiątym legionie) bardzo pochlebną opinię".

2. Zaimek zwrotny może sygnalizować koreferencję $z$ innym wyrazem niż podmiot zdania (własnego lub nadrzędnego), jeśli:

a. desygnatem tego wyrazu jest obiekt osobowy stanowiący tzw. podmiot logiczny czy psychologiczny, a więc obiekt będący punktem odniesienia dla orzekanej w wypowiedzeniu treści, bądź też ośrodkiem perspektywy, z której treść ta jest ukazywana:

Has adversus copias spes omnis consistebat Datami in se locique natura. (Nep., Dat. 8)

„Wobec tak wielkiej armii (nieprzyjacielskiej) dla Datamysa cała nadzieja tkwiła w nim samym i w sposobie ukształtowania terenu".

Illa $[\ldots]$ philosophorum de se ipsorum opinio firma in hoc viro et stabilis inventa est. (Cic., Brut. 114)

"Owa opinia filozofów o nich samych byla w tym czlowieku silnie ugruntowana".

Ipsi deo nihil minus gratum futurum sit, quam non omnibus patere ad se placandum et colendum viam. (Cic., Leg. 2, 25)

„Dla samego bóstwa nic nie byłoby mniej miłe niż to, że nie wszystkim dana byłaby możliwość przeblagania go i uczczenia".

Rerum suarum quas possent ferendarum secum dominis ius fiebat. (Liv., 32, 13)

„Wlaścicielom przysługiwało prawo zabrania z sobą ich rzeczy, (tych) które mogli (unieść)”.

A Ceasare valde liberaliter invitor [...], sibi ut sim legatus. (Cic., Att. 2, 18, 3)

„Przez Cezara bardzo uprzejmie jestem zapraszany, abym pełnil dla niego funkcję legata”.

Vos ex M. Favonio audistis Clodium sibi dixisse [...] periturum Milonem triduo. (Cic., Mil. 44)

„Usłyszeliście od Fawoniusza, że Klodiusz mu powiedział, iż Milon w ciągu trzech dni zginie”.

Faustulo spes fuerat regiam stirpem apud se educari. (Liv., 1, 5)

„Faustulus miał nadzieję, że to królewskie potomstwo wychowuje się u niego".

b. zaimek wyraża bezpośrednią zwrotność:

Ingenuit animantibus conservandi sui natura custodiam. (Cic., Nat. 2, 124)

„Natura wszczepila zwierzętom instynkt zachowywania siebie (scil. instynkt samozachowawczy)".

(Galli) huc magno cursu contenderunt, ut quam minimum spatii ad se colligendos armandosque Romanis daretur. (Caes., Gall. 3, 19)

„(Gallowie) Do tego miejsca szybko przybiegli, aby Rzymianom dane było jak najmnicj czasu na zorganizowanie się i uzbrojenie". 
c. zaimek stosowany jest $w$ ramach takich wyrażeń, jak: per se, propter se 'ze względu na siebie/niego', '(sam) przez się, inter se 'między sobą', a więc gdy wyrażana jest $w$ wypowiedzeniu pośrednia zwrotność czy wzajemność:

Caedem per se miserabilem miserabiliorem casus fecit. (Liv., 24, 26)

„Zabójstwo (to), samo przez się godne politowania, jeszcze bardziej żalosnym uczynil pzypadek".

Mens hominis $[\ldots]$ conprensionem $[\ldots]$ cum ipsam per se amat $[\ldots]$, tum etiam propter usum. (Cic., Lucull. 31)

„Umysł ludzki ceni postrzeganie zarówno ze względu na nie same, jak i z uwagi na jego użyteczność".

Ne iustitiam quidem recte quis dixerit per se ipsam optabilem, sed quia iucunditatis vel plurimum afferat. (Cic., Fin. 1, 53)

„Nawet sprawiedliwości ktoś słusznie mógłby nie uznać za godną pożądania samą przez się, ale dlatego, że dostarcza ona bodaj najwięcej przyjemności".

Si pravitatem inminutionemque corporis propter se fugiendam putamus, cur non etiam, ac fortasse magis, propter se formae dignitatem sequamur? (Cic., Fin. 5, 47)

„Skoro zniekształcenie i uszkodzenie ciała uważamy za coś nieznośnego ze względu na nie samo, dlaczego nie mielibyśmy w równym stopniu, a może i bardziej, zabiegać o świetność wyglądu dla niej samej?"

Ratio et oratio $[. .$.$] conciliat inter se homines. (Cic., Off. 1, 50)$

„Rozum i mowa jedna ludzi między sobą”.

Ingens certamen tribunis et inter se ipsos et cum consule fuit. (Liv., 39, 39)

„Trybunom dane było stoczyć ciężą walkę i między sobą, i z konsulem”.

d. zaimek zwrotny w datiwie ( $w$ funkcji dat. commodi / incommodi) występuje obok użytego emfatycznie zaimka zwrotno-dzierżawczego, wzmacniając emfazę:

Inest in hoc emussitata sua sibi ingenua indoles. (Pl., Mil. 632)

"Jest w nim jakaś doskonała, jemu wlaściwa przyrodzona zdolność".

Suo sibi gladio hunc iugulo. (Ter., Adelph. 958)

„Poderżnę mu gardło jego wlasnym mieczem”.

Quam (scil. anus) [...] cum suo sibi funiculo devinctam dedere praecipitem. (Apul., Met. $6,30)$

„Staruchę związaną tym jej powrozem (= ze stryczkiem u szyi) rzucili w przepaść”.

3. Zaimek zwrotny zależny składniowo od imiesłowu może wyrażać koreferencję z:

a. rzeczownikowym nadrzędnikiem imiesłowu lub z samym imiesłowem $w$ przypadku jego substantywizacji:

Miretur potius si quem bonum et fortem civem viderit, quam si quem aut timidum aut sibi potius quam rei publicae consulentem. (Cic., Sest. 1) 
„Niech się dziwi raczej, jeśli zobaczyłby jakiegoś dobrego i dzielnego obywatela, niż jeśli jakiegoś albo strachliwego albo troszczącego siç bardziej o siebie niż o rzeczpospolitą".

Habetis ducem memorem vestri, oblitum sui. (Cic., Catil. 4, 19)

„Macie przywódcę pamiętającego o was i zapominającego o sobie".

Nagamus [...] sibi iratis ferrum. (Sen., Benef. 2, 14, 2)

„Nie pozwalamy wziąć do ręki miecz (ludziom) zagniewanym na samych siebie (scil. aby nie zrobili sobie krzywdy, nie targnęli się na swoje życie)".

\section{b. rzeczownikiem stanowiącym podmiot zdania:}

(Dictator) qua gravitate animi criminantes se ad multitudinem inimicos tulerat, eadem et populi in se saevientis iniuriam tulit. (Liv., 22, 26)

„(Dyktator) z jaką powagą wcześniej znosił przeciwników oczerniających go przed tłumem, z taką samą zniósł niesprawiedliwość srożącego się na niego ludu".

Caesar principibus cuiusque civitatis ad se evocatis alias territando [...] alias cohortando magnam partem Galliae in officio tenuit. (Caes., Gall. 5, 54)

„Cezar, po tym jak wezwał do siebie naczelników każdego plemienia, już to zastraszając, już to dodając otuchy, znaczną część Galii utrzymywał w posłuszeństwie".

4. Zaimek zwrotny może odsyłać także do obiektu nieokreślonego, uogólnionego, który nie jest wyrażany przez żaden konkretny wyraz:

Imperare sibi maximum imperium est. (Sen., Lucil. 113, 30)

„Panować nad sobą to największa wladza”.

In se recedendum est. (Sen., Dial. 9, 17, 3)

„Trzeba wycofać siç w gląb samego siebie”.

Quid autem est amare [...], nisi velle bonis aliquem affici quam maximis, etiamsi ad se ex iis nihil redundet? (Cic., Fin. 2, 78)

„Na czym bowiem polega bycie przyjaznym, jeśli nie na chęci przysporzenia komuś jak największych dóbr, nawet gdyby dla siebie nic nie miało się z tego zyskać?"

Hermagoras $[\ldots]$ in $[\ldots]$ digressione $[. .$.$] putat oportere quandam inferri orationem$ a causa atque a iudicatione ipsa remotam, quae aut sui laudem, aut adversarii vituperationem contineat. (Cic., Inv. 1, 97)

„Hermagoras uważa, że w ramach dygresji należy wprowadzić jakąś opowieść, zupelnie niezwiązaną $z$ przedmiotem samej rozprawy sądowej, która zawieralaby albo pochwałę samego siebie, albo naganę przeciwnika".

Proelium [...] cum fiducia sui, sine contemptu hostium commissum est. (Liv., 8, 33)

„Bitwa zostala stoczona $z$ wiarą w siebie, bez lekceważenia przeciwników”. 
10.5. ZAIMKI WSKAZUJĄCE: HIC, HAEC, HOC; ISTE, ISTA, ISTUD; ILLE, ILLA, ILLUD

Zaimki wskazujące, inaczej deiktyczne, mają charakter przymiotnikowy i jako takie pełnią funkcję referencyjną, identyfikując - prymarnie jako korelat odpowiedniego gestu - desygnat swego rzeczownikowego nadrzędnika poprzez wskazanie relacji, w jakiej pozostaje on w stosunku do uczestników aktu mowy. Relacje te prymarnie mają charakter przestrzenny, a ujmujące je zaimki składają się na trójczłonowy system deiktyczny, w którym:

- hic charakteryzuje desygnat swego nadrzędnika jako bliski nadawcy komunikatu lub grupy nadawcy, a więc 'ten blisko mnie / nas';

- iste charakteryzuje desygnat swego nadrzędnika jako bliski odbiorcy komunikatu lub grupy odbiorcy, a więc 'ten bliski ciebie / was';

- ille charakteryzuje desygnat swego nadrzędnika jako odległy zarówno od (grupy) nadawcy, jak i od (grupy) odbiorcy komunikatu, a więc 'tamten (daleki)':

Tibi vixi, tibi moriturus fui, nulli alii in hoc pectore locus fuit. (Quint., Decl. Min. 332, 14)

„Dla ciebie (tylko) żyłem, dla ciebie gotów byłem umrzeć, dla nikogo innego w tym oto sercu nie było miejsca".

Quis te [...] instigat furor? Quid ensis iste quidve vociferatio [...] volunt? (Sen., Phaedr. 1156-1158)

"Co za szał tobą wlada? Cóż znaczy ten miecz (przy tobie) i krzyk?”

Haec urbs est Thebae. In illisce ${ }^{11}$ habitat aedibus Amphitruo. (Pl., Amph. 97-98)

„To (tutaj) miasto to Teby. W tamtym domu mieszka Amfitrion”.

Beatitudo $[\ldots]$ cur aut in solem illum aut in hunc mudum aut in aliquam mentem aeternam figura membrisque corporis vacuam cadere non potest? (Cic., Nat. 1, 95)

„Dlaczego szczęśliwość nie może przypaść w udziale albo temu tam slońcu, albo temu tu światu, albo jakiemuś wiecznemu rozumowi pozbawionemu kształu i członków ciała?"

Wtórnie, lecz w praktyce znacznie częściej, zaimki te sygnalizują dystans czasowy, emocjonalny, mentalny itp., zachodzący między desygnatami ich rzeczownikowych nadrzędników a uczestnikami aktu komunikacji, a więc:

- hic 'ten mój (nasz), ten związany ze mną (z nami) / dotyczący mnie (nas) / bliski mi (nam) / mnie (nam) współczesny' (często obok zaimka meus lub noster);

- iste 'ten twój (wasz), ten związany z tobą (wami) / dotyczący ciebie (was) / bliski ci (wam) / tobie (wam) współczesny' (często obok zaimka tuus lub vester);

- ille 'tamten ich, ów'.

Primum tum philosophia non illa de natura, quae fuerat antiquior, sed haec, in qua de bonis rebus et malis deque hominum vita et moribus disputatur, inventa dicitur. (Cic., Brut. 31)

"Dołączona do zaimka partykula epideiktyczna -ce dodatkowo wzmacnia jego demonstratywny charakter. 
„Powiada się, że wtedy whaśnie wynaleziona została filozofia, jednak nie tamta o naturze, która już wcześniej istniała, ale ta (bliższa nam), w której dysputuje się o dobu i złu oraz o ży. ciu i obyczajach ludzi".

Iam Q. Catulus non antiquo illo more, sed hoc nostro [...] eruditus (est). (Cic., Brut. 132) "Już Kwintus Katulus został wykszlalcony nie wedlug tamtego starodawnego sposobu, ale według tego naszego (= nam wspólczesnego)".

Ista tua studia vel maximis occupationibus meis anteferrem libenter. (Cic., Part. 1)

„Te twoje zainteresowania chętnie przedłożyłbym nad moje bodaj najważniejsze zajęcia”.

\{Labracas:\} Di te infelicent! \{Charmides:\} Isti capiti dicito! (Pl., Rud. 885)

„\{Labrakas:\} Niech cię piekło pochłonie! \{Charmenides:\} Powiedz to tej swojej lepetynie! (scil. „powiedz to do siebie!")".

Z zaimkiem iste, prawdopodobnie $\mathrm{z}$ uwagi na jego częste użycie - $\mathrm{w}$ sytuacji procesu sądowego bądź wystąpienia politycznego - w odniesieniu do rzeczy (spraw, cech) dotyczących przeciwnika (sądowego lub politycznego), wiązać się mogą różnego rodzaju negatywne, deprecjonujące konotacje ('ten zły / okropny / marny / kiepski / naganny'):

Quam diu etiam furor iste tuu nos eludet? (Cic., Catil. 1,1 )

„Jak długo jeszcze to (bezczelne) twoje szaleństwo będzie z nas drwilo?”

Exponam vobis, Quirites, ex quibus generibus hominum istae copiae comparentur. (Cic., Catil 2, 17)

„Opiszę wam, Kwiryci, z jakiego rodzaju ludzi organizowane są te (złożone z życiowych rozbitków) oddzialy".

$\mathrm{Z}$ kolei $\mathrm{z}$ zaimkiem ille, $\mathrm{z}$ uwagi na implikowaną przez niego cechę oddalenia, wiązać się mogą różnego rodzju konotacje pozytywne, aprecjonujące ('ów wspaniały / sławny / wielki / niedościgły'):

Cur non imitamur, Crasse, Socratem illum, qui est in Phaedro Platonis? (Cic., De orat. $1,28)$

„Dlaczego, Krassusie, nie naśladujemy owego Sokratesa, który ukazany zostal w Fajdrosie Platona?"

Est [...] illa Platonis vera et tibi, Catule, certe non inaudita vox. (Cic., De orat. 3, 21)

„Istnieje owa pełna prawdy i tobie, Katulusie, z pewnością dobrze znana wypowiedź Platona".

Ego sum ille rex Philippus. (Pl., Aul. 704)

(iron.) „Ja jestem tym wielkim królem Filipem”.

Realizowana przez zaimki wskazujące charakterystyka desygnatów ich rzeczownikowych nadrzędników może także polegać na odesłaniu do treści wyrażanych przez inne wyrazy, syntagmy bądź całe zdania w obrębie danej wypowiedzi. Jeśli odesłanie dotyczy fragmentu teksu poprzedzającego zaimek, mamy do czynienia $\mathrm{z}$ anaforą: 
Philippides [...], cum in certamine poetarum praeter spem vicisset et laetissime gauderet, inter illud gaudium repente mortuus est. (Gell., Noc. Att. 3, 15, 2)

„Filippides, gdy po niespodziewanej wygranej w konkursie poetyckim ogromnie się radowal, wśród tej radości nagle umarł".

Interim tamen, si feret flatus,danda sunt vela, dum nos indulgentia illa non fallat. (Quint., Inst. 10, 3, 7)

„Niekiedy jednak, jeśli niesie nas wiatr, możemy rozwinąć żagle, byleby tylko to szczędzenie sobie wysitku nie zwiodło nas zdradliwie".

Delegor [...] ligno monte devehundo puerque mihi praefectus imponitur [...]. Nec quicquam videbatur aliud excogitare puer ille nequissimus, quam ut me quoquo modo perditum iret. (Apul., Met. 7, 17-19)

„Wyznaczono mnie do zwózki drzewa z góry i przydzielony mi zostal chłopak jako poganiacz. Chyba nad niczym innym chlopak ten do cna zdeprawowany nie zamyślal, jak tylko żeby mnie jakimkolwiek sposobem ukatrupić".

Pompeius ad legiones Appianas est profectus; Labienum secum habet; ego tuas opiniones de his rebus exspecto. (Cic., Att. 7, 15, 3)

„Pompejusz wyruszył do legionów Appiana; ma ze sobą Labiena; czekam na twoją opinię w tych sprawach".

\{Syra:\} Tuos pater bellissumus amicam adduxit intro in aedis. \{Eutychus:\} Pol, haud censebam istarum esse operarum patrem. (PI., Merc. 812-815)

„\{Syra:\} Twój śliczniutki ojczulek kochankę sprowadzil do domu. \{Eutychus:\} Na Polluksa, nie wiedziatem, że ojciec jest od tych rzeczy".

Jeśli odesłanie dotyczy fragmentu tekstu następującego po zaimku, mamy do czynienia z kataforą, zwaną też odesłaniem uprzedzającym:

Nec iam ille senatus sumus, qui occiso Nerone delatores et ministros [...] puniendos flagitabat. (Tac., Hist. 4, 42)

„I nie jesteśmy już tym senatem, który po zabiciu Nerona domagal się ukarania donosicieli i ich slużalców".

Illa dubitatio erat, singulaene cohortes an universi ad stipendium petendum irent. (Liv., 28, 25)

„Ta wạtpliwość się pojawiła, czy po odbiór żołdu mają się udać poszczególne kohorty, czy wszyscy razem".

Ille unus dies, quo die me populus Romanus [...] honestavit, tantae mihi iucunditati fuit. (Cic., Dom. 76)

„Ten jeden dzień, w którym to dniu lud rzymski mnie uhonorowal, sprawil mi ogromną przyjemność".

Ex uxore hanc rem pergam exquirere, quis fuerit quem propter corpus suom stupricompleverit. (Pl., Amph. 1015-1016)

„Nadal będę próbowal dowiedzieć się tej rzeczy od żony, kim był czlowiek, dla którego zhańbila swe cialo".

Si me arbitrabare isto pacto, ut praedicas, cur conducebas? (PI., Pseud. 798-799)

„Jeśli oceniałeś mnie w ten sposób, jak tu opowiadasz, po co mnie wynajmowaleś?” 
Zaimki wskazujące mogą także podlegać substantywizacji i zajmować w wypowiedzeniu pozycje rzeczownikowe. Odsyłają wtedy do obiektów osobowych (przyjmując rodzaj męski lub żeński) lub do obiektów nieosobowych, zdarzeń czy sytuacji (przyjmując rodzaj nijaki), z zachowaniem wskazanych wyżej konotacji semantycznych oraz funkcji:

1. deiktycznych:

Sed finis sit; neque enim prae lacrimis iam loqui possumus, et hic se lacrimis defendi vetat. (Cic., Mil. 105)

„Ale kończmy już; z powodu łez dłużej nie mogę mówić, a i ten oto (scil. mój klient Milon) zdecydowanie nie chce być broniony przy pomocy lez".

'Arripite hunc', inquit, 'hic erat, hunc mulier nobis irata locavit'. (Prop., Eleg. 29a, 8-9)

"'Lapcie go', wola, 'to ten, to jego wskazała nam zagniewana dziewczyna".

Ne exspectetis, spectatores, dum illi huc ad vos exeant; nemo exibit. (Pl., Cist. 782-783)

„Nie oczekujcie, widzowie, że oni tu do was wyjdą; nikt nie wyjdzie".

Simulatque captivus [...] litteras [...] Considio porrigere coepisset, [...] ille 'unde' inquit 'istas?' (Ps.-Caes., Bell. Afr. 4)

„Skoro tylko jeniec zaczął wręczać list Konsydiuszowi, ten zapytal: 'od kogo go (przynosisz)?"'

2. anaforycznych:

Unus furiosus gladiator [...] contra patriam [...] gerit bellum; huic cedamus, huius condiciones audiamus? (Cic., Phil. 13, 16)

„Jeden szalony gladiator prowadzi wojnę z ojczyzną; jemu mamy ustąpić, przed jego warunkami się ugiąć?"

Eques Romanus [...] Q. Minucius iuratus dicit pecuniam datam [...]; dicent hoc multi Siculi. (Cic., Verr. 2, 2, 80)

„Ekwita rzymski Kwintus Minucjusz stwierdza pod przysięgą, że pieniądze zostały dane; potwierdzą to liczni Sycylijczycy".

Ita, sive (animi) dissipantur [...], sive permanent et conservant habitum suum, hoc etiam magis necesse est ferantur ad caelum. (Cic., Tusc. 1, 42)

„Tak więc, czy to dusze rozpływają się (po śmierci czlowieka), czy trwają i zachowują swą postać, to przez to jeszcze bardziej staje się czymś koniecznym, by wznosiły się ku niebu".

Fit in hostis impetus. [...] Illi sub murum se recipiunt. (Caes., Civ. 2, 14)

"Następuje atak na wrogów. Ci wycofują sie pod mur".

\{Atticus:\} Platonem videlicet dicis. \{Marcus:\} Istum ipsum, Attice. (Cic., Leg. 3, 1)

„(Attyk:\} Masz na myśli, oczywiście, Platona. \{Marek:\} Właśnie jego, Attyku”.

3. kataforycznych:

Sed mi hoc responde [...]: quid erat nomen nostrae matri? (Pl., Men. 1130-1131)

"Ale powiedz mi (jeszcze) to: jak było na imię naszej matce?" 
Quis potest esse [...] tam mente captus, qui neget haec omnia, quae videmus, [...] deorum immortalium nutu ac potestate administrari? (Cic., Catil. 3, 21)

„Któż może być tak szalony, by przeczyć, że to wszystko, co widzimy, kierowane jest wolą i mocą bogów nieśmiertelnych?"

Principes Britanniae [...], cum [...] paucitatem militum ex castrorum exiguitate cognoscerent, quae hoc erant etiam angustiora, quod sine impedimentis Caesar legiones transportaverat, optimum factu esse duxerunt [...] rem in hiemem producere. (Caes., Gall. 4, 30)

„Naczelnicy Brytanii, ponieważ odkryli niewielką liczebność wojska na podstawie malych rozmiarów obozu, który przez to jeszcze był mniejszy, że Cezar przeprawił legiony bez bagaży, doszli do przekanania, że najlepiej będzie przeciągnąć całą sprawę do zimy".

An paullum hoc esse tibi videtur, virginem vitiare civem? (Ter., Eun. 857-858)

"Czy (to) wydaje ci się drobnostką zgwałcić wolnourodzoną obywatelkę, dziewicę?"

Illud non succurrit, vivere nos quod maturarimus proficisci? (Liv., 2, 38)

„Czy nie przychodzi (wam) do głowy to, że żyjemy dlatego, iż przyspieszyliśmy odejście?”

Tantum illud vereor, ne quos privata amicitia Iugurthae [...] transvorsos agat. (Sall., Iug. $14,20)$

„Tego się tylko boję, żeby kogoś nie sprowadzila na manowce (jego) prywatna przyjaźń z Jugurtą".

Nonne huic simile est illud Sallustianum 'nam de Carthagine tacere satius puto quam parum dicere'? (Quint., Inst. 2, 13, 14)

„Czyż nie jest do tego podobne owo Sallustiuszowe (stwierdzenie): 'Uważam, że o Kartaginie lepiej jest zamilczeć, niż powiedzieć za mało".

Ista quae modo Mago iactavit Himilconi ceterisque Hannibalis satellitibus iam laeta sunt. (Liv., 23, 12)

„Te (słowa), które właśnie chełpliwie wygłosił Magon, cieszą już Himilkona i pozoslałych popleczników Hannibala".

Istum quem quaeris ego sum. (Pl., Curc. 419)

"Jestem tym, kogo szukasz".

Jednak zajmując pozycję podmiotu przy orzeczeniu imiennym, zaimki wskazujące najczęściej pozostają w składniowej kongruencji $\mathrm{z}$ rzeczownikowym orzecznikiem, zarówno co do kategorii liczby, jak i rodzaju gramatycznego:

Sed quis hic est, qui huc pergit? Attat hicquidem est parasitus Gnatho militis. (Ter., Eun. 228-229)

"Ale kimże jest ten, co tutaj idzie? Ach, to jest przecież pasożyt żołnierza, Gnaton”.

\{Agorastocles:\} Sed eccas video ipsas. \{Hanno:\} Haecine meae sunt filiae? (Pl., Poen. 1166) „\{Agorastokles:\} Lecz oto widzę już je właśnie. \{Hanno:\} Czy to są moje córki?”

Umożliwia to zaimkowym formom w rodzaju męskim i żeńskim wskazywanie także na obiekty nieosobowe: 
Non possum fidei causa imagines neque triumphos aut consulatus maiorum meorum ostentare, at [...] militaria dona, praeterea cicatrices advorso corpore; hae sunt meae imagines, haec nobilitas. (Sall., Iug. 85, 29-30)

„Dla uwiarygodnienia siebie nie mogę pokazać wizerunków przodków, ani ich tryumfów czy konsulatów, lecz tylko odznaczenia wojskowe, a prócz tego blizny na piersi; to są moje wizerunki przodków, to (jest) moje szlachectwo".

(Caesarem) clamantem: 'ista quidem vis est!' alter e Cascis aversum vulnarat paulum infra iugulum. (Suet., Iul. 82)

„(Cezara) wołającego: 'to jest gwatt!' jeden z Kasków rani od tyłu, nieco poniżej gardła”.

Animi est ista mollitia, non virtus, paulisper inopiam ferre non posse. (Caes., Gall. 7, 77) „Nie być w stanie przez pewien czas znosić niedostatków, to jest tchórzostwo, nie męstwo".

Zdarza się jednak, że w podobnych kontekstach użyta zostaje forma rodzaju nijakiego i tego typu kongruencja $\mathrm{z}$ orzecznikiem nie zostaje zachowana:

Illud non succurrit, vivere nos quod maturarimus proficisci? Si hoc profectio et non fuga est. (Liv., 2, 38)

„Czy nie przychodzi (wam) do glowy to, że żyjemy dlatego, iż przyspieszyliśmy odejście? Jeśli to jest odejście, a nie ucieczka".

Crebrius $[\ldots]$ et libertorum primi et medicorum intimi venere, sive cura illud sive inquisistio erat. (Tac., Agr. 43)

"Częściej przychodzili zarówno najważniejsi wyzwoleńcy, jak i najbardziej zaufani lekarze, (i nie wiadomo,) czy był to wyraz troskliwości, czy szpiegostwo".

Zaimkowa forma w rodzaju nijakim ( $w$ funkcji anaforycznej) stosowana jest także w wyrażeniach o charakterze eksplikatywnym ('to jest', 'to znaczy'):

Vos autem, hoc est populus Romanus, [...] satis habebatis animam retinere. (Sall., Iug. $31,20)$

„Wy zaś, to jest naród rzymski, zadowalaliście się tym, że mogliście zachować życie”.

Zaimki te (głównie hic) w rodzaju nijakim mogą ponadto identyfikować (deiktycznie, anaforycznie lub kataforycznie) będący przedmiotem referencji element (zakres) pojęcia, które wyrażane jest przez dopełniaczową przydawkę:

Hoc ad te litterarum dedi. (Cic., Fam. 2, 8, 3)

„Wystalem ci ten list”.

Abs te taciti requirunt, cur sibi hoc oneris imposueris. (Cic., Planc. 46)

"Milcząco pytają cię, dlaczego na nich ten ciężar nalożyleś".

Ita ad hoc aetatis a puerita fui. (Sall., Iug. 85, 7)

„W ten sposób postępowalem od dzieciństwa aż do tej chwili".

Qui me alter est audacior homo [...], qui hoc noctis solus ambulem? (Pl., Amph. 153-154)

"Jakiż czlowiek jest odważniejszy ode mnie, który o tej porze nocy samotnie spaceruję?" 
Anaforycznie użyte substantywizowane zaimki (na ogół hic i ille), występując równocześnie w jednym (tym samym) zdaniu, służą kontrastowaniu: zaimek hic sygnalizuje wówczas koreferencję z rzeczownikiem, który znajduje się bliżej po linii tekstu lub którego desygnat jest bliższy emocjonalnie nadawcy; zaimek ille jest koreferentny z rzeczownikiem „dalszym" tekstowo lub emocjonalnie:

Caesar beneficiis ac munificentia magnus habebatur, integritate vitae Cato; ille mansuetudine et misericordia clarus factus, huic severitas dignitatem addiderat. (Sall., Cat. 54)

„Cezar z powodu wyświadczanych dobrodziejstw i hojności był uważany za wielkiego, Katon z powodu nieskazitelności życia; tamten (pierwszy) stał się sławny dzięki lagodności charakteru i litościwości serca, temu (drugiemu) surowość obyczajów przydała godności".

Melior tutiorque est certa pax quam sperata victoria; haec in tua, illa in deorum manu est. (Liv., 30, 30)

„Lepszy i bezpieczniejszy jest pewny pokój niż spodziewane zwycięstwo; ten pierwszy jest w twoim ręku, to drugie - w rękach bogów".

Cave Catoni anteponas ne istum quidem ipsum, quem Apollo, ut ais, sapientissimum iudicavit; huius enim facta, illius dicta laudantur. (Cic., Lael. 10)

„Nie przedkładaj nad Katona nawet tego (człowieka, tj. Sokratesa), którego Apollo, jak powiadasz, uznal za najbardziej mądrego; u tamtego (pierwszego, tj. naszego Katona) chwalone są bowiem czyny, u tego (drugiego) tylko słowa".

Mogą także służyć wyliczaniu, specyfikowaniu itp. Używane są wtedy naprzemiennie różne zaimki wskazujące (np. hic - ille), powtarzany jest jeden z nich (np. hic - hic) lub też zaimki wskazujące kontrastowane są z innymi wyrazami odsyłającymi do określonych obiektów (np. hic - alius - ceteri - plurimi itp.):

Imperatorum utriusque partis haud ferme dispares spes erant; nam ne multum quidem aut numero aut genere militum hi aut illi praestabant. (Liv., 23, 29)

„Wodzowie obydwu stron żywili niemal jednakowe nadzieje zwycięstwo; bowiem ani ci, ani tamci nie mieli wyraźnej przewagi czy to pod względem liczby żolnierzy, czy to pod względem ich rodzaju".

Nec his aut illis proelium temptantibus fortuna partium alibi transacta. (Tac., Hist. 3, 5)

„Skoro ani ci, ani tamci nie próbowali stoczyć bitwy, losy obywdwu stron rozstrzygnęły się gdzic indziej".

Sese Rutuli exhortantur in arma: hunc decus egregium formae movet atque iuventae, hunc atavi reges, hunc claris dextera factis. (Verg., Aen. 7, 472-474)

„Rutulowie zagrzewają się do walki: tego pobudza wyjątkowy wdzięk i urok młodości (Turnusa), tamtego królewscy przodkowie, jeszcze innego prawica znana ze slawnych czynów".

Adsistit tabernaculis fruiturque fama sui, cum hic nobilitatem ducis, decorem alius, plurimi patientiam, comitatem [...] laudibus ferrent. (Tac., Ann. 2, 13)

„Przyslaje przy namiotach i napawa się swoją sława, gdy jeden (z żołnierzy) wychwala szlachetne pochodzenie wodza, inny urodę, wielu wytrwałość i uprzejmość". 
Podobne funkcje (deiktyczna, anaforyczna, kataforyczna) oraz konotacje semantyczne charakteryzują odpowiednie zaimki przysłówkowe, powiązane słowotwórczo z zaimkami wskazującymi:

hic 'tu, blisko mnie' istic 'tam, blisko ciebie' illic 'tam, daleko od nas' huc 'tu, dotąd' hinc 'stąd, ode mnie' istinc 'stamtąd, od ciebie' illinc 'stamtąd, z tamtego miejsca' hac 'tędy, koło mnie' istac 'tamtędy, koło ciebie' illac 'tamtędy, daleko od nas'

Ego hic esse et illic simitu hau potui. ( $\mathrm{Pl} .$, Most. 792)

„Ja nie moglem być równocześnie i tu, i tam”.

Quem ita obsides, [...] ut te ipse obsideas neque te istinc, si cupias, possis explicare. (Cic., Phil. 13, 25)

„Tak go (scil. Brutusa) oblegasz, że sam znalazłeś się w oblężeniu i nie możesz się stamtąd wydostać, choćbyś chciał".

Usque Hennam profecti sunt; tanta enim erat auctoritas [...] illius religionis, ut cum illuc irent, non ad aedem Cereris, sed ad ipsam Cererem proficisci viderentur. (Cic., Verr. 2, $4,108)$

„Wyruszyli aż do Henny; tak wielka byla bowiem powaga tamtejszego kultu, że gdy udawali się tam, wydawało im się, że idą nie do świątyni Cerery, lecz do samej Cerery".

'Terras licet' - inquit - 'et undas obstruat, at caelum certe patet: ibimus illac'. (Ov., Met. 8, 185-186)

„Choćby zabudowal' - powiada - 'ziemie i morza, to jednak niebo stoi otworem: pójdziemy więc tamtędy"'.

\subsection{ZAIMKI OKREŚLAJĄCE}

Termin ten tradycyjnie obejmuje trzy różne zaimki, utworzone na bazie etymologicznie tego samego pierwiastka $(e i-/-i)$.

\subsubsection{Is, ea, id (zaimek anaforyczny)}

Zaimek ten realizuje przede wszystkim funkcję anaforyczną, odsyłając do identyfikowanych kontekstowo, wcześniej wyrażonych treści (informacji), które desygnowane są przez rzeczowniki, grupy imienne bądź całe zdania. Używany może być zarówno przymiotnikowo:

Lucterius Cadurcus in Rutenos missus eam civitatem Arvernis conciliat. (Caes., Gall. 7, 7) „Lukteriusz Kadurkus wysłany przeciw Rutenom zjednal to plemię dla Arwernów”.

Causam capitis semel dixit, bello sociali, simul cum Timotheo, eoque iudicio est absolutus. (Nep., Iph. 3) 
„W sprawie gardłowej raz tylko bronił się w sądzie, w czasie wojny ze sprzymierzeńcami, wspólnie z Timoteosem, i w tym procesie zostal uniewinniony".

Vix spatium instruendi fuit: eo cursu hostes in proelium venerunt. (Liv., 31, 21)

„Ledwo starczyło czasu na ustawienie linii bojowej: $w$ ' takim pędzie wrogowie stawili się do bitwy".

Super hac quaestione [...] a Theophrasto disputatur, [...] eaque disputatio scripta est $[\ldots]$ in libro eius de amicitia primo. Eum librum M. Cicero videtur legisse. (Gell., Noc. Att. 1, $3,10)$

„Nad tą kwestią dyskutuje Teorfast i dyskusja ta zanotowana została w pierwszej księdze jego rozprawy o przyjaźni. Księgę tę prawdopodobnie czytał Cyceron".

jak i rzeczownikowo:

Mercator quidam fuit Syracusis senex; ei sunt nati filii gemini duo. (Pl., Men. 17-18)

„Żył w Syrakuzach pewien kupiec $w$ starszym wieku; jemu urodzili się dwaj synowie bliźniacy".

Filiolam ego unam habui, eam unam perdidi. (Pl., Rud. 106)

„Jedną miałem córeczkę, (i) ją jedną straciłem".

Darius [...] classem quingentarum navium comparavit eique Datim praefecit et Artaphernem. (Nep., Milt. 4)

„Dariusz wystawil flotę pięciuset okrętów i na jej czele postawil Datysa i Artafernesa”.

Helvetii [...] in Haeduorum fines pervenerant eorumque agros populabantur. (Caes., Gall. 1, 11)

„Helwetowie weszli na ziemie Eduów i pustoszyli ich pola.

Vim adhiberi ac metum placuit; itaque silentio noctis cum tectum villae qui ad id missi erant intrassent [...]. (Liv., 7, 39)

„Postanowiono użyć siły i zastraszenia; gdy wysłani w tym celu (żołnierze) weszli wśród nocnej ciszy do wnętrza domu [...]".

Superbe ab Samnitibus [...] legati prohibiti commercio sunt, contra ea benigne $a b$ Siculorum tyrannis adiuti. (Liv., 4, 52)

„Samnici w poczuciu dumy zabronili wysłańcom dokonania zakupów (zboża), zaś w przeciwieństwie do tego sycylijscy tyrani życzliwie ich wsparli".

Dum ero Laodiceae, id est ad Idus Maias. (Cic., Att. 6, 1, 24)

„Dopóki będę w Laodicei, to jest do Idów majowych (= 15 maja)”.

Użyty rzeczownikowo może cechować się koreferencją ze składnikiem zdania, w którym występuje, innym jednak niż podmiot lub funkcjonalny odpowiednik podmiotu (koreferencję z podmiotem lub jego odpowiednikiem sygnalizuje bowiem zaimek zwrotny):

Semper amavi, ut scis, M. Brutum propter eius summum ingenium, suavissimos mores, singularem probitatem atque constantiam. (Cic., Fam. 9, 14, 5)

„Zawsze kochałem, jak wiesz, Marka Brutusa, ze względu na jego charakter, miłe obyczaje, wyjątkową uczciwość i stanowczość". 
Deum adgnoscis ex operibus eius. (Cic., Tusc. 1, 70)

„Boga poznajesz z jego dzier”.

Może być koreferentny z podmiotem zdania, jeśli stanowi określnik drugiego podmiotu, pozostającego $\mathrm{z}$ pierwszym $\mathrm{w}$ relacji szeregowej:

Interfectus est [...] M. Fulvius consularis eiusque duo adulescentuli filii. (Cic., Phil. 8, 14) „Został zabity były konsul Marek Fulwiusz i jego dwaj mlodzi synowie”.

Może sygnalizować koreferencję $\mathrm{z}$ podmiotem lub dopełnieniem, samemu również wypełniając (redundatnie) te pozycje składniowe, jeśli wcześniej referent scharakteryzowany został jakimś innym rozbudowanym określnikiem zdaniowym lub niezdaniowym:

Arma [...], quae fixa in parietibus fuerant, ea sunt humi inventa. (Cic., Div. 1, 74)

„Broń, która zawieszona była na ścianach, znaleziona została na ziemi”.

(Numa) urbem novam conditam vi et armis, iure eam legibusque ac moribus de integro condere parat. (Liv., 1, 19)

„(Numa) Nowe miasto, zalożone z użyciem przemocy i broni, stara się na nowo powolać do życia przy użyciu prawa, ustaw i dobrych obyczajów".

' $H$ ' litteram, sive illam spiritum magis quam litteram dici oportet, inserebant eam veteres nostri plerisque vocibus verborum firmandis roborandisque. (Gall., Noc. Att. 2, 3,1)

„Gloskę 'H', czy też może należy ją nazywać raczej przydechem niż gloską, przodkowie nasi dodawali do wielu slów, aby wzmocnić i dodać sity ich brzmieniu".

W języku potocznym lub nacechowanym emocjonalnie koreferentny z podmiotem lub dopełnieniem i użyty (redundantnie) w tej samej funkcji składniowej zaimek może pojawić się również w sytuacji, gdy poprzedzający go linearnie określnik referenta nie jest rozbudowany i służy raczej jego identyfikacji niż charakterystyce:

Mihi sobrina Ampsigura tua mater fuit; pater tuos, is erat frater patruelis meus. (Pl., Poen. 1068-1069)

„Siostrą wujeczną była dla mnie twoja matka Ampsygura; a twój ojciec, to on zaś był moim bratem stryjecznym".

Amicos domini, eos habeat sibi amicos. (Cato, Agr. 5, 3)

„Przyjaciól pana (tych włánie) niech ma (i) za swoich przyjaciól".

Sed urbana plebes, ea vero praeceps erat. (Sall., Cat. 37)

„A miejski motloch, to ten dopiero rzucal się do dzialania całkiem na oślep".

Zaimek ten może również sygnalizować koreferencję ze składnikiem zdania syntaktycznie nadrzędnego. Składnikiem tym może być także podmiot, jeśli zdanie podrzędne (lub równoważnik zdania podrzędnego), w którym znajduje się zaimek, nie cechuje się tzw. „wewnętrzną zależnością", tzn. jeśli wyraża okoliczność zewnętrzną, a nie słowa, myśli, uczucia, intencje itp. przypisywane desygnatowi podmiotu zdania nadrzędnego ( $w$ takim bowiem przypadku koreferencję wyraża zaimek zwrotny): 
Caesar (ab Helvetis) obsides, arma, servos, qui ad eos perfugissent, poposcit. (Caes., Gall. $1,27)$

„Cezar zażądal (od Helwetów) zakładników, broni i niewolników, którzy do nich zbiegli”.

Fuit (Epaminondas) disertus, ut nemo ei Thebanus par esset eloquentia. (Nep., Epam. 5)

„Był (Epaminondas tak) wymowny, iż żaden Tebańczyk nie dorównywał mu elokwencją".

(Pleminius) mortuus [...] prius in vinclis est, quam iuducium de eo populi perficeretur. (Liv., 29, 22)

„(Pleminiusz) zmarł w więzieniu, zanim w jego sprawie zakończony został sąd przed ludem”.

Aratus $[\ldots]$, cum eius civitas quinquaginta annos a tyrannis teneretur, $[\ldots]$ clandestino introitu urbe est potitus. (Cic., Off. 2, 81)

„Aratus, gdy jego kraj od pięćdziesięciu już lat pozostawał w rękach tyranów, potajemnie wkroczywszy do miasta zawładnął nim".

Galba [...], missis ad eum undique legatis obsidibusque datis et pace facta, constituit cohortes duas in Nantuatibus conlocare. (Caes., Gall. 3, 1)

„Galba, po tym gdy zewsząd przysłano do niego posłów, wydano zakładników i zawarto pokój, postanowił rozmieścić dwie kohorty w kraju Nantuatów".

Niekiedy jednak zaimek anaforyczny sygnalizuje koreferencję z podmiotem zdania nadrzędnego wewnętrznie zależnego, stanowiąc tym samym ekwiwalent zaimka zwrotnego:

In quo genere Graeci $[\ldots]$ anteponunt $[\ldots]$ versutum et callidum factum Solonis, qui, quo $[\ldots]$ tutior eius $(=$ sua $)$ vita esset $[\ldots]$, furere se simulavit. (Cic., Off. 1, 108)

„Pod tym względem Grecy na pierwszym miejscu kładą podstępny i pomysłowy czyn Solona, który chcąc uczynić swe życie bezpieczniejszym, udał, że jest obłąkany".

Helwetii [...] persuadent Rauracis et Tulingis [...], uti [...] una cum iis proficiscantur. (Caes., Gall. 1, 5)

„Helwetowie naklaniają Rauraków i Tulingów, aby razem $z$ nimi (= Helwetami) ruszyli w droge".

Podobnie stanowić może ekwiwalent i zarazem koreferent zaimka względnego, występując $w$ zdaniu następującym po zdaniu względnym, które związane jest $\mathrm{z}$ nim stosunkiem współrzędności:

Sed omnes tum fere, qui nec extra urbem hanc vixerant neque eos aliqua barbaries domestica infuscaverat, recte loquebantur. (Cic., Brut. 258)

„Lecz wtedy niemal wszyscy, którzy mieszkali w tym mieście i nie otumaniło ich jakieś zepsucie językowe wyniesione $\mathrm{z}$ domu, mówili poprawnie".

Ipsius in mente insidebat species pulchritudinis eximia quaedam, quam intuens in eaque defixus ad illius similitudinem artem et manum dirigebat. (Cic., Orat. 9)

„W jego umyśle tkwila jakaś wyjątkowa wizja piękna, w którą wpatrując się i oczu od niej nie odrywając, na podobienstwo do niej kierował swą ręką i kszlałtował swe arcydzieła".

Koreferencja sygnalizowana przez ten zaimek obejmować może także treści wyrażane przez zdanie składniowo podrzędne (lub jeden z jego składników), poprzedzające linearnie zdanie nadrzędne, $w$ którym zaimek ten się znajduje: 
Bonine an mali sint, id haud quaeritant. (Pl., Men. 575)

"Czy są dobrzy, czy źli, tego nikt nie docieka".

Ne exstinctor patriae, ne proditor, ne hostis appelletur [...], id laborat, id metuit. (Cic., Sull. 88)

„By nie zostać nazwanym grabarzem ojczyzny, jej zdrajcą, wrogiem - tym się dręczy, tego się boi".

Qui multa simul incipit neque perficit, is festinat. (Cato, Or., fr. 131)

„Kto wiele rzeczy jednocześnie rozpoczyna i nie kończy, ten działa w pośpiechu”.

(w odniesieniu do 1 . os.:)

Fato datum erat, ut qui primus bellum intuli populo Romano [...], is ultro ad pacem petendam venirem. (Liv., 30, 30)

„Los sprawil, że ja, który jako pierwszy wypowiedziałem wojnę narodowi rzymskiemu, sam przychodzę prosić o pokój".

Jako podmiot przy orzeczeniu imiennym (lub jako funkcjonalny odpowiednik podmiotu przy odpowiedniku orzeczenia) zaimek ten często (choć nie zawsze) występuje w składni zgody $z$ orzecznikiem (funkcjonalnym odpowiednikiem orzecznika). W języku polskim tego rodzaju kongruencja nie występuje, a zaimek przyjmuje stałą formę o postaci „to":

Idem velle atque idem nolle, ea demum firma amicitia est. (Sall., Cat. 20, 4)

„Tego samego chcieć i tego samego nie chcieć, to jest dopiero mocna przyjaźñ".

Eas divitias, eam bonam famam magnamque nobilitatem putabant. (Sall., Cat. 7)

"To uważali za bogactwo, to za dobrą sławę i wielkie szlachectwo".

Labienus [...] cum quattuor legionibus Luteciam proficiscitur. Id est oppidum Parisiorum, positum in insula fluminis Sequanae. (Caes., Gall. 7, 57)

„Labienus z czterema legionami rusza do Lutecji. Jest to miasto Paryzjów, położone na wyspie znajdującej się w nurtach rzeki Sekwany".

Adfirmabant $[\ldots]$ consulatum superesse plebeiis; eam esse arcem libertatis, id columen. (Liv., 6, 37)

„Zapewniali, że (wlasnie) konsulatu brakuje plebejuszom; to jest (dopiero prawdziwa) twierdza wolności, to (jej) podpora".

ale:

Id tranquillitas erit. (Sen., Dial. 9, 2, 4)

"To będzie spokój ducha".

$\mathrm{W}$ połączeniu z poprzedzającym go atque, neque, et, sed... (quidem), lub następującym po nim -que, używany bywa dla uwydatnienia jakiejś szczególnej cechy, przypisywanej desygnatowi anaforyzowanego rzeczownika (tj. rzeczownika, do którego się odnosi). Odpowiada wtedy polskiemu „i to”; jeśli przypisanie danej cechy wiąże się z pewnym zastrzeżeniem, zaimek poprzedzany jest spójnikiem sed i nie znajduje zwykle polskiego odpowiednika: 
- Epistulam scripsi atque eam longam. =

- Epistulam scripsi et eam (quidem) longam. =

- Epistulam scripsi eamque longam. =

- Epistulam scripsi neque eam brevem.

- (= Epistulam scripsi et quidem longam.

- Epistulam scripsi et longam quidem.)

- „Napisałem list, i to długi (i to nie krótki)".

Est et alius ex historiis usus et is quidem maximus. (Quint., Inst. 10, 1, 34)

„Jest jeszcze i inny pożytek $\mathrm{z}$ historii, i to ogromny”.

In Galliam mutilatum ducit exercitum; cum una legione et ea vacillante $L$. fratrem exspectat. (Cic., Phil. 3, 31)

„Do Galii prowadzi uszczuplone wojsko; $\mathbf{z}$ jednym legionem, $\mathbf{i}$ to niepewnym (= na którym nie można polegać), czeka na brata Lucjusza".

Non intellegunt se hominis res gestas, et eius iuvenis, cum populi iam octingentesimum bellantis annum rebus conferre. (Liv., 9, 18)

„Nie rozumieją, że porównują czyny (jednego) człowieka, i to młodego, z dziejami narodu toczącego wojny już od ośmiuset lat".

Legionem neque eam plenissimam [...] propter paucitatem despiciebant. (Caes., Gall. 3, 2)

„Na legion, i to nie całkiem pelny, patrzyli z pogardą ze względu na jego niewielką liczebność".

Severitatem in senectute probo, sed eam [...] modicam. (Cic., Sen. 65)

„Aprobuję surowość u kogoś w starszym wieku, ale umiarkowaną".

$\mathrm{W}$ neutrum sg. w połączeniu $\mathrm{z}$ atque, et lub -que (tj. atque id, et id lub idque) używany jest do uwydatnienia jakiejś szczególnej okoliczności, charakteryzującej treść komunikowaną przez anaforyzowane wyrażenie; odpowiada wtedy również polskiemu „i to":

- Veniet nox atque id celeriter. $=$

- Veniet nox idque celeriter.

$\rightarrow \quad(=$ Veniet nox et celeriter quidem.

$\overrightarrow{-}=$ Veniet nox et quidem celeriter.)

- „Nadejdzie noc, i to wkrótce".

Negotium magnum est navigare atque id mense Quintili. (Cic., Att. 5, 12, 1)

„Wielkim utrapieniem jest żeglowanie, i to w lipcu”.

Cum hoc $[\ldots]$ decertandum est, idque confestim. (Cic., Phil. 5, 33)

„Z nim należy stoczyć rozstrzygającą walkę, i to natychmiast”.

Marce fili, annum iam audientem Cratippum idque Athenis abundare oportet praecepti: [...] philosophiae. (Cic., Off. 1, 1)

„Synu Marku, ktoś, kto już od roku słucha Kratypa, i to w Atenach, z pewnością dysponujধ sporym zasobem wskazówek filozoficznych".

Nec recito cuiquam nisi amicis idque coactus. (Hor., Serm. 1, 4, 73)

„I nie czylam (swoich utworów) nikomu, jak tylko przyjaciolom, i to przymuszony". 
Totos dies potabatur atque id locis pluribus. (Cic., Phil. 2, 67)

„Przez cale dnie pito, i to w wielu miejscach”.

Oprócz funkcji anaforycznej zaimek ten sekundarnie może również pełnić funkcję kataforyczną (antycypacyjną), odsyłając wprzód po linii tekstu do wyrażeń, które dopiero nastąpią $\mathrm{w}$ danym tekście. Także wówczas może przyjmować zarówno status przymiotnikowy:

Is collis, ubi castra posita erant, $[\ldots]$ tantum adversus in latitudinem patebat, quantum loci acies instructa tenere poterat. (Caes., Gall. 2, 8)

„To wzgórze, na którym rozłożony był obóz, było od przodu otwarte na szerokość odpowiadającą miejscu, jakie mógł zająć (= jakiego wymagał) ustawiony szyk bojowy".

Ea, quae secuta est, hieme [...] Germani [...] flumen Rhenum transierunt. (Caes., Gall. 4, 1) „Podczas tej zimy, która potem nastała, Germanie przekroczyli rzekę Ren”.

Germani [...] eo consilio Rhenum transierant, ut Ambiorigis finis depopularentur. (Caes., Gall. 6, 42)

„Germanie przeprawili się przez Ren z tym zamiarem, aby splądrować kraj Ambioryksa”.

Pedester exercitus, quod in ea loca erat deductus, ut invito Eumene elabi non posset, pacem ab eo petit. (Nep., Eum. 4)

„Piechota poprosila go o pokój, ponieważ została wciągnięta w takie miejsce, że wbrew woli Eumenesa nie mogla się (stamtąd) wydostać".

Ea tempora nostra sunt, ut ego iis mederi non possim. (Cic., Att. 10, 11, 1)

„Nasze czasy są takie, że nic na nie nie mogę poradzić”.

Ea est Romana gens, quae victa quiescere nesciat. (Liv., 9, 3)

„Naród rzymski jest taki, że pokonany nie potrafi zaznać spokoju".

Senatus $[\ldots]$ decrevit, uti consules $[\ldots]$ rem divinam facerent $[\ldots]$ cum precatione ea: 'quod senatus populusque Romanus de re publica [...] in animo haberet, ea res uti populo Romano [...] bene ac feliciter eveniret'. (Liv., 31, 5)

„Senat postanowil, aby konsulowie zlożyli ofiarę z następującymi slowami modlitwy: 'co senat $i$ lud rzymski zamierza $w$ sprawach publicznych, niech wyjdzie na dobro i szczęście narodu rzymskiego".

jak i rzeczownikowy:

Nihil $[\ldots]$ mihi videtur infelicius eo, cui nihil umquam evenit adversi. (Sen., Dial. 1, 3, 3) „Nic nie wydaje mi się większym nieszczęściem niż ktoś, komu nigdy nie przytrafiła się żadna przeciwność losu".

Ea dicimus, quae nescimus ipsi. (Cic., De orat. 2, 30)

"Mówimy to, czego sami nie wiemy".

Cur $[\ldots]$ ea probas, $[\ldots]$ quae sint inimica $[\ldots]$ dignitati tuae? (Cic., Phil. 10, 3)

„Dlaczego popierasz to, co nie licuje z twoją godnością?"

Cum $[. .$.$] dextram amplectens in id ne cui Romano traderetur fidem exposceret [...],$ amore captivae victor captus (est). (Liv., 30, 12) 
„Kiedy ściskając mu rękę, dopraszała się zapewnienia tego, że nie zostanie wydana żadnemu Rzymianinowi, zwycięzca zostal zniewolony milością do niewolnicy".

Valerius Messalinus [...] respondit [...] viri in eo culpam, si femina modum excedat. (Tac., Ann. 3, 34)

„Waleriusz Messalinus odpowiedział, że jest w tym wina męża, jeśli żona przekracza miarę".

Id quoque ait quaeri dignum, cur [...] mare omne incongelabile sit. (Gell., Noc. Att. 17, $8,16)$

"Twierdzi, że warte zbadania jest również to, dlaczego cale morze nie może zamarznąć".

Id huc revorti, uti me purgarem tibi. (Pl., Amph. 909)

"Wrócilem tu po to, by się przed tobą usprawiedliwić".

Naves [...] longas duodetriginta invenit instructas neque multum abesse ab eo, quin paucis diebus deduci possint. (Caes., Gall. 5, 2)

"Dowiaduje się, że zbudowano dwadzieścia osiem okrętów wojennych i że niewiele już brakuje do tego, by w ciągu kilku dni mogły one zostać spuszczone na wodę".

Lanuvinis [...] sacra sua [...] reddita, cum eo ut aedes lucusque Sospitae Iunonis communis Lanuvinis municipibus cum populo Romano esset. (Liv., 8, 14)

„Lanuwinom przywrócono ich kulty religijne, $z$ tym (jednak zastrzeżeniem), że świątynia i gaj Junony Sospity ma być miejscem kultu wspólnym dla mieszkańców Lanuvium i narodu rzymskiego".

Credo, id cogitasti: 'quidvis satis est dummodo vivat'. (Ter., Haut. 641)

„Sądzę, że pomyślałaś to (wlaśnie): 'wszystko jedno, byleby tylko żyła".

Użyty rzeczownikowo w neutrum sg. (id) zaimek ten stosowany również jest do antycypacji zdania względnego, odnoszącego się do całości zdania nadrzędnego, jeśli owo zdanie względne wtrącone jest w strukturę linearną zdania nadrzędnego, wyprzedzając jego główną myśl. Zaimek ten nie znajduje wtedy polskiego odpowiednika:

Belli peritus fuit et, id quod in tyranno non facile reperitur, minime libidinosus. (Nep., Reg. 2)

„Był doświadczony w prowadzeniu wojen i - co nie zdarza się często wśród tyranów - nie był wyuzdany".

Unum omnes illum prosequebantur, et, id quod numquam antea usu venerat nisi Olympiae victoribus, coronis aureis aeneisque vulgo donabatur. (Nep., Alc. 6)

„Wszyscy za nim tylko jednym szli i - co wcześniej praktykowano jedynie w stosunku do zwycięzców olimpijskich - został on obdarowany złotymi koronami i wstęgami".

Cum Scipione vixerim, quocum mihi coniuncta cura de publica re et de privata fuit [...] $e t$, id in quo est omnis vis amicitiae, voluntatum, studiorum, sententiarum summa consensio. (Cic., Lael. 15)

„Żyłem ze Scypionem, z którym lączyła mnie troska o sprawy publiczne i prywatne oraz - w czym przejawia się cala moc przyjaźni - pełna zgodność intencji, zainteresowań i poglądów". 
Non mihi quidem soli, sed, id quod admirari saepe soleo, maioribus quoque nostris hoc ita visum intellego mult is saeculis ante Socratem. (Cic., Tusc. 3, 8)

„Zauważam, że nie tylko mnie samemu, lecz także - czemu nieraz się dziwię - przodkom naszym podobnie się wydawalo na wiele wieków przed Sokratesem".

Specyficzne dla łaciny jest rzeczownikowe użycie formy rodzaju nijakiego tego zaimka, tj. id, w pozycji członu nadrzędnego syntagmy, której drugim (podrzędnym) elementem jest rzeczownikowa przydawka dopełniaczowa. Mimo składniowej nadrzędności $w$ ramach tej struktury, zaimek $i d, z$ uwagi na nieautonomiczny, wyłącznie kontekstowy (tj. anaforyczny lub kataforyczny) charakter jego semantyki, pełni de facto rolę określnika zależnego od niego rzeczownika w genetiwie, odsyłając do treści związanych z jego desygnatem. Realizując funkcję anaforyczną, aktualizuje (konkretyzuje) on znaczenie tego rzeczownika, tj. ogranicza jego zakres denotacyjny (ekstensję):

Advertere quosdam cultu externo in sedibus senatorum; et quinam forent rogitantes $[\ldots]$ audiverant earum gentium legatis id honoris datum, quae virtute et amicitia Romana praecellerent. (Tac., Ann. 13, 54)

„Zauważyli kilku ludzi w cudzoziemskich strojach na siedzeniach dla senatorów; dopytując się, co to za jedni, usłyszeli, że zaszczyt ten przyznano posłom tych ludów, które wyróżniają się męstwem i przyjaźnią wobec Rzymu".

Electos ex omnibus legionibus fortissimos viros [...] Caesar ei classi tribuerat, qui sibi id muneris depoposcerant. (Caes., Civ. 1, 67)

„Cezar przydzielił do tej floty wybranych ze wszystkich legionów najdzielniejszych żolnierzy, którzy uprosili dla siebie to zadanie".

Postquam ad id loci legati venerunt [...]. (Sall., Cat. 45, 3)

"Po tym, jak do tego miejsca przyszli posłowie [...]".

Id temporis ego adulescens Romae sectabar eum discendi gratia. (Gell., Noc. Att. 13, $18,3)$

„W tym czasie jako młodzieniec podążalem za nim w' Rzymic, by się (od niego) uczyć”.

Etsi nobis, qui id aetatis sumus, evigilatum fere est. (Cic., Rep. 3, 41)

„Chociaż my, którzy jesteśmy w tym wieku, raczej już nie zachow'ujemy stałej czujności”.

Si potuisset honeste scribere se in balneis cum id aetatis filio fuisse, non praeterisset. (Cic., Cluent. 141)

„Gdyby mógł uczciwie napisać, że był w laźni z synem w tym wieku, nie pominąłły tego”.

Z kolei realizując funkcję kataforyczną, odsyła do (następujących później) treści, stanowiących bliższą charakterystykę desygnatu owego rzeczownika:

Ad id ventum inopiae est, ut lora detractasque scutis pelles $[.$.$] mandere conarentur.$ (Liv., 23, 19)

„Doszło do takiego niedostatku, że (ludzie) próbowali przeżuwać rzemienie i zdarte z larcz skóry. 
Romanorum nemo id auctoritatis aderat, ut promissa eius magni penderentur. (Tac., Ann. 12, 18)

„Wśród Rzymian nie było nikogo o takim autorytecie, by jego obietnice mogły mieć jakieś większe znaczenie".

Id tantum hostium, quod ex adverso erat, conspexit. (Liv., 22, 4)

„Dostrzegl tylko tylu wrogów, ilu bylo naprzeciwko (niego)".

Te same funkcje, co zaimek is, tj. funkcję anaforyczną i kataforyczną, pełnią również zaimki przysłówkowe: ibi 'tam', eo 'tam, do tego miejsca', eodem 'tamże', inde 'stamtąd', ea 'tamtędy', tantum 'tyle', tum (tunc) 'wtedy', totiens 'tylekroć, tam, ita, sic 'tak' oraz przymiotnikowe: talis 'taki', tantus 'tak wielki', tot 'tylu'.

Te Syracusis natum esse dixisti: et hic natus est ibi. (Pl., Men. 1097)

„Powiedziałeś, że urodziłeś się w Syrakuzach: i ten (czlowiek również) tam się urodzil”.

Nemo $[. .$.$] est tam senex, qui se annum non putet posse vivere. (Cic., Sen. 24)$

„Nie ma (wśród nich) nikogo tak starego, by nie uważal, że może jeszcze pożyć przez rok”.

Plerique [...] habere talem amicum volunt, quales ipsi esse non possunt. (Cic., Lael. 82)

„Liczni pragną mieć takiego przyjaciela, jakim sami być nie potrafią".

Tum dona et grates deis decernuntur, $[\ldots]$ utque $[. .$.$] templum Saluti extrueretur eo loci,$ ex quo Scaevinus ferrum prompserat. (Tac., Ann. 15, 74)

„Następnie uchwalono dary i dziękczynienia dla bogów, oraz by zbudowano świątynię bogini Zbawienia w tym miejscu, z którego Scewinus zabral sztylet".

\subsubsection{Idem, eadem, idem (zaimek identyfikujący)}

Zaimek idem, eadem, idem 'taki sam', 'ten sam' wyraża pojęcie tożsamości (identyczności), w związku z czym jego sens czy też znaczenie aktualne (tj. występujące przy konkretnym użyciu) jest każdorazowo ustalane kontekstowo na zasadzie anafory bądź katafory. Może zajmować pozycje zarówno przymiotnikowe jak i rzeczownikowe.

Zajmując pozycje przymiotnikowe (przydawkowe lub orzecznikowe), przypisuje desygnatowi członu nadrzędnego charakterystykę identyfikowalną kontekstowo na zasadzie tożsamości (identyczności) poprzez:

1. odesłanie do treści wyrażonych wcześniej w toku wypowiedzenia, a więc na drodze anafory:

Tuam volt sororem ducere uxorem; et mihi sententia eademst. (Pl., Trin. 444-445)

„Chce pojąć za żonę twoją siostrę; i ja mam takie samo zdanie (na ten temat = również chcę tego)".

Sunt qui Artenam Veientium, non Volscorum fuisse credant; praebet errorem quod eiusdem nominis urbs inter Caere atque Veios fuit, sed eam reges Romani delevere. (Liv., 4,61 ) 
„Istnieją (historycy), którzy skłonni są uważać, że Artena należala do Wejentów, a nie do Wolsków; źródłem tej pomyłki jest to, że miasto o takiej samej nazwie znajdowało się miçdzy Cere a Wejami, ale zburzyli je królowie rzymscy".

Regulus accubans epulari coepit; mox idem ceteri omnes [...] faciunt et [...] avidius vino ciboque corpora onerant. Nequaquam eadem est tum rei forma apud Romanos: terra marique trepidatur, nautici tabernacula detendunt commeatumque in litore expositum in naves rapiunt. (Liv., 41, 2-3)

„Władca kładąc się przy stole, rozpoczął ucztę; wkrótce wszyscy pozostali czynią to samo i nader zachłannie pochłaniają wino i jedzenie. Zgoła nie taki sam stan rzeczy panuje wtedy wśród Rzymian: trwa gorączkowy pośpiech na lądzie i na morzu, marynarze zwijają namioty i wystawione na brzegu towary szybko znoszą na okręty".

2. odesłanie do treści wyrażonych później w toku wypowiedzenia (najczęściej w ramach zdania względnego lub innego zdania podrzędnego), a więc na drodze katafory:

Utinam lex esset eadem, quae uxori est, viro. (Pl., Merc. 823)

„Szkoda, że dla męża prawo nie jest takie samo, jakie jest dla żony”.

Fuit sponsa tua apud me eadem, qua apud soceros tuos [...], verecundia. (Liv., 26, 50)

„Twoja narzeczona cieszyła się u mnie takim samym szacunkiem, jakim (cieszyła się) u twoich teściów".

Amo [...] eodem pacto ut insani solent. (Pl., Merc. 262-263)

„Kocham w taki sam sposób, jak mają zwyczaj (kochać) szaleńcy”.

Często też zaimek ten służy zasygnalizowaniu lub podkreśleniu koreferencji członu nadrzędnego $z$ innym wyrażeniem użytym w wypowiedzeniu; wyrażenie to może, choć nie musi być tożsame również leksykalnie; może być także powierzchniowo niewyrażone (elidowane) lub określone dodatkowo innym zaimkiem:

(Cato) consulatum gessit cum L. Valerio Flacco [...]. Censor cum eodem Flacco factus, severe praefuit ei potestati. (Nep., Cato 2)

„(Katon) sprawowal konsulat razem z Lucjuszem Waleriuszem Flakkusem. Wybrany na cenzora wraz z tymże samym Flakkusem, surowo pelnił ten urząd".

Lycurgus [...] leges suas auctoritate Apollinis Delphici confirmavit; quas cum vellet Lysander commutare, eadem est prohibitus religione. (Cic., Div. 1, 96)

„Likurg wzmocnil swoje prawa autorytetem Apollina delfickiego; gdy Lizander chcial je zmienić, przez tę samą świętość zostal powstrzymany".

Austro lenissimo [...] ad Hydruntem [...] pervenimus eodemque vento postridie [...] Brundisium venimus. (Cic., Fam. 16, 9, 1)

„Przy bardzo łagodnym poludniowym wietrze dotarliśmy do Hydruntu i z tym samym wiatrem nazajutrz zawinęliśmy do Brundyzjum".

Qua nocte ad me venisti, eadem abis. (Pl., Amph. 532)

„Klórej nocy do mnie przybyłeś, (1o) tej samej odchodzisz". 
Amisissetis Asia, Quirites, nisi ad ipsum discrimen eius temporis divinitus Cn. Pompeium ad eas regiones Fortuna populi Romani attulisset. Huius adventus [...] Mithridatem insolita inflatum victoria continuit. [...] Quid? Idem iste Mithridates nonne ad eundem Cn. Pompeium legatum usque in Hispaniam misit? (Cic., Manil. 45-46)

„Utracilibyście Azję, Rzymianie, gdyby w krytycznym momencie tamtego okresu Fortuna ludu rzymskiego z boskiego zrządzenia nie przywiodla w te strony Gnejusza Pompejusza. Jego przybycie pohamowało Mitrydatesa pyszniącego się niezwykłym zwycięstwem. [...] A co? Czyż może tenże sam Mitrydates do tegoż właśnie Gnejusza Pompejusza nie wysłal posła aż do Hiszpanii?"

Sygnalizowanie czy podkreślanie koreferencji może mieć miejsce również w sytuacji, gdy składniowym nadrzędnikiem jest rzeczownikowo użyty zaimek, głównie wskazujący, który wtedy wspólnie z zaimkiem idem pełniącym funkcję przydawki odsyła do anaforyzowanego lub kataforyzowanego wyrażenia:

Caesar cum $[\ldots]$ se dimissurum oppugnationem diceret, universi ab eo ne id faceret petabant; sic se complures annos illo imperante meruisse, ut nullam ignominiam acciperent, numquam infecta re discederent [...]. Haec eadem centurionibus tribunisque militum mandabant, ut per eos ad Caesarem deferrentur. (Caes., Gall. 7, 17)

„Gdy Cezar zapowiadal, że przerwie oblężenie, wszyscy prosili go, by tego nie czynil; (mówili, że) przez tyle lat pod jego dowództwem tak postępowali, że nie okryli się żadną hańbą, i nigdy nie odstąpili od rozpoczętego dziela. Takie same (slowa) kierowali do centurionów i trybunów wojskowych, aby za ich pośrednictwem dotarly (one) do Ceazara".

Eam puellam hic senex amat efflictim, et item contra filius. [...] Postquam filium sensit suom eandem illam amare et esse impedimento sibi, hinc adulescentem peregre ablegavit pater. (Pl., Cas. 48-49, 60-61)

„W dziewczynie tej do szaleństwa zakochuje się ten tutaj stary, i tak samo z drugiej strony jego syn. (...) Ojciec po tym, gdy spostrzegl, że syn jego kocha tę samą (dziewczynę) i wchodzi mu w drogę, odprawil stąd mlodzieńca w podróż za granicę".

Pompeius eadem illa, quae per Scipionem ostenderat, agit. (Caes., Civ. 1, 6)

„Pompejusz mówi te same (rzeczy), które wcześniej przedstawił za pośrednictwem Scypiona (= Mówil wszystko to samo, co wcześniej...)".

Kontekstowe znaczenie tego zaimka, ustalane drogą anafory bądź katafory, ulega neutralizacji lub ograniczeniu w sytuacji, gdy zaimek ten nabiera znaczenia, które bliskie jest znaczeniu przymiotnikowemu i ma charakter raczej względny niż kontekstowy, tj. 'niezmienny, stały, (ciągle) ten sam'; 'jednakowy, równy, taki sam, identyczny'; 'ten sam' (w odniesieniu do kilku obiektów bądź okoliczności). W tym ostatnim znaczeniu zaimek idem wzmacniany jest czasem dodatkowo przez unus (unus idemque, unus et idem, unus atque idem, idem unusque itp. - 'jeden i ten sam').

Ex quo intellectum est [...] eos voluntatem semper eandem, libertatem non eandem semper habuisse. (Cic., Sest. 69)

„Na tej podstawie poznano, że zawsze mieli oni tę samą (dobrą) wolę, ale nie mieli zawsze tej samej wolności". 
Eadem est feminae marisque natura, eadem forma magnitudoque cornuum. (Caes., Gall. $6,26)$

„Taki sam jest wygląd samicy i samca, taki sam (jest) ksztatt i wielkość rogów”.

Erat difficile eodem tempore rapidissimo flumine opera perficere et tela vitare. (Caes., Civ. $1,50)$

„Trudno bylo w tym samym czasie prowadzić prace na bardzo bystrej rzece i osłaniać się przed pociskami".

Speluncam Dido dux et Troianus eandem deveniunt. (Verg., Aen. 4, 165-166)

„Dydona i wódz trojański dochodzą do tej samej jaskini”.

Neque uno, sed duobus pretiis unum et idem frumentum vendidisti. (Cic., Verr. 2, 3, 179)

„I nie za jedną, lecz za dwie zapłaty sprzedałeś jedno i to samo zboże".

Quasi vero non idem unumque bellum sit contra hoc iugum impiorum nefandum. (Cic., Phil. 11, 6)

„Jakby w istocie to nie jedna i ta sama wojna toczona była przeciwko tej zbrodniczej parze niegodziwców".

Zajmując pozycje rzeczownikowe, zaimek ten poprzez anaforę lub kataforę sygnalizuje koreferencję $z$ innym wyrażeniem użytym $w$ wypowiedzeniu; tym samym podkreśla bądź wskazuje na tożsamość (identyczność) obiektu, o którym orzeka się w wypowiedzeniu kilka różnych treści (przypisuje mu się kilka różnych cech) lub który stanowi element kilku ( $\mathrm{tj}$. dwu lub więcej) różnych predykacji (tzn. treści orzekanych o czymś/kimś).

Zaimek ten może na drodze anafory odsyłać do wyrażenia znajdującego się $\mathrm{w}$ zdaniu wcześniejszym lub $\mathrm{w}$ poprzedzającym zaimek zdaniu składowym zdania współrzędnie złożonego:

Tibi M. Bibulus quaerenti se de caelo servasse respondit, idemque in contione dixit [...] te omnino [...] tribunum non fuisse. (Cic., Dom. 40)

„Zapytany przez ciebie, Marek Bibulus odpowiedzial ci, że obserwowal niebo, i on też na zgromadzeniu powiedział, że w ogóle nie byleś trybunem ludu".

Ea primum moderatio tribuni metum patribus dempsit, aedemque auxit consulum invidiam. (Liv., 3, 59)

„Dopiero to umiarkowanie trybuna pozbawiło patrycjuszów strachu, lecz ono też jednocześnie zwiększyło ich niechęć do konsulów".

Veneri pol habeo gratiam, eandemque et oro et quaeso. (Pl., Mil. 1228)

„Wenerze okazuję życzliwość i równocześnie o nią też proszę i blagam”.

Bywa stosowany dla podkreślenia przeciwstawności (opozycyjności) treści przypisywanych w toku wypowiedzenia desygnatowi obu koreferentnych wyrażeń:

Sisenna [...] disputat somniis credi non oportere. Idem contra ostenta nihil disputat. (Cic., Div. 1, 99)

„Sisenna dowodzi, że w sny nie należy wierzyć. Jednocześnie jednak tenże sam (Sisenna) nie występuje przeciwko znakom wróżebnym". 
Valde me memorderunt epistulae tuae de Attica nostra; eaedem sane tamen sanaverunt. (Cic., Att. 13, 12, 1)

„Bardzo mnie zmartwiły twoje listy o naszej Attyce; $\mathbf{z}$ drugiej jednak strony zarazem zupelnie mnie one uspokoily".

W rodzaju nijakim może kontekstowo odsyłać do treści wyrażonych przez bardziej rozbudowane syntagmy bądź całe zdania:

Iuravit se nisi victorem in castra non reversurum, reliquosque ut idem facerent hortatus est. (Caes., Civ. 3, 87)

„Złożył przysięge, że powróci do obozu tylko jako zwycięzca i zachęcil pozostałych, by uczynili to samo".

Veterem in Hordeonium iram renovant, nec ullo legatorum tribunorumve obsistere auso [...] protractum e cubili interficiunt. Eadem in Voculam parabantur, nisi servili habitu [...] evasisset. (Tac., Hist. 4, 36)

„Na nowo wzniecają dawną nienawiść przeciw Hordeoniuszowi, i ponieważ żaden z legatów czy trybunów nie odważył sie sprzeciwić, wywlekają go z sypialni i mordują. To samo szykują wobec Wokuli, ale udało mu się ujść w przebraniu niewolnika".

Legatos ad consules mittunt [...] qui nuntiarent, ut [...] desertores de exercitu volonum conquirerent. Idem negotii P. Cornelii datum. (Liv., 25, 22)

„Wysylają do konsulów posłów z poleceniem, by odszukali zbiegów z wojska ochotników. To samo zadanie zlecono Publiuszowi Korneliuszowi".

Koreferencja sygnalizowana przez zaimek idem może dotyczyć także wyrażeń zawartych w tym samym co zaimek zdaniu:

Inerant feminae nobiles, inter quas uxor Arminii eademque filia Segestis. (Tac., Ann. 1, 57)

„Były tam kobiety powszechnie szanowane, wśród nich żona Arminiusza i zarazem córka Segestesa".

At qui sunt $i i$, qui rem publicam occupavere? Homines sceleratissumi, $[\ldots]$ nocentissumi et idem superbissumi. (Sall., Iug. 31)

„A kimże są ci, którzy okupowali rzeczpospolitą? To ludzie najbardziej zbrodniczy, szkodliwi i równocześnie najbardziej butni".

(Conon) contulit se ad Pharnabazum, satrapem Ioniae et Lydiae eundemque generum regis. (Nep., Con. 2)

"(Konon) udal się do Farnabazosa, satrapy Jonii i Lidii i zarazem zięcia króla".

Viros fortes et magnanimos eosdem bonos et simplices, veritatis amicos minimeque fallaces esse volumus. (Cic., Off. 1, 63)

„Chcemy, żeby ludzie dzielni i wielkoduszni byli równocześnie dobrzy i szczerzy, milujący prawdę i zupełnie pozbawieni falszu".

Podobnie jak w wyżej przywołanych przypadkach może podkreślać przeciwstawność (opozycyjność) treści przypisywanych w toku wypowiedzenia desygnatowi obu koreferentnych wyrażeń: 
Damocritus $[\ldots]$ rem magni discriminis consiliis nullam esse tam inimicam quam celeritatem dixit: celerem enim paenitentiam, sed eandem seram atque inutilem sequi, cum praecipita raptim consilia neque revocari neque in integrum restitui possint. (Liv., 31, 32)

„Damokrytos stwierdzil, że dla podejmowania decyzji o decydującym znaczeniu nic nie jest tak nieodpowiednie jak pośpiech; potem bowiem zwykle następuje szybka zmiana nastawienia, ale zarazem i tak już zbyt późna i bezużyteczna, skoro nagle podjętych decyzji nie można już odwołać i powrócić do pierwotnego stanu".

Zaimek ten występuje także w zdaniach złożonych o charakterze względnym, przybierając charakter korelatywny (współwzględny) i sygnalizując koreferencję z zaimkiem względnym. Jeśli poprzedza zdanie względne, wskazuje na współwyrażany przez oba zaimki obiekt, odsyłając do zaimka względnego poprzez kataforę:

Patres militarent, patres arma caperent, ut penes eosdem pericula belli, penes quos praemia, essent. (Liv., 2, 24)

„Niech patrycjusze idą na wojnę, patrycjusze niech dobywają mieczy, aby ci sami (ludzie) narażali się na niebezpieczeńsıwa wojny, kıórzy czerpią z niej korzyść".

Dixi $[\ldots]$ eosdem esse, qui Bibulum exire domo prohibuissent et qui me coegissent. (Cic., Fam. 1, 9, 7)

„Powiedziałem, że ci, którzy Bibulusowi wyjść z domu nie pozwolili, i ci, klórzy mnie (do wyjścia z domu) przymusili, to są (jedni i) ci sami ludzie".

Tu fac idem quod rogas me. (Pl., Pers. 43)

"Ty zrób to samo, o co mnie prosisz".

Jeśli występuje po zaimku względnym, odsyła do niego na drodze anafory:

Servio occiso quemcumque alium generum (rex) delegisset, eundem regni heredem facturus videbatur. (Liv., 1, 40)

„Gdyby Serwiusz został zabity, to jakiegokolwiek innego król wybrałby sobie zięcia, prawdopodobnie uczynitby go również dziedzicem tronu".

Ex quo efficitur, ut quidquid honestum sit, idem sit utile. (Cic., Off. 2, 10)

„Z tego wynika, że wszystko, co jest moralnie dobre, jest równocześnie pożyteczne”.

Qui fortis est, idem est fidens. (Cic., Tusc. 3, 14)

„Kto jest dzielny, to ten jest też ufny w sicbie”.

podkreślając przeciwstawność (opozycyjność) treści przypisywanych desygnatowi obu koreferentnych wyrażeń:

Vix [...] veri simile est, qui iudicaverint hostem Dolabellam ob rectissimum facinus, eosdem nobis parcere posse idem sentientibus. (Cic., Phil. 13, 36)

„Jest malo prawdopodobne, by ci, którzy uznali Dolabellę za wroga z tego powodu, że dobrze postąpil, mogli równocześnie uszanować nas, którzy mamy takie same (jak Dolabella) poglądy".

Hoc [...] mihi mirum videri solet, quod, qui tranquillo mari gubernare se negent posse [...], iidem ad gubernacula se accessuros profiteantur excitatis maximis fluctibus. (Cic., Rep. 1, 11) 
„Zwykle mnie zadziwia to, że ci, którzy twierdzą, iż przy spokojnym morzu nie mogą sterować (nawą państwową), oświadczają zarazem, że staną przy sterze, gdy nadejdzie wielki sztorm".

wskazując na konieczną konsekwencję lub towarzyszącą okoliczność:

Maiores aliud ius gentium, aliud ius civile esse voluerunt, quod civile, non idem continuo gentium, quod autem gentium, idem civile esse debet. (Cic., Off. 3, 69)

„Przodkowie uznali, że czym innym jest prawo narodów, a czym innym prawo cywilne, i że to, co należy do prawa cywilnego, nie musi rówocześnie znajdować się także $w$ prawie narodów, lecz to, co należy do prawa narodów, powinno znajdować się też $w$ prawie cywilnym".

Podobnie jak w użyciu przymiotnikowym, również zajmując pozycje rzeczownikowe zaimek ten może zatracać kontekstowy (anaforyczny bądź kataforyczny) charakter, przybierając znaczenie bardziej względne, tj. '(jedno i) to samo', '(jedna i) ta sama rzecz/osoba' (co przedtem, co zawsze; $w$ różnych okolicznościach, w odniesieniu do różnych obiektów):

Adeon homines inmutarier ex amore, ut non cognoscas eundem esse! (Ter., Eun. 225-226)

„Doprawdy ludzie tak zmieniają się pod wpływem milości, że trudno poznać, iż to ten sam czlowiek".

Nisi eundem et adversarium et testem habuerit Roscius, nolo vincat. (Cic., Q. Rosc. 9)

„Jeśli tego samego czlowieka Roscjusz nie będzie miał i za przeciwnika, i za świadka, to nie chcę, by wygraf".

Omnes idem volunt, idem defendunt, idem sentiunt. (Cic., Phil. 8, 8)

„Wszyscy tego samego pragną, tego samego bronią, to samo myślą".

Non omnes eadem mirantur amantque. (Hor., Epist. 2, 2, 58)

"Nie wszyscy podziwiają i kochają to samo".

Idem esse dicebat Socrates veritatem et virtutem. (Sen., Lucil. 71, 16)

„Sokrates powiadal, ze jednym i tym samym jest prawda i cnota".

W bliskim związku z omawianym zaimkiem pozostaje przysłówkowy zaimek item ('tak samo', 'w ten sam sposób', 'podobnie', 'również'), który odsyła do wcześniej wyrażonych treści predykatywnych lub atrybutywnych, sygnalizując ich aktualność w odniesieniu do innego (kolejnego) obiektu lub okoliczności. Tym zamym implikuje on elipsę anaforyzowanych wyrażeń predykatywnych lub atrybutywnych, co pozwala na uniknięcie ich powtórzeń:

Docet se Manlium praemisisse ad eam multitudinem, quam ad capiunda arma paraverat, item alios in alia loca opportuna, qui initium belli facerent. (Sall., Cat. 27)

„Informuje, że Manliusza wystal naprzód do tego thumu, który już uprzednio przygotowal do zbrojnego wystąpienia, i tak samo (wyslał) innych do różnych dogodnych miejsc, aby rozpoczęli wojnę".

Appetitio animi $[\ldots]$ non ad quodvis genus vitae, sed ad quandam forma vivendi videtur data, itemque et ratio et perfecta ratio. (Cic., Fin. 3, 23) 
„Wydaje się, że duchowy zapał zostal nam dany nie dla jakiegokolwiek rodzaju życia w ogólności, lecz z przeznaczeniem dla pewnego określonego sposobu bytowania, i tak samo też rozum i doskonały rozum (zostal nam dany dla określonego sposobu bytowania)".

Występując z przeczeniem, często nie znajduje bezpośredniego polskiego odpowiednika:

Hoc Herculi, lovis satu edito, potuit fortasse contingere, nobis non item. (Cic., Off. 1, 118)

„Być może Herkulesowi, zrodzonemu z posiewu Jowisza, mogło się to przydarzyć, nam nie (moglo się to przydarzyć)".

O spectaculum uni Crasso iucundum, ceteris non item! (Cic., Att. 2, 21, 4)

„O widowisko dla jednego tylko Krassusa mile, dla innych nie (mile)!"

Może także mieć charakter korelatywny (współwzględny), w połączeniu z ut, quemadmodum, quasi, quam si, atque:

Ut adhuc me attente audistis, item quae reliqua sunt audiatis. (Cic., Cluent. 66)

"Tak, jak do tej pory uważnie mnie słuchaliście, tak samo wysłuchajcie pozostałych rzeczy".

Cogita [...] item nos perhiberi quam si salsa muriatica esse autumantur. (Pl., Poen. 240-241)

„Pomyśl, że tak samo o nas się mówi, jak mówi się o marynowaniu słonych ryb”.

\subsubsection{Ipse, ipsa, ipsum (zaimek izolujący / intensyfikujący)}

Zaimek ipse 'sam' używany jest zarówno przymiotnikowo, jak i rzeczownikowo. Pod względem semantycznym można go określić jako izolujący albo intensyfikują$c y$, ponieważ jego podstawową funkcją jest wyodrębnianie i uwydatnianie elementu, który w toku wypowiedzenia jest wyróżniany lub - explicite bądź implicite - przeciwstawiany innym:

(Cimon) decem annorum exilio multatus est, cuius facti celerius Athenienses quam ipsum paenituit. (Nep., Cim. 3)

„(Kimon) skazany zostal na dziesięcioletnie uygnanie, czego wcześniej pożałowali Ateńczycy niż on sam".

Ibi mihi Tulliola mea fuit praesto natali suo ipso die. (Cic., Att. 4, 1,4)

„Tam przybyła do mnie moja Tulliola, dokładnie w sam dzień swoich urodzin”.

Thraces [...] ea, quae (Alcibiades) apportarat, abstulerunt, ipsum capere non potuerunt. (Nep., Alc. 9)

„Trakowie zrabowali wszystko, co Alkibiades wiózł ze sobą, jego samego jednak pojmać nie zdolali".

Ta opozycyjna, izolująca i zarazem intensyfikująca funkcja zaimka ipse wymaga często użycia różnych polskich odpowiedników, w zależności od kontekstu: 
1. '(on) sam (też/zaś)' (obok, oprócz, w opozycji do lub w odróżnieniu od innych/ pozostałych osób/rzeczy):

Super alios alii nuntiant dictatori omnes legiones Etruscorum capessisse pugnam [...], et ipse cernit ex superiore loco in quanto discrimine praesidium esset. (Liv., 10, 5)

"Gońcy kolejno donoszą dyktatorowi, że już wszystkie legiony etruskie podjęły walkę, a i on sam widzi z pagórka, w jak trudnym polożeniu jest załoga garnizonu".

Reliquos (hostes) atque ipsum Octavium in naves confugere coegerunt. (Caes., Civ. 3, 9)

„Pozostałych nieprzyjaciół i samego Oktawiusza zmusili do ucieczki na okręty”.

Legioni tribunus Vipstanus Messala praeerat, claris maioribus, egregius ipse. (Tac., Hist. 3, 9) „Na czele legionu jako trybun stał Wipstanus Messala, pochodzący od sławnych przodków, sam też człowiek wybitny".

Consul, quia collegae decretum triumphum audivit, ipse quoque triumphi ante victoriam flagitator Romam rediit. (Liv., 8, 12)

„Konsul, ponieważ usłyszał, że koledze jego uchwalono tryumf, sam także domagając się tryumfu, (jeszcze) przed zwycięstwem wrócił do Rzymu".

Contionatus apud milites $[. .$.$] mancipia aqtue inpedimanta in Italia relinquerent, ipsi$ expediti naves conscenderent, [...] II Nonas Ianuarias naves solvit. (Caes., Civ. 3, 8)

„Zwróciwszy się nazgromadzeniu do żołnierzy, by niewolników i bagaże pozostawili w ltalii, sami zaś bez obciążenia wsiedli na okręty, w przeddzień Nonów styczniowych podnosi kotwice".

Dulce [...] nomen est pacis, res vero ipsa cum iucunda tam salutaris. (Cic., Phil. 13, 1)

„Słodkie jest slowo 'pokój', zaś sama (nazwana nim) rzecz tak miła, jak i zbawienna".

Eapse $^{12}$ merum condidicit bibere, foribus dat aquam quam bibant. (Pl., Curc. 161)

(iron.) „Sama nauczyła się pić czyste wino, a drzwiom daje do picia wodę (tj. polewając zawiasy, by nie skrzypiaty)".

A. Cornelius dictatorem Mam. Aemilium dixit et ipse ab eo magister equitum est dictus. (Liv., 4, 31)

„Aulus Korneliusz mianował dyktatorem Mamerkusa Emiliusza, a sam został przez niego mianowany dowódcą jazdy".

Hac cum spe dimissi Tarentini. Ipsum ingens cupido incesserat Tarenti potiundi. (Liv., $24,13)$

„Z taką nadzieją odesłani zostali Tarentyjczycy. Jego zaś samego ogarnęło wielkie pragnienie zawładnięcia Tarentem".

2. 'osobiście', 'samemu', 'we własnej osobie':

Ancillae tuae credidi [...], tu mihi non credis ipsi? (Cic., De orat. 2, 276)

„Uwierzyłem twojej niewolnicy, a ty nic wierzysz mnie samemu (mnie osobiście)?”

Lippitudo haec, propter quam non ipse ad te scribo. (Cic., Att. 10, 14, 1)

„To zapalenie oczu, z powodu którego nie piszę do ciebie osobiście”.

12 Klas. ipsa. 
Asellio [...] res [...] eas, quibus gerendis ipse interfuit, conscripsit. (Gell., Noc. Att. 2, 13, 3)

„Asellio dokładnie opisał te działania, w których przeprowadzeniu brał osobiście udział".

Has tabellas [...] ipsi Lemniseleni fac des. (Pl., Pers. 195-196)

„Przekaż te tabliczki Lemniselenis we własnej osobie (do rąk wlasnych)”.

3. '(on) sam tylko,' '(on) sam jedynie’:

Exercitus maximos saepe pulsos et fugatos esse dico terrore ipso impetuque hostium sine cuiusquam non modo morte verum etiam volnere. (Cic., Caec. 41)

„Twierdzę, że ogromne wojska wielokrotnie zostały pokonane i przepędzone samym tylko strachem spowodowanym natarciem nieprzyjaciól, gdy nikt nie zostal nie tylko zabity, ale nawet ranny".

Interrogas quid petam ex virtute? Ipsam. (Sen., Dial. 7, 9, 4)

„Pytasz, co chcę osiągną́ dzięki cnocie? Jedynie ją samą (i nic innego)”.

4. 'samodzielnie', 'z własnej woli', 'dobrowolnie':

Helorum atque Herbesum dedentibus ipsis recipit. (Liv., 24, 35)

„Odzyskuje miasta Helorus i Herbesus, które dobrowolnie poddaty się".

Catilinam [...] ipsum egredientem verbis prosecuti sumus. (Cic., Catil. 2, 1)

„Katylinę odchodzącego $\mathbf{z}$ wlasnej woli wsparliśmy słowami”.

5. 'właśnie', 'dokładnie':

Te ipsum quaero. (Ter., Adelph. 266)

„Wlaśnie ciebie szukam”.

Castoris aedis [...] vota erat Latino bello a Postumio dictatore; filius eius duumvir ad id ipsum creatus dedicavit. (Liv., 2, 42)

„Wzniesienie świątyni Kastora ślubowal w czasie wojny latyńskiej dyktator Postumiusz; aktu poświęcenia dokonal jego syn, właśnie w tym celu mianowany duumwirem".

Cum Athenis decem ipsos dies fuissem [...], proficiscebar inde prid. Non. Quint. (Cic., Fam. 2, 8, 3)

„Po tym jak spędzilem w Atenach dokladnie dziesięć dni, ruszylem stamtąd w drogę szóstego lipca".

(Crassus) triennio ipso minor (fuit) quam Antonius. (Cic., Brut. 161)

"(Krassus) był dokdadnie o trzy lata mlodszy od Antoniusza".

Opportune te mihi, Phidippe, in ipso tempore ostendis. (Ter., Hec. 626-627)

"Szczęśliwie zjawiasz mi się, Fidypie, dokJadnie na czas ( $w$ samą porę)".

W odniesieniu do treści wyrażanych przysłówkiem stosowana jest forma w rodzaju nijakim (ipsum):

Nunc tamen ipsum sine te esse non possum. (Cic., Att. 12, 16)

„Jednak wlaśnie teraz nie mogę być bez ciebie". 
6. 'nawet', 'sam':

Ipse sapiens sustinet se in furore ne adprobet falsa pro veris. (Cic., Lucull. 53)

„Nawet (sam) mędrzec, gdy jest uniesiony gwałtownym uczuciem, powstrzymuje się (od wydania osądu), by nie uznać fałszu za prawdę".

Nobis monendi sunt ii $[\ldots]$, qui $[\ldots]$ dici se desiderant Atticos $[\ldots]$, ut mirentur hunc maxume, quo ne Athenas quidem ipsas magis credo fuisse Atticas. (Cic., Orat. 23)

„Muszę przypomnieć rym, którzy chcą być nazywani (mówcami) attyckimi, aby z podziwem patrzyli przede wszystkim na tego (scil. Demostenesa), od którego, jak sądzę, nawet same Ateny nie były bardziej attyckie".

Podobną intensyfikującą funkcję zaimek ten posiada występując przy zaimku dzierżawczym, osobowym i zwrotnym.

Przy zaimku dzierżawczym odnoszącym się do innego elementu niż podmiot zdania zaimek ipse używany jest w genetiwie:

Contentus ero nostra ipsorum amicitia. (Cic., Fam. 6, 16)

"Zadowolę się naszą wlasną tylko przyjaźnią" / „Zadowolę się przyjaźnią tylko nas samych”.

Deae providentis adorabile beneficium meamque ipsius fortunam memorabilem narraverat. (Apul., Met. 11, 18)

„Opowiedziała o czcigodnym dobrodziejstwie opatrznościowej bogini i o mym własnym niezwykłym losie".

Ferunt $[\ldots]$ Hannibalem $[. .$.$] deos hominesque accusantem in se quoque ac suum ipsius$ caput exsecratum. (Liv., 30, 20)

„Powiadają, że Hannibal oskarżając bogów i ludzi, również na siebie i swą wlasną głowę rzucał przekleństwa".

Jeśli zaimek dzierżawczy odnosi się do podmiotu, ipse najczęściej występuje w nominatiwie:

Tute introspice in mentem tuam ipse. (Cic., Fin. 2, 118)

"Ty sam wejrzyj w swoje serce".

Iulius Celsus tribunus in vinclis laxatam catenam $[\ldots]$ in diversum tendens suam ipse cervicem perfregit. (Tac., Ann. 6, 14)

„Trybun Juliusz Celsus ciągnąc $w$ więzieniu rozluźniony lańcuch $w$ przeciwne strony, sam skręcil swój kark".

Ego tui Bruti rem sic ago, ut suam ipse non ageret. (Cic., Att. 5, 18, 4)

„Sprawę twojego Brutusa tak prowadzę, jak sam swojej by nie poprowadził”.

Nos id potissimum consecuti sumus, $[\ldots]$ ut nostram ipsi sententiam tegeremus. (Cic., Tusc. 5, 11)

„Do tego przede wszystkim dążyliśmy, by ukryć nasze własne zdanie”.

Eam vos fraudem deum primo benignitate, dein vestra ipsi virtute [...] vitastis. (Liv., $24,38)$ 
„Wy tego podstępu uniknęliście wpierw dzięki laskawości bogów, a następnie dzięki waszemu wlasnemu męstwu".

Rzadziej w takim kontekście używany jest w genetiwie:

Huiusce rei coniecturam de tuo ipsius studio, Servi, facillime ceperis. (Cic., Mur. 9)

„Wniosek, jaki nasuwa się z tej sprawy, latwo zrozumiesz, Serwiuszu, na podstawie twojego wlasnego zaangażowania".

Nostram ipsorum libertatem subrui et temptari patimur. (Liv., 41, 23)

„Pozwalamy, by nasza własna wolność byla podważana i wystawiana na próbę".

Do wyrażania stosunków dzierżawczch (i im podobnych) w odniesieniu do trzeciej osoby stosowany też bywa sam zaimek ipse w genetiwie (ipsius/ipsorum), w miejsce zaimka dzierżawczo-zwrotnego (suus) lub anaforycznego (eius/eorum):

(Caesar) certior factus hostes sub monte consedisse milia passuum ab ipsius castris octo, qualis esset natura montis [...] qui cognoscerent misit. (Caes., Gall. 1, 21)

"(Cezar) powiadomiony o tym, że nieprzyjaciele zajęli pozycje u podnóża góry w odległości ośmiu tysięcy kroków od jego obozu, wyslal (ludzi), by zbadali naturalne wlaściwości (owej) góry".

Nec in eum consules acrius quam ipsius collegae coorti sunt. (Liv., 2, 43)

„Nawet konsulowie nie wystąpili przeciw niemu ostrzej niż jego koledzy (na urzędzie)".

Demochares $[\ldots]$ earum rerum historiam, quae erant Athenis ipsius aetate gestae $[\ldots]$ perscripsit. (Cic., Brut. 286)

„Demochares spisal dzieje tych wydarzeń, które rozgrywały się w Atenach w jego czasach”.

Conveniunt duces [...]; intellegabant omnes tam celeriter copias ipsorum contrahi non posse, quam Antigonus adfuturs videbatur. (Nep., Eum. 9)

„Zbierają się wodzowie; wszyscy zdawali sobie sprawę, że niemożliwe jest ściągnięcie ich wojsk w tak krótkim czasie, w jakim mógł nadejść Antygonus".

Przy zaimku osobowym i zwrotnym zaimek ipse występuje w składni zgody albo $z$ podmiotem (tzn. użyty jest $w$ nominatiwie), albo $z$ zaimkiem osobowym lub zwrotnym - w zależności od dyktowanego kontekstem ukierunkowania przeciwstawienia:

Me ipse consolor. „Sam się pocieszam” (nikt inny mnie nie pociesza).

Me ipsum consolor. „Pocieszam samego siebie” (a nie kogoś innego).

Puer sibi ipse nocet. „Chłopiec szkodzi sobie sam” (nikt inny mu nie szkodzi).

Puer sibi ipsi nocet. „Chłopiec szkodzi samemu sobie” (a nie komuś innemu).

Veritas se ipsa defendit. „Prawda broni się sama” (nie musi jej bronić nikt inny).

Veritas se ipsam defendit. „Prawda broni samej siebie” (a nie czegoś innego).

Nosce te ipse! „Sam poznaj siebie!” (nie czekaj, aż poznają cię inni).

Nosce te ipsum! „Poznaj samego siebie!” (a nie kogoś innego). 
Medice, cura te ipse! „Lekarzu, sam się lecz!” (nie czekaj, aż wyleczą cię inni).

Medice, cura te ipsum! „Lekarzu, lecz samego siebie!” (a nie innych).

In templo Herculis valvae $[\ldots]$ subito se ipsae aperuerunt. (Cic., Div. 1, 74)

„W świątyni Herkulesa drzwi nagle same się otworzyły”.

Populus me sibilat; at mihi plaudo ipse domi. (Hor., Serm. 1, 1, 66-67)

„Lud mnie wygwizduje, a ja sam przyklaskuję sobie w domu”.

Noctu ad unum omnes desperata salute se ipsi interficiunt. (Caes., Gall. 5, 37)

„Nocą, straciwszy nadzieję na ocalenie, wszyscy co do jednego sami pozbawiają się życia”.

Pompeianus miles fratrem suum, dein cognito facinore se ipsum interfecit. (Tac., Hist. $3,51)$

„Żołnierz pompejański (nieświadomie) zabił swego brata, potem zaś, rozpoznawszy swą zbrodnię, siebie samego".

Praecipitur, ut nobismet ipsis imperemus. (Cic, Tusc. 2, 47)

„Daje się zalecenie, byśmy sobie samym rozkazywali".

In tenebris et multitudine semet ipsa impediente [...] Charilaus [...] ab sociis in urbem receptus $[. .$.$] tolli clamorem iussit. (Liv., 8,26$ )

„W ciemnościach, gdy tłum sam sobie przeszkadzal, Charylaus wpuszczony do miasta przez wspólników, nakazał wznieść okrzyk".

Często jednak spotyka się odstępstwa od ścisłego przestrzegania tych zasad; istnieje wyraźna tendencja polegająca na preferencji składni zgody z podmiotem. Dzieje się to zwłaszcza w ramach struktury per se ipse (obok ipse per se), podobnie jak w jej polskim odpowiedniku, tj. „sam przez się":

Non ita abundo ingenio, ut te consoler, cum ipse me non possim.(Cic., Fam. 4, 8, 1)

„Nie mam aż tyle telentu, by pocieszyć ciebie, kiedy samego siebie nie mogę".

Hostes populi Romani [...] fuimus primum per nos ipsi quoad nostra arma, nostrae vires nos tutari poterant; postquam his parum fidebamus, Pyrrho regi nos adiunximus. (Liv., 23, 42)

„Byliśmy wrogami narodu rzymskiego najpierw' sami przez się, dopóki chronić nas mogły nasze wojska i nasze siły; gdy już nie mogliśmy na nich polegać, przyłączyliśmy się do króla Pyrrusa".

Virtus [...] est per se ipsa laudabilis. (Cic., De orat. 2, 343)

"Cnota jest sama przez się chwalebna”.

Praesertim cum is ardor, qui est mundi, non agitatus ab alio neque externo pulsu, sed per se ipse ac sua sponte moveatur. (Cic., Nat. 2, 31)

„Zwlaszcza że ów ogień, który jest charakterystyczny dla świata, porusza się nie wskutek oddziaływania czegoś innego czy pod wpływem zewnętrznego impulsu, lecz sam przez się i $z$ wlasnej woli".

Aequitas lucet ipsa per se. (Cic., Off. 1, 30)

„Słuszność jest jasna sama przez się (= jest oczywista, nie budzi wątpliwości)”. 
Quid est cur virtus ipsa per se nonefficiat bonos? (Cic., Tusc. 5, 17)

„Dlaczegoż cnota sama przez się nie mialaby czynić ludzi szczęśliwymi?”

Zaimek ipse pojawia się też $w$ zdaniach podrzędnych wewnętrznie zależnych, gdzie sygnalizuje koreferencję $\mathrm{z}$ podmiotem zdania nadrzędnego, a więc zajmuje pozycję wypełnianą zwykle przez zainek zwrotny. Dzieje się tak dla wzmocnienia kontrastu i ujednoznacznienia referencji w przypadku, gdy współwystępujący z nim zaimek zwrotny lub dzierżawczo-zwrotny odsyła do podmiotu (własnego) zdania podrzędnego:

(Caesar) ad [...] consilium adhibitis centurionibus vehementer eos incusavit, $[\ldots]$ cur de sua virtute aut de ipsius diligentia desperarent. (Caes., Gall. 1, 40)

"(Cezar) wezwawszy na zgromadzenie centurionów, ostro ich zganil (pytając), z jakiegoż powodu mieliby zwątpić w swoją waleczność bądź w jego (Cezara) zapobiegliwość".

Neque vero his rebus (Lacedaemonii) amici Alcibiadi sunt facti $[\ldots]$, nam $[\ldots]$ pertimuerunt, ne caritate patriae ductus aliquando ab ipsis descisceret et cum suis in gratiam rediret. (Nep., Alc. 5)

„Wskutek tych wydarzeń Spartanie nie stali się przyjaciólmi Alkibiadesa, bowiem ogarnąl ich strach, że wiedziony milością do ojczyzny kiedyś od nich odstąpi i pojedna się ze swoimi".

Czasem jednak stosowany jest zaimek ipse również wtedy, gdy kontekst wykluczałby ewentualną dwuznaczność zaimka zwrotnego lub anaforycznego, użytego w jego miejsce; stosowany jest więc wyłącznie w celu emfazy, dla podkreślenia zwrotności czy wzajemności wyrażanych w zdaniu relacji:

Iugurtha $[\ldots]$ legatos ad consulem [...] mittit, qui tantummodo ipsi liberisque vitam peterent. (Sall., Iug. 46)

„Jugurta wysyła do konsula posłów, którzy mieli prosić o darowanie życia tylko jemu samemu i (jego) dzieciom".

Quae in ipsum valebant crimina, contulit in illum. (Cic., Verr. 2, 1, 41)

„Oskarżenia wysuwane przeciwko sobie przeniósł na tamtego".

Rex $[\ldots]$ Piraeum pergit, ut dum Philocles [...] comminanda [...] oppugnatione contineret urbe Athenienses, ipsi Piraeum [...] expugnandi facultas esset. (Liv., 31, 26)

„Król kieruje się w stronę Pireusu, aby w czasie, gdy Filokles grożąc szturmem zatrzyma Ateńczyków w mieście, on sam mial okazję do zajęcia Pireusu".

Linquit Calydonius heros concilium [...], ipsi ceu regna negentur. (Stat., Theb. 2, 476-477)

„Opuszcza kalidoński bohater zebranie, jakby jemu samemu odmawiano władzy”.

Illa $[\ldots]$ sapientia $[\ldots]$ rerum est divinarum et humanarum scientia, in qua continetur deorum et hominum communitas est societas inter ipsos. (Cic., Off. 1, 153)

„Owa mądrość polega na znajomości spraw boskich i ludzkich, która obejmuje także rozeznanie wspólnoty bogów i ludzi oraz ich powiązania $z$ sobą".

Wreszcie zaimek ipse w nominatiwie może być też wtrącany w obręb struktury równoważnika zdaniowego o postaci ablativus absolutus, jeśli funkcjonalny odpowiednik orzeczenia ma formę participium perfecti passivi i sygnalizuje diatezę bierną, 
zaś agens wyrażanej przez to participium czynności (pierwszy argument wyrażanego przez nie predykatu) jest tożsamy $z$ desygnatem podmiotu zdania nadrzędnego. Zaimek ipse przy równoważniku stanowi wówczas wykładnik owego agensa, sygnalizując równocześnie jego tożsamość $\mathrm{z}$ desygnatem podmiotu zdania nadrzędnego i wchodząc $z$ podmiotem $w$ formalny związek zgody (kongruencji) pod względem kategorii przypadka, liczby i rodzaju:

(Sempronius) causa ipse pro se dicta [...], quindecim milibus aeris damnatur. (Liv., 4, 44) „(Semproniusz), przeprowadziwszy samemu proces $w$ swojej obronie, został skazany na piętnaście tysięcy asów (grzywny)".

Imperatores [...] iunctis et ipsi exercitibus [...] ad sedem hostium pervenere. (Liv., 29, 2)

"Wodzowie, sami również połączywszy (swe) wojska, dotarli do siedziby nieprzyjaciól."

Quid [...] aliud nobis quam caedem Crassi, amisso et ipse Pacoro, infra Ventidium deiectus Oriens obiecerit? (Tac., Ger. 37)

„Cóż innego prócz krwawej klęski Krassusa móglby nam rzucić w twarz pobity przez Wentydiusza Wschód, po tym jak sam także utracil Pakorusa?"

\subsection{ZAIMKI NIEOKREŚLONE}

Większość zaimków tej klasy może zajmować pozycje rzeczownikowe i przymiotnikowe. W odniesieniu do niektórych z nich zróżnicowanie pozycji składniowej wiąże się z pewnym (nieznacznym) zróżnicowaniem postaci formalnej w nom. i acc. sg.; wyodrębnia się w związku z tym ich postaci rzeczownikowe i przymiotnikowe. Często jednak również formy przymiotnikowe podlegają kontekstowej substantywizacji. Pełniąc funkcje rzeczownikowe, wskazują one przede wszystkim na obiekt niezidentyfikowany, tj. taki, którego identyfikacja jest z punktu widzenia nadawcy komunikatu niemożliwa, nieistotna lub niepożądana (por. pol. ktoś, coś, ktokolwiek). Zajmując pozycje przymiotnikowe, charakteryzują desygnat swego rzeczownikowego nadrzędnika jako niezidentyfikowany (por. pol. jakiś, pewien, jakikolwiek).

W porównaniu z językiem polskim system łacińskich zaimków nieokreślonych jest o wiele bardziej rozbudowany i skomplikowany, a ich dystrybucja uwzględnia status obiektu, który charakteryzują bądź na który wskazują. W tym względzie jedną z podstaw opozycji istniejącej między poszczególnymi zaimkami nieokreślonymi jest presupozycja istnienia desygnowanego (lub określanego) obiektu bądź jej brak. Stąd pewne zaimki stosowane będą w kontekstach prezentujących ukazywaną sytuację jako rzeczywistą, realną (a więc zaimki implikujące istnienie danego obiektu), inne $w$ kontekstach prezentujących ją jako nierzeczywistą, nierealną (implikując nieistnienie, negację, nieprawdopodobieństwo), jeszcze inne, gdy mowa jest o sytuacji hipotetycznej czy możliwej (implikując potencjalność, prawdopodobieństwo). Inną podstawą opozycji jest identyfikowalność (konkretność) desygnatu bądź jego nieidentyfikowalność (niekonkretność, ogólność, generyczność). 


\subsubsection{QUIS, QUID (postać rzeczownikowa) QUI, QUAE (QUA), QUOD (postać przymiotnikowa)}

Zaimek ten wskazuje na obiekt hipotetyczny, którego istnienie jest możliwe. Ma jednak charakter neutralny, nie suponując ani jego istnienia, ani nieistnienia. Występuje więc głównie $w$ kontekstach prezentujących ukazywaną sytuację jako możliwą, hipotetyczną czy potencjalną, bez przesądzania co do jej prawdopodobieństwa. Jego polskimi odpowiednikami są najczęściej formy zaimkowe ktoś, coś, jakiś.

Typowym kontekstowym składniowym tego zaimka są zatem implikujące możliwość spójniki: si, nisi, ne, cum:

Si quid in te peccavi, $[\ldots]$ ignosce! (Cic., Att. 3, 15, 4)

„Jeśli w czymś zawiniłem względem ciebie, wybacz!"

Si quis de contentione principatus laborat $[\ldots]$ stultissime facit. (Cic., Phil. 14, 18)

„Jeśli ktoś usilnie zabiega o przywództwo, postępuje bardzo glupio".

Si quis minorem gloriae fructum putat ex Graecis versibus percipi quam ex Latinis vehementer errat. (Cic., Arch. 23)

„Jeśli ktoó uważa, że z pisania greckiej poezji uzyskuje się mniejszą sławę niż z pisania wierszy lacińskich, bardzo się myli".

Si quis non adfuerit, hunc omnes poterunt et interitus mei et perditissimorum consiliorum auctorem fuisse. (Cic., Phil. 3, 19)

"Jeśli ktoś nie będzie obecny, wszyscy będą mogli go uważać za orędownika zarówno mojego upadku, jak i najbardziej zgubnych rad".

Ne mi obstiterit obviam nisi quis satis diu vixisse sese homo arbitrabitur. (PI., Capt. 791-792)

„Niech (nikt) nie staje mi na drodze, chyba że ktoś uzna, że żyje już wystarczająco dlugo".

Nemo superest nisi quem hostis caedendo fessus reliquit. (Liv., 25, 6)

"Nikt się nie uratowal, chyba że kogoś wróg zmęczony zabijaniem pozostawil (przy życiu)".

Sed tamen non vereor ne quis audeat dicere ullius in Sicilia quaesturam aut clariorem aut gratiorem fuisse. (Cic., Planc. 64)

„I nie obawiam się, że ktoś odważy się twierdzić, iż czyjaś kwestura na Sycylii była bardziej slawna czy popularna (niż moja)".

Atque etiam hoc praeceptum officii diligenter tenendum est, ne quem umquam innocentem iudicio capitis arcessas. (Cic., Off. 2, 51)

„Trzeba również pilnie przestrzegać tej zasady, byś kogoś niewinnego nigdy nie oskarżał przed sądem o coś, za co grozi kara smierci".

An tibi irasci tum videmur, cum quid in causis acrius et vehementius dicimus? (Cic., Tusc. $4,55)$

„Czy sądzisz, że ogarnia mnie gniew wtedy, gdy wypowiadam coś ostrzej i gwattowniej podczas rozpraw sądowych?” 
Iucundum est secum esse quam diutissime, cum quis se dignum quo frueretur effecit. (Sen., Lucil. 58, 32)

„Miło jest jak najdłużej obcować z sobą, gdy ktos uczynil siebie godnym tego, z czego korzysta".

W funkcji przydawkowej (rzadko):

Praetor $[\ldots]$ castra [...] in campo locat cum gravi edicto si quis miles aut in urbe restitisset aut secum extulisset quod suum non esset. (Liv., 29, 21)

„Pretor zakłada obóz na otwartym polu, zarządzając równocześnie surowe kary w przypadku, gdyby jakiś żołnierz pozostal w mieście albo wyniósł ( $\mathrm{z}$ niego) coś, co nie byłoby jego wlasnością".

Rei publicae statum [...], nisi quis nos deus respexerit, elapsum scito esse de manibus uno hoc iudicio. (Cic., Att. 1, 16, 6)

„Wiedz, że po tym jednym wyroku stan państwa wymknie nam się $z$ rąk, chyba że jakiś bóg spojrzy na nas laskawym okiem".

Caesar silvas caedere instituit, et ne quis inermibus [...] militibus ab latere impetus fieri posset, omnen eam materiam, quae erat caesa, conversam ad hostem conlocabat. (Caes., Gall. 3, 29)

„Cezar zarządził wyrąb lasu i aby uniemożliwić jakiś atak z boku na nieuzbrojonych żolnierzy, nakazał wszystkie ścięte drzewa układać zwracając (korony) w stronę nieprzyjaciela".

Podobnym kontekstem są zdania warunkowo-koncesywne, wprowadzane przez spójniki cum, quamvis, etiamsi, oraz zdania pytajne rozpoczynane najczęście od partykuły num:

Potest autem, cum quis divinationem habeat, errare aliquando nec vera cernere. (Cic., Div. 2, 107)

„Choćby jednak i ktoś mial dar wróżenia, może czasem się mylić i nie dostrzegać prawdy”.

Sedisti in quattuordecim ordinibus, cum esset lege Roscia decoctoribus certus locus constitutus, quamvis quis fortunae vitio, non suo decoxisset. (Cic., Phil. 2, 44)

"(W teatrze) zasiadałeś $w$ (pierwszych) czternastu rzędach, chociaż ustawa Roscjusza wyznaczyla osobne miejsce bankrutom, nawet gdyby ktoś zrządzeniem losu, a nie z własnej winy zbankrutowal".

Etiamsi quis ex ea caede effugisset, adeo raptim a captis prioribus castris in altera transcursum castra ab Romanis est, ut praevenire nuntius cladis non posset. (Liv., 25, 39)

„Nawet gdyby ktoś wydostal się z tej rzezi, to Rzymianie tak szybko przerzucili się ze zdobytego już obozu do drugiego, że żadna wieść o klęsce nie mogla ich wyprzedzić".

D. Bruti iudicium [...], quod ex hodierno eius edicto perspicere potuistis, num cui tandem contemnendum videtur? (Cic., Phil. 4, 7)

„Czy stanowisko Decymusa Brutusa, które mogliście poznać z dzisiejszego jego edyktu, komuś wydaje sį̨ godne potępienia?"

Poza tym potencjalność (hipotetyczność) treści wyrażanej przez zdanie z zaimkiem quis sygnalizowana może także być przez czasowniki modalne typu (fieri) potest: 
Fieri $[\ldots]$ potest, ut recte quis sentiat et id, quod sentit, polite eloqui non possit. (Cic., Tusc. $1,6)$

„Może się zdarzyć, że ktoś słusznie myśli, lecz tego, co myśli, nie potrafi elegancko wyrazić".

Potest autem quis, cum divinationem habeat, errare aliquando nec vera cernere. (Cic., Div. 1, 71)

„Może bowiem ktoś, choćby i mial dar wróżenia, mylić się czasem i nie dostrzegać prawdy”.

Oprócz tego, zaimek ten może mieć również znaczenie generyczne i wskazywać na określony typ obiektu w ramach kontekstów desygnujących treści nieaktualne, $t j$. (zwyczajowo) powtarzające się, habitualne. Towarzyszy mu wtedy często spójnik ubi:

Ita fit, ubi quid tanto opere exspectas. (Pl., Cas. 390)

"Tak się (zwykle) dzieje, gdy czegoś bardzo oczekujesz".

Atque ubi quis ex principibus in concilio dixit se ducem fore $[\ldots]$ consurgunt ii, qui et causam et hominem probant. (Caes., Gall. 6, 23)

„I (za każdym razem) gdy ktoś z naczelników plemiennych na powszechnym zgromadzeniu mówi, że będzie wodzem (wyprawy wojennej), podnoszą się ci, którzy i (samą) sprawę i wodza aprobują".

\subsubsection{QUISQUAM, QUICQUAM (QUIDQUAM), ULLUS, ULLA, ULLUM}

Zaimki te mają charakter antytetyczny, tzn. występują w wypowiedzeniach, które wyrażają sens negatywny (przeczący), choć nie zawsze zawierają bezpośrednie i jawne wykładniki negacji. Wskazują na obiekty, których istnienie w kontekście sytuacji, o jakiej mowa jest $w$ wypowiedzeniu, neguje się lub uważa za nieprawdopodobne, wątpliwe, niewiarygodne. Dlatego ich polskimi odpowiednikami są często zaimki przeczące (nikt, nic, żaden) lub zaimki nieokreślone z postfiksem -kolwiek (ktokolwiek, cokolwiek, jakikolwiek).

Zwykle zaimek quisquam używany jest $w$ funkcjach rzeczownikowych, natomiast ullus występuje w funkcji przydawki lub orzecznika. Dość częste są jednak również wypowiedzenia, w których quisquam pełni rolę przydawki, a ullus zajmuje pozycje rzeczownikowe.

Generalnie można wyodrębnić dwa podstawowe konteksty, w których zaimki te są stosowane. Jednym $\mathrm{z}$ nich są zdania zawierające jawne, formalne wykładniki negacji w postaci partykuł lub spójników przeczących (non (modo), neque, nec, ne ... quidem), zaimków przeczących (nemo, nihil, numquam, nusquam) albo wyrażającego nieistnienie przyimka (sine). Podane niżej przykłady, egzemplifikujące użycie zaimków quisquam i ullus $w$ tym kontekście, uporządkowane zostały według kryterium składniowego, uwzględniając: 
1. Użycie zaimka quisquam $\mathrm{w}$ pozycjach rzeczownikowych:

Neque domi neque in urbe invenio quemquam, qui illum viderit. (Pl., Amph. 1010)

"Ani w domu, ani w mieście nie mogę znaleźć nikogo, kto go widziar".

Nec recito cuiquam nisi amicis, idque coactus. (Hor., Serm. 1, 4, 73)

„I nie deklamuję (swoich utworów) nikomu, jak tylko przyjaciolom, i to przymuszony".

Iuro $[. .$.$] me [. .$.$] nec illos nec alium quemquam regnare Romae passurum. (Liv., 1, 59)$

„Przysięgam, że nie pozwolę, aby oni albo ktokolwiek inny panowal w Rzymie”.

Neque erat omnium quisquam, qui adspectum modo tantae multitudinis sustineri posse arbitraretur. (Caes., Gall. 7, 76)

„I spośród wszystkich nie było nikogo, kto uważalby, że można znieść (bez strachu) sam widok takiej masy (wojska)".

(Hannibal) ad Prusiam in Pontum pervenit [...] neque aliud quicquam egit quam regem armavit et exercuit adversus Romanos. (Nep., Hann. 10)

„(Hannibal) przybył do Prusjasza, do Pontu, i nie robil nic innego, jak tylko zbroil króla i zaprawial go (do walki) przeciw Rzymianom".

Nec vero necesse est quemquam a me nominari. (Cic., Phil. 2, 1)

"I doprawdy nie ma potrzeby, aby ktokolwiek byl przeze mnie wymieniany z nazwiska".

Non oportere ait quemquam a sermone principis tristem discedere. (Suet., Tit. 8, 1)

„Powiada, że nie wypada, by ktokolwiek po rozmowie z cesarzem odchodzil smutny”.

2. Użycie zaimka quisquam w pozycjach przymiotnikowych (przydawkowych):

Nec post illorum obitum quisquam dux in illa urbe fuit dignus memoria. (Nep., Timoth. 4)

„I po ich śmierci nie było (już) w tym państwie żadnego wodza zasługującego na pamięć".

Numquam hominem quemquam conveni unde abierim lubentius. (Pl., Epid. 80)

„Nie spotkatem jeszcze żadnego czlowieka, od którego chętniej bym odszedl".

Adversus consentientes nec regem quemquam satis validum nec tyrannum fore. (Liv., $34,49)$

„Przeciwko (nim) zjednoczonym ani żaden król nie będzie dostatecznie silny, ani tyran”.

Quod neque ego habeo neque quisquam alia mulier. (PI., Cist. 66)

"Czego ani ja nie mam, ani żadna inna kobieta”.

Adiungitur unus aut alter ex omnibus servis, plerumque vilissimus nec cuiquam serio ministerio adcommodatus. (Tac., Dial. 29)

„Dołączany jest ten czy inny spośród niewolników, przeważnie bardzo kiepski i niezdatny do żadnego poważnego zadania".

3. Użycie zaimka ullus w pozycjach przydawkowych:

Cicero $[\ldots]$ respondit non esse consuetudinem populi Romani ullam accipere ab hoste armato condicionem. (Caes., Gall. 5, 41) 
„Cyceron odpowiedzial, że nie jest zwyczajem narodu rzymskiego przyjmowanie jakiegokolwiek warunku od uzbrojonego nieprzyjaciela".

Fit $[. .$.$] tyrannus, quo neque taetrius neque foedius [...] animal ullum cogitari potest.$ (Cic., Rep. 2, 48)

„Staje się tyranem, a nie można sobie wyobrazić żadnego stworzenia szkaradniejszego albo wstrętnieszego od niego".

Experti [...] sunt Romani Macedonem hostem [...] non modo cum clade ulla, sed ne cum periculo quidem suo. (Liv., 9, 19)

„Rzymianie zmierzyli się z wrogiem macedońskim nie tylko bez żadnej klęski, ale nawet bez narażania siç na niebezpieczeństwo".

Fieri $[\ldots]$ non potest, ut una ulla res modo mala sit, modo bona. (Sen., Lucil. 31, 3)

„Nie jest możliwe, by jakakolwiek jedna rzecz była raz zła, a innym razem znów dobra”.

Z zaprzeczonym przymiotnikiem (tj. przymiotnikiem z przedrostkiem przeczącym) pełniącycm funkcję wykładnika negacji:

Inhonesta est [...] in ullo actu pigritia. (Sen., Lucil. 74, 30)

„Opieszałość nie jest chwalebna w żadnym działaniu”.

4. Użycie zaimka ullus w pozycjach orzecznikowych:

Tenemusne quid sit animus, ubi sit, denique sitne an [...] ne sit quidem ullus? (Cic., Lucull. 124)

„Czy wiemy, czym jest dusza, gdzie się znajduje, wreszcie czy w ogóle istnieje, czy też nie ma jej wcale?"

Prima causa $[. .$.$] tantum commendationis habuit, ut non ulla esset, quae non digna no-$ stro patrocinio videretur. (Cic., Brut. 312)

„Pierwsza (moja) sprawa sądowa zyskała takie uznanie, że nie było żadnej, która nie wydawałaby się odpowiednia do tego, bym wystąpil w niej jako obrońca".

5. Użycie ullus w pozycjach rzeczownikowych:

Sistunt $[\ldots]$ gradum sine ullius imperio. (Liv., 9, 2)

„Wstrzymują marsz bez niczyjego rozkazu".

Neque [...] ullos militum commilitones appellabat. (Suet., Aug. 25)

"I żadnych (spośród) żołnierzy nie nazywał towarzyszami broni".

Nec ullo de familiaribus nostris repugnante [...] saevo pavore trepidam (me) de medio matris gremio rapuere. (Apul., Met. 4, 26)

„I gdy nikt z naszych domowników nie stawiał oporu, drżącą od wielkiego strachu porwali mnie z objęć matki".

Nemo ullius nisi fugae memor. (Liv., 2, 59)

„Nikt o niczym nie myśli, jak tylko o ucieczce".

Neque enim verbis sollemnibus ulla incipiam nec Castaliae vocalibus undis. (Stat., Silv. 5, $5,1-2)$ 
„Niczego bowiem nie rozpocznę ani uroczystymi słowami, ani zaczerpniętymi z dźwięcznych zdrojów kastalskich".

Drugim charakterystycznym dla tych zaimków kontekstem są wypowiedzenia, które nie zawierają formalnych wykładnikow negacji, lecz ich negatywna wartość wynika $\mathrm{z}$ kontekstu, a więc ma charakter pragmatyczny, implicytny. Wskazać można na kilka typów tego rodzaju kontekstów:

1. Pytania retoryczne implikujące zaprzeczenie ze strony słuchaczy:

Cannensem vero quisquam exercitum fugae aut pavoris insimulare potest, ubi plus quinquaginta milia hominum ceciderunt? (Liv., 25, 6)

„Czy ktokolwiek może posądzać o ucieczkę czy strach wojsko, które walczyło pod Kannami, gdzie ponad pięćdziesiąt tysięcy ludzi padło w walce?"

Pro di immortales! Essene quemquam tanta audacia praeditum, qui [...] quod sibi probare non possit, id persuadere alteri conetur! (Cic., Q. Rosc. 4)

„Na bogów nieśmiertelnych! Czyż może istnieć ktoś tak zuchwaly, kto mialby śmialość przekonywać innych do tego, do czego siebie przekonać nie może!"

Estne quisquam omnium mortalium, de quo melius existimes tu? (Cic., Q. Rosc. 18)

„Czyż pośród wszystkich ludzi jest ktoś, o kim ty sam móglbyś wyrazić lepsze zdanie?”

Censen te posse reperire ullam mulierem, quae careat culpa? (Ter., Hec. 662-663)

"Sądzisz, że możesz znaleźć jakąś kobietę, która byłaby bez wad?”

Gladiisne [...] et pilis perfringere ac subruere muros ullae manus possunt? (Tac., Hist. $3,20)$

"Czy jakiekolwiek ręce mogą mieczami i oszczepami rozbić i obalić mury (miasta)?"

2. Wypowiedzenia ukazujące pewne wyrażane w nich treści jako dalekie od rzeczywistości, niemożliwe albo też dziwne, zaskakujące, trudne do uwierzenia, nieprawdopodobne. Wśród tego rodzaju wypowiedzeń znajdują się m.in. zdania wyrażające $\mathrm{w}$ kontekście warunkowym tezy, którym przypisuje się status nieprawdziwych lub mało prawdopodobnych, a także wypowiedzi o charakterze ironicznym, w których negatywny stosunek autora nie jest sygnalizowany wprost, lecz poprzez (pozorną) afirmację:

Id $[\ldots]$ putare quemquam hominem, nihil homine esse melius, summae adrogantiae censet esse. (Cic., Nat. 3, 26)

„Sądzil, że to, iż jakikolwiek czlowiek miałby tak myśleć, a mianowicie że nie ma (na świecie) nic doskonalszego od czlowieka, byloby nieslychanym zuchwalstwem".

Venus $[\ldots]$ furens animi $[\ldots]$ te $[\ldots]$ ad extremum supplicium expetit et $[\ldots]$ ultionem flagitat; tu vero rerum mearum tutelam nunc geris et aliud quicquam cogitas nisi de tua salute? (Apul., Met. 6, 2)

„Wenus szalejąc domaga się ciebie, by zadać ci najokrutniejsze tortury; ty zaś porządkujesz moje sprzęty i możesz myśleć o czymkolwiek innym niż o swoim ocaleniu?"

Iocari me putas? Moriar si quisquam me tenet praeter te. (Cic., Att. 16, 5, 3)

„Myślisz, że żartuję? Niech skonam, jeśli ktoś (inny) oprócz ciebie mnie (tu) zatrzymuje”. 
Quem di diligunt, adulescens moritur [...]; hunc si ullus deus amaret, plus annis decem [...] iam [...] mortuom esse oportuit. (Pl., Bacch., 816-819)

„Kogo bogowie kochaja, ten umiera jako młodzieniec; gdyby tego tu jakiś bóg kochal, musiałby już nie żyć od ponad dziesięciu lat".

Cuius amici $[. .$.$] , si beluae tam immani tamque taetrae possunt ulli esse amici, hac conso-$ latione utuntur, etiam T. Albucio supplicationem hunc ordinem denegasse. (Cic., Prov. 15)

„Jego przyjaciele - jeśli tak straszny i tak odrażający potwór może mieć jakichkolwiek przyjaciół - tym się pocieszają, że również Tytusowi Albucjuszowi senat odmówił uchwalenia ofiar dziękczynnych".

Negant sapientem suscepturum ullam rei publicea partem, extra quam si eum tempus et necessitas coegerit $[. .$.$] , quasi vero maior cuiquam necessitas accidere possit, quam accidit$ nobis. (Cic., Rep. 1, 10)

(iron.) „Odmawiają mędrcowi prawa do jakiegokolwiek angażowania się w politykę z wyjąlkiem sytuacji, gdy zmusza go do tego jakaś wynikająca z okoliczności potrzeba, jakby mogła przydarzyć się komuś pilniejsza potrzeba niż ta, która przydarzyła się mnie".

3. Zdania zawierające zestawianie czy porównywanie, w których drugi człon tego zestawienia, wprowadzany przez quam 'niż', implikuje kontekstową (pragmatyczną) negację.

Quod verbum in pectus Iugurthae altius, quam quisquam ratus erat, descendit. (Sall., lug. 11)

„Ta wypowiedź zapadła w serce Jugurty głębiej, niż ktokolwiek przypuszczal (= nie było nikogo takiego, kto przypuszczal...)".

Videte quanto taetrior hic tyrannus Syracusanis fuerit quam quisquam superiorum. (Cic., Verr. 2, 4, 123)

„Zobaczcie, o ile on był bardziej odrażającym tyranem Syrakuzańczykow niż ktokolwiek $\mathrm{z}$ jego poprzedników (= żaden $\mathrm{z}$ jego poprzedników nie był bardziej odrażający)".

Nec enim muliebris umquam inimicitias mihi gerendas putavi, praesertim cum ea, quam omnes semper amicam omnium potius quam cuiusquam inimicam putaverunt. (Cic., Cael. 32)

„Nigdy bowiem nie uważałem, że powinienem wchodzić w konflikt $z$ kobietami, a zwłaszcza $z$ taką, którą wszyscy zawsze uważali raczej za przyjaciółkę wszystkich niż za nieprzyjaciółkę kogokolwiek (= uważali, że nie było nikogo takiego, kogo byłaby nieprzyjaciółką)".

Solis calor et candor inlustrior est quam ullius ignis. (Cic., Nat. Deor. 2, 40)

„Żar i blask słońca jest jaśniejszy niż jakiegokolwiek plomienia (= nie ma takiego płomienia, którego blask byłby jaśniejszy od blasku słońca)".

Moriendi impetum cepit [...], magis pudore [...], quam desperatione ulla aut diffidentia copiarum. (Suet., Oth. 9)

„Postanowił targnąć się na swoje życie, raczej z poczucia przyzwoitości niż z powodu jakiejśs rozpaczy albo niewiary $\mathrm{w}$ (swe) siły wojskowe (= nie było rozpaczy czy niewiary, które bylyby powodem jego samobójstwa)".

Ait $[\ldots]$ multo maiorem indolem in eo animi ingeniique esse quam in ullo gentis eius unquam fuisset. (Liv., 29, 31) 
„Mówi, że w nim są o wiele większe wrodzone zalety ducha i umysłu, niż kiedykolwiek były w kimś (innym) z jego rodu (= nigdy nie bylo nikogo z jego rodu, w kim byłyby większe zalety)".

Por. tez:

Hannibal [...] subibat muros cum repente in eum nihil minus quam tale quicquam timentem patefacta porta erumpunt Romani. (Liv., 29, 7)

„Hannibal podchodzil pod mury, gdy nagle na niego, który niczego nie obawial się mniej jak czegoś takiego, z otwartej bramy napadają Rzymianie".

Do tej grupy zaliczyć można także zdania złożone, których podrzędnym składnikiem jest wprowadzane przez priusquam lub antequam zdanie okolicznikowe czasu wyrażające następczość, jeśli owo zdanie podrzędne odnosi sie do zdarzenia czy sytuacji nierzeczywistej (hipotetycznej); w istocie bowiem mamy tu do czynienia z porównaniem, czego wyrazem jest możliwość wystąpienia tmezy (prius ... quam ... 'wcześniej ... niż ...):

Priusquam quicquam conaretur, Divitiacum ad se vocari iubet. (Caes., Gall. 1, 19)

„Zanim cokolwiek przedsięwziąl, kazal wezwać do siebie Dywicjaka (= niczego nie przedsięwziąl, zanim nie wezwal Dywicjaka)".

Prius [...] rem transegit, quam quisquam eum facturum id suspicaretur. (Cic., Phil. 2, 21) „Wcześniej przeprowadzil sprawę, niż ktokolwiek mógl podejrzewać, że to uczyni (= nikt nie mógł podejrzewać, zanim tego nie zrobil)".

Navalis hostis ante adesse potest, quam quisquam venturum esse suspicari queat. (Cic., Rep. 2, 6)

„Nieprzyciel przemieszczający się na okrętach może zjawić się wcześniej, niż ktokolwiek zdolałby podejrzewać, że przybędzie (= nikt nie zdoła przypuszczać)".

Por. też:

Citius amore tui fratrem tuum odisse desinam, quam illius odio quicquam de nostra benevolentia detraham. (Cic., Fam. 5, 2, 10)

„Szybciej z powodu milości do ciebie zaprzestanę nienawiści do twego brata, niż z powodu tej nienawiści ujmę coś z życzliwości, jaka istnieje między nami (= niczego nie ujmę)".

4. Syntagmy lub zadania podrzędne, w których pragmatyczna negacja determinowana jest przez nadrzędne czasowniki lub wyrażenia typu: nego, prohibeo, interdico, impedio, caveo, aspernor, multum / tantum abest:

Arcesilaos negabat esse quicquam, quod sciri posset. (Cic., Acad. 1, 45)

„Arkesilaos zaprzeczal, jakoby istniało coś, co mogloby być poznane (= twierdzil, że nie istnieje nic takiego, co mogloby być poznane)".

Interdicit $[\ldots]$ omnibus ne quemquam interficiant. (Caes., Gall. 7, 40)

„Wszystkim zakazuje zabijania kogokolwiek".

Iuvenes $[. .$.$] prohibuit ullum nocturnum spectaculum frequentare nisi cum aliquo maiore$ natu propinquorum. (Suet., Aug. 31) 
„Młodzieży zabronił udziału w jakimkolwiek nocnym widowisku, chyba że wraz z kimś starszym z rodziny".

Cave praeterbitas ullas aedis, quin roges, senex hic ubi habitat Periphanes. (Pl., Epid. 437)

„Uważaj, by nie minąć żadnego domu bez pytania, gdzie mieszka ten starzec Perifanes”.

Primo quidam ex his aspernantium tale quicquam praebuerunt speciem. (Liv., 40,5)

„Początkowo niektórzy z nich sprawiali pozory (osób) odrzucających coś takiego (nie akceptujących czegoś takiego)".

Tantum afuit ab eo, ut ulla ignominia iis exercitibus quaereretur, ut [...] Caudinae legiones, quae sine armis redierant Romam, armatae remissae (sint) in Samnium. (Liv., 25, 6)

„Tak daleko było do tego, by próbowano zarzucić tym wojskom jakąkolwiek hańbę, że legiony, które spod Kaudium wrócilu do Rzymu bez broni, uzbrojono i ponownie wysłano do Samnium".

Do tej grupy zaliczyć można także syntagmy i zdania zależne od wyrażeń typu miror 'dziwię się, że...'; moleste fero (patior, accipio) 'jest mi przykro, że.... Wyrażenia te suponują bowiem, że to, co jest treścią następujących po nich wypowiedzeń, nie powinno było zaistnieć (wydarzyć się):

Miror, quo modo tam ineptum quidquam tibi venire in mentem, mi vir, potuit. (Ter., Heaut. 1004-1005)

„Dziwię się, w jaki sposób coś tak glupiego mogło ci, mój mężu, przyjść do głowy”.

De Pletorio $[. .$.$] permoleste tuli quemquam prius audisse quam me. (Cic., Att. 15, 17, 1)$ „Bardzo mi było przykro, że o Pletoriuszu ktoś (inny) dowiedział się wcześniej niż ja”.

Zaimki te mogą również występować w kontekstach pozbawionych negacji, zarówno eksplicytnej, jak i implicytnej. Ich funkcją jest wówczas kwantyfikacja desygnowanego obiektu do pewnego minimum wielkości, wartości czy ilości, bliskiego niestnieniu:

Quam diu quisquam erit, qui te defendere audeat, vives. (Cic., Catil. 1, 6)

„Dopóki będzie choćby jeden czlowiek, kıóry odważyłhy się ciebie bronić, będziesz żył”.

Qui cum in convivium venisset, si quicquam caelati adspexerat, manus abstinere $[. .$.$] non$ poterat. (Cic., Verr. 2, 4, 48)

„Gdy przybył na ucztę, to jeśli dostrzegł nawet najdrobniejszy przedmiot z cyzelowanego srebra, nie potrafil zachować rąk przy sobie".

Cuivis potest accidere, quod cuiquam potest. (Sen., Dial. 6, 9, 5)

„To, co może przydarzyć się choćby jednemu, może przydarzyć się każdemu”.

Cur eget indignus quisquam te divite? (Hor., Serm. 2, 2, 103)

„Dlaczegoż w nędzy jest bodaj jeden czlowiek, który na to nie zasłużył, podczas gdy ty jesteś bogaczem?"

Consul $[. .$.$] nusquam remisso certamine dum quicquam superfuit lucis hostem tenuit.$ (Liv., 4, 39)

„Konsul, nigdzie nie przerywając bitwy, angażowal (walką) nieprzyjaciela tak długo, aż już niemal zupełnie nie było światła (= zapadł zmrok)". 
Quidquid bene dictum est ab ullo, meum est. (Sen., Lucil. 16, 7)

"Cokolwiek dobrze zostalo powiedziane nawet przez kogoś jednego, jest moje”.

Magno malo ulla voce interpellatum silentium luitur. (Sen., Lucil. 43, 7)

„Wielkim cierpieniem okupowane jest przerwanie ciszy bodaj najmniejszym dźwiękiem”.

W podobnych kontekstach, jak scharakteryzowane wyżej zaimki quisquam i ullus, stosowane są ich przysłówkowe odpowiedniki, tj. umquam i usquam, odnoszące się do okoliczności - odpowiednio - czasu i miejsca:

Non tacebo umquam. (Pl., Rud. 1402)

„Nigdy nie będę milczał”.

Tempus habes tale, quale nemo habuit umquam. (Cic., Phil. 7, 27)

"Masz taką okazję, jakiej nikt nigdy (dotąd) nie miał".

Di me perdant [...], sei illam uxorem duxero umquam. (Pl., Cist. 498)

„Niech mnie pieklo pochlonie, jeśli kiedykolwiek pojmę ją za żonę".

Quid mecum tibi fuit umquam [...] negoti? (PI., Men. 370)

"A cóż ty kiedykolwiek miałaś wspólnego ze mną?"

(Istam) plus [...] amat quam te umquam amavit. (Pl., Epid. 66)

„Ją bardziej kocha, niż kiedykolwiek (kochal) ciebie”.

Nullius usquam terrarum rei cura Romanos [...] effugiebat. (Liv., 22, 33)

„Rzymianie nie zaniedbywali żadnej sprawy nigdzie na świecie”.

Nurum ac nepotes numquam aliter $[\ldots]$ quam catenatos $[\ldots]$ movit, prohibitis $[\ldots]$ obviis ac viatoribus respicere usquam vel consistere. (Suet., Tib. 64)

„Synowej i wnuków nigdy nie pozwalał przewozić inaczej, jak tylko zakutych w kajdany, zabraniając (rówocześnie) przechodniom i podróżnym gdziekolwiek zaglądać lub zatrzymywać się".

An, opsecro, usquam sunt homines volatici? (Pl., Poen. 475)

"Ale na bogów, czy są gdzieś na swiecie ludzie skrzydlaci?"

\subsubsection{ALIQUIS, ALIQUID (postać rzeczownikowa) $A L I Q U I(S), A L I Q U A, A L I Q U O D$ (postać przymiotnikowa)}

Zaimek ten wskazuje na obiekt niescharakteryzowany, ale istniejący. Może występować w podobnych kontekstach składniowych co omówiony wyżej zaimek quis, a jego polskimi odpowiednikami również są najczęściej zaimki ktoś, coś, jakiś, pewnien, czasem ktokolwiek, jakikolwiek. Różni się jednak od zaimka quis tym, że presuponuje istnienie obiektu, do którego odsyła. Jego referentem jest zatem obiekt rzeczywisty, a nie hipotetyczny, możliwy czy potencjalny. W związku z tym pojawiał się będzie w wypowiedzeniach ukazujących prezentowaną sytuację jako rzeczywistą 
lub w kontekstach implikujących przekonanie autora wypowiedzi o istnieniu danego obiektu. Por. np:

Sedisti in quattuordecim ordinibus, cum esset lege Roscia decoctoribus certus locus constitutus, quamvis quis fortunae vitio, non suo decoxisset. (Cic., Phil. 2, 44)

"(W teatrze) zasiadałeś w (pierwszych) czternastu rzędach, chociaż ustawa Roscjusza wyznaczyła osobne miejsce bankrutom, nawet gdyby ktoś zrządzeniem losu, a nie z własnej winy zbankrutował".

wobec:

Et quamquam aliquid ipse poteram, tamen invenire malo paratiores. (Cic., Fin. 2, 119)

„I chociaż sam mógłbym coś (powiedzieć na ten temat), to jednak wolę poszukać ludzi lepiej przygotowanych (do tego niż ja)".

Por. też:

Si quis amor est sine sollicitudine, sine desiderio, sine cura [...]. Sin autem est aliquis amor, ut est certe, qui nihil absit ab insania [...]. (Cic, Tusc. 4, 72)

„Jeśli jest jakaś miłość pozbawiona troski, niepokoju, pragnień (..... Jeżeli jednak jest jakaś miłość, a jest na pewno, która niczym nie różni się od szaleństwa $[\ldots]$ ]".

Supozycję istnienia referenta omawianego zaimka wyraźnie obrazują także poniższe przykłady:

Quo autem die has Valerio dabam, exspectabam aliquem meorum. (Cic., Att. 13, 15)

"Tego dnia, w' którym przekazywałem Waleriuszowi ten (włánie list do ciebie), oczekiwałem (też pow'rotu) kogoś z moich (posłańców z listem od ciebie)".

Themistocles $[\ldots]$ dixit in contione se habere consilium rei publicae salutare, sed id sciri non opus esse; postulavit, ut aliquem populus daret, quicum communicare. (Cic., Off. $3,49)$

„Temistokles na zgromadzeniu ludowym oświadczyl, że ma zbawienny dla państwa plan, lecz nie powinien on być (powszechnie) znany; zażądal (więc), by lud wyznaczył kogoś, komu by swój pomysł przedstawił".

Ita, quem ad modum in senatu semper est aliquis, qui interpretem postulet, sic isti (scil. Stoici) nobis cum interprete audiendi sunt. (Cic., Fin. 5, 89)

„Tak, jak w senacie zawsze znajdzie się ktoś, kto prosi o thumacza'", tak i tych (tj. stoików) powinniśmy wysluchiwać przy pomocy tłumacza"'14.

Fuisse credo tum quoque aliquos, qui discerptum regem patrum manibus taciti arguerent. (Liv., 1, 16)

${ }^{13}$ Większość rzymskich senatorów w czasach Cycerona dobrze znała grekę i dozwolone było przemawianie przed rzymskim senatem po grecku, co w szczególności praktykowali posłowie $\mathrm{i}$ inni przedstawiciele greckich bądź greckojęzycznych miast. Jak poświadcza jednak m.in. przywolany cytat, nie wszyscy członkowie senatu byli na tyle biegli w grece, by słuchać przemówień w tym języku bez pomocy tlumacza.

14 To nieco złośliwe stwierdzenie związane jest $z$ zarzutem formulowanym tu pod adresem stoików, iż do określania znanych pojęć stosują coraz to nowe nazwy. 
„Jestem przekonany, że również wtedy byli tacy, którzy po cichu twierdzili, że król zostal rozszarpany rękami patrycjuszów".

Aliquis vir bonus nobis diligendus est ac semper ante oculos habendus. (Sen., Lucil. 11, 8) „Powinniśmy wybrać sobie jakiegoś prawego czlowieka i zawsze mieć go przed oczami”.

Właściwym dla tego zaimka kontekstem będą też zdania warunkowe (i im podobne), w których zaimek odnosi się do obiektów istniejących bądź takich, których istnienie się suponuje:

Si aliquis ex is, qui in eodem synoecio potant, nomen poetae olfecerit, totam concitabit viciniam. (Petron., Sat. 93, 3)

„Jeśli ktoś z tych, którzy piją razem z nami w tym domu, zwęszy tu poetę, to (natychmiast) postawi na nogi całą okolicę".

Tantus erit ambitionis furor, ut nemo tibi post te videatur, si aliquis ante te fuerit. (Sen., Lucil. 104, 10)

„Zaślepienie spowodowane polityczną rywalizacją urośnie tak bardzo, iż będzie ci się zdawalo, że nie ma nikogo za tobą, jeśli tylko ktoś będzie przed tobą".

Dicitur [...] etiam carere, cum aliquid non habeas et non habere te sentias. (Cic., Tusc. 1,88 )

„Używa się także slowa 'brakować, gdy czegoś nie masz i czujesz, że (tego) nie masz”.

Z presupozycją istnienia obiektu, do którego odsyła zaimek aliquis, wiąże się również jego stosowanie w zdaniach imperatywnych i zawierających negację:

Dic aliquid dignum promissis! Incipe! (Hor., Serm. 2, 3, 6)

„Powiedz coś godnego (zlożonych) obietnic! Dalej, zaczynaj!”

Non tulit Caelius adsentientem et exclamavit: 'dic aliquid contra, ut duo simus!' (Sen., Dial. 5, 8, 6)

„Nie mógl znieś Celiusz (towarzysza ciągle mu) przytakującego i wykrzyknąl: 'powiedz (wreszcie) coś przeciwnego (temu, co ja mówię), by bylo wiadomo, że jest nas dwóch!"

Referte nunc animum ad hominum [...] formam et figuram; nullam partem corporis sine aliqua necessitate adfictam [...] reperietis. (Cic., De orat. 3, 179)

„Spójrzcie teraz na ksztalt i postać czlowieka; nie znajdziecie żadnej części ciała, która bylaby przydana bez jakiejś potrzeby".

Cum autem id facere non possem, quievi, nec abiecte nec sine aliqua dignitate casum illum temporum et dolorem tuli. (Cic., Phil. 3, 28)

„Kiedy już tego czynić nie moglem, usunąlem się w cień i nie małodusznie ani nie bez pewnej godności znioslem ból spowodowany wypadkami owego czasu".

Neque umquam sine aliqua recitatione apud eum cenatum est. (Nep., Att. 14)

„I nigdy nie nie jadło się u niego kolacji bez jakiejśs recytacji”.

Ita enim dicimus 'sine causa', ut dicamus sine externa et antecedente causa, non sine aliqua. (Cic., De fato 24)

„W takim znaczeniu używamy wyrażenia 'bez przyczyny', jakbyśmy mówili: bez zewnętrznej i uprzedniej przyczyny, a nie bez jakiejkolwiek". 
W pewnych kontekstach zaimek ten stoi w opozycji do zaimka ullus, sygnalizującego niestnienie referenta; por. np.:

(His philosophis) qui mancam fore putaverunt sine aliqua accessione virtutem [...], eos antepono [...], qui summum bonum [...] in virtute posuerunt. (Cic., Fin. 3, 30)

"(Nad tych filozofów), którzy uznali, że bez jakiegoś dodatku (sama) cnota będzie niewystarczająca (jako najwyższe dobro), przedkładam tych, którzy za najwyższe dobro uznali (samą) cnotę".

wobec:

Helvetii [...] legatos ad eum (scil. Ceasarem) mittunt [...], cuius legationis Nammeius et Verucloetius principem locum obtinebant, qui dicerent sibi esse in animo sine ullo maleficio iter per provinciam facere [...]; rogare, ut eius voluntate id sibi facere liceat. (Caes., Gall. 1, 7)

„Helwetowie wyprawili do Cezara posłów; na czele tego poselstwa stali Nammejusz i Werukloecjusz, którzy mieli oświadczyć, że Helwetowie zamierzają przejść przez prowincję bez żadnych występków; proszą, by za jego zgodą wolno im było to uczynić".

Zdarza się jednak, iż wokreślonym konteście oba zaimki mogą wystąpić w podobym znaczeniu:

Ac primo quidem (adulescentes) totius rationis ingnari, qui neque exercitationis ullam vim neque aliquod praeceptum artis esse arbitrarentur, tantum, quantum ingenio et cogitatione poterant, consequebantur. (Cic., De orat. 14)

„Z początku młodzieńcy, nieświadomi całej (obowiązującej w sztuce wymowy) metodologii, ponieważ nie sądzili, że ma jakiekolwiek znaczenie ćwiczenie albo że są jakieś zasady sztuki, osiągali tyle, na ile pozwalał im wrodzony talent i zdolność myślenia".

Pod względem sygnalizowania istnienia/nieistnienia referenta zaimek ten występuje także w opozycji do quisquam; por. np.:

Omnia fecerit oportet, quae interdicta et denuntiata sunt, prius quam aliquid postulet. (Cic., Phil. 7, 26)

„Trzeba, by wszystko, co mu zostało nakazane i oznajmione, wypełnił wcześniej, nim czegoś zażąda".

wobec:

Quod verbum in pectus Iugurthae altius, quam quisquam ratus erat, descendit. (Sall., Iug. 11)

„Ta wypowiedź zapadła w serce Jugurty głębiej, niż ktokolwiek przypuszczał (= nie było nikogo takiego, kto przypuszczał...)".

Bywa jednak, że zaimki te mają bardzo zbliżone znaczenia; por. np.:

Illud excutiendum est, ut sciatur, quid sit carere, ne relinquatur aliquid erroris in verbo. (Cic., Tusc. 1, 88)

„Przedmiotem naszych dociekań musimy uczynić uzyskanie wiedzy o tym, czym jest brak, aby nie pozostał jakiś/żaden błąd w używaniu (oznaczającego to pojęcie) słowa". 
wobec:

Ego ad te ne haec quidem scribo, quae palam in re publica turbantur, ne cuiusquam animum meae litterae interceptae offendant. (Cic., Q. r. 3, 7, 3)

„Nie piszę ci nawet o tych rzeczach, które jawnie sa przedmiotem wzburzenia w państwie, aby mój list nie uraził czyichś/niczyich uczuć, gdyby wpadł w niepowołane ręce".

Możliwość wystąpienia zaimków aliquis i quisquam/ullus w podobnych kontekstach wiąże się $\mathrm{z}$ tym, iż mogą one implikować kwantyfikację, tzn. konotować pojęcie stopnia wielkości czy wartości referenta. Zaimki te mogą więc tym samym wskazywać na pewne minimum (wielkości czy wartości), ale czynią to $\mathrm{z}$ przeciwstawnych perspektyw: zaimek aliquis zorientowany jest na potwierdzanie minimum istnienia czegoś, podczas gdy zaimek quisquam/ullus zorientowany jest na ograniczanie istnienia do minimum ${ }^{15}$; por. np.:

Ite mecum, ut, dum lucis aliquid superest, [...] qua pateat hinc exitus, exploremus. (Liv., 7, 34)

„Chodźcie ze mną, abyśmy, dopóki jest jeszcze trochę światła, sprawdzili, gdzie znajduje się wyjście stąd".

Consul $[\ldots]$ nusquam remisso certamine dum quicquam superfuit lucis hostem tenuit. (Liv., 4, 39)

„Konsul nigdzie nie przerywając bitwy, angażował (walką) nieprzyjaciela tak długo, aż już niemal zupełnie nie było światła (= zapadł zmrok)".

Z uwagi na wskazaną wyżej właściwość zaimek aliquis, konotując minimum wartości, może taki̇e przybierać sens deprecjonujący, np.:

Tu, cum tibi sive deus sive mater [...] rerum omnium natura dederit animum, sic te ipse abicies atque prosternes, ut nihil inter te atque inter quadripedem aliquam putes interesse? (Cic., Parad. 1, 14)

„Ty, chociaż czy to od hoga, czy to od matki wszechrzeczy, natury, otrzymałeś duszę, sam siebie tak poniżysz i upokorzysz, by uważać, że nie ma żadnej różnicy między tobą a jakimśs tam (pierwszym lepszym, jakimkolwiek) czworonogiem?"

Z kolei konotując maksimum wartości może nabrać znaczenia aprecjonującego, np.:

Iste se aliquem putat, quod custodit litigatorum turba limen obsessum. (Sen., Dial. 5, $37,3)$

„Tamten uważa się za kogoś ważnego, bo pilnuje progu (domu) obleganego przez tłum procesujących się (osób)"'16.

(Caesar) contionem apud milites habuit hortatusque est, ne ea, quae accidissent, graviter ferrent [...]; habendam fortunae gratiam, quod Italiam sine aliquo vulnere cepissent. (Caes., Civ. 3, 73)

16 Por. pol.: „Chciałby być kimś w życiu”. 
„(Cezar) przemówił na zgromadzeniu do żolnierzy, nawolując, by nie zalamywali się tym, co się stało; należy dziękować losowi, że Italię zajęli bez poważniejszych strat".

Na niescharakteryzowany obiekt lub pojęcie, stanowiące okoliczność, wskazują zaimki przysłówkowe: alicubi 'gdzieś, aliquo 'dokądś', alicunde 'skądś, aliqua 'którędyś', aliquando 'kiedyś,' aliquotiens 'kilka razy', aliquantum 'nieco'; niescharakteryzowaną cechę wyraża zaimek przymiotnikowy aliquot 'kilka':

Utinam hic prope adesset alicubi atque audiret haec. (Ter., Adelph. 453)

„Szkoda, że go gdzieś w pobliżu nie ma i tego nie słyszy”.

Iube hunc abire hinc aliquo. (Ter., Heaut. 585)

„Każ, żeby on sobie stąd dokądś poszedr".

Id aliquotiens in die cotidie facito. (Cato, Agr. 88, 1)

„Czyń to kilka razy każdego dnia".

Aliquot dies perdura! (PI., Curc. 240-241)

„Parę dni wytrzymaj!"

\subsubsection{QUIDAM, QUIDDAM (postać rzeczownikowa) QUIDAM, QUAEDAM, QUODDAM (postać przymiotnikowa)}

Polskie odpowiedniki tego zaimka są podobne do odpowiedników zaimka aliquis, a więc: ktoś, coś; jakiś, pewien. Podobnie też jak zaimek aliquis odnosi się on do obiektu istniejącego, jednak w przeciwieństwie do niego wskazuje na obiekt konkretny, identyfikowalny, podczas gdy aliquis wskazuje na obiekt niekonkretny, nieidentyfikowalny. Np. w zdaniu:

Themistocles [...] dixit in contione se habere consilium rei publicae salutare, sed id sciri non opus esse; postulavit, ut aliquem populus daret, quicum communicare. (Cic., Off. 3,49 )

„Temistokles na zgromadzeniu ludowym oświadczyl, że ma zbawienny dla państwa plan, lecz nie powinien on być (powszechnie) znany; zażądal (więc), by lud wyznaczyl kogoś, komu by swój pomysl przedstawil".

zaimek aliquem implikuje, iż zdaniem Temistoklesa z pewnością jest taki ktoś, komu mógłby on swój plan wyjawić, jednak nie ma on na myśli jakiejś jednej, konkretnej osoby (teoretycznie owym „kimś” może być obywatel X, albo obywatel Y, albo jeszcze ktoś inny), dlatego zaimek ten nie ma konkretnego, identyfikowalnego referenta. $\mathrm{Z}$ kolei w zdaniu:

Video $[\ldots]$ esse hic in senatu quosdam, qui tecum una fuerunt. (Cic., Catil. 1, 8) „Widzę że tu w senacie są pewni ludzie, którzy byli razem z tobą".

zaimek quosdam odnosi się do bardzo konkretnych, identyfikowalnych osób, tj. do znanych autorowi tej wypowiedzi (tj. Cyceronowi), i zapewne jego słuchaczom, uczestników spisku Katyliny. 
Konkretność (identyfikowalność) referentów zaimka quidam może wynikać $z$ tego, że - tak, jak w powyższym przykładzie - są to osoby (bądź rzeczy) znane zarówno autorowi wypowiedzi, jak i jej odbiorcy (bądź odbiorcom). W takim przypadku użycie tego zaimka pozwala na aluzyjne odniesienie się do czegoś, bez nazywania tego wprost. Jednak konkretność referenta tego zaimka lub rzeczownika określanego przez ten zaimek, może również wynikać $z$ tego, iż referentem tym jest obiekt znany tylko autorowi wypowiedzi, np.:

Quidam Numam Pompilium, regem nostrum, fuisse Pythagoreum ferunt. (Cic., De orat. 2, 154)

„Niektórzy utrzymują, że Numa Pompiliusz, nasz król, byl pitagorejczykiem”.

Sunt quaedam, quae honeste non possum dicere. (Cic., Phil. 2, 47)

"Są pewne sprawy, o których nie wypada mi mówić".

Fateor in ista ipsa (scil. tribunicia) potestate inesse quiddam mali. (Cic., Leg. 3, 23)

„Przyznaję, że w samej tej władzy (trybuńskiej) tkwi coś zlego (tzn. władza ta ma pewne złe cechy)".

Interim dum ante ostium sto, notus mihi quidam obviam venit. (Ter., Eun. 843)

"I gdy tymczasem stałem tak przed drzwiami, nadszedł z przeciwka pewien mój znajomy".

Est res quaedam, quam occultabam tibi dicere; nunc eam narrabo. (Pl., Pers. 493)

„Jest pewna rzecz, którą przed tobą zataiłem; teraz o niej opowiem".

Wreszcie konkretność referenta, do którego odnosi się zaimek quidam lub rzeczownik nim określany, może także wynikać z tego, iż jest nim osoba (lub rzecz), która choć nie jest dokładnie znana autorowi wypowiedzi, to jednak jest uczestnikiem znanego mu określonego zdarzenia bądź sytuacji. Dlatego zaimek ten często występuje w wypowiedzeniach o charakterze faktywnym, które dotyczą konkretnych zdarzeń mających miejsce w przeszłości lub teraźniejszości:

Quod cum fieret, non inridicule quidam ex militibus decimae legionis dixit plus quam pollicitus est Caesarem ei facere. (Caes., Gall. 1, 42)

„Gdy to się działo, ktoś z żolnierzy dziesiątego legionu dowcipnie stwierdzil, że Cezar robi więcej niż obiecal".

Duo quidam, cum iam in alto navigarent, $[\ldots]$ naufragum quendam natantem et manus ad se tendentem animadverterunt. (Cic., Inv. 2, 153)

„Jacyś dwaj, gdy żeglowali już po pełnym morzu, zobaczyli jakiegoś rozbitka plynącego i wyciągającego do nich ręce".

Quidam ante portam oppidi Gallus [...] ab latere dextro traiectus exanimatusque concidit. (Caes., Gall. 7, 25)

„Jakiś Gall przed bramą miasta, ugodzony w prawy bok, padl, straciwszy przytomność".

Mercator quidam fuit Syracusis senex; ei sunt nati filii gemini duo. (Pl., Men. 17-18)

„Żył w Syrakuzach pewien kupiec $w$ starszym wieku; jemu urodzili się dwaj synowie bliźniacy". 
Bywa jednak stosowany także w wypowiedzeniach o charakterze uogólniającym:

Omne animal adpetit quaedam et fugit a quibusdam. (Cic., Nat. 3, 33)

„Każda żywa istota czegośs (konkretnego) pożąda i czegoś (konkretnego) unika”.

W liczbie mnogiej zaimek ten, użyty na ogół (choć nie wyłącznie) rzeczownikowo, może mieć dodatkowo wartość kwantytatywną, identyfikując pewną grupę (ilość, liczbę) obiektów, która (explicite lub implicite) wyodrębniana jest z większej całości albo przeciwstawiana innej grupie:

Attalus [...] Macedonum fere omnibus et quibusdam Andriorum ut manerent persuasit. (Liv., 31, 45)

„Attalos namówił do pozostania prawie wszystkich Macedończyków i pewną część Andryjczyków".

Arx tantum retenta (est), in quam inter tumultum captae urbis [...] quidam effugere. (Liv., 23, 30)

„Obroniony został jedynie zamek, do którego schronila się pewna ilość ludzi wśród tumultu spowodowanego zdobyciem miasta".

Cum quidam ad Germanicum perfugissent, reliqui [...] in silvas disperguntur. (Tac., Ann. $1,56)$

„Po tym, jak niektórzy uciekli do Germanika, pozostali rozproszyli się po lasach..

Multi palam, quidam, in quibus minus speciosa criminatio erat futura, clam interfecti (sunt). (Liv., 1, 54)

„Wielu stracono jawnie, niektórzy zaś, których oskarżenie mogloby nie wyglądać zbyt ladnie, zostali posłani na śmierć potajemnie".

Itaque nescire, quid sibi (Antiochus) vellet, quibusdam videri; quidam ludere eum simpliciter, quidam haud dubie insanire aiebant. (Liv., 41, 20)

„Toteż niektórym wydawalo się, że Antioch nie wie, czego chce; inni twierdzili, że zwyczajnie się bawi, jeszcze inni, że bez wątpienia jest chory na umyśle".

por. też.:

In quo (libro) non sane multa mutavi, sed quaedam. (Cic., Att. 13, 21, 1)

„W której to (księdze) nie poczynitem rzecz jasna wielu zmian, ale jednak kilka rzeczy (zmienilem)".

$\mathrm{Na}$ związek tego zaimka $\mathrm{z}$ konkretnym referentem wskazuje także częste występowanie jego przymiotnikowej postaci w połączeniu z nazwą własną. Funkcją tego rodzaju zastosowania zaimka quidam jest najczęściej zasygnalizowanie, iż tożsamość referenta (nazwy własnej) jest wprawdzie identyfikowalna, ale niezbyt szeroko znana, z czym wiąże się też supozycja braku znajomości referenta ze strony adresata wypowiedzi:

Mittitur ad eos C. Arpinius eques Romanus, familiaris Titurii, et $Q$. Iunius ex Hispania quidam, qui iam ante missu Caesaris ad Ambiorigem ventitare consuerat. (Caes., Gall. $5,27)$ 
„Wyslany zostaje do nich Gajusz Arpiniusz, ekwita rzymski zaprzyjaźniony z Tyturiuszem, oraz niejaki Kwintus Juniusz z Hiszpanii, który już wcześniej na zlecenie Cezara posłowal do Ambioryksa".

Hoc Orphicum carmen Pythagorei ferunt cuiusdam fuisse Cerconis. (Cic., Nat. 1, 107)

„Pitagorejczycy utrzymują, że ten (znany nam) poemal orficki był (dziełem) jakiegoś Cerkona".

Tres ex illis [...], Adranadorus et Zoippus, generi Hieronis, et Thraso quidam [...], in se convertebant animum adulescentis. (Liv., 24, 5)

„Trzej $\mathbf{z}$ nich, tj. Adranadoros i Zoippos, zięciowie Hierona, oraz niejaki Trazon, zwracali na siebie uwagę mlodzieńca".

Przymiotnikowa postać zaimka może też służyć do zamazywania czy poszerzania granic pojęć, wyrażanych przez łączące się z nią wyrazy. Umieszczona przy przymiotniku podkreśla, że obiekt określany przez ten przymiotnik nie jest łatwy do scharakteryzowania, że jest czymś niezwykłym, i dlatego przymiotnik ten użyty jest w pewnym specyficznym znaczeniu, gdyż jako taki nie do końca oddaje specyfikę charakteryzowanego obiektu:

Haec ergo atque eiusmodi solacia admoveo Liberali nostro incredibili quodam patriae suae amore flagranti. (Sen., Lucil. 91, 13)

„Z tymi i podobnymi pocieszeniami zwracam się więc do naszego Liberalisa, pałającego jakąs taką wprost niewiarygodną miłością do swej ojczyzny".

Użyta w połączeniu $\mathrm{z}$ rzeczownikiem łagodzi niezwykłość jego - często metaforycznego - użycia; dlatego zazwyczaj towarzyszą mu wtedy również partykuły quasi, tamquam, velut:

(Haeret) in eorum mentibus mortem non interitum esse [...], sed quandam quasi migrationem commutationemque vitae. (Cic., Tusc. 1, 27)

„Tkwi w ich umysłach przekonanie, że śmierć nie jest pogrążeniem się w nicość, lecz jakimś jakby przeniesicnicm się i zmianą sposobu życia".

Pacis est comes [...] et iam bene constitutae civitatis quasi alumna quaedam eloquentia. (Cic., Brut. 45)

„Szluka wymowy jest lowarzyszką pokoju i jakby jaką̧ś wychowanką dobrze już urządzonego państwa".

\subsubsection{QUISPIAM, QUIDPIAM (postać rzeczownikowa) QUISPIAM, QUAEPIAM, QUODPIAM (postać przymiotnikowa)}

Zaimek ten używany był rzadziej niż inne zaimki nieokreślone. Jego specyfika funkcjonalna wydaje się też mniej wyrazista i dość zmienna w czasie. Najczęściej wskazywał na obiekt, którego status można określić jako prawdopodobny. Tym samym jego zakres funkcjonalny lokowałby się pomiędzy zamkiem quis, implikującym 
czystą potencjalność, hipotetyczność, a zaimkiem aliquis, suponującym istnienie wskazywanego obiektu. Spotyka się go więc w wypowiedzeniach wyrażających prawdopodobieństwo, $z$ których najbardziej typowe stanowi retoryczna formuła służąca do wprowadzenia (uprzedzenia) prawdopodobnych zarzutów czy pytań ze strony adwersarzy bądź słuchaczy, np.:

Quaeret quispiam: 'quid? illi ipsi summi viri $[\ldots]$ istane doctrina, quam tu effers laudibus eruditi fuerunt?' (Cic., Arch. 15)

„Zapyta ktoś: 'jakże to? a czy sami owi wielcy ludzie posiedli to wykształcenie, które tak bardzo wychwalasz?"'

Tu igitur ipse de te? - dixerit quispiam. (Cic., Phil. 14, 13)

„Ty więc sam o sobie (to mówisz)? - ktoś mógłby powiedzieč".

Iniquum me esse quispiam dicet, qui ex lucri magnitudine coniecturam capiam furti. (Cic., Verr. 2, 3, 111)

„Ktoś powie, że jestem niesprawiedliwy, gdyż na podstawie (samej) wysokości zysku czynię domysły o kradzieży".

Poza tym występuje w zdaniach pytajnych, warunkowych, dopełnieniowych i innych, implikujących prawdopobodobieństwo:

Num tu pudicae cuipiam insidias locas? (Pl., Curc. 25)

"Czy ty przypadkiem nie szykujesz zasadzki na jaką̧śs skromną kobietę?"

Amator novus quispiam? (Pl., Truc. 724)

„Jakiś nowy kochanek?"

Ex quo intellegitur corporis voluptatem [...] contemni et reici oportere, sin sit quispiam, qui aliquid tribuat voluptati, diligenter ei tenendum esse eius fruendae modum. (Cic., Off. $1,106)$

„Wynika $z$ tego, że rozkosz zmyslowa zasługuje na wzgardę i odrzucenie, ale jeśli znajdzie się ktoś, kto przyznałby rozkoszy jakąśs wartość, to powinien on pilnie przestrzegać miary w jej używaniu".

Vereor ne haec forte cuipiam nimis antiqua et iam obsoleta videantur. (Cic., Verr. 2, 1,56)

„Boję się, że komuś te (przyklady) mogą wydać się zbyt staromodne i już przestarzałe".

Nisi vero cuipiam L. Caesar $[\ldots]$ crudelior nudius tertius visus est, cum sororis suae $[\ldots]$ virum $[\ldots]$ vita privandum esse dixit. (Cic., Catil. 4, 13)

„Chyba że komuś Lucjusz Cezar wydał się wczoraj zbyt okrutny, gdy powiedział, że mąż jego siostry zasługuje na śmierć".

Forsitan aliquis aliquando eiusmodi quidpiam fecerit. (Cic., Verr. 2, 2, 78)

"Być może ktoś kiedyś coś tego rodzaju uczynil".

Jak widać z powyższych przykładów, wypowiedzenia, w których pojawia się zaimek quispiam, stanowią również konteksty typowe dla użycia zaimka quis lub aliquis, co zdaje się potwierdzać pośredni charakter quispiam i jego nacechowanie sprowadzające się do implikacji prawopodobieństwa. 


\subsubsection{QUIVIS, QUIDVIS (postać rzeczownikowa), QUIVIS, QUAEVIS, QUODVIS (postać przymiotnikowa), \\ QUILIBET, QUIDLIBET (postać rzeczownikowa), QUILIBET, QUAELIBET, QUODLIBET (postać przymiotnikowa)}

Zaimki te nie różnią się istotnie między sobą. Pełnią funkcję uogólniającą, implikującą swobodny wybór desygnatu. Mają też charakter absolutny, tj. nie względny, czym różnią się od pary zaimków quisquis i quicumque. Ich polskimi odpowiednikami są najczęściej zaimki ktokolwiek, jakikolwiek, każdy. Czasem zaimki te szczególnie eksponują indyferentność (obojętnie jaki, pierwszy z brzegu) lub implikują depreconującą ocenę (byle kto, byle jaki):

Omitto divitias, quas cum quivis, quamvis indignus, habere possit, in bonis non numero; quod enim est bonum, id non quivis habere potest. (Cic., Tusc. 5, 46)

„Pomijam bogactwo, którego nie zaliczam do dóbr, ponieważ ktokolwiek, nawet ktoś niegodny, może je posiadać; tego zaś, czym jest dobro, nie każdy może posiadać".

Sunt $[\ldots]$, qui quidvis perpetiantur, cuivis deserviant, dum quod velint, consequantur. (Cic., Off. 1, 109)

„Są tacy, kıórzy zgodziliby się na cokolwiek, gotowi są służyć komukolwiek, byleby tylko osiągnçli to, czego pragną".

Iam res Romana adeo erat valida, ut cuilibet finitimarum civitatum bello par esset. (Liv., $1,9)$

„Pańtwo rzymskic było już tak silne, że każdemu z pogranicznych miası mogło sprostać w. wojnie".

Cuiusvis hominis est errare. (Cic., Phil. 12, 5)

„Cechą każdego czlowieka jest mylić się".

Tranquillo [...], ut aiunt, quilibet gubernator est. (Sen., Lucil. 85, 34)

„Na spokojnym morzu, jak powiadają, każdy jest (dobrym) sternikiem”.

An hoc, si Claudiae familiae non sim [...], sed unus Quiritium quilibet [...] reticere possim? (Liv., 6, 40)

„A (nawet) gdybym nie był $z$ rodu Klaudiuszów, lecz pierwszym lepszym Rzymianinem, to czy mógłbym to przemilczeć?"

Non dubito, tu quid responsurus sis [...]; non quemvis hoc idem interrogarem. (Cic., Tusc. 5, 55)

„Gdy chodzi o ciebie, to nie mam wątpliwości, co byś odpowiedzial; (jednak) nie zadałbym tego wlaśnie pytania byle komu".

Cui contingit habere rem non quamlibet, hunc non quemlibet dixeris. (Sen., Lucil. 87, 17) „Komu przytrafi się mieć rzecz nie byle jaką, tego nie nazwiesz byle kim".

Non in omnes bonum cadit nec quemlibet possessorem patitur. (Sen., Lucil. 87, 20)

„Dobro nic przypada w udziale wszystkim i nic toleruje byle kogo jako jego posiadacza”. 
Status zaimków uogólniających absolutnych mają także zaimki: przymiotnikowe:

- qualislibet - 'jakikolwiek', 'jaki bądź;

- quantuslibet, quantusvis - 'jakkolwiek wielki', 'dowolnie wielki'; oraz przysłówkowe:

- ubivis, ubilibet - 'gdziekolwiek', 'byle gdzie';

- quovis, quolibet - 'dokądkolwiek';

- undelibet - 'skądkolwiek';

- quavis, qualibet - 'którędykolwiek'.

Cartaginem Novam interim oppugnare statuit, urbem [...] sitam [...] super portum satis amplum quantaevis classi. (Liv., 26, 42)

„Postanowil tymczasem oblegać Nową Kartaginę, miasto polożone nad portem wystarczająco obszernym dla (pomieszczenia) dowolnie wielkiej floty".

Nec recito cuiquam nisi amicis [...], non ubivis coramve quibuslibet. (Hor., Serm. 1, 4, 73-74)

„I nie czytam (swoich utworów) nikomu, jak tylko przyjaciolom, i nie byle gdzie albo przed byle kim".

\subsubsection{QUISQUIS, QUIDQUID (postać rzeczownikowa), QUISQUIS, (QUAEQUE), QUODQUOD (postać przymiotnikowa)}

\section{QUICUMQUE, QUAECUMQUE, QUODCUMQUE}

Zaimki te również pełnią funkcję uogólniającą, implikującą swobodny wybór, lecz w przeciwieństwie do quivis i quilibet najczęściej mają charakter względny:

Quisquis homo huc profecto venerit, pugnos edet. (Pl., Amph. 309)

„Ktokolwiek tu przyjdzie, posmakuje (moich) pięści (dosł.: „będzie jadt moje pięści” = pobiję go)".

Quisquis enim sentit, quem ad modum sit affectus, eum necesse est aut in voluptate esse aut in dolore. (Cic., Fin. 1, 38)

„Ktokolwiek bowiem odczuwa, w jaki sposób coś na niego oddziałuje, ten w sposób konieczny musi (zawsze) czuć albo przyjemność, albo cierpienie".

Quidquid tangebam, crescebat tamquam favus. (Petron., Sat. 76, 8)

"Czegokolwiek się dotknąlem, urastalo jak plaster miodu".

Quicumque tuum violavit volnere corpus, morte luet merita. (Verg., Aen. 11, 848-849)

„Ktokolwiek zranil twoje cialo, przyplaci to zasłużoną śmiercią".

Quicumque is est, ei me profiteor inimicum. (Cic., Fam. 10, 31, 3)

„Kimkolwiek on jest, oświadczam, że jestem jego wrogiem”.

Di tibi dent quaecumque optes. (Pl., Mil. 1038)

„Niech bogowie dadzą ci (wszystko), czegokolwiek byś sobie życzył”. 
Niekiedy jednak, zwłaszcza w okresie poklasycznym, zaimki te mogą mieć wartość absolutną. Dotyczy to w szczególności zaimka quicumque:

Quemcumque mortalium arcere tecto nefas habetur. (Tac., Germ. 21)

"Odpędzanie jakiegokolwiek czlowieka od drzwi domu uchodzi za niegodziwość".

Adsentatio erga quemcumque principem sine adfectu peragitur. (Tac., Hist. 1, 15)

„Przytakiwanie jakiemukolwiek cesarzowi dokonuje się bez (prawdziwego) uczucia”.

Ciceronem cuicumque eorum (scil. Graecorum) fortiter opposuerim. (Quint., Inst. 10, 1, 105)

"Cycerona zdecydowanie mógłhym przeciwstawić któremukolwiek spośród Greków".

Zaimek quicumque może podlegać tmezie:

Studia (philosophiae) renovare coepimus, ut [...] prodessemus civibus nostris, qua re cumque possemus. (Cic., Div. 2, 7)

„Zacząłem na nowo oddawać się filozofii, by nieść pomoc współobywatelom, w jakiejkolwiek sprawie byłoby to możliwe".

Status zaimków uogólniających względnych mają także zaimki: przymiotnikowe:

- qualiscumque - 'jakikolwiek';

- quantusquantus, quantuscumqe - 'jakkolwiek wielki';

oraz przysłówkowe:

- ubiubi, ubicumque - 'gdziekolwiek';

- quoquo, quocumque - 'dokądkolwiek';

- undeunde, undecumque - 'skądkolwiek';

- quaqua, quacumque - 'którędykolwiek';

- quandocumque - 'kiedykolwiek';

- quotienscumque - 'ilekroćkolwiek'.

Homines benevolos, qualescumque sunt, grave est insequi contumelia. (Cic., Att. 14, 14, 5) „Ludzi (nam) życzliwych, jacykolwiek by oni nie byli, przykro jest atakować obelżywymi slowami".

Ubicumque homo est, ibi benefici locus est. (Sen., Dial. 7, 24, 3)

"Gdziekolwiek jest (drugi) człowiek, tam jest miejsce dla świadczenia dobrodziejstw".

Quotienscumque me vidit (videt autem saepe), gratias tibi agit singularis. (Cic., Fam. 13, $41,1)$

„Ilekroć mnie widzi (a widuje mnie często), składa ci wielkie podziękowania". 


\subsubsection{QUISQUE, QUIDQUE (postać rzeczownikowa) QUISQUE, QUAEQUE, QUODQUE (postać przymiotnikowa) \\ UNUSQUISQUE, UNUMQUIDQUE (postać rzeczownikowa) UNUSQUISQUE, UNAQUAEQUE, UNUMQUODQUE (postać przymiotnikowa)}

Zaimki te mają status zaimków uogólniających dystrybutywnych. Ich podstawowymi polskimi odpowiednikami są każdy, każdy jeden, jednak wiele kontekstów, w których występuje zaimek quisque, wymaga przekładu wykorzystującego inne środki leksykalno-frazeologiczne. W odróżnieniu od omnes zaimki te podkreślają odrębność sposobu, w jaki każdy z obiektów należących do jakiejś grupy podlega czynności (sytuacji, właściwości), o której mowa w wypowiedzeniu; służą więc do indywidualizowania elementów grupy, której przypisywana jest wspólna cecha; por. np.:

Laudati $[$... $]$ pro contione omnes sunt, donatique pro merito quisque. (Liv., 38, 23)

„Na zgromadzeniu wojskowym pochwalono wszystkich, i obdarowano każdego według (jego) zasług"'?

Zaimek quisque generalnie funkcjonuje jako enklityka, stąd na ogół nie występuje na początku zdania. Wyróżnić można kilka preferowanych dla tego zaimka kontekstów, tj. kilka typów jednostek wyrazowych, po których zaimek ten pojawia się najczęściej. Konteksty te stanowią:

1. Zaimek zwrotny i dzierżawczo-zwrotny:

Volt sibi quisque credi. (Liv., 22, 22)

„Każdy chce, by to jemu wlaśnie ufano".

Praeceptum Apollinis [...] monet ut se quisque noscat. (Cic., Tusc. 1, 52)

„Zalecenie Apollina napomina, aby każdy poznal siebie (samego)”.

Hostes [...] concilio convocato constituerunt optimum esse domum suam quemque reverti. (Caes., Gall. 2, 10)

„Nieprzyjaciele na zwołanym zgromadzeniu zdecydowali, iż najlepszym rozwiązaniem jest, aby każdy powrócil do swego kraju".

Iustitia praecipit parcere omnibus, consulere generi hominum, suum cuique reddere. (Cic., Rep. 3, 24)

„Sprawiedliwość nakazuje wszystkich szanować, troszczyć się o dobro rodzaju ludzkiego, każdemu oddać to, co jego".

17 Jednak omnis może mieć również znaczenie dystrybutywne: In omni enim arte vel studio [...] optimum quidque rarissimum est. (Cic., Fin. 2, 81) „W każdej bowiem sztuce albo w każdym zajęciu, im coś jest lepsze, tym jest rzadsze". 
w funkcji przydawkowej:

Consumitur vigiliis reliqua pars noctis, cum sua quisque miles circumspiceret, quid secum portare posset. (Caes., Gall. 5, 31)

„Pozostała część nocy minęła bezsennie, ponieważ każdy żołnierz przegłądal swoje rzeczy (wybierając), co może ze sobą zabrać".

Zaimek ten występuje w mianowniku liczby pojedynczej również przy podmiocie i orzeczeniu w liczbie mnogiej, także w pierwszej lub drugiej osobie:

At nostri repentino metu perculsi sibi quisque pro moribus consulunt. (Sall., Iug. 58, 2)

"A tymczasem nasi, zdjęci naglym strachem, troszczą się każdy o siebie, stosownie do swego temperamentu".

Bonum publicum simulantes pro sua quisque potentiam certabant. (Sall., Cat. 38)

"Udając (troskę o) dobro publiczne walczyli każdy o swoje wpływy".

Vos separatim sibi quisque consilium capitis. (Sall., Cat. 52, 23)

„Podejmujecie decyzje z osobna, każdy w swoim interesie”.

przy podmiocie identyfikowalnym tylko kontekstowo:

Fit concursus per vias, filios suos quisque visunt. (Pl., Epid. 212)

"Na ulicach tłok, przychodzą (by każdy mógł) zobaczyć swych synów”.

przy funkcjonalnym odpowiedniku podmiotu (w ramach ablativus absolutus):

Exercitus eius [...] amisso duce ac passim multis sibi quisque imperium petentibus brevi dilabitur. (Sall., Iug. 18)

"Jego wojsko szybko się rozproszyło po tym, gdy stracilo wodza i w różnych miejscach liczni starali się (każdy) dla siebie zdobyć naczelne dowództwo".

Rzadziej w takim kontekście pojawia się orzeczenie w liczbie pojedynczej:

Pictores, et ii, qui signa fabricantur, et vero etiam poetae suum quisque opus a vulgo considerari vult. (Cic., Off. 1, 147)

„I malarze, i ci, którzy tworzą posagi, a nawet i poeci, każdy chce, aby jego dzielo było publicznie komentowane".

Czasem zdarza się, że quisque poprzedza zaimek zwrotny; dzieje się tak zwykle wtedy, gdy na zaimku zwrotnym spoczywa szczególny nacisk (emfaza):

Quanti quisque se ipse facit, tanti fiat ab amicis. (Cic., Amic. 56)

„Jak wysoko każdy siebie sam ceni, tak powinien też być ceniony przez przyjaciól”.

Neminem cedere atque obstinatos mori in vestigio quemque suo vidit. (Liv., 28, 22)

„Zobaczył, że nikt się nie cofa, i że nieustępliwie umierają tam, gdzie każdy pozostawil odcisk swojej wlasnej stopy".

por. tez:

Id maxime quemque decet, quod est cuique maxime suum. (Cic., Off. 1, 113)

„To najbardziej każdemu przystoi, co jest w najwyższym stopniu przynależne jego własnej naturze". 
2. Superlatiwus przymiotnika:

Ex ceteris philosophis nonne optumus et gravissimus quisque confitetur multa se ignorare? (Cic., Tusc. 3, 69)

„A spośród pozostałych filozofów, to czy co lepszy i ważniejszy nie przyznaje, że wielu rzeczy nie wie?"

Ex ingenti captivorum numero trecenti quinquaginta octo delecti, nobilissimus quisque, qui Romam mitterentur. (Liv., 7, 19)

„Z ogromnej liczby jeńców wybranych zostało trzystu pięćdziesięciu ośmiu, co najznakomitszych, którzy mieli zostać wysłani do Rzymu".

w liczbie mnogiej:

Sequere illum impetum animi, quo ad optima quaeque [...] ibas. (Sen., Lucil. 31, 1)

„Idź za tym popędem duszy, dzięki któremu (dotąd) podążałeś za wszystkim tym, co najlepsze".

w funkcji przydawkowej:

Quis non videt in optuma quaque re publica plurimum auspica [...] valere. (Cic., Div. $1,95)$

„Któż nie wie, że w każdym bardzo dobrze urządzonym państwie wróżby odgrywały ogromną rolę".

Niekiedy w miejsce superlatiwu użyty zostaje w podobnej funkcji przymiotnik w stopniu równym:

Recitantur litterae Caesaris, quis incusabat egregium quemque et regendis exercitibus idoneum abnuere id munus. (Tac., Hist. 5, 27)

„Odczytano pismo Cezara, w którym uskarżal się, że co bardziej wybitni i zdatni do kierowania wojskami urząd ten odrzucają".

Z superlatiwem poprzedzającym zaimek quisque współwystępuje często drugi superlatiwus we frazie werbalnej, co może odpowiadać polskiej syntagmie korelatywnej: im ... tym ...:

In omni enim arte vel studio vel quavis scienta vel in ipsa virtute optimum quidque rarissimum est. (Cic., Fin. 2, 81)

„W każdej bowiem sztuce, w każdym zajęciu, w jakiejkolwiek nauce albo nawel w samej cnocie, wszystko to, co najlepsze, jest też najbardziej rzadkie (= im coś jest lepsze, tym jest rzadsze)".

Trahimur omnes studio laudis et optimus quisque maxime gloria ducitur. (Cic., Arch. 26)

„Wszystkich nas pociąga pragnienie slawy i im kto lepszy, to tym bardziej dąży do osiągnięcia chwały".

w liczbie mnogiej:

In rebus asperis et tenui spe fortissima quaeque consilia tutissima sunt. (Liv., 25, 38)

„W sytuacjach trudnych i niemal beznadziejnych, im śmielsze są plany, tym są bezpieczniejsze". 
w funkcji przydawkowej:

Maximae cuique fortunae minime credendum est. (Liv., 30, 30)

„Im większe szczęście, tym mniej należy mu ufać”.

Velim sic statuas, tuas mihi litteras longissimas quasque gratissimas fore. (Cic., Fam. 7, $33,2)$

„Chciałbym, byś był przekonany, że im twój list do mnie będzie dłuższy, tym będzie (mi) milszy".

\section{Liczebniki porządkowe:}

Ex fuso exercitu $[\ldots]$ decimus quisque fusti feritur. (Tac., Ann. 14, 44)

"Z rozbitego wojska co dziesiąty zachlostywany jest na śmierć (dosł.: każdy dziesiąty)”.

$w$ funkcji przydawkowej:

Tertio quoque verbo orationis suae me appellabat. (Cic., Fam. 5, 2, 8)

„W swojej mowie co trzy slowa wymienial moje imię".

Libros Sibyllinos ex senatus consulto decemviri cum adissent, renuntiaverunt ieiunium instituendum Cereri esse, et id quinto quoque anno servandum. (Liv., 36, 37)

„Po tym, gdy na mocy uchwały senatu decemwirowie zajrzeli do ksiąg sybillińskich, oświadczyli, że na cześć Cerery należy ustanowić specjalny post i zachowywać go co cztery lata (dosł.: każdego piątego roku)".

4. Zaimki względne i pytajne, wprowadzające zdania podrzędne (dopełnieniowe, przydawkowe, okolicznikowe, podmiotowe, $w$ tym pytania zależne):

Defendat, quod quisque sentit. (Cic., Tusc. 4, 7)

„Niech każdy broni tego, co myśli”.

Quam quisque norit artem, in hac se exerceat. (Cic., Tusc. 1, 42)

"Niach każdy zajmuje się tą sztuką, którą poznar".

Non est meae consuetudinis initio dicendi rationem reddere, qua de causa quemque defendam. (Cic., Rab. Perd. 1)

„Nie jest moim obyczajem, rozpoczynając przemówienie, przedstawiać powody, dlaczego kogoś bronię".

Sepulcra exstant, quo quisque loco cecidit. (Liv., 1, 25)

„Pozostaly grobowce (tam), gdzie każdy padr”.

w liczbie mnogiej:

Omnes $[\ldots]$ incenduntur ad studia gloria, iacentque ea semper, quae apud quosque improbantur. (Cic., Tusc. 1, 4)

„Wszyscy pobudzani są do uprawiania nauk nadzieją na sławę, i (dlatego) zawsze leżą odłogiem te, które wśród poszczególnych (narodów) nie są cenione". 
w funkcji przydawkowej:

Ad classis aedificandas [...] quantum pecuniae quaeque civitas daret, Aristides electus est qui constutueret. (Nep., Arist. 3)

„Wybrano Arystydesa, aby wyznaczyl, ile pieniędzy każde państwo ma dawać na budowç”.

5. Partykuły i spójniki wprowadzające zdania korelatywne, dopełnieniowe, okolicznikowe:

Ut enim quisque sibi plurimum confidit $[\ldots]$, ita in amicitiis expetendis colendisque maxime excellit. (Cic., Lael. 30)

„Bowiem im kto więcej ufności pokłada w sobie samym, tym bardziej góruje nad innymi w poszukiwaniu i pielęgnowaniu przyjaźni".

Alius alio ferocius, quia quo quisque asperius adversus Romanos locutus esste, eo spes gratiae maior erat. (Liv., 35, 17)

„Jeden (występowal) bardziej agresywnie od drugiego, ponieważ im kto ostrzej przemówił przeciw Rzymianom, tym większą mial nadzieję na względy (u króla Antiocha)".

Proinde ut quisque Fortuna utitur, ita praecellet. (Pl., Pseud. 679-680)

„Jak komu dopisze szczęście, tak będzie wybijał się ponad innych”.

Varios voltus digredientium ab nuntiis cerneres, ut cuique laeta aut tristia nuntiabantur. (Liv., 22, 7)

„Można było dostrzec różne twarze ludzi odchodzących od posłańców, $\mathbf{w}$ zależności od tego, czy komuś przekazywano radosne, czy smutne wieści".

Omniaque ut quidque actum est memoravit. (PI., Bacch. 1097)

"I wszystko, jak co się wydarzyło, przypomniał".

w liczbie mnogiej:

Equites Mauri atque Getuli non acie [...], sed catervatim, ut quosque fors conglobaverat, in nostros incurrunt. (Sall., lug. 97)

„Jeźdźcy mauretańscy i getulscy, nie w szyku bojowym, lecz w bezładnej gromadzie, jak poszczególnych (ludzi) zgromadził przypadek, najeżdżają na naszych".

w funkcji przydawkowej:

Nostri [...], ut quaeque pars castrorum [...] premi videbatur, eo occurrere et auxilium ferre. (Caes., Gall. 3, 4)

„Nasi, według tego jak któraś część obozu wydawała się zagrożona, (to) tam biegli i nieśli pomoc".

Legati $[\ldots]$, quo quaeque opulentior civitas erat, eo accuratius agebant. (Liv., 42, 45)

„Posłowie, im które miasto było zamożniejsze, tym staranniej realizowali swą misje”.

Poza tymi kontekstami zaimek ten pojawia się rzadziej:

Suos cohortatus [...] certas cuique partes ad custodiam urbis attribuit. (Caes., Civ. 1, 17)

„Dodawszy swoim (ludziom) otuchy, przydzielit każdemu (z nich) określone miejsca do obrony miasta". 
w funkcji przydawkowej:

Binos cuiusque anni consules numerasti. (Apul., Apol. 89)

„Policzyłeś po dwóch konsulów każdego roku”.

Zaimek quisque traci znaczenie dystrybutywne $w$ wyrażeniach typu cuiusque modi, cuiusque generis 'wszelkiego rodzaju', przyjmując funkcję uogólniającą absolutną:

Coloni $[\ldots]$ canes rabidos et immanes $[\ldots]$ iubilationibus $[. .$.$] et cuiusque modi vocibus$ nobis inhortantur. (Apul., Met. 8, 17)

„Chłopi pokrzykiwaniem i wszelkiego rodzaju wrzaskami szczują na nas rozwścieczone, ogromne psy".

Interea Manlius in Etruria plebem sollicitare [...], praeterea latrones quoiusque generis, quorum in ea regione magna copia erat. (Sall., Cat. 28)

„Tymczasem Manliusz w Etrurii podburzal tłum, a oprócz tego zbójców wszelkiego rodzaju, których w tej okolicy byla wielka ilość".

Niekiedy jednak znaczenia uogólniającego absolutnego nabiera także w innych kontekstach:

Omnia aedificia, quae quisque conspexerat, incendebantur. (Caes., Gall. 6, 43)

„Wszelkie zabudowania, które ktokolwiek dostrzegl, były podpalane”.

Zaimek unusquisque stanowi połączenie liczebnika unus i zaimka quisque. Połączenie to często pisane jest rozdzielnie (unus quisque), stąd też jego status jest czymś pośrednim między złożeniem a syntagmą. Podkreśla indywidualizację, odrębność każdego elementu grupy, a więc wzmacnia dystrybutywność wyrażaną przez quisque. Używany jest w podobnych kontekstach co zaimek quisque, jednak może również być stosowany na początku zdania:

Suo enim unus quisque studio maxime ducitur. (Cic., Fin. 5, 5)

„Bowiem każdego najbardziej pociągają jego własne zainteresowania”.

Aspice, quanto aliter unusquisque populo vivat, aliter sibi. (Sen., Lucil. 94, 69)

„Zauważ, jak bardzo każdy żyje inaczej dla ludzi, a inaczej dla siebie”.

Nemo invenitur, qui pecuniam suam dividere velit; vitam unusquisque quam multis distrubuit! (Sen., Dial. 10, 3, 1)

„Nie ma nikogo, kto chcialby rozdzielić (między innych) swoje pieniądze, a z jakże wieloma każdy podzielił się swoim życiem!"

Sit denique inscriptum in fronte unius cuiusque, quid de re publica sentiat. (Cic., Catil. 1, 32)

„Niech wreszcie na czole każdego jednego będzie wypisane, co myśli o rzeczpospolitej”.

Omnium societatum nulla est [...] carior quam ea, quae cum re publica est uni cuique nostrum. (Cic., Off. 1, 57)

„Ze wszystkich związków żaden nie jest droższy od tego, który lączy każdego jednego z nas z ojczyzną". 
In castris Curionis magnus omnium incessit timor inimis [...]. Unusquisque enim opiniones fingebat et ad id, quod ab alio audierat, sui aliquid timoris addebat. (Caes., Civ. 2, 29)

„W obozie Kuriona wszystkich ogarnął wielki strach. Każdy bowiem snuł whasne domysły i do tego, co usłyszal od kogoś innego, dodawal jakieś swoje obawy".

w funkcji przydawkowej:

Caesar $[\ldots]$ in unumquemque collem turrem castellaque facere coepit. (Ps.-Caes., Bell. Afr. 38)

"Cezar zacząl na każdym wzgórzu budować wieże i forty".

Lysander $[\ldots]$ decem delegerat in una quaque civitate, quibus summum imperium $[\ldots]$ committeret. (Nep., Lys. 1)

„Lyzander wybral dziesięciu (ludzi) w każdym państwie, by powierzyć im najuyższą władzę".

Zaimkami uogólniającymi dystrybutywnymi są także zaimki przysłówkowe: undique 'zewsząd, z każdego miejsca' i ubique 'wszędzie, w każdym miejscu'. Ubique w klasycznej prozie używane było zwykle po zaimku względnym lub pytajnym:

Undique in murum lapides iaci coepti sunt. (Caes., Gall. 2, 6)

„Zewsząd zaczęły być rzucane na mur kamienie".

Porsinna [...] in plano ripisque Tiberis castra posut, navibus undique accitis [...] ut praedatum milites trans flumen $[\ldots]$ traiceret (Liv., 2, 11)

„Porsynna rozlożył obóz na równinie i brzegach Tybru, ściągnąwszy zewsząd łodzie, aby przerzucać przez rzekę żołnierzy dla dokonywania rabunków".

Mundus, quoniam omnia cmplexus est neque est quicquam, quod non insit in eo, perfectus undique est. (Cic., Nat. 2, 38)

„Swiat, ponieważ wszystko obejmuje i nie istnieje nic, co byłoby poza nim, jest z każdej strony doskonały".

Omnes legiones, omnes copiae, quae ubique sunt, rei publicae sunt. (Cic., Phil. 10, 12)

„Wszystkie legiony, wszystkie wojska, które znajdują się w jakimkolwiek miejscu, należą do rzeczpospolitej".

Posito ubique bello magna pars senatus extremum discrimen adiit. (Tac., Hist. 2, 52)

„Gdy wojna już wszędzie ustała, znaczna część senatorów popadła w skrajne niebezpieczeństwo".

\subsection{ZAIMKI BINARNE}

Pod względem semantycznym zaimki binarne mają status kwantyfikatorów numerycznych (ilościowych) charakteryzujących obiekty, na które wskazują, jako tworzące zbiory dwuelementowe (pary) lub jako stanowiące (pojedyncze) składniki takich zbiorów. Pod względem gramatycznym mogą przyjmować status zarówno rzeczownikowy, jak i przymiotnikowy. 


\subsubsection{UTERQUE, UTRAQUE, UTRUMQUE $A M B O, A M B A E, A M B O$}

Zaimek binarny uterque ma charakter dystrybutywny i odpowiada polskim wyrażeniom typu: jeden $i d r u g i, k a z \dot{d} y y d w u$, obaj (oddzielnie). Służy do wskazywania na parę obiektów w sposób zindywidualizowany, podkreślający odrębność sposobu, w jaki każdy z nich uczestniczy w sytuacji będącej treścią wypowiedzenia. Refleksem tej indywidualizującej funkcji jest współwystępowanie liczby pojedynczej:

Cum enim mecum in Tusculano esses et in bibliotheca separatim uterque nostrum ad suum studium libellos quos vellet evolveret, incidisti in Aristotelis Topica quaedam. (Cic., Top. 1)

„Kiedy bowiem przebywaleś ze mną w Tuskulanum i w bibliotece każdy z nas (dwóch) oddzielnie, stosownie do swoich zainteresowań, przeglądał książi, którymi był zainteresowany, natknąleś się na jakieś Topiki Arystotelesa".

In Galliam invasit Antonius, in Asiam Dolabella, in alienam uterque provinciam. (Cic., Phil. 11, 4)

„Galię najechał Antoniusz, Azję Dolabella, każdy z nich na cudzą (dla siebie) prowincję".

Z kolei zaimek ambo ma charakter unifikujący: 'obaj (razem)'. Ujmuje zatem parę obiektów w sposób kolektywny, implikując, iż uczestniczą one w wyrażanej w zdaniu sytuacji w sposób identyczny, niezróżnicowany; jego formalnym wyróżnikiem jest też w związku z tym liczba mnoga:

Ambo $[\ldots]$ ab eodem Philone nihil scire didicistis. (Cic., Nat. 1, 17)

„Obaj od tegoż samego Filona nauczyliście się, że nic nie wiecie”.

Populi quidem Romani iudicia multa ambo habetis. (Cic., Phil. 1, 36)

„Naród rzymski obu was już wielokrotnie osądzil”.

Zróżnicowanie funkcjonalne zaimków uterque i ambo widoczne jest w szczególności, gdy wpółwystępują one jednym tekście:

Hoc unum esse tempus de pace agenda, dum sibi uterque confideret et pares ambo viderentur. (Caes., Civ. 3, 10)

„To jest jedyny czas na prowadzenie rokowań pokojowych, dopóki każdy z nich (dwóch) poklada wiarę w sobie samym i obaj uchodzą za równych sobie".

Zaimka uterque w liczbie mnogiej używa się zazwyczaj w znaczeniu 'jedni i drudzy' oraz w odniesieniu do rzeczowników należących do klasy pluralia tantum:

Accessit et ad haec pestilentia, commune malum, quod facile utrorumque animos averteret a belli consiliis. (Liv., 25, 26)

„Doszła do tego zaraza, wspólne wszystkim nieszczęście, które umysly jednych i drugich

(tj. Rzymian i Punijczyków) latwo odwrócilo od planów wojennych". 
Sic utrosque reprehendas: et eos, qui semper inquieti sunt, et eos, qui semper quiescunt. (Sen., Lucil. 3, 5)

„Tak więc skarć jednych i drugich: i tych, którzy wiecznie są niespokojni, i tych, którzy stale zachowują spokój".

(Eumenes dixit Perseum) Seleuci filiam duxisse [...], sororem dedisse Prusiae [...]; celebratas esse utrasque nuptias gratulatione donisque innumerabilium legationum. (Liv., 24, 12)

„(Eumenes powiedział, że Perseus) pojął za żonę córkę Seleukosa, siostrę (zaś) wydał za Prusjasza; oba śluby obchodzono wśród gratulacji i darów ze strony niezliczonych poselstw".

Zaimkami binarnymi dystrybutywnymi są również zaimki przysłówkowe, m.in. utrimque ' $z$ jednej i drugiej strony', 'po obu stronach', utroque 'w jedną i drugą stronę', 'w obu kierunkach', 'do obu miejsc', utrubique 'w jednym i drugim miejscu', 'w obu przypadkach':

Multa utrimque vulnera accipiuntur. (Caes., Gall. 7, 81)

„Z jednej i drugiej strony (po obu stronach) doznaje się wiele ran”.

Utroque coloniae missae. (Liv., 1, 11)

„Do obu miejsc wyslano osiedleńców".

Praeda opulenta utrubique est parta. (Liv., 10,39)

„W obu miejscach zdobylo bogaty lup".

\subsubsection{NEUTER, NEUTRA, NEUTRUM}

Zaimek ten jest zaimkiem binarnym przeczącym o znaczeniu ani jeden, ani drugi, 'żaden $z$ dwóch'. Może występować $w$ funkcji rzeczownikowej lub przymiotnikowej, implikując negację zdaniową:

De Scauro et Rutilio breviter licet dicere, quorum neuter summi oratoris habuit laudem et est uterque in multis in mult is causis versatus. (Cic., Brut. 110)

„O Skaurusie i Rutyliuszu wypada opowiedzieć krótko, z nich bowiem żaden nie uzyskał sławy wybitnego mówcy, a jeden i drugi uwikłany był w liczne procesy sądowe".

Neutra acies laeta ex eo certamine abiit: victi Rutuli, victores Aborigenes Troianique ducem Latinum amisere. (Liv., 1, 2)

„Ani jedna, ani druga armia nie wyszła z tej walki zadowolona: Rutulowie (zostali) pobici, zwycięscy Aboryginowie i Trojanie stracili wodza Latynusa". 
10.8.3. UTER, UTRA, UTRUM

\section{ALTERUTER, ALTERUTRA, ALTERUTRUM UTERVIS, UTRAVIS, UTRUMVIS UTERLIBET, UTRALIBET, UTRUMLIBET}

Są to zaimki binarne swobodnego wyboru, absolutne. Dwa pierwsze mają charakter ekskluzywny, a więc odpowiadają polskim wyrażeniom: jeden albo drugi, któryś $z$ dwóch, jeden $z$ dwóch:

Omnium controversiarum, quae essent inter aratorem et decumanum, si uter velit, edicit se recuperatores daturum. (Cic., Verr. 2, 3, 35)

„Oglasza, że w przypadku wszelkich sporów między rolnikiem a dzierżawcą podatkowym, jeśliby któryś z nich chcial, wyznaczy sędziów polubownych".

Brevis morbus ac praeceps alterutrum faciet: aut extinguetur aut extinguet. (Sen., Lucil. $78,17)$

„Krótkotrwala i gwałtownie przebiegająca choroba doprowadzi do jednego z dwojga: albo (sama) zaniknie, albo doprowadzi do śmierci (chorego)."

'Si enim' inquit 'alterutrum concessero necessarium esse, necesse erit cras Hermarchum aut vivere aut non vivere'. (Cic., Lucull. 97)

„Jeśli bowiem - powiada - zgodzę się, że konieczne jest jedno $\mathbf{z}$ dwojga, to $w$ konsekwencji będzie też musiało być tak, że jutro Hermarchus albo będzie żyl, albo nie będzie żyl".

Dicitur $[\ldots]$ patrem et filium pro vita rogantis sortiri [...] iussisse, ut alterutri concederetur. (Suet., Aug. 13)

Podobno rozkazal, by ojciec i syn, proszący o darowanie życia, ciągnęli losy o to, aby jednemu z nich udzielono tej laski (= któremu z nich ma być udzielona ta laska)."

W wypowiedzeniach zawierających negację zdaniową zaimki te wyrażają koniunkcję, a więc mają znaczenie „żaden $\mathrm{z}$ dwóch”, „ani jeden, ani drugi”:

[...] cum accusator et reus duae res quasi cognatae coniunctaeque sint neque utra sine altera constare possit $[\ldots]$.

„[...] chociaż oskarżyciel i oskarżony to dwie rzeczy, które są jakby powiązane i polączone, i żadna z nich dwojga nie może istnieć bez drugiej (...)".

Exercitum cum $[. .$.$] ad pugnam cohortaretur [...], in primis commemoravit testibus se mi-$ litibus uti posse, quanto studio pace petisset [...], neque se umquam abuti militum sanguine neque rem publicam alterutro exercitu privare voluisse. (Caes., Civ. 3, 90)

„Gdy zagrzewal wojsko do bitwy, przede wszystkim wspomnial, że może powołać się na świadectwo (samych) żołnierzy co do tego, jak bardzo zabiegał o pokój, i że nigdy nie chcial nadużywać żołnierskiej krwi ani pozbawić rzeczpospolitej któregokolwiek z obu wojsk."

Dwa kolejne mają charakter inkluzywny, a więc odpowiadają polskim wyrażeniom: którykolwiek $z$ dwóch, przynajmniej jeden $z$ dwóch, jeden $z$ nich albo obydwa:

Meander fecit Andriam et Perinthiam. Qui utramvis recte norit, ambas noverit. (Ter., Andr. 9-10) 
"Meander napisał Dziewczynę z Andros i Dziewczynę z Peryntu. Kto zna którałkolwiek (choćby jedną) z tych sztuk, zna je obic".

Duo [...] tempora inciderunt, quibus aliquid contra Caesarem Pompeio suaserim. [...] Quorum si utrumvis persuasissem, in has miserias numquam incidissemus. (Cic., Phil. 2, 24)

„Dwie były sytuacje, w których zasugerowałem coś Pompejuszowi przeciwko Cezarowi. Gdyby choć do jednej $\mathbf{z}$ tych rzeczy udało mi się (go) przekonać, nigdy nie popadlibyśmy w te nieszczęścia".

Utrumlibet ex his incredibile est, aut aliquid beato restare, quod esse quam quod est malit, aut id illum non malle, quod illo melius est. (Sen., Lucil. 85, 21)

„Przynajmniej jedno lub drugie z tych (twierdzeń) jest nie do przyjęcia: albo to, że dla człowieka szczęśliwego istnieje jeszcze coś, co wolałby bardziej niż to, co ma, albo to, że nie woli on tego, co jest lepsze od tego, co ma".

\subsubsection{UTERCUMQUE, UTRACUMQUE, UTRUMCUMQUE}

Ten zaimek jest $\mathrm{z}$ kolei zaimkiem binarnym swobodnego wyboru, o charakterze względnym:

Nam si ita ego istorum aliquem rogarem: 'quicquid non perdidisti, habeasne an non habeas, postulo, ut aias aut neges', utrumcumque breviter responderit, capietur. (Gell., Noc. Att. 16, 2, 9)

„Bo jeśli do kogoś $z$ nich zwróciłbym się $w$ ten sposób: 'chcę, byś potwierdził lub zprzeczyl, czy masz, czy też nie masz tego, czego nie zgubiłeś', to którejkolwiek z dwu krótkich odpowiedzi udzieli (tzn. czy odpowie 'tak', czy 'nie'), wpadnie w pułapkę".

\subsubsection{ALTER, ALTERA, ALTERUM (ALIUS, ALIA, ALIUD)}

Zaimek alter, - $a$, -um ma charakter opozycyjny (przeciwstawiający), wskazując na jeden $z$ dwóch obiektów współtworzących parę. Jego polskimi odpowiednikami mogą być wyrażenia:

a. 'jeden ( $\mathrm{z}$ dwóch)’:

(Agesilaus) statura fuit humili et corpore exiguo et claudus altero pede. (Nep., Ages. 8) "(Agesilaos) był niskiego wzrostu, a także drobnej budowy ciała i kulawy na jedną nogę".

Illi alterum metuunt, nos utrumque. (Cic., Att. 8, 11, 3)

"Tamci boją się (tylko) jednego ( $\mathrm{z}$ nich), my obydwu (jednego i drugiego)".

Necesse est enim sit alterum de duobus, ut aut sensus omnino omnes mors auferat, aut in alium quendam locum ex his locis morte migretur. (Cic., Tusc. 1, 97)

„Musi bowiem nastạpić jedno z dwojga, tak, iż albo śmierć zabiera wszystkie w ogóle zmysły, albo wraz ze śmiercią wędruje się stąd do jakiegoś innego miejsca". 
Consilium inde habitum iamne tempus esset deducendi ab Samnio exercitus, aut utriusque aut certe alterius. (Liv., 10, 44)

„Następnie odbyto naradę (na tym), czy nie nadszedł już czas na wyprowadzenie wojsk z Samnium, albo obydwu, albo przyjmniej jednego".

b. '(ten) drugi (spośród dwóch)':

In ea civitate duo de principatu inter se contendebant, Indutiomarus et Cingetorix, ex quibus alter, simulatque de Ceasaris legionumque adventu cognitum est, ad eum venit, se suosque omnes in officio futuros [...] confirmavit [...]. At Indutiomarus [...] bellum parare instituit. (Caes., Gall. 5, 3)

„W plemieniu tym dwóch ludzi wspótzawodniczyło o przywództwo: Indutiomarus i Cyngetoryks; ten drugi $z$ nich, gdy tylko rozeszła się wieść o nadejściu Cezara $z$ wojskiem, przybył do niego i zapewnil, że on oraz wszyscy jego ludzie dochowają posłuszeństwa (Cezarowi). A tymczasem Indutiomarus zacząl szykować się do wojny".

(Caesar) mittit $P$. Vatinium legatum, qui ea, quae maxime ad pacem pertinere viderentur, ageret $[. .$.$] ; responsum est ab altera parte Aulum Varronem profiteri se [...] ad conloqu-$ ium venturum. (Caes., Civ. 3, 19)

„(Cezar) wyslał legata Publiusza Watyniusza, aby mówił o sprawach mogących mieć największe znaczenie dla pokoju; z drugiej strony padła odpowiedź, że Aulus Warron obiecuje, iż przybędzie na rozmowę".

Duo haud amplius milia peditum [...] vix inito proelio cum Magone effugerunt; Hanno, alter imperator, cum eis, qui postremi [...] advenerant, vivus capitur. (Liv., 28, 2)

„Nie więcej niż dwa tysiące piechoty uciekło z Magonem; Hannon, drugi wódz, wraz z tymi, którzy przybyli na końcu, dostaje się do niewoli".

Oprócz ściśle pojętej kwantyfikacji binarnej zaimek ten jako przydawka może być używany także $w$ innych, pokrewnych funkcjach semantycznych, wyrażając:

a. podobieństwo: 'drugi tego samego rodzaju', 'drugi taki sam':

Tum vero ad hoc retracti ex distantibus locis in sedem antiquam videbamur, ut iterum periremus et alterum excidium patriae videremus. (Liv., 28, 39)

„Wtedy wydawało się, że po to tylko zostaliśmy sprowadzenie z odległych miejsc do dawnej siedziby, byśmy ponownie zginęli i oglądali drugi upadek ojczyzny".

Quem ad modum nostrum hoc consilium Capua probabit, quae temporibus his Roma altera est? (Cic., Phil. 12, 7)

„W jaki sposób tę naszą decyzję przyjmie Kapua, która w tych czasach stała się drugim Rzymem?"

Praebebo etiam hostiam, ut Coriolanus sit plane alter Themistocles. (Cic., Brut. 43)

„Dam ci nawet zwierzę ofiarne, by Koriolanus stał się już całkowicie drugim Temistoklesem”.

b. (rzadko) kontrast: 'inny', 'odmienny':

(Alexander) adulescens in incremento rerum, nondum alteram fortunam expertus, decessit. (Liv., 19, 17)

„(Aleksander) umarł jako młody człowiek, gdy jego potęga ciągle rosła, nie zdążywszy zaznać odmiennego losu". 
W pozycjach rzeczownikowych alter często wskazuje na niescharakteryzowaną, uogólnioną osobę (rzecz), inną niż ta, o której mowa w wypowiedzeniu:

Acerbitatem inimicorum docet, qui quod ab altero postularent, in se recusarent. (Caes., Civ. 1, 32)

„Wskazał na cynizm nieprzyjaciół, którzy to, czego domagają się od kogoś innego, w stosunku do samych siebie odrzucają".

Verum illud verbumst, quod dici solet, omnis sibi malle melius esse quam alteri. (Ter., Andr. 426-427)

„Prawdą jest to powiedzenie, które często się powtarza, że wszyscy wolą, żeby to im było lepiej niż drugiemu".

Przy wyliczaniu dwóch lub większej liczby obiektów ma znaczenie 'drugi':

Duos flamines adiecit, Marti unum, alterum Quirino. (Liv., 1, 20)

„Dodal jeszcze dwóch kapłanów, jednego dla Marsa, drugiego dla Kwiryna”.

Cum in natura tria sint, unum gaudere, alterum dolere, tertium nec gaudere nec dolere, hic (scil. Epicurus) primum et tertium putat idem esse nec distinguit a non dolendo voluptatem. (Cic., Tusc. 3, 47)

„Chociaż istnieją trzy naturalne stany: pierwszy czuć radość, drugi czuć ból, trzeci zaś nie czuć ani radości, ani bólu, Epikur uważa, że pierwszy i trzeci stan to to samo i nie odróżnia rozkoszy od braku bólu".

Powtórzenie tego zaimka w obrębie zdania (w kolejnych członach zdania złożonego) może wyrażać:

a. przeciwstawienie dwóch obiektów:

Eorum neuter triumphavit, quod alteri illum honorem collega, alteri mors praeripuit. (Cic., Pis. 62)

„Z nich dwojga żaden nie odbył tryumfu, ponieważ jednemu ten zaszczyt odebrał kolega (sprawujący wraz z nim urząd), drugiemu zaś śmierć".

In quo quid potest esse mali, cum mors nec ad vivos pertineat nec ad mortuos? Alteri nulli sunt, alteros non attinget. (Cic., Tusc. 1, 91)

„Co może być w tym złego, skoro śmierć nie przynależy ani żywym, ani umarlym? Jedni bowiem (już) nie istnieją, drugich ona nie dotknie".

b. wzajemność w odniesieniu do dwóch obiektów:

Caesar $[\ldots]$ legionem $[\ldots]$ nonam in sinistro (cornu) conlocaverat $[\ldots]$ et huic sic adiunxit octavam, ut paene unam ex duabus efficeret, atque alteram alteri praesidio esse iusserat. (Caes., Civ. 3, 89)

„Cezar umieścil dziewiąty legion na lewym skrzydle i dołączył do niego ósmy tak, by $\mathrm{z}$ dwóch legionów uczynić niemal jeden, i nakazal, by jeden drugiemu udzielał wsparcia".

c. dystrybutywność:

Facit recta in anguis impetum: alterum altera prehendit eos manu perniciter. (Pl., Amph. 1115-1116) 
„Rzuca się wprost do ataku na węże: natychmiast je chwyta, jednego jedną ręką, drugiego drugą".

O ile zaimek alter wyraża przede wszystkim opozycję ilościową binarną, o tyle zaimek alius prymarnie wskazuje na:

a. zróżnicowanie jakościowe ('inny', 'odmienny'):

Sentit idem quod Xenocrates, quod Aristoteles, loquitur alio modo. (Cic., Leg. 1, 55)

„Ma te same poglądy co Ksenokrates, co Arystoteles, wyraża je jednak w inny sposób".

Longe alia proficiscentis ex urbe Germanici exercitus species. (Tac., Hist. 2, 99)

„Zdecydowanie inny (był) wygląd wyruszającej z Rzymu armii germańskiej”.

Quam cito alium fecisti me. (Pl., Trin. 160-161)

"Jak szybko uczynileś mnie innym".

b. opozycję ilościową otwartą, nieograniczoną ('inny spośród wielu'):

Alium illa amat, non illum. (Pl., Bacch. 593)

„Innego ona kocha, nie jego".

In alium diem hanc litem cum dialecticis differam. (Sen., Lucil. 45, 13)

„Na inny dzień przełożę ten spór z dialektykami”.

Może jednak podobnie jak alter:

a. wyrażać podobieństwo: 'drugi tego samego samego rodzaju', 'drugi taki sam': Nec Alpes aliae sunt, quas dum (hostes) superant, comparari nova possint praesidia. (Liv., 21, 41)

„Nie ma też drugich Alp, by w czasie, gdy wrogowie przez nie się przedzierają, mogły być zorganizowane nowe oddziały dla ochrony".

Iamque proximas civitates $[\ldots]$ fama pervaserat $[. .$.$] non maria, sed terras Venerem$ aliam $[. .$.$] pullulasse. (Apul., Met. 4, 28)$

„Przez sąsiednie kraje przeloczyła się wieść, że nie morza, lecz ziemie zrodziły drugą Wenus".

b. w pozycjach rzeczownikowych wskazywać na niescharakteryzowaną, uogólnioną osobę (rzecz), inną niż ta, o której mowa w wypowiedzeniu:

Laudabunt alii claram Rhodon aut Mytilenen. (Hor., Carm. 1, 7, 1)

„Inni będą wychwalać sławną (wyspę) Rodos albo Mitylenę".

Miseret te aliorum, tui nec miseret nec pudet. (PI., Trin. 431)

"Żal ci innych, a siebie samego ani nie żalujesz, ani się nie wstydzisz".

Est proprium stultitiae aliorum vitia cernere, oblivisci suorum. (Cic., Tusc. 3, 73)

"Jest właściwe glupocie dostrzegać wady innych, zapominać o swoich".

c. wskazywać na obiekty przy ich wyliczaniu; dotyczy to wyliczania zarówno dwóch obiektów, jak i większej ich liczby: 
Sublata priore lege duas promulgavit, unam, qua mercedes habitationum annuas conductoribus donavit, aliam tabularum novarum. (Caes., Civ. 3, 21)

„Wycofawszy poprzednią ustawę, oglosił dwie (nowe): jedną, poprzez którą zwolnil najemców od rocznego czynszu, drugą w sprawie umorzenia długów".

Alia parte ipse (scil. Hannibal) adortus ets, alia Campani omnes. (Liv., 26, 5)

"Z jednej strony zaatakowal sam Hannibal, $z$ drugiej wszyscy Kampańczycy".

Aeque et alia inter auctores discrepant. Praesidium Punicum alius decem, alius septem, alius haud plus quam duum milium fuisse scribit. (Liv., 26, 49)

„Podobnie i co do innych rzeczy zachodzą różnice między poszczególnymi autorami. Jeden pisze, że załogę punicką stanowiło dziesięć tysięcy ludzi, inny, że siedem, jeszcze inny, że nie więcej niż dwa tysiące ludzi".

Alia animalia gradiendo, alia serpendo ad pastum accedunt, alia volando, alia nando. (Cic., Nat. 2, 122)

„Jedne zwierzęta docierają do pożywienia, krocząc, drugie pełzając, inne latając, a jeszcze inne pływając".

Powtórzenie tego zaimka w obrębie zdania (w kolejnych członach zdania złożonego) może wyrażać:

a. przeciwstawienie:

Numquam aliud natura, aliud sapientia dicit. (Iuv., Sat. 14, 321)

„Nigdy nie jest tak, że natura mówi co innego, a co innego mądrość”.

Alii vestrum anseres sunt, qui tantum modo clamant, nocere non possunt, alii canes, qui et latrare et mordere possunt. (Cic., S. Rosc. 57)

„Jedni $z$ was są gęsiami, które tylko gęgają, ale szkodzić nie mogą, inni są psami, które i szczekać, i gryźć umieją".

b. wzajemność:

Milites alius alium, ut adderet gradum, hortabantur. (Liv., 26, 9)

„Żołnierze zachęcali się nawzajem (jeden drugiego), by przyspieszać kroku”.

Milites [...] ipsa festinatione et certamine alii alios impediunt. (Liv., 26, 44)

„Żołnierze, rywalizując, kto kogo prześcignie, przeszkadzają sobie wzajemnie”.

c. dystrybutywność:

Alius in alia est re magis utilis. (Cic., S. Rosc. 111)

"Każdy w czymśs innym jest bardziej użyteczny".

Ipsarumque virtutum in alia alius mavult excellere. (Cic., Off. 1, 115)

"I nawet gdy chodzi o same cnoty, każdy woli wybijać się w innej".

d. porównanie:

Venio ad epistulas tuas, quas ego sescentas uno tempore accepi, aliam alia iucundiorem. (Cic., Att. 7, 2, 3) 
„Teraz przechodzę do twoich listów, których mnóstwo otrzymałem w krótkim czasie, jeden milszy od drugiego".

Powtórzenie tego zaimka ze spójnikiem atque w środku ma znaczenie 'coraz to inny', 'ciągle nowy':

Neque [...] lugurthae dies aut nox ulla quieta fuit [...]: omni strepitu pavescere, alio atque alio loco, saepe contra decus regium, noctu requiecere. (Sall., Iug. 72)

„I nie miał Jugurta ani jednego dnia, ani jednej nocy spokojnej: przy każdym szeleście drżał ze strachu, nocował w coraz to innym miejscu, często z narażeniem na szwank królewskiej godności".

Crescebat interim urbs munitionibus alia atque alia appetendo loca. (Liv., 1, 8)

"Tymczasem miasto się rozrastało, obejmując obwarowaniami coraz to nowe obszary”.

Podobne funkcje pełnią derywowane od tego zaimka zaimki przysłówkowe: aliter 'inaczej', alibi 'gdzie indziej,' alias 'kiedy indziej' itp.:

Quod eo anno frumentum in Gallia propter siccitates angustius provenerat, coactus est aliter ac superioribus annis exercitum in hibernis conlocare. (Caes., Gall. 5, 24)

„Ponieważ tego roku zbiory zbóż w Galii były mniejsze z powodu suszy, został zmuszony do tego, by inaczej niż w latach poprzednich rozlokować wojsko w obozach zimowych".

Tum Scipio [...] sibi maximum nomen imperatoris esse dixit [...]; regium nomen, alibi magnum, Romae intolerabile esse. (Liv., 27, 19)

„Wtedy Scypion powiedzial, że dla niego największe naczenic ma tytuł wodza; tytul królewski, gdzie indziej wielki, w Rzymie jest bardzo źle widziany".

Dilectum consules multo intentiore quam alias cura habebant. (Liv., 42, 32)

„Pobór do wojska konsulowie przeprowadzili ze znacznie większą starannością niż kiedy indziej".

Powtórzenie tych zaimków wyraża zwykle przeciwstawienie, natomiast ich użycie obok zaimka alius - dystrybutywność:

Inde clamor in totam contionem est perlatus; alibi preces, alibi minae audiebantur. (Liv., 8,32 )

„Stamtąd krzyk rozszerzył się na całe zgromadzenie; $\boldsymbol{w}$ jednym miejscu słychać było prośby, w innym groźby".

Interim prope cotidie cum omni equitatu Indutiomarus sub castris eius (scil. Labieni) vagabatur, alias ut situm castrorum cognosceret, alias conloquendi aut territandi causa. (Caes., Gall. 5, 57)

„Tymczasem niemal codziennie Indutiomarus z całą konnicą krążył wokół obozu Labienusa, raz aby poznać jego rozplanowanie, kiedy indziej znów by nawiązać rozmowy albo zastraszyć (jego ludzi)".

Milites decem pastorum habitu mittit pecoraque diversos alium alibi haud procul Romanis pascere iubet praesidiis. (Liv., 9, 2)

„Wysyła dziesiçciu żołnierzy w przebraniu pastuchów i nakazuje im, by w rozproszeniu, każdy w innym miejscu, paśli bydło w pobliżu rzymskich posterunków". 
Illum aliter cum aliis de nobis locutum audiebam. (Cic., Att. 7, 8, 1)

„Słyszałem, że on $\mathbf{z}$ każdym inaczej rozmawiał na mój temat".

Illi alias aliud eisdem de rebus [...] iudicant. (Cic., De orat. 2, 30)

"O tych samych rzeczach mają oni za każdym razem inny pogląd".

\subsection{ZAIMEK WZGLĘDNY QUI, QUAE, QUOD}

Zaimek względny qui, quae, quod jest wskaźnikiem zespolenia w ramach zdania złożonego względnie. Jest zwykle pierwszym elementem zdania podrzędnego, ewentualnie poprzedzonym przyimkiem. Występować może $w$ funkcji rzeczownikowej lub przymiotnikowej. Zajmując pozycję rzeczownikową, stanowi rzeczownikowy człon składniowy zdania podrzędnego względnego, związany syntaktycznie i semantycznie z jednym z rzeczownikowych składników zdania nadrzędnego. Składnik ten stanowi semantyczny korelat (odpowiednik) zaimka względnego. Związek syntaktyczny zaimka względnego $z$ jego semantycznym korelatem $w$ zdaniu nadrzędnym opiera się na kongruencji (składni zgody) pod względem kategorii liczby i rodzaju, natomiast związek semantyczny polega na sygnalizowaniu (na zasadzie anafory lub katafory) koreferencji, czyli tożsamości obiektu, na który wskazuje, z obiektem stanowiącym desygnat tegoż korelatu. Tym samym zaimek względny sygnalizuje, że zdanie względne, do którego należy, posiada pewien wspólny ze zdaniem nadrzędnym składnik semantyczny. Jako element zdania podrzędnego wypełnia pustą pozycję otwieraną przez strukturę syntaktyczną tego zdania, co determinuje jego funkcję składniową i związaną z nią wartość kategorii przypadka. W zależności więc od pozycji, którą w tej strukturze wypełnia, pod względem syntaktycznym może stanowić np.:

a. podmiot:

(Ceasar) Ariminum [...] proficiscitur ibique tribunos plebis, qui ad eum confugerant, convenit. (Caes., Civ. 1, 8)

"(Cezar) wyruszył do Ariminum i tam spotkał się z trybunami ludowymi, którzy wcześniej do niego zbiegli".

b. dopełnienie:

Oppugnas eum, quem neque metuere potes, neque odisse debes. (Cic., S. Rosc. 147)

"Atakujesz tego, którego ani nie możesz się obawiać, ani nie powinieneś nienawidzić".

c. przydawkę (dopełniaczową):

Erat in Carnutibus summo loco natus Tasgetius, cuius maiores in sua civitate regnum obtinuerant. (Caes., Gall. 5, 25)

„Żył w kraju Karnutów wywodzący się ze znakomitego rodu Tasgetius, którego przodkowie sprawowali władzę królewską w swoim plemieniu". 
d. okolicznik:

Illi, quibus Damasippi mors laetitiae fuerat, paulo post ipsi trahebantur. (Sall., Cat. $51,34)$

„Ci, dla których śmierć Damazypa była powodem do radości, niedługo potem sami byli wleczeni (na śmierć)".

Są zdania, w których pozycja otwierana w zdaniu nadrzędnym dla semantycznego korelata zaimka względnego nie zostaje wypełniona. Dotyczy to zwłaszcza korelatów o charakterze zaimkowym. Mamy wówczas do czynienia z tzw. zdaniami względnymi swobodnymi:

Multis [...] serviet, qui corpori servit. (Sen., Lucil. 14, 1)

„Sługą wielu (rzeczy) będzie (ten), kto jest sługą (swego) ciała".

Quem di diligunt, adulescens moritur. (Pl., Bacch. 816-817)

„Kogo bogowic kochają, (ten) umiera jako młody człowiek”.

Xerxes $[. .$.$] praemium proposuit, qui invenisset novam voluptatem. (Cic., Tusc. 5, 20)$

„Kserkses obiecał nagrodę (temu), kto wynalazłby jaką̧ś nową przyjemność”.

Są wreszcie i takie zdania, w których semantycznym korelatem zaimka względnego nie jest jeden element, lecz cała treść (semantyczna zawartość) zdania nadrzędnego. Zdanie podrzędne względne stanowi wówczas tzw. zdanie rozwijające, wyrażając swego rodzaju podumowanie czy komentarz do tej treści; wprowadzane jest przez zaimek względny występujący w liczbie pojedynczej i rodzaju nijakim:

Unum (Balbo) obicitur, natum esse Gadibus, quod negat nemo. (Cic., Balb. 5)

„Jedno zarzuca się (Balbusowi), że mianowicie urodził się w Gades, czemu nikt nie przeczy”.

Ob eas $[\ldots]$ res ex litteris Caesaris dies quindecim supplicatio decreta est, quod ante id tempus accidit nulli. (Caes., Gall. 2, 35)

„Z powodu tych rzeczy na podstawie pisemnego sprawozdania Cezara uchwalono pięlnastodniowe modly dziękczynne, co wcześniej nie zdarzyło się w stosunku do nikogo".

Z kolei przyjmując status przymiotnikowy (tzn. pełniąc funkcję przydawkową), zaimek względny sygnalizuje, że określany przezeń rzeczownik ma swój semantyczny korelat w zdaniu nadrzędnym. Korelatem tym może być wyraz, którego określony zaimkiem względnym rzeczownik jest powtórzeniem lub znaczeniowym odpowiednikiem, albo zaimek pełniący funkcję anaforyczną lub kataforyczną. Określany zaimkiem względnym rzeczownik przyjmować może różne wartości kategorii przypadka i pełnić różne funkcje składniowe, sam zaś zaimek względny występuje zwykle w prepozycji do niego, zachowując kongruencję pod względem kategorii liczby, rodzaju i przypadka:

Erant omnino itinera duo, quibus itineribus domo exire (Helveti) possent. (Caes., Gall. 1,6) "Istniały w sumie dwie drogi, którymi (to drogami) Helweci mogli wyjść ze swego kraju”.

Eodem anno a Campanis Cumae, quam Graeci tum urbem tenebant, capiuntur. (Liv., $4,44)$ 
nW tym samym roku zdobyte zostają przez Kampańczyków Kumy które to miasto zajmowali wówczas Grecy".

Quae pars civitatis Helvetiae insignem calamitatem populo Romano intulerat, ea princeps poenas persolvit. (Caes., Gall. 1, 12)

„Która część plemienia Helwetów zadala narodowi dotkliwą klęskę, tą jako pierwsza poniosla karę".

Neque eam, quam profuisse aliis vim celeritatemque viderant, imitari potuerunt. (Caes., Gall. 6, 40)

„I nie potrafili naśladować tej siły (uderzenia) i szybkości, która, jak zauważyli, była bardzo pomocna innym".

Jednak podobnie jak w przypadku zdań z rzeczownikowo użytym zaimkiem względnym, również i w tym przypadku korelat rzeczownika określonego zaimkiem względnym może zostać $w$ zdaniu nadrzędnym pominięty na powierzchni:

Quod tibi nomen est, fecit mihi. (Pl., Capt. 313)

„Jakie imię ty nosisz, (to) nadal (również) mnie".

Caesar necessariis rebus imperatis ad cohortandos milites, quam in partem fors obtulit, decucurrit. (Caes., Gall. 2, 21)

„Cezar po wydaniu niezbędnych rozkazów pobiegł na oślep, w jaka stronę los go skierował, aby dodać otuchy żołnierzom".

Semantycznym korelatem rzeczownika określonego przymiotnikowym zaimkiem względnym może też być treść całego zdania nadrzędnego, konceptualizowana przez tenże rzeczownik:

(Cimon) decem annorum exilio multatus est, cuius facti celerius Athenienses quam ipsum paenituit. (Nep., Cim. 3)

"(Kimon) skazany został na dziesięcioletnie wygnanie, którego (to) çyłnu wcześniej pożałowali Ateńczycy niż on sam".

Zaimek względny, użyty zarówno rzeczownikowo, jak i przymiotnikowo, może także pełnić funkcję anaforyczną, nie sygnalizując podrzędności składniowej zdania, którego jest elementem. Mamy wtedy do czynienia z tzw. „połączeniem względnym” dwóch zdań niezależnych składniowo:

Neocles [...] uxorem Acarnanam civem duxit, ex qua natus est Themistocles. Qui cum minus esset probatus parentibus [...], a patre exheredatus est. Quae contumelia non fregit eum, sed erexit (Nep., Them. 1)

„Neokles pojął za żonę obywatelkę z Akarnanii, i ze związku z nią przyszedł na świat Temistokles. On to, ponieważ nie zyskal uznania w oczach rodziców, przez ojca został wydziedziczony. Ta zniewaga nie załamała go jednak, lecz (raczej go) podźwignęła".

Więcej na temat zaimka względnego i zdań względnych, zob. niżej: Składnia 4.3.2. 


\subsection{ZAIMKI PYTAJNE}

Zaimki pytajne sygnalizują niewiedzę nadawcy komunikatu co do tożsamości lub określonych właściwości obiektu wskazanego w danym wyrażeniu zdaniowym, albo co do określonych okoliczności towarzyszących sytuacji, która jest treścią danego wypowiedzenia. Stanowią formalne znaczniki niezależnych i zależnych składniowo zdań pytajnych należących do klasy pytań o uzupełnienie, dlatego można im przypisać status operatorów (wykładników) nacechowanej modalności intencjonalnej (interrogatywnej). Jednak ponieważ zajmują w strukturze treściowej zdania pozycje niewypełnione przez wyrażenia pełnoznaczne, a w strukturze syntaktycznej pozycje wypełniane przez leksemy autosyntagmatyczne, a więc pozycje otwierane dla członów syntaktycznych (podmiotu, dopełnienia, przydawki, okolicznika), tradycyjnie zaliczane są do klasy zaimków, a nie partykuł. Ze względu na ich cechy semantyczne i gramatyczne wyodrębnić można zaimki pytajne rzeczowne, przymiotne i przysłówkowe.

Podstawowe zaimki pytajne rzeczowne to: quis?, quid? oraz uter?, utra?, utrum?, które sygnalizują niewiedzę co do tożsamości obiektu osobowego lub rzeczowego. W zdaniu zajmują pozycje otwierane dla rzeczownikowych członów syntaktycznych i odpowiadają polskim wyrażeniom: 'kto? co?', 'czyj?', 'który -a, -e (kto) z dwóch?':

Occiso Sex. Roscio quis primus Ameriam nuntiat? (Cic., S. Rosc. 96)

„Po zabiciu Sekstusa Roscjusza kto jako pierwszy przynosi wiadomość o tym do Amerii?”

Quid est in Antonio praeter libidinem, crudelitatem, petulantiam, audaciam? (Cic., Phil. $3,28)$

„Co (jeszcze) jesı w Antoniuszu oprócz pożądania, okrucieństwa, bezczelności i zuchwałości?"

Peccat uter nostrum cruce dignius? (Hor., Serm. 2, 7, 47)

„Który z nas dwóch grzeszy w sposób bardziej zasługujący na krzyż?”

Zaimek quis?, quid? stosowany jest także przymiotnikowo (w funkcji przydawki lub orzecznika), sygnalizując oczekiwanie na identyfikację obiektu desygnowanego przez określany rzeczownik:

Quis [...] gracilis te puer [...] urget [...], Pyrrha? (Hor., Carm. 1, 5, 1-3)

„Jakiż to przystojny chlopiec ściska cię w ramionach, Pyrro?"

Quis est, qui conplet aures meas, tantus et tam dulcis sonus? (Cic., Rep. 6, 18)

„Co to za donośny i tak mily dźwięk, klóry napelnia moje uszy?”

Zaimki pytajne przymiotne sygnalizują niewiedzę co do (określonych) cech obiektu desygnowanego przez określany przez nie rzeczownik. Najbardziej ogólne znaczenie ma zaimek qui?, quae?, quod? 'jaki? jaka? jakie?', który oprócz pytań o właściwości (charakterystykę) może także współtworzyć pytania o identyfikację obiektu. Poza tym do grupy tej należą zaimki: qualis, -e? - 'jaki? jakiego rodzaju/typu?', qu- 
antus, -a-, um? 'jak wielki?', quot? 'ilu?'. W strukturze składniowej zdania zaimki te pełnią funkcje przymiotnikowych przydawek lub orzeczników:

Quae haec summa eorum potentia est? Tantum posse liberti solent. (Tac., Dial. 13)

"Jaka jest ta ich wielka potęga? Tyle to przecież mogą (nawet) wyzwoleńcy".

Patrem occidit Sex. Roscius. Qui homo? Adulescentulus corruptus et ab hominibus nequam inductus? Annos natus maior quadraginta. (Cic., S. Rosc. 39)

„Sekstus Roscjusz zabil ojca. Jaki to czlowiek? Zepsuty młodzieniaszek namówiony przez niegodziwych ludzi? (Nie,) lat ma przeszlo czterdzieści".

\{Menaechmus:\} Prandi in navi, inde huc sum egressus, te conveni. \{Erotium:\} [...] Quam tu mihi nunc navem narras? (Pl., Men. 402)

„\{Menechmus:\} Zjadłem obiad na okręcie, zszedłem z niego tutaj, spotkalem ciebie. \{Erotium:\} $\mathbf{O}$ jakim okręcie ty mi tu teraz opowiadasz?"

Qualis esset natura montis et qualis in circuitu ascensus qui cognoscerent misit. Renuntiatum est facilem esse. (Caes., Gall. 1, 21)

„Wyslał (ludzi), by zbadali, jaki jest charakter góry i jaki (jest do niej) dostęp z poszczególnych stron. W odpowiedzi doniesiono, że jest latwy".

Cum igitur tanta vis iustitiae sit, ut ea etiam latronum opes firmet atque augeat, quantam eius vim $[\ldots]$ in constituta re publica fore putamus? (Cic., Off. 2, 40)

„Skoro więc moc sprawiedliwości jest tak wielka, że utwierdza i powiększa nawet potęgę rozbójników, to jak wielka naszym zdaniem będzie jej sila w dobrze urządzonym państwie?"

Vereor $[\ldots]$ ne [...] minus dilucide appareat quantus fuerit ille vir. (Nep., Pel. 1)

„Obawiam się, będzie nie dość wyraźnie widoczne, jak wielkim był on człowiekiem”.

Numerate saltem quot ipsi sitis, quot adversarios habeatis. (Liv., 6, 18)

„Policzcie przynajmniej, ilu was jest, ilu macie przeciwników”.

Zaimki pytajne przysłówkowe sygnalizują niewiedzę co do określonych okoliczności związanych z sytuacją, która jest treścią danego zdania. Do tej grupy zaimków należą: ubi? 'gdzie?', quo? 'dokąd?', qua? 'w którą stronę?, którędy?', utro? 'w którą $\mathrm{z}$ dwu stron?', unde? 'skąd?', quando? 'kiedy?', quotiens? 'ile razy?', quantum? 'ile?' itp. W strukturze składniowej zdania pełnią funkcje okoliczników:

\{Agorastocles:\} Quo te agis? \{Adelphasium:\} Egone? In aedem veneris. (Pl., Poen. 333)

"\{Agorastokles:\} Dokąd idziesz? \{Adelfazjum:\} Ja? Do świątyni Wenery".

'Unde venis et quo tendis?' rogat. (Hor., Serm. 1, 9, 62-63)

"Skądże to przychodzisz i dokąd zmierzasz?' pyta".

Dic mihi praeterea, Pansa, Ventidius ubi sit. (Cic., Phil. 12, 23)

„Powiedz mi jeszcze, Panso, gdzie przebywa Wentydiusz".

Quotiens dicendum est tibi? (Pl., Amph. 619)

„Ile razy trzeba ci powtarzać?”

Interrogabat $[\ldots]$, quando ausuros exposcere remedia, nisi novum et nutantem adhuc principem precibus vel armis adirent? (Tac., Ann. 1, 17) 
„Pytal, kiedy odważą się zażądać jakichśs środków zaradczych, skoro do nowego i chwiejnego jezcze cesarza nie zwracają się z prośbami albo $\mathrm{z}$ bronią $\mathrm{w}$ ręku".

Zaimek uter oraz przymiotnikowe i przysłówkowe zaimki pytajne mogą również pełnić funkcję zaimków względnych:

Utri eorum Macedonia evenisset, in supplementum legionum tria milia militum Romanorum scriberet. (Liv. 32, 8)

„Któremu z nich dwóch (konsulów) przypadlaby (w drodze losowania) Macedonia, (to ten) miał dla uzupełnienia legionów dokonać zaciągu trzech tysięcy żołnierzy rzymskich".

Mihi $[\ldots]$ gratior illi videtur $[\ldots]$ aenea statua futura et ea pedestris quam inaurata equestris, qualis L. Sullae primum statuta est. (Cic., Phil. 9, 13)

„Wydaje mi się, że milszy mu (będzie) w przyszlości pomnik spiżowy, i to pieszy, niż pozłacany konny, jaki po raz pierwszy uchwalono dla Lucjusza Sulli".

Non sum, qualis eram bonae sub regno Cinarae. (Hor., Carm. 4, 1, 3-4)

"Nie jestem już (taki), jaki bylem pod whadzą dobrej Cynary".

Sequitur $[\ldots]$ victoria $[\ldots]$, quantam de Samnitibus nemo ad eam diem $[\ldots]$ pepererat. (Liv., 10, 38)

„Następuje zwycięstwo, jakiego nikt do tego dnia nie odniósł nad Samnitami”.

Expulso [...] Tarquinio tantum odium populum Romanum regalis nominis tenuit, quantum tenuerat post obitum [...] Romuli desiderium. (Cic., Rep. 2, 52)

„Po wypędzeniu Tarkwiniusza ogarnęla naród rzymski tak wielka nienawiść do wladzy królewskiej, jak wielka byla ich tęsknota po śmierci Romulusa".

Quot casus exercitus victi fuerant, tot in curas distracti animi eorum erant. (Liv., 22, 7)

Ile przytrafiło się klęsk pokonanego wojska, tyle trosk napełniało ich skołatane serca".

Naves [...] omnes Uticam relinquunt et, quo imperatum est, transeunt. (Caes., Civ. 2, 25)

„Wszystkie okręty opuszczają Utykę i przepływają, gdzie nakazano".

Quantum [...] augebatur militum numerus, tanto maiore pecunia in stipendium opus erat. (Liv., 5,10$)$

"O ile wzrastala liczba żołnierzy, o tyle więcej trzeba było pieniędzy na żold".

Quod [...] agitatur aliunde, quando finem habet motus, vivendi finem habeat necesse est. (Cic., Rep. 6, 27)

„Coś, co jest poruszane przez czynnik zewnętrzny, w sposób nieunikniony znajduje kres istnienia (wtedy), kiedy ruch ustaje".

Praesumptum habeant, quoties fugas et caedes iussit princeps, toties grates deis actas [...] fuisse. (Tac., Ann. 14, 64)

„Niech z góry wiedzą, że ilekroć cesarz nakazywal wygnania i rzezie, tylekroć bogom składano (za to) podziękowania".

Poza tym zaimki pytajne mogą nadawać zdaniom charakter eksklamatywny lub samodzielnie stanowić wypowiedzenia o funkcji emotywnej:

Quam brevi tempore quot et quanti poetae [...] extiterunt! (Cic., Tusc. 4, 5)

„W jak krótkim czasie jakżesz liczni i jak wielcy poeci się pojawili!” 
At quanta merces rhetori data est! (Cic., Phil. 2, 43)

"A jak wielką zapłatę wręczono retorowi!"

Quotiens tu me designatum, quotiens vero consulem interficere conatus es! (Cic., Catil. 1, 15) „Ileż to razy usilowałeś mnie zabić jako desygnowanego na urząd konsula, ileż razy już po objęciu przeze mnie urzędu!"

Deinde magis magisque Trimalchio intuens eum (scil. porcum) 'quid? quid?' inquit 'porcus hic non est exintaratus? Non mehercule est; voca, voca cocum in medio!' (Petron., Sat. 49, 3-4)

„Następnic, wpatrując się coraz bardziej w świnię, rzecze Trymalchion: 'Co?! Co?! Świnia nie jest wypatroszona? No nie jest, do diaska. Wołać, wolać mi tu zaraz kucharza!'”

\subsection{ZAIMKI PRZECZĄCE}

Zaimki przeczące to ogólne kwantyfikatory negacji. Inherentnie wyrażają one przeczenie i nie wymagają wsparcia w postaci negacji czasownikowej, by wyrazić nieistnienie i stanowić wykładnik negacji zdaniowej.

Zaimkami przeczącymi są zaimki rzeczownikowe nemo 'nikt' i nihil (nil) 'nic' oraz zaimki przymiotnikowe nullus 'żaden' i binarny neuter 'żaden z dwóch'.

Pecunia corrumpere pudentem nemo potest. (Cic., Rep. 5, 11)

„Nikt nie jest $w$ stanie przy pomocy pieniędzy zdeprawować przyzwoitego czlowieka”.

Nihil est victoria dulcius. (Cic., Verr. 2, 5, 66)

„Nic nie jest milsze od zwycięstwa”.

Nulla lex satis commoda est omnibus. (Liv., 34, 3)

"Żadna ustawa nie zadowala wszystkich."

Nihil [...] scribit respondisse haruspices, si neuter anguis emissus esset. (Cic., Div. 2, 62)

„Pisze, że nic nie odpowiedzieli haruspikowie w odniesieniu do sytuacji, gdyby żaden $\mathbf{z}$ dwu węży nie został wypuszczony".

Ostatni z tych zaimków dużo częściej jednak podlega substantywizacji i występuje w pozycjach rzeczownikowych, w szczególności jako człon nadrzędny dla rzeczownikowej przydawki partytywnej:

Neuter consulum potuerat bello abesse. (Liv., 9, 44)

„Źaden ( $\mathrm{z}$ dwóch) konsulów nie mógł opuścić terenu wojny”.

Duobus nupsi, neuter fecit, quod novae nuptae solet. (Pl., Cas. 1011)

„Dwóch mnie poslubilo, żaden (z nich) nie zrobił tego, co zwykle czyni się pannie mlodej”.

Zaimek nihil może także wystąpić w miejsce partykuły przeczącej, wzmacniając negację zdaniową:

Oenomao tuo nihil utor. (Cic., Fam. 9, 16, 4)

"Twojego Oinomaosa w ogóle nie używam". 
Z kolei zaimek nullus może być używany predykatywnie, tj. w funkcji orzecznikowej, dając w efekcie również wzmocnione zanegowanie treści predykatu (orzeczenia):

De mortuis loquor, qui nulli sunt. (Cic., Tusc. 1, 87)

"Mówię o zmarłych, którzy w ogóle nie istnieją".

Hic patera nulla in cistulast. (Pl., Amph. 792)

"Tu nie ma żadnej czary w skrzynce".

Fortasse tu huc vocatus es ad prandium, ille, qui vocavit, nullus venit? (Pl., Rud. 143) ${ }^{18}$

„Może ty zostałeś tu zaproszony na śniadanie, a ten, kto (cię) zaprosil, w ogóle nie przyszedr?"

Haec bona in tabulas publicas nulla redierunt. (Cic., S. Rosc. 128)

„Te dobra do publicznych rejestrów w ogóle nie weszły”.

Dla emfazy (wzmocnienia) przeczącej funkcji samych zaimków nemo, nihil i nullus bywają one zestawiane $\mathrm{z}$ nieokreślonymi zaimkami antytetycznymi, tj. (odpowiednio) z quisquam, quicquam i ullus; jest to właściwość języka emocjonalnego, w szczególności potocznego:

Lepidiorem uxorem nemo quisquam [...] habet. (Pl., Cas. 1008)

"Absolutnie nikt nie ma cudowniejszej żony".

Hic tibi nil est quicquam incommodi. (Ter., Hec. 400)

"On nie jest dla ciebie absolutnie niczym klopotliwym".

Tardo amico nihil est quicquam inaequius. (Pl., Poen. 504)

„Nie ma nic, ale to nic gorszego niż opieszały przyjaciel”.

Quaedam animalium [...] aut caeca natura gignuntur aut inodora inauritave. Nullum autem ullum gigni animal Aristoteles dicit, quod aut gustus sensu careat, aut tactus. (Gell., Noc. Att. 6, 6, 2)

„Niektóre zwierzęta rodzą się albo ślepe z natury, albo bez zmysłu zapachu czy słuchu. Jednak zdaniem Arystotelesa nie rodzi się absolutnie żadne zwierzę, które byłoby pozbawione zmysłu smaku bądź dotyku".

Zaimkami przeczącymi są również zaimki przysłówkowe numquam 'nigdy' i nusquam 'nigdzie', które sygnalizują niezaistnienie sytuacji zdefiniowanej $\mathrm{w}$ danym wyrażeniu zdaniowym poprzez zanegowanie jej lokalizacji w czasie lub przestrzeni:

Numquam tam vehementer cum senatu consociati fuistis. (Cic., Phil. 4, 12)

„Nigdy nie byliście tak ściśle zjednoczeni z senatem”.

Hic uxorem numquam duxit. (Nep., Epam. 10)

"On nigdy się się nie ożenil".

Ego vero nusquam esse illos puto. (Cic., Tusc. 1, 11)

I* W tym przykładzie i następnym funkcja realizowana przez zaimek nullus odpowiada typowi przydawki orzecznikowej określanej jako praedicativum; zob. niżej, Skladnia 3.2.2.4.2. 
„Ja zaś myślę, że nie ma ich nigdzie”.

Nusquam benigne legatio audita est. (Liv., 1, 9)

„Nigdzie poselstwo nie zostało wysłuchane życzliwie”.

\subsection{WYBRANA LITERATURA}

Bertocchi, Casadio (1980, 1983), Bertocchi, Maraldi (1990, 2005), Bertocchi (1994, 1996, 2000), Bertocchi, Maraldi, Orlandini (2010), Bodelot (1996), De Jong (1996, 1998), Maraldi (2000), Orlandini (2000), Pieroni (2002, 2010), Pompei (2002), Rosén (2000b), Schoof (2005), Stumpf (1976) 


\section{1. \\ Charakterystyka funkcjonalna liczebników}

\subsection{LICZEBNIKI JAKO KLASA LEKSEMÓW}

Liczebniki to klasa leksemów, która - podobnie jak zaimki - ma status odrębnej części mowy, chociaż składające się na nią wyrazy nie są definiowalne w kategoriach gramatycznych, tzn. nie cechują się żadnymi specyficznymi właściwościami morfologiczno-składniowymi, które odróżniałyby je od wyrazów należących do innych gramatycznych klas leksemów (części mowy). Podstawą wydzielenia liczebników jako odrębnej części mowy jest semantyka, czyli kryterium znaczeniowe. Wyrazy te charakteryzują się mianowicie pewną wspólną ogólną cechą znaczeniową, jaką jest kwantyfikacja numeryczna, czyli wyrażanie charakterystyki liczbowej (ilościowej). Kryterium semantyczne, tzn. typologiczne zróżnicowanie tej charakterystyki, leży także u podstaw wyodrębniania tradycyjnych podklas liczebników, tj. liczebników głównych, porządkowych, podziałowych, wielorakich (mnożnych) i frekwentatywnych. Pod względem gramatycznym natomiast liczebniki stanowią zbiór niejednolity (heterogeniczny): liczebniki główne, porządkowe, podziałowe i wielorakie generalnie mają gramatyczny status przymiotników, liczebniki frekwentatywne (przysłówki liczebnikowe) status przysłówków, zaś liczebnik główny milia 'tysiące' w większości swych użyć posiada gramatyczne cechy rzeczownika. Niektóre spośród liczebników charakteryzują się pewnymi szczególnymi właściwościami morfologicznymi, które spotykane są jednak również wśród leksemów należących do innych części mowy. Do właściwości tych zaliczyć należy przede wszystkim (dyktowany względami semantycznymi) klasyfikujący (selektywny) charakter gramatycznej kategorii liczby (wiele $\mathrm{z}$ nich to pluralia tantum) oraz zerowy paradygmat formalny (czyli formalna nieodmienność). Przedstawiona niżej bardziej szczegółowa charakterystyka liczebników przeprowadzona została w oparciu o ich tradycyjny podział na poszczególne podklasy semantyczne. 


\subsection{LICZEBNIKI GŁÓWNE (NOMINA NUMERALIA CARDINALIA)}

\subsubsection{Charakterystyka gramatyczna liczebników głównych}

Liczebniki główne identyfikują liczebność zbioru elementów desygnowanych przez określany rzeczownik. Poza liczebnikiem milia 'tysiące' (i bardzo rzadko także mille 'tysiąc') wszystkie mają gramatyczny status przymiotników. Pod względem składniowym pełnią funkcję przydawek (lub orzeczników) pozostających w składni zgody co do kategorii liczby, rodzaju i przypadka z członem syntaktycznie nadrzędnym, czyli $z$ określanym rzeczownikiem. Stanowią więc człon podrzędny (determinowany, akomodowany) w ramach związku kongruencji atrybutywnej. Por. np.:

Trecenti servi venerunt. - „Przyszło trzystu niewolników”.

Trecentos servos vidi. - „Zobaczyłem trzystu niewolników”.

De trecentis servis mihi scripsit. - „Napisał mi o trzystu niewolnikach”.

wobec:

Laboriosi servi venerunt. - „Przyszli pracowici niewolnicy”.

Laboriosos servos vidi. - „Zobaczyłem pracowitych niewolników”.

De laboriosis servis mihi scripsit. - „Napisal mi o pracowitych niewolnikach”.

Trecentae rosae floruerunt. - „Zakwitło trzysta róż".

Trecentas rosas vidi. - „Zobaczylem trzysta róż”.

Hortus cum trecentis rosis. - "Ogród z trzystoma różami”.

wobec:

Pulchrae rosae floruerunt. - "Zakwitly piękne róże”.

Pulchras rosas vidi. - „Zobaczyłem piękne róże”.

Hortus cum pulchris rosis. - „Ogród z pięknymi różami".

Poza liczebnikiem unus, - $a$, um wszystkie pozostałe liczebniki główne cechują się ograniczonym paradygmatem funkcjonalnym pod względem kategorii liczby, zredukowanym do wartości pluralis; inaczej mówiąc, są to pluralia tantum.

Liczebniki wyrażające wartość pełnych setek od 200 do 900 przyjmują końcówki paradygmatu formalnego deklinacji I, występując w rodzaju żeńskim, oraz końcówki paradygmatu deklinacji II, występując $w$ rodzaju męskim lub nijakim. Liczebniki wyrażające wartości 1, 2, i 3 charakteryzują się swoistymi paradygmatami formalnymi, łączącymi cechy paradagmatów rzeczownikowo-przymiotnikowych i zaimkowych (zob. niżej: 11.2.4.):

Haec quadringentorum annorum aetas $[\ldots]$ num valde longa est? (Cic., Rep. 1,58 )

„Czy ten okres czterystu lat to bardzo dlugo?”

Ergo his annis quadringentis Romae rex erat? (Cic., Rep. 1, 58)

„Czyli czterysta lat temu w Rzymie panował król?”

In hora saepe ducentos $[. .$.$] versus dictabat stans pede in uno. (Hor., Serm. 1, 4. 9-10)$

(iron.) „Często w ciągu godziny dyktowal dwieście wierszy, stojąc na jednej nodze”. 
Post hanc habitam contionem duabus tribusve horis optatissimi nuntii et litterae venerunt. (Cic., Phil. 14, 16)

„Po zakończeniu tego zebrania w ciągu dwóch lub trzech godzin nadeszly oczekiwane wieści i listy".

Videtis $[\ldots]$ igitur unius viri consilio $[. .$.$] ortum novum populum. (Cic., Rep. 2, 21)$

„Widzicie zatem nowe społeczeństwo, powolane do życia zamyslem jednego czlowieka".

Liczebnik unus, - $a$, -um występuje w liczbie mnogiej, jeśli jego składniowym nadrzędnikiem jest rzeczownik należący do klasy pluralia tantum, a także gdy przyjmuje znaczenie typu '(jako) jedyni':

Una castra iam facta ex binis. (Caes., Civ. 1, 74)

"Powstał już jeden obóz wojskowy z dwóch".

Ubii autem, qui uni ex Transrhenanis ad Caesarem legatos miserant, amicitiam fecerant. (Caes., Gall. 4, 16)

„Ubiowie zaś, którzy jako jedyni spośród plemion zareńskich wysłali do Cezara posłów, zawarli (z nim) uklad o przyjaźni".

Liczbniki główne wyrażające wartości od 4 do 20 , a także wartości pełnych dziesiątek (20,30, 40 itd.), pełnych dziesiątek pomniejszonych o jeden lub dwa $(28,29$; 38, 39 itp.), wartość 100 oraz 1000 mają defektywny paradygmat formalny w zakresie kategorii rodzaju i przypadka, co przy zredukowanym paradygmacie funkcjonalnym pod względem kategorii liczby daje w rezultacie zerowy paradygmat formalny (nieodmienność). Paradygmat funkcjonalny tych liczebników nie jest jednak ograniczony pod względem kategorii rodzaju i przypadka, co znaczy, iż mogą wyrażać wszystkie wartości rodzaju i przypadka, jednak w odróżnieniu od pozostałych liczebników czynią to za pośrednictwem tej samej formy tekstowej:

Octo/Viginti/Centum servi venerunt. - „Przyszło ośmiu/dwudziestu/stu niewolników”. Octo/Viginti/Centum servos vidi. - „Zobaczyłem ośmiu/dwudziestu/stu niewolników”. De octo/viginti/centum servis mihi scripsit. - "Napisał mi o ośmiu/dwudziestu/stu niewolnikach".

Octo/Viginti/Centum rosae floruerunt. - „Zakwitło osiem/dwadzieścia/sto róż”.

Octo/Viginti/Centum rosas vidi. - „Zobaczyłem osiem/dwadzieścia/sto róż”.

Hortus cum octo/viginti/centum rosis. - „Ogród z ośmioma/dwudziestoma/stu różami”.

W trzech pierwszych powyższych przykładach formy liczebnikowe octo, viginti i centum wyrażają więc odpowiednio: nominativus, accusativus i ablativus pluralis rodzaju męskiego, natomiast $w$ trzech pozostałych przykładach formy te reprezentują odpowiednio: nominativus, accusativus i ablativus pluralis rodzaju żeńskiego. Są one tak samo przydawkami występującymi $w$ składni zgody $z$ określanymi rzeczownikami, jak przymiotnikowe liczebniki odmienne, np. desygnujące wartości pełnych setek, z którymi pozostają w dystrybucji komplementarnej (uzupełniającej), stanowiąc ich funkcjonalne alternanty i syntaktyczne ekwiwalenty. Charakteryzując się identycznymi jak one właściwościami dystrybucyjnymi, tak samo wyrażają wszystkie 
te wartości poszczególnych kategorii morfologicznych, które wynikają z (czy też są wymagane dla), pozycji składniowych zajmowanych przez nie. A zatem skoro w zdaniu: Trecenti servi venerunt liczebnik trecenti ma wartość nom. pl. masc., to analogicznie w zdaniu: Centum servi venerunt liczebnik centum również występować musi w nom. pl. masc. Jedyna różnica sprowadza się do tego, że (nieodmienne) liczebniki typu centum nie dysponują formalnymi wykładnikami tych kategorii (nie przyłączają odpowiednich końcówek), i tym samym nie dysponują formalnymi wykładnikami syntaktycznego związku kongruencji atrybutywnej, którego są (podrzędnym) członem:

Maxume $[. .$.$] sunt admirabiles motus earum quinque stellarum, quae falso vocantur er-$ rantes. (Cic., Nat. 2, 51)

„Szczególnie godne podziwu są ruchy tych pięciu gwiazd, które niesłusznie nazywane są błędnymi".

Caesar $[\ldots]$ cohortibus decem ad mare relictis $[\ldots]$ de tertia vigilia ad hostes contendit. (Caes., Gall. 5, 9)

„Cezar, pozostawiwszy dziesięć kohort nad morzem, o trzeciej straży nocnej ruszył ku nieprzyjacielowi".

Luxus $[\ldots]$ mensae $[\ldots]$ per annos centum profusis sumptibus exerciti paulatim exolevere. (Tac., Ann. 3, 55)

„Luksusy stołu, klórym oddawano się przez sto lat, nie szczędząc wydatków, powoli odchodziły w niepamięć".

In $[\ldots]$ triumpho undequinquaginta coronae aureae translatae sunt. (Liv., 37, 58)

„W pochodzie tryumfalnym niesiono czterdzieści dziewięć zlotych wieńców”.

Z przytoczonych przykładów widać też, że stanowione przez liczebniki przydawki mogą zarówno poprzedzać określane rzeczowniki, jak i następować po nich; mogą także być oddzielone od nich innymi składnikami zdania:

Cum coniectus in carcerem triginta iussu tyrannorum venenum ut sitiens obduxisset, reliquum sic e poculo eiecit, ut id resonaret. (Cic., Tusc. 1, 96)

„Gdy, wtrącony do więzienia na rozkaz trzydziestu tyranów, napil się trucizny, resztę z kubka tak wylal, że aż słychać było plusk".

M. Iunius et Ti. Sempronius [...] dilectu edicto iuniores ab annis septemdecim [...] scribunt; quattuor ex his legiones et mille equites effecti. (Liv., 22, 57)

„Marek Juniusz i Tyberiusz Semproniusz, oglosiwszy pobór do wojska, zaciągają mlodych mężczyzn od siedemnastego roku życia; uzyskano z nich cztery legiony i tysiąc jeźdźców".

\subsubsection{Liczebniki mille i milia}

Jak już zaznaczono wyżej, liczebnik mille 'tysiąc' również jest przymiotnikiem plurale tantum o zerowym paradygmacie formalnym (nieodmiennym), jednak o pełnym paradygmacie funkcjonalnym w zakresie kategorii przypadka i rodzaju. 
Składniowo pełni on funkcję przydawki względem rzeczownika, który występować może w każdym przypadku i w każdym rodzaju gramatycznym. Stanowiąc przydawkę określonego rzeczownika nacechowany jest tymi samymi co on wartościami kategorii przypadka i rodzaju, choć nie dysponuje ich formalnymi wykładnikami (końcówkami). Pod względem cech gramatycznych mille nie różni się więc niczym od omówionych wyżej liczebników typu: quinque, octo, decem, triginta czy centum:

Spectant oculi te mille loquentem. (Hor., Epist. 1, 6, 19)

"Tysiąc oczu patrzy na ciebie, gdy przemawiasz".

Volux $[\ldots]$ repente in campis patentibus cum mille [...] equitibus sese ostendit. (Sall., Iug. 105)

„Nagle na otwartym polu pojawia się Woluks z tysiącem jeźdźców”.

Da mi basia mille, deinde centum. (Catull. 5, 7)

"Daj mi pocalunków tysiąc, a potem jeszcze sto".

Omnia quaecumque agimus subiecta esse mille casibus scio. (Liv., 30, 31)

„Wiem, że wszystko, cokolwiek czynimy, zależy od tysiąca różnych okoliczności”.

Locus erat castrorum editus et paulatim ab imo acclivis circiter passus mille. (Caes., Gall. 3, 19)

„Miejsce zajęte przez obóz znajdowało się na wzgórzu i od podnóża powoli wznosilo się na przestrzeni okolo tysiąca kroków".

Z kolei liczebnik milia 'tysiące' ma gramatyczny status odmiennego rzeczownika plurale tantum rodzaju nijakiego. $W$ zdaniu pełni więc rzeczownikowe funkcje składniowe, np. podmiotu, dopełnienia czy okolicznika. Towarzyszy mu zwykle przydawka dopełniaczowa stanowiona przez rzeczownik identyfikujący obiekty, do których odnosi się wyrażana przez ten liczebnik wartość liczbowa (tysiące czego?):

Tibi curarum milia quanta dabit! (Prop., Eleg. $1,5,10$ )

"Ileż tysięcy trosk ci przysporzy!"

Facies enim, quod multa milia servorum, multa milia pauperum faciunt. (Sen., Lucil. $18,8)$

„Uczynisz bowicm (to), co czyni wiele tysięcy niewolników, wiele tysięcy nędzarzy”.

Z przywołanych wyżej przykładów widać, że oprócz wspomnianej przydawki dopełniaczowej (curarum milia, milia servorum, milia pauperum) liczebnikowi temu towarzyszy także przydawka przymiotnikowa, pozostająca z nim w związku zgody (quanta milia, multa milia). Najczęściej przydawkę taką stanowią inne liczebniki główne, określające ilość tysięcy:

Docet omnes peditatus equitatusque copias Treverorum tria milia passuum longe ab suis castris consedisse. (Caes., Gall. 5, 47)

"Powiadamia, że wszystkie oddzialy piechoty $i$ konnicy Trewerów zajęły stanowiska w odległości trzech tysięcy kroków (rzymskich) od jego obozu". 
Equitum milia erant sex. (Caes., Gall. 1, 48)

„Jeźdźców było sześć tysięcy”.

Labieno $[\ldots]$ cum $[\ldots]$ equitum milibus duobus relicto $[\ldots]$, ipse $[\ldots]$ ad solis occasum naves solvit. (Caes., Gall. 5, 8)

„Pozostawiwszy Labienusa $z$ dwoma tysiącami jeźdźców, sam o zachodzie słońca podnosi kotwice".

Caesar $[\ldots]$ circiter tribus milibus hostium ex novissimo agmine interfectis altero die ad Alesiam castra castra fecit. (Caes., Gall. 7, 68)

"Cezar, zgladziwszy około trzech tysięcy wrogich żołnierzy z tylnej straży (wojsk Wercyngetoryksa), następnego dnia rozbił obóz pod Alezją".

Duorum milium aeris damnato multam dixerunt. (Liv., 2, 52)

„Skazanemu zasądzili grzywnę dwóch tysięcy asów".

Można zatem stwierdzić, że gramatyczny status liczebnika milia jest identyczny ze statusem jego polskiego odpowiednika, tj. 'tysiące'; por. np.: tria milia florum 'trzy tysiące kwiatów'.

Z kolei status liczebnika mille jest odmienny od statusu polskiego liczebnika 'tysiąc', bowiem mille jest przymiotnikiem wchodzącym $\mathrm{z}$ rzeczownikiem $\mathrm{w}$ związek zgody, natomiast liczebnik 'tysiąc' jest rzeczownikiem, który - tak jak milia i 'tysiące' - otwiera miejsce dla rzeczownikowej przydawki dopełniaczowej; por.: mille flores 'tysiąc kwiatów'.

Tym samym realacja zachodząca między formami 'tysiąc' i 'tysiące' jest odmienna od relacji, w jakiej pozostają względem siebie formy mille i milia. 'Tysiąc' i 'tysiące' to dwie formy fleksyjne tego samego leksemu rzeczownikowego, stojące względem siebie w opozycji w ramach fleksyjnej kategorii liczby. Inaczej mówiąc, wyraz 'tysiące' jest formą liczby mnogiej w stosunku do formy 'tysiąc'. Natomiast mille i milia nie są formami fleksyjnymi jednego leksemu, lecz reprezentują dwa różne leksemy, tj. przymiotnik plurale tantum (mille) i rzeczownik plurale tantum rodzaju nijakiego (milia). Milia nie jest więc formą liczby mnogiej liczebnika mille, gdyż milia i mille to dwie odrębne jednostki słownikowe. Poza tym mille także jest wyrazem w liczbie mnogiej (por. mille flores: ducenti flores) i stąd nieakceptowalna jest np. fraza unum mille ('jeden tysiąc'). Poświadczone są jednak $w$ lacińskich tekstach przypadki interferencji, polegające na rzeczownikowym użyciu liczebnika mille:

Mille annorum perpetuo vivont. (PI., Mil. 1079)

"Żyją nieprzerwanie (przez) tysiąc lat".

Mandatum [...], qui Romae essent, ne quis ultra mille passuum ab Roma abesset. (Liv., $43,11)$

„Polecono, by spośród osób, które przebywają w Rzymie, nikt nie oddalał się z miasta na odległość większą niż tysiąc kroków".

lub przymiotnikowym użyciu liczebnika milia:

Qui locus a Foro Iuli quattuor et viginti millia passus abest. (Cic., Fam. 10, 17, 1) „Miejsce to jest oddalone od Forum Julijskiego o dwadzieścia cztery tysiące kroków”. 


\subsubsection{Struktura semantyczna i syntaktyczna wyrażeń liczebnikowych}

Liczebniki przymiotnikowe mogą tworzyć złożone z nich wyrażenia liczebnikowe, określane także terminem liczebników złożonych, desygnujące wartości liczbowe sięgające 1999. Z punktu widzenia składniowego wszystkie liczebniki wchodzące $w$ skład takich wyrażeń pełnią funkcje zestawionych szeregowo orzeczników lub przydawek rzeczownika desygnującego zbiór obiektów, któremu dana wartość liczbowa jest w wyrażeniu przypisywana. Wchodzące w skład wyrażenia liczebnikowego liczebniki zestawione są asyndetycznie bądź za pośrednictwm spójnika et, rzadziej ac lub atque. Pod względem semantycznym liczba wyrażana przez dane wyrażenie liczebnikowe jest wynikiem operacji dodawania (sumowania) wartości liczbowych, wyrażanych przez poszczególne liczebniki będące składnikami tego wyrażenia (np.: mille octingenti quadraginta septem $=1000+800+40+7=1847$ ). Wyrażenia oparte na odejmowaniu (duo de viginti, un(um) de triginta itp.) zostały zgramatykalizowane na poziomie morfologicznym (zuniwerbalizowane: duodeviginti, undetriginta itp.). Wyrażenie liczebnikowe może znajdować się w prepozycji lub postpozycji w stosunku do określanego rzeczownika, bezpośrednio przy nim lub oddzielone od niego innymi składnikami zdania:

Centum octoginta sex homines erant. (Liv., 8, 8)

„Było stu osiemdziesięciu sześciu ludzi”.

Transiere Rhenum [...] centum tredecim Trevirorum senatores. (Tac., Hist. 5, 19)

„Przeszlo przez Ren stu trzynastu trewirskich senatorów”.

Mago, frater Hannibalis [...], mille quingentos equites, viginti elephantos, mille argenti talenta in Italia transmissurus erat cum praesidio sexaginta navium longarum. (Liv., 23, 32)

„Magon, brat Hannibala [...], mial przeprawić do Italii tysiąc pięciuset jeźdźców, dwadzieścia słoni i tysiąc talentów srebra pod eskortą sześciuset okrętów wojennych".

Capta $[\ldots]$ signa militaria ducenta undequinquaginta. (Liv., 33, 10)

„Znaków wojskowych zdobyto dwieście czterdzieści dziewięć".

Misit in Africam [...] funditores Baliares octingentos septuaginta, equites mixtos ex multis gentibus mille docentos. (Liv., 21, 21)

„Wyslat do Afryki ośmiuset siedemdziesięciu procarzy balearskich, tysiąc dwustu jeźdźców zebranych z różnych ludów".

Ad haec peditum auxilia additi equites Libyphoenices [...] guadringenti quinquaginta et Numidae Maurique [...] ad mille octingenti et [...] elephanti viginti unus. (Liv., 21, 22)

„Do tych posiłkowych oddziałów piechoty dodanych zostało czterysta pięćdziesięciu jeźdźców libiofenickich oraz do tysiąca ośmiuset Numidów i Maurów, a także dwadzieścia jeden sloni".

Samo wyrażenie liczebnikowe, choć stanowi zwartą jednostkę semantyczną, nie cechuje się wysokim poziomem zgramatykalizowania. Jego poszczególne składniki nie wymagają liniowej ciągłości i mogą być przedzielone innymi elementami zdania: 
Ante hunc intra centum annos et viginti nemo praeter $P$. Cornelium Calussam pontifex maximus creatus fuerat, qui sella curuli non sedisset. (Liv., 25, 5)

„Przed nim przez sto dwadzieścia lat nikt oprócz Publiusza Korneliusza Kalussy nie zostal wybrany na stanowiska najwyższego kaplana, kto wcześniej nie zasiadalby na krześle kurulnym".

Octoginta erant et tres naves. (Liv., 27, 29)

"Okrętów było osiemdziesiąt trzy".

Liczebniki wyrażające liczby rzędu dziesiątek i jedności mogą też w ramach wyrażenia liczebnikowego wystąpić $\mathrm{w}$ odwróconym porządku linearnym; obligatoryjnie są one wtedy łączone spójnikiem et:

Signa militaria duo et viginti capta. (Liv., 30, 18)

"Chorągwi zdobyto dwadzieścia dwie".

Romae tribus una et viginti factae. (Liv., 2, 21)

„W Rzymie utworzono dwadzieścia jeden dzielnic".

Regnavit Ancus quattuor et viginti annos. (Liv., 1, 35)

„Ankus panowal przez dwadzieścia cztery lata".

Spójnik ten wystąpić jednak może również wtedy, gdy porządek ten nie jest odwrócony, a także pomiędzy innymi składnikami wyrażenia liczebnikowego:

Socios navales libertini ordinis in viginti et quinque naves ex civibus Romanis $C$. Licinius praetor scribere iussus. (Liv., 42, 27)

„Do służby na dwudziestu pięciu okrętach nakazano pretorowi Gajuszowi Licyniuszowi powołać wyzwoleńców będących obywatelami rzymskimi".

Mille et septingenti fuere in navibus captis milites nautaeque. (Liv., 21, 50)

"Na zdobytych okrętach znajdowalo się tysiąc siedmiuset żołnierzy i marynarzy”.

Dla wyrażenia wartości liczbowych w przedziale 11 -19 w miejsce (jednowyrazowych) liczebników stosowane bywają - choć rzadko - oparte na sumowaniu (niezuniwerbalizowane) wyrażenia liczebnikowe (liczebniki złożone):

Fundos decem et tris reliquit. (Cic., S. Rosc. 20)

„Pozostawil trzynaście posiadłości”.

Decem et septem oppida. (Liv., 33, 21)

„Siedemnaście miast".

Filium Gala Massinissam habebat septem decem annos natum. (Liv., 24, 49)

"Gala mial syna Masynissę, liczącego sobie siedemnaście lat".

Ap. Claudius censor circumactis decem et octo mensibus [...] nulla vi compelli ut abdicaret potuit. (Liv., 9, 33)

„Cenzor Appiusz Klaudiusz, mimo że upłynę̧ło już osiemnaście miesięcy, żadną siłą nie mógł zostać przymuszony do ustąpienia z urzędu". 
Argenti decem et novem pondo. (Liv., 45, 43)

„Dziewiętnaście funtów srebra”.

Podobnie oparte na dodawaniu wyrażenia liczebnikowe mogą być stosowane w miejsce liczebników bazujących w warstwie morfologicznej na mechanizmie odejmowania (undeviginti, duodequinquaginta itp.):

Vixit annis viginti novem. (Suet., Cal. 59)

"Żyl lat dwadzieścia dziewięç".

Novem et triginta elephanti pilis confixi. (Liv., 24, 42)

"Trzydzieści dziewięć słoni pokłutych zostało oszczepami”.

Ex ingenti captivorum numero trecenti quinquaginta octo delecti $[\ldots]$, qui Romam mitterentur. (Liv., 7, 19)

„Z ogromnej liczby jeńców wybrano trzystu pięćdziesięciu ośmiu, którzy mieli zostać wysłani do Rzymu".

Signa militaria capta octo et septuaginta. (Liv., 31, 49)

"Zdobyto siedemdziesiąt osiem znaków wojskowych".

Zarówno pojedyncze liczebniki przymiotnikowe, jak i złożone z nich wyrażenia liczebnikowe, mogą ulegać (kontekstowej) substantywizacji:

Omnia sunt externa unius virtute terra marique pacata. (Cic., Catil. 2, 11)

„Wszędzie na zewnątrz, dzięki męstwu jednego (człowieka), zaprowadzono pokój na lądzie i morzu".

Cursor ad Olympia proficisci cogitans visus est in somnis curru quadrigarum vehi. Mane ad coniectorem. [...] Is autem: 'Vincare', inquit, 'necesse est; an non intellegis quattuor ante te cucurrisse?' (Cic., Div. 2, 144)

„Biegacz wybicrający sį̧ na igrzyska olimpijskie we śnie zobaczył siebie, jak jedzie na wozie ciągnionym przez cztery konie. $Z$ rana (udaje się) do tłumacza snów. Ten zaś: 'Nieodwołalnie przegrasz', powiada; 'czyż nie dostrzegasz, że czworo biegło przed tobą?"'.

De exercitu Romano septuaginta et tres amissi. (Liv., 35, 1)

„Z wojska rzymskiego utracono siedemdziesięciu trzech (ludzi)”.

Substantywizowanym liczebnikom i wyrażeniom liczebnikowym często towarzyszą określniki partytywe w postaci rzeczownikowej przydawki przyimkowej lub dopełniaczowej (genetivus partitivus):

Ducenti ab Romanis, octingenti hostium cecidere. (Liv., 22, 16)

„Zginęlo dwustu (spośród) Rzymian, ośmiuset (spośród) nieprzyjaciól".

Antias Valerius scribit [...] ex victoribus mille quadringentos octoginta quattuor cecidisse. (Liv., 36, 38)

„Waleriusz z Ancjum pisze, że spośród zwycięzców padlo tysiąc czterysta osiemdziesięciu czworo". 
Ad mille et septingenti caesi, non plus centum Romanorum sociorumque occisis. (Liv., $22,41)$

„Zginęlo do tysiąca siedmiuset (Punijczyków), przy nie więcej niż stu zabitych spośród Rzymian i sprzymierzeńców".

Ad mille trecenti Carthaginienisium caesi et undesexaginta vivi capti. (Liv., 23, 37)

„Do tysiąca trzystu Kartagińczyków zginęło, a pięćdziesięciu dziewięciu zostało pojmanych żywcem".

Warto jeszcze zaznaczyć, iż podobnie jak w języku polskim, liczebniki główne mogą być także używane dla wyrażenia ogólnego pojęcia 'bardzo wiele, mnóstwo'. Dotyczy to w szczególności liczebników desygnujących "okrągle" wartości liczbowe, a więc takich jak: decem 'dziesięć', centum 'sto', mille 'tysiąc', a także liczebnika sescenti, $-a e,-a$ 'sześćset':

An ignoras, inepte, nudum nec a decem palaestritis despoliari posse? (Apul., Met. 1, 15)

„Nie wiesz, glupcze, że golego nie jest w stanie zlupić nawet dziesięciu atletów?"

Centum doctum hominum consilia sola haec devincit dea, Fortuna. (PI., Pseud. 678-679)

„Sto pomystów mądrych ludzi ta jedna bogini obróci wniwecz: Fortuna”.

Venio ad epistulas tuas, quas ego sescentas uno tempore accepi, aliam alia iucundiorem. (Cic., Att. 7, 2, 3)

„Teraz przechodzę do twoich listów, których mnóstwo otrzymatem w krótkim czasie, jeden milszy od drugiego".

Z kolei jako określniki rzeczownika pars (w liczbie mnogiej) przyjmują funkcję odpowiadającą licznikowi ułamka o mianowniku większym o jeden w stosunku do wartości przez nie wyrażanej, np.: duae partes 'dwie trzecie', tres partes 'trzy czwarte' itd.:

Caesar certior factus est tres iam partes copiarum Helvetios [...] flumen traduxisse. (Caes., Gall. 1, 12)

„Cezar zostal powiadomiony, że już trzy czwarte wojsk Helweci przeprawili przez rzekę".

\subsubsection{Struktura semantyczna i syntaktyczna wyrażeń liczebnikowych z liczebnikiem milia}

Wyrażenia liczebnikowe $\mathrm{z}$ rzeczownikowym liczebnikiem milia 'tysiące' desygnują wartości liczbowe od 2000 wzwyż. Mogą one wyrażać wyłącznie określoną liczbę tysięcy jakichś obiektów lub - oprócz liczby tysięcy - wyrażać także wartości liczbowe niższych rzędów (setek, dziesiątek, jedności).

Wyrażanie liczby tysięcy dokonuje się poprzez operację multiplikacji (mnożenia), w ramach której liczebnik milia jest multiplikandem desygnującym wartość liczbową podlegającą multiplikacji (tj. 1000), natomiast funkcję multiplikatora pełnią przymiotnikowe liczebniki główne lub złożone z nich wyrażenia liczebnikowe 
(np.: quinque milia $=5 \times 1000=5000$; septingenta triginta sex milia $=736 \times 1000=$ $736000)$.

Jeśli wyrażenie liczebnikowe z liczebnikiem milia wyraża liczbę złożoną nie tylko $\mathrm{z}$ wielokrotności tysięcy, ale także $\mathrm{z}$ wartości liczbowych niższych rzędow, tj. setek, dziesiątek, jedności, te ostatnie wyrażane są za pośrednictwem odpowiadających im przymiotnikowych liczebników głównych, przy wykorzystaniu mechanizmu sumowania (np.: viginti tria milia (et) sescenti quinquaginta duo $=23 \times 1000+600+50+2=$ $23652)$.

Wyrażenia liczebnikowe z liczebnikiem milia służą także wyrażaniu liczb przekraczających milion, ponieważ $w$ języku łacińskim nie istnieje liczebnik wyrażający wartość liczbową miliona. Przy wyrażaniu tej wartości, a także jej wielokrotności, liczebnik milia pełni funkcję multiplikanda, zaś funkcję multiplikatora realizuje wyrażenie liczebnikowe samo w sobie również oparte na multiplikacji, którego składnikami są liczebniki frekwentatywne wyrażające wartości poszczególnych dziesiątek, setek lub tysiąca (multiplikator) oraz liczebnik podziałowy centena (multiplikand), np.: decies centena milia 'dziesięć razy po sto tysięcy' = 1000 000; quadragies centena milia 'czterdzieści razy po sto tysięcy' $=4000000$; quingenties centena milia 'pięćset razy po sto tysięcy' = 50000 000; milies centena milia 'tysiąc razy po sto tysięcy' $=100000000$. W miejsce pojedynczego liczebnika frekwentatywnego może wystąpić ciąg połączonych szeregowo liczebników frekwentatywnych (np.: septingenties quinquagies centena milia 'siedemset pięćdziesiąt razy po sto tysięcy' = 75000 000; milies quingenties centena milia 'tysiąc pięćset razy po sto tysięcy' = 150000 000; quadragies (quater decies) milies centena milia 'czterdzieści tysięcy razy po sto tysięcy' $=4000000000$, czyli cztery miliardy). Elementem tego ciągu może być liczebnik frekwentatywny wyrażający jedności, jeśli oprócz liczby milionów wyrażana jest też określona liczba setek tysięcy (np.: tricies quinqies centena milia 'trzydzieści pięć razy po sto tysięcy' = 3500000 ).

$\mathrm{Z}$ punktu widzenia składniowego wyrażania liczebnikowe wyrażające wyłącznie określoną liczbę tysięcy mają strukturę grupy imiennej, której ośrodkiem (członem nadrzędnym, konstytutywnym, określanym) jest liczebnik milia; może on wystąpić w dowolnym przypadku i w strukturze składniowej zdania pełnić może każdą z funkcji, którą realizować mogą leksemy rzeczownikowe ( $\mathrm{tj}$. funkcję podmiotu, dopełnienia, orzecznika, okolicznika itd.). Z kolei człony podrzędne grupy (określniki) stanowione są przez:

1. rzeczownik $w$ genetiwie liczby mnogiej, pełniący funkcję przydawki dopełniaczowej i desygnujący zbiór obiektów, któremu przypisywana jest dana wartość liczbowa;

2. przymiotnikowy liczebnik główny (lub ciąg połączonych szeregowo przymiotnikowych liczebników głównych), pełniący funkcję przydawki pozostającej w składni zgody (kongruencji atrybutywnej) z liczebnikiem milia i stanowiący multiplikator; w przypadku wyrażenia desygnującego liczbę miliona lub wyższą miejsce przymiotnikowego liczebnika głównego zajmuje przymiotnikowy liczebnik podziałowy cente$n a$, określony przysłówkowym liczebnikiem frekwentatywnym (ciągiem liczebników frekwentatywnych), pełniącym funkcję okolicznika. 
Rzeczownik w genetiwie może linearnie poprzedzać (pozostałą) część grupy złożoną z liczebników, następować po niej lub zajmować pozycję pomiędzy liczebnikiem milia a liczebnikiem przymiotnikowym. W związku ze wspomnianym wyżej niskim poziomem zgramatykalizowania wyrażeń liczebnikowych poszczególne człony grupy mogą być również linearnie rozdzielone innymi składnikami zdania:

Erant capitum Helvetiorum milia ducenta sexaginta tria. (Caes., Gall. 1, 29)

"Helwetów bylo dwieście sześćdziesiąt trzy tysiące".

In hostium exercitu [...] equitum sex et quadraginta milia [...] scripsere fuisse. (Liv., $10,30)$

„Napisali, że w wojsku nieprzyjaciół bylo czterdzieści sześć tysięcy jeźdźców".

Docet omnes [...] copias Treverorum tria milia passuum longe ab suis castris consedisse. (Caes., Gall. 5, 47)

„Powiadamia, że oddziały Trewerów zajęły stanowisko w odleglości trzech tysięcy kroków od jego obozu".

Ab exploratoribus certior factus est Ariovisti copias a nostris milia passuum quattuor et viginti abesse. (Caes., Gall. 1, 41)

„Zostal powiadomiony przez zwiadowców, że oddziały Ariowista są oddalone od naszych o dwadzieścia cztery tysiące kroków".

Possum [...] dicere Dionem sestertium deciens centena milia numerasse, ut causam certissimam obtineret. (Cic., Verr. 2, 1, 28)

„Mogę powiedzieć, że Dion zapłacil milion sesterców, aby wygrać proces sądowy, którego nie można było przegrać".

Niekiedy $z$ użyciem liczebnika frekwentatywnego (przysłówkowego) tworzy się również wyrażenia liczebnikowe wyrażające wartości niższe niż milion:

In hostium exercitu peditum sexiens centena milia [...] scripsere fuisse. (Liv., 10, 30)

„Napisali, że w nieprzyjacielskim wojsku było sześćset tysięcy żolnierzy piechoty."

Zamiast liczebnika podziałowego centena wyrażenie liczebnikowe pełniące funkcję multiplikatora może (wraz z liczebnikiem frekwentatywnym) współtworzyć liczebnik główny centum:

Omnem Galliam, quae [...] patet [...] circuitu ad bis et tricies centum milia passuum, $[\ldots]$ in provinciae formam redegit. (Suet., Iul. 25)

„Całą Galię, która rozpościera się w obwodzie na blisko trzy miliony dwieście tysięcy kroków, sprowadzil do statusu prowincji".

Aeris gravis travecta viciens centum milia et quingenta triginta tria milia. (Liv., 10, 46)

„Przewieziono (na wozach w pochodzie tryumfalnym) dwa miliony pięćset trzydzieści trzy tysiące ciężkiej monety (tj. asów brązowych)".

Implikowany przez liczebnik milia rzeczownik w genetiwie może zostać niewyrażony na powierzchni, jeśli jest on identyfikowalny kontekstowo:

Placuit, ut Litaviccus decem illis milibus, quae Ceasari ad bellum mitterentur, praeficeretur. (Caes., Gall. 7, 37) 
„Uzgodniono, że Litawikkus stanie na czele owych dziesięciu tysięcy (żołnierzy), którzy mieli zostać wysłani do Cezara dla wsparcia (jego) działań wojennych".

Octo ferme inde milia castra posuit. (Liv., 24, 36)

"Mniej więcej osiem tysięcy (kroków) stamtąd rozbił obóz".

Clodi [...] in aediculis habitat decem, ut opinor, milibus. (Cic., Cael. 17)

„W domku Klodiusza mieszka, jak sądzę, za dziesięć tysięcy (sesterców)”.

Milia frumenti $[\ldots]$ triverit $[\ldots]$ centum. (Hor., Serm. 1, 1, 45)

"Wymłóci sto tysięcy (korców) zboża".

Aediles curules [...] tritici deciens centena milia [...] populo discripserunt. (Liv., 33, 42) „Edylowie kurulni przydzielili ludowi milion (miar) pszenicy”.

Ex milibus quinque ad mille caesi. (Liv., 10,30)

„Z pięciu tysięcy (Samnitów) poległo do tysiąca”.

W ramach wyrażeń liczebnikowych desygnujących wartości od miliona wzwyż może zostać pominięta na powierzchni (tj. pozostać domyślna) określana przysłówkowymi liczebnikami grupa imienna centena milia, zwłaszcza przy wskazywaniu na kwoty pieniężne nominowane w sestercach, a więc np.: sexagies sestertium (= sexagies centena milia sestertium) 'sześć milionów sesterców':

Legavit populo Romano quadringenties, tribubus tricies quinquies sestertium. (Suet., Aug. 101)

„Ludowi rzymskiemu pozostawil w testamencie czterdzieści milionów, gminom trybusowym (lącznie) trzy miliony pięćset tysięcy sesterców".

Nec plus perventurum ad heredes suos quam milies et quingenties professus, quamvis viginti proximis annis quaterdecies milies ex testamentis amicorum percepisset. (Suet., Aug. 101)

„I oświadczyl, iż jego spadkobiercom przekazanych zostanie nie więcej niż sto pięcdziesiąt milionów sesterców, chociaż $w$ ciągu ostatnich dwudziestu lat z zapisów testamentonych przyjaciól uzyskał cztery miliardy (sesterców)".

Sume tibi deciens! (Hor., Serm. 2, 3, 237)

„Weź sobie milion!"

W przypadku wyrażania nie tylko określonej liczby tysięcy, ale także wartości liczbowych niższych rzędów (setek, dziesiątek, jedności), wyrażenie liczebnikowe ma strukturę dwudzielną. Pierwszą jego część stanowi grupa imienna desygnująca liczbę tysięcy, o budowie scharakteryzowanej powyżej; drugą konstytuuje jedno-, dwu- lub trójelementowy ciąg przymiotnikowych liczebników głównych, wyrażający wartości liczbowe rzędu setek, dziesiątek i jedności, którego składniki pozostają w składni zgody z rzeczownikiem desygnującym zbiór obiektów określany wyrażeniem liczebnikowym. W rezultacie, struktura składniowa całego wyrażenia liczebnikowego otwiera dwa miejsca dla rzeczownika desygnującego zbiór obiektów, któremu przypisywana jest dana charakterystyka liczbowa: jedno, w genetiwie, w ramach grupy imiennej desygnującej liczbę tysięcy, i drugie w przypadku wynikającym z pozycji składniowej 
determinowanej strukturą zdania, będące punktem odniesienia dla przydawkowego ciągu liczebników desygnujących wartoście setek dziesiątek i jedności, np.:

${ }^{*}$ Consul profectus est cum septingentis sexaginta tribus milibus militum et ducentis octoginta duobus militibus.

„Konsul wyruszył z siedmiuset sześćdziesięcioma trzema tysiącami dwustu osiemdziesięcioma dwoma żołnierzami".

W rzeczywistości jednak nigdy nie są wypełniane w strukturze powierzchniowej oba miejsca, lecz tylko jedno $\mathrm{z}$ nich; $\mathrm{w}$ drugim $\mathrm{z}$ nich rzeczownik pozostaje jedynie w strukturze głębokiej (domyślny). Zdanie to może więc przybrać albo postać:

Consul profectus est cum septingentis sexaginta tribus milibus et ducentis octoginta duobus militibus.

albo postać:

Consul profectus est cum septingentis sexaginta tribus milibus militum et ducentis octoginta duobus.

Oczywiście, w tym drugim przypadku możliwe są jeszcze, zasygnalizowane wyżej, odmienne warianty ulokowania rzeczownika w ramach grupy imiennej desygnującej liczbę tysięcy, a więc np.:

Consul profectus est cum militum septingentis sexaginta tribus milibus et ducentis octoginta duobus.

Consul profectus est cum milibus militum septingentis sexaginta tribus et ducentis octoginta duobus.

Por.:

Tredecim milia octingentos quinquaginta pedites [...] misit in Africam. (Liv., 21, 21) „Trzynaście tysięcy ośmiuset pięćdziesięciu żołnierzy piechoty wysłał do Afryki".

Hasdrubali $[\ldots]$ eam provinciam destinat firmatque eum $[\ldots]$ peditum Afrorum undecim milibus octingentis quinquaginta, Liguribus trecentis, Baliaribus quingentis. (Liv., 21, 22)

„Prowincję tę powierza Hazdrubalowi i wzmacnia go jedenastoma tysiącami ośmiuset pięćdziesięcioma żołnierzami piechoty afrykańskiej, trzystoma Ligurami i pięciuset Balerczykami".

Jeżeli wyrażana liczba przekracza milion i zawiera w sobie także określoną liczbę setek tysięcy, dziesiątek tysięcy i tysięcy, to może zostać niewyrażona na powierzchni (pozostać domyślna) określana przysłówkowym liczebnikiem frekwentatywnym grupa imienna centena milia, denotująca (wraz z tymże liczebnikiem przysłówkowym) liczbę milionów (co wynika zapewne $\mathrm{z}$ tendencji do unikania powtarzania liczebnika milia, a więc do unikania wyrażeń typu: vicies centena milia et ducenta triginta quinque milia $=2235000$ ):

Accepi $[\ldots]$ viciens ducenta triginta quinque milia quadringentos decem et septem nummos. (Cic., Verr. 2, 1, 36) 
„Przyjąłem dwa miliony dwieście trzydzieści pięć tysięcy czterysta siedemnaście sesterców".

Może też zostać pominięty na powierzchni sam liczebnik milia przy pozostawieniu liczebnika centena:

Censa sunt civium quinquagies novies centena octoginta quattuor milia septuaginta duo. (Tac., Ann. 11, 25)

„Spisowi poddanych zostało pięć milionów dziewięćset osiemdziesiąt cztery tysiące siedemdziesięciu dwóch obywateli".

Jeżeli tego typu liczba przekracza milion, ale jest niższa od dwóch milionów, to dla wyrażenia wartości liczbowej miliona, zamiast analogicznego z powyższymi przykładami wyrażenia z liczebnikiem przysłówkowym (w tym przypadku decies), może zostać zastosowana kombinacja liczebników głównych mille ... milia, czyli 'tysiąc ... tysięcy':

Dedi stipendio $[\ldots]$ mille sescenta triginta quinque milia quadringentos decem et septem nummos. (Cic., Verr. 2, 1, 36)

„Wydałem na żołd milion sześśset trzydzieści pięć tysięcy czterysta siedemnaście sesterców".

W ramach jednego zdania lub sekwencji zdań współrzędnych mogą wystąpić wyrażenia liczebnikowe (współ)stanowione zarówno przez grupy imienne oparte na rzeczownikowym liczebniku milia (z rzeczownikiem w genetiwie jako członem podrzędnym), jak i przez przydawkowe ciągi liczebników przymiotnikowych (z rzeczownikiem jako członem nadrzędnym, determinującym składnię zgody).

Duo et viginti milia peditum, mille ducentos equites confecit. (Liv., 23, 40)

„Wystawil dwadzieścia dwa tysiące piechoty i dwustu jeźdźców”.

Jeśli do konstytutywnych (nadrzędnych) elementów wyrażeń liczebnikowych jednego i drugiego typu odnosi się ten sam składnik zdania podlegający składni zgody (np. imiesłowowy pub przymiotnikowy orzecznik), najczęściej przyjmuje on postać kongruentną (tylko) z jednym z nich:

Decem milia peditum Hannoni ad praesidium obtinendae regionis data (sunt) et mille equites. (Liv., 21, 23)

„Dla zabezpieczenia terenu, który miał zostać zajęty, dano Hannonowi dziesięć tysięcy piechoty i tysiąc jazdy".

Capta eo proelio tria milia peditum et equites mille et quingenti dicuntur. (Liv., 22, 49)

„Podobno w tej bitwie pojmanych zostało trzy tysiące żolnierzy piechoty i tysiąc pięćset jeźdźców".

Quattuor et viginti peditum Romanorum milia scripta (sunt) et mille octingenti equites, sociorum quadraginta milia peditum, quattuor milia et quadringenti equites; naves $d u-$ centae viginti quinqueremes, celoces viginti deducti (sunt). (Liv., 21, 17)

„Powołano pod broń dwadzieścia cztery tysiące rzymskiej piechoty i tysiąc ośmiuset jeźdźców, spośród sprzymierzeńców czterdzieści tysięcy piechoty, cztery tysiące czterystu jeźdźców; zebranych zostało dwadzieścia ciężkich okręlów, lekkich lodzi dwadzieścia". 
Duodetriginta milia hostium occisa Antias Valerius scribit, capta tria milia et quadringentos, signa militaria centum viginti quattuor, equos mille ducentos triginta, carpenta ducenta quadraginta septem. (Liv., 36, 38)

„Waleriusz z Ancjum pisze, że dwadzieścia osiem tysięcy nieprzyjaciół zostalo zabitych, pojmanych trzy tysiące czterystu; chorągwi wojskowych (zostało zdobytych) sto dwadzieści cztery, koni tysiąc dwieście trzydzieści, wozów dwieście czterdzieści siedem".

Z drugiej strony zdarza się, iż formalna składnia zgody jest w zdaniu łamana. Dotyczy to sytuacji, gdy element podrzędny nie jest co do kategorii rodzaju kongruentny $\mathbf{z}$ formalnie nadrzędnym liczebnikiem milia, lecz $\mathrm{z}$ zależnym od niego rzeczownikiem w genetiwie, desygnującym zbiór obiektów; może się tak zdarzyć nawet wówczas, gdy rzeczownik ten jest kontekstowo elidowany:

Caesa ibi hostium duo milia quadringenti, minus duo milia capti. (Liv., 10, 46)

„Nieprzyjaciól zostało tam wyciętych dwa tysiące czterystu, wziętych do niewoli niecale dwa tysiące".

Hominum milia sex $[\ldots]$, sive tomore perterriti $[\ldots]$, sive spe salutis inducti $[\ldots]$, e castris Helvetiorum egressi ad Rhenum finesque Germanorum contenderunt. (Caes., Gall. 1, 27) „Sześć tysięcy ludzi, czy to przerażonych obawą, czy to powodowanych nadzieją na ratunek, wymknąwszy się z obozu Helwetów, podążyło w stronę Renu i kraju Germanów".

Por. też:

Equitum milia erant sex, totidem numero pedites velocissimi ac fortissimi. (Caes., Gall. 1, 48)

„Jeźdźców było sześć tysięcy, i tyleż samo bardzo szybkich i odważnych żolnierzy piechoty".

Bardzo rzadko liczebnik milia pełni funkcję rzeczownikowej przydawki apozycyjnej w stosunku do rzeczownika desygnującego zbiór obiektów:

Census $[\ldots]$ perficitur $[\ldots]$; censa civium capita centum septendecim milia trecenta undeviginti. (Liv., 3, 24)

„Dokończone zostaje oszacowanie liczby obywateli; doliczono się stu siedemnastu tysięcy trzystu dziewiętnastu obywateli".

\subsubsection{Ogólne zestawienie liczebników głównych i podstawowych schematów tworzenia złożonych liczebników głównych}

Uwaga: obok przyjętej w poniższym zestawieniu pisowni milia spotyka się (rzadko) w tekstach również grafię millia. 


\begin{tabular}{|c|c|c|c|c|c|}
\hline 1 & unus, -a, -um & 27 & $\begin{array}{l}\text { viginti septem } \\
\text { septem et viginti }\end{array}$ & 100 & centum \\
\hline 2 & duo, duae, duo & 28 & duodetriginta & 125 & $\begin{array}{l}\text { centum viginti } \\
\text { quinque }\end{array}$ \\
\hline 3 & tres, tria & 29 & undetriginta & 138 & $\begin{array}{l}\text { centum } \\
\text { duodequadraginta }\end{array}$ \\
\hline 4 & quattuor & 30 & triginta & 200 & ducenti, -ae, -a \\
\hline 5 & quinque & 31 & $\begin{array}{l}\text { triginta unus /-a/ -um } \\
\text { unus /-a/-um et } \\
\text { triginta }\end{array}$ & 300 & trecenti, $-\mathrm{ae},-\mathrm{a}$ \\
\hline 6 & sex & 36 & $\begin{array}{l}\text { triginta sex } \\
\text { sex et triginta }\end{array}$ & 400 & quadringenti, -ae, -a \\
\hline 7 & septem & 38 & duodequadraginta & 500 & quingenti, -ae, $-\mathrm{a}$ \\
\hline 8 & octo & 39 & undequadraginta & 600 & sescenti, -ae, -a \\
\hline 9 & novem & 40 & quadraginta & 700 & septingenti, -ae, -a \\
\hline 10 & decem & 48 & duodequinquaginta & 800 & octingenti, -ae, -a \\
\hline 11 & undecim & 49 & undequinquaginta & 900 & nongenti. -ae, $-\mathrm{a}$ \\
\hline 12 & duodecim & 50 & quinquaginta & 1000 & mille \\
\hline 13 & tredecim & 58 & duodesexaginta & 2000 & duo milia \\
\hline 14 & quattuordecim & 59 & undesexaginta & 3000 & tria milia \\
\hline 15 & quindecim & 60 & sexaginta & 10000 & decem milia \\
\hline 16 & sedecim & 68 & duodeseptuaginta & 15000 & quindecim milia \\
\hline 17 & septendecim & 69 & undeseptuaginta & 3000 & triginta milia \\
\hline 18 & \begin{tabular}{|l} 
duodeviginti \\
(octodecim)
\end{tabular} & 70 & septuaginta & 100000 & centum milia \\
\hline 19 & undeviginti & 78 & duodeoctoginta & 150000 & $\begin{array}{l}\text { centum } \\
\text { quinquaginta milia }\end{array}$ \\
\hline 20 & viginti & 79 & undeoctoginta & 200000 & ducenta milia \\
\hline 21 & \begin{tabular}{|l|} 
viginti unus $/$-a/-um \\
unus $/$-a/-um et viginti
\end{tabular} & 80 & octoginta & 1000000 & $\begin{array}{l}\text { decies centena } \\
\text { milia }\end{array}$ \\
\hline 22 & $\begin{array}{l}\text { viginti duo / duae } \\
\text { duo / duae et viginti } \\
\end{array}$ & 88 & duodenonaginta & 1500000 & $\begin{array}{l}\text { decies quinquies } \\
\text { centena milia }\end{array}$ \\
\hline 23 & $\begin{array}{l}\text { viginti tres / tria } \\
\text { tres / tria et viginti }\end{array}$ & 89 & undenonaginta & 2000000 & vicies centena milia \\
\hline \multirow[t]{5}{*}{24} & $\begin{array}{l}\text { viginti quattuor } \\
\text { quattuor et viginti }\end{array}$ & 90 & nonaginta & 10000000 & $\begin{array}{l}\text { centies centena } \\
\text { milia }\end{array}$ \\
\hline & & 98 & nonaginta octo & 100000000 & milies centena milia \\
\hline & & 99 & $\begin{array}{l}\begin{array}{l}\text { nonaginta novem } \\
\text { (undecentum) }\end{array} \\
\end{array}$ & 300000000 & $\begin{array}{l}\text { ter milies centena } \\
\text { milia }\end{array}$ \\
\hline & & & & 1000000000 & $\begin{array}{l}\text { decies milies } \\
\text { centena milia }\end{array}$ \\
\hline & & & & 3000000000 & $\begin{array}{l}\text { tricies milies } \\
\text { centena milia }\end{array}$ \\
\hline
\end{tabular}


11.2.4. Pradygmaty formalne liczebników: unus, duo, tres, milia

\begin{tabular}{|l|l|l|l|l|l|l|l|l|l|}
\cline { 2 - 10 } & \multicolumn{3}{c|}{ unus, $-a,-$ mm } & \multicolumn{3}{c|}{ duo, duae } & \multicolumn{2}{c|}{ tres, tria } & milia \\
\cline { 2 - 10 } & \multicolumn{3}{|c|}{ singularis } & \multicolumn{3}{c|}{ pluralis } & \multicolumn{2}{c|}{ pluralis } & pluralis \\
\cline { 2 - 10 } & masc. & fem. & neutr & masc. & fem. & neutr. & $\begin{array}{c}\text { masc./ } \\
\text { fem. }\end{array}$ & neutr. & neutr. \\
\hline nom. & unus & una & unum & duo & duae & duo & tres & tria & milia \\
\hline gen. & unius & unius & unius & duorum & duarum & duorum & trium & trium & milium \\
\hline dat. & uni & uni & uni & duobus & duabus & duobus & tribus & tribus & milibus \\
\hline acc. & unum & unam & unum & duo(s) & duas & duo & tres (tris) & tria & milia \\
\hline abl. & uno & una & uno & duobus & duabus & duobus & tribus & tribus & milibus \\
\hline
\end{tabular}

Uwaga: liczebnik unus, - $a$, - um w liczbie mnogiej cechuje się regularnym paradygnatem formalnym deklinacji I (fem.) i II (masc. i neutr.).

\subsection{LICZEBNIKI PORZĄDKOWE (NOMINA NUMERALIA ORDINALIA)}

Liczebniki porządkowe identyfikują pozycję w szeregu (ciągu, zbiorze) zajmowaną przez desygnat nadrzędnego rzeczownika. Posiadają gramatyczny status przymiotnika i pod względem składniowym pełnią zwykle funkcję przydawki lub orzecznika. $Z$ rzeczownikowym członem nadrzędnym powiązane są związkiem kongruencji atrybutywnej (zgody), opartym na kategorii liczby, rodzaju i przypadka. Ich paradygmat formalny ukonstytuowany jest przez końcówki deklinacji I (w odniesieniu do rodzaju żeńskiego) oraz II (w odniesieniu do rodzaju męskiego i nijakiego):

Sextius Baculus [...] diem iam quintum cibo caruerat. (Caes., Gall. 6. 38)

„Sekstius Bakulus już piąty dzień nie przyjmowal pokarmów".

Hastati legionis undecimae conglobant sese. (Liv., 30, 18)

„Włócznicy jedenastego legionu zwierają szyki”.

Lucius Verginius $[\ldots]$ sexagesimo anno post libertatem receptam virginem filiam sua manu occidit. (Cic., Fin. 2, 66)

„Lucjusz Werginiusz w sześćdziesiątym roku po odzyskaniu wolności wlasnoręcznie zabił dziewiczą córkę".

Trecentesimo quippe anno post Romam conditam tabulae conpositae scriptaeque sunt. (Gell., Noc. Att. 20, 1, 6)

„Tak więc w' trzechsetnym roku po założeniu Rzymu ustawy dwunatu tablic zostały ulożone i spisane".

Serapionis librum ad me misisti, ex quo quidem ego [...] millesimam partem vix intellego. (Cic., Att. 2, 4, 1)

„Wysłateś mi książkę Serapiona, z kıórej rozumiem ledwie tysięczną część”. 
Jak wszystkie leksemy przymiotnikowe, mogą one ulegać kontekstowej substantywizacji:

In coetu turbulento variae fuere sententiae, ut primus vivam cremari censeret puellam, secundus bestiis obici suaderet, tertius patibulo suffigi iuberet, quartus tormentis excarnificari praeciperet. (Apul., Met. 6, 31)

„W rozgorączkowanym thumie pojawily się różne opinie, tak, iż jeden uznał, że dziewczyna powinna zostać spalona żywcem, drugi doradzal, by została rzucona na pożarcie dzikim zwierzętom, trzeci nakazywal, by ją ukrzyżować, czwarty zalecał, by zamęczyć ją torturami".

Liczebniki porządkowe mogą także tworzyć złożone z nich wyrażenia liczebnikowe (liczebniki złożone). Zestawione są wtedy asyndetycznie bądź połączone spójnikiem et. Liczba wyrażana przez dane wyrażenie liczebnikowe jest wynikiem operacji dodawania (sumowania) wartości liczbowych, wyrażanych przez poszczególne liczebniki będące składnikami tego wyrażenia (np.: octingentesimus quadragesimus septimus 'osiemset czterdziesty siódmy'). Podobnie jak w przypadku liczebników głównych, wyrażenie liczebnikowe złożone z liczebników porządkowych może znajdować się w prepozycji lub postpozycji w stosunku do określanego rzeczownika, bezpośrednio przy nim lub oddzielone od niego innymi składnikami zdania:

Ex quo intellegi $[\ldots]$ potest anno fere centesimo et quadragesimo post mortem Numae primum Italiam Pythagoram attigisse. (Cic., Rep. 2, 28)

„Na tej podstawie można wywnioskować, że w roku niemal sto czterdziestym po śmierci Numy (Pompiliusza) Pitagoras po raz pierwszy dotknął ziemi italskiej".

Bellum [...] coeptum est circa annum fere post conditam Romam trecentesimum vicesimum tertium. (Gell., Noc. Att. 17, 21, 16)

„Wojna rozpoczęla się okolo roku trzysta dwudziestego trzeciego po założeniu Rzymu”.

Liczebniki wyrażające liczby rzędu dziesiątek i jedności mogą w ramach wyrażenia liczebnikowego wystąpić w odwróconym porządku linearnym; zwykle, choć nie zawsze, są one wtedy łączone spójnikiem et:

Macedo Alexander [...] nonne tertio et tricesimo anno mortem obii? (Cic., Phil. 5, 48)

„Czy Aleksander Macedoński nie zmarl w trzydziestym trzecim roku (̇̇ycia)?”

Periit (Vitellius) cum fratre et filio anno vitae septimo quinquagesimo. (Suet., Vit. 18)

"Zginąl Witeliusz razem z bratem i synem w pięćdziesiątym siódmym roku życia”.

W ramach rzędu jedności w miejsce liczebników primus i secundus częściej, choć nie wyłącznie, występują (odpowiednio) unus i alter:

(Plato) uno et octogesimo anno scribens mortuus est. (Cic., Sen. 13)

"(Platon) zmarl w osiemdziesiątym pierwszym roku (życia), pisząc".

Anno quingentesimo quinquagesimo primo ab urbe condita $[\ldots]$ bellum cum rege Philippo initum est. (Liv., 31, 5)

„W roku pięćset pięćdziesiątym pierwszym od założenia miasta rozpoczęto wojnę z królem Filipem". 
(Titus) excessit [...] altero et quadragesimo aetatis anno. (Suet., Tit. 11)

"(Tytus) zmarł w czterdziestym drugim roku życia".

(Hannibal) rex factus est, postquam praetor fuerat, anno secundo et vicesimo. (Nep., Hann. 7)

„(Hannibala) uczyniono królem w dwudziestym drugim roku po tym, gdy został naczelnym wodzem".

W tekstach klasycznej łaciny tego typu wyrażenia liczebnikowe ograniczone są do rzędu jedności, dziesiątek i setek. Liczebnik millesimus nie wchodzi w skład takich wyrażeń, występując zwykle samodzielnie i często przyjmując ogólne znaczenie "bardzo wiele' (lub 'bardzo mało, jak w przywołanym wyżej przykładzie - millesima pars 'tysięczna część'). W późniejszej łacinie zaczęto tworzyć wyrażenia liczebnikowe także z liczebnikiem millesimus, w tym wyrażające wartości liczbowe zawierające $\mathrm{w}$ sobie wielokrotność tysiąca. Ta część takiego wyrażenia, która odnosi się do wielokrotności tysiąca, opiera się wówczas na operacji multiplikacji (mnożenia) w ten sposób, iż liczebnik millesimus jest multiplikandem desygnującym wartość liczbową podlegającą multiplikacji, natomiast funkcję multiplikatora pełnią liczebniki frekwentatywne (przysłówkowe), np.: bis millesimus 'dwutysięczny', quadragies millesimus ducentesimus septuagesimus quintus 'czterdzieści tysięcy dwieście siedemdziesiąty piąty'.

Zdarza się, że dwuczłonowe wyrażenia liczebnikowe w przedziale 13-17 (np.: tertius decimus 'trzynasty') oraz wyrażające rząd dziesiątek i jedności (np.: unus et vicesimus 'dwudziesty pierwszy') zapisywane są jako jeden wyraz tekstowy. $Z$ kolei jednowyrazowe liczebniki oparte na odejmowaniu (np.: undevicesimus 'dziewiętnasty') zastępowane są (dwuelementowymi) wyrażeniami liczebnikowymi opartymi na dodawaniu (np. nonus decimus):

Nono decimo aetatis anno L. Crassus C. Carbonem, unoetvicesimo Caesar Dolabellam, altero et vicesimo Asinius Pollio C. Catonem [...] iis orationibus insecuti sunt, quas hodieque cum admiratione legimus. (Tac., Dial. 34)

„W dziewiętnastym roku życia Lucjusz Krassus zaatakowal Gajusza Karbona, w dwudziestym pierwszym Cezar Dolabellę, w dwudziestym drugim Azyniusz Pollion Gajusza Katona, (a uczynili to) w tych mowach, które i dzisiaj z podziwem czytamy".

Caecina [...] partem equitum ad occupandam Cremonam praemisit. Mox vexilla primae, quartae, quintaedecimae, sextaedecimae legionum, dein quinta et duoetvicensima secutae. (Tac., Hist. 2, 100)

„Cecyna $[\ldots]$ część jazdy wysłał przodem w celu zajęcia Kremony. Wkrótce potem ruszyły oddziały pierwszego, czwartego, piętnastego i szesnastego legionu, następnie (legion) piąty i dwudziesty drugi".

Formy akuzatiwu i ablatiwu liczby pojedynczej rodzaju nijakiego, a więc formy typu: primum/primo, tertium/tertio, quartum/quarto itp., mogą ulegać adwerbializacji, przybierając znaczenie 'po raz pierwszy', po raz trzeci' itd.; w znaczeniu 'po raz drugi' używana jest forma iterum:

Natus erat Agricola Gaio Caesare tertium consule. (Tac., Agr. 44) "Agrykola urodził się, gdy po raz trzeci konsulem był Gajusz Cezar". 
Cum Carthaginiensibus eodem anno foedus tertio renovatum. (Liv., 9, 43)

„W tym samym roku po raz trzeci odnowiono przymierze $z$ Kartagińczykami”.

Scipio [...] dixisse dicitur si quintum pareret mater eius, asinum fuisse parituram. (Cic., De orat. 2, 267)

„Podobno Scypion powiedzial, że gdyby jego matka po raz piąty rodzila, musiałaby chyba urodzić osla".

Eodem anno lectisternium Romae quinto post conditam urbem [...] habitum est. (Liv., 8, 25)

„W tym samym roku w Rzymie po raz piąty od zalożenia miasta urządzono rytualną ucztę dla bogów".

Formy primo i primum używane są również w znaczeniu: 'najpierw, na początku'; forma primum oraz wyrażenia in primo i in primis także $\mathrm{w}$ znaczeniu: 'przede wszystkim,' 'w pierwszej kolejności,' 'po pierwsze':

Postumius Milioniam oppugnare adortus vi primo atque impetu, dein postquam ea parum procedebant opere ac vineis demum iniunctis muro cepit. (Liv., 10, 34)

„Postumiusz najpierw próbował zdobyć Milionię silą i szturmem, po tym jednak, gdy okazato się to mało skuteczne, zdobył ją w końcu przy pomocy prac i machin oblężniczych przysuniętych do murów".

Primum Elidem, dein Thebas venit. (Nep., Alc. 4)

„Najpierw udal się do Elidy, następnie do Teb”.

Qui honos [...] mihi maximus videtur, primum quia iustus est. (Cic., Phil. 5, 41)

„Zaszczyt ten uważam za bardzo wielki, przede wszystkim dlatego, że jest w pełni zasłużony".

Primum igitur est de honesto [...], tum pari ratione de utili, post de comparatione eorum disserendum. (Cic., Off. 1, 10)

„W pierwszej kolejności należy przeprowadzić dyskusję na temat tego, co jest cnotliwe, następnie, w podobny sposób, na temat tego, co jest pożyteczne, potem przeprowadzić porówanie jednego $z$ drugim".

Tantum vobis, quantum facere possum, Quirites, pollicebor: primum, qua sanctissimi homines pietate erga deos immortalis esse soleant, eadem me erga populum semper fore [...]; deinde, quoniam me in civitatem res publica ipsa reduxit, nullo me loco rei publicae defuturum. (Cic., P. red. ad Quir. 18)

„Tyle, Kwiryci, wam obiecam, ile mogę spełnić: po pierwsze, że zawsze zachowam wobec ludu takie samo poczucie obowiązku, jakie żywią zwykle najcnotliwsi ludzie względem bogów; po drugie, ponieważ sama rzeczpospolita ponownie wprowadzila mnie w poczet obywateli, nigdy nie odmówię swej służby dla niej".

Quemadmodum ex amphora primum quod est sincerissimum effluit $[\ldots]$, sic in aetate nostra quod est optimum in primo est. (Sen., Lucil. 108, 26)

„Jak $z$ amfory najpierw wylewa się to, co jest najbardziej czyste, tak i w życiu naszym to, co jest najlepsze, jest na początku (= w pierwszym jego okresie)".

In primis autem respuendae voluptates. (Sen., Lucil. 104, 34)

"A więc przede wszystkim należy odrzucić rozkosze". 


\subsubsection{Ogólne zestawienie liczebników porządkowych i podstawowych schematów tworzenia złożonych liczebników porządkowych}

\begin{tabular}{|c|c|c|c|}
\hline 1 & primus. -a. -um (unus. -a. -um) & 28 & duodetricesimus. -a. -um \\
\hline 2 & secundus. -a. -um (alter, -era, -erum) & 29 & undetricesimus. -a. -um \\
\hline 3 & terlius. -a. -um & 30 & tricesimus, $-\mathrm{a},-$ um \\
\hline 4 & quartus, -a. -um & 38 & duodequadragesimus, - a, -um \\
\hline 5 & quintus, -a, -um & 39 & undequadragesimus, -a. -um \\
\hline 6 & sextus, -a, -um & 40 & quadragesimus, -a, -um \\
\hline 7 & septimus, -a. -um & 50 & quinquagesimus, $-\mathrm{a},-$ um \\
\hline 8 & octavus, -a. -um & 60 & sexagesimus. -a, -um \\
\hline 9 & nonus, -a. -um & 70 & septuagesimus, -a, -um \\
\hline 10 & decimus. -a. -um & 80 & octogesimus. -a. -um \\
\hline 11 & undecimus, -a. -um & 90 & nonagesimus, -a, -um \\
\hline 12 & duodecimus, -a. -um & 100 & centesimus, -a. -um \\
\hline 13 & tertius. $-\mathrm{a},-$ um decimus, $-\mathrm{a}-\mathrm{um}$ & 125 & $\begin{array}{l}\text { centesimus, -a, -um } \\
\text { vicesimus. -a. -um quintus. -a. -um }\end{array}$ \\
\hline 14 & quartus, -a. -um decimus, -a, -um & 200 & ducentesimus, -a, -um \\
\hline 15 & quintus. -a. -um decimus, -a, -um & 300 & trecentesimus. -a. - um \\
\hline 16 & sextus. -a. -um decimus. -a. -um & 400 & quadringentesimus. -a. -um \\
\hline 17 & septimus, -a. -um decimus, -a. -um & 500 & quingentesimus, -a, -um \\
\hline 18 & duodevicesimus, -a, -um & 600 & sescentesimus, -a, - um \\
\hline 19 & undevicesimus, -a. - -um & 700 & septingentesimus. -a, -um \\
\hline 20 & vicesimus. -a. -um & 800 & octingentesimus, -a, -um \\
\hline 21 & $\begin{array}{l}\text { vicesimus, -a, -um unus, -a, -um } \\
\text { (primus, -a, -um) } \\
\text { unus, -a. -um et vicesimus, -a, -um }\end{array}$ & 900 & nongentesimus, -a. -um \\
\hline 22 & $\begin{array}{l}\text { vicesimus, -a, -um alter, -era, -erum } \\
\text { (secundus, -a,-um) } \\
\text { alter. -era, -erum et vicesimus. -a. -um }\end{array}$ & 1000 & millesimus, -a, -um \\
\hline 23 & $\begin{array}{l}\text { vicesimus, -a, -um terlius, -a, -um } \\
\text { tertius, -a. -um el vicesimus. -a, -um }\end{array}$ & 1386 & $\begin{array}{l}\text { millesimus, -a. -um } \\
\text { trecentesimus, -a, -um } \\
\text { octogesimus, -a, -um sextus, -a. -um }\end{array}$ \\
\hline 24 & $\begin{array}{l}\text { vicesimus, -a. -um quartus, -a. -um } \\
\text { quartus, -a, -um et vicesimus. -a. -um }\end{array}$ & 2000 & bis millesimus. -a. -um \\
\hline
\end{tabular}

Uwaga: obok przyjętej w powyższym zestawieniu pisowni typu: vicesimus, tricesimus itp. rozpowszechniona była również krytykowana przez gramatyków grafia typu: vicensimus, tricensimus. Należy jednak zaznaczyć, że formy: vicesimus/vicensimus itp. stanowiły warianty wyłącznie ortograficzne, nieróżniące się między sobą w zakresie wymowy (zob. wyżej, Fonologia i fonetyka 6.4.). 


\subsection{LICZEBNIKI PODZIAŁOWE (NOMINA NUMERALIA DISTRIBUTIVA)}

Liczebniki podziałowe charakteryzują desygnaty nadrzędnego składniowo rzeczownika pod względem sposobu ich zorganizowania w obrębie zbioru, który stanowią. W języku polskim odpowiadają im wyrażenia złożone z przyimka po i liczebnika głównego, np.: po trzech / po trzy (trójkami), po czterech / po cztery itp. Posiadają one gramatyczny status przymiotnika o paradygmacie formalnym ukonstytuowanym przez końcówki deklinacji I (w odniesieniu do rodzaju żeńskiego) oraz deklinacji II ( $w$ odniesieniu do rodzaju męskiego i nijakiego). $Z$ nadrzędnym składniowo rzeczownikiem wchodzą w związek zgody (akomodacji, kongruencji atrybutywnej), oparty na kategorii liczby, rodzaju i przypadka, pełniąc zwykle funkcję przydawki:

Primam aciem quaternae cohortes ex V legionibus tenebat. (Caes., Civ. 1, 83)

„Pierwszy szereg tworzyły po cztery kohorty z pięciu legionów (czyli lącznie 20 kohort)”.

Quibus ex rapina victus quadripedum, quini digiti in prioribus pedibus, in reliquis quaterni. (Plin., Nat. hist. 11, 244)

„Czwonogi, które są drapieżnikami, mają po pięć palców na przednich lapach, na pozostatych (scil. na tylnych) po czery".

Ursae mammas quaternas gerunt, delphini binas in ima alvo papillas tantum. (Plin., Nat. hist. 11, 235)

„Niedźwiedzice mają po cztery piersi, delfiny tylko po dwa sutki w dolnej części brzucha".

Britanni $[\ldots]$ uxores habent deni duodenique inter se communes et maxime fratres cum fratribus parentesque cum liberis. (Caes., Gall. 5, 14)

„Brytowie mają (w grupach) po dziesięciu lub dwunastu wspólne żony, zazwyczaj bracia $\mathrm{z}$ braćmi i ojcowie z synami".

Vicena iugera pedites, quadragena equites acceperunt. (Liv., 35, 9)

„Po dwadzieścia jugerów (ziemi) otrzymali żołnierze piechoty, po czterdzieści jeźdźcy”.

Tanta $[. .$.$] praeda fuit, ut in equitem quadringeni denarii, peditibus duceni dividerentur.$ (Liv., 45, 34)

„Zdobycz była tak wielka, że każdemu z jeźdźców przydzielono po czterysta denarów, żolnicrzom picchoty po dwieście".

Podobnie jak liczebniki główne i podziałowe mogą ulegać kontekstowej substantywizacji:

Ariovistus, ex equis ut conloquerentur et praeter se denos ad conloquium adducerent, postulavit. (Caes., Gall. 1, 43)

„Ariowist zażądal, aby rozmawiali siedząc na koniach, i żeby przyprowadzili z sobą na rozmowę po dziesięciu (ludzi)".

Singulis vobis novenos ex turmis manipulisque vestri similes eligite. (Liv., 21, 54)

„Dla każdego $z$ was wybierzcie $z$ oddziałów konnicy i piechoty po dziewięciu podobnych wam (ludzi)". 
Zestawione asyndetycznie liczebniki podziałowe tworzą wyrażenia liczebnikowe (liczebniki złożone), stanowiące ciągi przydawek pozostających z nadrzędnym rzeczownikiem w związku zgody co do kategorii liczby, rodzaju i przypadka. Wyrażenia te desygnują wyższe wartości liczbowe na zasadzie sumowania wartości wyrażanych przez poszczególne elementy składowe:

Iugera $[\ldots]$ centena quadragena equites acceperunt. (Liv., 40, 34)

"Jeźdźcy otrzymali po sto czterdzieści jugerów ziemi”.

Militibus, qui currum secuti sunt, centenos vicenos quinos asses divisit. (Liv., 36, 40) „Żołnierzom, którzy szli za rydwanem tryumfalnym, przydzielił po sto dwadzieścia pięć asów".

Łaciński system liczebnikowy nie dysponuje liczebnikiem podziałowym wyrażającym wartość tysiąca. Wartość ta, a także jej wielokrotność, wyrażana jest przez liczebnik złożony o strukturze grupy imiennej, której członem konstytutywnym (nadrzędnym) jest rzeczownikowy liczebnik główny milia, zaś członem podrzędnym (akomodowanym) jest liczebnik podziałowy pozostający $z$ tym pierwszym w składni zgody. Semantyka tej grupy oparta jest na mechanizmie multiplikacji, w którym liczebnik milia pełni funkcję multiplikanda, a liczebnik podziałowy funkcję multiplikatora. Tego rodzaju liczebnikową grupę imienną uzupełnia rzeczownik w genetiwie (pluralis), desygnujący grupę obiektów, której przypisywana jest dana wartość liczbowa i stanowiący w stosunku do nadrzędnego liczebnika milia przydawkę dopełniaczową, np.: singula milia sestertium 'po tysiąc (po jednym tysiącu) sesterców', dena milia equitum 'po dziesięć tysięcy jeźdźców' itp.:

Legavit $[\ldots]$ pretorianis militibus singula milia nummorum [...], legionariis trecenos nummos. (Suet., Aug. 101)

„Pretorianom zostawił w testamencie po tysiąc denarów, legionistom po trzysta”.

Praetoribus in Hispanias octona milia peditum socium ac nominis Latini data et quadringeni equites. (Liv., 23, 28)

„Pretorom do (obu) Hiszpanii przydzielono po osiem tysięcy piechoty spośród sprzymierzeńców i Latynów oraz po czterystu jeźdźców".

Jeśli wyrażana jest nie tylko określona liczba tysięcy, ale także wartości liczbowe niższych rzędów (setek, dziesiątek, jedności), wyrażenie liczebnikowe ma - podobnie jak w przypadku liczebników głównych - strukturę dwudzielną. Pierwszą jego część stanowi grupa imienna desygnująca liczbę tysięcy, o budowie scharakteryzowanej powyżej; drugą konstytuuje liczebnik lub ciąg liczebników podziałowych, wyrażający wartości liczbowe niższych rzędów i determinowany syntaktycznie (na zasadzie składni zgody) przez rzeczownik desygnujący zbiór obiektów:

Duae legiones scribi iussae, quina milia in singulas et duceni pedites, treceni equites. (Liv., 41,9)

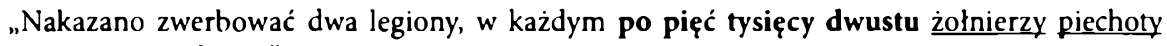
i po trzystu jeźdźców". 
Rzeczownik desygnujący zbiór obiektów może jednak zostać związany z tą częścią wyrażenia liczebnikowego, która wyraża liczbę tysięcy; występuje wtedy w genetiwie, stanowiąc przydawkę dopełniaczową rzeczownikowego liczebnika milia, przy czym liczebniki desygnujące niższe wartości liczbowe zachowują swoją formę tak, jakby rzeczownik znajdował się po nich:

Finitus ibi quoque in legiones militum numerus, peditum quina milia duceni et treceni equites. (Liv., 43, 12)

„Określono tam również liczbę żołnierzy przypadających na legiony, (a mianowicie) po pięć tysięcy dwustu żołnierzy piechoty i po trzystu konnych".

W odniesieniu do rzeczowników, które należą do klasy pluralia tantum lub w liczbie mnogiej cechują się odrębnym (specyficznym) znaczeniem, liczebniki podziałowe oprócz wyrażania dystrybutywności przyjmują również funkcję liczebników głównych, przy czym dla wartości równej liczbie jeden stosowany jest liczebnik uni, -ae, -a:

Ex unis geminas mihi conficies nuptias. (Ter., Andr. 674)

„Z jednych zaślubin zrobisz mi dzisiaj podwójne".

Una castra iam facta ex binis. (Caes., Civ. 1, 74)

„Powstal już jeden obóz wojskowy z dwóch”.

Hostium cepi bina castra, praedae videlicet plena et commeatuum. (Liv., 23, 12)

„Zdobylem dwa nieprzyjacielskie obozy, rzecz jasna, pełne łupów i żywności".

Por. też:

Non dicimus biga una, quadrigae duae, nuptiae tres, sed pro eo unae bigae, binae quadrigae, trinae nuptiae. (Varr., Ling. 19, 67)

Pewne zróżnicowanie $\mathrm{w}$ tym względzie istnieje $\mathrm{w}$ przypadku wartości równej liczbie „trzy”. Polega ono na tym, że dla realizacji funkcji liczebnika głównego (przy rzeczownikach klasy pluralia tantum) stosowana jest glównie forma trini, -ae, -a, natomiast dla wyrażania dystrybutywności forma terni, -ae, -a:

Litteras $[\ldots]$ missas in trinis annalibus invenio. (Liv., 10, 18)

„W trzech kronikach rocznikowych znajduję, że został wysłany list".

Milites dato signo celeriter ad munitionem perveniunt eamque transgressi trinis castris potiuntur. (Caes., Gall. 7, 46)

„Żołnierze na dany znak szybko podeszli do muru i przekroczywszy go, zawładnęli trzema obozami".

Tullia mea venit ad me $[. .$.$] litterasque reddidit trinas. (Cic., Att. 11, 17)$

"Tulia mea przybyla do mnie i przywiozla trzy listy".

Legiones decem effectae: ternae inde datae consulibus, quattuor dictatus usus. (Liv., 2, 30)

„Powołano pod broń dziesięć legionów: z nich po trzy przydzielono (dwom) konsulom, nad czterema objąl dowództwo dyktator". 
Agrum $[\ldots]$ Campanum $[\ldots]$ divisit $[\ldots]$ ad viginti milibus civium, quibus terni pluresve liberiessent. (Suet., Iul. 20)

„Ziemię Kampańską przydzielił blisko dwudziestu tysiącom obywateli, którzy mieli po troje lub więcej dzieci".

Et ipsis imperatum, ut [...] raptim cibum caperent binis ternisve summum ex manipulis aquandi causa missis. (Liv., 31, 42)

„Również im nakazano, by szybko spożyli posilek, wyslawszy po dwóch lub co najwyżej trzech ludzi z (poszczególnych) oddziałów po wodę".

Por. jednak:

Dum $[\ldots]$ terna $[\ldots]$ transierint Rutulis hiberna subactis. (Verg., Aen. 1, 265-266) „Gdy trzy zimy miną od pokonania Rutulów”.

Ponadto liczebniki podziałowe stosowane są także w odniesieniu do zbiorów obiektów tworzących pewną określoną grupę (zestaw, komplet), a także w stosunku do zdarzeń współwystępujących $\mathrm{z}$ sobą $\mathrm{w}$ danym czasie albo stanowiących cyklicznie powtarzalne serie (sekwencje); w odniesieniu do liczby trzy używana jest w tej funkcji głównie forma trini, -ae, -a:

Cenam ternis ferculis, aut cum abundantissime senis, praebebat. (Suet., Aug. 74)

„Uczty wydawał zlożone z trzech dań albo - jeśli szczególnie suto przyjmował - z sześciu”.

Quaterni quinique exercitus saepe per eos annos in Etruria, in Umbria [...], in Samno, in Lucanis gerebant bellum. (Liv., 9, 19)

„Często $w$ tych latach cztery i pięć armii naraz prowadziło wojny w Etrurii, w Umbrii, w Samnium, w Lukanii".

Stephanionem togatarium [...] per trina theatra virgis caesum relegaverit. (Suet., Aug. 45) „Stefaniona, aktora występującego $w$ togatach, wychłostanego rózgami po kolei we wszystkich trzech teatrach', zeslal na wygnanie".

Imagunculam puellarem [...] trinis [...] in die sacrificiis colere perseveravit. (Suet., Ner. 56)

„Posążek przedstawiający młodą dziewczynę uparcie czcił trzykrotnymi ofiarami w ciągu dnia".

C. Valerius Procillus, cum a custodibus [...] trinis catenis vinctus traheretur, in ipsum Caesarem [...] incidit. (Caes., Gall. 1, 53)

„Gajusz Waleriusz Procyllus, gdy zakuty w potrójne łańcuchy wleczony był przez strażników, natknąl się na samego Cezara".

Na temat użycia liczebnika centena (milia) w ramach złożonych liczebników głównych, zob. wyżej (11.2.2.1.). 


\subsubsection{Ogólne zestawienie liczebników podziałowych i podstawowych schematów tworzenia złożonych liczebników podziałowych}

\begin{tabular}{|c|c|c|c|}
\hline 1 & singuli, -ae, -a & 28 & duodetriceni, -ae, -a \\
\hline 2 & bini, -ae, -a & 29 & undetriceni, -ae, -a \\
\hline 3 & terni, -ae, -a (trini, -ae, -a) & 30 & triceni, -ae, -a \\
\hline 4 & quaterni, -ae, -a & 38 & duodequadrageni, -ae, -a \\
\hline 5 & quini, - ae, -a & 39 & undequadrageni, -ae, -a \\
\hline 6 & seni, -ae, -a & 40 & quadrageni, -ae, -a \\
\hline 7 & septeni, -ae, -a & 50 & quinquageni, -ae, -a \\
\hline 8 & octoni, -ae, -a & 60 & sexageni, -ae, -a \\
\hline 9 & noveni, -ae, -a & 70 & septuageni, -ae, -a \\
\hline 10 & deni, -ae, -a & 80 & octogeni, -ae, -a \\
\hline 11 & undeni, -ae, -a & 90 & nonageni, -ae, -a \\
\hline 12 & duodeni, -ae, -a & 100 & centeni, -ae, -a \\
\hline 13 & terni, -ae, -a deni, -ae, -a & 125 & $\begin{array}{l}\text { centeni, -ae, -a viceni, -ae, -a } \\
\text { quini, -ae, -a }\end{array}$ \\
\hline 14 & quaterni, -ae, -a deni, -ae, -a & 200 & duceni, -ae, -a \\
\hline 15 & quini, -ae, -a deni, -ae, -a & 300 & treceni, -ae, -a \\
\hline 16 & seni, -ae, -a deni, -ae, -a & 400 & quadringeni, -ae, -a \\
\hline 17 & septeni, -ae, -a deni, -ae, -a & 500 & quingeni, -ae, -a \\
\hline 18 & $\begin{array}{l}\text { duodeviceni, -ae, -a / } \\
\text { octoni, -ae, -a deni, -ae, -a } \\
\end{array}$ & 600 & sesceni, -ae, -a \\
\hline 19 & $\begin{array}{l}\text { undeviceni, -ae, -a / } \\
\text { noveni, -ae, -a deni, -ae, -a }\end{array}$ & 700 & septingeni, -ae, -a \\
\hline 20 & viceni, -ae, -a & 800 & octingeni, -ae, -a \\
\hline 21 & $\begin{array}{l}\text { viceni, -ae, -a singuli, -ae, -a } \\
\text { singuli, -ae, -a et viceni, -ae, -a } \\
\end{array}$ & 900 & nongeni, -ae, -a \\
\hline 22 & $\begin{array}{l}\text { viceni, -ae, -a bini, -ae, -a } \\
\text { bini, -ae, -a et viceni, -ae, -a }\end{array}$ & 1000 & singula milia \\
\hline 23 & $\begin{array}{l}\text { viceni, -ae, -a terni, -ae, -a (trini, -ae, -a) } \\
\text { terni, -ae, -a et viceni, -ae, -a }\end{array}$ & 1496 & $\begin{array}{l}\text { singula milia (et) quadringeni, -ae, -a } \\
\text { nonageni, -ae, -a seni, -ae, -a }\end{array}$ \\
\hline 24 & $\begin{array}{l}\text { viceni, -ae, -a quaterni, -ae, -a } \\
\text { quaterni, -ae, -a et viceni, -ae, -a }\end{array}$ & 2000 & bina milia \\
\hline & & 10000 & dena milia \\
\hline
\end{tabular}

\subsection{LICZEBNIKI WIELORAKIE (NOMINA NUMERALIA MULTIPLICATIVA)}

Liczebniki wielorakie (mnożne) charakteryzują desygnat nadrzędnego rzeczownika pod względem liczbowego aspektu jego struktury. Posiadają gramatyczny status przymiotników o paradygmacie formalnym trzeciej deklinacji (typu samogłoskowego) $\mathbf{z}$ homonimicznymi formami nominatiwu singularis dla wszystkich trzech rodzajów gramatycznych. Do klasy tej należy bardzo nieliczna grupa leksemów. Generalnie poświadczone są jedynie formy: simplex, -licis 'pojedynczy', duplex, -licis 'podwójny', 
triplex, -licis 'potrójny', quadruplex, -licis 'poczwórny', quinquiplex, -licis 'pięcioraki', septemplex, -licis 'siedmioraki', decemplex, -licis 'dziesięcioraki', centumplex, -licis 'stukrotny'. Poza trzema pierwszymi spotykane są w tekstach bardzo rzadko:

Decem regii lembi $[\ldots]$ simplici ordine, quam poterant proxime litus tenentes, intrarunt urbem. (Liv., 44, 12)

„Dziesięć królewskich łodzi, posuwając się pojedynczym rzędem i trzymając się możliwie najbliżej wybrzeża, przedostało się do miasta".

Cohortem [...] duplici stipendio [...] donavit. (Caes., Civ. 3, 53)

„Kohortę nagrodzil podwójnym żołdem".

Triplex Piraei portus constitutus est. (Nep., Them. 6)

"Wybudowano potrojny port w Pireusie".

Scipio [...] onerariarum quadruplicem ordinem pro muro adversus hostem opposuit. (Liv., 30, 10)

„Scypion $[\ldots]$ naprzeciw nieprzyjaciół ustawił przed murem poczwórny rząd okrętów transportowych".

Tanto plus virtute valuerunt Athenienses, ut decemplicem numerum hostium profligarint. (Nep., Milt. 5)

„Tak bardzo Ateńczycy górowali męstwem, że rozgromili dziesięciokrotnie większą liczbę nieprzyjaciór".

Centumplex murus rebus servandis parumst. (PI., Pers. 560)

"(Nawet) stukrotny mur nie wystarcza do ochrony".

\subsection{LICZEBNIKI FREKWENTATYWNE / PRZYSŁÓWKOWE (ADVERBIA NUMERALIA)}

Liczebniki te mają gramatyczny status przysłówków. Pod względem znaczeniowym precyzują liczbowo frekwentatywność (iteratywność, powtarzalność) przypisaną w wpowiedzeniu sytuacji (czynności, okoliczności) wyrażanej przez składniowy nadrzędnik. Nadrzędnikiem tym może być człon syntaktyczny stanowiony przez czasownik, przymiotnik lub rzeczownik, wobec którego liczebnik zajmuje pozycję okolicznika lub przydawki:

Ne plus quam semel certemus. (Tac., Hist. 2, 47)

„Byśmy nie walczyli więcej niż jeden raz”.

L. Paulum, bis consulem, domitorem Graeciae, omnium oculi conspicere urbem curru ingredientem avent. (Liv., 45, 39)

„Lucjusza Paulusa, dwukrotnie konsula, pogromcę Grecji, oczy wszystkich pragną zobaczyć, jak wkracza do miasta na rydwanie".

Ter depugnavit Caesar cum civibus, in Thessalia, Africa, Hispania. (Cic., Phil. 2, 75)

„Trzy razy prowadzil Cezar walkę z obywatelami: w Tessalii, w Afryce, w Hiszpani”. 
Trepidam civitatem $[\ldots]$ dictator $[\ldots]$ increpuit quod $[\ldots]$ hostem sexiens victum pertimescant. (Liv., 4, 32)

„Strwożonych obywateli dyktator zganil, że lękają się wroga sześć razy (już przez nich) pokonanego".

Deciens in die mutat locum. (Pl., Stich. 501)

„Dziesięć razy na dzień zmienia miejsce (pobytu)”.

Zestawione szeregowo tworzyć mogą, podobnie jak inne liczebniki, wyrażenia liczebnikowe (liczebniki złożone), których semantyka opiera sie na sumowaniu:

Quater et tricies virtutis causa donatus ab imperatoribus sum. (Liv., 42, 34)

"Trzydzieści cztery razy za męstwo odznaczony zostałem przez wodzów”.

Na temat liczebników frekwentatywnych w ramach złożonych liczebników głównych, porządkowych i podziałowych zob. wyżej.

\subsubsection{Ogólne zestawienie liczebników frekwentatywnych i podstawowych schematów tworzenia złożonych liczebników frekwentatywnych}

\begin{tabular}{|l|l|l|l|}
\hline 1 & semel & 28 & duodetricies / vicies octies \\
\hline 2 & bis & 29 & undetricies / vicies novies \\
\hline 3 & ter & 30 & tricies \\
\hline 4 & quater & 38 & duodequadragies / tricies octies \\
\hline 5 & quinquies & 39 & undequadragies / tricies novies \\
\hline 6 & sexies & 40 & quadragies \\
\hline 7 & septies & 50 & quinquagies \\
\hline 8 & octies & 60 & sexagies \\
\hline 9 & novies & 70 & septuagies \\
\hline 10 & decies & 80 & octogies \\
\hline 11 & undecies & 90 & nonagies \\
\hline 12 & duodecies & 100 & centies \\
\hline 13 & terdecies & 125 & centies vicies quinquies / \\
& & & centies quinquies et vicies \\
\hline 14 & quaterdecies & 200 & ducenties \\
\hline 15 & quindecies & 300 & trecenties \\
\hline 16 & sedecies & 400 & quadringenties \\
\hline 17 & septiesdecies & 500 & quingenties \\
\hline 18 & duodevicies & 600 & sescenties \\
\hline 19 & undevicies & 700 & septingenties \\
\hline 20 & vicies & 800 & octingenties \\
\hline 21 & vicies (et) semel / semel et vicies & 900 & nongenties \\
\hline 22 & vicies (et) bis / bis et vicies & 1000 & milies \\
\hline 23 & vicies (et) ter / ter et vicies & 1496 & milies quadringenties nonagies sexies \\
\hline 24 & vicies (et) quater / quater et vicies & 2000 & bis milies \\
\hline & & 10000 & decies milies \\
\hline & & \\
\hline
\end{tabular}


Uwaga: obok pisowni uwzględnionej w powyższym zestawieniu bardzo rozpowszechniona (również u najlepszych autorów) była grafia typu: deciens, viciens, trecentiens itp., chociaż krytykowali ją gramatycy.

\subsection{WYBRANA LITERATURA}

De La Villa (2010), Keyser (1988), Wolanin (2002) 


\section{2. \\ Charakterystyka funkcjonalna czasowników}

\subsection{CZASOWNIKI JAKO KLASA LEKSEMÓW}

Jako nazwy cech czynnościowych (procesualnych, stanowych, relacyjnych) czasowniki prymarnie zajmują pozycję członu określającego wobec rzeczownikowego członu określanego. Jest to klasa leksemów reprezentowana przez wyrazy gramatyczne, których prymarną funkcją składniową jest funkcja orzeczenia, czyli członu podrzędnego (akomodowanego) w ramach związku składniowego predykacji. Pełniąc funkcję orzeczenia, czasowniki sygnalizują wartość kategorii osoby podmiotu, a przypisywaną jego desygnatowi cechę czynnościową ujmują w ramy czasowe i modalne. Sekundarnie, przyjmując nieosobowe formy $w$ ramach kategorii finitywności, pełnić mogą funkcję podmiotu, przydawki, dopełnienia, okolicznika, a także funkcjonalnego odpowiednika orzeczenia ( $w$ ramach równoważników zdań znanych jako accusativus cum infinitivo oraz ablativus absolutus), wiążąc się $\mathrm{z}$ innymi członami syntaktycznymi (podrzędnymi lub nadrzędnymi względem nich) związkiem kongruencji atrybutywnej, rekcji lub przynależności. Pod względem morfologicznym rzeczownikom przysługuje kategoria czasu, aspektu, strony, trybu, osoby, liczby, a także finitywności.

\subsection{CZAS (TEMPUS) - TZW. CONSECUTIO TEMPORUM}

Czas jest kategorią gramatyczną prymarną dla czasownika, która w języku łacińskim posiada 6 wartości: praesens, imperfectum, perfectum, plusquamperfectum, futurum (primum), fururum exactum (secundum). Jest to kategoria niezdeterminowana i niedeterminująca, o charakterze fleksyjnym i funkcji nominatywnej (semantycznej). Nominatywna funkcja kategorii czasu polega na wyrażaniu charakterystyki czasowej (temporalnej) desygnatu, tj. na wskazywaniu relacji czasowych zachodzących pomiędzy zdarzeniem desygnowanym przez dany czasownik, a określonym momentem, będącym punktem czasowego odniesienia. W typowej sytuacji aktu mowy owym punktem temporalnego odniesienia jest moment mówienia. $W$ takim właśnie użyciu kategorii czasu, polegającym na aktualizacji zdarzenia desygnowanego przez 
czasownik poprzez zrelacjonowanie go w stosunku do momentu wypowiedzi, kategoria ta wyraża tzw. czas bezwzględny. Czas bezwzględny posiada trzy wartości: teraźniejszość, przeszłość i przyszłość. Wyrażanie czasu bezwzględnego jest prymarną funkcją kategorii czasu. W łacinie wartość praesens gramatycznej kategorii czasu wyraża czas bezwględny teraźniejszy, wartość imperfectum i perfectum czas bezwzględny przeszły, a wartość futurum primum czas bezwzględny przyszły:

Gripe, accede huc; tua res agitur. (Pl., Rud. 1148)

„Podejdź tu, Grypusie; rozstrzyga się twoja sprawa”.

Quod in conspectu omnium res gerebatur neque recte aut turpiter factum celari poterat, utrosque et laudis cupiditas et timor ignominiae ad virtutem excitabat. (Caes., Gall. 7, 80)

„Ponieważ bitwa rozgrywała się na oczach wszystkich i nie moglo zostać ukryte ani właściwe zachowanie, ani haniebne, jednych i drugich zagrzewalo do męstwa tak pragnienie slawy, jak i strach przed hańbą".

Caesar cognito consilio eorum ad flumen Tamesin in fines Cassivellauni exercitum duxit. (Caes., Gall. 5, 18)

„Ceazar po rozpoznaniu ich planów poprowadził wojsko ku rzece Tamesis do kraju Kassywelaunusa".

Scribam ad te plura alias. (Cic., Fam. 2, 7, 3)

"Wiecej napiszę ci innym razem".

Sekundarną funkcją kategorii czasu jest wyrażanie czasu względnego. Polega ono na zrelacjonowaniu zdarzenia desygnowanego przez czasownik $w$ stosunku do innego niż moment mówienia punktu na osi czasu. Punktem tym jest czas przebiegu innego zdarzenia, wskazanego przez inny wyraz (najczęściej inny czasownik) współwystępujący w danej wypowiedzi, który to wyraz (czasownik) wyraża już bezwzględną charakterystykę czasową swego desygnatu. Wartościami czasu względnego są: równoczesność, uprzedniość, następczość. Za względu na to, iż punkt czasowego odniesienia, w stosunku do którego dokonywana jest względna charakterystyka czasowa, może być ulokowany w teraźniejszości, przeszłości lub przyszłości, otrzymujemy w sumie 9 wariantów względnej charakterystyki czasowej:

- równoczesność $\mathrm{w}$ stosunku do momentu w teraźniejszości/przeszłości/przyszłości,

- uprzedniość w stosunku do momentu w teraźniejszości/przeszłości/przyszłości, - następczość w stosunku do momentu w teraźniejszości/przeszłości/przyszłości.

Bezwzględna charakterystyka czasowa dokonywana jest więc w odniesieniu do chwili mówienia, czyli określonego momentu rzeczywistości pozajęzykowej (zewnątrzjęzykowej), natomiast względna charakterystyka czasowa dokonywana jest w odniesieniu do czasu przebiegu określonego zdarzenia wewnątrztekstowego. Ponieważ jednak czas owego zdarzenia wewnątrztekstowego, stanowiącego punkt odniesienia dla względnej charakterystyki czasowej, scharakteryzowany jest już bezwzględnie (jako teraźniejszy, przeszły lub przyszły), w ostatecznej instancji charakterystyka temporalna zdania oparta jest zawsze na czasie bezwzględnym. 
Wyrażanie czasu względnego w łacinie

1. Jednym ze środków wyrażania czasu względnego w łacinie jest zastosowanie specjalnych czasownikowych formacji morfologicznych, których prymarną funkcją jest właśnie wyrażanie czasu względnego. Łacina dysponuje dwiema takimi formacjami. Jedną $\mathrm{z}$ nich jest indicativus plusquamperfecti, który wyraża uprzedniość w stosunku do momentu w przeszłości, drugą indicativus futuri exacti (secundi), który wyraża uprzedniość w stosunku do momentu w przyszłości:

(Pausaniam) procul ab eo loci infoderunt, quo erat mortuus. (Nep., Paus. 5)

"Pauzaniasza pochowali z dala od tego miejsca, w którym (wcześniej) umarł”.

Lacedaemonii [...] Agim regem, id quod numquam antea apud eos acciderat, necaverunt. (Cic., Off. 2, 80)

"Lacedemończycy zamordowali króla Agisa, co nigdy wcześniej u nich się nie zdarzalo".

Illi quod nemo fecerat fecerunt. (Cic., Phil. 2, 114)

"Ono dokonali tego, czego nikt (wcześniej) nie dokonal".

Ut sementem feceris, ita metes. (Cic., De orat. 2, 261)

„Jak (wcześniej) posiejesz, tak (później) zbierzesz".

Nondum habeo quantum sat est; si ad illam summam pervenero, tunc me totum philosophiae dabo. (Sen., Lucil. 17, 5)

„Jeszcze nie mam wystarczającej ilości pieniędzy; kiedy dojdę do tej kwoty, wtedy cały poświęcę się filozofii".

De qua (scil. Carthagine) vereri non ante desinam, quam illam excisam esse cognovero. (Cic., Sen. 18)

„Nie wcześniej przestanę obawiać się (Kartaginy), aż dowiem się, że została całkowicie zniszczona",

Cenabis bene, mi Fabulle, apud me [..] si tecum attuleris bonam atque magnam caenam. (Catull. 13, 1-4)

„Dobrze u mnie zjesz, mój Fabulusie, jeśli (wcześniej) przyniesiesz z sobą dużo dobrego jedzenia".

2. Czas względny wyrażają czasownikowe formacje nieosobowe participium i infinitivus. Wartości kategorii czasu, jakie formacje te mogą przyjmować, są zawsze wartościami czasu względnego według następujących zasad:

- praesens = równoczesność,

$\rightarrow$ perfectum = uprzedniość,

- futurum = następczość.

Video puerum in horto laborantem. - „Widzę chłopca pracującego w ogrodzie”.

Vidi puerum in horto laborantem. - "Zobaczyłem chłopca pracującego w ogrodzie".

Videbo puerum in horto laborantem. - "Zobaczę chłopca pracującego w ogrodzie”.

Video puerum in horto laboraturum. - „Widzę chłopca zamierzającego pracować w ogrodzie". 
Vidi puerum in horto laboraturum. - „Zobaczyłem chłopca zamierzającego pracować w ogrodzie".

Videbo puerum in horto laboraturum. - „Zobaczę chłopca zamierzającego pracować w ogrodzie".

Puer in horto laboraturus est / erat / erit. - „Chłopiec ma / mial / będzie miał zamiar pracować w ogrodzie."

Dux bello finito triumphum agit. - „Zakończywszy wojnę, wódz odbywa tryumf”.

Dux bello finito triumphum egit. - "Zakończywszy wojnę, wódz odbył tryumf”.

Dux bello finito triumphum aget. - „Zakończywszy wojnę, wódz odbędzie tryumf”.

Regnante Numa multa templa aedificantur. - „Gdy rządzi Numa, wznoszone są liczne świątynie".

Regnante Numa multa templa aedificabantur. - „Gdy rządzil Numa, były wznoszone liczne świątynie".

Regnante Numa multa templa aedificabuntur. - "Gdy będzie rządził Numa, zostaną wzniesione liczne świątynie".

Video te in horto laborare. - „Widzę, że pracujesz w ogrodzie”.

Vidi te in horto laborare. - „Widziałem, że pracujesz w ogrodzie”.

Videbo te in horto laborare. - "Zobaczę, że pracujesz w ogrodzie”.

Credunt te hoc fecisse. - „Wierzą, że to zrobiłes”.

Credebant te hoc fecisse. - „Wierzyli, że to zrobiłes".

Credent te hoc fecisse. - „Uwierza, ze to zrobiles".

Spero te ad me venturum esse. - „Spodziewam się, że przyjdziesz do mnie”.

Sperabam te ad me venturum esse. - „Spodziewałem się, że przyjdziesz do mnie”.

Sperabo te ad me venturum ess. - „Bedę się spodziewal, że przyjdziesz do mnie”.

3. Czas względny mogą wyrażać formacje coniunctivi użyte w zdaniach podrzędnych. Sposób sygnalizowania przez nie czasu względnego określa zasada znana jako consecutio temporum. Przyporządkowuje ona poszczególnym wartościom kategorii czasu koniunktiwów określony rodzaj względnej charakterystyki temporalnej w następujący sposób:

- wartość praesens sygnalizuje równoczesność lub następczość w stosunku do momentu w teraźniejszości lub przyszłości (czyli nieuprzedniość w stosunku do czasu nieprzeszłego);

- wartość imperfectum sygnalizuje równoczesność lub następczość w stosunku do momentu w przeszłości (czyli nieuprzedniość w stosunku do czasu przeszłego);

- wartość perfectum sygnalizuje uprzedniość w stosunku do momentu w teraźniejszości lub przyszłości (czyli uprzedniość w stosunku do czasu nieprzeszłego);

- wartość plusquamperfectum sygnalizuje uprzedniość w stosunku do momentu w przeszłości: 


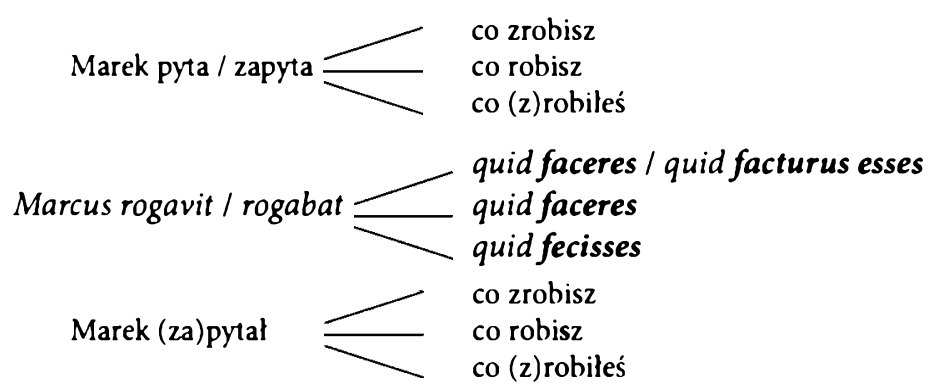

4. Czas względny równoczesny w stosunku do momentu w przeszłości wyrażać mogą formacje indikatiwu i infinitiwu praesentis. Ma to zwykle miejsce przy informowaniu o zdarzeniach zachodzących równocześnie lub bezpośrednio po zdarzeniu będącym punktem czasowego odniesienia. Wskazane formacje, wyrażające tego rodzaju czas względny, tradycyjnie określane są jako (odpowiednio) praesens historicum oraz infinitivus historicus (vel narrativus).

Equitatus ad campestres munitiones accedere et reliquae copiae pro castris sese ostendere coeperunt. Vercingetorix ex arce Alesiae suos conspicatus ex oppido egreditur; a castris longurios, musculos [...] reliquaeque quae eruptionis causa paraverat profert. Pugnatur uno tempore omnibus locis atque omnia temptantur; quae minime visa pars firma est, huc concurritur. Romanorum manus tantis munitionibus distinetur nec facile pluribus locis occurrit. (Caes., Gall. 7, 83-84)

„Konnica zaczęła podchodzić do umocnień na równinie, a pozostałe oddziały (poczęły) ukazywać się przed obozem. Wercyngetoryks, ujrzawszy z twierdzy alezyjskiej swoich, wychodzi z obozu; każe wynieść długie żerdzie, szopy oblężnicze i cały pozostały sprzęl, jaki wcześniej przygotował z myślą o dokonaniu wypadu. Walka toczy się jednocześnie we wszystkich miejscach i próbuje się wszystkiego; która część umocnień zdawała się (nieprzyjaciołom) najslabiej broniona, tam się zbiegaja. Wojsko rzymskie rozciągnięte jest na rozległych umocnieniach i niełatwo stawia (dostateczny) opór w wielu miejscach (równocześnie)".

Animadvertit Caesar unos ex omnibus Sequanos [...] tristes capite demisso terram intueri. Eius rei quae causa esset miratus ex ipsis quaesivit. Nihil Sequani respondere, sed in eadem tristitia taciti permanere. (Caes., Gall. 1, 32)

„Zauważył Cezar, że spośród wszystkich tylko Sekwanowie, opuściwszy głowy ze smutkiem, wpatrywali się w ziemię. Zdziwiony zapylal ich, jaka jest tego przyczyna. Sekwanowie nic nie odpowiedzieli, lecz milcząc, trwali ciągle w tym smutku".

$\mathrm{Na}$ opozycję: bezwzględne / względne użycie kategorii czasu nakłada się opozycja: aktualne / nieaktualne użycie kategorii czasu.

W przypadku aktualnego użycia kategorii czasu mamy do czynienia z (mniej lub bardziej precyzyjnym) odniesieniem do jakiegoś konkretnego momentu czy przeciągu czasu, w którym przebiegało, przebiega lub będzie przebiegało dane zdarzenie.

W przypadku niektualnego użycia kategorii czasu mamy do czynienia ze zdarzeniami czy stanami niezwiązanymi z żadnym konkretnym momentem czy odcinkiem czasu. Dotyczy to najczęściej dwojakiego rodzaju zdarzeń lub stanów: 
1. Zdarzeń powtarzających się, zachodzących cyklicznie; mówimy wtedy o czasie nieaktualnym habitualnym:

Idem esse dicebat Socrates veritatem et virtutem. (Sen., Lucil. 71, 16)

„Sokrates mawial, że prawda i cnota są jednym i tym samym”.

Ut [...] Romae consules, sic Karthagine quotannis annui bini reges creabantur. (Nep., Hann. 7)

„Jak bowiem w Rzymie konsulowie, tak w Kartaginie co roku wybierani byli dwaj królowie, sprawujący wladzę przez rok".

2. Zdarzeń lub stanów mających charakter wszechczasowy lub pozaczasowy; mówimy wtedy o czasie nieaktualnym omnitemporalnym (gnomicznym):

Homo est animal mortale rationale. (Quint., Inst. 7, 3, 15)

„Człowiek jest istotą śmiertelną i myślącą".

Bene qui latuit, bene vixit. (Ov., Trist. 3, 4, 25)

„Kto dobrze się ukrył przed światem, dobrze przeżyl zycie”.

Numquam erit felix, quem torquebit felicior. (Sen., Dial. 5, 30, 3)

„Nigdy nie zazna szczęścia ten, dla kogo przedmiotem udręki będzie ktoś szczęśliwszy”.

\subsection{ASPEKT}

W przeciwieństwie do czasu, kategorii gramatycznej sygnalizującej obiektywne relacje zachodzące między zdarzeniami, aspekt jest kategorią gramatyczną wyrażającą subiektywne różnice w sposobie ujmowania zdarzenia desygnowanego przez czasownik. Kategoria ta ma dwie wartości: aspekt niedokonany i aspekt dokonany.

Wartość aspekt niedokonany ukazuje zdarzenie w sposób kursywny, tj. jako będące $\mathrm{w}$ toku, jako przebiegające $\mathrm{w}$ jakimś odcinku czasowym wyznaczonym przez gramatyczną kategorię czasu, a więc przedstawia dane zdarzenia niejako od wewnątrz, w trakcie dziania się:

Scribebam epistulam. - „Pisalem list”.

Audiebam Ciceronem in foro perorantem. - „Słuchałem Cycerona przemawiającego na Forum".

Wartość aspekt dokonany ukazuje zdarzenie jako skończony, wewnętrznie niepodzielny fakt, dla którego przebieg w czasie jest nieistotny, a więc ujmuje zdarzenie niejako z zewnątrz i przedstawia je w sposób kompleksowy, zamknięty:

Epistulam scripsi. - „Napisałem list”.

Ciceronem audivi. - „Ustyszałem Cycerona”.

W języku łacińskim gramatyczna kategoria aspektu ograniczona jest wyłącznie do form czasu przeszłego. Opiera się ona na opozycji: ind. imperfecti (czas przeszły niedokonany) - ind. perfecti (czas przeszły dokonany). 
W zakresie czasu teraźniejszego istnieje tylko jedna formacja: ind. praesentis. Semantyczna funkcja tej wartoścji kategorii czasu (praesens) narzuca równocześnie tej formacji inherentnie niedokonany aspekt.

W zakresie czasu przyszłego również istnieje tylko jedna formacja: ind. futuri (primi), która jest niescharakteryzowana co do aspektu i dlatego odpowiada obu formacjom czasu przyszłego w języku polskim:

Epistulam scribam. - „Będę pisał list / Napiszę list”.

Spośród formacji wyrażających czasy względne, jedynie te $z$ nich, które wyrażają równoczesność, można związać $z$ określoną wartością kategoii aspektu, tj. z niedokonanością, ze względu na inherentną niedokonaność zdarzeń ukazywanych jako równoczesne $\mathrm{z}$ innymi:

Vidi puerum librum legentem. - „Zobaczyłem chłopca czytającego (= który czytał) książkę".

Vidi puerum librum legere - „Zobaczyłem, że chłopiec czyta książkę".

Formacje wyrażające inne wartości czasu względnego są w zasadzie niescharakteryzowane co do aspektu, przy czym wyrażanie czasu względnego uprzedniego w sposób naturalny bliższe jest aspektowi dokonanemu:

Idem fecerat me consule in sororis viro, quod hoc tempore in sororis filio fecit. (Cic., Phil. 8,1 )

„To samo uczynil/czynil za mojego konsulatu w sprawie męża siostry, co uczynil teraz w sprawie syna siostry".

Illi quod nemo fecerat fecerunt. (Cic., Phil. 2, 114)

„Uczynili oni to, czego nikt wcześniej nie uczyniz/czynir”.

Lacedaemonii [...] Agim regem, quod numquam antea apud eos acciderat, necaverunt. (Cic., Off. 2, 80)

„Lacedemończycy zamordowali króla Agisa, co nigdy wcześniej u nich się nie zdarzyło/ zdarzalo".

Ut sementem feceris, ita metes. (Cic., De orat. 2, 261)

„Jak posiejesz, tak zbierzesz. / Jak będziesz sial, tak będziesz zbieral”.

De (Carthagine) vereri non ante desinam, quam illam excisam esse cognovero. (Cic., Sen., 18).

„Nie wcześniej przestanę obawiać się Kartaginy, aż dowiem się / będę wiedzial, że została calkowicie zniszczona".

C. Caesar adversus Pharnacem [...] dimicaturus in colle instruxit aciem. (Frontinus, Strat. 2, 2, 3)

„Gajusz Cezar, zamierzając stoczyć / toczyć walkę z Farnakesem, ustawil na wzgórzu oddział w szyku bojowym".

Ceasar neque iam sibi legatos audiendos neque condiciones accipiendas arbitrabatur. (Caes., Gall. 4, 13)

„Cezar uważał, że przez niego nie powinni już być ani posłowie wysłuchani/wysłuchiwani, ani warunki przyjęte/przyjmowane". 
Nostri eruptione facta multis eorum interfectis, capto etiam nobili duce Lugotorige, suos incolumes reduxerunt. (Caes., Gall. 5, 22)

„Nasi, uczyniwszy wypad, po tym gdy wielu spośród wrogów zabili, a nawet pojmali (ich) pochodzącego ze znakomitego rodu wodza Lugotoryksa, bez uszczerbku wycofali się".

Omnium prope annales Fabium dictatorem adversus Hannibalem rem gessisse tradunt. (Liv. 22, 31)

„Kroniki niemal wszystkich autorów przekazują, że Fabiusz jako dyktator prowadzil/przeprowadzil wojnę przeciwko Hannibalowi".

Responsum a $Q$. Fabio praetore est Liguribus [...] nulli alii quam consulibus senatum crediturum esse. (Liv. 40, 34)

„Ligurom udzielona została przez pretora Kwintusa Fabiusza odpowiedź, że senat nie uwierzy/nie będzie wierzył nikomu innemu jak tylko konsulom".

Por. też:

Video puerum librum lecturum. - „Widzę chłopca zamierzającego czytać/przeczytać książkę".

Scio puerum librum lecturum esse. - „Wiem, że chłopiec będzie czytal/przeczyta książkę".

Scio puerum librum legisse. - „Wiem, że chłopiec przeczytał/czytal książkę”.

Marcus rogat quid facias (facturus sis). - „Marek pyta, co będziesz robil/zrobisz”.

Marcus rogavit quid faceres (facturus esses). - „Marek zapytal, co będziesz robil/ zrobisz".

Marcus rogat quid feceris. - „Marek pyta, co zrobileś/robiles”.

Marcus rogavit quid fecisses. - „Marek zapytal, co zrobileś/robiłeś”.

\subsection{STRONA (GENUS)}

Strona jest gramatyczną kategorią łacińskiego czasownika, która przybierać może dwie wartości: activum (strona czynna) i passivum (strona bierna). Wykładniki tych wartości mają charakter morfologiczny, przy czym morfologiczny status form fleksyjnych stojących w bezpośredniej opozycji w ramach tej kategorii nie jest jednakowy w obrębie całego paradygmatu formalnego czasownika. Wszystkie mianowicie osobowe (finitywne) formy fleksyjne wyrażające wartość activum stanowią syntetyczne wyrazy gramatyczne, w których wykładnikami wartości kategorii strony są końcówki fleksyjne (osobowe); mają one charakter skumulowany i oprócz wartości kategorii strony sygnalizują również określone wartości kategorii osoby i liczby, a więc np.: laudo, laudabo, laudabam, laudarem (act. 1. os. sg.). Natomiast spośród osobowych form nacechowanych wartością passivum, część również wyraża się poprzez syntetyczne wyrazy gramatyczne $\mathrm{z}$ końcówkowymi wykładnikami kategorii strony (osoby i liczby), np.: laudor, laudabor, laudabar, lauder, laudarer (pass. 1. os. sg.), natomiast inna część reprezentowana jest poprzez analityczne wyrazy gramatyczne, w których 
wykładnikiem wartości kategorii strony jest temat imiesłowowego członu konstytutywnego tych formacji, a więc temat participium (perfecti) passivi, np.: laudatus sum, laudatus ero, laudatus eram, laudatus sim, laudatus essem itp. (wykładnikiem kategori osoby jest końcówka czasownika posiłkowego, a kategorii liczby końcówka czasownika posiłkowego i końcówka imiesłowu). Syntetyczność bądź analityczność poszczególnych form fleksyjnych zależy od wyrażanych przez nie wartości kategorii czasu (i trybu). Mimo tych różnic morfologiczny (fleksyjny) charakter tej kategorii nie budzi wątpliwości, gdyż w ramach paradygmatu fleksyjnego czasownika formy analityczne konsekwentnie wypełniają miejsca otwierane przez sieć regularnych opozycji funkcjonalnych; por. np.:

laudo 'chwalę' - laudor 'jestem chwalony'

laudabo 'pochwalę' - laudabor 'zostanę pochwalony'

laudavi 'pochwaliłem' - laudatus sum 'zostałem pochwalony'.

Dla większości czasowników kategoria strony ma charakter fleksyjny. Istnieją jednak takie klasy leksemów czasownikowych, które kategorię tę uwzględniają w sposób selektywny. $Z$ jednej strony są to nieprzechodnie activa tantum, jak np.: florere 'kwitnąc', nare 'pływać', esse 'być', $\mathrm{z}$ drugiej passiva tantum znane jako tzw. verba deponentia, jak np.: vereri 'bać się, pati 'cierpieć, mentiri 'kłamać'. Specyficzną klasą czasowników są tzw. verba semideponentia, które w zależności od współwyrażanej wartości kategorii czasu przybierają albo wyłącznie wykładniki strony czynnej, albo wylącznie strony biernej, tzn. formacje praesentis, imperfecti i futuri primi stanowią activa tantum, natomiast formy perfecti, plusquamprfecti i futuri exacti (secundi) to passiva tantum (odwrotną dystrybucję wykładników kategorii strony wykazuje w zasadzie tylko paradygmat czasownika reverto, -ere, reverti 'powracać'). Wspólną cechą wszystkich tych tych klas leksemów jest to, że reprezentujące je formy fleksyjne nie tworzą bezpośrednich opozycji morfologicznych w zakresie kategorii strony.

Prymarna funkcja kategorii strony ma charakter wewnątrztekstowy (nienominatywny) i polega na sygnalizowaniu różnic diatezy.

Diateza związana jest ze znaczeniem czasownika, a więc $z$ wyrażaną przez czasownik treścią, która $w$ ramach wypowiedzenia przypisywana jest określonemu obiektowi bądź obiektom. Treść ta nazywana jest znaczeniem predykatywnym, sensem predykatywnym albo po prostu predykatem, a czasownik będący wykładnikiem danego sensu predykatywnego (predykatu) określany jest terminem wyrażenie predykatywne. Charakterystyczną właściwością predykatu jest to, że implikuje on określone obiekty warunkujące jego aktualizację. Obiekty te nazywane są argumentami predykatu, a językowe wykładniki tych argumentów nazywane są wyrażeniami argumentowymi. Liczba implikowanych argumentów zależy od specyfiki danego predykatu, tj. jego wewnętrznej (immanentnej) struktury. Np. predykaty reprezentowane przez czasowniki dormire 'spać' czy florere 'kwitnąć" implikują tylko jeden argument, tj. argument nosiciela danej cechy, czyli kto/co 'śpi', 'kwitnie'. Z kolei predykaty reprezentowane np. przez czasowniki laudare 'chwalić' czy ducere 'prowadzić' implikują 
dwa argumenty, tj. kto/co 'chwali,' 'prowadzi' oraz kogo/co 'chwali', 'prowadzi'. Kryterium określania liczby implikowanych przez dany predykat argumentów stanowi informacyjna autonomiczność (kompletność) struktury złożonej z wykładników predykatu i argumentów, autonomiczność polegająca na tym, że przekaz informacji dokonywany przez tę strukturę nie wymaga kooperacji kontekstu językowego lub sytuacyjnego. Por. np. kompletność wyrażeń:

Marcus dormit. - „Marek śpi”.

Flos floret. - „Kwiat kwitnie”.

Marcus laudat amicum. - „Marek chwali przyjaciela”.

Consul ducit exercitum. - „Konsul prowadzi wojsko”.

wobec niekompletności wyrażeń wymagających kooperacji kontekstu:

"Marcus laudat. - „Marek chwali".

"Consul ducit. - „Konsul prowadzi”.

Możemy w związku z tym mówić o predykatach jedno-, dwu-, trójargumentowych oraz o czasownikach będących wykładnikami predykatów jedno-, dwu-, trójargumentowych. Np. czasowniki: dare 'dawać' czy privare 'pozbawiać' stanowią reprezentacje predykatów trójargumentowych: kto, co, komu 'daje’; kto, kogo, czego 'pozbawia'.

Argumenty predykatów ponadjednoargumentowych cechują się pewną naturalną hierarchizacją. Najwyższą pozycję w hierarchii argumentów danego predykatu zajmuje argument będący głównym nosicielem sensu predykatywnego. W przytoczonych wyżej przykładach argumenty te desygnowane są przez wyrażenia argumentowe: Marcus, Flos, Consul. Argument zajmujący najwyższą pozycję w hierarchi argumentów danego predykatu zwany jest pierwszym argumentem. Argumenty zajmujące $w$ naturalnej hierarchizacji argumentów predykatu niższe pozycje określane są odpowiednio jako argument drugi, argument trzeci.

Semantyczne właściwości predykatów znajdują swe odbicie w właściwościach syntaktycznych reprezentujących je wyrażeń predykatywnych (czasowników). Wyrażenia te wykazują mianowicie predyspozycje do wchodzenia $w$ różnego rodzaju związki składniowe $\mathbf{z}$ wyrażeniami argumentowymi reprezentującymi poszczególne argumenty. Inaczej mówiąc, czasownikowe wyrażenie predykatywne otwiera w strukturze zdaniowej miejsca dla składników imiennych (uzupełnień), stanowiących wykładniki argumentów predykatu reprezentowanego przez to wyrażenie predykatywne. Diateza to właśnie sposób składniowego wyrażania (składniowego uporządkowania wykładników) argumentów przy czasownikowym wyrażeniu predykatywnym.

W ramach prymarnej dystrybucji składniowej czasownik pełni funkcję orzeczenia, czyli członu konstytutywnego wyrażenia zdaniowego. Stanowiąc konstytutywny człon wyrażenia zdaniowego czasownik wchodzi przede wszystkim w związek kongruencji predykatywnej z podmiotem. W ramach tego związku podmiot determinuje wartość kategorii osoby i liczby orzeczenia. Ponieważ podmiot jest jedynym 
składnikiem imiennym (członem syntaktycznym) determinującym postać członu konstytutywnego zdania (orzeczenia), jest on składnikiem imiennym syntaktycznie wyróżnionym. Wszystkie inne składniki imienne, konotowane przez orzeczenie, są składnikami wyłącznie determinowanymi na zasadzie związku rekcji, stanowiąc w zdaniu dopełnienia. Zdanie, $w$ którym pierwszy argument predykatu reprezentowanego przez czasownikowe orzeczenie ujawniany jest przez składnik imienny syntaktycznie wyróżniony, czyli przez mianownikowy podmiot, charakteryzuje się diatezą, którą nazywamy diatezą nienacechowaną. Sygnalizowanie diatezy nienacechowanej stanowi prymarną funkcję wartości activum kategorii strony, jak np. w zdaniach:

Marcus laudat amicum. - „Marek chwali przyjaciela”.

Consul ducit exercitum. - „Konsul prowadzi wojsko”.

A więc diateza nienacechowana to taka, w której syntaktyczne uporządkowanie składników imiennych konotowanych przez czasownik odpowiada naturalnej hierarchizacji argumentów predykatu reprezentowanego przez ten czasownik (pierwszy argument $=$ podmiot ).

$\mathrm{Z}$ kolei zdanie, $w$ którym pierwszy argument predykatu ujawniany jest przez inny, niepodmiotowy czlon syntaktyczny, lub nie jest ujawniany wcale, charakteryzuje się diatezą, którą nazywamy diatezą nacechowaną. Sygnalizowanie diatezy nacechowanej stanowi prymarną funkcję wartości passivum kategorii strony, jak np. w zdaniach:

Amicus laudatur (a Marco). - „Przyjaciel jest chwalony (przez Marka)”.

Exercitus ducitur (a consule). - „Wojsko jest prowadzone (przez konsula)”.

A więc diateza nacechowana to taka, w której syntaktyczne uporządkowanie składników imiennych nie odpowiada naturalnej hierarchizacji argumentów predykatu reprezentowanego przez czasownik, tzn. pierwszy argument ujawniany jest przez człon syntaktyczny zależny składniowo (akomodowany). Diatezę nacechowaną, którą ilustrują podane wyżej przykłady, nazywamy diatezą nacechowaną bierną. Charakteryzuje się ona tym, że przez mianownikowy podmiot ujawniany jest drugi argument predykatu reprezentowanego przez czasownik, natomiast wykładnikiem pierwszego argumentu - jeśli zostaje on ujawniony - jest akomodowany (zależny składniowo) składnik imienny $\underline{\mathrm{w}}$ ablatiwie (tzw. ablativus agentis vel rei efficientis), mający status okolicznika (sprawcy), który zwykle współtworzony jest przez przyimek (morfem swobodny) $a b$, jeżeli jego desygnatem jest obiekt ożywiony bądź personalizowany:

Populus [...] inopia urgebatur. (Sall., Iug. 41)

„Lud był nękany przez niedostatek”.

Sophocles [...] a filiis in iudicium vocatus est. (Cic., Sen. 22)

„Sofokles przez synów zostal pozwany do sądu". 
Qui appetitus $[\ldots]$ non satis a ratione retinentur, ii sine dubio finem et modum transeunt. (Cic., Off. 1, 102)

„Popędy, które nie są wystarczająco trzymane w ryzach przez rozum, niewątpliwie przekraczają granice i właściwą miarę".

W przypadku, gdy głównym wykładnikiem predykatu jest imiesłowowa forma participium futuri passivi (gerundivum), współkonstytuująca wyrażenie predykatywne wraz z osobową formą czasownika esse, a więc w przypadku struktury zdaniowej zwanej coniugatio periphrastica passiva, desygnujący pierwszy argument predykatu okolicznik (sprawcy) stanowiony jest przez składnik imienny wyrażony w datiwie; wyjątkowo okolicznik sprawcy wyrażony przez składnik imienny $w$ datiwie pojawia się również przy czasowniku w formie osobowej jako podstawowym wykładniku treści predykatywnej:

Caesari omnia uno tempore erant agenda. (Caes., Gall. 2, 20)

"Cezar musial wszystkie rzeczy robić w jednym czasie".

Infert se $[. .$.$] per medios miscetque viris neque cernitur ulli. (Verg., Aen. 1, 439-440)$

"Wkracza pomiędzy ludzi mieszając się z nimi, a przez nikogo nie zostaje zauważony”.

Diatezę nacechowaną bierną sygnalizować mogą oczywiście wyłącznie tzw. czasowniki przechodnie, czyli takie, które dopuszczają możliwość ujawnienia przez podmiot zdania drugiego argumentu reprezentowanego przez siebie predykatu. Czasowniki mogące sygnalizować tę diatezę reprezentować zatem muszą predykaty co najmniej dwuargumentowe, przy czym nie wszystkie czasowniki reprezentujące predykaty dwuargumentowe są przechodnie, tzn. nie wszystkie dopuszczają możliwość ujawnienia przez podmiot drugiego argumentu; np. czasownik servire 'służyć' reprezentuje predykat dwuargumentowy (kto komu 'służy'), jednak nie dopuszcza możliwości ujawnienia przez podmiot drugiego argumentu (nie dopuszcza transformacji biernej zdania).

Rodzaj diatezy zdaniowej sygnalizowanej przez łacińskie czasowniki zależy jednak nie tylko od samej wartości kategorii strony (activum/passivum). Funkcje tych wartości mogą być bowiem modyfikowane przez dodatkowe czynniki formalne. Jednym $z$ takich czynników jest ograniczenie pod względem kategorii strony paradygmatu funkcjonalnego czasownika, tzn. takie jego ukształtowanie, iż formy fleksyjne reprezentujące dany czasownik nie wchodzą z sobą $\mathrm{w}$ bezpośrednią opozycję pod względem kategorii strony. Tego rodzaju paradygmatem cechują się nie tylko czasowniki nieprzechodnie, czyli activa tantum, ale także tzw. verba deponentia, czyli passiva tantum, oraz tzw. verba semideponentia, które w zależności od współwyrażanej wartości kategorii czasu przybierają wykładniki albo wyłącznie strony czynnej, albo wyłącznie strony biernej, i tym samym reprezentujące je formy fleksyjne - podobnie jak formy reprezentujące deponentia - nie tworzą par stojących względem siebie w bezpośredniej opozycji fleksyjnej co do kategorii strony. Takie ograniczenie paradygmatu funkcjonalnego staje się indeksem obligatoryjności sygnalizowania diatezy nienacechowanej przez czasownik: 
His confectis rebus (Caesar) citeriorem Galliam revertitur atque inde ad exercitum proficiscitur. (Caes., Gall. 5, 2)

„Po przeprowadzeniu tych spraw (Cezar) powraca do Galii Bliższej, a stamtąd udaje się do wojska".

Hoc verbo quoque Romani utebantur, sicut philosophia nunc quoque utuntur. (Sen., Lucil. 89, 7)

„Tego wyrazu używali także Rzymianie, tak jak do dziś używają słowa 'filozofia”'.

Caesar [...] milites cohortatus est, ut beneficio fortunae uterentur castraque oppugnarent. (Caes., Civ. 3, 95)

„Cezar zachęcil żolnierzy, by wykorzystali przychylność losu i podjęli szturm na obóz".

Gaudeo, si tibi quid feci aut facio, quod placeat. (Ter., Andr. 40-41)

"Cieszę się, jeśli ci uczynilem albo czynię coś, co sprawia ci przyjemność".

Vah, frustra sum igitur gavisus miser. (Ter., Heaut. 857)

"Ojej, daremnie się więc, nieszczęsny, ucieszyłem".

Neque tu hoc dicere audebis. (Cic., Verr. 2, 2, 167)

„I nie odważysz się tego powiedzieć".

Tu apud patres conscriptos contra me dicere dicere ausus es. (Cic., Phil. 2, 51)

„Wobec senatorów odważyleś się przemawiać przeciwko mnie”.

Oprócz diatezy nacechowanej biernej istnieje jeszcze inna, specyficzna odmiana diatezy nacechowanej, której odmienność w stosunku do diatezy biernej polega na tym, że żaden $\mathrm{z}$ argumentów predykatu reprezentowanego przez czasownik nie jest (i nie może być) ujawniany przez mianownikowy podmiot. Diatezę tę nazwać można diatezą nacechowaną niepodmiotową, a jej formalnym wyróżnikiem jest obligatoryjność określonych wartości kategorii osoby i liczby (oraz rodzaju) czasownikowego wykładnika predykatu, a mianowicie 3. os. sg. (neutr.); ten typ diatezy cechuje np. zdania:

Iam advesperascit. (Ter., Andr. 5581)

"Już się zmierzcha".

Interdum ninguit. (Colum., Rust. 11, 2, 31)

„Od czasu do czasu śnieży (= pada śnieg)".

[...] si scias, quam me pudeat nequitiae tuae, cuius te ipsum non pudet. (Cic., Phil. 2, 76) „[...] gdybyś wiedzial, jak bardzo wstyd mi za twoją niegodziwość, której ty sam się nie wstydzisz".

Eos, qui secus, quam decuit, vixerunt, peccatorum suorum [...] maxume paenitet. (Cic., Div. 1, 64)

„Ci, którzy żyli inaczej niż przystało, najbardziej żalują swoich grzechów”.

Diatezę nacechowaną niepodmiotową sygnalizować mogą czasowniki także przy użyciu biernych wykładników kategorii strony; por. np.: 
Ad arma concurritur. (Caes., Gall. 7, 4)

„Biegnie się do broni”.

Regio $[. .$.$] abscessum est. (Liv., 24, 1)$

"Odstąpiono od (miasta) Regium".

Sic itur ad astra. (Verg., Aen. 9, 641)

"Tak idzie się do gwiazd".

Non igni, non ferro abstinetur. (Sen., Benef. 7, 27, 1)

"Nie stroni się ani od ognia, ani od miecza”.

Immo vero istic nec viventibus quidem ullis parcitur. (Apul., Met. 2, 20)

„Co więcej, tutaj nawet żywych się nie szczędzi".

Etiam tum legato a centurionibus parebatur. (Tac., Ann., 1, 21)

„Jeszcze wtedy legatowi byli posluszni setnicy”.

W przeciwieństwie do zdań o diatezie nacechowanej biernej w żadnym z podanych powyżej zdań orzeczenie nie otwiera miejsca dla mianownikowego podmiotu. Tym samym w zdaniach tych żaden argument predykatu, reprezentowanego przez czasownikowe orzeczenie, nie jest ujawniany przez wyrazienie argumentowe o postaci mianownikowego podmiotu: wszystkie ujawniane argumenty reprezentowane są przez wyrażenia argumentowe stanowiące wyłącznie zależne składniowo od orzeczenia (akomodowane) człony syntaktyczne. Warto przy tym zauważyć, że sygnalizowanie diatezy niepodmiotowej nie jest systemowo związane $\mathrm{z}$ jedną tylko wartością kategorii strony. Takie bowiem uporządkowanie syntaktyczne składników imiennych, w którym żaden $z$ argumentów predykatu nie jest ujawniany przez mianownikowy podmiot, implikowane może być przez (reprezentujące ten predykat) czasownikowe orzeczenie zarówno w activum jak i w passivum. Nie znaczy to jednak, że dany czasownik sygnalizować może diatezę niepodmiotową występując (dowolnie) zarówno w activum jak i w passivum. W odniesieniu do poszczególnych czasowników sygnalizowanie tej diatezy ograniczone jest bowiem na ogół wyłącznie do jednej z wartości kategorii strony. Np. występujące w podanych wyżej zdaniach czasowniki: currere, abscedere, ire itd. mogą sygnalizować diatezę niepodmiotową zdania wyłącznie $\mathrm{w}$ passivum, podobnie jak czasownik advesperascere wyłącznie w activum. Jedynie większość tzw. verba affectuum implikować może diatezę niepodmiotową występując zarówno w activum jak i passivum. A zatem to, czy diateza niepodmiotowa sygnalizowana jest przez czasownikowe wyrażenie predykatywne $\mathrm{w}$ activum czy w passivum, nie jest zdeterminowane gramatycznie, lecz leksykalnie, tzn. uzależnione jest od indywidualnych cech czasownika konstytuującego to wyrażenie.

Należy jednak dodać, że tylko niewielka liczba czasowników łacińskich, jak np. advesperascere, sygnalizować może wyłącznie diatezę niepodmiotową. Większość z nich, oprócz diatezy niepodmiotowej, sygnalizować może także diatezę nienacechowaną, a część (tzn. czasowniki przechodnie) również nacechowaną bierną. Por. np.:

Non te haec pudent? (Ter., Adelph. 754)

„Nie wstydzisz się tych rzeczy?" 
Haec condicio me non paenitet. (Pl., Stich., 51)

„Obecny stan nie wzbudza mego żalu (nie smuci mnie)".

Nostri celeriter ad arma concurrunt. (Caes., Gall. 5, 39)

„Nasi (żołnierze) prędko biegną do broni”.

Nec ab armis aut loco suo miles abscedebat. (Liv., 24, 37)

"I nie odstępowal żołnierz od broni ani od wyznaczonego mu miejsca".

Meus sodalis it cum praeda Apoecides. (Pl., Epid. 394)

„Idzie mój druh ze zdobyczą, Apecydes”.

Labienus [...] nostros exspectabat proelioque abstinebat. (Caes., Gall. 1, 22)

"Labienus wyczekiwał naszych (żołnierzy) i powstrzymywal się od walki”.

Quo quidem die nihil aegrius factum est multo labore meo, quam ut manus ab illo appellatore abstinerentur. (Cic., Verr. 2, 4, 146)

„Tego dnia nic nie przyszło z większym trudem, przy wielkim moim wysitku, jak (to,) aby ręce (rozgniewanych ludzi) utrzymane zostaly z dala od tego, który się odwołar".

Iam [...] nec amicis quidem nostris vel omnino ullis hospitibus parcitis. (Apul., Met. 1, 25) „Już nawet naszych przyjaciół nie oszczędzacie, ani w ogóle żadnych gości”.

Aspis [...] non solum imperio regis non parebat, sed etiam finitimas regiones vexabat. (Nep., Dat. 4)

„Aspis nie tylko nie byl posluszny wladzy królewskiej, lecz jeszcze niepokoil sąsiednie regiony".

A zatem dla większości czasowników sygnalizowanie diatezy nacechowanej niepodmiotowej to tylko realizacja jednego $z$ dwóch lub trzech możliwych sposobów składniowego ujawniania argumentów implikowanych przez reprezentowany przez nie predykat. $Z$ diatezą tą związane jest jednak określone nacechowanie formalne czasownika, na które składają się dwa elementy. Jednym $\mathrm{z}$ nich jest określona wartość kategorii strony. Wartość ta nie jest zdeterminowana systemowo, lecz - jak stwierdziliśmy wyżej - stanowi indywidualną cechę poszczególnych leksemów czasownikowych, ponieważ jedne $\mathrm{z}$ nich sygnalizują diatezę niepodmiotową $\mathrm{w}$ formie activum, inne $\mathrm{w}$ formie passivum. Dodajmy, że dla części czasowników, tj. nieprzechodnich (a więc np. dla ire), wartość passivum służy sygnalizowaniu wyłącznie tej diatezy, pozwalając na nieujawnianie (ukrycie) pierwszego argumentu reprezentowanego przez nie predykatu. Drugim wyróżnikiem formalnym diatezy niepodmiotowej jest określona wartość kategorii osoby i liczby (oraz rodzaju) czasownika, a mianowicie 3. sg. (neutr.). Formalnym wykładnikiem tej diatezy jest więc nie tylko kategoria strony, lecz również kategoria osoby i liczby. Możemy więc mówić w tym przypadku o złożonym wykładniku diatezy, w ramach którego określona (determinowana leksykalnie) wartość kategorii strony sprzężona jest $\mathrm{z}$ określonymi (determinowanymi systemowo) wartościami kategorii osoby i liczby.

Tradycyjnie w odniesieniu do języka łacińskiego (choć oczywiście nie tylko w stosunku do niego) wyodrębnia się jeszcze jest tzw. diatezę zwrotną, czyli medium. 
Diateza ta sygnalizowana jest tylko przez czasowniki przechodnie, a więc reprezentujące predykaty co najmniej dwuargumentowe, a jej specyfika polega na tożsamości pierwszego i drugiego argumentu predykatu desygnowanego przez wyrażenie predykatywne. W zdaniach cechujących się tą diatezą czasownikowy wykładnik predykatu występuje $\mathrm{w}$ activum, pierwszy argument predykatu ujawniany jest przez mianownikowy podmiot zdania, zaś drugi argument przez akomodowany człon imienny $\mathrm{w}$ akuzatiwie, stanowiony przez zaimek zwrotny ( $s e$ ) lub funkcjonalnie zwrotny (osobowy: me, te, nos, vos), koreferentny z podmiotem. Ze względu na fakt reprezentowania pierwszego argumentu predykatu przez mianownikowy podmiot syntaktyczne uporządkowanie wyrażeń argumentowych w tej diatezie odpowiada diatezie nienacechowanej. Można więc uznać diatezę zwrotną za szczególną odmianę diatezy nienacechowanej, której wyróżnikiem jest wypełnienie pozycji otwieranej dla wykładnika drugiego argumentu predykatu przez zaimek (funkcjonalnie) zwrotny, koreferentny $z$ mianownikowym (podmiotowym) wykładnikiem pierwszego argumentu. Formalną konsekwencją sposobu ujawniania argumentów predykatu w ramach tej diatezy jest także intranzytywizacja, czyli zablokowanie możliwości transformacji biernej zdania. Diatezę tę ilustrują zdania:

An qui se interficit homicida sit? (Quint., Inst. 7, 3, 7)

"Czy ten, kto się zabija, jest mordercą?"

Classiarii cum [...] hortarentur, ut domos suas discederent moenibusque se defenderent, Themistocles unus restitit. (Nep., Them. 4)

„Gdy żołnierze na okrętach zachęcali, by rozejść się do swoich domów i bronić się zza murów, Temistokles jako jedyny sprzeciwil się temu".

Apud maiores tanta religionis vis fuit, ut quidam imperatores etiam se ipsos dis immortalibus $[. .$.$] pro re publica devoverent. (Cic., Nat. 2,10)$

„Wśród przodków tak wielka była siła religii, że niektórzy wodzowie nawet siebie samych ofiarowywali bogom nieśmiertelnym dla obrony państwa".

Absconde te in otio, sed et ipsum otium absconde. (Sen., Lucil. 68, 1)

„Ukryj się w odosobnieniu, lecz równocześnie ukryj i samo to odosobnienie”.

Bardzo rzadko diatezę zwrotną sygnalizują również (przechodnie) verba deponentia. Wówczas diateza ta związana jest, oczywiście, z pasywnymi wykładnikami kategorii strony oraz zaimkiem (funkcjonalnie) zwrotnym jako wykładnikiem drugiego argumentu predykatu:

His ego tuis scriptis me consolor. (Cic., Att. 9, 10, 10)

„Tymi twoimi listami ja się pocieszam”.

Od czasowników sygnalizujących diatezę zwrotną należy odróżnić czasowniki, przy których identyczne nacechowanie formalne, tj. końcówki aktywne + zaimek zwrotny, stanowi wykładnik dekauzatywizacji. Czasownikiem takim jest np. aperire 'otwierać, który w połączeniu z zaimkiem zwrotnym se przyjmuje znaczenie 'otwierać się, jak np. w zdaniu: 
In Herculis fano [...] valvae clausae subito se aperuerunt. (Cic., Div. 2, 67)

„W świątyni Herkulesa [...] zamknięte drzwi nagle otworzyly się".

Diateza implikowana przez se aperire nie jest zwrotnym wariantem diatezy sygnalizowanej przez aperire, ponieważ zaimek zwrotny se przy czasowniku aperire nie stanowi wykładnika żadnego argumentu predykatu, reprezentowanego przez ten czasownik Stanowi natomiast słowotwórczy formant derywujący od czasownika aperire formację pochodną, reprezentującą inny predykat, który różni się od predykatu reprezentowanego przez czasownik aperire liczbą implikowanych argumentów, tzn. aperire 'otwierac' reprezentuje predykat dwuargumentowy, natomiast pochodna formacja se aperire 'otwierać się' predykat jednoargumentowy. Diateza sygnalizowana przez formację se aperire jest zatem diatezą nienacechowaną czynną: pierwszy (i jedyny) argument reprezentowanego przez tę formację predykatu ujawniany jest przez mianownikowy podmiot. Dla formacji tej, którą trzeba traktować jako odrębną w stosunku do aperire jednostkę leksykalną, kategoria strony ma charakter selektywny: se aperire to activum tantum. A zatem obligatoryjność końcówek activi czasownika $\mathrm{w}$ połączeniu $\mathrm{z}$ zaimkiem se stanowić może zarówno wykładnik zwrotnego wariantu diatetycznego czasownika, jak i wykładnik formantu słowotwórczego, derywującego dekauzatywne formacje pochodne.

Formantem derywującym dekauzatywne formacje pochodne mogą być też pasywne wykładniki strony w połączeniu z nieotwieraniem (blokadą) miejsca dla niepodmiotowego wykładnika (wyrażenia) argumentowego; por. np.:

Sed aperiuntur aedes, quo ibam. (Pl., Trin. 400)

"Lecz oto otwierają się drzwi domu, do którego szedłem”.

Por. też np.:

Italici omnibus se manipulis miscuerant. (Tac., Hist. 3, 22)

„Żołnierze legionu italskiego zmieszali się ze wszystkimi oddziałami”.

Convenit ne unis castris miscerentur omnes. (Liv., 10)

„Uzgodniono, aby nic mieszali się wszyscy w jednym obozie".

Philippum Nicander haud dissimili oratione incitabat: [...] neque ut ante se moveat Philippus quam Antiochus cum exercitu transierit in Graeciam suadere. (Liv., 35, 12)

„Filipa podburzal Nikander podobnymi słowami, (mówiąc, że) wcale nie doradza, by Filip ruszal się (= wszczynal wojnę), zanim Antioch z wojskiem przejdzie do Grecji".

Ita. eo anno evenit, ut quotienscumque dictator ab exercitu recessisset, hostes in Samnio moverentur. (Liv., 8, 35)

„Tak się tego roku zdarzyło, że ilekroć dyktator oddalił się od wojska, ruszali się (= wszczynali bunt) nieprzyjaciele w Samnium".

Nepos erat oratoris Hortensii, inlectus a divo Augusto [...] ducere uxorem, suscipere liberos, ne clarissima familia extingueretur. (Tac., Ann. 2, 37)

„Byl wnukiem mówcy Hortensjusza, zachęconym przez boskiego Augusta do ożenku i spłodzenia dzieci, aby stynny ród nie wygasł". 
Dekauzatywizacja, dokonana z zastosowaniem tak jednego, jak i drugiego formantu, implikuje równocześnie intranzytywizację obu formacji pochodnych.

Należy dodać, że w języku łacińskim brak jest niemotywowanych (niepochodnych) czasowników zwrotnych określanych jako reflexiva tantum, w których zaimek se (lub jego funkcjonalny odpowiednik) byłby nieodłącznym, funkcjonalnie pustym składnikiem leksemu czasownikowego, jak np. morfem się w pol.: bać się, podobać się, mścić się itp. Wszystkie łacińskie tzw. czasowniki zwrotne, tj. czasowniki używane w połączeniu z zaimkiem zwrotnym, mają swój niezwrotny odpowiednik (są pochodne od swych niezwrotnych podstaw derywacyjnych). Nie jest również możliwe użycie czasowników zwrotnych (czasowników w połączeniu z zaimkiem zwrotnym) w konstrukcjach niepodmiotowych, tzn. takich jak np.: pol. Dobrze mu się pracuje, We wsi buduje się nowq szkołę itp., ani w konstrukcjach podmiotowych z diatezą bierną, takich jak np. pol. We wsi buduje się nowa szkoła.

W żaden sposób kategoria strony osobowej formy czasownika nie determinuje diatezy zdaniowej w przypadku, gdy czasownik ten nie stanowi podstawowego wykładnika treści predykatywnej. Dotyczy to głównie czasowników, które w ramach orzeczeń złożonych, współtworzonych $z$ innymi (nieosobowymi) formami czasownikowymi, są wykładnikami nacechowanej modalności, a także tzw. czasowników fazowych, habitualnych oraz czasownika esse współtworzącego wraz z participium futuri orzeczenie określane terminem coniugatio periphrastica. W takich przypadkach determinantem diatezy zdaniowej jest wartość kategorii strony czasownika $\mathrm{w}$ formie nieosobowej (tj. infinitiwu lub participium), będącego wykładnikiem podstawowej treści predykatywnej; por. np.:

Videbor $[\ldots]$ honorem homini amicissimo denegavisse. (Cic., Phil. 11, 19)

„Będzie się zdawało, $\underline{\text { ze }}$ wielkiemu przyjacielowi odmówiłem przyznania zaszczytnego urzędu".

Dicatur sane eiectus esse a me, dum modo eat in exsilium. (Cic., Catil. 2, 15)

"Niech się mówi, że zostal przeze mnie wypędzony, byleby tylko poszedł na wygnanie".

Quid faciat custos, cum [...] illa [...], quo [...] sui comites vetantur ire, eat? (Ov., Ars 3, 633-636)

„Cóż może zrobić strażnik, gdy ona chodzi tam, dokąd nie wolno wejść towarzyszą̧cym jej mężczyznom?"

Consules creari iussi sunt. (Liv., 4, 12)

„Nakazano, by zostali wybrani konsulowie”.

Armis Italia non potest vinci. (Rhet. Her., 4, 43)

"Zbrojnie Italia nie może zostać zwyciężona”.

Pacem etiam qui vincere possunt volunt. (Liv., 7, 40)

„Pokoju chcą również ci, którzy mogą zwyciężyć".

Ab duobus consulibus Casilinum oppugnari coepit. (Liv., 24, 19)

„Kasylinum zaczęlo być oblegane przez dwóch konsulów”. 
Crassus [...] oppidum Sotiatium oppugnare coepit. (Caes., Gall. 3, 21)

„Krassus zacząl oblegać miasto Socjalów”.

Ordo in sententiis rogandis servari solet. (Cic., Phil. 5, 35)

"Zwykle zachowywany jest porządek przy pytaniu (senatorów) o zdanie".

Nonne his vestigiis ad caput meficii perveniri solet? (Cic., S. Rosc. 74)

„Czyż nie takimi tropami zwykle dochodzi się do źródla przestępstwa?"

Paupertas tolerabilis est, si ignominia abest, quae vel sola opprimere animos solet. (Sen., Dial. 12, 13, 2)

„Ubóstwo jest do zniesienia, jeśli nie towarzyszy mu utrata dobrego imienia, która już sama zwykle przygnębia umyst".

Voluntas ipsa rectum petens laudanda est. (Sen., Benef. 5, 2, 2)

"Sama chęć zmierzająca ku dobru powinna być chwalona”.

Iam steterant acies ferro mortique parati, iam lituus pugnae signa daturus erat. (Ov., Fast. 3, 215-216)

„Już stały oddziały gotowe na śmiertelny bój, już trąbka miala dać sygnał do walki”.

Gdy orzeczenie współtworzy osobowa forma czasownika o funkcji modalnej, a wykładnikiem podstawowej treści predykatywnej jest forma rzeczownikowa lub przymiotnikowa, sygnalizowana diateza zawsze ma charakter nienacechowany czynny, nawet jeśli forma czasownikowa występuje w passivum:

Tibi nos peregrini videmur. (Cic., Sull. 24)

"Tobie my wydajemy się cudzoziemcami".

Pigrum quin immo iners videtur sudore adquirere, quod possis sanguine parare. (Tac., Germ. 14)

„Czymś gnuśnym a nawet tchórzliwym wydaje się pozyskiwanie w pocie czoła tego, co można zdobyć przelewem krwi".

Athenienses maxime in eam rem idonei visi sunt. (Liv., 35, 32)

"Ateńczycy wydali się najbardziej odpowiedni do tej rzeczy".

Id agunt, ut philosophia potius difficilis, quam magna videatur. (Sen., Lucil. 71, 6) „Spawiają, że filozofia wydaje się raczej trudna niż wielka”.

Oczywiście wartość kategorii strony osobowej formy czasownika esse nie determinuje również diatezy zdaniowej w przypadku, gdy stanowi składnik opisowych formacji fleksyjnych typu laudatus est, laudatus erat itp., jako że w formacjach tych wykładnikiem podstawowej treści predykatywnej i tym samym determinantem diatezy jest pasywna forma participium.

Podsumowując można więc stwierdzić, że prymarną funkcją funkcją kategorii strony łacińskich czasowników jest sygnalizowanie diatezy zdaniowej, przy czym prymarną funkcją wartości activum jest sygnalizowanie diatezy nienacechowanej, zaś prymarną funkcją wartości passivum sygnalizowanie diatezy nacechowanej. Jed- 
nak charakterystyka funkcjonalna kategorii strony w łacinie przedstawia się w sposób bardziej złożony niż mogłoby to wynikać z jej wewnętrznej struktury, opartej na (tylko) dwuczłonowej opozycji o wartościach: activum/passivum. Wynika to $\mathrm{z}$ faktu, że $w$ każdym $z$ obu zasadniczych rodzajów diatezy, tj. $w$ diatezie nienacechowanej i w diatezie nacechowanej, występują dwie jej odmiany, tj. nienacechowana czynna i nienacechowana zwrotna, oraz nacechowana bierna i nacechowana niepodmiotowa. System sygnalizowanych przez łacińskie czasowniki diatez można więc przedstawić następująco:

\begin{tabular}{|l|l|l|l|}
\hline \multicolumn{2}{|c|}{ diateza nienacechowana } & \multicolumn{2}{c|}{ diateza nacechowana } \\
\hline $\begin{array}{l}\text { pierwszy argument ujawniany jest przez mia- } \\
\text { nownikowy podmiot }\end{array}$ & $\begin{array}{l}\text { pierwszy argument ujawniany jest przez ako- } \\
\text { modowany składnik imienny lub nie jest ujaw- } \\
\text { niany w ogóle }\end{array}$ \\
\hline \multicolumn{1}{|c|}{ czynna } & \multicolumn{1}{c|}{ zwrotna } & \multicolumn{1}{c|}{ bierna } & niepodmiotowa \\
\hline $\begin{array}{l}\text { drugi argument - jeśli } \\
\text { jest implikowany } \\
\text { - ujawniany jest } \\
\text { przez akomodowany } \\
\text { składnik imienny }\end{array}$ & $\begin{array}{l}\text { drugi argument, } \\
\text { tożsamy z pierwszym, } \\
\text { ujawniany jest przez } \\
\text { zaimek zwrotny }\end{array}$ & $\begin{array}{l}\text { drugi argument } \\
\text { ujawniany jest przez } \\
\text { mianownikowy } \\
\text { podmiot }\end{array}$ & $\begin{array}{l}\text { żaden argument nie } \\
\text { jest ujawniany przez } \\
\text { mianownikowy } \\
\text { podmiot }\end{array}$ \\
\hline
\end{tabular}

Uwzględnienie tego faktu implikuje przypisanie wartości activum jako jej funkcji prymarnej, sygnalizowanie diatezy nienacechowanej czynnej, natomiast wartości passivum - diatezy nacechowanej biernej. Samo wewnętrzne zróżnicowanie obu podstawowych diatez, tj. istnienie wariantu zwrotnego (obok czynnego) diatezy nienacechowanej oraz wariantu niepodmiotowego (obok biernego) diatezy nacechowanej, związane jest z obecnością dodatkowych czynników formalnych, które nie tylko rozszerzają zakres funkcjonalny obu wartości kategorii strony, ale także w inny sposób modyfikują ich charakterystykę funkcjonalną i tym samym stanowią współwykładnik diatezy sygnalizowanej przez daną formę czasownikową. Czynnikami tymi są: 1.) selektywny sposób uwzględniania kategorii strony przez czasownik; czynnik ten jest indeksem diatezy nienacechowanej czynnej, modyfikując $w$ ten sposób funkcję wartości passivum w odniesieniu do leksemów o statusie verbum (semi) deponens;

2.) obligatoryjność 3. os. sg. (neutr.) w ramach kategorii osoby i liczby (oraz rodzaju) czasownika; czynnik ten jest indeksem diatezy nacechowanej niepodmiotowej, modyfikując przez to funkcję zarówno wartości activum, jak i passivum;

3.) wypełnianie przez zaimek (funkcjonalnie) zwrotny se (me, te, nos, vos) miejsca otwieranego przez czasownik przechodni dla akomodowanego składnika imiennego reprezentującego drugi argument predykatu; czynnik ten jest indeksem diatezy nienacechowanej zwrotnej, modyfikując w ten sposób funkcję wartości activum (w odniesieniu do verba deponentia wartości passivum).

Ogólny schemat funkcjonalny kategorii strony $\mathrm{w}$ lacinie przedstawia się zatem jak w podanej niżej tabeli: 


\begin{tabular}{|l|l|l|l|}
\hline $\begin{array}{c}\text { wartość } \\
\text { kategorii } \\
\text { strony }\end{array}$ & \multicolumn{1}{|c|}{$\begin{array}{c}\text { współwykładnik diatezy } \\
\text { (nacechowanie formalne) }\end{array}$} & $\begin{array}{c}\text { sygnalizowana } \\
\text { diateza }\end{array}$ & \multicolumn{1}{c|}{ przyklad } \\
\hline \multirow{5}{*}{ activum } & - & $\begin{array}{l}\text { nienacechowana } \\
\text { czynna }\end{array}$ & Consul mittit epistulam. \\
\cline { 2 - 5 } & zaimek zwrotny se & $\begin{array}{l}\text { nienacechowana } \\
\text { zwrotna }\end{array}$ & Milites se defendunt. \\
\cline { 2 - 5 } & obligatoryjność 3. sg. & $\begin{array}{l}\text { nacechowana } \\
\text { niepodmiotowa }\end{array}$ & Paenitet eum consilii. \\
\hline \multirow{5}{*}{ passivum } & $\begin{array}{l}\text { nacechowana } \\
\text { bierna }\end{array}$ & Epistula mittitur a consule. \\
\cline { 2 - 5 } & obligatoryjność 3. sg. (neutrum) & $\begin{array}{l}\text { nacechowana } \\
\text { niepodmiotowa }\end{array}$ & Curritur ad arma. \\
\cline { 2 - 5 } & selektywność kategorii strony & $\begin{array}{l}\text { nienacechowana } \\
\text { czynna }\end{array}$ & Caesar sequitur hostem. \\
\cline { 2 - 5 } & $\begin{array}{l}\text { selektywność kategorii strony } \\
\text { zaimek zwrotny se }\end{array}$ & $\begin{array}{l}\text { nienacechowana } \\
\text { zwrotna }\end{array}$ & Tuis scriptis se consolatur. \\
\hline
\end{tabular}

Widać więc, że zakres funkcjonalny wartości activum kategorii strony jest szerszy niż wartości passivum: może ona bowiem uczestniczyć w sygnalizowaniu wszystkich rodzajów i odmian diatezy, podczas gdy wartość activum nie może sygnalizować diatezy nacechowanej biernej.

Na zakres funkcjonalny wartości kategorii strony wpływają jednak jeszcze dwa dodatkowe czynniki o charakterze semantycznym.

Jeden $\mathrm{z}$ nich związany jest $\mathrm{z}$ dekauzatywizacją i stanowi indeks diatezy nienacechowanej czynnej. W przypadku form activi jego formalny wykładnik jest tożsamy z wykładnikiem diatezy zwrotnej, tzn. jest nim współobecność zaimka zwrotnego lub funkcjonalnie zwrotnego (valvae se aperuerunt), zaś w przypadku form passivi wykładnikiem tym jest zablokowanie $w$ strukturze składniowej zdania miejsca dla niepodmiotowego wyrażenia argumentowego (aedes aperiuntur).

Drugi czynnik związany jest $\mathrm{z}$ brakiem stanowienia przez formę czasownikową wykładnika podstawowej treści predykatywnej orzekanej w zdaniu. Dotyczy to osobowych form czasowników będących składnikami orzeczeń złożonych, w których podstawowe treści predykatywne wyrażane są przez formy bezokolicznowe lub imiesłowowe (fuit laudandus, potest laudari, incipit laudari, solet laudari, videtur laudavisse, dicitur laudavisse itp.). W ramach takich orzeczeń formy osobowe są wykładnikiem formalno-składniowego związku kongruencji predykatywnej, a często także nacechowanej modalności, habitualności bądź fazowości. Diateza zdaniowa determinowana jest wówczas przez wartość kategorii strony bezokolicznika bądź imiesłowu, natomiast funkcjonalny status kategorii strony form osobowych jest zróżnicowany. W przypadku czasowników modalnych, fazowych i habitualnych kategoria ta jest w zasadzie funkcjonalnie pusta, zaś w odniesieniu do form typu: videtur, dicitur, których leksykalna semantyka nie ma jako taka charakteru modalnego, wartość passivum może być interpretowana jako indeks kontekstowego przyjęcia przez nie właśnie funkcji modalnej. Podobnie w przypadku, gdy formy te współtworzą orzeczenie 
z formami rzeczownikowymi lub przymiotnikowymi jako podstawowymi wykładnikami treści predykatywnych (videtur magnus, dicitur (esse) amicus), sygnalizując diatezę nienacechowaną. Tym samym sygnalizowanie statusu wykładnika funkcji modalnej stanowiłoby dodatkową funkcję wartości passivum, aktualizowaną $\mathrm{w}$ odniesienieniu do określonej klasy czasowników współtworzących - wraz z formami bezokolicznikowymi, przymiotnikowymi i rzeczownikowymi - nacechowane modalnie orzeczenia złożone.

$\mathrm{Na}$ temat kategorii strony form imiesłowowych i bezokolicznikowych zob. tez niżej, rozdz. 12.8.1 i 12.8.2.

\subsection{TRYB (MODUS)}

Tryb jest kategorią morfologiczną czasownika o charakterze fleksyjnym. Prymarnie pełni on funkcję semantyczną, której istotą jest sygnalizowanie modalności zdaniowej'. Sekundarnie, w obrębie zdań złożonych, może być (współ)wykładnikiem podrzędności/nadrzędności syntaktycznej zdania składowego.

Kategoria gramatyczna trybu posiada trzy wartości: indicativus, imperativus i coniunctivus.

Formacje morfologiczne wyrażające określoną wartość kategorii trybu są również nacechowane pod względem pozostałych werbalnych kategorii gramatycznych, tj. czasu, strony, osoby i liczby (formacje analityczne także rodzaju).

Wartość indicativus nie narzuca reprezentującym ją formacjom żadnych ograniczeń co do sposobu i zakresu uwzględniania wszystkich pozostałych werbalnych kategorii morfologicznych.

Wartość coniunctivus narzuca ograniczenie liczby wartości kategorii czasu do czterech (praesens, imperfectum, perfectum, plusquamperfectum).

Wartość imperativus narzuca ograniczenie liczby wartości kategorii czasu do dwóch (praesens i futurum) oraz osoby również do dwóch (druga i trzecia) - czasem do jednej (druga lub trzecia).

\subsubsection{Indicativus}

Indikatiwus jest wartością kategorii trybu, która służy przede wszystkim sygnalizowaniu nienacechowanej (asertorycznej) modalności zdaniowej, np.:

Legati Aurunci senatum adeunt. (Liv., 2, 26)

"Posłowie Aurunków przybywają do senatu".

Nostri fotriter impetum eorum tulerunt. (Caes., Civ. 3, 37)

„Nasi dzielnie wytrzymali ich atak".

I Na temat modalności zdaniowej zob. niżej: Składnia 3.1.1. 
Legati ad Fabium consulem missi sunt. (Liv., 9, 41)

„Poslowie zostali wyslani do Fabiusza konsula".

Igitur de Catilinae coniuratione [...] paucis absolvam. (Sall., Catil. 4, 3)

"A zalem o spisku Katyliny pokrótce opowiem".

Czasowniki w indikatiwie mogą jednak występować rówież w zdaniach o modalności nacechowanej, np. w zdaniach pytajnych, gdzie modalność intencjonalna sygnalizowana jest poprzez partykuły / zaimki pytajne, względnie poprzez samą intonację, albo w zdaniach deklaratywnych, w których za pośrednictwem partykuł markowana jest nacechowana modalność epistemiczna, np.:

An id ioco dixisti? (Pl., Amph. 964)

¿Czy powiedziales to żartem?"

Ubi sunt hi fundi, Brute? (Cic., De orat. 2, 224)

"Gdzie są te posiadłości ziemskie, Brutusie?"

Est Simo intus? (Ter., Andr. 790)

„Simon jest w domu?"

Forsan et haec olim meminisse iuvabit. (Verg., Aen. 1, 203)

"Może kiedyś wspominanie także i tego będzie sprawialo radość".

Czasowniki $\mathbf{w}$ indikatiwie mogą też same stanowić leksykalny wykładnik nacechowanej modalności epistemicznej lub deontycznej/dynamicznej:

Bonum putant esse aliqui id, quod utile est. (Sen., Lucil. 120, 2)

„Niektórzy sądzą, że dobrem jest to, co jest pożyteczne".

Credebatur obsidione domitos hostes in fidem venisse. (Liv., 8, 26)

„Panowalo przekonanie, że nieprzyjaciele, zmuszeni oblężeniem, poddali się".

In Hispania Hercules, sicuti Afri putant, interiit. (Sall., Iug. 18)

„W Hiszpani, jak sądzą mieszkańcy Afryki, umarł Herkules".

C. Sulpicius Olympus [...] mortuus est C. Sacerdote praetore, nescio an antequam Verres praeturam petere coeperit. (Cic., Verr. 2, 1, 125)

„Gajusz Sulpicjusz Olympus umarł za pretury Gajusza Sacerdosa, bodaj/chyba jeszcze zanim Werres zaczął starać się o preturę".

Ego crimen oportet diluam. (Cic., S. Rosc. 36)

"Wypada, żebym ja odparł oskarżenie".

Nolo vincat. (Cic., Q. Rosc. 9)

„Nie chce, by wygrał”.

Mogą również współtworzyć strukturę orzeczenia sygnalizującego nacechowaną modalność epistemiczną lub deontyczną/dynamiczną:

Malum mihi videtur esse mors. (Cic., Tusc. 1,9)

„Wydaje mi się, że śmierć jest złem”. 
Erat (candelabrus) eo splendore, qui ex clarissimis et pulcherrimis gemmis esse debebat. (Cic., Verr. 4, 65)

„(Swiecznik) lśnił takim blaskiem, że musial być (= na pewno został) (wykonany) z najwspanialszych i najpiękniejszych klejnotów".

Corpore nihil nisi praesens et quod adest sentire possumus. (Cic., Fin. 1, 55)

„Za pośrednictwem ciała możemy odczuwać tylko to, co istnieje w danym momencie i co jest obecne".

Nolui tam vehementer agere hoc prima actione. (Cic., Verr. 2, 5, 163)

„Nie chciałem zbyt intensywnie zajmować się tą sprawą w pierwszej części procesu”.

Voluntas ipsa rectum petens laudanda est. (Sen., Benef. 5, 2, 2)

"Sama chęć zmierzająca ku dobru powinna być chwalona”.

Dictator ac magister equitum castra in viam deferunt, qua Hannibal ducturus erat. (Liv., $22,15)$

„Dyktator i dowódca jazdy przenoszą obóz na drogę, którą mial L powinien iść Hannibal”.

Wreszcie mogą też, choć rzadko, denotowaną przez siebie treść ukazywać w określonej, nacechowanej perspektywie modalnej, intencjonalnej bądź epistemicznej:

Si quid acciderit novi, facies ut sciam. (Cic., Fam. 114, 8, 1)

„Jeśli zdarzyloby się coś nowego, powiadom mnie".

Haec erit bono genere nata, nihil scit nisi verum loqui. (Pl., Pers. 645)

„Ona musi być z dobrego domu; mówi tylko prawdę".

\subsubsection{Imperativus}

Ta wartość kategorii trybu służy wyrażaniu imperatywnej modalności intencjonalnej, a więc do formułowania nakazów, rozkazów, poleceń czy prośb:

Perge quo cepisti! Egredere aliquando ex urbe! [...] Proficiscere! (Cic., Catil. 1, 10)

„Kończ, coś zaczął! Wyjdź wreszcie z miasta! Ruszaj!”

Dic mihi praeterea, Pansa, Vintidius ubi sit. (Cic., Phil. 12, 23)

„Powiedz mi jeszcze, Panso, gdzie jest Wentydiusz".

Audite vero, optumi viri, ea, quae saepissime inter me et Scipionem de amicitia disserebantur. (Cic., Lael. 33)

„Posluchajcie zatem, znakomici mężowie, tego, co często było przedmiotem moich rozmów ze Scypionem o przyjaźni".

Imperativus futuri stosowany jest do wyrażania nakazów, zaleceń czy próśb odnoszących się do przyszłości (których wykonanie odłożone jest w czasie) lub takich, które mają charakter ogólny, ponadczasowy lub przynajmniej niezwiązany wyłącznie $\mathrm{z}$ chwilą, w której nakazy te są formułowane. $Z$ tego względu formacja ta często używana jest w ogólnych wskazówkach, przepisach czy zasadach prawnych: 
\{Cocus:\} Mercedem cedo. \{Lysimachus:\} Cras petito; dabitur. Nunc abi. (Pl., Merc. 769-770)

„\{Kucharz:\} Zapłać mi! \{Lizymachus:\} Poproś jutro, to dostaniesz. Teraz odejdź!”

Sed cum valetudini tuae diligentissime consuleris, tum, mi Tiro, consulito navigationi. (Cic., Fam. 16, 4, 3)

„Ale dopiero po tym, gdy już należycie zatroszczysz się o swe zdrowie, pomyśl, mój Tironie, o żegludze".

Sic habeto, mi Tiro, neminem esse, qui me amet, quin idem te amet. (Cic., Fam. 16, 4, 4)

„Bądź przekonany, mój Tironie, że nie ma nikogo, kto będąc moim przyjacielem, nie sprzyjałby również tobie".

Incestum pontifices supremo supplicio sanciunto. (Cic., Leg. 2, 22)

„Za kazirodztwo niech pontyfikowie wymierzają najwyższą karę”.

Piro florente dapem pro bubus facito. Postea verno arare incipito. (Cato, Agr. 131, 1) „Gdy zakwitnie grusza, złóż ofiarę za woły. Następnie rozpocznij wiosenną orkę".

Do wyrażania zakazów lub próśb o charakterze zaprzeczonym stosuje się:

1. Formę imperatywną czasownika z partykułą ne (spójnikiem neve):

Salvast navis, ne time. (Pl., Merc. 173)

"Z okrętem nic się nie stało, nie bój się".

Equo ne credite, Teucri. (Verg., Aen. 2, 48)

"Nie ufajcie koniowi, Trojanie".

Impius ne audeto placare donis iram deorum. (Cic., Leg. 2, 22)

„Bezbożnik niech nie waży się lagodzić gniewu bogów darami”.

Hoc (scil.Borea) flante ne arato, [...] semen ne iacito. (Plin., Nat. hist. 18, 334)

„Gdy wieje północny wiatr, nie prowadź orki, nie siej”.

Hominem mortuum [...] in urbe ne sepelito neve urito. (Cic., Leg. 2, 58)

„Zmarłego niech (nikt) nie grzebie ani nie poddaje kremacji na terenie miasta”.

2. Bezokolicznik czasownika i formę imperatywną noli/nolite; również mitte/mittite w znaczeniu 'przestań, poniechaj', a w języku poetyckim także fuge/fugite, parcel parcite:

Quod iam a me expectare noli. (Cic., Fin. 2, 118)

„Tego już ode mnie nie oczekuj”.

Nolite existumare maiores nostros armis rem publicam ex parva magnam fecisse. (Sall., Cat. 52)

„Nie sądźcie, że nasi przodkowie przy pomocy oręża rzeczpospolitą z małej uczynili wielką”.

Mitte male loqui. (Pl., Pers. 207)

„Przestań już zlorzeczyć”.

Quid sit futurum cras, fuge quaerere. (Hor., Carm. 1, 9, 13)

„Co przydarzy się jutro, nie pytaj". 
Parce pias scelerare manus. (Verg., Aen. 3, 42)

„Nie plam zbożnych rąk".

3. Czasownik w koniunktiwie praesentis (rzadziej, w starszej literaturze, w koniunktiwie perfecti) i formę imperatywną cave/cavete (ne):

Cave vocem mittas. (Liv., 8, 32)

„Nie mów ani słowa”.

Cavete rumores credulitate vestra alatis. (Liv., 44, 22)

„Nie podsycajcie plotek waszą latwowiernością".

Cave ne falsam gratiam studeas inire. (Ter., Heaut. 302-303)

„Nie staraj się pozyskać pozornej życzliwości”.

Cave quicquam, nisi quod rogabo te, mihi responderis. (Pl., Amph. 608)

"Nie opowiadaj mi tu niczego poza tym, o co cię zapytam".

\subsubsection{Coniunctivus}

Koniunktiwus jest tą wartością kategorii trybu, która stanowi podstawowy dla łaciny środek fleksyjny różnicowania modalności. Za pośrednictwem koniunktiwu może być wyrażanych bardzo wiele różnych odmian nacechowanej modalności, związanych z komunikowaniem treści o charakterze niefaktywnym (nieasertorycznym). Wtórnie koniunktiwus sygnalizuje podrzędność składniową zdań składowych w ramach zdań złożonych.

\subsubsection{Koniuktiwus jako wykładnik nacechowanej modalności intencjonalnej}

Poprzez koniunktiwus sygnalizowana może być intencjonalna modalność o charakterze wolitywnym, a więc modalność imperatywna i dezyderatywna.

\subsection{Modalność imperatywna}

Formacje koniunktywne konstytuują wyrażenia imperatywne o różnym stopniu kategoryczności, a więc rozkazy, zakazy, nakazy, zalecenia, ostrzeżenia, prośby, wezwania, zachęty itp. W tej funkcji używane są przede wszystkim formacje coniunctivi praesentis. W zakazach, zaleceniach i ostrzeżeniach o charakterze przeczącym stosowany jest koniunktiwus praesentis lub perfecti, a negacja wyrażana jest za pośrednictwem partykuły ne (rzadko również non) albo zaimków lub spójników przeczących.

Funkcje imperatywne, realizowane przez czasowniki w pierwszej osobie liczby mnogiej, tradycyjnie określane są jako hortatywne (coniunctivus hortativus): 
Amemus patriam, pareamus senatui, consulamus bonis. (Cic., Sest. 143)

„Kochajmy ojczyznę, bądźmy posluszni senatowi, troszczmy się o dobrych obywateli”.

Oremus, accusemus, gravius denique minitemur. (Ter., Hec. 717-718)

„Prośmy, oskarżajmy, a w końcu posuńmy się i do poważniejszych gróźb”.

Quoniam omnia commoda nostra [...] legibus obtinemus, a legibus non recedamus. (Cic., Cluent. 155)

„Skoro wszystkie nasze pożytki posiadamy dzięki prawom, od praw nie odstępujmy”.

Funkcje imperatywne o charakterze przeczącym, realizowane przez czasowniki w drugiej osobie liczby pojedynczej lub mnogiej, tradycyjnie określane są jako prohibitywne (coniunctivus prohibitivus):

Ne exspectetis, spectatores, dum illi huc ad vos exeant nemo exibit. (Pl., Cist. 782-783)

„Nie czekajcie, widzowie, aż oni tu do was wyjdą; nikt nie wyjdzie".

Ne vos quidem, iudices [...], mortem timueritis. (Cic., Tusc. 1, 98)

„Również wy, sędziowie, nie bójcie się śmierci”.

Nihil ignoveris $[\ldots]$, nihil gratiae causa feceris [...], misericordia commotus ne sis. (Cic., Mur. 65)

„Niczego nie wybaczaj, niczego nie rób z życzliwości, nie daj się wzruszyć litością".

W pozostałych przypadkach funkcje te określane są jako jussywne (coniunctivus iussivus):

Proin tu ab istoc procul recedas. (Pl., Capt. 551)

"Trzymaj się więc $z$ dala od niego".

Caveant intemperantiam, meminerint verecundiae. (Cic., Leg. 1, 122)

„Niech wystrzegają się nieumiarkowania, pamiętają o poczuciu przyzwoitości”.

Nemo exspectet, ut alieno tantum labore sit disertus. (Quint., Inst. 7, 10, 14)

„Niech nikt nie oczekuje, że stanie się wymowny wylącznie dzięki wysiłkowi innych ludzi (scil. nauczycieli)".

De sepulcris [...] nihil est apud Solonem amplius quam 'ne quis ea deleat neve alienum inferat'. (Cic., Leg. 2, 64)

„W sprawie grobowców nie ma u Solona niczego ponad (zalecenie): 'niech nikt ich nie niszczy i nie chowa tam kogoś obcego"'.

Ne quis sit admiratus. (Cic., Off. 2, 35)

„Niech nikt się nie dziwi”.

\subsection{Modalność dezyderatywna}

Ten typ modalności związany jest w wyrażaniem życzeń. Funkcja koniunktiwu, polegająca na konstytuowaniu wypowiedzi o charakterze dezyderatywnym, tradycyjnie 
określana jest jako optatywna (coniunctivus optativus). Jej współwykładnikiem często jest partykuła optatywna utinam 'oby', a przeczenie wyrażane jest za pośrednictwem partykuły ne (bardzo rzadko non). Wartość gramatycznej kategorii czasu formacji koniunktywnych użytych $w$ tej funkcji jest indeksem charakterystyki temporalnej wyrażanych przez nie treści optatywnych, a także ich statusu ontologicznego, a mianowicie:

1. wartości praesens i imperfectum sytuują wyrażane treści optatywne w teraźniejszości lub przyszłości, przy czym praesens przypisuje im status stanu możliwego (potentialis), a więc status życzeń ukazanych jako możliwe do spełnienia, zaś imperfectum przypisuje im status stanu sprzecznego z rzeczywistością (irrealis sensu stricto), a więc status życzeń ukazanych jako nierealne;

2. wartości perfectum i plusquamperfectum sytuują wyrażane treści optatywne w przeszłości, przy czym wartość perfectum nadaje im status stanu możliwego (potentialis), a więc status życzeń, które mogły się spełnić, zaś plusquamperfectum status stanu sprzecznego $z$ rzeczywistością (irrealis sensu stricto), a więc status życzeń nierealnych, tzn. werbalizujących stan, który nie nastąpił w przeszłości:

Haec habui de senectute quae dicerem; ad quam utinam perveniatis, ut ea, quae ex me audistis, re experti probare possitis. (Cic., Sen. 85)

„Tyle miałem do powiedzenia na temat starości; obyście do niej dożyli, aby doświadczywszy jej, mogliście potwierdzić sluszność tego, co ode mnie usłyszeliście".

Utinam L. Caesar valeret, Ser. Sulpicius viveret; multo elius haec causa ageretur a tribus, quam nunc agitur ab uno. (Cic., Phil. 8, 22)

„Gdybyz tak Lucjusz Cezar byl w peini sil, a Serwiusz Sulpicjusz żyl jeszcze; o wiele lepiej sprawa ta prowadzona byłaby przez trzech, niż jest teraz przez jednego".

\{Advocati:\} Quicum litigas apscessit. \{Agorastocles:\} Utinam hinc abierit malam crucem! (Pl., Poen. 798-799)

„\{Swiadkowic:) Twój przeciwnik uciekł. (Agorastokles:) Oby (Mam nadzicję, że) uciekł na zlamanie karku!"

Etiam illud moleste fero, quod ex urbe parum comitatus exierit. Utinam ille (scil. Catilina) omnis secum suas copias eduxisset! (Cic., Catil. 2, 4)

„Również i to mnie gnębi, że tylko niewielka ilość (jego) towarzyszy' opuściła miasto. Oby byl (= szkoda, że nie) wyprowadzil z sobą wszystkich swoich ludzi!"

Życzenia wyrażane $z$ użyciem czasownika w koniunktiwie często mają postać utartych formul, zaklęć czy zarzekania się, w związku z czym status przypisywany im za pośrednictwem określonej wartości kategorii czasu często ma charakter skonwencjonalizowany lub subiektywny, związany $z$ funkcją komunikacyjną (pragmatyczną, retoryczną), jaką dane wyrażenie pełni; por. np.:

Sagunti ruinae - falsus utinam vates sim - nostris capitibus incident. (Liv., 21, 10)

„Ruiny Saguntu - obym był fałszywym prorokiem - na nasze zwalą się głowy”.

Illud utinam ne vere scriberem, ea te re publica carere, in qua neminem prudentem hominem res ulla delectet. (Cic., Fam. 5, 17, 3) 
„Oby nie bylo prawdą to, co piszę, że mianowicie zostałeś pozbawiony takiej rzeczpospolitej, w której roztropnemu czlowiekowi nic nie może się podobać".

Pereat, qui crastina curat. (App. Verg.: Copa, 37)

„Oby zginąl / Niech zginie, kto troszczy się o to, co będzie jutro".

Ne vivam si scio. (Cic., Att. 4, 17, 5)

„Obym skonal / Niech skonam, jeśli wiem”.

W języku poetyckim życzenia wyrażane są również za pośrednictwem czasownika $w$ koniunktiwie $z$ towarzyszeniem partykuł uti/ut lub si/o si:

Ut pereat positum robigine telum! (Hor., Serm. 2, 1, 43)

„Niech zginie od rdzy odłożona na bok broń".

Si nunc se nobis ille aureus arbore ramus ostendat! (Verg., Aen. 6, 187-188)

„Gdyby tak teraz ukazała się nam na drzewie owa złota gałązka!"

O si urnam argenti fors quae mihi monstret! (Hor., Serm. 2, 6, 10)

„O, gdyby tak jakiśs szczęśliwy traf pozwolił mi odnaleźć (ukryty przez kogoś) dzban pełen pieniędzy!"

Jeszcze innym środkiem formułowania życzeń jest użycie czasowników w koniunktiwie $\mathrm{w}$ połączeniu $\mathrm{z}$ koniunktywnymi formami 1 . os. czasu praesentis lub imperfecti czasowników velle, nolle (w odniesieniu do tych ostatnich, zastowanie form indykatywnych lub współwystępowanie infinitiwu czasownika implikuje raczej wyrażenie woli czy chęci, a więc modalność dynamiczną, a nie dezyratywną jak w poniższych przykładach):

Hoc ignoscant di immortales velim [...] populo Romano. (Cic., Phil. 1, 13)

"Chcialbym aby (= Oby) bogowie nieśmiertelni wybaczyli to narodowi rzymskiemu”.

Vellem adesset M. Antonius. (Cic., Phil. 1, 16)

"Chcialbym, aby Marek Antoniusz byl tu obecny".

Nollem accidisset tempus, in quo perspicere possis, quanti te, quanti Pompeium [...], quanti Brutum facerem. (Cic., Fam. 3, 10, 2)

„Chcialbym, aby nie była nadarzyła się ta sposobność, w której mogleś poznać, jak wysoko oceniam ciebie, Pompejusza, Brutusa".

\subsubsection{Koniuktiwus jako wykładnik nacechowanej modalności epistemicznej}

Czasowniki w koniunktiwie wyrażanym treściom mogą nadać status stanu:

1. Potencjalnego (coniunctivus potentialis):

Credas non de puero scriptum, sed a puero. (Plin., Epist. 4, 7, 7)

„Mógłbyś (= Można było) uwierzyć, że zostało to napisane nie o chłopcu, lecz przez chlopca". 
Conchyliatis $\mathrm{Cn}$. Pompei peristromatis servorum in cellis lectos stratos videres. (Cic., Phil. 2,67)

„Mógłbys (= Można było) zobaczyć łóżka w pomieszczeniach dla niewolników przykryte purpurowymi narzutami Pompejusza".

Nil ego contulerim iucundo sanus amico. (Hor., Serm. 1, 5, 44)

„Będąc przy zdrowych zmysłach, niczego nie mógłbym porównać do drogiego przyjaciela (= nic nie może się równać $z \ldots .$.$) .$

$\mathrm{W}$ tej funkcji czasowniki w koniunktiwie współwystępować mogą również z partykułami oznaczającymi możliwość:

Forsitan quaeratis, quis iste terror sit. (Cic., S. Rosc. 5)

„Być może zapytalibyście, co to za strach".

Riserit aliquis fortasse hoc praeceptum. (Cic., De orat. 2, 99)

„Być może ktoś wyśmiałby tę wskazówkę”.

2. Przyzwolonego (coniunctivus concessivus):

Ne sit sane summum malum dolor, malum certe est. (Cic., Tusc. 2, 14)

„Niechby / Choćby i nie byl ból złem największym, złem jednak z pewnością jest”.

Sit fur, sit sacrilegus, sit flagitiorum omnium vitiorumque princeps; at est bonus imperator. (Cic., Verr. 2, 5, 4)

„Niech będzie, że jest złodziejem, że jest świetokradcą, że jest królem wszelkich przywar i występków; jednakowoż jest dobrym wodzem (= Choćby i był złodziejem... / Niechby i byl złodziejem... / Nawet jeśli jest/byłby złodziejem...).

'Malus civis, improbus consul, seditiosus homo Cn. Carbo fuit.' Fuerit aliis: tibi quando esse coepit? (Cic., Verr. 2, 1, 37)

„Gneusz Karbo był złym obywatelem, niegodziwym konsulem, zbunlowanym czlowiekiem.

Niechby i byl dla innych: dla ciebie, kiedy zacząl być (takim)?"

3. Sprzecznego z rzeczywistością (coniunctivus irrealis):

Utinam fecisset! Non supplicium deprecarer, sed praemium postularem. (Cic., Rab. 31)

„Oby to był zrobil! (= Szkoda, że tego nie zrobil). Wtedy nie prosilbym o oddalenie kary (jak muszę to, niestety, czynić teraz), lecz wnioskowalbym o nagrodę".

Video ita esse faciendum et iam ante fecissem, sed me multa impediverunt. (Cic., Fam. 14, $19,1)$

„Widzę, że tak należy uczynić, i już wcześniej uczyniłbym, ale wiele rzeczy stanęlo mi na przeszkodzie".

Uno proelio victus Alexander bello victus esset. (Liv., 9, 19)

„Pokonany w jednej bitwie Aleksander przegrałby (całą) wojnę".

4. Hipotetycznego, zakładanego (suppositivus):

Revivescat $M$. Curius $[\ldots]$ et videat aliquem $[\ldots]$ mullos exceptantem de piscina et $[\ldots]$ murenarum copia gloriantem; nonne hunc hominem [...] servum iudicet? (Cic., Parad. $5,38)$ 
„Załóżmy (Przypuśćmy), że Manliusz Kuriusz ożyl i zobaczyl kogoś łowiącego w stawie ryby i szczycącego się posiadaniem wielkiej ilości muren; czyż nie uznałby tego czlowieka za niewolnika?"

5. Wynikającego z opinii innych osób (evidentialis, ex mente aliena):

\{Chremes:\} Si, Simo, hunc noris satis, non ita arbitrere: bonus est hic vir. \{Simo:\} Hic vir sit bonus? (Ter., Andr. 914-915)

„|Chremes:\} Jeśli, Simonie, znałbyś go lepiej, nie uważałbyś tak: to dobry czlowiek. \{Simo:\} To ma być dobry czlowiek?"

6. Prawdopodobnego, wspólnie $z$ operatorami werbalnymi typu nescio an, haud scio an, dubito an:

Ac nescio an (Hannibal) mirabilior adversis quam secundis rebus fuerit, quippe qui cum in hostium terra per annos tredecim $[\ldots]$ varia fortuna bellum gereret, $[\ldots]$ nulla $[\ldots]$ adversus ducem seditio exstiterit. (Liv., 28, 12)

„I nie wiem czy nie byl (Hannibal) bardziej godny podziwu w sytuacjach trudnych niż pomyślnych, bo przecież choć przez trzynaście lat ze zmiennym szczęściem prowadzil wojnę na ziemi nieprzyjaciól, to nie powstał żaden bunt przeciwko wodzowi".

Omnium ineptiarum $[\ldots]$ haud scio an nulla sit maior quam $[\ldots]$ de rebus $[\ldots]$ non necessariis argutissime disputare. (Cic., De orat. 2,18 )

„Ze wszystkich niedorzeczności chyba żadna nie jest większa niż ta, która polega na subtelnym dysputowaniu o rzeczach niepotrzebnych".

Si per se virtus sine fortuna poneranda est, dubito an hunc primum omnium ponam. (Nep., Thras. 1)

„)eśli należaloby oceniać samo tylko męstwo jako takie, bez uwzględnienia roli losu, to chyba jego postawilbym ponad wszystkich".

\subsubsection{Koniuktiwus jako wykładnik nacechowanej modalności deontycznej}

Stanowiąc wykładnik modalności deontycznej tryb koniunktiwus wyrażać może:

1. Powinność:

'Moreretur', inquies [...]. Fecisset certe, si sine maximo dedecore $[\ldots]$ potuisset emori. (Cic., Rab. Post. 29)

„Powinien był popełnić samobójstwo', powiesz. I zapewne zrobiłby to, gdyby mógl umrzeć bez wielkiej hańby".

Potius doceret non esse aequam (causam Transpadanorum), quia non esset utilis rei publicae. (Cic., Off. 3, 88)

„Powinien byl raczej przekonywać, że (roszczenie miast transpadańskich) nie jest sluszne, ponieważ nie jest pożyteczne dla państwa".

Saltem aliquid de pondere detraxisset et paulo minoris aestimavisset ea quam Peripatetici, ut sentire quoque aliud, non solum dicere videretur. (Cic., Fin. 4, 57)

„Powinien byl przynajmniej nieco pomniejszyć wagę (tych rzeczy) i przypisać im nieco mniejszą wartość niż Perypatetycy, aby wydawalo się, że również myśli inaczej, a nie tylko mówi". 
Formacje koniunktywne $\mathrm{w}$ tej funkcji najczęściej używane są w ramach pytań o charakterze deliberatywnym, dubitatywnym czy retorycznym, stąd też funkcja ta, aktualizowana w tego typu wypowiedzeniach, określana bywa jako deliberatywana bądź dubitatywna (coniunctivus deliberativus / dubitativus):

Quid ergo agam, Phidippe? (Ter., Hec. 715)

"Cóż więc mam (= powinnam) robić, Fidypie?"

Contra rem suam me [...] venisse questus est. An ego non venirem contra alienum pro familiari et necessario? (Cic., Phil. 2, 3)

„Użalal siç, że wystąpiłem (sądownie) przeciwko niemu. Czyż miałem (= powinienem byl) nie występować przeciwko obcemu w obronie przyjaciela i krew'nego?"

Haec cum viderem, quid agerem, iudices? [...] Contenderem contra tribunum plebis privatus armis? (Cic., Sest. 43)

„Gdy to wszystko widziałem, co miałem robić, sędziowie? Mialem z bronią w ręku walczyć przeciwko trybunowi ludowemu, będąc człowiekiem prywatnym?"

2. Możliwość:

Quid faciat custos, cum [...] illa [...], quo [...] sui comites vetantur ire, eat? (Ov., Ars 3, 633-636)

„Cóż może zrobić strażnik, gdy ona chodzi tam, dokąd nie wolno wejść towarzyszącym jej mężczyznom?”

\subsubsection{Koniuktiwus jako wykładnik podrzędności składniowej zdań składowych $w$ ramach zdań złożonych}

Użycie form koniunktywnych czasownikowego orzeczenia jest $w$ klasycznej łacinie jednym z dwu podstawowych - obok spójnikowych konektorów - środków sygnalizowania podrzędności składniowej zdań. Można sądzić, iż genezę obecności koniunktiwu w zdaniach zależnych wiązać należy z nacechowaną modalnością wyrażanych przez nie treści, implikowaną przez treść zdania nadrzędnego. Tak na przykład obecność koniunktiwu w zdaniach dopełnieniowych zależnych od nadrzędnych orzeczeń oznaczających wolę, zamiar, rozkaz, żądanie, powstrzymywanie, postanawianie, decydowanie itp. wiązać można z sygnalizowaniem przez tę wartość kategorii trybu modalności o charakterze wolitywnym (jussywnym, hortatywnym, prohibitywnym, dezyderatywnym). $Z$ kolei $z$ sygnalizowaniem przez koniunktiwus nacechowanej modalności epistemicznej (potentialis) wiązać można występowanie formacji koniunktywnych $w$ zdaniach podmiotowych zależnych od nadrzędnych wyrażeń predykatywnych oznaczających stawanie się, zdarzanie, następowanie itp. czy np. w dopełnieniowych pytaniach zależnych.

Związek z funkcjami modalnymi koniunktiwu znaleźć można również w semantyce określonych zdań podrzędnych okolicznikowych. W tym względzie z pewnością wyraźne jest powiązanie zdań celowych $\mathrm{z}$ modalnością deontyczną (intencjonalną). W zdaniach skutkowych dopatrywać się można związku z modalnością epistemiczną 
wyrażaną przez coniunctivus potentialis zakładając, że skutek prymarnie ma charakter potencjalny lub hipotetyczny. Także w wielu innych typach zdań okolicznikowych mamy do czynienia $z$ wyrażaniem treści niefaktywnych, np. w zdaniach warunkowych, koncesywnych (jeśli przyzwolenie ma charakter domniemany) czy przyczynowych (jeśli przyczyna ma charakter rzekomy lub pozorny). Z biegiem czasu, wskutek oddziaływania analogii i związanego $z$ nim procesu ciągłego rozszerzania zakresu stosowalności koniunktiwu, w większości zdań zależnych formacja ta stopniowo wyparła formy indykatywne, stając się (w poczuciu mówiących) formalnym wyznacznikiem podrzędności składniowej (coniunctivus obliquus).

\subsection{OSOBA (PERSONA)}

Osoba czasownika jest kategorią o charakterze fleksyjnym, syntaktycznie zależnym (determinowanym), nienominatywnym (tekstowym, semantycznie pustym). Przysługuje czasownikowym formom finitywnym, a więc formom fleksyjnym, za pośrednictwem których leksemy czasownikowe realizują swoją prymarną funkcję składniową orzeczenia zdaniowego lub funkcję łącznikowego składnika orzeczenia złożonego. Stanowi indeks wartości kategorii osoby syntaktycznie nadrzędnego rzeczownika (zaimka lub innego funkcjonalnego odpowiednika rzeczownika), zajmującego w strukturze składniowej zdania pozycję gramatycznego podmiotu. Tym samym wskazuje na status desygnatu podmiotu w obrębie sytuacji aktu mowy, identyfikując go poprzez wartość 1 . osoby $z$ nadawcą komunikatu lub grupą, do której należy nadawca lub nadawca i odbiorca komunikatu; poprzez wartość 2 . osoby $z$ odbiorcą lub grupą, do której należy odbiorca, ale nie należy nadawca komunikatu; poprzez wartość 3 . osoby $z$ obiektem lub grupą obiektów, z których żaden nie jest uczestnikiem aktu językowego porozumiewania się. Z uwagi na sprzężony charakter kategorii osoby czasownikowego orzeczenia i rzeczownikowego podmiotu kategoria ta stanowi jedną z formalnych podstaw składniowego związku kongruencji predykatywnej. Wykładnikiem wartości kategorii osoby czasownika jest końcówka fleksyjna, wpółwyrażająca (wraz wartościami kategorii osoby) również określone wartości kategorii liczby i strony:

Tu me amas, ego te amo. (Pl., Most. 305)

"Ty mnie kochasz, ja kocham ciebie".

Vos me imperatoris nomine appellavistis. (Caes., Civ, 2, 32)

.Wy nadaliście mi tytul imperatora".

Sed nos et solititudini tuae praesidium praebebimus et compendiosum ad tuos iter monstrabimus. (Apul., Met. 6, 30)

"Lecz my znajdziemy lekarstwo na twoją samotność i wskażemy najkrótszą drogę do twych bliskich".

Milites $[. .$.$] hostium phalangem perfregerunt. (Caes., Gall.1, 25, 2)$

"Żolnierze przelamali nieprzyjacielską falangę". 
Interfecus est etiam fortissime pugnans Crastinus. (Caes., Civ. 3, 99)

„Zostal zabity również bardzo dzielnie walczący Krastinus".

Multa sunt incommoda in vita. (Cic., Nat. 1,23)

„Liczne są niedogodności w życiu".

Armis Italia non potest vinci. (Rhet. Her., 4, 43)

„Zbrojnie Italia nie może zostać zwyciężona”.

Czasownikowe orzeczenie zawiera indeks wartości kategorii osoby rzeczownikowego podmiotu również wtedy, gdy ten ostatni, ze względu na ekonomię wypowie$\mathrm{dzi}$, nie jest wyrażony $\mathrm{w}$ strukturze powierzchniowej zdania, lecz identyfikowalny kontekstowo lub konsytuacyjnie (domyślny). Dotyczy to w szczgólności 1. i 2. osoby, które w sposób jednoznaczny konotują w pozycji podmiotowej odpowiednie zaimki osobowe:

Video, patres conscripti, in me omnium vestrum ora atque oculos esse conversos. (Cic., Catil. 4,1$)$

„Widzę, senatorowie, że na mnie zwrócone są twarze i oczy was wszystkich".

Te Syracusis natum esse dixisti. (Pl., Men. 1097)

„Mówileś, żeś urodził się w Syrakuzach".

Propter virtutem [...] iure laudamur. (Cic., Nat. 3, 87)

„Za cnotę słusznie jesteśmy chwaleni”.

De vobis ac de vestris liberis cogitate. (Cic., Catil. 4,1 )

„Pomyślcie o sobie i o swoich dzieciach".

Moleste antea ferebat miles se suo sumptu operam rei publicae praebere [...]. Gaudet nunc fructui sibi rem publicam esse et laetus stipendium accipit; aequo igitur animo patiatur se ab re familiari, cui gravis impensa non est, paulo diutius abesse. (Liv., 5, 4)

„Przedtem ciężko było żołnierzowi służyć rzeczpospolitej na własny koszt. Dzisiaj cieszy się, że rzeczpospolita przynosi mu korzyści i z radością przyjmuje żołd; niechaj więc ze spokojem godzi się na dłuższy pobyl z dala od swych włości, skoro nie musi już za to ponosić ciężkich kosztów".

Kategoria osoby czasownika, ograniczona do wartości 3. osoby, może jednak również nie być indeksem wartości kategorii osoby podmiotu, lecz współwykładnikiem niepodmiotowej, nacechowanej diatezy zdaniowej, której specyfika polega na nieotwieraniu w strukturze składniowej miejsca dla mianownikowego podmiotu:

Iam advesperascit. (Ter., Andr. 5581)

"Już się zmierzcha".

Me civitatis morum piget taedetque. (Sall., Iug. 4, 9)

„Zloszczą mnie i brzydzą obyczaje spoleczeństwa”.

Regio $[\ldots]$ abscessum est. (Liv., 24, 1)

„Odstąpiono od (miasta) Regium". 
Sic itur ad astra. (Verg., Aen. 9, 641)

"Tak idzie się do gwiazd".

Wartością 3. osoby nacechowana jest forma czasownikowa również wtedy, gdy miejsce podmiotu wypełniane jest przez zdanie podrzędne podmiotowe lub przez równoważnik podrzędnego zdania podmiotowego (accusativus cum infinitivo):

Ex quo evenit, ut et Tarquinius augure Atto Navio uteretur et populus de suis rebus ad eum referret. (Cic., Div. 1, 32)

„W konsekwencji nastąpiło (to), że i Tarkwiniusz korzystal z (rad) augura Attusa Nawiusza, i lud ze swoimi sprawami zwracal się do niego".

Constat $[\ldots]$ ad salutem civium civitatumque incolumitatem $[\ldots]$ inventas esse leges. (Cic., Leg. 2, 11)

"Jest wiadomym, że prawa zostały wynalezione dla dobra obywateli i pomyślności państw".

Dla niewielkiej grupy czasowników kategoria osoby ma charakter selektywny i ograniczona jest wyłącznie do wartości 3. osoby. Czasowniki te określone zatem mogą być jako tertia persona tantum. Do grupy tej należą m.in. przywołany wyżej czasownik advesperascit, czasowniki modalne: licet, oportet, czasownik semimodalny decet, a także czasownik libet/lubet. Na ogół sygnalizują one diatezę nacechowaną niepodmiotową, przy czym czasowniki (semi)modalne i czasownik libet stanowią orzeczenia bądź wspólnie $z$ formami bezokolicznikowymi innych czasowników, bądź samodzielnie, tzn. z elipsą bezokolicznika albo otwierając miejsce dla zdania podrzędnego lub jego równoważnika (accusativus cum infinitivo):

Nunc licet mihi libere quidvis loqui. (Pl., Amph. 393)

„Teraz wolno mi swobodnie mówić, cokolwiek zechcę".

Defaenerare hominem egentem hau decet. (Pl., Vid. 89)

"Nie należy rujnować lichwą czlowieka ubogiego".

Nunc neque vivere lubet neque mori licet sine dedecore. (Sall., Iug. 14)

„Teraz ani nie ma się ochoty żyć, ani nie można umrzeć bez narażenia się na hańbę”.

Nunc, dum tibi lubet licetque, pota, perde rem. (Pl., Most. 20)

„Teraz, póki masz ochotę i wolno ci, pij, trać majątek”.

Sicuti regi lubuerat, pax convenit. (Sall., Iug. 38)

"Zawarto pokój na takich warunkach, na jakich królowi spodobalo się (go zawrzeć)".

Ego crimen oportet diluam. (Cic., S. Rosc. 36)

"Wypada, żebym ja odparł oskarżenie".

Diu qui domi otiosi dormierunt, decet animo aequo nunc stent. (PI., Poen. 21-22)

"Wypada by ci, którzy próżnując spali dlugo w domu, teraz stali nie okazując wzburzenia".

Quid me oportet facere? (PI., Capt. 955)

„Co powinienem robić?" 
Heia, mea luno, non decet esse te tam tristem tuo Iovi. (Pl., Cas. 230) "Ejże, ma Junono, nie godzi się, byśs była tak zagniewana na swego Jowisza”.

Jednak czasownik semimodalny decet (w znaczeniach pozamodalnych) sygnalizuje również diatezę nienacechowaną, dlatego może przybierać obie wartości kategorii liczby (tj. zarówno singularis jak i pluralis):

Istuc facinus [...] nostro generi non decet. (Pl., Amph. 820)

"Taki czyn nie przystoi naszemu rodowi".

Deos decent opulentiae. (Pl., Trin. 490)

„Bogactwa odpowiednie są dla bogów".

Quem (= me) tenues decuere togae. (Hor., Epist. 1, 14, 32)

„Zdobily mnie zwiewne logi".

Arma decent umeros. (Stat., Theb. 9, 332)

„Zbroja zdobi barki”.

Z kolei czasownik libet często występuje w zdaniach względnych, w których zaimek względny (lub funkcjonalnie względny) w rodzaju nijakim stanowi człon zależny od elidowanego bezokolicznika. Konsekwencją tej elipsy stała się możliwość przyjmowania przez zaimek względny funkcji mianownikowego podmiotu i tym samym również wystąpienie nienacechowanej diatezy ( $w$ tym także $z$ czasownikiem libet $\mathrm{w}$ liczbie mnogiej), na co wskazuje ostatni z przytoczonych niżej przykładów:

Loquar libere quae volam et quae lubebit. (Pl., Truc. 212)

„Powiem bez skrępowania to, co będę chciala i będę miala ochotę (powiedzieć)".

Facite quod vobis lubet. (Ter., Adelph. 991)

„Róbcie, co wam się podoba (robić)".

Arma, viros, pecuniam, postremo quicquid animo lubet, sume, utere. (Sall., Iug. 110)

„Broń, ludzi, pieniądze, wreszcie czegokolwiek dusza zapragnie, bierz, używaj”.

Cetera item, quae cuique libuissent, dilargitus est. (Suet., Iul. 20)

"Tak samo hojnie udzielał pozostałych rzeczy, co tylko komuś się spodobalo".

Warto też zaznaczyć, że w czasach perfektywnych czasownik libet przyjmować może wartość zarówno activum, jak i passivum:

Vellem [...] plura Crasso libuisset scribere. (Cic., Brut. 163)

"Chciałbym, aby Krassus nabral ochoty pisać więcej”.

Libitum est vobis me ad haec inpellere. (Cic., Leg. 2,69)

"Spodobało się wam zachęcić mnie do tego".

Wartością 3. os. i sygnalizowaniem diatezy niepodmiotowej charakteryzują się zwykle (choć nie w każdym przypadku) także czasowniki: pigere, pudere, paenitere, taedere, a więc tzw. verba affectuum (więcej na ich temat zob. 7.5.3.2. pkt. 3). 
Wreszcie istnieją czasowniki, dla których selektywność kategorii osoby, ustalona na wartości 3. os., ma charakter ograniczony i sprzężona jest z przyjęciem umożliwiającej sygnalizowanie diatezy niepodmiotowej wartości passivum w ramach kategorii strony:

Sic itur ad astra. (Verg., Aen. 9, 641)

"Tak idzie się do gwiazd".

Aliter $[. .$.$] cum tyranno, aliter cum amico vivitur. (Cic., Lael. 90)$

„Inaczej żyje się z tyranem, inaczej z przyjacielem”.

Na temat wartości kategorii osoby czasownikowego orzeczenia odnoszącego się do kilku podmiotów zróżnicowanych co do kategorii osoby zob. niżej, Składnia 3.3.1.2.

\subsection{LICZBA (NUMERUS)}

Liczba czasownika, podobnie jak osoba, jest kategorią gramatyczną o charakterze fleksyjnym, syntaktycznie zależnym (determinowanym), nienominatywnym (tekstowym, semantycznie pustym). W odniesieniu do form finitywnych (osobowych) determinowana jest przez wartość kategorii liczby rzeczownikowego podmiotu, stanowiąc drugą - obok kategorii osoby - podstawę składniowego związku kongruencji predykatywnej. Oparta jest na dwuczłonowej opozycji: singularis (liczba pojedyncza) - pluralis (liczba mnoga). Swój formalny wykładnik znajduje w czasownikowej końcówce fleksyjnej (osobowej), będącej nośnikiem informacji zarówno o wartości kategorii liczby, jak i osoby oraz strony.

Populus [...] inopia urgebatur. (Sall., Iug. 41)

"Lud byl nękany przez niedostatek".

Milites [...] aggerem latum pedes trecentos triginta, altum pedes octoginta exstruxerunt. (Caes., Gall. 7, 24)

„Żołnierze zbudowali wał oblężniczy długi na trzysta trzydzieści stóp, wysoki na osiemdziesiąl stóp".

W przypadku form fleksyjnych analitycznych (opisowych) wartość kategorii liczby sygnalizowana jest także przez końcówkę fleksyjną składnika imiesłowowego, która dodatkowo uwględnia również wartość kategorii rodzaju i przypadka rzeczownikowego (podmiotowego) nadrzędnika:

Aristides $[\ldots]$ exilio decem annorum multatus est. (Nep., Arist. 1, 3)

"Arystydes zostal ukarany wygnaniem dziesiçciu lat (dziesięcioletnim)".

Legati ad Fabium consulem missi sunt. (Liv., 9, 41)

„Posłowie zostali wyslani do konsula Fabiusza". 


\section{Pisonis $[. .$.$] praeclara vox a te [. .$.$] iure laudata est. (Cic., Phil. 12, 14)$}

"Znakomita mowa Lucjusza Pizona słusznie została przez ciebie pochwalona".

Jeśli osobowa forma czasownika implikuje niepodmiotową diatezę zdaniową lub jeśli miejsce otwierane przez nią dla podmiotu wypełniane jest przez zdanie podrzędne podmiotowe albo równoważnik podrzędnego zdania podmiotowego (accusativus cum infinitivo), forma ta przybiera wartość singularis:

Sic itur ad astra. (Verg., Aen. 9, 641)

"Tak idzie się do gwiazd".

Di utrum sint necne sint quaeritur. (Cic., Nat. 3, 17)

„Poszukuje się (odpowiedzi na pytanie), czy bogowie istnieją, czy też nie”.

Placet Stoicis $[. .$.$] ad usum hominum omnia creari. (Cic., Off. 1, 22)$

„Odpowiada stoikom (pogląd), że wszystko tworzone jest na użytek ludzi".

$\mathrm{Na}$ temat szczególnych zasad doboru wartości kategorii liczby czasownikowego orzeczenia zob. niżej, Składnia 3.3.1.2.

$\mathrm{Na}$ temat kategorii liczby form nieosobowych (participium, infinitivus, gerundium, supinum) zob. niżej, rozdz. 12.8 .

\subsection{FINITYWNOŚĆ}

Finitywność jest kategorią morfologiczną czasownika o charakterze fleksyjnym i funkcji wewnątrztekstowej polegającej na sygnalizowaniu pozycji syntaktycznej czasownika. Podstawowa opozycja w ramach tej kategorii to: verbum finitum (forma osobowa) - verbum infinitum (forma nieosobowa).

Wartość verbum finitum sygnalizuje użycie leksemu czasownikowego $\mathrm{w}$ jego prymarnej funkcji składniowej, tj. w funkcji orzeczenia. W zakresie verbum infinitum czasownik laciński dysponuje czterema wartościami: participium, infinitivus, gerundium, supinum. Przyjęcie którejś z wartości verbum infinitum sygnalizuje użycie leksemu czasownikowego w sekundarnej dla niego funkcji składniowej. A zatem kategoria finitywności czasownika stanowi morfologiczny środek umożliwiający czasownikowi sekundarną dystrybucję składniową i tym samym odpowiada funkcjonalnie kategorii przypadka rzeczownika: verbum finitum jest odpowiednikiem casus rectus (nominatiwu), zaś formacje verbi infiniti odpowiadają casus obliqui (przypadkom zależnym).

Formalne wykładniki poszczególnych wartości verbi infinitivi mają charakter złożony, tematyczno-(derywacyjno-)sufiksalny, tzn. wykładnikami tymi są określone alternanty tematyczne (derywacyjne) danego leksemu czasownikowego oraz określone sufiksy. Oba te wykładniki cechują się charakterystycznymi właściwościami morfotaktycznymi (dystrybucyjnymi). Wśród formacji reprezentujących tak verbum finitum jak i poszczególne wartości verbi infiniti znajdują się zarówno syntetyczne jak i analityczne wyrazy gramatyczne. 


\subsubsection{Participium}

Participium jest syntetyczną formacją morfologiczną umożliwiającą leksemom czasownikowym pełnienie funkcji atrybutywnych (przydawkowych), a więc tych, które są prymarnymi funkcjami przymiotników. $Z$ tego względu formacje te charakteryzują się formalnymi (końcówkowymi) wykładnikami fleksyjnych kategorii liczby, rodzaju i przypadka, na których opiera się związek kongruencji atrybutywnej. Kategorie te mają dla participium charakter kategorii syntaktycznie zależnych (zdeterminowanych), semantycznie pustych, identyfikujących jedynie człon nadrzędny związku atrybucji, który współtworzą zajmując w jego ramach pozycję członu zależnego od rzeczownikowego nadrzędnika:

Fugientem consulem vix quinquaginta secuti sunt. (Liv., 22, 50)

„Za uciekającym konsulem poszło zaledwic pięćdziesięciu (ludzi)”.

Depulsi ab iugo Romani non ante restiterunt quam in planiorem vallem perventum est. (Liv., 33, 7)

„Odepchnięci od wierzcholka Rzymianic nie wcześniej stawili opór, aż walka przesniosła się na równiejszy teren $w$ dolinie".

Podobnie jak przymiotniki, participia mogą ulegać substantywizacji. Status ich nominalnych kategorii fleksyjnych jest wówczas identyczny jak u rzeczowników. Wartość masculinum i femininum kategorii rodzaju sygnalizuje osobowe desygnaty, wartość neutrum zwykle desygnaty nieosobowe:

Navigantibus moveri videntur quae stant. (Cic., Div. 2, 120)

„Żeglującym wydają się poruszać rzeczy, które stoją (nieruchomo na brzegu)".

Ducunt volentem fata, nolentem trahunt. (Sen., Lucil. 107, 11)

„Przeznaczenie prowadzi tego, kto poddaje się jego woli, zaś kogoś, kto nie chce mu się poddać, wlecze na silę".

Praeterita mutare non possumus. (Cic., Pis. 59)

„Minionych rzeczy nie możemy zmienić”.

Pugnantia te loqui non vides? (Cic., Tusc. 1, 13)

„Nie widzisz, że mówisz rzeczy stojące z sobą w sprzeczności?”

Calamitosus est animus futuri anxius et ante miserias miser, qui sollicitus est ut ea, quibus delectatur, ad extremum usque permaneant; nullo enim tempore conquiescet et expectatione venturi praesentia, quibus frui poterat, amittet. (Sen., Lucil. 98, 6)

„Biedny jest umysł niepokojący się tym, co ma nastąpić, i jeszcze przed nadejściem nieszczęścia nieszczęśliwy jest ktoś, kto kłopocze się, by to, co sprawia mu radość, trwalo aż do końca jego dni; nigdy bowiem nie zazna on spokoju, i wskutek oczekiwania na to, co ma nadejsć, straci sposobność korzystania z tego, co przynosi bieżąca chwila".

Participia różnią się jednak od leksemów przymiotnikowych tym, że uwzględniają jeszcze dwie werbalne kategorie morfologiczne, a mianowicie czas i stronę. Wykładniki tych kategorii mają charakter skumulowany i złożony. Są nimi: 1) okre- 
ślony alternant tematyczny (derywacyjny) danego leksemu czasownikowego, oraz 2) określony sufiks.

Gramatyczna kategoria czasu participium wyraża czas względny. Kategoria ta ma trzy wartości:

1. perfectum - wyrażające uprzedniość,

2. praesens - wyrażające równoczesność,

3. futurum - wyrażające następczość.

Gramatyczna kategoria strony participium sygnalizuje diatezę, czyli sposób ujawnienia (składniowe uporządkowanie wykładników) argumentów predykatu, reprezentowanego przez to participium. Kategoria ta, podobnie jak w przypadku form osobowych, ma dwie wartości: activum (strona czynna) i passivum (strona bierna).

Chociaż struktura wartości obu tych kategorii gramatycznych participium (tj. czasu i strony) potencjalnie pozwala na wytworzenie sześcioelementowego systemu opozycyjnego, to jednak system łacińskich participiów - ze względu na obie te kategorie - tworzy tylko czteroelementową sieć opozycyjną, złożoną z:

a. participium praesentis activi,

b. participium perfecti passivi,

c. participium futuri activi,

d. participium futuri passivi, zwanego gerundivum.

Nie zostały zatem zaktualizowane wartości: praesentis passivi i perfecti activi. Tym samym formacje participium tworzą bezpośrednią opozycję morfologiczną ze względu na kategorię strony tylko w zakresie futurum (part. fut. act. - part. fut. pass.: laudaturus 'mający chwalić' - laudandus 'mający być chwalonym'), tj. tylko wtedy, gdy ze względu na kategorię czasu nacechowane są równocześnie wartością futurum. Dwie pozostałe formacje participium tworzą ze względu na kategorię strony opozycję pośrednią (part. praes. act. - part. perf. pass.: laudans 'chwalący' - laudatus 'pochwalony').

Z kolei ze względu na kategorię czasu system łacińskich participiów obejmuje dwie pary formacji pozostających względem siebie $w$ bezpośredniej opozycji morfologicznej. Jedną z nich tworzą part. praes. act. i part. fut. act., zaś drugą part. perf. pass. i part. fut. pass. Kategoria ta ograniczona jest zatem do dwu dwuczłonowych opozycji o wartościach: praesentis - futurum (dla wartości activum w ramach kategorii strony: laudans - laudaturus) oraz perfectum - futurum (dla wartości passivum w ramach kategorii strony: laudatus - laudandus).

Prymarną funkcją wartości activum kategorii strony participiów jest sygnalizowanie diatezy nienacechowanej czynnej, w której pierwszy argument predykatu reprezentowanego przez to participium ujawniany jest w zdaniu przez składnik imienny syntaktycznie nadrzędny (akomodujący) względem tego participium. Por. np.:

Fugientem consulem vix quinquaginta secuti sunt. (Liv., 22, 50)

"Za uciekającym konsulęm poszto zaledwie pięćdziesięciu (ludzi)”. 
Senones Galli multitudine ingenti ad Clusium venerunt legionem Romanam castraque oppugnaturi. (Liv., 10, 26)

„Senonowie galliccy w wielkiej liczbie podeszli pod Kluzjum, chcąc zaatakować rzymski legion i obóz".

Z kolei prymarną funkcją wartości passivum kategorii strony participiów jest sygnalizowanie diatezy nacechowanej biernej, w której pierwszy argument predykatu reprezentowanego przez to participium ujawniany jest $w$ zdaniu przez składnik imienny syntaktycznie podrzędny względem tego participium, występujący w ablatiwie ( $\mathrm{z}$ przyimkiem $a b$ ) lub $\mathrm{w}$ datiwie, albo nie jest ujawniany $\mathrm{w}$ ogóle. Por. np.:

Haec in philosophia ratio [...], repetita ab Arcesila, confirmata a Carneade, usque ad nostram viguit aetatem. (Cic., Nat. 1, 11)

„Ten sposób uprawiania filozofii [...], podjęty na nowo przez Arkesilaosa, ugruntowany przez Karneadesa, cieszy się powodzemiem do dnia dzisiejszego".

Puella $[. .$.$] amata nobis quantum amabitur nulla. (Catull. 8, 4-5)$

"Dziewczyna kochana przeze mnie tak, jak nie będzie kochana żadna inna”.

Volsci $[\ldots]$ certamine victi fuga effusa Satrici moenia petunt. (Liv., 7, 27)

„Wolskowie pokonani w potyczce w masowej ucieczce zmierzają ku murom Satrykum".

Maiores nostros [...] non [...] venerandos a nobis et colendos putatis? (Cic, Leg. Agr. 2, 95)

„Czy nie sądzicie, że przodkowic nasi powinni być czczeni przęz nas i poważani?”

Ceasar neque iam sibi legatos audiendos neque condiciones accipiendas arbitrabatur. (Caes., Gall. 4, 13)

„Cezar uważal, że przez niego nie powinni już być ani posłowic wysluchiwani, ani warunki przyjmowane".

Satis ad Gallicam ostentationem minuendam militumque animos confirmandos factum existimans in Haeduos movit castra. (Caes., Gall. 7, 53)

„Uznając, że wystarczająco wiele już uczyniono, by galijska chełpliwość zostala ukrócona, a duch bojowy żolnierzy wzmocniony, ruszył do kraju Eduów".

Jednak participia perfecti passivi deponentiów i semideponentiów sygnalizują diatezę nienacechowaną (czynną). Nie mają one bezpośrednich odpowiedników w języku polskim, w związku z tym sens takiego imiesłowu, jak np. hortatus (od hortor, -ari, -atus sum) mogą oddać wyrażenia typu 'zachęciwszy', 'po tym jak zachęcił', 'taki, który zachęcil' itp. (nigdy zaś: 'zachęcony'). Por. np.:

Sabinus suos hortatus cupientibus signum dat. (Caes., Gall. 3, 19)

"Sabinus zachęciwszy swoich (żołnierzy do walki), pełnym już zapału daje sygnał do walki".

Habetis ducem memorem vestri, oblitum sui. (Cic., Catil. 4, 19)

"Macie wodza, który pamięta o was, a zapomnial (= nie myśli) o sobie".

(Belgae) paulisper apud oppidum morati agrosque Remorum depopulati $[. .$.$] ad castra$ Caesaris omnibus copiis contenderunt. (Caes., Gall. 2, 7) 
„(Belgowie), zatrzymawszy się na krótko pod miastem i spustoszywszy ziemie Remów, ze wszystkimi swoimi siłami podąyyli ku obozowi Cezara".

(Atticus) idoneum tempus ratus studiis obsequendi suis Athenas se contulit. (Nep., Att. 2)

"(Attyk), uznawszy czas za odpowiedni do zajęcia się swoimi studiami, wyjechal do Aten”.

Is finis Bucari sequendi fuit, nec ingredi flumen auso, nec habere credenti se iam quem sequeretur. (Liv., 9, 32)

„Na tym zakończył się pościg dla Bukara, który ani nie odważył się wejść do rzeki, ani nie wierzyl, że ma jeszcze kogo ścigać".

Rex tot hominum salute tam sibi necessariorum magnopere gavisus confestim cum epistula Artabazum ad Pausaniam mittit. (Nep., Paus. 2)

„Król bardzo ucieszywszy się z powodu ocalenia tak wielu tak bliskich mu ludzi, natychmiast wyslat do Pauzaniasza Artabazosa z listem".

Participia futuri passivi (gerundiva) tych czasowników sygnalizują natomiast diatezę nacechowaną bierną. Dotyczy to deponentiów przechodnich, czyli tych, które $\mathrm{w}$ formach osobowych wymagają dopełnienia w accusatiwie, a także takich jak: utor, fruor, fungor i vescor, które wymagają dopełnienia w ablatiwie. Por. np.:

(Vercingetorix) Rutenos Cadurcosque ad fines Volcarum Arecomicorum depopulandos mittit. (Caes., Gall. 7, 64)

„Wercyngetoryks wysłal Rutenów i Kadurków do kraju Wolków Arekomickich, aby go spustoszyli (dosł.: do kraju mającego zostać spustoszonym)".

Maiores nostros [...] non [...] venerandos a nobis et colendos putatis? (Cic, Leg. Agr. 2, 95)

„Czy nie sądzicie, że przodkowie nasi powinni być czczeni przez nas i poważani?"

(Caesar) in praesentia Pompei sequendi rationem omittit. (Caes., Civ. 1, 30)

„(Cezar) na chwilę obecną zarzuca zamiar ścigania Pompejusza (dost.: Pompejusza mającego być ściganym)".

Equidem ecastor tuam nec chlamydem do foras nec pallium cuiquam utendum. (PI., Men. 658-659)

„Ja, na Kastora, ani twojej chlamidy nie daję w obce ręce, ani twojego plaszcza nie użyczam nikomu do użytku (dosł.: nie użyczam nikomu twojego plaszcza jako mającego być (przez niego) używanym)".

Quam est hic fortunatus putandus [...], qui inperia consulatusque nostros muneris fungendi gratia subeundos, non praemiorum aut gloriae causa adpetendos putet? (Cic., Rep. $1,27)$

„Za jak bardzo szczęśliwego trzeba uważać tego, który jest przekonany, że nasze dające władzę funkcje i konsulaty należy obejmować z uwagi na konieczność spełnienia obowiązku (dost.: $\mathrm{z}$ uwagi na obowiązek mający być spełnionym), a nie ubiegać się o nie dla nagród i slawy".

Poza tym deponentia i semideponentia posiadają w swym paradygmacie obydwa participia aktywne, tj. participium praesentis activi i participium futuri activi, które również w ich przypadku sygnalizują diatezą nienacechowaną (czynną), a więc np: 
- hortans 'zachęcający'; hortaturus 'mający zachęcać';

- sequens 'ścigający, podążający za (kimś/czymś)'; secuturus 'mający ścigać, podążać za (kimś/czymś)';

- utens 'używający'; usurus 'mający używać':

Lentulus [...] ad L. Manlium inter prima signa hortantem ac subsidia, quibus res postulabat locis, inducentem venit. (Liv., 29, 2)

„Lentulus przybył do Lucjusza Manliusza zagrzewającego (żołnierzy do walki) wśród pierwszych oddziałów i wprowadzającego wojska posiłkowe wszędzie tam, gdzie wymagała tego sytuacja".

Zeno $[. .$.$] Socraten [. .$.$] Latino verbo utens scurram Atticum fuisse dicebat. (Cic., Nat. 1$, 93)

„Zenon posługując się łacińskim wyrażeniem powiadał, że Sokrates był attyckim błaznem”.

Subito [...] Alexandrinae neves apparuerunt, quae praemitti solent et nuntiare secuturae classis adventum. (Sen., Lucil. 77, 1)

„Nagle pojawiły się aleksandryjskie stalki, które zwykle wysyłane są naprzód i zapowiadają przybycie mającej za nimi podązać floty".

Philippus [...] sub tumulo in proxima planitie consedit, prima luce indequentis diei hostem adgressurus. (Liv., 31, 42)

„Filip usadowił się pod pagórkiem na najbliższej równinie, zamierzając zaatakować wroga o świcie następnego dnia".

A zatem selektywny charakter kategorii strony form osobowych deponentiów i semideponentiów nie ogranicza zasobu tworzonych przez nie participiów: deponentia i semideponentia tworzyć mogą wszystkie participia, zarówno pasywne jak i aktywne. Jednak diateza sygnalizowana przez participium perfecti passivi jest diatezą nienacechowaną (czynną), a sygnalizowana przez participium futuri passivi jest diatezą nacechowaną (bierną). Wskutek tego trzy participia tych czasowników (tj. praesentis activi, futuri activi i perfecti passivi) sygnalizują diatezę nienacechowaną, która w ten sposób skorelowana jest ze wszystkimi wartościami kategorii czasu, natomiast tylko jedno participium (futuri passivi) sygnalizuje diatezę nacechowaną, która skorelowana jest $\mathrm{z}$ czasem przyszłym. Tym samym diateza nienacechowana nie jest już w przeciwieństwie do form osobowych - diatezą obligatoryjną (jedyną) w systemie participiów deponentiów, lecz jest diatezą preferowaną.

Jednak należy pamiętać, że participia perfecti niektórych deponentiów, oprócz diatezy nienacechowanej (czynnej), mogą wyrażać także diatezę nacechowaną (bierną), np.:

- adeptus (od adipiscor) - 'osiągnięty', obok: 'osiągnąwszy';

- expertus (od experior) - 'znany, wypróbowany', obok: 'taki, który poznał coś, jest doświadczony w czymś;

- meditatus (od meditor) - 'obmyślony', obok: 'obmyśliwszy';

- ultus (od ulciscor) - 'pomszczony', obok: 'pomściwszy'. 
Wyłącznie nacechowaną diatezę sygnalizuje imiesłów testatus (od testor) 'poświadczony'.

Z kolei diatezę nienacechowaną (obok nacechowanej) mogą wyrażać participia perfecti niektórych czasowników o fleksyjnym charakterze kategorii strony (a więc nie będących (semi)deponentiami), np.:

$\rightarrow$ potus (od bibo) - 'wypiwszy',

- cenatus (od ceno) - 'zjadłszy obiad',

- pransus (od prandeo) - 'zjadłszy śniadanie',

- iuratus (od iuro) - 'złożywszy przysięgę,'

- adultus (od adolesco) - 'stawszy się dorosłym',

- cautus (od caveo) - 'zabezpieczywszy się.

Ze względu na swe właściwości semantyczne, związane z dewerbalnym pochodzeniem, użyte przydawkowo (atrybutywnie) participia mogą stanowić semantyczne odpowiedniki orzeczeń zdań podrzędnych okolicznikowych. Użycie participium, cechujące się taką właśnie charakterystyką semantyczną, nazywane jest participium coniunctum:

Ut oculus, sic animus se non videns alia cernit. (Cic., Tusc. 1, 67)

"Jak oko, tak i dusza, nie widząc (= chciaż nie widzi) siebie, dostrzega (jednak) inne rzeczy”.

Consul Larisam est profectus, ibi de summa belli consultaturus. (Liv., 36, 14)

„Konsul wyruszył do Larysy, zamierzając tam odbyć naradę (= aby odbyć naradę) nad ogólem spraw dotyczących wojny".

Ne mente quidem recte uti possumus multo cibo et potione completi. (Cic., Tusc. 5, 100)

„Nawet nie możemy wlaściwie posługiwać się umysłem, przepełnieni (= jeśli jesteśmy przepelnieni) wielką ilością jedzenia i picia".

Specyficznym rodzajem participium coniunctum jest wystąpienie participium $\mathrm{w}$ ramach konstrukcji składniowej zwanej ablativus absolutus. W strukturze tej participium jest określnikiem wyrażonego w ablatiwie składnika imiennego, który nie jest implikowany przez strukturę składniową zdania i nie jest członem syntaktycznym zależnym od jakiegokolwiek składnika zdania, lecz wpółtworzy (wraz z participium) grupę imienną stanowiącą pod względem semantycznym złożony określnik orzeczenia o charakterze okolicznikowym. Określnikowi temu można przypisać status równoważnika zdania okolicznikowego, $w$ którym składnik imienny pełni rolę funkcjonalnego odpowiednika podmiotu, a związane $\mathrm{z}$ nim związkiem atrybucji participium rolę funkcjonalnego odpowiednika orzeczenia. Zastosowanie participium w tej funkcji ograniczone jest głównie do participium praesentis i participium perfecti:

Hostes abiectis armis terga verterunt. (Caes., Gall. 4, 37)

„Wrogowie porzuciwszy broń (dosł.: gdy broń zostala (przez nich) porzucona) rozpoczynaja ucieczkę".

Maximas [...] virtutes iacere omnis necesse est voluptate dominante. (Cic., Fin. 2, 117)

„Nieunikniony jest upadek wszystkich największych cnót, jeśli rządzi rozkosz”. 
Participia futuri, oprócz czasu i diatezy, wyrażają zwykle także pewne nacechowanie modalne o charakterze deontycznym (bądź dynamicznym). I tak participium futuri activi implikuje modalność związaną z pojęciem:

1. Konieczności, nieuchronności (zdarzenia, czynności):

Cocles $[\ldots]$ in Tiberim desiluit multisque superincidentibus telis incolumis ad suos tranavit, rem ausus plus famae habituram ad posteros quam fidei. (Liv., 2, 10)

„Kokles skoczył do Tybru i mimo wielu spadających za nim pocisków bez szwanku dopłynął do swoich, odważywszy się na czyn, który wśród potomnych mial zyskać więcej sławy niż wiary".

(Iugurtha), postquam Roma egressus est, fertur [...] dixisse: 'urbem venalem et mature perituram, si emptorem invenerit'. (Sall., lug. 35)

"(Jugurta) po tym, gdy opuścil Rzym, powiedział ponoć: 'O, miasto sprzedajne i skazane na rychłą zgubę, jeśli tylko znajdzie kupca"'.

2. Zamiaru, chęci (działania):

C. Caesar adversus Pharnacem [...] dimicaturus in colle instruxit aciem. (Frontin., Strat. $2,2,3)$

„Gajusz Cezar, zamierzając stoczyć walkę z Farnakesem, ustawił na wzgórzu oddział w szyku bojowym".

3. Zdolności, dyspozycji, gotowości (do działania):

Quia ex tam propinquis stativis parum tuta frumentatio erat, dispersos milites per agros equitibus extemplo invasuris, $[\ldots]$ castra ad Ottolobum $[\ldots]$ movit. (Liv., 31, 36)

„Ponieważ z uwagi na bliskość kwater (nieprzyjaciół) zaopatrywanie się w żywność nie było wystarczająco bezpieczne, jako że rozproszonych po polach żołnierzy mogla znienacka zaatakować konnica, przeniósł obóz po miejscowość Ottolobos".

Z kolei modalność sygnalizowana przez participium futuri passivi (gerundivum) implikuje powinność bądź zobowiązanie, najczęściej ujęte jako cel czy intencja czyjegoś działania:

Cassius [...] Minucium libertis tradidit excruciandum. (Ps.-Caes., Bell. Allex. 55)

„Kasjusz wydał Minucjusza wyzwoleńcom na tortury (tj. wydal jako tego, który mial być torturowany)".

Pecuniam Staieno dedit Oppianicus [...] ad corrumpendum iudicium. (Cic., Cluent. 84) „Oppianikus dał Stajenusowi pieniądze na przekupienie sądu ( $\mathrm{tj}$. dał pieniądze na sąd, który mial być przekupuiony)".

Nacechowanie modalne participium futuri passivi ulega jednak często neutralizacji, podobnie jak jego charakterystyka temporalna; semantycznie zbliża się ono wtedy do rzeczownika odsłownego:

A rebus gerendis senectus abstrahit. (Cic., Sen. 15)

„Starość odstręcza od zajmowania się bieżącymi sprawami”. 
M. $[\ldots]$ Scaurus [...], vir regendae rei publicae scientissimus, si audierit hanc auctoritatem gravitatis et consilii sui vindicari a te [...], huc veniat et hanc loquacitatem nostram vultu ipso aspectuque conterreat. (Cic., De orat. 1, 214)

„Marek Skaurus, czlowiek doskonale znający się na rządzeniu państwem, gdyby usłyszal, że rościsz sobie pretensje to tego autorytetu, który wynika z jego powagi i rozsądku, przybyłby tu i tę naszą gadatliwość pohamowałby samym wyrazem twarzy".

Quem ceperant exsules montem [...] pecori bonus alendo erat. (Liv., 29, 31)

„Góra, którą zajęli wygnańcy, dobrze się nadawała do wypasu bydka”.

Oprócz pełnienia funkcji atrybutywnej w grupie imiennej participia mogą także sekundarnie stanowić składnik orzeczenia, a więc mogą być użyte predykatywnie. Występują wtedy w nominatiwie, a funkcję łącznika pełnią zazwyczaj osobowe formy czasownika esse. Szczególna rola przypada w tym względzie participium perfecti passivi, współtworzącemu analityczne formy fleksyjne reprezentowanego przez siebie leksemu. Za pośrednictwem predykatywnie użytych patricipiów sygnalizowane mogą być wszystkie podstawowe rodzaje diatez. Syntaktyczne uporządkowanie wyrażeń argumentowych konotowanych przez predykatywnie użyte participia na ogół zgodne jest $\mathrm{z}$ uporządkowaniem odpowiadającym poszczególnym diatezom sygnalizowanym przez formy osobowe reprezentowanych przez te participia czasowników.

I tak, diateza nienacechowana czynna sygnalizowana jest przez predykatywnie użyte:

1. Participia praesentis activi:

Istae imagines ita nobis dicto audientes sunt, ut, simul atque velimus, accurrant? (Cic., Div. 2, 138)

„Czy te obrazy tak są nam na słowo posluszne, że przybiegają, jak tylko sobie tego zażyczymy?"

2. Participia perfecti passivi czasowników należących do klasy verba deponentia lub semideponentia; participia te współtworzą wówczas analityczne formy fleksyjne czasowników tych klas:

Usus est Thrasybulus non minus prudentia quam fortitudine. (Nep., Thras. 2)

„Trazybulos poslużyl się rozwagą w nic mniejszym stopniu niż odwagą".

Tu apud patres conscriptos contra me dicere dicere ausus es. (Cic., Phil. 2, 51)

„Wobec senatorów odważyleś się przemawiać przeciwko mnie”.

3. Participia futuri activi; zastosowanie tego participium $\mathrm{w}$ funkcji orzecznikowej tradycyjnie określane jest terminem coniugatio periphrastica activa; wiąże się $\mathrm{z}$ nim podobne jak $\mathrm{w}$ przypadku użycia atrybutywnego nacechowanie modalne oparte na pojęciu:

- konieczności, nieuchronności (zdarzenia, czynności):

Iam lituus pugnae signa daturus erat. (Ov., Fast. 3, 216)

"Już trąbka miala dać sygnal do walki". 
- zamiaru, chęci (działania):

Non estis cenaturi? (Pl., Merc. 750)

„Nie zamierzacie jeść kolacji?”

- zdolności, dyspozycji, gotowości (do działania)

Ad quem (scil. tumulum) capiendum si luce palam iretur, [...] haud dubie hostis breviore via praeventurus erat. (Liv., 22, 24)

„Gdyby wyruszono zdobyć wzgórze za dnia, bez wątpienia przeciwnik dotarłby / byłby gotów / zdolny dotrzeć tam wcześniej, mając (do niego) krótszą drogę".

Diatezę nacechowaną bierną sygnalizują użyte predykatywnie:

1. Participia perfecti passivi przechodnich czasowników niedeponencjalnych, współtworząc analityczne formy fleksyjne reprezentowanych przez siebie leksemów czasownikowych:

Ad Voleronem Publilium [...] lictor missus est a consulibus. (Liv., 2, 55)

„Do Wolerona Publiliusza zostal wyslany przez konsulów liktor".

2. Participia futuri passivi przechodnich czasowników niedeponencjalnych i deponencjalnych, współtworząc typ orzeczenia zwany coniugatio periphrastica passiva, przy którym wykładnik pierwszego argumentu (jeśli jest aktualizowany powierzchniowo) przyjmuje zwykle formę wyrażenia imiennego $w$ datiwie (auctoris), a nie w ablatiwie (jak to ma najczęściej miejsce w przypadku innych orzeczeń sygnalizujących tę diatezę). Ponadto orzeczenie to nacechowane jest modalnie, implikując pojęcie powinności, zobowiązania lub konieczności:

Caesari omnia uno tempore erant agenda. (Caes., Gall. 2, 20)

„Wszystkie rzeczy musiały być prowadzone przez Cezara w jednym czasie".

Voluntas ipsa rectum petens laudanda est. (Sen., Benef. 5, 2, 2)

"Sama chęć zmierzająca ku dobru powinna być chwalona".

Illi auctores sequendi sunt, qui [...] legatum in Etruria fuisse Africanum tradunt. (Liv., 38,56 )

„Powinni być respektowani (przy ustalaniu historycznej prawdy) ci autorzy, którzy przekazują, że (Scypion) Afrykański był legatem w Etrurii".

Diateza nacechowana niepodmiotowa sygnalizowana jest przez użyte predykatywnie oba participia pasywne czasowników (występujących w znaczeniach) nieprzechodnich. Participia te mają wówczas formę mianownika liczby pojedynczej rodzaju nijakiego, a współtworząca $\mathrm{z}$ nimi orzeczenie forma czasownika esse obligatoryjnie wyraża wartość 3 . osoby liczby pojedynczej. Jak zatem zaznaczono wyżej, imiesłowowymi wykładnikami głównych treści predykatywnych orzeczeń sygnalizujących diatezę niepodmiotową mogą być:

1. Participia perfecti passivi, współkonstytuując analityczne formy fleksyjne reprezentowanych przez siebie leksemów czasownikowych: 
Regio $[\ldots]$ abscessum est. (Liv., 24, 1)

„Odstąpiono od (miasla) Regium".

Apollinem tam humilis victoriae puditum est. (Apul., Flor. 3, 46)

"Apollinowi wstyd było tak haniebnego zwycięstwa".

2. Participia futuri passivi, współkonstytuując typ orzeczenia znany jako (niepodmiotowa) coniugatio periphrastica passiva; podobnie jak w przypadku, gdy participia te współtworzą orzeczenie sygnalizujące diatezę bierną, pierwszy argument predykatu, jeśli jest ujawniany, znajduje swój wykładnik w postaci wyrażenia imiennego $\mathrm{w}$ datiwie (auctoris); $\mathrm{z}$ orzeczeniem tym również związane jest nacecechowanie modalne oparte na pojęciu powinności, zobowiązania lub konieczności:

Militibus $[\ldots]$ simul de navibus desiliendum et in fluctibus consistendum et cum hostibus erat pugnandum. (Caes., Gall. 4, 24)

„Żołnierze musieli równocześnie wyskoczyć $z$ okrętów, ustawić się w wodzie i walczyć z nieprzyjaciółmi".

Hic vincendum aut moriendum, milites, est. (Liv., 21, 43)

„Tutaj, żołnierze, trzeba (nam) zwyciężać albo umierać".

Valde enim invidendum est eius statuis, cuius tropaeis non invidemus. (Cic., Deiot. 34)

(iron.) „Rzeczywiście, należy patrzeć z wielką niechęcią na posąg tego, którego pomnik zwycięstwa nie budzi naszej niechęci".

Dla uniknięcia dwuznaczości wykładnikiem pierwszego argument predykatu może być wyrażenie imienne $w$ ablatiwie (z przyimkiem $a b$ ), jeśli inny argument ujawniany jest przez składnik imienny w datiwie:

Aguntur bona multorum civium, quibus est a vobis [...] consulendum (Cic., Manil. 6)

"Gra toczy się o majątki wielu obywateli, o kıóre musicie się zatroszczyć".

Wymagające dopełnienia w ablatiwie participia futuri passivi czasowników deponencjalnych utor i fruor, chociaż mogą być użyte atrybutywnie sygnalizując diatezę bierną (np.: Quae bona [...] huic Heraclio [...] omnia utenda ac possidenda tradiderat (Cic., Verr. 2, 2, 46) - „Dobra te wszystkie owemu Herakliuszowi przekazał do użytku i posiadania (dosł.: jako mające być użytkowane i posiadane)"), to jednak współtworzone przez nie orzeczenia (w ramach coniugatio periphrastica passiva) generalnie sygnalizują diatezę wyłącznie niepodmiotową:

Tuo tibi iudicio est utendum. (Cic., Tusc. 2, 63)

„Powinieneś kierować się twoim (własnym) osądem".

Quid est $[\ldots]$ in homine sagaci ac bona mente melius? Eius bono fruendum est igitur, si beati esse volumus. (Cic., Tusc. 5, 67)

"Cóż jest w' człowieku lepszego niż bystry i roztropny umyst? Z jego dobrodziejstwa należy więc korzystać, jeśli chcemy być szczęśliwi". 
Zachowując scharakteryzowane wyżej właściwości dotyczące sygnalizowania diatezy oraz modalności, participia mogą też stanowić orzeczniki w ramach orzeczeń tworzonych $z$ formami osobowymi czasowników innych niż esse, w tym jako imiesłowowe składniki (złożonych bądź analitycznych) bezokoliczników pełniących przy tych czasownikach funkcję orzeczników, często z elipsą posiłkowej formy esse. Szczególnie często tego typu imiesłowowe orzeczniki współtworzą orzeczenia $z$ formami osobowymi czasowników będących wykładnikami nacechowanej modalności epistemicznej:

L. Sisenna [...] parum mihi libero ore locutus videtur. (Sall., Iug. 95)

"Wydaje mi się, że Lucjusz Sisenna wypowiedzial się w sposób nie do końca bezstronny".

Quoniam famosae urbis supremum diem tradituri sumus, congruens videtur primordia eius aperire. (Tac., Hist. 5, 2)

„Ponieważ zamierzam przedstawić ostatnie chwile slawnego miasta, wydaje się czymś stosownym ukazać jego początki".

Magna Cn. Pompeio Iuba miserat auxilia maioraque missurus existimabatur. (Ps.-Caes., Bell. Alex. 51, 1)

„Juba wysłal Gnejuszowi Pompejuszowi duże oddziały posiłkowe i spodziewano się, że wyśle jeszcze większe".

Facis, ut rursus plebes in Aventinum sevocanda esse videatur. (Cic., Mur. 15)

„Sprawiasz, że plebs chyba znowu powinien zostać odwolany na Awentyn”.

Cuius consilium reprehendendum non videtur. (Caes., Civ. 3, 51)

"Nie wydaje się, by jego decyzję należało zganić".

Non praetereunda videtur oratio Critognati propter eius singularem ac nefariam crudelitatem. (Caes., Gall. 7, 77)

„Wydaje się, że nie może być pominięte milczeniem przemówienie Krytognatusa ze względu na jego wyjątkowe i niegodziwe okrucieństwo".

Festinandum ceteris videbatur. (Tac., Hist. 1, 33)

„Pozostałym (osobom) wydawalo się, że należy się spieszyć”.

Participia mogą też być wykładnikami głównych treści predykatywnych jako składniki lub orzecznikowe rozszerzenia bezokoliczników stanowiących funkcjonalne odpowiedniki orzeczeń w ramach równoważników zdań podrzędnych typu accusativus cum infinitivo:

Perditorum hominum coniurationem patefactam esse decrevistis. (Cic., Catil. 4, 5)

"Ogłosiliście, że spisek nikczemników zostal wykryty".

Reperti sunt duo equites Romani, qui [...] se illa ipsa nocte paulo ante lucem me [...] interfecturos esse pollicerentur. (Cic., Catil. 1, 9)

„Znalaźli się dwaj ekwici rzymscy, którzy obiecali, że tej wlaśnie nocy tuż przed świtem zamordują mnie". 
Z uwagi na możliwość elipsy posiłkowej formy esse, w niektórych przypadkach semantyka pozwala na przypisanie participium zarówno statusu konstytutywnego składnika funkcjonalnego odpowiednika orzeczenia, stanowionego przez infinitiwus ( $\mathrm{z}$ elipsą esse) w ramach równoważnika zdania (accusativus cum infinitivo), jak i statusu orzecznika, np.:

Civitas [...], si voce L. Crassi carebit, ornamento quodam se spoliatam putabit. (Cic., De orat. 144)

„Społeczeństwo, jeśli zostanie pozbawione możliwości słuchania głosu Lucjusza Krassusa, uzna się za ograbione z pewnego rodzaju klejnotu (uzna, że zostalo ugrabione z pewnego rodzaju klejnotu)".

Mortem Caesaris ulciscendam putat. (Cic., Phil. 13, 39)

„Uważa śmierć Cazara za godną pomszczenia. (Uważa, że śmierć Cezara powinna być pomszczona)".

Participium, głównie futuri passivi (gerundivum), może również stanowić konstytutywny składnik funkcjonalnego odpowiednika orzeczenia w ramach równoważnika podrzędnego zdania dopełnieniowego sygnalizującego diatezę niepodmiotową:

Est apud Platonem Socrates [...] dicens [...] sibi post tertium diem esse moriendum. (Cic., Div. 1, 52)

„Jest u Platona Sokrates mówiący, że za trzy dni będzie musial umrzeć".

Aratos ab love incipiendum putat. (Quint., Inst. 10, 1, 46)

„Aratos uważa, że należy zacząć od Jowisza”.

Caesar non exspectandum sibi statuit, dum [...] in Santonos Helvetii pervenirent. (Caes., Gall. 1, 11)

„Ceasar uznal, że nie powinien czekać, aż Helw'etowie dotrą do kraju Santonów”.

\subsubsection{Infinifivus}

Laciński infinitivus jest formacją morfologiczną umożliwiającą leksemom czasownikowym wypełnianie w strukturze składniowej zdania rzeczownikowych pozycji podmiotu bądź dopełnienia. Oprócz tego może pełnić rolę orzecznika, a także funkcjonalnego odpowiednika orzeczenia, zarówno w równoważnikach zdań niezależnych składniowo (jako tzw. infinitivus historicus), jak i w ramach równoważnika zdania podrzędnego, zwanego accusativus cum infinitivo. Może także współtworzyć niezdaniowe wyrażenia o funkcji ekspresywno-impresywnej (jako tzw. infinitivus exclamativus). Jego określniki mają charakter i status typowy dla czasowników, a więc są to przysłówkowe i rzeczownikowe okoliczniki, a także związane rekcją rzeczownikowe dopełnienia, zachowujące tę samą wartość kategorii przypadka, którą przyjmują w odniesieniu do form osobowych reprezentowanego przez infinitiwus leksemu czasownikowego. Jeśli jednak infinitiwus występuje w funkcji gramatycznego podmiotu lub dopełnienia, może być określany także przydawkami o charakterze przymiotnikowym. 
Infinitiwus, w zależności od struktury morfologicznej danej formacji, w różny sposób uwzględnia nominalne kategorie gramatyczne rodzaju, liczby i przypadka, przy czym paradygmat funkcjonalny tej ostatniej kategorii (przypadka), ze względu na zakres pełnionych przez infinitivus funkcji składniowych, ograniczony jest wyłącznie do wartości nominativus i accusativus. Poza tym infinitiwy uwzględniają jeszcze dwie werbalne kategorie morfologiczne, tj. czas i stronę.

Gramatyczna kategoria czasu infinitiwów wyraża czas względny. Ma ona trzy wartości:

1. praesens - wyrażające równoczesność,

2. perfectum - wyrażające uprzedniość,

3. futurum - wyrażające następczość.

Gramatyczna kategoria strony infinitiwu sygnalizuje diatezę, czyli sposób ujawnienia (składniowe uporządkowanie wykładników) argumentów predykatu reprezentowanego przez ten infinitiwus. Kategoria ta, podobnie jak w przypadku form osobowych oraz participiów, ma dwie wartości:

1. activum - strona czynna, sygnalizująca prymarnie diatezę nienacechowaną,

2. passivum - strona bierna, sygnalizująca prymarnie diatezę nacechowaną.

A zatem struktura wartości obu tych kategorii gramatycznych infinitiwu (tj. czasu i strony) pozwala na wytworzenie sześcioelementowego systemu opozycyjnego. I właśnie taką sześcioelementową sieć opozycyjną tworzy system łacińskiego infinitiwu. Na system ten składa się bowiem:

$\rightarrow$ infinitivus praesentis activi,

$\rightarrow$ infinitivus praesentis passivi,

- infinitivus perfecti activi,

- infinitivus perfecti passivi,

$\rightarrow$ infinitivus futuri activi,

- infinitivus futuri passivi.

Jednak struktura morfologiczna poszczególnych elementów tego systemu (czyli poszczególnych formacji infinitiwu), a co za tym idzie typologia formalnych wykładników wartości kategorii czasu i strony infinitiwów, jest zróżnicowana.

I tak oba infinitiwy praesentis oraz infinitiwus perfecti activi mają strukturę morfologiczną syntetycznych wyrazów gramatycznych. Formalnymi wykładnikami wartości kategorii czasu tych infinitiwów są odpowiednie alternanty tematyczne danych leksemów czasownikowych (praesentis/perfecti), zaś wykładnikami wartości kategorii strony są odpowiednie sufiksy. W zakresie nominalnych kategorii gramatycznych (liczby, rodzaju i przypadka) infinitiwy te cechują się defektywnym paradygmatem formalnym.

$\mathrm{Z}$ kolei infinitivus futuri activi i infinitivus perfecti passivi mają strukturę morfologiczną analitycznych wyrazów gramatycznych, złożonych $z$ odpowiedniego participium (futuri activi / perfecti passivi) tworzonego na bazie określonego (w obu przypadkach tego samego) alternantu tematycznego czasownika, oraz $\mathrm{z}$ infinitiwu praesentis czasownika (posiłkowego) esse. Formalne wykładniki wartości kategorii czasu i strony mają zatem w odniesieniu do tych formacji charakter skumulowany 
i złożony - tematyczno-sufiksalny. W związku z tym, że elementem składowym tych infintiwów jest participium, infinitiwy te posiadają także morfologiczne skumulowane wykładniki kategorii liczby rodzaju i przypadka w postaci końcówek deklinacyjnych, przyłączanych przez dane participia. Ich paradygmat formalny w zakresie nominalnych kategorii gramatycznych nie jest więc defektywny. Należy zaznaczyć, że posiłkowy składnik tych formacji, tj. bezokolicznik esse, dość często jest elidowany (pomijany na powierzchni).

Infinitivus futuri passivi jest również reprezentowany przez analityczny wyraz gramatyczny, na który składa się formacja złożona z tematu participii perfecti i sufiksu -um oraz formacja o postaci iri. Formalne wykładniki wartości kategorii czasu i strony mają tu zatem również charakter skumulowany i złożony, tematyczno-sufiksalny. W zakresie nominalnych kategorii gramatycznych (liczby, rodzaju i przypadka) paradygmat formalny tego infinitiwu jest defektywny.

Stanowiąc funkcjonalny odpowiednik rzeczownika, infinitivus może zajmować pozycję podmiotu lub dopełnienia. Jak już wspomniano wyżej, jego określnikiem może być zarówno przysłówkowy lub rzeczownikowy okolicznik, jak i przymiotnikowa przydawka, a także związane rekcją rzeczownikowe dopełnienie, zachowujące tę samą wartość kategorii przypadka, którą przyjmuje w odniesieniu do form osobowych reprezentowanego przez infinitiwus leksemu czasownikowego. Poza tym, jeśli infinitiwus występuje $w$ funkcji gramatycznego podmiotu zdania, określany jest przez orzeczenie. Podrzędne w stosunku do infinitiwu człony syntaktyczne, pozostające z nim w związku kongruencji (tj. przymiotnikowe przydawki i orzeczniki, a także orzeczenia), wskazują na jego nacechowanie liczbą pojedynczą, rodzajem nijakim oraz wartością nominativus lub accusativus - w zależności od zajmowanej pozycji składniowej. Użycie infinitiwów $w$ funkcji podmiotu lub dopełnienia, a więc $w$ funkcjach niepredykatywnych, służy przekazaniu determinowanej znaczeniem leksykalnym czasownika uogólnionej treści przedmiotowej, której diateza zależy od wartości kategorii strony infinitiwu i odpowiada diatezie sygnalizowanej przez nacechowane tą wartością formy osobowe reprezentowanego przez niego czasownika. Podane niżej przykłady ilustrują użycie infinitiwów $w$ funkcji:

a. podmiotu:

Urgere [...] iacentis aut praecipitantis impellere certe est inhumanum. (Cic., Rab. Post. 2)

„Deptać leżących albo popychać lecących w przepaść z pewnością jest czymś nieludzkim”.

Pulchrum est benefacere rei publicae. (Sall., Catil. 3, 1)

"Czymś pięknym jest wyświadczać przysługi państwu”.

Atqui vivere, Lucili, militare est. (Sen., Lucil. 96, 5)

„A przecież życie, Lucyliuszu, jest (jakby ciągłym) odbywaniem służby wojskowej”.

Quos omnis eadem cupere, eadem odisse, eadem metuere in unum coegit. (Sall., Iug. 31) „Ich wszystkich pragnienie tego samego, nienawiść do tego samego i strach przed tym samym polączyły w jedno". 
Timeri [...] tam domi molestum est quam foris, tam a servis quam a liberis. (Sen., Lucil. $105,4)$

„Bycie przedmiotem lęku jest uciążliwe tak w domu, jak i poza nim, i to zarówno ze strony niewolników, jak i ludzi wolnych".

a.1. Funkcjonalnego odpowiednika podmiotu w ramach równożnika zdania podrzędnego dopełnieniowego (accusativus cum infinitivo).

Hieronymus $[\ldots]$ censet summum bonum esse sine ulla molestia vivere. (Cic., Fin. 2, 16) „Hieronim uważa, że najwyższym dobrem jest życie bez żadnych przykrości”.

Praesidibus [...] rescripsit boni pastoris esse tondere pecus, non deglubere. (Suet., Tib. 32) „Zarządcom (prowincji) odpisał, że dobremu pasterzowi przystoi strzyc owce, a nie obdzierać (je) ze skóry".

b. Dopełnienia:

Beate $[\ldots]$ vivere $[\ldots]$ vos in voluptate ponitis. (Cic., Fin. 2,86 )

"Szczęśliwe życie wy pokladacie w rozkoszy".

Bene ferre magnam disce fortunam. (Hor., Carm. 1, 27, 74-75)

„Naucz się dobrze znosić powodzenie".

Nostrum illud vivere triste aspexi. (Pers., Sat. 1, 9-10)

„Spojrzałem na to nasze smutne życie”.

Avaritia [...] deos neglegere, omnia venalia habere edocuit. (Sall., Cat. 10)

"Chciwość nauczyła lekceważyć bogów, wszystkim kupczyć".

Indigne passus (est) senatus non cessari ab sacrilegiis. (Liv., 31, 12)

„Senat z oburzeniem przyjął to, że nie porzuca się praktyk świętokradczych”.

Oro ut matures venire. (Cic., Att. 4, 1, 8)

„Proszę, byś spieszył się z przybyciem”.

w ramach zdania o diatezie niepodmiotowej:

Neque me vixisse paenitet. (Cic., Sen. 84)

"I nie żałuję, że żyłem”.

dopełnienia przymiotnika/imiesłowu (często o charakterze poetyckiego grecyzmu):

Res accidit Patavi in transpadana Italia memorari digna. (Gell., Noc. Att. 15, 18, 1)

„W Patavium na terenie Italii Transpadańskiej zdarzyła się rzecz godna (tego), by o niej mówić/przypominać".

(Galli) paulatim adsuefacti superari multisque victi proeliis ne se quidem ipsi cum illis (scil. Germanis) virtute comparant. (Caes., Gall. 6, 24)

"(Gallowie) z wolna przyzwyczajeni do ponoszenia porażek i pokonani w wielu bitwach nawet sami nie porównują się już z Germanami co do męstwa".

Bezokolicznikowi, zarówno w pozycji podmiotu, jak i dopełnienia, może towarzyszyć uzupełnienie orzecznikowe, wyrażone przez rzeczownik bądź przymiotnik 
(najczęściej w akuzatiwie) albo (głównie w przypadku bezokolicznika czasownika o funkcji modalnej) przez inny bezokolicznik:

Superiorem esse contra improbos minus est negotii quam bonis exaequari. (Cic., P. red. ad Quir. 22)

„Być lepszym w porównaniu z niegodziwcami przysparza mniej trudności niż dorównanie dobrym".

Maximum est in amicitia parem esse inferiori. (Cic., Lael. 69)

„Najważniejszą rzeczą w przyjaźni jest traktowanie na równi kogoś zajmującego niższą pozycję (spoleczną)".

Satis est non esse mendacem. (Cic., De orat. 2, 51)

„Wystarczy nie być klamca”.

Malignos fieri maxime ingrati docent. (Publ. Syr., Sent. M, 1)

"Niewdzięcznicy najbardziej skłaniają do tego, by stać się skappym”.

Quam miserum est id negare non posse, quod sit turpissimum confiteri! (Cic., Phil. 2, 61) „Jakżesz godnym politowania jest nie móc zaprzeczyć temu, czego przyznanie byłoby rzeczą bardzo haniebną!"

Multo est turpius oratori nocuisse videri causae quam non profuisse. (Cic., De orat. 2, 295)

„Czymś o wiele haniebniejszym dla mówcy jest sprawiać wrażenie, że zaszkodzil sprawie, niż 르 jej nie dopomógl".

$\mathrm{Z}$ pełnieniem funkcji podmiotu lub dopełnienia związane jest również użycie infinitiwu w charakterze (postpozycyjnej bądź prepozycyjnej) apozycji epegzegetycznej (eksplikatywnej), identyfikującej obiekt wyrażony zaimkiem lub rzeczownikiem generycznym:

Id enim iniustissimum ipsum est, iustitiae mercedem quaerere. (Cic., Leg. 1, 49)

„Bowiem tô właśnie jesı największą niesprawiedliwością, a mianowicie domaganie się zapłaty za sprawiedliwość".

Ecce res magna est, habere inbecillitatem hominis, securitatem dei. (Sen., Lucil. 53, 12)

„Wielka to Izecz mieć całą słabość ludzkiej istoty i równocześnie boską wolność od lęku”.

Cum igitur hoc sit extremum, congruenter naturae convenienterque vivere, necessario sequitur omnes sapientes semper feliciter $[\ldots]$ vivere. (Cic., Fin. 3, 26)

„Skoro zatem to jest celem ostatecznym, a mianowicie życie zgodnie z naturą i stosownie do niej, to nieuchronnie wynika z tego, że wszyscy mędrcy żyją szczęśliwie".

At hi $[\ldots]$ per summum scelus omnia ea sociis adimere, quae fortissumi viri victores reli-

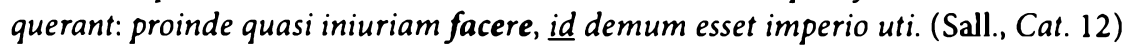

„Ci zaś w najbardziej zbrodniczy sposób odbierali sprzemierzeńcom to wszystko, co pozostawili im najbardziej dzielni mężowie jako zwycięzcy; tak, jakby wyrządzanie krzywdy byłoby dopiero używaniem władzy".

Inpune quae lubet facere, $\underline{\text { id }}$ est regem esse. (Sall., Iug. 31, 26)

„Czynić bezkarnie wszystko, czego się tylko zapragnie, to jest (= oznacza) być królem”. 
Istuc ipsum, non esse, cum fueris, miserrimum puto. (Cic., Tusc. 1, 12)

„To właśnie, a mianowicie nie istnieć, kiedy wcześniej istniełeś, uważam za coś najbardziej nieszczęsnego".

Misereri, invidere, gestire, laetari, haec omnia morbos Graeci appellant. (Cic., Tusc. 3, 7) „Odczuwanie litości, zazdrości, pożądania, radości, wszystko to Grecy nazywają chorobami".

W ograniczonym zakresie (i najczęściej w poezji) infinitiwus realizować może także funkcje okolicznikowe:

a. Celu:

Illa autem in arcem abiit aedem visere Minervae. (Pl., Bacch. 900-901)

„Ta zaś poszla na wzgórze zamkowe (aby) odwiedzić świątynį Minerwy”.

Non nos aut ferro Libycos populare penatis venimus, aut raptas ad litora vertere praedas. (Verg., Aen. 1, 527-528)

„Nie przyszliśmy ani plądrować mieczem libyjskie domostwa, ani znosić na brzeg wydarte (wam) lupy".

Arma $[\ldots]$ Lauso donat habere umeris. (Verg., Aen. 10, 700-701)

„Zbroję ofiaruje Lausowi, by mial (ją jako osłonę) dla ramion”.

b. Względu (jako człon podrzędny w stosunku do przymiotnika):

Lucilius $[\ldots]$ durus conponere versus. (Hor., Serm. 1, 4, 6-8)

"Lucyliusz szorstki gdy idzie o ukladanie wierszy".

Fortis et asperas tractare serpentes. (Hor., Carm. 1, 37, 26-27)

(o Kleopatrze:) „Dzielna (na tyle), by wziąć w ręce budzące odrazę węże”.

Zajmując $w$ zdaniu pozycję orzecznika infinitiwus stanowi determinujący diatezę składnik orzeczenia złożonego, w którym łącznikiem mogą być formy osobowe czasownika esse lub innego o podobnym znaczeniu, będącego jedynie wykładnikiem czasownikowych kategorii predykacji, albo czasowników wnoszących dodatkowe nacechowanie semantyczne, np. czasowników fazowych typu incipio, habitualnych typu soleo, konatywnych typu studeo lub modalnych typu: malo, volo, possum, debeo, videor, dicor itp.:

Atqui vivere, Lucili, militare est. (Sen., Lucil. 96, 5)

"A przecież żyć, Lucyliuszu, to (jakby ciągle) odbywać służbę wojskową".

Aliud enim, quidquid est, aegrotare est, hoc animam egerere. (Sen., Lucil. 54, 2)

„Wszystko bowiem inne, czymkolwiek by to nie bylo, jest chorowaniem, to zaś (jest) konaniem".

Mors est non esse. (Sen., Lucil. 54, 4)

„Smierć jest niebytem”.

Luxuria [...] iam tum incipiebat pullulare. (Nep., Cato 2)

„Zbytek już wtedy zaczynał się szerzyć (dosł.: puszczać pędy, pączkować)”. 
Vides quosdam optantes mortem, et quidam magis quam rogari solet vita. (Sen., Lucil. 30, 12) „Możesz dostrzec pewnych ludzi pragnących śmierci, i to bardziej niż zwykle pożądane jest życie".

Omnis $[. .$.$] et animadversio et castigatio contumelia vacare debet. (Cic., Off. 1,88)$ "Zarówno wszelka krytyka, jak i nagana, powinna być wolna od obelg".

Malui viginti diebus post sentantiam meam laudari ab omnibus, quam a paucis hodie vituperari. (Cic., Phil. 6, 16)

.Wolatem dwadzieścia dni po wygloszeniu mojej opinii byćc chwalony przez wszystkich, niż dzisiaj przez kilku być ganiony".

Ei mihi videntur fortunate beateque vixisse $[\ldots]$, quibus $[\ldots]$ rerum gestarum gloria $[\ldots]$ perfrui licuit. (Cic., Brut. 8)

,Wydaje mi się, że ci żyli szczęśliwic i pomyślnie, którym wolno bylo cieszyć się chwalą (własnych) dokonań".

Niektóre spośród tych czasowników mogą implikować niepodmiotową diatezę struktury zdaniowej jako całości, nie otwierając w niej miejsca dla mianownikowego podmiotu. Treść predykatywna, wyrażana przez współtworzące $z$ nimi orzeczenia bezokoliczniki, nabiera wówczas charakteru przedmiotowego, a jej diateza uzależniona jest od wartości kategorii strony bezokolicznika i odpowiada diatezie, którą sygnalizują nacechowane tą wartością formy osobowe czasownika reprezentowanego przez dany bezokolicznik:

In castris Pompei videre licuit trichilas structas. (Caes., Civ. 3, 95)

„W obozie Pompejusza można bylo zobaczyć pobudowane altany".

Utram igitur putas legem molliorem? Opinor, illam veterem, qua vel cito absolvi vel tarde condemnari licebat. (Cic., Verr. 2, 1, 26)

„Którą z tych dwóch ustaw uważasz za lagodniejszą? Sądzę, że tę dawniejszą, wedlug której można było albo szybko zostać uniewinnionym, albo późno skazanym".

Eos numquam oportebit consilii sui paenitere. (Cic., Phil. 14, 30)

„Trzeba żeby nigdy nie żałowali swej decyzji".

Cui parci potuit? (Liv., 21, 14)

„Kogo można było oszczędzić?"

Nonne his vestigiis ad caput maleficii perveniri solet? (Cic., S. Rosc. 74)

„Czyż nie takimi tropami dochodzi się zwykle do źródła przestępstwa?”

Infinitiwy mogą również wpółtworzyć orzeczniki wraz z formami imiennymi (rzeczownikowymi bądź przymiotnikowymi), które stanowią wówczas wykładniki podstawowych treści predykatywnych:

Mendicus beatus esse nemo potest. (Cic., Fin. 5, 84)

„Żaden nędzarz nie może być szczęśliwy”. 
Iam omitte iratus esse. (Pl., Pers. 431)

"Przestań już być zagniewanym".

Fieri $[\ldots]$ studebam eius prudentia doctior. (Cic., Lael. 1)

„Usiłowalem stać się mạdrzejszy dzięki jego wiedzy".

M. Antonius gladiator appellari solet. (Cic., Phil. 7, 17)

"Marek Antoniusz zwykle nazywany jest gladiatorem”.

O Palaemon, qui Herculis socius esse diceris. (Pl., Rud. 160-161)

„O Palemonie, który ponoć jesteś druhem Herkulesa”.

(Caesar) fuisse traditur excelsa statura, colore candido, teretibus membris, ore paulo pleniore, nigris vegetisque oculis. (Suet., Iul. 45)

"(Cezar) według przekazów cechowal się wysokim wzrostem, bladą cerą, zaokrąglonymi czlonkami, twarza nieco zbyt pełna, czarnymi i bystrymi oczami".

$\mathrm{z}$ formami osobowymi czasowników modalnych w ramach zdań o diatezie niepodmiotowej:

Vel pace vel bello clarum fieri licet. (Sall., Cat. 3)

"Zarówno w czasie pokoju, jak i na wojnie, można stać się sławnym".

Licuit esse otioso Themistocli. (Cic., Tusc. 1, 33)

"Wolno było Temistoklesowi być nieaktywnym (w życiu publicznym)".

Esse oportet animo prompto semper atque intento. (Gell., Noc. Att. 13, 28, 3)

"Trzeba zachowywać postawę nieustannej gotowości i czujności".

Jako funkcjonalny odpowiednik orzeczenia infinitiwus stosowany jest $\mathbf{w}$ dwojakiego rodzaju strukturach syntaktycznych. Jedną z nich jest równoważnik zdania podrzędnego, znany jako accusativus cum infinitivo, drugą równoważnik zdania niezależnego składniowo, w którym stanowiony przez bezokolicznik funkcjonalny odpowiednik orzeczenia określany jest terminem infinitivus historicus.

Accusativus cum infinitivo stanowi równoważnik zdania podrzędnego, najczęściej dopełnieniowego lub podmiotowego. $\mathrm{W}$ jego ramach funkcjonalny odpowiednik podmiotu aktualizowany jest przez formę imienną (najczęściej rzeczownikową lub zaimkową) $w$ akuzatiwie. Stanowiony przez infinitiwus funkcjonalny odpowiednik orzeczenia związany jest $\mathrm{z}$ występującym $\mathrm{w}$ akuzatiwie odpowiednikiem podmiotu, jako członem nadrzędnym, związkiem konguencji atrybutywnej, dlatego participia współtworzące analityczne formy infinitiwów uwzględniają morfologicznie wyrażaną przez niego wartość kategorii liczby, rodzaju i przypadka:

(Stoici) aiunt manere animos, cum e corpore excesserint. (Cic., Tusc. 1, 78)

"(Stoicy) powiadaja, że dusze nadal istnieją po tym, gdy wyjdą z cial".

Dicit montem [...] ab hostibus teneri. (Caes., Gall. 1, 22)

„Powiada, że góra opanowana jest przez nieprzyjaciól". 
Omnium prope annales Fabium dictatorem adversus Hannibalem rem gessisse tradunt. (Liv., 22, 31)

„Kroniki niemal wszystkich autorów przekazują, że Fabiusz jako dyktator prowadził wojnę przeciwko Hannibalowi".

An vero tu parum putas investigatas esse a nobis labis imperii tui? (Cic., Pis. 83)

„Czy doprawdy uważasz, ze nie zostały przez nas do końca wyśledzone wady twoich rządów?"

Responsum a $Q$. Fabio praetore est Liguribus [...] nulli alii quam consulibus senatum crediturum esse. (Liv., 40, 34)

„Ligurom udzielona została przez pretora Kwintusa Fabiusza odpowiedż, że senat nie uwierzy nikomu innemu jak tylko konsulom".

Hisce homines iniussu populi Romani Quiritium foedus ictum iri spoponderunt. (Liv., $9,10)$

„Ci tutaj ludzie bez upoważnienia ludu rzymskiego Kwirytów zaręczyli, że przymierze zostanie zawarte".

Infinitiwus użyty jako funkcjonalny odpowiednik orzeczenia $w$ ramach równoważnika zdania podrzędnego sygnalizować może również diatezę nacechowaną niepodmiotową, z czym wiąże się nieotwieranie miejsca dla wyrażanego $\mathrm{w}$ akuzatiwie funkcjonalnego odpowiednika podmiotu. Diateza ta sygnalizowana jest przez infinitivus czasownika - podobnie jak w przypadku jego użycia orzecznikowego - za pośrednictwem tych wartości kategorii strony, które służą sygnalizowaniu diatezy niepodmiotowej formom osobowym tego czasownika:

Nuntium ad consulem remittunt perventum ad hostem esse. (Liv., 44, 3)

"Wysyłają do konsula wiadomość, że doszli (dosł.: doszło się) do nieprzyjaciela".

Gallis parci quam maxime iubet. (Liv., 21, 45)

„Rozkazuje, by Gallów jak najbardziej oszczędzano".

W ramach równoważnika zdania podrzędnego infinitiwus może też współstanowić funkcjonalny odpowiednik orzeczenia o charakterze złożonym, w szczególności jeśli jest wykładnikiem nacechowanej modalności. Współstanowi go wraz $\mathrm{z}$ innymi składnikami o charakterze funkcjonalnych odpowiedników orzeczników, którymi mogą być:

a. Formy rzeczownikowe:

Consul [...] se M. Valerium Messalam [...] dictatorem dicturum esse aiebat. (Liv., 27, 5)

„Konsul twierdzil, że zamianuje Marka Waleriusza Messalę dyktatorem”.

(Milites) suam virtutem inrisui fore perdoluerunt. (Caes., Civ. 2, 15)

"(Żołnierze) ubolewali, że ich męstwo zostanie wystawione na pośmiewisko".

Hieronymus censet summum bonum esse sine ulla molestia vivere. (Cic., Fin. 2, 16)

„Hieronim uważa, że najwyższym dobrem jest życie bez żadnych przykrości”. 
Praesidibus [...] rescripsit boni pastoris esse tondere pecus, non deglubere. (Suet., Tib. 32) „Zarządcom (prowincji) odpisal, że dobremu pasterzowi przystoi strzyc owce, a nie obdzierać (je) ze skóry".

b. Formy przymiotnikowe lub imiesłowowe:

Optimo et nobilissimo cuique meam orationem gratissimam esse oportet. (Cic., S. Rosc. 142)

„Wypada, aby moja mowa była jak najmilsza każdemu najlepszemu i najbardziej szlachetnemu człowiekowi".

Nonnulli etiam Ceasari nuntiabant, cum castra moveri ac signa ferri iussisset, non fore dicto audientes milites. (Caes., Gall. 1, 39)

„Niektórzy nawet informowali Cezara, że gdyby kazal zwinąć obóz i ruszyć w drogę, żołnierze nie będą posłuszni rozkazowi".

c. Infinitiwus innego czasownika, determinujący diatezę:

\section{c.1. Nienacechowaną:}

Pronuntiat Sthenium litteras publicas corrupisse videri. (Cic., Verr. 2, 2, 93)

„Oznajmia, że Stenius prawdopodobnie sfałszował publiczne dokumenty”.

\section{c.2. Nacechowaną bierną:}

(Clodius) dictitabat palam consulatum Miloni eripi non posse. (Cic., Mil. 26)

„(Klodiusz) nieustannie powtarzał wobec wszystkich, że konsulat nie może być odebrany Milonowi".

\section{c.3. Nacechowaną niepodmiotową:}

Clamat Epicurus [...] non posse iucunde vivi, nisi sapienter, honeste iusteque vivatur. (Cic., Fin. 1, 57)

„Epikur woła, że nie można żyć przyjemnie, jeśli nie żyje się mądrze, szlachetnie i uczciwie”.

d. Dwa infinitiwy innych czasowników, z których jeden (nie modalny) determinuje diatezę:

Conantur ostendere multa posse videri esse, quae omnino nulla sint. (Cic., Lucull. 47) „Usiłują wykazać, że liczne rzeczy, które w ogóle nie istnieją, mogą uchodzić za istniejacę".

e. Infinitiwus determinujący diatezę i forma rzeczownikowa lub przymiotnikowa:

Censebat $[\ldots]$ regem unum ducem, unum imperatorem videri debere. (Liv., 35, 42)

„Uważal [...], że król powinien być posırzegany jako jedyny przywódca, jedyny wódz”.

Quid aliud respondeatis, quam vos triumphantis videri velle? (Liv., 45, 38)

"Cóż innego odpowiedzielibyście, jak (to), że chcecie być oglądani jako tryumfujacy".

f. Participium futuri passivi, implikujące deontyczną modalność opartą na pojęciu powinności lub konieczności i sygnalizujące diatezę: 


\section{fl. bierną:}

Scis amicitias sancte colendas esse. (Sen., Lucil. 94, 26)

„Wiesz, że związki przyjaźni powinny być nabożnie szanowane”.

\section{f.2. niepodmiotową:}

\section{Laetandum esse ausus es scribere Trebonium dedisse poenas? (Cic., Phil. 13, 22)}

„Poważyłeś się pisać, że należy sie cieszyć, iż Treboniusz poniósł karę?”

Infinitivus futuri activi czasownika esse, reprezentowany przez formę tekstową fore, może współtworzyć funkcjonalny odpowiednik orzeczenia wraz z komponentem orzecznikowym o postaci participium perfecti passivi czasownika stanowiącego wykładnik podstawowej treści predykatywnej. Tego typu funkcjonalny odpowiednik orzeczenia wyraża następczość $w$ aspekcie dokonanym $\mathrm{i}$ jest substytutem formy infinitiwu futuri passivi czasownika wyrażającego treść predykatywną, niescharakteryzowanej co do aspektu i niezbyt często używanej. Sygnalizuje diatezę nacechowaną bierną i nie posiada systemowego odpowiednika determinującego diatezę nienacechowaną (może sygnalizować diatezę nienacechowaną jedynie w przypadku, gdy wyrażające podstawową treść predykatywną participium perfecti passivi reprezentuje leksem należący do klasy tzw. verba deponentia - zob. niżej):

Cognovit missas legationes ab nonnullis civitatibus ad Germanos invitatosque eos, uti ab Rheno discederent; omnia quaeque postulassent ab se fore parata. (Caes., Gall. 4, 6)

„Dowiedzial się, że niektóre plemiona (gallickie) wyprawiły poselstwa do Germanów i zachęciły ich, by podeszli od Renu (bliżej ku nim): (zapewnity, że) wszystko, czego zażądają, zostanie przez nich przygotowane".

(Peripatetici) dicunt [..] metum [..] si qui sustulisset, omnem vitae diligentiam sublatam fore. (Cic., Tusc. 4, 46)

„(Perypatetycy) twierdzą. że gdyby ktoś usunął (z ludzkiej świadomości) lęk, usunięta zostanie (przez to) wszelka dbałość o (wlaściwe) życie".

Unum illud tibi persuadeas velim, omnia mihi fore explicata, si te videro. (Cic., Att. 2)

„Chciałbym, żebyś co do tego jednego nabral przekonania, że mianowicie wszystkie moje problemy zostaną rozwiązane, skoro tylko cię zobaczę".

Wyrazem tendencji do unikania użycia form infinitiwu futuri (passivi i activi) jest również zastępowanie ich osobowymi formami czasowników $\mathrm{w}$ koniunktiwie, pełniącymi funkcję orzeczenia $w$ zdaniach podrzędnych funkcjonalnie podmiotowych. Zdania te wypełniają miejsce funkcjonalnego odpowiednika podmiotu w równoważnikach zdań typu accusativus cum infinitivo,w których funkcjonalnym odpowiednikiem orzeczenia jest bezokolicznik fore. Wprowadzane są one za pośrednictwem konektora ut, a przyjmowaną przez ich orzeczenia wartość kategorii czasu reguluje zasada concecutio temporum. Struktury tego typu znajdują swe szczególne (choć nie wyłączne) zastosowanie w przypadku, gdy w paradygmacie formalnym i funkcjonalnym danego leksemu czasownikowego brak jest infinitiwu futuri:

In consilio [...] dixerat, priusquam concurrerent acies, fore uti exercitus Caesaris pelleretur. (Caes., Civ. 3, 86) 
„Podczas narady wojennej powiedział, że zanim oddziały uderzą na siebie, (dojdzie do tego, ie) wojsko Cezara zostanie rozpędzone".

Signa legionum $[\ldots]$ conspiciuntur, quas $C$. Fabius $[\ldots]$ miserat suspicatus fore $[\ldots] \underline{\text { ut }}$

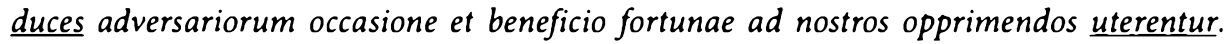
(Caes., Civ. 1, 40)

„Dostrzeżono znaki legionów, które przysłał Gajusz Fabiusz podejrzewając, (iż stanie się tak,) ㄹe nieprzyjacielscy dowódcy wykorzystaja okazję i przychylność losu, aby napaść na naszych".

(Otho) speraverat $[\ldots]$ fore ut adoptaretur a Galba. (Suet., Oth. 5)

"(Othon) miał nadzieję, (iż stanie się tak,) ㄹe zostanie adopotowany przez Galbę".

An non putamus fore ut eos paeniteat professos esse et prae se tulisse odium in Antonium? (Cic., Phil. 12, 7)

„Czy nie uważamy, (że dojdzie do tego,) $\underline{\text { ze }}$ oni pożałują, iż otwarcie wyznali i okazali nienawiść do Antoniusza?"

Jak zaznaczono wyżej, drugą strukturą, w której infinitiwus może pełnić rolę funkcjonalnego odpowiednika orzeczenia, jest równoważnik zdania niezależnego składniowo. Występujący w jego ramach bezokolicznikowy odpowiednik orzeczenia wypełnia miejsce otwierane dla formy osobowej czasownika i tradycyjnie określany jest terminem infinitivus historicus. Nazywany jest też bezokolicznikiem historycznym albo narracyjnym, jako że jego zastosowanie związane jest $z$ tekstową funkcją dramaturgicznego ożywienia narracji. Zastępuje więc głównie czasownikowe formy osobowe czasów przeszłych (lub funkcjonalnie przeszłych), jednak sam występuje w zasadzie wyłącznie w praesens (historicum). Jeśli sygnalizuje diatezę nienacechowaną, pierwszy argument reprezentowanego przez niego predykatu ujawniany jest przez mianownikowy odpowiednik podmiotu:

Nihil Sequani respondere, sed in eadem tristitia taciti permanere. (Caes., Gall. 1, 32)

„Nic Sekwanowie nie odpowiadają, lecz w tym samym smutku trwają w milczeniu”.

Postea tempore et loco constituto, in colloquium uti de pace veniretur, Bocchus Sullam modo, modo Iugurthae legatum appellare, benigne habere, idem ambobus polliceri. Illi pariter laeti ac spei bonae pleni esse. (Sall., Iug. 113)

„Gdy później ustalono czas i miejsce, w którym miano się zejść na rozmowy w sprawie pokoju, Bokchus wzywał do siebie raz Sullę, raz posła Jugurty; uprzejmie się z nimi obchodzil, obu to samo obiecywal. Ci zaś jednakowo byli zadowoleni i pelni dobrej nadzici".

Wreszcie infinitiwus może być elementem niezdaniowego wyrażenia o funkcji ekspresywno-impresywnej. Jest to tzw. infinitivus exclamativus lub interrogativo-exclamativus. Ewentualny funkcjonalny podmiot takiego wyrażenia występuje $\mathrm{w}$ akuzatiwie, stąd infinitiwus tego rodzaju stanowić też może funkcjonalny odpowiednik orzeczenia w ramach użytego niezależnie składniowo równoważnika zdania typu accusativus cum infinitivo:

Non puduisse verberare hominem senem! (Ter., Adelph. 562)

„Że też nie wstyd było bić starego człowieka!” 
Foras aedibus me eici? (PI., Asin. 127)

„Żeby mnie wyrzucać za drzwi?"

Tene hoc, Atti, dicere!? (Cic., Cluent. 84)

"I ty to mówisz, Acjuszu!?"

Mene incepto desistere victam nec posse Italia Teucrorum avertere regem! (Verg., Aen. 1, 37-38)

„Żebym ja miala odstąpić, pokonana, od swego zamiaru i nie mogla zawrócić z drogi do Italii króla Teukrów!"

Paradygmat czasowników należących do klas verba deponentia i verba semideponentia obejmuje - uwzględniając kryterium kategorii czasu i strony - jedynie trzy infinitiwy. Wszystkie one sygnalizują diatezę nienacechowaną (czynną), przy czym korelacja wyrażanych przez nie wartości kategorii czasu i strony przedstawia się nieco inaczej w odniesieniu do leksemów każdej z tych klas, a mianowicie:

1. paradygmat czasowników należących do klasy verba deponentia (a więc np. czasownika loquor, $-i$, locutus sum) ukonstytuowany jest przez:

- infinitivus praesentis passivi (np. loqui);

$\rightarrow$ infinitivus perfecti passivi (np. locutus, -a, -um esse);

$\rightarrow$ infinitivus futuri activi (np. locuturus, -a, -um esse).

2. paradygmat czasowników należących do klasy verba semideponentia (a więc np. czasownika gaudeo, -ere, gavisus sum) ukonstytuowany jest przez:

- infinitivus praesentis activi (np. gaudere);

- infinitivus perfecti passivi (np. gavisus, -a, -um esse);

- infinitivus futuri activi (np. gavisurus, -a, -um esse).

Cechujący się nieregularną fleksją semideponens fio, fieri tworzy jednak infinitivus praesentis passivi.

Niesygnalizowanie diatezy nacechowanej biernej odróżnia zatem system infinitiwów deponentiów i semideponentiów od systemu tworzonych przez nie participiów. Tym samym charakterystyka funkcjonalna systemu infinitiwów deponentiów i semideponentiów dokładnie odpowiada charakterystyce funkcjonalnej ich form osobowych. Podobnej paraleli nie tworzy już jednak charakterystyka formalna infinitiwów deponentiów, ponieważ infinitivus futuri tych czasowników cechuje się aktywnymi wykładnikami kategorii strony.

Warto też zaznaczyć, że z uwagi na wyjątkową pozycję paradygmatów leksemów deponencjalnych i semideponencjalnych $w$ ramach łacińskiej fleksji, istniała tendencja do ich stopniowej eliminacji i unifikacji systemu koniugacyjnego. Wskutek tej tendencji dochodziło do konwersji, a więc do sytuacji, w której obok leksemu o paradygmacie deponencjalnym (np.: revertor, $-i$, reversus sum) pojawiał się leksem hominimiczny o paradygmacie regularnym (np.: reverto, -ere, -ti), który po okresie czasowej koegzystencji stopniowo wypierał ten pierwszy. 
Jak zaznaczono wyżej, wszystkie infinitiwy czasowników deponencjalnych i semideponencjalnych sygnalizują generalnie diatezę nienacechowaną i nie tworzą bezpośrednich opozycji fleksyjnych (formalno-funkcyjnych) w ramach kategorii strony. Mogą zajmować te same pozycje składniowe, które zajmują infinitiwy pozostałych leksemów czasownikowych, a więc pozycje:

a. Podmiotu:

Nulli contigit inpune nasci. (Sen., Dial. 6, 15, 4)

„Nikomu nie udało się urodzić się bezkarnie”.

Ipsum Latine loqui est illud quidem [... in magna laude ponendum. (Cic., Brut. 140)

„Samo w sobie (poprawne) mówienie po łacinie należy uznać za wielce chwalebne”.

b. Dopełnienia:

Mori [...] nemo sapiens miserum duxit, ne beato quidem. (Cic., Fam. 6, 3, 3)

„Żaden mędrzec nie uznał umierania za coś nieszczęsnego, nawel w odniesieniu do kogoś szczęśliwego".

Piget, piget esse secutum! (Ov., Met. 11, 778)

„Żal, żal, że rzucilem się w pościg!"

c. Orzecznika:

Caesar $[. .$.$] cum omnibus copiis eos sequi coepit. (Caes., Gall. 1, 26)$

"Cezar ze w'szystkimi swoimi oddziałami zacząl ich ścigacé.

Oblivisci non possum, quae volo. (Cic., Fin. 2, 104)

"Nic mogę zapomnieć (tego), co (zapomnieć) chciałbym”.

Quo solo genere exercitationis dicitur usus esse Sulpicius. (Quint., Inst. 10, 5, 4)

„Tym typem ćwiczenia jako jedynym poslugiwal się ponoć Sulpicjusz".

w ramach zdania o diatezie niepodmiotowej:

Ei mihi videntur fortunate beateque vixisse $[\ldots]$, quibus $[\ldots]$ rerum gestarum gloria $[\ldots]$ perfrui licuit. (Cic., Brut. 8)

„Wydaje mi się, że ci żyli szczęśliwie i pomyślnie, którym wolno było cieszyć się chwalą (własnych) dokonań".

d. Funkcjonalnego odpowiednika orzeczenia:

d.1. W ramach równoważnika zdania zależnego składniowo (accusativus cum infinitivo):

Namque et irasci nos et gaudere et timere et admirari et dolere et indignari $[\ldots]$ fingimus. (Quint., Inst. 9, 2, 26)

„Bowiem udajemy, że (my) się gniewamy, cieszymy, boimy, podziwiamy, cierpimy, oburzamy".

Turpe $[. .$.$] sibi existimabat [\ldots]$ ab reliquis copiis adversariorum suorum ex fuga collectis se cruentam adeptum (esse) existimari victoriam. (Ps-Ceas., Bell. Afr. 31) 
„Uważal za rzecz haniebną dla siebie to, by sądzono o nim, iż osiągną (on) krwawe zwycięstwo nad pozbieranymi z ucieczki resztkami wojsk jego przeciwników".

Non spero esse passuros illos, qui arma habent. (Liv., 3, 47)

„Nie spodziewam się, by zgodzili się cii, którzy są pod bronią".

d.2.w ramach równoważnika zdania niezależnego składniowo (infinitivus historicus):

Hannibal, quamquam parte dimidia auctas hostium copias cernebat, tamen adventu consulum mire gaudere. (Liv., 22, 40)

„Hannibal, chociaż dostrzegal, że wojska porzeciwników wzrosly o polowę, to jednak dziwnie cieszyl się przybyciem konsulów".

Jako funkcjonalne odpowiedniki orzeczenia infinitiwy (semi)deponentiów rzadko sygnalizują diatezę nacechowaną niepodmiotową:

Miltiades (persuadebat) [...] hostes [...] fore tardiores, si animadverterent auderi adversus se tam exiguis copiis dimicari. (Nep., Milt.. 4)

„Miltiades (przekonywał), że nieprzyjaciele stracą impet, jeśli zauważą, że starcza odwagi, by walczono przeciw nim przy użyciu tak niewielkich oddziałów".

\subsubsection{Gerundium}

Gerundium, czyli rzeczownik odsłowny, jest formacją morfologiczną umożliwiającą leksemom czasownikowym pełnienie określonych sekundarnych funkcji syntaktycznych rzeczownika, tj. funkcji realizowanych przez niego $\mathrm{w}$ genetiwie, datiwie i ablatiwie, a także funkcji okolicznikowych lub przydawkowych realizowanych $\mathrm{w}$ akuzatiwie $\mathrm{z}$ udziałem przyimków (głównie ad). Przyjmując te właśnie wartości kategorii przypadka, gerundium (wraz z supinum) uzupełnia dystrybucję składniową leksemów czasownikowych w zakresie tych rzeczownikowych funkcji składniowych, których nie realizuje infinitiwus:

Caesar Brundisium ad suos severius scripsit, nacti idoneum ventum ne occasionem navigandi dimitterent. (Caes., Civ. 3, 25)

„Cezar $w$ zdecydowanych slowach napisal do swoich $w$ Brundyzjum, by natrafiwszy na dogodny wiatr nie zmarnowali możliwości żeglowania".

Constabat sententiam eam $[\ldots]$ ab eo dictam et eundem $[\ldots]$ scribendo adfuisse. (Cic., De orat. 3,5$)$

„Wiadomo było, że myśl ta przez niego została wypowiedziana, a on sam byl obecny przy spisaniu (jej)".

Quocirca intellegi necesse est in ipsis rebus, quae discuntur et cognoscuntur, invitamenta esse, quibus ad discendum cognoscendumque moveamur. (Cic., Fin. 5, 52)

„Na tej podstawie trzeba wyciągnąć wniosek, że w samych rzeczach, których uczymy się i które poznajemy, zawarte są zachęty, którymi pobudzani jesteśmy do uczenia się i poznawania".

Hominis $[\ldots]$ mens discendo alitur et cogitando. (Cic., Off. 1, 105) 
„Umysł ludzki karmiony jest (= wzrasta) uczeniem się i rozmyślaniem”.

Syntaktycznymi nadrzędnikami gerundium mogą więc być składniki zdania stanowione zarówno przez rzeczowniki (względem których pełni ono funkcję przydawki), jak i przez czasowniki, przymiotniki bądź przysłówki (w stosunku do których pełni rolę dopełnienia lub okolicznika).

Jako rzeczownik odsłowny gerundium uwzględnia, jak już sygnalizowano wyżej, fleksyjną kategorię przypadka. Jego paradygmat funkcjonalny w zakresie tej kategorii jest jednak ograniczony do wartości: genetivus, dativus, accusativus (obligatoryjnie w połączeniu z przyimkiem) i ablativus, przy czym użycie gerundium w datiwie jest bardzo rzadkie. Przypadek jest też jedyną kategorią fleksyjną uwzględnianą przez tę formację, jako że pozostaje ona niescharakteryzowana co do kategorii rodzaju i liczby. Wynika to $z$ faktu, że nie przyjmuje ona ani predykatywnych, ani atrybutywnych określników na zasadzie związku kongruencji (zgody). Nie zajmuje bowiem nigdy pozycji syntaktycznego podmiotu (która wypełniana jest przez formacje bezokolicznikowe), a ze swoimi członami podrzędnymi związana jest - podobnie jak formy osobowe czasownika - jedynie związkiem przynależności lub rekcji. Stąd jedną $z$ istotnych właściwości składniowych gerundium jest to, że generalnie jego określnikami nie są przymiotnikowe przydawki, lecz okoliczniki stanowione przez:

a. Przysłówki:

Quam multa $[. .$.$] exempla in orationibus bene dicendi reliquerunt! (Cic., Fin. 4, 5)$

"Jakżesz wiele przykładów dobrego przemawiania pozostawili w swych mowach!"

Scribendi recte sapere est et principium est fons. (Hor., Ars 309)

„Początkiem i źródlem poprawnego pisania jest mądrość”.

Libri 'Tusculanarum disputationum' res ad beate vivendum maxime necessarias aperuerunt. (Cic., Div. 2, 2)

"Księgi Rozmów tuskulariskich ukazały rzeczy najbardziej potrzebne do szczęśliwego życia".

b. Rzeczowniki lub rzeczownikowe wyrażenia przyimkowe:

Eam vos fraudem [...] vestra ipsi virtute dies noctesque perstando ac pervigilando in armis vitastis. (Liv., 24, 38)

„Wy tego podstępu uniknęliście dzięki waszemu własnemu męstwu, przez całe dni i noce

trwając (na miejscu) i czuwając pod bronią (dosł.: trwaniem na miejscu i czuwaniem...)".

Academiam quidam utilissimam credunt, quod mos in utramque partem disserendi ad exercitationem forensium causarum proxime accedat. (Quint., Inst. 12, 2, 25)

„Niektórzy uważają Akademię za najbardziej użyteczną (szkołę), ponieważ zwyczaj dysputowania na obydwie strony (t $\mathrm{j} . \mathrm{z}$ uwzględnieniem argumentów $\mathrm{i}$ kontrargumentów) najbardziej zbliża się do praktyki sądowej".

Zupełnie wyjątkowo zdarzają się określniki o charakterze przymiotnikowej przydawki:

Quod opus [...] qui commode tractaverit, cuicumque discendo sufficiet. (Quint., Inst. 1, 9,3) 
„Kto wykona to zadanie w sposób należyty, podola jakiemukolwiek uczeniu się (tj. uczeniu się wszelkich innych rzeczy)".

Pod względem semantycznym gerundium stanowi nazwę abstrakcyjnie, przedmiotowo ujętych czynności lub procesów, i dlatego, chociaż jest formacją odczasownikową, nie uwzględnia fleksyjnej kategorii czasu. Nie uwzględnia też fleksyjnie kategorii strony, zaś diateza desygnowanych przez nie treści generalnie ma charakter nienacechowany, stąd np. ars amandi to 'sztuka kochania' (a nie 'sztuka bycia kochanym'). Właściwości te dotyczą formacji gerundialnych reprezentujących zarówno leksemy czasownikowe o pełnym paradygmacie funkcjonalnym, jak i te o paradygmacie ograniczonym pod względem kategorii strony, tj. (semi)deponencjalne:

Si [...] aliquando oculi peccent, tamen [...] inest in iis vis videndi. (Cic., Div. 2, 108)

„Nawet jeśli oczy niekiedy się mylą, to jednak tkwi w nich zdolność widzenia".

Caesar finem loquendi fecit. (Caes., Gall. 1, 46)

„Cezar zakończyl rozmowę".

Erat $[\ldots]$ socius populandi rex Garamantum. (Tac., Ann. 4, 23)

„Wspólnikiem grabieży byl król Garamantów”.

Caesar [...] alias territando [...], alias cohortando magnam partem Galliae in officio tenuit. (Caes., Gall. 5, 54)

„Cezar jednych zastraszając, innym dodając odwagi, utrzymywal znaczną częśc Galii w posłuszeństwie".

Szczególnym przypadkiem jest gerundium w akuzatiwie z przyimkiem ad, użyte jako określnik przymiotnika i odpowiadające funkcjonalnie supinum na - $u$. Jeśli gerundium to reprezentuje czasownik przechodni, sygnalizowania przez nie diateza może być zróżnicowana co do rangi argumentu desygnowanego przez rzeczownikowy nadrzędnik określanego przymiotnika (wyrażony na powierzchni lub tylko implikowany); por. np.:

Hominem adduxeris $[. .$.$] ad pronuntiandum expeditum. (Cic., De orat. 2, 131)$

„Przyprowadzisz człowieka uzdolnionego do wyglaszania (mów)".

Non solum ad discendum propensi sumus, verum etiam ad docendum. (Cic., Fin. 3, 66)

„Jesteśmy predysponowani nie tylko do uczenia się, ale i do nauczania".

Nos ad audiendum parati sumus. (Cic., Tusc. 1, 17)

"Jeśli chodzi o mnie, jestem gotów do sluchania".

wobec:

Tune solus ignoras longe faciliores ad expugnandum domus esse maiores? (Apul., Met. 4, 9)

"Czy tylko ty jeden nie wicsz, że większe domy są znacznie latwiejsze do zdobycia".

Rem quaeris praeclaram iuventuti ad discendum nec mihi difficilem ad perdocendum. (Cic., Sest. 96)

„Pytasz o rzecz znakomitą (jako temat) do nauki dla mlodzieży i niezbyt dla mnie trudną do wylożenia". 
Oratorem [...] eum puto esse, qui et verbis ad audiendum iucundis et sententiis ad probandum accomodatis uti possit. (Cic., De orat. 1, 213)

„Uważam, że mówcą jest ten, kto potrafi poslugiwać sie zarówno slowami przyjemnymi do sluchania, jak i myślami nadającymi się do zaakceptowania".

Bardzo rzadko gerundia sygnalizują diatezę nacechowaną (bierną) również w innych kontekstach:

Haec frequentia $[. .$.$] convenit uno tempore undique comitiorum, ludorum censendique$ causa. (Cic., Verr. 1, 1, 54)

"Ten wielki tłum ludzi zgromadził się zewsząd $\mathrm{w}$ tym samym czasie $\mathrm{z}$ powodu wyborów, igrzysk i (obowiązku) poddania się oszacowaniu (cenzorskiemu)".

Mogą też reprezentować dekauzatywne formacje pochodne (w passivum), derywowane od czasowników przechodnich:

Libertorum praecipue suspexit [...] Harpocran, cui lectica per urbem vehendi $[\ldots]$ ius tribuit. (Suet., Claud. 28)

„Spośród wyzwoleńców szczególnie poważał Harpokrasa, któremu przyznał prawo podróżowania po mieście w lektyce".

Ludicra exercendi aut venandi consuetudine adamare solemus. (Cic., Fin. 1,69)

„Zwykle wskutek przyzwyczajenia lubimy rozrywki uprawiania ćwiczeń fizycznych lub polowania".

Jeśli gerundium reprezentuje predykat ponadjednoargumentowy, to otwiera ono miejsce także dla związanych rekcją dopełnień, stanowiących wykładniki jego argumentów niższej rangi, przy czym wystąpienie uzupełnień dopełnieniowych poświadczone jest stosunkowo rzadko i niemal wyłącznie w odniesieniu do form gerundialnych użytych $w$ genetiwie bądź $w$ ablatiwie bez towarzyszącego przyimka. Należy też podkreślić, że dopełnienia akomodowane są przez gerundium w sposób analogiczny, jak ma to miejsce w przypadku odpowiadających mu form osobowych, tzn. składniowa rekcja gerundium nie odbiega do rekcji form osobowych reprezentujących ten sam leksem, a to ( $w$ odniesieniu do dopełnienia bliższego) stanowi istotną różnicę $\mathrm{w}$ porównaniu $\mathrm{z}$ językiem polskim (por. np.: scribimus libros - facultas scribendi libros : 'piszemy książki' - 'możliwość pisania książek'):

Efferor studio patres vestros, quos colui et dilexi, videndi. (Cic., Sen. 83)

„Ponosi mnie pragnienie zobaczenia waszych ojców, których szanowatem i kochałem”.

Probrosis feminis $[. .$.$] ademit ius [. .$.$] capiendi legata hereditatesque. (Suet., Dom. 8)$

„Występnym kobietom odebral prawo przyjmowania prawnych zapisów i spadków”.

(Res) eadem [...] tribunis materiam criminandi ad plebem consules praebuit. (Liv., $3,31)$

„Ta sama rzecz dała trybunom asumpt do oskarżania konsulów wohec ludu".

Utendi voce multiplex ratio (est). (Quint., Inst. 11, 3, 17)

"Sposoby posługiwania się glosem są wielorakie". 
Accidit mihi, quod homini $[\ldots]$ cupido satis faciendi rei publicae bonisque omnibus accidere solet. (Cic., Fam. 10, 18, 1)

„Przydarzyło mi się to, co zwykle przydarza się komuś ogarniętemu pragnieniem zadość czynienia rzeczpospolitej i wszystkim dobrym (ludziom)".

Servitutem timendo in eum statum rem publicam adduxerant. (Liv., 3, 37)

"Obawiając się znicwolenia doprowadzili rzeczpospolitą do tego stanu”.

Romanus cedentem hostem effuse sequendo [...] opportunus huic eruptioni fuit. (Liv., 6, 24)

„Rzymianie, postępując w swobodnym szyku za uchodzącem nieprzyjacielem, byli dla niego wygodnym celem ataku".

(Themistocles) maritimos praedones consectando mare tutum reddidit. (Nep., Them. 2)

„Ścigając morskich korsarzy uczynil Temistokles morze na powrót bezpiecznym".

Sporadycznie rzeczownikowe określniki gerundium akomodowane są nie jako determinowane czasownikową rekcją dopełnienia, ale jako typowe dla form rzeczownikowych przydawki dopełniaczowe:

Agitur, utrum M. Antonio facultas detur [...] urbis, agrorum suis latronibus condonandi. (Cic., Phil. 5, 6)

„Gra toczy się o to, czy Markowi Antoniuszowi dana zostanie możliwość wydania miasta i gruntów jego lotrom".

De se homines [...], quibus ne reiciendi quidem amplius quam trium iudicum praeclarae leges Corneliae faciunt potestatem, hunc hominem tam crudelem [...] nolunt iudicare. (Cic., Verr. 2, 2, 77)

„Ludzie, którym przesławna ustawa Kormeliuszowa nie daje nawet możliwości odrzucenia więcej niż trzech șędziów, nie chcą, by ten człowiek, tak okrutny, sprawował nad nimi sądy".

Aliquod fuit principium generandi animalium. (Varr., Rust. 2, 1, 3)

"Istniała pewna pierwotna zasada plodzenia istot żywych".

Treści wyrażane przez syntagmę złożoną z gerundium określonego czasownika oraz rzeczownikowego dopełnienia bliższego mogą zostać wyrażone także przez grupę imienną składającą się z (odpowiadającego dopełnieniu) rzeczownika zajmującego pozycję syntaktyczną odpowiadającą pozycji gerundium oraz użytego atrybutywnie względem niego participium futuri passivi (gerundivum) danego czasownika, np.: ars rem publicam administrandi = ars rei publicae administrandae 'sztuka kierowania państwem'. Zastosowanie struktur $\mathrm{z}$ atrybutywnie użytym gerundivum możliwe jest w odniesieniu do czasowników przechodnich, zarówno o pełnym paradygmacie funkcjonalnym pod względem kategorii strony, jak i deponencjalnych, $w$ tym również w odniesieniu do czasowników deponencjalnych: utor, fruor, fungor, potior, vescor, konotujących dopełnienie $\mathrm{w}$ ablatiwie. Warto zaznaczyć, że frekwencja tych struktur jest wyższa niż syntagm złożonych z gerundium i dopełnienia (bliższego):

Huius acerbitatis eventum altera acerbitate non videndi fratris vitavi. (Cic., Att. 3, 9, 1)

„Tej przykrej sytuacji uniknąłem (okupując to) z kolei przykrością niezobaczenia brata”. 
Eleusinem profectus (est) spe $[\ldots]$ templi castellique $[\ldots]$ capiendi. (Liv., 31, 25)

„Ruszył w kierunku Eleuzyny z nadzieją na przejęcie świątyni i fortecy”.

Quis enim ignorat eos usque ad hanc diem retinere illam immanem ac barbaram consuetudinem hominum immolandorum. (Cic., Font. 31)

„Któż bowiem nie wie, że oni do dnia dzisiejszego zachowują ów okrutny i barbarzyński zwyczaj skladania w ofierze ludzi".

Praesidium $[\ldots]$ cohortium duodecim pontis tuendi ponit. (Caes., Gall. 6, 29)

„Ustanawia straż w sile dwunastu kohort dla ochrony mostu”.

Postea per incrementa aetatis exorta e seminibus suis ratiost et utendi consilii reputatio. (Gell., Noc. Att. 12, 5, 7)

„Później, $z$ upływem czasu, ze swoich zarodków rozwinął się rozum i namysl nad korzystaniem z zady".

Mihi $[\ldots]$ iustitiae fruendae causa videntur olim bene morati reges instituti. (Cic., Off. 2, 41)

„Wydaje mi się, że po to wlaśnie, by umożliwić korzystanie z dobrodziejstw sprawiedliwości, cechujący się dobrymi obyczajami ludzie zostali niegdyś ustanowieni królami".

In eodem tanta prudentia fuit [...], ut hodie stet Asia Luculli institutis servandis et quasi vestigiis persequendis. (Cic., Lucull. 3)

„Była w tym człowieku tak wielka roztropność, że do dziś Azja utrzymuje się dzięki przestrzeganiu ustanowień Lukullusa i jakby podażaniu jego śladem".

Quod ad multitudinem servis liberandis auctam [...] attinet [...], iam feceram haec [...], cum societatem mecum pepigistis. (Liv., 34, 31)

„Co do powiększonej liczby ludności poprzez wyzwalanie niewolników, to uczynitem to jeszcze zanim zawarliście ze mną przymierze".

Nullum $[\ldots]$ officium referenda gratia magis necessarium est. (Cic., Off. 1,47 )

„Żaden obowiązek nie wymaga spełnienia bardziej niż odwzajemnienie (doznanej) życzliwości”.

Niekiedy w jednym zdaniu znaleźć można obok siebie obydwie struktury, tj. gerundium $\mathrm{z}$ rzeczownikowym dopełnieniem oraz rzeczownik $\mathrm{z}$ atrybutywnie (przydawkowo) użytym gerundivum:

Omnis provincias obeundi, liberos populos agris multandi, regnorum vendendorum summa potestas datur. (Cic., Leg. Agr. 2, 34)

„Dana zostala nieograniczona możliwość objeżdżania wszystkich prowincji, karania wolnych narodów odebraniem ziem, sprzedawania królestw".

Germani $[. .$.$] neque consilii habendi neque arma capiendi spatio dato perturbantur, co-$ piasne adversusus hostem ducere [...] an fuga salutem petere praesataret. (Caes., Gall. 4, 14)

„Germanie, ponieważ nie bylo czasu ani na odbycie narady, ani na chwycenie za broń, popadają w zamęt nie wiedząc, czy lepiej wyprowadzić wojsko przeciwko nieprzyjacielowi, czy szukać ratunku w ucieczce".

Jak już zasygnalizowano wyżej, praktycznie nie spotyka się w klasycznej łacinie przykładów zdań, w których rzeczownikowe dopełnienie bliższe towarzyszyłoby 
gerundium użytemu $\mathrm{w}$ datiwie, akuzatiwie bądź $\mathrm{w}$ ablatiwie $\mathrm{z}$ przyimkiem. Treści wymagające zastosowania tych właśnie form fleksyjnych wyrażane są więc wyłącznie za pośrednictwem rzeczowników określanych przydawkowym gerundivum:

Consules [...] T. Maenium dilectui habendo praefecerunt. (Liv., 39, 20)

„Konsulowie wyznaczyli Tytusa Meniusza jako kierującego przeprowadzeniem poboru (do wojska)".

Gens nata instaurandis reperandisque bellis $[\ldots]$ brevi replevit exercitum. (Liv., 24, 42)

„Naród urodzony dla powtarzania i wznawiania wojen w krótkim czasie przywrócił pelny stan osobowy wojska".

Ver $[\ldots]$ ostendit $[\ldots]$ fructus futuros, reliqua autem tempora demetendis fructibus et percipiendis accomodata sunt. (Cic., Sen. 70)

„Wiosna ukazuje przyszłe owoce, zaś pozostałe pory roku są odpowiednie dla zhierania owoców i (ich) gromadzenia".

Vivis non ad deponendam, sed ad confirmandam audaciam. (Cic., Catil. 1, 4)

„Żyjesz nie dla zaniechania, lecz dla umocnienia (swej) zuchwałości”.

Sapiens $[. .$.$] erit enim instructus ad mortem contemnendam. (Cic., Fin. 2, 56-57)$

„Mędrzec będzie bowiem przygotowany do pogardzania śmiercia”.

Quorum erant $[\ldots]$ corpora imsueta ad onera portanda. (Caes., Civ. 1, 78)

"Ich ciala były nienawykle do noszenia ciężarów".

Libri 'Tusculanarum disputationum' res ad beate vivendum maxime necessarias aperuerunt: primus est de contemnenda morte, secundus de tolerando dolore $\underline{\text { de }} \underline{\text { aegritudine }} \underline{\text { le- }}$ nienda tertius. (Cic., Div. 2, 2)

„Księgi Rozmów tuskulańskich ukazały rzeczy najbardziej potrzebne do szczęśliwego życia: pierwsza traktuje o pogardzię dla śmierci, druga o znoszeniu bólu, $\underline{0 \text { uśmierzaniu zmartwień }}$ trzecia".

Illud potius praecipiendum fuit, ut $[\ldots]$ diligentiam adhiberemus in amicitiis comparandis. (Cic., Lael. 60)

„Należało raczej zalecić, byśmy dochowali staranności przł zawieraniu przyjaźni”.

In omni $[\ldots]$ actione suscipienda tria sunt tenenda. (Cic., Off. 1, 141)

"Przy podejmowaniu każdej działalności należy trzymać się trzech zasad".

Charakterystyczne pod tym względem jest np. szeregowe zestawienie w obrębie jednego zdania poprzedzonych przyimkiem ablatywnych form gerundialnych bez dopełnienia obok syntagm rzeczownikowych $\mathrm{z}$ gerundivum jako przydawką (zamiast gerundium $\mathrm{z}$ dopełnieniem):

Istuc te quoque impediet in navigando et in conserendo, in uxore ducenda, in liberis procreandis. (Cic., Lucull. 109)

„To przeszkodzi ci również w podróży morskiej i w zasiewach, w unyborze żony, w płodzeniu dzieci".

In interpretando, in definiendo, in explicanda aequitate nihil erat Crasso copiosius. (Cic., Brut. 144) 
„W kwestii interpretowania, definiowania, wyjaśniania (istoty) sprawiedliwości nie było niczego bardziej wyczerpującego od (wywodów) Krassusa".

Pojedyncze przypadki użycia gerundium $\mathrm{w}$ datiwie $\mathrm{z}$ rzeczownikowym dopełnieniem spotyka się tylko u Plauta:

Hominem investigando operam huic dissimulabiliter dabo. (Pl., Mil. 260)

"Oddam się temu potajemnemu tropieniu człowieka”.

Unika się jednak stosowania struktur $\mathrm{z}$ atrybutywnie użytym gerundivum $\mathrm{w}$ odniesieniu do rzeczownikowych zaimków nieokreślonych, przeczących i innych o znaczeniu uogólniającym. W takich przypadkach notowane jest $w$ zasadzie wyłącznie uzycie gerundium $\mathrm{z}$ zaimkowym dopełnieniem, $\mathrm{w}$ tym również $\mathrm{w}$ (wyszczególnionych wyżej) kontekstach, w których rzeczownikowe dopełnienie nie jest spotykane:

Utetur (orator facetiis) in narrando aliquid venuste. (Cic., Orat. 87)

„Mówca posłuży się dowcipem przy opowiadaniu czegoś w sposób powabny”.

Erat omnino tum mos [...], ut faciles essent in suum cuique tribuendo. (Cic., Brut. 85)

„W ogóle było wtedy w zwyczaju, iż wszyscy byli skłonni do przydzielania każdemu tego, $\underline{\text { co }}$ mu się należy"'.

Pictoribus atque poetis quidlibet audendi semper fuit aequa potestas. (Hor., Ars 9-10)

„Malarzom i poetom zawszy przysługiwala jednakowa możliwość poważenia się, na oㅡ tylko chcieli (scil. licentia poetica)".

Cum ita nati factique sumus, ut et agendi aliquid et diligendi aliquos et liberalitatis et referendae gratiae principia in nobis contineremus [...], non sine causa [...] in pueris virtutum quasi scintillas videmus, e quibus accendi philosophi ratio debet. (Cic., Fin. 5, 43)

„Skoro zostaliśmy zrodzeni i stworzeni tak, iż mamy w sobie predyspozycje i do czynienia czegoś, i do kochania określonych ludzi, i do życzliwości, i do wyrażania wdzięczności, to nie bez powodu widzimy $w$ dzieciach jakby zarodki cnót, od których rozpalić winien się umysł filozofa".

Quid est [...] quod laboremus? Portus enim praesto est, quoniam mors ibidem est, aeternum nihil sentiendi receptaculum. (Cic., Tusc. 5,117 )

„Dlaczegóż mielibyśmy się męczyć? Port jest w zasięgu ręki, skoro jest tam śmierć - wieczne schronienie, w którym nic się nie czuje".

Częste jest natomiast użycie gerundivum w odniesieniu do zaimków o funkcji kataforycznej bądź anaforycznej:

Ex quo intellegitur corporis voluptatem non satis esse dignam hominis praestantia [...], sin sit quispiam, qui aliquid tribuat voluptati, diligenter ei tenendum esse eius fruendae modus. (Cic., Off. 1, 106)

„Wynika $z$ tego, że rozkosz cielesna nie jest wystarczająco godna doskonałości będącej udzialem czlowieka, i że gdyby jednak znalazł się ktoś, kto przypisalby rozkoszy jakąś wartość, to powinien on pilnie przestrzegać miary w jej używaniü".

${ }^{2}$ Ale: Iustitia in suo cuique tribuendo (cernitur) (Cic., Fin. 5, 67) „Sprawiedliwość daje się rozpoznać w przydzielaniu każdemu tego, co mu się należy". 
Quae autem libidini subiecta sunt, ea sic definiuntur, ut ira sit libido poeniendi eius, qui videatur laesisse iniuria [...], desiderium libido eius, qui nondum adsit, videndi. (Cic., Tusc. 4, 21)

„Te zaś (stany duchowe), które należą do kategorii żądz, definiują w ten sposób, że gniew to żądza ukarania tego, o kim się sądzi, iż niesprawiedliwie wyrządzil krzywdę, zaś tęsknota to żądza zobaczenia kogoś, kto na razie jest nieobecny".

Hostis Antonius iudicatus Italia cesserat [...]; non solum inimici [...], sed etiam qui adversariis eius se dabant et in eo laedendo aliquam consecuturos sperabant commoditatem, Antonii familiares insequebantur. (Nep., Att. 9)

„Uznany za wroga Antoniusz ustąpił z Italii; nie tylko jego nieprzyjaciele, lecz również ci, którzy zaprzedali się jego przeciwnikom i spodziewali się, że poprzez oczernianie go osiągną jakąś korzyść, prześladowali najbliższych Antoniusza".

Oczywiście, zaimki te mogą również funkcjonować jako dopełnienia form gerundialnych:

Quid contra dicerem mecum ipse meditabar, neque tam refellendi tui causa, quam ea, quae minus intellegebam, requirendi. (Cic., Nat. 3, 1)

„Rozważałem $w$ duchu, co odrzec przeciwko temu, i to nie tyle $z$ chęci odparcia ciebie (tj. odparcia twoich tez), co raczej dowiedzenia się tego, o czym miałem niewielkie pojęcie".

Podobnie unika się określania przydawkowym gerundium substantywizowanych przymiotników (zwłaszcza w rodzaju nijakim i w liczbie mnogiej). Formy te występują na ogół jako dopełnienia formacji gerundialnych:

Agebat infelicem Alexandrum furor aliena vastandi. (Sen., Lucil. 94, 62)

„Popędzał nieszczęsnego Aleksandra szał niszczenia tego, co obce”."

Videsne Diogenem eum fuisse, qui diceret artem se tradere bene disserendi et vera ac falsa diiudicandi? (Cic., De orat. 2, 157)

„Wiesz, że Diogenes był tym, który twierdzil, że naucza sztuki poprawnego dyskutowania oraz rozróżniania prawdy i fałszu".

Ecce Romanos quoque invasit inane studium supervacua discendi. (Sen., Dial. 10, 13,3)

„Oto również i Rzymian ogarnęła gorączka dociekania spraw zupełnie zbytecznych”.

Tum vero apparuit $a b$ ira et ab odio urbem oppugnatam esse: nemo capiendi vivos $[\ldots]$ memor est, trucidant inermes iuxta atque armatos. (Liv., 28, 20)

„Wtedy to można było zobaczyć, że przypuszczono atak na miasto z gniewu i nienawiści: nikt nie myślał o braniu (do niewoli) ̇ywych, zabijano bezbronnych na równi z uzbrojonymi".

Necessitate Caesar coactus privatos ambiendo et blande appellando aliquantum numerum frumenti $[\ldots]$ congesserat. (Ps.-Ceas., Bell. Afr. 21)

„Przymuszony koniecznością Cezar, nagabując prywatne osoby i zwracając się (do nich) z prośbami o udzielenie pomocy, zebrał pewną ilość zboża".

Okazjonalnie spotyka się jednak syntagmy złożone z substantywizowanego przymiotnika i przydawkowego gerundivum:

Natura cupiditatem ingenuit homini veri videndi. (Cic., Fin. 2, 46)

„Natura wszczepiła człowiekowi żadzę poznania prawdy”. 
Z kolei w odniesieniu do zaimków osobowych i zaimka zwrotnego stosowane są konstrukcje zarówno $z$ gerundium jak i z gerundivum, przy czym gerundivum występuje zawsze w liczbie pojedynczej rodzaju nijakiego, nawet jeśli określane przez nie zaimki oznaczają mnogość lub odnoszą się do obiektów płci żeńskiej. Podane niżej przykłady stanowią egzemplifikację współtworzonych przez zaimki osobowe i zaimek zwrotny syntagm z:

\section{a. Gerundium:}

Quem (scil. Iugurtham) tanta lubido extinguendi me invasit, ut neque vos neque deos immortalis in animo habet. (Sall., Iug. 24)

"(Jugurtę) ogarnęla taka żądza zniszczenia mnie, że nie liczy się ani z wami, ani z bogami nieśmiertelnymi".

Saepe iam [...] impetum cepi consolandi te. (Sen., Dial. 12, 1)

„Wiele już razy poczulem pragnienie pocieszenia cię".

Alius nemo facultatem habet decipiendi nos. (Cic., Fam. 11, 2, 2)

„Nikt inny nie ma możliwości oszukania nas".

Vobis restituendi vos in amicitiam societatemque nostram fortuna oblata est. (Liv., 31, 31) „Dana wam zostala sposobność ponownego umieszczenia siebie $w$ rzędzie naszych przyjaciół i sprzymierzeńców".

Legati nihil aliud petere, quam ut $[\ldots]$ tyranno potestatem $[\ldots]$ purgandi se faceret. (Liv., $38,14)$

„Posłowie nie prosili o nic innego, jak tylko o to, by dał wladcy możliwość oczyszczenia się (z zarzutów)".

Simul territos hostes vidit, Gallica nullum spatium respirandi recipiendique se dedit. (Liv., $10,28)$

„Gallicki oddzial, gdy tylko dostrzegł nieprzyjaciół w popłochu, nie dal (im) ani chwili na oddech i zebranie się (razem)".

b. Gerundivum:

Calvenus Taurus philosophus et alii quidam sectatores eius cum Athenis visendi mei gratia venissent, medicus [...] narrare Tauro coeperat, quid incommodi paterer. (Gell., Noc. Att. $18,10,3)$

„Kiedy filozof Kalwenus Taurus i paru innych, którzy byli jego uczniami, przybyli z Aten, by mnię odwiedzić, lekarz zacząl Taurusowi opowiadać, jakich dolegliwości doznaję".

Quid contra dicerem mecum ipse meditabar, neque tam refellendi tui causa, quam ea, quae minus intellegebam, requirendi. (Cic., Nat. 3,1 )

„Rozważalem $w$ duchu, co odrzec przeciwko temu, i to nie tyle $z$ chęci odparcia ciebie ( $\mathrm{tj}$. odparcia twoich tez), co raczej dowiedzenia się tego, o czym mialem niewielkie pojęcie".

w odniesieniu do kobiety:

\{Phronesium:\} Dic mihi, benene ambulatumst? \{Diniarchus:\} Huc quidem, Hercle, ad te bene, quia tui videndi copia est. (PI., Truc. 368-370) 
„\{Fronezjum:\} Powiedz mi, dobrze minęla ci podróż? \{Diniarchus:\} Tu do ciebie, na Herkulesa, dobrze, bo mam możliwość zobaczenia cię".

Tum nos in ancipiti periculo constituti vel opprimendi nostri vel deserendi socii remedium e re nata validum [...] comminiscimus. (Apul., Met. 4, 11)

„Wtedy my, postawieni wobec dwojakiego niebezpieczeństwa: albo pogrążenia nas (samych), albo porzucenia towarzysza, wymyślamy skuteczny ratunek, który wynikał wprost z naszego polożenia".

Ab L. Roscio [...] certior factus est magnas Gallorum copias [...] oppugnandi sui causa convenisse. (Caes., Gall. 5, 53)

„Został powiadomiony przez Lucjusza Roscjusza, że wielkie siły zbrojne Gallów zgromadziły się z zamiarem zaatakowania go (scil. Roscjusza)".

Multi principes civitatis Roma non tam sui conservandi, quam tuorum consiliorum reprimendorum causa profugerunt. (Cic., Catil. 1, 7)

„Wiele czolowych postaci życia państwowego opuściło Rzym, nie tyle dla ratowania siebie, ile dla unicestwienia twoich zamiarów".

Omnibus portis eruptione facta neque cognoscendi, quid fieret, neque sui colligendi hostibus facultatem relinquunt. (Caes., Gall. 3,6 )

„Dokonawszy wypadu ze wszystkich bram nie pozostawiają nieprzyjaciolom możliwości ani zorientowania się, co się dzieje, ani zebrania się razem".

Miejsca otwierane przez gerundium dla dopełnienia mogą być wypełniane także przez:

a. Zdania podrzędne dopełnieniowe:

Omnibus portis eruptione facta neque cognoscendi, quid fieret, neque sui colligendi hostibus facultatem relinquunt. (Caes., Gall. 3, 6)

„Dokonawszy wypadu ze wszystkich bram nie pozostawiają nieprzyjaciołom możliwości ani zorientowania się, oㅡ się dzieje, ani zebrania się razem".

Tanta (est eius) in explicando, quod velit, gratia. (Quint., Inst. 10, 1, 121)

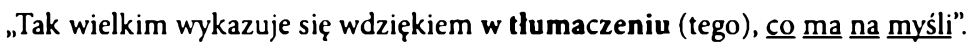

b. Równoważniki zdań podrzędnych dopełnieniowych (accusativus cuminfinitivo):

Viderent ne vetando in curia libere homines loqui, extra curiam etiam moverent vocem. (Liv., 3, 39)

„Niech baczą, by zabraniając ludziom swobodnego wypowiadania się w kurii, nie wywołali głośnych wypowiedzi poza kurią".

\subsubsection{Supinum}

Supinum jest syntetyczną formacją morfologiczną, która występuje stosunkowo rzadko i nie ma odpowiednika w języku polskim. Umożliwia ona leksemom czasownikowym pełnienie określonych funkcji okolicznikowych, w związku z czym 
nie uwzględnia żadnych gramatycznych kategorii fleksyjnych, występuje natomiast $w$ dwu odmiennych wariantach formalno-funkcyjnych.

Pierwszy $\mathrm{z}$ tych wariantów ma postać formacji złożonej z czasownikowego tematu participium perfecti oraz sufiksu -um i służy pełnieniu funkcji okolicznika celu przy czasownikach, zarówno przechodnich jak i nieprzechodnich, wyrażających działanie, ruch, zachowanie, postawę itp. Sygnalizuje diatezę nienacechowaną i reprezentować może także czasowniki deponencjalne:

Stultitiast $[. .$.$] venatum ducere invitas canes. (Pl., Stich. 139)$

„Głupotą jest prowadzić na polowanie niechętne (temu) psy”.

(Dionysius) Sophrosynen [...] Dionysio filio [...] nuptum dedit. (Nep., Dion. 1)

„(Dionizjusz) Sofrozynę dał za żonę swojemu synowi Dionizjuszowi”.

Sessum it praetor. (Cic., Nat. 3, 74)

"Pretor idzzie (by) zasiąść (na swoim miejscu)".

(Themistocles) testularum suffragiis e civitate eiectus Argos habitatum concessit. (Nep., Them. 8)

„Usunięty z państwa wyrokiem sądu skorupkowego udal się (Temistokles) do Argos, by (tam) zamieszkać".

Non mea culpa saepe ad vos oratum mitto, patres conscripti, sed vis Iugurthae subigit. (Sall., Iug. 24)

„Nie z wlasnej winy tak często wysłam do was (posłów) z prośbami, lecz przemoc Jugurty przymusza (mnie do tego)".

Supinum to może być określone okolicznikiem, a także uzupełniane dopełnieniem akomodowanym zgodnie $\mathrm{z}$ właściwościami rekcyjnymi reprezentowanego przez tę formację leksemu czasownikowego:

Adulescentulus [...] in Asiam ad regem militatum abiit. (Ter., Heaut. 113-117)

„Mlodzieniec udal się do Azjii slużyć w wojsku u boku króla”.

Ille geminus [...] hodie in Epidamnum veniet [...] quaeritatum geminum germanum suom. (Pl., Men. 69-71)

„Ow bliźniak przybędzie dziś do Epidamnus odszukać swego brata bliźniaka”.

Huc mihi venisti sponsam praereptum meam. (PI., Cas. 102)

„Przyszedleś tutaj sprzątnąć mi moją narzeczonä".

In ea castra $[\ldots]$ legati ab Roma venerunt questum iniurias et ex $[\ldots]$ foedere res repetitum. (Liv., 3, 25)

„Do obozu tego przybyli poslowie z Rzymu, aby uskarżyć się na wyrządzone krzywdy i na podstawie zawartej umowy domagać się zwrotu (zagrabionych) rzeczy".

Miejsce otwierane przez supinum dla dopełnienia może też być wypełnione przez podrzędne składniowo zdanie dopełnieniowe:

Vicere seniores, ut legati prius mitterentur questum iniurias postulatumque, ut pro iure gentium violato Fabii dederentur. (Liv., 5, 36) 
„Przeważyła wola starszych, aby wcześniej wyslać posłów $\mathbf{w}$ celu zaprotestowania przeciwko bezprawiu i zażądania, by za pogwałcone prawo narodów wydani zostali Fabiusze".

Drugi wariant supinum jest formacją utworzaną przez dodanie do czasownikowego tematu participium perfecti sufiksu -u. Supinum to służy głównie pełnieniu funkcji okolicznika względu lub zakresu przy przymiotnikach użytych zarówno atrybutywnie jak i predykatywnie. Sygnalizuje diatezę nacechowaną (bierną), tzn. składnik imienny syntaktycznie nadrzędny względem określanego przez nie przymiotnika ujawnia argument drugiej rangi reprezentowanego przez nie predykatu, w związku z czym supinum to nie otwiera miejsca dla dopełnieniowego składnika imiennego:

Bonam atque iustam rem oppido imperas et factu facilem. (Ter., Heaut. 704)

"Dobrą i nader uczciwą rzecz nakazujesz, i latwą do zrobienia".

Sempronius consul [...] haud ullum dignum memoratu fecit. (Liv., 25, 1)

„Konsul Semproniusz nie dokonal niczego wartego zapamiętania”.

Quae virtutis moderationisque fama Indos etiam ac Scythas auditu modo cognitos pellexit ad amicitiam suam populique Romani [...] petendam. (Suet., Aug. 21)

„Owa sława męstwa i umiaru nawet Indów i Scytów, znanych tylko ze słyszenia, skłonila do zabiegania o przyjaźn z nim (scil. Augustem) i narodem rzymskim".

O rem non modo visu foedam, sed etiam auditu! (Cic., Phil. 2, 63)

„Co za rzecz, wstrętna nie tylko do oglądania, ale nawet do słuchania (o niej)!"

Uva $[\ldots]$ primo est peracerba gustatu, dein maturata dulcescit. (Cic., Sen. 53)

„Winne grono z początku jest bardzo cierpkie w smaku, później, gdy dojrzeje, staje się słodkie".

Minus, Hercule, calles pravissimis opinionibus ea putari mendacia, quae vel auditu nova vel visu rudia [...] videantur; quae si paulo accuratius exploraris, non modo compertu evidentia, verum etiam factu facilia senties. (Apul., Met. 1, 3)

„Na Herkulesa, wskutek fałszywych uprzedzeń masz mniejszą świadomość tego, że na ogól bierze się za klamstwa rzeczy, które wydają się albo nowe dla uszu, albo nadzwyczajne dla oczu; jeśli jednak zbadasz je trochę dokładniej, uznasz je nie tylko za oczywiste co do możliwości udowodnienia ich prawdziwości, ale i latwę do wykonania".

W przypadku, gdy określany przez to supinum przymiotnik użyty jest predykatywnie, tzn. jeśli pełni on funkcję orzecznika lub funkcjonalnego odpowiednika orzecznika (w ramach równoważnika zdania o postaci accusativus cum infinitivo), pozycja (funkcjonalnego odpowiednika) podmiotu może zostać wypełniona przez infinitivus, zdanie podrzędne podmiotowe lub równoważnik zdania podmiotowego (accusativus cum infinitivo):

Optimum [...] factu visum est anteluculo furtim evadere. (Apul., Met. 1, 14)

"Czymś najlepszym do zrobienia wydała się ucieczka jeszcze przed świtem”.

Caesar [...] sibi difficile factu esse intellexit simul et oppidum uno tempore oppugnare et in acie [...] ex iniquiore loco pugnare. (Ps.-Caes., Bell. Afr. 42)

„Cezar zrozumial, że trudne do wykonania byłoby dla niego równoczesne atakowanie miasta i prowadzenic walki w szyku bojowym z niedogodnej pozycji". 
Quoivis facile scitust, quam fuerim miser. (Ter., Hec. 296)

„Dla każdego jest łatwe do poznania, jak bardzo byłem nieszczęśliwy."

Difficile dictu est, quantopere conciliet animos comitas adfabilitasque sermonis. (Cic., Off. $2,48)$

.Trudne jest do wyrażenia słowami (= Trudno opowiedzieć), jak bardzo zjednuje umysty delikatność i uprzejmość w rozmowie".

Quam difficiles plerisque videntur calamitatum societates! Ad quas non est facile inventu, qui descendant. (Cic., Lael. 64)

„Jak trudne wydaje się wielu ludziom dzielenie cudzego nieszczęścia! Nie latwo znaleźć takich, którzy by na to przystali".

Difficile factu est me id sentire, quod tu velis. (Cic., Nat. 3, 1)

"Trudne do spetnienia jest (to), bym ja myślat tak, jak ty chcesz".

Miejsce podmiotu (lub funkcjonalnego odpowiednika podmiotu) przy przymiotnikowym orzeczniku (lub funkcjonalnym odpowiedniku orzecznika) określanym supinum zająć może też kataforyczny zaimek odsyłający do apozycyjnego, rozszerzającego (równoważnika) zdania podmiotowego o charakterze eksplikatywnym (epegzegetycznym):

Nunc hoc mihi factu est optumum, ut ted auferam, aula, in in Fidei fanum. (Pl., Aul. 582-583)

„Teraz najlepsze dla mnie do zrobienia jest to, bym cię, garnuszku, stąd zabrał do świątyni Wierności".

Quod difficile erat factu, ut eam turrem sine periculo quis incenderet. (Ps.-Caes., Bell. Hisp. 18)

„Trudne było do wykonania to, aby wieżę tę ktoś podpalił bez narażenia się na niebezpieczeństwo".

Enimvero id auditu etiam dicere indignum esse Hegesianax Thraciae et Chersonesi urbibus arceri Antiochum. (Liv., 34, 58)

"Hegesjanaks odrzekł, iż doprawdy nie jest to nawet godne wysłuchania, by Antioch był odsuwany od miast Tracji i Chersonezu".

Si hoc optimum factu iudicarem, patres conscripti, Catilinam morte multari, unius usuram horae gladiatori isti ad vivendum non dedissem. (Cic., Catil. 1, 29)

„Jeśli to uznałbym za najlepsze do zrobienia, senatorowie, a mianowicie żeby Katylina został ukarany śmiercią, nawet godziny życia nie darowałbym temu bandycie".

Rzadko supinum jest także określnikiem nieprzymiotnikowych wyrażeń predykatywnych typu: fas est, nefas est, opus est, pudet $\mathrm{w}$ ramach podobnych do opisanych wyżej struktur składniowych:

Humanus [...] animus [...] cum alio nullo nisi cum ipso deo, si hoc fas est dictu, comparari potest. (Cic., Tusc. 5,38 )

„Ludzka dusza $z$ niczym innym, jak tylko z samym bogiem, jeśli godzi sį̣ tak powiedzieć, nie może być porównywana". 
Videtis nefas esse dictu miseram fuisse talem senectutem. (Cic., Sen. 13)

„Widzicie, że nie godzi się powiedzieć, iż taka starość była nieszczęśliwa”;

Quod [...] vix auditu fas esse debeat, laudis et gloriae et ingenii loco plerique iactant, cantari saltarique commentarios suos. (Tac., Dial. 26)

„To, czego z trudem godzi się słuchać, liczni przedstawiają jako przejaw sławy, chwaty i talentu, że mianowicie do słów ich spisanych przemówień śpiewa się i tańczy".

Sed ita dictu opus est [...] me mea omnia bona doti dixisse illi. (Ter., Heaut. 941-942)

„Ale trzeba mówić, że przyrzekłem mu w posagu wszystkie moje dobra”.

Nisi si Gallos et Germanos et (pudet dictu) Britannorum plerosque [...] fide et adfectu teneri putatis. (Tac., Agr. 32)

„Chyba że uważacie, iż Gallowie i Germanowie i - wstyd powiedzieć - liczni spośród Brytańczyków trzymają się (przy Rzymianach) wskutek wierności wynikającej z przywiązania (do nich)".

\subsection{WYBRANA LITERATURA}

Ahern (1987), Bednarski (1983, 1992), Bergh (1975), Bolkestein (1985b), Calboli (1962c, 1962d, 1990c), Coleman (1985a), Eklund (1984-1986), Foubert (2005), Garcia-Hernández (1996), Gianollo (2005), Haverling (2002), Haverling (2010), Joffre (1995), Lehmann (1983, 1985), Lehmann (2002), Maraldi (1994, 1996), Mellet, Joffre, Serbat (1994), Mensink (1994), Panhuis (1984b), Pieroni (2000), Pinkster (1983c, 1985b, 1992, 1998), Risch E., 1984, Risselada (1991, 1993), Robino (2000), Rosén (1980, 1995), Stempel (1994), Suárez Martínez (2005), Tesarová-Nováková (1984), Vester (1977), Vester (1985, 1991), Wolanin (2001) 


\section{3. \\ Charakterystyka funkcjonalna przyimków}

Przyimki to klasa leksemów nieautosyntagmatycznych synsyntagmatycznych. Oznacza to, że reprezentujące je w ramach wypowiedzeń wyrazy gramatyczne samodzielnie nie stanowią członów syntaktycznych lecz współtworzą je $z$ innymi wyrazami gramatycznymi jako elementami konstytutywnymi, modyfikując ich funkcję relacyjną. Wyrazami tymi są odmienne przez przypadki formy imienne, najczęściej rzeczownikowe bądź zaimkowe, rzadziej substantywizowane przymiotniki, imiesłowy lub odczasownikowe gerundium, a współtworzone $\mathrm{z}$ nimi czlony syntaktyczne to głównie okoliczniki, rzadziej przydawki, dopełnienia (dalsze) i orzeczniki. Tym samym, wraz z końcówkami fleksyjnymi form imiennych, stanowią współwykładniki akomodacji członów syntaktycznych, które $\mathrm{z}$ formami tymi współkonstytuują.

Pewna grupa przyimków cechuje się homonimią w stosunku do leksemów przysłówkowych, stąd możliwe jest przypisanie im statusu przysłówków, które w ramach sekundarnej dystrybucji składniowej przyjmują funkcję przyimków; por. np.:

Quorum cohortes militum postero die ante oppidum Iuba conspicatus [...] magnam partem eorum interfici iussit. (Caes., Civ. 2, 44)

„Gdy kohorty tych żołnierzy Juba dostrzegł następnego dnia przed miastem, znaczną ich część kazal zabić".

wobec:

Orgetorix $[\ldots]$ persuadet Castico $[. .$.$] , ut regnum in civitate sua occuparet, quod pater$ ante habuerat. (Caes., Gall. 1, 3)

„Orgetoryks nakłonil Kastykusa, aby przejął w swoim kraju władzę królewską, którą poprzednio sprawował (jego) ojciec".

Cum iam prope castra venisset, vi morbi oppressus vitam amiserit. (Cic., Phil. 9, 15)

„Gdy już podszcdl blisko obozu, złożony atakiem choroby umarl”.

wobec:

Etenim prope est spelunca quaedam conversa ad aquilonem infinita altitudine. (Cic., Verr. 2, 4, 197)

„W pobliżu znajduje się bowiem jakaś pieczara zwrócona na północ, nieskończenie głęboka”. 
Memineram persaepe te cum cum Panaetio disserere solitum coram Polybio. (Cic., Rep. $1,34)$

„Pamiętam, że bardzo często dyskutowałeś z Panajtiosem przy Polibiuszu (= w obecności Polibiusza)".

wobec:

Eadem fere, quae ex nuntiis litterisque cognoverat, coram perspicit. (Caes., Gall. 5, 11)

„Niemal wszystko to samo, czego dowiedział się z ustnych i pisemnych doniesień, ujrzał osobiście (= na wlasne oczy)".

Specyficzną właściwością gramatyczną przyimków jako klasy leksemów jest z jednej strony ich nieodmienność, czyli nieuwzględnianie żadnych kategorii fleksyjnych, $z$ drugiej zaś ich zróżnicowanie co do łączliwości $z$ formami imiennymi w zależności od wyrażanej przez te formy wartości kategorii przypadka. Zróżnicowanie to stanowi podstawę podziału przyimków na takie, które tworzą człony syntaktyczne $\mathrm{z}$ formami imiennymi w akuzatiwie, oraz takie, które człony te tworzą $\mathrm{z}$ formami imiennymi w ablatiwie, przy czym trzy leksemy przyimkowe (tj. in, sub i super) mogą je tworzyć $z$ formami w obu tych przypadkach. $Z$ kolei specyfiką współtworzonych przez przyimki członów syntaktycznych jest to, iż mogą one być liniowo nieciągłe, tzn. ich składniki mogą być rozdzielone innymi elementami wypowiedzenia (członami syntaktycznymi), np.:

Ea est $[\ldots]$ vox bene iudicantium de excellenti virtute. (Cic., Tusc. 3, 3)

"To jest glos ludzi wypowiadających słuszny sąd o nieprzeciętnej cnocie”.

W przypadku, gdy dany przyimek wpółtworzy dwa lub więcej członów syntaktycznych zestawionych szeregowo, $w$ drugim $z$ nich (i kolejnych) może zostać pominięty powierzchniowo, np.:

De exercitatione et consuetudine et commentatione dixi. (Cic., Tusc. 2, 42)

„Powiedzialem już o wprawie, przyzwyczajeniu i gotowości”.

W ramach wpółtworzonych członów syntaktycznych przyimki występują zwykle w prepozycji względem konstytutywnego członu imiennego, niektóre jednak mogą wystąpić również $\mathrm{w}$ postpozycji:

Hunc adversus tamen Timotheus postea $[\ldots]$ bellum gessit. (Nep., Timoth. 4)

„Przeciwko niemu prowadzil jednak później Timoteos wojnę”.

Przyimki lączące się z formami imiennymi w akuzatiwie wpółtworzyć mogą z nimi:

a. Okoliczniki:

Sic bellum, quod rex adversus Datamen susceperat, sedatum est. (Nep., Dat. 8)

„W ten sposób wojna, którą król podjął przeciwko Datamesowi, została zakończona".

Ad multam noctem etiam ad impedimenta pugnatum est. (Caes., Gall. 1, 27)

„Walczono do późnej nocy również przy taborach”. 
Inter haec parata atque decreta Cethegus semper querebatur de ignavia sociorum. (Sall., Cat. 43)

„Wśród tych przygotowań i ustaleń Cetegus nieustannie skarżył się na opieszalość (swych) wspólników".

Neque saepe accidit, ut neglecta quispiam religione [...] capta apud se occultare [...] auderet. (Caes., Gall. 6, 17)

„I nie zdarza się często, by ktoś, lekceważąc nakazy religijne, odważył się ukryć u siebie zdobycze wojenne".

Hominem adduxeris [...] ad pronuntiandum expeditum. (Cic., De orat. 2,131 )

„Przyprowadzisz czlowieka uzdolnionego do wyglaszania (mów)”.

b. Przydawki:

Hunc [...] reditu ad Antonium prohiberi negabant oportere. (Cic., Phil. 8, 32)

„Uważali, że nie należy zakazywać mu powrotu do Antoniusza”.

Huius (scil. Hamilcaris) perpetuum odium erga Romanos maxime concitasse videtur secundum bellum Poenicum. (Nep., Ham. 4)

„Wydaje się, że jego (scil. Hamilkara) nieprzerwana nienawiść do Rzzymian w największym stopniu przyczyniła się do wybuchu drugiej wojny punickiej".

Aliquantum ea quoque res duci famae et auctoritatis apud milites addicit. (Liv., 44, 33)

"Również ta rzecz przydala dowódcy trochę slawy i autorytetu u żołnierzy”.

c. Orzeczniki:

Pontem, qui erat ad Genavam, iubet rescindi. (Caes., Gall. 1, 7)

„Most, który znajdowal się pod Genawą, kazał zerwać”.

Labieno scribit, ut quam plurimas possit iis legionibus, quae sint apud eum, naves instruat. (Caes., Gall. 5, 11)

„Labienusowi napisał, by przy pomocy tych legionów, które są przy nim (= są pod jego rozkazami), zbudowal jak najwięcej okrętów".

d. Dopełnienia (dalsze):

Legatos ad Dumnorigem Heduum mittunt. (Caes., Gall. 1, 9)

"Wysyłają posłów do Dumnoryksa z plemienia Eduów".

Podobnie przyimki łączące się $\mathrm{z}$ formami imiennymi w ablatiwie współtworzyć mogą:

a. Okoliczniki:

Omittam [...] dolorem [...], quem optimus quisque pro patria et pro suis suscipit. (Cic., Fin. 1, 24)

„Pominę udrękę, którą każdy szlachetny człowiek podejmuje dla ojczyzny i dla swoich (wspólobywateli)".

Perseum filium cum modica manu circummisit, ut a superioribus locis urbem adgrederetur. (Liv., 40, 22) 
„Syna Perseusza $\mathbf{z}$ niewielkim oddziałem posłał okrężną drogą, aby $\mathbf{z}$ wyżej polożonych miejsc zaatakowal miasto".

$\boldsymbol{A} \boldsymbol{b}$ hora tertia bibebatur, ludebatur, vomebatur. (Cic., Phil. 2, 104)

"Od godziny trzeciej pito, bawiono się, rzygano".

Intellegunt neminem ne minimum quidem maleficium sine causa admittere. (Cic., $S$. Rosc. 73)

„Rozumieją, że nikt nawet najmniejszego wykroczenia nie dopuszcza się bez przyczyny”.

Utetur (orator facetiis) in narrando aliquid venuste. (Cic., Orat. 87)

"Mówca posluży się dowcipem przy opowiadaniu czegoś w sposób powabny".

b. Orzeczniki:

Mons erat sine aqua. (Caes., Civ. 3, 97)

"Wzgórze było bez (= pozbawione) wody".

Saepe [...] redeo ad Scipionem, cuius omnis sermo erat de amicitia. (Cic., Lael. 62)

"Często powracam do Scypiona, którego wszelkie rozmowy były o (= dotyczyły) przyjaźni".

Simili $[\ldots]$ sunt in culpa qui officia deserunt mollitia animi. (Cic., Fin. 1, 33)

„W podobnym błędzie są (= tkwią) ci, którzy zaniedbują obowiązki wskutek slabości charakteru".

c. Przydawki:

Auctore Icilio Numitorioque secessio ab decemviris facta est. (Liv., 3, 51)

„Za sprawą Icyliusza i Numitoriusza nastąpiło odejście (żolnierzy) od decemwirów (= bunt przeciw decemwirom)".

Vidistis simulacrum Cereris e marmore. (Cic., Verr. 2, 4, 109)

"Zobaczyliście posąg Cerery z marmuru”.

d. Dopełnienia (dalsze):

Caesar dixit $[\ldots]$ duces a pace abhorruisse. (Caes., Civ. 1, 85)

"Cezar odpowiedzial, że wodzowie wzbraniali się przed pokojem".

De eorum fide constantiaque dubitatis? (Caes., Gall. 7, 77)

"Czy wątpicie w ich wierność i stalość?"

Jak już wspomniano wyżej, przyimki in, sub oraz super mogą współtworzyć człony syntaktyczne $\mathrm{z}$ formami imiennymi wyrażonymi zarówno $\mathrm{w}$ akuzatiwie, jak i w ablatiwie. W przypadku wyrażania relacji przestrzennych, człony utworzone $\mathrm{z}$ formami imiennymi w akuzatiwie stosowane są zwykle w odniesieniu do treści o charakterze dynamicznym (denotując punkt odniesienia związany z ruchem), natomiast człony $\mathrm{z}$ formami imiennymi w ablatiwie występują $\mathbf{w}$ kontekście treści o charakterze statycznym (identyfikując miejsce):

Germani frequentes $[\ldots]$ ad eum in castra venerunt. (Caes., Gall. 4, 13)

„Germanowie thumnie przybyli do niego do obozu”. 
Caesar iis, quos in castris retinuerat, discedendi potestatem fecit. (Caes., Gall. 4, 15)

"Cezar tym, których wcześniej zatrzymał w obozie, dał możliwość swobodnego odejścia”.

Nonae legionis milites [...] sub montem, in quo erat oppidum positum Ilerda, succedunt. (Caes., Civ. 1, 45)

„Żołnierze dziewiątego legionu podchodzą pod wzgórze, na klórym położone było miasto Ilerda".

(Ceasar) ab exploratoribus certior factus hostes sub monte consedisse [...], qualis esset natura montis [...], qui cognoscerent, misit. (Caes., Gall. 1, 21)

„(Cezar) powiadomiony przez zwiadowców, że nieprzyjaciele zjaęli pozycje pod wzgórzem, wysłał (ludzi), którzy mieli rozpoznać, jakie są naturalne uwarunkowania wzgórza".

(Herodotus scripsit) Delphinum repente inter undas adnavisse fluitantique sese homini subdidisse et dorso super fluctus edito vectavisse. (Gell., Noc. Att. 16, 19, 16)

„(Herodot napisal, że) nagle wśród morskiej toni przypłynąl delfin, zanurkowal pod płynącym człowiekiem i wynurzywszy grzbiet ponad fale, poniósł (go)".

Ensis cui super inpia cervice pendet, non Siculae dapes dulcem elaborabunt sapores. (Hor., Carm. 3, 1, 17-19)

„Komu nad bezbożną szyją wisi miecz, (u tego) sycylijskie potrawy nie pobudzą smaku”.

W określonych kontekstach status zbliżony do przyimkowego zyskują także leksemy causa i gratia użyte w ablatiwie i wpółtworzące (najczęściej w postpozycji) człony syntaktyczne $\mathrm{z}$ formami imiennymi $\mathrm{w}$ genetiwie:

Clamorem militum audit, quos rex in oppido praesidii causa reliquerat. (Caes., Civ. 3, 106)

"Usłyszal okrzyki żołnierzy, których król pozostawil w mieście dla ochrony".

Huic permisit [...], uti in his locis legionem hiemandi causa conlocaret. (Caes., Gall. 3, 1) „Pozwolił mu, by w' tych okolicach rozlokowal legion na przezimowanie”.

Cuius sententias communis utilitatis gratia [...] rettuli.

„lego opinie zrelacjonowałem ku wspólnemu pożytkowi”.

Fuit $[\ldots]$ tanta liberalitate, cum compluribus locis praedia hortosque haberet, ut numquam in eis custodem imposuerit fructus servandi gratia. (Nep., Cim. 4)

"Cechował się tak wielką wspaniałomyślnością, że mając $w$ wielu miejscach posiadłości i ogrody, nigdy nie umieścił w nich stróża dla pilnowania owoców".

Podobnie do statusu przyimkowego zbliża się leksem quam w ramach wypowiedzeń wyrażających porównywanie czy zestawianie obiektów (zob. też wyżej: 7.5.6.1. pkt 5):

Brutum abiectum [...] excitavi, quem non minus amo quam tu. (Cic., Att. 5, 20, 6) „Podjąłem na nowo zaniedbane sprany Brutusa, którego kocham nie mniej niż tỵ”.

Senex $[\ldots]$ est $[\ldots]$ meliore condicione quam adulescens. (Cic., Sen. 68)

„Starzec jest w lepszym położeniu niż młodzieniec”. 
In leges meas dabo [...], perpetuom annum hunc mihi uti serviat nec quemquam interea alium admittat prorsus quam me ad se virum. (Pl., Asin. 234-236)

„Zastrzegę w moich prawach, że przez cały ten rok ma mi slużyć i w tym czasie nie dopuścić do siebie absolutnie żadnego innego mężczyzny niż mnie".

\subsection{WYBRANA LITERATURA}

De La Villa (1996), Luraghi $(1989,2005)$ 


\section{4. \\ Charakterystyka funkcjonalna spójników}

Spójniki to klasa nieodmiennych leksemów nieautosyntagmatycznych intersyntagmatycznych, czyli takich, których tekstowe reprezentacje w ramach wypowiedzenia nie stanowią członów syntaktycznych, lecz prymarnie pełnią funkcję konektorów, tj. wykładników relacji semantyczno-syntaktycznych, zachodzących między zdaniowymi i niezdaniowymi składnikami wypowiedzenia. W zależności od tego, czy wyrażane przez spójnikowe konektory relacje mają charakter niepodrzędny (współrzędny), czy nadrzędno-podrzędny, tradycyjnie dzieli się spójniki, podobnie jak stanowione przez nie konektory, na współrzędne (parataktyczne) i podrzędne (hipotaktyczne).

Spójniki współrzędne (parataktyczne) prymarnie pełnią funkcję parataktycznych konektorów będących wykładnikami niepodrzędnych (współrzędnych) relacji zachodzących zarówno między członami syntaktycznymi zdania, pozostającymi względem siebie $w$ stosunku szeregowym, jak i między zdaniami składowymi lub równoważnikami zdań składowych zdania złożonego. Relacje te pod względem semantycznym są zróżnicowanie, w związku z czym wyróżnia się spójniki:

a. Kopulatywne (łączne):

Caesar $[. .$.$] primam et secundam aciem in armis esse [...] iussit. (Caes., Gall. 1, 49)$ "Cezar rozkazal, by pierwszy i drugi szereg żolnierzy stał pod bronią".

Huic Ceasar legioni indulserat praecipue et propter virtutem confidebat maxime. (Caes., Gall. 1, 40)

„Temu legionowi Cezar szczególnie sprzyjał i ze względu na męstwo najbardziej ufał”.

His de causis aguntur omnia raptim atque turbate. (Caes., Civ. 1, 5)

„Z tych powodów wszystko dzieje się pospiesznie i chaotycznie”.

Equestribus proeliis saepe ex equis desiliunt ac pedibus proeliantur. (Caes., Gall. 4, 2)

„W trakcie konnych utarczek często zeskakują z koni i walczą jak piechurzy”.

Acerrime reliqui resistebant nec dabat suspicionem fugae quisquam. (Caes., Gall. 7, 62)

„Pozostali (żołnierze) stawiali zwzięty opór i nie dawał nikt podstaw do podejrzeń o chęć ucieczki". 
Sed qui ab eo (scil. Pompeio) missi erant [...] liberius cum militibus regis conloqui coeperunt eosque hortari, ut suum officium Pompeio praestarent neve eius fortunam despicerent. (Caes., Civ. 3, 103)

„Lecz wyslannicy (Pompejusza) zaczęli swobodniej rozmawiać z żołnierzami króla i naklaniać ich, aby wypełnili swoje zobowiązanie wobec Pompejusza i nie okazywali pogardy dla jego losu".

b. Dysjunktywne (alternatywne, rozłączne):

Supplicia eorum, qui in furto aut in latrocinio aut aliqua noxii sint comprehensi, gratiora dis immortalibus esse arbitrantur. (Caes., Gall. 6, 16)

„Uważaja, że bogom bardziej mile są ofiary z tych, którzy przyłapani zostali na kradzieży albo na rozboju, albo jako winni jakiegoś innego wykroczenia".

Duodecim tabulae, cum perpaucas res capite sanxissent, in his hanc quoque sanciendam putaverunt, si quis occentavisset sive carmen condidisset. (Cic., Rep. 4, 12)

„Ustawy dwunastu tablic, chociaż bardzo niewiele spraw obwarowaly karą śmierci, to jednak (autorzy tych ustaw) uznali, że powinna mieć ona zastosowanie również $w$ stosunku do sytuacji, gdyby ktoś wyglaszal lub ukladal obelżywe teksty".

Locum sepulcro in campo Esquilino C. Pansa consul, seu quo in loco videbitur, $[\ldots]$ adsignet. (Cic., Phil. 9, 17)

„Niech konsul Gajusz Pansa wyznaczy miejsce dla grobu na polu Eskwilińskim albo gdzie uzna to za stosowne".

c. Adwersatywne (przeciwstawne):

Quae contumelia non fregit eum, sed erexit. (Nep., Them. 1)

"Ta zniewaga nie zlamała go, lecz dodała mu sil".

Cassius plebeii Romae generis, verum antiqui honoratique, $[\ldots]$ facilitate saepius quam industria commendabatur. (Tac., Ann. 6, 15)

„Kasjusz, pochodzący z rzymskiego rodu plebejskiego, ale starego i poważanego, jednal sobie życzliwość raczej lagodnością charakteru, niż energią w działaniu".

Magna res, magna dignitas, summa autem gratia. (Cic., Mur. 29)

„Wielki majątek, wielka godność, największe jednak wpływy”.

d. Konkluzywne (rezultatywne, konskutywne):

Iam habet, quod petit [...], ergo gratus sum. (Sen., Benef. 2, 33)

"Już ma to, czego pragnie, zatem nie jestem niewdzięczny".

e. Eksplikatywne (wyjaśniające):

Nihil est quod quisquam magnitudinem artium ex eo, quod senes discunt, pertimescat, namque aut senes ad eas accesserunt aut usque ad senectutem in studiis detinentur. (Cic., De orat. 3,89 )

„Nie ma powodu, by ktoś mial się przerazić ogromem nauk na podstawie tego, że (jeszcze) starcy uczą się, bowiem (oni) albo dopiero jako starcy zaczęli się uczyć, albo aż do starości nauka ich absorbuje". 
Addidit praecepta (etenim aderat Meherdates), ut non dominationem $[\ldots]$ cogitaret. (Tac., Ann. 12, 11)

„Dodal też pouczenia (byl tam bowiem obecny Meherdates), aby nie myślal o tyranii”.

Spójniki parataktyczne mogą występować w zestawieniach, w których pierwszy składnik presuponuje wystąpienie wyliczenia określonych elementów treściowych, zaś drugi (lub każdy kolejny) stanowi właściwy konektor identyfikujący relacje między tymi elementami:

Reminisceretur et veteris incommodi populi Romani et pristinae virtutis Helvetiorum. (Caes., Gall. 1, 13)

„Niech pamięta i o dawnej klęsce ludu rzymskiego i o wcześniejszej waleczności Helwetów”.

Augur eo se sacerdotio praeditum esse dixit, ut comitia auspiciis vel impedire vel vitiare posset. (Cic., Phil. 2, 80)

„Augur oświadczyl, że sprawuje tego rodzaju urząd kaplański, iż poprzez wróżby może albo uniemożliwić, albo unieważnić komicja".

Conatus est Caesar reficere pontes, sed nec magnitudo fluminis permittebat, neque ad ripam dispositae cohortes adversariorum perfici patiebantur. (Caes., Civ. 1, 50)

„Cezar usiłował odbudować mosty, lecz ani wielkość rzeki na to nie pozwalała, ani rozlokowane na brzegu kohorty nieprzyjaciól nie dopuszczaly do podjęcia budowy".

Spójniki podrzędne (hipotaktyczne) prymarnie pełnią funkcję hipotaktycznych konektorów będących wykładnikami relacji zachodzących głównie między zdaniami składowymi (lub równoważnikami zdań składowych) zdania złożonego niewspółrzędnie (nadrzędno-podrzędnie). W przypadku zdań podrzędnych dopełnieniowych, podmiotowych, przydawkowych czy orzecznikowych wprowadzający je stanowiony przez spójnik konektor jest wyłącznie wskaźnikiem podrzędności syntaktycznej, pozbawionym funkcji semantycznej:

Allobrogibus imperavit, ut iis frumenti copiam facerent. (Caes., Gall. 1, 28)

"Allobrogom nakazal, aby dostarczyli im zapasu zboża".

Accidit perincommode, quod eum nusquam vidisti. (Cic., Att. 1, 17, 2)

„Tak się nieszczęśliwie zdarzyło, że nigdzie się z nim nie zobaczyłeś".

Neque abest suspicio [...], quin ipse sibi mortem consciverit. (Caes., Gall. 1, 4)

„I nie brak podejrzeń, że sam sobie zadal śmierć".

Eloquentia [...] sit talis, ut res potius quam se ostendat. (Sen., Lucil. 75, 5)

„Sztuka wymowy niech będzie taka, by ukazywala raczej rzeczy (komunikowane za jej pośrednictwem) niż siebie samą".

Z kolei spójniki stanowiące konektory wprowadzające zdania podrzędne okolicznikowe zwykle wnoszą także określone nacechowanie znaczeniowe, w związku z czym są wykładnikami relacji o charakterze syntaktyczno-semantycznym, zachodzących między zdaniem nadrzędnym a podrzędnym. Jeśli uwzględnić kryterium znaczeniowe, wyróżnia się zatem spójniki: 
a. Celowe (finalne):

Quidam cenent tecum quia digni sunt, quidam ut sint. (Sen., Lucil. 47,15)

„Niech pewni ludzie spożywają z tobą obiad dlatego, że są tego godni, inni, by stali się (godnymi)".

Angustias [...] Themistocles quaerebat, ne multitudine circuiretur. (Nep., Them. 3)

„Temistokles szukał cieśniny, by nie zostać otoczonym wskutek przewagi liczebnej (wrogów)".

Bituriges ad Haeduos [...] legatos mittunt subsidium rogatum, quo facilius hostium copias sustinere possinnt. (Caes., Gall. 7, 5)

„Biturygowie wysyłają do Eduów posłów z prośbą o pomoc, by łatwiej mogli (razem) powstrzymać oddziały nieprzyjaciół".

b. Przyczynowe (kauzalne):

Tu id semper facis, quia semper potes. (Cic., Quinct. 35)

„Ty zawsze to czynisz, ponieważ zawsze możesz".

Noctu ambulabat in publico Themistocles, quod somnum capere non posset. (Cic., Tusc. $4,44)$

„Nocą Temistokles spacerowal po mieście, ponieważ (jak twierdzil) nie mógł zasnąć”.

Haec in praesentia nota esse debebunt, voluptatem semovendam esse, quando ad maiora quaedam [...] nati sumus. (Cic., Fin. 5, 21)

„Na razie trzeba będzie przyjąć do wiadomości, że rozkosz powinno się odrzucić, skoro zostaliśmy stworzeni do czegoś większego".

c. Przyzwolenia (koncesywne):

Nec dubia nec difficilis Romanis, quamquam ingentem Galli terrorem memoria pristinae cladis attulerat, victoria fuit. (Liv., 6, 42)

„Dla Rzymian zwycięstwo nie było ani wątpliwe, ani trudne, chociaż ze względu na pamięć o dawnej klęsce Gallowie wywołali (wśród nich) wielki strach".

At Catilinae crudelis animus eadem illa movebat, tametsi praesidia parabantur et ipse lege Plautia interrogatus est ab L. Paulo. (Sall., Cat. 31)

„Tymczasem okrutny umysl Katyliny ciaggle obmyślal to samo, mimo ze przygotowywano (już) środki zaradcze, a on sam na podstawie prawa Plaucjusza został pozwany przed sąd przez Lucjusza Paulusa".

(Socrates), cum facile posset educi e custodia, noluit. (Cic., Tusc. 1, 71)

"(Sokrates), choć latwo mógł zostać wyprowadzony z więzienia, nie chciał".

d. Czasu (temporalne):

Milites, postquam victoriam adepti sunt, nihil relicui victis fecere. (Sall., Cat. 11)

„Żołnierze, (po tym) gdy odnieśli zwycięstwo, nic nie pozostawili zwyciężonym”.

Fulgentis gladios hostium videbant Decii, cum in aciem eorum inruebant. (Cic., Tusc. 2,59)

„Decjusze widzieli błyszczące miecze wrogów, gdy wdzierali się w ich szereg”. 
In omnibus [...] negotiis priusquam adgrediare, adhibenda est praeparatio diligens. (Cic., Off. 1, 73)

„Zanim w jakiejkolwiek sprawie przystapisz do działania, potrzebne jest staranne przygotowanie".

e. Warunku (kondycjonalne) i związane z nimi spójniki zastrzeżenia:

In eis etiam causis, in quibus omnis res nobis cum iudicibus est, non cum populo, tamen si a corona relictus sim, non queam dicere. (Cic., Brut. 192)

„Nawet w tych sprawach, w których wszystko zależy od sędziów, a nie od ludu, to jednak gdybym zostal opuszczony przez krąg stuchaczy, nie zdolałbym przemawiać".

Nisi tu (Tarentum) amisisses, numquam recepissem. (Cic., Sen. 11)

"Gdybyśs ty Tarentu nie utracil, (ja) nigdy bym (go) nie odzyskał".

Oderint, dum probent. (Suet., Tib. 56)

„Niech (mnie) nienawidzą, byleby (mnie) uznawali”.

f. Skutkowe (konsekutywne):

(Hannibal) adeo gravi morbo adficitur oculorum, ut postea numquam dextro aeque bene usus sit. (Nep., Hann. 4)

„(Hannibal) został dotknięty tak ciężką chorobą oczu, że później nigdy już na prawe (oko) nie widział równie dobrze".

Nil tam difficilest, quin quaerendo investigari possiet. (Ter., Heaut. 675)

„Nic nie jest tak trudne, by szukając, nie można było zanleźć (jakiegoś rozwiązania)”.

g. Porównania (zestawienia, charakterystyki):

Ego tui Bruti rem sic ago, ut suam ipse non ageret. (Cic., Att. 5, 18,4)

„Sprawę twojego Brutusa tak prowadzę, jak sam własnej by nie poprowadzil”.

Quorum neutrum tam facile, quam tu arbitraris, conceditur. (Cic., Div. 1, 10)

„Na żadną z obu tych rzeczy nie można zgodzić się tak latwo, jak sądzisz".

Trzeba dodać, że zarysowana wyżej tradycyjna, ogólna systematyka spójników jako konektorów, ma w znacznym stopniu charakter umowny, jako że liczne spośród nich cechują się semantyczną wielofunkcyjnością (wieloznacznością). W istocie więc jest to systematyka nie tyle spójników jako jednostek leksykalnych, co raczej systematyka funkcji przez nie realizowanych. Dotyczy to przy tym nie tylko spójników hipotaktycznych (ut, cum, quod), ale także parataktycznych; np. spójnik et, tradycyjnie zaliczany do klasy spójników kopulatywnych, może mieć również charakter adwersatywny, jak np. w zdaniu:

Aliquando non fulgurat et tonat. (Sen., Nat. 2, 18,1)

„Niekiedy nie ma blyskawicy, a jednak grzmi”. 
Spójniki mogą także stanowić składniki konektorów złożonych, w tym również tworzących zestawienia:

Cleonem etiam temporibus illis turbulentum illum quidem civem, sed tamen eloquentem constat fuisse. (Cic., Brut. 28)

„Wiadomo, że w tych czasach żył również Kleon, skory wprawdzie do wywoływania zamicszek, ale wymowny".

Claudio imperium adepto (Nero) non solum paternas opes reciperavit, sed et Crispi Passieni, vitrici sui, hereditate ditatus est. (Suet., Ner. 6)

„Po tym, gdy Klaudiusz doszedł do władzy, Neron nie tylko odzyskał majątek ojcowski, ale także wzbogadzil się spadkiem po Kryspusie Pasjenusie, swoim ojczymie".

Ita fit, ut adsint, propterea quod officium sequuntur, taceant autem idcirco quia periculum vitant. (Cic., S. Rosc. 1)

„Jest tak, iż są obecni dlatego, że wypełniają swój obowiązek, milczą zaś $\mathbf{z}$ tego powodu, íe unikają niebezpieczeństwa".

(Na temat konektorów zob. też niżej: 3.2.3.)

Oprócz swej prymarnej funkcji (składników) konektorów, sekundarnie spójniki mogą również pełnić funkcje (składników) operatorów tekstowych:

a. Nawiązania międzywypowiedzeniowego:

Agite, ite actutum, nam mi amatori seni coquendast cena. Atque, quom recogito, nobis coquendast, non quoi conducti sumus. (Pl., Merc. 741-742)

„Dalej, chodźcie prędko, bo muszę staremu amantowi przygotować ucztę. Jednak, gdy o tym myślę, to (dochodzę do wniosku, że raczej) sobie powinienem przygotować, nie temu, który mnie wynająr".

Milites dato signo celeriter ad munitiones perveniunt eamque transgressi trinis castris potiuntur; ac tanta fuit in capiendis castris celeritas, ut Teutomatus [...] vix se ex manibus praedantium militum eriperet. (Caes., Gall. 7, 46)

„Żołnierze na dany znak szybko podchodzą pod obwarowanie i po jego sforsowaniu zawladnęli trzema obozami; a taka była szybkość w zajmowaniu obozów, że Teutomatus ledwo wyrwał się z rąk plądrujących (je) żołnierzy".

Ad quos (scil. Sugambros) cum Caesar nuntios misisset, qui postularent eos, qui sibi Galliaeque bellum intulissent, sibi dederent, responderunt populi Romani imperium Rhenum finire [...]. Ubii autem, qui uni ex Transrhenis ad Caesarem legatos miserant [...], magnopere orabant, ut sibi auxilium ferret. (Caes., Gall. 4, 16)

„Gdy Cezar wysłał do Sugambrów posłów z żądaniem, by wydali mu tych, którzy jemu i Galli wypowiedzieli wojnę, odpowiedzieli mu, że władza ludu rzymskiego kończy się na Renie. Natomiast Umbrowie, którzy jako jedyni spośród plemion zareńskich wyprawili do Cezara posłów, usilnie blagali, by przyszedł im z pomocą". 
b. Presupozycji:

De Philotimo idem et ego arbitrabar. (Cic., Att. 12, 48, 1)

"O Filotymie również ja myślatem to samo".

Timeo Danaos et dona ferentis. (Verg., Aen. 2, 49)

"Obawiam się Danaów, nawet przynoszących dary".

Maxime ab omni [...] contagione Romanorum abstinebat, ut neque scribi sibi vellet. (Liv., $40,20)$

„Powstrzymywal się jak tylko mógł od kontaktów z Rzymianami, tak że nawet nie chciał, by do niego pisali".

Duo milia iugerum campi Leontini Sexto Clodio rhetori adsignasti, et quidem immunia. (Cic., Phil. 2, 43)

„Przyznaleś retorowi Sekstusowi Klodiuszowi dwa tysiące iugerów (ziemi) na Polu Leontyńskim, i to zwolnionych od podatku".

(Na temat operatorów tekstowych zob. też niżej: 3.2.4.)

\subsection{WYBRANA LITERATURA}

De Dardel (1983), Herman (1995), Luraghi (2001), Mellet (1995), Poirier (1995), Torrego (2009) 


\section{5. \\ Charakterystyka funkcjonalna partykuł}

Partykuły to klasa nieodmiennych leksemów nieautosyntagmatycznych asyntagmatycznych, czyli takich, których tekstowe reprezentacje prymarnie nie współtworzą struktury syntaktycznej zdania (wypowiedzenia), lecz pełnią funkcję operatorów tekstowych służących realizacji określonej strategii nadawczo-odbiorczej czy też osiąganiu określonych celów komunikacyjnych ze strony nadawcy $w$ ramach tzw. warstwy tekstowej wypowiedzenia. Wśród partykuł, i stanowionych przez nie operatorów, wyodrębnić można kilka podstawowych klas funkcjonalnych, a mianowicie:

a. Partykuły nawiązania międzywypowiedzeniowego, mające na celu nadanie tekstowi spójności retorycznej poprzez identyfikację relacji, w jakiej pozostaje rozpoczynany segment wypowiedzi (zdanie) w stosunku do wcześniej wyrażonych treści:

E fundo ornatissimo eiectus, ignominiis omnibus appetitus [...], nihil alienum tamen vita superiore commisit. Itaque hoc te obsecrat, $C$. Aquili, ut, quam existimationem, quam honestam in iudicium tuum prope acta iam aetate decursaque attulit, eam liceat ei secum ex hoc loco efferre. (Cic., Quinc. 98-99)

„Wyrzucony ze znakomitej posiadłości, atakowany wszelkimi obelgami, niczego się jednak nie dopuścil, co staloby w sprzeczności z jego dotychczasowym życiem. O to zatem cię blaga, Gajuszu Akwiliuszu, by tę opinię, tak nieposzlakowaną, z którą w twoim sądzie u kresu swego życia się zjawil, wolno było z tego miejsca z sobą wrynieść".

Quin igitur ista ipsa explicas nobis [...] et conscribis de iure subtilius quam ceteri? Nam a primo tempore aetatis iuri studere te memini. (Cic., Leg. 1, 13)

„Dlaczegoż więc tych właśnie zgadnień nam nie objaśniasz i nie chcesz napisać rozprawy o prawie cywilnym w sposób bardziej wnikliwy niż inni? Przecież pamiętam, że od wczesnej mlodości uczyleś się prawa".

Redeamus ad edictum. Id quidem quem ad modum iubet possidere? (Cic., Quinct. 84)

„Pow'róćmy do edyktu. Ten zaś, w jaki sposób nakazuje objąć w posiadanie?”

Ubi sunt ergo $i$, quos miseros dicis, aut quem locum incolunt? Si enim sunt, nusquam esse non possunt. (Cic., Tusc. 1, 11)

„Gdzie więc są ci, których nazywasz nieszczęślinymi, albo jakie miejsce zamieszkują? Jeśli bowiem istnieją, nie może być lak, że nie ma ich nigdzie". 
Sekundarnie partykuły tego typu mogą także stanowić parataktyczne konektory o charakterze konkluzywnym bądź eksplikatywnym:

C. Gracchi frumentaria magna (fuit) largitio, exhauriebat igitur aerarium. (Cic., Off. 2, 72)

„Prowadzone przez Gajusza Grakchusa rozdawnictwo zboża bylo ogromne, a więc ogołacało skarbiec publiczny".

Tace dum parumper, nam concrepuit ostium. (Pl., Men. 348)

„Tymczasem zamilcz na chwilę, skrzypnęły bowiem drzwi”.

b. Partykuły modalne, będące wykładnikami nacechowanej modalności zdaniowej; ze względu na rodzaj sygnalizowanej modalności wyróżnić można:

b.1. Partykuły konstytuujące operatory modalności epistemicznej, które wyrażanej treści predykatywnej przypisują status stanu prawdziwego (koniecznego) albo stanu możliwego lub prawdopodobnego:

Tredecim milia quadringentos septuaginta cecidisse in acie ac fuga, mille septingentos quinquaginta vivos captos, signa viginti septem militaria relata in quibusdam annalis invenio, ubi etsi adiectum aliquid numero sit, magna certe caedes fuit. (Liv., 3, 8)

„W niektórych kronikach znajduję informacje o trzynastu tysiącach czterystu siedemdziesięciu poległych $w$ walce i podczas ucieczki, tysiącu siedmiuset pięćdziesięciu pojmanych żywcem, dwudziestu siedmiu przejętych chorągwi, i nawet gdyby tam pewne liczby zostaly zawyżone, klęska 2 pewnością byla wielka".

Levius [...] vaniusque profecto est sua decreta et consulta tollere quam aliorum. (Liv., $3,21)$

„Bez wątpienia czymś bardziej nieodpowiedzialnym i niedorzecznym jest pogwałcać własne zarządzenia i uchwały niż cudze".

Forsitan non indigni simus, qui nobismet ipsi multam inrogemus. (Liv., 30, 30)

„Być może nie jesteśmy niegodni tego, byśmy sami nałożyli sobie karę”.

Causam fortasse diceremus apud victorem, quem ad modum apud vos dicimus. (Liv., $45,23)$

„Chyba stanęlibyśmy jako oskarżeni przed zwycięzcą, tak jak teraz stoimy przed wami”.

b.2. Partykuły konstytuujące operatory modalności intencjonalnej interrogatywnej bądź dezyderatywnej:

Utrum quid agatur non vides? (Cic., S. Rosc. 73)

"Czy nie widzisz, o co chodzi?"

An, quod diligenter defenditur, id tibi indignum facinus videtur? (Cic., S. Rosc. 148)

"Czy to, że jest rzetelnie broniony, wydaje ci się godnym potępienia występkiem?"

Num quaerenda causa, quae te ad tantum facinus adduxerit? (Cic., S. Rosc. 86)

„Czyż trzeba szukać powodu, który cię do tak wielkiej zbrodni przywiódl?"

Utinam tam facile vera invenire possim, quam falsa convincere. (Cic., Nat. 1, 91)

"Obym mógl równie latwo znaleźć prawdę, jak wykazać fałsz". 
c. Partykuły presupozycji, które implikując treści niewyrażone wprost w danej wypowiedzi, sygnalizować mogą intencję, $\mathrm{z}$ jaką autor przedstawia komunikowaną w wypowiedzeniu sytuację, bądź też sposób, w jaki wiąże ją z kontekstem lub konsytuacją, w której jest komunikowana. W dużej części leksemy te tradycyjnie klasyfikowane są w gramatykach i słownikach jako przysłówki, jednak ich cechy semantyczne skłaniają do przypisania ich tekstowym reprezentacjom funkcji raczej operatora tekstowego niż okolicznika, i tym samym do nadania im statusu partykuły:

Eius modi domum [...] hactenus comprobavit, ut se diceret quasi hominem tandem habitare coepisse. (Suet., Ner. 31)

„Tego rodzaju dom w taki tylko sposób pochwalił, że powiedzial, iż wreszcie zaczyna mieszkać jak czlowiek".

De re una solum dissident, de ceteris mirifice congruunt. (Cic., Leg. 1, 53)

„W jednej tylko sprawie się różnią, w pozostałych nad podziw się zgadzają".

Othoni nondum auctoritas inerat ad prohibendum scelus. (Tac., Hist. 1, 45)

„Otho jeszcze nie mial wystarczającego autorytetu, by zapobiec zbrodni”.

Iam ad quattuor milia equitum habebat. (Liv., 29, 34)

„Miał już blisko cztery tysiące jeźdźców”.

Etiam ad innocentium supplicia descendunt. (Caes., Gall. 6, 16)

„Posuwają się do skladania ofiar nawet $z$ niewinnych ludzi”.

d. Partykuły kwantyfikacji i negacji, sygnalizujące stopień adekwatności użytych składników wypowiedzenia w stosunku do komunikowanej sytuacji; podobnie jak w przypadku leksemów konstytuujących operatory presupozycji, również wyrazy pełniące funkcję operatorów kwantyfikacji najczęściej klasyfikowane są jako przysłówki, choć ich status faktycznie bliższy jest partykułom:

A Perusia et Cortona et Arretio, quae ferme capita Etruriae populorum ea tempestate erant, legati $[\ldots]$ indutias in triginta annos impetraverunt. (Liv., 9, 37)

„Posłowie z Peruzji, Kortony i Arrecjum, które wtedy były niejako stolicami ludów etruskich, uzyskali rozejm na trzydzieści lat".

Vixit $[. .$.$] in summa pauperie et paene inopia. (Suet., Gramm. 11, 4)$

„Żył w skrajnym ubóstwie i niemal w nędzy".

Ne faciam, inquis, omnino versus? (Hor., Ser. 2, 1, 5-6)

„Powiadasz, bym w ogóle nie pisal wierszy?"

Ab consule non parabatur, sed gerebatur iam bellum. (Liv., 31, 33)

„Przez konsula nie była przygotowywana wojna, lecz już prowadzona”.

Hisce oculis, ne nega. (Ter., Heaut. 564)

„Na własne oczy (widziałem), nie zaprzeczaj”. 
e. Partykuły emotywne, które mogą mieć charakter ekspresywny, służąc wyrażaniu emocji autora wypowiedzi, bądź impresywny, służąc przywołaniu uwagi adresata wypowiedzi:

Ei, perii miser. (Pl., Amph. 668)

„Aj, przepadtem, nieszczęsny”.

\{Aeschinus:\} Placet, pater lepidissime. \{Demea:\} Euge! Iam lepidus vocor. (Ter., Adelph. 910-911)

„\{Eschinus:\} Doskonale, kochany ojcze. \{Demeasz:\} Łał! Już mnie nazywa kochanym!”

En adsum tuis commota, Luci, precibus. (Apul., Met. 11, 5)

„Oto przybywam, poruszona twoimi, Lucjuszu, prośbami”.

Hic $[\ldots]$ si $[\ldots]$ decidit $[\ldots]$ in puteum foveamve, licet 'succurrite' longum clamet, 'io cives', non sit, qui tollere curet. (Hor., Ars 457-460)

„Jeśli ktoś taki wpada do studni albo rowu, to choćby dlugo krzyczał 'na pomoc! hej, obywatele!', nie znajdzie się nikt, kto by pospieszył, by (go) wydobyć".

(Na temat operatorów tekstowych zob. też niżej: 3.2.4.)

\subsection{WYBRANA LITERATURA}

Bertocchi (1995), Biville (1996), Denooz (2005), Huitink (2005), Kroon (1994, 1998, 2005), Kroon, Risselada (1998, 2002), Langslow (2000), Risselada (1994, 1996, 1998b), Rosén (2009), 

SKŁADNIA 



\section{1. \\ Ogólna typologia składniowa wypowiedzeń}

Wszelkie wypowiedzenia, rozumiane jako jednostki językowe, które - w ramach określonego kontekstu lub niezależnie od niego - są autonomiczne pod względem komunikacyjnym, można ogólnie podzielić na wypowiedzenia zdaniowe (zdania) i wypowiedzenia niezdaniowe (równoważniki zdań).

Uwzględniając specyfikę składniową języka łacińskiego możemy przyjąć, iż zdaniem jest takie wypowiedzenie, którego jednym ze składników jest orzeczenie, tj. człon składniowy (część zdania) stanowiony lub współstanowiony przez osobową formę czasownika, będący wykładnikiem tzw. treści predykatywnej, lub krócej: predykatu.

Biorąc pod uwagę kryterium sposobu, w jaki reprezentowany jest człon konstytutywny (czyli orzeczenie), zdania można podzielić na pojedyncze (proste), czyli zawierające tylko jedno orzeczenie, oraz złożone, czyli zawierające więcej niż jedno orzeczenie, przy czym z uwagi na istnienie orzeczeń złożonych, składających się $\mathrm{z}$ łącznika i orzecznika, jako zdania złożone klasyfikowane są również zdania zawierające więcej niż jeden łącznik lub więcej niż jeden orzecznik.

Wypowiedzenia, które nie zwierają w swym składzie orzeczenia, czyli członu syntaktycznego (współ)stanowionego przez osobową formę czasownika, to wypowiedzenia niezdaniowe, inaczej równoważniki zdań. Równoważniki zdań dzielą się na niezależne składniowo (samodzielne i niesamodzielne semantycznie) oraz zależne składniowo (czyli równoważniki zdań podrzędnych). 


\section{Wypowiedzenia niezdaniowe} niezależne składniowo

\section{(równoważniki zdań niezależne składniowo)}

Wypowiedzenia niezdaniowe, zwane też równoważnikami zdań, charakteryzują się tym, że w swej strukturze składniowej nie zawierają orzeczenia, czyli członu syntaktycznego (współ)stanowionego przez osobową formę czasownika. Z uwagi na stopień funkcjonalnej autonomii tego typu wypowiedzeń dzielą się one na dwie podstawowe klasy: wypowiedzenia samodzielnie semantycznie i wypowiedzenia niesamodzielne semantycznie.

Wypowiedzenia samodzielne semantycznie cechują się komunikacyjną autonomią, tzn. ich sens jest zrozumiały bez kooperacji kontekstu. Wyróżnić można ich kilka podstawowych typów.

Jeden $\mathrm{z}$ nich tworzą wypowiedzenia, które spotykane są $\mathrm{w}$ tekstach o charakterze narracyjnym i charakteryzują się tym, że ich struktura składniowa nie odbiega od struktury zdania $\mathrm{z}$ wyjątkiem tego, iż miejsce otwierane w niej dla orzeczenia wypełniane jest przez jego funkcjonalny odpowiednik w postaci bezokolicznikowej formy czasownika. Użyty w taki sposób bezokolicznik tradycyjnie znany jest jako tzw. infinitivus historicus, czyli bezokolicznik historyczny, zwany też narracyjnym. Stanowi on równoważnik osobowych form czasowników w czasie przeszłym lub teraźniejszym (praesens historicum), chociaż morfologicznie nacechowany jest co do gramatycznej kategorii czasu wyłącznie wartością praesens. Stosowanie wypowiedzeń z historycznym bezokolicznikiem związane jest $\mathrm{z}$ tekstową funkcją dramaturgicznego ożywienia narracji, zwłaszcza przy relacjonowaniu sekwencji zdarzeń następujących szybko po sobie lub dziejących równocześnie:

Brevi spatio interiecto [...] hostes ex omnibus partibus signo dato decurrere, lapides gaesaque in vallum conicere. Nostri primo integris viribus fortiter repugnare neque ullum frustra telum ex loco superiore mittere, ut quaeque pars castrorum nudata defensoribus premi videbatur, eo occurrere et auxilium ferre, sed hoc superari, quod diuturnitate pugnae hostes defessi proelio excedebant, alii integris viribus succedebant; quarum rerum a nostris propter paucitate fieri nihil poterat. (Caes., Gall. 3, 4) 
„Wkrótce potem wrogowie na dany sygnal zaczęli ze wszystkich stron zbiegać w dół i zrzucać na wal kamienie i oszczepy. Nasi, początkowo będąc jeszcze w pełni sil, dzielnie stawiali opór i z wyżej polożonych stanowisk żadnego pocisku nie wyrzucali na próżno, a która część obozu wskutek braku obrońców wydawała się być w zgrożeniu, tam biegli i nieśli pomoc; druga strona miala jednak przewagę wskutek tego, iż zmęczeni długotrwalą walką przeciwnicy ustępowali z pola walki i zastępowali ich inni ze świeżymi siłami, a z powodu niewielkiej liczebności żołnierzy $z$ naszej strony' żaden taki manewr nie był możliwy".

Innego rodzaju wypowiedzenia wynikają z kontekstu sytuacyjnego; mogą one być wyrazem (emocjonalnej) reakcji na określone zdarzenia, czyjeś słowa, zachowania itp. Charakterystyczne dla nich jest niezależne składniowo użycie rzeczownikowych form $\mathrm{w}$ akuzatiwie (exclamationis), bezokoliczników i struktur składniowych o postaci accusativus cum infinitivo, współwystępowanie operatorów ekspresywnych i impresywnych. Niektóre z nich są silnie nacechowane emocjonalnie i mają charakter wykrzyknień, zawołań czy zaklęć wyrażających zdziwienie, zaskoczenie, oburzenie, irytację, strach, politowanie, żal itp.:

Nugas! (Pl., Most. 1087)

"(Co za) bzdury!"

Non puduisse verberare hominem senem! (Ter., Adelph. 562)

„Że też nie wstyd było bić starego człowieka!"

Foras aedibus me eici? (Pl., Asin. 127)

„Żeby mnie wyrzucać za drzwi?"

At te Romae non fore! (Cic., Att. 5, 20, 7)

"A ciebie ma nie być w Rzymie!"

O stultum hominem!. (Cic., Off. 3, 100)

"Co za głupi czlowiek!"

Heu me infelicem! (Ter., Hec. 282)

„O ja nieszczęsny!"

Inne mogą mieć postać zawiadomień czy wezwań:

Em tibi pateram! (Pl., Amph. 778)

"Oto twój kielich!"

Ecce me. (Pl., Cist. 283)

„Oto ja (jestem)".

Eho mecum, Crito. (Ter., Andr. 951)

"Hej, (chodź) ze mną, Kritonie".

Ehodum huc, virgo! (Pl., Pers. 610)

„Hej, tutaj do mnie, dziew'czyno!" 
Inną klasę wypowiedzeń niezdaniowych tworzą wypowiedzenia niesamodzielne semantycznie. Są one silnie uwikłane $\mathrm{w}$ kontekst i tylko $\mathrm{w}$ połączeniu $\mathrm{z}$ nim zrozumiały jest ich sens. Zwykle są częścią dialogu, stanowiąc odpowiedzi na pytania, repliki, dopowiedzenia, komentarze itp.:

\{Alcmena:\} Cenavisti mecum, ego accubui simul. \{Amphitruo:\} In eodem lecto? \{Alcmena:\} In eodem. (Pl., Amph. 804-805)

„\{Alkmena:\} Jadleś ze mną kolację, ja położyłam się obok ciebie. \{Amfitrion:\} Na tym samym lożu? \{Alkmena:) Na tym samym".

\{Pamphilus:\} Egon dicam? \{Davos:\} Quor non? \{Pamphilos:\} Numquam faciam. (Ter., Andr. 384)

„\{Pamfilus:\} Ja mam to powiedzieć? \{Dawus:\} A dlaczego nie? \{Pamfilus:\} Nigdy tego nie zrobię".

\{Menedemus:\} Ubinamst quaeso? \{Chremes:\} Apud me domi. \{Menedemus:\} Meus gnatus? \{Chremes:\} Sic est. (Ter., Heaut. 430-431)

„\{Menedemus:\} Proszę, (powiedz) gdzie jest? \{Chremes:\} U mnie w domu. \{Menedemus:\} Mój syn? \{Chremes:\} Tak jest". 


\section{3. \\ Zdanie}

Jak zaznaczono wyżej, zdania (wypowiedzenia zdaniowe) cechują się posiadaniem w swym składzie orzeczenia. Konstytutywny dla zdania charakter orzeczenia wynika $\mathrm{z}$ tego, iż tylko ono w sposób sformalizowany i obligatoryjny ujmuje wyrażaną przez siebie cechę (treść predykatywną) w tzw. ramy czasowo-modalne oraz identyfikuje status, jaki posiada $w$ ramach aktu mowy obiekt, któremu cecha ta jest w wypowiedzeniu przypisywana. Jest to możliwe dzięki właściwościom morfologicznym (współ)konstytuującej orzeczenie osobowej formy czasownika, która zawsze nacechowana jest pod względem gramatycznej kategorii czasu, trybu i osoby. Wyrażając określoną wartość gramatycznej kategorii czasu osobowa forma czasownika charakteryzuje oznaczaną przez siebie treść temporalnie: jako teraźniejszą, przeszłą lub przyszłą w stosunku do aktu komunikacji; równoczesną, uprzednią lub następczą w stosunku do jakjegoś innego punktu na osi czasu. Poprzez nacechowanie pod względem kategorii trybu ukazuje ją (niekiedy przy współudziale dodatkowych czynników formalnych) w określonej perspektywie modalnej (jako stan faktyczny lub jako stan nierzeczywisty, tj. niezgodny z rzeczywistością, możliwy, hipotetyczny, postulatywny itp.). Przyjmując określoną wartość kategorii osoby ujawnia status desygnowanego przez podmiot obiektu, któremu przypisywana jest wyrażana treść (identyfikując go jako nadawcę komunikatu, odbiorcę komunikatu lub obiekt niebędący uczestnikiem aktu komunikacji). Ponadto dzięki fleksyjnej kategorii liczby jest współwykładnikiem kwantyfikacji ilościowej (numerycznej) desygnatu podmiotu, a poprzez określoną wartość kategorii strony charakteryzuje wypowiedzenie pod względem diatezy, tj. pod względem sposobu składniowego ujawniena argumentów implikowanych przez wyrażaną treść predykatywną. Dlatego też zdanie, jako schemat składniowy, który $z$ uwagi na specyfikę funkcjonalną czasownikowego orzeczenia jest najbardziej kompletny (bogaty) co do zasobu informacji przekazywanych środkami gramatycznymi, stanowi podstawową strukturę płaszczyzny syntaktycznej.

$\mathrm{Z}$ punktu widzenia składniowego orzeczenie ma status członu podrzędnego (determinowanego, akomodowanego) $\mathrm{w}$ ramach związku składniowego predykacji. Związek ten łączy orzeczenie z podmiotem i opiera się na kongruencji (zgodzie) w zakresie kategorii osoby i liczby. Pozycja członu nadrzędnego (determinującego, 
akomodującego), czyli pozycja podmiotowa, może w zdaniu pozostać niewypełniona, tzn. podmiot może nie być powierzchniowo wyrażony, lecz jedynie - ze względu na ekonomię językową - implikowany kontekstowo. Istnieją również zdania, w których pozycja podmiotowa w ogóle nie jest otwierana, mimo to struktura taka może zostać uznana za zdanie, jeśli jeden z jej składników spełnia kryteria odpowiadające orzeczeniu.

\subsection{MODALNOŚĆ ZDANIOWA}

\subsubsection{Pojęcie modalności}

Modalność to termin obejmujący szerokie spektrum złożonych zagadnień, stanowiących domenę badań zarówno ze strony lingwistów, jak i logików. Istnieją w związku z tym różne definicje pojęcia, które jest tym terminem określane, oraz różne koncepcje dotyczące zakresu zjawisk językowych, które są nim obejmowane. Wyodrębnia się też różne rodzaje (typy, odmiany) modalności, które identyfikowane są za pośrednictwem dodatkowych określników terminu modalność. Generalnie terminem tym określa się trzy podstawowe właściwości treści komunikowanych $w$ wypowiedzeniu zdaniowym:

1. status, jaki nadany zostaje komunikatowi zdaniowemu z punktu widzenia intencji jego nadawcy; ten rodzaj modalności określany jest jako modalność intencjonalna;

2. status, jaki nadany zostaje komunikowanym treściom z punktu widzenia ich relacji wobec rzeczywistości pozajęzykowej; ten rodzaj modalności dotyczy więc statusu ontologicznego nadanego $w$ wypowiedzeniu relacjonowanym zdarzeniom (sytuacjom) i nosi nazwę modalności epistemicznej;

3. status, jaki w ramach komunikatu językowego przypisywany jest komunikowanym zdarzeniom (sytuacjom) z punktu widzenia relacji logicznych zachodzących między tworzącymi (stanowiącymi) je elementami (podmiotami); ten rodzaj modalności nazywany jest z kolei modalnością logiczną, w ramach której wyróżnia się modalność deontyczną i modalność dynamiczną.

\subsubsection{Modalność intencjonalna}

Biorąc pod uwagę kryterium modalności intencjonalnej wyodrębnia się cztery podstawowe typy wypowiedzeń zdaniowych:

1. deklaratywa (oznajmienia, powiadomienia), których gramatycznym wyróżnikiem są zdania oznajmujące, np.: Marek wyjechat do Rzymu;

2. interrogatywa (pytania), których gramatycznym wyróżnikiem są zdania pytajne; dzielą się one na dwie podstawowe kategorie (klasy): 
- pytania o rozstrzygnięcie, implikujące potwierdzenie lub zaprzeczenie, a w przypadku pytań o charakterze alternatywnym wybór spośród zasugerowanych wariantów lub ich odrzucenie (i ewentualne wskazanie innego rozwiązania), np.: Czy Marek wyjechat do Rzymu?, Marek wyjechat do Rzymu czy do Aten?

- pytania o uzupełnienie, implikujące uzyskanie wiedzy co do konkretnych, wskazanych w pytaniu okoliczności, np.: Kto wyjechat do Rzymu?, Dokad wyjechat Marek?

3. imperatywa (rozkazy, nakazy, zakazy, wezwania, zachęty, zalecenia, prośby), których gramatycznym wyróżnikiem są zdania rozkazujące, np.: Wyjedź do Rzymu, Marku!, Nie wyjeżdzaj do Rzymu, Marku!, Niech Marek wyjedzie do Rzymu!, Wyjedźmy do Rzymu!, Wyjedźcie do Rzymu!

4. dezyderatywa, których gramatycznym wyróżnikiem są zdania życzące, np.: Oby Marek wyjechat do Rzymu.

Te czery typy wypowiedzeń zdaniowych, i związane z nimi intencje nadawcy, stanowią podstawowy zrąb modalności intencjonalnej, wyrażanej gramatycznie. Należy jednak pamiętać, iż rzeczywisty cel wypowiedzenia często determinowany jest kontekstowo lub konsytuacyjnie, niezależnie od zastosowanych środków o charakterze gramatycznym, a niekiedy wbrew nim. Np. zdanie formalnie oznajmujące: Jutro posprzątasz mieszkanie może z punktu widzenia intencji mówiącego stanowić rozkaz. Poza tym funkcję intencjonalną podobną do tej, która realizowana jest przez zdania rozkazujące, mogą pełnić także zdania nacechowane formalnie jako pytajne, np.: Czy mógbyś wreszcie przestać krzyczeć? (= Przestań wreszcie krzyczeć!).

$\mathrm{Z}$ drugiej strony intencji, $\mathrm{z}$ jakimi formułowane są wypowiedzenia, wyróżnić można znacznie więcej niż wskazane wyżej cztery, jednak nie znajdują one jednoznacznego wyróżnika o charakterze gramatycznym. Przywołać tu można choćby wypowiedzenia mające status obietnicy, groźby, nagany, obrazy, pociechy, usprawiedliwienia, ekspresji emocji itp. Intencje te zwane są aktami illokucyjnymi, jako że ich aktualizacja towarzyszy lokucji, czyli aktowi użycia danego wypowiedzenia, a w odniesieniu do samych wypowiedzeń je wyrażających mówi się o ich wartości (sile) illokucyjnej. Intencje te określa się również terminem implikatury, który akcentuje różnice między gramatyczną postacią i dosłowną treścią wypowiedzenia, a tym, co może ono implikować (np. wypowiedziane przez wykładowcę zdanie: $W$ tej sali jest zimno, chociaż formalnie ma postać oznajmienia, to jednak faktycznie implikować może skierowaną do studentów prośbę o zamknięcie okna). Kwestie te, z uwagi na ich kontekstowy charakter, nie mają jednak charakteru stricte gramatycznego, lecz są przedmiotem opisu w ramach takich kierunków badań językoznawczych, jak teoria aktów mowy czy pragmatyka językowa (językoznawcza).

\subsubsection{Modalność epistemiczna}

Modalność epistemiczną, podobnie jak intencjonalną, nadaje relacjonowanym treściom przede wszystkim autor wypowiedzi (nadawca komunikatu). Nazywana jest 
ona też wówczas modalnością zdaniową (propozycjonalną) lub ramą modalną zdania. Wyróżnia się ogólnie dwa typy modalności epistemicznej, tj. modalność asertoryczną (nienacechowaną) oraz modalność nieasertoryczną (nacechowaną).

O modalności asertorycznej mówimy wówczas, gdy autor wypowiedzi przypisuje komunikowanym treściom status faktu, i tym samym swemu komunikatowi językowemu nadaje status asercji, czyli zobiektywizowanego twierdzenia relacjonującego określony stan rzeczy (zdarzenie, sytuację) w sposób zgodny z rzeczywistością (prawdziwy). Ten typ modalności sygnalizowany jest głównie przez tryb oznajmujący czasownika (orzeczenia) bez dodatkowych wykładników (operatorów) modalnych, i dlatego często określany jest również jako modalność nienacechowana (neutralna). Przykładem wypowiedzi o modalności asertorycznej (nienacechowanej) może być zdanie: Marek wyjechat do Rzymu.

$\mathrm{Z}$ modalnością nieasertoryczną (nacechowaną) mamy zaś do czynienia wówczas, gdy autor wypowiedzi komunikuje daną treść predykatywną nie w sposób zobiektywizowany jako (zwykły) fakt, lecz jako stan, który jest możliwy, prawdopodobny, niepewny, wątpliwy, hipotetyczny czy konieczny. Istnieje zatem wiele różnych odmian modalności nieasertorycznej, które opierają się na przypuszczeniach, hipotezach, założeniach, spekulacjach czy przekonaniach, i wszystkie one traktowane są jako odmiany epistemicznej modalności nacechowanej. Jej sygnalizowaniu służą różne środki formalne, które w sposób eksplicytny zawieszają asercję. Mogą one mieć charakter zarówno leksykalny (partykuły, wyrażenia przyimkowe, czasowniki modalne), jak i gramatyczny (tryb przypuszczający czasownika). Różne odmiany nacechowanej modalności nieasertorycznej reprezentują podane niżej przykłady:

- Marek chyba / prawdopodobnie wyjechat do Rzymu.

- Marek podobno wyjechat do Rzymu.

- Wydaje się, ze Marek wyjechat do Rzymu.

- Marek mógł wyjechać do Rzymu.

- Być może Marek wyjechat do Rzymu.

- Możliwe, że Marek wyjechat do Rzymu.

- Watpliwe, by Marek wyjechat do Rzymu.

- Marek na pewno / z pewnościa wyjechat do Rzymu.

- Marek bez watpienia / niewątpliwie wyjechat do Rzymu.

- Marek musial wyjechać do Rzymu. (= nie może być inaczej, wszytko na to wskazuje, że wyjechat).

Należy też pamiętać, że chociaż (nacechowaną) modalnością objęta jest przede wszystkim treść predykatywna wyrażana przez orzeczenie, to jednak podlegać jej może również inny składnik wypowiedzenia, np.: Marek wyjechał prawdopodobnie do Rzymu (a nie do Aten).

Jak zaznaczyliśmy już wcześniej, modalność epistemiczna, oparta na opozycji: modalność asertoryczna / modalność nieasertoryczna, nadawana jest wyrażanym językowo treściom przede wszystkim przez autora wypowiedzi (nadawcę komunikatu językowego) i wtedy nazywana też bywa ramą modalną zdania lub modalnością zdaniową (propozycjonalną). O tego typu modalności mówi się też, iż ma charakter 
ekstradyktalny, gdyż jej źródłem jest właśnie osoba autora, a więc obiekt zewnętrzny w stosunku do komunikowanej językowo sytuacji, będący poza wyrażoną w komunikacie treścią (extra dictum). Jednak modalność ta może również zostać wprowadzona do wnętrza wypowiedzenia (intra dictum) i przyjąć charakter intradyktalny, tzn. może zostać związana $\mathrm{z}$ jednym ze składników treści wypowiedzenia jako jej źródłem, jak np. w zdaniu: Zosi wydaje się, że Marek wyjechał do Rzymu, gdzie nadanie za pośrednictwem operatora wydaje się ( $\dot{z} e)$ - nacechowanej modalności temu, co wyraża czasownik wyjechał, nie nastąpiło bezpośrednio ze strony autora wypowiedzi, lecz przypisane zostało Zosi, a więc jednemu z elementów wyrażonej w tej wypowiedzi treści (czyli jednemu ze składników dictum czy też jednemu ze składników tzw. „świata przedstawionego"). Nie znaczy to jednak, że zdanie to pozbawione jest modalności ekstradyktalnej. Jej wykładnik tkwi w tymże samym „wydaje się", a wyraża się poprzez tryb oznajmujący tego czasownika bez dodatkowych operatorów modalnych, co sygnalizuje nienacechowaną, asertoryczną modalność ektradyktalną (zdaniową). Można zresztą zdaniu temu nadać również nieasertoryczną (nacechowaną) modalność ekstradyktalną (propozycjonalną), np.: Prawdopodobnie / Być może Zosi wydaje się, że Marek wyjechat do Rzymu, gdzie operator "prawdopodobnie / być może" sygnalizuje nacechowaną modalność ekstradyktalną, zaś operator „wydaje się (zie)" sygnalizuje nacechowaną modalność intradyktalną.

Widać więc, że epistemiczna modalność ekstradyktalna i intradyktalna mogą współistnieć $\mathrm{w}$ jednym wypowiedzeniu. Ze szczególnym przypadkiem takiego współistnienia mamy do czynienia w przypadku, gdy nadawca komunikatu jest równocześnie jednym $z$ elementów treści wypowiedzenia, jak np. w zawierających elementy autorefleksji zdaniach typu:

- Chyba mi się wydaje, że Marek wyjechat do Rzymu.

- Być może mi się wydaje, że Marek wyjechał do Rzymu.

Można więc stwierdzić, że jeśli samodzielnym wykładnikiem modalności jest osobowa forma czasownika, to sygnalizowana przez nią modalność może mieć status modalności intradyktalnej. Pośrednio może ona być równocześnie modalnością autora wypowiedzi (= modalnością, której źródłem jest autor wypowiedzi), jeśli został on wprowadzony (explicite bądź implicite) w jej obręb jako jeden ze składników dictum (Wydaje (mi) się, że Marek wyjechat do Rzymu). I jeśli, tak jak w przytoczonych wyżej przykładach, sama treść predykatywna wyrażana jest przez osobową formę czasownika, to osobowa forma czasownika, będąca wykładnikiem modalności, jest równocześnie wykładnikiem odrębnego predykatu.

Niekiedy jako odmiana ekstradyktalnej modalności epistemicznej traktowana jest również interrogatywna modalność intencjonalna, $z$ uwagi na związany $z$ nią niski poziom pewności (niewiedzę) co do przebiegu lub określonych okoliczności relacjonowanej sytuacji (zdarzenia); chodzi zatem o wyrażenia pytajne typu: Czy Marek wyjechat do Rzymu?, Dokad Marek wyjechat? itp. 


\subsubsection{Modalność logiczna (deontyczna, dynamiczna)}

Modalność logiczna ma charakter wyłącznie intradyktalny i dotyczy, jak już wcześniej zasygnalizowaliśmy, charakteru stosunków logicznych, jakie zachodzą między składnikami dictum (świata przedstawionego), a dokładniej między jednym $\mathrm{z}$ tych składników a przypisywaną mu treścią predykatywną. W odniesieniu do przykładu, którym posługiwaliśmy się wyżej, byłby to stosunek zachodzący między tym, co wyrażają słowa: Marek i wyjechał. O modalności deontycznej mówimy wówczas, gdy stosunek ten nie opiera się na bezpośredniej, prostej łączności (styczności), jak np. w zdaniu: Marek wyjechał do Rzymu, lecz na konieczności (w sensie przymusu), powinności (w sensie zobligowania) czy możliwości (w sensie zdolności do czegoś lub zgody / pozwolenia na coś). Wykładnikami tego typu modalności są najczęściej tzw. czasownikj modalne, jak np. w zdaniach:

- Marek musial wyjechać do Rzymu.

- Marek powinien był / miał wyjechać do Rzymu.

- Marek mógł wyjechać do Rzymu. / Markowi wolno bylo wyjechać do Rzymu.

Modalność logiczna współwystępuje, oczywiście, w jednym wypowiedzeniu z modalnością epistemiczną, również tą nacechowaną, jak np. w zdaniach:

- Prawdopodobnie Marek musial wyjechać do Rzymu.

- Możliwe, że Marek powinien byl wyjechać do Rzymu.

Elementem wewnątrztekstowym (składnikiem dictum), z którym wiązana jest w wypowiedzeniu intradyktalna modalność deontyczna, może być również nadawca komunikatu, np.: (Ja) powinienem wyjechać do Rzymu.

Nie wyklucza to możliwości nadania zdaniu również określonej nacechowanej modalności epistemicznej (ekstradyktalnej, zdaniowej), np.: Chyba powinienem wyjechać do Rzymu.

W przypadku szerzej rozumianego pojęcia modalności logicznej, oprócz stosunków wynikających $\mathrm{z}$ uwarunkowania zewnętrznego (konieczność, powinność, możliwość), obejmuje się nim również stosunki wynikające $z$ wewnętrznej postawy obiektu, $z$ którym wiązana jest dana treść predykatywna, a więc stosunki wynikające z (jego) woli, chęci, postawy, zamiaru, potrzeby itp. Tego rodzaju odmiana modalności nazywana bywa modalnością dynamiczną, a jej egzemplifikację stanowić mogą np. zdania:

- Marek chce / pragnie wyjechać do Rzymu.

- Marek zamierza wyjechać do Rzymu.

- Marek woli wyjechać do Rzymu.

Niekiedy termin "modalność logiczna" tradycyjnie rezerwuje się wyłącznie dla modalności deontycznej, a dla określenia rodzaju modalności, obejmującej zarówno modalność deontyczną, jak i dynamiczną, stosuje się termin „modalność zdarzeniowa" (ang. event modality).

Z kolei w obręb modalności deontycznej włącza się imperatywne i dezyderatywne odmiany modalności intencjonalnej z uwagi na związaną z nimi implikację konieczności bądź powinności. Tym samym tego rodzaju modalność deontyczna na- 
biera charakteru ekstradyktalnego (Marku, wyjedź do Rzymu!, Oby Marek wyjechat do Rzymu.).

Dodajmy jeszcze, że status modalny wszystkich wskazanych wyżej rodzajów i odmian ma również zastosowanie w odniesieniu do zdań, w których treść predykatywna (bądź inny składnik dicum) podlega negacji, a więc np.: Marek nie wyjechał do Rzymu, Marek prawdopodobnie nie wyjechat do Rzymu, Marek nie musial wyjechać do Rzymu, Marek nie zamierzat wyjechać do Rzymu itp.

\subsubsection{Modalność $w$ lacinie}

\subsubsection{Modalność intencjonalna}

Gdy uwzględnić kryteria gramatyczne, modalność intencjonalna w łacinie znajduje swój wyraz, podobnie jak w języku polskim, przede wszystkim w czterech podstawowych typach wypowiedzeń zdaniowych, którymi są:

1. Deklaratywa, czyli zdania oznajmujące; cechuje je indicativus lub coniunctivus czasownika (współ)stanowiącego orzeczenie, np.:

Domus patris longe a foro aberat. (Cic., Cael. 18)

„Dom ojca znajdował się daleko od forum”.

Forsitan etiam hoc fecerit odio Caesaris. (Ps.-Caes., Bell. Alex. 58)

„Być może także i to uczynił z nienawiści do Cezara”.

Jak już wspomniano, deklaratywa mogą (kontekstowo bądź konsytuacyjne) nabierać innej niż zwykłe oznajmienie wartości illokucyjnej, np. imperatywnej (postulatywnej) czy ekspresywnej (eksklamacyjnej), np.:

Si quid acciderit novi, facies ut sciam. (Cic., Fam. 114, 8, 1)

"Jeśli zdarzyłoby się coś nowego, powiadom(isz) mnie".

Quam brevi tempore quot et quanti poetae [...] extiterunt! (Cic., Tusc. 4, 5)

„W jak krótkim czasie jakżesz liczni i jak wielcy poeci się pojawili!"

2. Interrogatywa, czyli zdania pytajne; podobnie jak deklaratywa, charakteryzuje je indicativus lub coniunctivus czasownikowego orzeczenia; jak już zaznaczono, wśród zdań pytajnych ogólnie wyróżnia się:

a. pytania o rozstrzygnięcie, implikujące potwierdzenie lub zaprzeczenie, a w przypadku pytań o charakterze alternatywnym wybór spośród zasugerowanych wariantów lub ich odrzucenie (i ewentualne wskazanie odrębnego rozwiązania); mogą być wprowadzane przez partykuły pytajne (an, utrum, num), związany postfiksalny morfem interrogatywny -ne lub sygnalizowane wyłącznie poprzez intonację, np.: 
De reliquis rei publicae malis licetne dicere? (Cic., Phil. 1, 14)

"Czy o pozostałych nieszczęściach rzeczpospolitej wolno (mi) mówić?"

Utrum ea vestra an nostra culpa est? (Cic., Lucull. 95)

"Czy to jest wasza albo nasza wina?"

An id ioco dixisti? (Pl., Amph. 964)

„Czy powiedzialeś to żartem?”

Num negare audes? (Cic., Catil. 1, 8)

„Czy odważysz sie zaprzeczyć?"

Hic vir sit bonus? (Ter., Andr. 915)

„To ma być dobry człowiek?"

Ipse percussit an aliis occidendum dedit? (Cic., S. Rosc. 74)

„Sam zadal cios, czy zabicie (go) zlecil innym?"

b. pytania o uzupełnienie, implikujące uzyskanie wiedzy co do konkretnych, wskazanych w pytaniu okoliczności; wprowadzane są przez pytajne zaimki rzeczownikowe, przymiotnikowe lub przysłówkowe, np.:

Sed quis hic est, qui huc pergit? (Ter., Eun. 228)

„Ale kimże jest ten, co tutaj idzie?"

Quam tu mihi nunc navem narras? (Pl., Men. 402)

"O jakim okręcie ty mi tu teraz opowiadasz?"

Ubi sunt hi fundi, Brute? (Cic., De orat. 2, 224)

„Gdzie są te posiadłości ziemskie, Brutusie?”

Jak widać z przywołanych wyżej przykładów, nie zawsze rzeczywistą intencją zdań pytajnych jest uzyskanie informacji. W niektórych przypadkach odpowiedzi na pytania są oczywiste (także dla pytającego) i w istocie zdania takie mają charakter deklaratywny, służąc wyrażeniu określonych treści w sposób nacechowany stylistycznie lub/i ekspresyjnie (oburzenie, ironia, kpina, złość). Takie zdania to tzw. pytania retoryczne:

Quid est in Antonio praeter libidinem, crudelitatem, petulantiam, audaciam? (Cic., Phil. $3,28)$

„Co (jeszcze) jest w Antoniuszu oprócz pożądania, okrucieństwa, bezczelności i zuchwałości?"

D. Bruti iudicium [...], quod ex hodierno eius edicto perspicere potuistis, num cui tandem contemnendum videtur? (Cic., Phil. 4, 7)

„Czy stanowisko Decymusa Brutusa, które mogliście poznać z dzisiejszego jego edyktu, komuś wydaje się godne potępienia?"

Niekiedy pytania pełnią przede wszystkim funkcję ekspresywną (emotywną), stanowiąc językowy środek wyrażenia np. zdziwienia, zniecierpliwienia, zdenerwowania, radości czy innych stanów emocjonalnych; pytania wyrażające nie- 
pewność, niezdecydowanie czy wątpliwości noszą nazwę pytań deliberatywnych (dubitatywnych); wszystkie te typy zdań pytajnych również mogą być stosowane jako zabieg retoryczny:

Quotiens dicendum est tibi? (Pl., Amph.619)

„Ile razy trzeba ci powtarzać?"

Quam diu etiam furor iste tuu nos eludet? (Cic., Catil. 1, 1)

„Jak dlugo jeszcze to (bezczelne) twoje szaleństwo będzie $z$ nas drwilo?"

Quis me est fortunatior, qui ex improviso filiam inveni meam? (PI., Rud. 1191-1192)

„Któż jest szczęśliwszy ode mnie, który niespodziewanie odnalazł swą córkę?"

Quid agam, iudices? Quo accusationis meae rationem conferam? Quo me vertam? (Cic., Verr. 2, 5, 2)

„Co mam czynić, sędziowie? Do czego odnieść podstawę mego oskarżenia? Ku czemu się zwrócić?"

Wreszcie, zdania pytajne mogą implikować prośbę, np.:

Potesne mi auscultare? (Pl., Poen. 309)

"Czy mógłbyś mnie usłuchać?"

3. Imperatywa, czyli zdania rozkazujące (postulatywne); w zależności od stopnia ich kategoryczności (zobligowania odbiorcy) będą to więc: rozkazy, nakazy, zakazy, wezwania, zalecenia, zachęty, ostrzeżenia, prośby itp.; cechuje je tryb imperativus lub coniunctivus czasownika, np.:

Perge quo cepisti! Egredere aliquando ex urbe! [...] Proficiscere! (Cic., Catil. 1, 10)

„Kończ, coś zaczą!! Wyjdź wreszcie z miasta! Ruszaj!”

Proin tu ab istoc procul recedas. (Pl., Capt. 551)

"Trzymaj się więc z dala od niego".

Pythio Apollini [...] donum mittitote! (Liv., 23, 11)

"Apollinowi Pytyjskiemu wyślijcie dar!"

Equo ne credite, Teucri. (Verg., Aen. 2, 48)

„Nie ufajcie koniowi, Trojanie".

Nolite existumare maiores nostros armis rem publicam ex parva magnam fecisse. (Sall., Cat. 52)

„Nie sądżcie, że nasi przodkowie przy pomocy oręża rzeczpospolitą z małej uczynili wielką".

Nihil ignoveris [...], nihil gratiae causa feceris [...], misericordia commotus ne sis. (Cic., Mur. 65)

„Niczego nie wybaczaj, niczego nie rób z życzliwości, nie daj się wzruszyć litością".

Cum dabis posthac aliquid domum litterarum, mei memineris! (Cic., Fam. 15, 17, 4)

„Gdy później będziesz przekazywal jakieś listy do domu, pamiętaj i o mnie (scil. dołącz również list do mnie)". 
Nemo exspectet, ut alieno tantum labore sit disertus. (Quint., Inst. 7, 10, 14)

„Niech nikt nie oczekuje, że stanie się wymowny wyłącznie dzięki wysiłkowi innych ludzi (scil. nauczycieli)".

Persequamur eorum mortem, qui indignissime interierunt, atque hos latrones interficiamus. (Caes., Gall. 7, 38)

"Pomścijmy śmierć tych, którzy tak niegodnie zginęli, i zabijmy tych bandytów".

4. Dezyderatywa, czyli zdania wyrażające życzenia; ich wyróżnikiem jest tryb coniunctivus czasownikowego orzeczenia, a bardzo często również optatywna partykuła utinam 'oby', 'niechby':

Falsus utinam vates sim! (Liv., 21, 10)

„Obym był fałszywym prorokiem”.

Utinam L. Caesar valeret, Ser. Sulpicius viveret; multo melius haec causa ageretur a tribus, quam nunc agitur ab uno. (Cic., Phil. 8, 22)

„Gdybyż tak Lucjusz Cezar był w pełni sil, a Serwiusz Sulpicjusz żył jeszcze; o wiele lepiej sprawa ta prowadzona byłaby przez trzech, niż jest teraz przez jednego".

Pereat, qui crastina curat. (App. Vergil.: Copa, 37)

„Oby zginął (niech zginie), kto troszczy się o to, co będzie jutro".

Utinam me mortuum prius vidisses. (Cic., Q. fr. $1,3,1$ )

„Obyś był wcześniej zobaczył mnie martwym (= szkoda, że wcześniej nie umarłem)”.

\subsubsection{Modalność epistemiczna}

Podstawowym środkiem wyrażania w łacinie nienacechowanej modalności asertorycznej jest użycie trybu oznajmującego (indicativus) czasownika. Sygnalizowaniu poszczególnych odmian modalności nacechowanej służy natomiast kilka różnych środków formalnych, takich jak: partykułowe operatory modalne, tryb coniunctivus czasownika, złożone orzeczenie znane jako tzw. nominativus cum infinitivo, czasowniki modalne czy wyrażenia o charakterze parentetycznym.

\subsection{Partykułowe operatory modalne}

Partykuły stanowią podstawowy środek leksykalny sygnalizowania epistemicznej modalności o charakterze zdaniowym (propozycjonalnym), a więc modalności ekstradyktalnej. W strukturze składniowej wypowiedzenia pełnią one funkcję tekstowego operatora (modalnego). Przy użyciu partykuł typu: sane, certe, profecto wyrażone zostaje przekonanie co do konieczności lub prawdziwości stanu komunikowanego przez wyrażenie predykatywne, np.: 
Is est, certe is est, is est profecto. (Pl., Trin. 1071-1072)

"To on, to jest na pewno on, on to jest bez wątpienia".

Reliquorum factorum eius, patres conscripti, difficilis est sane reprehensio et lubrica. (Cic., Phil. 2, 59)

„Krytyka jego pozostałych czynów, senatorowie, jest doprawdy trudna i niebezpieczna”.

Z kolei za pośrednictwem partykuł takich jak: forsan, forsitan, fortasse itp. wyrażaną treść ukazuje się jako możliwą czy prawdopodobną. Czasownikowe orzeczenie, będące wykładnikiem nacechowanego $w$ ten sposób predykatu, może występować w indikatiwie:

Forsan et haec olim meminisse iuvabit. (Verg., Aen. 1, 203)

„Może kiedyś wspominanie także i tego będzie sprawialo radość".

Forsitan [...] quaeris, quare solus Corinthea vera possideam. (Petron., Sat. 50)

„Być może zastanawiasz się, dlaczego tylko ja sam posiadam prawdziwe korynckie (brązy)".

Quaeres fortasse, quo modo, et recte. (Cic., Tusc. 2, 43)

„Być może zapytasz, w jaki sposób, i będzie to pytanie zasadne”.

Dicet fortasse quispiam [...]. (Cic., Sull. 84)

„Być może ktoś powie $[\ldots]$ ]".

Może jednak występować również w koniunktiwie, a więc w trybie, który także samodzielnie stanowić może wykładnik tego typu modalności. Wobec szerokiego zakresu funkcjonalnego koniunktiwu dodanie partykuły ujednoznacznia status modalny wypowiedzenia i czyni go bardziej wyrazistym:

Forsitan quaeratis, quis iste terror sit. (Cic., S. Rosc. 5)

„Być mozie zapytalibyście, co to za strach".

Riserit aliquis fortasse hoc praeceptum. (Cic., De orat. 2, 99)

„Być może ktoś wyśmialby tę wskazówkę".

Użycie wyżej wymienionych partykuł obok czasownika w koniunktiwie spotyka się również w zdaniach warunkowych, w których w ten sposób sygnalizowana jest możliwość zaistnienia sytuacji wyrażonej w następniku okresu warunkowego, w tym także okresu nierzeczywistości. Tym samym sytuacja wyrażona w następniku ukazywana jest nie jako pewna, lecz jedynie możliwa konsekwencja stanu wyrażonego w poprzedniku:

Forsan isto uterer beneficio, si non ei summum scelus adiungeretur. (Ps.-Caes., Bell. Afr. 45)

„Być może skorzystalbym z tego dobrodziejstwa, gdyby nie było ono związane z największą zbrodnią".

Partykuły te sygnalizować mogą tego typu nacechowaną modalność również w odniesieniu do składnika niestanowiącego treści predykatywnej: 
Exonera civitatem vano forsitan metu. (Liv., 2, 2)

"Uwolnij miasto od być może nieuzasadnionego strachu".

Wtedy również może wystąpić orzeczenie w koniunktiwie, chociaż wyrażana przez nie treść nie podlega nacechowaniu modalnemu. Można więc w tym przypadku mówić o pewnego rodzaju attractio, czy raczej accomodatio modi:

Forsitan etiam hoc fecerit odio Caesaris. (Ps.-Caes., Bell. Alex. 58)

„Być może także i to uczynił $z$ nienawiści do Cezara (= także i to uczynil być może z nienanwiści)".

Forsitan in suscipienda causa temere, impulsus adulescentia, fecerim. (Cic., S. Rosc. 31) „Być może podejmując się obrony w (tej) sprawie postąpiłem nierozważnie, pchnięty impulsem mlodości (= postapiłem być może nierozważnie)".

\subsection{Coniunctivus}

Wartość coniunctivus $\mathrm{w}$ ramach gramatycznej kategorii trybu czasownika jest najważniejszym środkiem morfologicznym służącym sygnalizowaniu nacechowanej modalności epistemicznej. Za jego pośrednictwem wyrażanym w wypowiedzeniu treściom można nadać status stanu:

a. Potencjalnego (potentialis):

Credas non de puero scriptum, sed a puero. (Plin., Epist. 4, 7, 7)

„Móglbyś (= można bylo) uwierzyć, że zostało to napisane nie o chłopcu, lecz przez chłopca”.

Conchyliatis Cn. Pompei peristromatis servorum in cellis lectos stratos videres. (Cic., Phil. $2,67)$

„Móglbyś (= można bylo) zobaczyć łóżka w pomieszczeniach dla niewolników przykryte purpurowymi narzutami Pompejusza".

Haud facile discerneres utrum (Hannibal) imperatori ani exercitui carior esset. (Liv., 21, 4)

„Niełatwo mógłbyś rozstrzygnąć, czy Hannibal droższy był wodzowi, czy wojsku”.

Nil ego contulerim iucundo sanus amico. (Hor., Serm. 1, 5, 44)

„Będąc przy zdrowych zmysłach, niczego nie mógłbym porównać do drogiego przyjaciela (= nic nie może się równać $z \ldots .$.$) .$

b. Przyzwolonego (concessivus):

Ne sit sane summum malum dolor, malum certe est. (Cic., Tusc. 2, 14)

„Niechby (choćby) i nie byl ból złem największym, złem jednak z pewnością jest”.

'Malus civis, improbus consul, seditiosus homo Cn. Carbo fuit'. Fuerit aliis: tibi quando esse coepit? (Cic., Verr. 2, 1, 37)

„Gneusz Karbo był złym obywatelem, niegodziwym konsulem, zbuntowanym człowiekiem.

Niechby i byl dla innych: dla ciebie, kiedy zaczął być (takim)?" 
Age, sit ita factum: quae causa fuit cur Romam properaret? (Cic., Mil. 49)

„Zgoda, choćby i tak bylo: $\mathbf{z}$ jakiego powodu jednak pospieszyl do Rzymu?"

c. Sprzecznego z rzeczywistością (irrealis):

Utinam fecisset! Non supplicium deprecarer, sed praemium postularem. (Cic., Rab. 31)

„Oby to był zrobit! (= szkoda, że tego nie zrobil). Wtedy nie prosiłbym o oddalenie kary (jak muszę to, niestety, czynić teraz), lecz wnioskowałbym o nagrodę".

Video ita esse faciendum et iam ante fecissem, sed me multa impediverunt. (Cic., Fam. 14, $19,1)$

„Widzę, że tak należy uczynić, i już wcześniej uczyniłbym, ale wiele rzeczy stanęło mi na przeszkodzie".

Uno proelio victus Alexander bello victus esset. (Liv., 9, 19)

„Pokonany w jednej bitwie Aleksander przegrałby (całą) wojnę”.

d. Hipotetycznego, zakładanego (suppositivus):

Revivescat $M$. Curius [...] et videat aliquem [...] mullos exceptantem de piscina et $[. .$. murenarum copia gloriantem; nonne hunc hominem [...] servum iudicet? (Cic., Parad. 5, 38)

„Załóżmy (przypuśćmy), że Manliusz Kuriusz ożyl i zobaczyl kogoś lowiącego w stawie ryby i szczycącego się posiadaniem wielkiej ilości muren; czyż nie uznałby tego czlowieka za niewolnika?"

e. Wynikającego z opinii innych osób (evidentialis, ex mente aliena):

\{Chremes:\} Si, Simo, hunc noris satis, non ita arbitrere: bonus est hic vir. \{Simo:\} Hic vir sit bonus? (Ter., Andr. 914-915)

„\{Chremes:\} Jeśli, Simonie, znałbyś go lepiej, nie uważałbyś tak: to dobry człowiek. \{Simo:\} To ma być dobry czlowiek?"

\subsection{Nominativus cum infinitivo}

Jednym $z$ charakterystycznych dla łaciny środków sygnalizowania nacechowanej modalności jest rodzaj złożonego orzeczenia w zdaniach, które w naszej tradycji gramatycznej niezbyt szczęśliwie określane są jako tzw. (składnia) nominativus cum infinitivo. Srodek ten służy przede wszystkim do zawieszania asercji i nadawania wyrażanym treściom predykatywnym statusu prawdopodobieństwa.

W ramach tego orzeczenia wykładnikami nacechowanej modalności są osobowe formy czasowników w passivum, reprezentujące leksemy należące do pewnej określonej klasy semantycznej. Formy te są równocześnie wykładnikami syntaktycznego związku kongruencji predykatywnej (z podmiotem), opartego na gramatycznej kategorii osoby i liczby, wskutek czego podlegają akomodacji w zakresie tych kategorii do wartości, którymi nacechowany jest podmiot. Wykładnikiem podstawowej treści 
predykatywnej, a więc orzecznikiem, jest forma infinitiwu czasownika lub forma infinitiwu z orzecznikowym komponentem imiennym (rzeczownikowym lub przymiotnikowym). Nominativus cum infinitivo jest więc syntaktycznym środkiem sygnalizowania nacechowanej modalności, którego istotą jest określona struktura wewnętrzna złożonego morfologicznie orzeczenia. Tym samym nie jest konstrukcją składniową rozumianą jako struktura złożona $\mathrm{z}$ członów składniowych. Uwydatniony w nazwie nominativus identyfikuje bowiem mianownikowy podmiot, który nie stanowi żadnego specjalnego wyróżnika tego fenomenu językowego (mianownikowy podmiot jest cechą zdecydowanej większości łacińskich zdań, nie zaś jakąśs szczególną właściwością zdań określanych jako nominativus cum infinitivo), natomiast drugi (obok infinitiwu) konstytutywny element tego zjawiska gramatycznego, tj. osobowa forma czasownikowa w passivum, nie jest w jego tradycyjnej nazwie uwzględniany.

Jednym z leksemów czasownikowych, którego osobowe formy w passivum stanowić mogą w ramach tego typu orzeczeń wykładniki nacechowanej modalności, jest czasownik videre, który treściom predykatywnym wyrażanym przez bezokolicznikowy orzecznik, współkonstytuujący wraz z nim orzeczenie, nadaje w sposób najbardziej ogólny i subiektywny status stanu prawdopodobnego; por. np.:

- Dux milites laudat. - „Wódz chwali żołnierzy”. (modalność nienacechowana, asertywna)

- Dux milites laudare videtur. - „Wódz prawdopodobnie chwali żołnierzy” (= chyba chwali..., zdaje się chwalić..., wydaje się, że chwali...).

Jak wspomniano wyżej, stanowiony przez czasownik w passivum wykładnik modalności jest równocześnie formalnym wykładnikiem składniowego związku predykacji, łączącego orzeczenie, które współtworzy, z podmiotem. Tym samym wyrażane przez niego wartości kategorii liczby i osoby determinowane są przez wartości reprezentowane $w$ tym zakresie przez mianownikowy podmiot. W przypadku (kontekstowego) niewypełnienia pozycji otwieranej w strukturze składniowej dla podmiotu, co ma miejsce zwłaszcza wtedy, gdy podmiot jest w l. lub 2. osobie, sygnalizowane przez czasownik w passivum wartości liczby i osoby są indeksem wartości, jakie $w$ ramach tych kategorii reprezentuje pominięty na powierzchni (domyślny) podmiot:

- Duces milites laudare videntur. - „Prawdopodobnie / Wydaje się, że wodzowie chwalą żołnierzy".

- (Tu) Milites laudare videris. - "Prawdopodobnie / Wydaje się, że (ty) chwalisz żołnierzy".

- (Vos) Milites laudare videmini. - „Prawdopodobnie / Wydaje się, że (wy) chwalicie żołnierzy".

$\rightarrow$ (Ego) Milites laudare videor. - „Prawdopodobnie / Wydaje się, że (ja) chwalę żołnierzy".

- (Nos) Milites laudare videmur. - „Prawdopodobnie / Wydaje się, że (my) chwalimy żołnierzy". 
Modalność sygnalizowana poprzez orzeczenie tego typu w zasadzie ma charakter intradyktalny. Wynika to faktu, iż jej wykładnikiem jest właśnie osobowa forma czasownika, która modalność ekstradyktalną (zdaniową, propozycjonalną), a także intencjonalną, sygnalizuje poprzez określoną wartość kategorii trybu, tj. indikatiwus bądź koniunktiwus; por. np.:

- Duces milites laudare videntur. - „Wydaje się, że wodzowie chwalą żołnierzy”.

- Duces milites laudare videantur. - „Może / Mogłoby się wydawać, że wodzowie chwalą żołnierzy” / "Niech się wydaje, że wodzowie chwalę żołnierzy”.

W związku z tym pasywna forma czasownika videre otwiera miejsce dla zależnego członu imiennego w datiwie, desygnującego obiekt stanowiący ośrodek (źródło) perspektywy modalnej, np.:

- Consuli dux milites laudare videtur. - „Konsulowi wydaje się, że wódz chwali żołnierzy".

- Consulibus dux milites laudare videtur. - „Konsulom wydaje się, że wódz chwali żołnierzy".

- Consuli duces milites laudare videntur. - „Konsulowi wydaje się, że wodzowie chwalą żołnierzy".

- Consulibus milites laudare videris. - „Konsulom wydaje się, że chwalisz żołnierzy”.

- Tibi milites laudare videmur. - „Tobie wydaje się, że chwalimy żołnierzy”.

- Vobis milites laudare videor. - „Wam wydaje się, że chwalę żołnierzy”.

Oczywiście również osoba nadawcy może zostać wprowadzona w obręb treści wypowiedzeniowej (dictum) jako jeden $\mathrm{z}$ jej składników:

- Mihi dux milites laudare videtur. - „Mnie się wydaje, że wódz chwali żołnierzy”.

- Nobis milites laudare videris. - „Nam się wydaje, że chwalisz żołnierzy”.

Niewypełnienie pozycji otwieranej przez czasownik w passivum dla składnika imiennego $\mathrm{w}$ datiwie implikuje niezdeterminowany, a więc uogólniony ośrodek (źródło) perspektywy modalnej:

- Dux milites laudare videtur. - „(wszystkim/powszechnie) Wydaje się, że wódz chwali żołnierzy".

Modalność ekstradyktalną (i intencjonalną), jak wspomnieliśmy wyżej, sygnalizuje tryb osobowej formy w passivum:

- Consuli dux milites laudare videatur. - „Konsulowi mogłoby się wydawać (niech się wydaje), że wódz chwali żołnierzy".

- Vobis milites laudare videar. - „Wam może się wydawać (niech się wydaje), że chwalę żołnierzy".

- Dux milites laudare videatur. - „(wszystkim/powszechnie) Mogłoby się wydawać (Niech się wydaje), że wódz chwali żołnierzy".

$\mathrm{Z}$ uwagi na fakt, iż uogólnienie ośrodka perspektywy modalnej oznacza włączenie do niego także nadawcy, brak przy czasowniku videre $\mathrm{w}$ passivum wyrażonego 
powierzchniowo składnika imiennego $\mathrm{w}$ datiwie może być tożsamy ze wskazaniem implicite właśnie na osobę nadawcy jako na obiekt, $\mathrm{z}$ którym wiązana jest modalność (videtur $=$ mihi videtur). Dlatego $\mathrm{w}$ polskich odpowiednikach takich zdań sygnalizowana przez nie modalność często wyrażana jest za pośrednictwem partykuł chyba, prawdopodobnie, które generalnie służą wyrażaniu odautorskiej modalności zdaniowej (propozycjonalnej).

W szczególności utożsamienie ośrodka perspektywy modalnej z nadawcą, przy braku jego leksykalnego (zaimkowego) wykładnika, ma miejsce w przypadku, gdy nadawca jest równocześnie podmiotem predykacji, a więc gdy pasywna forma czasownika videre występuje $\mathrm{w}$ 1. os.; por. np.:

Audire vocem visa sum modo militis. (Ter., Eun. 454)

"Wydawało mi się, że wlaśnie słyszę głos żołnierza”.

Itaque, patres conscripti, $[\ldots]$ immortalitatem quandam per vos esse adepti videmur. (Cic., p. red. in sen. 3)

„Przeto, senatorowie, wydaje mi się, że osiągną̧lem dzį̧ki wam pewien rodzaj nieśmiertelności".

Igitur, ut Aratos ab Iove incipiendum putat, ita nos rite coepturi [esse] ab Homero videmur. (Quint., Inst. 10, 1, 46)

„Zatem jak Aratos uważa, że należy zacząć od Jowisza, tak mnie wydaje się, że rozpocznę w sposób należyty (zaczynając) od Homera".

Perspektywa modalna, w jakiej ukazywana jest treść predykatywna zdania, może być nie tylko przypisywana różnym składnikom „świata przedstawionego” (dictum) jako jej ośrodkom, ale także różnie charakteryzowana temporalnie, tzn. oprócz teraźniejszości, czyli czasu samego komunikatu językowego, może być lokowana także w przeszłości lub przyszłości. Indeksem charakterystyki temporalnej perspektywy modalnej są wyrażane przez jej wykładnik (czyli formę osobową czasownika w passivum) wartości gramatycznej kategorii czasu:

- (Consuli) Dux milites laudare videbatur / visus est. - „(Konsulowi) Wydawało się, że wódz chwali żołnierzy".

- (Vobis) Milites laudare videbor. - „(Wam) Będzie się wydawało, że chwalę żołnierzy".

Z drugiej strony, różna charakterystyka temporalna może zostać przypisana także treści predykatywnej, której wykładnikiem jest bezokolicznikowy orzecznik. Charakterystykę tę, która jest niezależna od charakterystyki temporalnej modalności, sygnalizuje wartość gramatycznej kategorii czasu bezokolicznikowego orzecznika:

- (Consulibus) Dux milites laudavisse videtur. - „(Konsulom) Wydaje się, że wódz pochwalił zołnierzy".

- (Consuli) Duces milites laudaturi esse videntur. - "(Konsulowi) Wydaje się, że wodzowie pochwalą żołnierzy".

- (Mihi) Duces milites laudavisse videbantur. - „(Mnie) Wydawało się, że wodzowie pochwalili żołnierzy". 
- (Consulibus) Milites laudaturi esse videbamini. - „(Konsulom) Wydawało się, że pochwalicie żołnierzy".

- (Vobis) Milites laudavisse videbor. - „(Wam) Będzie się wydawało, że pochwalilem żołnierzy".

Oprócz charakteryski temporalnej, bezokolicznikowy orzecznik, poprzez wyrażanie określonej wartości kategorii strony, sygnalizuje również diatezę zdaniową. $\mathrm{Na-}$ leży podkreślić, że to właśnie bezokolicznikowy orzecznik decyduje o diatezie, a nie osobowa forma czasownika stanowiąca łącznik, która występuje zawsze w passivum i w żaden sposób nie przesądza diatezy, stanowiąc jedynie wykładnik modalności oraz związku predykacji z podmiotem:

- (Consuli) Dux milites laudare videtur. - „(Konsulowi) Wydaje się, że wódz chwali żołnierzy".

- (Consuli) Milites a duce laudari videntur. - „(Konsulowi) Wydaje się, że żołnierze są chwaleni przez wodza".

- (Consulibus) Milites a duce laudati esse videntur. - „(Konsulom) Wydaje się, że żołnierze zostali pochwaleni przez wodza".

- (Nobis) Miles a duce laudatum iri videtur. - „(Nam) Wydaje się, że żołnierz zostanie pochwalony przez wodza".

W podobny sposób sygnalizowana jest nacechowana modalność również w przypadku, gdy głównym wykładnikiem treści predykatywnej jest forma przymiotnikowa, imiesłowowa lub rzeczownikowa. Czasownik, który w zdaniach wyrażających modalność nienanecechowaną występuje wówczas w formie osobowej i pełni funkcję wykładnika związku predykacji (łącznika), przyjmuje postać infinitiwu. Jeśli jest nim czasownik esse, to może on zostać pominięty w sytuacji, gdy charakterystyka temporalna przypisana perspektywie modalnej jest tożsama $\mathrm{z}$ charakterystyką temporalną przypisaną treści predykatywnej; por. np.:

- Virtus militum magna est. - „Męstwo żołnierzy jest wielkie”.

- Virtus militum magna (esse) videtur. = „Wydaje się, że męstwo żołnierzy jest wielkie". / "Męstwo żołnierzy wydaje się wielkie”.

- Virtus militum magna (esse) videbatur. = „Wydawało się, że męstwo żołnierzy jest wielkie".

- Virtus militum magna fuisse videtur. = „Wydaje się, że męstwo żołnierzy było wielkie".

- Socrates parens philosophiae est. - „Sokrates jest ojcem filozofii”.

- Socrates parens philosophiae esse videbatur. - „Wydawało się, że Sokrates jest ojcem filozofii". / "Sokrates wydawał się (być) ojcem ojcem filozofii”.

- Romanis Socrates parens philosophiae esse videbatur. - „Rzymianom wydawało się, że Sokrates jest ojcem filozofii". 
- Res multae operae erat. - „Rzecz wymagała wielkiego wysiłku”.

- Res multae operae fuisse videtur. - „Wydaje się, że rzecz wymagała wielkiego wysiłku".

- Res multae operae fuisse videatur. - „Mogłoby się wydawać / Niech się wydaje, że rzecz wymagała wielkiego wysiłku".

- Consules tenui valetudine sunt. - „Konsulowie są słabego zdrowia”.

- Consules tenui valetudine esse videntur. - „Wydaje się, że konsulowie są słabego zdrowia”. I „Konsulowie wydają się (być) słabego zdrowia”.

- Marcus propinquam uxorem duxit. - „Marek pojął za żonę krewną”.

- Marcus propinquam uxorem duxisse videbitur. - „Będzie się wydawało, że Marek pojął za żonę krewną".

- Vercingetorix rex ab suis appelatus est. - „Wercyngetoryks przez swoich ludzi został obwołany królem".

- Vercingetorix rex ab suis appellatus esse videtur. - „Wydaje się, że Wercyngetoryks przez swoich ludzi został obwołany królem".

Jak widać z ostatniego spośród przytoczonych wyżej przykładów, poszczególne elementy (wyrazy gramatyczne i tekstowe) wchodzące w skład tego typu orzeczenia mogą zostać linearnie rozdzielone innymi składnikami wypowiedzenia ( $\mathrm{tj}$. innymi wyrazami). Dotyczy to nie tylko orzeczeń z imiennymi komponentami orzecznikowymi, ale również takich, w których orzecznik stanowiony jest wyłącznie przez czasownikową formę bezokolicznikową. Niżej podano kilka przykładowych zdań ilustrujących zastosowanie tego orzeczenia w klasycznej literaturze lacińskiej:

Huius (scil. Hamilcaris) perpetuum odium erga Romanos maxime concitasse videtur secundum bellum Poenicum. (Nep., Ham. 4)

„Wydaje się, że w wielkim stopniu jego (scil. Hamilkara) zatwardziała nienawiść do Rzymian wznieciła drugą wojnę punicką".

Laudavisse mihi videris nostram rem publicam. (Cic., Rep. 2, 64)

"Wydaje mi się, że pochwalileś naszą rzeczpospolitą".

Ei mihi videntur fortunate beateque vixisse $[\ldots]$, quibus $[\ldots]$ rerum gestarum gloria $[\ldots]$ perfrui licuit. (Cic., Brut. 8)

„Wydaje mi się, że ci żyli szczęśliwie i pomyślnie, którym wolno było cieszyć się chwałą (własnych) dokonań".

Sufficere cohortes alaeque $[\ldots]$ profligato iam bello videbantur. (Tac., Hist. 3, 50)

„Wydawalo się, że wobec rozstrzygniętej już wojny kohorty posiłkowe i oddzialy jazdy są wystarczające".

Parum mihi visus es eos, quibus cedere non soles, sustinere. (Cic., Phil. 8, 1)

„Zdało mi się, iż mało stanowczo odpierasz tych, którym zwykle nie ustępujesz".

Videbor $[\ldots]$ honorem homini amicissimo denegavisse. (Cic., Phil. 11, 19)

„Będzie się zdawalo, ze wielkiemu przyjacielowi odmówiłem przyznania zaszczytnego urzędu". 
Malum mihi videtur esse mors. (Cic., Tusc. 1, 9)

„Wydaje mi się, że śmierć jest złem”.

Tibi nos peregrini videmur. (Cic., Sull. 24)

"Tobie my wydajemy się cudzoziemcami".

Tu autem etiam membra ipsa sensusque considera, qui tibi $[\ldots]$ non comites solum virtutum, sed ministri etiam videbuntur. (Cic., Fin. 2, 113)

„Ty zaś zastanów się również nad samymi członkami ciała i zmysłami, które wydadzą ci się nie tylko współtowarzyszami cnót, lecz także ich slugami".

Is [...] mihi videtur amplissimus, qui sua virtute in altorem locum pervenit. (Cic., S. Rosc. 83)

„Ten wydaje mi się najbardziej godny szacunku, kto doszedł do wyższej pozycji dzięki własnej concie".

Athenienses maxime in eam rem idonei visi sunt. (Liv., 35, 32)

"Ateńczycy wydali się najbardziej odpowiedni do tej rzeczy”.

Quid enim videatur ei magnum in rebus humanis, cui aeternitas omnis totiusque mundi nota sit magnitudo? (Cic., Tusc. 4, 37)

„Cóż bowiem wśród rzeczy ludzkich może wydawać się wielkim temu, któremu znana jest cała wiecznośc i ogrom całego świata?"

Nec solum fidem meam, quod fortasse videatur satis esse, sed $[\ldots]$ curam, consilium vigilantiamque praestabo. (Cic., Phil. 7, 20)

„Nie tylko dochowam wierności, co być może mogloby się wydawać wystarczające, lecz nie odmówię także starań, rady i czujności".

Oprócz modalności epistemicznej, wyrażanej osobową formą czasownika videre w passivum, treść predykatywna, której wykładnikiem jest infinitiwus czasownika, może być dodatkowo objęta jeszcze innego rodzaju modalnością, np. deontyczną, sygnalizowaną przez czasownik modalny, który występuje wówczas również $w$ infinitiwie:

Liger ex nivibus creverat, ut omnino vado non posse transiri videretur. (Caes., Gall. 7, 55)

„Rzeka Liger od (topniejących) śniegów wezbrała, tak iż wydawalo się, że w ogóle nie może być przekroczona w' bród".

Quod [...] expositum ad imitandum est, praesertim cum illi eam gloriam consecuti sint, quae vix caelo capi posse videatur. (Cic., Phil. 2, 114)

„Jest to godne naśladowania, zwlaszcza że zyskali oni taką sławę, która chyba tylko w niebie może być osiągnięta".

Sygnalizowanie nacechowanej modalności epistemicznej za pośrednictwem orzeczenia współtworzonego przez pasywne formy czasownika videre dokonuje się również $w$ ramach zdań, które na ogół nie są już określane terminem nominativus cum infinitivo (przy ścisłym rozumieniu tego terminu). Orzeczenie to może bowiem otwierać miejsce dla podmiotu wyrażonego nie przez rzeczownik w nominatiwie, 
lecz przez infinitivus lub równoważnik podrzędnego zdania podmiotowego (accusativus cum infinitivo). Głównym wykładnikiem treści predykatywnej jest wówczas zwykle nie infinitivus, lecz przymiotnik w rodzaju nijakim, a współtworząca wraz $\mathrm{z}$ nim orzeczenie pasywna forma czasownika videre cechuje się ograniczeniem wartości kategorii osoby i liczby do 3. sg.:

Pigrum quin immo et iners videtur sudore adquirere, quod possis sanguine parare. (Tac., Germ. 14)

„Czymś gnuśnym a nawet tchórzliwym wydaje się pozyskiwanie w pocie czoła tego, co można zdobyć przelewem krwi".

Populo Romano iam a principio imperi melius visum [est] amicos quam servos quaerere. (Sall., Iug. 102)

„Narodowi rzymskiemu już od początku (jego) panowania wydawalo się czymś lepszym szukanie raczej przyjaciół niż niewolników".

Turpe mihi ipsi videbatur in eam urbem me audere reverti, ex qua Brutus cederet. (Cic., Phil. 1, 9)

„Mnie samemu zdawało się czymśs nieprzyzwoitym to, że ja śmiem wracać do tego miasta, z którego Brutus ustąpil".

Orzeczenie to może także w ogóle nie otwierać miejsca dla podmiotu, a więc sygnalizować diatezę niepodmiotową zdania; forma pasywna czasownika videre występuje wówczas również obligatoryjnie w 3. os. sg., a funkcję orzecznika pełnią czasowniki w bezokoliczniku przybierając tę wartość kategorii strony, za pośrednictwem której sygnalizują diatezę niepodmiotową w formach osobowych:

Erat [...] iter a proposito diversum, contrariamque in partem iri videbatur. (Caes., Civ. 1, 69)

„Maszerowano $\mathrm{w}$ innym kierunku niż zakładany i wydawało się, że idzie się (= marsz przebiega) w przeciwną stronę".

por.: Hac ad summum bonum itur? (Sen., Lucil. 48, 10)

"Czy tą drogą idzie się ku najwyższemu dobru?"

In eo non numquam variari inter eos et dubitari videtur. (Cic., Fin. 5,12 )

"Wydaje się, że w tej sprawie nickiedy dochodzi między nimi do różnic i wątpliwości".

por.: De Servi matre dubitatur. (Sen., Lucil. 108, 30)

"Istnieje wątpliwość co do matki Serwiusza".

Funkcję orzecznika może pełnić również participium futuri passivi w nom./acc. sg. neutr., które sygnalizuje diatezę niepodmiotową także współtworząc orzeczenia z osobowymi formami czasownika esse:

Festinandum ceteris videbatur. (Tac., Hist. 1, 33)

„Pozostałym (osobom) wydawało się, że należy się spieszyć”.

por. Festinandum est. (Sen., Dial. 6, 10,4)

„Należy się spieszyć”. 
Pasywna osobowa forma czasownika videre może również stanowić samodzielne orzeczenie wyrażenia zdaniowego o charakterze parentetycznym, które wtrącone jest w szyk linearny zdania denotującego treść objętą sygnalizowaną przez to wyrażenie modalnością; orzeczenie tego wyrażenia może nadawać mu diatezę:

a. Podmiotową:

Satis, ut videmur, de omnibus orationis partibus diximus. (Cic., Inv. 1, 109)

„Wystarczająco, jak się wydaje, opowiedziałem o wszystkich częściach przemówienia”.

Aspicis me et quidem, ut videris, iratus. (Cic., Phil. 2, 76)

„Spoglądasz na mnie i to, jak się wydaje, mocno poirytowany”.

Docuistis, ut vobis videmini, bonum solum esse, quod honestum sit. (Cic., Fin. 4, 46)

„Dowiedliście, jak wam się zdaje, że dobrem jest tylko to, co jest szlachetne”.

b. Niepodmiotową:

Parietes [...], ut mihi videtur, huius curiae tibi gratias agere gestiunt. (Cic., Marcell. 10)

"Sciany tego budynku kurii, jak mi się zdaje, bardzo pragną złożyć ci podziękowania”.

Czasownik videre w passivum może także sygnalizować nacechowaną modalność epistemiczną występując $w$ formie bezokolicznikowej. Współtworzy wtedy orzeczenie złożone zdania lub funkcjonalny odpowiednik złożonego orzeczenia równoważnika zdania podrzędnego (accusativus cum infinitivo).

Jako składnik orzeczenia złożonego współtworzy je z osobową formą czasownika, najczęściej fazowego (np. incipit), habitualnego (np. solet) lub modalnego. W tym ostatnim przypadku chodzi o czasowniki wyrażające modalność deontyczną (np.: potest, debet) lub dynamiczną (np.: vult, mavult). Wtedy też modalność epistemiczna, wyrażana przez pasywny bezokolicznik czasownika videre, objęta jest modalnością (deontyczną/dynamiczną), której wykładniki stanowią osobowe formy tych czasowników. Podstawowa treść predykatywna desygnowana jest zwykle przez komponent orzecznikowy w postaci formy przymiotnikowej lub rzeczownikowej, albo w postaci bezokolicznika innego czasownika:

Tirynthius $[\ldots]$ maior $[\ldots]$ videri coepit. (Ov., Met. 9, 268-270)

„Tyryntyjczyk (scil. Herkules) zacząl wydawać się większy”.

Crudele gladiatorum spectaculum et inhumanum non nullis videri solet. (Cic., Tusc. 2, 41)

„Nicktórym widowisko gladiatorskie zwykle wydaje się okrutne i nieludzkie”.

Haec peregrinatio mediocris vobis videri potest? (Cic., Tusc. 1, 98)

"Czy taka wędrówka może wydawać się wam błaha?"

Cuius scientiam de omnibus constat fuisse, eius ignoratio de aliquo purgatio debet videri. (Cic., Sull. 39)

„O kim wiadomo, że znał wszystkich (uczestników spisku), to jego nicznajomość jakicjś osoby powinna uchodzić za (jej) oczyszczenie (z zarzulu o udzial w spisku)". 
Adeo [...] neminem noxiae paenitebat, ut etiam insontes fecisse videri vellent. (Liv., 2, 54) „Do tego stopnia nikt nie żałował występku, że nawet niewinni chcieli uchodzić za jego sprawców".

Cogitanti $[\ldots]$ Fabio, cui rei potissimum insisteret, ne otiosam provinciam habuisse videri posset, optimum visum est in Cretam insulam traicere. (Liv., 37, 60)

„Fabiuszowi, rozmyślającemu o tym, czym powinien się zająć, by nie mógl sprawiać wrażenia, że objąl prowincję zupełnie spokojną, najlepszym rozwiązaniem wydała się przeprawa na Kretę".

Non potes ipse videri incendisse tuam, Tongiliane, domum? (Mart., Epigr. 3, 52, 3-4)

„Czyż nie możesz wywolywać wrażenia, że sam podpaliłeś swój dom, Tongilianie?”

Wykładnikiem podstawowej treści predykatywnej, objętej (złożoną) modalnością, może też być nie orzecznikowy składnik orzeczenia, lecz równoważnik zdania o postaci accusativus cum infinitivo. Implikujące go orzeczenie sygnalizuje wówczas diatezę niepodmiotową i złożone jest tylko z pasywnego bezokolicznika czasownika videre oraz formy 3. os. sg. jednego z wymienionych wyżej czasowników:

Nullum [...] verbum est ambiguum [...] nec aliud dici videri debet, quam quod se dicere sentit is, qui dicit. (Gell., Noc. Att. 11, 12, 2)

„Żadne słowo nie jest dwuznaczne i nie powinno wydawać się, że powiedziane zostało coś innego niż to, co sądzi, że mówi ten, który mówi".

Jako składnik funkcjonalnego odpowiednika złożonego orzeczenia, pasywny infinitiwus czasownika videre współtworzy je z bezokolicznikiem innego czasownika, formą rzeczownikową lub przymiotnikową jako komponentami orzecznikowymi, w ramach równoważnika zdania podrzędnego (accusativus cum infinitivo):

Pronuntiat Sthenium litteras publicas corrupisse videri. (Cic., Verr. 2, 2, 93)

"Oznajmia, że Stenius prawdopodobnie sfalszowal publiczne dokumenty".

Matrem Phalaridis scribit Ponticus Heraclides [...] visam esse videre in somnis simulacra deorum, quae ipsa domi consecravisset. (Cic., Div. 1, 46)

„Heraklides z Pontu pisze, że matka Falarysa ponoć widziala we śnie posągi bogów, które sama poświęciła w (swym) domu".

Occidendi sui consilium inisse me videri vult. (Liv., 40,12)

"Chce, by wydawało się, że ja powziąlem zamiar zamordowania go".

Ratio id iudicare vult, quod aequum est, ira id aequum videri vult, quod iudicavit. (Sen., Dial. 3, 18, 1)

„Rozum chce zawyrokować to, co jest sprawiedliwe, gniew chce, by za sprawiedliwe uchodzilo to, co zawyrokował".

Oprócz pasywnych form czasownika videre wykładnikiem nacechowanej modalności intradyktalnej $w$ ramach orzeczeń zdań typu nominativus cum infinitivo mogą być także osobowe formy w passivum innych czasowników, takich jak np.: dicere, putare, existimare, credere, arguere, nuntiare, scribere, narrare, audire, tradere, 
ferre $\mathrm{i}$ in. Sygnalizowana przez nie modalność również polega na ukazaniu relacjonowanej w ramach dictum sytuacji jako stanu prawdopodobnego bądź możliwego, przy czym dodatkowo wskazuje się w tym przypadku na pewne zewnętrzne przesłanki, pozwalające na przypisanie tej sytuacji właśnie takiego statusu, tj. statusu stanu prawdopodobnego czy możliwego. Przesłanki te ujawniane są w warstwie leksykalnej tych czasowników, a stanowią je takie czynniki, jak np.: powszechna opinia, ogólne przekonanie, zachowane przekazy, dochodzące wieści itp. Ten rodzaj modalności ma więc charakter nieco bardziej „zobiektywizowany” w porównaniu z tym, który sygnalizowany jest przez pasywne formy czasownika videre, a jego źródło, jak już zaznaczyliśmy, ujawniane lub przynajmniej implikowane jest przez semantykę odnośnych czasowników. W związku z tym struktury tego rodzaju nie otwierają już miejsca dla składnika imiennego, który byłby odpowiednikiem członu zależnego (w datiwie), dla którego miejsce otwiera pasywna forma czasownika videre. Niekiedy typ modalności, w którym wskazane zostają przesłanki (dowody, potwierdzenia) pozwalające na przypisanie określonego statusu treściom stanowiącym „świat przedstawiony” (dictum), nazywany bywa evidentialis (evidential modality). Poniżej zamieszczone zostały przykłady ilustrujące omawiany typ orzeczenia i związany z nim rodzaj modalności:

O Palaemon, $[. .$.$] qui Herculis socius esse diceris. (Pl., Rud. 160-161)$

„O Palemonie, który ponoć (= jak mówią) jesteś druhem Herkulesa”.

Quo tempore (Augustus) existimatur lorica sub veste munitus ferroque cinctus praesedisse. (Suet., Aug. 35)

„W tym czasie (August) podobno (= jak się sądzi) przewodniczyl obradom chroniony pancerzem ukrytym pod szatą i przepasany sztyletem".

Annos septuaginta natus [...] Ennius ita duo quae maxima putantur onera, paupertatem et senectutem, ut eis paene delectari videretur. (Cic., Sen. 14)

„Mając siedemdziesiat lat Enniusz w taki sposób znosil owe dwa ciężary, które uchodzą za największe, tj. ubóstwo i starość, iż zdawal się niemal nimi radować".

(Primus Antionius) scriptitasse Othoni credebatur, ducem se partibus efferens. (Tac., Hist. 2, 86)

"(Prymus Antoniusz), jak wierzono, często pisal do Othona, oferując stronnictwu siebie jako wodza".

Occidisse patrem Sex. Roscius arguitur. (Cic., S. Rosc. 37)

„Twierdzi się, że Sekstus Roscjusz zabil ojca”.

Caesar a Gergovia discessisse audiebatur. (Caes., Gall. 7, 1)

„Slychać było glosy, że Cezar odstąpił od Gergowii”.

Exercitus regius exitatusque omnis venire Alexandriam nuntiatur. (Caes., Civ. 3, 109)

„Dociera wieść, że całe wojsko królewskie wraz z konnicą udaje się do Aleksandrii”.

Etiam ille sapientissimus vir, Ithacam ut videret, immortalitatem scribitur repudiasse. (Cic., Leg. 2, 3)

„Można przeczytać, że nawet ów najbardziej roztropny mąż, aby zobaczyć Itakę, wzgardzić mial niesmiertelnością". 
Narratur $[. .$.$] emissum cursu deprendere telum. (Stat., Theb. 6, 567-568)$

"Opowiada się o nim, że biegnąc (dopędza i) przechwytuje wypuszczoną strzalę".

Haec proditio ab Samnitibus facta (eese) traditur. (Liv., 8, 26)

„Przekazuje się, że ta zdrada dokonana zostala przez Samnitów”.

(Caesar) fuisse traditur excelsa statura, colore candido, teretibus membris, ore paulo pleniore, nigris vegetisque oculis. (Suet., Iul. 45)

"(Cezar) według przekazów cechowal się wysokim wzrostem, bladą cerą, zaokrąglonymi czlonkami, twarzą nieco zbyt pełną, czarnymi i bystrymi oczami".

Dictator [...] aedem Castori vovisse fertur ac pronuntiasse militi praemia, qui primus [...] castra hostium intrasset. (Liv., 2, 20)

„Dyktator miał ponoć (= według przekazów) ślubować wzniesienie świątyni Kastorowi i obiecać nagrodę żolnierzowi, który jako pierwszy wedrze się do obozu nieprzyjaciól".

Dicatur sane eiectus esse a me, dum modo eat in exsilium. (Cic., Catil. 2, 15)

„Niech się mówi (= Niech panuje opinia), że zostal przeze mnie wypędzony, byleby tylko poszedl na wygnanie".

Modalność o charakterze ewidencjalnym może być za pośrednictwem wskazanych wyżej (i innych) czasowników wyrażana także poprzez zdania, w których czasowniki te nie współstanowią (wraz z formami bezokolicznikowymi) orzeczeń, lecz stanowią samodzielnie orzeczenia (wyrażenia predykatywne) konstytuujące zdania, natomiast sytuacja objęta wyrażaną przez nie (ewidencjalną) modalnością znajduje swój językowy wykładnik najczęściej w postaci równoważnika zdania podrzędnego składniowo (accusativus cum infinitivo). Zdania takie mają więc generalnie postać zdań składniowo złożonych i nie są już określane terminem nominativus cum infinitivo. Czasowniki stanowiące orzeczenia zdań nadrzędnych występują głównie w stronie czynnej, choć niektóre mogą wystąpić także w stronie biernej. Jeśli występują w stronie czynnej, w pozycji (mianownikowego) podmiotu ujawniany jest pierwszy argument denotowanego przez nie predykatu, często za pośrednictwem zaimka nieokreślonego lub kwantytatywnego, przez co pozostaje on niezidentyfikowany. $\mathrm{Z}$ kolei równoważnik zdania podrzędnego (accusativus cum infinitivo) wypełnia pozycję otwieraną dla dopełnienia. W przypadku niewypełnienia pozycji podmiotu pierwszy argument, jeśli nie jest implikowany kontekstowo, pozostaje ukryty lub ma charakter uogólniony:

Bonum putant esse aliqui id, quod utile est. (Sen., Lucil. 120, 2)

„Niektórzy sądzą, że dobrem jest to, co jest pożyteczne”.

Plerique existimant $[\ldots]$ bellum eo die potuisse finiri. (Caes., Civ. 3, 51)

„Wielu uważa, że wojna tego dnia mogla zostać zakończona”.

Fuisse [...] quendam ferunt Demaratum Corinthium et honore et auctoritate et fortunis facile civitatis suae principem. (Cic., Rep. 2, 34)

„Powiadają, że pewien Koryntyjczyk Demaratos dzięki swemu autorytetowi, wpływom i majątkowi byl niekwestionowanym przywódcą swego miasta". 
Jeśli czasowniki te występują w stronie biernej, obligatoryjnie przyjmują wartości 3. os. sg., gdyż pozycję podmiotu wypełnia równoważnik zdania podrzędnego ( $a c c u-$ sativus cum infinitivo), zaś pierwszy argument denotowanego predykatu ujawniony może zostać przez podrzędny składniowo (okolicznikowy) człon imienny. W przypadku jego braku pierwszy argument może być implikowany przez kontekst albo też pozostać ukrytym lub uogólnionym:

Inter principia condendi huius operis movisse numen ad indicandam tanti imperii molem traditur deos. (Liv., 1, 55)

„Na początku tego przedsięwzięcia podobno bogowie zestali znak dla wskazania na ogrom (przyszłego) tak wielkiego państwa".

Credebatur obsidione domitos hostes in fidem venisse. (Liv., 8, 26)

„Panowało przekonanie, że nieprzyjaciele zmuszeni oblężeniem poddali się".

Cum iam Caesar progressus esset a castris [...], per speculatores nuntiatur ei copias hostium haud longe a sese visas (esse). (Ps.-Caes, Bell. Afr., 12)

„Gdy Cezar wyszedł już z obozu, doniesiono mu za pośrednictwem zwiadowców, że w niewielkiej odleglości od niego zobaczono nieprzyjacielskie wojsko".

Wreszcie czasowniki te mogą stanowić podstawę wyrażeń zdaniowych o charakterze parentetycznym, które zwykle wtrącone są w obręb (szyk linearny) zdania denotującego treść objętą modalnością, nie zawierając semantyczno-syntaktycznych wykładników powiązania $\mathrm{z}$ nim:

Qua ex parte est Hibernia insula, dimidio minor, ut existimatur, quam Britannia. (Caes., Gall. 5, 13)

„Z tej strony znajduje się wyspa Hibernia (scil. Irlandia), o połowę mniejsza, jak się uważa, od Brytanii".

In Hispania Hercules, sicuti Afri putant, interiit. (Sall., Iug. 18)

„W Hiszpani, jak sądzą mieszkańcy Afryki, umarł Herkules”.

Podobnie jak w przypadku czasownika videri, również te czasowniki mogą sygnalizować nacechowaną modalność występując w infinitiwie. Wpółtworzą wówczas złożone orzeczenie wspólnie $\mathrm{z}$ osobowymi formami innych (modalnych) czasowników oraz z orzecznikowymi formami rzeczownikowymi, przymiotnikowymi bądź bezokolicznikowymi:

Quae servitus est, si haec libertas existimari potest? (Cic., Parad. 5, 40)

"Czym jest niewola, jeśli to może być postrzegane jako wolność?"

$V$ Vita $[\ldots]$ virtutibus $[\ldots]$ respondens recta et honesta et constans et naturae congruens existimari potest. (Cic., Fin. 5, 66)

„Życie odpowiadające cnotom może uchodzić i za wlaściwe, i za szlachetne, i za oparte na trwalych zasadach, i za zgodne z naturą".

Sed fuit hoc in utroque eorum, ut Crassus $[. .$.$] existimari vellet [\ldots]$ nostrorum hominum in omni genere prudentiam Graecis anteferre. (Cic., De orat. 2, 4)

„Lecz obaj się tym cechowali, tak iż Krassus chciał, by sądzono, że mądrość naszych ludzi w każdej dziedzinie przedkłada nad Greków". 
Bez komponentu orzecznikowego orzeczenie to sygnalizuje diatezę niepodmiotową, otwierając miejsce dla równoważnika zdania podrzędnego wyrażającego treść objętą modalnością:

In castris Pompei videre licuit $[\ldots]$ multa $[\ldots]$, quae nimiam luxuriem et victoriae fiduciam designarent, ut facile existimari posset nihil eos de eventu eius diei timuisse. (Caes., Civ. 3, 96)

„W obozie Pompejusza można było zobaczyć wiele rzczy, które wskazywały na nadzwyczajny przepych i wiarę w zwycięstwo, tak iż latwo można było sądzić, że nie trwożyli się oni o wynik (bitwy) w tym dniu".

Qua parte belli vicerant, ea tum quoque rem gesturos [esse] Romanos credi poterat. (Liv., 21, 22)

„Można było żywić wiarę, że Rzymianię również wtedy przeprowadza rzecz przy użyciu tej strategii wojskowej, z pomocą której wcześniej zwyciężyli".

Bezokolicznik tych czasowników może też stanowić składnik funkcjonalnego odpowiednika orzeczenia $w$ ramach równoważnika zdania podrzędnego (accusativus cum infinitivo), najczęściej obok rzeczownikowego komponentu orzecznikowego:

Atticum se [...] Calvus noster dici oratorem volebat. (Cic., Brut. 284)

„Nasz Kalwus chciał uchodzić za attyckiego mówce”.

Ego me cupio non mendacem putari. (Cic., Leg. 1,4)

„Nie chcę być uważany za klamcẹ".

$\mathrm{Na}$ temat złożonego orzeczenia $\mathrm{w}$ zdaniach typu nominativus cum infinitivo, w którym wykładnikiem nacechowanej modalności są pasywne formy czasowników: iubere, cogere, vetare, prohibere zob. niżej (Modalność logiczna: 3.1.2.3.4.).

\subsection{Czasowniki modalne}

Podobnie jak w języku polskim, czasowniki modalne służą w łacinie głównie wyrażaniu modalności logicznej (deontycznej - zob. niżej: 3.1.2.3.1.). Niekiedy jednak, również tak jak w języku polskim, mogą wyrażać modalność epistemiczną, nadając wyrażanym treściom status stanu możliwego, wysoce prawdopodobnego, pewnego czy koniecznego, np.:

Si talis disiunctio falsa potest esse, nulla vera est. (Cic., Lucull. 97)

„Jeśli taka dysjunkcja może być fałszywa, to żadna nie jest prawdziwa (= Jeśli może być tak, że jest falszywa...)".

Ut demonstratae sunt mihi, hasce aedis esse oportet, Demaenetus ubi dicitur habitare. I, puere, pulta! (Pl., Asin. 381-382)

„Według tego, co mi pokazano, to musi/powinien być dom, w którym ponoć mieszka Demenetus. Idź, chlopcze, zapukaj!"

Erat (candelabrus) eo splendore, qui ex clarissimis et pulcherrimis gemmis esse debebat. (Cic., Verr. 4, 65) 
„Swiecznik lśnił takim blaskiem, że musial być (= na pewno został) wykonany z najwspanialszych i najpiękniejszych klejnotów".

Ergo si solida ac sine inani corpora prima sunt, $[\ldots]$ sint haec aeterna necessest. (Lucr., 538-539)

„A zatem jeśli pierwotne cialka są zwarte i pozbawione próżni, to (niedwolalnie) muszą one być wieczne".

\subsection{Inne wyrażenia czasownikowe}

Nacechowana modalność epistemiczna może być wyrażana także za pośrednictwem wielu innych czasowników i wyrażeń czasownikowych. Mogą one konstytuować odrębne zdania, nadrzędne składniowo wobec tych, które wyrażają treści objęte daną perspektywą modalną:

Fieri potest, ut errem. (Cic., Fin. 23)

„Być może się mylę".

Non $[. .$.$] dubito quin tibi ingenio praestiterit nemo. (Cic., Rep. 1, 37)$

„Nie wątpię (Jestem pewien), że talentem nikt cię nie przewyższyl”.

$\mathrm{Z}$ kolei wyrażenia werbalne $\mathrm{z}$ partykułą an typu: nescio an, haud scio an, dubito an mogą nie mieć charakteru predykatywnego, lecz przyjmować funkcję operatora modalnego zawieszającego asercję i nadającego treściom wyrażanym przez czasowniki w koniunktiwie status stanu prawdopodobnego czy możliwego („nie wiem czy nie...," „chyba”, „bodaj”, „prawdopodobnie”):

C. Sulpicius Olympus [...] mortuus est $C$. Sacerdote praetore, nescio an antequam Verres praeturam petere coeperit. (Cic., Verr. 2, 1, 125)

„Gajusz Sulpicjusz Olympus umarł za pretury Gajusza Sacerdosa, bodaj/chyba jeszcze zanim Werres zacząl starać się o preturę".

Ac nescio an (Hannibal) mirabilior adversis quam secundis rebus fuerit, quippe qui cum in hostium terra per annos tredecim $[\ldots]$ varia fortuna bellum gereret, $[\ldots]$ nulla $[\ldots]$ adversus ducem seditio exstiterit. (Liv., 28, 12)

„I nie wiem czy nie byl (Hannibal) bardziej godny podziwu w sytuacjach trudnych niż pomyślnych, bo przecież choć przez trzynaście lat ze zmiennym szczęściem prowadził wojnę na ziemi nieprzyjaciól, to nie powstał żaden bunt przeciwko wodzowi".

Crudele gladiatorum spectaculum et inhumanum non nullis videri solet, et haud scio an ita sit, ut nunc fit. (Cic., Tusc. 2, 41)

„Niektórym widowisko gladiatorskie często wydaje się czymś okrutnym i nieludzim, i nie wiem, czy tak wlaśnie nie jest (i chyba tak wlaśnie jest), gdy chodzi o to, jak dzisiaj one przebiegają".

Si per se virtus sine fortuna poneranda est, dubito an hunc primum omnium ponam. (Nep., Thras. 1)

„Jeśli należaloby oceniać samo tylko męstwo jako takie, bez uwzględnienia roli losu, to chyba jego postawilbym ponad wszystkich". 
Podobnie $\mathrm{w}$ odniesieniu do niepredykatywnego składnika zdania, z zachowaniem orzeczenia w koniunktiwie (attractio modi):

Ingens eo die res ac nescio an maxima illo bello gesta sit. (Liv., 23, 16)

„Dokonała się tego dnia rzecz niezwykła i nie wiem czy nie największa w tej wojnie”.

Pewną przesłanką formalną świadczącą o tym, że wyrażenia te mają charakter raczej operatorów niż wyrażań predykatywnych otwierających miejsce dla dopełnieniowych zdań podrzędnych, może być ich współwystępowanie z zaimkiem przeczącym nullus, a nie nieokreślonym antytetycznym ullus:

Omnium ineptiarum $[\ldots]$ haud scio an nulla sit maior quam $[\ldots]$ de rebus $[\ldots]$ non necessariis argutissime disputare. (Cic., De orat. 2, 18)

„Ze wszystkich niedorzeczności chyba żadna nie jest większa niż ta, która polega na subtelnym dysputowaniu o rzeczach niepotrzebnych".

\subsection{Futurum}

Stosunkowo rzadko, w mowie potocznej, nacechowany modalnie bywa czas przyszły, implikując duże prawdopodobieństwo lub pewność co do prawdziwości określonej sytuacji w teraźniejszości:

Haec erit bono genere nata, nihil scit nisi verum loqui. (Pl., Pers. 645)

„Ona musi być z dobrego domu; mówi tylko prawdę".

\subsection{Interrogatywa}

Biorąc pod uwagę implikację niepewności co do prawdziwości treści denotowanej przez wyrażenie predykatywne, za nacechowane pod względem modalności epistemicznej uważane są przynajmniej niektóre wypowiedzenia o charakterze pytajnym, np.:

Ipse percussit an aliis occidendum dedit? (Cic., S. Rosc. 74)

„Sam zadal cios, czy zabicie (go) zlecił innym?”

Z kolei ze względu na nieasertoryczny charakter wypowiedzeń pytajnych jako takich za nacechowane modalnie uważane mogą być wszystkie interrogatywa.

\subsubsection{Modalność logiczna (deontyczna, dynamiczna)}

Terminem modalność logiczna obejmujemy tu dwa typy modalności intradyktalnej, odnoszące się do relacji zachodzących między składnikami imiennymi dictum a przypisywaną im charakterystyką. Jednym $\mathrm{z}$ tych typów jest tzw. modalność 
deontyczna, opierająca się na pojęciu możliwości, powinności (zobligowania) czy konieczności, drugim tzw. modalność dynamiczna, której wyznacznikami są takie pojęcia jak: wola, chęć, zamiar, nastawienie itp. Podobnie jak w przypadku modalności epistemicznej, modalność logiczna znajduje w łacinie kilka różnych wykładników formalnych. Mają one charakter bądź to leksykalny (tzw. czasowniki i wyrażenia modalne) bądź gramatyczny (tryb coniunctivus czasownika, niektóre konstrukcje partycypialne, pewne struktury orzeczeniowe znane jako tzw. nominativus cum infinitivo).

Jak już wspomniano, deontyczny ekstradyktalny charakter przypisywany jest także imperatywnej i dezyderatywnej modalności intencjonalnej z uwagi na jej związek z pojęciem konieczności bądź powinności; jej wykładnikami są imperatywne i koniunktywne formy czasowników wyrażające iussywność, prohibitywność, hortatywność i (wraz z partykułą utinam) optatywność (zob. wyżej: 3.1.2.1.).

\subsection{Czasowniki i wyrażenia modalne}

Jako modalne określa się w łacinie czasowniki: posse, licere, debere, oportere oraz wyrażenie necesse est. Wszystkie one cechują się tym, że ich prymarną funkcją semantyczną jest właśnie wyrażanie różnych odcieni modalności deontycznej: od możliwości, poprzez powinność, zobligowanie, aż do konieczności. Większość z nich, jak wskazano wyżej, sygnalizować może także opartą na tych pojęciach modalność epistemiczną. Ilustrację sygnalizowanej przez nie modalności deontycznej stanowić mogą podane niżej przykłady:

Corpore nihil nisi praesens et quod adest sentire possumus. (Cic., Fin. 1, 55)

„Za pośrednictwem ciala możemy odczuwać tylko to, co istnieje $w$ danym momencie i co jest obecne".

Id quod scire potuit et debuit dixit. (Cic., Q. Rosc. 42)

"Powiedzial to, co mógl i powinien był wiedzieć".

Nunc licet mihi libere quidvis loqui. (Pl., Amph. 393)

„Teraz wolno mi swobodnie mówić, cokolwiek zechcę".

Mihi necesse est ire hinc. (Pl., Amph. 501)

„Muszę stąd odejść".

Quid me oportet facere? (Pl., Capt. 955)

„Co powinienem robić?"

Ego crimen oportet diluam, vos [...] audaciae resistere [...] debetis. (Cic., S. Rosc. 36)

„Wypada, żebym ja odparł oskarżenie, a wy powinniście przeciwstawić się bezczelności”.

Poza tym, modalność tego typu wyrażać mogą także czasowniki i wyrażenia określane jako semimodalne, takie jak: quire/nequire, decere, valere, opus esse, których zakres funkcjonalny ograniczony jest wyłącznie do wyrażania modalności deontycznej. 
Non queo plura scribere. (Cic., Att. 3, 12, 3)

„Nie zdołam ( = nie mogę, nie jestem w stanie) napisać więcej”.

Heia, mea Iuno, non decet esse te tam tristem tuo Iovi. (Pl., Cas. 230)

„Ejże, ma Junono, nie godzi się / nie wypada, byś była tak zagniewana na swego Jowisza”.

Diu qui domi otiosi dormierunt, decet animo aequo nunc stent. (Pl., Poen. 21-22)

„Wypada by ci, którzy próżnując spali długo w domu, teraz stali nie okazując wzburzenia”.

Nec continere suos ab direptione castrorum valuit. (Liv., 38, 23)

"I nie byl w stanie / nie mógl powstrzymać swoich ludzi od grabieży obozu”.

Hic opus est aliquot ut maneas dies. (Pl., Poen. 1421)

„Trzeba, abyś tu przez kilka dni pozostaY".

Opus est te animo valere, ut corpore possis. (Cic., Fam. 16, 14, 2)

„Trzeba, abyś był silny na duchu, byś mógł (być silny także) ciałem”.

Z kolei wykładnikami modalności dynamicznej, wyznaczonej przez kategorie woli, chęci, zamiaru czy nastawienia, są głównie czasowniki: velle, malle, nolle:

Charisi vult Hegesias esse similis. (Cic., Brut. 286)

„Hegesjasz chce być podobny do (scil. chce naśladować) Charysjusza”.

In animis ego vestris omnis triumphos meos, omnia ornamenta honoris [...] condi et conlocari volo. (Cic., Catil. 3, 26)

„Chce, żeby wszystkie moje tryumfy, wszystkic oznaki czci, w waszych sercach zostały zlożone i przechowane".

Si vis, ut loquar, ipse tace! (Mart., Epigr. 5, 52,6)

„Jeśli chcesz, bym to ja mówil, sam zamilcz!"

Leno argentum hoc volo a me accipiat. (Pl., Pseud. 1122-1123)

"Chcę, żeby stręczyciel przyjąl ode mnie te pieniądze".

Cum omnia gymnasia philosophi teneant, tamen eorum auditores discum audire quam philosophum malunt. (Cic., De orat. 2, 21)

„Chociaż wszystkie gimnazja opanowali filozofowie, to jednak ich słuchacze wolą słyszeć świst rzuconego dysku niż wywód filozofa".

Sunt $[\ldots]$ tyranni, sed se [...] malunt reges vocari. (Cic., Rep. 3, 23)

"Są tyranami, ale wolą, by nazywani byli królami".

Malo te sapiens hostis metuat quam stulti cives laudent. (Liv., 22, 39)

„Wolę, żeby się ciebie bal mądry nieprzyjaciel, niż żeby cię chwalili glupi obywatele."

Nolui tam vehementer agere hoc prima actione. (Cic., Verr. 2, 5, 163)

„Nie chcialem zbyt intensyw'nie zajmować się tą sprawą w pierw'szej części procesu”.

Id vos ignorare nolui. (Nep., Att. 21)

„Nie chciałem, byście byli nieświadomi tego". 
Nolo vincat. (Cic., Q. Rosc. 9)

„Nie chce,, by wygral”.

Podobną funkcję pełnić mogą, oczywiście, również inne czasowniki lub wyrażenia wyrażające wolę, chęć czy zamiar, np.: cupere, desiderare, in animo habere itp. W eliptycznych zdaniach względnych lub parentetycznych, często o charakterze warunkowym, a także w wypowiedzeniach pełniących funkcje replik, w odniesieniu do treści zdania głównego (lub podlegającego replice) stosowane bywa też orzeczenie stanowione przez pasywną formę czasownika videre w 3. os. sg.:

Locum sepulcro in campo Esquilino C. Pansa consul, seu quo in loco videbitur, [...] adsignet. (Cic., Phil. 9, 17)

„Niech konsul Gajusz Pansa wyznaczy miejsce dla grobu na polu Eskwilińskim albo gdzie uzna to za właściwe (= zechce)".

Recognoscat agedum mecum, si videtur, quam multa pro hoste et adversus nos fuerint. (Liv., 44, 38)

„Smiało, niech więc rozważy wraz ze mną, jeśli zechce, jak wiele przemawialo na korzyść wroga a przeciwko nam".

Tamen, si tibi videtur, accipe a me auxilia. (Sen., Lucil. 13, 3)

"Jednak, jeśli uznasz to za stosowne, przyjmij ode mnie pomoc".

Quid igitur? Contra Brutumne me dicturum putas? - Tu vero, ut videtur; nam praefinire non est meum. (Cic., Tusc. 5, 22)

„Cóż więc? Sądzisz, że będę wypowiadal się przeciwko Brutusowi? - Zrobisz jak zechcesz; nie jest przecież moją rzeczą dawać ci zalecenia".

\subsection{Coniunctivus}

W ramach modalności deontycznej tryb coniunctivus może wyrażać:

a. Powinność:

'Moreretur', inquies [...]. Fecisset certe, si sine maximo dedecore [...] potuisset emori. (Cic., Rab. Post. 29)

„'Powinien byl popelnić samobójstwo', powiesz. I zapewne zrobilby to, gdyby mógl umrzeć bez wielkiej hańby".

Saltem aliquid de pondere detraxisset et paulo minoris aestimavisset ea quam Peripatetici, ut sentire quoque aliud, non solum dicere videretur. (Cic., Fin. 4, 57)

„Powinien był przynajmniej nieco pomniejszyć wagę (tych rzeczy) i przypisać im nieco mniejszą wartość niż Perypatetycy, aby wydawało się, że również myśli inaczej, a nie tylko mówi".

Quid ergo agam, Phidippe? (Ter., Hec. 715)

"Cóż więc mam (= powinnam) robić, Fidypie?" 
Nos [...] non poetarum voce moveamur? (Cic., Arch. 19)

"My mamy się nie wzruszać glosem poety?"

Haec cum viderem, quid agerem, iudices? [...] Contenderem contra tribunum plebis privatus armis? (Cic., Sest. 43)

„Gdy to wszystko widziałem, co mialem robić, sędziowie? Mialem z bronią w rę̧ku walczyć przeciwko trybunowi ludowemu, będąc czlowiekiem prywatnym?"

b. Możliwość:

Quid faciat custos, cum [...] illa [...], quo [...] sui comites vetantur ire, eat? (Ov., Ars 3, 633-636)

„Cóż może zrobić strażnik, gdy ona chodzi tam, dokąd nie wolno w'ejść towarzyszącym jej mężczyznom?"

\subsection{Konstrukcje partycypialne}

Jednym z gramatycznych środków wyrażania w łacinie modalności logicznej są również konstrukcje partycypialne, których składnikiem jest participium futuri passivi (gerundivum) lub participium futuri activi. Oba te participia mogą być używane predykatywnie (orzecznikowo) lub atrybutywnie (przydawkowo).

\subsection{Participium futuri passivi}

Partipum futuri passivi (gerundivum) sygnalizować może modalność deontyczną związaną z pojęciem powinności, zobowiązania lub konieczności. Użyte predykatywnie współtworzy - wraz z formą osobową czasownika esse - złożone orzeczenie, pełniąc $w$ jego ramach funkcję orzecznika. Orzeczenia tego typu znane są jako tzw. coniugatio periphrastica passiva. W przypadku czasowników (użytych $\mathrm{w}$ znaczeniach) przechodnich, zdania przez nie konstytuowane charakteryzują się diatezą bierną, a zatem współwyrażana przez modalnie nacechowane orzeczenie powinność czy konieczność wiązana jest $\mathrm{z}$ (desygnowanym przez podmiot) obiektem stanowiącym drugi argument denotowanego przez to orzeczenie predykatu:

Voluntas ipsa rectum petens laudanda est. (Sen., Benef. 5, 2, 2)

"Sama chęć zmierzająca ku dobru powinna być chwalona".

Quoniam $[\ldots]$ bellum gerendum est, imperator est deligendus. (Cic., Phil. 11, 16)

„Ponieważ trzeba prowadzić wojnę, należy wybrać wodza”.

Tacitae magis et occultae inimicitiae timendae sunt quam indictae atque apertae. (Cic., Verr. 2, 5, 182)

"Bardziej należy obawiać się cichych i skrywanych wrogości niż zadeklarowanych i jawnych". 
Pierwszy argument może jednak również zostać wyrażony. Jego wykładnikiem jest fakultatywny, podrzędny składniowo składnik imienny, stanowiony przez rzeczownik (zaimek) w datiwie (tzw. dativus auctoris):

Isti nobis $[\ldots]$ audiendi sunt. (Cic., Fin. 5, 89)

„Oni muszą/powinni być przez nas sluchani”.

Caesari omnia uno tempore erant agenda. (Caes., Gall. 2, 20)

„Wszystkie rzeczy musialy być wykonywane przez Cezara w jednym czasie".

W przypadku czasowników (użytych w znaczeniach) nieprzechodnich zdanie cechuje się diatezą niepodmiotową, tzn. zdanie takie nie otwiera w swej strukturze składniowej miejsca dla mianownikowego podmiotu. Jednak również $w$ tego typu zdaniach pierwszy argument predykatu może zostać ujawniony przez fakultatywny składnik imienny (dativus auctoris), zaś ewentualne argumenty niższej rangi przez człony dopełnieniowe. Niewypełnienie pozycji otwieranej dla fakultatywnego składnika imiennego $w$ datiwie (brak datiwu auctoris) implikuje uogólniony (lub tożsamy z nadawcą/grupą nadawcy) charakter pierwszego argumentu:

Cum iis est vobis, milites, pugnandum, quos terra marique priore bello vicistis. (Liv., $21,40)$

„Przychodzi wam, żołnierze, walczyć z tymi, których w poprzedniej wojnie pokonaliście na lądzie i morzu".

Catoni $[. .$.$] moriendum potius quam tyranni vultus aspiciendus fuit. (Cic., Off. 1, 112)$

„Katonowi wypadało raczej umrzeć, niż oglądać twarz tyrana”.

wpółtworząc funkcjonalny odpowiednik orzeczenia $w$ ramach równoważnika zdania podrzędnego accusativus cum infinitivo:

Est apud Platonem Socrates [...] dicens [...] sibi post tertium diem esse moriendum. (Cic., Div. 1, 52)

„Jest u Platona Sokrates mówiący, że za trzy dni będzie musiał umrzeć / przyjdzie mu umrzeć".

Parendum [...] religioni fuit nec patrius mos tam contumaciter repudiandus. (Cic., Div. $2,71)$

„Należalo okazać posłuszeństwo nakazom religii i nie odrzucać tak uparcie ojczystego obyczaju".

Hic vincendum aut moriendum, milites, est. (Liv., 21, 43)

„Tutaj, żołnierze, trzeba (nam) zwyciężać albo umierać”.

Participium futuri passivi może być użyte jako orzecznik również przy formach osobowych innych (niż esse) czasowników. Struktury takie nie są już jednak określane terminem coniugatio periphrastica passiva:

Meretricem hanc primum adeundam censeo. (Ter., Hec. 716)

„Uważam, że najpierw należy (powinniśmy) podejść do tej hetery”. 
Jak wspomniano już wyżej, participia futuri passivi mogą być używane także atrybutywnie jako określniki (przydawki) różnych składników imiennych zdania, często (choć nie zawsze) zachowując swe znaczenie modalne:

Cassius [...] Minucium libertis tradidit excruciandum. (Ps.-Caes., Bell. Alex. 55)

„Kasjusz wydał Minucjusza wyzwoleńcom na tortury (tj. wydal jako tego, który miał być torturowany)".

Pecuniam Staieno dedit Oppianicus [...] ad corrumpendum iudicium. (Cic., Cluent. 84)

„Oppianikus dal Stajenusowi pieniądze na przekupienie sądu ( $t \mathrm{t}$. dal pieniądze na sąd, który mial być przekupuiony)".

\subsection{Participium futuri activi}

Participum futuri activi może być wykładnikiem modalności deontycznej oznaczając zdarzenia (sytuacje, czynności), które mają lub miały, muszą lub musiały, powinny lub powinny były nastąpić; tym samym implikuje konieczność, nieuchronność lub duże prawdopodobieństwo. Sygnalizuje diatezę czynną. Użyte predykatywnie pełni funkcję orzecznika $\mathrm{w}$ ramach orzeczenia współtworzonego $\mathrm{z}$ formą osobową czasownika esse. Tego typu orzeczenie tradycyjnie określane jest terminem coniugatio periphrastica activa:

Omnia, quae ventura sunt, in incerto iacent. (Sen., Dial. 10, 9, 2)

„Wszystko, co ma/musi nastąpić, jesı niepewne".

Iam steterant acies ferro mortique parati, iam lituus pugnae signa daturus erat. (Ov., Fast. 3, 215-216)

„Już stały oddziały gotowe na śmiertelny bój, już trąbka miała dać sygnal do walki".

Dictator ac magister equitum castra in viam deferunt, qua Hannibal ducturus erat. (Liv., $22,15)$

„Dyktator i dowódca jazdy przenoszą obóz na drogę, którą mial/powinien isć Hannibal”.

Participia te mogą być także użyte atrybutywnie, stanowiąc często typ przydawki zwany praedicativum:

Sic, $[\ldots]$ conmilitones, prandete tamquam apud inferos cenaturi. (Sen., Lucil. 82, 21)

„Tak, towarzysze, jedzcie śniadanie, jakbyście obiad mieli spożyć wśród bogów podziemnych".

Tamquam semper victuri vivitis. (Sen., Dial. 10, 3, 4)

„Żyjecie, jakbyście mieli żyć wiecznie”.

Oprócz deontycznej participum to może wyrażać także modalność dynamiczną, opartą na chęci, intencji, zamiarze:

Nihil $[. .$.$] de eorum sententia dicturus sum, qui turpissimam servitutem deditionis nomi-$ ne appellant. (Caes., Gall. 7, 77) 
„Nie zamierzam niczego mówić na temat opinii tych, klórzy najbardziej podłą niewolę nazywają poddaniem się".

Nocte profectus Vermina, qui ex occulto adgressurus erat. (Liv., 29, 33)

„Nocą wyruszył Wermina, klóry mial zamiar zaatakować z ukrycia”.

Non estis cenaturi? (Pl., Merc. 750)

„Nie zamierzacie jeść kolacji?”

Fortuna mecum bellum gerit: non sum imperata facturus; iugum non recipio, immo, quod maiore virtute faciendum est, excutio. (Sen., Lucil. 51, 8)

"Los toczy ze mną wojnę: ja nie zamierzam wykonywać (jego) rozkazów; jarzma nie przyjmuję, a nawet zrzucam je (z siebie), co wymaga (jeszcze) większego męstwa".

Funkcje tę zachowuje również jako określnik atrybutywny, najczęściej typu praedicativum:

Senones Galli multitudine ingenti ad Clusium venerunt legionem Romanam castraque oppugnaturi. (Liv., 10, 26)

„Senonowie galliccy w wielkiej liczbie podeszli pod Kluzjum, chcąc zaatakować rzymski legion i obóz".

Niekiedy semantyka tego participium implikuje przypisywanie charakteryzowanemu przez nie obiektowi gotowości, dyspozycji czy zdolności do określonego działania, i w rezultacie denotować może ono sytuacje (zdarzenia), które hipotetycznie byłyby możliwe lub pewne:

Carthaginienses [...], quia metus et periculum cessandi non dabat tempus prima luce oppugnaturis hostibus castra, $[\ldots]$ augent vallum, munimento sese $[. .$.$] defensuri. (Liv.,$ $28,15)$

„Kartagińczycy, ponieważ strach i niebezpieczeństwo nie dawało (im) czasu na ociąganie się w stytuacji, gdy o świcie nieprzyjaciele mogli/gotowi byli zaatakować obóz, powiększają wał obronny zamierzając bronić się zza szańców".

Quia ex tam propinquis stativis parum tuta frumentatio erat, dispersos milites per agros equitibus extemplo invasuris, $[\ldots]$ castra ad Ottolobum $[\ldots]$ movit. (Liv., 31, 36)

„Ponieważ z uwagi na bliskość kwater (nieprzyjaciół) zaopatrywanie się w żywność nie było wystarczająco bezpieczne, jako że rozproszonych po polach żołnierzy mogla znienacka zaatakować konnica, przeniósł obóz po miejscowość Ottolobos".

Ad quem (scil. tumulum) capiendum si luce palam iretur, [...] haud dubie hostis breviore via praeventurus erat. (Liv., 22, 24)

„Gdyby otwarcie wyruszono zdobyć wzgórze za dnia, bez wątpienia przeciwnik dotarlby / bylby gotów / bylby zdolny dotrzeć tam wcześniej, mając (do niego) krótszą drogę".

\subsection{Nominativus cum infinitivo}

Jak wskazano wyżej, zdania ze złożonym orzeczeniem, które tradycyjnie określane są jako tzw. nominativus cum infinitivo, służą przede wszystkim do wyrażania 
nacechowanej modalności epistemicznej. Jednak w przypadku, gdy ich orzeczenia współstanowione są przez osobowe, pasywne formy takich czasowników jak: iubere, cogere, vetare czy prohibere, wyrażają modalność deontyczną implikując konieczność wynikającą z nakazu bądź zakazu:

Decemviri libros adire iussi sunt. (Liv., 22, 57)

„Decemwirom nakazano, by zajrzeli do ksiąg (sybilińskich)”.

Consules creari iussi sunt. (Liv., 4, 12)

„Nakazano, by zostali wybrani konsulowie".

Miserior igitur, qui suscipit in se scelus, quam is, qui alterius facinus subire cogitur. (Cic., Phil. 11, 9)

„Bardziej godny pożalowania jest więc ten, kto dokonuje zbrodni, niż ten, kto jest zmuszony stać się ofiarą zbrodni kogoś innego".

Quid faciat custos, cum [...] illa [...], quo [...] sui comites vetantur ire, eat? (Ov., Ars 3, 633-636)

„Cóż może zrobić strażnik, gdy ona chodzi tam, dokąd nie wolno wejść towarzyszącym jej mężczyznom?"

Plura scribere fletu prohibeor. (Cic., Att. 11, 9, 3)

„Nie mogę napisać więcej z powodu płaczu (= Placz nie pozwala mi napisać więcej)".

\subsection{Imperatywa i dezyderatywa}

Imperatywa i dezyderatywa, a więc wypowiedzenia o nacechownej modalności intencjonalnej, interpretowane są również jako wypowiedzenia o nacechowanej modalności deontycznej, $z$ uwagi na implikowane przez nie pojęcie powinności (zobowiązania, konieczności, możliwości):

Pythio Apollini [...] donum mittitote! (Liv., 23, 11)

„Apollinowi Pytyjskiemu wyślijcic dar!"

Persequamur eorum mortem, qui indignissime interierunt, atque hos latrones interficiamus. (Caes., Gall. 7, 38)

„Pomścijmy śmierć tych, którzy tak niegodnie zginęli, i zabijmy tych bandytów".

Falsus utinam vates sim! (Liv., 21, 10)

„Obym byl falszywym prorokiem!”

Pereat, qui crastina curat. (App. Verg.: Copa, 37)

"Oby zginąl / Niech zginie, kto troszczy się o to, co będzie jutro". 


\subsubsection{Współwystępowanie modalności}

Jak wspomniano już wcześniej, różne rodzaje (nacechowanej) modalności mogą współwystępować w odniesieniu do jednego wyrażenia predykatywnego. W ramach nacechowanej modalności epistemicznej wyrażana może więc być również modalność deontyczna, np.:

Quod [...] expositum ad imitandum est, praesertim cum illi eam gloriam consecuti sint, quae vix caelo capi posse videat ur. (Cic., Phil. 2, 114)

„Jest to godne naśladowania, zwłaszcza że zyskali oni taką slawę, która chyba tylko w nicbie może być osiągnięta".

De Crassi oratione sic existimo, ipsum fortasse melius potuisse scribere, alium [...] neminem. (Cic., Brut. 298)

„Na temat wymowy Krassusa mam taki pogląd, iż on sam być może mógl (był w stanie) pisać lepiej, ale (poza nim) już nikt inny".

Si tibi hoc sumis, nisi qui patricius sit, neminem bono esse genere natum, facis, ut rursus plebes in Aventinum sevocanda esse videatur. (Cic., Mur. 15)

„Jeśli uważasz, że tylko patrycjusze są dobrze urodzeni, to sprawiasz, że plebs chyba znowu powinien zostać odwolany na Awentyn (przez swych przywódców, by walczyć o należne mu prawa)".

Cuius consilium reprehendendum non videtur. (Caes., Civ. 3, 51)

„Nie wydaje się, by jego decyzję należalo zganić”.

Non praetereunda videtur oratio Critognati propter eius singularem ac nefariam crudelitatem. (Caes., Gall. 7, 77)

„Wydaje się, że nie powinno (nie może) być pominięte milczeniem przemówienie Krytognatusa ze względu na jego wyjątkowe i niegodziwe okrucieństwo".

Minime decere videtur, patres conscripti, $[.$.$] errare eum, cui vos maximis saepe de rebus$ adsentiamini. (Cic., Phil.12, 1)

„Wydaje się, że nie wypada, senatorowie, aby mylił się ten, z którym wy często zgadzacie się w sprawach najważniejszych".

Nieco rzadziej mamy do czynienia z sytucją odwrotną, tzn. $\mathrm{z}$ wyrażaniem nacechowanej modalności epistemicznej w ramach modalności deontycznej:

Si tibi nos peregrini videmur, [...] quam tibi illos competitores tuos peregrinos videri necesse erit, qui [...] tecum de honore ac de mno dignitate contendent! (Cic., Sull. 24)

"Jeżeli my wydajemy ci się cudzoziemcami, to jak bardzo będą musieli wydawać ci się cudzoziemcami owi twoi rywale, którzy wspótzawodniczyć z tobą będą o urzędy i wszelkie godności!"

Haec peregrinatio mediocris vobis videri potest? (Cic., Tusc. 1, 98)

"Czy taka wędrówka może wydawać się wam błaha?"

Quae servitus est, si haec libertas existimari potest? (Cic., Parad. 5, 40)

„Czym jest niewola, jeśli to może być postrzegane jako wolność?” 
Cuius scientiam de omnibus constat fuisse, eius ignoratio de aliquo purgatio debet videri. (Cic., Sull. 39)

„O kim wiadomo, że znał wszystkich (uczestników spisku), to jego nieznajomość jakiejś osoby powinna uchodzić za (jej) oczyszczenie (z zarzutu o udzial w spisku)".

Cogitanti $[\ldots]$ Fabio, cui rei potissimum insisteret, ne otiosam provinciam habuisse videri posset, optimum visum est in Cretam insulam traicere. (Liv., 37, 60)

„Fabiuszowi, rozmyślającemu o tym, czym powinien się zająć, by nie mógl sprawiać wrażenia, że objął prowincję zupełnie spokojną, najlepszym rozwiązaniem wydała się przeprawa na Kretę".

Non potes ipse videri incendisse tuam, Tongiliane, domum? (Mart., Epigr. 3, 52, 3-4)

„Czyż nie możesz wywolywać wrażenia, że sam podpalileś swój dom, Tongilianie?”

Modalność epistemiczna może być wyrażana w ramach modalności dynamicznej:

(Agricola) maluit videri invenisse (milites) bonos quam fecisse. (Tac., Agr. 7)

„(Agrykola) wolal by się wydawalo, że zastal (zołnierzy) karnymi, niż że (ich takimi) uczynil".

Adeo $[\ldots]$ neminem noxiae paenitebat, ut etiam insontes fecisse videri vellent. (Liv., 2,54)

„Do tego stopnia nikt nie żalowal występku, że nawet niewinni chcieli uchodzić za jego sprawców".

Może też współwystępować modalność epistemiczna ekstradyktalna $z$ intradyktalną:

Nec solum fidem meam, quod fortasse videatur satis esse, sed $[\ldots]$ curam, consilium vigilantiamque praestabo. (Cic., Phil. 7, 20)

„Nie tylko dochowam wierności, co być może mogłoby się wydawać wystarczające, lecz nie odmówię także starań, rady i czujności".

$\mathrm{Z}$ kolei modalność deontyczna może wpółwystępować również z modalnością dynamiczną:

Debetis velle quae velimus. (Pl., Amph. 39)

„Powinniście chcieć tego, czego my byśmy sobie życzyli”.

Jak można było zauważyć na podstawie wcześniej przytaczanych przykładów, zarówno nacechowana modalność epistemiczna, jak i deontyczna, może być wyrażana przy różnych nacechowaniach intencjonalnych wypowiedzi:

Revivescat $M$. Curius $[\ldots]$ et videat aliquem [...] mullos exceptantem de piscina et $[\ldots]$ murenarum copia gloriantem; nonne hunc hominem [...] servum iudicet? (Cic., Parad. $5,38)$

„Załóżmy/Przypuśćmy, że Manliusz Kuriusz ożył i zobaczył kogoś lowiącego w stawie ryby i szczycącego się posiadaniem wielkiej ilości muren; czyż nie uznalby tego czlowieka za niewolnika?" 
\{Chremes:\} Si, Simo, hunc noris satis, non ita arbitrere: bonus est hic vir. \{Simo:\} Hic vir sit bonus? (Ter., Andr. 914-915)

„\{Chremes:\} Jeśli, Simonie, znałbyś go lepiej, nie uważalbyś tak: to dobry czlowiek. \{Simo:\} To ma być dobry człowiek?"

Quid enim videatur ei magnum in rebus humanis, cui aeternitas omnis totiusque mundi nota sit magnitudo? (Cic., Tusc. 4, 37)

„Cóż bowiem wśród rzeczy ludzkich może wydawać się wielkim temu, któremu znana jest cała wiecznośc i ogrom całego świata?"

Dicatur sane eiectus esse a me, dum modo eat in exsilium. (Cic., Catil. 2, 15)

„Niech się mówi (= Niech panuje opinia), że zostal przeze mnie wypędzony, byleby tylko poszedł na wygnanie".

Quid me oportet facere? (Pl., Capt. 955)

„Co powinienem robić?"

Utinam saluti nostrae consulere possimus! Dignitati certe consulemus. (Cic., Fam. 15, 1, 6)

„Obym mógl zadbać o nasze bezpieczeństwo! () naszą godność zadbam na pewno".

Non possum adduci ut suspicer te pecunia captum. [...] Novi firmitatem tuam. Atque utinam ut culpam, sic etiam suspicionem vitare potuisses! (Cic., Phil. 1, 33)

„Nic nie jest w stanie sprawić, bym podejrzewal, że dałeś się przekupić. Znam twoją nieugiętość. Obyś byl mógl (= Szkoda, że nie mogłeś), jak uniknąłeś występku, tak samo uniknąć również podejrzenia (że go popełnileś; niestety takie podejrzenie na ciebie padło)".

Warto przy tej okazji zauważyć, że jeśli wyrażana przez czasownik w koniunktiwie epistemiczna lub deontyczna potencjalność ujęta zostanie $w$ ramy retorycznego pytania implikującego negatywną odpowiedź, to $w$ rezultacie desygnowanej przez ten czasownik treści przypisany zostanie status stanu niemożliwego (nierzeczywistego - irrealis), a więc status analogiczny jak w przypadku potencjalności zanegowanej:

Quis [...] quicquam politius aut elegantius aut omnino melius aut exspectaret aut posse fieri putaret? (Cic., Brut. 194)

„Któż czegoś subtelniejszego albo elegantszego lub w ogóle lepszego mógłby albo oczekiwać, albo sądzić, że może w ogóle istnieć?"

Uno proelio victus Alexander bello vistus esset; Romanum [...], quem Cannae non fregerunt, quae fregisset acies? (Liv., 9, 19)

„Pokonany w jednej bitwie Aleksander przegrałby (calą) wojn̨̧; Rzymianina. którego nie zlamaly Kanny, jakaż bitwa moglaby zlamać?"

\subsubsection{Status składniowy leksykalnych wykładników modalności}

Leksykalnymi wykładnikami (bądź współwykładnikami) modalności są zwykle partykuły, zaimki lub czasowniki. 


\subsection{Partykuły}

Partykuły przyjmują w zdaniu status operatorów tekstowych, np.:

Num negare audes? (Cic., Catil. 1, 8)

„Czy odważysz sie zaprzeczyć?"

Forsan et haec olim meminisse iuvabit. (Verg., Aen. 1, 203)

„Może kiedyś wspominanie także i tego będzie sprawialo radość”.

Falsus utinam vates sim. (Liv., 21, 10)

„Obym byl fałszywym prorokiem".

\subsection{Zaimki}

Zaimki stanowią przede wszytkim wykładniki intencjonalnej modalności interrogatywnej. Konstytuują one człony syntaktyczne zdania, zajmując określone pozycje otwierane przez jego strukturę składniową. Mogą więc pełnić w wypowiedzeniu np. funkcję:

a. Podmiotu:

Quid est in Antonio praeter libidinem, crudelitatem, petulantiam, audaciam? (Cic., Phil. 3,28 )

„Co (jeszcze) jest w Antoniuszu oprócz pożądania, okrucieństwa, bezczelności i zuchwalości?”

b. Przydawki:

Quam tu mihi nunc navem narras? (Pl., Men. 402)

„O jakim okręcie ty mi tu teraz opowiadasz?"

c. Orzecznika:

Qualis esset natura montis et qualis in circuitu ascensus qui cognoscerent misit. Renuntiatum est facilem esse. (Caes., Gall. 1, 21)

„Wysłał (ludzi), by zbadali, jaki jest charakter góry i jaki (jest do niej) dostęp z poszczególnych stron. W odpowiedzi doniesiono, ze jest latwy".

d. Dopełnienia:

Cui dono lepidum novum libellum? (Catull., 1, 1)

„Komu ofiaruję zabawną, nową książeczkę?”

e. Okolicznika:

Ubi sunt hi fundi, Brute? (Cic., De orat. 2, 224)

„Gdzie są te posiadlości ziemskie, Brutusie?" 


\subsection{Czasowniki}

Status składniowy czasownikowych wykładników modalności jest zróżnicowany.

A. Osobowe formy czasowników, będących wykładnikami modalności epistemicznej, mogą stanowić konstytutywny człon:

a. Zdania nadrzędnego składniowo względem (rówoważnika) zdania wyrażającego treść objętą modalnością:

Bonum putant esse aliqui id, quod utile est. (Sen., Lucil. 120, 2)

„Niektórzy sądzą, że dobrem jest to, co jest pożyteczne”.

Credebatur obsidione domitos hostes in fidem venisse. (Liv., 8, 26)

„Panowalo przekonanie, że nieprzyjaciele zmuszeni oblężeniem poddali się".

Fieri potest, ut errem. (Cic., Fin. 23)

„Być może się mylę".

b. Zdania parentetycznego:

Qua ex parte est Hibernia insula, dimidio minor, ut existimatur, quam Britannia. (Caes., Gall. 5, 13)

„Z tej strony znajduje się wyspa Hibernia (scil. Irlandia), o połowę mniejsza, jak się uważa, od Brytanii".

In Hispania Hercules, sicuti Afri putant, interiit. (Sall., lug. 18)

„W Hiszpanii, jak sqadzą mieszkańcy Afryki, umarl Herkules”.

c. Wyrażenia o charakterze operatora modalnego:

C. Sulpicius Olympus [...] mortuus est $C$. Sacerdote praetore, nescio an antequam Verres praeturam petere coeperit. (Cic., Verr. 2, 1, 125)

„Gajusz Sulpicjusz Olympus umarl za pretury Gajusza Sacerdosa, bodaj/chyba jeszcze zanim Werres zacząl starać się o preturę".

B. Osobowe formy czasowników w passivum, występujące w zdaniach znanych jako tzw. nominativus cum infinitivo, stanowią składnik złożonego orzeczenia, w którym funkcję orzecznika pełnią:

a. Bezokoliczniki (innych) czasowników:

Laudavisse mihi videris nostram rem publicam. (Cic., Rep. 2, 64)

„Wydaje mi się, że pochwaliteś naszą rzeczpospolitą".

Occidisse patrem Sex. Roscius arguitur. (Cic., S. Rosc. 37)

„Twierdzi się, że Sekstus Roscjusz zabił ojca”.

Decemviri libros adire iussi sunt. (Liv., 22, 57)

„Decemwirom nakazano, by zajrzeli do ksiąg (sybilińskich)”. 
b. Bezokoliczniki wraz $\mathrm{z}$ formami rzeczownikowymi lub przymiotnikowymi:

Malum mihi videtur esse mors. (Cic., Tusc. 1, 9)

„Wydaje mi się, że śmierć jest złem”.

O Palaemon, [...] qui Herculis socius esse diceris. (Pl., Rud. 160-161)

„O Palemonie, który ponoć (= jak mówią) jesteś druhem Herkulesa”.

c. Formy rzeczownikowe lub przymiotnikowe:

Tibi nos peregrini videmur. (Cic., Sull. 24)

"Tobie my wydajemy się cudzoziemcami".

Athenienses maxime in eam rem idonei visi sunt. (Liv., 35, 32)

"Ateńczycy wydali się najbardziej odpowiedni do tej rzeczy".

C. Pasywne bezokoliczniki czasowników występujących w zdaniach znanych jako tzw. nominativus cum infinitivo stanowić mogą:

a. Składnik orzeczenia złożonego, współtworzonego wspólnie z formami osobowymi czasowników fazowych, habitualnych bądź modalnych oraz z formami rzeczownikowymi, przymiotnikowymi bądź bezokolicznikowymi (innych czasowników) jako komponentami orzecznikowymi:

Tirynthius [...] maior [...] videri coepit. (Ov., Met. 9, 268-270)

„Tyryntyjczyk (scil. Herkules) zacząl wydawać się większy”.

Crudele gladiatorum spectaculum et inhumanum non nullis videri solet. (Cic., Tusc. 2, 41)

„Niektórym widowisko gladiatorskie zwykle wydaje się okrutne i nieludzkie".

Vita $[\ldots]$ virtutibus $[\ldots]$ respondens recta et honesta et constans et naturae congruens existimari potest. (Cic., Fin. 5, 66)

„Życie odpowiadające cnotom może uchodzić i za właściwe, i za szlachetne, i za oparte na trwatych zasadach, i za zgodne z naturą".

Cuius scientiam de omnibus constat fuisse, eius ignoratio de aliquo purgatio debet videri. (Cic., Sull. 39)

„O kim wiadomo, że znał wszystkich (uczestników spisku), to jego nieznajomość jakiejś osoby powinna uchodzić za (jej) oczyszczenie (z zarzutu o udzial w spisku)".

Adeo $[\ldots]$ neminem noxiae paenitebat, ut etiam insontes fecisse videri vellent. (Liv., 2, 54) „Do tego stopnia nikt nie żałował występku, że nawet niewinni chcieli uchodzić za jego sprawców".

Non potes ipse videri incendisse tuam, Tongiliane, domum? (Mart., Epigr. 3, 52, 3-4)

„Czyż nie możesz wywoływać wrażenia, że sam podpaliłeś swój dom, Tongilianie?”

Sed fuit hoc in utroque eorum, ut Crassus $[\ldots]$ existimari vellet $[\ldots]$ nostrorum hominum in omni genere prudentiam Graecis anteferre. (Cic., De orat. 2, 4)

„Lecz obaj się tym cechowali, tak iż Krassus chciał by sądzono, że mądrość naszych ludzi w każdej dziedzinie przedkłada nad Greków". 
b. Składnik orzeczenia złożonego sygnalizującego diatezę niepodmiotową i otwierającego miejsce dla równoważnika zdania podrzędnego wyrażającego treść objętą modalnością:

Nullum [...] verbum est ambiguum [...] nec aliud dici videri debet, quam quod se dicere sentit is, qui dicit. (Gell., Noc. Att. 11, 12, 2)

„Żadne słowo nie jest dwuznaczne i nie powinno wydawać się, że powiędziane zostało coś innego niż to, co sądzi, że mówi ten, który mówi".

In castris Pompei videre licuit $[\ldots]$ multa $[\ldots]$, quae nimiam luxuriem et victoriae fiduciam designarent, ut facile existimari posset nihil eos de eventu eius diei timuisse. (Caes., Civ. 3, 96)

„W obozie Pompejusz można było zobaczyć wiele rzczy, które wskazywały na nadzwyczajny przepych i wiarę w zwycięstwo, tak iż latwo można było sądzić, że nie trwożyli șię oni o wynik (bitwy) w tym dniu".

Qua parte belli vicerant, ea tum quoque rem gesturos (esse) Romanos credi poterat. (Liv., 21, 22)

„Można było żywić wiarę, że Rzymianię również wtedy przeprowadzą rzecz przy użyciu tej strategii wojskowej, z pomocą której wcześniej zwyciężyli".

c. Składnik funkcjonalnego odpowiednika orzeczenia, współtworzonego w ramach równoważnika zdania podrzędnego wraz z formami rzeczownikowymi, przymiotnikowymi bądź bezokolicznikowymi (innych czasowników) jako komponentami orzecznikowymi:

Cur mortem malum tibi videri dicis? (Cic., Tusc. 1, 25)

„Dlaczego twierdzisz, że śmierć wydaje się tobie złem?"

Atticum se [...] Calvus noster dici oratorem volebat. (Cic., Brut. 284)

„Nasz Kalwus chcial uchodzić za attyckiego mówcę".

Ego me cupio non mendacem putari. (Cic., Leg. 1, 4)

"Nie chcę być uważanym za kłamcẹ".

Si tibi nos peregrini videmur, $[\ldots]$ quam tibi illos competitores tuos peregrinos videri necesse erit, qui [...] tecum de honore ac de mno dignitate contendent! (Cic., Sull. 24)

"Jeżcli my wydajemy ci się cudzoziemcami, to jak bardzo będą musieli wydawać ci się cudzoziemcami owi twoi rywale, którzy współzawodniczyć z tobą będą o urzędy i wszelkie godności!"

Ratio id iudicare vult, quod aequum est, ira id aequum videri vult, quod iudicavit. (Sen., Dial. 3, 18, 1)

„Rozum chce zawyrokować to, co jest sprawiedliwe, gniew' chce, by za sprawiedliwe uchodzilo to, co zawyrokowal".

Pronuntiat Sthenium litteras publicas corrupisse videri. (Cic., Verr. 2, 2, 93)

"Oznajmia, że Stenius prawdopodobnie sfałszował publiczne dokumenty".

Matrem Phalaridis scribit Ponticus Heraclides [...] visam esse videre in somnis simulacra deorum, quae ipsa domi consecravisset. (Cic., Div. 1, 46) 
„Heraklides z Pontu pisze, że matka Falarysa ponoć widziała we śnie posągi bogów, które sama poświęcila w (swym) domu".

Occidendi sui consilium inisse me videri vult. (Liv., 40, 12)

"Chce, by wydawalo się, że ja powziałtem zamiar zamordowania go".

D. Czasowniki $\mathrm{w}$ formie participium futuri passivi i participium futuri activi stanowić mogą:

a. Orzecznikowy składnik orzeczenia złożonego, najczęściej przy osobowej formie czasownika esse (czyli w ramach tzw. coniugatio periphrastica passiva oraz coniugatio periphrastica passiva):

Quoniam $[. .$.$] bellum gerendum est, imperator est deligendus. (Cic., Phil. 11, 16)$

„Ponieważ trzeba prowadzić wojnę, należy wybrać wodza”.

Parendum [...] religioni fuit. (Cic., Div. 2, 71)

"Należało okazać posluszeństwo nakazom religii".

Meretricem hanc primum adeundam censeo. (Ter., Hec. 716)

"Uważam, że najpierw należy (powinniśmy) podejść do tej hetery”.

Omnia, quae ventura sunt in incerto iacent. (Sen., Dial. 10, 9, 2)

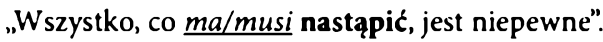

Nihil [...] de eorum sententia dicturus sum qui turpissimam servitutem deditionis nomine appellant. (Caes., Gall. 7, 77)

„Nie zamierzam niczego mówić na temat opinii tych, którzy najbardziej podłą niewolę nazywają poddaniem się".

b. Przydawkę, pod względem semantycznym często o charakterze predykatywnym:

Cassius [...] Minucium libertis tradidit excruciandum. (Ps.-Caes., Bell. Alex. 55)

„Kasjusz wydał Minucjusza wyzwoleńcom na tortury (tj. wydal jako tego, który mial być torturowany)".

Senones Galli multitudine ingenti ad Clusium venerunt legionem Romanam castraque oppugnaturi. (Liv., 10, 26)

„Senonowie galliccy w wielkiej liczbie podeszli pod Kluzjum, chcąc zaatakować rzymski legion i obóz".

Participium futuri passivi może również stanowić orzecznikowy człon funkcjonalnego odpowiednika orzeczenia $w$ równoważniku zdania podrzędnego (accusativus cum infinitivo):

Primores patrum $[\ldots]$ censuere $[\ldots]$ extemplo novos tribunos creandos esse. (Liv., 5, 9) „Najważniejsi z senatorów uznali, że natychmiast powinni zostać wybrani nowi trybuni".

sygnalizując diatezę niepodmiotową:

Laetandum esse ausus es scribere Trebonium dedisse poenas? (Cic., Phil. 13, 22)

„Mialeś czelność napisać, iż należy się cieszyć, że Treboniusz poniósł karę?" 
Z kolei participium futuri activi rzadko zajmuje pozycję funkcjonalnego odpowiednika orzeczenia $\mathrm{w}$ ramach równoważnika zdania podrzędnego typu ablativus absolutus:

Carthaginienses [...], quia metus et periculum cessandi non dabat tempus prima luce oppugnaturis hostibus castra, $[\ldots]$ augent vallum, munimento sese $[\ldots]$ defensuri. (Liv., $28,15)$

„Kartagińczycy, ponieważ strach i niebezpieczeństwo nie dawało (im) czasu na ociąganie się w stytuacji, gdy o świcie nieprzyjaciele mogli/gotowi byli zaatakować obóz, powiększają wał obronny zamierzając bronić się zza szańców".

Quia ex tam propinquis stativis parum tuta frumentatio erat, dispersos milites per agros equitibus extemplo invasuris, $[\ldots]$ castra ad Ottolobum $[\ldots]$ movit. (Liv., 31, 36)

„Ponieważ z uwagi na bliskość kwater (nieprzyjaciół) zaopatrywanie się w żywność nie było wystarczająco bezpieczne, jako że rozproszonych po polach żołnierzy mogla znienacka zaatakować konniça, przeniósl obóz po miejscowość Ottolobos".

E. Czasowniki modalne i wyrażenia modalne również mogą mieć różny status składniowy.

W formie osobowej mogą one współtworzyć orzeczenie wraz z bezokolicznikami lub bezokolicznikami i formami imiennymi (rzeczownikowymi lub przymiotnikowymi) jako orzecznikami, przy czym jeśli jednym ze składników tego orzeczenia jest pasywny bezokolicznik sygnalizujący diatezę epistemiczną, komponentem orzecznikowym może być również bezokolicznik innego czasownika. Czasowniki i wyrażenia modalne mogą wyrażać w ten sposób modalność:

a. Epistemiczną:

Si talis disiunctio falsa potest esse, nulla vera est. (Cic., Lucull. 97)

„Jeśli taka dysjunkcja może być fałszywa, to żadna nie jest prawdziwa (= Jeśli może być tak, że jest falszywa...)".

Erat (candelabrus) eo splendore, qui ex clarissimis et pulcherrimis gemmis esse debebat. (Cic., Verr. 4, 65)

„Swiecznik lśnił takim blaskiem, że musial być (= na pewno zostal) wykonany $\underline{z}$ najwspanialszych i najpiękniejszych klejnotów".

b. Deontyczną:

Corpore nihil nisi praesens et quod adest sentire possumus. (Cic., Fin. 1, 55)

„Za pośrednictwem ciala możemy odczuwać tylko to, co istnieje w danym momencie i co jest obecne".

Id quod scire potuit et debuit dixit. (Cic., Q. Rosc. 42)

"Powiedział to, co mógl i powinien byl wiedzieć".

Non queo plura scribere. (Cic., Att. 3, 12, 3)

„Nie zdolam (= nie mogę, nie jestem w stanie) napisać więcej”.

Nec continere suos ab direptione castrorum valuit. (Liv., 38, 23)

"I nie byl w stanie powstrzymać swoich ludzi od grabieży obozu". 
Cuius scientiam de omnibus constat fuisse, eius ignoratio de aliquo purgatio debet videri. (Cic., Sull. 39)

„O kim wiadomo, że znał wszystkich (uczestników spisku), to jego nieznajomość jakiejś osoby powinna uchodzić za (jej) oczyszczenie (z zarzulu o udzial w spisku)".

Quae servitus est, si haec libertas existimari potest? (Cic., Parad. 5, 40)

„Czym jest niewola, jeśli to może być postrzegane jako wolnośś?"

Cogitanti $[\ldots]$ Fabio, cui rei potissimum insisteret, ne otiosam provinciam habuisse videri posset, optimum visum est in Cretam insulam traicere. (Liv., 37, 60)

„Fabiuszowi, rozmyślającemu o tym, czym powinien się zająć, by nie mógl sprawiać wrażenia $\underline{\text { że }}$ objạ prowincję zupełnie spokojną, najlepszym rozwiązaniem wydała się przeprawa na Kretę".

c. Dynamiczną:

Charisi vult Hegesias esse similis. (Cic., Brut. 286)

„Hegesjasz chce być podobny do (scil. chce naśladować) Charysjusza”.

Cum omnia gymnasia philosophi teneant, tamen eorum auditores discum audire quam philosophum malunt. (Cic., De orat. 2, 21)

„Chociaż wszystkie gimnazja opanowali filozofowie, to jednak ich słuchacze wola słyszeć świst rzuconego dysku niż wywód filozofa".

Nolui tam vehementer agere hoc prima actione. (Cic., Verr. 2, 5, 163)

„Nie chcialem zbyt intensywnie zajmować się tą sprawą w pierwszej części procesu”.

Adeo [...] neminem noxiae paenitebat, ut etiam insontes fecisse videri vellent. (Liv., 2, 54)

„Do tego stopnia nikt nie żałował występku, ze nawet niewinni chcieli uchodzić za jego sprawców".

Sed fuit hoc in utroque eorum, ut Crassus $[\ldots]$ existimari vellet $[\ldots]$ nostrorum hominum in omni genere prudentiam Graecis anteferre. (Cic., De orat. 2, 4)

„Lecz obaj się tym cechowali, tak iż Krassus chcial, by sądzono ̌e mądrość naszych ludzi w każdej dziedzinie przedkłada nad Greków".

d. Intencjonalną (imperatywną):

Nolite existumare maiores nostros armis rem publicam ex parva magnam fecisse. (Sall., Cat. 52)

„Nie şadźcie, że nasi przodkowie przy pomocy oręża rzeczpospolitą z makej uczynili wielką".

Jako składniki orzeczeń złożonych osobowe formy czasowników i wyrażeń modalnych implikować mogą niepodmiotową diatezę struktury zdaniowej jako całości, nie otwierając w niej miejsca dla mianownikowego podmiotu. Treść predykatywna, wyrażana przez współtworzące $z$ nimi orzeczenia bezokoliczniki, nabiera wówczas charakteru przedmiotowego, a jej diateza uzależniona jest od wartości kategorii strony bezokolicznika i odpowiada diatezie, którą sygnalizują nacechowane tą wartością formy osobowe czasownika reprezentowanego przez dany bezokolicznik: 
Nunc licet mihi libere quidvis loqui. (Pl., Amph. 393)

„Teraz wolno mi swobodnie mówić, cokolwiek zechcę".

Mihi necesse est ire hinc. (Pl., Amph. 501)

"Muszę stąd odejść".

Defaenerare hominem egentem hau decet. (Pl., Vid. 89)

„Nie należy rujnować lichwą człowieka ubogiego".

Sententiis adicere licet oratorium robur, et omissa supplere, effusa substringere. (Quint., Inst. 10, 5, 4)

„Można dodać myślom oratorskiego wigoru, uzupelnić to, co pominięto, a to, co wyrażono zbyt rozwlekle, powściagnąc".

Utram igitur putas legem molliorem? Opinor, illam veterem, qua vel cito absolvi vel tarde condemnari licebat. (Cic., Verr. 2, 1, 26)

„Którą z tych dwóch ustaw uważasz za lagodniejszą? Sądzę, że tę dawniejszą, wedlug której można bylo albo szybko zostać uniewinnionym, albo późno skazanym".

Cui parci potuit? (Liv., 21, 14)

"Kogo można bylo oszczędzić?"

Neque tamen ulli civitati Germanorum persuaderi potuit, ut Rhenum transiret. (Caes., Gall. 5, 55)

„Jednak żadnego plemienia germańskiego nie można bylo przekonać, by przeszło przez Ren”.

Czasowniki modalne i wyrażenia modalne $w$ formie osobowej mogą też stanowić odrębne orzeczenie będące konstytutywnym członem zdania nadrzędnego w ramach zdania złożonego. Tym samym denotowany przez nie status modalny znajduje swój językowy wykładnik w postaci jednego, odrębnego zdania, natomiast sytuacja, której ów status jest przypisywany, wyrażana jest poprzez drugie, podrzędne wyrażenie zdaniowe lub równoważnik zdania podrzędnego (accusativus cum infinitivo). W przypadku, gdy czasowniki i wyrażenia modalne stanowiące odrębne orzeczenia wyrażają modalność epistemiczną lub deontyczną, to zwykle diateza konstytuowanych przez nie zdań jest diatezą niepodmiotową. Poniżej znajdują się przykłady zdań, w których predykatywnie użyte czasowniki modalne bądź wyrażenia modalne wyrażają:

a. Modalność epistemiczną $w$ stosunku do sytuacji denotowanej przez zdanie podrzędne:

Ergo si solida ac sine inani corpora prima sunt, [...] sint haec aeterna necessest. (Lucr., 538-539)

„A zatem jeśli pierwotne cialka są zwarte i pozbawione próżni, to (niedwolalnie) muszą one być wieczne".

b. Modalność epistemiczną w stosunku do sytuacji denotowanej przez równoważnik zdania podrzędnego (accusativus cum infinitivo): 
Ut demonstratae sunt mihi, hasce aedis esse oportet, Demaenetus ubi dicitur habitare. I, puere, pulta! (Pl., Asin. 381-382)

„Według tego, co mi pokazano, to musi / powinien być dom, w którym ponoć mieszka Demenetus. Idź, chlopcze, zapukaj!"

Necesse est paria esse peccata. (Cic., Fin. 4, 77)

„W sposób konieczny (= musi tak być, że) wszelkie wykroczenia moralne są sobie równe (co do ciężaru gatunkowego)".

c. Modalność deontyczną $w$ stosunku do sytuacji denotowanej przez zdanie podrzędne:

Ego crimen oportet diluam, vos [...] audaciae resistere [...] debetis. (Cic., S. Rosc. 36)

„Wypada, żebym ja odparł oskarżenie, a wy powinniście przeciwstawić się bezczelności”.

Diu qui domi otiosi dormierunt, decet animo aequo nunc stent. (Pl., Poen. 21-22)

„Wypada by ci, którzy próżnując spali długo w domu, teraz stali nie okazując wzburzenia”.

Hic opus est aliquot ut maneas dies. (Pl., Poen. 1421)

„Trzeba, abyś tu przez kilka dni pozostał".

d. Modalność deontyczną w stosunku do sytuacji denotowanej przez równoważnik zdania podrzędnego (accusativus cum infinitivo):

Heia, mea Iuno, non decet esse te tam tristem tuo Iovi. (Pl., Cas. 230)

"Ejże, ma Junono, nie godzi się / nie wypada, byś była tak zagniewana na swego Jowisza".

Opus est te animo valere, ut corpore possis. (Cic., Fam. 16, 14, 2)

„Trzeba, abyś był silny na duchu, byś mógł (być silny także) ciałem”.

Quid me oportet facere? (Pl., Capt. 955)

„Co powinienem robić?"

Z kolei użyte predykatywnie czasowniki wyrażające modalność dynamiczną sygnalizują diatezę nienacechowaną konstytuowanych przez siebie zdań, zaś objęte tą modalnością treści również mogą być wyrażane przez:

a. Zdania podrzędne:

Si vis, ut loquar, ipse tace! (Mart., Epigr. 5, 52,6)

„Jeśli chcesz, bym to ja mówił, sam zamilcz!”

Leno argentum hoc volo a me accipiat. (Pl., Pseud. 1122-1123)

"Chcę, żeby stręczyciel przyjął ode mnie te pieniądze".

Malo te sapiens hostis metuat quam stulti cives laudent. (Liv., 22, 39)

"Wolę, żeby się ciebie bał mądry nieprzyjaciel, niż żeby cię chwalili glupi obywatele".

Nolo vincat. (Cic., Q. Rosc. 9)

"Nie chce, by wygral". 
b. Równoważnik zdania podrzędnego (accusativus cum infinitivo):

In animis ego vestris omnis triumphos meos, omnia ornamenta honoris $[\ldots]$ condi et conlocari volo. (Cic., Catil. 3, 26)

„Chcę, żeby wszystkie moje tryumfy, wszystkie oznaki czci, w waszych sercach zostaly zlożone i przechowane".

Sunt $[\ldots]$ tyranni, sed se $[\ldots]$ malunt reges vocari. (Cic., Rep. 3, 23)

„Są tyranami, ale wolą, by nazywani byli królami”.

Id vos ignorare nolui. (Nep., Att. 21)

„Nie chcialem, byście byli nieświadomi tego".

Czasowniki modalne tworzyć też mogą orzeczenia zdań nadrzędnych wspólnie z pasywnymi bezokolicznikami wyrażającymi modalność epistemiczną. Orzeczenia te sygnalizują wtedy diatezę niepodmiotową a treść objęta wyrażaną przez nie złożoną modalnością desygnowana jest przez równoważnik zdania podrzędnego (accusativus cum infinitivo):

Nullum $[\ldots]$ verbum est ambiguum $[\ldots]$ nec aliud dici videri debet, quam quod se dicere sentit is, qui dicit. (Gell., Noc. Att. 11, 12, 2)

„Żadne słowo nie jest dwuznaczne i nie powinno wydawać się, że powiedziane zostało coś innego niż to, co sądzi, że mówi ten, który mówi".

In castris Pompei videre licuit $[\ldots]$ multa $[\ldots]$, quae nimiam luxuriem et victoriae fiduciam designarent, ut facile existimari posset nihil eos de eventu eius diei timuisse. (Caes., Civ. 3, 96)

„W obozie Pompejusza można było zobaczyć wiele rzczy, które wskazywały na nadzwyczajny przepych i wiarę w zwycięstwo, tak iż latwo można było sądzić, że nie trwożyli șį̧ oni o wynik (bitwy) w tym dniu".

Qua parte belli vicerant, ea tum quoque rem gesturos (esse) Romanos credi poterat. (Liv., 21, 22)

„Można było żywić wiarę, że Rzymianię również wtedy przeprowadzą rzecz przy użyciu tej strategii wojskowej, z pomocą której wcześniej zwyciężyli".

W formach bezokolicznikowych czasowniki modalne mogą:

a. Współtworzyć, wraz z formami innych czasowników (w tym także modalnych), orzeczenie:

Quod $[\ldots]$ expositum ad imitandum est, praesertim cum illi eam gloriam consecuti sint, quae vix caelo capi posse videatur. (Cic., Phil. 2, 114)

„Jest to godne naśladowania, zwłaszcza że zyskali oni taką slawę, która chyba tylko w niebie może być osiągnięta".

Minime decere videtur patres conscripti, $[. .$.$] errare eum, cui vos maximis saepe de rebus$ adsentiamini. (Cic., Phil.12, 1)

„Wydaje się, $\underline{\text { ze }}$ nie wypada, senatorowie, aby mylit się ten, z którym wy często zgadzacie się w sprawach najważniejszych". 
Debetis velle quae velimus. (Pl., Amph. 39)

"Powinniścię chcieć tego, czego my byśmy sobie życzyli".

b. Współtworzyć, wraz z formami bezokolicznikowymi innych czasowników (i ewentualnie formami imiennymi), funkcjonalny odpowiednik orzeczenia w ramach równoważnika zdania podrzędnego (accusativus cum infinitivo):

Quis [...] quicquam politius aut elegantius aut omnino melius aut exspectaret aut posse fieri putaret? (Cic., Brut. 194)

„Któż czegoś subtelniejszego albo elegantszego lub w ogóle lepszego móglby albo oczekiwać, albo sądzić, że może w ogóle istnieć?"

De Crassi oratione sic existimo, ipsum fortasse melius potuisse scribere, alium [...] neminem. (Cic., Brut. 298)

„Na temat wymowy Krassusa mam taki pogląd, iż on sam być może mógł (był w stanie) pisać lepiej, ale (poza nim) już nikt inny".

Me forti animo esse oportere censebas. (Cic., Brut. 330)

„Uznałeś, że trzeba, abym był silnego ducha”.

\subsubsection{Wybrana literatura}

Bolkestein (1980), Brown, Joseph, Wallace (2009), Calboli (1962b), Lenoble (2005), Magni (2005, 2010), Moussy (2001b), Stephens (1991), Wolanin (2011)

\subsection{SKŁADNIKI ZDANIA}

\subsubsection{Ogólna typologia składników zdania}

Podstawowymi składnikami zdania są człony syntaktyczne, tradycyjnie zwane też częściami zdania, takie jak: orzeczenie, podmiot, przydawka, dopełnienie, okolicznik. Stanowione są one głównie przez wyrazy gramatyczne reprezentujące leksemy autosyntagmatyczne, tj. czasowniki, rzeczowniki, przymiotniki, przysłówki. Relacje zachodzące między członami syntaktycznymi, mające charakter nadrzędno-podrzędny, zwane są związkami syntaktycznymi (składniowymi). Opierają się one na kongruencji (zgodzie, akomodacji), rekcji lub przynależności. $Z$ kolei relacje mające charakter współrzędny to związki (połączenia) szeregowe. Wykładnikami tych ostatnich mogą być stanowione przez spójniki konektory, które w przypadku zdań złożonych mogą być także wykładnikami stosunku współrzędności lub podrzędności zdań składowych względem siebie. Nadrzędną pozycję w zdaniu zajmuje relacja zachodząca między podmiotem a orzeczeniem, w związku z czym zdaniu przypisuje się zbudowę dwudzielną: podmiot i człony syntaktyczne zależne składniowo od nie- 
go tworzą tzw. grupę podmiotu, zaś orzeczenie i człony syntaktycznie od niego zależne składają się na grupę orzeczenia, zwaną też grupą predykatywną lub werbalną.

Człony syntaktyczne i konektory tworzą strukturę syntaktyczną zdania, a pod względem semantycznym konstytuują tzw. warstwę przedmiotową wypowiedzenia, czyli odnoszą się bezpośrednio do rzeczywistości pozajęzykowej przedstawionej w wypowiedzeniu. Oprócz tego, zdanie może także zawierać składniki znajdujące się poza strukturą syntaktyczną, które służą realizacji określonej strategii nadawczo-odbiorczej tworząc tzw. warstwę tekstową wypowiedzenia. Składnikami tymi mogą być adresatywy i wyrażenia adresatywne, których podstawą są rzeczownikowe formy wokatywne, a także operatory tekstowe, stanowione najczęściej przez różnego rodzaju partykuły. Wśród operatorów tekstowych można wyróżnić: operatory nawiązania miedzywypowiedzeniowego, operatory modalności, operatory presupozycji oraz operatory ekspresywno-impresywne.

Jak już wspomniano, konstytutywnym i tym samym obligatoryjnym składnikiem zdania jest orzeczenie. Obecność pozostałych składników determinowana jest semantyką orzeczenia, kontekstem wypowiedzenia, a także intencją autora co do zakresu informacyjnego wypowiedzi, jej kształtu retorycznego i funkcji komunikacyjnej. Szyk linearny (kolejność) poszczególnych składników zdania nie jest regulowany zasadami gramatyki i zależy od ogólnej struktury informacyjnej danego zdania i jego ulokowania w szerszym kontekście komunikacyjnym.

\subsubsection{Człony syntaktyczne (części zdania)}

Jak już wspomniano wyżej, człony syntaktyczne, tradycyjnie zwane częściami zdania, budują - wraz z konektorami - tzw. warstwę przedmiotową zdania, tzn. są podstawowymi wykładnikami tzw. świata przedstawionego. Niżej scharakteryzowane zostałe tradycyjnie wyodrębniane w składni łacińskiej części zdania, tj.: orzeczenie, podmiot, przydawka, dopełnienie, okolicznik.

\subsubsection{Orzeczenie}

Orzeczenie jest konstytutywnym składnikiem zdania, zajmującym pozycję członu podrzędnego (determinowanego, akomodowanego) w ramach składniowego związku kongruencji, łączącego je z gramatycznym podmiotem. Związek ten nosi nazwę związku predykacji (kongruencji predykatywnej), a jego wyróżnikiem jest to, że w jego ramach orzeczenie akomodowane jest do podmiotu pod względem gramatycznej kategorii osoby i liczby. Orzeczenie jest wykładnikiem podstawowej właściwości (cechy), która w zdaniu przypisywana jest desygnatowi podmiotu (orzekana jest o desygnacie podmiotu). Właściwość ta nazywana jest predykatem lub treścią predykatywną, dlatego orzeczenie określane też bywa terminem wyrażenie predykatywne (określnik predykatywny) lub wykładnik predykatu (wykładnik treści predykatywnej). Wyrażany 
predykat orzeczenie charakteryzuje gramatycznie pod względem czasu i modalności, determinując równocześnie diatezę zdania, czyli sposób składniowego uporządkowania wykładników implikowanych przez predykat argumentów. Tym samym orzeczenie otwiera miejsce dla uzupełnień, czyli dla związanych rekcją dopełnień nominalnych lub zdaniowych, a także dla uzupełnień (określników) fakultatywnych, czyli dla związanych związkiem przynależności okoliczników. Pod względem morfologicznym orzeczenie może mieć charakter prosty lub złożony.

\subsection{Orzeczenie proste}

Orzeczenie proste stanowione jest przez osobowę formę czasownika, będącą:

a. Syntetycznym wyrazem gramatycznym, np:

Milites $[\ldots]$ hostium phalangem perfregerunt. (Caes., Gall.1, 25, 2)

„Żołnierze przelamali nieprzyjacielską falangę".

Cur iustitia laudatur? (Cic., Fin. 2, 52)

„Dlaczego chwalona jest sprawiedliwość?"

b. Analitycznym wyrazem gramatycznym, np.:

Interfecus est etiam fortissime pugnans Crastinus. (Caes., Civ. 3, 99)

„Zostal zabity również bardzo dzielnie walczący Krastinus”.

Legati ad Fabium consulem missi sunt. (Liv., 9, 41)

"Posłowie zostali wyslani do Fabiusza konsula".

\subsection{Orzeczenie złożone}

Orzeczenie złożone składa się z dwu (lub więcej) wyrazów gramatycznych. Jednym z nich jest (syntetyczna lub analityczna) osobowa forma czasownika będąca wykładnikiem syntaktycznego związku predykacji, a więc forma sygnalizująca wartość kategorii liczby i osoby podmiotu; ten składnik orzeczenia złożonego zwany jest łącznikiem. Drugi (lub kolejny) składnik orzeczenia złożonego (drugi wyraz gramatyczny), zwany orzecznikiem, jest najczęściej - choć nie zawsze - wykładnikiem głównej treści predykatywnej. Stanowiony on może być przez formy wyrazowe reprezentujące leksemy należące do różnych klas (różnych części mowy). Jeśli są nimi formy przymiotnikowe lub rzeczownikowe, orzeczenie takie zwane jest orzeczeniem imiennym.

Orzecznik przymiotnikowy (lub realizowany przez przymiotnikowy zaimek) może wystąpić:

a. W nominatiwie, np.:

Pares virtutes sunt. (Cic., Parad. 22)

„Cnoty są sobie równe”. 
Non est tuus iste libellus (Mart. Epigr. 8.3.1.)

„Ta książeczka nie jest twoja”.

Multa sunt incommoda in vita. (Cic., Nat. 1, 23)

„Liczne są niedogodności w życiu”.

b. W akuzatiwie, np.:

(Themistocles) maritimos praedones consectando mare tutum reddidit. (Nep., Them. 2)

(Temistokles) scigając morskich korsarzy na powrót uczynil morze bezpiecznym".

Iste (scil. Verres) $[\ldots]$ parietes $[\ldots]$ nudos ac deformatos reliquit. (Cic., Verr. 4, 122)

„Ten zaś (scil. Werres) ściany pozostawil nagie i oszpecone".

Orzecznik rzeczownikowy (lub realizowany przez rzeczownikowy zaimek bądź substantywizowany przymiotnik) może wystąpić w:

a. W nominatiwie, np.:

Haec quidem vita mors est. (Cic., Tusc. 1, 75)

„Tego rodzaju życie jest śmiercią".

Q. Rubrius Varro a senatu hostis [...] iudicatus est. (Cic., Brut. 168)

„Kwintus Rubrius Warron został przez senat uznany za wroga”.

Tun is es, qui per voluptatem tuam in me aerumnam observisti gravem? (Pl., Epid. 556-557)

„Czy ty jesteś tym, który dla swej przyjemności sprowadził na mnie wielką udrękę??"

Mutabile semper femina (est). (Verg., Aen. 4, 569-570)

„Kobieta jest zawsze czymś zmiennym”.

b. W genetiwie, np.:

Temeritas [...] est florent is aetatis. (Cic., Sen. 20)

„Lekkomyślność jest (cechą) młodego wieku".

Res erat multae operae. (Caes., Gall. 5, 11)

„Rzecz wymagala wielkiego wysiłku".

Ars, quae circumfertut, eius est. (Quint., Inst. 2,15,4)

„Traktat o sztuce retorycznej, który jest w obiegu, jest jego".

c. W datiwie, np.:

Est igitur homini cum deo similitudo. (Cic., Leg. 1, 25)

„Jest zatem człowiekowi przynależne podobieństwo do boga".

M. Petronius [...] suis saluti fuit. (Caes., Gall. 7, 50)

„Marek Petroniusz był ratunkiem dla jego żołnierzy”. 
d. W akuzatiwie, np.:

Ego P. Clodium arbitrabar perniciosum civem. (Cic., Phil. 8, 16)

„Ja uważałem Publiusza Klodiusza za obywatela szkodliwego (dla państwa)”.

Tum illic autem Lemnius propinquam uxorem duxit. (Pl., Cist. 173-174)

"Wtedy zaś tenże Lemnijczyk pojąl za żonę krewną".

e. W ablatiwie, np.:

Gladiatores [...] animo meliore sunt quam pars patriciorum. (Cic., Catil. 2, 26)

"Gladiatorzy cechują się większą odwagą niż część patrycjuszy”.

Britanni $[\ldots]$ capillo $[\ldots]$ sunt promisso. (Caes., Gall. 5,14 )

"Brytowie mają długie wlosy".

Orzecznikiem $w$ ramach orzeczenia złożonego może być również nieosobowa forma czasownika, $\mathrm{tj}$.:

a. Infinitiwus, np.:

Atqui vivere, Lucili, militare est. (Sen., Lucil. 96, 5)

„A przecież życie, Lucyliuszu, jest (jakby ciągłym) odbywaniem służby wojskowej”.

Mors est non esse. (Sen., Lucil. 54, 4)

„Smierć jest niebytem".

Infinitiwus najczęściej stanowi (determinujący diatezę) orzecznik w ramach orzeczenia, w którym funkcję lącznika pełnią czasowniki implikujące bezokolicznikowe uzupełnienia, w tym czasowniki fazowe typu: incipio, pergo, habitualne typu soleo, modalne typu: licet, possum, debeo, volo, nolo lub inne formy czasownikowe sygnalizujące nacechowaną modalność, np. videor, dicor:

Nasica unus ex omnibus ausus est monere consulem. (Liv., 44, 36)

„Spośród wszystkich jeden Nazyka ośmielil się napomnieć konsula”.

Luxuria [... I iam tum incipiebat pullulare. (Nep., Cato 2)

„Zbytek już wtedy zaczynal się szerzyć (dosł.: puszczać pędy, pączkować)”.

Virtus, probitas, integritas in candidato $[. .$.$] requiri solet. (Cic., Planc. 62)$

„Od kandydata zwykle oczekiwana jest dzielność, uczciwość, rzetelność".

Nunc licet mihi libere quidvis loqui. (Pl., Amph. 393)

„Teraz wolno mi swobodnie mówić, cokolwiek zechcę".

Volui $[$... $]$ prodesse rei publicae. (Cic., Phil. 2, 76)

"Chcialem pomóc rzeczpospolitej".

Redire ad se videtur. (Cic., Phil. 8, 25)

„Chyba powraca do przytomności”. 
b. Participium, np.:

Tuis [...] audiens sum imperiis. (Pl., Truc. 125)

„Jestem posłuszny twoim rozkazom”.

Defensurus est me reum. (Sen., Benef. 2, 21, 3)

"Zamierza bronić mnie jako oskarżonego".

Voluntas ipsa rectum petens laudanda est. (Sen., Benef. 5, 2, 2)

"Sama chęć zmierzająca ku dobru powinna być chwalona”.

Rzadko pojawia się w tej funkcji także liczebnik, a sporadycznie również przysłówek, np.:

Sapienta et sapiens duo sunt. (Sen., Lucil. 117, 15)

„Mądrość i mędrzec są dwojgiem (stanowią dwa różne pojęcia)".

Equitum milia erant sex. (Caes., Gall. 1, 48)

"Jeźdźców bylo sześć tysięcy".

Commius $[\ldots]$ cum equitibus venerat, qui $[\ldots]$ erant quingenti. (Mirt., Gall. 8.10)

„Kommiusz przybył z jeźdźcami, których było pięćset”.

Haec commemoro, quae sunt palam. (Cic., Pis. 11)

„Wspominam te rzeczy, które sa powszechnie znane”.

Alia probabilia, contra alia dicimus. (Cic., Off. 2,7)

„Jedne rzeczy nazywamy prawdopodobnymi, inne nazywamy przeciwnie (tj. nieprawdopodobnymi)".

Superiorem esse contra improbos minus est negotii quam bonis exaequari. (Cic., p. red. ad Quir. 22)

„Być lepszym w' porównaniu z niegodziwcami przysparza mniej trudności niż dorównanie dobrym".

W przypadku wyrażania bardziej złożonych treści predykatywnych, w szczególności nacechowanych modalnie, orzecznikami mogą być dwa wyrazy gramatyczne stanowione przez dwie (różne) formy imienne: infinitiwus, rzeczownik, (substantywizowany) przymiotnik, participium, np.:

Socrates $[\ldots]$ parens philosophiae iure dici potest. (Cic., Fin. 1, 2)

"Sokrates stusznie może zostać nazwany ojcem filozofii”.

Nec vir bonus ac iustus haberi debet, qui, ne malum habeat, abstinet se ab iniuria. (Cic., Fin., 2, 71)

„I nie powinien być uważany za czlowieka uczciwego i sprawiedliwego ten, kto powtrzymuje się od wyrządzania krzywdy po to (tylko), aby samemu nié zaznać czegoś złego".

Tanagraea quaedam meretrix fuisse dicitur. (Cic., Dom. 111)

"Pewna Tanagrea podobno była kurtyzaną".

Mendicus beatus esse nemo potest. (Cic., Fin. 5, 84)

„Żaden nędzarz nie może być szczęśliwy”. 
Malum mihi videtur esse mors. (Cic., Tusc. 1,9)

„Wydaje mi się, że śmierć jest złem”.

Improbi $[\ldots]$ inopes $[\ldots]$ existimandi sunt. (Cic., Parad. 52)

„Niegodziwi powinni być uważani za biednych”.

Erat (candelabrus) eo splendore, qui ex clarissimis et pulcherrimis gemmis esse debebat. (Cic., Verr. 4, 65)

„(Świecznik) lśnił takim blaskiem, że musial być (wykonany) z najwspanialszych i najpiękniejszych klejnotów".

W skrajnych przypadkach na orzeczenie, oprócz formy osobowej czasownika, składać się mogą nawet trzy różne formy imienne:

Miltiades [...] non videbatur posse esse privatus. (Nep., Milt. 8)

„Miltiades chyba nie mógl być (czlowiekiem) prywatnym (tj. niepiastującym urzędów)".

Vos certe victores conspici velle debebatis. (Liv., 45, 38)

„Wy z pewnością powinniście byli chcieć być oglądani jako zwycięzcy”.

\subsubsection{Uzupełnienie orzecznikowe (komplement orzecznikowy)}

Uzupełnienie orzecznikowe to składnik innego niż orzeczenie (i funkcjonalny odpowiednik orzeczenia) członu syntaktycznego, współtworzonego wraz z nieosobową formą czasownika. Uzupełnienie to stanowione jest najczęściej przez rzeczownik lub przymiotnik i jest podstawowym wykładnikiem treści przedmiotowych wyrażanych przez dany człon syntaktyczny (najczęściej podmiotowy lub przydawkowy):

Habere $[. .$.$] quaestui rem publicam non modo turpe est, sed sceleratum etiam et nefa-$ rium. (Cic., Off. 2, 77)

,Traktowanie państwa jako obiektu zysku (= wyzyskiwanie państwa) jest czymś nie tylko odrażającym, ale także zbrodniczym i niegodziwym".

Nimia'st miseria nimis pulchrum esse hominem. (PI., Mil. 68)

„Wielki to (jest) kłopot być zbyt pięknym czlowiekiem”.

Contentum [...] suis rebus esse maximae sunt certissimaeque divitiae. (Cic., Parad. 51) „Być zadowolonym z tego,co się ma, jest największym i najpewniejszym bogactwem".

(Atticus) idoneum tempus ratus studiis obsequendi suis Athenas se contulit. (Nep., Att. 2) "(Attyk), uznawszy czas za dogodny do zajęcia się swoimi studiami, wyjechal do Aten”.

\subsubsection{Podmiot}

Podmiot to człon syntaktyczny cechujący się brakiem zależności składniowej od jakiegokolwiek innego składnika wypowiedzenia oraz nadrzędnością składniową 
w ramach związku głównego zdania, czyli w ramach składniowego związku predykacji, lączącego go $z$ orzeczeniem. Podmiot może być zatem zdefiniowany jako niepodrzędna składniowo część zdania, będąca członem nadrzędnym w ramach związku predykacji $z$ orzeczeniem. Z punktu widzenia semantycznego stanowi wykładnik obiektu (pojęcia), o którym orzekany jest predykat denotowany przez orzeczenie (wyrażenie predykatywne). Prymarnie pozycja podmiotu wypełniana jest przez formy rzeczownikowe ( $w$ tym rzeczownikowe lub substantywizowane zaimki oraz liczebnik milia) w nominatiwie, np.:

Milites [...] hostium phalangem perfregerunt. (Caes., Gall.1, 25, 2)

"Żołnierze przełamali nieprzyjacielską falangę".

Domus patris longe a foro aberat. (Cic., Cael. 18)

„Dom ojca znajdowal się daleko od forum".

Deficit enim non voluntas sed spes. (Cic., Att. 7, 21, 1)

„Brakuje bowiem nie woli, lecz nadziei”.

Trecenti $[$...] captivi ad portas nocte venerunt. (Sen., Controv. 5, 7, 1)

„Trzystu jeńców przybyło nocą do bram".

Tu me amas, ego te amo. (Pl., Most. 305)

"Ty mnie kochasz, ja kocham ciebie".

Id non quivis habere potest. (Cic., Tusc. 5,46 )

„Tego nie może posiadać ktokolwiek".

Milia octo armatorum ab equitibus interclusa positis armis in deditionem venerunt. (Liv. $5,32)$

„Osiem tysięcy zbrojnych, odcietych przez jazdę, złożywszy broń poddało się".

Sekundarnie pozycję podmiotu zajmować mogą także wyrazy gramatyczne reprezentujące inne klasy leksemów, a więc:

a. Substantywizowany przymiotnik w nominatiwie, np.:

Improbi $[\ldots]$ inopes $[\ldots]$ existimandi sunt. (Cic., Parad. 52)

„Niegodziwi powinni być uważani za biednych".

Deleantur innocentes, honesti, boni, tota res publica! (Cic., Phil. 8, 16)

„Niech zostaną unicestwieni niewinni, zacni, dobrzy, cała rzeczpospolita".

b. Substantywizowane participium w nominatiwie, np.:

Amantes non longe a caro corpore abesse volunt. (Catull., 66, 31-32)

„Kochankowie nie chcą być $z$ dala od ukochanej osoby”.

Etiam mortui miseri sunt. (Cic., Tusc. 1, 9)

„Nawet zmarli są nieszczęśliwi”. 
c. Infinitiwus, w tym także z uzupełnieniem orzecznikowym, np.:

Atqui vivere, Lucili, militare est. (Sen., Lucil. 96, 5)

„A przecież życie, Lucyliuszu, jest (jakby ciągłym) odbywaniem służby wojskowej”.

Ipsum Latine loqui est [...] in magna laude ponendum. (Cic., Brut. 140)

„Samo (poprawne) mówienie po lacinie należy uznać za wielce chwalebne”.

Superiorem esse contra improbos minus est negotii quam bonis exaequari. (Cic., p. red. ad Quir. 22)

„Być lepszym w porównaniu z niegodziwcami przysparza mniej trudności niż dorównanie dobrym".

Maximum est in amicitia parem esse inferiori. (Cic., Lael. 69)

„Najważniejszą rzeczą w przyjaźni jest traktowanie na równi kogoś zajmującego niższą pozycję (spoleczną)".

\subsubsection{Przydawka}

Przydawka to człon syntaktyczny, który jest podrzędny składniowo względem każdej części zdania stanowionej przez rzeczownik (lub jego funkcjonalny odpowiednik). Prymarnie przydawka jest zatem członem podrzędnym w względem podmiotu, uwzględniając jednak sekundarną dystrybucję składniową rzeczownika, może stanowić człon podrzędny w stosunku do rzeczownikowego dopełnienia, okolicznika, orzecznika, adresatywu, innej rzeczownikowej przydawki, a także funkcjonalnego odpowiednika podmiotu lub orzecznika. Pod względem semantycznym stanowi ona określnik (człon określający) w ramach grupy imiennej, będący wykładnikiem cechy (treści atrybutywnej) przypisywanej nadrzędnikowi.

Prymarnie funkcję przydawki realizują wyrazy gramatyczne reprezentujące przymiotniki oraz przymiotnikowe zaimki i liczebniki, które łączą się z rzeczownikowym członem nadrzędnym związkiem kongruencji atrybutywnej, czyli związkiem zgody pod względem kategorii liczby, rodzaju i przypadka, np.:

Domi militiaeque boni mores colebantur. (Sall., Cat. 9)

„W czasie pokoju i w czasie wojny pielęgnowane byly dobre obyczaje”.

Caesar $[\ldots]$ castris idoneum locum delegit. (Caes., Gall. 1, 49)

"Cezar wybral dogodne dla obozu miejsce".

Ego P. Clodium arbitrabar perniciosum civem. (Cic., Phil. 8, 16)

„Ja uważalem Publiusza Klodiusza za obywatela szkodliwego (dla państwa)”.

Quandoque enim fatalis et meus dies veniet. (Tac., Dial. 13)

„Kiedyś bowiem nadejdzie także i mój dzień przeznaczenia”.

Aliquis vir bonus nobis diligendus est ac semper ante oculos habendus. (Sen., Lucil. 11, 8)

„Powinniśmy wybrać sobie jakiegoś prawego czlowieka i zawsze mieć go przed oczami”. 
Cartaginem Novam interim oppugnare statuit $[\ldots]$, sitam [...] super portum satis amplum quantaevis $\underline{\text { classi. }}$. (Liv., 26, 42)

„Postanowił tymczasem oblegać Nową Kartaginę, położoną nad portem wystarczająco obszernym dla dowolnie wielkiej floty".

In hora saepe ducentos $[\ldots]$ versus dictabat stans pede in uno. (Hor., Serm. 1,4,9-10)

(iron.) „Często w' ciągu godziny dyktował dwieście wierszy stojąc na jednej nodze”.

In [...] triumpho undequinquaginta coronae aureae translatae sunt. (Liv., 37, 58)

„W pochodzie tryumfalnym niesiono czterdzieści dziewięc złotych wieńców”.

Sekundarnie funkcję przydawki pełnić mogą wyrazy gramatyczne reprezentujące leksemy innych klas. Najczęściej są to formy reprezentujące rzeczowniki oraz rzeczownikowe (lub substantywizowane) zaimki występujące:

a. W genetiwie, np.:

Domus patris longe a foro aberat. (Cic., Cael. 18)

"Dom ojca znajdowal się daleko od forum".

Sarmenta in cornibus iuvencorum deligata incendit. (Nep., Hann. 5, 2)

"Zapala gałązki przywiązane do rogów bydląt".

Navium figura [...] permoti barbari constiterunt. (Caes., Gall., 4, 25)

"Zaskoczeni ksztaltem okrętów harbarzyńcy przystanęli".

Nostri melior pars animus est. (Sen., Nat. 14)

„Lepszą częścią nas jest dusza”.

b. W datiwie, np.:

Receptui signum $[. .$.$] audire non possumus. (Cic., Phil. 13, 15)$

"Sygnału do odwrotu nie możemy usłyszeć".

Iustitia est obtemperatio scriptis legibus institutisque populorum. (Cic., Leg. 1, 42)

"Sprawiedliwość to podporzadkowanie się spisanym ustawom i postanowieniom (poszczególnych) ludów".

Dies colloquio dictus est ex eo die quintus. (Caes., Gall. 1, 42)

"Jako dzień dla obycia rozmowy wyznaczony został dzień piąty (licząc) od tego".

c. W akuzatiwie, np.:

Neque ante consulis Romam adventum nec postquam is rediit. (Liv., 22, 61)

"Ani przed przybyciem konsula do Rzymu, ani po tym, gdy przybyl".

Nocturnus introitus Zmyrnam. (Cic., Phil. 11, 5)

"Nocne wkroczenie do Smyrny".

Domum reditionis spe sublata. (Caes., Gall. 1, 5)

„Odjąwszy sobie nadzieję na powrót do domu”. 
d. W ablatiwie, np.:

Erat inter Labienum atque hostem difficili transitu flumen ripisque praeruptis. (Caes., Gall. 6, 7)

„Między Labienusem a nieprzyjacielem znajdowala się rzeką o trudnej przeprawie (= trudna do przeprawy) i urwistych brzegach".

Tantam spem attulerat exploratae victoriae tua praeclara Mutina eruptio. (Cic., Fam. 11, $14,1)$

„Tak wielką nadzieję na pewne zwycięstwo przyniósl twój slawny wypad z Mutiny".

Palaestra et tot locis sessiones gymnasiorum et Graecorum disputationum memoriam quodam modo commovent. (Cic., De orat. 2, 20)

„Palestra i ławki $w$ tylu miejscach $w$ pewien sposób przywodzą na pamięc gimnazja i toczone w nich przez Greków dysputy".

e. W ablatiwie z przyimkiem, np.:

Auctore Icilio Numitorioque secessio ab decemviris facta est. (Liv., 3, 51)

„Za sprawą Icyliusza i Numitoriusza nastąpiło odejście (żołnierzy) od decemwirów (= bunt przeciw decemwirom)".

Vidistis simulacrum Cereris e marmore. (Cic., Verr. 2, 4, 109)

"Zobaczyliście posag Cerery z marmuru”.

Mittitur ad eos [...] Q. Iunius ex Hispania quidam. (Caes., Gall. 5, 27)

„Wysylany jest do nich niejaki Kwintus Luniusz (pochodzący) z Hiszpanii”.

Przydawki te najczęściej łączą się ze swoim członem nadrzędnym związkiem przynależności, chociaż w przypadku pewnych nadrzędników, zwłaszcza odczasownikowych, można zapewne mówić również o rekcji (np. obtemperatio legibus).

Poza tym pozycja przydawki wypełniana może być także przez:

a. Partcipium, np.:

Ut oculus, sic animus se non videns alia cernit. (Cic., Tusc. 1, 67)

"Jak oko, tak i dusza nie widząc siebie, dostrzega jednak inne rzeczy".

( Belgae) paulisper apud oppidum morati agrosque Remorum depopulati $[\ldots]$ ad castra Ceasaris omnibus copiis contenderunt. (Caes., Gall. 2, 7)

„(Belgowie) zatrzymawszy się na krótko pod miastem i spustoszywszy ziemie Remów, podążyli wszystkimi swoimi oddzialami ku obozowi Cezara".

Senones [...] ad Clusium venerunt legionem Romanam castraque oppugnaturi. (Liv., $10,26)$

"Senonowie przybyli pod Kluzjum, mając zamiar oblegać rzymski legion i obóz".

Ego illum excruciandum [...] carnufici dabo. (Pl., Poen. 1302)

„Przekażę go katu na tortury". 
b. Gerundium, np.:

Neque ulla nostris facultas aut administrandi aut auxiliandi dabatur. (Caes., Gall. 4, 29)

„Nasi nie mieli żadnej możliwości ani kierowania, ani pomagania”.

(Voluptatum) potiendi spe inflammati multos labores magnosque susceperant. (Cic., Fin. $1,60)$

„Rozpaleni nadzieją zyskania rozkoszy podjęli wiele trudnych wysiłków”.

c. Przysłówek, np.:

Non tu nunc hominum mores vides? (Pl., Pers. 385)

"Nie dostrzegasz obyczajów dzisiejszych ludzi??"

L. Paulum, bis consulem domitorem Graeciae, omnium oculi conspicere [...] avent. (Liv., $45,39)$

„Oczy wszystkich pragną zobaczyć Lucjusza Paulusa, dwukrotnie konsula, pogromcę Grecji”.

Quid mihi $[\ldots]$ erat $[\ldots]$ hinc abitio quidve in navem inscensio? ( $\mathrm{Pl} .$, Rud. 502-503)

„Na cóż mi był wyjazd stąd, na cóż wejście na okręt?"

\subsection{Przydawka apozycyjna}

Przydawka apozycyjna stanowiona jest przez rzeczownik pozostający ze swoim rzeczownikowym członem nadrzędnym w związku zgody, przede wszystkim pod względem kategorii przypadka. Sytuowana jest zwykle po określanym rzeczowniku (tzn. w postpozycji do niego). Funkcję tę mogą pełnić rzeczowniki występujące w każdym przypadku. Przydawka apozycyjna i określany rzeczownik charakteryzują się tym, że są referencyjnie tożsame (mają tego samego referenta lub wspólnie go wyznaczają):

Gallos ab Aquitanis Garunna flumen [...] dividit. (Caes., Gall. 1, 1)

"Gallów oddziela od Akwitanów rzeka Garunna".

Phocion [...] causam apud Philippum regem [...] iussus est dicere. (Nep., Phoc. 3)

"Fokionowi nakazano bronić się przed królem Filipem”.

L. Cotta legatus $[\ldots]$ adversus os funda vulneratur. (Caes., Gall. 5, 35)

„Legat Lucjusz Kotta zostal raniony z procy prosto w twarz".

Bardzo często apozycyjna przydawka nie występuje samodzielnie, lecz stanowi ośrodek (człon konstytutywny) przydawkowej grupy imiennej, oddzielonej intonacyjnie (interpunkcyjnie) od rzeczownikowego nadrzędnika pauzą (przecinkami). Grupa taka zwykle nie ma charakteru restryktywnego (identyfikującego desygnat nadrzędnego rzeczownika) i czasem zwana jest przydawką orzekającą lub dopełnieniem określającym: 
Quid ego de M. Marcello loquar, qui Syracusas, urbem ornațissimạm, cepit? (Cic., Verr. 2, $1,55)$

„Cóż mam powiedzieć o Marku Marcellu, który zdobył Syrakuzy, prọeśwịietnẹ miasto".

Hos viros bonos $[\ldots]$ putemus, quia sequantur naturam optimam bene vivendi ducem. (Cic., Lael. 19)

„Ich uważajmy za ludzi prawych, ponieważ idą za głosem natury naj!̣p̣ṣẹi przewodniczki dọbrẹọ żyç̣ạ".

Externus timor maximum concordiae vinculum, [...] inter se iungebat animos. (Liv., $2,39)$

„Strach przed niebezpieczeństwem z zewnątrz, najlẹpszẹ spoiwo zgody. jednoczył wzajemnie ich serca".

Przydawka apozycyjna, będąca określnikiem nazwy własnej użytej w formie lokatywnej, występuje $w$ ablatiwie (z przyimkiem in lub bez przyimka):

Archias $[\ldots]$ primum Antiochiae $[\ldots]$ celebri quondam urbe, $[\ldots]$ antecellere omnibus ingenii gloria coepit. (Cic., Arch. 4)

„Archiasz najpierw $\underline{w}$ Antiochii, slawnym niegdyś mieście, zacząl wszystkich przewyższać slawą (swego) talentu".

Albae constiterunt, in urbe opportuna, munita, propinqua. (Cic., Phil. 4, 6)

„Zatrzymali się $\underline{\mathbf{w}}$ Albie, mieście dogodnym, obwarowanym, blisko położonym”.

Przydawka apozycyjna lub przydawkowa grupa imienna może stanowić określnik kilku członów rzeczownikowych zestawionych szeregowo; przydawka (lub konstytutywny człon przydawkowej grupy imiennej) występuje wówczas w liczbie mnogiej:

Legati ab Ptolemaeo et Cleopatra regibus vocati sunt. (Liv., 44, 19)

„Przywolani zostali postowie od królów Ptolemeusza i Kleopatry”.

Nec $\underline{P}$ Popilius neque $Q$. Metellus clarisssimi viri atque amplisssimi, vim tribuniciam sustinere potuerunt. (Cic., Cluent. 95)

„Ani Publiusz Popiliusz, ani Kwintus Metellus, znạạomị̣ị i dọstọjṇ̣ mężowie, nie mogli oprzeć się władzy trybuńskiej".

Również przydawki apozycyjne oraz konstytuowane przez nie przydawkowe grupy imienne mogą występować w połączeniu szeregowym charakteryzując $z$ kolei jeden wspólny rzeczownikowy człon nadrzędny:

Mardonius, satrapes regius natione Medus, regis gener, [...] haud ita magna manu Graeciae fugatus est. (Nep., Paus. 1)

„Mardoniusz, satrapa krộlewwsḳi, z.pocḥọdzẹṇiạ Med, zięć krọ̣la, został rozgromiony przez nie tak wielki oddzial wojsk greckich". 


\subsection{Przydawka orzecznikowa (praedicativum)}

Przydawka orzecznikowa, określana często terminem praedicativum, to przydawka charakteryzująca się pewnymi szczególnymi cechami semantycznymi. Stanowiona jest ona przez pozostający $w$ składni zgody $z$ określanym rzeczownikiem przymiotnik, imiesłów lub rzeczownik, a jej specyfika znaczeniowa polega na tym, iż $\mathrm{z}$ jednej strony charakteryzuje desygnat nadrzędnego rzeczownika, $z$ drugiej zaś wyrażany przez czasownikowe orzeczenie predykat, a to $z$ uwagi na szczególną aktualność oznaczanej cechy w odniesieniu do treści predykatywnej. Chociaż więc formalnie przydawka ta ma status adnominalny, to semantycznie ma charakter adwerbalny (orzecznikowy bądź okolicznikowy):

Primi Alexandrini legati $[\ldots]$ vocati sunt. (Liv., 44, 19)

„Jako pierwsi przywolani zostali posłowie aleksandryjscy”.

Senatus frequens $[\ldots]$ in curiam venit. (Cic., De orat. 3,2 )

"Senat w (niemal) pelnym składzie zebrał się w kurii".

Sera tamen tacitis Poena venit pedibus. (Tib., 1, 9, 4)

„Chociaż póżno, Kara jednak przychodzi, cicho stąpając".

Ea Sex. Roscium inopem, eiectum domo atque expulsum ex suis bonis, fugientem latronum tela et minas recepit domum. (Cic., S. Rosc. 27)

„Ona przyjęła do swego domu Sekstusa Roscjusza dotkniętego biedą, wypędzonego z domu i własnych dóbr, uciekającego przed bronią i groźbami zbójców".

Senones Galli multitudine ingenti ad Clusium venerunt legionem Romanam castraque oppugnaturi. (Liv., 10, 26)

„Senonowie galliccy w wielkiej liczbie podeszli pod Kluzjum, chcąc zaatakować rzymski legion i obóz".

Cassius [...] Minucium libertis tradidit excruciandum. (Ps.-Caes., Bell. Alex. 55)

"Kasjusz wydal Minucjusza wyzwoleńcom na tortury".

Ti. Sempronius ex ea pecunia, quae ipsi attributa erat, [...] basilicam [...] faciendam curavit, quae postea Sempronia appellata est. (Liv., 44, 16)

„Tyberiusz Semproniusz z tych pieniędzy, które zostały mu przydzielone, zatroszczył się o zbudowanie bazyliki, która później nazwana została bazyliką Semproniusza".

Defendi rem publicam adulescens, non deseram senex. (Cic., Phil. 2, 118)

„Broniłem rzeczpospolitej jako mlodzieniec, nie opuszczę (jej) jako starzec”.

Claudius $[. .$.$] cum magno gaudio et gratulatione victor in castra redit. (Liv., 23, 47)$

„Klaudiusz wśród wielkiej radości i gratulacji powraca do obozu jako zwycięzca”.

Vel imperatore vel milite me utimini. (Sall., Cat. 20)

„Posłużcie się mną albo jako naczelnym wodzem, albo jako (zwykłym) żolnierzem”. 
W sytuacji, gdy przydawka ta ma znaczenie przyczynowe lub limitacyjne (ograniczające), może jej towarzyszyć ut; w przypadku znaczenia porównawczego ut lub tamquam:

Possum falli ut homo. (Cic., Att. 13, 21a, 2)

"Mogę się mylić jako czlowiek (= jako że jestem czlowiekiem)".

Quos tum, ut pueri, refutare [...] solebamus. (Cic., De orat. 2, 2)

"(Argumenty) tych ludzi wtedy, będąc dziećmi, odpieraliśmy".

Canem et felem ut deos colunt. (Cic., Leg. 1, 32)

„Psa i kota czczą jak bogów (= tak, jakby byli bogami)”.

Sic, $[\ldots]$ conmilitones, prandete tamquam apud inferos cenaturi. (Sen., Lucil. 82, 21)

„Tak, towarzysze, jedzcie śniadanie, jakbyście obiad mieli spożyć wśród bogów podziemnych".

\subsubsection{Dopełnienie}

Dopełnienie to część zdania podrzędna składniowo względem członu syntaktycznego stanowionego przez czasownik, przymiotnik lub przysłówek, desygnująca obiekt implikowany (wymagany) przez semantykę (znaczenie, treść) swojego nadrzędnika. Prymarnie dopełnienie jest więc członem podrzędnym względem czasownikowego orzeczenia, przymiotnikowej przydawki lub przysłówkowego okolicznika. Uwzględniając jednak sekundarną dystrybucję składniową czasowników, przymiotników i przysłówków, dopełnienie może stanowić człon podrzędny względem innych członów syntaktycznych, np. bezokolicznikowego podmiotu, wyrażonej przez gerundium lub participium przydawki, wyrażonego przez supinum okolicznika, funkcjonalnego odpowiednika orzeczenia $w$ ramach składni accusativus cum infinitivo lub ablativus absolutus, wyrażonego przez substantywizowany przymiotnik podmiotu lub dopełnienia, itd. Funkcję dopełnienia pełnią rzeczowniki lub ich funkcjonalne odpowiedniki, a więc wyrażenia imienne stanowione przez rzeczowne lub substantywizowane zaimki, a także substantywizowane przymiotniki i imiesłowy, rzadziej bezokoliczniki.

Implikowaniu przez semantykę czasownika, przymiotnika lub przysłówka określonego obiektu towarzyszy znaczny poziom zdeterminowania formalnej postaci desygnującego ten obiekt wyrażenia (czyli dopełnienia). Dotyczy to w szczególności wartości kategorii przypadka stanowiącego to wyrażenie rzeczownika (lub jego funkcjonalnego odpowiednika) oraz ewentualnego wpółwystępowania swobodnego morfemu przyimkowego. Dlatego też związek lączący dopełnienie z jego skkadniowym nadrzędnikiem ma charakter związku rekcji. Jednak zarówno implikacja semantyczna po stronie składniowego nadrzędnika, jak i determinacja formalna po stronie członu zależnego, a także współwystępowanie obu tych zjawisk, bywają niekiedy problematyczne, wskutek czego granica między dopełnieniem a okolicznikiem 
(jako członem syntaktycznym nieimplikowanym i niezdeterminowanym formalnie przez swój składniowy nadrzędnik) bywa nieostra.

Wśród dopełnień konotowanych przez pewną klasę czasowników (tj. przez tzw. czasowniki przechodnie) wyodrębnia się dopełnienie bliższe, które - w odróżnieniu od dopełnienia dalszego - charakteryzuje się tym, że w przypadku zmiany diatezy zdaniowej na bierną jego desygnat może zostać ujawniony przez mianownikowy podmiot.

Dopełnienie bliższe, konotowane przez czasowniki przechodnie, stanowione jest przez rzeczowniki lub ich funkcjonalne odpowiedniki (zaimkowe, przymiotnikowe, imiesłowowe, bezokolicznikowe, liczebnik milia) w akuzatiwie, np.:

Mecum posuisti moenia Troiae. (Ov., Met. 12, 587)

„Wraz ze mną zbudowaleś mury Troi".

Ego illum exercitum [...] magno opere contemno. (Cic., Catil. 2, 5)

„Ja z całej duszy gardze tym wojskiem".

Populus Romanus [...] non amat profusas epulas. (Cic., Mur. 76)

"Lud rzymski nie lubi zbytkownych uczt".

Eius modi coniunctionem tectorum oppidum vel urbem appellaverunt. (Cic., Rep. 1, 47)

„Tego rodzaju skupisko domów nazwali grodem lub miastem”.

Eam unam perdidi. (Pl., Rud. 106)

„Ją jedną stracilem”.

Bructeros sua urentis $[\ldots]$ L. Stertinius $[\ldots]$ fudit. (Tac., Ann. 1, 60)

"Brukterów palących swoje włości rozgromil Lucjusz Stertyniusz".

Humanius est deridere vitam quam deplorare. (Sen., Dial. 9, 15)

„Bardziej po ludzku jest pośmiać się z życia, niż lamentować nad nim”.

Efferor studio patres vestros $[\ldots]$ videndi. (Cic., Sen. 83)

"Jestem przejęty pragnieniem zobaczennia waszych ojców".

Haedui [...] legatos ad Caesarem mittunt rogatum auxilium. (Caes., Gall. 1, 11)

„Eduowie wysyłają do Cezara posłów, aby prosić o pomoc”.

M. Antonius [...] in eo libro quem unum reliquit, disertos ait se vidisse multos, eloquentem omnino neminem. (Cic., Orat. 18)

„Marek Antoniusz w jedynej księdze, jaką pozostawil, mówi, że widzial wielu wygadanych, ale wymownego zgola nikogo".

Praeterita mutare non possumus. (Cic., Pis. 59)

„Minionych rzeczy nie możemy zmienniç".

Beate $[\ldots]$ vivere $[\ldots]$ vos in voluptate ponitis. (Cic., Fin. 2,86 )

"Szczęśliwe życie wy pokladacic w rozkoszy".

Milia frumenti $[\ldots]$ triverit $[\ldots]$ centrum. (Hor., Serm. 1,1,45)

"Wymbóci sto tysięcy (korców) zboża". 
Dopełnienie dalsze, konotowane przez czasowniki tak przechodnie jak i nieprzechodnie, stanowione może być przez rzeczowniki lub ich funkcjonalne odpowiedniki:

a. W genetiwie, np.:

Flagitiorum suorum recordabitur. (Cic., Pis. 13)

„Będzie sobie przypominal swe niegodziwe czyny".

(Fannius) C. Verrem insimulat avaritiae et audaciae. (Cic., Verr. 2, 1, 128)

„Fanniusz zarzuca Gajuszowi Werresowi chciwość i bezczelność”.

Neque me militum neque vos ducis paenituit. (Tac., Agr. 33, 3)

"Ani ja nie wstydzilem się za żolnierzy, ani wy za wodza".

Dum custodis eges. (Hor., Serm. 1, 4, 118)

„Dopóki potrzebujesz opiekuna”.

Erat Iugurtha [...] appetens gloriae militaris. (Sall., Iug. 7, 1)

„Jugurta byl żadny chwały wojennej”.

b. W datiwie, np.:

Auxilium promittet Achaia Troiae. (Ov., Met. 13, 325)

"Grecja obieca Troi pomoc".

Cretensibus obsides imperavit. (Cic., Manil. 35)

„Kreteńczykom nakazał (dać) zakładników”.

Sp. Tarpeius Romanae praeerat arci. (Liv., 1, 11,6)

„Spuriusz Tarpejusz stal na czele rzymskiego zamku”.

Equo ne credite, Teucri. (Verg., Aen. 2, 48)

„Nie wierzcie (trojańskiemu) koniowi, Teukrowie".

Pulchrum est benefacere rei publicae. (Sall., Cat. 3, 1)

„Czymś pięknym jest wyświadczać przysługi państwu".

c. W akuzatiwie, np.:

(Catilina) iuventutem [...] mala facinora edocebat. (Sall., Cat. 16)

"(Katylina) uczyl młodzież złych uczynków".

Caesar Germanos levis armaturae equitumque partem flumen traicit. (Caes., Civ. 1, 83)

„Cezar lekkozbrojnych Germanów i część konnicy przerzuça przez rzekę".

Non decet regem saeva nec inexorabilis ira. (Sen., Clem. 1, 5, 6)

"Nie przystoi królowi srogi i nieubłagany gniew”.

Neque [...] haec Dionysium fugiebant. (Nep., Di. 2, 1)

"I nie uchodziły te rzeczy uwagi Dionizjusza".

Taedebat populum omnium magistratuum eius anni. (Liv., 9, 7)

„Lud çzuł niechęć do wszystkich urzędnikow tego roku”. 
d. W ablatiwie (również z przyimkiem), np.:

Qui si reliquis flagitiis et sceleribus abstinere potuisset. (Cic., Phil. 13, 17)

"Nawet gdyby mógł powstrzymać się od pozostałych niegodziwości i zbrodni”.

Priores eius orationes non carent vitiis. (Tac., Dial. 22)

„Wcześniejsze jego mowy nie șa wolne od błędów”.

Cruore scaena abundavit. (Suet., Cal. 57)

"Scena sptynęla krwią".

Graecis utimur verbis. (Quint., Inst. 1, 5, 58)

"Posługujemy się greckimi slowami".

Multae $[. .$.$] civitates ab Afranio desciscunt. (Caes., Civ. 1, 60)$

"Liczne plemiona odsteppuja od Afraniusza".

Graviter et severe voluptatem secrevit a bono. (Cic., Fin. 2, 24)

„Poważnie i zdecydowanie oddzielił rozkosz od dobra".

Sententia iudicum de ambitu condemnatos restituit. (Suet., Iul. 41)

"Skazanych wyrokiem sądowym za nadużycia wyborcze przywrócil do dawnej godności”.

Dopełnienie dalsze, konotowane przez przymiotniki, może być stanowione przez rzeczowniki lub ich funkcjonalne odpowiedniki:

a. W genetiwie, np.:

Q. Scaevola [...] peritissimus iuris [...] est habitus. (Cic., Brut. 212)

„Kwintus Scewola byl uważany za bardzo bieglego w prawie”.

Erat in oppido multitudo insolens belli diuturnitate otii. (Caes., Gall. 2, 36)

"Przebywało w mieście mnóstwo ludzi odwykłych od wojny wskutek długotrwałego pokoju”.

b. W datiwie, np.:

Caesar $[. .$.$] castris idoneum locum delegit. (Caes., Gall. 1, 49)$

"Cezar wybral dogodne dla obozu miejsce".

Gratum multitudini spectaculum fuit. (Liv., 2, 7)

"Widok byl mily dla tlumu”.

Non erat Othonis mollis et corpori similis animus. (Tac., Hist. 1, 22)

„Dusza Othona nie była zniewieściala i podobna ciału”.

c. W ablatiwie, np.:

Plena religione civitas [erat]. (Liv., 7, 28)

"Miasto przepełnione było zabobonnym przerażeniem".

Quis enim non modo liber, sed etiam servus libertate dignus fuit, cui nostra salus cara non esset? (Cic., Leg. 3, 25) 
„Jakiż znalazł się bowiem człowiek, nie tylko wolny, ale nawet niewolnik godny wolności, któremu nie leżaloby na sercu moje ocalenie?"

Dopełnienie dalsze, konotowane przez przysłówki, może być stanowione przez rzeczowniki lub ich funkcjonalne odpowiedniki w datiwie, np.:

Cum igitur hoc sit extremum, congruenter naturae convenienterque vivere, necessario sequitur omnes sapientes semper feliciter [...] vivere. (Cic., Fin. 3, 26)

„Skoro zatem to jest celem ostatecznym, a mianowicie życie zgodnie z naturą i stosownie do niej, to nieuchronnie wynika z tego, że wszyscy mędrcy żyją szczęśliwie".

\subsubsection{Okolicznik}

Okolicznik to człon składniowy, który od dopełnienia różni się jedynie tym, że jego desygnat nie jest implikowany (wymagany) przez semantykę jego składniowego nadrzędnika. Okolicznik nie jest zatem przez człon nadrzędny konotowany, a jedynie fakultatywnie przyłączany, wskutek czego związek, który łączy go z członem nadrzędnym, to związek przynależności. Podobnie jak dopełnienie, okolicznik jest więc członem zależnym prymarnie od czasownikowego orzeczenia, przymiotnikowej przydawki lub przysłówkowego okolicznika. Gdy uwzględnić jednak sekundarną dystrybucję składniową czasowników, przymiotników i przysłówków, okolicznik może stanowić człon podrzędny względem innych członów syntaktycznych, np. bezokolicznikowego podmiotu, wyrażonej przez gerundium lub participium przydawki, funkcjonalnego odpowiednika orzeczenia w ramach składni accusativus cum infinitivo lub ablativus absolutus, wyrażonego przez substantywizowany przymiotnik podmiotu lub dopełnienia itd.

Prymarnie funkcje okolicznika pełnią przysłówki, np.:

Nostri fotriter impetum eorum tulerunt. (Caes., Civ. 3, 37)

„Nasi dzielnie wytrzymali ich atak”.

Se putant satis magnam adeptos esse dicendi gloriam. (Cic., Brut. 92)

"Uważają, że osiągnęli dostatecznie wielką sławę oratorską".

Maiores nostri longe aliter et de illo et de ceteris talibus viris existimabant. (Cic., $S$. Rosc. 50)

„Przodkowie nasi zdecydowanie inaczej myśleli i o nim i o pozostałych takich ludziach”.

Sekundarnie funkcję okolicznika pełnić mogą także rzeczowniki i rzeczownikowe (lub substantywizowane) zaimki, a także substantywizowane przymiotniki oraz liczebnik milia:

a. W genetiwie, np.:

Legati adiecerunt $[. .$.$] cum ceterorum id interesse, tum praecipue Rhodiorum. (Liv., 42,$ $46,4)$

„Posłowie dodali, że o ile jesı to ważne dla (wszystkich) pozostałych, o tyle najbardziej dla Rodyjczyków". 
Omnium oratorum [...] acutissimum iudico [...] Q. Sertorium (Cic., Brut. 180) "Za najbardziej przenikliwego spośród wszystkich mówców uważam Sertoriusza".

Desipiebam mentis. (Pl., Epid. 138)

"Byłem chory na umyśle".

Repperit [...] Pompeium remanere Brundisii cum cohortibus viginti. (Caes., Civ. 1, 25)

„Dowiedział się, że Pompejusz pozostał w Brundyzjum z dwudziestoma kohortami”.

b. W datiwie, np.:

P. Crassus [...] tertiam aciem laborantibus nostris subsidio misit. (Caes., Gall. 1, 52)

„Publiusz Krassus trzeci szyk przyslał na pomoc naszym (żołnierzom), będącym w trudnym położeniu".

Non vitae sed scholae discimus. (Sen., Lucil. 106, 12)

"Uczymy się nie dla życia, ale dla szkoły".

Quae est ista servitus tam claro homini tamque nobili? (Cic., Parad. 41)

„Czym jest ta niewola dla tak slawnego czlowieka $i$ tak szlachetnego?"

Caesari omnia uno tempore erant agenda. (Caes., Gall. 2, 20)

"Cezar musial wszystkie rzeczy robić w jednym czasie".

Festinandum ceteris videbatur. (Tac., Hist. 1, 33)

"Pozostali uważali, że należy się spieszyć".

O vita misero longa felici brevis! (Sen., Controv. 7, 3, 8)

„O życie, dla nieszczęśnika dłlugiee, dla szczęśliwca krótkiẹ!"

It clamor caelo. (Verg., Aen. 5, 451)

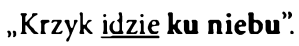

c. W akuzatiwie (również z przyimkiem), np.:

Dionysius [...] navigabat Syracusas. (Cic., Nat. 3, 83)

„Dionizjusz plynąl do Syrakuz".

Manus ad caelum et sidera tollit. (Ov., Met. 2, 487)

"Ręce wznosi do nieba i gwiazd".

Zama quinque dierum iter a Carthagine abest. (Liv., 30, 29)

„Zama jest oddalona od Kartaginy o drogę pięciu dni (= o pięć dni marszu)".

Milites [...] aggerem latum pedes trecentos triginta, altum pedes octoginta exstruxerunt.

(Caes., Gall. 7, 24)

„Żołnierze zbudowali wal oblężniczy długi na trzysta trzydzieści stóp, wysoki na osiemdziesiąt stóp".

Carneades [...] vixit nonaginta annos. (Cic., Lucull. 16)

"Karneades ży̆l dziewięćdziesiąt lat”.

Caedit $[\ldots]$ nigrantes terga iuvencos. (Verg., Aen. 5, 96-97)

„Zabija w ofierze byczki o czarnych grzbietach” (dost. byczki czarne co do grzbietów)”. 
Ego illud adsentior Theophrasto. (Cic., De orat. 3, 184)

"Co do tego zgadzam się z Teofrastem".

Suebi $[\ldots]$ maximam partem lacte atque pecore vivunt. (Caes., Gall. 4, 1)

„Swebowie w przeważającej mierze żywią się mlekiem i mięsem udomowionego bydła”.

Qui locus a Foro Juli quattuor et viginti milia passus abest. (Caes., Gall. 4, 1)

"Miejsce to jest oddalone od Forum Julijskiego o dwadzieścia cztery tysiące kroków”.

d. W ablatiwie (również z przyimkiem), np.:

Nuntius ei domo venit ephororum missu. (Nep., Ages. 4)

"Przybył do niego z ojczystego kraju poseł na polecenie eforów".

Ei ferrum e manibus extorsimus. (Cic., Catil. 2, 2)

„Miecz wydarliśmy mu $\mathbf{z}$ rąk”.

Volturcius [...] gladio se a multitudine defendit. (Sall., Cat. 45)

"Wolturcjusz mieczem broni się przed tlumem".

Deum adgnoscis ex operibus eius. (Cic., Tusc. 1, 70)

„Boga poznajesz z jego dziel”.

Sophocles $[\ldots]$ a filiis in iudicium vocatus est. (Cic., Sen. 22)

"Sofokles przez synów zostal pozwany do sądu".

Nihil est otiosa senectute iucundius. (Cic., Sen. 49)

„Nic nie jest milsze od pozbawionej przymusowych zajęć starości”.

Ponte navibus effecto tramissoque exercitu primus Ornospades [...] in castra venit. (Tac., Ann. 6, 37)

„Po zbudowaniu $\mathbf{z}$ okrętów mostu (scil. pontonowego) i przeprawieniu wojska pierwszy przybył do obozu Ornopades".

Quidam morbo aliquo et sensus stupore suavitatem cibi non sentiunt. (Cic., Phil. 2, 115)

„Niektórzy z powodu jakiejś choroby i otępienia zmysłów nie czuja słodyczy potraw”.

Pacem maritimam summa virtute atque incredibili celeritate confecit. (Cic., Flacc. 28)

„Pokój na morzu ustanowił z najwyższym męstwem i z niewiarygodną szybkością".

Pozycję okolicznikową zajmować mogą także nieosobowe formy czasownika, tj.:

a. Infinitiwus, np.:

Illa autem in arcem abiit aedem visere Minervae. (Pl., Bacch. 900-901)

"Ona zaś poszła na wzgórze zamkowe odwiedzić świątynię Minerwy".

b. Gerundium, np.:

Non possunt nisi cadendo descendere. (Sen., Dial. 9, 10,6)

"Nie potrafią zejść inaczej, jak tylko upadając". 
c. Supinum, np.:

Ibo, Hercle, aliquo quaeritatum ignem. (Pl., Rud. 766)

"Pójdẹ gdzieś, na Herkulesa, żeby poszukać ognia".

d. (substantywizowane) participium, np.:

Navigantibus moveri videntur quae stant. (Cic., Div. 2, 120)

„Żeglującym wydają się poruszać rzeczy, które stoją (nieruchomo na brzegu)".

\subsubsection{Konektory}

Konektory to składniki zdania, które wraz z członami syntaktycznymi współtworzą tzw. warstwę przedmiotową wypowiedzenia. Stanowione są głównie przez spójniki będące wykładnikami (wskaźnikami, indeksami) relacji syntaktyczno-semantycznych zachodzących między członami syntaktycznymi (częściami zdania) pozostającymi względem siebie przede wszystkim w stosunku szeregowym (niepodrzędnym), a także wykładnikami relacji syntaktycznych lub syntaktyczno-semantycznych zachodzących między zdaniami składowymi (składnikami zdaniowymi) zdania złożonego. Ze względu na specyfikę swej funkcji konektory nazywane też bywają wykładnikami zespolenia, przy czym nie zawsze cechują się linearną stycznością (bezpośrednim sąsiedztwem) z zespalanymi członami syntaktycznymi. Według tego, czy podmioty wyrażanych przez konektory relacji są wzajemnie niezależne (równorzędne), czy zależne składniowo, wyodrębnić można konektory parataktyczne (współrzędne) i hipotaktyczne (podrzędne).

\subsubsection{Konektory parataktyczne (współrzędne)}

Konektory parataktyczne mogą być wykładnikami relacji syntaktyczno-semantycznych zachodzących zarówno między członami syntaktycznymi zdania, jak i między zdaniami składowymi (równoważnikami zdań składowych) zdania złożonego. Pod względem syntaktycznym relacje te mają charakter niepodrzędny (równorzędny), natomiast pod względem semantycznym są zróżnicowane. I właśnie ze względu na zróżnicowanie stosunków znaczeniowych, wyrażanych przez konektory współrzędne, dzielą się one ogólnie na kilka podstawowych typów:

a. Konektory kopulatywne (łączne), stanowione np. przez spójniki: et, atque, ac, neque, nec:

Flumen est Arar, quod per fines Haeduorum et Sequanorum in Rhodanum influit. (Caes., Gall. 1, 12) „Jest rzeka Arar, która (płynąc) przez kraj Eduów i Sekwanów wpada do Rodanu”. 
Dicit liberius atque audacius. (Caes., Gall. 1, 18)

"Mówi swobodniej i śmielej".

Reliqui sese fugae mandarunt atque in proximas silvas abdiderunt. (Caes., Gall. 1, 12)

„Pozostali rzucili się do ucieczki i schronili się w najbliższych lasach”.

Omnes [...] colles ac loca superiora [...] ab exercitu tenebantur. (Caes., Gall., 3, 14)

„Wszystkie wzgórza i wyżej położone miejsca zajęte były przez wojsko”.

Equestribus proeliis saepe ex equis desiliunt ac pedibus proeliantur. (Caes., Gall. 4, 2)

„W trakcie konnych utarczek często zeskakują z koni i walczą jak piechurzy”.

Castris egressi nullo certo ordine neque imperio [...] fecerunt, ut consimilis fugae profectio videretur. (Caes., Gall. 2, 11)

„Wyszedłszy z obozu bez określonego porządku $\mathbf{i}$ rygoru sprawili, iż wymarsz wydawał się całkiem podobny do ucieczki".

Hostes terga vertunt neque prius fugere destiterunt, quam ad flumen Rhenum $[\ldots]$ pervenerunt. (Caes., Gall. 1, 53)

„Nieprzyjaciele pierzchnęli i nie pierwej zaprzestali ucieczki, aż dotali do rzeki Ren”.

Romanorum manus tantis munitionibus distinetur nec facile pluribus locis occurrit. (Caes., Gall. 7, 84)

„Wojsko rzymskic rozciągnięte jest na rozległych umocnieniach i nie latwo stawia (dostateczny) opór w wielu miejscach (równocześnie)".

W przypadku wskazywania na relacje zachodzące między wieloma różnymi (zdaniowymi i niezdaniowymi) składnikami zdania mogą współwystępować w ramach jednego zdania konektory stanowione przez (te same lub różne) spójniki lub przez spójniki i postfiksalny morfem spójnikowy -que:

Boii et Tulingi [...] agmen hostium claudebant et novissimis praesidio erant. (Caes., Gall. 1,25 )

„Bojowie i Tulingowie zamykali kolumnę marszową nieprzyjaciół i stanowili osłonę (jej) tylnych oddziałów".

Hunc omnem locum copiae Gallorum compleverant fossamque et maceriam sex in altitudinem pedum praeduxerant. (Caes., Gall. 7, 69)

"Całe to miejsce zajęły wojska Gallów i przeprowadzily fosę oraz kamienną zaporę o wysokości sześciu stóp".

Belgae $[\ldots]$ a cultu atque humanitate provinciae longissime absunt minimeque ad eos mercatores saepe commeant atque ea, quae ad effeminandos animos pertinent, important proximique sunt Germanis. (Caes., Gall. 1, 1)

„Belgowie są bardzo oddaleni od cywilizacji i kultury (rzymskiej) prowincji i bardzo rzadko przybywają do nich kupcy i przywożą towary przyczyniające się do zniewieścienia charakterów, i są też sąsiadami Germanów".

Spójnik neve (neu) 'i (niech) nie', 'ani (niech) nie', 'i żeby nie' wprowadza nacechowane modalnie zdanie współrzędne zawierające negacje lub dodatkowy niezdaniowy składnik objęty negacją w ramach zdania o nacechowanej modalności: 
Adveniat $[\ldots]$, neve exhorrescat. (Verg., Aen. 7, 265)

"Niech przybywa i niech się nie obawia".

Sed qui ab eo (scil. Pompeio) missi erant [...] liberius cum militibus regis conloqui coeperunt eosque hortari, ut suum officium Pompeio praestarent neve eius fortunam despicerent. (Caes., Civ. 3, 103)

„Lecz wysłannicy Pompejusza zaczęli swobodniej rozmawiać z żołnierzami króla i nakłaniać ich, aby wypełnili swoje zobowiązanie wobec Pompejusza i nie okazywali pogardy dla jego losu".

Hoc te primum rogo, ne contrahas animum neve te obrui magnitudine negotii sinas. (Cic., Q.fr. 1, 1, 4)

„Przede wszystkim proszę cię o to, byś nie upadał na duchu i byś nie pozwolił się przygnieść ciężarem obowiązków".

Imperat Cassivellauno ne Mandubracio neu Trinovantibus noceat. (Caes., Gall. 5, 22)

„Nakazuje Kassywellaunusowi, aby Mandubracjuszowi ani Trynowantom nie wyrządzal szkody".

Konektory kopulatywne (i nie tylko kopulatywne) mogą też tworzyć złożone ze spójników zestawienia, których pierwszy człon lokowany jest przed pierwszym spośród relacjonowanych względem siebie elementów zdania. Człon ten pełni w zasadzie funkcję operatora tekstowego, suponującego (uprzedzającego, zapowiadającego) pojawienie się wyliczenia:

Per exploratores Caesar cognovit et montem a suis teneri et Helvetios castra moveri et Considium timore perterritum, quod non vidisset, pro viso sibi renuntiavisse. (Caes., Gall. $1,23)$

„Przez zwiadowców Cezar dowiedzial się i tego, że góra jest w rę̧ach jego żołnierzy, i tego, że Helwetowie zwinęli obóz, i tego, że zdjęty strachem Konsydiusz powiadomil go o zobaczeniu rzeczy, której (naprawdę) nie zobaczył".

Hi neque vultum fingere neque interdum lacrimas tenere poterant. (Caes., Gall. 1, 39)

„Ci nie mogli ani zmienić wyrazu twarzy, ani powstrzymać niekiedy lez”.

Conatus est Caesar reficere pontes, sed nec magnitudo fluminis permittebat, neque ad ripam dispositae cohortes adversariorum perfici patiebantur. (Caes., Civ. 1, 50)

„Cezar usilował odbudować mosty, lecz ani wielkość rzeki na to nie pozwalała, ani rozlokowane na brzegu kohorty nieprzyjaciół nie dopuszczaly do podjęcia budowy".

b. Konektory dysjunktywne (rozłączne, alternatywne), stanowione np. przez spójniki: aut, vel, sive, seu:

Qui locus ingenium patronis requirit aut oratoris eloquentiam magno opere desiderat? (Cic., S. Rosc. 34)

„Jakiż element (rozpatrywanej sprawy sądowej) potrzebuje talentu obrońcy albo zdecydowanie wymaga krasomówczej elokwencji?"

Omnis gratia, potentia, honos, divitiae apud illos sunt aut ubi illi volunt. (Sall., Cat. 20)

„Wszelkie znaczenie, wpływy, zaszczyty, bogactwa są u nich albo tam, gdzie oni chcą". 
Cum P. Decius se in Samnium vel in Etruriam proficisci paratum esse ostendisset, tanta laetitia ac gratulatio fuit, ut [...] triumphus [...] non bellum decretum consulibus videretur. (Liv., 10, 26)

„Gdy Publiusz Decjusz oświadczył, że gotów jest wyruszyć do Samnium albo do Etrurii, zapanowała taka radość i zadowolenie, iż można było odnieść wrażenie, że to tryumf, a nie prowadzenie wojny zadekretowano konsulom".

Sublicae $[\ldots]$ agebantur $[\ldots]$, ut si arborum trunci sive naves $[\ldots]$ essent a barbaris missae [...], earum rerum vis minueretur neu ponti nocerent. (Caes., Gall. 4, 17)

„Pale były wbijane ( $w$ dno rzeki), aby w razie, gdyby (do rzeki) wrzucane były przez barbarzyńców pnie drzew albo łodzie, nisząca siła tych przedmiotów była osłabiona i na zgrażały one mostowi".

Locum sepulcro in campo Esquilino C. Pansa consul, seu quo in loco videbitur, $[\ldots]$ adsignet. (Cic., Phil. 9, 17)

„Niech konsul Gajusz Pansa wyznaczy miejsce dla grobu na polu Eskwilińskim, albo gdzie uzna to za stosowne".

Konektory te często występują w podobnych zestawieniach, jak wskazane wyżej konektory kopulatywne:

Abditi in tabernaculis aut suum fatum querebantur, aut cum familiaribus suis commune periculum miserabantur. (Caes., Gall. 1, 39)

„Ukryci w namiotach albo narzekali na swój los, albo wraz z towarzyszami użalali się nad ich wspólnym niebezpieczeństwem".

Verberato vel intra pomerium vel extra pomerium. (Liv., 1,26)

"Niech zostanie ubiczowany albo w obrębie murów miasta, albo poza murami".

Tum dictator $[\ldots]$ censuram minuere parat, seu nimiam potestatem ratus, seu $[\ldots]$ diuturnitate offensus. (Liv., 4, 24)

„Wtedy dyktator zamierzył umniejszyć rangę urzędu cenzorskiego, czy to uważając wladzę (jej przysługującą) za zbyt, czy to zrażony długością (pełnienia tego urzędu)".

Sive casu sive consilio deorum immortalium, quae pars civitatis Helvetiae insignem calamitatem populo Romano intulerat, ea princeps poenam solvit. (Caes., Gall. 1, 12)

„Albo przypadkiem, albo z woli bogów nieśmiertelnych, ta część plemienia Helwetów, która zadał narodowi rzymskiemu ciężką klęskę, jako pierwsza poniosła karę".

c. Konektory adwersatywne (przeciwstawne), stanowione np. przez spójniki: sed, verum, et, autem, neque:

Interiores plerique frumenta non serunt, sed lacte et carne vivunt. (Caes., Gall. 5, 14)

„Mieszkańcy środkowej części (Brytanii) na ogól nie sieją zbóż, lecz żywią się mięsem i mlekiem".

Spatia omnis temporis non numero dierum, sed noctium finiunt. (Caes., Gall. 6, 18)

„Wszelkie odstępy czasowe określają (mierzą) nie liczbą dni, lecz nocy”.

Qui ne deliberavit quidem [...], verum statim [...] consurrexit et fratrem Ascylton elegit. (Petron., Sat. 80, 6) 
„Nawet się on nie zastanawiał, ale od razu podniósł się i wskazał na Askyltosa jako swego wybrańca".

Cassius plebeii Romae generis, verum antiqui honoratique, [...] facilitate saepius quam industria commendabatur. (Tac., Ann. 6, 15)

„Kasjusz, pochodzący $\mathrm{z}$ rzymskiego rodu plebejskiego, ale starego i poważanego, jednał sobie życzliwość raczej lagodnością charakteru niż energią w dzialaniu".

Fieri $[. .$.$] potest, ut recte quis sentiat et id, quod sentit, polite eloqui non possit. (Cic., Tusc.$ $1,6)$

„Może się zdarzyć, że ktoś mysli poprawnie, ale tego, co myśli, nie potrafi wyrazić w gladki sposób".

Aliquando non fulgurat et tonat. (Sen., Nat. 2, 18, 1)

„Niekiedy nie ma błyskawicy, a jednak grzmi”.

Pugnatum est diu atque acriter, cum Sotiates [...] in sua virtute totius Aquitaniae salutem positam putarent, nostri autem, quid sine imperatore [...] efficere possent, perspici cuperent. (Caes., Gall. 3, 21)

„Walczono długo i zaciekle, jako że Socjaci byli przekonani, iż ocalenie całej Akwitanii zalcży od ich męstwa, natomiast nasi chcieli, by zobaczono, co mogą zdziałać (nawet) bez naczelnego wodza".

Magna res, magna dignitas, summa autem gratia. (Cic., Mur. 29)

„Wielki majątek, wielka godność, największe jednak wpływy".

At ii, qui praesidio contra castra Labieni erant relicti [...], subsidio suis ierunt collemque ceperunt, neque nostrorum militum victorum impetum sustinere potuerunt. (Caes., Gall. 7,62 )

"A tymczasem ci, którzy zostali pozostawieni jako ochrona naprzeciwko obozu Labienusa, ruszyli na pomoc swoim i zajęli wzgórze, jednak atakowi naszych zwycięskich żołnierzy oprzeć się nie zdolali".

Konektory adwersatywne mogą też wyrażać przeciwstawienie $w$ stosunku do składnika mającego charakter koncesywny. Stanowione one są przez spójniki: tamen, nihilominus, ale mogą również posiadać budowę złożoną, stanowiąc kombinacje spójników typu: sed tamen, verum tamen, sed nihilominus. Najczęściej tworzą zestawienia ze spójnikami lub partykułami koncesywnymi:

Etiamsi nulla sit utilitas ex amicitia, tamen ipsi amici propter se ipsos amentur. (Cic., Fin. 1,69 )

„Nawet gdyby z przyjaźni nie wynikała żadna korzyść, to jednak przyjaciele ze względu na siebie samych darzyliby się uczuciem".

Non postulo id quidem, aveo tamen audire. (Cic., Tusc. 1, 16)

„Wcale się tego nie domagam, jednak z chęcią posłucham”.

Haec cum audisset legatus vester tribunique militum, [..] ausi sunt nihilominus sacrilegas admovere manus intactis illis thesauris. (Liv., 29, 18)

„Chociaż wiedział o tym wasz legat i trybunowie wojskowi, to tym niemniej poważyli się położyć świętokradcze ręce na owych nietykalnych skarbach". 
Cleonem etiam temporibus illis turbulentum illum quidem civem, sed tamen eloquentem constat fuisse. (Cic., Brut. 28)

„Wiadomo, że w tych czasach żył również Kleon, skory wprawdzie do wywoływania zamieszek, ale wymowny".

Nunc (natura) quod amplius est facit: quosdam enim (animos) edit corporibus inpeditos, sed nihilominus perrumpentis obstantia. (Sen., Lucil. 66, 3)

„Tymczasem natura czyni (jeszcze) coś więcej: rodzi bowiem pewne dusze skrępowane (ułomnymi) ciałami, ale mimo to przełamujące (związane z tym) ograniczenia".

Adwersatywny charakter mają także tworzące zestawienia konektory proste typu ut ... sic ..., i mające złożony charakter konektory o postaci: non solum... sed (etiam/quoque/et) ..., non solum / non modo ... verum etiam ..., non modo / non solum ... sed ne ... quidem ... itp.:

Ut ad bella suscipienda Gallorum alacer ac promptus est animus, sic mollis ac minime resistens ad calamitates ferendas mens eorum est. (Caes., Gall. 3, 19)

„Jak są Gallowie z usposobienia skorzy i chętni do podejmowania wojen, tak psychicznie są slabi i nieodporni w przypadku konieczności znoszenia niepowodzeń".

Caesar non solum publicas, sed etiam privatas iniurias ultus est. (Caes., Gall. 1, 12)

„Cezar pomścił nie tylko publiczne, ale i prywatne krzywdy”.

Tantum hostium non solum intra muros est, sed in arce, supra forum curiamque. (Liv., $3,17)$

„Mnóstwo nieprzyjaciół jest nie tylko w obrębie murów, ale i na zamku, ponad forum i kurią".

Iam circa Icilium non solum multitudo, sed duces quoque multitudinis erant. (Liv., 3, 49)

"Wokól Icyliusza znalazł się już nie tylko tłum, ale również przywódcy tłumu".

Claudio imperium adepto (Nero) non solum paternas opes reciperavit, sed et Crispi Passieni, vitrici sui, hereditate ditatus est. (Suet., Ner. 6)

„Po tym, gdy Claudiusz doszedł do whadzy, Neron nie tylko odzyskał majątek ojcowski, ale także wzbogadzil się spadkiem po Kryspusie Pasjenusie, swoim ojczymie".

Causam dicit is, cui non modo luctum mors patris attulit, verum etiam egestatem. (Cic., S. Rosc. 13)

„Broni się przed sądem ten, któremu śmierć ojca przyniosła nie tylko żalobę, ale i biedę".

Non modo frumenta in agris matura non erant, sed ne pabuli quidem satis magna copia suppetebat. (Caes., Gall. 1, 16)

„Nie tylko zboża na polach nie były jeszcze dojrzale, lecz również paszy nie było w wystarczającej ilości".

d. Konektory konkluzywne (rezultatywne, konsekutywne), stanowione np. przez przysłówek ideo, partykuły: itaque, ergo, igitur; zwykle łączą składniki zdaniowe i występują stosunkowo rzadko, jako że reprezentujące je leksemy częściej pełnią funkcje operatorów tekstowych nawiązania międzywypowiedzeniowego: 
Te velle uxorem aiebat tuo nato dare, ideo aedificare hic velle aiebat in tuis. (Pl., Most. 1027-1028)

„Mówil, że chcesz dać synowi małżonkę, dlatego chcesz, mówil, budować coś tu na swoim”.

Maiores nostri longe aliter et de illo et de ceteris talibus viris existimabant, itaque ex minima tenuissimaque re publica maximam et florentissimam nobis reliquerunt. (Cic., $S$. Rosc. 50)

„Nasi przodkowie o nim i pozostalych takich ludziach myśleli zupełnie inaczej, toteż z bardzo niewielkiej i slabej pozostawili nam republikę ogromną i kwitnącą".

C. Gracchi frumentaria magna [fuit] largitio, exhauriebat igitur aerarium. (Cic., Off. 2, 72)

„Prowadzone przez Gajusza Grakchusa rozdawnictwo zboża było ogromne, a więc ogołacało skarbiec publiczny".

Iam habet, quod petit [...], ergo gratus sum. (Sen., Benef. 2, 33)

„Już ma to, czego pragnie, zatem nie jestem niewdzięczny”.

Non intenditur virtus, ergo ne beata quidem vita, quae ex virtute est. (Sen., Lucil. 92, 24) "Nie intensyfikuje się cnota, a zatem również i życiowe szczęście, które pochodzi od cnoty”.

e. Konektory eksplikatywne (wyjaśniające, przyczynowe), stanowione np. przez spójnik namque, partykułę nam, łączą jedynie składniki zdaniowe i - podobnie jak w przypadku konektorów konkluzywnych - reprezentujące je leksemy pełnią najczęściej funkcje operatorów tekstowych nawiązania międzywypowiedzeniowego:

Nihil est quod quisquam magnitudinem artium ex eo, quod senes discunt, pertimescat, namque aut senes ad eas accesserunt aut usque ad senectutem in studiis detinentur. (Cic., De orat. 3,89 )

„Nie ma powodu, by ktoś miał się przerazić ogromem nauk na podstawie tego, że (jeszcze) starcy uczą się, bowiem (oni) albo dopiero jako starcy zaczęli się uczyć, albo aż do starości nauka ich absorbuje".

Tace dum parumper, nam concrepuit ostium. (Pl., Men. 348)

„Tymczasem zamilcz na chwilę, skrzypnęly bowiem drzwi”.

Niekiedy konektory eksplikatywne, stanowione przez: nam, namque, enim, etenim, wprowadzają zdania parentetyczne (wtrącone, nawiasowe):

Tribuni plebi certamen intulerunt, ut pars quaestorum - nam ad id tempus patricii creati erant - ex plebe fieret. (Liv., 4, 43)

„Trybuni ludowi wysunęli rodzące spór żądanie, aby część kwestorów - do tej pory bowiem wybierani byli (wylącznie) patrycjusze - pochodzila z ludu".

Florentissimum Italiae latus [...] armis Vitelii (namque et praemissae a Caecina cohortes advenerant) tenebatur. (Tac., Hist. 2, 17)

„Najbardziej kwitnący rejon Italii przez wojska Witeliusza (nadeszly już bowiem także kohorty wysłane wcześniej przez Cecynę) byl zajęty".

(Venus) hunc [...] perducit ad illam civitatem et Psychen - hoc enim nomine puella nuncupabatur - ostendit. (Apul., Met. 4, 30) 
„(Wenus) prowadzi go do owego kraju i Psyche - takie bowiem imię nosila dziewczyna osobiście mu pokazuje".

Addidit praecepta (etenim aderat Meherdates), ut non dominationem [...] cogitaret. (Tac., Ann. 12, 11)

„Dodał też pouczenia (byl tam bowiem obecny Meherdates), aby nie myślał o tyranii".

\subsubsection{Konektory hipotaktyczne (podrzędne)}

Konektory podrzędne są wykładnikami relacji syntaktycznych lub syntaktyczno-semantycznych zachodzących przede wszystkim między zdaniami składowymi (równoważnikami zdań składowych) zdania złożonego. Pod względem syntaktycznym relacje te mają charakter nadrzędno-podrzędny, tzn. konektor sygnalizuje wprowadzenie zdania syntaktycznie podrzędnego, które w szyku linearnym ulokowane może być po zdaniu nadrzędnym, przed nim lub w jego obrębie. Pod względem semantycznym relacje implikowane przez konektory podrzędne są zróżnicowane.

Konektory wprowadzające zdania podrzędne dopełnienieniowe, podmiotowe, przydawkowe czy orzecznikowe są czystymi wskaźnikami syntaktycznymi, semantycznie pustymi, wiążącymi zdanie podrzędne ze zdaniem nadrzędnym, w którym określona pozycja syntaktyczna pozostała niewypełniona lub w którym znajduje się wyrażenie treściowo niekompletne. Konektory te stanowione są najczęściej przez spójniki: ut, quod (rzadziej cum), a także przez implikujące negację spójniki: quin, ne, quominus, jak np. w zdaniach:

a. Dopełnieniowych:

Pompeius suis praedixerat, ut Caesaris impetum exciperent. (Caes., Civ. 3, 92)

„Pompejusz nakazal swoim ludziom, aby przyjęli atak Cezara”.

Hoc scio, quod scribit nulla puella tibi. (Mart. Epigr. 11, 64, 2)

"To wiem, że żadna dziewczyna do ciebie nie pisze".

Hoc te primum rogo, ne contrahas animum. (Cic., Q. fr. 1, 1, 4)

„Przede wszystkim proszę cię o to, byś nie upadał na duchu”.

Dubita, si potes, quin ille, seu victus seu victor redierit, caedem facturus sit. (Cic., Att. 10, $10,5)$

„Powątpiewaj w to, jeśli potrafisz, że ów, czy to jako pokonany, czy jako zwycięzca, dokona rzezi (= Niech ci się wydaje, że (może) nie dokona rzezi)".

Caligula canendi voluptate ita afferebatur, ut ne publicis quidem spectaculis temperaret quominus tragoedo pronuntianti concineret. (Suet., Cal., 54)

„Kaligula tak bardzo pałał chęcią śpiewania, że nawet $w$ czasie publicznych widowisk nie mógł się powstrzymać przed wtórowaniem (= aby nie wtórować) śpiewem recytującemu aktorowi tragicznemu". 
b. Podmiotowych:

Vitam in peregrinatione exigentibus hoc evenit, ut multa hospitia habeant, nullas amicitia. (Sen., Lucil. 2, 2)

„Ludziom spędzającym życie na podróżowaniu przypada w udziale to, że cieszą się licznymi związkami gościnności, nie mają jednak żadnych związków przyjaźni".

Controversia non erat, quin verum dicerent. (Cic., Caecin., 31)

„Nie było przedmiotem sporu (to), że nie mówią prawdy (= Było pewne, że mówią prawdę)”.

c. Orzecznikowych

(Ad te) pertinet esse te talem, ut tuas laudes obscuratura nulla umquam sit oblivio. (Cic., Marcell. 30)

„Twoją sprawą jest być takim, żeby twoich zasług nigdy nie przysłoniło żadne zapomnienie”.

d. Przydawkowych, zwykle o charakterze eksplikacyjnym:

Unum habet adsidua infelicitas bonum, quod quos semper vexat, novissime indurat. (Sen., Dial. 12, 2, 3)

„Długotrwałe nieszczęście zawiera w sobie to jedno dobro, iż tych, których nieustannie nęka, ostatecznie wzmacnia".

De voluntate tua, ut simul simus [...], non dubito. (Cic., Att. 12, 26, 1)

„W twoją chęć, abyśmy byli razem, nie wątpię".

Fuit quoddam tempus, cum in agris homines passim bestiarum more vagabantur. (Cic., Inv. 1, 2)

"Był taki czas, kiedy ludzie wszędzie błąkali się po ziemi jak dzikie zwierzęta".

Dies fere nullus est, quin hic [...] domum meam ventitet. (Cic., Att. 1, 1, 3)

„Prawie nie ma dnia, żeby nie nachodzil on mego domu”.

Konektory wprowadzające zdania podrzędne okolicznikowe najczęściej są nacechowane również semantycznie i tym samym są wykładnikami relacji syntaktyczno-semantycznych zachodzących między zdaniami składowymi zdania złożonego. W zależności od rodzaju implikowanej relacji znaczeniowej można wyodrębnić:

a. Konektory celowe (finalne), stanowione np. przez spójniki: ut/uti 'aby', 'ażeby', 'żeby'; ne 'aby nie'; quo 'aby przez to' (często obok komparatiwu):

Maiores nostri ab aratro adduxerunt Cincinnatum illum, ut dictator esset. (Cic., Fin. $2,12)$

„Przodkowie nasi wprost od pługa przywolali owego Cyncynnata, aby zostal dyktatorem”.

Suum quisque igitur noscat ingenium acremque se et bonorum et vitiorum suorum iudicem praebeat, ne scaenici plus quam nos videantur habere prudentiae. (Cic., Off. 1, 114)

„Niech zatem każdy pozna swój charakter i stanie się surowym sędzią swoich wad i zalet, aby nie wydawało się, że aktorzy są mądrzejsi od nas". 
Saga sumi dixi plcere, quo omnes acrius graviusque incumberent ad ulciscendas rei publicae iniurias. (Cic., Phil. 6, 2)

„Powiedziałem, że jest rzeczą wlaściwą przywdzianie żołnierskich plaszczy, aby przez to wszyscy energiczniej i z większą determinacją starali się o pomszczenie krzywd wyrządzonych rzeczpospolitej".

b. Konektory przyczynowe (kauzalne), które mogą być stanowione samodzielnie przez spójniki, np.: quia, quoniam, quod, quando, cum 'ponieważ, gdyż', lub mieć charakter złożony, np.: propterea quod; ea de causa quod; ob eam causam quod; idcirco quia ' $\mathrm{z}$ tego powodu, że; dlatego, że':

Ei moriendum fuit, quoniam homo nata fuerat. (Cic., Fam., 4, 5, 4)

„Musiała umrzeć, ponieważ urodzila się czlowiekiem”.

Inde L. Tarquinius reganre coepit, cui Superbo cognomen facta indiderunt, quia socerum gener sepultura prohibuit. (Liv., 1, 49)

„Następnie rozpoczął rządy Lucjusz Tarkwiniusz, którego czyny nadaly mu przydomek 'Pyszny', ponieważ jako zięć zakazal grzebania teścia".

Necata [...] est anus Vitia, Fufii Gemini mater, quod filii necem flevisset. (Tac., Ann. $6,10)$

„Stracona została staruszka Wicja, matka Fufiusza Geminusa, ponieważ oplakiwala śmierć syna".

Haec in praesentia nota esse debebunt, voluptatem semovendam esse, quando ad maiora quaedam $[\ldots]$ nati sumus. (Cic., Fin. 5, 21)

„Na razie trzeba będzie przyjąć do wiadomości, że rozkosz powinno się odrzucić, skoro zostaliśmy stworzeni do czegoś większego".

Ita fit, ut adsint, propterea quod officium sequuntur, taceant autem idcirco quia periculum vitant. (Cic., S. Rosc. 1)

„Jest tak, iż są obecni dlatego, że wypełniają swój obowiązek, milczą zaś z tego powodu, że unikają niebezpieczeństwa".

c. Konektory przyzwolenia (koncesywne), stanowione np. przez spójniki: quamquam, etsi, tametsi, cum, quamvis, etiamsi (etiam si), ut, licet 'chociaż', 'mimo że', 'choćby', 'nawet jeśli'. Jeśli wprowadzane przez nie zdania poprzedzają zdanie nadrzędne lub wbudowane są w obręb jego szyku linearnego, kontrast, w jakim ukazana zostaje ich treść $w$ stosunku do treści zdania nadrzędnego, często bywa uwydatniany w zdaniu nadrzędnym spójnikiem adwersatywnym, najczęściej tamen, który pozostaje w zestawieniu ze spójnikiem koncesywnym:

Mihi quidem Scipio, quamquam est subito ereptus, vivit tamen semperque vivet. (Cic., Lael. 102)

„Wszak Scypion, chociaż został mi nagle zabrany, to jednak (dla mnie) żyje i żyć będzie zawsze".

(Rutilius), etsi damnatus est, mihi videtur tamen inter viros optimos atque innocentissimos esse numerandus. (Cic., Font., 38) 
„(Rutyliusz), mimo że został skazany przez sąd, to jednak wydaje mi się godnym zaliczenia w poczet ludzi najświetniejszych i najbardziej niewinnych".

(Socrates), cum facile posset educi e custodia, noluit. (Cic., Tusc. 1, 71)

„(Sokrates), choć latwo mógl zostać wyprowadzony z więzienia, nie chciał”.

Est, etiam si non appellatur, hostis. (Cic., Prov. 12)

"Jest wrogiem, nawet jeśli nie byłby tak nazywany".

(Minos) terras licet [...] et undas obstruat, at caelum certe patet. (Ov., Met. 8, 185-186)

"Choćby i zabudowal (Minos) ziemie i morza, to jednak niebo z pewnością stoi otworem".

d. Konektory czasowe (temporalne), stanowione np. przez spójniki: cum, ubi 'kiedy', 'gdy'; postquam, posteaquam, simul(ac), simulatque, ut (primum), ubi (primum), cum (primum) 'gdy', 'po tym jak,' 'skoro tylko', 'odkąd'; antequam, priusquam, dopuszczające tmesis (i tym samym tworzące wówczas zestawienia): prius .... quam, ante ... quam 'zanim, wcześniej ... niż'; dum, donec, quoad, quamdiu 'podczas gdy', 'tak długo jak', 'dopóki, aż':

Gallo narravi, cum proxime Romae fui, quid audissem neque nominavi Balbum. (Cic., Att., 13, 49, 2)

„Opowiedziałem Gallusowi, gdy byłem w pobliżu Rzymu, co usłyszałem, ale nie wspomniatem o Balbusie".

(Lacedaemonii), postquam [...] audiverunt muros strui, legatos Athenas miserunt. (Nep., Them. 6)

„(Lacedemończycy), po tym jak usłyszeli, żc budowane są mury, wyslali do Aten posłów”.

Ante quam de re publica [...] dicam [...], exponam vobis breviter consilium et profectionis et reversionis meae. (Cic., Phil., 1, 1)

„Zanim powiem o państwie, krótko przedstawię wam powody zarówno mego wyjazdu, jak i powrotu".

Hostes terga verterunt neque prius fugere destiterunt, quam ad flumen Rhenum [...] pervenerunt. (Caes., Gall., 1, 53)

„Nieprzyjaciele rzucili się do odwrotu i nie wcześniej zaprzestali ucieczki, aż doszli do rzeki Ren".

Ut aegroto, dum anima est, spes esse dicitur, sic ego, quoad Pompeius in Italia fuit, sperare non destiti. (Cic., Att. 9, 10, 3)

„Jak chory, dopóki tli się w nim życie, ponoć zachowuje nadzieję, tak i ja, tak długo jak Pompejusz byl w ltalii, nie tracilem wiary".

Dum reliquae naves eo convenirent, ad horam nonam in ancoris exspectavit. (Caes., Gall. $4,23)$

„Rzuciwszy kotwice odczekal do godziny dziewiątej, aż pozostałe okręty dopłyną w to miejsce".

e. Konektory warunku (kondycjonalne), stanowione np. przez spójniki: si 'jeśli', ‘jeśliby', 'jezeli', 'gdyby', nisi, ni 'jeśli nie', 'o ile nie', 'gdyby nie', 'chyba że' i bliskie im konektory zastrzeżenia, stanowione np. przez spójniki: modo, dum, dummodo, si modo 'byleby tylko', 'jeśli tylko'; 'pod warunkiem, że': 
Si quid in te peccavi, ignosce! (Cic., Att. 3, 15, 4)

"Jeśli w czymś wobec ciebie zawinilem, wybacz!"

Quae [...] vita fuisset Priamo, si ab adulescentia scisset, quos eventus senectutis esset habiturus? (Cic., Div. 2, 22)

„Jakież życie miałby Priam, gdyby od mlodości wiedzial, co go spotka na starość?"

Nocens, nisi accusatus fuerit, condamnari non potest. (Cic., S. Rosc. 56)

„Winny, jeśli nie zostałby oskarżony, nie może być skazany”.

Tranassem ista (freta) [...], dummodo te complecti possem. (Sen., Lucil. 45, 2)

„Wpław bym przepłynął te cieśniny, bylebym tylko mógl cię uściskać".

Oderint, dum probent. (Suet., Tib. 56)

„Niech (mnie) nienawidzą, byleby (mnie) uznawali”.

f. Konektory skutkowe (konsekutywne), stanowione przez spójniki ut '(tak...,) że / by', quin '(tak...,) że / by nie':

(Atticus) poemata pronuntiabat et Graece et Latine sic, ut supra nihil posset addi. (Nep., Att. 4)

„(Attyk) zarówno greckie, jak i lacińskie wiersze recytowal tak, że niemożliwe było uczynienie jakiejkolwiek poprawki".

Nemo tam divos habuit faventes, crastinum ut posset sibi polliceri. (Sen., Thy., 619-620)

„Nikt nie zyskal sobie przychylności bogów do tego stopnia, by mógł obiecywać sobie dożycie kolejnego dnia".

Nil tam difficilest, quin quaerendo investigari possiet. (Ter., Heaut. 675)

„Nic nie jest tak trudne, by szukając, nie można było zanleżć (jakiegoś rozwiązania)".

g. Konektory porównania (zestawienia, charakterystyki), stanowione np. przez spójniki: atque, ac, ut, sicut, quam 'jak'; ac si, ut si, velut, tamquam 'jakby':

Et vitast eadem et animu' te erga idem ac fuit. (Ter., Heaut. 265)

„I (jej) życie, i jej uczucie wobec ciebie są takie same, jak byly".

Ego tui Bruti rem sic ago, ut suam ipse non ageret. (Cic., Att. 5, 18, 4)

"Sprawę twojego Brutusa tak prowadzę, jak sam wlasnej by nie poprowadzil".

Quorum neutrum tam facile, quam tu arbitraris, conceditur. (Cic., Div. 1, 10)

„Na żadną z obu tych rzeczy nie można zgodzić się tak latwo, jak sądzisz”.

Eius negotium sic velim suscipias, ut si esset res mea. (Cic., Fam. 2, 14, 1)

„Chcialbym, abyś jego sprawę tak podjąl, jakby to była moja rzecz".

Sic vive cum hominibus, tamquam deus videat; sic loquere cum deo, tamquam homines audiant. (Sen., Lucil. 10,5)

„Z ludźmi żyj tak, jakby widzial to bóg; z bogiem rozmawiaj tak, jakby sluchali tego ludzie”. 
W odniesieniu do składników niezdaniowych:

Gallorum eadem atque Belgarum oppugnatio est. (Caes., Gall. 2, 6)

„Gallów' sposób zdobyłwania miast jest taki sam jak Belgów”.

\subsubsection{Konektory jako wskaźniki relacji semantycznych, łączących człony syntaktyczne pozostające $w$ stosunku nadrzędno-podrzędnym}

Jak zaznaczyliśmy wyżej, w odniesieniu do składników niezdaniowych, konektory są wykładnikami relacji syntaktyczno-semantycznych zachodzących między członami syntaktycznymi pozostającymi względem siebie przede wszystkim w stosunku niepodrzędnym. Jednak również części zdania pozostające względem siebie w składniowym stosunku nadrzędno-podrzędnym mogą być łączone pewnymi konektorami, i to zarówno parataktycznymi, jak i hipotaktycznymi, mimo że te ostatnie, jak również wspomniano wyżej, są z kolei wykładnikami relacji zachodzących przede wszystkim między składnikami zdaniowymi zdań złożonych. W opisywanej tu funkcji używane są w szczególności konektory adwersatywne i koncesywne. Obecność konektorów w ramach strukur niewymagających ich użycia wnosi dodatkowe znaczenie relacyjne, implikowane przez semantykę konektorów:

Permittente [...] Gaio revocatus est, verum sub condicione ne quam partem curamve rei publicae attingeret. (Suet., Tib. 13)

„Za zgodą Gajusza zostal odwolany ( $z$ wygnania), jednak pod warunkiem, że nie będzie próbowal związać się z żadnym stronnictwem politycznym ani wpływać na zarząd państwem".

Tyrannus [...] fuit appellatus, sed iustus. (Nep., Milt. 8)

„By\} (wprawdzie) nazywany tyranem, ale sprawiedliwym”.

Phrynen non Hyperidis actione, quamquam admirabili, sed conspectu corporis [...] putant periculo liberatam. (Quint., Inst. 2, 15, 9)

„Uważa się, że Phryne wyszła cało z procesu nie dzięki obronie Hyperejdesa, chociaż wspaniałej, lecz dzięki urodzic swego ciała".

Podobnie jak w przypadku składników zdaniowych, członowi syntaktycznemu opatrzonemu konektorem koncesywnym może zostać przeciwstawiony drugi (współrzędny), opatrzony konektorem adwersatywnym:

Caesar [...], quamquam sua sponte [...], tamen approbatione auctoritatis meae, colonias patris adiit. (Cic., Phil. 5, 23)

"Cezar, chociaż z wlasnej woli, jednak za moją aprobalą, udał się do kolonii założonych przez ojca". 


\subsubsection{Operatory tekstowe}

Operatory tekstowe to składniki zdania leżące poza jego strukturą składniową. Nie są one bezpośrednimi wykładnikami żadnego $z$ elementów tzw. świata przedstawionego, kreowanego przez człony syntaktyczne i konektory w ramach tzw. warstwy przedmiotowej zdania, lecz służą realizowaniu przez nadawcę określonej strategii nadawczo-odbiorczej, (współ)tworząc tzw. warstwę tekstową wypowiedzenia. $\mathrm{Na}$ realizację wspomnianej strategii, mającej na celu osiągnięcie zamierzonych celów komunikacyjnych, składa się m.in. budowanie spójności retorycznej tekstu poprzez odpowiednie włączanie kolejnych segmentów wypowiedzi w kontekst, nadanie wyrażanym treściom pożądanej perspektywy modalnej, sygnalizowanie stosunku, oceny czy sposobu postrzegania określonych elementów treści przez autora wypowiedzi, wyrażanie emocji i wpływanie na emocje odbiorcy, aktywizowanie jego uwagi. Wyodrębnić można w związku z tym kilka grup (klas) operatorów tekstowych.

\subsubsection{Operatory nawiązania międzywypowiedzeniowego (spójności retorycznej)}

Funkcją operatorów nawiązania międzywypowiedzeniowego, służących nadaniu tekstowi spójności retorycznej, jest sygnalizowanie realacji, w jakiej pozostaje rozpoczynany segment wypowiedzi (zdanie) w stosunku do wcześniej wyrażonych treści, nadając mu status np. kolejnego (dodatkowego) elementu w sekwencji, przeciwstawienia, paraleli, konkluzji, eksplikacji, uzasadnienia, potwierdzenia, argumentu itp. Operatory te występują zwykle na początku zdania (niekiedy w drugiej pozycji) i stanowione są przez partykuły, spójniki i przysłówki o znaczeniu addytywnym (np.: praeterea, porro, ceterum, item, atque, ac), adwersatywnym (np.: at, autem, quidem, atque), konkluzywnym (np. igitur, ergo, itaque, quocirca, proinde), eksplikatywnym (np. nam, enim) itp. Wiele spośród pełniących tę funkcję leksemów jest wieloznacznych, liczne też mogą przyjmować funkcję konektorów. W niektórych przypadkach rozstrzygnięcie $\mathrm{w}$ kwestii statusu operatora bądź konektora jest trudne $\mathrm{z}$ uwagi na możliwość różnej segmentacji tekstu, odzwierciedlanej interpunkcją. Rozwiązaniem pozwalającym na uniknięcie tej trudności mogłoby być przyjęcie szerokiej definicji konektora jako składnika zdania będącego wykładnikiem wszelkich relacji, tj. relacji zachodzących nie tylko między niezdaniowymi (i zdaniowymi) składnikami danego zdania (złożonego), ale także między (zdaniowymi) składnikami całej wypowiedzi, zwłaszcza że również sygnalizowanie relacji wewnątrzzdaniowych wiąże się $w$ wielu przypadkach z nadawaniem wypowiedzi spójności retorycznej. Na potrzeby tego opracowania przyjęto jednak umowną zasadę przypisywania statusu operatora nawiązania międzywypowiedzeniowego tym jednostkom leksykalnym, które wprowadzają zdania oddzielone od poprzednich kropką lub średnikiem. Zamieszczone niżej cytaty ilustrują użycie tego typu operatorów w tekstach: 
(Druides) in primis hoc volunt persuadere non interire animas, sed ab aliis post mortem transire ad alios, atque hoc maxime ad virtutem excitari putant metu mortis neglecto. Multa praeterea de sideribus atque eorum motu [...] disputant et iuventuti tradunt. (Caes., Gall. 6, 14)

„(Druidzi) przede wszystkim do tego chcą przekonać, że dusze nie giną, lecz po śmierci przechodzą z jednych (cial) do innych, i uważają, że przekonanie to, usuwając strach przed śmiercią, bardzo pobudza do waleczności. Ponadto wiele dysputują o ciałach niebieskich oraz ich ruchu i (wiedzę o tym) przekazują młodzieży".

Ser. Tullius regnavit annos quattuor et quadraginta ita, ut bono etiam moderatoque succedenti regi difficilis aemulatio esset; ceterum id quoque ad gloriam accessit, quod cum illo simul $[\ldots]$ regna occiderunt. (Liv., 1,48 )

„Serwiusz Tulliusz panowal przez czterdzieści cztery lata w taki sposób, że nawet dobremu i powściągliwenu następcy trudno byłoby mu dorównać; poza tym do jego chwały przyczyniło się również to, że wraz z nim zakończyły się rządy królewskie".

Milites dato signo celeriter ad munitiones perveniunt eamque transgressi trinis castris potiuntur; ac tanta fuit in capiendis castris celeritas, ut Teutomatus [...] vix se ex manibus praedantium militum eriperet. (Caes., Gall. 7,46)

„Żołnierze na dany znak szybko podchodzą pod obwarowanie i po jego sforsowaniu zawladnęli trzema obozami; a taka była szybkość w zajmowaniu obozów, że Teutomatus ledwo wyrwal się z rąk plądrujących (je) żołnierzy".

Ad quos (scil. Sugambros) cum Caesar nuntios misisset, qui postularent eos, qui sibi Galliaeque bellum intulissent, sibi dederent, responderunt populi Romani imperium Rhenum finire [...]. Ubii autem, qui uni ex Transrhenis ad Caesarem legatos miserant [...], magnopere orabant, ut sibi auxilium ferret. (Caes., Gall. 4, 16)

„Gdy Cezar wystał do Sugambrów postów z żądaniem, by wydali mu tych, którzy jemu i Galli wypowiedzieli wojnę, odpowiedzieli mu, że władza ludu rzymskiego kończy się na Renie. Natomiast Umbrowie, którzy jako jedyni spośród plemion zareńskich wyprawili do Cezara posłów, usilnie błagali, by przyszedł im z pomocą".

Agite, ite actutum, nam mi amatori seni coquendast cena. Atque, quom recogito, nobis coquendast, non quoi conducti sumus. (Pl., Merc. 741-742)

„Dalej, chodźcie prędko, bo muszę staremu amantowi przygotować ucztę. Jednak, gdy o tym myślę, to (dochodzę do wniosku, że raczej) sobie powinienem przygotować, nie temu, który mnie wynająt".

Nescio alias; me quidem semper scio fecisse sedulo, ut ex illiu' commodo meum compararem commodum. (Ter., Heaut. 396-397)

„Nie wiem jak inne; wiem, że ja w każdym razie zawsze bardzo się starałam, aby z jego szczęścia wynikało także moje".

Erat penes principes tota res publica [...] non oppositis tribunis plebis, nullis aliis adiunctis magistratib us, non provocatione ad populum contra necem et verbera relicta. Ergo horum ex iniustitia subito exorta est maxima perturbatio et totius commutatio rei publicae. (Cic., Rep. 2, 63)

„Cale państwo znajdowało się we władzy patrycjuszów, jako że nie istniała dla nich przeciwwaga w postaci trybunów ludowych, nie zostaly dodane żadne nowe urzędy i nie pozostawiono prawa odwolania się do ludu od wyroku skazującego na śmierć lub chlostę. Tak więc wskutek niesprawiedliwości wynikającej z tego stanu wkrótce zrodzily się wielkie zamieszki i przemiany ustrojowe państwa". 
Moleste antea ferebat miles se suo sumptu operam rei publicae praebere [...]. Gaudet nunc fructui sibi rem publicam esse et laetus stipendium accipit; aequo igitur animo patiatur se ab re familiari, cui gravis impensa non est, paulo diutius abesse. (Liv., 5,4$)$

„Przedtem ciężko było żołnierzowi służyć rzeczpospolitej na własny koszt. Dzisiaj cieszy się, że rzeczpospolita przynosi mu korzyści i z radością przyjmuje żołd; niechaj więc ze spokojem godzi się na dłuższy pobyt z dala od swych włości, skoro nie musi już za to ponosić ciężkich kosztów".

Eiusmodi tempestates sunt consecutae, uti $[\ldots]$ continuatione imbrium diutius sub pellibus milites contineri non possent. Itaque [...] Caesar exercitum reduxit et in Aulercis [...] in hibernis conlocavit. (Caes., Gall. 3, 29)

„Nastały dni $z$ tak zlą pogodą, że wskutek nieustających deszczów nie można było dłużej trzymać żołnierzy pod namiotami. Cezar wycofał zatem wojsko i rozmieścił w obozach zimowych w kraju Aulerków".

In amicitia [...] nihil fictum est, nihil simulatum est, quidquid est, id est verum et voluntarium. Quapropter a natura mihi videtur potius quam ab indigentia orta amicitia, adplicatione magis animi cum quodam sensu amandi quam cogitatione, quantum illa res utilitatis esset habitura. (Cic., Lael. 26-27)

„W przyjaźni nic nie jest sztuczne, nie ma niczego udawanego, a wszystko co jest, jest prawdziwe i dobrowolne. Dlatego wydaje mi się, że przyjaźń bierze swój początej raczej z natury niż z potrzeby, raczej z przywiązania ludzkiego charakteru do jakiegoś poczucia milości niż z kalkulowania, ile ta rzecz przyniesie korzyści".

In conspectu Caesaris atque omnis exercitus res gerebatur, ut nullum paulo fortius factum latere posset. Omnes enim colles et loca superiora, unde erat propinquus despectus in mare, ab exercitu tenebantur. (Caes., Gall. 3, 14)

„Walka toczyła się na oczach Cezara i calego wojska, tak że żaden co odważniejszy czyn nie mógł pozostać niezauważony. Wszystkie bowiem wzgórza i wyżej położone miejsca, skąd roztaczał się widok na niedalekie morze, zajęte były przez wojsko".

(Legati) iusserunt pronuntiari, ut (milites) impedimenta relinquerent atque in orbem consisterent. Quod consilium [...] hostes ad pugnam alcriores effecit, quod non sine summo timore et desperatione id factum videbatur. Praeterea accidit [...], ut vulgo milites ab signis discederent, quaeque quisque eorum carissima haberet, ab impedimentis petere atque arripere properaret, clamore et fletu omnia complerentur. At barbaris cosnilium non defuit. Nam duces eorum tota acie pronuntiari iusserunt, nequis ab loco discederet; illorum esse praedam atque illis reservari quaecumque Romani reliquissent; proinde omnia in victoria posita existimarent. (Caes., Gall. 5, 33-34)

„(Legaci) kazali ogłosić, aby żołnierze porzucili tabory i ustawili się w szyku kolistym. Manewr ten zachęcił nieprzyjaciół do walki, ponieważ sprawił wrażenie, że uczyniono to $z$ wielkiego przerażenia i desperacji. Ponadto zdarzyło się, że żołnierze tłumnie zaczęli odchodzić od swych oddziałów i każdy $z$ nich spieszył, aby z taborów wydobyć i zabrać to, co mial nacenniejszego, a wszystko wypelniał krzyk i lament. Natomiast barbarzyńcom nie zabrakło roztropności. Ich wodzowie bowiem rozkazali oglosić calemu ustawionemu do boju oddzialowi, by nikt nie opuszczal swego stanowiska; wszystko, co Rzymianie porzuca, stanowi ich lup i dla nich jest przeznaczone; dlatego niech będą przekonani, że wszystko zależy od męstwa".

Inscendam aliquem in arborem indeque observabo, aurum ubi abstrudat senex. Quamquam hic manere me erus sese iusserat; certum est, malam rem potius quaeram cum lucro. (Pl., Aul. 679-681) 
„Wdrapię się na jakieś drzewo, skąd zobaczę, gdzie stary chowa zloto. Chociaż pan kazal mi tutaj zostać; ale niech tam: lepiej poszukam guza, ale z zyskiem!"

Specyficzny, świadczący również o funkcjonalnej bliskości operatorów nawiązania międzywypowiedzeniowego i konektorów, jest status takich leksemów jak np.: sin 'jeśli jednak, lecz jeżeli', quodsi 'jeśli zaś, a gdyby; jeżeli więc, zatem jeśli’, które $\mathrm{z}$ jednej strony nawiązują do treści wyrażonej w poprzedzającym zdaniu, $\mathrm{z}$ drugiej natomiast sygnalizują wprowadzenie poprzednika okresu warunkowego $\mathrm{w}$ zdaniu, do którego należą (przy czym zdanie poprzedzające stanowić może zarówno współrzędny składnik w ramach zdania złożonego, jak i zdanie odrębne, zakończone kropką lub średnikiem):

Pro quibus rebus (Caesar) hortatur ac postulat, ut (senatores) rem publicam suscipiant atque una secum administrarent; sin timore defugiant, illis se oneri non futurum et per se rem publicam administraturum. (Caes., Civ. 1, 32)

„W związku z tym (Cezar) napomina i domaga się, aby (senatorowie) podjęli troskę o państwo i wspólnie z nim sprawowali rządy; jeśliby jednak ze strachu uchylali sie od tego, nie będzie dla nich ciężarem i będzie rządzić rzeczpospolitą".

'Etiam nunc', inquit, 'regredi possumus; quodsi ponticulum transierimus,omnia armis agenda erunt'. (Suet., Iul. 32)

"Jeszcze teraz', powiada, 'możemy się wycofać; ale jeśli przejdziemy przez ten mostek, o wszystkim decydować będzie musiał oręż".

Epicurei num desistunt de isdem, de quibus et ab Epicuro scriptum est et ab antiquis, ad arbitrium suus scribere? Quodsi Graeci leguntur a Graecis isdem de rebus alia ratione compositis, quid est, cur nostri a nostris non legantur? (Cic., Fin. 1, 6)

„Czy epikurejczycy rezygnują z pisania na swój sposób o tym, o czym pisal już i Epikur i żyjący przed nimi (zwolennicy tego kierunku)? Jeżeli więc Grecy czytają Greków omawiających te same rzeczy innym sposobem, to dlaczego Rzymianie nie mieliby czytać naszych autorów?"

\subsubsection{Operatory modalne}

Jak wiadomo, orzeczenie obligatoryjnie sygnalizuje określony rodzaj modalności za pośrednictwem wartości kategorii trybu (współ)konstytuującego go czasownika (por:: audit/audiat/audi), albo poprzez swoją wewnętrzną strukturę leksykalno-morfologiczną (por.: potest audire / audire videtur / auditurus est). Do operatorów modalnych zaliczamy takie składniki zdania, które modyfikują modalność orzeczenia nie wchodząc w jego skład, tzn. po ich usunięciu orzeczenie zachowuje swój status, ma poprawną formalnie postać i wyraża tę samą treść predykatywną, choć w innej perspektywie modalnej (por. np.: certe scio - scio, wobec: potest audire - audire, czy auditurus est - est).

Za pośrednictwem operatorów modalnych, których funkcję pełnią głównie partykuły, wyrażana jest $w$ łacinie przede wszystkim epistemiczna modalność zdaniowa (propozycjonalna, ekstradyktalna). Np. za pośrednictwem operatorów stanowionych 
przez partykuły typu: sane, certe, profecto wyrażone zostaje przekonanie co do konieczności lub prawdziwości stanu komunikowanego przez wyrażenie predykatywne:

Is est, certe is est, is est profecto. (Pl., Trin. 1071-1072)

"To on, to jest na pewno on, on to jest bez wątpienia".

Reliquorum factorum eius, patres conscripti, difficilis est sane reprehensio et lubrica. (Cic., Phil. 2, 59)

„Krytyka jego pozostałych czynów, senatorowie, jest doprawdy trudna i niebezpieczna”.

Z kolei partykuły takie jak: forsan, forsitan, fortasse itp. pełnią funkcję operatorów, które wyrażaną treść ukazują jako możliwą czy prawdopodobną:

Forsan et haec olim meminisse iuvabit. (Verg., Aen. 1, 203)

„Może kiedyś wspominanie także i tego będzie sprawialo radość".

Forsitan [...] quaeris, quare solus Corinthea vera possideam. (Petron., Sat. 50)

„Być może zastanawiasz się, dlaczego tylko ja sam posiadam prawdziwe korynckie (brązy)”.

Quaeres fortasse, quo modo, et recte. (Cic., Tusc. 2, 43)

„Być może zapytasz, w jaki sposób, i będzie to pytanie zasadne".

Operatory nadające treściom predykatywnym status stanu prawdopodobnego czy możliwego mogą jednak mieć również bardziej złożoną strukturę, np. wyrażenia werbalnego z partykułą an typu: nescio an, haud scio an, dubito an ('nie wiem czy nie..., 'chyba', 'bodaj,' 'prawdopodobnie'):

C. Sulpicius Olympus [...] mortuus est $C$. Sacerdote praetore, nescio an antequam Verres praeturam petere coeperit. (Cic., Verr. 2, 1, 125)

„Gajusz Sulpicjusz Olympus umarl za pretury Gajusza Sacerdosa, bodaj/chyba jeszcze zanim Werres zaczął starać się o preturę".

Crudele gladiatorum spectaculum et inhumanum non nullis videri solet, et haud scio an ita sit, ut nunc fit. (Cic., Tusc. 2, 41)

„Niektórym widowisko gladiatorskie często wydaje się czymś okrutnym i nieludzkim, i nie wiem, czy tak właśnie nie jest ( = i chyba tak wlaśnie jest), gdy chodzi o to, jak dzisiaj one przebiegaja".

Si per se virtus sine fortuna poneranda est, dubito an hunc primum omnium ponam. (Nep., Thras. 1)

„Jeśli należałoby oceniać samo tylko męstwo jako takie, bez uwzględnienia roli losu, to chyba jego postawiłbym ponad wszystkich".

Operatory partykułowe służą także do wyrażania dwojakiego rodzaju modalności intencjonalnej. Jedną $\mathrm{z}$ nich jest modalność interrogatywna, którą mogą sygnalizować operatory takie jak: utrum, an, num 'czy?', np.:

Utrum ea vestra an nostra culpa est? (Cic., Lucull. 95)

„Czy to jest wasza albo nasza wina?"

An id ioco dixisti? (Pl., Amph. 964) 
„Czy powiedziałeś to żartem?"

Num negare audes? (Cic., Catil. 1, 8)

"Czy odważysz się zaprzeczyć?"

Oprócz tego partykuła utinam jest wykładnikiem modalności dezyderatywnej, np.:

Falsus utinam vates sim! (Liv., 21, 10)

„Obym był falszywym prorokiem!"

Utinam me mortuum prius vidisses. (Cic., $Q$. fr. $1,3,1$ )

„Obyś był wcześniej zobaczył mnie martwym (= Szkoda, że wcześniej nie umarłem)".

\subsubsection{Operatory presupozycji}

Operatory presupozycji to składniki wypowiedzenia, które implikują (= presuponują) dodatkowe, niewyrażone wprost treści, odwołując się do okoliczności znanych nadawcy i odbiorcy lub stanowiących kontekst danej wypowiedzi. Por. np. zdanie: Marek zdat egzamin $z$ matematyki ze zdaniami: Nawet Marek zdat egzamin $z$ matematyki / Wreszcie Marek zdał egzamin z matematyki. W tych dwóch ostatnich każdy $\mathrm{z}$ wyrazów je rozpoczynających presuponuje jakieś treści, których nie wyraża wprost. Np. w pierwszym z nich wyraz nawet może implikować informację, że egzamin był łatwy, a wiedza matematyczna nie była szczególnym atutem Marka, albo że bardzo wiele osób zdecydowało się na wybór egzaminu z matematyki, chociaż być może tak jak Marek - tego nie planowali. W drugim z nich wyraz wreszcie może presuponować, że Marek kilkakrotnie bez powodzenia próbował zdać egzamin z matematyki albo kilkakrotnie go przekładal, albo bardzo długo się do niego przygotowywał. Jak wspomniano, treści te nie są jednak wyrażane wprost, a jedynie presuponowane, zaś identyfikacja tego, która $\mathrm{z}$ możliwych (wariantywnych) informacji jest presuponowana, determinowana jest wiedzą nadawcy i odbiorcy komunikatu na temat realnych okoliczności, których dotyczy dane wypowiedzenie, bądź jego wcześniejszym kontekstem. Należy zauważyć, że omawiane wyrazy mogą też konotować określoną interpretację komunikowanej sytuacji ze strony nadawcy, jego subiektywną ocenę zdarzenia czy postawę wobec niego lub jego uczestników. Dzięki temu operatory presupozycji stać się mogą narzędziem swoistego "cieniowania” czy „konturowania” wypowiedzi, uwypuklania jej określonych elementów, a także dyskretnego komentowania, wartościowania, prowadzenia subtelnej, intelektualnej gry z odbiorcą. W odniesieniu do przywołanych wyżej operatorów nawet i wreszcie można powiedzieć, że pierwszy z nich pozwala ukazać określone treści jako coś nieoczywistego, drugi jako coś (od dawna) oczekiwanego.

W języku lacińskim funkcję operatorów presupozycji pełnią przede wszystkim partykuły i przysłówki typu: iam, praeterea, tandem, denique, demum, solum, praecipue, etiam, quidem, ne ... quidem: 
Iam res Roman adeo erat valida, ut cuilibet finitimarum civitatum bello par esset. (Liv., $1,9)$

„Już państwo rzymskie było na tyle silne, że każdemu sąsiedniemiu miastu mogło sprostać na wojnie".

Eodem tempore duobus praeterea locis pugnatum est. (Caes., Civ. 3, 52)

„W tym samym czasie walczono oprócz tego w dwóch innych miejscach”.

Profectus est aliquando tandem in Hispaniam; sed tuto, ut ait, pervenire non potuit. (Cic., Phil. 2, 75)

„Kiedyś wyruszył wreszcie do Hiszpanii; nie mógł jednak - jak twierdzi - bezpiecznie dotrzeć".

Tum demum Liscus oratione Caesaris adductus, quod antea tacuerat, proponit. (Caes., Gall. 1, 17)

„Wtedy dopiero Liskus, pod wpływem przemówienia Cezara, wyjawia to, co wcześniej przemilczał".

De re una solum dissident, de ceteris mirifice congruunt. (Cic., Leg. 1, 53)

„Co do jednej tylko rzeczy różnią się (oni między sobą), w pozostałych (kwestiach) są nadzwyczaj zgodni".

(Principes Germanorum) gaudent praecipue finitimarium gentium donis. (Tac., Germ. 15)

„(Naczelnicy plemion germańskich) cieszą się zwłaszcza z darów otrzymywanych od sąsiednich ludów".

Dulce enim etiam nomen est pacis. (Cic., Phil. 13, 1)

„Słodkie jest bowiem nawet (samo) słowo 'pokój”".

Omnes id quidem facere debebamus. (Cic., Phil. 8, 30)

„Wszyscy to wlaśnie powinniśmy byli czynič".

Proficiscitur in Hispaniam Caesar paucis tibi ad solvendum propter inopiam tuam prorogatis diebus. Ne tum quidem sequeris. (Cic., Phil. 2, 74)

„Wyrusza Cezar do Hiszpanii, przedłużając o kilka dni termin spłaty długu z powodu twego ubóstwa. Nawet wtedy nie ruszasz za nim".

W funkcji tej mogą wystąpić również spójniki: et, neque, nec:

De Philotimo idem et ego arbitrabar. (Cic., Att. 12, 48, 1)

„O Filotymie również ja myślałem to samo”.

Neque eo anno quicquam belli externi fuit. (Liv., 3, 32)

„Również tego roku nie było żadnej wojny poza granicami".

Maxime ab omni $[\ldots]$ contagione Romanorum abstinebat, ut neque scribi sibi vellet. (Liv., $40,20)$

„Powstrzymywał się jak tylko mógl od kontaktów z Rzymianami, tak że nawet nie chcial, by do niego pisali". 
Ita primis repulsis Maharbal cum maiore robore virorum missus nec ipse eruptionem cohortium sustinuit. (Liv., 23, 18)

„Po tym, gdy pierwsi zostali $w$ ten sposób odpędzeni, również sam Maharbal, wysłany $\mathbf{z}$ większą masą ludzi, nie wytrzymał ataku kohort".

Pod względem funkcjonalnym (semantycznym) cechy operatora presupozycji wykazuje również zaimek ipse, choć $\mathrm{z}$ drugiej strony jego właściwości morfologiczne i sposób wiązania się z innymi składnikami zdania pozwalają na formalne przypisanie mu (jak wszystkim innym zaimkom) statusu członu syntaktycznego:

Exercitus maximos saepe pulsos et fugatos esse dico terrore ipso impetuque hostium sine cuiusquam non modo morte verum etiam volnere. (Cic., Caecin. 41)

„Twierdzę, że ogromne wojska wielokrotnie zostały pokonane i przepędzone samym tylko strachem spowodowanym natarciem nieprzyjaciól, gdy nikt nie został nie tylko zabity, ale nawet ranny".

Te ipsum quaero. (Ter., Adelph. 266)

„Wlaśnie ciebie szukam”.

Nunc tamen ipsum sine te esse non possum. (Cic., Att. 12, 16)

„Jednak właśnie teraz nie mogę być bez ciebie".

Ipse sapiens sustinet se in furore ne adprobet falsa pro veris. (Cic., Lucull. 53)

„Nawet mędrzec, gdy jest uniesiony gwałtownym uczuciem, powstrzymuje się (od wydania osądu), by nie uznać fałszu za prawdę".

Nobis monendi sunt ii [...], qui [...] dici se desiderant Atticos [...], ut mirentur hunc maxume, quo ne Athenas quidem ipsas magis credo fuisse Atticas. (Cic., Orat. 23)

„Muszę przypomnieć tym, którzy chcą być nazywani (mówcami) attyckimi, aby z podziwem patrzyli przede wszystkim na tego ( $\mathrm{tj}$. Demostenesa), od którego, jak sądzę, nawet same Ateny nie były bardziej attyckie".

Iulius Celsus tribunus in vinclis laxatam catenam [...] in diversum tendens suam ipse cervicem perfregit. (Tac., Ann. 6, 14)

„Trybun Juliusz Celsus ciągnąc $w$ więzieniu rozluźniony lańcuch w przeciwne strony, sam skręcil swój kark".

Nostram ipsorum libertatem subrui et temptari patimur. (Liv., 41, 23)

„Pozwalamy, by nasza wlasna wolność byla podważana i wystawiana na próbę".

Ponadto spójnik et oraz kombinacje tego spójnika, enklitycznego -que, spójnika atque i neque z partykułami vero, quidem oraz zaimkiem is pełnić mogą funkcję operatora modulującego komunikowaną treść i implikującego określoną interpretację czy ocenę wyrażanej sytuacji poprzez podkreślenie szczególnego znaczenia jakiejś cechy bądź okoliczności dotyczących któregoś z jej elementów:

Caesar effecit [...], ut potius privato paucorum et latronum, quam regio consilio susceptum bellum videretur. (Caes., Civ. 3, 109)

"Cezar sprawił, iż wydawało się, że wojna została wywołana raczej wskutek osobistego zamysłu kilku ludzi, i to bandytów, niż w wyniku decyzji króla". 
Dicitur quidem istuc $[\ldots]$ a Cotta, et vero saepius, credo, ne communia iura migrare videatur. (Cic., Div. 1, 8)

„To właśnie mówi Kotta, i to nader często, jak sądzę, by nie wydawało się, że wykracza poza powszechnie przyjęte prawa".

Duo milia iugerum campi Leontini Sexto Clodio rhetori adsignasti, et quidem immunia. (Cic., Phil. 2, 43)

„Przyznałeś retorowi Sekstusowi Klodiuszowi dwa tysiące iugerów (ziemi) na Polu Leontyńskim, i to zwolnionych od podatku".

Hortatus est, ne ea, quae accidissent, graviter ferrent, neve [...] multis secundis proeliis unum adversum, et id mediocre, opponerent. (Caes., Civ. 3, 73)

„Wezwal, by tego, co się stało, nie przeżywali tak ciężko i by wielu zwycięskich bitew nie stawiali na równi z jedną przegraną, i to niezbyt ważną".

Est et alius ex historiis usus et is quidem maximus. (Quint., Inst. 10, 1, 34)

„Jest jeszcze $\mathrm{i}$ inny pożytek $\mathrm{z}$ historii, $\mathrm{i}$ to ogromny”.

Totos dies potabatur atque id locis pluribus. (Cic., Phil. 2, 67)

„Przez cale dnie pito, i to $w$ wielu miejscach”.

Cum hoc $[. .$.$] decertandum est, idque confestim. (Cic., Phil. 5, 33)$

„Z nim należy stoczyć rozstrzygającą walkę, i to natychmiast".

Legionem neque eam plenissimam [...] propter paucitatem despiciebant. (Caes., Gall. $3,2)$

„Na legion, i to nie całkiem pełny, patrzyli z pogardą ze względu jego niewielką liczebność".

\subsubsection{Operatory kwantyfikacji i negacji}

Za pomocą operatorów kwantyfikujących sygnalizuje się stopień czy też zakres adekwatności określonych składników wypowiedzenia w stosunku do odpowiadających im elementów sytuacji (treści) komunikowanej przez to wypowiedzenie. Operatory te stanowione są przez przysłówki i przyimki typu: prope, paene, fere, circa, vix, omnino, quasi 'prawie,' 'niemal,' 'około,' 'ledwo', 'zupełnie,' 'całkiem,' 'w ogóle'.

Accepi ab Aristocrito tris epistulas, quas ego lacrimis prope delevi. (Cic., Fam. 14, 3, 1)

„Otrzymałem od Arystokryta trzy listy, które łzami niemal zmazałem”.

Cum Samnitibus bellum per centum prope annos [...] tulerimus. (Liv., 23, 5)

„Wojnę z Samnitami prowadziliśmy przez prawie sto lat".

Hispani fere omnes incolumes $[\ldots]$ in castra contenderunt. (Liv., 22, 18)

„Hiszpanie niemal wszyscy bez szwanku udali się do obozu”.

Deleta (est) Ausonum gens vix certo defectionis crimine. (Liv., 9, 25)

„Lud Auzonów został wycięty, chociaż zarzut dopuszczenia się buntu był nie całkiem pew'ny". 
(Dixit) non esse tamen desertam omnino rem publicam. (Liv., 2, 27)

"(Powiedział, że) ojczyzna nie została jednak zupelnie opuszczona".

Nemo fuit omnino militum, quin vulneratur. (Caes., Civ. 3, 53)

„Nie było w ogóle nikogo spośród żołnierzy, kto nie zostalby ranny".

Blisko operatorów kwantyfikacji lokowane są często kwantyfikatory negacji stanowione przez partykuły non, haud, które mogą być interpretowane jako indeksy nieadekwatności opatrzonych nimi wyrażeń w stosunku do komunikowanej sytuacji:

Quae contumelia non fregit eum, sed erexit. (Nep., Them. 1)

"Ta zniewaga nie zlamala go, lecz dodala mu sil”.

Profecto me, haud uxorem, ulciscitur. (PI., Men. 126)

„Wszak to na mnie się mści, nie na żonie".

Oczywiście, wskazać można wiele innych jeszcze leksemów wyrażających przeczenie, jednak ich tekstowe reprezentacje w strukturze wypowiedzenia (zdania) z różnych względów nie są klasyfikowane jako operatory negacji. Np. partykuły i spójniki typu: ne, neque, nec, neve, neu pełnią - odpowiednio - funkcje implikujących negację konektorów albo operatorów presupozycji lub modalności. Z kolei zaimki przeczące: nemo, nihil, nullus, neuter, numquam, nusquam wypełniają pozycje członów syntaktycznych. Wyjątek mogą stanowić jedynie zaimki nihil i nemo użyte w miejsce partykuły przeczącej, które wyrażając wzmocnioną negację, kumulują funkcje operatora negacji i kwantyfikacji:

Oenomao tuo nihil utor. (Cic., Fam. 9, 16, 4)

„Twojego Oinomaosa w ogóle nie używam”.

Fortasse tu huc vocatus es ad prandium, ille, qui vocavit, nullus venit? (Pl., Rud. 143)

„Może ty zostaleś tu zaproszony na śniadanie, a ten, kto (cię) zaprosil, w ogóle nie przyszedt?"

\subsubsection{Operatory emotywne (ekspresywne i impresywne)}

Operatory ekspresywne to składniki wypowiedzenia, które zdradzają emocje żywione przez jego autora, lub - użyte w sposób świadomy - celowo je sygnalizują, stając się w ten sposób narzędziem służącym osiąganiu określonych celów komunikacyjnych. Należy zaznaczyć, iż w ramach aktu komunikacji emocje ujawniane są na bardzo wiele i bardzo różnych sposobów, np. poprzez modulację głosu, stosowanie zdrobnień, spieszczeń, zgrubień, odpowiednie nacechowanie stylistyczne wypowiedzi itp. Status operatorów emotywnych mają jednak tylko te leksykalne składniki wypowiedzenia, które w jego ramach nie pełnią żadnej funkcji przedstawieniowej, stanowiąc wyłącznie językowy wykładnik ekspresji. Status taki będą więc miały przede

1 W tym przykładzie funkcja realizowana przez zaimek nullus odpowiada typowi przydawki, określanej jako praedicativum; zob. wyżej: 3.2.2.4.2. 
wszystkim wszelkie wyrażenia o charakterze eksklamatywnym, a więc wykrzyknienia, wyrażenia wykrzyknikowe, zawołania, zaklęcia, przekleństwa itp.:

Syrum inpulsorem, vah, quibus illum lacerarem modis! (Ter., Adelph. 315)

„Syrusa podżegacza, ach, na ileż to sposobów rozszarpałbym go na kawałki!”

Eheu, quam nunc totu' displiceo mihi, quam pudet! (Ter., Heaut. 1043-1044)

"Och, jaką czuję teraz niechęć do siebie, jak mi wstyd!”

Quid aliud volui dicere? Ehem, curate istam diligenter virginem. (Ter., Eun. 504-505)

„Co to ja jeszcze chcialem powiedzieć? Aha, zadbajcie pilnie o tę dziewczynę".

Euge euge, lepide, laudo commentum tuom. (Pl., Mil. 241)

„Brawo, świetnie, podoba mi się twój pomysł”.

Quis, pro deum fidem, ita conparatus [...] fortissimum virum non vicerit? (Liv., 44, 38)

„Któż, na litość boską, tak przygotowany nie pokonałby nawet najdziel niejszego czlowieka?”

Est mihi iucunda [...] vestra erga me voluntas, sed eam per deos immortalis deponite atque [..] de vobis ac de vstris liberis cogitate. (Cic., Catil. 4,1 )

„Mila jest mi wasza życzliwość dla mnie, lecz, na bogów niesmiertelnych, poniechajcie jej i pomyślcie o sobie, i swoich dzieciach".

Specyficznym rodzajem operatora ekspresywnego, charakterystycznego dla potocznego języka mówionego, jest tzw. dativus ethicus, stanowiony przez użyte $\mathrm{w}$ datiwie zaimki osobowe:

At tibi repente paucis post diebus [...] venit ad me Caninius. (Cic., Fam. 9, 2)

"A tu ci nagle po paru dniach przychodzi do mnie Kaniniusz".

Tu mihi $[\ldots]$ istius audaciam defendis? (Cic., Verr. 3, 213)

"Ty mi tu bronisz zuchwalstwa tego lajdaka?"

Z kolei operatory impresywne stanowione są przez wykrzyknienia, mające na celu głównie przyciągnięcie uwagi adresata komunikatu:

Heus, tibi dico. (Ter., Hec. 523)

„Hej, do ciebie mówię!”

Propero ad filiam. Eho mecum, Crito. (Ter., Andr. 951)

"Idę do córki. Hej, (chodź) ze mną, Kritonie".

Ehodum huc, virgo. (Pl., Pers. 610)

„Hej, tutaj do mnie, dziewczyno!"

\subsubsection{Wyrażenia adresatywne}

Wyrażenia adresatywne to składniki wypowiedzenia, którym także można przypisać status (szeroko rozumianych) operatorów tekstowych $z$ uwagi na ich funkcję 
polegającą na budowaniu określonej strategii nadawczo-odbiorczej wypowiedzenia. Prymarnie członem konstytutywnym wyrażeń adresatywnych jest rzeczownik w wokatiwie, mający status adresatywu i pełniący impresywną funkcję apelu (apostrofy). Wyrażenie adresatywne może więc być ograniczone do samego tylko adresatywu (rzeczownika w wołaczu) lub może być rozbudowane, przyjmując postać zależnej od niego grupy imiennej i/lub zdania względnego (przydawkowego):

Quo usque tandem abutere, Catilina, patientia nostra? (Cic., Catil. 1, 1)

„Doprawdy jak długo jeszcze, Katylino, będziesz nadużywał naszej cierpliwości?”

Video, patres conscripti, in me omnium vestrum ora atque oculos esse conversos. (Cic., Catil. 4, 1)

„Widzę, senatorowie, że na mnie zwrócone są twarze i oczy was wszystkich".

Nolite arbitrari, o mihi carissimi filii, me cum a vobis discessero, nusquam aut nullum fore. (Cic., Sen. 79)

„Nie chciejcie sądzić, o najbardziej mi drodzy synowie, że kiedy już od was odejdę (= umrę), to nie będzie mnie nigdzie albo w ogóle nie będę istnial".

O genitor, cui Cocyti penetralia parent, si modo vera mihi fas est impune profari, vota tibi cedent. (Petron., Sat. 121, 1 (103-105))

„O rodzicielu, któremu podlegają wlości Kokytu, jeśli tylko wolno mi bezkarnie powiedzieć prawdę, to życzenia twe się spelnią".

Adresatywem (członem konstytutywnym wyrażenia adresatywnego) mogą być również substantywizowane formy przymiotnikowe $\mathrm{i}$ imiesłowowe $\mathrm{w}$ wokatiwie. Tego typu adresatywy spotykane są przede wszystkim w poezji:

Quo moriture ruis maioraque viribus audes? (Verg., Aen. 10, 811)

„Dokąd, zatraceńcze, gnasz, porywając się na rzeczy ponad siły?"

Anchisa generate, deum certissima proles, Cocyti stagna alta vides Stygiamque paludem. (Verg., Aen. 6, 322-323)

„Synu Anchizesa, niewątpliwy potomku bogów, patrzysz na glębokie rozlewiska Kocytu i stygijskie bagna".

Tum Cocles: 'Tiberine pater', inquit, 'te sancte precor, haec arma et hunc militem propitio flumine accipias'. (Liv., 2, 10)

„Wtedy Kokles: 'Ojcze Tyberynie', rzecze, 'blagam cię, święty, ugość laskawie w suym życzliwym nurcie ten oręż i tego żołnierza."

W funkcji adresatywnej używane też bywają rzeczowniki w mianowniku, zapewne z uwagi na częstą homonimię wyrazów tekstowych reprezentujących formy wokatiwu i nominatiwu danego leksemu:

Agedum, pontifex publicus populi Romani, praei verba, quibus me pro legionibus devoveam! (Liv., 8, 9)

„Dalej więc, publiczny kaplanie narodu rzymskiego, włpowiadaj slowa, przez których powtórzenie mam się poświęcić za legiony!". 
Da, meus ocellus, [...] argentum mihi. (PI., Asin. 664-665)

"Moje oczko, daj mi to srebro".

\subsubsection{Wybrana literatura}

De Jong (1989), De La Villa (1996), Giannecchini (1985-1986), Herman (1991), Huitink (2005), Kroon, Risselada (1998, 2002), Kroon (1994, 1998, 2005), Langslow (2000), Luraghi (1997, 2010), Maraldi (1980, 1985, 1985), Ramat (1994), Risselada (1994), Risselada (1996, 1998b), Rosén (1996b), Rosén (2009), Torrego (2009), Wharton (1995)

\subsection{ZWIĄZKI SKŁADNIOWE}

Związki składniowe, inaczej związki syntaktyczne, to realacje formalno-semantyczne o charakterze nadrzędno-podrzędnym, których podmiotami są człony syntaktyczne (części zdania) lub ich składniki. Relacje o charakterze współrzędnym określane są terminem związku (połączenia) szeregowego.

O nadrzędno-podrzędnym charakterze relacji między członami syntaktycznymi decydują zarówno względy semantyczne (znaczeniowe), jak i formalne. Z punktu widzenia semantycznego realacja ta opiera się na tym, iż jeden z członów (podrzędny) stanowi określnik drugiego (nadrzędnego), lub też uzupełnienie, które jest przez niego implikowane (wymagane) albo dla którego otwiera on miejsce. $\mathrm{Z}$ punktu widzenia formalnego relacja ta polega zaś na tym, iż postać (forma) jednego z członów ( $t j$. podrzędnego) jest przez drugi (nadrzędny) determinowana, czy też - mówiąc inaczej - jest do niego akomodowana (dostosowywana). Większość związków składniowych charakteryzuje się zarówno wskazanymi wyżej cechami semantycznymi, jak i formalnymi, niektóre jednak opierają się jedynie na właściwościach semantycznych. W zależności od tego, czy i w jaki sposób uwzględniane są czynniki formalne w ramach relacji łączącej człony syntaktyczne, wyodrębnia się trzy podstawowe rodzaje związków składniowych, tj. związek kongruencji, inaczej zgody (w tym dwie jego odmiany, tj. związek kongruencji atrybutywnej i związek kongruencji predykatywnej), związek rekcji, inaczej rządu, i związek przynależności.

\subsubsection{Związek kongruencji (zgody)}

Związek kongruencji (zgody) opiera się na determinacji formy członu podrzędnego przez człon nadrzędny, albo inaczej: akomodacji (dostosowaniu) formy członu podrzędnego do formy członu nadrzędnego. Elementami podlegającymi determinacji (akomodacji) są wartości określonych kategorii fleksyjnych, którymi nacechowane są oba człony, tak więc wykładniki tych wartości, mające charakter morfemiczny, stanowią formalne wskaźniki zespolenia syntaktycznego (wykładniki akomodacji/ determinacji) w ramach tego związku. $Z$ kolei sposób akomodacji (determinacji) 
w jego ramach polega na tym, że wartości kategorii fleksyjnych, wyrażane przez człon nadrzędny, są powtarzane w członie podrzędnym (akomodacja), czy też są one przez człon nadrzędny narzucane członowi podrzędnemu (determinacja). Ze względu na to, że związek ten może łączyć różne człony syntaktyczne (części zdania) i opierać się na różnych kategoriach fleksyjnych, wyodrębnia się dwie jego odmiany, tj. związek kongruencji atrybutywnej (inaczej: związek atrybucji) i związek kongruencji predykatywnej (inaczej: związek predykacji).

\subsubsection{Związek kongruencji atrybutywnej (związek atrybucji)}

Związek atrybucji zachodzi między członem syntaktycznym (współ)stanowionym przez formę rzeczownikową a jego podrzędnym składniowo określnikiem o charakterze (głównie) przymiotnikowym. W ramach tego związku człon rzeczownikowy determinuje wartości kategorii liczby, przypadka i rodzaju przymiotnikowego członu podrzędnego, lub inaczej: podrzędny człon przymiotnikowy akomodowany jest pod względem sygnalizowanych wartości kategorii liczby, przypadka i rodzaju do wartości tych kategorii wyrażanych przez nadrzędny człon rzeczownikowy. Należy przy tym zazanaczyć, że o ile wartości kategorii liczby i przypadka mają swoje morfologiczne wykładniki w obu członach, o tyle wartość kategorii rodzaju ma swój morfologiczny wskaźnik tylko w członie przymiotnikowym. Wynika to $\mathrm{z}$ faktu, iż dla leksemów przymiotnikowych wszystkie trzy wymienione kategorie, tj. liczba, przypadek i rodzaj, mają charakter fleksyjny, a ich wartości znajdują swój skumulowany wykładnik w końcówce fleksyjnej. Innymi słowy, końcówka fleksyjna przymiotnika jest skumulowanym wykładnikiem wartości wszystkich tych trzech kategorii fleksyjnych, tj. liczby, przypadka i rodzaju. Natomiast w odniesieniu do rzeczowników kategoria rodzaju ma charakter nie fleksyjny, lecz klasyfikujący (selektywny). Rzeczownik scharakteryzowany jest jedną wartością kategorii rodzaju przysługującą mu jako jednostce leksykalnej, i wartość ta nie jest ujawniana morfologiczne przez reprezentujące go wyrazy gramatyczne, tzn. końcówka fleksyjna formy rzeczownikowej jest skumulowanym wykładnikiem tylko wartości kategorii liczby i przypadka, a już nie rodzaju. A zatem elementem morfologicznym, który determinuje sygnalizowaną przez końcówkę przymiotnikową akomodację formy przymiotnikowej co do kategorii liczby, przypadka i rodzaju, jest zarówno rzeczownikowa końcówka, ujawniająca wartość kategorii liczby i przypadka, jak i rzeczownikowy temat, identyfikujący reprezentowany przez niego leksem i tym samym przynależną mu wartość kategorii rodzaju. Można więc powiedzeć, że akomodacja członu przymiotnikowego polega na kongruentnym zharmonizowaniu treści gramatycznej zawartej w jego końcówce $\mathrm{z}$ treścią gramatyczną zawartą zarówno w końcówce fleksyjnej rzeczownika, jak i w jego temacie; albo inaczej: sygnalizowana przez końcówkę fleksyjną przymiotnika akomodacja następuje zarówno do końcówki fleksyjnej, jak i do tematu rzeczownika jako nośników określonych informacji gramatycznych. 
Podstawowymi strukturami składniowymi, powiązanymi związkiem kongruencji atrybutywnej, są grupy imienne złożone z rzeczownikowego członu nadrzędnego i przymiotnikowego członu podrzędnego. Człon nadrzędny konstytuowany może być jednak nie tylko przez rzeczowniki, ale i przez rzeczownikowe zaimki, substantywizowane przymiotniki i participia, liczebnik milia. Natomiast człon podrzędny, oprócz przymiotników tworzyć mogą przymiotnikowe zaimki i participia. W ramach grupy imiennej człon nadrzędny pełnić może różne funkcje składniowe, tj. podmiotu (funkcjonalnego odpowiednika podmiotu), dopełnienia, przydawki, okolicznika, adresatywu czy orzecznika (funkcjonalnego odpowiednika orzecznika), natomiast człon podrzędny zajmuje zawsze pozycję przydawki:

Fit magna caedes. (Caes., Gall. 7, 70)

„Następuje wielka rzeź".

Senatus frequens $[\ldots]$ in curiam venit. (Cic., De orat. 3,2 )

„Senat w (niemal) pelnym skladzie zebral się w kurii".

Rem [...] magnam complexus sum. (Cic., Att., 4, 16, 2)

„Podjąłem rzecz wielką".

Cassius [...] Minucium libertis tradidit excruciandum. (Ps.-Caes., Bell. Alex. 55)

„Kasjusz wydał Minucjusza wyzwoleńcom na tortury”.

Erat inter Labienum atque hostem difficili transitu flumen ripisque praeruptis. (Caes., Gall. 6, 7)

„Między Labienusem a nieprzyjacielem znajdowała się rzeka o trudnej przeprawie (= trudna do przeprawy) i urwistych brzegach".

Multa milia hominum $[\ldots]$ cepit. (Liv., 39, 32)

„Pojmał wiele tysięcy ludzi”.

Quae vigilantibus accidunt vatibus, eadem nobis dormientibus. (Cic., Div. 1, 115)

„To samo, co wieszczom na jawie (czuwającym), przytrafia się również nam we śnie ('spiącym)".

Quanta multitudo hominum convenerit ad hoc iudicium, vides. (Cic., S. Rosc. 11)

"Widzisz, jak wielki tlum ludzi zebrał się na tę rozprawę".

Deinde concludebas summum malum esse dolorem. (Cic., Fin. 2, 63)

„Następnie wyciągaleś wniosek, że największym złem jest cierpienie”.

Nolite arbitrari, o mihi carissimi filii, me cum a vobis discessero, nusquam aut nullum fore. (Cic., Sen. 79)

„Nie chciejcie sądzić, o najbardziej mi drodzy synowie, że kiedy już od was odejdę (= umrę), to nie będzie mnie nigdzie albo w ogóle nie będę istnial".

Da, meus ocellus, [...] argentum mihi. (Pl., Asin. 664-665)

„Moje oczko, daj mi to srebro".

Poza grupą imienną w związek kongruencji atrybutywnej wchodzą także: 
a. Podmiot i imiesłowowy bądź przymiotnikowy składnik orzeczenia (złożonego):

Legati ad Fabium consulem missi sunt. (Liv., 9, 41)

„Poslowie zostali wyslani do konsula Fabiusza”.

Licinius Crassus [...] aedilitatem curulem petiturus erat. (Liv., 25, 5)

„Licyniusz Krassus zamierzał ubiegać się o edylat kurulny”.

Voluntas ipsa rectum petens laudanda est. (Sen., Benef. 5, 2, 2)

„Sama chęć zmierzająca ku dobru powinna być chwalona".

Gratum multitudini spectaculum fuit. (Liv., 2, 7)

„Widok był mily dla tłumu”.

Non erat Othonis mollis et corpori similis animus. (Tac., Hist. 1, 22)

„Dusza Othona nie byla zniewieściala i podobna ciału”.

Ille mi par esse deo videtur. (Catull. 51,1)

„Wydaje mi się, że jest on równy bogom”.

Etiam mortui miseri sunt. (Cic., Tusc. 1, 9)

"Nawet zmarli są nieszczęśliwi".

b. Rzeczownikowy orzecznik i imiesłowowy składnik orzeczenia, jeśli ten pierwszy usytuowany jest między podmiotem a imiesłowem:

Numquam aeque [...] ac modo paupertas mihi onu' visumst et miserum et grave. (Ter., Phorm. 93-94)

„Nigdy tak ja teraz (Nigdy dotąd) bieda nie wydawala mi się wielkim i przygniatającym ciężarem".

Gens universa Veneti appellati (sunt). (Liv., 1, 1)

"Caly lud zostal nazwany Wenetami".

c. Rzeczownikowa przydawka apozycyjna i imiesłowowy lub przymiotnikowy składnik (funkcjonalnego odpowiednika) orzeczenia, głównie jeśli apozycyjna przydawka stanowiona jest przez rzeczownik generyczny typu: oppidum, urbs, mons, civitas itp., oznaczający gatunek (rodzaj), do którego należy desygnat (funkcjonalnego odpowiednika) podmiotu, będącego najczęściej nazwą własną:

Corioli oppidum captum (est). (Liv., 2, 33)

„Miasto Korioli zostalo zdobyte".

Urbem Syracusas maximam esse Graecarum, pulcherrimam omnium saepe audistis. (Cic., Verr. 2, 4, 117)

„Często słyszeliście, że miasto Syrakuzy jest największym spośród (miast) greckich, najpiękniejszym ze wszystkich".

Niekiedy kongruencja rzeczownikowej apozycji z przymiotnikowym (imiesłowowym) składnikiem orzeczenia wynika z ich wzajemnej szczególnej łączliwości semantycznej: 
Corinthum patres vestri, totius Graeciae lumen, exstinctum esse voluerunt. (Cic., Manil. 11)

„Przodkowie wasi chcieli, by Korynt, światlość Grecji, zagasl(a)”.

d. Dopełnienie i przymiotnikowy składnik orzeczenia (orzecznik) lub przymiotnikowe uzupełnienie orzecznikowe, wyrażone w akuzatiwie:

(Themistocles) maritimos praedones consectando mare tutum reddidit. (Nep., Them. 2)

"(Temistokles) scigając morskich korsarzy na powrót uczynil morze bezpiecznym".

Iste (scil. Verres) $[\ldots]$ parietes $[\ldots]$ nudos ac deformatos reliquit. (Cic., Verr. 4, 122)

„Ten zaś (scil. Werres) ściany pozostawił nagie i oszpecone".

(Atticus) idoneum tempus ratus studiis obsequendi suis Athenas se contulit. (Nep., Att. 2)

"Attyk, uznawszy czas za dogodny do zajęcia się swoimi studiami, wyjechal do Aten".

e. Funkcjonalny odpowiednik podmiotu i imiesłowowy składnik analitycznego infinitiwu, będącego funkcjonalnym odpowiednikiem orzeczenia $w$ ramach równoważnika zdania (podrzędnego) typu accusativus cum infinitivo:

Constat $[\ldots]$ ad salutem civium civitatumque incolumitatem $[\ldots]$ inventas esse leges. (Cic., Leg. 2, 11)

„Jest wiadomym, że prawa zostały wynalezione dla dobra obywateli i pomyślności państw”.

Ille virtutem suam non defuturam esse profitetur. (Cic., Phil. 3, 34)

„Oświadcza on, że jego męstwa nie zabraknie”.

Per analogiam, za pozostający w związku kongruencji atrybutywnej z funkcjonalnym odpowiednikiem podmiotu może być uznany także syntetyczny infinitivus, jako syntaktyczny ekwiwalent infinitiwów analitycznych, pozbawiony formalnych wykładników powiązania składniowego:

Ex captivis Caesar cognovit Vercingetorigem [...] castra movisse propius Avaricum. (Caes., Gall. 7, 18)

„Cezar dowiedzial się od jeńców, że Wercyngetoryks przesunąl obóz bliżej Awarikum”.

(Stoici) aiunt manere animos, cum e corpore excesserint. (Cic., Tusc. 1, 78)

„(Stoicy) powiadają, że dusze nadal istnieją po tym, gdy wyjdą z cial”.

f. Funkcjonalny odpowiednik podmiotu i przymiotnikowy lub imiesłowowy równoważnik orzecznika, współtworzący funkcjonalny odpowiednik orzeczenia w ramach równoważnika zdania podrzędnego typu accusativus cum infinitivo:

Possum igitur [...] suscensere dicenti non omnis bonos esse beatos? (Cic., Tusc. 5, 25)

"Czyż mogę zatem oburzać się na kogoś mówiącego, że nie wszyscy dobrzy są szczęśliwi?"

Primores patrum $[\ldots]$ censuere $[\ldots]$ extemplo novos tribunos creandos esse. (Liv., 5, 9)

„Najważniejsi z senatorów uznali, że natychmiast powinni zostać wybrani nowi trybuni”. 
g. Funkcjonalny odpowiednik podmiotu i imiesłowowy lub przymiotnikowy odpowiednik orzeczenia (orzecznika) ramach równoważnika podrzędnego zdania okolicznikowego typu ablativus absolutus.

Q. Titurius et $L$. Cotta legati, qui in Menapiorum fines legiones duxerant, omnibus eorum agris vastatis, frumentis succisis, aedificiis incensis [...] ad Caesarem se receperunt. (Caes., Gall. 4, 28)

„Legaci Kwintus Tyturiusz i Lucjusz Kotta, którzy poprowadzili legiony do kraju Menapiów, po tym, gdy wszystkie ziemie Menapiów zostały już spustoszone, zboże wyżęte, a budynki spalone, powrócili do Cezara".

(Claudius) historiam in adulescentia hortante T. Livio, Sulpicio vero Flavo etiam adiuvante, scribere adgressus est. (Suet., Claud. 41)

"(Klaudiusz) przystąpił do pisania swego dzieła historycznego już w mlodości, gdy Tytus Liwiusz go zachęcal, a Sulpicjusz Flawus nawet pomagal".

Człon podrzędny w ramach związku kongruencji atrybutywnej może być stanowiony także przez liczebniki główne (oprócz milia), porządkowe, podziałowe i wielorakie, będące zarówno składnikami grupy imiennej, jak i zajmujące pozycję orzecznika (funkcjonalnego odpowiednika orzecznika):

Videtis $[\ldots]$ igitur unius viri consilio $[\ldots]$ ortum novum populum. (Cic., Rep. 2, 21) „Widzicie zatem nowe społeczeństwo, powołane do życia zamysłem jednego czlowieka”.

Darius $[. .$.$] classem quingentarum navium comparavit. (Nep., Milt. 4, 1)$

„Dariusz wystawił flotę pięciuset okrętów”.

Commius $[\ldots]$ cum equitibus venerat, qui $[\ldots]$ erant quingenti. (Hirt., Gall. 8,10 )

„Kommiusz przybył z jeźdźcami, których było pięćset”.

Hastati legionis undecimae conglobant sese. (Liv., 30, 18)

„Włócznicy jedenastego legionu zwierają szyki”.

Primam aciem quaternae cohortes ex $V$ legionibus tenebat. (Caes., Civ. 1, 83)

„Pierwszy szereg tworzyły po cztery kohorty z pięciu legionów (czyli łącznie 20 kohort)”.

Cohortem [...] duplici stipendio [...] donavit. (Caes., Civ. 3, 53)

„Kohortę nagrodzil podwójnym żoldem”.

W odniesieniu do liczebników głównych należy dodać, że status członu podrzędnego $w$ ramach związku kongruencji atrybutywnej należy przypisać również tym z nich, które cechują się zerowym paradygmatem formalnym (nieodmiennością), czyli takim, jak np.: quinque, decem, triginta, centum, mille. Są one bowiem funkcjonalnymi alternantami i syntaktycznymi ekwiwalentami pozostałych liczebników głównych, charakteryzując się takimi samymi jak one właściwościami dystrybucyjnymi. Posiadają zatem identyczny (nieograniczony) paradygmat funkcjonalny, a jedyna różnica sprowadza się do defektywności ich paradygmatu formalnego w zakresie kategorii rodzaju i przypadka, w związku z czym nie dysponują one morfologicznymi (końcówkowymi) wykładnikami wartości tych kategorii i tym samym formalnymi wskaźnikami akomodacji: 
In $[\ldots]$ triumpho undequinquaginta coronae aureae translatae sunt. (Liv., 37, 58)

„W pochodzie tryumfalnym niesiono czterdzieści dziewięć zlotych wieńców”.

Aristides [...] exilio decem annorum multatus est. (Nep., Arist. 1, 3)

"Arystydes został ukarany wygnaniem dziesięciu lat (dziesięcioletnim)".

Non quaero unde quadraginta amphoras mellis habueris. (Cic., Verr., 2, 2, 183)

„Nie dociekam, skąd mialeś czterdzieści amfor miodu”.

Określniki o charakterze liczebnikowym szczególnie często tworzą dwu- lub trzyelementowe wyrażenia złożone $\mathrm{z}$ połączonych asyndetycznie bądź spójnikowo (przymiotnikowych) liczebników, pełniących funkcje (zestawionych szeregowo) przydawek bądź orzeczników:

Mago $[\ldots]$ mille quingentos equites $[. .$.$] in Italia transmissurus erat. (Liv., 23, 32)$

"Magon mial przeprawić do Italii tysiąc pięciuset jeźdźców".

Centum octoginta sex homines erant. (Liv., 8, 8)

„Było stu osiemdziesięciu sześciu ludzi”.

Erant capitum Helvetiorum milia ducenta sexaginta tria. (Caes., Gall. 1, 29)

„Helwetów było dwieście sześćdziesiąt trzy tysiące".

Duo et viginti milia peditum, mille ducentos equites confecit. (Liv., 23, 40)

„Wystawil dwadzieścia dwa tysiące piechoty i tysiąc dwustu jeźdźców".

(Na temat powiązań składniowych w ramach wyrażeń liczebnikowych zob. też Morfologia 11.2.2.)

Z kolei wśród form mogących stanowić człon nadrzędny (określany) w ramach związku atrybucji wskazać należy jeszcze bezokoliczniki. One również pozbawione są formalnych znaczników łączności syntaktycznej, jednak na ich nacechowanie pod względem kategorii liczby, rodzaju i przypadka wskazują morfologicznie zależne od nich człony przydawkowe lub orzecznikowe:

Ipsum Latine loqui est [...] in magna laude ponendum. (Cic., Brut. 140)

„Samo (poprawne) mówienie po lacinie należy uznać za wielce chwalebne”.

Habere [...] quaestui rem publicam non modo turpe est, sed sceleratum etiam et nefarium. (Cic., Off. 2, 77)

„Traktowanie państwa jako obiektu zysku (= wyzyskiwanie państwa) jest nie tylko odrażające, ale także zbrodnicze i niegodziwe".

W przypadku, gdy jeden atrybutywny określnik przymiotnikowy odnosi się do większej liczby rzeczownikowych nadrzędników o różnych cechach gramatycznych, zwykle zachowuje kongruencję w stosunku do najbliższego $\mathrm{z}$ nich: 
C. Volusenus, [...] vir et consilii magni et virtutis, ad Galbam adcurrit. (Caes., Gall. 3, 5) „Gajusz Wolusenus, człowiek zarówno o wielkiej rozwadze, jak i o (wielkim) męstwie, podbiega do Galby".

Res erat multae operae ac laboris. (Caes., Gall. 5, 11)

"Rzecz wymagala wielkiego wysilku i (wielkiej) pracy".

Falsa vita moresque mei superant. (Sall., Iug. 28)

„Fałszom zadają kłam moje obyczaje i (mój) życiorys”.

Przymiotnikowy określnik stanowiący podstawę bardziej rozbudowanej grupy przydawkowej o charakterze apozycyjnym, intonacyjnie (interpunkcyjnie) oddzielonej od nadrzędnych rzeczowników o różnym rodzaju gramatycznym, przybiera formę liczby mnogiej rodzaju nijakiego, jeśli rzeczowniki te oznaczają obiekty nieożywione:

Labor voluptasque, dissimillima natura, societate quadam inter se naturali sunt iuncta. (Liv., 5, 4)

„Trud i przyjemność, $z$ natury zupełnie niepodobne do siebie, związane są (jednak) z sobą jakimś naturalnym związkiem".

W przypadku, gdy jeden predykatywny określnik przymiotnikowy (imiesłowowy) odnosi się do więcej niż jednego rzeczownikowego nadrzędnika, może on:

a. Zachować kongruencję $\mathrm{w}$ stosunku do najbliższego $\mathrm{z}$ nich:

Factus est [...] strepitus et grata contionis admurmuratio. (Cic., Verr. 1, 1, 45)

„Rozlegl się szmer i pomruk zadowolenia (całego) zgromadzenia”.

Medico diligenti, priusquam conetur aegro adhibere medicinam, non solum morbus eius [...], sed etiam natura corporis cognoscenda est. (Cic., De orat. 2, 186)

„Dbały lekarz, zanim zdecyduje się podać choremu lekarstwo, powinien poznać nie tylko jego chorobę, ale i naturalne uwarunkowania (jego) ciała".

Video, patres conscripti, in me omnium vestrum ora atque oculos esse conversos. (Cic., Catil. 4,1$)$

„Widzę, senatorowie, że na mnie zwrócone są oczy i twarze was wszystkich”.

Patres $[\ldots]$ decrevere legatos sortesque oraculi Pythici exspectandas. (Liv., 5, 15)

„Senatorowie zadecydowali, że należy oczekiwać na posłów i odpowiedź wyroczni pytyjskiej".

b. Wystąpić w liczbie mnogiej, nawet jeśli rzeczownikowe nadrzędniki są w liczbie pojedynczej:

Locutus est sese pro Caesaris in se beneficiis plurimum ei confiteri debere, quod [...] ei et filius et fratris filius a Caesare remissi essent. (Caes., Gall. 5, 27)

„Powiedział, że przyznaje, iż ze względu na dobrodziejstwa wyświadczone jego osobie przez Cezara wiele mu zawdzięcza, ponieważ i jcgo syn, i bratanek, zostali mu za sprawą Cezara zwróceni". 
c. Wystąpić w liczbie mnogiej rodzaju męskiego, jeśli nadrzędne rzeczowniki o różnych rodzajach gramatycznych (w tym także w liczbie pojedynczej) oznaczają obiekty ożywione:

Huc evasit, quam pridem pater mihi et mater mortui essent. (Ter., Eun. 517-518)

„Do tego się uciekla, (tj. zapytała,) jak dawno temu zmarł mój ojciec i matka”.

Uxor deinde ac liberi amplexi (sunt eum). (Liv., 2, 40)

"Następnie żona i dzieci usciskały go".

d. Wystąpić $\mathbf{w}$ liczbie mnogiej $\mathrm{w}$ rodzaju nijakim, jeśli nadrzędne rzeczowniki o różnych rodzajach gramatycznych ( $w$ tym także w liczbie pojedynczej) oznaczają obiekty nieożywione:

Honores, imperia, victoriae [...] fortuita sunt. (Cic., Off. 2, 20)

"Godności, władza, zwycięstwa są zależne od przypadku”.

Fregenis murus et porta de caelo tacta erant. (Liv., 32, 29)

"We Fregenach miejski mur i brama zostaly rażone piorunem".

e. Wystąpić w liczbie mnogiej rodzaju męskiego lub nijakiego, jeśli nadrzędne rzeczowniki o różnych rodzajach (w tym także w liczbie pojedynczej) oznaczają zarówno obiekty ożywione, jak i nieożywione:

Rex regiaque classis una profecti (sunt). (Liv. 21, 50)

„Król i królewska flota ruszyli w drogę razem (z nim)".

Ad Eumenen et ad Antiochum communia mandata (missa sunt) natura inimica inter se esse liberam civitatem et regem. (Liv., 44, 24)

„Do Eumenesa i do Antiocha wyslano wspólne poslanie (mówiące, iż) z natury rzeczy wrogo są względem siebie usposobieni: wolne państwo i król (ustrój królewski)".

Jeśli nadrzędnikiem jest rzeczownik o znaczeniu kolektywnym, przymiotnikowy określnik predykatywny może zachowywać kongruencję nie w stosunku do niego, ale w stosunku do - niewyrażonych powierzchniowo (domyślnych, implikowanych) rzeczowników nazywających obiekty składające się na daną zbiorowość:

Multitudo ingens $[\ldots]$ odio humani generis convicti sunt. (Tac., Ann. 15, 44)

„Wielka ilość (ludzi) zostala uznana za winnych nienawiści do rodzaju ludzkiego".

Signo [...] dato iuventus Romana ad rapiendas virgines discurrit. Magna pars forte in quem quaeque inciderat raptae. (Liv., 1, 9)

„Na dany znak mlodzież rzymska rozbiega się, by porywać dziewczęta. Wielka (ich) çz̧̧ść porwana (została) na oślep, jaka komu wpadła w ręce".

Również w odniesieniu do zaimków o znaczeniu kolektywnym (np.: uterque, quisque, unusquisque), występujących w liczbie pojedynczej, przymiotnikowy określnik może zostać wyrażony w liczbie mnogiej:

Quorum uterque $[\ldots]$ hostes iudicati erant. (Vell. Pat., Hist. Rom. 2, 66)

"Z nich jeden i drugi zostal uznany za wroga". 
Intimus quisque libertorum vincti abreptique (sunt). (Tac., Ann. 15, 35)

"Co bardziej zaufani spośród wywoleńców zostali skrępowani i porwani".

Przymiotnikowy określnik może być wyrażony w liczbie mnogiej także wtedy, gdy odnosi się do jednego nadrzędnika rzeczownikowego w singularis, określonego rzeczownikową przydawką socjatywną $\mathrm{w}$ ablatiwie $\mathrm{z}$ przyimkiem cum:

Demosthenes cum ceteris, qui bene de re publica meriti existimabantur, populi scito in exilium erant expulsi. (Nep., Phoc. 2)

„Demostenes wraz z pozostalymi, których uważano za zasłużonych dla rzeczpospolitej, na mocy uchwaly ludu zostali skazani na wygnanie".

W przypadku, gdy obiekty ożywione (osobowe) denotowane są przez rzeczowniki, których rodzaj gramatyczny nie jest skorelowany $z$ rodzajem naturalnym tych obiektów, przymiotnikowy określnik może przybrać wartość gramatycznej kategorii rodzaju odpowiadającą ich rodzajowi naturalnemu:

Capita coniurationis $[\ldots]$ virgis caesi ac securi percussi (sunt). (Liv., 10, 1)

„Przywódcy sprzysiężenia zostali ubiczowani rózgami i ścięci toporem”.

Jeśli miejsce otwierane $\mathrm{w}$ strukturze składniowej zdania dla podmiotu wypełniane jest przez podrzędne zdanie podmiotowe, przymiotnikowy (imiesłowowy) określnik predykatywny obligatoryjne wyraża wartości nom. sg. neutr.:

In te positum est, ut nostrae sollicitudinis finem quam primum facere possimus. (Cic., Att. $16,16 \mathrm{~b}, 1)$

„Od ciebie jest uzależnione (to), abyśmy mogli jak najszybciej położyć kres naszemu zmartwieniu".

In primis videndum erit [...], ut suum quisque teneat neque de bonis privatorum publice deminutio fiat. (Cic., Off., 2, 73)

„Przede wszystkim przedmiotem troski będzie musiało być (to), aby każdy zachował to, co jego, i żeby z powodu interesu publicznego nie nastąpilo uszczuplenie majątków prywatnych".

Podobnie wartości te są sygnalizowane w przypadku, gdy diateza zdaniowa ma charakter niepodmiotowy, a więc gdy w strukturze składniowej zdania w ogóle nie jest otwierane miejsce dla gramatycznego podmiotu:

Regio [...] abscessum est. (Liv., 24, 1)

„Odstappiono od (miasta) Regium".

Apollinem tam humilis victoriae puditum est. (Apul., Flor. 3, 46)

"Apollinowi wstyd bylo tak haniebnego zwycięstwa".

Człon podrzędny w ramach związku kongruencji atrybutywnej stanowić mogą również rzeczowniki, zarówno w obrębie grupy imiennej, jak i poza nią.

$\mathrm{W}$ ramach grupy imiennej za powiązane $\mathrm{z}$ członem nadrzędnym związkiem atrybucji uważać można rzeczownikowe przydawki apozycyjne (konstytutywne składniki apozycyjnych grup imiennych): 
L. Cotta legatus $[\ldots]$ adversus os funda vulneratur. (Caes., Gall. 5, 35)

"Legat Lucjusz Kotta zostal raniony z procy prosto w twarz".

Hos viros bonos $[. .$.$] putemus, quia sequantur naturam, optimam bene vivendi ducem.$ (Cic., Lael. 19)

„Ich uważajmy za ludzi prawych, ponieważ idą za glosem natury, najlepszej przewodniczki dobrego życia".

L. Tarquinius [...] fratrem habuerat Arruntem Tarquinium, iuvenem mitis ingenii. (Liv., $1,46,4)$

„Lucjusz Tarkwiniusz miał brata Arrunta Tarkwiniusza, mlodzieńca o lagodnym usposobieniu".

Mardonius, satrapes regius, natione Medus, regis gener, [...] haud ita magna manu Graeciae fugatus est. (Nep., Paus. 1)

„Mardoniusz, satrapa królewski, z pochodzenia Med, zięć króla, został rozgromiony przez nie tak wielki oddział wojsk greckich".

Id temporis ego adulescens Romae sectabar eum discendi gratia. (Gell., Noc. Att. 13, $18,3)$

„W tym czasie ja jako mlodzieniec podążalem za nim w Rzymie, by się (od niego) uczyć”.

Jednak z uwagi na selektywny charakter kategorii rodzaju rzeczowników, a w pewnych przypadkach także liczby (pluralia tantum), kongruencja może nie obejmować (którejś z) tych kategorii:

Externus timor, maximum concordiae vinculum, [...] inter se iungebat animos. (Liv., 2, 39)

„Strach przez niebezpieczeństwem z zewnątrz, najlepsze spoiwo zgody, jednoczył wzajemnie ich serca".

Gallos ab Aquitanis Garunna flumen [...] dividit. (Caes., Gall. 1, 1)

„Gallów oddziela od Akwitanów rzeka Garunna”.

Quid ego de M. Marcello loquar, qui Syracusas, urbem ornatissimam, cepit?

"Cóż mam powiedzieć o Marku Marcellu, który zdobył Syrakuzy, prześwietne miasto".

Przydawka apozycyjna lub apozycyjna grupa imienna może stanowić określnik kilku członów rzeczownikowych zestawionych szeregowo; przydawka (lub konstytutywny składnik apozycyjnej grupy imiennej) występuje wówczas w liczbie mnogiej:

Legati ab Ptolemaeo et Cleopatra regibus vocati sunt. (Liv., 44, 19)

„Przywołani zostali posłowie od królów Ptolemeusza i Kleopatry”.

Nec P. Popilius neque Q. Metellus, clarissimi viri atque amplissimi, vim tribuniciam sustinere potuerunt. (Cic., Cluent. 95)

„Ani Publiusz Popiliusz, ani Kwintus Metellus, znakomici i dostojni mężowie, nie mogli oprzeć się władzy trybuńskiej". 


\subsubsection{Związek kongruencji predykatywnej (związek predykacji)}

Związek predykacji zachodzi między rzeczownikową formą wyrazową konstytuującą gramatyczny podmiot zdania a osobową formą czasownika (współ)konstytuującą orzeczenie. W ramach tego związku osobowa forma czasownika akomodowana jest pod względem kategorii liczby i osoby do wartości, którymi w zakresie tych kategorii nacechowany jest wyraz stanowiący podmiot. Akomodacja ta sygnalizowana jest morfologicznie przez formę czasownikową za pośrednictwem końcówki (osobowej), która jest skumulowanym wykładnikiem wartości obu tych kategorii. $\mathrm{Z}$ kolei po stronie podmiotu, jako członu nadrzędnego (akomodującego, determinującego), morfologiczny wykładnik znajduje tylko wartość kategorii liczby, natomiast kategoria osoby stanowi dla reprezentujących podmiot form wyrazowych kategorię o charakterze klasyfikującym (selektywnym), przy czym wartości 1. i 2. osoby wyrażają jedynie zaimki osobowe (odpowiednio ego, nos oraz $t u, v o s$ ), a wszystkie inne formy rzeczownikowe systemowo nacechowane są wartością 3. osoby. Tym samym forma osobowa czasownika, a dokładniej jej końcówka, jest formalnym indeksem wartości kategorii osoby podmiotu, czyli indeksem statusu jego desygnatu w ramach sytuacji aktu mowy:

Tu me amas, ego te amo. (Pl., Most. 305)

„Ty mnie kochasz, ja kocham ciebie”.

Pro his nos habemus luxuriam atque avaritiam. (Sall., Cat. 52)

„Zamiast tych (zalet) my mamy zbytek i chciwość”.

Potestatem omnem vos habetis. (Cic., Mil. 4)

„Wy macie wszelką wladzę".

Cruore scaena abundavit. (Suet., Cal. 57)

„Scena splynęla krwią".

Domi militiaeque boni mores colebantur. (Sall., Cat. 9)

„W czasie pokoju i w czasie wojny pielęgnowane były dobre obyczaje".

W przypadku, gdy składnikiem orzeczenia jest forma imiesłowowa lub przymiotnikowa, wchodzi ona $\mathrm{z}$ wyrazem reprezentującym podmiot $\mathrm{w}$ związek kongruencji atrybutywnej:

Legati ad Fabium consulem missi sunt. (Liv., 9, 41)

„Posłowie zostali wysłani do konsula Fabiusza”.

Gratum multitudini spectaculum fuit. (Liv., 2, 7)

„Widok byl mily dla tlumu”.

Podmiot wyrażony formą bezokolicznikową nacechowany jest wartościami 3 . os. sg.: 
Humanum amare est. (Pl., Merc. 319)

"Czymś ludzkim jest kochać".

Ipsum Latine loqui est [...] in magna laude ponendum. (Cic., Brut. 140)

„Samo (poprawne) mówienie po lacinie powinno być uznane za wielce chwalebne”.

Bardzo często podmiot, czyli człon nadrzędny w ramach związku predykacji, nie jest wyrażony na powierzchni, tzn. jego miejsce w strukturze syntaktycznej zdania pozostaje niewypełnione. Dotyczy to głównie sytuacji, gdy jego desygnat jest identyfikowalny kontekstowo. Osobowa forma czasownika nadal jednak podlega wówczas akomodacji, tj. jej końcówka uwzględnia gramatyczne parametry (kategorii liczby i osoby) niewyrażonego powierzchniowo (domyślnego) podmiotu:

Hac re cognita Caesar mittit complures equitum turmas eodem media nocte; imperat his, ut paulo tumultuosius omnibus locis pervagerentur. Prima luce magnum numerum impedimentorum ex castris mulorumque produci [...] iubet. His paucos addit equites. (Caes., Gall. 7, 45)

„Dowiedziawszy się o tym Cezar o pólnocy wysyła tam liczne oddziały jeźdźców; poleca im, aby z nieco większym hałasem krążyli po wszystkich miejscach. $O$ świcie rozkazuje wyprowadzić z obozu dużą ilość koni jucznych i wołów. Dolącza do nich niewielką liczbę jeźdźców".

Probri insimulasti pudicissimam femminam. (Cic., Phil. 2, 99)

„Najbardziej cnotliwą kobietę fałszywie oskarżyłeś o cudzołóstwo".

Habemus senatus consultum in te, Catilina. (Cic., Catil. 1, 3)

„Mamy uchwałę senatu skierowaną przeciwko tobie, Katylino".

Sygnalizowane przez końcówkę osobową czasownika wartości kategorii liczby i osoby mogą jednak nie być wynikiem akomodacji i tym samym końcówka może nie stanowić wskaźnika łączności syntaktycznej z podmiotem. Sytuacja taka zachodzi w strukturach zdaniowych, które w ogóle nie otwierają miejsca dla gramatycznego podmiotu, a więc w zdaniach cechujących się diatezą wykluczającą ujawnienie jakiegokolwiek argumentu predykatu przez mianownikowy podmiot. Wartości kategorii liczby i osoby, wyrażane przez końcówkę osobową czasownika, tracą wówczas charakter zmiennych determinowanych akomodacją i przyjmują status wartości stałych, tj. sg. 3. os., stając się formalnym wyróżnikiem diatezy niepodmiotowej:

Advesperascit et mihi ad villam revertendum est. (Cic., Fin. 4, 79)

„Zmierzcha się i trzeba mi już wracać do (mej) posiadłości”.

Sic itur ad astra. (Verg., Aen. 9, 641)

"Tak idzie się do gwiazd".

Non igni, non ferro abstinetur. (Sen., Benef. 7, 27, 1)

„Nie stroni się ani od ognia, ani od miecza”.

Me civitatis morum piget taedetque. (Sall., Iug. 4, 9)

„Zloszczą mnie i brzydzą obyczaje społeczeńst wa”. 
Male rem gerentibus parentibus bonis interdici solet. (Cic., Sen. 22)

„Źle gospodarujących rodziców zwykle pozbawia się kontroli nad majątkiem”.

Incipiet dominae quemque pudere suae. (Ov., Rem. 710)

„Zacznie każdemu być wstyd swojej pani (serca)".

Nunc licet mihi libere quidvis loqui. (Pl., Amph. 393)

„Teraz wolno mi swobodnie mówić, cokolwiek zechcę".

Cui parci potuit? (Liv., 21, 14)

„Kogo można było oszczędzić?"

Podobnie stały jest charakter sygnalizowanych przez końcówkę osobową czasownika wartości kategorii liczby i osoby, tj. sg. 3. os., w przypadku, gdy pozycja otwierana przez niego dla podmiotu wypełniana jest przez podrzędne zdanie podmiotowe (równoważnik zdania podmiotowego), a więc gdy oznaczany przez czasownik predykat implikuje argument nieprzedmiotowy (zdaniowy, propozycjonalny):

Q. Caecilio sorti evenit, ut cum consule in Bruttiis adversus Hannibalem bellum gereret. (Liv., 28, 9)

„Kwintusowi przypadło $w$ wyniku losowania, że wraz z konsulem ma prowadzić wojnę z Hannibalem na terenie Bruttium".

Di utrum sint necne sint quaeritur. (Cic., Nat. 3, 17)

„Poszukuje się (odpowiedzi na pytanie), czy bogowie istnieją, czy też nie”.

Placet Stoicis [...] ad usum hominum omnia creari. (Cic., Off. 1, 22)

"Odpowiada stoikom (pogląd), że wszystko tworzone jest na użytek ludzi".

Jeśli osobowa forma czasownika (współ)konstytuująca orzeczenie odnosi się do więcej niż jednego podmiotu, może ona:

a. Wystąpić w liczbie mnogiej, nawet jeśli rzeczowniki reprezentujące podmioty są w liczbie pojedynczej:

Mors Hamilcaris [...] et pueritia Hannibalis distulerunt bellum. (Liv., 21, 2)

„Śmierć Hamilkara i chłopięcy wiek Hannibala odwlekly wojnę".

Fregenis murus et porta de caelo tacta erant. (Liv., 32, 29)

„We Fregenach miejski mur i brama zostały rażone piorunem".

b. Wystąpić w liczbie pojedynczej:

Iam passim caedes ac fuga erat. (Liv., 31, 36)

„Wszędzie już trwała rzeź i ucieczka”.

Mens $[. .$.$] et ratio et consilium in senibus est. (Cic., Sen. 67)$

„Rozum, rozsądek i namysł jest cechą ludzi starszych”.

Hoc mihi et Peripatetici et vetus Academia concedit. (Cic., Lucull. 113)

"I perypatetycy, i dawna Akademia pozwala(ją) mi na to". 
Interfectus est Gracchus et M. Fulvius consularis eiusque duo adulescentuli filii. (Cic., Phil. 8, 14)

„Zabity zostal Grakchus, były konsul Marek Fulwiusz i jego dwaj mlodzi synowie”.

W przypadku, gdy osobowa forma czasownika (współ)konstytuująca orzeczenie odnosi się do podmiotów o różnych wartościach kategorii osoby, to jeśli jednym $\mathrm{z}$ tych podmiotów jest zaimek 1. osoby, forma czasownikowa wyrażona będzie w 1 . osobie liczby mnogiej, jeśli natomiast jest nim zaimek 2. osoby (przy braku zaimka 1 . osoby), forma czasownikowa wyrażona będzie w 2. osobie liczby mnogiej:

\{Theopropides:\} Eas (scil. aedes) quanti destinat? \{Tranio:\} Talentis magnis totidem quot ego et tu sumus. (Pl., Most. 643-644)

\{Teopropides:\} Kupuje dom za ile? \{Tranio:\} Za tyle wielkich talentów, ile ja i ty (razem) stanowimy".

Ego et vos scimus inurbanum lepido seponere dicto. (Hor., Ars 272-273)

„Ja i wy potrafimy odróżnić prostackie wyrażenie od eleganckiego".

Ego et Maximus meus biduum iam beatissimum agimus. (Sen., Lucil. 87, 2)

"Ja i mój Maksymus już dwa dni bardzo przyjemnie spędzamy".

Errastis $[. .$.$] vehementer et tu et non nulli conlegae tui. (Cic., Leg. Agr. 1, 23)$

„Bardzo się pomyliliście, i ty, i niektórzy twoi koledzy”.

Meam cladem vos et omnes boni maximum esse rei publicae vulnus iudicastis. (Cic., Sest. 31)

„Wy i wszyscy dobrzy (obywatele) osądziliście, że moja klęska jest ogromną raną (zadaną) rzeczpospolitej".

Jeśli funkcję podmiotu pełnią rzeczowniki lub zaimki w liczbie pojedynczej, które cechują się znaczeniem kolektywnym, orzeczenie może wystąpić w liczbie mnogiej; właściwość ta określana bywa terminem constructio ad sensum:

Adfuere ingens multitudo cum luminibus (Tac., Ann., 14, 8)

„Nadszedl wielki tłum $z$ pochodniami”.

Nulla $[\ldots]$ fuit civitas praeter Larissaeos [...] quin Caesari parerent atque imperata facerent. (Caes., Civ. 3, 81)

„Z wyjątkiem Larysyjczyków nie znalazło się ani jedno miasto, które nie ulegloby Cezarowi i nie wykonywalo jego poleceń".

Dissensio inter Aetolos orta est: pars imperio parendum regis et eundum censebant, pars subsistendum Heracleae. (Liv., 36, 16)

„Powstała wśród Etolów różnica zdań: część (z nich) uważala, że należy usłuchać rozkazu króla i iść, część, że należy pozostać w Heraklei".

Uterque eorum ex castris [...] exercitum educunt. (Caes., Civ. 3, 30)

"Każdy z nich (dwóch) wyprowadza wojsko z obozu".

Bonum publicum simulantes pro sua quisque potentia certabant.

„Udając dobro publiczne każdy walczył o swoje wpływy”. 
Orzeczenie może wystąpić w liczbie mnogiej także wtedy, gdy podmiotem jest rzeczownik w liczbie pojedynczej, określony rzeczownikową przydawką socjatywną w ablatiwie z przyimkiem cum:

Syru' cum illo vostro consusurrant, conferunt consilia ad adulescentes. (Ter., Heaut. 473-474)

„Syrus z tym waszym (chlopakiem) szeptają po kątach, układają (jakieś) plany dla młodzieńców".

Ipse dux cum aliquot principibus capiuntur. (Liv., 21, 60)

„Sam wódz wraz z kilkoma znacznymi osobistościami zostają pojmani”.

(Współ)konstytuująca orzeczenie osobowa forma czasownika może zachowywać kongruencję w stosunku do rzeczownikowego orzecznika (a nie podmiotu), jeśli ulokowany jest on (lub jego określnik) między podmiotem a czasownikiem, a także w stosunku do rzeczownikowej przydawki apozycyjnej, jeśli stanowiona jest ona przez rzeczownik generyczny typu: oppidum, urbs, mons, civitas, gens itp., oznaczający gatunek (rodzaj), do którego należy desygnat podmiotu, będącego najczęściej nazwą własną:

Contentum [...] suis rebus esse maximae sunt certissimaeque divitiae. (Cic., Parad. 51)

"Bycie zadowolonym z tego, co się ma, jest największym i najpewniejszym bogactwem".

Quas geritis vestis, sordida lana fuit. (Ov., Ars 3, 222)

"Szaty, które nosicie, były (kiedyś) brudną wełną (przędzą)".

Oppidum Gonni viginti milia ab Larisa abest. (Liv., 36, 10)

„Miasto Gonny oddalone jest dwadzieścia tysięcy (kroków) od Larysy”.

Moschi, gens ante alias socia Romanis, avia Armeniae incursavit. (Tac., Ann. 13, 37)

"Moschowie, lud hardziej niż inne sprzymierzony z Rzymianami, najechali bezdroża Armenii".

\subsubsection{Związek rekcji (rządu)}

Podstawą związku rekcji są cechy znaczeniowe leksemów stanowiących (poprzez reprezentujące je wyrazy gramatyczne) człony nadrzędne w ramach tego związku, a mianowicie ich niekompletność semantyczna skutkująca implikacją (konotacją) uzupełnień. Pod wzgledem formalnym leksemy te determinują określone cechy gramatyczne wyrażeń będących wykładnikami implikowanych przez nie uzupełnień, lub inaczej: formalna postać konotowanych przez te leksemy uzupełnień akomodowana (dostosowywana) jest do narzucanych przez nie wymogów formalnych. W przeciwieństwie do akomodacji opartej na związku kongruencji akomodacja $w$ ramach rekcji nie polega na powtarzaniu (iteracji) cech gramatycznych wyrażanych morfologicznie przez człon nadrzędny, w związku z czym morfologiczne wykładniki składniowego związku rekcji (wskaźniki zespolenia syntaktycznego) obecne są tylko w członie podrzędnym (akomodowanym, determinowanym). Cechą gramatyczną 
podlegającą akomodacji jest przede wszystkim wartość kategorii przypadka, a niekiedy również obecność określonego przyimka w strukturze morfologicznej członu akomodowanego (podrzędnego), w związku z czym wskaźnik zepolenia składniowego może sprowadzać się do końcówki fleksyjnej (jako wykładnika wartości kategorii przypadka) lub może mieć charakter złożony, nieciągły, obejmując końcówkę i swobodny morfem przyimkowy. Dlatego elementami akomodowanymi (determinowanymi, podrzędnymi) w ramach związku rekcji są przede wszystkim człony syntaktyczne (współ)stanowione przez rzeczowniki i ich funkcjonalne odpowiedniki ( $t j$. rzeczownikowe zaimki, substantywizowane przymiotniki i imiesłowy, bezokoliczniki, gerundium, liczebnik milia), które w strukturze składniowej zdania klasyfikowane są jako dopełnienia ( $w$ przypadku zależności od członu rzeczownikowego jako przydawki). Z kolei elementami akomodującymi (determinującymi, nadrzędnymi) są głównie człony składniowe (współ)stanowione przez czasowniki, rzadziej przymiotniki, rzeczowniki, przysłówki.

Ze względu na liczbę elementów implikowanych i akomodowanych przez człon nadrzędny wyróżnia się tzw. rekcję pojedynczą, np.: laudare (aliquem/aliquid) 'chwalić' (kogoś/coś), parere (alicuilalicui rei) 'być posłusznym' (komuś/czemuś) oraz tzw. rekcję złożoną (powójną), np.: dare (aliquid alicui) 'dawać' (coś komuś), seiungere (aliquid ab aliqua re) 'oddzielać' (coś od czegoś). Sposób akomodacji uzupełnienia (dopełnienia) może być niejednolity (zróżnicowany, wariantywny), np.: saevire (in aliquem; alicui) 'srożyć się' (na kogoś). Ponieważ zjawisko rekcji powiązane jest bezpośrednio z wyrażanym znaczeniem, to również ogólne właściwości rekcyjne poszczególnych jednostek leksykalnych bywają niejednolite $z$ uwagi na cechującą liczne leksemy wieloznaczność; por. np.: consulere (de aliqua re) 'debatować' (o czymś) consulere (aliquem aliquid; aliquem de aliqua re) 'radzić się' (kogoś co do czegoś) consulere (alicui rei) 'troszczyć się' (o coś).

Implikacja uzupełnienia (dopełnienia) nie zawsze musi wiązać się z jego aktualizacją (obecnością) w strukturze powierzchniowej zdania. Implikowany element semantyczny może bowiem być identyfikowalny kontekstowo i nie znajdować w wypowiedzeniu swego leksykalnego wykładnika. Poza tym miejsce otwierane przez leksem rządzący (regujący) dla składnika rządzonego (regowanego) może zostać wypełnione przez strukturę o charakterze zdaniowym, tj. przez podrzędne zdanie dopełnieniowe. Można więc powiedzieć, że rekcja stanowi właściwość składniową określonych leksemow, która przejawia się w semantyczno-formalnych związkach łączących stanowione przez nie człony syntaktyczne nie tylko $z$ innymi, podrzędnymi względem nich członanami składniowymi, ale i z podrzędnymi składnikami wypowiedzenia, które mają charakter zdaniowy. Z drugiej strony należy jednak podkreślić, iż stojące u podstawy związku rekcji pojęcie niekompletności semantycznej i związanej z nią implikacji uzupełnień nie jest w pełni ostre. W niektórych bowiem przypadkach trudno jednoznacznie rozstrzygnąć, czy uzupełnienie jest implikowane (ma charakter obligatoryjny), czy dołączane dodatkowo (fakultatywnie), co skutkuje pewnym zatarciem granicy między związkiem rekcji a związkiem przynależności, i tym samym między dopełnieniem a okolicznikiem. 
Jak wspomniano wyżej, człony akomodujące (nadrzędne) w ramach związku rekcji stanowione mogą być przez leksemy różnych klas, użyte zarówno w ich prymarnych funkcjach składniowych, jak i sekundarnych; czlonami tymi mogą zatem być:

a. Leksemy czasownikowe:

Flagitiorum suorum recordabitur. (Cic., Pis. 13)

"Będzie sobie przypominal swe niegodziwe czyny”.

Implentur veteris Bacchi pinguisque ferinae. (Verg., Aen. 1, 215)

"Opychają się starym winem i tlustą dziczyzną".

Huic Caesar legioni indulserat praecipue. (Caes., Gall. 1, 40)

„Temu legionowi Cezar szczególnie sprzyjal".

Darius $[. .$.$] classem quingentarum navium comparavit. (Nep., Milt. 4, 1)$

„Dariusz wystawil flotę pięciuset okrętów".

(Catilina) iuventutem [...] mala facinora edocebat. (Sall., Cat. 16)

"(Katylina) uczyl mlodzież zlych uczynków".

Taedebat populum omnium magistratuum eius anni. (Liv., 9, 7)

„Lud czul niechęć do wszystkich urzędników tego roku".

Epaminondas $[\ldots]$ perfecit, $[\ldots]$ ut auxilio sociorum Lacedaemonii privarentur. (Nep., Epam. 6)

„Epaminondas sprawil, że Lacedemończycy zostali pozbawieni pomocy sprzymierzeńców”.

De eorum fide constantiaque dubitatis? (Caes., Gall. 7, 77)

„Czy wątpicie w ich wierność i stalość?”

Maior [...] pars eorum victus in lacte, caseo, carne consistit. (Caes., Gall. 6, 22)

"Główna część ich pożywienia słłada się z mleka, sera i mięsa”.

(Psyche) virginitati suae $[\ldots]$ metuens et pavet et horrescit. (Apul., Met. 5, 4)

"(Psyche) obawiając się o swe dziewictwo, trwoży się i drży ze strachu”.

M. Valerius consul $[\ldots]$ provincia exercituque mandato $L$. Cincio praetori $[\ldots]$ senatum extemplo habuit. (Liv., 27, 5)

„Konsul Marek Waleriusz, powierzywszy zarząd prowincji i wojsko pretorowi Lucjuszowi Cyncjuszowi, bezzwlocznie zwolat posiedzenie senatu".

Senex iuvenem amplexus $[\ldots]$ aiebat $[\ldots]$. (Liv., 1, 26)

„Starzec, objąwszy mlodzieńca, mówil [...]”.

Ea stultitiast facinus magnum timido cordi credere. (Pl., Pseud. 576)

„Glupotą jest powierzyć wiclki czyn bojaźliwemu sercu".

(Themistocles) maritimos praedones consectando mare tutum reddidit. (Nep., Them. 2)

"(Temistokles) scigając morskich korsarzy, uczynił na powrót morze bezpiecznym".

Caesar dixit $[\ldots]$ duces a pace abhorruisse. (Caes., Civ. 1, 85)

„Cezar odpowiedział, że wodzowie wzbraniali się przed pokojem”. 
b. Leksemy przymiotnikowe:

Erat in oppido multitudo insolens belli diuturnitate otii. (Caes., Gall. 2, 36)

„Przebywało w mieście mnóstwo ludzi odwyklych od wojny wskutek dlugotrwalego pokoju”.

Caesar [...] castris idoneum locum delegit. (Caes., Gall. 1, 49)

"Cezar wybrał dogodne dla obozu miejsce".

Ait $[\ldots]$ se dictatorem $L$. Quinctium facturum; ibi animum parem tantae potestati esse. (Liv., 4, 13)

„Powiada, że uczyni dyktatorem Lucjusza Kwinkcjusza; w nim bowiem tkwi duch dorównujący tak wielkiej wladzy".

Q. Scaevola [...] peritissimus iuris [...] est habitus. (Cic., Brut. 212)

"Kwintus Scewola był uważany za bardzo bieglego w prawie".

Plena religione civitas (erat). (Liv., 7, 28)

„Miasto przepelnione było zabobonnym przerażeniem”.

Quis enim non modo liber, sed etiam servus libertate dignus fuit, cui nostra salus cara non esset? (Cic., Leg. 3, 25)

„Jakiż znalazł się bowiem człowiek, nie tylko wolny, ale nawet niewolnik godny wolności, któremu nie leżałoby na sercu moje ocalenie?"

c. Leksemy rzeczownikowe:

$[\ldots]$ omnes [...], qui in hac civitate intellegentiam iuris habuerunt. (Cic., Phil. 9, 10)

„[...] wszyscy, którzy w tym państwie posiedli znajomość prawa".

Neque ulla nostris facultas aut administrandi aut auxiliandi dabatur. (Caes., Gall. 4, 29)

„Nasi nie mieli żadnej możliwości ani kierowania, ani pomagania".

Iustitia est obtemperatio scriptis legibus institutisque populorum. (Cic., Leg. 1, 42)

„Sprawiedliwość jest podporządkowaniem się prawom pisanym i postanowieniom (poszczególnych) ludów".

d. Leksemy przysłówkowe:

Cum igitur hoc sit extremum, congruenter naturae convenienterque vivere, necessario sequitur omnes sapientes semper feliciter [...] vivere. (Cic., Fin. 3, 26)

„Skoro zatem to jest celem ostatecznym, a mianowicie życie zgodnie $\mathbf{z}$ naturą i stosownie do niej, to nieuchronnie wynika z tego, że wszyscy mędrcy żyją szczęśliwie".

\subsubsection{Związek przynależności}

Związek przynależności opiera się na powiązaniach semantycznych między członami syntaktycznymi, $z$ których jeden (nadrzędny) ma status określanego, a drugi (podrzędny) określającego, przy czym semantyka członu nadrzędnego nie implikuje uzupełnienia o charakterze odpowiadającym treści wyrażanej przez człon podrzęd- 
ny. Innymi słowy człon podrzędny nie jest wykładnikjem treści stanowiącej konieczne uzupełnienie znaczenia nadrzędnika, lecz treści, która jest jego uzupełnieniem nieobligatoryjnym (dodatkowym, fakultatywnym), wynikającym z realizacji określonego celu komunikacyjnego nadawcy wypowiedzi. Pod względem formalnym brak jest determinacji postaci członu podrzędnego; człon ten albo $\mathrm{w}$ ogóle nie posiada formalnych wykładników akomodacji (jeśli reprezentowany jest przez formę przysłówkową), albo wykładniki te łączą funkcję wskaźników związku syntaktycznego z funkcją semantyczną (np. w przypadku wyrażeń rzeczownikowo-przyimkowych). Człony nadrzędne (określane) w ramach tego związku stanowione mogą być przez czasowniki, przymiotniki, przysłówki oraz rzeczowniki i ich funkcjonalne odpowiedniki, występujące zarówno w swych prymarnych, jak i sekundarnych funkcjach składniowych, natomiast pozycje członów podrzędnych (określających) wypełniać mogą przysłówki, a także użyte w sekundarnych funkcjach składniowych formy rzeczownikowe (często w połączeniu z przyimkami), przymiotnikowe oraz czasownikowe (np. supinum czy gerundium).

Człony, które w ramach tego związku zależne są od rzeczowników (lub ich funkcjonalnych odpowiedników), mają status składniowy przydawek:

Quid mihi $[\ldots]$ erat $[\ldots]$ hinc abitio? (PI., Rud. 502-503)

„Na cóż mi był wyjazd stąd?”

L. Paulum, bis consulem [...], omnium oculi conspicere [...] avent. (Liv. 45, 39)

„Oczy wszystkich pragną zobaczyć Lucjusza Paulusa, dwukrotnie konsula".

Ipsa consuetudo adsentiendi periculosa esse videtur. (Cic., Lucull. 68)

„Sam zwyczaj uznawania (czegoś) za prawdziwe wydaje się niebezpieczny”.

Mercedem tanta virtus [...] laudis gloriaeque desiderat. (Cic., Phil. 5, 35)

"Tak wielkie męstwo domaga się zapłaty (w postaci) slawy i chwały".

Omnia superioris noctis consilia ad me perlata esse sentiunt. (Cic., Catil. 2, 6)

„Widzą, że wszystkie plany z poprzedniej nocy zostały mi doniesione”.

Quid enim gladiatoribus clamores innumerabilium civium? (Cic., Phil. 1, 36)

„Co bowiem (znaczą) okrzyki niezliczonych obywateli skierowane do (= na cześć) gladiatorów?"

L. Cotta, homo summo ingenio summaque prudentia [...] supplicationem decrevit. (Cic., Phil. 2, 13)

„Lucjusz Kotta, czlowiek o wybitnym intelekcie i wielkiej mądrości, zarządził modły dziękczynne".

Exercitus nostri interitus ferro, fame, frigore, pestilentia. (Cic., Pis. 40)

„Zaglada naszego wojska od miecza, z powodu glodu, zimna, zarazy”.

Vidistis simulacrum Cereris e marmore. (Cic., Verr. 2, 4, 109)

"Zobaczyliście posąg Cerery z marmuru".

Mittitur ad eos [...] Q. Iunius ex Hispania quidam. (Caes., Gall. 5, 27)

„Wysyłany jesı do nich niejaki Kwintus Juniusz (pochodzący) z Hiszpanii”. 
W przypadku, gdy człon nadrzędny konstytuowany jest przez wyrazy reprezentujące inne klasy leksemów (tj. czasowniki, przymiotniki, przysłówki), człon podrzędny ma status okolicznika:

Nostri fotriter impetum eorum tulerunt celeriterque ad suos quisque ordines redit. (Caes., Civ. 3, 37)

"Nasi dzielnie wytrzymali ich atak i każdy szybko wrócil do swoich szeregów".

Non vitae sed scholae discimus. (Sen., Lucil. 106, 12)

„Uczymy się nie dla życia, ale dla szkoły”.

Quidam morbo aliquo et sensus stupore suavitatem cibi non sentiunt. (Cic., Phil. 2, 115)

"Niektórzy z powodu jakiejś choroby i otępienia zmyslów nie czują słodyczy potraw”.

Prodigiis atque portentis di immortales nobis futura praedicunt. (Cic., Phil. 4, 10)

„Za pośrednictwem cudownych znaków i wróżb bogowie nieśmiertelni przepowiadają nam przyszłośćn.

Perseum filium cum modica manu circummisit, ut a superioribus locis urbem adgrederetur. (Liv., 40, 22)

„Syna Perseusa z niewielkim oddzialem posyła okrężną drogą, aby ten zaatakował miasto $\mathbf{z}$ wyżej polożonego terenu".

Secunda vigilia magno cum strepitu ac tumultu castris egressi (sunt). (Caes., Gall. 2, 11)

„O drugiej straży nocnej wyszli z obozu wśród ogromnego zgiełku i zamieszania".

Caesar Gomphos pervenit, quod est oppidum primum Thessaliae venientibus ab Epiro. (Caes., Civ. 3, 80)

„Cezar przybył do Gomf, które są pierwszym miastem Tessalii dla idących z Epiru”.

Ponte navibus effecto tramissoque exercitu primus Ornospades [...] in castra venit. (Tac., Ann. 6, 37)

„Po zbudowaniu z okrętów mostu (scil. pontonowego) i przeprawieniu wojska pierwszy przybyl do obozu Ornopades".

Multo minoris vendidit $[\ldots]$ quam tu. (Cic., Verr. 2, 3, 43)

„Sprzedal o wiele taniej niż ty”.

Satis diu vixit. (Sen., Dial. 6, 24, 1)

„Żył dostatecznie długo".

Qui decimae legionis aquilam ferebat, obtestatus deos ut ea res legioni feliciter eveniret, 'desilite' inquit 'commilitones'. (Caes., Gall. 4, 25)

„Chorąży niosący orla dziesiątego legionu, wezwawszy bogów, aby ta rzecz wypadla szczęśliwie dla legionu, zawolat: 'skaczcie, towarzysze broni!'”

\subsubsection{Wybrana literatura}

Greenough, Kittredge, Howard, D'Ooge (1903 (1983), s. 163-175), Lehmann (2002), Pinkster (1969, 1985a), Risselada (1984), Ros (2001), Traina, Bertotti (1965-1969, vol. 1, s. 15-31) 


\subsection{WYRAŻANIE NEGACJI}

W języku łacińskim negacja może mieć zróżnicowany charakter (zakres) i znajdować może różne wykładniki formalne, przede wszystkim w postaci przeczących bądź implikujących negację partykuł, spójników bądź zaimków.

Partykuła przecząca non 'nie', rzadziej haud (haut, hau), wyraża zaprzeczenie twierdzenia zawartego w zdaniu lub negację jednego $\mathrm{z}$ jego elementów:

Non sum ita hebes, ut istud dicam. (Cic., Catil. 1, 12)

„Nie jestem tak glupi, by twierdzić coś takiego".

Quae contumelia non fregit eum, sed erexit. (Nep., Them. 1)

"Ta zniewaga nie złamała go, lecz dodała mu sil".

Praetorianus miles non virtute se, sed proditione victum fremebat. (Tac., Hist. 2, 44)

"Żołnierz pretoriański wykrzykiwał, że nie męstwem, lecz zdradą został pokonany”.

Haud possunt [...] moveri. (Lucretius, 3, 571)

„Nie mogą poruszać się".

Profecto me, haud uxorem, ulciscitur. (Pl., Men. 126)

„Wszak to na mnie się mści, nie na żonie”.

Saltus $[. .$.$] haud sine clade, maiore tamen iumentorum quam hominum pernicie, supera-$ tus (est). (Liv., 21, 35)

„Wzgórze zostało pokonane nie bez szkody, jednak przy większych stratach w zwierzętach jucznych niż w ludziach".

W przypadku negacji większej liczby elementów zdania w odniesieniu do każdego z nich stosuje się partykułę non lub spójnik przeczący neque/nec, co odpowiada polskiemu wyrażeniu: ani..., ani...:

Non cibus nobis, non umor, non vigilia, non somnus sine mensura quadam salubria sunt. (Sen., Nat. 6, 2, 3)

"Ani jedzenie, ani picie, ani bezsenność, ani sen nie są dla nas zdrowe bez pewnej miary”.

Neque nox tenebris obscurare coetus nefarios nec privata domus parietibus continere voces coniurationis tuae potest. (Cic., Catil. 1,6)

„Ani noc nie może ukryć zbrodniczych zgromadzeń, ani prywatny dom zamknąć w swych ścianach odgłosów twego spisku".

Caesar $[\ldots]$ nec postulantibus nec cogitantibus $[\ldots]$ nobis $[\ldots]$ firmissimum exercitum ex invicto genere veteranorum militum comparavit. (Cic., Phil. 3, 3)

„Cezar, chociaż ani tego nie żądaliśmy, ani o tym nie myśleliśmy, wystawił potężną armię złożoną z niezwyciężonych weteranów wojskowych".

Mihi nemo est amicior nec iucundior nec carior Attico. (Cic., Att. 16, 16a, 5)

„Nikt nic jest mi bardziej bliski ani milszy, ani bardziej drogi od Attyka”.

Mauri neque fugere, neque arma capere, neque omnino facere [...] quicquam poterant. (Sall., Iug. 99)

„Maurowie nie mogli ani uciekać, ani chwycić za broń, ani w ogóle zrobić cokolwiek". 
Id, quod neque est, neque fuit, neque futurum est. (PI., Amph. 553)

"To, czego ani nie ma, ani nie bylo, ani nie będzie".

Przeczący spójnik neque/nec może także wyrażać zaprzeczenie twierdzenia zawartego $w$ drugim zdaniu składowym zdania złożonego współrzędnie, przy pierwszym zdaniu składowym niezaprzeczonym; ma wtedy znaczenie odpowiadające polskim wyrazeniom: i nie, $i$ również nie, jednak nie:

Risus omnium [...] coortus est, neque quisquam iudex ausus est de eo ferre suffragium. (Nep., Epam. 8)

„Rozlegl się śmiech wszystkich (zgromadzonych) i żaden sędzia nie odważył się glosować w jego sprawie".

Traderent elephantos [...], quos haberent domitos, neque domarent alios. (Liv., 30, 37)

"Niech wydadzą slonie, które mają oswojone, i niech innych nie oswajają".

Sole orto Gracchus in aciem copias educit nec hostes moram dimicandi fecerunt. (Liv., $24,15)$

„O wschodzie stońca Grakchus wyprowadza wojsko do bitwy, i również nieprzyjaciele nie zwlekali z podjęciem walki".

At ii, qui praesidio contra castra Labieni erant relicti [...], subsidio suis ierunt collemque ceperunt, neque nostrorum militum victorum impetum sustinere potuerunt. (Caes., Gall. $7,62)$

„A tymczasem ci, którzy zostali pozostawieni jako ochrona naprzeciwko obozu Labienusa, ruszyli na pomoc swoim i zajęli wzgórze, jednak atakowi naszych zwycięskich żołnierzy oprzeć się nie zdolali".

Oprócz funkcji konektora może on również pełnić funkcję implikującego negację operatora presupozycji o znaczeniu nawet nie, również nie:

Maxime ab omni $[\ldots]$ contagione Romanorum abstinebat, ut neque scribi sibi vellet. (Liv., $40,20)$

„Powstrzymywał się jak tylko mógł od kontaktów z Rzymianami, tak że nawet nie chciał, by do niego pisali".

Ita primis repulsis Maharbal cum maiore robore virorum missus nec ipse eruptionem cohortium sustinuit. (Liv., 23, 18)

„Po tym gdy pierwsi zostali $w$ ten sposób odpędzeni, również sam Maharbal, wyslany $z$ większą masą ludzi, nie wytrzymal ataku kohort".

Neque eo anno quicquam belli externi fuit. (Liv., 3, 32)

„Również tego roku nie było żadnej wojny poza granicami”.

Partykuła ne stosowana jest dla zaprzeczenia wyrażanej przez czasownik treści predykatywnej, która nacechowana jest modalnie. Występuje więc przy czasowniku $\mathrm{w}$ imperatiwie lub koniunktiwie, współuczestnicząc $w$ formułowaniu zakazu czy zawierającego negację życzenia, wezwania, polecenia, przyzwolenia itp.:

Ne istuc Iuppiter optimus maximus sinit. (Liv., 28, 28)

„Oby na to Jowisz Najlepszy i Największy nie pozwolił!” 
Concurrebant legati, centuriones tribunique militum: ne dubitaret proelium commitere. (Caes., Civ. 1, 71)

„Zbiegali się (do Cezara) legaci, centurionowie i trybuni wojskowi (mówiąc): niech nie waha się wydać bitwę".

Alcumena, adest auxilium, ne time! (Pl., Amph. 1064)

"Alkmeno, nadchodzi pomoc, nie bój się!"

Tu ne quesieris [...] quem tibi finem di dederint. (Hor., Carm. 1, 11, 1)

„Nie pytaj, jaki koniec przeznaczyli ci bogowie”.

Molestus ne sis! (Pl., Aul. 458)

„Nie naprzykrzaj się!”

Ne sit sane summum malum dolo, malum certe est. (Cic., Tusc. 2, 14)

„Niechby nawet ból nie był złem największym, złem jednak z pewnością jest”.

Podobnie spójnik ne 'aby nie' wprowadza zdanie podrzędne dopełnieniowe, podmiotowe lub przydawkowe, którego treścią jest zakaz, albo okolicznikowe celu zawierające negację:

Orat, opsecrat ne Casinam uxorem ducam. (Pl., Cas. 322)

„Prosi, zaklina, bym nie żenił się z Kasiną”.

Missi legati [...]; denuntiatum est ne Brutum obsideret. (Cic., Phil. 12, 11)

„Wysłano posłów; (przez nich) oznajmiono, aby nie oblegał Brutusa”.

Gracchus legem tulit ne de capite civium Romanorum iniussu vestro iudicaretur. (Cic., Rab. Perd. 12)

„Grakchus przeprowadził ustawil zakazującą sądzenia obywateli rzymskich w prawach gardłowych bez waszej zgody".

M. Calidius [...] censebat, ut Pompeius in suas provincias proficisceretur, ne qua esset armorum causa". (Caes., Civ. 1, 2)

„Marek Kalidiusz wnioskowal, by Pompejusz udał się do swoich prowincji, aby nie dawać pretekstu do wszczęcia wojny".

Spójnik neve (neu) 'i (niech) nie', 'ani (niech) nie', 'i żeby nie' wprowadza zaprzeczone zdanie współrzędne lub dodatkowy niezdaniowy element objęty negacją, odpowiadając funkcjonalnie partykule i spójnikowi ne:

Adveniat $[\ldots]$, neve exhorrescat. (Verg., Aen. 7, 265)

„Niech przybywa i niech się nie obawia”.

Sed qui ab eo (scil. Pompeio) missi erant [...] liberius cum militibus regis conloqui coeperunt eosque hortari, ut suum officium Pompeio praestarent neve eius fortunam despicerent. (Caes., Civ. 3, 103)

„Lecz wyslannicy (Pompejusza) zaczęli swobodniej rozmawiać z żołnierzami króla i nakłaniać ich, aby wypełnili swoje zobowiązanie wobec Pompejusza i nie okazywali pogardy dla jego losu". 
Imperat Cassivellauno ne Mandubracio neu Trinovantibus noceat. (Caes., Gall. 5, 22)

„Nakazuje Kassywellaunusowi, aby Mandubracjuszowi ani Trynowantom nie wyrządzal szkody".

Partykuła ne $\mathrm{w}$ połączeniu z partykułą quidem uwydatnia określony element struktury semantycznej wypowiedzenia, będący składnikiem treści objętej negacją. Wyrażanie (lub jego część), które desygnuje ten element, lokowane jest (zwykle) pomiędzy obu tymi partykułami:

Ne bonum verbum quidem unum dixit. (Pl., Truc. 543)

„Nawet jednego dobrego słowa nie powiedzial”.

Ne minimam quidem moram interposuisti. (Cic., Phil. 10,1)

„Nie dopuścileś nawet do najmniejszej zwłoki”.

Ne T. quidem Postumius contemnendus in dicendo est. (Cic., Brut. 269)

„Ani też Tytus Postumiusz nie zasluguje na lekceważenie jako mówca”.

Consul $[\ldots]$ non modo legum aut patrum maiestatis, sed ne deorum quidem satis metuens. (Liv., 22, 3)

„Konsul nieprzejawiający respektu nie tylko wobec praw czy majestatatu senatu, ale nawet wobec bogów".

Tam infandum facinus [...] ne audivi quidem. (Ter., Eun. 664)

"O tak strasznej rzeczy nawet nie styszalem (dotąd)".

Dla osłabienia przeczenia w miejsce non używane jest minus; zwłaszcza w wyrażeniu si(n) minus:

Frumento, quod flumine Arari navibus subveherat, propterea minus uti poterat, quod iter ab Arari Helvetii averterant, a quibus discedere nolebat. (Caes., Gall. 1, 16)

„Ze zboża, które dowozil na statkach rzeką Arar, nie bardzo mógl korzystać z tego powodu, ze Helwetowie oddalili się od Araru, a nie chciał z nimi stracić lączności".

Hoc nempe ab homine exigitur, ut prosit hominibus: si fieri potest, multis; si minus, paucis; si minus, proximis; si minus, sibi. (Sen., Dial. 8, 3, 5)

„Tego bez wątpienia wymaga się od człowieka, by był pożyteczny dla ludzi: jeśli to możliwe, dla wielu; jeśli nie bardzo (jest to możliwe), to chociaż dla kilku; jeśli i to nie, to przynajmniej dla najbliższych; jeśli i to nie, to choć dla samego siebie".

W łacinie obowiązuje zasada pojedynczego przeczenia. Oznacza to, że zaimki przeczące: nemo, nihil, nullus, neuter, numquam, nusquam samodzielnie stanowią wykładnik negacji zdaniowej, w związku z czym orzeczenie nie wymaga użycia partykuły przeczącej:

„Nie ma nikogo..." = Nemo est...

„Nigdy nie powiedzial..." = Numquam dixit...

Aquandi causa nemo egreditur ex castris. (Caes., Civ. 1, 81)

"Nikt nie wyrusza z obozu po wodę". 
Nihil est victoria dulcius. (Cic., Verr. 2, 5, 66)

„Nic nie jest milsze od zwycięstwa”.

Nulla lex satis commoda est omnibus. (Liv., 34, 3)

"Żadna ustawa nie zadowala wszystkich".

Numquam [...] tantum pavoris tumultusque intra moenia Romana fuit. (Liv., 22, 54)

"Nigdy nie było tyle strachu i zamętu w murach Rzymu".

W zdaniu z ogólną negacją zdaniową wyrażoną partykułą przeczącą lub zaimkiem przeczącym mogą wystąpić dodakowe wykładniki negacji (z zachowaniem ogólnej negacji zdaniowej), jeśli mają one charakter szczegółowy, tzn. jeśli odnoszą się do konkretnych składników zdania, które są wyszczególniane (ani..., ani...) lub poddawane emfazie (nawet nie...):

Intellegat nihil nec expedire nec utile esse, quod sit iniustum. (Cic., Off. 3,76 )

„Niech zrozumic, że nic nie jest ani przydatne, ani korzystne, co nie jest sprawiedliwe”.

Nulla $[\ldots]$ vitae pars neque publicis neque privatis $[\ldots]$ in rebus $[\ldots]$ vacare officio potest. (Cic., Off. 1, 4)

„Żadna sfera życia, ani ta dotycząca spraw publicznych, ani ta dotycząca spraw' prywatnych. nie może być wolna od obowiązków".

Intellegunt neminem ne minimum quidem maleficium sine causa admittere. (Cic., $S$. Rosc. 73)

„Rozumieją, że nikı nawet najmniejszego złego czynu nie dopuszcza się bez powodu”.

W zdaniu z ogólną negacją zdaniową, wyrażoną partykułą przeczącą lub zaimkiem przeczącym, konkretne (kolejne, dodatkowe) składniki wypowiedzenia mogą być także negowane za pośrednictwem antytecznych zaimków nieokreślonych, odpowiadających poszczególnym zaimkom przeczącym:

- nemo = quisquam 'nikt'

- nihil = quidquam 'nic'

- nullus = ullus 'żaden'

- numquam = umquam 'nigdy'

- nusquam = usquam 'nigdzie'.

Neque erat omnium quisquam, qui adspectum modo tantae multitudinis sustineri posse arbitraretur. (Caes., Gall. 7, 76)

„I spośród wszystkich nie było nikogo, kto uważalhy, że można znieść (bez strachu) sam widok takiej masy (wojska)".

(Hannibal) ad Prusiam in Pontum pervenit [...] neque aliud quicquam egit quam regem armavit et exercuit adversus Romanos. (Nep., Hann. 10)

„Hannibal przybyl do Prusjasza, do Pontu, i nie robił nic inncgo, jak tylko zbroił króla i zaprawiał go (do walki) przeciw Rzymianom".

Tempus habes tale, quale nemo habuit umquam. (Cic., Phil. 7, 27)

„Masz taką okazję, jakiej nikt nigdy (dotąd) nie miał”. 
Nullius usquam terrarum rei cura Romanos $[\ldots]$ effugiebat. (Liv., 22, 33)

„Rzymianie nie zaniedbywali żadnej sprawy nigdzie na świecie”.

Fidem tuam, quae nusquam erat neque umquam fuerat, implorant. (Cic., Verr. 2, 5, 108) „Apelują do twej lojalności, której nigdzie (= w żadnej sprawie) nie dochowałeś i której nigdy nie miales".

Numquam maior consensus vester in ulla causa fuit. (Cic., Phil. 4, 12)

„Nigdy (dotąd) nie byliście bardziej zgodni w żadnej sprawie".

Równoległe wystąpienie partykuły przeczącej i zaimka przeczącego w jednym wypowiedzeniu daje wyrażenie twierdzące (afirmatywne), którego znaczenie zależy od umiejscowienia partykuły przeczącej w stosunku do zaimka: jeśli partykuła przecząca poprzedza zaimek, rezultatem jest tzw. częściowa (nieokreślona, nieidentyfikująca) afirmacja. Jeśli partykuła występuje po zaimku, wyrażana jest totalna (absolutna, uogólniająca) afirmacja:

- non nemo (nonnemo) = 'ktoś, niejeden'

- non nihil (nonnihil) $=$ 'cos'

- non nullus (nonnullus) = 'niektóry, pewien'

- non numquam (nonnumquam) = 'nieraz, niekiedy'

- non nusquam (nonnusquam) = 'gdzieniegdzie' nemo non = 'każdy' nihil non = 'wszystko' nullus non = 'wszyscy' numquam non = 'zawsze' nusquam non = 'wszędzie'

Video de istis, qui se popularis haberi volunt, abesse non neminem. (Cic., Catil. 4, 10)

„Widzę, że niejeden spośród tych, którzy chcą uchodzić za przyjaciól ludu, jest nieobecny”.

Nemo non ita exit e vita, tamquam modo intraverit. (Sen., Lucil. 22, 14)

„Każdy tak rozstaje się z życiem, jakby dopiero co przyszedr (na świat)”.

At non numquam bonos exitus habent boni. (Cic., Nat. 3, 89)

"Ale przeciez niekiedy dobry los spotyka (również) dobrych (ludzi)".

Forensia $[\ldots]$ et calceos numquam non intra cubiculum habuit ad subitos repentinosque casus parata. (Suet., Aug. 73)

„Wyjściowe ubranie i buty zawsze mial w sypialni przygotowane na nagle i nieprzewidziane wypadki".

Zdarza się jednak, że zdania zawierające równocześnie partykułę przeczącą i zaimek przeczący, albo dwa zaimki przeczące, zachowują sens negatywny. Tego rodzaju emfatyczna negacja stanowiła zapewne redundancję typową dla języka potocznego czy emocjonalnego:

Iura te non nociturum esse homini de hac re nemini. (Pl., Mil. 1411)

„Przysięgnij, że nie uczynisz nikomu krzywdy w związku z lą sprawą”.

Debebat Epicrates nummum nullum nemini. (Cic., Verr. 2, 2, 60)

„Epikrates nie był winny nikomu żadnych pieniędzy”.

Cechą języka emocjonalnego czy potocznego była również emfaza (wzmocnienie) funkcji zaimków przeczących poprzez zestawienie ich $z$ odpowiadającymi im nieokreślonymi zaimkami antytetycznymi: 
Lepidiorem uxorem nemo quisquam [...] habet. (Pl., Cas. 1008)

„Absolutnie nikt nie ma cudowniejszej żony”.

Hic tibi nil est quicquam incommodi. (Ter., Hec. 400)

"On nie jest dla ciebie absolutnie niczym kłopotliwym".

Quaedam animalium [...] aut caeca natura gignuntur aut inodora inauritave. Nullum autem ullum gigni animal Aristoteles dicit, quod aut gustus sensu careat, aut tactus. (Gell., Noc. Att. 6, 6, 2)

„Niektóre zwierzęta rodzą się albo ślepe z natury, albo bez zmysłu zapachu czy słuchu. Jednak zdaniem Arystotelesa nie rodzi się absolutnie żadne zwierzę, które byłoby pozbawione zmysłu smaku bądź dotyku".

Wzmocnioną negację zdaniową wyrażają także zaimki przeczące nihil i nullus użyte w miejsce partykuły przeczącej lub predykatywnie (orzecznikowo):

Oenomao tuo nihil utor. (Cic., Fam. 9, 16, 4)

„Twojego Oinomaosa w ogóle nie używam”.

De mortuis loquor, qui nulli sunt. (Cic., Tusc. 1, 87)

„Mówię o zmarłych, którzy w ogóle nie istnieją".

Hic patera nulla in cistulast. (Pl., Amph. 792)

„Tu nie ma żadnej czary w skrzynce".

Fortasse tu huc vocatus es ad prandium, ille, qui vocavit, nullus venit? (Pl., Rud. 143)

„Może ty zostałeś tu zaproszony na śniadanie, a ten, kto (cį̨) zaprosil, w ogóle nie przyszedł?"

Negację mogą wyrażać również wyrazy o immanentnym znaczeniu przeczącym, najczęściej nacechowane wyrażającym negację prefiksem (np.: negare, nescire, invitus, inscius). Generalnie wystąpienie w zdaniu dwóch elementów o funkcji przeczącej, np. dwóch partykuł przeczących czy partykuły i czasownika lub przymiotnika z prefiksem przeczącym, nadaje wypowiedzeniu charakter twierdzący (afirmatywny):

Qui mortem in malis ponit, non potest eam non timere. (Cic., Fin. 3, 29)

„Kto śmierć zalicza do rzeczy złych, nie może się jej nie bać (= musi się jej bać)”.

Pictor, cum vi artis suae efficit, ut quaedam eminere in opere, quaedam recessisse credamus, ipse ea plana esse non nescit. (Quint., Inst. 2, 17, 21)

„Malarz, chociaż mocą swej sztuki wywołuje w nas wrażenie, że pewne rzeczy na obrazie wysunięte są do przodu, a inne pozostają bardziej $w$ tyle, to jednak sam nie jest nieświadomy tego (= dobrze wie), że wszystkie te rzeczy są (w rzeczywistości) płaskie".

Fuit haec oratio non ingrata Gallis. (Caes., Gall. 7, 30)

„Przemówienie to nie bylo niemile (= było miłe) Gallom”.

${ }^{2}$ W tym przykładzie funkcja realizowana przez zaimek nullus odpowiada typowi przydawki, określanej jako praedicativum; zob. wyżej: 3.2.2.4.2. 
Wyróżnia się także zdania, które nie mają formalnych wykładników negacji, jednak implikują ogólny sens negatywny, który wynika z determinowanej kontekstem intencji wypowiedzi, w związku z czym określany jest terminem negacji pragmatycznej. $Z$ tego rodzaju pragmatyczną negacją mamy do czynienia np. w pytaniach retorycznych zakładających zaprzeczenie ze strony odbiorcy czy w wypowiedzeniach ukazujących wyrażane treści jako niemożliwe, nieprawdopodobne, zaskakujące, trudne do uwierzenia, wątpliwe. Charakterystyczną cechą tego typu wypowiedzeń, nacechowanych pragmatyczną negacją, jest obecność antytetycznych zaimków nieokreślonych:

Estne quisquam omnium mortalium, de quo melius existimes tu? (Cic., Q. Rosc. 18)

"Czyż pośród wszystkich ludzi jest ktos, o kim ty sam móglbyś wyrazić lepsze zdanie?”

An, opsecro, usquam sunt homines volatici? (Pl., Poen. 475)

"Ale na bogów, czy są gdzieś na świecie ludzie skrzydlaci?"

Iocari me putas? Moriar si quisquam me tenet praeter te. (Cic., Att. 16, 5, 3)

„Myślisz, że żartuję? Niech skonam, jeśli ktoś (inny) oprócz ciebie mnie (tu) zatrzymuje”.

Id [...] putare quemquam hominem, nihil homine esse melius, summae adrogantiae censet esse. (Cic., Nat. 3, 26)

„Sądził, że to, iż jakikolwiek czlowiek mialby tak myśleć, a mianowicie że nie ma (na świecie) nic doskonalszego od czlowieka, byłoby niesłychanym zuchwalstwem".

Cuius amici [...], si beluae tam immani tamque taetrae possunt ulli esse amici, hac consolatione utuntur, etiam T. Albucio supplicationem hunc ordinem denegasse. (Cic., Prov. 15) „Jego przyjaciele - jeśli tak straszny i tak odrażający potwór może mieć jakichkolwiek przyjaciól - tym się pocieszają, że również Tytusowi Albucjuszowi senat odmówil uchwalenia ofiar dziękczynnych".

Di me perdant, sei illam uxorem duxero umquam. (Pl., Cist. 498)

„Niech mnie pieklo pochlonie, jeśli kiedykolwiek pojmę ją za żonę".

\subsubsection{Wybrana literatura}

Huitink (2005), Mayer (2001), Molinelli (1989), Orlandini (2000, 2001) 


\section{4. \\ Zdania złożone}

Zdania złożone to zdania zawierające więcej niż jedno orzeczenie lub takie, które oprócz orzeczenia zawierają także funkcjonalny odpowiednik orzeczenia (w ramach równoważnika zdania podrzędnego typu accusativus cum infinitivo lub ablativus $a b$ solutus), np.:

Abditi in tabernaculis aut suum fatum querebantur, aut cum familiaribus suis commune periculum miserabantur. (Caes., Gall. 1, 39)

„Ukryci w namiotach albo narzekali na swój los, albo wraz z towarzyszami użalali się nad ich wspólnym niebezpieczeństwem".

Pompeius suis praedixerat, ut Caesaris impetum exciperent. (Caes., Civ. 3, 92)

„Pompejusz nakazal swoim ludziom, aby przyjęli atak Cezara”.

Dicit montem [...] ab hostibus teneri. (Caes., Gall. 1, 22)

„Powiada, że góra opanowana jest przez nieprzyjaciót".

Fugato omni equitatu Vercingetorix copias suas $[\ldots]$ reduxit. (Caes., Gall. 7, 68)

„Przepędziwszy całą konnicę, Wercyngetoryks ściągnąl z powrotem swoje oddzialy”.

Orzeczenia (funkcjonalne odpowiedniki orzeczeń) stanowią konstytutywne elementy (równoważników) zdań składowych zdania złożonego. W przypadku, gdy orzeczenia stanowione są przez analityczne formy fleksyjne czasowników, jedno (lub więcej) z nich może być ograniczone tylko do części imiesłowowej:

Item M. Metius repertus et ad eum reductus est. (Caes., Gall. 1, 53)

„Również Marek Mecjusz został odnaleziony i do niego (scil. do Cezara) przyprowadzony”.

W przypadku, gdy orzeczenia mają charakter złożony, jedno (lub więcej) z nich może być ograniczone do (części) orzecznika lub łącznika:

Habere $[. .$.$] quaestui rem publicam non modo turpe est, sed sceleratum etiam et nefari-$ um. (Cic., Off. 2, 77)

„Wyzyskiwanie państwa jest czymś nie tylko odrażającym, ale także zbrodniczym i niegodziwym". 
Crudele gladiatorum spectaculum et inhumanum non nullis videri solet. (Cic., Tusc. $2,41)$

„Niektórym widowisko gladiatorskie zwykle wydaje się okrutne i nieludzkie”.

(Caesar) fuisse traditur excelsa statura, colore candido, teretibus membris, ore paulo pleniore, nigris vegetisque oculis. (Suet., Iul. 45)

„(Cezar) wedlug przekazów cechowal się wysokim wzrostem, bladą cerą, zaokrąglonymi czlonkami, twarza nieco zbyt pełną, czarnymi i bystrymi oczami".

Vita $[\ldots]$ virtutibus $[\ldots]$ respondens recta et honesta et constans et naturae congruens existimari potest. (Cic., Fin. 5, 66)

„Życie odpowiadające cnotom może uchodzić i za właściwe, i za szlachetne, i za oparte na trwałych zasadach, i za zgodne z naturą".

Dictator [...] aedem Castori vovisse fertur ac pronuntiasse militi praemia, qui primus [...] castra hostium intrasset. (Liv., 2, 20)

„Dyktator mial ponoć ślubować wzniesienie świątyni Kastorowi i obiecać nagrodę żołnierzowi, który jako pierwszy wedrze się do obozu nieprzyjaciól".

Aliquis vir bonus nobis diligendus est ac semper ante oculos habendus. (Sen., Lucil. 11, 8)

„Powinniśmy wybrać sobie jakiegoś prawego człowieka i zawsze mieć go przed oczami”.

Sententiis adicere licet oratorium robur, et omissa supplere, effusa substringere. (Quint., Inst. 10, 5, 4)

„Można dodać myślom oratorskiego wigoru, uzupełnić to, co pominięto, a to, co wyrażono zbyt rozwlekle, powściągnąe".

Id quod scire potuit et debuit dixit. (Cic., Q. Rosc. 42)

"Powiedział to, co mógl i powinien był wiedzieć".

Granica oddzielająca zdanie złożone od kolejnego zdania (lub wypowiedzenia niezdaniowego) zaznaczana jest interpunkcyjnie przez kropkę, średnik, pytajnik lub wykrzyknik, a w przypadku, gdy następuje po nim cytat, także przez dwukropek.

\subsection{KRYTERIA KLASYFIKACJI I TYPOLOGIA ZDAŃ ZŁOŻONYCH}

Zdania złożone klasyfikowane są według trzech głównych kryteriów. Jednym $\mathrm{z}$ nich jest rodzaj stosunku syntaktyczno-semantycznego, łączącego zdania składowe w ramach zdania złożonego. Stosunek ten może polegać na równorzędności (niepodrzędności), czyli braku zależności składniowej i znaczeniowej zdań składowych względem siebie, lub może mieć charakter nadrzędno-podrzędny, czyli może polegać na zależności składniowo-semantycznej jednego zdania od drugiego. W pierwszym przypadku mówimy o zdaniach złożonych współrzędnie, w drugim o zdaniach złożonych podrzędnie.

Drugim kryterium jest sposób zespolenia zdań składowych w obrębie zdania złożonego. Ze względu na tę właściwość zdania złożone dzielą się na takie, w których brak jest leksykalnego wykładnika zespolenia, oraz takie, w których występuje lek- 
sykalny wykładnik (wskaźnik) zespolenia. Pierwsze z nich zwane są zdaniami asyndetycznymi lub bezspójnikowymi, zaś wśród drugich, $z$ uwagi na status wskaźnika zespolenia, wyróżnia się zdania spójnikowe i zdania względne. W zdaniach spójnikowych wykładnik zespolenia ma status konektora, który może mieć charakter prosty, jeśli stanowiony jest przez pojedynczy spójnik, lub złożony, gdy stanowiony jest przez kombinację wyrazów tekstowych reprezentujących leksemy spójnikowe, partykułowe i/lub przysłówkowe. Umownie do zdań spójnikowych zalicza się także zdania, w których wykładnikami zespolenia są związane postfiksalne morfemy spójnikowe typu -que lub -ve. Z kolei w zdaniach względnych wykładnik zespolenia, którym jest zaimek względny, ma status członu syntaktycznego zdania podrzędnego.

Trzecie kryterium ma charakter ilościowy i sprowadza się do liczby zdań składowych tworzących zdanie złożone. Pod tym względem zdania złożone dzielą się na zdania dwukrotnie złożone i zdania wielokrotnie złożone. Wyodrębnić można trzy podstawowe typy zdań wielokrotnie złożonych, biorąc pod uwagę relacje, w jakich pozostają względem siebie tworzące je zdania składowe: 1) zdania wielokrotnie złożone współrzędnie, w których wszystkie zdania składowe pozostają względem siebie w stosunku równorzędności; 2) zdania wielokrotnie złożone podrzędnie, w których wszystkie zdania składowe pozostają względem siebie w stosunku nadrzędno-podrzędnym; 3) zdania wielokrotnie złożone współrzędno-podrzędnie, w których pewne ze zdań składowych pozostają z określonymi zdania składowymi w stosunku równorzędności, $z$ innymi zaś $w$ stosunku nadrzędno-podrzędnym.

Zdania składowe tworzące zdanie złożone wyrażać mogą wszystkie odmiany modalności intencjonalnej. Mogą więc mieć one charakter zdań oznajmujących (deklaratywnych), pytajnych (interrogatywnych), rozkazujących (imperatywnych, postulatywnych) oraz życzących (dezyderatywnych). Mogą też wyrażać wszelkie typy modalności epistemicznej i logicznej (deontycznej, dynamicznej), a także sygnalizować wszystkie rodzaje diatez.

\subsection{ZDANIA ZŁOŻONE WSPÓŁRZĘDNIE}

Zdania złożone współrzędnie charakteryzują się tym, że tworzące je zdania składowe łączy stosunek równorzędności (niepodrzędności) składniowo-znaczeniowej. Jednak mimo niepodrzędności znaczeniowej relacje semantyczne zachodzące między zdaniami składowymi są zróżnicowane, w związku z czym wyróżnia się kilka podstawowych typów zdań złożonych współrzędnie, a mianowicie:

a. Zdania łączne (kopulatywne), które mogą mieć charakter asyndetyczny (bezspójnikowy) lub posiadać wykładniki zespolenia w postaci stanowionych przez spójniki konektorów typu: et, atque, ac, neque, nec, neu, neve lub w postaci postfiksalnego morfemu spójnikowego -que:

Veni, vidi, vici. (Sen., Suas. 2, 22)

"Przybyłem, zobaczyłem, zwyciężyłem". 
Huic Ceasar legioni indulserat praecipue et propter virtutem confidebat maxime. (Caes., Gall. 1, 40)

„Temu legionowi Cezar szczególnie sprzyjał i ze względu na męstwo najbardziej ufał”.

Reliqui sese fugae mandarunt atque in proximas silvas abdiderunt. (Caes., Gall. 1, 12)

„Pozostali rzucili się do ucieczki i schronili się w najbliższych lasach".

Est $[\ldots]$ adventus (Caesaris) in exspectatione, neque tu id ignoras. (Cic., Fam. 9, 6, 1) „Oczekiwane jest przybycie Cezara, i ty o tym dobrze wiesz".

Acerrime reliqui resistebant nec dabat suspicionem fugae quisquam. (Caes., Gall. 7, 62)

„Pozostali (żołnierze) stawiali zwzięty opór i nie dawal nikt podstaw do podejrzeń o chęć ucieczki".

Adveniat $[\ldots]$, neve exhorrescat. (Verg., Aen. 7, 265)

„Niech przybywa i niech się nie obawia”.

Te semper amavi dilexique. (Cic., Fam. 15, 17, 1 )

„Zawsze cię kochałem i poważałem”.

Aliorum iudicio permulta nobis et facienda et non facienda et mutanda et corrigenda sunt. (Cic., Off. 1, 147)

„Z woli innych ludzi musimy wiele rzeczy robić, wielu nie robić, wiele rzeczy zmieniać i wiele poprawiać".

Dictator [...] aedem Castori vovisse fertur ac pronuntiasse militi praemia. (Liv., 2, 20)

„Dyktator miał ponoć ślubować wzniesienie świątyni Kastorowi i obiecać nagrodę żołnierzowi".

Hi neque vultum fingere neque interdum lacrimas tenere poterant. (Caes., Gall. 1, 39)

„Ci nie mogli ani zmienić wyrazu twarzy, ani powstrzymać niekiedy lez".

b. Zdania rozłączne (dysjunktywne, alternatywne), z konektorami w postaci spójników typu: aut, vel, sive, seu:

Cenam coque, aut abi in malam cruciatum. (Pl., Aul. 458-459)

"Gotuj obiad albo idź precz na złamanie karku".

Sequimini me vel [...] ducite. (Petron., Sat. 99, 4)

"Chodźcie za mną albo (sami) prowadźcie”.

Si quis occentavisset sive carmen condidisset. (Cic., Rep. 4, 12)

„Gdyby ktoś wygłaszał lub układał obelżywe teksty”.

Hic vincendum aut moriendum, milites, est. (Liv., 21, 43)

„Tutaj, żołnierze, trzeba (nam) zwyciężać albo umierać".

c. Zdania przeciwstawne (adwersatywne), asyndetyczne lub z konektorami typu: sed, verum, et, autem, neque. W przypadku, gdy poprzedzające zdanie składowe ma odcień koncesywny, może wystąpić konektor tamen lub konektory złożone typu: sed tamen, verum tamen: 
Vos vincetis, illi fugient. (Liv., 6, 7)

„Wy będziecie zwyciężać, oni uciekać".

Homines sumus, non dei. (Petron., Sat. 75, 1)

„Jesteśmy ludźmi, nie bogami”.

Quae contumelia non fregit eum, sed erexit. (Nep., Them. 1)

"Ta zniewaga nie złamała go, lecz dodała mu sił".

Tu eum orato, ego autem orabo vilicum. (Pl., Cas. 273)

„Ty proś jego, ja natomiast będę prosić zarządcę".

Est istuc quidem honestum, verum hoc expedit. (Cic., Off. 75)

"Tamto jest wprawdzie szlachetne, jednak to (tutaj) jest korzystne".

Otiosi videmur, et non sumus. (Sen., Lucil. 56, 11)

„Uchodzimy za spokojnych, lecz nie jesteśmy (takimi)”.

Id $[\ldots]$ utile videbatur, neque erat. (Cic., Off. 3, 41)

"To wydawalo się korzystne, ale (takie) nie było".

Naturam expelles furca, tamen usque recurret. (Hor., Epist. 1, 10, 24)

„Będziesz przepędzał naturę widlami, a i tak ciągle będzie wracać".

Magnus mihi quidem videtur, sed tamen non summus. (Cic., Tusc. 2, 44)

„Owszem, wydaje mi się wielki, ale jednak nie największy”.

Difficile factu est, sed conabor tamen. (Cic., Rep. 1, 65)

„Jest (to) trudne do wykonania, ale spróbuję".

Atheniensium res gestae [...] satis amplae magnificaeque fuere, verum aliquanto minores tamen quam fama feruntur. (Sall., Cat. 8)

„Dokonania Ateńczyków były nader wielkie i wspaniałe, ale jednak nieco mniej doniosłe niż się sądzi".

Adwersatywny charakter można przypisać również zdaniom, w których wskaźnikiem zespolenia są tworzące zestawienia konektory złożone typu: non solum... sed etiam/quoquelet..., non solum / non modo... verum etiam..., non modo / non solum... sed ne... quidem... itp.:

Hi propter virtutem non solum apud Ceasarem in honore erant, sed etiam apud exercitum cari habebantur. (Caes., Civ. 3, 59)

„Ze względu na męstwo nie tylko cieszyli się oni poważaniem u Cezara, lecz także cenieni byli przez wojsko".

Non modo sine cura quiescere, sed ne spirare quidem sine metu possunt. (Cic., S. Rosc. 65) „Nie mogą nie tylko odpoczywać bez niepokoju, ale nawet oddychać bez strachu”.

d. Zdania konkluzywne (rezultatywne, konsekutywne), z konektorami typu: ideo, itaque, ergo, igitur: 
Maiores nostri longe aliter et de illo et de ceteris talibus viris existimabant, itaque ex minima tenuissimaque re publica maximam et florentissimam nobis reliquerunt. (Cic., $S$. Rosc. 50)

„Nasi przodkowie o nim i pozostałych takich ludziach myśleli zupełnie inaczej, toteż $\mathbf{z}$ bardzo niewielkiej i słabej pozostawili nam republikę ogromną i kwitnącą".

C. Gracchi frumentaria magna (fuit) largitio, exhauriebat igitur aerarium. (Cic., Off. 2, 72)

„Prowadzone przez Gajusza Grakchusa rozdawnictwo zboża było ogromne, a więc ogołacało skarbiec publiczny".

e. Zdania eksplikatywne (wyjaśniające, przyczynowe) z konektorami typu: nam, namque, enim, etenim; zdania tego rodzaju mogą mieć również charakter parentetyczny (nawiasowy):

Cave, cave, namque in malos asperrimus parata tollo cornua. (Hor., Epod. 6, 11-12)

„Strzeż się, strzeż, bowiem rozwścieczony na drani podnoszę rogi gotowe do ataku”.

Tace dum parumper, nam concrepuit ostium. (Pl., Men. 348)

„Tymczasem zamilcz na chwilę, skrzypnęly bowiem drzwi”.

(Venus) hunc $[\ldots]$ perducit ad illam civitatem et Psychen - hoc enim nomine puella nuncupabatur - ostendit. (Apul., Met. 4, 30)

„Wenus prowadzi go do owego kraju i Psyche - takie bowiem imię nosiła dziewczyna - osobiście mu pokazuje".

Addidit praecepta (etenim aderat Meherdates), ut non dominationem [...] cogitaret. (Tac., Ann. 12, 11)

„Dodal też pouczenia (był tam bowiem obecny Meherdates), aby nie myślał o tyranii”.

\subsection{ZDANIA ZŁOŻONE PODRZĘDNIE}

Zdania złożone podrzędnie cechują się tym, że konstytuujące je zdania składowe pozostają względem siebie w stosunku nadrzędno-podrzędnym, tzn. jedno ze zdań wykazuje zależność składniowo-znaczeniową od drugiego. Zdanie cechujące się tą zależnością ma status zdania podrzędnego, zaś drugie $\mathrm{z}$ nich status zdania nadrzędnego. Zależność składniowo-znaczeniowa zdania podrzędnego polega na tym, iz wypełnia ono miejsce otwierane w strukturze składniowo-znaczeniowej zdania nadrzędnego dla określonego członu syntaktycznego. Innymi słowy, zdanie podrzędne zastępuje określony człon syntaktyczny zdania nadrzędnego, czy też stanowi jego funkcjonalny odpowiednik. Nie jest zdeterminowany gramatycznie linearny porządek (szyk) zdań składowych w obrębie zdania złożonego podrzędnie. Oznacza to, że zdanie podrzędne może następować po zdaniu nadrzędnym, może je poprzedzać lub może być wbudowane (zagnieżdżone) w linerny ciąg zdania nadrzędnego. 


\subsubsection{Kryteria klasyfikacji i typologia zdań podrzędnych}

w ramach zdań złożonych podrzędnie

Kryteria klasyfikacji zdań podrzędnych w ramach zdań złożonych podrzędnie uwzględniają trzy zasadnicze czynniki.

Jednym $\mathrm{z}$ nich jest miejsce $\mathrm{w}$ strukturze składniowej zdania nadrzędnego, które wypełniane jest przez zdanie podrzędne, czyli to, jaki człon syntaktyczny zdania nadrzędnego zastępowany jest przez zdanie podrzędne. Na podstawie tego kryterium wyodrębnia się zdania podrzędne: podmiotowe, dopełnieniowe, przydawkowe, okolicznikowe (czasu, celu, skutku, przyzwolenia itp.), a także zdania orzecznikowe (czyli zdania zastępujące składnik członu syntaktycznego, tj. orzecznik).

Drugim czynnikiem jest sposób zespolenia zdania podrzędnego ze zdaniem nadrzędnym. W oparciu o to wyróżnia się zdania podrzędne: asyndetyczne (bezspójnikowe), spójnikowe oraz względne.

Trzeci czynnik to sposób czy też zakres udziału zdania podrzędnego w suplementacji struktury semantyczno-syntaktycznej zdania nadrzędnego, czyli to, czy za pośrednictwem zdania podrzędnego następuje całkowita substytucja członu syntaktycznego zdania nadrzędnego, a więc uzupełnienie zdania nadrzędnego o zdaniowy ekwiwalent członu syntaktycznego, czy też za pośrednictwem zdania podrzędnego następuje rozszerzenie (rozbudowanie) niepełnoznacznego członu syntaktycznego zdania nadrzędnego, wyrażonego zaimkiem kataforycznym lub anaforycznym. W zależności od tego kryterium wprowadza się podział na zdania podrzędne uzupełniające i rozszerzające.

Biorąc pod uwagę wszystkie te trzy kryteria, w ramach zdań złożonych podrzędnie wyróżnić można:

a. zdania podrzędne podmiotowe:

a.1.1. asyndetyczne uzupełniające, np.:

Quaeritur, natura an doctrina possit effici virtus. (Cic., Top. 82)

„Jest przedmiotem pytania, czy cnota może być osiągnięta dzięki naturze, czy dzięki nauce”.

a.1.2. asyndetyczne rozszerzające, np.:

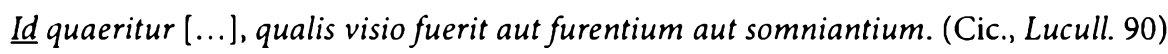
„Jest przedmiotem dociekania to, jakie były wrażenia czy to szaleńców, czy ludzi śpiących".

a.2.1. spójnikowe uzupełniające, np.:

Fieri non potuit, ut $P$. Cornelius Ti. Sempronius consules fuerint. (Liv., 21, 15, 4)

„Nie mogło się zdarzyć, żeby Publiusz Korneliusz i Tytus Semproniusz zostali konsulami”.

a.2.2. spójnikowe rozszerzające, np.:

(Est) magnificum illud etiam Romanisque hominibus gloriosum, ut Graecis de philosophia litteris non egeant. (Cic, Div., 2,5)

"Również to jest wspaniale i chwalebne dla Rzymian, że nie potrzebowali greckiej literatury filozoficznej". 
a.3.1. względne uzupełniające, np.:

Deum colit, qui novit (eum). (Sen., Lucil. 95, 47)

„Szanuje boga, kto go poznal”.

\section{a.3.2. względne rozszerzające, np.:}

Illi, quibus Damasippi mors laetitiae fuerat, paulo post ipsi trahebantur. (Sall., Cat. 51, 34) „Ci, dla których śmierć Damazypa była powodem do radości, niedługo potem sami byli wleczeni (na śmierć)".

b. Zdania podrzędne dopełnieniowe:

b.1.1. asyndetyczne uzupełniające, np.:

Considera, C. Piso, quis quem fraudasse dicatur. (Cic., Q. Rosc. 21)

„Rozważ, Gajuszu Pizonie, kto kogo prawdopodobnie oszukał”.

b.1.2. asyndetyczne rozszerzające, np.:

Hoc quaeramus, verum sit an falsum. (Cic., Cluent. 124)

„Spróbujmy dociec tego, czy jest (to) prawdziwe, czy falszywe”.

b. 2.1. spójnikowe uzupełniające, np.:

Faciam, ut huius diei locique meique semper meminerit. (PI., Capt. 800)

„Sprawię, że ten dzień, to miejsce i mnie (samego) na zawsze zapamięta”.

b.2.2. spójnikowe rozszerzające, np.:

Illud autem te, mi Lucili, rogo [...], ut philosophiam in praecordia ima demittas. (Sen., Lucil. 20, 1)

¿Q to cię, mój Lucyliuszu, proszę, byś filozofię wziął sobie glęboko do serca".

\section{b.3.1. względne uzupełniające, np.:}

Redeuntes milites, quos possunt, consectantur. (Caes., Gall. 5, 58)

„Jeźdźcy w drodze powrotnej ścigali kogo tylko mogli".

\section{b.3.2. względne rozszerzające, $\mathrm{np}$.:}

Cur eos, quos omnes poene verari debemus, solus oppugnas? (Cic., Phil. 10. 4)

„Dlaczego tych, których wszyscy powinniśmy niemal czcić, sam jeden atakujesz?"

c. Zdania podrzędne przydawkowe:

c.l. asyndetyczne uzupełniające, np.:

Non fuit causa, cur tantum laborem caperes. (Cic., Q. Rosc. 49)

„Nie było uzasadnienia, dlaczego miałbyś podjąć się takiego trudu”.

c.2.1. spójnikowe uzupełniające, np.:

De voluntate tua, ut simul simus [...], non dubito. (Cic., Att. 12, 26, 1)

„W twoją chęć, byśmy byli razem, nie wątpię". 


\section{c.2.2. spójnikowe rozszerzające, np.:}

Doctorum est ista consuetudo [...], ut iis ponatur, de quo disputent quamvis subito. (Cic., Lael. 17)

„Uczonych dotyczy ten zwyczaj, że przedstawia im się (to), o czym mają dyskutować po upływie dowolnie krótkiego czasu (scil. natychmiast, bez wcześniejszego przygotowania)".

\section{c.3.1. względne uzupełniające, np.:}

Interea Commius reliquique duces, quibus summa imperii permissa erat, cum omnibus copiis ad Alesiam perveniunt. (Caes., Gall. 7, 79)

„Tymczasem Kommiusz i pozostali wodzowie, którym powierzone zostalo naczelne dowództwo, przybywają ze wszystkimi oddzialami pod Alezję".

\section{c.3.2. względne rozszerzające, np.:}

Viridovix $[\ldots]$ summam imperii tenebat earum omnium civitatum, quae defecerant. (Caes., Gall. 3, 17)

„Wirydowiks sprawowal naczelne dowództwo nad wszystkimi tymi plemionami, które zbuntowały się (przeciw Cezarowi)".

d. Zdania podrzędne okolicznikowe (np. czasu):

d.1.1. spójnikowe uzupełniające, np.:

Metellus [...], postquam nox aderat, in castra cum exercitu revortitur. (Sall., Iug. 58)

"Metellus, gdy zapadla noc, powraca z wojskiem do obozu".

d.1.2. spójnikowe rozszerzające, np.:

Trebellium [...] oderat tum, cum ille tabulis novis adversabatur. (Cic., Phil. 6, 11)

„Trebelliusza nienawidzil wtedy, gdy ten sprzeciwial się nowym księgom rachunkowym (tzn. ustawie znoszącej dlugi)".

d.2.1. względne uzupełniające, np.:

Quot dies erimus in Tusculano, agamus haec. (Cic., Tusc. 1, 119)

„Ile dni spędzimy w posiadlości tuskulańskiej, (przez tyle dni) zajmujmy się tymi rzeczami”.

d.2.2. względne rozszerzające (miejsca), np.:

Quae minime visa pars firma est, huc concurritur. (Caes., Gall. 7, 84)

„ Która część (umocnień) wydala się najsłabsza, tam spieszono".

e. Zdania podrzędne orzecznikowe:

e.l. względne uzupełniające, np.:

Non ego sum, qui te dudum conduxi. (PI., Merc. 758)

„To nie ja jestem (tym), który cię nają". 


\section{e.2. względne rozszerzające, np.:}

Neque is sum [...], qui gravissime ex vobis mortis periculo terrear. (Caes., Gall. 5, 30) „I nie jestem tym, który najbardziej z was miałby być przerażony niebezpieczeństwem śmierci".

Jak już wspomniano, składnikami zdań złożonych podrzędnie mogą być także równoważniki zdań podrzędnych, znane jako tzw. accusativus cum infinitivo oraz ablativus absolutus, które generalnie mają charakter asyndetyczny i w większosci przypadków uzupełniający. W związku z tym w zależności od miejsca, które wypełniają one w strukturze syntaktycznej zdania nadrzędnego, wyróżnia się:

a. W odniesieniu do struktury accusativus cum infinitivo:

a.1. asyndetyczne uzupełniające równoważniki zdań podrzędnych dopełnieniowych, np.:

Nomen Attici perire Ciceronis epistulae non sinunt. (Sen., Lucil. 21, 4)

„Listy Cycerona nie pozwalają, by imię Attyka zaginęlo (w niepamięci)".

a.2. asyndetyczne rozszerzające równoważniki zdań podrzędnych dopełnieniowych, np.:

Illud cognosces profecto, mihi te neque cariorem neque iucundiorem esse quemquam. (Cic. Fam. 2, 3, 2)

„Poznasz to niezawodnie, że (mianowicie) nikt nie jest mi droższy ani milszy od ciebie”.

a.3. asyndetyczne uzupełniające równoważniki zdań podrzędnych podmiotowych, np.:

Caesari nuntiatum est equites Ariovisti propius tumulum accedere. (Caes., Gall. 1, 46)

"Cezarowi doniesiono, że jeźdźcy Ariowista podchodzą bliżej ku wzniesieniu”.

a.4. asyndetyczne uzupełniające równoważniki zdań podrzędnych przydawkowych, np.:

Nuntio adlato omnes eorum milites in potestate Caesaris teneri, concurrunt ad Aristium. (Caes., Gall. 7, 43)

„Po tym, gdy nadeszła wiadomość, iż wszyscy ich żołnierze znajdują się w rękach Cezara, pospieszyli do Arystiusza".

b. W odniesieniu do struktury ablativus absolutus:

b.1. asyndetyczne uzupełniające równoważniki zdań okolicznikowych (czasu), np.:

Q. Titurius et $L$. Cotta legati $[\ldots]$ aedificiis incensis [...] ad Caesarem se receperunt. (Caes., Gall. 4, 38)

„Legaci Kwintus Tyturiusz i Lucjusz Kotta po tym, gdy budynki zostały spalone, powrócili do Cezara". 
Jednak w ramach zdań wielokrotnie złożonych równoważniki zdań podrzędnych typu accusativus cum infinitivo i ablativus absolutus mogą też same stanowić struktury nadrzędne wobec zależnych od nich składniowo zdań podrzędnych. Wyróżnia się wówczas:

a. Zdania funkcjonalnie podmiotowe, jeśli w strukturze równoważnika zdania wypełniają pozycję otwartą dla funkcjonalnego odpowiednika podmiotu, a więc:

a.1. w stosunku do równoważnika typu accusativus cum infinitivo jako struktury nadrzędnej

a.1.1. zdania funkcjonalnie podmiotowe spójnikowe uzupełniające, np.:

Doce posse fieri, ut qui diu vixit, parum vixerit. (Sen., Lucil. 49, 10)

„Poucz, iż może się zdarzyć, że (ten), kto żył długo, przeżył mało".

(Philodamus) negavit moris esse Graecorum, ut in convivio virorum accumberent mulieres. (Cic., Verr., 2, 1, 66)

„(Filodamus) stwierdził, że nie jest właściwe dla obyczaju greckiego, aby podczas uczty dla mężczyzn zajmowały miejsce przy stole (także) kobiety".

\section{a.1.2. zdania funkcjonalnie podmiotowe względne uzupełniające, np.:}

Placet Stoicis, quae in terris gignantur, ad usum hominum omnia creari. (Cic., Off. 1, 22)

"Stoicy wyznają pogląd, iż (to), co rodzi się na ziemi, wszystko tworzone jest na użytek ludzi”.

In his oratoribus illud animadvertendum est, posse esse summos, qui inter se sint dissimiles. (Cic., Brut. 204)

„W odniesieniu do tych mówców należy zwrócić uwagę na to, że mogą być najwybitniejszymi (tacy), którzy są do siebie zupełnie niepodobni".

a.2. w stosunku do równoważnika typu ablativus absolutus jako struktury nadrzędnej

a.2.1. zdania funkcjonalnie podmiotowe asyndetyczne uzupełniające, np.:

Sed tu $[\ldots]$ nuntiato quid adveneris susceptoque quod offeretur $[\ldots]$ canis saevitiam offula reliqua redime. (Apul., Met. 6, 19)

„Ty zaś, gdy już powiesz, po co przychodzisz i gdy przyjmiesz, co będzie ci dawane, ułagodź wściekłość psa pozostałym kawałkiem jedzenia".

\section{a.2.2. zdania funkcjonalnie podmiotowe względne uzupełniające, np.:}

Sed tu [...] nuntiato quid adveneris susceptoque quod offeretur [...] canis saevitiam offula reliqua redime. (Apul., Met. 6, 19)

„Ty zaś, gdy już powiesz, po co przychodzisz i gdy przyjmiesz, co będzie ci dawane, ułagodź wściekłość psa pozostałym kawałkiem jedzenia".

b. Zdania funkcjonalnie orzecznikowe, jeśli w strukturze równoważnika zdania wypełniają pozycję otwartą dla funkcjonalnego odpowiednika orzecznika, a więc:

b.l.w stosunku do równoważnika typu accusativus cum infinitivo jako struktury nadrzędnej 
b.1.1. zdania funkcjonalnie orzecznikowe spójnikowe rozszerzające, np.:

(Ad te) pertinet esse te talem, ut tuas laudes obscuratura nulla umquam sit oblivio. (Cic., Marcell. 30)

„Twoją sprawą jest być takim, żeby twoich zasług nigdy nie przysłoniło żadne zapomnienie”.

\section{b.1.2. zdania funkcjonalnie orzecznikowe względne rozszerzające, np.:}

Talem te esse oportet, qui te ab impiorum civium societate seiungas. (Cic., Fam. 10, 6, 3) „Trzeba, abyś był takim, który trzyma się z dala od związków z nieprawymi ludźmi”.

Jeśli pozycję, która w strukturze równoważnika zdania otwierana jest dla funkcjonalnego odpowiednika podmiotu, wypełnia równoważnik zdania typu accusativus cum infinitivo, będzie on miał wówczas status równoważnika zdania funkcjonalnie podmiotowego, zwykle o charaktererze asyndetycznym uzupełniającym. Strukturą nadrzędną dla tego rodzaju równoważnika zdania funkcjonalnie podmiotowego może zatem być:

a. (inny) równoważnik zdania podrzędnego typu accusativus cum infinitivo, np.:

Publice maximam putant esse laudem quam latissime a suis finibus vacare agros. (Caes. Gall. 4, 3)

„Uważaja, że w wymiarze publicznym największą chwałą jest to, by na jak największą odleglość od ich granic pola zionęly pustka".

b. równoważnik zdania podrzędnego typu ablativus absolutus, np.:

Oram Asiae legens pervenit in Lyciam, Patarisque cognito vivere Ptolomaeum navigandi quidem in Aegyptum omissum consilium est. (Liv., 33, 41)

„Płynąc wzdluż wybrzeża Azji dotarł do Licji i gdy w Patarach dowiedział się, że Ptolemeusz żyje, zarzucony (przez niego) został plan poptynięcia do Egiptu".

W kolejnych rozdziałach bliżej scharakteryzowane zostaną najpierw zdania podrzędne względne, $z$ uwagi na ich specyfikę wynikającą ze statusu zaimka względnego jako wykładnika zespolenia i równoczesnie członu syntaktycznego, następnie zdania podrzędne spójnikowe i asyndetyczne oraz równoważniki zdań podrzędnych.

\subsubsection{Zdania względne}

\subsubsection{Wprowadzenie}

Zdania podrzędne względne to zdania, których wykładnikiem zespolenia ze zdaniem nadrzędnym jest zaimek względny. Podstawowym łacińskim zaimkiem względnym jest zaimek qui, quae, quod. Oprócz tego łacina dysponuje zaimkami względnymi nieokreślonymi uogólniającymi swobodnego wyboru, tj. zaimkami nieograniczonymi quisquis i quicumque, oraz zaimkiem binarnym utercumque. Zaimki te mogą przyjmować status rzeczownikowy lub przymiotnikowy. Funkcję 
przymiotnikowego zaimka względnego pełnią także zaimki: qualis, quantus, qualiscumque, quot. Ponadto istnieją zaimki względne o charakterze przysłówkowym. Funkcję tę pełnią zaimki: ubi, unde, quo, qua, oraz zaimki uogólniające: ubicumque, quaqua, quotienscumque itp.

\subsubsection{Zdania z zaimkiem względnym o charakterze rzeczownikowym i przysłówkowym}

Zdania względne, w których wykładnik zespolenia (czyli zaimek względny) ma charakter rzeczownikowy lub przysłówkowy, są wynikiem pronominalizacji, czyli procesu polegającego na tym, iż określony składnik wypowiedzi, nominalny (rzeczownikowy) lub adwerbalny (przysłówkowy), zastępowany jest zaimkiem $\mathrm{w}$ celu uniknięcia jego powtarzania $\mathrm{w}$ toku wypowiedzi. W procesie pronominalizacji generalnie wykorzystywane są dwie procedury. Jedną z nich jest anaforyzacja, np.: Mercator quidam fuit Syracusis senex; ei sunt nati filii gemini duo (Pl., Men. 17-18) "Żył w Syrakuzach pewien kupiec w starszym wieku; jemu urodzili się dwaj synowie bliźniacy". Drugą zaś procedurą jest relatywizacja, której efektem są właśnie zdania względne i która od tej pierwszej różni się tym, iż wykorzystywane w jej ramach zaimki, czyli zaimki względne, oprócz pełnienia funkcji anaforycznej sygnalizują równocześnie podrzędność składniową zdania, w którym występują, np.: Erat in Carnutibus summo loco natus Tasgetius, cuius maiores in sua civitate regnum obtinuerant (Caes., Gall. 5, 25) „Żył w kraju Karnutów wywodzący się ze znakomitego rodu Tasgetius, którego przodkowie sprawowali władzę królewską w swoim plemieniu". Tak więc cechą charakterystyczną tego typu zdań względnych jest z jednej strony podrzędność (zależność) składniowa, $z$ drugiej zaś to, że posiadają one pewien wspólny ze zdaniami nadrzędnymi składnik semantyczny, do którego odsyła zaimek względny. Składnik ten wyrażany jest leksykalnie w zdaniu nadrzędnym głównie za pośrednictwem rzeczownika (niekiedy $z$ towarzyszącym mu zaimkiem is, ille, hic lub innym) lub innego zaimka, stanowiąc semantyczny i zarazem leksykalny ana- bądź kataforyzowany korelat zaimka względnego.

\subsection{Zdania $z$ rzeczownikowym korelatem zaimka względnego}

Wobec rzeczownika, stanowiącego leksykalny korelat zaimka względnego, rzeczownikowo użyty zaimek względny zachowuje składnię zgody (kongruencję) co do kategorii liczby i rodzaju, przy czym występując w liczbie mnogiej może odnosić się do dwóch (lub więcj) rzeczownikowych korelatów w singularis. Z kolei przybierana przez niego wartość kategorii przypadka determinowana jest jego pozycją syntaktyczną w ramach zdania, w którym się znajduje. Może więc występować $\mathrm{w}$ różnych przypadkach zajmując typowe dla rzeczowników pozycje składniowe, np.: 
a. Podmiotu:

(Ceasar) Ariminum [...] proficiscitur ibique tribunos plebis, qui ad eum confugerant, convenit. (Caes., Civ. 1, 8)

„(Cezar) wyruszył do Ariminum i tam spotkał się z trybunami ludowymi, którzy wcześniej do niego zbiegli".

b. Dopełnienia:

$O b$ eas causas ei munitioni, quam fecerat, T. Labienum legatum praeficit. (Caes., Gall. $1,10)$

„Z tych powodów dowódcą tych fortyfikacji, które zbudowal, mianował legata Tytusa Labienusa".

c. Przydawki:

Eo L. Caesar adulescens venit, cuius pater Caesaris erat legatus. (Caes., Civ. 1, 8)

„Przybył tam mlody Lucjusz Cezar, którego ojciec był legatem Cezara”.

d. Okolicznika:

Naves habent Veneti plurimas, quibus in Britanniam navigare consuerunt. (Caes., Gall. $3,8)$

„Wenetowie mają wiele okrętów, którymi zwykle przeprawiają się do Brytanii”.

Podobnie może $\mathrm{w}$ różnych przypadkach występować i różne pozycje syntaktyczne w zdaniu nadrzędnym zajmować relatywizowany rzeczownik, stanowiący leksykalny korelat zaimka względnego; może więc zajmować pozycję np.:

a. Podmiotu:

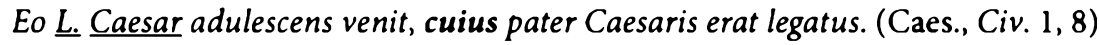

„Przybyl tam mlody Lucjusz Cezar, którego ojciec był legatem Cezara”.

b. Dopełnienia:

(Ceasar) Ariminum [...] proficiscitur ibique tribunos plebis, qui ad eum confugerant, convenit. (Caes., Civ. 1, 8)

„(Cezar) wyruszył do Ariminum i tam spotkał się z trybunami ludowymi, którzy wcześniej do niego zbiegli".

c. Orzecznika:

Alii vestrum anseres sunt, qui tantum modo clamant, nocere non possunt, alii canes, qui et latrare et mordere possunt. (Cic., S. Rosc. 57)

„Jedni $z$ was są gessiami które tylko gęgają, ale szkodzić nie mogą, inni są psami, które i szczekać, i gryźć umieją".

d. Przydawki:

Adiacere corpora hominum, quos $[. .$.$] sitis peremerat. (Tac., Ann. 4, 49)$

„Obok leżały ciała ludzi, których zabilo pragnienie”. 
e. Okolicznika:

Quam copiose ab eo (scil. Xenophonte) agri cultura laudatur in eo libro, qui est de tuenda re familiari! (Cic., Lael. 59)

„Jakże wymownie wychwalane jest przez Ksenofonta rolnictwo w tej książce, która poświęcona jest zarządzaniu majątkiem!"

Relacje między wartością kategorii przypadka i pozycją składniową zaimków względnych a wartością kategorii przypadka i pozycją składniową ich leksykalnych korelatów także mają zróżnicowany charaker. Oba te elementy mogą wystąpić w tym samym przypadku i pełnić w swoich zdaniach tę samą funkcję składniową, jak np. w zdaniu:

Huic quoque accidit $[\ldots]$, ut nonulli milites, qui lignationis $[\ldots]$ causa in silvas discessissent, repentino equitum adventu interciperentur. (Caes., Gall. 5, 39)

„Jemu także się przytrafiło (to), że pewni żołnierze, którzy udali się do lasów po drewno, zostali odcięci wskutek niespodziewanego ataku jeźdźców".

Częściej jednak występują w różnych przypadkach i zajmują odmienne pozycje syntaktyczne, jak np. w zdaniach:

(Ceasar) Ariminum [...] proficiscitur ibique tribunos plebis, qui ad eum confugerant, convenit. (Caes., Civ. 1, 8)

"(Cezar) wyruszył do Ariminum i tam spotkał się z trybunami ludowymi, którzy wcześniej do niego zbiegli".

Quam copiose ab eo (scil. Xenophonte) agri cultura laudatur in eo libro, qui est de tuenda re familiari! (Cic., Lael. 59)

„Jakże wymownie wychwalane jest przez Ksenofonta rolnictwo w tej książce, która poświęcona jest zarządzaniu majątkiem!"

Przysłówkowe zaimki względne generalnie zajmują $\mathrm{w}$ zdaniu podrzędnym pozycję okolicznika. Ich korelatem $\mathbf{w}$ zdaniu nadrzędnym może być zaimek przysłowny będący również okolicznikiem, jak np.:

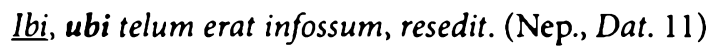

„Tam, gdzie wcześniej została zakopana broń, usiadr".

Praesumptum habeant, quoties fugas et caedes iussit princeps, toties grates deis actas $[\ldots]$ fuisse. (Tac., Ann. 14, 64)

„Niech z góry wiedzą, że ilekroć cesarz nakazywal wygnania i rzezie, tylekroć bogom składano (za to) podziękowania".

Quantum [...] augebatur militum numerus, tanto maiore pecunia in stipendium opus erat. (Liv., 5, 10)

"O ile wzrastala liczba żolnierzy, o tyle więcej trzeba było pieniędzy na żołd". 
Częściej jednak jest nim rzeczownik, który pełnić może różne funkcje składniowe, np.:

a. Podmiotu:

Insula Delus [...], quo omnes undique $[\ldots]$ commeabant $[\ldots]$, sine muro nihil timebat. (Cic., Manil. 55)

„Wyspa Delos, dokąd wszyscy zewsząd zjeżdżali się, (nawet) nie mając murów, niczego się nie obawiala".

Is collis, ubi castra posita erant, $[\ldots]$ tantum adversus in latitudinem patebat, quantum loci acies instructa tenere poterat. (Caes., Gall. 2, 8)

„To wzgórze, na którym rozłożony był obóz, było od przodu otwarte na szerokość odpowiadającą miejscu, jakie mógł zająć (= jakiego wymagał) ustawiony szyk bojowy".

b. Dopełnienia:

Numquam hominem quemquam conveni, unde abierim lubentius. (Pl., Epid. 80)

"Nie spotkałem jeszcze żadnego czlowieka, od którego chętniej bym odszedr".

Veritas $[\ldots]$ locum, ubi consistat, reperire non poterit. (Cic., Quinct. 5)

„Prawda nie będzie mogła znaleźć miejsca, gdzie pozostałaby na dłużej”.

c. Przydawki:

Tres viae sunt ad Mutinam, quo festinat animus. (Cic., Phil. 12, 22)

"Są trzy drogi do Mutyny, dokąd wyrywa się serce".

d. Okolicznika:

Cum intellegeret in illis locis sibi bellum gerendum, ubi paucis ante annis L. Valerius Praeconinus legatus [...] interfectus esset atque unde L. Manlius proconsul impedimentis amissis profugisset, non mediocrem sibi diligentiam adhibendam intellegebat. (Caes., Gall. $3,20)$

„Ponieważ zdawał sobie sprawę, że będzie musial prowadzić wojnę na tych terenach, gdzie kilka lat wcześniej polegt legat Lucjusz Walerius Prekoninus i skąd po stracie taborów uciek! prokonsul Lucjusz Manlius, rozumial doskonale, że będzie to wymagało od niego znacznego zaangażowania".

In arcem, quo ruere fugientium turbam videbat, pergit. (Liv., 4, 34) „Rusza w stronę zamku, dokąd, jak widzial, gnal thum uciekających".

Biorąc pod uwagę usytuowanie zdań względnych w stosunku do zdań nadrzędnych, a także zaimków względnych w stosunku do ich leksykalnych korelatów, wyodrębnić możemy struktury, w których:

1. Zdanie względne występuje w postpozycji do zdania nadrzędnego, czyli dołączane jest do zdania nadrzędnego (występuje po zdaniu nadrzędnym); tym samym leksykalny korelat poprzedza zaimek względny:

(Helveti) pro gloria belli atque fortitudinis angustos se fines habere arbitrabantur, qui in longitudinem milia passuum CCXL, in latitudinem CLXXX patebant. (Caes., Gall. 1, 2) 
„(Helwetowie) uważali, że w stosunku do (ich) slawy wojennej i męstwa zajmowali zbyt mały obszar, który ciągnął się na długość dwustu czterdziestu tysięcy krokow, i szerokość stu osiemdziesięciu tysięcy".

Erat in Carnutibus summo loco natus Tasgetius, cuius maiores in sua civitate regnum obtinuerant. (Caes., Gall. 5, 25)

„Żył w kraju Karnutów wywodzący się ze znakomitego rodu Tasgetius, którego przodkowie sprawowali władzę królewską w swoim plemieniu".

Paulo ante tertiam vigiliam est animadversum fumare aggerem, quem cuniculo hostes succenderant. (Caes., Gall. 7, 24)

„Tuż przed trzecią strażą nocną zauważono, że wydobywa się dym z nasypu, który wrogowie podpalili przy użyciu podkopu".

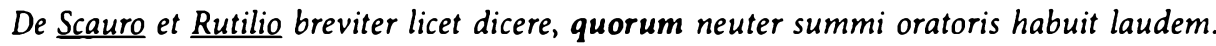
(Cic., Brut. 110)

„O Skaurusie i Rutyliuszu wypada opowiedzieć krótko, $\mathbf{z}$ nich bowiem żaden nie uzyskal slawy wybitnego mówcy, a jeden i drugi uwikłany był w liczne procesy sądowe".

Viridovix $[\ldots]$ summam imperii tenebat earum omnium civitatum, quae defecerant. (Caes., Gall. 3, 17)

„Wirydowiks [...] sprawowal naczelne dowództwo na wszystkimi tymi plemionami, które zbuntowały się (przeciw Cezarowi)".

Tres viae sunt ad Mutinam, quo festinat animus. (Cic., Phil. 12, 22)

„Są trzy drogi do Mutyny, dokąd wyrywa się serce".

2. Zdanie względne jest wbudowane (zagnieżdżone) w szyk linearny zdania nadrzędnego. Ze względu na wzajemne usytuowanie zaimka względnego i jego leksykalnego korelatu można wyróżnić dwa podtypy tego rodzaju struktur, a mianowicie takie, w których:

a. Znajdujący się w zdaniu nadrzędnym korelat poprzedza zaimek względny:

Hostes [...] vadis repertis partem suarum copiarum traducere conati sunt eo consilio, ut $[\ldots]$ castellum, cui praeerat $Q$. Titurius legatus, expugnarent. (Caes., Gall. 2, 9)

„Wrogowie, gdy znaleźli brody (w rzece), próbowali przeprowadzić (nimi) część swoich wojsk z tym zamiarem, by zdobyć umocnienie, którym dowodzil legat Kwintus Tyturiusz".

Interea Commius reliquique duces, quibus summa imperii permissa erat, cum omnibus copiis ad Alesiam perveniunt. (Caes., Gall. 7, 79)

„Tymczasem Kommiusz i pozostali wodzowie, którym powierzone zostało naczelne dowództwo, przybywają ze wszystkimi oddziałami pod Alezję".

Neque enim temere praeter mercatores illo adit quisquam, neque his ipsis quicquam praeter oram maritimam atque eas regiones, quae sunt contra Galliam, notum est. (Caes., Gall. 4, 20)

„Nikı bowiem, oprócz kupców, bez przyczyny tam się nie udaje, i nawet im nic poza mors kim wybrzeżem i tymi rejonami, które leżą naprzeciwko Galii, nie jest znane".

Utinam lex esset eadem, quae uxori est, viro. (Pl., Merc. 823)

„Szkoda, że dla męża prawo nie jest takie samo, jakie jest dla żony”. 
Veritas $[\ldots]$ locum, ubi consistat, reperire non poterit. (Cic., Quinct. 5) „Prawda nie będzie mogla znaleźć miejsca, gdzie pozostalaby na dlużej”.

Wspólny obu zdaniam składowym składnik semantyczny może być w następującej po zdaniu względnym części zdania nadrzędnego dodatkowo denotowany przez inny rzeczownik, będący apozycyjnym określnikim korelata poprzedzającego zdanie względne:

Postea vero quam intellexerunt isti virum fortem, quem summe provincia exspectabat, $Q$. Arrium, non succedere, statuerunt nihil se tam [...] reconditum posse habere, quod non istius cupiditati apertissimum [...] esset. (Cic., Verr. 2, 4, 43)

„Gdy zrozumieli oni, że szanowany czlowiek, którego prowincja bardzo wyczekiwala, Kwintus Arriusz, nie będzie następcą (Werresa), uznali, że niczego nie uda się im tak dobrze schować, by znalazło się to poza zasięgiem jego (scil. Werresa) chciwości".

b. Znajdujący się w zdaniu nadrzędnym korelat następuje po zaimku względnym:

(Ceasar) Cavarinum cum equitatu Senonum secum proficisci iubet, ne quis aut ex huius iracundia, aut ex eo, quod meruerat, odio civitatis, motus existat. (Caes., Gall. 6, 5)

„(Cezar) nakazuje, by Kawarynus z konnicą Senonów wyruszył wraz nim, tak aby nie doszlo do jakichś zamieszek, czy to z powodu jego gwałtownego usposobienia, czy też z powodu tej, na którą sobie zasłużył, nienawiści współplemieńców".

Ambiorix $[\ldots]$ postero die in Nervios pervenit hortaturque ne $[\ldots]$ ulciscendi Romanos pro iis, quas acceperint, iniuriis occasionem dimittant. (Caes., Gall. 5, 38)

„Ambioryks następnego dnia przybywa do Nerwiów i namawia (ich), by nie rezygnowali z okazji zemszczenia się na Rzymianach za te krzywdy, których doznali".

Tertiae cohortis centuriones ex eo, quo stabant, loco recesserunt. (Caes., Gall. 5, 43)

„Centurioni trzeciej kohorty wycofali się z tego miejsca, w którym stali”.

Ea, quae secuta est, hieme [...] Germani [...] flumen Rhenum transierunt. (Caes., Gall. $4,1)$

„Podczas tej zimy, która potem nastała, Germanie przekroczyli rzekę Ren”.

Fuit sponsa tua apud me eadem, qua apud soceros tuos [...], verecundia. (Liv., 26, 50)

„Twoja narzeczona cieszyła się u mnie takim samym szacunkiem, jakim (cieszyła się) u twoich teściów".

Veniet iterum, qui nos in lucem reponat, dies. (Sen., Lucil. 36, 10)

„Nadejdzie po raz wtóry dziéń, który ponownie wyda nas na światlo (świata)".

3. Zdanie względne występuje w prepozycji do zdania nadrzędnego, czyli poprzedza zdanie nadrzędne. Tym samym leksykalny korelat następuje po zaimku względnym:

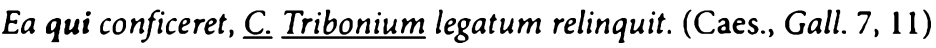

„(Jako tego), który miał to wykonać, pozostawil (na miejscu) legata Gajusza Treboniusza". 


\subsection{Zdania z zaimkowym korelatem zaimka względnego}

Semantyczny korelat zaimka względnego może także być wyrażony w zdaniu nadrzędnym przez zajmujący pozycję rzeczownikową zaimek, najczęściej anaforyczny (is) lub wskazujący (ille, hic, iste), rzadziej nieokreślony, przeczący lub osobowy. Podobnie jak w przypadku korelatów rzeczownikowych, może on pełnić różne funkcje skłaniowe, a zdania, w których on występuje, nazywane są zaimkowymi zdaniami względnymi. Zaimkowe korelaty zaimka względnego, za wyjątkiem zaimków osobowych, realizują głównie funkcję foryczną, tj. anaforyczną lub kataforyczną. Z funkcją anaforyczną mamy do czynienia, gdy zaimkowy korelat $w$ zdaniu nadrzędnym następuje linearnie po zaimku względnym, jeśli natomiast poprzedza on zaimek względny, realizuje funkcję kataforyczną. Biorąc pod uwagę usytuowanie zdania względnego w stosunku do zdania nadrzędnego, oraz zaimka względnego w stosunku do jego zaimkowego korelata, można wyodrębnić struktury, w których:

1. Zdanie względne występuje w postpozycji do zdania nadrzędnego, a więc zaimkowy korelat poprzedza zaimek względny pełniąc funkcję kataforyczną:

Athenodorus ait ne ad cenam quidem se iturum ad eum, qui sibi nil pro hoc debiturus sit. (Sen., Dial. 9, 7, 2)

„Atenodorus twierdzi, że nié pójdzie nawet na obiad do tego kto za to w ogóle nie będzie się czuł zobowiązany".

Sunt enim quidam, qui molestas amicitias faciunt. (Cic., Lael. 72)

„Istnieją bowiem pewni (ludzie), którzy związki przyjaźni czynią przykrymi”.

Tu fac idem quod rogas me. (Pl., Pers. 43)

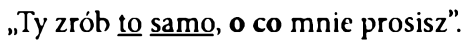

Nihil est, quod non emi possit. (Cic., Leg. Agr. 1, 15)

„Nie ma niczego, czego nie można by kupič".

Neque domi neque in urbe invenio quemquam, qui illum viderit. (Pl., Amph. 1010)

„Ani w domu, ani w mieście nie mogę znaleźć nikogo, kto go widział”.

2. Zdanie względne poprzedza zdanie nadrzędne, a więc zaimkowy korelat występuje po zaimku względnym pełniąc funkcję anaforyczną:

Quos laborantes conspexerat, his subsidia submittebat. (Caes., Gall. 4, 26)

„Których (żołnierzy) dostrzegł w trudnej sytuacji, tym przysyłał wsparcie”.

Quod ubi Caesar resciit, quorum per fines (fugitivi) ierant, his, uti conquirerent (eos) et reducerent [...], imperavit. (Caes., Gall. 1, 28)

„Gdy Ceazar o tym się dowiedział, nakazal tym, przez których ziemie zbiedzy przeszli, aby ich odszukali i przyprowadzili".

Ita fit, ut, quod bonum sit, id etiam honestum sit. (Cic., Fin. 3, 27)

„Dzieje się tak, iż to, co jest dobre, jest również szlachetne”". 
Qui fortis est, idem est fidens. (Cic., Tusc. 3, 14)

„Kto jest dzielny, to ten jest też ufny w siebie".

Quisquis enim sentit, quem ad modum sit affectus, eum necesse est aut in voluptate esse aut in dolore. (Cic., Fin. 1, 38)

„Ktokolwiek bowiem odczuwa, w jaki sposób coś na niego oddziałuje, ten w sposób konieczny musi (zawsze) czuć albo przyjemność, albo cierpienie".

Praesumptum habeant, quoties fugas et caedes iussit princeps, toties grates deis actas $[\ldots]$ fuisse. (Tac., Ann. 14,64)

„Niech z góry wiedzą, że ilekroć cesarz nakazywał wygnania i rzezie, tylekroć bogom skladano (za to) podziękowania".

3. Zdanie względne wprowadzone jest $w$ obręb szyku linearnego zdania nadrzędnego, przy czym zaimkowy korelat poprzedza zaimek względny realizując funkcję kataforyczną:

Illi, qui Graeciae formam rerum publicarum de derunt, corpora iuvenum firmari labore voluerunt. (Cic., Tusc. 2, 36)

„Ci, którzy Grecji nadali ustrój republikański, chcieli, by ciała mlodzieńców wzmacnialy się poprzez wysilek".

Ipse in eum, cui legatus [...] fuerat, inimicissimum atque improbissimum testimonium dedit. (Cic., Verr. 2, 1, 41)

„Sam przeciwko temu, dla którego był legatem, złożył najbardziej wrogie i niegodziwe świadectwo".

Platonem reliquosque Socraticos et deinceps eos, qui ab his profecti sunt, legunt omnes. (Cic., Tusc. 2, 8)

„Platona i pozostałych sokratyków, a także tych, którzy od nich się wywodzą, czytają wszyscy".

Ista, quae modo Mago iactavit, Himilconi ceterisque Hannibalis satellitibus iam laeta sunt. (Liv., 23, 12)

„Te (słowa), które właśnie chełpliwie wyglosił Magon, cieszą już Himilkona i pozostatych popleczników Hannibala".

Quis potest esse [...] tam mente captus, qui neget haec omnia, quae videmus, $[\ldots]$ deorum immortalium nutu ac potestate administrari? (Cic., Catil. 3, 21)

„Któż może być tak szalony, by przeczyć, że to wszystko, co widzimy, kierowane jest wolą i mocą bogów nieśmiertelnych?"

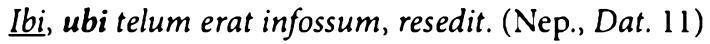

„Tam, gdzie wcześniej została zakopana broń, usiadr".

Czasem w zdaniach tego typu szerszy kontekst może wskazywać, że zaimkowy korelat pełni w istocie funkcję anaforyczną, odsyłając do wcześniejszego elementu wypowiedzi:

Quod est tibi cum Brutis bellum? Cur eos, quos omnes poene verari debemus, solus oppugnas? (Cic., Phil. 10. 4) 
„Co to za wojnę prowadzisz z Brutusami? Dlaczego tych (tj. Brutusów), których wszyscy powinniśmy niemal czcić, sam jeden atakujesz?"

Wyjątkowo zdarza się też współwystępowanie katafory i anafory w ramach jednej struktury względnej z dwoma zaimkami w zdaniu nadrzędnym:

$\underline{H a e c}$, quae possum (conspicere), ea mihi profecto cuncta vehementer placent. (Pl., Most. 841)

„To, co mogę zobaczyć, to wszystko doprawdy bardzo mi się podoba”.

Zaimek względny i jego zaimkowy korelat nominalizować mogą też treść, która dodatkowo zostaje wyeksplikowana przez następującą później strukturę zdaniową lub niezdaniową o charakterze apozycyjnym:

Sed ego id respondeo, quod animum adverti, te dolorem [...] ferre moderate. (Cic., Lael. 8)

„Lecz ja w odpowiedzi mówię tô, co zauważyłem, że mianowicie ból znosisz spokojnie”.

Viros [...] bonos eos, qui habentur, numeremus, Paulos, Catones, Galos, Scipiones, Philos. (Cic., Lael. 21)

„Do ludzi dobrych zaliczajmy tych, którzy za takich uchodzą, a mianowicie Paulusów, Katonów, Gallów, Scypionów, Filusów".

Jak zaznaczono już wyżej, zaimki osobowe będące korelatami zaimków względnych nie pełnią funkcji forycznej:

Iniquum me esse quispiam dicet, qui ex lucri magnitudine coniecturam capiam furti. (Cic., Verr. 2, 3, 111)

„Ktoś powie, że ja jestem niesprawiedliwy, który na podstawie (samej tylko) wysokości zysku czynię domysty o kradzieży".

Vos, qui hunc accusatis, omnis eius servos habetis. (Cic., Q. Rosc. 77)

"Wy, którzy go oskarżacie, posiadacie wszystkich jego niewolników".

\subsection{Zdania swobodne}

Rzeczownikowe lub przysłówkowe zaimki stanowiące korelaty zaimka względnego, realizując funkcję foryczną ( $\mathrm{tj}$. anaforyczną lub kataforyczną), w istocie markują jedynie pozycję syntaktyczną semantycznego korelatu zaimka względnego, i dlatego możliwe jest ich pomijanie (elidowanie) w strukturze powierzchniowej zdania. Zdarza się to w sytuacji, gdy pozycja ta związana jest $\mathrm{z}$ tą samą wartością kategorii przypadka, jaką przyjmuje zaimek względny, albo gdy w sposób czytelny determinowana jest przez inne składniki zdania, stanowione np. przez czasowniki otwierające miejsce dla podmiotu czy determinowanych ich rekcją dopełnień. Z kolei rzadziej są elidowane, jeśli pozycja ta ma charakter okolicznikowy, w szczególności, gdy jest wypełniana $\mathrm{z}$ udziałem przyimka. Zdania, w których zaimkowy korelat zaimka względnego nie jest w zdaniu nadrzędnym powierzchniowo wyrażony, czyli gdy otwarta dla niego pozycja nie została wypełniona, nazywane są zdaniami względnymi swobodnymi: 
Multis [...] serviet, qui corpori servit. (Sen., Lucil. 14, 1)

„Sługą wielu (rzeczy) będzie (ten), kto jest slugą (swego) ciała”.

Quicumque tuum violavit volnere corpus, morte luet merita. (Verg., Aen. 11, 848-849)

„Ktokolwiek zranił twoje ciało, (ten) przypłaci to zasłużoną śmiercią".

Redeuntes milites, quos possunt, consectantur atque occidunt. (Caes., Gall. 5, 58)

"Jeźdźcy w drodze powrotnej ścigają i zabijają kogo tylko mogą".

Quidquid tangebam, crescebat tamquam favus. (Petron., Sat. 76, 8)

"Czegokolwiek się dotknąłem, (to) urastało jak plaster miodu".

Quem di diligunt, adulescens moritur. (Pl., Bacch. 816-817)

„Kogo bogowie kochają, (ten) umiera jako młody człowiek”.

Negat [...] ius esse, qui miles non sit, cum hoste pugnare. (Cic., Off. 1, 37)

„Twierdzi, że nie jest rzeczą słuszną, by (ten), kto nie jest żołnierzem, walczył z wrogiem”.

Xerxes $[. .$.$] praemium proposuit, qui invenisset novam voluptatem. (Cic., Tusc. 5, 20)$

„Kserkses obiecał nagrodę (temu), kto wynalazłby jakąś nową przyjemność”.

Illam iube abs te abire, quo lubet. (Pl., Mil. 974)

„Każ jej odejść od ciebie (tam), dokąd zechce”.

Naves [...] omnes Uticam relinquunt et, quo imperatum est, transeunt. (Caes., Civ. 2, 25)

„Wszystkie okręty opuszczają Utykę i przepływaja, gdzie nakazano”.

Quid dulcius, quam habere, quicum omnia audeas sic loqui, ut tecum? Qui esset tantus fructus in prosperis rebus, nisi haberes, qui illis aeque ac tu ipse gauderet? Adversas vero ferre difficile esset sine eo, qui illas gravius etiam quam tu ferret. (Cic., Lael. 22)

„Cóż jest milszego, niż mieć (kogoś), $\mathbf{z}$ kim odważyłbyś się na każdy temat rozmawiać tak, jak z sobą samym? Jaka korzyść z powodzenia byłaby równie wielka, gdybyś nie miał (kogoś), kto cieszyłby się z niego tak bardzo, jak ty sam? Przeciwności zaś losu trudno byłoby znosić bez kogoś, kto znosiłby je z cięższym nawet sercem, niż ty".

Wypełnianie bądź niewypełnianie przez zaimki pozycji otwieranych dla nich przez strukturę syntaktyczną zdania może zależeć też od czynników stylistycznych czy pragmatycznych, jak np. kontrastowanie:

Si mihi perget, quae volt, dicere, ea , quae non volt, audiet. (Ter., Andr. 920)

„Jeśli nadal będzie mi mówil, co chce, usłyszy to, czego nie chce”.

$Z$ drugiej strony możliwa jest reasumpcja zaimka przez apozycyjny rzeczownik pełniący funkcję eksplikacyjną:

Sed redeamus ad eum, qui iam unus restat, Hortensium. (Cic., Brut. 279)

„Lecz powróćmy do tego, który pozostal już jako ostatni (do omówienia), tj. do Hortensjusza". 


\subsection{Zdania rozwijające}

Są również takie zdania, w których semantycznym korelatem zaimka względnego nie jest jeden element, lecz cała treść (semantyczna zawartość) zdania nadrzędnego. Zdanie podrzędne względne stanowi wówczas tzw. zdanie rozwijające, wyrażając swego rodzaju podumowanie czy komentarz do tej treści i zyskując status zdania, które semantycznie bliskie jest zdaniu współrzędnemu, choć formalnie powiązane jest wykładnikiem zespolenia o charakterze podrzędnym. Wprowadzane jest zwykle przez quod, jeśli znajduje się po zdaniu nadrzędnym:

Unum (Balbo) obicitur, natum esse Gadibus, quod negat nemo. (Cic., Balb. 5)

„Jedno zarzuca się (Balbusowi), że mianowicie urodzil się w Gades, czemu nikt nie przeczy”.

Ob eas $[\ldots]$ res ex litteris Caesaris dies quindecim supplicatio decreta est, quod ante id tempus accidit nulli. (Caes., Gall. 2, 35)

„Z powodu tych rzeczy, na podstawie pisemnego sprawozdania Cezara uchwalono piętnastodniowe modly dziękczynne, co wcześniej nie zdarzyło się w stosunku do nikogo".

Jeśli zdanie rozwijające jest wtrącone $w$ obręb struktury linearnej zdania nadrzędnego, wprowadzane jest również przez quod lub przez id quod (id in quo itp.). Zdanie takie często poprzedza główną myśl wyrażoną w zdaniu nadrzędnym:

Quocirca et absentes adsunt, et egentes abundant, et imbecllii valent, et, quod difficilius dictu est, mortui vivunt. (Cic., Lael. 23)

„I dlatego i nieobecni są blisko, i ubodzy mają dostatek, i słabi odzyskują siły, i - co trudniej powiedzeć - umarli żyją".

Belli peritus fuit et, id quod in tyranno non facile reperitur, minime libidinosus. (Nep., Reg. 2)

„Był doświadczony w prowadzeniu wojen i - co nie zdarza się często wśród tyranów - nie był wyuzdany".

Non mihi quidem soli, sed, id quod admirari saepe soleo, maioribus quoque nostris hoc ita visum intellego multis saeculis ante Socratem. (Cic., Tusc. 3, 8)

„Zauważam, że nie tylko mnie samemu, lecz także - czemu nieraz się dziwię - przodkom naszym podobnie się wydawalo na wiele wieków przed Sokratesem".

Cum Scipione vixerim, quocum mihi coniuncta cura de publica re et de privata fuit [...] et, id in quo est omnis vis amicitiae, voluntatum, studiorum, sententiarum summa consensio. (Cic., Lael. 15)

„Žylem ze Scypionem, z którym lączyla mnie troska o sprawy publiczne i prywatne oraz - w czym przejawia się cała moc przyjaźni - petna zgodność intencji, zainteresowań i poglądów". 


\subsubsection{Zdania z zaimkiem względnym o charakterze przymiotnikowym}

\subsection{Zdania z zaimkiem qui, quae, quod użytym przydawkowo}

Zaimek względny qui, quae, quod użyty przydawkowo również jest wykładnikiem nieautonomiczności (podrzędności) składniowej zdania, w którym występuje. Sam jednak nie odsyła bezpośrednio do żadnego obiektu (elementu semantycznego), lecz sygnalizuje, że obiekt desygnowany przez określany przezeń rzeczownik, stanowi składnik struktury semantycznej zarówno zdania podrzędnego, jak i nadrzędnego. Innymi słowy, sygnalizuje, że określany przezeń rzeczownik (który przyjmować może różne wartości kategorii przypadka i pełnić różne funkcje składniowe) ma swój semantyczny korelat $w$ zdaniu nadrzędnym. Tym samym w zdaniach tych nie mamy do czynienia z pronominalizacją, lecz wyłącznie z sygnalizowaniem konferencji. W tej funkcji zaimek względny występuje zwykle w prepozycji do określanego rzeczownika, zachowując wobec niego kongruencję (składnię zgody) pod względem kategorii liczby, rodzaju i przypadka. Może też być określnikiem kilku połączonych szeregowo rzeczowników, w szczególności o tym samym rodzaju gramatycznym. Wśród zdań z przydawkowo użytym zaimkiem względnym wyodrębnić możemy struktury, w których:

1. Zdanie względne poprzedza zdanie nadrzędne (tzn. występuje w prepozycji do niego). Struktury takie bliskie są zdaniom złożonym o charakterze współrzędnym (korelatywnym), a więc znajdują się na granicy między hipotaksą a parataksą. Zwykle ich druga składowa rozpoczyna się od rekapitulującego zaimka o funkcji anaforycznej, markującego pozycję semantycznego korelata rzeczownika określonego zaimkiem względnym ${ }^{1}$ :

Quae pars civitatis Helvetiae insignem calamitatem populo Romano intulerat, ea princeps poenas persolvit. (Caes., Gall. 1, 12)

„Która çzęść plemienia Helwetów zadała narodowi dotkliwą klęskę, ta jako pierwsza poniosła karę".

Qua nocte templum Ephesiae Dianae deflagravit, eadem constat $[\ldots]$ natum esse Alexandrum. (Cic., Div. 1, 47)

„Wiadomo, że której nocy spłonęła świątynia Diany Efeskiej, to tẹ samej urodzil się Aleksander".

Quae gravissime adflictae erant naves, earum materia atque aere ad reliquas reficiendas utebatur. (Caes., Gall. 4, 31)

„Które okrety były najbardziej zniszczone, to pochodzące $z$ nich drewno i brąz wykorzystywal do naprawy pozostalych".

1 W tłumaczeniu na jęz̧k polski dołączonỵch niżej przykładów starano się zachować struklurę lacińskich oryginałów. niekiedy kosztem stỵlisty cznej poprawności. 
Quae minime visa pars firma est, huc concurritur. (Caes., Gall. 7, 84)

„Która częśś (umocnień) wydała się najslabsza, tam spieszono".

Podobnie jak w przypadku zdań z rzeczownikowym zaimkiem względnym anaforyczny zaimek otwierający drugie ze zdań może być również i tutaj pominięty na powierzchni:

Quae civitates commodius suam rem publicam administrare existimantur, habent legibus sanctum, si quis quid de re publica a finitimis rumore ac fama acceperit, uti ad magistratum deferat neve cum quo alio communicet. (Caes., Gall. 6, 20)

„Które plemiona uchodzą za lepiej zorganizowane pod względem administracyjnym, (to te) uznają za prawnie usankcjonowane (to), że jeśli ktoś dowiedziałby się czegoś na temat spraw publicznych z plotek czy poglosek usłyszanych od mieszkańców sąsiednich krajów, ma o tym donieść władzom i nikomu innemu tego nie przekazywać".

Quod tibi nomen est, fecit mihi. (PI., Capt. 313)

"Jakie imię ty nosisz, (to) nadal (również) mnie".

Z drugiej strony w drugim ze zdań składowych obok zaimka może zostać powtórzony rzeczownik będący wykładnikiem wspólnego składnika struktury treściowej obu zdań:

Quibus diebus Cumae liberatae sunt obsidione, iisdem diebus et in Lucanis ad Grumentum Ti. Sempronius [...] cum Hannone Poeno prospere pugnat. (Liv., 23, 37)

„W tych samych dniach, w których Kumy zostały wyswobodzone $z$ oblężenia, również Tyberiusz Seproniusz po Grumentum w Lukanii z powodzeniem stacza bitwę z Punijczykiem Hannonem".

2. Zdanie względne następuje w postpozycji do zdania nadrzędnego, a więc dołączane jest po zdaniu nadrzędnym. Rzeczownik określony zaimkiem względnym, będący wykładnikiem wspólnego dla obu zdań składowych elementu semantycznego, stanowi powtórzenie lub bliskoznaczny odpowiednik rzeczownika desygnującego ten element w zdaniu nadrzędnym:

Erant omnino itinera duo, quibus itineribus domo exire (Helveti) possent. (Caes., Gall. $1,6)$

„Istniały w sumie dwie drogi, którymi (to $\underline{\text { drogami) }}$ (Helweci) mogli wyjść ze swego kraju”.

Omnibus rebus ad profectionem comparatis (Helveti) diem dicunt, qua die ad ripam Rhodani omnes conveniant. (Caes., Gall. 1, 6)

„Po przeprowadzeniu wszystkich przygotowań do wymarszu (Helwetowie) wyznaczają dzień, w którym to 迎u wszyscy mieli się zebrać nad brzegiem Rodanu".

Caesari nuntiaverunt pulverem maiorem $[\ldots]$ in ea parte videri, quam in partem legio iter fecisset. (Caes., Gall. 4, 32)

„Cezarowi doniesiono, że widać większy tuman kurzu po tej stronie, w którą (to stronę) poszedl legion".

Emptum est ex senatus consulto frumentum ab Siculis praetore Verre, pro quo frumento pecunia omnis soluta non est. (Cic., Caecin. 32) 
„Z dekretu senatu zakupione zostało od Sycylijczyków zboże podczas pretury Werresa, za które to zboże nie zapłacono całej należnej sumy".

Helvetii [...] legatos ad eum mittunt [...], cuius legationis Nammeius et Verucloetius principem locum obtinebant. (Caes., Gall. 1, 7)

„Helweci wysyłają do niego posłów, w którym to poselstwie Nammejus i Werukloecjusz zajmowali naczelne miejsce".

Zdania tego typu nie różnią się zasadniczo od zdań postpozycyjnych z rzeczownikowym zaimkiem względnym, o których mowa była wyżej (zob. 4.3.2.2.1.). Poza względami natury stylistycznej, dodanie rzeczownika po zaimku względnym motywowane jest tu często dążeniem do większej wyrazistości czy usunięcia potencjalnych dwuznaczności. Jest to szczególnie widoczne wtedy, gdy zaimek względny jest bardziej odległy od wyrazu w zdaniu nadrzędnym, który desygnuje wspólny dla obu zdań element semantyczny, lub gdy między tym wyrazem a zaimkiem znajduje się jakiś inny składnik imienny, do którego potencjalnie zaimek mógłby się odnosić.

3. Zdanie względne wprowadzone jest w strukturę linearną zdania nadrzędnego. Określony zaimkiem względnym rzeczownik może stanowić powtórzenie rzeczownika występującego w zdaniu nadrzędnym. Może też w zdaniu nadrzędnym znajdować odpowiednik $\mathrm{w}$ postaci innego rzeczownika odsyłającego do tego samego elementu semantycznego albo w postaci kongruentnego $\mathrm{z}$ nim kataforycznego zaimka markującego pozycję takiego rzeczownika:

Ille unus dies, quo die me populus Romanus [...] honestavit, tantae mihi iucunditati fuit. (Cic., Dom. 76)

„Ten jeden dzień, w którym to dniu lud rzymski mnie uhonorował, sprawil mi ogromną przyjemność".

Namque altera ex parte Bellovaci, quae civitas in Gallia maximam habet opinionem virtutis, instabant. (Caes., Gall. 7, 59)

„Bowiem $z$ jednej strony nastawali Bellowakowie, które to plemię cieszy się opinią najbardziej walecznego w Galii".

Eodem anno a Campanis Cumae, quam Graeci tum urbem tenebant, capiuntur. (Liv., $4,44)$

„W tym samym roku zdobyte zostają przez Kampańczyków Kumy, które to miasto zajmowali wówczas Grecy".

Neque eam, quam profuisse aliis vim celeritatemque viderant, imitari potuerunt. (Caes., Gall. 6, 40)

„I nie potrafili naśladować tej siłł (uderzenia) i szybkości, która, jak zauważyli, była bardzo pomocna innym".

Może jednak też nie mieć w ogóle żadnego leksykalnego odpowiednika w zdaniu nadrzędnym, jeśli pozycja otwarta $w$ nim dla zaimka forycznego pozostanie niewypełniona: 
Caesar necessariis rebus imperatis ad cohortandos milites, quam in partem fors obtulit, decucurrit. (Caes., Gall. 2, 21)

„Cezar po wydaniu niezbędnych rozkazów pobiegł na oślep, w jaką stronę los go skierował, aby dodać otuchy żolnierzom".

Ex hac fuga protinus, quae undique convenerant auxilia discesserunt. (Caes., Gall. 5, 17) „Po tej ucieczce natychmiast oddziały posilkowe, które ściągnęly ze wszystkich stron, rozpierzchty się".

Należy jeszcze dodać, że określany zaimkiem względnym rzeczownik może nie posiadać $w$ zdaniu nadrzędnym jednego, bezpośredniego korelatu semantycznego, lecz konceptualizować może całą treść zdania nadrzędnego. Tego rodzaju zdanie względne, podobnie jak w przypadku zdań $z$ rzeczownikowym zaimkiem względnym, ma status zdania rozwijającego:

(Cimon) decem annorum exilio multatus est, cuius facti celerius Athenienses quam ipsum paenituit. (Nep., Cim. 3)

„(Kimon) skazany został na dziesięcioletnie wygnanie, którego (to) czynu wcześniej pożałowali Ateńczycy niż on sam".

\subsection{Zdania z zaimkami qualis, quantus, quot}

Wymienione wyżej zaimki pytajne mogą przybierać status zaimków względnych. Pełnią wtedy zwykle funkcję przydawkową lub orzecznikową, jednak mogą też ulegać substantywizacji, wypełniając pozycje rzeczownikowe, np. podmiotową lub dopełnieniową. Konceptualizują cechę, która w sposób eksplicytny bądź implicytny stanowi również składnik treści zdania nadrzędnego, przypisany temu samemu obiektowi, co w zdaniu podrzędnym, lub innemu. Cecha ta może być w zdaniu nadrzędnym wyrażona jednym bądź kilkoma określnikami, które stanowią wówczas leksykalny korelat zaimka względnego:

Mihi $[\ldots]$ gratior illi videtur $[\ldots]$ aenea statua futura et ea pedestris quam inaurata equestris, qualis L. Sullae primum statuta est. (Cic., Phil. 9, 13)

„Wydaje ıni się, że milszy mu (będzie) w przyszlości pomnik spiżowy, i to pieszy, niż pozlacany konny, jaki po raz pierwszy zostal ustanowiony dla Lucjusza Sulli".

Ad aperta (somnia) et clara veniamus, quale est de illo interfecto a caupone Megaris. (Cic., Div. 2, 135)

„Przejdźmy do (snów) wyraźnych i zrozumiałych, jakim jest (sen) o owym (człowieku) zamordowanym przez wlaściciela gospody z Megary".

(Elephanti) octoginta $[. .$.$] erant, quot nulla unquam in acie ante (Hannibal) habuerat.$ (Liv., 30, 33)

„(Słoni) było osiemdziesiąt, której to liczby (słoni) nigdy dotąd w żadnej bitwie (Hannibal) nie posiadar". 
Może być też jedynie sygnalizowana forycznym zaimkiem:

Unusquisque [...] hoc animo reputet $[. .$.$] , qualis nostra vis virtusque fuerit, talem deinde$ fortunam illius urbis ac Romani imperii fore. (Liv., 21, 41)

„Niech każdy rozważy w swoim umyśle to, że jaką wykażemy się siłą i męstwem, taki będzie dalszy los tego miasta i państwa rzymskiego".

Plerique $[. .$.$] habere talem amicum volunt, quales ipsi esse non possunt. (Cic., Lael. 82)$

„Liczni pragną mieć takiego przyjaciela, jakim sami być nie potrafią".

Nec meus servos umquam tale fecit, quale tu mihi. (Pl., Men. 1027)

"I nigdy też mój sługa nie uczynił mi czegoś takiego, co ty (mi uczynułeś)".

Expulso [...] Tarquinio tantum odium populum Romanum regalis nominis tenuit, quantum tenuerat post obitum [...] Romuli desiderium. (Cic., Rep. 2, 52)

„Po wypędzeniu Tarkwiniusza ogarnęła naród rzymski tak wielka nienawiść do władzy królewskiej, jak wielka ogarnęła (ich) wcześniej tęsknota po śmierci Romulusa".

Neque hoc tanti laboris est, quanti videtur. (Cic., De orat. 3, 190)

„I nie wymaga to tak wielkiego trudu, jak się wydaje”.

Quot casus exercitus victi fuerant, tot in curas distracti animi eorum erant. (Liv., 22, 7)

„Ile przytrafiło się klęsk pokonanego wojska, tyle trosk napełniało ich skołatane serca”.

W przypadku pominięcia zaimka w strukturze powierzchniowej zdania nadrzędnego jest ona tam jedynie implikowana (bez żadnego formalnego wykładnika):

(Dicebant) unum [...] virum [...], qualis Ap. Claudius fuerit, momento temporis discussurum illos coetus fuisse. (Liv., 2, 28)

„(Mówili), że jeden człowiek (taki), jakim był Appiusz Klaudiusz, w jednej chwili rozpędzilby te zbiegowiska".

Sequitur $[\ldots]$ victoria $[\ldots]$, quantam de Samnitibus nemo ad eam diem $[\ldots]$ pepererat. (Liv., 10, 38)

„Następuje (takie) zwycięstwo, jakiego nikt do tego dnia nie odniósł nad Samnitami”.

Non sum, qualis eram bonae sub regno Cinarae. (Hor., Carm. 4, 1, 3-4)

„Nie jestem już (taki), jaki byłem pod władzą dobrej Cynary”.

Jeśli w zdaniu nadrzędnym zaimkowy korelat przydawkowo użytego zaimka względnego byłby określnikiem tego samego rzeczownika, który określany jest przez zaimek względny, to może zostać pominięty w strukturze powierzchniowej zdania nadrzędnego również ten rzeczownik:

Quot dies erimus in Tusculano, agamus haec. (Cic., Tusc. 1, 119)

„Ile dni spędzimy w posiadłości tuskulańskiej, (przez tyle dni) zajmujmy się tymi rzeczami”.

Pietas me poscit [...], qualia nec Siculae moderantur carmina rupes nec fati iam certus olor. (Stat., Silv. 3, 3, 173-175)

„Synowska miłość domaga się ode mnie (takich pieśni), jakich nie wyśpiewają ani sycylijskie skały, ani łabądź pewien już bliskiej śmierci". 
Biorąc pod uwagę szyk linearny, zdanie względne może znajdować się:

a. W postpozycji do zdania nadrzędnego:

Moveor [...] tali amico orbatus, qualis [...] nemo umquam erit. (Cic., Lael. 10)

„Jestem glęboko przejęty straciwszy takiego przyjaciela, jakim nikt już nigdy nie będzie”.

b. W prepozycji do zdania nadrzędnego:

Qualem in nos eum esse voluit, talis ipse in ceteros exstitit. (Cic., Phil. 13, 17)

„Jakim chcial, żeby tamten był w stosunku do nas, takim sam stal się w stosunku do pozostatych".

c. W obrębie struktury linearnej zdania nadrzędnego:

(Dicebant) unum [...] virum [...], qualis Ap. Claudius fuerit, momento temporis discussurum illos coetus fuisse. (Liv., 2, 28)

"(Mówili), że jeden czlowiek (taki), jakim był Appiusz Klaudiusz, w jednej chwili rozpędzitby te zbiegowiska".

Konceptualizowana przez zaimek względny cecha może zostać sprecyzowana w zdaniu podrzędnym zależnym od zdania względnego:

Super has introcessit alia (puella) [...], designans Venerem, qualis fuit Venus, cum fuit virgo. (Apul., Met. 10, 31)

„Po nich weszla inna dziewczyna, odgrywająca rolę Wenery (takiej), jaką byla Wenus w wieku jeszcze dziewiczym".

Jeśli odpowiednikiem zaimka względnego jest foryczny zaimek, wyrażenie może przybrać postać równoważnika zdania:

Quot homines, tot sententiae. (Ter., Phorm. 454)

„Ilu ludzi, tyle (różnych) opinii".

\subsubsection{Semantyczne funkcje zdań względnych}

\subsection{Zdania względne restryktywne}

Restryktywny charakter mogą mieć zdania względne zarówno z rzeczownikowym bądź przysłówkowym, jak i przymiotnikowym zaimkiem względnym.

W odniesieniu do zdań względnych $\mathrm{z}$ rzeczownikowym lub przysłówkowym zaimkiem względnym restryktywny charakter zdania względnego polega na wyznaczaniu referenta korelatu zaimka względnego bądź określeniu jego aktualnego znaczenia (tj. znaczenie, jakie posiada on $w$ danym zdaniu). Dotyczy to więc sytuacji, gdy znajdujący się w zdaniu nadrzędnym korelat zaimka względnego nie wskazuje jednoznacznie na konkretny obiekt (bądź klasę obiektów) rzeczywistości pozajęzykowej, i dopiero treść zdania względnego, poprzez ukonkretnienie (zawężenie) opi- 
su, pozwala na jego (jej) identyfikację. Leksykalnym korelatem zaimka względnego w zdaniach o charakterze restryktywnym mogą być:

a. Rzeczowniki:

(Ceasar) Ariminum [...] proficiscitur ibique tribunos plebis, qui ad eum confugerant, convenit. (Caes., Civ. 1, 8)

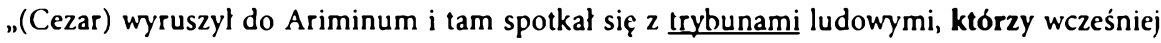
do niego zbiegli".

Adiacere corpora hominum, quos $[. .$.$] sitis peremerat. (Tac., Ann. 4, 49)$

"Obok leżały ciała ludzi, których zabiło pragnienie”.

Hostes $[\ldots]$ vadis repertis partem suarum copiarum traducere conati sunt eo consilio, ut [...] castellum, cui praeerat Q. Titurius legatus, expugnarent. (Caes., Gall. 2, 9)

„Wrogowie, gdy znaleźli brody (w rzece), próbowali przeprowadzić (nimi) część swoich wojsk z tym zamiarem, by zdobyć umocnienie, którym dowodził legat Kwintus Tyturiusz".

Veniet iterum, qui nos in lucem reponat, dies. (Sen., Lucil. 36, 10)

„Nadejdzie po raz wtóry dzień, który ponownie wyda nas na światło (świata)”.

Veritas $[. .$.$] locum, ubi consistat, reperire non poterit. (Cic., Quinct. 5)$

„Prawda nie będzie mogła znaleźć miejsca, gdzie pozostałaby na dłużej”.

Censen te posse reperire ullam mulierem, quae careat culpa? (Ter., Hec. 662-663)

„Sądzisz, że możesz znaleźć jakąś kobietę, która byłaby bez wad?”

Jeśli rzeczowniki określone są forycznymi zaimkami, zaimki te współuczestniczą (zwykle poprzez mechanizm katafory) w realizowaniu restryktywnej funkcji zdań względnych, która polegać może na identyfikacji bądź to obiektu, bądź jego cechy:

Ob eas causas ei munitioni, quam fecerat, $T$. Labienum legatum praeficit. (Caes., Gall. 1, 10) „Z tych powodów dowódcą tych fortyfikacji, klóre zbudowal, mianowal legata Tytusa Labienusa".

Viridovix [...] summam imperii tenebat earum omnium civitatum, quae defecerant. (Caes., Gall. 3, 17)

„Wirydowiks sprawowal naczelne dowództwo na wszystkimi tymi plemionami, które zbuntowały się (przeciw Cezarowi)".

Ambiorix $[\ldots]$ postero die in Nervios pervenit hortaturque ne $[\ldots]$ ulciscendi Romanos pro iis, quas acceperint, iniuriis occasionem dimittant. (Caes., Gall. 5, 38)

„Ambioryks następnego dnia przybywa do Nerwiów i namawia (ich), by nie rezygnowali z okazji zemszczenia się na Rzymianach za te krzywdy, których doznali".

Nec iam ille senatus sumus, qui occiso Nerone delatores et ministros [...] puniendos flagitabat. (Tac., Hist. 4, 42)

„I nie jesteśmy już tym senatem, który po zabiciu Nerona domagał się ukarania donosicieli i ich służalców". 
"Szkoda, że dla męża prawo nie jest takie samo, jakie jest dla żony".

Ea est Romana gens, quae victa quiescere nesciat. (Liv., 9, 3)

„Naród rzymski jest taki, że pokonany nie potrafi zaznać spokoju".

b. Rzeczownikowo użyte zaimki (z wyłączeniem zaimków osobowych):

Unusquisque [...] opiniones fingebat et ad $\underline{i d}$, quod ab alio audierat, sui aliquid timoris addebat. (Caes., Civ. 2, 29)

„Każdy snuł własne domysły i do tego, co usłyszał od kogoś innego, dodawał jakieś swoje obawy".

Dixi $[\ldots]$ eosdem esse, qui Bibulum exire domo prohibuissent et qui me coegissent. (Cic., Fam. 1, 9, 7)

„Powiedzialem, że ci, którzy Bibulusowi wyjść z domu nie pozwolili, i ci, którzy mnie (do wyjścia z domu) przymusili, to są (jedni i) çi sami ludzie".

Cui contingit habere rem non quamlibet, hunc non quemlibet dixeris. (Sen., Lucil. 87, 17)

„Komu przytrafi się mieć rzecz nie byle jaką, tego nie nazwiesz byle kim”.

Ex quo efficitur, ut quidquid honestum sit, idem sit utile. (Cic., Off. 2, 10)

„Z tego wynika, że wszystko, co jest moralnie dobre, jest równocześnie pożyteczne”.

Estne quisquam omnium mortalium, de quo melius existimes tu? (Cic., Q. Rosc. 18)

„Czyż pośród wszystkich ludzi jest ktoś, o kim ty sam mógłbyś wyrazić lepsze zdanie?”

Quam diu quisquam erit, qui te defendere audeat, vives. (Cic., Catil. 1,6)

„Dopóki będzie choćby jeden człowiek, który odważyłby się ciebie bronić, będziesz żył”.

Fuisse credo tum quoque aliquos, qui discerptum regem patrum manibus taciti arguerent.

(Liv., 1, 16)

„Jestem przekonany, że również wtedy byli łaç, którzy po cichu twierdzili, że król został rozszarpany rę̧kami patrycjuszów".

Ubicumque homo est, ibi benefici locus est. (Sen., Dial. 7, 24, 3)

"Gdziekolwiek jest (drugi) człowiek, tam jest miejsce dla świadczenia dobrodziejstw”.

Zdania względne swobodne $\mathrm{z}$ punktu widzenia semantycznego również mogą być uznane za restryktywne, bowiem chociaż korelat zaimka względnego nie jest w nich powierzchniowo wyrażony, to jednak otwarta jest dla niego w zdaniu nadrzędnym pozycja, a treść zdania względnego identyfikuje jego potencjalnego referenta bądź jego potencjalne akualne znaczenie:

Quisquis homo huc profecto venerit, pugnos edet. (Pl., Amph. 309)

„Ktokolwiek tu przyjdzie, (ten) posmakuje (moich) pięści (dosł.: „będzie jadł moje pięści” = pobiję go)".

Dicam quidem certe, quod sentio. (Cic., Har. Resp. 50)

„Z pewnością powiem (to), co myśl̨̧".

Di tibi dent, quaecumque optes. (Pl., Mil. 1038)

„Niech bogowie dadzą ci (wszystko to), czegokolwiek byś sobie życzyl”. 
Quotienscumque me vidit [...], gratias tibi agit singularis. (Cic., Fam. 13, 41, 1)

„Ilekroć mnie widzi, (tylekroć) składa ci wielkie podziękowania”.

Quod [...] agitatur aliunde, quando finem habet motus, vivendi finem habeat necesse est. (Cic., Rep. 6, 27)

„Coś, co jest poruszane przez czynnik zewnętrzny, w sposób nieunikniony znajduje kres istnienia (wtedy), kiedy ruch ustaje".

Z kolei restryktywny charakter zdań z przymiotnikowym (przydawkowym) zaimkiem względnym sprowadza się do wyznaczenia referenta bądź aktualnego znaczenia rzeczownika lub zaimka, który w zdaniu nadrzędnym stanowi semantyczny odpowiednik rzeczownika określanego zaimkiem względnym:

Quam quisque norit artem, in hac se exerceat. (Cic., Tusc. 1, 42)

„Jaką kto poznat sztukę nia niech się zajmuje”.

Quae pars civitatis Helvetiae insignem calamitatem populo Romano intulerat, ea princeps poenas persolvit. (Caes., Gall. 1, 12)

„Która çzęść plemienia Helwetów zadala narodowi dotkliwą klęskę, ta jako pierwsza poniosla karę".

Omnibus rebus ad profectionem comparatis (Helveti) diem dicunt, qua die ad ripam Rhodani omnes conveniant. (Caes., Gall. 1, 6)

„Po przeprowadzeniu wszystkich przygotowań do wymarszu (Helwetowie) wyznaczają dzień,

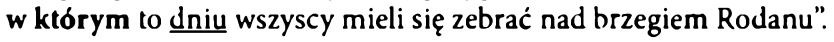

Servio occiso quemcumque alium generum (rex) delegisset, eundem regni heredem facturus videbatur. (Liv., 1, 40)

„Gdyby Serwiusz zostal zabity, to jakiegokolwiek innego król wybrałby sobie zięcia, to tego prawdopodobnie uczynilby również dziedzicem tronu".

W restryktywnych zdaniach swobodnych z przymiotnikowo użytym zaimkiem względnym zaimek będący semantycznym odpowiednikiem rzeczownika określonego zimkiem względnym nie zostaje wyrażony na powierzchni:

Quod tibi nomen est, fecit mihi. (Pl., Capt. 313)

"Jakie imię ty nosisz, (to) nadal (również) mnie".

Sepulcra exstant, quo quisque loco cecidit. (Liv., 1, 25)

„W jakim miejscu kto polegl, (wszędzie tam) pozostaty grobowce”.

Restryktywny charakter mają zwykle również zdania z przymiotnikowymi zaimkami qualis, tantus i quot. Identyfikują one wówczas określoną cechę jednego ze składników struktury semantycznej zdania nadrzędnego:

(Dicebant) unum [...] virum [...], qualis Ap. Claudius fuerit, momento temporis discussurum illos coetus fuisse. (Liv. 2, 28)

"(Mówili), że jeden człowiek (taki), jakim był Appiusz Klaudiusz, w jednej chwili rozpędziłby te zbiegowiska". 
Sequitur $[\ldots]$ victoria $[\ldots]$, quantam de Samnitibus nemo ad eam diem $[\ldots]$ pepererat. (Liv., 10, 38)

"Następuje (takie) zwycięstwo, jakiego nikt do tego dnia nie odniósł nad Samnitami”.

Bardzo często cecha ta markowana jest $w$ zdaniu nadrzędnym forycznym zaimkiem:

Plerique [...] habere talem amicum volunt, quales ipsi esse non possunt. (Cic., Lael. 82)

„Liczni pragną mieć takiego przyjaciela, jakim sami być nie potrafią".

Expulso [...] Tarquinio tantum odium populum Romanum regalis nominis tenuit, quantum tenuerat post obitum [...] Romuli desiderium. (Cic., Rep. 2, 52)

„Po wypędzeniu Tarkwiniusza ogarnęla naród rzymski tak wielka nienawiść do władzy królewskiej, jak wielka ogarnęła (ich) wcześniej tęsknota po śmierci Romulusa".

Quot casus exercitus victi fuerant, tot in curas distracti animi eorum erant. (Liv., 22, 7)

„Ile przytrafiło się klęsk pokonanego wojska, tyle trosk napełniało ich skołatane serca”.

\subsection{Zdania względne nierestryktywne}

Nierestryktywny charakter mogą mieć zdania zarówno z rzeczownikowym jak i przymiotnikowym zaimkiem względnym. Funkcję leksykalnego korelata rzeczownikowego zaimka względnego (lub odpowiednika rzeczownika określonego przymiotnikowym zaimkiem względnym) pełnią w nich głównie rzeczowniki, ewentualnie zaimki osobowe.

Istotą zdań nierestryktywnych z rzeczownikowym zaimkiem względnym jest to, że leksykalny korelat zaimka względnego samodzielnie identyfikuje referenta lub ujawnia aktualne znaczenie, natomiast zdanie względne przypisuje jego desygnatowi dodatkową, uzupełniającą charakterystykę; ma zatem charakter sui generis apozycyjny:

Erat in Carnutibus summo loco natus Tasgetius, cuius maiores in sua civitate regnum obtinuerant. (Caes., Gall. 5, 25)

„Żył w kraju Karnutów wywodzący się ze znakomitego rodu Tasgetius, którego przodkowie sprawowali władzę królewską w swoim plemieniu".

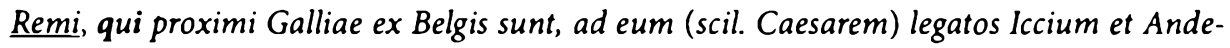
cumborium, primos civitatis, miserunt. (Caes., Gall 2, 3)

„Remowie, którzy spośród Belgów zamieszkują najbliżej Galli, wysłali do Cezara jako posłów Ikcjusza i Andekumboriusza, najznakomitszych swych obywateli".

Rem [...] commovisti nova disputatione dignam, quam in aliud tempus differamus. (Cic., Brut. 297)

„Poruszyleś zagadnienie godne nowej dyskusii, którą odlóżmy (jednak) na inny czas”.

(Helveti) pro gloria belli atque fortitudinis angustos se fines habere arbitrabantur, qui in longitudinem milia passuum CCXL, in latitudinem CLXXX patebant. (Caes., Gall. 1, 2) 
"(Helwetowie) uważali, że w stosunku do (ich) slawy wojennej i męstwa zajmowali zbyt mały obszar, który ciągnął się na dlugość dwustu czterdziestu tysięcy kroków i szerokość stu osiemdziesięciu tysięcy".

(Fortunam) nemo ab inconstantia et temeritate seiunget, quae digna certe non sunt deo. (Cic., Nat. 3, 61)

„Nikt nie uzna, że fortuna nie ma nic wspólnego z niestałością i przypadkowością, które (to cechy) $z$ pewnością nie są godne boga".

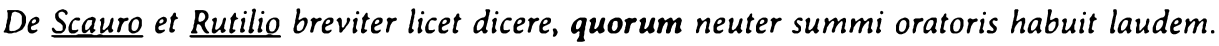
(Cic., Brut. 110)

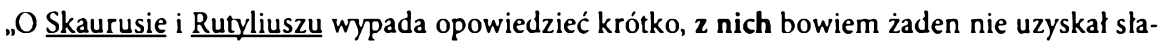
wy wybitnego mówcy".

Arx tantum retenta (est), in quam inter tumultum captae urbis [...] quidam effugere. (Liv., 23, 30)

"Obroniony zostal jedynie zamek, do którego schroniła się pewna ilość ludzi wśród tumultu spowodowanego zdobyciem miasta".

Vos, qui hunc accusatis, omnis eius servos habetis. (Cic., Q. Rosc. 77)

„Wy, którzy go oskarżacie, posiadacie wszystkich jego niewolników".

W przypadku nierestryktywnych zdań z przymiotnikowym zaimkiem względnym podobną właściwością cechuje się odpowiednik rzeczownika określanego zaimkiem względnym:

Namque altera ex parte Bellovaci, quae civitas in Gallia maximam habet opinionem virtutis, instabant. (Caes., Gall. 7, 59)

„Bowiem z jednej strony nastawali Bellowakowie, które to plemię cieszy się opinią najbardziej walecznego w Galii".

Emptum est ex senatus consulto frumentum ab Siculis praetore Verre, pro quo frumento pecunia omnis soluta non est. (Cic., Caecin. 32)

„Z dekretu senatu zakupione zostało od Sycylijczyków zboże podczas pretury Werresa, za które to zboże nie zapłacono calej należnej sumy".

Eodem anno a Campanis Cumae, quam Graeci tum urbem tenebant, capiuntur. (Liv., 4, 44)

„W tym samym roku zdobyte zostają przez Kampańczyków Kumy, które to miasto zajmowali wówczas Grecy".

Nierestryktywny charakter mogą mieć także zdania z zaimkami qualis, quantus, quot, jeśli w zdaniu nadrzędnym odpowiada im niezaimkowy korelat leksykalny:

Mihi $[\ldots]$ gratior illi videtur $[. .$.$] aenea statua futura et ea pedestris quam inaurata equ-$ estris, qualis L. Sullae primum statuta est. (Cic., Phil. 9, 13)

„Wydaje mi się, że milszy mu (będzie) w przyszłości pomnik spiżowy, i to pieszy, niż pozlacany konny, jaki po raz pierwszy zostal ustanowiony dla Lucjusza Sulli".

(Elephanti) octoginta [...] erant, quot nulla unquam in acie ante (Hannibal) habuerat. (Liv., 30, 33) 
„(Słoni) było osiemdziesiąt, której to liczby (słoni) nigdy dotąd w żadnej bitwie Hannibal nie posiadaY".

\subsection{Zdania względne predykatywne (względno-okolicznikowe)}

Właściwością zdań tego typu jest to, iż chociaż z punktu widzenia syntaktycznego mają one status zdań atrybutywnych (przydawkowych), to jednak semantycznie mają charakter raczej predykatywny niż atrybutywny, tzn. charakteryzują nie tyle desygnat korelatu zaimka względnego, ile raczej predykat zdania nadrzędnego, wnosząc określone znaczenie okolicznikowe. Tradycyjnie zdania takie określane są jako względno-okolicznikowe. Generalnie mają charakter nierestryktywny i cechuje je zwykle orzeczenie z czasownikiem w koniunktiwie. Ich przymiotnikowym odpowiednikiem jest tzw. praedivativum, a imiesłowowym tzw. participium coniunctum:

At hi (scil. Pompeiani) [...] exercitu Caesaris luxuriem obiciebant, cui semper omnia ad necessarium usum defuissent. (Caes., Civ. 3, 96)

„I to właśnie ci ludzie zarzucali zbytek wojsku Cezara, któremu (= chociaż jemu) nieustannie brakowalo wszystkiego, co niezbędne do codziennego użytku".

Sarmentis virgultisque collecis, quibus fossas Romanorum compleant, ad castra pergunt. (Caes., Gall. 3, 18)

„Nazbierawszy chrustu ¿ gałçzi, którymi mieli (= aby nimi) wypelnić rowy obronne Rzymian, ruszyli w stronę obozu".

Iniquum me esse quispiam dicet, qui ex lucri magnitudine coniecturam capiam furti. (Cic., Verr. 2, 3, 111)

„Ktoś powie, że jestem niesprawiedliwy ja, który (= ponieważ) na podstawic (samej tylko) wysokości zysku czynię domysły o kradzieży".

Predykatywny charakter zdania względnego czasem dodatkowo podkreślany jest odpowiednią partykułą:

Videbatur [...] nobis exercitus Ceasaris [...] audaciae plus habere, quippe qui patriae bellum intulisset. (Cic., Div. 2, 114)

„Wydawało się nam, że wojsko Cezara jest bardziej zuchwałe, które przecież (= ponieważ) wypowiedziało wojnę (wlasnej) ojczyźnie".

Podobny charakter mogą mieć również zdania z przymiotnikowo użytym zamkiem względnym:

Omnibus rebus ad profectionem comparatis (Helveti) diem dicunt, qua die ad ripam Rhodani omnes conveniant. (Caes., Gall. 1, 6)

„Po przeprowadzeniu wszystkich przygotowań do wymarszu (Helwetowie) wyznaczają $\underline{\mathrm{dzien}}$, w którym to dniu wszyscy mieli się zebrać (= aby w tym dniu wszyscy zebrali się) nad brzegiem Rodanu". 


\subsubsection{Syntaktyczne funkcje zdań względnych}

\subsection{Zdania $z$ zaimkiem względnym uẋytym rzeczownikowo}

Zdania, w których rzeczownikowo użyty zaimek względny ma rzeczownikowy korelat w zdaniu nadrzędnym, są zdaniami przydawkowymi uzupełniającymi:

Paulo ante tertiam vigiliam est animadversum fumare aggerem, quem cuniculo hostes succenderant. (Caes., Gall. 7, 24)

„Tuż przed trzecią strażą nocną zauważono, że wydobywa się dym z nasypu, który wrogowie podpalili przy użyciu podkopu".

Interea Commius reliquique duces, quibus summa imperii permissa erat, cum omnibus copiis ad Alesiam perveniunt. (Caes., Gall. 7, 79)

„Tymczasem Kommiusz i pozostali wodzowie, którym powierzone zostalo naczelne dowództwo, przybywają ze wszystkimi oddzialami pod Alezję".

Delectabatur autem mirifice lectione librorum, de quibus audiebat. (Cic., Lucull. 4)

"Niezwykle delektowal się więc lekturą ksiażekek, o których słyszał”.

Veniet iterum, qui nos in lucem reponat, dies. (Sen., Lucil. 36, 10)

„Nadejdzie po raz wtóry dzień, który ponownie wyda nas ma światło (świata)”.

Ea qui conficeret, $\underline{C}$. Tribonium legatum relinquit. (Caes., Gall. 7, 11)

"(Jako tego), który miał to wykonać, pozostawil (na miejscu) legata Gajusza Treboniusza".

Arx tantum retenta (est), in quam inter tumultum captae urbis [...] quidam effugere. (Liv., 23, 30)

„Obroniony został jedynie zamek, do którego schronila się pewna ilość ludzi wśród tumultu spowodowanego zdobyciem miasta".

Jeśli rzeczownikowy korelat $w$ zdaniu nadrzędnym określony jest przymiotnikowym zaimkiem forycznym, zdania względne mają status zdań przydawkowych rozszerzających:

Viridovix $[\ldots]$ summam imperii tenebat earum omnium civitatum, quae defecerant. (Caes., Gall. 3, 17)

„Wirydowiks $[\ldots]$ sprawowal naczelne dowództwo nad wszystkimi tymi plemionami, które zbuntowaly się (przeciw Cezarowi)".

Neque enim temere praeter mercatores illo adit quisquam, neque his ipsis quicquam praeter oram maritimam atque eas regiones, quae sunt contra Galliam, notum est. (Caes., Gall. 4, 20)

„Nikt bowiem, oprócz kupców, bez przyczyny tam się nie udaje, i nawet im nic poza morskim wybrzeżem i tymi rejonami, które leżą naprzeciwko Galii, nie jest znane".

(Ceasar) Cavarinum cum equitatu Senonum secum proficisci iubet, ne quis aut ex huius iracundia, aut ex $\underline{\text { eo }}$, quod meruerat, odio civitatis, motus existat. (Caes., Gall. 6, 5)

"(Cezar) nakazuje, by Kawarynus z konnicą Senonów wyruszył wraz nim, tak aby nie doszlo do jakichś zamieszek, czy to zpowodu jego gwaltownego usposobienia, czy też z powodu tej, na którą sobie zasłużyl, nienawiści wspólplemieńców". 
Ambiorix [...] postero die in Nervios pervenit hortaturque ne [...] ulciscendi Romanos pro iis, quas acceperint, iniuriis occasionem dimittant. (Caes., Gall. 5, 38)

"Ambioryks następnego dnia przybywa do Nerwiów i namawia (ich), by nie rezygnowali z okazji zemszczenia się na Rzymianach za te krzywdy, których doznali".

Zdania, w których korelatem zaimka względnego jest w zdaniu nadrzędnym rzeczownikowy zaimek o funkcji forycznej, również mają charakter zdań rozszerzających, ale ich funkcja składniowa determinowana jest przez pozycję składniową zajmowaną $\mathrm{w}$ zdaniu nadrzędnym przez zaimkowy korelat. W związku z czym zdanie względne zaimkowe może mieć status zdania rozszerzającego:

\section{a. Podmiotowego:}

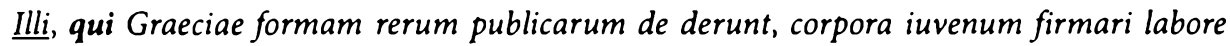
voluerunt. (Cic., Tusc. 2, 36)

,Ci, którzy Grecji nadali ustrój republikański, chcieli, by ciała młodzieńców wzmacnialy się poprzez wysilek".

Illi, quibus Damasippi mors laetitiae fuerat, paulo post ipsi trahebantur. (Sall., Cat. 51, 34)

„Ci. dla których śmierć Damazypa była powodem do radości, niedługo potem sami byli wleczeni (na śmierć)".

It a fit, ut, quod bonum sit, id etiam honestum sit. (Cic., Fin. 3, 27)

„Dzieje się tak, iż tô, co jest dobre, jest również szlachetne”.

Nihil est, quod non emi possit. (Cic., Leg. Agr. 1, 15)

„Nie ma niczego, czego nie można by kupić".

Sunt enim quidam, qui molestas amicitias faciunt. (Cic., Lael. 72)

„Istnieją bowiem pewni (ludzie), którzy związki przyjaźni czynią przykrymi”.

Zdanie względne rozszerzające funkcjonalny odpowiednik podmiotu:

Pro di immortales! Essene quemquam tanta audacia praeditum, qui [...] quod sibi probare non possit, id persuadere alteri conetur?! (Cic., Q. Rosc. 4)

„Na bogów nieśmiertelnych! Czyż może istnieć ktoś tak zuchwały, kto miałby śmiałość przekonywać innych do tego, do czego siebie przekonać nie może?!"

b. Dopełnieniowego:

Cur eos, quos omnes poene verari debemus, solus oppugnas? (Cic., Phil. 10. 4)

„Dlaczego tych, których wszyscy powinniśmy niemal czcić, sam jeden atakujesz?”

Sed ego $\underline{i d}$ respondeo, quod animum adverti, te dolorem [...] ferre moderate. (Cic., Lael. 8)

„Lecz ja w odpowiedzi mówię tô, co zauważyłem, że mianowicie ból znosisz spokojnie”.

$\underline{H a e c}$, quae possum (conspicere), ea mihi profecto cuncta vehementer placent. (Pl., Most. 841)

„To, co mogę zobaczyć, to wszystko doprawdy bardzo mi się podoba”. 
Quos laborantes conspexerat, his subsidia submittebat. (Caes., Gall. 4, 26)

„Których (żołnierzy) dostrzegl w trudnej sytuacji, tym przysyłal wsparcie".

Quod ubi Caesar resciit, quorum per fines (fugitivi) ierant, his, uti conquirerent (eos) et reducerent [...], imperavit. (Caes., Gall. 1, 28)

„Gdy Ceazar o tym się dowiedzial, nakazal tym, przez których ziemie zbiedzy przeszli, aby ich odszukali i przyprowadzili".

c. Orzecznikowego:

Neque is sum [...], qui gravissime ex vobis mortis periculo terrear. (Caes., Gall. 5, 30)

„I nie jestem tym, który najbardziej $z$ was miałby być przerażony niebezpieczeństwem śmierci".

Tun is es, qui per voluptatem tuam in me aerumnam obsevisti gravem? (Pl., Epid. 556-557)

„Czy to ty jesteś tym, który dla swej przyjemności sprowadzil na mnie wielką udrękę?"

\section{d. Okolicznikowego:}

Athenodorus ait ne ad cenam quidem se iturum ad eum, qui sibi nil pro hoc debiturus sit. (Sen., Dial. 9, 7, 2)

"Atenodorus twierdzi, że nie pójdzie nawet na obiad do tego, kto za to w ogóle nie będzie się czul zobowiązany".

Ipse in eum, cui legatus [...] fuerat, inimicissimum atque improbissimum testimonium dedit. (Cic., Verr. 2, 1, 41)

„Sam przeciwko temu, dla którego byl legatem, zlożyl najbardziej wrogie i niegodziwe świadectwo".

Adversas [...] ferre difficile esset sine eo, qui illas gravius etiam quam tu ferret. (Cic., Lael. 22)

„Przeciwności losu trudno byłoby znosić bez kogoś, kto znosiłby je z cięższym nawet sercem, niż ty".

Gdy korelatem są zaimki osobowe, zdanie względne ma charakter zdania uzupełniającego przydawkowego:

Nec mihi soli (virtus Scipionis) versatur ante oculos, qui illam semper in manibus habui, sed etiam posteris erit clara et insignis. (Cic., Lael. 102)

„I nie tylko mnie jednemu cnota Scypiona staje przed oczami, który zawsze miałem ją blisko siebie, lecz także potomnym będzie jaśnieć i blyszczeć".

Vos, qui hunc accusatis, omnis eius servos habetis. (Cic., Q. Rosc. 77)

„Wy, którzy go oskarżacie, posiadacie wszystkich jego niewolników”.

Zdania względne swobodne są zdaniami uzupełniającymi, a ich funkcję składniową określa otwarta, niewypełniona przez zaimek foryczny pozycja składniowa w zdaniu nadrzędnym. W związku z tym zdania względne swobodne mogą mieć status zdania uzupełniającego: 
a. Podmiotowego:

Multis [...] serviet, qui corpori servit. (Sen., Lucil. 14, 1)

„Shugą wielu (rzeczy) będzie (ten), kto jest sługą (swego) ciała".

Quem di diligunt, adulescens moritur. (PI., Bacch. 816-817)

„Kogo bogowie kochają, (ten) umiera jako młody czlowiek”.

Stulte feci, qui hunc amisi. (Pl., Mil. 1376)

„Glupio uczyniłem (ja), który go utraciłem”.

Sunt, qui Artenam Veientium, non Volscorum fuisse credant. (Liv., 4, 61)

„Istnieją (tacy), którzy skłonni są uważać, że Artena należala do Wejentów, a nie do Wolsków".

Zdanie względne funkcjonalnie podmiotowe, tj. uzupełniające funkcjonalny odpowiednik podmiotu wyrażany $w$ akuzatiwie $w$ ramach równoważnika $z$ dania o postaci accusativus cum infinitivo:

Negat [...] ius esse, qui miles non sit, cum hoste pugnare. (Cic., Off. 1, 37)

„Twierdzi, że nie jest rzeczą słuszną, by (ten), kto nie jest żołnierzem, walczył z wrogiem”.

b. Dopełnieniowego:

Dicam quidem certe, quod sentio. (Cic., Har. Resp. 50)

"Z pewnością powiem (to), co myślę".

Redeuntes milites, quos possunt, consectantur atque occidunt. (Caes., Gall. 5, 58)

„Jeżdźcy w drodze powrotnej ścigali i zabijali kogo tylko mogli”.

Xerxes [...] praemium proposuit, qui invenisset novam voluptatem. (Cic., Tusc. 5, 20)

„Kserkses obiecal nagrodę (temu), kto wynalazłby jakąś nową przyjemność”.

Quid dulcius, quam habere, quicum omnia audeas sic loqui, ut tecum? Qui esset tantus fructus in prosperis rebus, nisi haberes, qui illis aeque ac tu ipse gauderet? (Cic., Lael. 22)

„Cóż jest milszego, niż mieć (kogoś), z kim odważyłbyś się na każdy temat rozmawiać tak, jak z sobą samym? Jaka korzyść z powodzenia byłaby równie wielka, gdybyś nie mial (kogoś), kto cieszyłby się z niego tak bardzo, jak ty sam?"

c. Orzecznikowego:

Non ego sum, qui te dudum conduxi. (Pl., Merc. 758)

"To nie ja jestem (tym), który cię najął".

Jak już wspomniano wcześniej (zob. 4.3.2.2.4.), zdania, w których semantycznym korelatem zaimka względnego jest cała treść predykatywna zdania nadrzędnego, mają status zdań rozwijających. 


\subsection{Zdania z zaimkiem względnym użytym przymiotnikowo (przydawkowo)}

Jeśli zdanie nadrzędne zawiera rzeczownik, który jest wykładnikiem wspólnego dla obu zdań składowych elementu semantycznego (i tym samym jest leksykalnym odpowiednikiem rzeczownika określonego zaimkiem względnym), zdanie względne ma status zdania przydawkowego uzupełniającego:

Erant omnino itinera duo, quibus itineribus domo exire (Helveti) possent. (Caes., Gall. 1, 6)

"Istniały w sumie dwie drogi, którymi (to drogami) Helweci mogli wyjść ze swego kraju".

Emptum est ex senatus consulto frumentum ab Siculis praetore Verre, pro quo frumento pecunia omnis soluta non est. (Cic., Caecin. 32)

„Z dekretu senatu zakupione zostało od Sycylijczyków zboże podczas pretury Werresa, za które to zboże nie zapłacono całej należnej sumy".

Helvetii [...] legatos ad eum mittunt [...], cuius legationis Nammeius et Verucloetius principem locum obtinebant. (Caes., Gall. 1, 7)

„Helweci wysylają do niego posłów, w którym to poselstwię Nammejus i Werukloecjusz zajmowali naczelne miejsce".

Namque altera ex parte Bellovaci, quae civitas in Gallia maximam habet opinionem virtutis, instabant. (Caes., Gall. 7, 59)

„Bowiem z jednej strony nastawali Bellowakowie, które to plemię cieszy się opinią najbardziej walecznego w Galii".

Eodem anno a Campanis Cumae, quam Graeci tum urbem tenebant, capiuntur. (Liv., $4,44)$

„W tym samym roku zdobyte zostają przez Kampańczyków Kumy które to miasto zajmowali wówczas Grecy".

Jeśli rzeczownik ten został określony przymiotnikowym zaimkiem forycznym, zdanie względne ma status zdania przydawkowego rozszerzającego:

Quibus diebus Cumae liberatae sunt obsidione, iisdem diebus et in Lucanis ad Grumentum Ti. Sempronius [...] cum Hannone Poeno prospere pugnat. (Liv., 23, 37)

,W tych samych dniach, w których Kumy zostały wyswobodzone z oblężenia, również Tyberiusz Seproniusz po Grumentum w Lukanii z powodzeniem stacza bitwę z Punijczykiem Hannonem".

Caesari nuntiaverunt pulverem maiorem [...] in ea parte videri, quam in partem legio iter fecisset. (Caes., Gall. 4, 32)

„Cezarowi doniesiono, że widać większy tuman kurzu po tej stronie, w którą (to stronę) poszedt legion".

Jeśli w zdaniu nadrzędnym wykładnikiem wspólnego dla obu zdań składowych elementu semantycznego (i tym samym leksykalnym odpowiednikiem rzeczownika określonego zaimkiem względnym) jest rzeczownikowy lub przysłówkowy zaimek foryczny, zdanie względne jest zdaniem rozszerzającym, a jego funkcję składniową 
determinuje pozycja składniowa zajmowana przez ten zaimek. W związku z tym zdanie względne może mieć status zdania rozszerzającego:

a. Podmiotowego:

Quae pars civitatis Helvetiae insignem calamitatem populo Romano intulerat, ea princeps poenas persolvit. (Caes., Gall. 1, 12)

„Która część plemienia Helwetów zadała narodowi dotkliwą klęskę, ta jako pierwsza poniosła karę".

b. Dopełnieniowego:

Neque eam, quam profuisse aliis vim celeritatemque viderant, imitari potuerunt. (Caes., Gall. 6, 40)

„I nie potrafili naśladować tej siły (uderzenia) i szybkości, która, jak zauważyli, była bardzo pomocna innym".

c. Przydawkowego:

Quae gravissime adflictae erant naves, earum materia atque aere ad reliquas reficiendas utebatur. (Caes., Gall. 4, 31)

„Które okręty byly najbardziej zniszczone, to pochodzące z nich drewno i brąz wykorzystywał do naprawy pozostałych".

c. Okolicznikowego:

Qua nocte templum Ephesiae Dianae deflagravit, eadem constat [...] natum esse Alexandrum. (Cic., Div. 1, 47)

„Wiadomo, że której nocy splonęla świątynia Diany Efeskiej, to tej samej urodzil się Aleksander".

Quae minime visa pars firma est, huc concurritur. (Caes., Gall. 7, 84)

„Która çzęść (umocnień) wydala się najstabsza, tam spieszono".

Zdania względne swobodne są zdaniami uzupełniającymi, a ich funkcję składniową określa otwarta, niewypełniona przez zaimek foryczny pozycja składniowa w zdaniu nadrzędnym. W związku z tym zdania względne mogą mieć status zdania uzupełniającego:

a. Podmiotowego:

Quae civitates commodius suam rem publicam administrare existimantur, habent legibus sanctum, si quis quid de re publica a finitimis rumore ac fama acceperit, uti ad magistratum deferat neve cum quo alio communicet. (Caes., Gall. 6, 20)

„Które plemiona uchodzą za lepiej zorganizowane pod względem administracyjnym, (to te) uznają za prawnie usankcjonowane (to), że jeśli ktoś dowiedziabby się czegoś na temat spraw publicznych z plotek czy poglosek uslyszanych od mieszkańców sąsiednich krajów, ma o tym donieść władzom i nikomu innemu tego nie przekazywać".

Ex hac fuga protinus, quae undique convenerant auxilia, discesserunt. (Caes., Gall. 5, 17) „Po tej ucieczce natychmiast oddzialy posilkowe, które ściągnęly ze wszystkich stron, rozpierzchly się". 
b. Dopełnieniowego:

Quod tibi nomen est, fecit mihi. (Pl., Capt. 313)

"Jakie imię ty nosisz, (to) nadal (również) mnie".

c. Okolicznikowego:

Caesar necessariis rebus imperatis ad cohortandos milites, quam in partem fors obtulit, decucurrit. (Caes., Gall. 2, 21)

„Cezar po wydaniu niezbędnych rozkazów pobiegl na oślep, w jaką stronę los go skierowal, aby dodać otuchy żołnierzom".

Jeśli określany zaimkiem względnym rzeczownik konceptualizuje całą treść zdania nadrzędnego, zdanie względne jest zdaniem rozwijającym:

(Cimon) decem annorum exilio multatus est, cuius facti celerius Athenienses quam ipsum paenituit. (Nep., Cim. 3)

„(Kimon) skazany został na dziesięcioletnie wygnanie, którego (to) czynu wcześniej pożałowali Ateńczycy niż on sam".

\subsection{Zdania z zaimkami qualis, quantus, quot}

Zdania te najczęściej są zdaniami przydawkowymi. Jeśli odpowiada im w zdaniu nadrzędnym zaimkowy korelat o funkcji forycznej, mają charakter zdań przydawkowych rozszerzających:

Sequitur $[\ldots]$ victoria $[\ldots]$, quantam de Samnitibus nemo ad eam diem $[\ldots]$ pepererat. (Liv., 10, 38)

„Następuje (takie) zwycięstwo, jakiego nikt do tego dnia nie odniósł nad Samnitami”.

(Dicebant) unum [...] virum [...], qualis Ap. Claudius fuerit, momento temporis discussurum illos coetus fuisse. (Liv., 2, 28)

„(Mówili), że jeden człowiek (taki), jakim był Appiusz Klaudiusz, w jednej chwili rozpędzilby te zbiegowiska".

Moveor [...] tali amico orbatus, qualis [...] nemo umquam erit. (Cic., Lael. 10)

„Jestem głęboko przejęty straciwszy takiego przyjaciela, jakim nikı już nigdy nie będzie”.

Quot casus exercitus victi fuerant, tot in curas distracti animi eorum erant. (Liv., 22, 7)

„Ile przytrafiło się klęsk pokonanego wojska, tyle trosk napelniało ich skołatane serca”.

Mogą jednak pełnić także inne funkcje składniowe, np. funkcje zdań podrzędnych:

a. Orzecznikowych:

Non sum, qualis eram bonae sub regno Cinarae. (Hor., Carm. 4, 1, 3-4)

"Nie jestem już (taki), jakj byłem pod wladzą dobrej Cynary”. 
b. Dopełnieniowych:

Pietas me poscit [...], qualia nec Siculae moderantur carmina rupes nec fati iam certus olor. (Stat., Silv. 3, 3, 173-175)

„Synowska miłość domaga się ode mnie (takich pieśni), jakich nie wyśpiewają ani sycylijskie skały, ani labądź pewien już bliskiej śmierci".

c. Okolicznikowych:

Quot dies erimus in Tusculano, agamus haec. (Cic., Tusc. 1, 119)

„Ile dni spędzimy w posiadlości tuskulańskiej, (przez tyle dni) zajmujmy się tymi rzeczami”.

\subsection{Zdania z przysłówkowymi zaimkami względnymi}

Jeśli korelatem przysłówkowego zaimka względnego jest w zdaniu nadrzędnym przysłówek (zaimek przysłowny), zdanie względne ma charakter zdania okolicznikowego rozszerzającego:

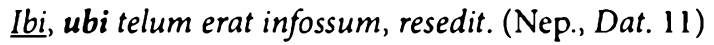

„Tam, gdzie wcześniej została zakopana broń, usiadr".

Swobodne zdanie względne z przysłówkowym zaimkiem względnym jest zdaniem okolicznikowym uzupełniającym:

Illam iube abs te abire, quo lubet. (PI., Mil. 974)

„Każ jej odejść od ciebie, dokąd zechce”.

Gdy korelatem przysłówkowego zaimka względnego jest rzeczownik, zdanie względne ma charakter zdania przydawkowego uzupełniającego:

Veritas [...] locum, ubi consistat, reperire non poterit. (Cic., Quinct. 5)

„Prawda nie będzie mogła znaleźć miejsca, gdzie pozostalaby na dlużej”.

Tres viae sunt ad Mutinam, quo festinat animus. (Cic., Phil. 12, 22)

„Są trzy drogi do Mutyny, dokąd wyrywa się serce".

Numquam hominem quemquam conveni, unde abierim lubentius. (PI., Epid. 80)

„Nie spotkalem jeszcze żadnego czlowieka, od którego chętniej bym odszedr".

Jeśli rzeczownikowy korelat określony jest przymiotnikowym zaimkiem forycznym, zdanie względne zyskuje status zdania przydawkowego rozszerzającego:

Tertiae cohortis centuriones ex e- , quo stabant, loco recesserunt. (Caes., Gall. 5, 43)

„Centurioni trzeciej kohorty wycofali się z tego miejsca, w którym stali”. 


\subsubsection{Tryb orzeczenia w zdaniach względnych}

Orzeczenie zdań względnych występuje zwykle w indikatiwie, jak np. w zdaniu: Irascimur [...] saepe non illis, qui laeserunt, sed eis, qui laesuri sunt. (Sen., Dial. 3, 3, 1)

„Często gniewamy się nie na tych, którzy (nas) skrzywdzili, lecz na tych, którzy chcą nas skrzywdzić".

Może jednak zostać wyrażone w koniunktiwie. Najczęściej ma to miejsce w sytuacji, o której była już mowa wyżej (zob. 4.3.2.4.3.), tzn. gdy zdanie względne z punktu widzenia semantycznego (funkcjonalnego) ma charakter predykatywny, a więc jeśli jest zdaniem względno-okolicznikowym:

a. Celu:

Sarmentis virgultisque collecis, quibus fossas Romanorum compleant, ad castra pergunt. (Caes., Gall. 3, 18)

„Nazbierawszy chrustu i gałęzi, którymi mieli (= aby nimi) wypełnić rowy obronne Rzymian, ruszyli w stronę obozu".

b. Przyzwolenia:

At hi (scil. Pompeiani) [...] exercitu Caesaris luxuriem obiciebant, cui semper omnia ad necessarium usum defuissent. (Caes., Civ. 3, 96)

„I to właśnie ci ludzie zarzucali zbytek wojsku Cezara, któremu (= chociaż jemu) nieustannie brakowało wszystkiego, co niezbędne do codziennego użytku".

c. Skutku:

Secutae sunt complures dies continuae tempestates, quae et nostros in castris continerent et hostem a pugna prohiberent. (Caes., Gall. 4, 34)

„Przez wiele kolejnych dni następowały nieustanne ulewy, które (= tak, że w rezultacie) i naszych zatrzymywały w obozie, i nieprzyjaciela powstrzymywały od działań bojowych".

d. Przyczyny:

Videbatur [...] nobis exercitus Ceasaris [...] audaciae plus habere, quippe qui patriae bellum intulisset. (Cic., Div. 2, 114)

„Wydawało się nam, że wojsko Cezara jest bardziej zuchwałe, które przecież (= ponieważ) wypowiedziało wojnę (własnej) ojczyźnie".

e. Warunku:

Nemo aliter philosophus sensit, in quo modo esset auctoritas. (Cic., Div. 2, 86) „Inaczej nie myślał żaden filozof, który (= jeśli) tylko cieszył się jakimś autorytetem”.

Orzeczenie może zostać wyrażone $\mathrm{w}$ koniunktiwie również wtedy, gdy nacechowane jest modalnie, tzn. jeśli wyraża niefaktywność, a więc np.: możliwość, konieczność, potencjalność, hipotetyczność, prawdopodobieństwo, postulatywność, 
życzenie, zachętę itp. Do tej kategorii należą także zdania zaprzeczone, w których zaimek względny odnosi się do obiektu hipotetycznego lub ukazanego - explicite bądź implicite - jako nieistniejący w kontekście wyrażanej w zdaniu względnym treści. W pewnych przypadkach nacechowanie modalne orzeczenia i predykatywny charakter zdania względnego są ze sobą sprzężone (jak np. w zdaniach względno-celowych), w związku z czym trudno jest o jednoznaczną kwalifikację zdań tego typu:

Veritas [...] locum, ubi consistat, reperire non poterit. (Cic., Quinct. 5)

„Prawda nie będzie mogła znaleźć miejsca, gdzie mogłaby pozostać na dłużej”.

Omnibus rebus ad profectionem comparatis (Helveti) diem dicunt, qua die ad ripam Rhodani omnes conveniant. (Caes., Gall. 1, 6)

„Po przeprowadzeniu wszystkich przygotowań do wymarszu Helwetowie wyznaczają dzień, w którym to dniu wszyscy mieli się zebrać nad brzegiem Rodanu".

Rem [...] commovisti nova disputatione dignam, quam in aliud tempus differamus. (Cic., Brut. 297)

„Poruszyłeś zagadnienie godne nowej dyskusji, którą odłóżmy (jednak) na inny czas”.

Non enim latroni, sed regi credidit [...], nec ei regi, qui alienus ab hoc imperio esset, sed ei, quicum foedus feriri in Capitolio viderat. (Cic., Rab. Post. 16)

„Nie pożyczyl bowiem pieniędzy bandycie, lecz królowi, i to nie takiemu królowi, który bylby wrogi temu państwu, lecz temu, z którym widzial zawarte na Kapitolu przymierze".

Neque enim naves erant aliae, quibus reportari possent. (Caes., Gall. 4, 29)

„I nie było innych okrętów, na których mogliby wrócič".

Numquam hominem quemquam conveni, unde abierim lubentius. (Pl., Epid. 80)

„Nie spotkałem jeszcze żadnego czlowieka, od którego chętniej bym odszedr".

Pro di immortales! Essene quemquam tanta audacia praeditum, qui [...] quod sibi probare non possit, id persuadere alteri conetur?! (Cic., Q. Rosc. 4)

„Na bogów nieśmiertelnych! Czyż może istnieć ktoś tak zuchwały, kto miałby śmialość przekonywać innych do tego, do czego siebie przekonać nie może?!"

Ea qui conficeret, $C$. Tribonium legatum relinquit. (Caes., Gall. 7, 11)

"(Jako tego), który mial to wykonać (= aby to wykonal), pozostawil (na miejscu) legata Gajusza Treboniusza".

Hannibal [...] nihil unquam satis dictum praemonitumque ad cohortandos milites ratus, vocatis ad contionem certa praemia pronuntiat, in quorum spem pugnarent. (Liv., 21, 45)

„Hannibal uważając, że nigdy nie dość słów zachęty dla pobudzenia waleczności żołnierzy, zebranym na zgromadzeniu zadeklarowal określone nagrody, z nadzieją na które mieliby walczyć (= aby z nadzieją na nie walczyli)".

Czasem użycie koniunktiwu wiąże się ze wskazywaniem przez zimek względny na obiekt niekonkretny:

At etiam sunt, qui dicant, Quirites, a me eiectum esse Catilinam. (Cic., Catil. 2, 12) "A jednak, Kwiryci, są (tacy), którzy twierdzą, że Katylina zostal przeze mnie zmuszony do wygnania". 
Eo postquam Caesar pervenit, obsides, arma, servos, qui ad eos perfugissent, poposcit. (Caes., Gall. 1, 27)

„Gdy Cezar tam przybył, zażądal wydania zakładników, broni i niewolników, którzy do nich zbiegli".

Poza tym użycie koniunktiwu w zdaniach względnych może być motywowane syntaktycznie, jeśli zdanie to zależne jest składniowo od innego zdania podrzędnego $\mathrm{z}$ orzeczeniem $\mathrm{w}$ koniunktiwie lub od jego równoważnika $\mathrm{z}$ funkcjonalnym odpowiednikiem orzeczenia $w$ infinitiwie:

Legati ab Haeduis [...] veniebant [...] questum, quod Harudes, qui nuper in Galliam transportati essent, fines eorum popularentur. (Caes., Gall. 1, 37)

„Przybywali posłowie Eduów ze skargą, że Harudowie, którzy niedawno przesiedleni zostali do Galii, pustoszą ich kraj".

Nam cum Socrates omnesque Socratici Zenoque et ii, qui ab eo essent profecti, manerent in antiquorum philosophorum sententia [...], Dicearchus Peripateticus cetera divinationis genera sustulit, somniorum et furoris reliquit. (Cic., Div. 1, 5)

„Bowiem chociaż Sokrates i wszyscy sokratycy, a także Zenon i ci, którzy od niego się wywodza, pozostali przy opinii dawnych filozofów, to jednak perypatetyk Dicearch wszystkie inne rodzaje wróżbiarstwa odrzucil, i tylko wróżby ze snów i wyrzeczone w proroczym szale pozostawil (jako prawdziwe)".

Ita fit, ut, quod bonum sit, id etiam honestum sit. (Cic., Fin. 3, 27)

„Dzieje się tak, iż to, co jest dobre, jest również szlachetne”.

Hoc unum plane tibi adprobare vellem, omnia me illa sentire, quae dicerem. (Sen., Lucil. 75, 3)

„Chciałbym do tego jednego cię przekonać, że mianowicie ja czuję to wszystko, o czym mówię".

(Caesar) contionem apud milites habuit hortatusque est, ne ea, quae accidissent, graviter ferrent. (Caes., Civ. 3, 73)

„(Cezar) przemówił na zgromadzeniu do żołnierzy nawołując, by nie załamywali siç tym, co się stało".

Generalnie jednak użycie koniunktiwu w zdaniach względnych nie stanowiło ścisłej reguły. Spotykamy bowiem przykłady zastosowania indikatiwu w kontekstach, które zgodnie $\mathrm{z}$ wyżej sformułownymi zasadmi wymagałyby raczej koniunktiwu:

Stulte feci, qui hunc amisi. (PI., Mil. 1376)

„Glupio uczynilem (ja), który (= ponieważ) go utracilem”.

Hostes [...] vadis repertis partem suarum copiarum traducere conati sunt eo consilio, ut [...] castellum, cui praeerat Q. Titurius legatus, expugnarent. (Caes., Gall. 2, 9)

„Wrogowie, gdy znaleźli brody (w rzece), próbowali przeprowadzić (nimi) część swoich wojsk z tym zamiarem, by zdobyć umocnienie, którym dowodzil legat Kwintus Tyturiusz".

Poza tym w zdaniach względnych wystąpić mogą także orzeczenia w imperatiwie, choć zdarza się to bardzo rzadko: 
Multas ad res perutiles Xenophontis libri sunt, quos legite, quaeso, studiose, ut facitis. (Cic., Lael. 59)

„W wielu kwestiach bardzo użyteczne są książki Ksenofonta, które, proszę, czytajcie pilnie, tak, jak czynicie do dotychczas".

\subsubsection{Uwagi na temat wybranych cech składniowych zdań względnych}

Zaimek względny generalnie stanowi pierwszy w szyku linearnym składnik zdania względnego. Poprzedza go zwykle jedynie przyimek, jeśli współtworzy z nim wyrażenie przyimkowe:

Delectabatur autem mirifice lectione librorum, de quibus audiebat. (Cic., Lucull. 4)

„Niezwykle delektowal się więc lekturą książek, o których słyszal”.

Sporadycznie spotyka się konstrukcje, w których inne składniki zdania względnego poprzedzają zaimek:

Asse panem quem emisses, non potuisses cum altero devorare. (Petron., Sat. 44, 11)

„Chleba, który kupitbyś za jednego (tylko) asa, nie byłbyś w stanie zjeść nawet pospołu z kimś drugim".

Jeśli zaimek względny odnosi się do kilku rzeczownikowych korelatów w zdaniu nadrzędnym, występuje w liczbie mnogiej i podlega składni zgody co do gramatycznego rodzaju według następujących zasad:

1. W przypadku rzeczowników o różnym rodzaju gramatycznym i desygnatach osobowych przybiera rodzaj męski:

Faciebant hoc itidem $[. .$.$] grandes natu matres et item parvi liberi [...], quorum utru-$ mque aetas laborem et industria meam, fidem et misericordiam vestram requirebat. (Cic., Verr. 2, 5, 129)

„Czyniły to w ten sam sposób starsze już matki i małe dzieçi, których wiek wymagał zarówno mojego wysitku i troskliwości, jak i waszego wsparcia oraz milosierdzia".

2. W przypadku rzeczowników o różnym rodzaju gramatycznym i desygnatach nieosobowych zaimek:

a. przybiera rodzaj nijaki:

(Fortunam) nemo ab inconstantia et temeritate seiunget, quae digna certe non sunt deo. (Cic., Nat. 3, 61)

„Nikt nie uzna, że fortuna nie ma nic wspólnego z nicstalością i przypadkowością, które (to cechy) z pewnością nie są godne boga".

b. przybiera rodzaj zgodny $z$ rodzajem stojącego najbliżej niego rzeczownika:

Ipsos (scil. Allobroges) oppida vicosque, quos incenderant, restituere iussit. (Caes., Gall. $1,28)$ 
„Rozkazał, żeby oni sami (tj. Allobrogowie) odbudowali miasta i wsię, które wcześniej spalili".

Zaimek względny odnoszący się do rzeczownika kolektywnego (zbiorowego) w liczbie pojedynczej może przybierać wartość liczby mnogiej (tzw. constructio ad sensum):

Caesar equitatum $[\ldots]$ omnem $[\ldots]$ praemittit, qui videant, quas in partes hostes iter faciant. (Caes., Gall. 1, 15)

„Cezar całą konniç̧ wysyła naprzód, by śledzila, w jakim kierunku nieprzyjaciele będą się posuwali".

Zaimek względny, którego korelatem w zdaniu nadrzędnym jest rzeczownik określony rzeczownikową przydawką apozycyjną, może wykazywać kongruencję bądź z ową przydawką, bądź z określanym przez nią rzeczownikiem. Dotyczy to w szczególności geograficznych nazw własnych:

Helvetii continentur una ex parte flumine Rheno [...], qui agrum Helvetium a Germanis dividit. (Caes., Gall. 1, 2)

„Helwetowie geograficznie ograniczeni są z jednej strony rzeką Ren, która oddziela kraj Helwetów od Germanów".

Caesar [...] naves interim longas aedificari in flumine Ligeri, quod influit in Oceanum [...], iubet. (Caes., Gall. 3, 9)

„Cezar rozkazał tymczasem budować okręty wojenne na rzece Liger, która wpływa do Oceanu".

Flumen est Arar, quod [...] in Rhodanum influit. (Caes., Gall. 1, 12)

„Jest (tu) rzeka Arar, która uchodzi do Rodanu”.

Jeśli orzeczenie zdania względnego zawiera rzeczownikowy orzecznik, zaimek względny wykazuje składnię zgody nie ze swoim korelatem w zdaniu nadrzędnym, lecz z tymże orzecznikiem. Jest to tzw. congruentia inversa, która ma jednak miejsce wyłącznie w zdaniach względnych nierestryktywnych (tj. apozycyjnych):

Vercingetorix [...] Alesiam, quod est oppidum Mandubiorum, iter facere coepit. (Caes., Gall. 7, 68)

„Wercyngetoryks rozpoczął marsz do Alezji, która jest miastem (plemienia) Mandubiów”.

Caesar [...] litteris [...] Labieni certior fiebat omnes Belgas, quam tertiam esse Galliae partem dixeramus, contra populum Romanum iurare. (Caes., Gall. 2, 1)

„Cezar dowiadywał się z listów Labienusa, że wszyscy Belgowie, którzy - jak wcześniej powiedzieliśmy - stanowią trzecią część Galii, zmawiają się przeciw ludowi rzymskiemu".

Pompeio enim patre, quod imperi populi Romani lumen fuit, exstincto, interfectus est patris simillimus filius. (Cic., Phil. 5, 39)

„Gdy bowiem zmarl Pompejusz ojciec, który był światłem państwa rzymskiego, zabity (też) zostal najbardziej do ojca podobny syn". 
Ne appellarent consilium, quae vis ac necessitas appellanda esset. (Liv., 7, 20)

„Niech nie nazywają zamierzonym dzialaniem (tego), co należałoby nazwać przymusem i koniecznościa".

W przypadku zdań restryktywnych zaimek względny zachowuje kongruencję ze swym korelatem w zdaniu nadrzędnym:

Est genus quoddam hominum, quod Hilotae vocatur. (Nep., Paus. 3)

„Istnieje (w Sparcie) pewna klasa ludzi, która zwana jest Helotami”.

Fines (Cassivelauni) a maritimis civitatibus flumen dividit, quod appellatur Tamesis. (Caes., Gall. 5, 11)

„Kraj Kassywelaunusa od plemion nadmorskich oddziela rzeka, która nazywana jest Tamesis".

Ibi urbe, quae caput insulae est, biduum nequiquam summo labore oppugnata $[\ldots]$ ex Baliaribus insulis legati pacem petentes ad Scipionem venerunt. (Liv., 22, 20)

„Tam, gdy miasto, które jest stolicą wyspy, przez dwa dni bez powodzenia bylo zaciekle szturmowane, przybyli do Scypiona poslowie z wysp Balearów z prośbą o pokój".

Zdania, w których korelatem zaimka względnego są zaimki osobowe, na ogół nie mają charakteru restryktywnego, a jeśli zaimek względny, którego korelatem jest zaimek osobowy 1. lub 2. osoby, pełni w nich funkcję podmiotu, to również on przyjmuje wartość 1 . lub 2. osoby, czego wyrazem jest odpowiednia końcówka czasownika będącego orzeczeniem:

Nec mihi soli (virtus Scipionis) versatur ante oculos, qui illam semper in manibus habui, sed etiam posteris erit clara et insignis. (Cic., Lael. 102)

"I nie tylko mnie jednemu cnota Scypiona staje przed oczami, który zawsze mialem ją blisko siebie, lecz także potomnym będzie jaśnieć i błyszczeć".

Qui me alter est audacior homo [...], qui hoc noctis solus ambulem? (PI., Amph. 153-154) "Jakiż czlowiek jest odważniejszy ode mnie który o tej porze nocy samotnie spaceruję?"

Vos, qui hunc accusatis, omnis eius servos habetis. (Cic., Q. Rosc. 77)

„Wy którzy go oskarżacie, posiadacie wszystkich jego niewolników".

Zaimek względny pełniący funkcję podmiotu może być nacechowany wartością 1. lub 2. osoby, nawet nie mając bezpośredniego korelata w postaci zaimka osobowego:

Fato datum erat, ut qui primus bellum intuli populo Romano [...], is ultro ad pacem petendam venirem. (Liv., 30, 30)

„Los sprawił, że (ja), który jako pierwszy wypowiedzialem wojnę narodowi rzymskiemu, sam przychodzę prosić o pokój".

Podobnie wartość 1 . lub 2. osoby zachowuje zajmujący pozycję podmiotu zaimek względny, gdy jego korelatem jest wyrażony zaimkiem is orzecznik, charakteryzujący (wyrażony zaimkiem lub domyślny) podmiot w 1. lub 2. osobie, co także sygnalizowane jest przez końcówkę osobową czasownika będącego orzeczeniem. Pod tym względem składnia łacińska odbiega od zasad składni języka polskiego: 
Neque is sum [...], qui gravissime ex vobis mortis periculo terrear. (Caes., Gall. 5,30 ) „I nie jestem tym, który najbardziej $z$ was miałby być przerażony niebezpieczeństwem śmierci".

Tun is es, qui per voluptatem tuam in me aerumnam obsevisti gravem? (Pl., Epid. 556-557)

„Czy to ty jesteś tym, który dla swej przyjemności sprowadził na mnie wielką udrękę̧?”

Z uwagi na wyłącznie kataforyczną funkcję zaimka is, markującego pozycję składniową orzecznika, może on w tym kontekście zostać niewyrażony w strukturze powierzchniowej zdania, jeśli jest werbalizowany sam zaimkowy podmiot:

Non ego sum, qui te dudum conduxi. (Pl., Merc. 758)

„To nie ja jestem (tym), który cię najął”.

Zdarza się, że należący do zdania nadrzędnego rzeczownikowy lub zaimkowy korelat zaimka względnego występuje nie w tym przypadku, jakiego wymaga zajmowana przez niego pozycja składniowa, lecz w tym samym, w którym występuje zaimek względny. Zwykle wtedy korelat ten bezpośrednio poprzedza zaimek względny, a zdanie względne poprzedza orzeczenie zdania nadrzędnego. W bardziej rozbudowanych strukturach często korelat ten bezpośrednio po zdaniu względnym podlega reasumpcji za pośrednictwem zaimka, którego przypadek odpowiada już zajmowanej przez niego pozycji składniowej. Zjawisko to znane jest jako tzw. attractio inversa i spotykane jest dość często $w$ łacinie archaicznej, w tym w tekstach Plauta. Prawdopodobnie było ono charakterystyczne dla języka mówionego:

Urbem, quam statuo, vestra est. (Verg., Aen. 1, 573)

"Miasto, które wznoszę, wasze jest".

Naucratem, quem convenire volui, in navi non erat. (Pl., Amph. 1009)

"Naukratesa, którego chciałem spotkać, nie było na statku".

Sed istum, quem quaeris, ego sum. (Pl., Curc. 419)

"Jednakże tym, którego szukasz, to ja jestem".

Hunc chlamydatum, quem vides, ei Mars iratust. (Pl., Poen. 644-645)

,Ten w płaszczu, którego widzisz, to na niego Mars się zezłościł".

Eius servus, qui hunc (scil. symbolum) ferebat cum quinque argenti minis, tuam qui amicam hinc arcessebat, ei os sublevi modo. (Pl., Pseud. 718-719)

„Jego sługa, który przyniósł ten znak razem z pięcioma minami srebra, który przyszedł, by zabrać stąd twoją dziewczynę, to jemu właśnie zagratem na nosie".

Sed $\underline{\text { tu}}$, qui pro tam corrupto dicis causam filio, eademne erat haec disciplina tibi, cum tu adulescens eras? (Pl., Bacch. 420-421)

"A ty, który bronisz tak zdemoralizowanego syna, to czy ciebie tak samo wychowywano, gdy sam byłeś młody?"

Tego typu attractio w zasadzie dotyczy wyłącznie asymilacji do nominatiwu bądź akuzatiwu. Sporadycznie spotyka się również asymilację do datiwu: 
Qui invident, egent; $\underline{\text { illis, }}$ quibus invidetur, $\underline{i}$ rem habent. (Pl., Truc. 745)

„Ci, którzy zazdroszczą, są w biedzie; çi, którym się zazdrości, to oni mają wszystkiego pod dostatkiem".

Dużo rzadziej zdarza się asymilacja korelatu, który znajduje się po zdaniu względnym:

Populo ut placerent, quas fecisset, fabulas. (Ter., Andr. 3)

"Aby podobały się publiczności sztuki, które stworzył".

Bardzo rzadko zdarza się też asymilacja zaimka względnego, który nie pojawia się w przypadku wymaganym dla zajmowanej przez niego pozycji w zdaniu podrzędnym, lecz w tym, w którym występuje jego rzeczownikowy korelat w zdaniu nadrzędnym. Jest to tzw. attractio relativi:

Persuades $[\ldots]$ Laevinum $[\ldots]$ unius assis non umquam pretio pluris licuisse, notante iudice, quo nosti, populo. (Hor., Serm. 1, 6, 8-15)

„Przekonujesz, że Lewinus nigdy nie był wart więcej niż jednego asa według osądu ș̨̧dziego, którego znasz, tj. ludu".

In eo loco, quo paulo ante commemoravi, ante oppidum constitit. (Ps.-Caes., Bell. Afr. 41)

„W tym miejscu, które przywołałem nieco wcześniej, zatrzymał się przed miastem”.

Haec $[\ldots]$ in his quibus dixi libris pervulgata sunt. (Gell., Noc. Att. 10, 23, 2)

„Rzeczy te rozpowszechnione zostały w tych ksiegach, o których wspomniałem."

Przy identycznym orzeczeniu (lub jego części) w zdaniu nadrzędnym i względnym, nie musi być ono powtarzane w obu zdaniach:

His ego litteris lectis in eadem opinione fui, qua reliqui omnes, te cum omnibus copiis ad Corfinium esse venturum. (Cic., Att. 8, 11d, 3)

„Po przeczytaniu tego listu mialem takie samo przekonanie, jakie (mieli) wszyscy inni, że mianowicie ze wszystkimi oddziałami przybędziesz pod Korfinium".

Patres militarent, patres arma caperent, ut penes eosdem pericula belli, penes quos praemia, essent. (Liv., 2, 24)

„Niech patrycjusze idą na wojnę, patrycjusze niech dobywają mieczy, aby niebezpieczeństwa wojny były udziałem tych samych ludzi, kıórych udziałem (są) korzyści (z niej płynące)".

W przypadku dwóch zdań względnych współrzędnych w stosunku do siebie zaimek względny $w$ drugim $z$ nich może zostać pominięty lub zastąpiony zaimkiem anaforycznym:

Bocchus cum peditibus, quos Volux [...] adduxerat neque in priore pugna adfuerant, postremam Romanorum aciem invadunt. (Sall., Iug. 101)

„Bokchus z żołnierzami piechoty, których przyprowadzil Woluks i (którzy) nie brali udziału w poprzedniej bitwie, atakuje tylną linię bojową Rzymian".

Omnes tum fere, qui nec extra urbem hanc vixerant neque eos aliqua barbaries domestica infuscaverat, recte loquebantur. (Cic., Brut. 158)

„Wtedy niemal wszyscy, którzy nie mieszkali gdzieś poza miastem i nic skaziło ich tu na miejscu jakieś barbarzyństwo językowe, mówili poprawnie". 
Ut bestiis aliud alii praecipui a natura datum est, quod suum quaeque retinet nec discedit ab eo sic homini multo quiddam praestantius. (Cic., Tusc. 5, 38)

„Jak każdemu ze zwierząt dane zostało przez naturę coś szczególnego, co każde z nich zachowuje jako sobie wlaściwe i nie odstępuje od tego tak czlowiekowi (dane zostało) coś znacznie wspanialszego".

Ipsius in mente insidebat species pulchritudinis eximia quaedam, quam intuens in eaque defixus ad illius similitudinem artem et manum dirigebat. (Cic., Orat. 9)

„W jego umyśle tkwila jakaś wyjątkowa wizja piękna, w którą wpatrując się i oczu od niej nie odrywając, na podobieństwo do niej kierowal swą ręką i ksztaltowal swe arcydziela".

Zdarza się jednak również powtórzenie zaimka:

Quam copiose ab eo (scil. Xenophonte) agri cultura laudatur in eo libro, qui est de tuenda re familiari, qui Oeconomicus inscribitur! (Cic., Lael. 59)

„Jakże wymownie wychwalane jest przez Ksenofonta rolnictwo w tej książce, która poświęcona jest zarządzaniu majątkiem, która nosi tytuł Oeconomicus!"

Spotyka się również bardziej złożone konstrukcje, w których zaimek względny stanowi składnik zdania (lub jego równoważnika) bezpośrednio zależnego składniowo nie od tego zdania, w jakim znajduje się jego leksykalny lub zaimkowy korelat, lecz od innej nadrzędnej struktury zdaniowej. Ulokowana jest ona po zdaniu względnym, a wykładnik zespolenia zdania względnego $z$ tą strukturą znajduje się po zaimku względnym:

Magna (est) vis conscientiae, quam qui neglegunt, cum me violare volent, se indicabunt. (Cic., Catil. 3, 27)

„Wielka jest siła powszechnej świadomości, i (dlatego) ci, którzy ją lekceważą, kiedy będą chcieli uczynić mi krzywdę, sami się zdradzą (jako sprawcy tej krzywdy, ponieważ powszechnie znane są ich zle zamiary w stosunku do mnie)".

Eis etiam praemia postulat, quibus ut ignoscatur si postulet, impudentissimus iudicetur. (Cic., Phil. 8, 25)

„Chce wręcz nagród dla tych, dla których jeśliby prosil (tylko) o wybaczenie, (to już) zostałby uznany za bezczelnego".

Caesar [...] litteris [...] Labieni certior fiebat omnes Belgas, quam tertiam esse Galliue partem dixeramus, contra populum Romanum iurare. (Caes., Gall. 2, 1)

„Cezar dowiadywał się z listów Labienusa, że wszyscy Belgowie, którzy - jak wcześniej powiedzieliśmy - stanowią trzecią część Galii, zmawiają się przeciw ludowi rzymskiemu".

Nec Alpes aliae sunt, quas dum (hostes) superant, comparari nova possint praesidia. (Liv., 21, 41)

„Nie ma też drugich Alp, by w czasie, gdy wrogowie przez nie się przedzierają, mogty być zorganizowane nowe oddzialy dla ochrony".

Jeśli treściowym składnikiem również tej struktury zdaniowej jest obiekt, do którego odsyła zaimek względny, może on zostać wyrażony zaimkiem o funkcji anaforycznej: 
Saepissime et legi et audivi nihil mali esse in morte, ex qua si resideat sensus, immortalitas illa potius quam mors ducenda sit. (Cic., Fam. 5, 16, 4)

„Bardzo często czytałem i słyszałem, że nie ma nic złego w śmierci, po której jeśli pozostawatoby czucie, to powinna ona raczej być uważana za nieśmiertelność niż śmicrć".

Podobne konstrukcje spotyka się także $\mathrm{w}$ odniesieniu do zdań z zaimkiem względnym użytym przymiotnikowo. W tym przypadku mamy do czynienia ze zdaniami względnymi zależnymi od nadrzędnych struktur zdaniowych innych niż te, w których ma swój leksykalny lub zaimkowy korelat rzeczownik określany zaimkiem względnym:

Iter in ea loca facere coepit, quibus in locis esse Germanos audiebat. (Caes., Gall. 4, 7)

„Rozpoczął marsz do tych miejsc, w których (to miejscach), jak słyszal, przebywali Germanie".

Neque eam, quam profuisse aliis vim celeritatemque viderant, imitari potuerunt. (Caes., Gall. 6, 40)

„I nie potrafili naśladować tẹ siłł (uderzenia) i szybkości, która, jak zauważyli, była bardzo pomocna innym".

\subsubsection{Tzw. „połączenie względne”}

Tradycyjnie wyodrębnia się także tzw. „połączenie względne”, czyli zjawisko polegające na tym, że od zaimka względnego rozpoczyna się nowe zdanie, niezależne składniowo od zdania poprzedzającego. Zaimek względny pełni wtedy funkcję anaforyczną, wykazując koreferencję z jednym ze składników poprzedzającego zdania (tj. ze swoim leksykalnym korelatem), nie implikując przy tym podrzędności składniowej. Zasadność wyodrębniania takich struktur bywa jednak kwestionowana wobec dość często obserwowanego w takich przypadkach braku jednoznacznych przesłanek pozwalających na obiektywne ustalenie granicy między zdaniami, wskutek czego o zaistnieniu tego rodzaju "połączenia względnego" decydują de facto wydawcy tekstów:

Neocles [...] uxorem Acarnanam civem duxit, ex qua natus est Themistocles. Qui cum minus esset probatus parentibus [...], a patre exheredatus est. (Nep., Them. 1)

„Neokles pojął za żonę obywatelkę z Akarnanii, i ze związku z nią przyszedł na świat Temistokles. On to, ponieważ nie zyskał uznania w oczach rodziców, przez ojca został wydziedziczony".

Tres viae sunt ad Mutinam, quo festinat animus, ut quam primum [...] D. Brutum aspicere possim; cuius in complexu libenter extremum vitae spiritum ediderim, cum omnes actiones horum mensum [...] pervenerint ad eum, qui mihi fuit propositus, exitum. (Cic., Phil. 12, 22)

„Są trzy drogi do Mutyny, dokąd wyrywa się serce, abym mógł jak najprędzej oglądać Decymusa Brutusa; $w$ jego objęciach chętnie wydałbym ostatnie w życiu tchnienie, gdyby wszystkic (moje) działania z oslatnich miesięcy osiągnęły ten cel, który sobic w'yznaczylem". 
Zaimek względny może też nie wykazywać koreferencji z jednym, konkretnym składnikiem poprzedzającego zdania, lecz reasumować jego treść:

Macedo Alexander, cum ab ineunte aetate res maximas gerere coepisset, nonne tertio et tricesimo anno mortem obiit? Quae est aetas nostris legibus decem annis minor quam consularis. Ex quo iudicari potest virtutis esse quam aetatis cursum celeriorem. (Cic., Phil. $5,48)$

"A czyż Aleksander Macedoński, po tym jak od wczesnej młodości zacząl dokonywać wielkich czynów, nie zmarl $w$ trzydziestym trzecim roku życia? Jest to według naszych praw wiek o dziesięć lat mlodszy od konsularnego. $Z$ tego można wysnuć wniosek, że przyrost męstwa następuje szybciej niż (przyrost) lat".

Jak widać już z powyższego przykładu, omawiane zjawisko dotyczy nie tylko zdań z rzeczownikowo użytym zaimkiem względnym, ale i tych, w których ma on charakter przymiotnikowy (przydawkowy). W tym drugim przypadku określany zaimkiem względnym rzeczownik wykazuje koreferencję z jednym ze składników poprzedzającego zdania lub konceptualizuje zasadniczą treść tego zdania:

Nec vero umquam discedebam nec a re publica deiciebam oculos ex eo die, quo in aedem Telluris convocati sumus. In quo templo, quantum in me fuit, ieci fundamenta pacis Atheniensiumque renovavi vetus exemplum. (Cic., Phil. 1, 1)

"I nigdy nie oddalałem się ani nie odwracałem oczu od rzeczypospolitej, począwszy od tego dnia, w którym zostaliśmy zwołani do świątyni bogini Ziemi. W tym to przybytku, na ile tylko byłem w stanie, polożyłem podwaliny pod pokój i przywolałem dawny przykład Ateńczyków".

Obicitur mihi meus ille discessus; cui ego crimini respondere sine mea maxima laude non possum. (Cic., Dom. 95)

„Czyni mi się zarzut z tego mojego wyjazdu; na to oskarżenie nie mogę odpowiedzieć inaczej, jak tylko nie szczędąc sobie największych pochwal".

Delituit caelum et subitis lux candida cessit nubibus ac tenuis graviore favonius austro immaduit; qualem Lybiae Saturnia nimbum attulit, Iliaco dum dives Elissa marito donatur. (Stat., Sil. 3, 1, 71-75)

„Niebo skrylo się $\mathrm{i}$ jasne światło ustąpiło nieoczekiwanym chmurom, zaś delikatny Fawoniusz przesiąknął deszczem od gwałtowniejszego Austra; taką ulewę sprowadziła na Afrykę Saturnia (tj. Junona) wtedy, gdy bogata Elissa oddawala się iliackiemu mężowi".

Z drugiej strony dwa fakty zdają się potwierdzać możliwość wystąpienia zaimka względnego w strukturach niezależnych składniowo, w których pełni on funkcję anaforyczną. Jednym $z$ nich jest dystans, jaki może go dzielić od jego leksykalnego korelata, względem którego zachowuje koreferencję:

Labienus [...] cum quattuor legionibus Luteciam proficiscitur. Id est oppidum Parisiorum, positum in insula fluminis Sequanae. Cuius adventu ab hostibus cognito magnae ex finitimis civitatibus copiae convenerunt. (Caes., Gall. 7, 57)

„Labienus z czterema legionami rusza do Lutecji. Jest to miasto Paryzjów, polożone na wyspie znajdującej się w nurtach rzeki Sekwany. Gdy o jego przybyciu dowiedzieli się wrogowie, zgromadzily się (tam) wielkie oddziały (przybyłe z) sąsiednich plemion". 
Drugą przesłanką mogą być wypowiedzi stanowione przez wieloelementowe sekwencje czy ciągi konstrukcji składniowych otwieranych przez zaimek względny, które - $z$ uwagi na ich strukturę informacyjną - trudno byłoby uznać za jedno zdanie:

Caesar equitatum [...] omnem [...], quem ex omni provincia [...] coactum habebat, praemittit, qui videant, quas in partes hostes iter faciant. Qui cupidius novissimum agmen insecuti alieno loco cum equitatu Helvetiorum proelium committunt, et pauci de nostris cadunt. Quo proelio sublati Helvitii [...] nostros lacessere coeperunt. (Caes., Gall. 1, 15)

„Cezar wysyła naprzód wszystkich jeźdźców, których sprowadził z całej prowincji, aby śledzili, w jakim kierunku nieprzyjaciele będą się posuwać. Oni to, ze zbytnią gorliwością atakując tylną straż (nieprzyjaciól), w niedogodnym dla siebie miejscu wdali się w bitwę $\mathrm{z}$ helwecką konnicą i kilku naszych zginęło. Tą potyczką podniesieni na duchu, Helwetowie zaczęli naszych prowokować".

Nie bez znaczenia pozostaje wreszcie fakt, iż tego typu konstrukty znajdują bezpośrednie paralele $w$ postaci niepodrzędnych struktur zdaniowych, w których miejsce zaimka względnego zajmują zaimki is, hic lub ille. Tym samym należałoby uznać, że zaimki względne nie implikują podrzędności składniowej w sposób bezwarunkowy, lecz raczej współ-syganlizują ją wraz $z$ intonacją zdaniową.

W niektórych przypadkach zachodzi duża zbieżność między zdaniami względnymi a zdaniami pytajnymi zależnymi. Zastosowanie koniunktiwu w kontekście, który nie jest typowy dla tego trybu w zdaniach względnych, może wtedy przemawiać za pytajnym, a nie względnym charakterem danego zdania. Gdyby przyjąć to założenie, pierwsze $z$ podanych niżej zdań należałoby uznać za zdanie pytajne zależne, drugie zaś za zdanie względne:

T. Labienus $[\ldots]$ ex loco superiore quae res in nostris castris gererentur conspicatus $X$ legionem subsidio nostris misit. (Caes., Gall. 2, 26)

„Tytus Labienus dojrzawszy z wyżej położonego miejsca, jakie rzeczy dzieją się w naszym obozie, przysłał naszym na pomoc dziesiąty legion".

Patefacio vobis, quas isti penitus abstrusas insidias se posuisse arbitrantur contra $\mathrm{Cn}$. Pompei dignitatem. (Cic., Leg. Agr. 2, 49)

„Wyjawię wam, jaki głęboko utajony podstęp ci (ludzie), jak sądzili, uknuli, by ugodzić w honor Gnejusza Pompejusza".

\subsubsection{Zdania spójnikowe}

Zdania podrzędne spójnikowe charakteryzują się tym, że ich wykładnikiem zespolenia ze zdaniem nadrzędnym jest konektor stanowiony przez spójnik. Konektor ten sygnalizuje relacje syntaktyczne bądź syntaktyczno-semantyczne, w jakie wchodzi zdanie podrzędne ze zdaniem nadrzędnym. Podstawowym kryterium klasyfikacji i typologii zdań podrzędnych spójnikowych jest to, jaki człon syntaktyczny zdania nadrzędnego zastępowany lub rozszerzany jest przez zdanie podrzędne. Na podstawie tego kryterium wyodrębnia się uzupełniające (zastępujące) bądź rozszerzające 
zdania podrzędne: podmiotowe, przydawkowe, dopełnieniowe, orzecznikowe i okolicznikowe. W ramach zdań podrzędnych okolicznikowych dokonuje się podziału z uwzględnieniem kryterium semantycznego, wyodrębniając zdania podrzędne: okolicznikowe celu, skutku, przyczyny, przyzwolenia, czasu, itd. W przypadku, gdy w ramach zdania wielokrotnie złożonego strukturą bezpośrednio nadrzędną dla zdania podrzędnego jest równoważnik zdania (np. accusativus cum infinitivo lub ablativus absolutus), to jeśli zdanie podrzędne zastępuje lub rozszerza funkcjonalny odpowiednik podmiotu bądź orzecznika tego równoważnika, określane jest jako zdanie podrzędne funkcjonalnie podmiotowe bądź funkcjonalnie orzecznikowe.

Podrzędnym (wtórnym, dodatkowym) kryterium klasyfikacji jest obecność/nieobecność forycznego zaimka (lub innego wyrażenia ogólnego o podobnym charakterze), markującego w strukturze syntaktycznej zdania nadrzędnego funkcję składniową, która pełniona jest $\mathrm{w}$ ramach tej struktury przez zdanie podrzędne (np.: Mihi [...] illud molestissimum est, quod solvendi sunt nummi Caesari (Cic., Att. 7, 8, 5) - ,To sprawia mi wielką przykrość, że muszą zostać wypłacone pieniądze Cezarowi”). Obecność tego rodzaju elementu z punktu widzenia funkcjonalnego (pragmatycznego) powoduje zogniskowanie uwagi odbiorcy na zdaniu podrzędnym, do którego odsyła, a w przypadku zdań okolicznikowych również wyeksplikowanie jego funkcji semantycznej (np.: Legum [...] idcirco omnes servi sumus, ut liberi esse possimus (Cic., Cluent. 146) „Po to jesteśmy niewolnikami praw, byśmy mogli być wolni”), zaś z punktu widzenia składniowego pogłębia integrację tego zdania ze zdaniem nadrzędnym. W oparciu o to kryterium wyróżnia się zdania podrzędne rozszerzające, czyli takie, które są kataforyzowane bądź anaforyzowane przez markujący ich pozycję składniową w zdaniu nadrzędnym zaimek foryczny, oraz zdania podrzędne uzupełniające, czyli takie, które nie znajdują zaimkowego korelatu w zdaniu nadrzędnym.

\subsubsection{Zdania podmiotowe}

Zdania podrzędne podmiotowe są funkcjonalnym odpowiednikiem podmiotu zdania nadrzędnego, który konotowany jest przez orzeczenie obligatoryjnie nacechowane wartością 3. os. liczby pojedynczej. Pod względem znaczeniowym zdanie podmiotowe jest wykładnikiem jednego $\mathrm{z}$ argumentów implikowanych przez predykat stanowiący treść (znaczenie) orzeczenia zdania nadrzędnego. Argument, którego językowym wykładnikiem jest podrzędne zdanie podmiotowe, ma status argumentu nieprzedmiotowego (inaczej: propozycjonalnego), a więc takiego, który stanowiony jest przez określoną sytuację (stan rzeczy), a nie przez pojedynczy obiekt, jak w przypadku argumentów przedmiotowych, znajdujących swój językowy wykładnik w postaci rzeczownikowych wyrażeń argumentowych mających status członów syntaktycznych (podmiotu lub dopełnienia).

Wykładnikiem zespolenia spójnikowych zdań podrzędnych podmiotowych są konektory stanowione najczęściej przez spójniki ut lub quod, które pełnią wyłącznie funkcję syntaktyczną. W zdaniach podrzędnych, w których konektorem jest spójnik 
ut, osobowe formy czasowników pełniące funkcję (składników) orzeczeń występują w koniunktiwie (według zasad tzw. consecutio temporum), natomiast w zdaniach, w których rolę konektora pełni spójnik quod, mają zwykle (choć nie zawsze) postać indikatiwu. Oba konektory wprowadzać mogą zarówno zdania o treści niezaprzeczonej, jak i zdania o treści zaprzeczonej, w których wykładnikiem negacji są zaimki przeczące (np.: nihil, nemo, nusquam) lub partykuły (non, ne).

Generalnie wśród zdań podrzędnych podmiotowych można wyróżnić:

a. Zdania uzupełniające (zastępujące), które w strukturze składniowej zdania nadrzędnego wypełniają pozycję gramatycznego podmiotu, otwieraną przez orzeczenie:

Perseape evenit, ut utilitas cum honestate certet. (Cic., Part. 89)

„Często zdarza się, że pożytek stoi w sprzeczności z uczciwością".

Quid, si accedit eodem, ut tenuis ante fueris? (Cic., S. Rosc. 86)

„A co, jeśli dochodzi do tego (jeszcze i to), że byleś ubogi?".

In te positum est, ut nostrae sollicitudinis finem quam primum facere possimus. (Cic., Att. $16,16 \mathrm{~b}, 1)$

„Od ciebie zależy (to), byśmy mogli jak najprędzej polożyć kres naszej trosce".

Fortasse per te stetit, ut iniuriam hic quoque faceret. (Quint., Decl. Min. 250, 8)

"Być może ty przyczyniłeś się do tego, że także on dopuszczał się bezprawia".

Iustitiae primum munus est, ut ne cui quis noceat. (Cic., Off. 1, 20)

„Pierwszym wymogiem sprawiedliwości jest (10), by nikt nie szkodzil komuś drugiemu”.

Accidit perincommode, quod eum nusquam vidisti. (Cic., Att. 1, 17, 2)

„Tak się pechowo zdarzyło, że nigdzie się z nim nie zobaczyłeś”.

Non tam ista me sapientiae $[. .$.$] fama delectat, [.$.$] quam quod amicitiae nostrae memo-$ riam spero sempiternam fore. (Cic., Lael. 15)

"Cieszy mnie nie tyle cala ta sława mędrca, ile raczej (to), że mogę żywić nadzieję, iż pamięć o naszej przyjaźni będzie wieczna".

Eo accedebat, quod iudices e lege Rupilia dati non erant. (Cic., Verr. 2, 2, 42)

„Do tego dochodzilo (jeszcze to), że nie zostali wyznaczeni sędziowie na podstawie ustawy Rupiliusza".

Liberis satis est, quod nati sunt. (Quint., Decl. Min. 330, 5)

"Dzieciom wystarcza (to), że się urodzity".

Quod (Regulus) rediit, nobis nunc mirabile videtur. (Cic., Off. 3, 111)

"(To), że Regulus powrócil, wydaje się nam dziś zadziwiające".

Mirabile videtur, quod non rideat haruspex cum haruspicem viderit. (Cic., Nat. 1, 71)

„Dziwnym się wydaje, że wieszczbiarz nie uśmiecha się na widok (drugiego) wieszczbiarza”. 
b. Zdania rozszerzające, które rozszerzają (eksplikują) podmiot zdania nadrzędnego stanowiony przez (semantycznie pusty) zaimek kataforyczny lub inne wyrażenie ogólne o podobnym charakterze:

(Est) magnificum illud etiam Romanisque hominibus gloriosum, ut Graecis de philosophia litteris non egeant. (Cic., Div. 2, 5)

„Również to (jest) wspaniałe i chwalebne dla Rzymian, że nie potrzebowali greckiej literatury filozoficznej".

Soli $[. .$.$] hoc contingit sapienti, ut nihil faciat invitus. (Cic., Parad. 35)$

„Jedynie udziatem mędrca jest tô, że niczego nie czyni wbrew woli".

Mihi [...] illud molestissimum est, quod solvendi sunt nummi Caesari. (Cic., Att. 7, 8, 5)

„To sprawia mi wielką przykrość, że muszą zostać wypłacone pieniądze Cezarowi”.

Una haec res me torquet, quod non omnibus in rebus [...] Pompeium [...] secutus sim. (Cic., Att. 9, 10, 2)

„Ta jedna rzecz mnie dręczy, że nie we wszystkich sprawach szedlem za Antoniuszem (wspierając go)".

Jeśli zdania podrzędne zastępują lub rozszerzają podmiot zdania głównego, w którym treść predykatywna ma charakter negatywny (zaprzeczony), wprowadzane są za pośrednictwem konektora quin, który także współwyraża negację (w ramach zdania podrzędnego) oraz implikuje orzeczenie w koniunktiwie:

Id fieri non potest, quin sentiant. (Ter., Hec. 397)

„Nie jest możliwe, by stalo się tak, że się nie dowiedzą" (= Nie jest to możliwe, by się nie dowiedzieli).

Plicatricem clementer non potest, quin munerem. (Pl., Mil. 695)

„Nie jest możliwe, bym nie obdarowala uprzejmie garderobianej”.

Ego vero istos [...] libertatis inimicos tantum abest ut ornem, ut effici non possit, quin eos tam oderim, quam rem publicam diligo. (Cic., Phil. 11, 36)

„Do tego stopnia daleki jestem od wychwalania tych wrogów wolności, że nie jest możliwe, bym ich nie nienawidzil tak bardzo, jak bardzo kocham rzeczpospolitą".

Quoniam per eum non stetisset, quin praestaretur. (Liv. 2, 31)

„Ponieważ nie było jego winą to, że nie wywiązano się z zobowiązań”.

Jeśli jednak w zdaniu nadrzędnym negacji podlegają treści, które same w sobie obciążone są negatywnymi konotacjami (zaprzeczać, wątpić, kwestionować, powstrzymywać, przeszkadzać, zwodzić itp.), a więc gdy struktura treściowa zdania nadrzędnego nabiera charakteru zbliżonego do litotes, negacja w zdaniu podrzędnym ulega neutralizacji:

Non dubium est, quin M. Tullius omnium sit eloquentissimus. (Gell., Noc. Att. 17, 13, 2)

„Nie podlega wątpliwości (= jest pewne), że Marek Tulliusz jest najwymowniejszy ze wszystkich". 
Dubitari non potest, quin $[\ldots]$ partes quoque et corporis et animi $[\ldots]$ colantur et per se ipsae appetantur. (Cic., Fin. 5, 37)

„Nie może być przedmiotem wątpliwości (to), iż również części ciala i duszy są szanowane i same przez się pożądane".

Neque [...] dubitari potest, quin artis pars magna contineatur imitatione. (Quint., Inst. $10,2,1)$

"I nie może budzić wątpliwości (to), że znaczna część sztuki opiera się na naśladowaniu".

Neque [...] Caesarem fefellit, quin ab iis cohortibus [...] initium victoriae oriretur. (Caes., Civ. 3, 94)

„I nie zwiodło Cezara (jego przekonanie o tym), że początek zwycięstwa wyjdzie od tych kohort".

Zaprzeczenie treści zdania podrzędnego wymaga w takim przypadka wprowadzenia odrębnego wykładnika negacji:

Hoc haud dubiumst, quin Chremes tibi non det gnatam. (Ter., Andr. 391)

„To nie ulega wątpliwości, że Chremes nie da ci córki (za żonę)”.

Ac ne illud quidem in controversiam venit, quin non omnes in hoc morbo sic curari possint. (Cels., Med. 3, 21, 16)

„I to nawet nie podlega dyskusji, że w przypadku tej choroby nie wszyscy mogą być tak leczeni".

Mihi non est dubium quin (legiones) venturae non sint. (Cic., Fam., 2, 17, 5)

„Dla mnie nie podlega wątpliwości, że (legiony) nie przyjdą".

Do zdań podmiotowych rozszerzających mogą być zaliczane również zdania zależne od zdań nadrzędnych, w których pozycję podmiotu zajmuje rzeczownikowy zaimek przeczący lub antytetyczny o funkcji kataforycznej (chociaż ze względu na swą specyfikę zdania takie mogą być również uznawane za zdania przydawkowe lub orzecznikowe):

In castello nemo fuit $[\ldots]$ militum, quin vulneraretur. (Caes., Civ. 3, 53)

„W strażnicy nie bylo nikogo spośród żołnierzy, kto nie zostałby ranny".

Nemo Lilybaei fuit, quin viderit, nemo in Sicilia, quin audierit. (Cic., Verr. 2, 5, 140)

„Nie było nikogo w Lilibeum, kto by nie widział; nikogo na Sycylii, kto by nie słyszał”.

Quas nationes nemo umquam fuit, quin frangi domarique cuperet. (Cic., Prov. 33)

„Nigdy nie było nikogo, kto by nie chcial, aby te narody zostały pokonane i poskromione”.

Nihil est, quin intereat. (Cic., Nat. 3, 31)

"Nie ma niczego, co nie podlegałoby zniszczeniu”.

Nec quisquam est, quin ita existimet. (Cic., ad Brut. 16, 1)

„I nie ma nikogo, kto nie uważałby w ten sposób”. 
Ten sam typ reprezentują także zdania o postaci pytań retorycznych implikujących negatywną odpowiedź, gdy w zdaniu nadrzędnym miejsce zaimka przeczącego zajmuje zaimek pytajny pełniący funkcję podmiotu:

Ecquis fuit, quin lacrimaret? (Cic., Verr. 2, 5, 121)

"Czy był ktoś, kto nie zapłakal?"

Quis est, quin intellegat? (Cic., Fin. 5, 64)

„Kto jest (taki), że nie rozumie?”

Quis est omnium his moribus, quin divitiis et sumptibus, non probitate neque industria cum maioribus suis contendat? (Sall., Iug. 4, 7)

„Czyż znajdzie się przy dziejszym stanie obyczajów ktoś taki, kto by nie współzawodniczył z przodkami w bogactwie i zbytku, lecz (współzawodniczył) w prawości i pracowitości?"

Podobnie, miejsce dla podrzędnego zdania podmiotowego rozszerzającego otwierają zdania, w których wypełniający pozycję podmiotu rzeczownikowy zaimek przeczący lub antytetyczny stanowi równocześnie, wraz ze spójnikiem nisi, wykładnik presupozucji ('tylko', 'jedynie', 'nic (innego) jak tylko' itp.); konektorem w tego typu zdaniach podrzędnych jest spójnik ut, w związku z czym zdanie podrzędne nie ma charakteru zaprzeczonego:

Relinquebatur Caesari nihil nisi uti equitatu agmen adversariorum male haberet. (Caes., Civ. 1, 63)

„Pozostawalo Cezarowi jedynie nękać oddzial wrogów przy pomocy konnicy”.

Neque quicquam aliud agitur hoc iudicio nisi ut antiquissimi socii et fidelissimi [...] in agros atque in sedes suas revertantur. (Cic., Verr. 2, 3, 228)

"I nie chodzi w tym sądzie o nic innego, jak tylko żeby najdawniejsi i najwierniejsi sprzymierzeńcy powrócili do swych ziem i siedzib".

Neque enim quicquam erat reliquum nisi uti $[\ldots]$ triumphus tibi navalis decerneretur. (Cic., Verr. 2, 5, 67)

„Bo nic już nie pozostało jak tylko to, żeby przyznany ci zostal triumf morski”.

Zaprzeczenie treści zdania podrzędnego wymaga odrębnego wykładnika negacji: Aliud agitur nihil nisi ut eis ne quid desit, quibus satis nihil est. (Cic., S. Rosc. 8)

„Nie chodzi o nic innego, jak tylko (o to), żeby nie brakowało czegoś tym, którzy nigdy nie mają dość".

Z podobnego typu zdaniem podrzędnym podmiotowym rozszerzającym będziemy mieć do czynienia także w przypadku pytań retorycznych implikujących negatywną odpowiedź, gdy w zdaniu nadrzędnym pozycję podmiotu, zamiast zaimka przeczącego, zajmie zaimek pytajny:

Quid restat nisi ut $[\ldots]$ sinatis? (Liv. 5, 53)

„Co pozostaje, jeśli nie to, byście wyrazili zgodę?" 
Quid ergo aliud intellegetur nisi uti ne quae pars naturae neglegatur? (Cic., Fin. 4, 41)

„Cóż zatem innego będzie się (przez to) rozumialo, jeśli nie to, by nie była zaniedbywana żadna część przyrodzonej istoty?".

Zdania podrzędne funkcjonalnie podmiotowe zastępują lub rozszerzają funkcjonalny odpowiednik podmiotu równoważnika zdania (accusativus cum infinitivo); charakteryzują się podobnymi właściwościami jak zdania omówione powyżej:

Doce $[\ldots]$ posse fieri $[\ldots]$, ut qui diu vixit, parum vixerit. (Sen., Lucil. 49, 10)

„Poucz, iż może się zdarzyć, że (ten), kto żył długo, przeżył malo".

Ex quo effici vult Socrates, ut discere nihil aliud sit nisi recordari. (Cic., Tusc. 1, 57)

„Sokrates chce, żeby z tego wynikalo, że uczenie się nie jest niczym innym, jak tylko przypominaniem sobie".

(Philodamus) negavit moris esse Graecorum, ut in convivio virorum accumberent mulieres. (Cic., Verr. 2, 1, 66)

„(Filodamus) stwierdzil, że nie jest whaściwe dla obyczaju greckiego, aby podczas uczty dla mężczyzn zajmowały miejsce przy stole (także) kobiety".

In consilio $[\ldots]$ dixerat $[\ldots]$ fore uti exercitus Caesaris pelleretur. (Caes., Civ. 3, 86)

„Podczas narady wojennej powiedzial, iż stanie się (tak), ze wojsko Cezara zostanie rozpędzone".

Crassus, cum [...] omnium voces audirentur exspectari diutius non oportere quin ad castra iretur, cohortatus suos [...] ad hostium castra contendit. (Caes., Gall. 3, 24)

„Krassus, gdy zewsząd słychać było głosy, iż nie powinno być już dłużej wyczekiwane (to), by ruszyć na obóz, dodawszy swoim otuchy, uderzył na nieprzyjacielski obóz" (= słychać było glosy, iż nie należy dłużej zwlekać z tym, by ruszyć na obóz).

Sic habeto, mi Tiro, neminem esse, qui me amet, quin idem te amet. (Cic., Fam. 16, 4, 4)

„Bądź przekonany, mój Tironie, że nie ma nikogo, kto będąc moim przyjacielem, nie sprzyjałby również tobie".

Non intellegitis nihil aliud agi nisi ut proscriptorum liberi quavis ratione tollantur? (Cic., S. Rosc. 152)

„Nie uważacie, że nie chodzi o nic innego, jak tylko (o to), żeby dzieci proskrybowanych jakimkolwiek sposobem zostaly uśmiercone?"

(Quaerit) reliqui quid esse, nisi ut fortiter moriatur?

„(Zapytuje), ç pozostaje, jeśli nie (to), by dzielnie zniósl śmierć?”

Zdania podrzędne podmiotowe i funkcjonalnie podmiotowe mogą być wprowadzane również za pośrednictwem implikującego (w zdaniu podrzędnym) negację konektora quominus / quo minus, bez względu na zaprzeczenie bądź niezaprzeczenie treści predykatywnej zdania nadrzędnego; orzeczenie zdania podrzędnego występuje wtedy również w koniunktiwie:

Caesar [...] cognovit per Afranium stare, quominus proelio dimicaretur. (Caes., Civ. 1, 41) "Cezar zorientował się, że to z powodu Afraniusza dzieje się tak, że nie dochodzi do bitwy”. 
Precatione res transigitur, per quem populum fiat, quo minus legibus dictis stetur, ut eum [...] luppiter feriat. (Liv. 9, 5)

„Sprawa doprowadzana jest do końca przez zaklęcie, aby Jowisz dotknął ciosem ten naród, $\mathrm{z}$ którego winy dzieje się (to), że zadeklarowana umowa nie jest dotrzymywana".

Legati Tarentini interveniunt denuntiantes [...] per utros stetisset, quo minus discederetur ab armis, adversus eos se pro altris pugnaturos. (Liv. 9, 14)

„Wkraczaja posłańcy z Tarentu, zapowiadając, że która z dwóch stron byłaby winna temu, że nie zaprzestaje się walki, przeciw tej sami się zwrócą, wspierając drugą stronę".

Rhodii [...] adiecerunt [...] per quos stetisset, quo minus belli finis fieret, adversus eos quid sibi faciendum esset, Rhodios consideraturos esse. (Liv. 44, 14)

„Rodyjczycy dodali, że rozważą, co powinni uczynić przeciwko tym, z powodu których doszloby do tego, że nie następuje zakończenie wojny".

Utrisque apparuit nihil per alteros stare, quo minus incepta persequerentur. (Liv. 6, 33)

„Dla obu stron stało się jasne, że od żadnej z nich nie zależy, by plany (drugiej strony) nie były realizowane".

Nec per ipsum (Corvinum) stetit, quo minus laetitiam nitoremque nostrorum temporum exprimeret. (Tac., Dial. 21)

„I nie było jego (tj. Korwina) winą, że nie oddawał (w swych mowach) kwiecistości i blasku (charakterystycznych dla) naszych czasów".

I podobnie jak w przypadku konektora quin, jeśli w zdaniu nadrzędnym (lub równoważniku zdania nadrzędnego) zaprzeczeniu podlegają treści o charakterze negatywnym (zaprzeczać, wątpić, kwestionować, powstrzymywać, przeszkadzać, zwodzić itp.), negacja w zdaniu podrzędnym ulega neutralizacji; por. np.:

Praetor Samnitibus respondit nec, quo minus perpetua cum eis amicitia esset, per populum Romanum stetisse, nec contradici quin [...] amicitia de integro reconcilietur; quod ad Sidicinos attineat, nihil intercedi quo minus Samniti populo pacis bellique liberum arbitrium sit. (Liv. 8, 2)

„Pretor odpowiedział Samnitom, że ani nie zależało od narodu rzymskiego, że przyjaźń z nimi nie była trwała, ani nie wzbudza sprzeciwu (to), aby przyjaźn na nowo zostala przy-

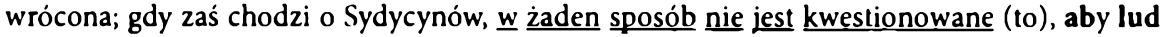
samnicki mial wolny wybór wojny bądź pokoju (z nimi) ".

Jeśli w zdaniu nadrzędnym treść predykatywna nie podlega negacji, zdanie podrzędne podmiotowe może być wprowadzone także za pośrednictwem konektora ne, który w zdaniu tym implikuje negację, nacechowaną modalność i wystąpienie orzeczenia $\mathrm{z}$ czasownikową formą $\mathrm{w}$ koniunktiwie:

Missi legati [...]; denuntiatum est, ne Brutum obsideret. (Cic., Phil. 12, 11)

"Wysłano posłów; (przez nich) oznajmiono, aby nie oblegal Brutusa”.

Senatus consulto cautum est, ne qua bacchanalia Romae neve in Italia essent. (Liv. 39, 18)

„Postanowieniem senatu zostało zastrzeżone, by żadne bakchanalia nie odbywały się w Rzymie, ani w (całej) Italii". 
De reddenda re publica $[\ldots]$ cogitavit $[\ldots]$ memor obiectum sibi $[\ldots]$ quasi per ipsum staret, ne redderetur. (Suet., Aug. 28)

„Zamyślał o przywróceniu ustroju republikańskiego, pomny stawianego mu zarzutu, jakoby z jego winy działo się tak, że nie jest przywracany" (= .. od niego zależało, by nie zostal przywrócony).

Ostenderent prioribus proeliis per duces, non per milites, stetisse, ne vincerent. (Liv. 3, 61)

„Niech pokażă, że w poprzednich bitwach z winy wodzów, a nie żołnierzy, stało się tak, że nie zwyciężali".

Implikujące negację i orzeczenie $\mathrm{z}$ czasownikową formą w koniunktiwie konektory neque (nec) i neve (neu) stosowane są dla wprowadzenia kolejnego zdania podmiotowego, następującego po innym, współrzędnym względem niego, przy czym jeśli zdanie poprzedzające również jest zaprzeczone, używany jest tylko konektor neve (neu):

In primis videndum erit [...], ut suum quisque teneat neque de bonis privatorum publice deminutio fiat. (Cic., Off. 2, 73)

„Przedmiotem troski będzie przede wszystkim (to), aby każdy zachowal swoją własność i żeby z powodu interesu publicznego nie nastąpilo uszczuplenie majątków prywatnych".

Habent legibus sanctum, si quis quid de re publica [...] acceperit, uti ad magistratum deferat neve cum quo alio communicet. (Caes., Gall. 6, 20)

„Jest u nich nakazane prawem, by, jeśli ktoś dowie się czegoś na temat spraw publicznych, doniósł o tym wladzom, i by nie informował o tym nikogo innego".

Additum etiam utrorumque ignominiae est, ne in oppidis hibernarent neve hiberna propius ullam urbem decem milibus passuum aedificarent. (Liv., 26, 1)

„Dla napiętnowania jednych i drugich zostało jeszcze dodane, iż nie wolno im spędzać zimy w miastach ani budować kwater zimowych w odleglości mniejszej niż dziesięć tysięcy kroków od jakiegokolwiek miasta".

Stosunkowo rzadko zdania (funkcjonalnie) podmiotowe wprowadzane są także za pośrednictwem innych jeszcze konektorów, np. si:

Magno sibi usui fore arbitrabatur, si modo insulam adisset, genus hominum perspexisset, loca portus aditus cognovisset. (Caes., Gall. 4, 20)

„Uważal, że (już to) będzie dla niego z wielkim pożytkiem, jeśliby dotarł tylko na wyspę, przyjrzal się (miejscowej) ludności, poznal (tamtejsze) miejscowości, przystanie i wybrzeża dające dostęp do lądu".

\subsubsection{Zdania przydawkowe}

Spójnikowe zdania przydawkowe są odpowiednikami przydawkowych określników rzeczownikowych członów syntaktycznych zdania nadrzędnego, stąd ich składniowymi nadrzędnikami są człony syntaktyczne (części zdania) stanowione przez formy rzeczownikowe. Pod względem znaczeniowym zazwyczaj eksplikują (identyfikują, wyjaśniają) aktualny (kontekstowy) sens swego rzeczownikowgo nadrzędnika 
o ogólniejszym znaczeniu. Wykładnikami ich zespolenia ze zdaniem nadrzędnym są najczęściej spójniki quod i (rzadziej) cum, implikujące zwykle orzeczenie w indikatiwie, oraz spójnik $u t$, otwierający miejsce dla zdania z orzeczeniem (współ)stanowionym przez formę czasownikową w koniunktiwie. Wśród zdań tego typu wyodrębnić można:

a. Zdania uzupełniające:

Sequitur tertia vituperatio senectutis, quod eam carere dicunt voluptatibus. (Cic., Sen. 39) „Dalej następuje trzecia nagana starości, (polegająca na tym,) iż przypisuje się jej brak rozkoszy".

Unum habet adsidua infelicitas bonum, quod quos semper vexat, novissime indurat. (Sen., Dial. 12, 2, 3)

„Długotrwale nieszczęście zawiera $w$ sobie (to) jedno dobro, iż tych, których nieuslannie nęka, ostatecznie wzmacnia".

Fuit quoddam tempus, cum in agris homines passim bestiarum more vagabantur. (Cic., Inv. 1, 2)

„Byl pewien czas, kiedy ludzie wszędzie błąkali się po ziemi jak dzikie zwierzęta”.

De voluntate tua, ut simul simus [...], non dubito. (Cic., Att. 12, 26, 1)

„W twoją chęć, abyśmy byli razem, nie wątpię".

Novitates [...] si spem adferunt, ut [...] fructus appareat, non sunt illae quidem repudiandae. (Cic., Lael. 68)

„Jeśli nowe przyjaźnie dają nadziejç, że przyniosą (dobry) owoc, to nie powinny być one odrzucane".

Fit sermo inter eos, et invitatio, ut Graeco more biberetur. (Cic., Verr. 2, 1, 66)

"Zawiązuje się rozmowa między nimi i (pojawia się) zaproszenię, by pito na sposób grecki”.

\section{b. Zdania rozszerzające:}

Percipietis etiam illam ex cognitione iuris laetitiam et voluptatem, quod, quantum praestiterint nostri maiores prudentia ceteris gentibus, $[\ldots]$ intelegetis. (Cic., De orat. 1, 197)

„Z poznania prawa poczujecie również tẹ radość i przyjemność, że dostrzeżecie, jak bardzo nasi przodkowie przewyższali mądrością inne narody".

Doctorum est ista consuetudo, eaque Graecorum, ut iis ponatur, de quo disputent quamvis subito. (Cic., Lael. 17)

„Uczonych jest ten zuyczaj, i to greckich, ie przedstawia się im (to), o czym mają dyskutować, także bez przygotowania".

Germani $[\ldots]$ eo consilio Rhenum transierant, ut Ambiorigis finis depopularentur. (Caes., Gall. 6, 42)

„Germanie przeprawili sį̧ przez Ren z tym zamiarem, aby splądrować kraj Ambioryksa”.

Jeśli zdanie przydawkowe ma postać pytania zależnego, wprowadzane jest bez konektora: 
rozszerzające:

Illa dubitatio erat, singulaene cohortes an universi ad stipendium petendum irent. (Liv. $28,25)$

"Ta wątpliwość się pojawila, czy po odbiór żoldu mają się udać poszczególne kohorty, czy wszyscy razem".

Wykładnikiem zespolenia zdań podrzędnych przydawkowych może być również konektor quin. Implikuje on orzeczenie w koniunktiwie i negację we wprowadzanym przez siebie zdaniu podrzędnym, a stosowany jest wówczas, gdy rzeczownik określany przez to zdanie także podlega negacji:

Dies fere nullus est, quin hic [...] domum meam ventitet. (Cic., Att. $1,1,3$ )

"Prawie nie ma dnia, żeby nie nachodzil on mego domu”.

De talento nulla causa est, quin feras. (PI., Rud. 1397)

"Co do talentu, (to) nie ma żadnego powodu, byś go nie odebrał".

At controversia non erat, quin verum dicerent. (Cic., Caecin. 31)

"A przecież nie było sporu (dotyczącego tego), że nie mówią prawdy".

Jednak gdy znaczenie negowanego rzeczownika samo w sobie obciążone jest negatywnymi konotacjami (zakaz, przeszkoda, brak, wątpliwość itp.), lub gdy negacja ma charakter (implicytnie) podwójny (np. nie brakować, nie uniknąć, nie powstrzymać, nie poniechać itp.), negacja w zdaniu podrzędnym ulega neutralizacji:

Nec mora ullast, quin eam uxorem ducam. (Ter., Andr. 971)

„I nie ma już żadnej przeszkody, bym poją ją za żonę".

Neque abest suspicio [...], quin ipse sibi mortem consciverit. (Caes., Gall. 1, 4)

„I nie brak podejrzeń, że sam sobie zadal śmierć”.

Nec abstinuit consuetudine, quin [...] singulos valere dicentis appellaret. (Suet., Tib. 72)

„Nie odstąpil od zwyczaju, by (na zakończenie uczty) wymienić imiennie każdego (z gości) wypowiadającego slowa pożegnania".

Negację i orzeczenie w koniunktiwie implikuje również konektor ne, który stosowany może być także wtedy, gdy określany rzeczownik nie jest negowany; konektor ten wprowadza zdanie o nacechowanej modalności, którego treścią jest hipotetyczna sytuacja przyszła:

Gracchus legem tulit, ne de capite civium Romanorum iniussu vestro iudicaretur. (Cic., Rab. Perd. 12)

„Grakchus przeprowadzil ustawę (mającą na celu to), by nie sądzono obywateli rzymskich w sprawach gardlowych bez waszej zgody".

(Scipio) in Literninum concessit certo consilio, ne ad causam dicendam adesset. (Liv. 38, 52)

„Scypion usunąl się do swej posiadłości w Liternum z mocnym postanowieniem, że nie stawi się na rozprawę sądową". 
rozszerzające:

Redeat ad imperatorem suum Varius, sed ea lege, ne umquam Romam revertatur. (Cic., Phil. 8, 32)

„Niech wraca Warius do swego wodza, ale pod tym warunkiem, że nigdy nie wróci do Rzymu".

Cum $[\ldots]$ dextram amplectens in $\underline{i d}$, ne cui Romano traderetur, fidem exposceret $[\ldots]$, amore captivae victor captus [est]. (Liv. 30, 12)

„Kiedy ściskając mu rękę dopraszała się zapewnienia tego, że nie zostanie wydana żadnemu Rzymianinowi, zwycięzca zostal zniewolony miłością do niewolnicy".

W przypadku, gdy zanegowaniu podlega nacechowana modalnie treść zdania przydawkowego następującego po innym, współrzędnym w stosunku do niego, stosowany jest konektor neve (neu):

(Caesar) dat centurionibus negotium, ut $[\ldots]$ ad fodiendos puteos animum conferant, neve quam partem nocturni temporis intermittant. (Ps.-Ceas., Bell. Alex. 9)

„Cezar daje centurionom zadanie, by skupili uwagę na kopaniu studzien, $\mathrm{i}$ by nie zmarnowali nawet najmniejszej części pory nocnej".

Dialecticam [...] (virtutis) nomine appellant [...], quod habeat rationem, ne cui falso adsentiamur neve umquam captiosa probabilitate fallamur. (Cic., Fin. 3, 72)

„Dialektykę określają mianem cnoty, ponieważ opiera się na zaleceniu, byśmy nie zgadzali się na coś nieprawdziwego i byśmy nigdy nie dawali się oszukać pozornemu prawdopodobieństwu".

Jeśli zdanie określa rzeczownik oznaczający niebezpieczeństwo, strach, obawę (przed czymś) itp., to polskim odpowiednikiem takiego zdania może być zarówno struktura zawierającą negację ('obawa, by coś się nie stało'), jak i struktura pozbawiona negacji ('obawa, że coś się stanie'):

Ille quidem semper inpendebit timor ne rex [...] exsistat iniustus. (Cic., Rep. 2, 50)

"Zawsze też zagrażać będzie ta obawa, że król okaże się niesprawiedliwy” ( $=\ldots$ obawa, by król nie okazal się niesprawiedliwy).

Manebat metus, ne quis principum eadem imperitaret. (Tac., Ann. 12, 54)

„Pozostawal strach, íe jakiś (inny) cesarz zażąda tego samego” (= ... strach, by nie zażądał tego samego).

Est enim periculum, ne [...] impia fraude [...] obligemur. (Cic., Div. 1, 70)

„Istnieje bowiem niebezpieczeństwo, że uczynimy się wspólodpowiedzialnymi za zbrodnię bezbożności".

Określany rzeczownik może jednak podlegać negacji, podobnie jak zdanie podrzędne posiadać może dodatkowy wykładnik negacji, co implikuje określone konsekwencje semantyczne:

Neque enim est periculum ne te de re publica disserentem deficiat oratio. (Cic., Rep. $1,37)$ 
„Nie ma bowiem obawy (o to), że w trakcie dysputy o rzeczpospolitej zabraknie ci slów”.

Haud sane periculum est, ne non mortem aut optandam aut certe non timendam putet. (Cic., Tusc. 5, 118)

„Z pewnością nie ma niebezpieczeństwa, ze nie uzna śmierci za pożądaną, albo przynajmniej za taką, której nie należy się bać".

Oprócz zdań przydawkowych o znaczeniu eksplikatywnym wyróżnić można także zdania przydawkowe rezultatywne i porównawcze. Mają one status zdań rozszerzających zaimkowy określnik przydawkowy o funkcji kataforycznej (is, talis, idem). Wprowadzane są konektorem ut, w związku z czym czasownikowa forma (współ)tworząca ich orzeczenia występuje $\mathrm{w}$ koniunktiwie (zgodnie $\mathrm{z}$ zasadami tzw. consecutio temporum):

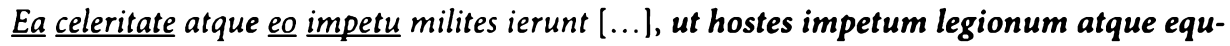
itum sustinere non possent ripasque dimitterent ac se fugae mandarent. (Caes., Gall. 5, 18)

„Z $\underline{\text { takă }}$ szybkością i z takim impetem żołnierze natarli, że nieprzyjaciele nie mogli wytrzymać uderzenia legionów i konnicy, opuszczali brzegi (rzeki) i rzucali się do ucieczki".

Habui filium talem, ut illum amare posset noverca. (Sen., Controv. 9, 6, 1)

„Mialem syna takiego, ze mogla go pokochać macocha".

Qui aliis nocent, ut in alios liberales sint, in eadem sunt iniustitia, ut si in suam rem aliena convertant. (Cic., Off. 1, 42)

„Ci, którzy jednym szkodzą, by wobec innych być szczodrym, wykazują się taka samą niesprawiedlliwością, jak gdyby przywlaszczali sobie cudze mienie".

Amo [...] eodem pacto, ut insani solent. (PI., Merc. 262-263)

„Kocham w taki sam sposób, jak mają zwyczaj [kochać] szaleńcy”.

Status przydawkowych zdań rozszerzających rezultatywnych będą miały również zdania, które stanowią rozszerzenie zaimkowej formy id użytej w pozycji członu nadrzędnego względem rzeczownikowej formy w genetiwie. W ramach tej syntagmy zaimek id, mimo swej składniowej nadrzędności, pełni de facto rolę kataforycznego określnika zależnego od niego rzeczownika w genetiwie, odsyłając do treści zdania podrzędnego, stanowiącej charakterystykę desygnatu tego rzeczownika:

Ad $\underline{i d}$ ventum inopiae est, ut lora detractasque scutis pelles $[\ldots]$ mandere conarentur. (Liv. 23, 19)

„Doszło do takiego niedostatku, że (ludzie) próbowali przeżuwać rzemienie i zdarte z tarcz skóry".

Romanorum nemo id auctoritatis aderat, ut promissa eius magni penderentur. (Tac., Ann. 12, 18)

„Wśród Rzymian nie bylo nikogo o takim autorytecie, by jego obietnice mogly mieć jakieś większe znaczenie". 


\subsubsection{Zdania dopełnieniowe}

Zdania dopełnieniowe $w$ strukturze składniowej zdania nadrzędnego zajmują miejsca dopełnień konotowanych przez czasownikowe wyrażenia predykatywne, a więc wypełniają pozycje otwierane przez czasownikowe wykładniki predykatów dla niepodmiotowych wyrażeń argumentowych. Wyrażenia argumentowe mające postać zdań (dopełnieniowych) są wykładnikami argumentów, które nazywane są argumentami nieprzedmiotowymi lub propozycjonalnymi, w odróżnieniu od argumentów przedmiotowych, których wykładnikami są rzeczownikowe wyrażenia argumentowe mające status członów syntaktycznych (podmiotów lub dopełnień). Tym samym zdania dopełnieniowe, jako wykładniki argumentów nieprzedmiotowych, odsyłają nie do pojedynczego obiektu, lecz do całej sytuacji (stanu rzeczy) jako argumentowego słładnika określonej struktury predykatowo-argumentowej, związanej $\mathrm{z}$ danym wyrażeniem predykatywnym (czasownikiem).

Sytuacje będące treścią zdań dopełnieniowych (czyli wyrażane przez te zdania argumenty nieprzedmiotowe) w większości mają charakter niefaktywny (nacechowany modalnie, hipotetyczny), stanowiąc wyraz (czyjejś) woli, życzenia, przewidywania, obawy, przekonania itp. Cechą charakterystyczną orzeczeń tych zdań jest w związku $\mathrm{z}$ tym osobowa forma czasownika w koniunktiwie (według zasady consecutio temporum). Z kolei czasownikowe wykładniki predykatów implikujących argumenty propozycjonalne, które wyrażane są przez zdania dopełnieniowe, tradycyjnie dzieli się na klasy semantyczne obejmujące leksemy oznaczające m.in.:

a) pytać, prosić, życzyć sobie; żądać, domagać się, nakazywać, polecać, zmuszać, nalegać, np.: rogare, optare, postulare, flagitare, petere, orare, precari, iubere, imperare, praecipere, mandare, cogere, instare itp.;

b) zachęcać, napominać, przestrzegać, pouczać, przekonywać, doradzać, nakłaniać, nalegać, zaklinać, np.: monere, hortari, (per)suadere, obsecrari itp.;

c) zamierzać, starać się, troszczyć się, zabiegać; wystrzegać się, zapobiegać, np.: cogitare, curarre, agere, cavere itp.;

d) bać się, lękać się, obawiać się, np.: timere, metuere, vereri itp.;

e) wątpić, niedowierzać: dubitare;

f) przeszkadzać, sprzeciwiać się, opierać się, zabraniać, odmawiać, powstrzymywać (się), opóźniać, zwlekać, np.: impedire, prohibere, obstare, resistere, deterrere, recusare, reprimere, (se) tenere, (se) continere itp.;

e) pozwalać, dopuszczać, zgadzać się; oczekiwać, np.: sinere, concedere itp.;

f) oświadczać, deklarować, pamiętać, nie wiedzieć, np.: dicere, meminisse, ignorare itp.;

g) wnioskować, sądzić, postanawiać, np.: ferre, censere, statuere, constituere, decernere, edicere itp. 
Zdania dopełnieniowe mogą jednak wyrażać także treści o charakterze rezultatywnym, implikowane przez wyrażenia predykatywne o znaczeniu 'sprawić, dokonać, osiągnąc', np.: agere, facere, efficere, perficere, assequi, adipisci itp.

Poza tym sytuacje będące treścią zdań dopełnieniowych mogą również mieć charakter faktywny, tzn. mogą być ukazywane jako stany rzeczywiste, implikowane przez predykaty typu 'pomijać, ignorować (to, że...)', 'dodawać (to, że ...)', 'cieszyć się (z tego, że...)', 'użalać się (na to, że...)', 'dziwić się (temu, że...)' itp., reprezentowane np. przez czasowniki mittere, praeterire, addere, gaudere, queri, mirari; $z$ tego typu statusem desygnowanych treści wiąże się zwykle użycie orzeczenia $z$ osobową formą czasownika w indikatiwie.

Podstawowym wykładnikiem zespolenia zdań dopełnieniowych ze strukturą składniową zdania nadrzędnego jest konektor stanowiony przez spójnik ut (uti). Implikuje on orzeczenie (współ)tworzone przez osobową formę czasownika w koniunktiwie (według zasad consecutio temporum). Zdania wprowadzane za pośrednictwem tego konektora zwykle wyrażają treści o nacechowanej modalności i najczęściej mają charakter zdań uzupełniających:

Dico, ut a me caveas. (Pl., Pseud. 511)

„Powiadam, byś się strzegł przede mną".

(Apollo) monet, ut se quisque noscat. (Cic., Tusc. 1, 52)

"(Apollon) napomina, aby każdy poznał samego siebie".

Orgetorix [...] persuadet Castico [...], ut regnum in civitate sua occuparet. (Caes., Gall. $1,3)$

„Orgetoryks nakłonil Kastykusa, aby objąl wladzę królewską w swoim plemieniu”.

(Caesar) finitimis imperavit, ut ab iniuria et maleficio se [...] prihiberent. (Caes., Gall. 2, 28)

"(Cezar) nakazal sąsiednim ludom, aby powstrzymali się od (wyrządzania) krzywd i szkód".

Concedo tibi, ut ea praetereas. (Cic., S. Rosc. 54)

„Pozwalam ci, byśs te rzeczy pominą̧".

Nemo exspectet, ut alieno tantum labore sit disertus. (Quint., Inst. 7, 10, 14)

"Niech nikt nie oczekuje, że stanie się wymowny wylącznie dzięki wysilkowi innych ludzi (scil. nauczycieli)".

Senatus $[. .$.$] decernit, uti consules dilectum habeant. (Sall., Cat. 36)$

„Senat uchwala, by konsulowie przeprowadzili pobór do wojska”.

Merui, ut fierem (liber). (Pl., Epid. 712)

„Zaslużylem, aby stać się wolnym czlowiekiem”.

Faciam, ut huius diei [...] semper meminerit. (Pl., Capt. 800)

„Postaram się, by ten dzień na zawsze zapamiętal”. 
Messala [...] perfecit, ut Sex. Roscii vita [...] sententiis iudicum permitteretur. (Cic., S. Rosc. 149)

"Messala sprawil, by życie Sekstusa Roscjusza powierzone zostało wyrokowi sędziów".

Efficere non possum, ut pluris facias eum. (Cic., Brut. 3, 6)

„Nie mogę sprawić, byś wyżej go cenił”.

Konektor quod wprowadza najczęściej zdania dopełnieniowe, których treść ma charakter faktywny, a czasownik (współ)tworzący orzeczenie występuje w indikatiwie:

Quam multi, quod nati sunt, queruntur. (Sen., Benef. 1, 1, 11)

„Jakże liczni użalają się (na to), że się urodzili".

Mitto quod quaedam nullis simulacris significari possunt. (Quint., Inst. 11, 2, 25)

„Pomijam (to), że pewne rzeczy nie mogą być wyrażone za pośrednictwem żadnych obrazów".

Adde metus et quod murus pulsatur ab hoste. (Ov., Pont. 3, 1, 25)

„Dodaj jeszcze strach i (to), że w mury uderzają wrogowie”.

Gaudeo, quod te interpellavi. (Cic., Leg. 3, 1)

"Cieszę się, że ci przerwalem”.

Velim mihi ignoscas, quod ad te scribo tam multa totiens. (Cic., Att. 7, 12, 3)

„Chcialbym, byś mi wybaczył, że tyle razy piszę do ciebie tak długie listy”.

Konektor quod może jednak rozpoczynać również zdania dopełnieniowe $z$ orzeczeniem w koniunktiwie, co zwykle sygnalizuje, iż treść danego zdania lub relacja, w jakiej ukazana ona została w stosunku do treści zdania nadrzędnego, uwzględnia punkt widzenia bądź intencję innego podmiotu niż autor wypowiedzenia (tzw. coniunctivus ex mente aliena):

Socrates accusatus est, quod corrumperet iuventutem. (Quint., Inst. 4, 4, 5)

"Sokrates zostal oskarżony (o to), że (jakoby) deprawował mlodzież".

(Cato) obiecit ut probrum M. Nobiliori, quod is in provinciam poetas duxisset. (Cic., Tusc. $1,3)$

„(Kalon) zarzucił Markowi Nobiliorowi jako coś hańbiącego (to), że zabral on (z sobą) do prowincji poetów".

Retorquet oculos $[\ldots]$ ad hanc urbem [...], quae quidem mihi laetari videtur, quod tantam pestem evomuerit forasque proiecerit. (Cic., Catil. 2, 2)

(O Katylinie) „Zwraca oczy ku temu miastu, które zda mi się cieszyć, iż taką zarazę wyrzucilo ze swych trzewi i wymiotło poza bramy".

Mitto, quod [...] inimicum meum tuum inimicum putaris. (Cic., Fam. 15, 4, 12)

„Pomijam (to), że mojego wroga uznałeś za swojego nieprzyjaciela”.

Konektor ne we wprowadzanym zdaniu podrzędnym implikuje negację jego treści predykatywnej, która charakteryzuje się nacechowaną modalnością i stąd wyra- 
żana jest orzeczeniem (współ)stanowionym przez formę czasownikową w koniunktiwie. Stosowany jest na ogół wówczas, gdy predykat zdania nadrzędnego nie jest zanegowany. Jeśli wprowadzane zdanie jest drugim (lub kolejnym) ze zdań dopełnieniowych, współrzędnych względem siebie, przyjmuje postać neve (neu):

Orat, opsecrat ne Casinam uxorem ducam. (Pl., Cas. 322)

„Prosi, zaklina, bym nie żenil się z Kasiną".

Persuadebo [...] tibi, ne umquam boni viri miserearis. (Sen., Dial. 1, 3, 1)

„Przekonam cię (do tego), że nigdy nie powinieneś litować się nad dobrym człowiekiem”.

Me obsecras amantissime, ne obliviscar vigilare et ut animadvertam, quae fiant. (Cic., Att. $6,1,20)$

„Po przyjacielsku usilnie mnie prosisz, abym nie omieszkał czuwać i abym zwracał uwagę, co się dzieje".

Pompeius suis praedixerat, ut Caesaris impetum exciperent neve se loco moverent. (Caes., Civ. 3, 92)

„Pompejusz nakazal swoim ludziom, aby przyjęli atak Cezara i nie ruszyli się z miejsca”.

Edixit ne quis civem Romanum vinctum aut clausum teneret [...], neu quis militis [...] bona possideret aut venderet. (Liv. 2, 24)

„Zarządzil, by nikt nie przetrzymywał obywatela rzymskiego w kajdanach lub w więzieniu, $i$ by nikt nie przywłaszczal sobie ani nie sprzedawal dóbr żołnierza".

Segni [...] legatos ad Ceasarem miserunt oratum, ne se in hostium numero duceret neve omnium Germanorum [...] unam esse causam iudicaret. (Caes., Gall. 6, 32)

„Segnowie wyslali do Cezara posłów, którzy mieli prosić, by nie zaliczal ich do swoich wrogów, i by nie sądzil, że istnieje wspólny interes wszystkich Germanów".

Konektor ten wprowadza również dopełnieniowe zdania podrzędne, dla których otwierają miejsce wyrażenia predykatywne określane jako verba timendi, a więc czasowniki o znaczeniu 'bać się, lękać się, obawiać się,' itp. (np.: timere, metuere, vereri $\mathrm{i}$ in.), oraz verba impediendi, a więc czasowniki o znaczeniu 'przeszkadzać, sprzeciwiać się, opierać się, zabraniać, odmawiać, powstrzymywać (się)' itp. (np.: impedire, prohibere, obstare, resistere, deterrere, recusare, reprimere, (se) tenere, (se) continere, $\mathrm{i}$ in.).

Treścią wprowadzanych konektorem ne podrzędnych zdań dopełnieniowych, implikowanych przez tzw. verba timendi, jest sytuacja hipotetyczna, ukazana jako obiekt czyjegoś lęku (obawy, strachu) przed jej (realnym) zaistnieniem. Struktury te sygnalizują zatem, iż nie chce się, by stało się to, co jest treścią zdania podrzędnego, lub też inaczej: wyrażają obawę (lęk), że (niestety) stanie się to, co jest treścią zdania podrzędnego. Polskimi odpowiednikami tych zdań mogą być zarówno konstrukcje zawierające negację („Obawiam się, by nie...”), jak i pozbawione negacji („Obawiam się, że..."):

(Lacedaemonii) pertimuerunt, ne (Alcibiades) caritate patriae ductus aliquando ab ipsis descisceret. (Nep., Alc. 5) 
„(Spartanie) przestraszyli się, by (Alkibiades), wiedziony milością do ojczyzny, kiedyś nie odstąpił od nich" (= ... przestraszyli się, że odstąpi ...).

Ne exheredaretur veritus est. (Cic., S. Rosc. 58)

„Bał się, by nie został wydziedziczony” (= Bał się, że zostanie wydziedziczony).

(Caesar) timens ne a multitudine equitum dextrum cornu circumveniretur, celeriter ex tertia acie singulas cohortas detraxit. (Caes., Civ. 3, 89)

„(Cezar) obawiając się, by prawe skrzydło nie zostało okrążone przez wielką liczbę jeźdźców, z trzeciej linii (szyku bojowego) szybko ściągnął po jednej kohorcie (z każdego legionu)" (= ... obawiając się, że zostanie okrążone ...).

Zarówno w zdaniu nadrzędnym, jak i podrzędnym, może pojawić się (dodatkowa) negacja, wnosząc stosowne implikacje znaczeniowe:

Non metuo, Quirites, ne [...] Antonius [...] vertat se et senatui pareat. (Cic., Phil. 6, 9)

„Nie obawiam się (tego), Kwiryci, że Antoniusz raptem się zmieni i będzie posluszny senatowi" (= Nie boję się tego, by się przypadkiem nie zmienil i nie stal się posłuszny = Jestem pewny, że się nie zmieni i że nie będzie posłuszny).

Accepi tuas litteras, quibus intellexi te vereri ne superiores mihi redditae non essent; omnes sunt redditae. (Cic., Fam. 14, 5, 1)

„Otrzymalem twój list, z którego wywnioskowatem, iż żywisz obawę, że poprzednie nie zostały mi doręczone; otóż wszystkie mi doręczono".

Gdy obawa dotyczy tego, że coś (niestety) się nie stanie, zdanie wyrażające pożadaną sytuację wprowadzane jest za pośrednictwem konektora ut (bez dodatkowej negacji):

Omnis labores te excipere video; timeo, ut sustineas. (Cic., Fam. 14, 2, 3)

„Widzę, że podejmujesz się wszelkich zadań; boję się, czy podołasz” (= obawiam się, że nie podolasz).

Por. też:

Ne verendum quidem est, ut (Caesar Octavianus) tenere se possit, ut moderari, ne [...] intemperantius suis opibus utatur. (Cic., Phil. 5, 48)

„Nie należy się obawiać, że (Cezar Oktawian) nie zdoła się pohamować, nie zdoła działać $z$ umiarem, że w sposób nieopanowany nadużyje swej władzy".

Z kolei treścią zdań dopełnieniowych implikowanych przez tzw. verba impediendi jest sytuacja hipotetyczna, ukazana w kontekście czyichś zabiegów (działań, zachowań, decyzji) zmierzających do tego, by nie stała się ona realnym faktem, bądź też w kontekście okoliczności uniemożliwiających jej zaistnienie; w języku polskim tego typu treść wyrażana jest na ogół bez wykładnika negacji, często poprzez formy rzeczownikowe:

Regulus sententiam ne diceret recusavit. (Cic., Off. 3, 100)

„Regulus odmówil wypowiedzenia swej opinii”. 
Continuo me ne incognito assentiar. (Cic., Acad. 2, 133)

„Powstrzymuję się od wyrażania zgody na coś, czego nie znam”.

Plura ne dicam tuae me [...] lacrimae impediunt. (Cic., Planc. 104)

„Przed tym, bym mówil dalej, powstrzymują mnie twoje tzy".

Konektor quin stosowany jest wówczas, gdy treść predykatywna zdania nadrzędnego podlega zaprzeczeniu lub jest nacechowana negatywnie. We wprowadzanym zdaniu podrzędnym również implikuje negację oraz orzeczenie (współ)stanowione przez fomę czasownikową w koniunktiwie:

(Tiberius) optinere non potuit, quin rata voluntas legatoris esset. (Suet., Tib. 31)

"(Tyberiusz) nie mógl uzyskać (tego), by wola spododawcy nie była obowiązująca".

Facere non possum, quin cotidie ad te mittam. (Cic., Att. 12, 27, 2)

„Nie mogę sprawić (tego), bym nie wysyłał ci codziennie listu”.

Miles hic non potuit pati, quin se armatus bestiae offerret. (Ps.-Caes., Bell. Afr. 84)

„Żolnierz ten nie mógl zaakceptować (tego), by nie rzucić się z bronią na dzikie zwierzę”.

Jeśli jednak w zdaniu podrzędnym negacja wyrażona jest poprzez zaimek przeczący, który nie jest jedynie wykładnikiem negacji (jak np. nihil utor '(w ogóle) nie używam'), lecz stanowi człon syntaktyczny, zdanie to wprowadzane jest za pośrednictwem konektora $u t$ :

Ut nihil ad te dem litterarum, facere non possum. (Cic, Att. 8, 14, 1)

„Nie mogę sprawić, by nie wysłać ci żadnego listu”.

Jeśli zaprzeczeniu podlega wyrażenie predykatywne, które samo w sobie ma charakter negatywny, negacja $\mathrm{w}$ zdaniu podrzędnym rozpoczynanym konektorem quin ulega neutralizacji:

Legatus $[\ldots]$ respondit $[\ldots]$ negare non posse, quin rectius sit etiam ad pacatos barbaros [...] exercitum mitti. (Liv. 40, 36)

„Legat odpowiedzial, iż nie może zaprzeczyć, że słuszniej jest wyslać wojsko do barbarzyńskiego kraju, nawet wówczas, gdy został on już ujarzmiony".

Zaprzeczenie wyrażenia predykatywnego o negatywnym znaczeniu w zdaniu nadrzędnym może mieć również formę implicytną, tzn. może mieć charakter pragmatyczny i przyjąć postać pytania retorycznego implikującego negatywną odpowiedź:

Quis ignorat [...], quin tria Graecorum genera sint vere? (Cic., Flacc. 64)

„Któż nie wie, że tak naprawdę trzy są greckie plemiona?" (= Nie ma nikogo, kto by nie wiedzial ...).

Podobnie jak ne, również konektor quin wprowadzać może zdania implikowane przez tzw. verba impediendi, jednak ma to miejsce w przypadku, gdy ten typ wyrażeń predykatywnych podlega w zdaniu nadrzędnym negacji: 
Quin loquar $[\ldots]$ numquam $[\ldots]$ me potes deterrere. (Pl., Amph. 559-560)

„Nigdy nie zdołasz mnie powstrzymać przed mówieniem”.

Germani retineri non poterant, quin in nostros tela conicerent. (Caes., Gall. 1, 47)

„Germanów nie można było powstrzymać przed obrzucaniem naszych (żołnierzy) pociskami".

Quoniam contra omnes [...] dicere, quae videntur, solemus, non possumus, quin alii a nobis dissentiant, recusare. (Cic., Lucull. 7)

„Ponieważ często przeciwstawiamy się innym, mówiąc, co uważamy za słuszne, nie możemy sprzeciwiać się temu, by inni (też) byli innego zdania niż my".

Testis $[\ldots]$ tergum laceratum virgis ostendit nihilum deprecans, quin $[\ldots]$ privatus (Oppius) iterum in se saeviret. (Liv. 3,58 )

„Swiadek odsłonił plecy pocięte rózgami, nie wzbraniając się (przed tym), by jako czlowiek prywatny (Oppiusz) powtórnie wymierzyl mu karę".

Negacja w zdaniu nadrzędnym może też mieć charakter implicytny, przyjmując postać pytania retorycznego implikującego odpowiedź negatywną:

Caesar [...] poteritne se tenere, quin D. Bruti sanguine poenas patrias persequatur? (Cic., Phil. 13, 46)

„Czy Cezar (Oktawian) będzie mógl się powstrzymać od pomszczenia krwią Decymusa Brutusa krzywd wyrządzonych ojcu?" (= Przecież Cezar nie będzie mógł się powstrzymać...).

Si sua voluntate tot socios reliquit hostibus deripiendos, qui recusare potest, quin et socii sibi consulant? (Liv. 32, 21)

„Jeśli $z$ własnej woli tylu sprzymierzeńców pozostawil na lup wrogom, to jak może sprzeciwiać się temu, by i sprzymierzeńcy sami zatroszczyli się o siebie?" (= . . to przecież nie może się sprzeciwiać temu, by ...).

Rzadko konektor ten wprowadza zdanie podrzędne, gdy verba impediendi $\mathrm{w}$ zdaniu nadrzędnym nie podlegają negacji:

Veranius [...], quin ultra bellum proferret, morte prohibitus est. (Tac., Ann. 14, 29)

„Weraniusza przed dalszym rozwijaniem działań wojennych powstrzymała śmierć”.

Konektor quin wprowadza również zdania dopełnieniowe implikowane przez czasownik dubitare w znaczeniu 'wątpić, powątpiewać". Chociaż znaczenie to zawiera w sobie implicytną negację ('przypuszczać, że nie'), to jednak konektor quin używany jest do wprowadzania zdań podrzędnych głównie wówczas, gdy czasownik ten podlega dodatkowo negacji. Zdania podrzędne implikowane przez najbliższy polski odpowiednik tego wyrażenia predykatywnego ('wątpić (w to), że ...') nie wymagają obecności wykładnika negacji. Negacja czasownika dubitare w zdaniu nadrzędnym może mieć charakter: 
a. eksplicytny, np.:

Illi non dubitant, quin ea vera sint, quae defendunt. (Cic., Lucull. 8)

„Tamci nie wątpią ( $w$ to), że prawdziwe są te rzeczy, których bronią".

Non dubitavi, quin tibi notissima et iura et merita populorum essent. (Cic., Fam. 13, 28a, 1)

"Nie wątpiłem, że doskonale znane ci są zarówno prawa, jak i zasługi narodów".

Neque dubitare debeant, quin [...] Romani una cum reliqua Gallia Haeduis libertatem sint erepturi. (Caes., Gall. 1, 17)

„I nie powinni wątpić, że Rzymianie wraz $z$ resztą Galii (również) Eduów pozbawią wolności".

Non $[\ldots]$ dubito, quin tibi ingenio praestiterit nemo. (Cic., Rep. 1, 37)

„Nie wątpię, że talentem nikt cię nie przewyższył”.

b. implicytny (pragmatyczny), najczęściej w postaci pytania retorycznego zakładającego odpowiedź negatywną, np.:

Si $[\ldots]$ senex anum praegnantem fortuito fecerit, quid dubitas, quin sit paratum nomen puero Postumus? (Pl., Aul. 163-164)

„Jeśli starzec spłodzi dziecko z żoną w starszym wieku, to jak możesz wątpić, że z góry znane jest już imię dziecka: Pogrobowiec?"

An dubitamus, quin nefario facinore admisso Romani iam ad nos interficiendos concurrant? (Caes., Gall. 7, 38)

„Czy wątpimy (jeszcze) w to, że dopuściwszy się (tej) niegodziwej zbrodni Rzymianie śpieszą już, by i nas pomordować?"

Habes somnum, imaginem mortis, eamque cotidie induis: et dubitas, quin sensus in morte nullus est, cum in eius simulacro videas esse nullum sensum? (Cic., Tusc. 92)

„Oto masz sen, obraz śmierci, i codziennie weń zapadasz: i wątpisz (jeszcze), że w śmierci nie ma żadnego czucia, chociaż widzisz, że nie ma go w tym, co jest jej podobizną?"

Dubita, si potes, quin ille, seu victus seu victor redierit, caedem facturus sit. (Cic., Att. 10, $10,5)$

„Powątpiewaj w to, jeśli potrafisz, że ów, czy to jako pokonany, czy jako zwycięzca, dokona rzezi" (= Ja nie wątpię (jestem pewien), że dokona).

Specyficznym kontekstem, w którym konektor quin wprowadza zdanie podrzędne dopełnieniowe, jest nadrzędna struktura zdaniowa $z$ wyrażeniem predykatywnym stanowionym przez czasownik abesse w 3. os. sing. oraz wyrażeniem kwantytatywnym typu: minimum, non/haud/nec multum, paulum, haud procul wypełniającym pozycję podmiotu. Struktura tego rodzaju pozwala na ukazanie sytuacji będącej treścią zdania podrzędnego jako stanu potencjalnego, bliskiego realizacji, ostatecznie jednak nie zaktualizowanego; $w$ języku polskim odpowiadają jej wyrażenia typu 'mało brakowało, by..., 'niemal (doszło do tego, iż)...' itp.:

Neque multum afuit, quin etiam castris [hostes] expellerentur. (Caes., Civ. 2, 35)

"I niewiele brakowalo, by nieprzyjaciele zostali wypędzeni nawet $z$ (ich) obozu". 
Non multum afuit, quin a Bructero quodam occideretur. (Suet., Tib. 19)

„Niewiele brakowalo, by zginął z ręki jakiegoś Bruktera”.

Titi Livii scripta et imagines paulum afuit, quin ex omnibus bibliothecis amoveret. (Suet., Cal. 34)

„Pism i wizerunków Tytusa Liwiusza omal nie usunąl ze wszystkich bibliotek”.

Minimum afuit, quin periret. (Suet., Aug. 14)

"Niemal zginą̧".

Legatos nostros haud procul afuit, quin violarent. (Liv. 5,4 )

„Mało brakowało, by dopuścili się gwaltu na naszych posłach".

Bliskość aktualizacji sytuacji będącej treścią zdania podrzędnego może zostać zasygnalizowana również poprzez ulokowanie $\mathrm{w}$ pozycji podmiotu zaimka pytajnego i nadanie zdaniu statusu pytania retorycznego implikującego negatywną odpowiedź:

Si $[\ldots]$ nunc sub umbra foederis aequi servitutem pati possumus, quid abest, quin [...] non Romanorum solum, sed Samnitium quoque dicto pareamus? (Liv. 8, 4)

"Jeśli teraz pod pozorem przymierza opartego na równości godzimy się znosić niewolę, to co jeszcze brakuje (do tego), byśmy gotowi byli słuchać rozkazów nie tylko Rzymian, ale i Samnitów?"

Jeśli pozycję podmiotu wypełnia wyrażenie kwantytatywne o znaczeniu przeciwnym do wyżej wskazanych, głównie tantum, mamy do czynieniena z sygnalizowaniem, iż sytuacja będąca treścią zdania podrzędnego daleka jest od aktualizacji, a zdanie to wprowadzane jest wówczas za pośrednictwem konektora $u t$ :

Tantum abest, ut inflammares nostros animos. (Quint., Inst. 11, 3, 155)

"Wiele brakuje, byś rozpalit nasze emocje”.

Tantum afuit ab eo, ut ulla ignominia iis exercitibus quaereretur, ut [...] Caudinae legiones, quae sine armis redierant Romam, armatae remissae [sint] in Samnium. (Liv. 25, 6)

„Tak daleko było do tego, by próbowano zarzucić tym wojskom jakąkolwiek hańbę, że legiony, które spod Kaudium wrócily do Rzymu bez broni, uzbrojono i ponownie wysłano do Samnium".

Dopełnieniowe zdania podrzędne $z$ orzeczeniem (współ)stanowionym przez czasownikową formę w koniunktiwie wprowadzać może także konektor quominus (quo minus). Jego podstawowym kontekstem są wyrażenia predykatywne z grupy tzw. verba impediendi, bez względu na to, czy podlegają one zanegowaniu w zdaniu nadrzędnym, czy nie. W związku z tym konektor ten może rozpoczynać zdanie podrzędne, gdy:

a. wyrażenie predykatywne w zdaniu nadrzędnym nie podlega negacji, a więc w kontekście analogicznym do tego, w którym stsosowany jest także konektor ne: 
Impedior $[\ldots]$ religione, quominus exponam, quam multa P. Sestius $[\ldots]$ ad me detulerit. (Cic., Sest. 8)

„Lęk przed bogami powstrzymuje mnie (przed tym), bym ujawnil, ile informacji przekazal mi Publiusz Sestiusz".

Nox atque praeda castrorum hostis, quo minus victoria uterentur, remorata sunt. (Sall., lug. 38)

„Noc i grabież obozu powstrzymały nieprzyjaciół przed (pełnym) wyzyskaniem zwycięstwa”.

Ad te voluimus $[\ldots]$ confugere, sed custodiis equitum Numidarum, quo id sine periculo minus faceremus, impediebamur. (Ps.-Caes., Bell. Afr. 35)

„Chcieliśmy do ciebie zbiec, jednak straże numidyjskiej konnicy nie pozwalały nam (na to), byśmy mogli to uczynić bez ryzyka".

Caesar $[\ldots]$ ad $T$. Sextium legatum $[\ldots]$ misit, ut $[\ldots]$ nostros $[\ldots]$ quominus libere hostes insequerentur, terreret. (Caes., Gall. 7, 49)

„Cezar wysłal do legata Tytusa Sekstiusza (rozkaz), aby odstraszal nieprzyjaciół od swobodnego pościgu za naszymi (żołnierzami)".

b. wyrażenie predykatywne $\mathrm{w}$ zdaniu nadrzędnym podlega negacji, a więc $\mathrm{w}$ kontekście analogicznym do tego, w którym stsosowany jest także konektor quin:

Vellem tua te occupatio non impedisset, quo minus [...] ad me, quid ageretur [...], perscriberes. (Cic., Att. 3, 22, 1)

„Chciałbym, by twoje zajęcia nie przeszkodzily ci ( $w$ tym), byś w twoich listach relacjonował $\mathrm{mi}$, co się dzieje".

Quo minus (Antonius) mihi inimicissimus sit, non recusabo. (Cic., Phil. 1, 27)

„Nie będę wzbraniał się (przed tym), by (Antoniusz) był moim największym wrogiem”.

(Caligula) canendi [...] voluptate ita efferebatur, ut ne publicis quidem spectaculis temperaret, quo minus tragoedo pronuntianti concineret. (Suet., Cal., 54)

„(Kaligula) tak bardzo pałał chęcią śpiewania, że nawet $w$ czasie publicznych widowisk nie mógl się powstrzymać przed wtórowaniem śpiewem recytującemu aktorowi tragicznemu".

Nihil obstat quominus et sapientia bonum sit et habere sapientiam. (Sen., Lucil. 117, 15)

„Nic nie przeszkadza, by zarówno mądrość była czymś dobrym, jak i posiadanie mądrości”.

Generalnie wśród zdań podrzędnych dopełnieniowych stosunkowo rzadko spotykane są zdania rozszerzające:

Illud te, mi Lucili, rogo atque hortor, ut philosophiam in praecordia ima demittas. (Sen., Lucil. 20, 1)

„Q $\underline{\text { to }}$ cię, mój Lucyliuszu, proszę i ( $\underline{\text { do }}$ tego) zachęcam, abyś filozofię wziął sobie glęboko do serca".

Hoc scio, quod scribit nulla puella tibi. (Mart. Epigr. 11, 64, 2)

„To wiem, że żadna dziewczyna nie pisze do ciebie."

Hoc te primum rogo, ne contrahas animum neve te obrui magnitudine negotii sinas. (Cic., Q.fr. 1, 1, 4) 
„Przede wszystkim proszę cię o to byś nie upadal na duchu i byś nie pozwolil się przygnieść ciężarem obowiązków".

Illud cave dubites, quin ego omnia faciam. (Cic., Fam. 5, 20, 6)

"Nie miej żadnych wątpliwości co do tego że ja zajmę się wszystkm”.

Naves [...] longas duodetriginta invenit instructas neque multum abesse ab $\underline{\text { eo, }}$ quin paucis diebus deduci possint. (Caes., Gall. 5, 2)

„Dowiaduje się, że zbudowano dwadzieścia osiem okrętów wojennych, i że niewiele już brakuje do tego, by w ciągu kilku dni moghy one zostać spuszczone na wodę".

\section{Rozszerzające dopełnieniowy zaimek o funkcji anaforycznej:}

Ne exstinctor patriae, ne proditor, ne hostis appelletur [...], id laborat, id metuit. (Cic., Sull. 88)

„By nie zostać nazwany grabarzem ojczyzny, jej zdrajcą, wrogiem - tym się dręczy, tego się boi".

Specyficzną odmianę zdań tego typu implikują nadrzędne struktury zdaniowe, w których pozycję dopełnienia zajmuje zaimek przeczący lub antytetyczny nihill quicquam (aliud), po którym następuje spójnik nisi; struktura taka nabiera charakteru wykładnika presupozycji ('nic (innego) jak tylko (to, że/by)' ...), odsyłającego do zdania podrzędnego:

Nihil aliud adsequeris, nisi ut ab omnibus mortalibus audacia tua cognoscatur et impudentia (Cic., S. Rosc. 95)

„Nie osiągniesz nic innego jak tylko (to), że przez wszystkich ludzi rozpoznane zostanie twoje zuchwalstwo i bezwstyd".

Matres [...] nihil aliud orabant, nisi ut filiorum suorum postremum spiritum ore excipere liceret. (Cic., Verr. 2, 5, 118)

„Matki nie blagaty o nic innego jak tylko o to, by wolno (im) było poczuć na ustach ostatni oddech ich synów".

Cum ille mihi nihil nisi ut iurarem permitteret, magna voce iuravi verissimum pulcherrimumque ius iurandum. (Cic., Fam. 5, 2, 7)

„Gdy on pozwolił mi jedynie na to, bym przysiągł, złożyłem najbardziej prawdziwą i najpiękniejszą przysięgę".

Neque nostrae disputationes quicquam aliud agunt, nisi ut in utramque partem dicendo et audiendo eliciant [...] aliquid, quod aut verum sit, aut ad id quam proxime accedat. (Cic., Lucull. 7)

„Nasze dysputy nie sprawiają niczego innego jak tylko to, że poprzez wyrażanie i wysluchiwanie argumentów za i przeciw wydobywają na jaw coś, co albo jest prawdą, albo jak najbardziej się do niej zbliża".

Nec quicquam aliud in hac epulatione captabant, nisi tantum ne esurirent. (Petron., Sat. $141,10)$

„Z tego ucztowania nie zyskiwali nic innego jak tylko to, że nie cierpieli tak bardzo glodu”. 
Z podobnego typu zdaniem dopełnieniowym rozszerzającym będziemy mieć do czynienia także w przypadku pytań retorycznych implikujących odpowiedź negatywną, gdy w zdaniu nadrzędnym pozycję dopełnienia, zamiast zaimka przeczącego lub antytetycznego, zajmie zaimek pytajny:

Quid egit aliud, nisi ut paene corpore suo Gallia prohiberet Antonium? (Cic., Phil. 6, 9) „Cóż uczynił innego jak nie to, że niemal własnym ciałem osłonil Galię przez Antoniuszem?”

\subsubsection{Zdania orzecznikowe}

Spójnikowe zdania orzecznikowe spotykane są stosunkowo rzadko. Zwykle mają one charakter zdań rozszerzających, implikowanych przez zajmujący pozycję orzecznika zaimek (is, talis, tantus) o funkcji kataforycznej. Wykładnikiem zespolenia jest najczęściej konektor $u t$, a orzeczenie (współ)konstytuowane jest przez formę czasownikową w koniunktiwie:

Neque enim is es, Catilina, ut te [...] pudor a turpitudine [...] revocarit. (Cic., Catil. 1, 22) „Nie jesteś bowiem, Katylino, taki, by poczucie wstydu mogło cię odwieść od dopuszczenia się podłości".

Eloquentia [...] sit talis, ut res potius quam se ostendat. (Sen., Lucil. 75,5$)$

„Sztuka wymowy niech będzie taka, by ukazywała raczej rzeczy (o których się mówi) niż siebie sama".

Cuius [scil. testamenti patris] vis non est ea, ut quaeratur, quae professio ex nostris speciosissima [...], sed quae civitati sit utilissima. (Quint., Decl. Min. 268, 1)

„Istota testamentu ojca nie jest taka ( $=$ nie polega na tym), by ustalono, która $z$ naszych profesji jest najpiękniejsza, lecz (by ustalono), która jest najbardziej użyteczna społeczeństwu".

Ea tempora nostra sunt, ut ego iis mederi non possim. (Cic., Att. 10, 11, 1)

„Nasze czasy są takię, że nic na nie nie mogę poradzić".

Podobnie rzadkie są spójnikowe zdania funkcjonalnie orzecznikowe. One także mają na ogół charakter zdań rozszerzających, a więc takich, które eksplikują semantycznie pusty zaimek kataforyczny zajmujący pozycję funkcjonalnego odpowiednika orzeczenia, najczęściej w równoważniku zdania typu accusativus cum infinitivo:

Ad te $[\ldots]$ pertinet esse te talem ut tuas laudes obscuratura nulla umquam sit oblivio. (Cic., Marcell. 30)

„Twoją sprawą jest być takim, żeby twoich zasług nigdy nie przysłoniło żadne zapomnienie”.

Tales [...] nos esse putamus, ut iure laudemur. (Cic., Off. 1, 91)

„Uważamy, iż jesteśmy tacy, że słusznie nas chwalą". 


\subsubsection{Zdania okolicznikowe}

Zdania okolicznikowe to zdania, które nie są implikowane przez żaden ze składników (równoważnika) zdania nadrzędnego, a więc nie stanowią wykładnika żadnego (przedmiotowego) argumentu treści predykatywnej wyrażanej w zdaniu nadrzędnym.W strukturze tego zdania zajmują miejsce okoliczników, stanowiąc ich propozycjonalne (zdaniowe) odpowiedniki. Podobnie jak one mają zatem status składników zdaniowych adiunktywnych, czyli przyłączanych fakultatywnie do struktury zdania nadrzędnego. Jednak mimo tego, że pod względem znaczeniowym ich związek ze zdaniem nadrzędnym jest mniej ścisły niż w przypadku zdań podmiotowych czy dopełnieniowych, charakteryzuje je brak pełnej autonomii syntaktycznej i semantycznej. Podstawowymi wykładnikami ich nieautonomiczności są konektory, które w większości przypadków sygnalizują podrzędność zarówno syntaktyczną, jak i semantyczną tych zdań, ukazując ich treść w określonej perspektywie treści zdania nadrzędnego. Konektory te stanowione są przez spójniki, z których jedne (np. quia, quamquam, postquam) są jednoznaczne, i tym samym identyfikują ową perspektywę systemowo, inne (np. ut, cum) cechują się wieloznacznością, w związku z tym charakter związku semantycznego, w jakim pozostaje treść zdania podrzędnego w stosunku do treści zdania nadrzędnego, identyfikują przy współudziale (kooperacji) kontekstu. Oprócz konektorów formalnym wykładnikiem podrzędności składniowo-semantycznej zdań okolicznikowych jest także nacechowana wartość kategorii trybu formy czasownikowej (współ)tworzącej ich orzeczenie.

Tradycyjna klasyfikacja zdań okolicznikowych, podobnie jak w przypadku systematyki okoliczników zdania pojedynczego, opiera się na kryterium znaczeniowym. Kryterium to zastosowane zostało również w niniejszym opracowaniu, jednak należy zaznaczyć, że wydzielone w oparciu o nie podstawowe typy zdań, tj. zdania okolicznikowe: celu, skutku, przyczyny, przyzwolenia, czasu, warunku i porównania, nie w pełni odpowiadają całej różnorodności zdań tego rodzaju i zróżnicowaniu stosunków znaczeniowych, jakie łączą je ze zdaniami nadrzędnymi. W pewnym przynajmniej zakresie systematyka ta ma więc charakter umowny czy uproszczony.

\subsection{Zdania okolicznikowe celu}

Treścią zdań podrzędnych okolicznikowych celu (zdań celowych) jest hipotetyczny stan rzeczy, który ukazywany jest jako przedmiot intencji (któregoś z) uczestników sytuacji, będącej treścią zdania nadrzędnego lub jego równoważnika (np. Marek wyjechat do Warszawy, aby odwiedzić kuzyna), albo jako przedmiot intencji związanej $\mathbf{z}$ wyrażoną w zdaniu nadrzędnym treścią o nacechowanej modalności deontycznej (np. Należy ograniczyć dostęp prywatnych samochodów do centrum miasta, aby zachęcić mieszkańców do bardziej powszechnego korzystania z transportu publicznego) lub intencjonalnej (np. Ograniczcie dostęp prywatnych samochodów do centrum miasta, 
aby zachęcić mieszkańców do bardziej powszechnego korzystania $z$ transportu publicznego!). Zdania celowe zajmują zwykle pozycję okoliczników określających wyrażenie predykatywne (orzeczenie) zdania nadrzędnego. Orzeczenie zdania podrzędnego okolicznikowego celu (współ)stanowi osobowa forma czasownika w koniunktiwie według zasady tzw. consecutio temporum. Ponieważ hipotetyczny stan rzeczy, będący przedmiotem intencji, czyli cel, ma zawsze charakter następczy, to ze wspomnianej zasady wynika, iż jeśli treść wyrażona w zdaniu nadrzędnym osadzona jest w teraźniejszości lub przyszłości, czasownikowa forma orzeczenia zdania celowego przyjmuje wartość coniunctivi praesentis, jeśli natomiast osadzona jest w przeszłości, przyjmuje wartość coniunctivi imperfecti.

Podstawowym konektorem wprowadzający zdania celowe jest spójnik ut/uti 'aby', 'ażeby', 'żeby', 'by':

Ego eo intro, ut quae opu' sunt parentur. (Ter., Adelph. 706)

"Idę do domu, by przygotowane zostało wszystko, co trzeba".

(Hostes) crebro [...], ut sint auxilio suis, subsistunt. (Caes., Civ. 1, 80)

„(Nieprzyjaciele) często przystają, by nieść pomoc swoim (towarzyszom walki)”.

Maiores nostri ab aratro adduxerunt Cincinnatum illum, ut dictator esset. (Cic., Fin. 2, 12)

„Przodkowie nasi wprost od pługa przywolali owego Cyncynnata, aby został dyktatorem”.

Milites equitesque in expeditionem misit, ut eos, qui fugerant, persequerentur. (Caes., Gall. $5,10)$

„Żołnierzy (piechoty) i jeźdźców wysłał na wyprawę, by ścigali tych, którzy uciekli”.

Należy jednak pamiętać, że osadzenie w przeszłości sytuacji, będącej treścią zdania nadrzędnego, może sygnalizować także pełniące funkcję orzeczenia wyrażenie predykatywne, ukonstytuowane przez formę czasownikową w czasie teraźniejszym (tzw. praesens historicum), co ma miejsce szczególnie często w tekstach o charakterze narratywnym:

Sp. Oppius, ut auxilio collegae esset, in forum ex altera parte inrumpit. (Liv. 3, 49) „Spuriusz Oppiusz, by przyjść z pomocą koledze, wdarł się na forum z drugiej strony”.

Podobnie sytuację odnoszącą się do teraźniejszości wyrażać może forma czasownikowa w perfectum, oznaczając stan aktualny w momencie komunikowania, będący rezultatem zajścia desygnowanej czynności (procesu, zdarzenia itp.):

Veni, ut auxilium feram. (Pl., Amph. 870)

„Przybyłem, by nieść pomoc".

Konektorem wprowadzającym zdania podrzędne celowe może też być spójnik quo 'aby (przez to)', który stosowany jest najczęściej (choć nie wyłącznie) w kontekście form stopnia wyższego przymiotników lub przysłówków: 
Caesar, quo facilius equitatum Pompeianum ad Dyrrachium contineret et pabulatione prohiberet, aditus [...] magnis operibus praemunivit castellaque his locis posuit. (Caes., Civ. 3, 58)

„Cezar, aby latwiej mógł pod Dyrrachium zamknąć konnicę Pompejusza i odciąć ją od zaopatrzenia w paszę, silnymi umocnieniami otoczył dojścia (do miejsca jej stacjonowania) i postawil tam strażnice".

Saga sumi dixi placere, quo omnes acrius graviusque incumberent ad ulciscendas rei publicae iniurias. (Cic., Phil. 6, 2)

„Powiedziałem, że jest rzeczą wlaściwą przywdzianie żołnierskich plaszczy, aby przez to wszyscy energiczniej i z większą determinacją starali się o pomszczenie krzywd wyrządzonych rzeczpospolitej".

L. Sulla exercitum [...], quo sibi fidum faceret, [...] luxuriose nimisque liberaliter habuerat. (Sall., Cat. 11)

„Lucjusz Sulla pozwalał na wszelki przepych i traktował wojsko nazbyt wspaniałomyślnie, by uczynić je sobie wiernym".

Zdania celowe wprowadzane są również za pośrednictwem implikujących negację konektorów: ne, quin, quominus / quo minus 'aby nie'; konektor ne stosowany jest głównie wówczas, gdy predykat zdania nadrzędnego nie jest negowany, konektor quin, gdy predykat ten podlega negacji, natomiast konektor quominus (quo minus) używany jest bez względu na negację bądź brak negacji treści predykatywnej zdania nadrzędnego:

Suum quisque igitur noscat ingenium acremque se et bonorum et vitiorum suorum iudicem praebeat, ne scaenici plus quam nos videantur habere prudentiae. (Cic., Off. 1, 114)

„Niech zatem każdy pozna swój charakler i stanie się surowym sędzią swoich zalet i wad, aby aktorzy nie wydawali się mądrzejszymi od nas".

Apud maiores $[\ldots]$ cunctis $[\ldots]$ civium $[\ldots]$ licitum petere magistratus, ac ne aetas quidem distinguebatur, quin prima iuventa consulatum [...] inirent. (Tac., Ann. 11, 22)

„U (naszych) przodków wszystkim obywatelom wolno było ubiegać się o urzędy, i nie wyróżnianiano nawet (jakiegoś) wieku ( $w$ tym celu), aby nie obejmowali (oni) urzędu konsula (już) we wczesnej młodości".

Edixit ne quis civem Romanum vinctum aut clausum teneret, quo minus ei nominis edendi apud consules potestas fieret. (Liv. 2, 24)

„Zarządził, by nikı nie przetrzymywał obywatela rzymskiego w kajdanach lub w więzieniu ( $w$ tym celu), aby ten nie miał możliwości zgloszenia się u konsula do wojska".

Si sensero hodie quicquam in his te nuptiis fallaciae conari, quo fiant minus $[\ldots]$, te in pistrinum [...] dedam. (Ter., Andr. 196-199)

„Jeśli dzisiaj zobaczę, że w sprawie tego ślubu próbujesz uciec się do jakiejś sztuczki, aby do niego nie doszło, poślę cię do pracy w mlynie".

Ex iuventute [...] proflgatissimus quisque, quominus in opera scaenae harenaeque edenda senatus consulto teneretur, famosi iudicii notam sponte subibant. (Suet., Tib. 35)

„Każdy co bardziej zdemoralizowany mlody czlowiek, by nie zostać pociągnięty do odpowiedzialności (karnej) na mocy uchwaly senatu zabraniającej występowania na sce- 
nie i arenie, dobrowolnie zglaszał się po złą notę sądu obyczjowego (zwalniającą z tej odpowiedzialności)".

Jeśli jednak negowany jest sam cel, a nie treść predykatywna będąca elementem sytuacji ukazywanej jako cel (przedmiot intencji), a więc gdy przeczy się temu, by ukazywana sytuacja była celem, stosowany jest konektor $u t$ poprzedzony wykładnikiem negacji (np. non):

Lento adiutorio opus est contra mala continua et fecunda, non ut desinant, sed ne vincant. (Sen., Dial. 4, 10, 8)

„Potrzeba długotrwałego wsparcia przeciwko uporczywemu i ciągle się odradzającemu złu, nie po to, by ustało, ale (po to), by nie zwyciężylo".

Z kolei gdy zawierające negację zdanie celowe znajduje się po innym, współrzędnym względem niego zdaniu, wprowadzane jest za pośrednictwem konektorów neque (nec) lub neve (neu), przy czym jeśli poprzedzające zdanie również jest zaprzeczone, stosowany jest wyłacznie konektor neve (neu):

Adiungam etiam de memoria, ut labore Crassum levem neque ei quicquam aliud, de quo disserat, relinquam, nisi ea, quibus haec exornentur. (Cic., De orat. 2, 350)

„Dodam jeszcze coś o pamięci, aby ulżyć Krassusowi, i by nie pozostawić mu już nic innego do rozważania, jak tylko kwestie dotyczące przyozdabiania (mów)".

Quantum coniti animo potes [...], tantum fac, ut efficias neve committas, ut [...] tute tibi defuisse videaris. (Cic., Off. 3, 6)

„Na jak wielki wysiłek umysłowy cię stać, na taki się zdobądź, byś osiągnąl swój cel, i byś nie wywołal wrażenia, że zabrakło twojego zaangażowania".

Praesidium [...] in vestibulo reliquit, ne quis adire curiam iniussu suo neve inde egredi possit. (Liv. 23, 2)

„Pozostawil w przedsionku straż, by bez jego rozkazu nikt nie mógł zbliżyć się do siedziby senatu, ani stamtąd wyjść".

Zdania celowe wprowadzone konektorem implikującym negację mogą zawierać dodatkowe wykładniki negacji, wskutek czego negacja ulega neutralizacji i zyskują one sens afirmatywny:

Non omnes, qui arma ferre possent, convocandos statuunt, sed certum numerum cuique civitati imperandum, ne tanta multitudine confusa nec moderari nec discerenere suos nec frumenti rationem habere possent. (Caes., Gall. 7, 75)

„Postanawiają, iż nie należy powolywać wszystkich zdolnych do noszenia broni, lecz wyznaczyć każdemu plemieniu określony kontyngent, aby nie stało się tak, że przy tak wielkiej i wymieszanej masie ludzkiej nie będą mogli ani utrzymać dyscypliny, ani rozpoznać swoich, ani zapewnić aprowizacji" ( $=\ldots$ aby mogli utrzymać dyscyplinę, rozpoznać swoich i zapewnić aprowizację).

W przypadku, gdy treść zdania nadrzędnego podlega negacji, podrzędne zdanie celowe może być wprowadzane także za pośrednictwem złożonego konektora o postaci nisi ut, który neutralizuje negatywny sens zdania nadrzędnego, nadając jedno- 
cześnie sytuacji będącej treścią wprowadzanego zdania podrzędnego status jedynej intencji związanej $\mathrm{z}$ treścią $\mathbf{z d a n i a}$ nadrzędnego:

Nemo enim studet eloquentiae nostrorum hominum, nisi ut in causis atque in foro eluceat. (Cic., De orat. 2, 55)

„Nikt bowiem $z$ naszych ludzi nie poświęca się sztuce nymowy $z$ innego powodu jak tylko po to, by błyszczał w sądach i na forum" (= Wszyscy poświęcają się sztuce wymowy wylącznie po to, by...).

Negacja w zdaniu nadrzędnym może mieć przy tym charakter wyłącznie pragmatyczny, co zachodzi np. w przypadku pytania retorycznego implikującego negatywną odpowiedź:

Quis nostrum exercitationem ullam corporis suscipit laboriosam, nisi ut aliquid ex ea commodi consequatur? (Cic., Fin. 1, 32)

„Któż z nas podejmuje jakieś uciążliwe ćwiczenia fizyczne $z$ innego powodu niż po to, by uzyskać dzięki niemu jakąś korzyść?" (= Nikt z nas nie podejmuje uciążliwych ćwiczeń fizycznych $\mathrm{z}$ innego powodu, niż po to, by ... = Wszyscy podejmujemy uciązliwe ćwiczenia fizyczne wyłącznie po to, by ...).

Podrzędne zdania okolicznikowe celu mogą także mieć status zdań rozszerzających. W przypadku zdań tego typu kataforyczny, okolicznikowy składnik zdania nadrzędnego bywa też jednak traktowany jako współwykładnik zespolenia i w odniesieniu do takich zdań mówi się o konektorze złożonym ('po to ... by', 'z tego powodu ... aby' itp.):

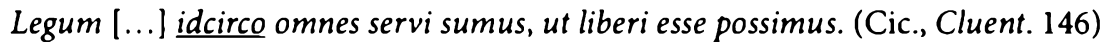

"므 to jesteśmy niewolnikami praw, byśmy mogli być wolni".

Id huc revorti, uti me purgarem tibi. (Pl., Amph. 909)

"Po to tu wróciłem, by się przed tobą usprawiedliwić".

Eo natus sum, ut Iugurthae scelerum ostentui essem. (Sall., Iug. 24)

"Na to się urodziłem, by na mej osobie mógł Jugurta ukazać światu swe zbrodnie".

Specyficzną odmianę zdań celowych stanowią takie, które wyrażają intencję związaną nie $\mathrm{z}$ treścią zdania nadrzędnego, lecz z samym aktem komunikacji; tym samym współtworzą nie tyle warstwę przedmiotową wypowiedzenia, ile raczej warstwę tekstową, tj. warstwę strategii nadawczo-odbiorczej:

Ut meam iam scias sententiam, neque ego ignosco, neque promitto quicquam. (Ter., Phorm. 1043-1044)

„Byś teraz już znał moje zdanie (powiem, że) ani nie wybaczam, ani niczego nie obiecuję”.

Ac ne longum sit, Quirites, tabellas proferri iussimus, quae a quoque dicebantur datae. (Cic., Catil. 3, 10)

„By długo się nie rozwodzić, Kwiryci, (powiem, że) nakaziliśmy przynieść tabliczki, które przez każdego z nich mialy zostać napisane". 
Te tua, me delectant mea, sed, ut ad Dionysium redeamus, omni cultu et victu humano carebat. (Cic., Tusc. 5, 63)

„Ciebie radują twoje rzeczy, mnie moje, jednak, by powrócić do Dionizjusza, to był on pozbawiony wszelkiej oglady i kultury życia".

Satis inconsiderati fuit, ne dicam audacis, rem ullam ex illis attingere. (Cic., Phil. 13, 12)

„Było czynem dość nierozważnym, by nie powiedzieć zuchwalym, tknąć cokolwiek z tych rzeczy".

Podobnie realizowaniu określonej strategii nadawczo-odbiorczej służą zdania, których treść związana jest wprawdzie z treścią zdania nadrzędnego, jednak intencjonalny (celowy) charakter przypisywany jest jej niejako sztucznie, z zewnątrz, przez autora wypowiedzenia, który nadaje jej w ten sposób status swoistego komentarza czy oceny sytuacji; zdania tego typu określić można jako pseudocelowe:

Exercitibus dimissis, cum et foris pax et domi concordia ordinum otium esset, ne nimis laetae res essent, pestilentia civitatem adorta coegit senatum imperare decemviris, ut libros Sibyllinos inspicerent. (Liv. 7, 27)

„Po tym, gdy rozpuszczono wojska, jako że poza granicami panowal pokój, a w kraju spokój dzięki zgodzie wszystkich stanów, by sprawy nie przyjęly zbyt dobrego obrotu dotknęla ludzi zaraza i zmusiła senat do tego, by nakazal decemwirom zajrzeć do ksiąg sybillińskich".

O pseudocelowym charakterze możemy mówić również w przypadku zdań, które wprowadzane są charakterystycznym dla zdań celowych konektorem, np. ne lub $u t$, jednak $w$ istocie wyrażają raczej np. skutek lub warunek niż cel:

Alpinis quoque ea gentibus haud dubie origo est, maxime Raetis, quos loca ipsa efferarunt ne quid ex antiquo praeter sonum linguae nec eum incorruptum retinerent. (Liv. 5, 33)

„Bez wątpienia tego ( $\mathrm{tj}$. etruskiego) pochodzenia są również ludy alpejskie, zwlaszcza Retowie, jednak sam kraj przez nich zamieszkiwany (swoją dzikością) wyzuł ich z wszelkiej cywilizacji na tyle, by niczego nie zachowali ze swej przeszlości prócz brzmienia języka, i to zepsutego" ( = ... wyzul ich z wszelkiej cywilazcji tak, że niczego nie zachowali ...).

'Ferro hinc tibi submovendus sum, Appi', inquit, 'ut tacitum feras, quod celari vis'. (Liv. 3, 45)

„'Byś mógł sprawić, by milczano o tym, co chcesz ukryć, powiada, 'mieczem musisz mnie stąd usunąć, Appiuszun.' (= Mieczem musisz mnie stąd usunąć, jeśli chcesz, by milczano ...).

Możemy mieć jednak do czynienia również z sytuacją odwrotną, gdy zdanie wyraża de facto cel, chociaż formalnie, $z$ uwagi na użycie konektora, wykazuje cechy zdań innego typu (np. warunkowych); dotyczy to w szczególności języka potocznego i często związane jest z zastosowaniem określonego skrótu językowego:

Nunc ibo intro ad hanc meretricem, quamquam suscenset mihi, si possum exorare, ut pallam reddat, quam referam domum. (Pl., Men. 1048-1049)

„Wejdę teraz do domu tej hetery, mimo iż gniewa się na mnie, (by sprawdzić), czy mogę ją ublagać, by oddala plaszcz". 


\subsection{Zdania okolicznikowe skutku}

Treścią zdań podrzędnych okolicznikowych skutku (zdań skutkowych / konsekutywnych) jest stan realny lub hipotetyczny (potencjalny, postulatywny), ukazany jako efekt bądź następstwo działań, zachowań, zdarzeń, sytuacji, okoliczności lub stanów (realnych bądź hipotetycznych), stanowiących treść zdania nadrzędnego lub równoważnika zdania nadrzędnego (np. accusativus cum infinitivo lub ablativus absolutus). Zdania te wprowadzane są najczęściej z użyciem konektora stanowionego przez spójnik ut/uti. Negacja wyrażana jest za pośrednictwem przeczących partykuł, spójników lub zaimków: (ut) non, (ut) neque, (ut) nihil, (ut) nemo, (ut) numquam itp. albo za pośrednictwem implikujących negację konektorów: quin, quominus (quo minus). Pod względem składniowym są funkcjonalnymi odpowiednikami okoliczników określających orzeczenie zdania nadrzędnego, jednak najczęściej rozszerzają ulokowane $w$ zdaniu nadrzędnym okolicznikowe określniki czasownikowych orzeczeń, przysłówkowych okoliczników bądź przymiotnikowych orzeczników lub przydawek, stanowione przez kataforyczne zaimki przysłówkowe: ita, sic, tam 'tak', tantum 'tak bardzo / tak wiele', adeo, (usque) eo 'do tego stopnia' itp. Mogą też stanowić okolicznikowy określnik przymiotnikowego zaimka tantus 'tak wielki', użytego kataforycznie w funkcji przydawki bądź orzecznika.

Orzeczenie zdań podrzędnych skutkowych (współ)tworzone jest przez osobową formę czasownikową w koniunktiwie (tzw. coniunctivus eventualis). Kryteria doboru wyrażanej przez te formę wartości kategorii czasu są trudne do jednoznacznej identyfikacji, na ogół jednak dobór ten wynika $z$ uwględnienia następujących zasad:

1. Stosowany jest coniunctivus praesentis, jeśli treść wyrażana w zdaniu podrzędnym ukazywana jest jako skutek aktualny w momencie aktu komunikacji lub w przyszłości:

Tanta vis probitatis est, ut eam [...] in hoste etiam diligamus. (Cic., Lael. 29)

"Tak wielka jest siła uczciwości, że cenimy ją nawet u wroga”.

Philosophia $[\ldots]$ tantum abest ut $[\ldots]$ laudetur, ut $[. .$.$] a multis etiam vituperetur. (Cic.,$ Tusc. 5, 6)

„Filozofia jest tak odległa od (= tyle jej brakuje do) tego, by ją chwalono, że przez wielu jest nawet potępiana".

Adeone me delirare censes, ut ista esse credam? (Cic., Tusc. 1, 10)

„Czy sądzisz, iż do tego stopnia stracilem rozum, by uwierzyć, że tak właśnie jest?”

(Servus) ita dormitet, servom sese ut cogitet. (Pl., Aul. 591)

„(Niewolnik) niech śpi tak, by pamiętal, że jest niewolnikiem”.

Spero sic moriar, ut mortuus non erubescam. (Petr., Sat. 57, 6)

"Mam nadzieję, iż umrę tak, że po śmierci nie zarumienię się (ze wstydu)".

(Virtutes) cum ita copulatae conexaeque sint, ut omnes omnium participes sint nec alia ab alia possit separari $[\ldots]$... (Cic., Fin. 5, 67) 
„Skoro (cnoty) są tak zespolone i powiązane, że wszystkie w sobie nawzajem uczestniczą i jedna od drugiej nie może być oddzielona [...]".

Quam (scil. Siciliam) iste (scil. Verres) per triennium ita vexavit ac perdidit, ut ea restitui in antiquum statum nullo modo possit. (Cic., Verr. 1, 1, 12)

„Sycylię Werres w ciągu trzech lat tak spustoszył i zrujnował, że w żaden sposób nie da się jej przywrócić do pierwotnego stanu".

Numquam tam male est Siculis, quin aliquid facete et commode dicant. (Cic., Verr. 2, 4, 95)

„Sycylijczycy nigdy nie są aż tak przygnębieni, by nie móc powiedzieć czegoś dowcipnie i inteligentnie".

Numquam accedo, quin abs te abeam doctior. (Ter., Eun. 791)

„Nigdy nie spotykam się (z tobą tak), bym nie odchodził od ciebie mądrzejszy”.

Nemo est tam fortis, quin rei novitate perturbetur. (Caes., Gall. 6, 39)

„Nikt nie jest aż tak mocny (psychicznie), by zaskoczony nowością sytuacji nie popaść w zamieszanie".

Cave praeterbitas ullas aedis, quin roges, senex hic ubi habitat Periphanes. (Pl., Epid. 437) „Uważaj, byś nie minął żadnego domu (tak), by nie zapytać, gdzie mieszka ten starzec Perifanes".

Nemo inpune stulte aliquid [...] dicit, quo minus et iudex respuat et adversarius exprobret. (Tac., Dial. 34)

„(W trakcie rozprawy sądowej) nikt nie mówi czegoś glupiego w sposób bezkarny (tak), żeby i sędzia tego nie odparł, i przeciwnik nie wytknął".

Nil tam difficilest, quin quaerendo investigari possiet. (Ter., Heaut. 675)

„Nic nie jest tak trudne, by szukając, nie można było znaleźć (jakiegoś rozwiązania)".

Nec sacrum nec tam profanum quicquam est, quin ibi ilico adsit. (Pl., Merc. 362)

„Nic nie jest na tyle święte czy ludzkie, by nie był on zaraz przy tym”.

2. Stosowany jest coniunctivus imperfecti, jeśli treść wyrażana w zdaniu podrzędnym ukazywana jest jako skutek aktualny w przeszłości i mający charakter duratywny (trwały w czasie, niemomentalny):

Multa rumores adfingebant, ut paene bellum confectum videretur. (Caes., Civ. 1, 53)

„Wiele zmyślonych rzeczy dodawano w plotkach, tak iż wydawalo się, że wojna jest niemal skończona".

(Atticus) poemata pronuntiabat et Graece et Latine sic, ut supra nihil posset addi. (Nep., Att. 4)

"(Attyk) zarówno greckie, jak i lacińskie wiersze recytowal tak, że niemożliwe było(by) uczynienie jakiejkolwiek poprawki".

Nemo tam divos habuit faventes, crastinum ut posset sibi polliceri. (Sen., Thy. 619- 620)

„Nikt nie zyskał sobie przychylności bogów do tego stopnia, by mógł obiecywać sobie dożycie kolejnego dnia". 
Nemo erat adeo tardus [...], quin statim castris exeundum atque occurendum putaret. (Caes., Civ. 1, 69)

„Nikt nie był do tego stopnia głupi, by nie sądzić, że należy natychmiast wyjść z obozu i zastąpić drogę (przeciwnikowi)".

Nihil tamen $[\ldots]$ flexerunt animos, quin $[\ldots]$ collem $[\ldots]$ virtute defenderent. (Liv. 5, 42)

"Absolutnie jednak nie stracili ducha (tak), by nie bronić wzgórza z (wielkim) męstwem".

Erat [...] ita non superstitiosus, ut illa plurima in sua patria sacrificia et fana contemneret, ita non timidus ad mortem, ut in acie sit ob rem publicam interfectus. (Cic., Fin. $2,63)$

„Był tak wolny od wszelkich przesądów, że za nic mial wszystkie te liczne w jego ojczystym mieście ofiary i świątynie, (oraz był) tak wyzbyty ze strachu przed śmiercią, że polegl w szyku bojowym, walcząc za rzeczpospolitą".

Quam ignominiam adeo aegre tulerat, ut rus migrarit et per multos annos et urbe et omni coetu careret hominum. (Liv. 27, 34)

„Zniewagą tą poczuł się tak bardzo dotknięty, że wyjechał na wieś i przez wiele lat powstrzymywal się od kontaktu z miastem i udziału we wszelkich spotkaniach z ludźmi".

Tantum afuit ab eo, ut ulla ignominia iis exercitibus quaereretur, ut et urbs Roma per eum exercitum, qui ab Allia Veios transfugerat, reciperaretur, et Caudinae legiones, quae sine armis redierant Romam, armatae remissae in Samnium eundem illum hostem sub iugum miserint. (Liv. 25, 6)

„Tak daleko było do tego, by próbowano zarzucić tym wojskom jakąkolwiek hańbę, że i Rzym odzyskiwano z pomocą tego wojska, które znad Allii uciekło do Wej, i legiony, klóre spod Kaudium wrócity do Rzymu bez broni, uzbrojone i ponownie wysłane do Samnium tego samego wroga przepuściły pod jarzmem".

3. Stosowany jest coniunctivus perfecti, jeśli:

a. treść wyrażana w zdaniu podrzędnym ukazywana jest jako skutek aktualny w przeszłości i mający charakter momentalny (nieduratywny), a więc jako zdarzenie ujęte $w$ aspekcie dokonanym:

Adeone pudorem [...] perdidisti, ut hoc [...] dicere ausus sis? (Cic., Phil. 2, 15)

"Czy do tego stopnia stracileś poczucie wstydu, ze odważyłeś się to powiedzieć?".

Acies eo usque est caesa, ut ex duodeviginti milibus hominum duo milia haud amplius evaserint. (Liv. 25, 21)

„Wojsko rozgromione zostało do tego stopnia, że z osiemnastu tysięcy ludzi uszlo cało nie więcej niż dwa tysiące".

Tempestas $[\ldots]$ tam denso regem operuit nimbo, ut conspectum eius contioni abstulerit. (Liv. 1, 16)

„Burza osłoniła króla tak gęstym oblokiem, że odebrała zgromadzonym możliwość widzenia go".

(Liber tuus) tanta [...] ducedine me tenuit et traxit, ut illum sine ulla dilatione perlegerim. (Sen., Lucil. 46, 1) 
„(Twoja książka) swym wielkim wdziękiem tak mnie ujęła i pociągnęla, że przeczytałem ją bez zadnej zwłoki".

Haec dicta adeo nihil moverunt quemquam, ut legati prope violati sint. (Liv. 3, 2)

„Te (zawierające groźby) słowa do tego stopnia nie wywarły na nikim wrażenia, że (wypowiadający je) postowie niemal zostali pobici".

Quo in tempore ipso adeo magno animo civitas fuit, ut consuli [...] redeunti et obviam itum frequenter ab omnibus ordinibus sit, et gratiae actae, quod de re publica non desperasset. (Liv. 22, 61)

„W laśnie w tym czasie panowal wśród ludzi tak wielki entuzjazm, że powracającemu konsulowi zarówno tlumnie wyszły naprzeciw wszystkie stany, jak i zlożono podziękowania za to, że nie zwątpił w rzeczpospolitą".

Erat [...] ita non superstitiosus, ut illa plurima in sua patria sacrificia et fana contemneret, ita non timidus ad mortem, ut in acie sit ob rem publicam interfectus. (Cic., Fin. 2,63 )

„Był tak wolny od wszelkich przesądów, że za nic miał wszystkie te liczne w jego ojczystym mieście ofiary i świątynie, (oraz był) tak wyzbyty ze strachu przed śmiercią, że polegl w szyku bojowym, walcząc za rzeczpospolitą".

Quam ignominiam adeo aegre tulerat, ut rus migrarit et per multos annos et urbe et omni coetu careret hominum. (Liv. 27, 34)

„Zniewagą tą poczuł się tak bardzo dotknięty, że wyjechal na wieś i przez wiele lat powstrzymywal się od kontaktu $z$ miastem i udzialu we wszelkich spotkaniach z ludźmi".

Tantum afuit ab eo, ut ulla ignominia iis exercitibus quaereretur, ut et urbs Roma per eum exercitum, qui ab Allia Veios transfugerat, reciperaretur, et Caudinae legiones, quae sine armis redierant Romam, armatae remissae in Samnium eundem illum hostem sub iugum miserint. (Liv. 25, 6)

„Tak daleko bylo do tego, by próbowano zarzucić tym wojskom jakąkolwiek hańbę, że i Rzym odzyskiwano z pomocą tego wojska, które znad Allii ucieklo do Wej, i legiony, które spod Kaudium wróciły do Rzymu bez broni, uzbrojone i ponownie wyslane do Samnium tego samego wroga przepuścily pod jarzmem".

Zdarza się jednak, że podobne treści wyrażane są za pośrednictwem czasownika w koniunktiwie imperfecti:

(Socratis) responso iudices sic exarserunt, ut capitis hominem innocentissimum condemnarent. (Cic., De orat. 1, 233)

"Odpowiedzią Sokratesa sędziowie tak się oburzyli, że (tego) najbardziej niewinnego czlowieka skazali na śmierć".

Ita ille demens erat, ut eum, quem conscium tanti sceleris habebat, a se dimitteret? (Cic., Deiot. 21)

„Czyż był on tak szalony, że temu, którego uważał za wspólnika tak wielkiej zbrodni, pozwolił odejść od siebie?".

b. treść zdania podrzędnego wyraża skutek z punktu widzenia podmiotu relacjonującego i tym samym ukazywana jest raczej jako uprzedniość w stosunku do momentu relacjonowania o niej niż jako następstwo stytuacji wyrażanej w zdaniu 
nadrzędnym; ma to miejsce szególnie w przypadku, gdy treść ta dotyczy samego podmiotu relacjonującego, bezpośrednio lub pośrednio, stanowiąc efekt jego oceny czy oglądu sytuacji, stanu jego wiedzy itp.:

(Hortensius) ardebat [...] cupuditate sic, ut in nullo umquam flagrantius studium viderim. (Cic., Brut. 302)

„(Hortensjusza) rozpalała ambicja tak bardzo, że w nikim nigdy nie widziałem gorętszego zapału".

Legati in senatum introducti nuntiarunt caedem $C$. Flamini consulis exercitusque allatam adeo aegre tulisse regem Hieronem, ut nulla sua propria [...] clade moveri magis potuerit. (Liv. 22, 37)

„Wprowadzeni do (siedziby) senatu posłowie stwierdzili, że wiadomość o śmierci konsula Gajusza Flaminiusza i stracie wojska tak dotknęła króla Hierona, że żadną własną klęską nie mógłby być bardziej wstrząśnięty".

(Hannibal) adeo gravi morbo adficitur oculorum, ut postea numquam dextro aeque bene usus sit. (Nep., Hann. 4)

„(Hannibal) dotknięty został tak ciężką chorobą oczu, że później prawym okiem nigdy nie widział już równie dobrze (jak lewym)".

4. Stosowany jest bardzo rzadko coniunctivus plusquamperfecti, jeśli treść wyrażana w zdaniu podrzędnym ukazywana jest jako skutek aktualny również uprzednio w stosunku do momentu w przeszłości, wskazywanego przez zdanie nadrzędne:

Tanta opibus Etruria erat, ut iam non terras solum, sed mare etiam [...] fama nominis sui implesset. (Liv. 1, 2)

„Tak potężna była Etruria dzięki swym zasobom, że już nie tylko ziemie, ale i morze (od dawna) napełniła slawą swego imienia".

Specyficznym typem zdań skutkowych są zdania restryktywne (ograniczające), wyrażające zastrzeżenia, których polskie odpowiedniki wprowadzane są za pośrednictwem wyrażeń typu: '(ale) w taki sposób, by..., '(ale) pod (tym) warunkiem, że..., '(jednak) na takiej zasadzie, że...' itp.:

Dabo egenti, sed ut ipse non egeam; succurram perituro, sed ut ipse non peream. (Sen., Benef. 2, 15)

„Dam potrzebującemu, ale tak, by samemu nie znależć się w potrzebie; pomogę, jeśli komuś grozi śmierć, ale tak, by samemu nie zginąć".

Et tamen ita probanda est mansuetudo atque clementia, ut adhibeatur rei publicae causa severitas. (Cic., Off. 1, 88)

„Eagodność i wyrozumiałość należy akceptować $w$ taki sposób (= pod tym warunkiem), że jest się (równocześnie) surowym w odniesieniu do tego, czego wymaga interes państwa".

Lanuvinis [...] sacra sua [...] reddita, cum eo ut aedes lucusque Sospitae Iunonis communis Lanuvinis municipibus cum populo Romano esset. (Liv. 8, 14)

„Lanuwinom przywrócono ich kulty religijne, $z$ tym (jednak zastrzeżeniem), że świątynia i gaj Junony Sospity ma być miejscem kultu wspólnym dla mieszkańców Lanuvium i narodu rzymskiego". 
Zastrzeżenia o nieco innym charakterze wyrażają również zdania, które zaliczane są do zdań warunkowych (zob. niżej, końcowa część podrozdziału 4.3.3.5.6.).

W niektórych przypadkach, mimo że zdanie podrzędne stanowi rozwinięcie typowego zaimka kataforycznego, implikującego zwykle zdanie skutkowe, jego treść w równym stopniu może być być kwalifikowana jako wyrażająca skutek, jak i cel:

Omnia sic transeunt, ut revertantur. (Sen., Lucil. 24, 26)

"Wszystko przemija w taki sposób, że znów powraca / by znów powrócić".

\subsection{Zdania okolicznikowe przyczyny}

Treścią zdań okolicznikowych przyczyny (zdań przyczynowych) są różnego rodzaju okoliczności ukazywane jako uzasadnienie treści komunikowanej w zdaniu nadrzędnym (lub równoważniku zdania nadrzędnego). W strukturze składniowej zdania nadrzędnego zdania te stanowią funkcjonalne odpowiedniki okoliczników określających przede wszystkim wyrażenie predykatywne (orzeczenie), rzadziej przydawkę.

Treści komunikowane $\mathrm{w}$ zdaniu nadrzędnym mogą mieć różny charakter, w związku z czym różny może też być charakter ich uzasadnienia wyrażanego w zdaniu podrzędnym; tym samym zróżnicowany jest też charakter relacji znaczeniowych zachodzących między obu zdaniami. Podstawowy typ relacji semantycznej między dwoma zdaniami, której przypisuje się charakter przyczynowy, dotyczy wyłącznie warstwy przedmiotowej wypowiedzenia („świata przedstawionego") i polega na ukazaniu w zdaniu podrzędnym określonego zdarzenia (działania, sytuacji, okoliczności) jako czynnika powodującego czy motywującego zaistnienie stanu (zdarzenia) przedstawionego w zdaniu nadrzędnym (np. Droga była mokra, ponieważ od rana padal deszcz). W łacinie głównymi konektorami w zdaniach o takich właściwościach znaczeniowych są spójniki quia i quod. Orzeczenie zdania podrzędnego (wpół)stanowione jest przez osobową formę czasownika w indikatiwie:

Sertorianum bellum a senatu privato ( $\mathrm{Cn}$. Pompei) datum est, quia consules recusabant. (Cic., Phil. 11, 18)

„Prowadzenie wojny z Sertoriuszem powierzone zostało przez senat (Pompejuszowi jako) człowiekowi prywatnemu, ponieważ konsulowie odmawiali (poprowadzenia jej)".

Qui erant cum Aristotele Peripatetici dicti sunt, quia disputabant inambulantes in Licio. (Cic., Acad. 1, 17)

„Ci, którzy przebywali z Arystotelesem, zostali nazwani Perypatetykami, ponieważ prowadzili dysputy spacerując w Likeionie".

Erant tamen, quibus videretur illius aetatis tertius Curio, quia splendidioribus fortasse verbis utebatur et quia Latine non pessume loquebatur. (Cic., Brut. 210)

„Byli jednak i tacy, którzy za trzeciego mówcę tego okresu uznaliby Kuriona, ponieważ używał być może bogatszego (niż inni) słownictwa i ponieważ nieźle władal laciną". 
Ego tibi, Carneade, praetor esse non videor, quia sapiens non sum? (Cic., Lucull. 137)

„Czy sądzisz, Karneadesie, że nie jestem pretorem, ponieważ nie jestem mędrcem?”.

Praedia mea tu possides, ego aliena misericordia vivo; concedo, et quod animus aequus est, et quia necesse est. (Cic., S. Rosc. 145)

„Dobra moje ty posiadasz, ja żyję z laski innych; przystaję na to, i dlatego, że się z tym pogodzilem, i dlatego, że jest to konieczne".

Nec altitudine solum tuta urbs, sed quod saxo undique absciso rupibus imposita est. (Liv. $32,4)$

„Miasto było bezpieczne nie tylko dzięki wysokiemu polożoniu, ale także dlatego, że ulokowane zostało na skale zewsząd opadającej urwiskami".

Dumnorix [...] Helvetiis erat amicus, quod ex ea civitate Orgetorigis filiam in matrimonium duxerat. (Caes., Gall. 1, 9)

„Dumnoryks pozostawal w przyjacielskich stosunkach $z$ Helwetami, ponieważ z tego plemienia wziął sobie kiedyś za żonę córkę Orgetoryksa".

(Themistocles), quod non satis tutum se Argis videbat, Corcyram demigravit. (Nep., Them. 8)

„(Temistokles), ponieważ w Argos nie czul się dostatecznie bezpieczny, wyjechal na Korkyrę".

(Zeno) sensibus [...] fidem tribuebat, quod [...] comprehensio facta sensibus et vera esse illi et fidelis videbatur. (Cic., Acad. 1, 42)

„(Zenon) ufał zmysłom, ponieważ spostrzeżenie zmyslowe uważal za prawdziwe i wiarygodne".

Zdania podrzędne przyczynowe, które wprowadzane są za pośrednictwem konektorów quia i quod, mogą mieć także status zdań rozszerzających. Odpowiadają im wtedy w zdaniu nadrzędnym foryczne zaimki przysłówkowe (lub inne wyrażenia ogólne o podobnym charakterze), takie jak: eo, ideo, propterea, idcirco, ob eam rem/ causam, eo magis/maxime/maior/maius, eo minus/minor. Wyrażenia te występują najczęściej w prepozycji do zdania przyczynowego (tj. poprzedzają je), a zatem pełnią funkcję kataforyczną:

Eoque nunc fit [...], ut minus multos tabella condemnet, quam solebat vox, quia populo licere sat is est. (Cic., Leg. 3, 39)

„I dlatego teraz dzieje się tak, iż mniej ludzi skazuje się za pośrednictwem tabliczek, niż zazwyczaj skazywało się przez okrzyki, ponieważ ludowi wystarcza sama możliwość (skazywania)".

An ideo non est dimicatum, quod quae pars firmior, eadem modestior fuit? (Liv. 4, 5)

„Czy może dlatego nie było walki, że strona, która była silniejsza, byla równocześnie bardziej umiarkowana?".

Omnes [...] ideo Aemiliae potius legi paruerunt, quam illi antiquae [...], quia hanc postremam iusserat populus et quia, ubi duae contrariae leges sunt, semper antiquae obrogat nova. (Liv. 9, 34)

„Wszyscy dlatego stosowali się raczej do ustawy Emiliusza, niż do tej dawniejszej, ponieważ ją jako ostatnią uchwalit lud, i ponieważ wtedy, gdy dwie ustawy są ze sobą sprzeczne, zawsze nowa unieważnia starą". 
Horum omnium (scil. Gallorum) fortissimi sunt Belgae propterea, quod a cultu atque humanitate provinciae longissime absunt. (Caes., Gall. 1, 1)

„Z nich wszystkich ( $t$ j. Gallów) najdzielniejsi są Belgowie dlatego, że najbardziej oddaleni są od kultury i cywilizacji prowincji".

Ita fit, ut adsint propterea, quod officium sequuntur, taceant autem idcirco, quia periculum vitant. (Cic., S. Rosc. 1)

„Jest tak, że są obecni dlatego, że wypełniają (swój) obowiązek, milczą zaś dlatego, ponieważ unikają niebezpieczeństwa".

Cuius (scil. Vercingetorigis) pater principatum totius Galliae obtinuerat et ob eam causam, quod regnum adpetebat, a civitate erat interfectus. (Caes., Gall. 7, 4)

"Jego (tj. Wercyngetoryksa) ojciec objął zwierzchnictwo nad całą Galią i z tego powodu, ze dązyl do władzy królewskiej, został przez wspólplemieńców zamordowany".

Ob eam rem, quia te servavi, me amisisti liberum. (Pl., Men. 1055)

"Za to, że cię uratowałem, wyzwoliłeś mnie (niewolnika)".

Quod eo magis iudico verum esse, quia lex Solonis id ipsum vetat. (Cic., Leg. 2, 59)

„Tym bardziej uważam to (wyjaśnienie) za słuszne, ponieważ prawo Solona tego właśnie zabrania" (= Uważam to (wyjaśnienie) za słuszne tym bardziej, że prawo Solona tego właśnie zabrania).

Iam is rumor ante de industria volgatus venerat ad Romanos, sed fidem auxere captivi eo maxime, quod sermo inter omnes congruebat. (Liv. 9, 2)

„Ta pogłoska, już wcześniej umyślnie rozpowszechniana, doszła do Rzymian, lecz jej wiarygodność utwierdzali pojmani ludzie najbardziej z tego powodu, że wszystkie ich relacje były z sobą zgodne".

Quod eo maius est illi (scil. Catoni) quam [...] nobis, quia nos ea philosophia plus utimur [...], in qua dicuntur ea, quae non multum discreperent ab opinione populari, Cato autem [...] ea sentit, quae non sane probantur in volgus. (Cic., Parad. proem. 2)

„To (zadanie) o tyle (= dlatego) trudniejsze jest dla Katona niż dla nas, że my wyznajemy raczej taką filozofię, w ramach której głosi się poglądy niewiele różniące się od powszechnej opinii, Katon natomiası ma takie zapatrywania, które nie bardzo aprobowane są przez pospólstwo".

Rzadziej mają charakter anaforyczny, lokując się $\mathrm{w}$ postpozycji do zdania podrzędnego:

Quo in genere quia praestat omnibus Demosthenes, idcirco a doctis oratorum est princeps iudicatus. (Cic., Brut. 141)

„Ponieważ w tej dziedzinie wszystkich przewyższa Demostenes, dlatego przez uczonych uznany (on) został za najwybitniejszego spośród mówców".

Quia non laboro [...] eo minus conturbor. (Cic., Lucull. 10)

„Ponieważ nie sprawia mi przykrości (ta syluacja), tym mniej czuję się zaniepokojony”.

W określonych kontekstach pragmatycznych i semantycznych orzeczenie zdań wprowadzanych za pośrednictwem konektorów quia i quod (współ)stanowione jest przez formę czasownikową w koniunktiwie (według zasady consecutio temporum), co stanowi sygnał (mniej lub bardziej wyraźnego) dystansowania się autora 
wypowiedzenia od jego treści. Zaznaczanie owego dystanu może wynikać z kilku okoliczności:

a. treść zdania podrzędnego ukazywana jest jako uzasadnienie (treści zdania nadrzędnego) przypisywane osobie trzeciej, tj. którejś z postaci (indywidualnej lub zbiorowej) „świata przedstawionego”, wskazanej wprost lub identyfikowalnej kontekstowo; uzasadnienie to ma zatem charakter subiektywny, a użycie koniunktiwu w wypowiedzeniach tego rodzaju znane jest jako tzw. coniunctivus ex mente aliena:

(Academici et Peripatetici) mentem [...] solam censebant idoneam, cui crederetur, quia sola cerneret id, quod semper esset simplex et unius modi et tale, quale esset. (Cic., Acad. $1,30)$

„(Akademicy i Perypatetycy) jedynie rozum uważali za godny zaufania, ponieważ (ich zdaniem) tylko on dostrzega to, co zawsze pozostaje proste i jednakowe, i (dostrzaga to) takim, jakie to rzeczywiście jest".

Corpora nostra non novimus [...], quam vim quaeque pars habeat ignoramus; itaque medici $[\ldots]$ aperuerunt, ut viderentur, nec eo tamen aiunt empirici notiora esse illa, quia possit fieri, ut patefacta et detecta mutentur. (Cic., Lucull. 122)

„Nie znamy naszych cial, nie wiemy jakie funkcje pełnią poszczególne jego organy; medycy zatem otworzyli (ciało), by (organy te) stały się widoczne, jednak empirycy twierdzą, zee nie stały się one przez to lepiej znane, ponieważ może być tak, że odstonięte i wydobyte na wierzch, ulegają jakiejś zmianie".

Eademque ratione ne temperantiam quidem propter se expetendam esse dicemus, sed quia pacem animis afferat et eos quasi concordia quadam placet ac leniat. (Cic., Leg. 1, 47)

„I na tej samej zasadzie powiemy, że również wstrzemięźliwości nie powinniśmy pragnąć ze względu na nią sama, ale dlatego, że (zdaniem Epikura) przynosi spokój duszom oraz lagodzi je i koi jakby jakimś poczuciem (wewnętrznej) harmonii".

Noctu ambulabat in publico Themistocles, quod somnum capere non posset quaerentibusque respondebat Miltiadis tropaeis se e somno suscitari. Cui non sunt auditae Demosthenis vigiliae? (Cic., Tusc. 4, 44)

„Nocą spacerowal Temistokles ulicami, ponieważ (rzekomo / jak mówil) nie mógł spać, a pytającym (go o to) odpowiadał, że budzą go ze snu pomniki zwycięstwa Miltiadesa. (A przecież) kto nie słyszał o nocach (świadomie) spędzanych bezsennie przez Temistoklesa?"

C. Caesari $[\ldots]$ honores $[\ldots]$ decrevistis unam ob causam, quod contra $M$. Antonium exercitum comparavisset. (Cic., Phil., 7, 10)

„Cezarowi przyznaliście zaszczyty z tego jednego powodu, że zebrał wojsko przeciwko Markowi Antoniuszowi" (= To było dla was jedynym powodem przyznania zaszczytów Cezarowi, że ...).

b. treść zdania podrzędnego ukazywana jest jako uzasadnienie (treści zdania nadrzędnego) pochodzące wprawdzie od autora wypowiedzenia, ale mające również charakter subiektywny, osobisty, wynikający z jego opinii, przekonań itp.: 
Mihi semper Peripateticorum Academiaeque consuetudo de omnibus rebus in contrarias partis disserendi non ob eam causam solum placuit, quod aliter non posset, quid in quaque re veri simile essset, inveniri, sed etiam quod esset ea maxuma dicendi exercitatio. (Cic., Tusc. 2, 9)

„Praktykowany przez perypatetyków i Akademię zwyczaj dyskutowania o wszystkim $z$ uwzględnieniem przeciwnych punktów widzenia zwsze mi się podobal nie tylko dlatego, że (moim zdaniem) inaczej trudno ustalić, co w każdej (dyskutowanej) sprawie jest najbliższe prawdy, ale również dlatego, że jest to (wedlug mnie) najlepsze ćwiczenie oratorskie".

c. treści zdania podrzędnego, ukazywanej jako uzasadnienie (treści zdania nadrzędnego), nadaje się status prawdopodobieństwa:

Possumus Appium Claudium suspicari disertum, quia senatum iamiam inclinatum a Pyrrhi pace revocaverit. (Cic., Brut. 55)

„Możemy domyślać się, że Appiusz Klaudiusz był wymowny, ponieważ mial odwieść od zawarcia pokoju z Pyrrusem senat, który już był niemal zdecydowany (by to uczynić)".

Najczęściej jednak użycie koniunktiwu $\mathrm{w}$ orzeczeniu wiąże się $\mathrm{z}$ negowaniem istnienia związku przyczynowego, a więc z sytuacją, gdy przeczy się temu, by treść zdania podrzędnego stanowiła uzasadnienie treści zdania nadrzędnego. W zdaniach tego typu konektor zwykle poprzedzony jest partykułą przeczącą (non quod... / non quia...). Często też zdaniu temu towarzyszy inne zdanie podrzędne przyczynowe, którego treść ukazywana jest jako rzeczywista przyczyna uzasadniająca stan wyrażony w zdaniu nadrzędnym, co implikuje użycie indikatywnej formy czasownikowej w jego orzeczeniu; jeśli zdanie to następuje w drugiej kolejności, jego konektor poprzedzony jest konektorem adwersatywnym (sed quia.../sed quod...):

Pugiles vero, etiam cum feriunt adversarium [...], ingemescunt, non quod doleant animove succumbant, sed quia profundenda voce omne corpus intenditur venitque plaga vehementior. (Cic., Tusc. 2, 56)

„Pięściarze zaś, nawet gdy uderzają przeciwnika, wydają jęki, (jednak) nie dlatego, by odczuwali ból bądź upadali na duchu, lecz dlatego, że wydając glos, cale cialo napina się i cios wychodzi silniejszy".

Abstulere me velut de spatio Graeciae res immixtae Romanis, non quia ipsas operae pretium esset perscribere, sed quia causae cum Antiocho fuerunt belli. (Liv. 35,40$)$

„Odciągnęły mnie niejako od właściwego toku opowieści sprawy Grecji, wplecione w dzieje rzymskie, nie dlatego, by ich opis sam w sobie wart był zachodu, ale dlatego, że znalazly się one wśród przyczyn wojny z Antiochem".

Sexaginta tres postero die comprehensi, a quibus praetor vim arcuerat, non quia salvos vellet, sed quia perire causa indicta nolebat [...], damnati omnes et traditi sunt ad supplicium. (Liv. 38, 33)

„Sześćdziesięciu trzech pojmanych następnego dnia, których pretor uchronił od przemocy, nie dlatego, by chciał ich ocalić, ale dlatego, że nie chcial ich śmierci bez sądu, zostało skazanych i wrydanych na stracenie". 
Jednak również w zdaniu wyrażającym rzeczywistą przyczynę orzeczenie może być (współ)stanowione przez formę czasownikową w koniunktiwie, jeśli przyczyna ta ma charakter subiektywny (ex mente aliena) lub prawdopodobny:

Comprehensio facta sensibus et vera esse illi (scil. Zenoni) et fidelis videbatur, non quod omnia, quae essent in re, comprehenderet, sed quia nihil, quod cadere in eam posset, relinqueret. (Cic., Acad. 1, 42)

„Spostrzeżenie zmysłowe Zenon uważał za prawdziwe i wiarygodne, (jednak) nie dlatego, by ogarniało wszystko, co zawarte jest w określonej rzeczy, lecz dlatego, że nie pomija niczego, co może podpadać pod postrzeganie zmyslowe".

Tum Ahala Servilius, tribunus militum, tacuisse se tam diu ait, non quia incertus sententiae fuerit $[. .$.$] , sed quia maluerit collegas sua sponte cedere auctoritati senatus. (Liv. 4, 57)$

„Wtedy trybun ludowy Ahala Serwiliusz powiada, iż milczał tak dlugo nie dlatego, by wahał się w swej opinii, ale dlatego, że wolał, aby koledzy $z$ własnej woli ulegli senatowi".

Z drugiej strony w zdaniu, którego konektor poprzedzony jest partykułą przeczącą, może wystąpić orzeczenie $w$ indikatiwie, zwłaszcza jeśli podkreśla się, że nie jest przedmiotem negacji sama sytuacja będąca treścią tego zdania, lecz tylko jej przyczynowy charakter:

Et invidi et malivoli et libidinosi et et timidi et misericordes, quia proclivi ad eas perturbationes sunt, non quia semper feruntur. (Cic., Tusc. 4, 28)

„(Ludzie są) i zazdrosni, i nieżyczliwi, i pożądliwi, i bojaźliwi, i litościwi, ponieważ mają skłonność do tych (zaburzonych) stanów emocjonalnych, a nie dlatego, że ciągle im podlegają".

Beoti petierunt [...], ut qui suae gentis militassent apud Philippum, sibi restituerentur. Id a Quinctio facile impetratum, non quia satis dignos eos credebat, sed quia [...] favor conciliandus nomini Romano apud civitates erat. (Liv. 33, 27)

„Beoci prosili o to, by ich ludzie, którzy służyli w wojsku u Filipa, zostali im zwróceni. Łatwo uzyskali na to zgodę od Kwinkcjusza, nie dlatego, że uważał on ich za wystarczająco godnych tego, ale dlatego, że trzeba było zabiegać o pozyskanie przychylności dla imienia rzymskiego wśród miast".

Gratus sum, non quia expedit, sed quia iuvat. (Sen., Lucil. 81, 20)

„Okazuję wdzięczność nie dlatego, że przynosi mi to korzyść, ale dlatego, że daje mi zadowolenie".

W przypadku zestawienia dwóch zdań podrzędnych zaprzeczenie relacji przyczynowej treści jednego z nich (względem treści zdania nadrzędnego) może przybrać również łagodniejszą formę poprzez użycie zestawionego konektora porównawczego, za pomocą którego dokonuje się ewaluacji przyczynowego statusu treści poszczególnych zdań. Jeśli złagodzonej negacji lub osłabieniu podlega przyczynowy charakter treści zdania występującego w pierwszej kolejności, konektor ten ma postać (non) tam (quia/quod) ... quam (quia/quod/ut) '(nie) tyle (z tego powodu, że) ... co raczej (dlatego, że / aby)', np:

Valuit $[. .$.$] ea legatio, non tam quia pacem volebant Samnites, quam quia nondum parati$ erant ad bellum. (Liv. 8, 19) 
„Poselstwo to okazało się skuteczne, nie tyle z tego powodu, że Samnici pragnęli pokoju, co raczej dlatego, że jeszcze nie byli przygotowani do wojny".

Epicydes [...] Bomilcarem [...] timentem navale proelium, non tam quod impar viribus aut numero navium esset $[. .$.$] , quam quod venti aptiores Romanae quam suae classi fla-$ rent, perpulit tamen, ut fortunam navalis certaminis experiri vellet. (Liv. 25, 27)

„Epicydes Bomilkara obawiającego się bitwy morskiej, nie tyle dlatego, że nie dorównywał (przeciwnikowi) silą czy liczbą okręlów, co raczej z tego powodu, że wialy wiatry pomyślniejsze dla rzymskiej niż dla jego floty, skłonil jednak do tego, by zdecydowal się spróbować szczęścia w starciu na morzu".

Jeśli osłabiany jest przyczynowy charakter treści drugiego ze zdań podrzędnych, zdanie to pozbawione jest wykładnika negacji przed konektorem przyczynowym, zaś zestawiony konektor porównawczy, relacjonujący względem siebie oba zdania podrzędne, przyjmuje postać magis (quialquod/ut) ... quam (quialquod/quo) 'bardziej/ raczej (ponieważ/aby) ... niż (dlatego, że)', np.:

Pars, magis quia locus fugae deerat, quam quod animi satis esset ad pugnam, cum substitissent, ab hoste $[\ldots]$ circumventi sunt. (Liv. 32, 12)

„Gdy część żołnierzy zatrzymała się, bardziej z tego powodu, iż brakowalo miejsca na ucieczkę, niż dlatego, że starczało im ducha do stoczenia walki, została okrążona przez nieprzyjaciół".

Antiochus [...] Ephesum ab Sardibus est profectus ad classem [...] visendam, magis quia terrestribus copiis exercitum Romanum [...] videbat sustineri non posse, quam quod res navalis ipsa per se aut temptata sibi umquam feliciter, aut tunc magnae et certae fiduciae esset. (Liv. 37, 26)

"Antioch wyruszył z Sardes do Efezu na inspekcję floty, raczej dlatego, iż wiedzial, że przy pomocy lądowych oddziałów nie jest $w$ stanie oprzeć się wojsku rzymskiemu, niż z lego powodu, by sama walka na morzu jako taka, czy to kiedykolwiek okazala się dlań szczęśliwa, czy to teraz była dla niego czymś, w czym mógłhy pokładać ufność w sposób pewny i nieskrępowany".

Mercatoribus est aditus magis eo, ut (Germani), quae bello ceperint, quibus vendant habeant, quam quo ullam rem ad se importari desiderent. (Caes., Gall. 4, 2)

„Otwierane są granice dla kupców raczej po to, by (Germanie) mieli komu sprzedawać to, co zagrabili na wojnie, niż dlatego, by potrzehowali dowozu jakichś towarów".

Zdanie podrzędne, którego treść ukazywana jest jako niepozostająca w związku przyczynowym $\mathrm{z}$ treścią zdania nadrzędnego, może także być za pośrednictwem ww. konektora zestawionego przeciwstawiona nie innemu zdaniu, lecz określonemu składnikowi zdania nadrzędnego (np. przydawce orzecznikowej (praedicativum) lub okolicznikowi przyczyny), wyrażającemu (rzeczywiste) uzasadnienie (przyczynę) treści zdania nadrzędnego:

Haec amore magis impulsus scribenda ad te putavi, quam quo te arbitrarer monitis et praeceptis egere. (Cic., Fam. 10, 3, 4)

„Uznalem, że powinienem ci to napisać raczej tknięty serdecznym uczuciem (do ciebie), niż dlatego, bym uważał, że potrzebujesz napomnień i wskazówek". 
Jeśli negowany jest przyczynowy status treści, która sama w sobie ma charakter przeczący, zdanie, które treść tę wyraża, może być wprowadzane za pośrednictwem poprzedzonego negacją konektora quia/quod i zawierać dodatkowy wykładnik negacji (a więc: non quialquod (...) non ...), lub też za pośrednictwem poprzedzonego negacją konektora quin (a więc: non quin ...), który sam w sobie implikuje (dodatkową) negację:

Sed Augustus quoque in epistulis ad C. Caesarem scriptis emendat, quod is 'calidum' dicere quam 'caldum' malit, non quia id non sit Latinum, sed quia sit odiosum. (Quint., Inst. 1, $6,19)$

„Ale również August w listach pisanych do Cezara poprawia go (zarzucając mu), iż woli mówić raczej 'calidum' niż 'caldum', (i czyni to) nie dlatego, że nie jest to po lacinie, ale dlatego, że jest to irytujące".

Ego me ducem in civili bello [...] negavi esse, non quin rectum esset, sed quia, quod multo rectius fuit, id mihi fraudem tulit. (Cic., Att. 7, 26, 2)

„Oświadczyłem, że nie stanę na czele wojny domowej, nie dlatego, że nie byłoby to rzeczą właściwą, ale dlatego, że (kiedyś) to, co było jeszcze bardziej właściwe, przyniosło mi (wielką) szkodę".

Iisdem de rebus volui ad te saepius scribere, non quin confiderem diligentiae tuae, sed rei me magnitudo movebat. (Cic., Fam. 16, 24, 1)

„Zdecydowałem się kilkakrotnie o tych rzeczach ci napisać nie dlatego, że nie ufałem twojej skrupulatności, ale (dlatego, że) skłaniała mnie do tego powaga sprawy".

Esse dico [...] optimum consulem, non quin pari virtute et voluntate alii fuerint, sed tantam causam non habuerunt, in qua et voluntatem suam et virtutem declararent. (Cic., Phil. 7, 6)

„Twierdzę, że jest najlepszym konsulem, nie dlatego, by nie było innych o takim samym męstwie i zdecydowaniu, lecz (dlatego, że inni) nie mieli takiej okazji, by zarówno swe zdecydowanie, jak i męstwo, mogli wykazać".

(Porsennae nuntiatur) non quin breviter (legatis eius) reddi responum potuerit [...] ideo potius delectos patrum ad eum missos, sed ut in perpetuum mentio eius rei finiretur. (Liv. $2,15)$

„(Porsennie oświadczono, że) nie dlatego, by nie można było dać krótkiej odpowiedzi jego posłom, wysłani zostali do niego co najznakomitsi senatorowie, ale dlatego, aby już nigdy więcej tej sprawy (tj. przywrócenia na tron Tarkwiniusza) nie poruszano".

Jednak wykładnik negacji, odbierający treści zdania podrzędnego status (rzeczywistej) przyczyny, może być ulokowany również w zdaniu nadrzędnym:

Nemo [...] ipsam voluptatem, quia voluptas sit, aspernatur aut odit aut fugit, sed quia consequuntur magni dolores eos, qui ratione voluptatem sequi nesciunt. (Cic., Fin. 1, 32)

„Samej rozkoszy nikt nie odrzuca, nienawidzi czy unika dlatego (tylko), że jest rozkoszą, ale dlatego, że ludzi, którzy nie potrafią dążyć do niej w sposób rozumny, spotykają wielkie cierpienia".

Ego ne Torquatum quidem [...] iratum existimo Gallo torquem detraxisse, nec Marcellum apud Clasticium ideo fortem fuisse, quia fuerit iratus. (Cic., Tusc. 4, 49) 
„Nie uważam, by nawet Torkwatus w gniewie zerwał Gallowi naszyjnik, ani by Marcellus pod Klastidium dlatego wykazał się mçstwem, że był zagniewany".

Neque [...] hoc, quia sum ipse augur, ita sentio. (Cic., Leg. 2, 31)

"I nie dlatego, że sam jestem augurem, tak uważam”.

Non eo haec dico, quin quae tu vis, ego velim. ( $\mathrm{Pl} .$, Trin. 341)

"Mówię to nie dlatego, bym nie chciał tego, czego ty chcesz".

Non idcirco causas Isocrates non defendit, quin id utile esse et honestum existumarit. (Gell., Noc. Att. 17, 13, 2)

„Nie $z$ tego powodu Izokrates nie występował jako obrońca w procesach sądowych, iz uważał, że nie jest to użyteczne i szlachetne".

Poza tym ulokowanie w zdaniu nadrzędnym wykładnika negacji spowodować może zaprzeczenie stosunku przyczynowości między treścią zdania podrzędnego a treścią zdania nadrzędnego poprzez wskazanie (w zdaniu nadrzędnym) na niezaistnienie stanu, który miałby zostać wywołany daną przyczyną (wyrażoną w zdaniu podrzędnym):

Nec, quia nusquam erat scriptum, ut contra omnis hostium copias in ponte unus adsisteret a tergoque pontem interscindi iuberet, idcirco minus Coclitem illum rem gessisse tantam fortitudinis lege atque imperio putabimus. (Cic., Leg. 2, 10)

„I nie jest też tak, że ponieważ nigdzie nie zostało napisane, by jeden człowiek stawił na moście opór całemu wojsku nieprzyjaciół nakazując, by za jego plecami mosı ten zburzono, to $z$ tego właśnie powodu nie będziemy uważali, iż ów sławny Kokles dokonał tak wielkiej rzeczy pod wpływem prawa i nakazu swej dzielności".

$\mathrm{Z}$ innego rodzaju zdaniami przyczynowymi mamy do czynienia w przypadku, gdy relacje znaczeniowe, które łączą treść zdania podrzędnego $\mathrm{z}$ treścią zdania nadrzędnego, wykraczają poza warstwę przedmiotową, ingerując - pośrednio lub bezpośrednio - w warstwę tekstową wypowiedzenia (warstwę strategi nadawczo-odbiorczej). Ingerencja ta z jednej strony polegać może na tym, że treść zdania podrzędnego ukazywana jest nie tyle jako przyczyna, która spowodowała stan będący treścią zdania nadrzędnego, ile raczej jako dowód czy też potwierdzenie, że stan ten nastąpił. $Z$ sytuacją taką mamy do czynienia np. w wypowiedzeniu: Marek jest $w$ domu, ponieważ $w$ jego pokoju pali się światło, w którym zdanie podrzędne nie informuje o tym, dlaczego Marek jest w domu, czy też co spowodowało, że Marek jest w domu (jak np. w zdaniu: Marek jest $w$ domu, ponieważ oczekuje na wizytę kolegi), ale o tym, skąd wiadomo, że Marek jest w domu. Tym samym zdanie to nabiera charakteru sui generis epistemicznego (ewidencjalnego), stanowiąc raczej uzasadnienie sądu (twierdzenia) wyrażonego $\mathrm{w}$ zdaniu nadrzędnym niż wskazanie przyczyny, która spowodowała stan będący treścią tego sądu. Z tego rodzaju treścią zdania podrzędnego, uwiarygadniającą treść komunikowaną w zdaniu nadrzędnym, związana zaś jest określona intencja, określona funkcja pragmatyczna (illokucyjna), a mianowicie skłonienie odbiorcy komunikatu do przyjęcia postawy zaufania względem treści komunikowanej w zdaniu nadrzędnym, przekonanie go o jej zgodności z rzeczywistością (prawdziwości). Dodajmy, że gdyby rzeczywiście chodziło o wskazanie relacji 
przyczynowej wyłącznie w obrębie warstwy przedmiotowej, to w takim przypadku relacji tej należałoby nadać przeciwny wektor, tj.: Ponieważ Marek jest $w$ domu, $w$ jego pokoju pali się światło. Warto też zaznaczyć, że w wypowiedzeniach omawianego tu typu treści zdań nadrzędnych charakteryzować się mogą także nacechowaną modalnością intencjonalną, deontyczną lub epistemiczną, a uzasadniające je zdania podrzędne często odwołują się do argumentacji o charakterze ogólnym czy powszechnie akceptowalnym, np.: Oby Marek wreszcie przyjechat, ponieważ mnóstwo ludzi o niego pytało; Idźcie już do domu, bo zaczyna się zmierzchać; Powinniśmy pomagać innym, skoro jesteśmy ludźmi; Oczy wszystkich zwrócone byly na niego, jako że był on osoba powszechnie znana.

$\mathrm{Z}$ drugiej strony treść zdania podrzędnego służyć może nie uwiarygodnieniu prawdziwości czy zasadności treści zdania nadrzędnego, lecz umotywowaniu samego faktu zakomunikowania tej treści, a więc uzasadnieniu samego aktu komunikacji, np.: Skoro tak bardzo cię to interesuje, Marek wrócil już do Krakowa; No więc syn Zosi ma troje, a nie dwoje dzieci, bo o nim, zdaje się, rozmawialiście wczoraj przy kolacji. Jak więc widać, zdania te nie mają związku z treścią zdania nadrzędnego, lecz wyłącznie z sytuacją, w której treść ta jest komunikowana. Tym bardziej z treścią zdania nadrzędnego nie łączy ich żadna relacja przyczynowa. Służą one wyłącznie uzasadnieniu samego aktu mowy, a więc pod względem funkcjonalnym sytuują się całkowicie na poziomie warstwy strategii nadawczo-odbiorczej.

Również w tym przypadku treść zdań nadrzędnych ujmowana może być w różne ramy modalne, np.: Czy na kolację przyjdzie również Zosia, bo chciałem jej pokazać mój nowy komputer; Idźcie wreszcie do domu, bo za chwilę chyba pęknie mi głowa od tego wrzasku.

Zdania podrzędne omówionych wyżej typów generalnie cechują się tym, że pod względem semantycznym ich związek ze zdaniem nadrzędnym jest mniej ścisły, co rzutuje na dobór konektorów, za pośrednictwem których zdania te są wprowadzane. W łacinie na ogół nie rozpoczynają ich konektory quia czy quod, które wyrażają relację przyczynową albo wylącznie (quia), albo prymarnie (quod), lecz takie, które implikują sens przyczynowy sekundarnie. Wśród nich wskazać można przede wszystkim te, które stanowione są przez spójniki prymarnie czasowe: quoniam, cum, quando, quandoquidem, ubi, postquam. Dlatego konektory te wprowadzają też często zdania podrzędne, których przyczynowy sens ma charakter tylko kontekstowy, wzbogacający niejako ich znaczenie czasowe, co odzwierciedla dobór polskich konektorów w zdaniach stanowiących ich tłumaczenia na język polski (skoro; ( $w$ sytuacji) gdy; wobec tego, że; jako że). O niższym poziomie treściowego zespolenia ze zdaniem nadrzędnym wszystkich zdań tego typu świadczy też fakt, iż na ogół nie mają one charakteru rozszerzającego, a jedynie uzupełniający, a więc nie towarzyszy im w zdaniu nadrzędnym zaimkowy korelat (ideo, propterea, idcirco 'dlatego / z tego powodu (że)'), implikujący konieczne uzupełnienie i tym samym silnie integrujący zdanie podrzędne $z$ nadrzędnym, a zarazem determinujący jego semantyczny (tj. przyczynowy) status. Nie bez znaczenia wydaje się również fakt, iż spójniki pełniące funkcję konektorów $w$ tych $z$ daniach na ogół nie są stosowane $w$ funkcji 
operatorów nawiązania międzywypowiedzeniowego $w$ zdaniach stanowiących odpowiedzi na pytania o przyczynę (powód). Wartość kategorii trybu czasownikowej formy orzeczenia tych zdań wynika $z$ reguł scharakteryzowanych wyżej w odniesieniu do zdań rozpoczynanych konektorami quod i quia, przy czym zdania rozpoczynane konektorem stanowionym przez wieloznaczny spójnik cum z zasady cechują się orzeczeniem $\mathrm{z}$ czasownikową formą $\mathrm{w}$ koniunktiwie. Ze względów wskazanych wyżej konektory w tych zdaniach bardzo rzadko poprzedzone są wykładnikiem negacji (partykułą przeczącą). Specyfikę charakteryzowanych powyżej zdań ilustrują poniższe przykłady:

Ei moriendum fuit, quoniam homo nata fuerat. (Cic., Fam. 4, 5, 4)

„Musiala umrzeć, skoro urodzila się człowiekiem".

Quoniam ad hunc locum perventum est, non alienum esse videtur de Galliae Germaniaeque moribus [...] proponere. (Caes., Gall. 6, 11)

„Skoro doszliśmy do tego miejsca, to chyba nie będzie czymś niestosownym przedstawienie obyczajów panujących w Galii i Germanii".

Ex omnibus urbis partibus orto clamore, qui longius aberant, repentino tumultu perterriti, cum hostem intra portas esse existimarent, sese ex oppido eiecerunt. (Caes., Gall. 7, 47)

„Gdy ze wszystkich części miasta podniósł się krzyk, ci, którzy znajdowali się dalej, przerażeni tą naglą wrzawą, jako że sądzili, że wróg jest już za bramą, wypadli z miasta".

Cum solitudo et vita sine amicis insidiarum et metus plena sit, ratio ipsa monet amicitias comparare. (Cic., Fin. 1, 66)

„Skoro samotność i życie bez przyjaciół pełne jest niebezpieczeństw i strachu, sam rozum nakazuje zawiązywanie przyjaźni".

Induxi in animum, ne oderim item ut alias, quando orasti. (Pl., Mil. 1269)

„Postanowilem nie odpychać (jej) tak jak inne, skoro (o to) prosiłes”.

Quando igitur, inquam, a Cotta et Sulpicio haec omnis fluxit oratio [...], revortar ad eos ipsos. (Cic., Brut. 201)

„Wobec tego zatem - rzekłem - że cały ten (mój) wywód wziął swój początek od Kotty i Sulpicjusza, do nich wlaśnie (teraz) powrócę".

Carthaginienses [...] augent vallum, munimento sese, quando in armis parum praesidii foret, defensuri. (Liv. 28, 15)

„Kartagińczycy powiększają wał obronny, zamierzając bronić się przy pomocy szańców, jako że zbyt malo ochrony dawała (im) broñ".

Illi $[\ldots]$ exopto, ut relicuam vitam exigat cum eo viro, me qui sit fortunatior, quandoquidem illam a me distrahit necessitas. (Ter., Hec. 490-492)

„Życzę jej, by pozostalą część życia spędzila z tym mężczyzną, który ma więcej szczęścia niż ja, skoro mnie odbiera ją nieuchronny wyrok losu".

Obsecro hercle oroque, ut istuc, quid sit, actutum indices, quandoquidem mihi supplicandum servolo video meo. (Pl., Merc. 170-171)

„Zaklinam (więc) i proszę, byś natychmiast powiedział, o co chodzi, skoro widzę, że kornie muszę blagać mego slugę". 
Ubi neutri transeundi initium faciunt [...], Caesar suos in castra reduxit. (Caes., Gall. 2,9)

„Wobec tego, że żadna ze stron nie rozpoczęla przeprawy, Cezar wycofal swoich żolnierzy na powrót do obozu".

Id Tiberii animum altius penetravit [...]: nihil relictum imperatoribus, ubi femina manipulos intervisat, signa adeat. (Tac., Ann. 1,69)

„To glębiej wryło się w świadomość Tyberiusza (który pomyślał): nic już nie pozostalo wodzom, skoro kobiela lustruje manipuły, przeprowadza inspekcje chorągwi".

Ne unde raperet quidem quicquam reliqui erat, omni undique frumento, postquam ager parum tutus erat, in urbes munitas convecto. (Liv. 22, 40)

„Nie pozostało już nawet nic, skąd mógłby rabować, po tym gdy całe zboże, ponieważ pola były mało bezpieczne, zewsząd zwiezione zostało do obwarowanych miast".

Jak już wspomniano, tylko wyjątkowo, i głównie w łacinie późniejszej, zdarza się, że zdania tego typu mają charakter rozszerzający:

Eo maxime [...] te dicere hoc oportet, quando, ut praedicas, peritus iuris es. (Gell., Noc. Att. 16, 10,4)

„Zwłaszcza z tego powodu powinieneś wypowiedzieć ten (swój pogląd), że, jak deklarujesz, jesteś prawnikiem".

Niekiedy konektorom rozpoczynającym zdania tego typu towarzyszą partykuły praesertim (cum/quoniam), quippe (cum/quando/quoniam/ubi), utpote (cum), które wskazują na przyczynowy sens tych zdań, jednocześnie jednak ich treściom nadają status dodatkowego czy wybranego czynnika uzasadniającego stan wyrażony w zdaniu nadrzędnym ('zwłaszcza że / gdy', 'szczególnie że / gdy') lub też status dodatkowej, uzupełniającej informacji, identyfikującej specjalne okoliczności czy uwarunkowania towarzyszące temu stanowi i objaśniające go ('jako że', 'w sytuacji gdy'):

Quem (scil. Vercingetorigem) perterriti omnes Arverni circumsistunt atque obsecrant, ut suis fortunis consulat neu se ab hostibus diripi patiatur, praesertim cum videat omne ad se bellum translatum. (Caes., Gall. 7, 8)

„Wszyscy Arwernowie przerażeni obstępują i zaklinają Wercyngetoryka, by zatroszczył się o ich dobytek i nie pozwolił, by zostali złupieni przez wrogów, zwłaszcza że widzi, iż cała wojna przeniosla się na ich terytorium".

Non impedio, praesertim quoniam feriati sumus. (Cic., Rep. 1, 20)

„Nie mam nic przeciwko (prowadzeniu dyskusji), zwłaszcza że przeżywamy dzień świąteczny".

Lacrimis madentes genas siccate tandem, quippe cum iam possitis, quam plangebatis, amplecti. (Apul., Met. 5, 7)

„Osuszcie wreszcie mokre od łez policzki, zwłaszcza gdy już możecie uściskać tę, którą opłakiwaliście".

Nec reprehendo, quippe cum ipse istam reprehensionem non fugerim. (Cic., Att. 10, 3 A, 1) „Nie ganię, zwłaszcza że sam takiej nagany nie uniknąłtbym”. 
Quorum (scil. obsidum) quantus numerus fuerit, piget scribere, quippe ubi alibi trecentos ferme, alibi tria milia septingentos viginti quattuor fuisse inveniam. (Liv. 26, 49)

„Jak wielka była liczba zakładników, wstyd pisać, jako że w jednym źródle znajduję, że było ich około trzystu, w innym, że trzy tysiące siedmiuset dwudziestu czterech".

Audierat omnia Antigonus, utpote cum inter dicentes et audientem palla interesset. (Sen., Dial. 5, 22, 2)

„Usłyszal to wszystko Antygonos, jako że między rozmawiającymi a (nim) słuchającym znajdowała się (tylko) zasłona".

Oprócz spójników prymarnie czasowych sens przyczynowy kontekstowo implikować mogą niekiedy również konektory stanowione przez spójniki innego typu, np. identyfikujące sposób (quasi, tamquam, ut) czy zakres (quatenus):

Furius Scribonianus in exilium agitur, quasi finem principis per Chaldaeos scrutaretur. (Tac., Ann. 12, 52)

„Furiusz Skrybonianus posylany jest na wygnanie, ponieważ mial (jakoby) za pośrednictwem Chaldejczyków dociekać (przyszłej) śmierci cesarza".

Carsidius Sacerdos, reus tamquam frumento hostem Tacfarinatem iuvisset, absolvitur. (Tac., Ann. 4, 13)

„Karsydiusz Sacerdos, oskarżony, ponieważ miał wspierać dostawą zboża wrogiego Takfarynasa, zostaje uwolniony".

Transire pontem non potuit, ut extrema resoluta erant. (Liv. 21, 47)

„Przejść przez (pontonowy) pomost nie mógl, jako że jego końce zostały już odczepione (od brzegu)".

Indignata dea est et laedere quatenus ipsum non poterat (nec vellet amans), irascitur illi, quae sibi praelata est. (Ov., Met. 14, 40-42)

„Oburzyła się bogini (tj. Circe), i ponieważ jemu samemu (tj. Glausowi) krzywdy wyrządzić nie mogła (i nie chciala, kochając go), obraca swój gniew przeciwko tej, która uznana została za bardziej niż ona pożądaną (tj. przeciwko Scylli)".

Należy jednak zaznaczyć, iż można zaobserwować przypadki przekraczania granicy dzielącej systemowy zakres dystrybucyjny spójników quia i quod od zakresu dystrybucyjnego pozostałych spójników stanowiących konektory zdań przyczynowych, a więc przypadki użycia np. spójnika quia w kontekstach typowych dla quoniam, i vice versa. Proces zacierania tej granicy nasila się zwłaszcza w łacinie poklasycznej.

\subsection{Zdania okolicznikowe czasu}

Zdania podrzędne okolicznikowe czasu (zdania czasowe) stanowią w większości określniki predykatywne, a więc określniki form czasownikowych (współ)stanowiących orzeczenia zdań nadrzędnych; mogą jednak również być określnikami form czasownikowych użytych w sekundarnych funkcjach sładniowych (np. form bezokolicznikowych czy imiesłowowych), a także określnikami przydawek. Najczęściej mają charakter zdań uzupełniających, rzadziej rozszerzających. 
Treścią zdań podrzędnych okolicznikowych czasu są różnego rodzaju sytuacje, zdarzenia czy inne okoliczności, które ukazywane są jako charakterystyka czasowa zdarzeń będących treścią zdania nadrzędnego. Charakterystyka ta dokonywana jest poprzez wskazanie stosunku czasowego wiążącego zdarzenia (sytuacje) będące treścią obu zdań. Generalnie stosunek ten może być trojaki, tzn. może polegać na:

1) równoczesności, czyli współwystępowaniu zdarzeń będących treścią obu zdań,

2) uprzedniości zdarzeń będących treścią zdania podrzędnego w stosunku do zdarzeń wyrażanych przez zdanie nadrzędne,

3) następczości zdarzeń wyrażanych przez zdanie podrzędne w stosunku do zdarzeń będących treścią zdania nadrzędnego.

\section{A. RÓWNOCZESNOŚĆ}

Gdy zdarzenia będące treścią obu zdań składowych łączy stosunek współczesności, zdanie podrzędne wprowadzane może być za pośrednictwem konektora stanowionego przez spójnik cum. Orzeczenie zdania podrzędnego (współ)stanowione jest wówczas najczęściej przez formę czasownikową $w$ indikatiwie, a treść tego zdania służy zwykle jedynie identyfikacji czasu, w jakim miało miejsce zdarzenie będące treścią zdania nadrzędnego. Konektor wprowadzający tego typu zdanie tradycyjnie charakteryzowany jest funkcjonalnie jako tzw. cum temporale:

Gallo [...] narravi, cum proxime Romae fui, quid audissem, neque nominavi Balbum. (Cic., Att. 13, 49, 2)

„Opowiedziałem Gallusowi, gdy bylem w pobliżu Rzymu, co usłyszalem, ale nie wspomnialem o Balbusie".

Sex (libros) de re publica [...] tum scripsimus, cum gubernacula rei publicea tenebamus. (Cic., Div. 2, 3)

„Sześć (ksiąg) o państwie napisałem wtedy, gdy dzierżyłem ster rzeczypospolitej”.

Quem (scil. Catilinam) quidem ego cum ex urbe pellebam, hoc providebam animo [...] non mihi esse [...] Cethegi furiosam temeritatem pertimescendam. (Cic., Catil. 3, 16)

„Gdy wypędzałem go (tj. Katylinę) z miasta, przewidywałem to, że nie będę się musiał obawiać szalonej porywczości Cethegusa".

Fulgentis gladios hostium videbant Decii, cum in aciem eorum inruebant. (Cic., Tusc. 2, 59)

„Decjusze widzieli blyszczące miecze nieprzyjaciól, gdy rzucali się w ich szereg”.

Cum Caesar in Galliam venit, alterius factionis principes erant Haedui, alterius Sequani. (Caes., Gall. 6, 12)

„Gdy Cezar przybył do Galli, przywódcami jednego stronnictwa byli Eduowie, drugiego Sekwanowie".

Zdanie podrzędne może również identyfikować - na zasadzie wpółczesności czas zdarzenia desygnowanego przez funkcjonalny odpowiednik orzeczenia $w$ równoważniku zdania podrzędnego (np. accusativus cum infnitivo): 
Salve [...] ianua, quam Balbo dicunt servisse benigne olim, cum sedes ipse senex tenuit. (Catull. 67, 2-4)

„Bądź pozdrowiona bramo domu, która ponoć życzliwie służyłaś Balbusowi lata temu, gdy starzec (ten) zajmowal to domostwo".

Treść zdania podrzędnego może jednak być dodatkowo nacechowana znaczeniowo, np. kontrastując $\mathrm{z}$ treścią zdania nadrzędnego lub stanowiąc dla niej uzasadnienie; często zdania tego typu realizują specyficzne funkcje pragmatyczne $\mathrm{w}$ ramach dyskursu, którego są elementami:

Cum pugnabant maxume, ego tum fugiebam maxume. (Pl., Amph. 199) "Gdy (oni) najbardziej zaciekle walczyli, ja wtedy najbardziej zaciekle uciekałem”.

Cum id, quod mihi horribile videtur, tu omnino malum negas esse, capior. (Cic., Tusc. 2, 29)

„Gdy zaprzeczasz, by to, co mnie wydaje się straszne, było jakimkolwiek złem, czuję się wprowadzonym w bląd".

Może również mieć charakter eksplikatywny, stanowiąc swego rodzaju interpretację znaczenia (sensu) treści zdania nadrzędnego. Konektor wprowadzający zdania tego typu określany jest tradycyjnie jako tzw. cum explicativum:

Cum tacent, clamant. (Cic., Catil. 1, 21)

"Gdy milczą, (to przez to) krzyczą" (= jasno wyrażają swoje zdanie).

Epicurus $[. .$.$] ex animis hominum extraxit radicitus religionem, cum dis immortalibus et$ opem et gratiam sustulit. (Cic., Nat. 1, 121)

„Epikur doszczętnie wykorzenił z ludzkich dusz religię, gdy (= przez to, że) odebrał bogom nieśmiertelnym możliwość udzielania (ludziom) pomocy i okazywania taskawości".

De qua (epistula) cum dixero, totum hoc crimen decumanum peroraro. (Cic., Verr. 2, 3, 154)

„Gdy (tylko) powiem o tym liście, (to tym samym od razu) zamknę cale to oskarżenie dotyczące dziesięciny".

Specyficzną odmianę zdań czasowych stanowią zdania, w których treść zdania nadrzędnego stanowi de facto okoliczność odnoszącą się do czasu przebiegu zdarzenia wyrażanego przez zdanie podrzędne. Konektor wprowadzający zdania tego rodzaju charakteryzowany jest funkcjonalnie jako tzw. cum inversum:

Hannibal iam [...] subibat muros, cum repente in eum [...] erumpunt Romani. (Liv. 29, 7)

„Hannibal już podchodził pod mury, gdy nagle zaatakowali go Rzymianie”.

Iamque haec facere noctu apparabant, cum matres familiae repente in publicum procurrerunt. (Caes., Gall. 7, 26)

„I już szykowali się do uczynienia tego nocą, gdy nagle matki rodzin wybiegly na ulice”. 
Do tej samej kategorii zaliczyć należy zdania, w których treść zdania nadrzędnego identyfikuje wprost czas przebiegu lub trwania zdarzenia wyrażanego przez zdanie podrzędne:

Iam bienniumst, quom tecum rem habet. (Pl., Merc. 535)

„Mijają już (= trwa już to) dwa lata, kiedy zadaje się z tobą".

Multi anni sunt, cum bella a proconsulibus et a propraetoribus administrantur, qui aupicia non habent. (Cic., Div. 2, 76)

„Wiele lat już mija, gdy (= podczas których) wojny prowadzone są przez prokonsulów i propretorów bez obserwacji znaków wróżebnych".

Treścią zdań okolicznikowych czasu, rozpoczynanych konektorem cum, mogą być również zdarzenia, których współwystępowanie ze zdarzeniami wyrażanymi przez zdanie nadrzędne ma charakter powtarzalny, cykliczny. W przypadku wprowadzania zdań tego rodzaju konektor charakteryzowany jest tradycyjnie jako tzw. cum iterativum:

Horum libros [...] delectationis causa, cum est otium, legere soleo. (Cic., De orat. 2, 59) "Ich książki czytam zwykle dla przyjemności, kiedy jest czas wolny od zajęć".

Confirmantur nostra consilia, cum sentimus prudentibus fideliterque suadentibus idem videri. (Cic., Fam. 2, 13, 1)

„Utwierdają się nasze postanowienia, gdy czujemy, że ludzie rozważni i udzielający (nam) szczerych rad sądzą to samo".

W zdaniu podrzędnym czasowym, wprowadzanym za pośrednictwem konektora cum, orzeczenie (współ)stanowione może być również przez formę czasownikową w koniunktiwie. Ma to miejsce w przypadku, gdy treść tego zdania służy nie tyle wskazaniu na sam czas, co raczej na okoliczności, w jakich zachodziło zdarzenie będące treścią zdania nadrzędnego, w szczególności zaś, gdy między zdarzeniami wyrażanymi przez oba zdania składowe zachodzi relacja czasowo-przyczynowa. $Z$ tego względu zdania tego typu spełniają też różne funkcje pragmatyczne $\mathrm{w}$ warstwie strategii nadawczo-odbiorczej. Przy wyrażaniu współwystępowania zdarzeń będących treścią zdań składowych, w zdaniu podrzędnym, zgodnie z zasadami consecutio temporum, stosowany jest coniunctivus imperfecti bądź praesentis. Ponieważ tego rodzaju nacechowanie semantyczne ma miejsce szczególnie często w tekstach narracyjnych relacjonujących wypadki przeszłe, stosowany w nich konektor tradycyjnie charakteryzowany jest funkcjonalnie jako tzw. cum historicum bądź cum narrativum:

Cum (Caesar) ad oppidum [...] castra [...] poneret, pueri mulieresque ex muro passis manibus suo more pacem ab Romanis petiverunt. (Caes., Gall. 2, 13)

„Kiedy (Cezar) pod miastem budowal obóz, dzieci i kobiety, swoim zwyczajem wyciągając ręce $\mathrm{z}$ wysokości miejskich murów, dopraszaly się od Rzymian pokoju".

Cum essem otiosus in Tusculano, accepi tuas litteras. (Cic., Fam. 9, 18, 1)

"Gdy odpoczywatem w mym domu w Tuskulum, otrzymałem twój list". 
Cum videas eos $[\ldots]$ dolore non frangi, debes existimare $[\ldots]$ non esse malum dolorem. (Cic., Tusc. 2, 66)

„Skoro widzisz, że nie dają się oni pokonać bólowi, powinieneś uważać, że ból nie jest złem”.

Z podobną relacją lączącą treści obu zdań składowych możemy mieć do czynienia również w przypadku, gdy odnoszą się one do sytuacji powtarzających się (cyklicznych):

(Timoleon) veniebat $[\ldots]$ in theatrum, cum ibi concilium populi haberetur. (Nep., Timol. 4)

"(Timoleon) przybywal do teatru, gdy odbywalo się tam zgromadzenie ludowe".

Treść zdania podrzędnego może jednak pozostawać w stosunku do treści zdania nadrzędnego również $\mathrm{w}$ relacji o charakterze warunkowym:

Quod [...], cum me nulla vis cogeret, facere non auderem. (Cic., Phil. 5, 51)

"Gdyby żadna sila mnie nie zmuszała, nie odważylbym się tego czynić".

Użycie form koniunktiwu w orzeczeniu zdań rozpoczynanych konektorem cum może mieć miejsce także wtedy, gdy treść tych zdań w zasadzie nie identyfikuje relacji czasowych, lecz przeciwstawiana jest treści zdania nadrzędnego. Konektor tych zdań tradycyjnie charakteryzowany jest wówczas jako tzw. cum adversativum:

Animal $[\ldots]$, quem vocamus hominem $[\ldots]$, solum est $[\ldots]$ ex tot animantium generibus atque naturis particeps rationis et cogitationis, quom cetera sint omnia experta. (Cic., Leg. 1, 22)

„Stworzenie, które nazywamy człowiekiem, jako jedyne spośród tylu rodzajów i kategorii istot żywych otrzymało $w$ udziale rozum i zdolność myślenia, podczas gdy wszystkie pozostałe (stworzenia) są (tego) pozbawione".

Ante id tempus nemo aut miles aut eques a Caesare ad Pompeium transierat, cum paene cotidie nonnulli a Pompeio ad Caesarem perfugerent. (Caes., Civ. 3, 61)

„Wcześniej ani (zwykły) żołnierz, ani żaden jeździec nie przeszedł od Cezara na stronę Pompejusza, podczas gdy od Pompejusza niemal codziennie kilku zbiegalo do Cezara".

Wystąpienie czasownikowej formy koniunktiwu w zdaniu czasowym, które wprowadzane jest konektorem cum, wynikać może także ze składniowej zależności tego zdania od zdania, w którym orzeczenie również (współ)stanowione jest przez czasownikową formę w koniunktiwie, a więc np. od zdania nacechowanego modalnie lub zależnego składniowo od jeszcze innego zdania nadrzędnego. Tego rodzaju asymilacja formy czasownikowej co do wartości kategorii trybu określana bywa terminem attractio modi, a samą formę podległą tej asymilacji identyfikuje się określeniem coniunctivus obliquus:

Quis non, cum haec videat, inriserit? (Cic., Leg. 2, 2)

„Któż, gdy to widzi, nie roześmiałby się?” 
Poza tym równoczesność sygnalizują również takie spójniki i zaimki wprowadzające zdania czasowe, jak dum, donec, quoad, quando, ubi, quamdiu. Wskazywać one mogą na współistnienie stanów będących treścią obu zdań składowych, eksponując duratywność oraz implikując uzależnienie (czasu) trwania jednego z nich od (czasu) trwania drugiego ('dopóki', 'tak długo jak'). Orzeczenie zdania podrzędnego stanowione jest wtedy zwykle przez formę czasownikową w indikatiwie. Na ogół wyraża ona tę samą wartość kategorii czasu gramatycznego (lub przynajmniej fizycznego), co forma konstytuująca orzeczenie zdania nadrzędnego:

Donec eris sospes, multos numerabis amicos. (Ov., Trist. 1, 9, 5)

„Dopóki będzie ci się szczęścilo, liczyć będziesz (= będziesz miał) wielu przyjaciól”.

Donec gratus eram tibi [...], Persarum vigui rege beatior. (Hor., Carm. 3, 9, 1-4)

„Dopóki cieszyłem się twą laską, żyłem szczęśliwszy niż perski król”.

Vixit, dum vixit, bene. (Ter., Hec. 461)

"Póki żył, żył dobrze” (= używał życia, niczego sobie nie odmawiał).

Tiberium adulescentem ego vero, dum tu aberis, cotidie invitabo ad cenam. (Suet., Claud. 4)

"Młodego Tyberiusza, ja długo ty będziesz nieobecna, ja będę codziennie zapraszal na obiad".

Ut aegroto, dum anima est, spes esse dicitur, sic ego, quoad Pompeius in Italia fuit, sperare non destiti. (Cic., Att. 9, 10, 3)

„Jak chory, dopóki oddycha, ma ponoć nadzieję, tak ja, póki Pompejusz był w Italii, nie przestałem żywić nadziei".

Populus [...] est moderatior, quoad sentit et sapit. (Cic., Rep. 1, 65)

„Lud zachowuje spory umiar, dopóki kieruje się rozumem i rozsądkiem”.

Disces, quamdiu voles; tam diu autem velle debebis, quoad te, quantum proficias, non paenitebit. (Cic., Off. 1, 2)

„Będziesz się uczył, jak długo zechcesz; chcieć zaś powinieneś tak długo, jak długo będziesz zadowolony z tego, jaki postępy czynisz".

Aurum sumpsit a Clodia [...], habuit, quamdiu voluit. (Cic., Cael. 31) "Złoto wziął od Klodii, mial (je), jak długo chcial".

Quamdiu missilibus pugnatum est, anceps pugna erat. (Liv. 34, 14)

„Dopóki walczono rzucając pociskami, bitwa pozostawala nierozstrzygnięla”.

Ubi satur sum, (intestina) nulla crepitant; quando esurio, tum crepant. (Pl., Men. 926)

„Gdy się najem, w brzuchu mi nie burczy; gdy jestem głodny, wtedy burczy”.

Zdania tego typu, w szególności rozpoczynane konektorem dum, mogą również wyrażać jedynie wpółwystępowanie (w czasie) zdarzeń, które są ich treścią, ze zdarzeniami wyrażanymi przez zdanie nadrzędne, bez implikacji ich wzajemnego uwarunkowania. Przy realacjonowaniu współwystępujących zdarzeń przeszłych orzeczenie zdania stanowione może być przez formę czasownikową $w$ indikatiwie czasu imperfectum, rzadziej plusquamperfectum (dla wyrażenia stanu aktualnego w przeszłości): 
Dum haec Veiis agebantur, interim arx Romae Capitoliumque in ingenti periculo fuit. (Liv. 5, 47)

„Gdy to działo się w Wejach, to w Rzymie tymczasem zamek i Kapitol znalazły się w wielkim niebezpieczeństwie".

Dum in unam partem oculos animosque hostium certamen averterat, pluribus locis scalis capitur murus armatique in urbem transcenderunt. (Liv. 324)

„Podczas gdy walka zwróciła oczy i uwagę nieprzyjaciól w jedną stronę, w wielu (innych) miejscach przy pomocy drabin sforsowano mury i uzbrojeni żołnierze wkroczyli do miasta".

Często jednak orzeczenie takich zdań stanowione jest przez formę czasownikową w indikatiwie czasu teraźniejszego (praesens), przy czym w zdaniu nadrzędnym towarzyszy jej czasownikowa forma orzeczenia w czasie przeszłym. Mimo różnicy wyrażanych wartości kategorii czasu $w$ zdaniach takich również mamy do czynienia $\mathrm{z}$ sygnalizowaniem współwystępowania (w czasie) treści predykatywnych desygnowanych w obu zdaniach składowych, bowiem wartość praesens kategorii czasu formy orzeczenia zdania podrzędnego wyraża wówczas czas względny, a więc równoczesność. Tego rodzaju zastosowanie wartości praesens dla sygnalizowania równoczesności $\mathrm{z}$ określonym momentem $\mathrm{w}$ przeszłości znane jest jako tzw. praesens historicum:

Dum haec a Caesare geruntur, Treveri [...] Labienum [...] adoriri parabant. (Caes., Gall. 6,7)

„Podczas gdy te dzialania prowadzone były przez Cezara, Trewerowie przygotowywali atak na Labienusa."

Hoc ipsa in itinere alterae dum narrat, forte audivi. (Ter., Heaut. 271-272)

„Gdy w drodze opowiadała to innej, przypadkiem usłyszałem”.

Quem [...] ardorem studii censetis fuisse in Archimede, qui dum in pulvere quaedam describit attentius, ne patriam quidem captam esse senserit? (Cic., Fin. 5, 50)

„Jakim, waszym zdaniem, zapałem do nauki wykazywal się Archimedes, który gdy kreślil coś $\mathrm{z}$ uwagą na piasku, nawet nie zauważyl, że zdobyte zostało jego rodzinne miasto?"

Współwystępowanie w przeszłości mogą wyrażać również czasownikowe formy w praesens (historicum) w orzeczeniach obu zdań składowych:

Dum haec apud Caesarem geruntur, Labienus [...] cum quattuor legionibus Luteciam proficiscitur. (Caes., Gall. 7, 57)

"Gdy to dzialo się u Cezara, Labienus z czterema legionami wyruszył do Lutecji".

Dum ea in Samnio [...] geruntur, Romanis in Etruria interim bellum ingens multis ex gentibus concitur. (Liv. 10, 18)

„Podczas gdy to dzialo się w Samnium, to w Etrurii tymczasem przeciwko Rzymianom wzniecano ogromną wojnę ze strony wielu ludów".

Z kolei współwystępowanie $w$ przyszłości sygnalizować może wyrażająca czas względny forma czasownikowa w praesens raczej wówczas, gdy równocześnie implikuje ona wyznaczenie czasu (okresu) trwania zdarzenia, będącego treścią zdania nadrzędnego ('dopóki...'): 
Nec me meminisse pigebit Elissae [...], dum spiritus hos regit artus. (Verg., Aen. 4, 335-336)

„I nie będzie budziło przykrości wspomnienie Elissy (= Dydony), póki duch wlada moimi członkami".

Niekiedy orzeczenia zdań wprowadzanych konektorami donec i dum wyrażane są za pośrednictwem form czasownikowych w koniunktiwie. Dotyczy to w szczególności (choć nie wyłącznie) wypowiedzeń o nacechowanej modalności:

Conducta veni, ut fidibus cantarem seni, dum rem divinam faceret. (Pl., Epid. 500-501)

„Przybyłam wynajęta, by przygrywać na lutni starcowi, gdy składać będzie ofiarę".

Nisi, dum in integro res sit [...], caveant ne possessione urbis pellantur. (Liv. 3, 10)

"Chyba że, dopóki sprawa będzie otwarta, zadbają o to, by nie zostali wypędzeni z miasta".

(Elephanti) nihil sane trepidabant, donec continenti velut ponte agerentur. (Liv. 21, 28)

„(Słonie) w ogóle się nie bały, dopóki pędzone były po przytwierdzonej do stałego lądu (tratwie) jak po moście".

\section{B. UPRZEDNIOŚĆ}

Zdania, których treść ukazywana jest jako okoliczność poprzedzająca zdarzenia wyrażane przez zdanie nadrzędne, wrowadzane są za pośrednictwem konektorów postquam, posteaquam, simul (ac/atque), ut (primum/semel), ubi (primum), cum (primum) ('gdy', 'po tym jak', 'skoro tylko', 'odkąd'). Orzeczenia tych zdań (współ)konstytuowane są przez formy czasownikowe $\mathrm{w}$ indikatiwie, najczęściej czasu perfectum, rzadziej plusquamperfectum:

(Lacedaemonii), postquam [...] audierunt muros instrui, legatos Athenas miserunt. (Nep., Them. 6)

„(Lacedemończycy), po tym jak usłyszeli, że budowane są mury, wysłali do Aten posłów”.

Posteaquam in Asiam exercitus vester est transgressus, numquam a consule abscessi. (Liv. $37,53)$

"Odkąd wasze wojsko wkroczyło do Azji, nigdy nie odstąpiłem od konsula".

Themistocles [...], ut Lacedaemonem venit, adire ad magistratus noluit. (Nep., Them. 7)

„Temistokles, gdy przybył do Sparty, nie chcial stawić się przed urzędnikami”.

Ut primum post discessum latronis [...] libere senatus haberi potuit, semper flagitavi, ut convocaremur. (Cic., Phil. 5, 30)

„Gdy tylko po ustąpieniu (tego) łotra senat mógł obradować swobodnie, nieustannie domagałem się, by nas (senatorów) zwolano na posiedzenie".

Equites, ut semel in hostem evecti sunt [...] partim ex ipsis equis, partim desilientes immiscentesque se peditibus pugnabant. (Liv. 31, 35)

„Jeźdźcy, gdy tylko natarli na wroga, jedni z samych koni, inni zeskakując z nich i mieszając się z piechurami, toczyli walkę". 
Ubi omnes idem sentire intellexit, posterum diem pugnae constituit. (Caes., Gall. 3, 23)

„Gdy zobaczył, że wszyscy myślą to samo (= zgadzają się), zdecydowal stoczyć bitwę następnego dnia".

Haec iuventutem, ubi familiares opes defecerant, ad facinora incendebant. (Sall., Cat. 13)

„Te rzeczy, po tym gdy już zabrakło pieniędzy odziedziczonych po rodzinie, pobudzaly młodych ludzi do zbrodni".

Ubi primum inluxit [...], castra ingenti gaudio concitantur. (Liv. 7, 36)

„Gdy tylko się rozwidniło, obóz zatętnił wielką radością".

Nostri simul in arido constiterunt [...], in hostes impetum fecerunt. (Caes., Gall. 4, 26)

„Skoro tylko nasi stanęli na suchym lądzie, przypuścili atak na nieprzyjaciół”.

Quod hic simul atque sensit, de amicorum cognatorumque sententia Romam confugit. (Cic., S. Rosc. 27)

„Gdy tylko on to spostrzegł, za radą przyjaciól i krewnych uciekł do Rzymu”.

Forma (współ)stanowiąca orzeczenie może również wystąpić w czasie imperfectum sygnalizując stan, którego osadzenie w czasie może być bliskie współczesności z czasem, w którym osadzona jest treść zdania nadrzędnego:

Postquam instructi utrimque stabant, cum paucis procerum in medium duces procedunt. (Liv. 1, 23)

"Gdy obie strony staly już w gotowości, na środek wyszli wodzowie z niewielką liczbą najznakomitszych wojowników".

Metellus [...], postquam nox aderat, in castra cum exercitu revortitur. (Sall., Iug. 58)

"Metellus, gdy zapadła noc, powraca z wojskiem do obozu".

Niekiedy orzeczenie (współ)konstytuowane jest także przez czasownik w czasie praesens (historicum) lub w czasie przyszłym futurum exactum:

Catilina, ubi eos [...] convenisse videt [...], in abditam partem aedium secedit. (Sall., Cat. 20)

„Katylina, gdy widzi, że oni się już zeszli, udaje się do glębiej polożonej części domu” (= po tym, gdy zobaczył ..., udał się ...).

Ubi prandero, dabo operam somno. (Pl., Pseud. 664)

"Gdy zjem śniadanie, polożę się spać".

Id quidem tibi hercle fiet, ut vapules, Demaenetum simul ac conspexero hodie. (Pl., Asin. 478-479)

„To tobie, do czorta, przydarzy się to, że oberwiesz, gdy tylko zobaczę dziś Demeneta”.

Zdania tego typu wyrażać mogą także okoliczności powtarzające się (cykliczne): Tum denique homines nostra intellegimus bona, quom, quae in potestate habuimus, ea amisimus. (Pl., Capt. 142-143)

"My, ludzie, dopiero wtedy doceniamy nasze dobra, gdy to, co posiadaliśmy, już utraciliśmy". 
Cum rosam viderat, tum incipere ver arbitrabatur. (Cic., Verr. 2, 5, 27)

„Gdy zobaczył różę, wtedy uznawal, że zaczyna się wiosna”.

Cum ad aliquod oppudum venerat [...], lectica usque in cubiculum deferebatur. (Cic., Verr. 2, 5, 27)

„(Po tym) gdy przybył do jakiegoś miasta, wnoszony był na lektyce aż do sypialni”.

Podobnie jak równoczesność, także uprzedniość może być wyrażana za pośrednictwem zdań o charakterze adwersatywnym:

Biennium iam factum est, postquam abii domo. (Pl., Merc. 12)

"Mijają już dwa lata, odkąd odszedłem z domu”.

W zdaniach, które wyrażają zdarzenia uprzednie w stosunku do treści zdań nadrzędnych, orzeczenie może zawierać również formę czasownikową w koniunktiwie. Dotyczy to głównie zdań wprowadzanych konektorem cum (historicum vel narrativum) w ramach wypowiedzeń relacjonujących zdarzenia przeszłe; zgodnie z zasadą consecutio temporum uprzedniość wobec zdarzeń przeszłych wyrażana jest za pośrednictwem form czasownikowych w koniunktiwie plusquamperfecti:

Caesari cum id nuntiatum esset [...], maturat ab urbe proficisci. (Caes., Gall. 1, 7)

„Gdy Cezarowi o tym doniesiono, przyśpieszył wyjazd z Rzymu".

Triremes duae cum ad Bagradam flumen pervenissent, unde castra Romana conspiciebantur, Carthaginem rediere. (Liv. 30, 25)

„Dwa trójrzędowe okręty, po tym gdy dopłynęły do rzeki Bagradas, skąd widać było rzymski obóz, zawrócily do Kartaginy".

Czasownikowa forma koniunktiwu wystąpić może jednak również w zdaniu podrzędnym wprowadzanym innym konektorem, jak wskazuje na to poniższy przykład zdania implikującego iteratywność:

„(Fetialis) id ubi dixisset, hastam in fines eorum emittebat. (Liv. 1, 32)

„(Podczas rytuału wypowiadania wojny fecjał) po tym, gdy wyrzekl te (słowa), rzucal wlócznię na ich (tj. wrogów) terytorium".

\section{NASTĘPCZOŚ́}

Zdania podrzędne, których treści odnoszą się do czasu późniejszego niż czas zdarzeń wyrażanych $w$ zdaniu nadrzędnym, podzielić można na dwie podstawowe grupy. Pierwszą z nich tworzą zdania wprowadzane konektorami antequam i priusquam ('zanim', 'dopóki nie'), które mogą przybierać postać konektorów złożonych (ante quam, prius quam) bądź zestawionych (prius ... quam, ante ... quam 'wcześniej ... niż'); w tym ostatnim przypadku składnikiem zdania podrzędnego jest element quam. Orzeczenia tych zdań (współ)tworzone mogą być przez formy czasownikowe $\mathrm{w}$ indikatiwie bądź koniunktiwie.

$\mathrm{W}$ odniesieniu do treści faktywnych (tj. rzeczywistych zdarzeń) w przeszłości stosowane są zwykle w orzeczeniu formy indikatiwu perfecti: 
Nec quievere, antequam $[\ldots]$ Latium omne subegere. (Liv. 8, 13)

„Nie spoczęli, dopóki nie podbili całego Lacjum”.

Is prius quam hinc abiit ipsemet in exercitum, gravidam Alcumenam uxorem fecit suam. (Pl., Amph. 102-103)

„Zanim sam odszedł on stąd do wojska, swoją żonę Alkmenę uczynił brzemienną".

Hostes terga verterunt neque prius fugere destiterunt, quam ad flumen Rhenum $[\ldots]$ pervenerunt. (Caes., Gall. 1, 53)

„Nieprzyjaciele rzucili się do odwrotu i nie wcześniej zaprzestali ucieczki, aż doszli do rzeki Ren".

Przy wskazywaniu na zdarzenia przyszłe używane są formy indikatiwu presentis lub futuri exacti (secundi), rzadziej futuri primi:

Ante quam pro L. Murena dicere instituo, pro me ipso pauca dicam. (Cic., Mur. 2)

„Zanim zacznę mówić w obronie Mureny, powiem parę słów we własnej obronie”.

Cui prius quam de ceteris rebus respondeo, de amicitia, quam a me violatam esse criminatus est, pauca dicam. (Cic., Phil. 2, 2)

„Zanim odpowiem mu w pozostałych sprawach, powiem krótko na temat przyjaźni, o której pogwałcenie mnie oskarżył".

De qua (scil. Carthagine) vereri non ante desinam, quam illam excisam esse cognovero. (Cic., Sen. 18)

„Nie wcześniej przestanę odczuwać zagrożenie ze strony Kartaginy, aż dowiem się, że została ona doszczętnie zburzona".

Numquam conquiescam neque defatigabor ante, quam illorum $[\ldots]$ rationes et pro omnibus et contra omnia disputandi percepero. (Cic., De orat. 3, 145)

„Nie spocznę i nie ustanę, dopóki nie poznam ich metod dyskutowania zarówno na rzecz każdej sprawy, jak i przeciwko każdej z nich".

Ante quam de re publica [...] dicam [...], exponam vobis breviter consilium et profectionis et reversionis meae. (Cic., Phil. 1, 1)

„Zanim powiem o państwie, krótko przedstawię wam powody zarówno mego wyjazdu, jak i powrotu".

Formy indikatiwu praesentis mogą być stosowane również w przypadku stwierdzeń o charakterze ogólnym, omnitemporalnym; w podobnych kontekstach używane też bywają formy indikatiwu perfecti wyrażając następczy stan będący efektem zajścia procesu (zdarzenia) desygnowanego przez czasownik:

Plus dolet, quam necesse est, qui ante dolet, quam necesse est. (Sen., Lucil. 98, 8)

„Bardziej, niż jest to konieczne, cierpi ten, kto cierpi wcześniej, niż jest to konieczne”.

Membris utimur prius, quam didicimus, cuius ea causa utilitatis habeamus. (Cic., Fin. 3,66 )

„Czlonkami ciała posługujemy się jeszcze zanim poznamy, dla jakiego pożytku są nam one dane". 
W odniesieniu do zdarzeń możliwych, planowanych, przewidywanych, oczekiwanych, spodziewanych, a także hipotetycznych lub niezrealizowanych, stosowane są czasownikowe formy koniunktiwu. W tekstach relacjonujących zdarzenia przeszłe najczęściej są to formy koniunktiwu imperfecti:

Antequam consules in Etruriam pervenirent, Senones Galii multitudine ingenti ad Clusium venerunt. (Liv. 10, 26)

„Zanim konsulowie dotarli do Etrurii, Senonowie galliccy w wielkiej liczbie przybyli pod Kluzjum".

Samnites [...] antequam in muris viderent armatos, satis animi habuerunt ad prohibendos urbis aditu hostes. (Liv. 10, 43)

„Samnici, dopóki (jeszcze) nie zobaczyli na murach uzbrojonych ludzi, mieli dość odwagi, by powstrzymywać wrogów przed wejściem do miasta".

Ante in frontem lateraque pugnari coeptum est, quam satis unstrueretur acies. (Liv. 22, 4) „Od frontu i na flankach zaczęto walczyć, zanim szyk bojowy został wystarczająco uformowany".

Prius quam tu suum sibi venderes, ipse possedit. (Cic., Phil. 2, 96)

„Zanim ty mógłbyś mu sprzedać jego wlasność, sam objąl ją w posiadanie”.

Undique abierat, antequam consentirent. (Liv. 23, 28)

„Z każdego miejsca uchodził wcześniej, nim uzgodniono jakieś wspólne działania (przeciwko niemu)".

(Bellum) gerendum extemplo, antequam contrahere copias hostes possent [...], censebant. (Liv. 41, 1)

„Uważali, że (wojnę) należy podjąć natychmiast, zanim nieprzyjaciele zdołają zebrać siły”.

(Pleminius) mortuus [...] prius in vinclis est, quam iudicium de eo populi perficeretur. (Liv. 29, 22)

„(Pleminiusz) zmarł w więzieniu, zanim w jego sprawie zakończony został sąd przed ludem”.

Prius [...] rem transegit, quam quisquam eum facturum id suspicaretur. (Cic., Phil. 2, 21) „Wcześniej przeprowadzil sprawę, niż ktokolwiek mógl podejrzewać (podejrzewalby), że to uczyni".

Rzadko używane są formy koniunktiwu plusquamperfecti:

E re publica fuit $[\ldots]$ et $M$. Claudium [...] in Campaniam proficisci, et comitia non prius edici, quam is inde $[\ldots]$ revertisset. (Liv. 23,31 )

„W interesie rzeczpospolitej było i to, by Marek Klaudiusz udał się do Kampanii, i to, by wybory nie były oglaszane, dpóki on stamtąd nie powróci".

Jeśli zdarzenia przeszłe relacjonowane są w zdaniu nadrzędnym za pośrednictwem czasownikowej formy w praesens historicum, czasownikowa forma koniunktiwu w zdaniu podrzędnym może wystąpić albo w imperfectum, albo w praesens: 
Priusquam quicquam conaretur, Divitiacum ad se vocari iubet. (Caes., Gall. 1, 19) „Zanim cokolwiek przedsięwziąl, kazal wezwać do siebie Dywicjaka” (= niczego nie przedsięwziąl, zanim nie wezwal Dywicjaka).

Vercingetorix, priusquam munitiones ab Romanis perficiantur, consilium capit omnem ab se equitatum noctu dimittere. (Caes., Gall. 7, 71)

„Zanim ukończone zostają przez Rzymian obwarowania, Wercyngetoryks podejmuje decyzje odesłania od siebie nocą konnicy".

Czasownikowa forma $\mathrm{w}$ koniunktiwie praesentis stosowana jest również $\mathrm{w}$ odniesieniu do sytuacji przyszłych, a także w wypowiedzeniach ogólnych o charakterze omnitemporalnym:

Antequam ad populares leges venias, vim istius caelestis legis explana. (Cic., Leg. 2, 9)

„Zanim przejdziesz do (omawiania) praw dotyczących ludu, objaśnij moc owego prawa niebiańskiego".

In omnibus [...] negotiis, priusquam adgrediare, adhibenda est praeparatio diligens. (Cic., Off. 1, 73)

„We wszystkich przedsięwzięciach, zanim (do któregoś) przystąpisz, potrzebne jest staranne przygotowanie".

Crepant aedificia, antequam corruant. (Sen., Lucil. 103, 2)

„Budynki trzeszczą, nim się zawalą".

Drugą grupę zdań podrzędnych, które wyrażają treści następcze, tworzą zdania wrowadzane konektorami dum, quoad i donec ('dopóki nie', 'aż'). Ich treścią są zdarzenia (sytuacje, działania, okoliczności), realne bądź hipotetyczne, które ukazywane są jako wyznaczające kres sytuacjom będącym treścią zdania nadrzędnego. Orzeczenia tych zdań, podobnie jak w zdaniach przedstawionych wyżej, (współ)stanowione mogą być przez formy czasownikowe $w$ indikatiwie bądź koniunktiwie.

Użycie formy indikatiwu perfecti w orzeczeniu wiąże się ze wskazaniem na zdarzenia (sytuacje, okoliczności) rzeczywiście zaistniałe w przeszłości; konektorami najczęściej są spójniki quoad i donec:

Hasdrubal $[. .$.$] procul ab hoste [. .$.$] tenebat se, quoad [...] quattuor milia peditum et qu-$ ingenti equites in supplementum missi ex Africa sunt. (Liv. 23, 26)

„Hazdrubal trzymał się $z$ dala od przeciwnika, dopóki $w$ ramach posiłków nie przysłano 2 Afryki czterech tysięcy piechoty i pięciuset jeźdźców".

Epaminondas [...] ferrum [...] usque eo retinuit (in vulnere), quoad renuntiatum est vicisse Boeotios. (Nep., Epam. 9)

„Epaminondas grot włóczni zatrzymał w ranie tak długo, aż doniesiono (mu), że Beotowie zwyciężyli".

De comitiis, donec rediit Marcellus, silentium fuit. (Liv. 23, 31)

„W sprawie wyborów, dopóki nie powrócil Marcellus, panowało milczenie”.

Neque [...] finis huic iniuriae crudelitatique fiebat, donec populus $[. .$.$] senatum clamore$ coegit, ut... (Cic., Verr. 2, 4, 87) 
"I nie było końca tej niesprawiedliwości i okrucieństwa, dopóki lud krzykiem nie wymógl na senacie, by..."

Usque eo timui ne quis de mea fide atque integritate dubitaret, donec ad reiciundos iudices venimus. (Cic., Verr. 2, 1, 17)

„Obawiałem się, by ktoś nie zwątpił w moją wiarygodność i uczciwość tak długo, aż doszliśmy do kwestii wyłączenia (z udzialu w procesie) sędziów".

Użycie form koniunktiwu praesentis lub imperfecti, albo indikatiwu praesentis lub futuri, implikuje wskazanie na zdarzenia czy sytuacje hipotetyczne, zakładane, planowane, oczekiwane, przewidywane, bądź też będące przedmiotem czyichś intencji lub zamiarów; konektorami są zwykle spójniki dum i quoad, rzadziej donec:

Nunc et Scaevola [...] paulum requiescet, dum se calor frangat. (Cic., De orat. 1, 265)

„Teraz również Scewola trochę odpocznie, aż upał zelżeje” (= dopóki upał nie zelżeje).

An id exspectamus, quoad ne vestigium quidem Asiae civitatum atque urbium relinquatur? (Cic., Phil. 11, 25)

„Czyż mamy na to (tak dlugo) czekać, aż nawet ślad nie pozostanie po krajach i miastach Azji?".

Lupus observavit, dum dormitarent canes. (Pl., Trin. 170)

„Wilk wyczekiwał, aż psy zasną".

Illa deam longo prudens sermone tenebat, dum fugerent nymphae. (Ov., Met. 3, 364-365)

„Ona sprytnie absorbowala boginię dlugą rozmową, dopóki nie uciekty nimfy”.

Ad hunc (scil. Eumenem) Olympias [...] cum litteras et nuntios misisset in Asiam consultum, utrum [...] in Macedoniam veniret [...], huic ille primum suasit, ne se moveret et exspectaret, quoad Alexandri filius regnum adipisceretur. (Nep., Eum. 6)

„Gdy Olimpias wystała do niego (scil. Eumenesa) posłów z listami pytając, czy ma udać się do Macedonii, to poradził on jej przede wszystkim, aby się nie ruszała z miejsca i czekała, aż syn Aleksandra uzyska wladzę".

Homines [...], quod sibi volunt, dum id impetrant, boni sunt; sed id ubi iam penes sese habent, ex bonis pessimi et fraudulentissimi fiunt. (Pl., Capt. 232-236)

„Ludzie, dopóki nie uzyskają tego, czego dla siebie pragną, są dobrzy; ale gdy już znajdzie się to $w$ ich rękach, $z$ dobrych stają się najgorszymi i najbardziej podstępnymi".

$\mathrm{Ne}$ [...] exsurgatis, donec a me erit signum datum. (Pl., Bacch. 758)

„Nie wstawajcie (od stolu), dopóki nie dam znaku”.

Mihi quidem usque curae erit, quid agas, dum, quid egeris, sciero. (Cic., Fam. 12, 19, 3)

„Ja zaś tak dlugo niepokoil się będę o to, co robisz, aż dowiem się, co uczynileś”.

Jednak niekiedy użycie form koniunktiwu imperfecti bliskie jest wskazaniu na sytuację zaistniałą w przeszości:

(Consules) mansere infensi [...], donec magistratu abirent. (Tac., Ann. 5 (6), 11)

"(Obaj konsulowe) pozostali wrogo (do siebie) nastawieni aż do czasu, gdy ustąpili z urzędu”. 
Jeśli w zdaniu nadrzędnym wykładnikiem treści predykatywnej (orzeczeniem) jest czasownik exspectare, konektorem wprowadzającym zdanie o podobnej funkcji może być także spójnik $u t$, przy czym zdaniu temu można przypisać również status zdania dopełnieniowego:

Neque exspectant $[. .$.$] ut de eorum imperio ad populum feratur. (Caes., Civ. 1, 6)$

„Nie czekają na to, by (uchwały senatu) w sprawie powierzena im dowództwa przedstawione zostały ludowi (do zatwierdzenia)" (= nie czekają, aż zostaną przedstawione).

Wykładnikiem treści pozostających w czasowej relacji następczości w stosunku do treści wyrażanych $\mathrm{w}$ zdaniu nadrzędnym mogą być również zdania o charakterze inwersatywnym, wprowadzane za pośrednictwem konektora cum (inversum):

Quod ad multitudinem servis liberandis auctam [...] attinet [...], iam feceram haec [...], cum societatem mecum pepigistis. (Liv. 34, 31)

„Co do powiększonej liczby ludności poprzez nyzwalanie niewolników, to uczynilem to jeszcze zanim zawarliście ze mną przymierze".

Zarówno zdania wprowadzane konektorami antequam, priusquam, jak i rozpoczynane konektorami dum, donec, quoad, wyrażać mogą treści zrelacjonowane następczo w stosunku do treści desygnowanych przez inny składnik zdania nadrzędnego niż orzeczenie, a więc np. przez użyty w funkcji dopełnienia bezokolicznik:

(Zeno) te docebit mori [...] antequam necesse erit. (Sen., Lucil. 104, 21)

"(Zenon) nauczy cię umicrać zanim będzie to konieczne".

Caesar [...] exspectare [...] dum hostium copiae augerentur equitatusque reverteretur, summae dementiae esse iudicabat. (Caes., Gall. 4, 13)

„Cezar uważał, że czekanie, aż wzrosną siły nieprzyjaciół i powróci (ich) konnica, byłoby największym szaleństwem".

\subsection{Zdania okolicznikowe przyzwolenia}

Treścią zdań okolicznikowych przyzwolenia (zdań koncesywnych / przyzwalających) są okoliczności, które ani nie warunkują, ani nie uzasadniają, ani nie wynikają z sytuacji będącej treścią zdania nadrzędnego, lecz raczej z sytuacją tą stoją w logicznej sprzeczności lub przynajmniej nie są w jej kontekście oczywiste. Pod względem funkcjonalnym stanowią narzędzie służące realizacji określonej strategii argumentacyjnej na poziomie dyskursu, polegającej na konstatacji braku wpływu na treści, które orzekane są w zdaniu nadrzędnym, takich okoliczności (rzeczywistych bądź hipotetycznych), co do których można sądzić, że wpływ ten wywrzeć mogły(by).

Generalnie wyróżnić można dwie podstawowe klasy zdań koncesywnych. Pierwszą z nich tworzą zdania czysto koncesywne. Charakteryzują się one tym, że implikują faktywność, tzn. wyrażanej przez nie treści przypisany jest status rzeczywistych zdarzeń (sytuacji, okoliczności itp.). Zdania tego typu zwykle zawierają orzeczenie 
(współ)stanowione przez formę czasownikową w indikatiwie, a w zdaniu nadrzędnym towarzyszy im korelatywna partykuła adwersatywna tamen. Najczęściej wprowadzane są za pośrednictwem konektorów jednoznacznie gramatykalizujących koncesywność, tj. quamquam, etsi, tametsi ('chociaż, 'mimo że / iż'):

Mihi quidem Scipio, quamquam est subito ereptus, vivit tamen semperque vivet. (Cic., Lael. 102)

„Wszak Scypion, chociaż został mi nagle odebrany, to jednak (dla mnie) żyje i żyć będzie zawsze".

Medici, quamquam intellegunt saepe, tamen numquam aegris dicunt illo morbo eos esse morituros. (Cic., Div. 2, 54)

„Lekarze, mimo że wiedzą, to jednak nigdy nie mówią chorym, że wskutek tej właśnie choroby (na którą cierpią) umrą".

Haec, quamquam sunt gravia atque acerba, fortuna vestra vobis suadet. (Liv. 21, 13)

„Te (warunki pokoju), chociaż są trudne i dolegliwe, położenie, w jakim się znaleźliście, nakazuje wam przyjąc".

(Legati), etsi ab hoste ea dicebantur, tamen non neglegenda existimabant. (Caes., Gall. $5,28)$

„(Legaci), chociaż wiadomości te pochodziły od wroga, uznali, że nie należy ich lekceważyć”.

(Rutilius), etsi damnatus est, mihi videtur tamen inter viros optimos atque innocentissimos esse numerandus. (Cic., Font. 38)

"(Rutyliusz), chociaż został skazany przez sąd, wydaje mi się jednak godnym zaliczenia w poczet ludzi najświetniejszych i najbardziej niewinnych".

Eo, etsi scio pol eis fore meum conspectum invisum hodie. (Ter., Hec. 788)

"Idę, chociaż wiem, na Polluksa, że mój widok będzie dla nich dzisiaj niemiły".

Tametsi erant munitiones castrorum magnae, tamen sinistro cornu $[\ldots]$ celeriter adgressus Pompeianos ex vallo deturbavit. (Caes., Civ. 3, 67)

„Chociaż umocnienia obozu byly potężne, to jednak po szybkim ataku z lewego rogu przepędzil Pompejańczyków z wału".

Tametsi illis quieta movere magna merces videbatur, tamen postulavere pleriqui, ut proponeret, quae condicio belli foret, quae praemia armis peterent. (Sall., Cat. 21)

„Chociaż zburzenie panującego spokoju wydawało im się bardzo korzystne, to jednak wielu domagało się, by przedstawił, na jakich warunkach wojna ma być prowadzona, co zyskają orężem".

W zdaniach tego typu orzeczenie wyrażone może być również przez formę czasownikową w koniunktiwie. Użycie koniunktiwu najczęściej jest motywowane składniowo (np. w tekstach relacjonujących cudze wypowiedzi), jednak w łacinie późniejszej można zaobserwować coraz częstsze stosowanie form koniunktiwu bez motywacji składniowej (tj. zastępowanie form indikatiwu formami koniunktiwu):

Legatos ad Bocchum mittit postulatum, ne sine causa hostis populo Romano fieret; habere tum magnam copiam societatis amicitiaeque coniungundae [...] et, quamquam opibus suis confideret, tamen non debere incerta pro certis mutare. (Sall., Iug. 83) 
„Wysyła posłów do Bokchusa z rządaniem, by bez przyczyny nie stawał się wrogiem narodu rzymskiego; ma teraz dobrą okazję do zawarcia z nim przymierza i nawiązania przyjaźni, i chociaż ufa w swą silę, nie powinien zamieniać pewności na niepewność".

Lepidi $[. .$.$] societate, quamquam magnis condicionibus invitaretur, abstinuit. (Suet.,$ Iul. 3)

„Powstrzymał się od przymierza z Lepidusem, mimo iż zachęcany byl bardzo dogodnymi warunkami".

Rzadko faktywność implikują również zdania przyzwalające wprowadzane konektorami quamvis i etiamsi:

Erat $[\ldots]$ inter eos dignitate regia, quamvis carebat nomine. (Nep., Milt. 2)

"Cieszył się wśród nich autorytetm królewskim, mimo że nie miał tytułu (królewskiego)".

(Oratores) tantum inter se distant genere dicendi, ut nemo sit alteri similis, quamvis plurimi se ad eorum, quos probant, imitationem composuerint. (Quint., Inst. 2, 8, 2)

"(Mówcy) tak bardzo różnią się między sobą co do stylu przemawiania, że żaden z nich nie jest podobny do drugiego, mimo że wielu nastawilo się na naśladowanie tych, których uznają za najlepszych".

Si quis cum uxore sua tamquam cum aliena concumbat, adulter erit, quamvis illa adultera non sit. (Sen., Dial. 2, 7, 4)

„Jeśli ktoś kładzie się ze swoją żoną w przekonaniu, że jest to żona kogoś innego, będzie cudzolożnikiem, mimo że ona cudzolożnicą nie jest".

Equidem sic arbitror, etiamsi multa fallant eos, qui [...] divinare videantur, esse tamen divinationem. (Cic., Div. 1, 124)

„Ja natomiast uważam, że chociaż wiele rzeczy zwodzi tych, którzy zdają się wróżyć, to jednak dar wróżenia istnieje".

Kontekstowo faktywną koncesywnością mogą charakteryzować się zdania rozpoczynane konektorem cum, który funkcjonalnie identyfikowany jest jako tzw. cum concessivum. W zdaniach tych orzeczenie (współ)stanowione jest przez forme czasownikową w koniunktiwie:

(Socrates), cum facile posset educi e custodia, noluit. (Cic., Tusc. 1, 71)

„(Sokrates), chociaż łatwo mógł zostać wyprowadzony z więzienia, nie chciał”.

Cum primi ordines hostium transfixi pilis concidissent, tamen acerrime reliqui resistebant. (Caes., Gall. 7, 62)

"Mimo że pierwsze szeregi nieprzyjaciół padły przeszyte włóczniami, to jednak pozostałe zaciekle stawiały opór".

Drugą klasę zdań okolicznikowych przyzwolenia stanowią koncesywne zdania warunkowe (zdania koncesywno-warunkowe). Charakteryzują się one tym, że wyrażana przez nie treść ma charakter niefaktywny, tzn. stanowi ona okoliczność hipotetyczną, zakładaną. Podstawowymi konektorami wprowadzającymi zdania tego typu są spójniki quamvis i etiamsi / etiam si ('nawet jeśli / gdyby'; 'nawet przyjąwszy / założywszy, że'). Orzeczenia tych zdań najczęściej (współ)tworzą formy czasownikowe w koniunktiwie: 
Mihi vero L. Aemilius et $P$. Africanus [...] fortunati videbantur, nec ulli bonarum artium magistri non beati putandi, quamvis consenuerint vires atque defecerint. (Cic., Sen. 29)

„Uważałem, że Lucjusz Emiliusz i Publiusz Afrykański byli szczęśliwi i że żaden nauczyciel cnoty nie powinien być uważany za nieszczęśliwego, nawet gdyby (jego) siły wskutek starości oslably i wyczerpały się".

Verum tamen homines, quamvis in turbidis rebus sint, tamen $[\ldots]$ interdum animis relaxantur. (Cic., Phil. 2, 39)

„Przecież ludzie, nawet jeśli znajdują się w bardzo trudnym polożeniu, to jednak czasem odprężają swój umysr".

Ne ei quidem ipsi, quod loquuntur, id sentiunt, nec ab iudicio omnium mortalium, quamvis impii nefariique sint, sicut sunt, dissentire possunt. (Cic., Phil. 4, 9)

„Nawet oni sami nie myślą tego, co mówią, i nawet przyjąwszy, że są niegodziwcami i nikczemnikami, jako też są, nie mogą nie zgodzić się z powszechną opinią wszystkich ludzi".

Possum, quamvis in aqua sim, non natare; si nato, non possum in aqua non esse. (Sen., Dial. 2, 7, 5)

„Mogę, nawet jeśli jestem zanurzony w wodzie, nie pływać; jeśli (jednak) pływam, nie mogę nie być zanurzony w wodzie".

Ego vero istum $[. .$.$] nequissimum servum, etiamsi in amplissima familia natus sit, appel-$ landum puto. (Cic., Parad. 36)

„Doprawdy uważam, że kogoś takiego należy nazwać najbardziej nikczemnym niewolnikiem, nawet jeśli urodzitby się w najzacniejszej rodzinie".

An Epicuro [...] dicere licebit [...] nullum sapienti esse tempus, etiamsi uratur, torqueatur, secetur, quin possit exclamare: 'quam pro nihilo puto!'? (Cic., Tusc. 5, 73)

„Czy wolno będzie Epikurowi powiedzieć, że dla mędrca nie ma takiej chwili, by nawet gdyby go przypalano, torturowano czy sieczono, nie mógl zawolać: 'jakżesz mam to wszystko za nic!?"

Creati (sunt) sex tribuni militum consulari potestate, ut etiamsi cui eorum incommoda valetudo fuisset, copia magistratuum rei publicae esset. (Liv. 5, 31)

„Wybrano sześciu trybunów wojskowych $z$ wladzą konsularną, aby nawet w przypadku, gdyby komuś z nich nie dopisalo zdrowie, państwo mialo wystarczającą liczbę urzędników".

W zdaniach wprowadzanych przez konektor etiamsi / etiam si orzeczenie (współ)stanowione też bywa przez formę czasownikową w indikatiwie, mimo to treść zdania zachowuje status niefaktywny (hipotetyczny):

In omni certamine, qui opulentior est, etiam si accipit iniuriam, tamen, quia plus potest, facere videtur. (Sall., Iug. 10)

„W każdym sporze ten, który jest silniejszy, nawet jeśli doznaje krzywdy, to jednak (tylko) dlatego, że więcej może, uchodzi za tego, który ją wyrządza".

Est, etiam si non appellatur, hostis. (Cic., Prov. 12)

„Jest wrogiem, nawet jeśli nie jest tak nazywany".

Etiamsi cui videbitur illa in optimis studiis et artibus quieta vitae ratio beatior, haec civilis laudabilior est et inlustrior. (Cic., Rep. 3,6) 
„Nawet jeśli ów spokojny sposób życia pośród znakomitych nauk i umiejętności wyda się komuś szczęśliwszy, to jednak ten oddany działalności publicznej jest bardziej godny pochwaly i przynoszący większą slawę".

Z kolei hipotetyczność (niefaktywność), która implikowana jest w zdaniach otwieranych konektorem quamvis, skutkuje możliwością sygnalizowania także nieokreśloności kwantytatywnej, tj. nieokreśloności natężenia cech jakościowych lub ilościowych ('bez względu na to, jak wielki/liczny'; 'choćby nie wiem jak wielki/liczny', 'jakkolwiek byłby wielki/liczny'). Uwzględniającą tę możliwość interpretację znaczeniową można zastosować zarówno w odniesieniu do niektórych z przytoczonych wyżej zdań wprowadzanych tym konektorem, jak i do podanych niżej:

Una voluptas e multis obsuratur in illa vita voluptaria, sed tamen ea, quamvis parva sit, pars est eius vitae, quae posita est in voluptate. (Cic., Fin. 4, 31)

„Jedna przyjemność spośród wielu gubi się w owym życiu oddanym przyjemnościom, jednak bez względu na to, jak niewielka by ona była, stanowi część tego życia, które oparte jest na przyjemności".

Paupertas si malum est, mendicus beatus esse nemo potest, quamvis sit sapiens. (Cic., Fin. $5,84)$

„Jeśli ubóstwo jest złem, to żaden biedak nie może być szczęśliwy, choćby był nie wiem jak mądry".

W konsekwencji zdania wprowadzane tym konektorem często niosą podwójny sens, a kontekst nie zawsze pozwala na jednoznaczną interpretację; por. np.:

Tanta $[. .$.$] inportunitas hominum est, ut quamvis multum acceperint, iniuriae loco sit$ plus accipere potuisse. (Sen., Dial. 5, 31, 1)

„Tak wielka jest zachłanność ludzi, że bez względu na to, jak wiele (oni) otrzymali, jako (swą) krzywdę traktują (samo to), że mogli otrzymać więcej (a nie otrzymali)".

„Tak wielka jest zachłanność ludzi, że nawet jeśli wiele otrzymali, jako (swą) krzywdę traktują (samo to), że mogli otrzymać więcej (a nie otrzymali)".

Stosunkowo rzadko zdania koncesywne warunkowe wprowadzane są za pośrednictwem konektorów quamquam i etsi:

Nam vi quidem regere patriam aut parentis, quamquam et possis et delicta corrigas, tamen inportunum est. (Sall., Iug. 3)

„Bowiem sprawowanie przemocą wladzy nad ojczyzną czy rodzicami, nawet jeśli potrafitbyś (to czynić) i poprawiał (przy tym cudze) blędy, jest jednak czymś nieodpowiednim".

Sunt enim, qui, quod sentiunt, etsi optimum sit, tamen invidiae metu non audent dicere. (Cic., Off. 1, 84)

„Są tacy, którzy tego, co myślą, choćby było najlepsze, nie odważają się wypowiedzieć ze strachu przed wzbudzeniem niechęci do siebie".

Spośród konektorów, które koncesywność implikują kontekstowo, zdania koncesywne warunkowe wprowadzać mogą te, które są stanowione przez spójniki si oraz 
ut. W zdaniach przez nie rozpoczynanych orzeczenia cechują się czasownikowymi formami w koniunktiwie:

Nec providerant impetum hostium milites, nec, si providissent, satis virium ad arcendum erat. (Tac., Hist. 4, 15)

„Ani nie przewidzieli żołnierze ataku nieprzyjaciół, ani, nawet gdyby byli przewidzieli, nie było wystarczających sil do odparcia go".

Legem illam appellare fas non est, et ut sit lex, non debemus illam Hirtii legem putare. (Cic., Phil. 13, 32)

„Nie należy tego nazywać ustawą, a nawet jeśli byłoby to ustawą, nie powinniśmy lego uwazać za ustawę (autorstwa) Hircjusza".

Qui (scil. ager Bruttius), ut omnis coleretur, exiguus tamen tanto alendo exercitui erat. (Liv. 28, 12)

„Ziemia bruttyjska, nawet gdyby w całości była uprawiana, była za mała na to, by wyżywić tak wielkie wojsko".

Warunkową koncesywność kontekstowo implikować może także konektor złożony etiam cum, otwierający zdania z czasownikowymi formami indikatiwu w orzeczeniu:

In quo scelere, iudices, etiam cum multae causae [...] inter se congruere videntur, tamen non temere creditur $[\ldots]$, neque testis incertus auditur, neque accusatoris ingenio res iudicatur. (Cic., S. Rosc. 62)

„W przypadku takiej zbrodni, sędziowie, nawet jeśli wiele okoliczności wydaje się układać w spójną całość, to jednak nie wierzy się bezpodstawnie, nie daje się posłuchu niepewnemu świadkowi ani nie osądza się rzeczy w oparciu o talent oskarżyciela".

Pugiles vero, etiam cum feriunt adversarium [...], ingemescunt. (Cic., Tusc. 2, 56)

„Pięściarze zaś, nawet gdy uderzają przeciwnika, wydają jęki”.

Do zdań koncesywnych warunkowych zalicza się też zdania przybierające postać alternatywnej pary swobodnego wyboru, $z$ indikatywną bądź koniunktywną formą czasownikową w orzeczeniu:

Quare sive habes quid, sive nil habes, scribe tamen aliquid. (Cic., Att. 12, 12, 2)

„Przeto czy masz coś, czy też nie masz nic (szczególnego do pisania), coś jednak mi napisz”.

Perspicitis genus hoc quam sit facetum, quam elegans, quam oratorium, sive habeas vere quod narrare possis [...], sive fingas. (Cic., De orat. 2, 241)

„Widzicie, jak zabawny, jak elegancki, jak odpowiedni dla mówcy jest ten rodzaj (żartu), czy to ma się coś prawdziwego, co można opowiedzieć, czy to się zmyśla".

Kontekstowo znaczenia koncesywne wykazują również zdania, w których orzeczeniu, (współ)stanowionemu zwykle przez czasownikową formę w koniunktiwie, towarzyszy forma licet, której status może być dyskusyjny. Struktura morfologiczna tej formy niewątpliwie ma charakter czasownikowy i w wielu przypadkach wyraz ten również pod względem składniowym pełni funkcję (współ)wykładnika predy- 
katu (orzeczenia). Przykładowo może wspólnie $\mathrm{z}$ formą bezokolicznikową stanowić współwykładnik predykatu o nacechowanej modalności deontycznej (licet petere magistratus 'wolno ubiegać się o urzędy') lub samodzielnie stanowić taki wykładnik, otwierając miejsce dla podrzędnego zdania (licet laudem Fortunam 'wolno, bym chwalił Los') lub równoważnika zdania (licet me id scire 'wypada, abym to wiedział'). Jednak sens koncesywny implikuje brak semantycznej i składniowej autonomii, w związku z czym w tego typu zdaniach licet zdaje się tracić swe znaczenie modalne i zyskiwać status konektora (spójnika) będącego wykładnikiem podrzędności syntaktycznej. Dość instruktywny w tym względzie może być ostatni z przytoczonych niżej przykładów, w którym licet i etiam si tworzą wyraźną paralelę. Wyrażana w tych zdaniach koncesywność może mieć charakter zarówno faktywny, jak i hipotetyczny (warunkowy):

Quae a me habes [...], licet multa videantur, plerique haudquaquam artibus tuis pares plura tenuerunt. (Tac., Ann. 14, 55)

„Chociaż tego, co masz ode mnie, wydaje się wiele, liczni, którzy w żaden sposób nie dorównują twoim zaletom, otrzymali więcej".

Terras licet [...] et undas obstruat (Minos), at caelum certe patet; ibimus illac. (Ov., Met. 8, 185-186)

„Chociaż (Minos) zagradza ziemię i morze, to jednak niebo stoi otworem; pojdziemy tamtędy".

Non est magnus pumilio, licet in monte constiterit; colossus magnitudinem suam servabit, etiam si steterit in puteo. (Sen., Lucil. 76, 31)

„Karzeł nie jest wysoki, nawet jeśli stanąłby na górze; olbrzym zachowa swą wielkość, nawet gdyby stanął w wydrążonym dole".

$\mathrm{Z}$ drugiej strony swoboda, $\mathrm{z}$ jaką licet może zajmować pozycje $\mathrm{w}$ szyku linearnym, w tym możliwość wystąpiena na końcu całej struktury zdaniowej, zdają się przemawiać za tym, że gramatyczny status tej formy nie był w pełni ustabilizowany:

Fremant omnes licet, dicam, quod sentio. (Cic., De orat. 1, 195)

„Choćby wszyscy krzyczeli z oburzenia, powiem, co myślę".

\subsection{Zdania okolicznikowe warunku}

Zdania podrzędne okolicznikowe warunku (zdania warunkowe) tworzą wraz ze zdaniem nadrzędnym tzw. okres warunkowy (modus), tj. zdanie złożone, którego treścią są dwie hipotetyczne sytuacje wzajemne $z$ sobą powiązane na zasadzie warunkowania bądź wynikania. Oznacza to, że sytuacja będąca treścią zdania podrzędnego ukazywana jest jako warunkująca zaistnienie sytuacji stanowiącej treść zdania nadrzędnego, lub też sytuacja będąca treścią zdania nadrzędnego ukazywana jest jako konsekwencja zaistnienia sytuacji stanowiącej treść zdania podrzędnego. Zdanie podrzędne stanowi tzw. poprzednik okresu warunkowego (protasis), zaś zdanie 
nadrzędne następnik okresu warunkowego (apodosis). Podstawowym konektorem wprowadzającym poprzednik jest spójnik si ('jeśli', 'jeżeli’; 'jeśliby', 'gdyby'). Jeśli treść poprzednika podlega przeczeniu, stosowane są konektory nisi, ni ('jeżeli nie’; 'jeśliby nie', 'gdyby nie'), lub konektor si w połączeniu $\mathrm{z}$ odrębnym wykładnikiem negacji w postaci partykuły przeczącej (non, neque) bądź zaimka przeczącego (nemo, nihil, numquam, nusquam). W przypadku, gdy poprzednik poprzedza linearnie następnik, stosowane mogą być również konektory quodsi ('jeżeli więc') lub sin ('jeżeli zaś, 'jeśli jednak'), które pełnią równocześnie funkcję operatorów nawiązania międzywypowiedzeniowego.

$\mathrm{Z}$ uwagi na zróżnicowanie sposobu, w jaki uwzględniany jest status modalny sytuacji wyrażanych w obu zdaniach, tradycyjnie wyodrębnia się trzy typy zdań złożonych warunkowych, a więc trzy typy okresów warunkowych: 1) okres warunkowy rzeczywistości (modus realis), 2) okres warunkowy możliwości (modus potentialis), 3) okres warunkowy nierzeczywistości (modus irrealis).

\section{A. OKRES WARUNKOWY RZECZYWISTOSCI (modus realis)}

Z okresem tym mamy do czynienia, kiedy nadawca przedstawia jedynie związek między jakąś (hipotetyczną) sytuacją a jej konsekwencjami, bez wyrażania poglądu na temat możliwości czy też prawdopodobieństwa zaistnienia tej sytuacji. Treścią zdań okresu warunkowego rzeczywistości mogą być tak sytuacje konkretne (jednostkowe), jak i ogólne. Zwykle zarówno w poprzedniku, jak i w następniku, orzeczenia (współ)stanowione są przez formy czasownikowe $w$ indikatiwie różnych czasów, w zależności od relacji temporalnych łączących sytuacje wyrażane w obu zdaniach składowych, przy czym forma indkatiwu praesentis $w$ poprzedniku często używana jest również dla wyrażenia sytuacji przyszłej:

Si di sunt, est divinatio. (Cic., Div. 2, 41)

„Jeśli bogowie istnieją, to istnieje (również) wróżbiarstwo".

Si nato, non possum in aqua non esse. (Sen., Dial. 2, 7, 5)

„Jeśli pływam, nie mogę nie być zanurzony w wodzie”.

Quam (scil. naturam) si sequemur ducem, numquam aberrabimus. (Cic., Off. 1, 100)

„Jeśli podążymy za naturą jako przewodniczką, nigdy nie zblądzimy”.

Itaque in urbe maneo, si licebit, manebo. (Cic., Phil. 12, 24)

„Pozostaję zatem w mieście (i) jeśli będzie mi wolno, pozostanę".

Cenabis bene, mi Fabulle, apud me [...], si tecum attuleris bonam atque magnam caenam. (Catull. 13, 1-4)

„Dobrze u mnie zjesz, mój Fabulusie, jeśli (wcześniej) przyniesiesz z sobą dużo dobrego jedzenia".

Perii, si me aspexerit. (Pl., Amph. 320)

„Przepadlem, jeśli mnie zobaczy”. 
Si bellum omittimus, pace numquam fruemur. (Cic., Phil. 7, 19)

„Jeśli odrzucimy wojnę, nigdy nie będziemy cieszyć się pokojem”.

Si vincimus, omnia nobis tuta erunt. (Sall., Cat. 58)

"Jeżeli zwyciężymy, zyskamy pełnię bezpieczeństwa".

Si parum intellexti, dicam denuo. (Pl., Rud. 1103)

„Jeśli niewiele zrozumiateś, powiem jeszcze raz".

Si peccavi [...], insciens feci. (Ter., Heaut. 631-632)

„Jeśli popełniłam błąd, zrobiłam to nieumyślnie".

Następnik wyrażać może treści dodatkowo nacechowane modalnie, w związku z czym jego orzeczenie (wpsół)konstytuować może nie tylko czasownikowa forma $\mathrm{w}$ indikatiwie, ale również $\mathrm{w}$ imperatiwie lub koniunktiwie:

Si pace frui volumus, bellum gerendum est. (Cic., Phil. 7, 19)

"Jeśli chcemy cieszyć się pokojem, musimy stoczyć wojnę".

Si ille tali ingenio exitum non reperiebat, quis reperiet? (Cic., Att. 12, 1, 1)

„Jeśli on, o takich zdolnościach, nie był w stanie znaleźć wyjścia (z tej sytuacji), to któż znajdzie?"

Si patriam prodere conabitur pater, silebitne filius? (Cic., Off. 3, 90)

„Jeśli ojciec próbowal będzie zdradzić ojczyznę, czy syn będzie milczał?"

Dic, si vis, de quo disputari velis. (Cic., Tusc. 2, 13)

„Powiedz, jeśli chcesz, co pragniesz uczynić przedmiotem dyskusji”.

Si quid in te peccavi $[\ldots]$, ignosce! (Cic., Att. 3, 15, 4)

"Jeśli w czymś wobec ciebie zawinilem, wybacz!"

Sed ad eos, si placet, qui vita excesserunt, revertamur. (Cic., Brut. 262)

„Lecz jeśli można, powrócimy do (omawiania) tych, którzy już nie żyją".

Si volumus aequi rerum omnium iudices esse, hoc primum nobis persuadeamus neminem nostrum esse sine culpa. (Sen., Dial. 4, 28, 1)

„Jeżeli chcemy być sprawiedliwymi sędziami wszelkich spraw, nabierzmy przede wszystkim przekonania co do tego, że nikt $\mathrm{z}$ nas nie jest bez winy".

Si quid habes certius, velim scire. (Cic., Att. 4, 10, 1)

„Jeśli masz jakąś pewniejszą wiadomość ( $w$ tej sprawie), to chciałbym (ją) znać".

Quin etiam corpus libenter obtulerim, si repraesentari morte mea libertas civitatis potest. (Cic., Phil. 2, 118)

„Chętnie móglbym nawet ofiarować swe cialo (= poświęcić życie), jeśli dzięki mej śmierci przywrócona może zostać wolność państwa".

Ad cenam petitionis causa si quis vocat, condemnetur? (Cic., Mur. 74)

„Jeśli ktoś zaprasza na przyjęcie z tego powodu, że ubiega się o urząd, to czy ma zostać potępiony?" 
Należy jednak zaznaczyć, że określone nacechowanie modalne (intencjonalne: imperatywne, postulatywne) wyrażać może także czasownikowa forma $\mathrm{w}$ indikatiwie (futuri) bez żadnych dodatkowych wykładników modalności:

Tu, quoniam necesse nihil est, sic scribes aliquid, si vacabis. (Cic., Att. 12, 38, 2)

„Ty (zaś), jako że nie ma żadnej pilnej potrzeby, to napisz(esz) mi coś wówczas, jeśli będziesz mial wolny czas".

W poprzedniku orzeczenie może zawierać formę w koniunktiwie, jeśli:

a. treść zdania ma charakter ogólny, a podmiot jest referencjalnie nieokreślony:

Quicquid (providentia) nobis dedit, breve est et exiguum, si compares mundi totius aevo. (Sen., Lucil. 74, 10)

„Wszytko, cokolwiek dala nam opatrzność, znikome jest i drobne, jeśli porównać to $z$ trwałością calego świata".

Si prohibita impune transcenderis, neque metus ultra, neque pudor est. (Tac., Ann. 3, 54)

„Jeśli przekroczy się zakaz nie ponosząc kary, to potem nie ma już ani strachu, ani poczucia wstydu".

b. poprzednik ma znaczenie koncesywne:

Inimicum habebas neminem. Si haberes, tamen non ita vixeras, ut metum iudicii propositum habere deberes. (Cic., Verr. 2, 5, 74)

„Wroga nie miałeś żadnego. A nawet jeśli miałeś, to jednak nie żyleś tak, byś musiał lękać się procesu sądowego".

c. wskazuje się na zdarzenie powtarzające się w przeszłości:

Ac tamen accusatores, si facultas incideret, poenis adficiebantur. (Tac., Ann. 6, 30)

„Jednak również oskarżyciele, jeśli nadarzała się taka możliwość, ponosili kary”.

Si quam (hastam Romani) incidissent aut praefregissent, hastile fragmento ipso acuto inter spicula integrarum hastarum velut vallum explebat. (Liv. 32, 17)

„Jeśli jakąś włócznię (z macedońskiej falangi) Rzymianie przecięli lub złamali, jej drzewce samym tym zaostrzonym (wskutek złamania) końcem uzupełniało, pośród grotów nietkniętych włóczni, jakby palisadę (z nich złożoną)".

W tym ostatnim przypadku orzeczenie może jednak być (współ)stanowione także przez formę czasownikową $w$ indikatiwie (plusquamperfecti):

Huc se referebant, hinc, si qua maior oppresserat vis, oppugnabant. (Caes., Civ. 2, 8)

„Do tego miejsca się wycofywali, stąd, jeśli nacierały jakieś większe siły, bronili się".

Si quod erat grande vas et maius opus inventum, laeti adferebant; si minus eius modi quidpiam venari potuerant [...], capiebantur patellae, paterae, turibula. (Cic., Verr. 2, 4, 47)

„Jeśli znalazło siç jakieś wielkie naczynie lub znamienitsze dzielo sztuki, z radością (je) przynosili (Werresowi); jeśli nic bardzo mogli upolować coś takiego, zabierali misy, puchary, kadzielnice". 


\section{B. OKRES WARUNKOWY MOŻLIWOŚCI (modus potentialis)}

Zdania okresu warunkowego możliwości implikują możliwość zaistnienia wyrażanej w poprzedniku sytuacji, której konsekwencje stanowią treść następnika. Orzeczenie, zarówno w poprzedniku, jak i następniku, zawiera formę czasownikową w koniunktiwie praesentis. Stosunkowo rzadko w poprzedniku pojawia się forma koniunktiwu perfecti dla zaznaczenia uprzedniości zdarzenia, będącego jego treścią, w stosunku do sytuacji wyrażanej w następniku:

Dies me deficiat, si reges imperatoresque temere in hostium terram transgressos cum maximis cladibus exercituumque suorum enumerare velim. (Liv. 28, 41)

„Zabrakłoby mi dnia, gdybym chciał wyliczać królów i wodzów, którzy pochopnie wkroczyli na teren nieprzyjaciól, przypłacając to wielkimi klęskami własnymi i klęskami swoich wojsk".

Hanc ego viam, iudices, si aut asperam atque arduam aut plenam esse periculorum aut insidiarum negem, mentiar. (Cic., Sest. 100)

„Gdybym, sędziowie, zaprzeczył temu, iż droga ta jest uciążliwa i żmudna, pełna niebezpieczeństw i zasadzek, sklamałbym".

Quid opponas tandem, si negem me umquam ad te istas litteras misisse? (Cic., Phil. 2, 8)

"Ale co odpowiedziałbyś, gdybym zaprzeczył, że kiedykolwiek wystałem do ciebie ten list?"

Si a corona relictus sim, non queam dicere. (Cic., Brut. 192)

"Gdybym zostal opuszczony przez krąg słuchaczy, nie zdolatbym przemawiać".

Si gladium quis apud te sana mente deposuerit, repetat insaniens, reddere peccatum sit, officium non reddere. (Cic., Off. 3, 95)

„Gdyby ktoś, będąc przy zdrowych zmyslach, zdeponowal u ciebie miecz, a potem domagał się jego zwrotu popadłszy w obłęd, to blędem byloby zwrócić go, obowiązkiem zaś nie zwracać".

Orzeczenie następnika zawierać może również formę czasownikową w indikatiwie. Ma to miejsce szczególnie w przypadku, gdy z orzeczeniem tym związana jest nacechowana modalność deontyczna (konieczność, możliwość, powinność), a więc gdy orzeczenie to (współ)tworzone jest przez czasowniki lub wyrażenia modalne typu: volo, possum, debeo, oportet, opus / necesse est, bądź też przez nacechowane modalnie participia futuri ( $w$ ramach tzw. coniugatio periphrastica). Jednak także $w$ innego rodzaju zdaniach spotyka się w orzeczeniu następnika formy indikatywne czasu przyszłego lub teraźniejszego:

Qui te neque debent adiuvare, si possint, neque possunt, si velint. (Cic., Verr. 2, 4, 20)

„Oni ani nie powinni ci pomóc, jeśliby mogli, ani nie mogliby, gdyby chcicli”.

Intrare, si possim, castra hostium volo. (Liv. 2, 12)

„Jeśli mógłbym, to chciałbym wejść do obozu wroga".

Quae si reiciamus, illa quoque, unde haec nata sunt, reiciemus. (Cic., Nat. 3, 47)

"Gidybyśmy te rzeczy odrzucili, to (tym samym) odrzucimy również to, co doprowadzilo do ich powstania". 
Nam saepe, si pecuniae [...] desint, facultas fuisse faciundi non videtur. (Cic., Inv. 2, 44)

"Często bowiem w odniesieniu do sytuacji, gdyby zabrakło pieniędzy, nie wydaje się, by była możliwość działania".

Si diligenter attendamus, apta inter se esse intellegimus haec, quae negotiis, et illa, quae personis sunt adtribuita. (Cic., Inv. 2, 44)

„Gdybyśmy się uważnie zastanowili, to zrozumielibyśmy, że to, co przypisane jest sprawom, i to, co przypisane jest ludziom, pozostaje z sobą w ścisłym związku".

Formalne cechy okresu warunkowego możliwości wykazują również zdania, których treścią są sytuacje obiektywnie nieprawdopodobne. Zdania tego typu pełnią funkcję retoryczną, służąc uwiarygodnieniu określonej tezy. Zastosowanie formalnych wykładników modus potentialis, będące swoistym zawieszeniem implikacji nieprawdopodobieństwa, ma na celu wzmocnienie argumentacyjnej, perswazyjnej siły wyrażanych treści (nb. poparcie tezy argumentem, któremu równocześnie odmawiałoby się prawdopodobieństwa, raczej osłabiałoby to twierdzenie, niż je wzmacniało); tradycyjnie zdania tego typu określane są terminem exempla ficta:

Si qui deus mihi largiatur, ut [...] repuerascam [...], valde recusem nec vero velim quasi decurso spatio ad carceres a calce revocari. (Cic., Sen. 83)

„Gdyby jakiś bóg gotów był udzielić mi tej łaski, bym na nowo stał się dzieckiem, stanowczo sprzciwiłbym się i nie chciałbym w sytuacji, gdy pokonałem już niemal cały dystans, zostać od mety przywolany z powrotem do linii startowej".

Omnes ex omni aetate, qui in hac civitate intellegentiam iuris habuerunt, si unum in locum conferantur, cum Ser. Sulpicio non sint comparandi. (Cic., Phil. 9, 10)

„Gdyby w jednym miejscu zostali zebrani ze wszystkich epok wszyscy ci, którzy w tym państwie posiedli znajomość prawa, nie dorównywaliby Serwiuszowi Sulpicjuszowi".

Si exsistat hodie ab inferis Lycurgus [...], nunc se patriam et Spartam antiquam agnoscere dicat. (Liv. 39, 37)

„Gdyby powstał dziś z grobu Likurg, powiedziałby, że teraz właśnie rozpoznaje swą ojczyzn̨̧ i dawną Spartę".

Quid non [...] fecistis, quod faciat, si reviviscat [...], Cn. Pompeius ipse? (Cic., Phil. $13,34)$

"Czego nie zrobiliście (takiego), co zrobilby, gdyby ożył, sam Gnejusz Pompejusz?"

Również w tego typu zdaniach następnik zawierać może orzeczenie (współ)tworzone przez formę czasownikową w indikatiwie czasu przyszłego lub teraźniejszego:

Si quis formicis det intellectum hominis, nonne et illae unam aream in multas provincias divident? (Sen., Nat. 1, proem. 10)

„Gdyby ktoś mrówkom dał ludzki rozum, to czyż one również nie podzielą jednego obszaru na wiele (odrębnych) działek?"

Orestes si accusetur matricidii, nisi hoc dicat: 'iure feci; illa enim patrem meum occiderat', non habet defensionem. (Cic., Inv. 1, 18)

„Orestes, gdyby został oskarżony o matkobójstwo, to jeśli nie powiedziałby: 'uczynilem słusz-

nie; ona bowiem zabila mego ojca', nie obroni(łby) się". 


\section{OKRES WARUNKOWY NIERZECZYWISTOSCI (modus irrealis)}

Zdania okresu warunkowego nierzeczywistości cechują się tym, że zawartemu w nich twierdzeniu o istnieniu określonych konsekwencji wynikających z jakiejś sytuacji towarzyszy równocześnie implikacja nierealności lub (tylko) niefaktywności owej sytuacji. W zdaniach tych sygnalizuje się zatem, iż wyrażana w poprzedniku sytuacja ma charakter wyłącznie hipotetyczny, pomyślany, teoretyczny, i wynika to albo $\mathrm{z}$ tego, że jej aktualizacja w rzeczywistości jest niemożliwa, nieprawdopodobna, nierealna, albo $\mathrm{z}$ tego, że chociaż mogłaby ona mieć miejsce, to jednak nie jest bądź nie została zaktualizowana. Orzeczenia w obu zdaniach składowych zawierają formy czasownikowe w koniunktiwie: czasu imperfectum - jeśli wyrażane sytuacje odnoszą się do teraźniejszości lub przyszłości, albo czasu plusquamperfectum - jeśli odnoszą się do przeszłości:

Si somnum capere possem, tam longis te epistulis non obtunderem. (Cic., Att. 8, 1, 4)

„Gdybym mógl spać, nie naprzykrzałbym ci się tak długimi listami”.

Divitias nego bonum esse, nam si essent, bonos facerent. (Sen., Dial. 7, 24, 5)

„Zaprzeczam temu, by bogactwa byly dobrem, howiem gdyby byly, czynilyby (ludzi) dobrymi".

Quae si $[\ldots]$ fato facta putarem, ferrem paulo facilius, sed omnia sunt mea culpa commissa. (Cic., Fam. 14, 1, 1)

„Gdybym uważal, że stało się tak wskutek zrządzenia losu, znositbym to trochę fatwiej, ale (niestety wiem, że) wszystko to dokonało się z mojej winy".

Quodsi ita natura paratum esset, ut ea dormientes agerent, quae somniarent, alligandi omnes essent, qui cubitum irent. (Cic., Div. 2, 122)

„Gdyby więc natura tak zrządzila, że śpiący czyniliby to, co im się śni, to trzeba by było związać wszystkich tych, którzy kladą się spać".

Haec mea, M. Antoni [...], de Pompeio et de re publica consilia [...] si valuissent, res publica staret, tu tuis flagitiis, egestate, infamia concidisses. (Cic., Phil. 2, 24)

„Gdyby, Marku Antoniuszu, tych moich rad w sprawie Pompejusza i rzeczpospolitej usluchano, rzeczpospolita ostalaby się, ty zaś byłbyś upadł pod ciężarem swych haniebnych postępków, nędzy i niesławy".

Si ante voluisses, esses (locuples); nunc sero cupis. (PI., Trin. 568)

„Gdybyś wcześniej chcial, byłbyś bogaczem; teraz za późno pragniesz".

Quas (naves) si occupavissent [...], portum ac mare totum in sua potestate haberent. (Caes., Civ. 3, 111)

„Gdyby zajęli byli te okręty, mieliby pod kontrolą port i cale morze”.

Si occidisset, recte fecisset, sed non occidit. (Quint., Inst. 7, 1, 16)

„Gdyby byl zabil, uczynithy slusznie, ale nie zabil".

Quae [...] vita fuisset Priamo, si ab adulescentia scisset, quos eventus senectutis esset habiturus? (Cic., Div. 2, 22)

"Jakież życie mialby Priam, gdyby od mlodości wiedzial, co go spotka na starość?" 
Niekiedy jednak treści desygnowane przez orzeczenie z czasownikową formą w koniunktiwie imperfecti odnosić się mogą do przeszłości:

(In senatum) si tum veniret, me [...] socium suorum in re publica consiliorum videre posset. (Cic., Sest. 63)

„Gdyby wtedy przyszedł (do senatu), mógłby zobaczyć, że jestem sprzymierzeńcem jego politycznych zamierzeń".

Quintus fuit mecum dies compluris et, si ego cuperem, ille vel pluris fuisset. (Cic., Att. 16, $5,2)$

„Kwintus spędził ze mną niemało dni, i gdybym chciał, spędzilby jeszcze więcej”.

Qui [...] si nihil ad percipiendam colendamque virtutem litteris adiuvarentur, numquam se ad earum studium contulissent. (Cic., Arch. 16)

„Gdyby w poznawaniu i doskonaleniu zalet moralnych literatura w ogóle nie była im pomocna, nigdy nie zdecydowaliby się na jej zgłębianie".

W ramach okresu warunkowego nierzeczywistości orzeczenie następnika może zawierać formę czasownikową w indikatiwie czasu przeszłego. Ma to miejsce w przypadku, gdy orzeczenie to nacechowane jest modalnie, tzn. gdy (współ)stanowione jest przez czasowniki i wyrażenia modalne typu: volo, possum, debeo, oportet, opus est, necesse est lub przez nacechowane modalnie imiesłowy czasu przyszłego (w ramach tzw. coniugatio periphrastica):

Deleri totus exercitus potuit, si fugientes persecuti victores essent. (Liv. 32, 12)

„Cale wojsko mogłoby ulec unicestwieniu, gdyby zwycięzcy rzucili się w pościg za uciekającymi".

Omnibus eum contumeliis onerasti, quem patris loco, si ulla in te pietas esset, colere debebas. (Cic., Phil. 2, 99)

„Obrzuciteś wszelkimi obelgami tego, którego powinineś szanować jak ojca, gdybyś miał w sobie jakiekolwiek poczucie powinności".

Si Romae Cn. Pompeius privatus esset hoc tempore, tamen ad tantum bellum is erat deligendus atque mittendus. (Cic., Manil. 50)

„Gdyby Gnejusz Pompejusz nie pelnil wtedy w Rzymie żadnych urzędów, to i tak wlaśnie jego należałoby wybrać i wyslać na tak wielką wojnę".

Si unum diem morati essetis, moriendum omnibus fuit. (Liv. 2, 38)

"Gdybyście się spóźnili o jeden dzień, wszyscy musieliby zginąć".

Ad quem (scil. tumulum) capiendum si luce palam iretur, [...] haud dubie hostis breviore via praeventurus erat. (Liv. 22, 24)

"Gdyby otwarcie wyruszono zdobyć wzgórze za dnia, bez wątpienia przeciwnik dotarlby (zdolny byłby dotrzeć) tam wcześniej, mając (do niego) krótszą drogę".

Quid [...] futurum fuit, si illa pastorum convenarumque plebs [...] agitari coepta esset tribuniciis procellis? (Liv. 2, 1)

"Co by było, gdyby ta gromada pastuchów i przyblędów zaczęla być wykorzystywana w rozruchach wszczynanych przez trybunów?" 
Forma indikatiwu może wystąpić w orzeczeniu następnika także wówczas, gdy ma on charakter ekspresywny (potoczny), lub gdy podkreśla się, że niewiele brakowało do zaistnienia sytuacji będącej jego treścią. Forma ta występuje wówczas w czasie:

\section{a. plusquamperfectum:}

Perieramus, si hic magistratus esset. (Sen., Controv., 10, 1, 1)

„Gdyby ten zostal urzędnikiem, to już po nas”.

Nisi Latini sua sponte arma sumpsissent, capti et deleti eramus. (Liv. 3,19)

„Gdyby Latynowie z wlasnej inicjatywy nie chwycili za broń, zostalibyśmy pojmani i unicestwieni (= to już nas nie ma)".

Et peractum erat bellum sine sanguine, si Pompeium Brundisi opprimere potuisset. (Flor., Epit. 2, 13)

„I gdyby zdolał pokonać Pompejusza pod Brundyzjum, to tym samym wojna byłaby już zakończona bez rozlewu krwi".

b. perfectum, obok operatorów typu paene, prope ('omal', 'prawie')

Paene in foveam decidi, ni hic adesses. (Pl., Pers. 594)

„Prawie już wpadlem w pułapkę, gdybyś mi tu nie pomógł”.

Pons sublicius iter paene hostibus dedit, ni unus vir fuisset, Horatius Cocles. (Liv. 2, 10)

„Wzniesiony na palach most niemal już stal otworem dla nieprzyjaciół, gdyby nie jeden człowiek, Horacjusz Kokles".

c. imperfectum:

Vincebat $[\ldots]$ auxilio loci paucitas, ni $[\ldots]$ Veiens in verticem collis evasisset. (Liv. 2, 50)

„Dzięki sprzyjającym warunkom terenowym (ta) niewielka grupa była już bliska zwycięstwa, (i zwyciężyłaby), gdyby Wejentowie nie wdarli się na szczyt pagórka".

Labebar longius, nisi me retinuissem. (Cic., Leg. 1, 52)

„Byłem bliski odejścia za bardzo od tematu, gdybym się tu nie zatrzymał”.

Niezależnie od podziału zdań warunkowych na struktury stanowiące okresy warunkowe rzeczywistości, możliwości i nierzeczywistości warto zwrócić uwagę na te z nich, w których poprzednik wprowadzany jest implikującym negację konektorem nisi. Zdania te cechują się bowiem zróżnicowaniem sposobu i siły związania obu tworzących je zdań składowych. W zależności od kontekstu i funkcji pełnionej przez zdanie warunkowe tego typu w obrębie wypowiedzi jego zdania składowe mogą być silniej lub słabiej z sobą powiązane znaczeniowo, a więc mogą wykazywać większą lub mniejszą kohezję. Ze ściślejszym powiązaniem mamy do czynieniena np. w przypadku, gdy intencją wypowiedzi jest wskazanie, iż wyrażane w poprzedniku niezaistnienie określonej sytuacji wywoła lub wywołałoby konsekwencje w postaci stanu będącego treścią następnika ('jeśli nie ... (to...)'):

Nisi tu properas mulierem abducere, ego illam eiciam. (Ter., Phorm. 436-437)

„Jeśli ty nie zabierzasz tej kobiety, (to) ja ją wyrzucę". 
Podobny charakter mają zdania o postaci zaklęć, w których modalność następnika nacechowana jest intencjonalnie:

Di deaeque me omnes pessumis exemplis interficiant, nisi ego illam anum interfecero siti fameque atque algu. (PI., Most. 192-193)

„Wszyscy bogowie i boginie niech mnie uśmiercą w najgorszy sposób, jeśli ja tej staruchy nie ukatrupię glodem, pragnieniem i chlodem".

Wiązanie może być słabsze, jeśli treść poprzednika (kontekstowo) może być interpretowana również $w$ ten sposób, iż ewentualne zaistnienie sytuacji będącej jego treścią jest lub byłoby jedynym warunkiem mogącym zmienić stan wyrażany przez następnik ('chyba że...'):

Circumvenior [...], nisi subvenitis. (Cic., Brut. 260)

„Znajdę się w pulapce, jeśli mi nie pomożecie” / „Znajdę się w pułapce, chyba że mi pomożecie".

Najmniejszy poziom kohezji wykazują zdania, w odniesieniu do których dopuszczalna jest wyłącznie ta ostatnia interpretacja; konektorowi nisi towarzyszyć może wtedy operator typu: forte, vero czy potius, a całość struktury bliska jest parataksie:

Nihil [...] Romae geritur, quod te putem scire curare, nisi forte scire vis me inter Niciam nostrum et Vidium iudicem esse. (Cic., Fam. 9, 10, 1)

„W Rzymie nie dzieje się nic, co by cię mogło, jak sądzę, zainteresować, chyba że przypadkiem chciałbyś wiedzieć, iż zostałem sędzią w sporze między naszym Nikiaszem a Widiuszem".

Dlatego nisi używane też bywa w sposób, który właściwy jest raczej operatorowi nawiązania międzywypowiedzeniowego niż konektorowi:

Quid es, quod mirere, si cum isdem me in hac causa vides adesse, cum quibus in ceteris intellegis afuisse? Nisi vero me unum vis ferum praeter ceteros, me asparum, me inhumanem existimari. (Cic., Sull. 7)

„Dlaczego więc dziwisz się, że widzisz, iż $w$ tej sprawie jestem razem z tymi, z którymi nie bylem, jak ci wiadomo, w innych? Chyba że chcesz, żebym jako jedyny byl uważany za szczególnie okrutnego, srogiego, nieludzkiego".

Zdania, w których poprzednik wprowadzany jest konektorem nisi i następnik również zawiera przeczenie, jako całość implikują sens pozytywny sprowadzający się do wskazania $w$ poprzedniku jedynego warunku uzależniającego zaistnienie sytuacji będącej (w postaci zanegowanej) treścią następnika. Tym samym struktury te stanowią równocześnie złożony operator wyłączności ('tylko jeśli...'). Zdania tego typu na ogół cechuje dość silna kohezja semantyczna (spójność znaczeniowa), tzn. treść poprzednika jest konieczna dla zrozumienia sensu następnika (czyli zdania nadrzędnego):

Nisi sciero prius ex te, tu ex me numquam hoc, quod rogitas, scies. (Pl., Pers. 218)

„Jeśli wcześniej nie otrzymam odpowiedzi od ciebie, ty nigdy nie dowiesz się ode mnie tego, o co pytasz" (= tylko jeśli wcześniej otrzymam odpowiedź od ciebie, dowiesz się ode mnie...). 
Neque solida atque robusta fuerit umquam eloquentia, nisi multo stilo vires acceperit. (Quint., Inst. 10, 1, 2)

„I nigdy umiejętność posługiwania się mową nie będzie / nie byłaby trwała i solidna, jeśli nie nabierze / nie nabrałaby sił poprzez częstą praktykę pisania" (= tylko jeśli nabierze/nabralaby sił poprzez.... będzie / byłaby trwała i solidna).

Orestes si accusetur matricidii, nisi hoc dicat: 'iure feci; illa enim patrem meum occiderat', non habet defensionem. (Cic., Inv. 1, 18)

„Orestes, gdyby został oskarżony o matkobójstwo, to jeśli nie powiedziałby: 'uczyniłem słusznie; ona bowiem zabila mego ojca', nie obroniłby się" (= tylko gdyby powiedział ..., obroniłby się...).

Bywa jednak, że kohezja jest słabsza, zwłaszcza jeśli poprzednik ulokowany jest w postpozycji względem następnika:

Pompeius neque a mari Dyrrachioque discedere volebat [...], neque munitiones Ceasaris prohibere poterat, nisi proelio decertare vellet. (Caes., Civ. 3, 44)

${ }_{n}$ Pompejusz ani nie chcial odstępować od morza i od Dyrrachium, ani nie był w stanie powstrzymać budowy umocnień Cezara, jeśli nie zdecydowalby się na stoczenie bitwy / chyba że zdecydowałby się na stoczenie bitwy".

Officium facere immemor est, nisi est admonitus. (Ter., Pseud. 1104)

„Nie pamięta o spełnianiu obowiązków, jeśli nie jest upominany / chyba że jest upominany”.

W przypadku zdań okresu nierzeczywistości tego typu negacja jest równoznaczna ze stwierdzeniem, że w rzeczywistości zaistniał stan, który w obu zdaniach składowych został zanegowany. Tym samym zdania te implikują wskazanie w poprzedniku jedynego lub koniecznego warunku, którego spełnienie umożliwiło zaistnienie stanu będącego (w postaci zanegowanej) treścią następnika. Jednak w związku $z$ tym, że warunek zawsze ma charakter hipotetyczny, to należałoby stwierdzić, iż w zdaniach tego typu implikowane jest wskazanie nie tyle warunku (ponieważ $w$ tym przypadku wiadomo, jak było naprawdę), co okoliczności (przyczyny), dzięki której stan ten mógł zaistnieć:

Neque [...] id facerem, nisi necesse esset. (Cic., S. Rosc. 83)

„I nie czynitbym lego, gdyby nie było to konieczne" (= tylko dlatego, że jest to konieczne, czynię to).

Neque [...] tam facile opes Carthaginis tantae concidissent, nisi illud [...] receptaculum classibus nostris pateret. (Cic., Verr. 2, 2, 3)

"I nie tak latwo upadłaby ogromna potęga Kartaginy, gdyby ten azyl dla naszej floty (ij. Sycylia) nie stał dla nas otworem" (= (tylko) dlatego, że ten azyl stal otworem, latwo upadła potęga Kartaginy).

'Mea opera, Q. Fabi, Tarentum recepisti'; 'certe [...], nam nisi tu amisisses, numquam recepissem'. (Cic., Sen. 11)

„'Dzięki mnie, Kwintusie Fabiuszu, odzyskałeś Tarent'; 'z pewnością, bowiem gdybyś go ty nie byl utracił, ja nigdy nie mógłbym go odzyskać'" (= (tylko) dlatego, że ty go straciłeś, ja moglem go odzyskać). 
Non potuit $[$...] fieri sapiens, nisi natus esset. (Cic., Fin. 2, 103)

„Nie móglby zostać mędrcem, gdyby się nie narodzil” (= (tylko) dlatego, że się narodzil, mógl zostać mędcem).

Tym samym, jeśli w zdaniach okresu nierzeczywistości następnik nie podlega negacji, oznacza to, iż w rzeczywistości nie nastąpił stan będący jego treścią, a poprzednik identyfikuje (w postaci zanegowanej) jedyną przyczynę ('tylko dlatego, że...'), dzięki której tak się stało:

Nisi Latini sua sponte arma sumpsissent, capti et deleti eramus. (Liv. 3, 19)

„Gdyby Latynowie $z$ własnej inicjatywy nie chwycili za broń, zostalibyśmy pojmani i unicestwieni" (= tylko dlatego, że Latynowie chwycili za broń, nie zostaliśmy pojmani...).

Zdania warunkowe rzadko mają charakter rozszerzający, tj. rzadko znajdują zaimkowy korelatyw w poprzedniku:

Ita $[\ldots]$ senectus honesta est, si se ipsa defendit. (Cic., Sen. 38)

„Wtedy (= pod tym warunkiem) starość jest obdarzana szacunkiem, jeśli sama potrafi się bronic".

Si quidem me amaret, tum istuc prodesset, Gnato. (Ter., Eun. 446)

„Gdyby rzeczywiście mnie kochała, wówczas to (że mnie kocha, zapewne) pomogloby, Gnatonie".

Niekiedy też następnik stanowiony jest nie przez treść predykatywną zdania nadrzędnego, lecz przez inny jego składnik, np. przydawkę predykatywną:

(Valerius Martialis) dedit [...] mihi quantum maximum potuit, daturus amplius, si potuisset. (Plin., Epist. 3, 21, 6)

"(Waleriusz Marcjalis) dał mi najwięcej jak tylko mógł, gotów dać więcej, gdyby mógl”.

Może też być stanowiony przez równoważnik zdania (podrzędnego):

Nuntiatum est nobis [...] eum [...], nisi de via fessus esset, continuo ad nos venturum fuisse. (Cic., Acad. 1, 1)

„Powiadomiono nas, że gdyby nie był zmęczony drogą, od razu przybylby do nas”.

Specyficzny jest charakter zdań warunkowych, w których treść jednego ze zdań składowych odnosi się nie tyle do sytuacji będącej treścią drugiego z nich, lecz do sytuacji związanej z samym aktem mowy. Chodzi zatem o zdania współtworzące warstwę strategii nadawczo-odbiorczej, a więc wkraczające na poziom dyskursu:

Si est in exsilio [...], quid amplius postulatis? (Cic., Lig. 13)

„Jeśli jest na wygnaniu, to czego żądacie więcej (jako kary dla niego)?”

Sed, nisi fallor, citius te quam scribis videbo. (Cic., Att. 4, 19, 1)

"Ale, jeśli się nie mylę, zobaczę cię wcześniej, niż piszesz".

Si vis, sane sint breviora. (Cic., Parad. 26)

„Jeśli chcesz, niechże to będą (= uznajmy, że są to) drobniejsze (występki)". 
Non edepol nunc ubi terrarum sim scio, si quis roget. (Pl., Amph. 336)

„Gdyby ktoś zapytał, to, na Polluksa, nie mam pojęcia, gdzie jestem”.

Do odrębnej kategorii zdań warunkowych tradycyjnie zalicza się również zdania wprowadzane konektorami: dum, dum modo, modo ('byleby', 'byle tylko', 'jeśli tylko'). Wyrażają one pewne zastrzeżenia warunkujące aktualizację treści desygnowanej przez zdanie nadrzędne lub dodatkową, postulowaną okoliczność, która ma towarzyszyć jej aktualizacji. Orzeczenie tych zdań wyrażane jest w koniunktiwie według zasad consecutio temporum:

Oderint, dum metuant. (Cic., Off. 1, 97)

„Niech nienawidzą, byleby się bali”.

(Gallia) omnis aequo animo belli patitur iniurias, dum modo repellat periculum servitutis. (Cic., Phil. 12, 10)

„(Galia) ze spokojem znosi wszelkie niebezpieczeństwa wojny, byleby tylko zażegnać niebezpieczeńtwo niewoli".

Magno me metu liberaveris, modo inter me et te murus intersit. (Cic., Catil. 1, 10)

„Uwolnisz mnie od wielkiego lęku, jeśli tylko odzieli mnie od ciebie mur”.

Poterimus autem, adnitamur modo. (Sen., Dial. 5, 42, 2)

„Zatem zdołamy, jeśli tylko dołożymy starań”.

\subsection{Zdania okolicznikowe porównania}

Nadrzędnikami zdań okolicznikowych porównania (zdań porównawczych) najczęściej są przymiotniki pełniące w zdaniu nadrzędnym funkcje orzeczników (lub ich funkcjonalnych odpowiedników w równoważnikach zdań), przydawek, albo innych członów syntaktycznych w przypadku, gdy podlegają one substantywizacji. Orzeczenia zdań okolicznikowych porównania generalnie zawierają formy czasownikowe $w$ indikatiwie, jeśli jednak ich treść nacechowana jest modalnie, orzeczenie (współ)konstytuowane jest przez formę czasownikową w koniunktiwie. Konektorami wprowadzającymi zdania porównawcze najczęściej są:

a. atque, ac - zwykle przy przymiotnikach wyrażających podobieńtwo, identyczność itp.:

Date operam, ne simili utamur fortuna atque usi sumus. (Ter., Phorm. 31)

„Postarajcie się, aby nie czekał nas los podobny (do tego), jakiego już doświadczyliśmy”.

(Boios Aedui) in parem iuris libertatisque condicionem atque ipsi erant receperunt. (Caes., Gall. 1, 28)

„(Eduowie) obdarzyli (Bojów) takim samymi prawami i przywilejami, z jakich sami korzystali". 
b. quam - przy przymiotnikach w komparatiwie:

Praevidete, ne duriorem condicionem statuatis ordini vestro, quam ferre possit. (Cic., Rab. Post. 15)

„Zadbajcie o to, abyście nie narzucili waszemu stanowi trudniejszych warunków, niż móglby znieść".

Peiores morimur quam nascimur. (Sen., Lucil. 22, 15)

„Umieramy gorsi, niż się rodzimy”.

c. quam ut - przy przymiotniku w komparatiwie, jeśli współwyrażany jest cel lub skutek:

Maior sum et ad maiora genitus, quam ut mancipium sim mei corporis. (Sen., Lucil. $65,21)$

"Jestem czymś więcej i do większych rzeczy stworzony, niż być niewolnikiem swojego ciala".

Quis non intellegit Canachi signa rigidiora esse, quam ut imitentur veritatem? (Cic., Brut. 70)

„Któż nie dostrzega, iż rzeźby Kanachosa są zbyt ostre, by mogly naśladować rzeczywistośćc”

Haec maior esse ratio videtur, quam ut hominum possit sensu aut cogitatione comprehendi. (Cic., De orat. 3, 21)

„Wydaje się, że ta zasada jest zbyt skomplikowana, by mogła zostać pojęta ludzkim umyslem i zmyslami".

Et apertior ista sententia est, quam ut interpretanda sit, et dissertior, quam ut adiuvanda. (Sen., Lucil. 21, 8)

„Myśl ta jest i zbyt zrozumiala, by trzeba było ją objaśniać, i zbyt przekonująca, by należało ją uzasadniać".

Rzadziej porównanie dotyczy treści predykatywnych wyrażanych przez (współ)stanowiącą orzeczenie formę czasownikową; zdanie często nabiera wtedy charakteru zbliżonego do parataksy:

Ut adhuc me attente audistis, item quae reliqua sunt audiatis. (Cic., Cluent. 66)

„Tak, jak do tej pory uważnie mnie sluchaliście, tak samo wysłuchajcie pozostałych rzeczy”.

Quemadmodum rationi nullum animal optemperat [...], sic non sequuntur, non audiunt affectus. (Sen., Lucil. 85, 8)

"Jak nie podporządkowuje się rozumowi żadne zwierzę, tak też nie stosują się i nie są mu posłuszne namiętności".

\subsubsection{Zdania asyndetyczne}

Zdania podrzędne asyndetyczne (bezspójnikowe) charakteryzują się tym, że nie posiadają żadnego leksykalnego wykładnika zespolenia ze zdaniem nadrzędnym. Podobnie jednak jak zdania spójnikowe i względne, wypełniają określoną pozycję w strukturze składniowej zdania nadrzędnego, w związku z czym wyróżnić można 
asyndetyczne zdania dopełnieniowe, przydawkowe, podmiotowe i okolicznikowe, a wśród nich zdania uzupełniające i rozszerzające. Mimo wspomnianego braku leksykalnego wykładnika zespolenia ich podrzędność składniowa zwykle markowana jest formalnie przez przyjęcie nacechowanej wartości kategorii trybu, tj. koniunktiwu, przez formę czasownikową (współ)konstytuującą ich orzeczenie (zgodnie z zasadami tzw. consecutio temporum).

Największą grupę zdań podrzędnych asyndetycznych stanowią zdania dopełnieniowe, a wśród nich zdania pytajne (zależne). Dzielą się one na dwie podstawowe klasy, tj. zdania partykułowo-pytajne i zdania zaimkowo-pytajne. Dodajmy, że partykuła pytajna, która wprowadza zdania pytajne pierwszej $\mathbf{z}$ tych klas, pełni funkcję tekstowego operatora nacechowanej modalności intencjonalnej (tj. interrogatywnej), a nie konektora, czego dowodzi jej obecność również w pytaniach niezależnych. W zdaniach drugiej klasy funkcję wykładnika interrogatywnej modalności pełni zaimek pytajny, stanowiący równocześnie określony człon syntaktyczny zdania podrzędnego. Niekiedy brak jest leksykalnego wykładnika modalności interrogatywnej, w szczególności gdy zdanie zawiera składniki zrelacjonowane względem siebie alternatywnie. W większości zdania dopełnieniowe pytajne mają charakter uzupełniający. Poniższe przykłady egzemplifikują:

a. Zdania dopełnieniowe partykułowo-pytajne:

Animadverte igitur, rectene hanc sententiam interpreter. (Cic., Fin. 2, 20)

„Zwróć zatem uwagę, czy poprawnie interpretuję to zdanie”.

Dubitabam tu has ipsas litteras essesne accepturus. (Cic., Att. 15, 9, 2)

„Nie byłem pewien, czy ten wlaśnie list dojdzie do ciebie”.

Socrates [...] Xenophonti consulenti, sequereturne Cyrum [...], exposuit, quae ipsi videbantur. (Cic., Div. 1, 122)

„Sokrates Ksenofontowi radzącemu się go, czy ma towarzyszyć Cyrusowi, przedstawił swoja opinię".

Utrum, quid agatur, non vides? (Cic., S. Rosc. 73)

"Czy nie widzisz, o co toczy się gra?"

Quaero [...], num possit aut contra imperatorem aut pro imperatore dici sine rei militaris usu. (Cic., De orat. 1, 60)

„Zasłanawiam się, czy można się wypowiadać przeciwko wodzowi lub za wodzem, nie mając doświadczenia w rzeczach wojskowych".

Exspectabam [...], si quid de eo ad me scriberes. (Cic., Att. 16, 2, 4)

„Czekalem, czy coś o nim mi napiszesz".

rozszerzające:

Bonine an mali sint, id haud quaeritant. (Pl., Men. 575)

„Czy są dobrzy, czy źli, tego nie dociekają". 
b. Zdania dopełnieniowe zaimkowo-pytajne:

Quaero, quis aut de misera vita possit gloriari, aut de non beata. (Cic., Fin. 3, 28) „Pytam, kto mógłby chlubić się czy to marnym życiem, czy nieszczęśliwym”.

Quid agas, scire cupio. (Cic., Fam. 2, 14, 1)

"Chciałbym wiedzieć, co porabiasz".

Qui inquirit, quid in se dictum sit [...], se ipse inquietat. (Sen.. Dial. 5, 11, 1)

„Kto docieka, co przeciw niemu powiedziano, sam wprawia się w niepokój”.

Considera, C. Piso, quis quem fraudasse dicatur. (Cic., Q. Rosc. 21)

„Rozważ, Gajuszu Pizonie, kto kogo prawdopodobnie oszukał”.

M. Catonis splendorem maculare voluerunt ignari quid gravitas, quid integritas, quid magnitudo animi, quid denique virtus valeret. (Cic., Sest. 60)

„Godność Marka Katona chcieli splamić nieświadomi (tego), jakie znaczenie ma powaga, niezłomność, szlachetność ducha, cnota".

Verum meam uxorem, Libane, nescis qualis sit? (Pl., Asin. 60)

„Ależ nie wiesz, Libanusie, jaka jest moja żona?”

rozszerzające:

Non ego istud curo, qui sit, unde sit. (Pl., Most. 627)

„Nie dbam o to, kim jest, skąd pochodzi”.

Ex uxore hanc rem pergam exquirere, quis fuerit quem propter corpus suom stupricompleverit. (Pl., Amph. 1015-1016)

„Nadal będę próbował dowiedzieć się tej rzeczy od żony, kim był czlowiek, dla którego zhańbila swe cialo".

c. Zdania bez leksykalnego wykładnika modalności intencjonalnej (interrogatywnej): rozszerzające:

Hoc quaeramus, verum sit an falsum. (Cic., Cluent. 124)

„Spróbujmy dociec tego, czy jest (to) prawdziwe, czy falszywe".

Drugą grupę asynetycznych zdań dopełnieniowych stanowią zdania, dla których miejsce otwiera czasownik modalny konstytuujący orzeczenie zdania nadrzędnego. Zdania te generalnie mają charakter uzupełniający:

Ego crimen oportet diluam. (Cic., S. Rosc. 36)

„Wypada, żebym ja odparł oskarżenie".

Diu qui domi otiosi dormierunt, decet animo aequo nunc stent. (Pl., Poen. 21-22)

„Wypada by ci, którzy próżnując spali długo w domu, teraz stali, nie okazując wzburzenia”.

Leno argentum hoc volo a me accipiat. (PI., Pseud. 1122-1123)

"Chcę, żeby stręczyciel przyjąt ode mnie te pieniądze". 
Velim mihi ignoscas. (Cic., Att. 7, 12, 3)

"Chciałbym, byś mi wybaczył".

Vellem adesset $M$. Antonius. (Cic., Phil. 1, 16)

"Chciałbym, aby Marek Antoniusz byl tu obecny”.

Malo te sapiens hostis metuat quam stulti cives laudent. (Liv. 22, 39)

„Wolę, żeby się ciebie bał mądry nieprzyjaciel, niż żeby cię chwalili głupi obywatele”.

Iam mallem Cerberum metueres, quam ista tam inconsiderate diceres. (Cic., Tusc. 1, 12)

„Wolałbym już, byś obawiał się Cerbera, niż żebyś tak nierozważnie wygadywał takie głupstwa".

Nolo vincat. (Cic., Q. Rosc. 9)

„Nie chcę, by wygrał".

Miejsce dla tego typu zdań otwiera także imperatywna forma czasownika cavere będąca współwykładnikiem zakazu, a więc nacechowanej modalności intencjonalnej:

Cave vocem mittas. (Liv. 8, 32)

„Nie mów ani słowa”.

Cavete rumores credulitate vestra alatis. (Liv. 44,22 )

„Nie podsycajcie plolek waszą latwowiernością".

Asyndetyczne zdania dopełnieniowe zaobserwować jednak możemy również przy szeregu innych zdań (nadrzędnych), w których pozycję orzeczenia zajmują czasowniki otwierające miejsce dla nieprzedmiotowych wyrażeń argumentowych:

Caesar [...] rogat, finem orandi faciat. (Caes., Gall. 1, 20)

„Cezar prosi, by zakończył prośby".

Huic imperat quas possit adeat civitates. (Caes., Gall. 4, 21)

„Nakazuje mu, aby dotarl, do jakich tylko ludów może".

Convocatos milites monuit via omnes irent nec deverti quemquam aut excedere ordine agminis paterentur. (Liv. 25, 9)

„Zwołanych na zgromadzenie żołnierzy upomniał, by wszyscy szli trzymając sį̧ drogi, i by nikomu nie pozwalali zbaczać albo wychodzić poza szyk maszerującej kolumny".

Spero sic moriar, ut mortuus non erubescam. (Petron., Sat. 57, 6)

„Mam nadzieję, iż umrę tak, że po śmierci nie zarumienię się (ze wstydu)”.

Zdania asyndetyczne podmiotowe mają głównie postać pytań zależnych, wśród których można wyróżnić:

a. Zdania podmiotowe zaimkowo-pytajne:

In [...] noxiis [...] primum quaeritur, quae causa malefici fuerit. (Cic., S. Rosc. 62)

„Przy wykroczeniach w pierwszej kolejności docieka się, jak byla przyczyna występku”. 
rozszerzające:

Quasi nunc id agatur, quis ex tanta multitudine occiderit. (Cic., S. Rosc. 92)

„Tak jakby teraz chodziło o to, kto z takiego mnóstwa ludzi zabił”.

Id quaeritur [...], qualis visio fuerit aut furentium aut somniantium. (Cic., Lucull. 90) „Jets przedmiotem dociekania to, jakie były wrażenia czy to szaleńców, czy ludzi śpiących".

b. Zdania podmiotowe partykułowo-pytajne:

Agitur, utrum M. Antonio facultas detur opprimendae rei publicae. (Cic., Phil. 5, 6)

„Idzie o to, czy Markowi Antoniuszowi dana zostanie możliwość zdlawienia państwa”.

funkcjonalnie podmiotowe:

Numquamne intelleges statuendum tibi esse, utrum illi [...] homicidae sint, an vindices libertatis?

„Czy nigdy nie zrozumiesz, że musi zostać przez ciebie rozstrzygnięte (to), czy oni są mordercami, czy obrońcami wolności?"

c. Zdania podmiotowe bez leksykalnego wykładnika modalności intencjonalnej (interrogatywnej):

Quaeritur, natura an doctrina possit effici virtus. (Cic., Top. 82)

„Jest przedmiotem pytania, czy cnota może być osiągnięta dzięki naturze, czy dzięki nauce".

Stosunkowo rzadko spotyka się zdania asyndetyczne przydawkowe. Zwykle mają one charakter eksplikatywny i przyjmują postać partykułowych pytań zależnych. Wśród nich można wskazać zdania:

a. Uzupełniające:

Non fuit causa, cur tantum laborem caperes. (Cic., Q. Rosc. 49)

"Nie było uzasadnienia, dlaczego miałbyś podjąć się (= żebyś podjął się) takiego trudu".

b. Rozszerzające:

Illa dubitatio erat, singulaene cohortes an universi ad stipendium petendum irent (Liv. 28,25 )

„Ta wątpliwość się pojawila, czy po odbiór żołdu mają się udać poszczególne kohorty, czy wszyscy razem".

Res in id discrimen deducta est, utrum ille poenas rei publicae luat, an nos serviamus. (Cic., Phil. 3, 29)

„Sprawa doszła do konieczności dokonania takiego (oto) rozstrzygnięcia, (a mianowicie) czy jemu rzeczpospolita wymierzy karę, czy też my zostaniemy niewolnikami".

Jeszcze rzadziej stosowane są asyndetyczne zdania okolicznikowe. $\mathrm{Z}$ podanych niżej przykładów pierwszy ma postać pytajnego zdania zależnego o charakterze rozszerzającym, drugi uzupełniającego zdania warunkowego na pograniczu parataksy: 
Ex eo, quantum cuique satis est, metiuntur homines divitiarum modum. (Cic., Parad. 44) "Ludzie ustalają miarę bogactwa na podstawie tego, ile każdemu (w jego sytuacji) wystarcza".

Filiam quis habet, pecunia opus est. (Cic., Parad. 44)

„(Jeśli) ktoś ma córkę (to), potrzebuje pieniędzy”.

Por. też:

Sit fur, sit sacrilegus, sit flagitiorum omnium vitiorumque princeps; at est bonus imperator. (Cic., Verr. 2, 5, 4)

„Niech będzie, że jest złodziejem, że jest świetokradcą, że jest królem wszelkich przywar i występków; jednakowoż jest dobrym wodzem".

\subsubsection{Równoważniki zdań podrzędnych}

Równoważniki zdań podrzędnych są strukturami składniowymi, których wyróżnikiem jest to, iż żadnemu z ich (dwóch) członów konstytutywnych z osobna nie można przypisać statusu członu syntaktycznego zdania, w obrębie którego się znajdują, wspólnie zaś denotują treść odpowiadającą bądź to nieprzedmiotowemu (propozycjonalnemu) argumentowi implikowanemu (najczęściej) przez wykładnik predykatu (tj. orzeczenie), bądź to adjunktywnemu (fakultatywnemu, okolicznikowemu) składnikowi zdaniowemu. Przypisanie tej strukturze statusu zdania uniemożliwia $z$ kolei fakt, iż oba jej człony konstytutywne nie łączy składniowy związek kongruencji predykatywnej (uwzględniający kluczową dla tego związku wartość kategorii osoby wykładnika predykatu), lecz związek kongruencji atrybutywnej, oparty na kategorii liczby, rodzaju i przypadka. Dlatego struktury te klasyfikujemy jako równoważniki zdań (podrzędnych), a ich członom konstytutywnym przypisujemy status funkcjonalnego odpowiednika podmiotu i funkcjonalnego odpowiednika orzeczenia. W łacinie występują dwa podstawowe rodzaje równoważników tego typu, z których jeden znany jest jako accusativus cum infinitivo, drugi jako ablativus absolutus. Zdaniom, których składnikami są te równoważniki, przypisujemy status zdań składniowo złożonych (podrzędnie). Inkorporacja obu równoważników do struktury zdania nadrzędnego zwykle ma charakter asyndetyczny (bezspójnikowy) i uzupełniający.

\subsubsection{Accusativus cum infinitivo}

Accusativus cum infinitivo najczęściej pełni funkcję równoważnika zdania podrzędnego dopełnieniowego lub podmiotowego, a więc pod względem semantycznym najczęściej jest wykładnikiem argumentu propozycjonalnego (nieprzedmiotowego). $\mathrm{W}$ jego ramach funkcjonalny odpowiednik podmiotu stanowiony jest zwykle przez formę imienną (rzeczownikową lub zaimkową) w akuzatiwie, zaś funkcjonalny odpowiednik orzeczenia przez formę bezokolicznikową czasownika. Gramatyczna kategoria czasu bezokolicznika wyraża czas względny, tzn. wartość praesens wyraża 
równoczesność, wartość perfectum uprzedniość, a wartość futurum następczość. Wartości te zrelacjonowane są w stosunku do czasu (bezwzględnego), na który wskazuje wartość gramatycznej kategorii czasu osobowej formy czasownikowej (współ)konstytuującej orzeczenie zdania nadrzędnego. Kategoria strony formy bezokolicznikowej determinuje diatezę równoważnika, a więc identyfikuje status desygnatu funkcjonalnego odpowiednika podmiotu jako argumentu predykatu wyrażanego przez bezokolicznik. Oba konstytutywne dla tej struktury składniki, tj. funkcjonalny odpowiednik podmiotu i funkcjonalny odpowiednik orzeczenia, łączy związek kongruencji atrybutywnej, w którym członem nadrzędnym (akomodującym) jest funkcjonalny odpowiednik podmiotu. Inne, niekonstytutywne (nieobligatoryjne) składniki tego równoważnika są identyczne jak składniki zdania, a więc mogą być nimi człony syntaktyczne (tj. dopełnienia, przydawki, okoliczni$\mathrm{ki})$, konektory czy operatory tekstowe. W podanych niżej zdaniach struktury accusativus cum infinitivo stanowią:

a. równoważnik zdania podmiotowego:

Caesari nuntiatum est equites Ariovisti propius tumulum accedere. (Caes., Gall. 1, 46)

"Cezarowi doniesiono, że jeźdźcy Ariowista podchodzą bliżej ku wzniesieniu”.

b. równoważniki zdania dopełnieniowego:

Dicit montem [...] ab hostibus teneri. (Caes., Gall. 1, 22)

„Powiada, że góra opanowana jest przez nieprzyjaciól”.

Omnium prope annales Fabium dictatorem adversus Hannibalem rem gessisse tradunt. (Liv. 22, 31)

„Kroniki niemal wszystkich autorów' przekazują, że Fabiusz jako dyktator prowadził wojnę przeciwko Hannibalowi".

Hisce homines iniussu populi Romani Quiritium foedus ictum iri spoponderunt. (Liv. $9,10)$

„Ci tutaj ludzie bez upoważnienia ludu rzymskiego Kwirytów zaręczyli, że przymierze zostanie zawarte".

Z uwagi na wspomniany związek kongruencji atrybutywnej, łączący funkcjonalny odpowiednik orzeczenia $z$ funkcjonalnym odpowiednikiem podmiotu, participia współtworzące analityczne formy bezokoliczników uwzględniają - na zasadzie składni zgody - wartości kategorii liczby, rodzaju i przypadka form imiennych reprezentujących funkcjonalny odpowiednik podmiotu:

równoważnik zdania dopełnieniowego:

An vero tu parum putas investigatas esse a nobis labis imperii tui? (Cic., Pis. 83)

„Czy doprawdy uważasz, że nie zostały przez nas do końca wyśledzone wady twoich rządow?". 
równoważnik zdania podmiotowego:

Responsum a $Q$. Fabio praetore est Liguribus [...] nulli alii quam consulibus senatum crediturum esse. (Liv. 40,34)

„Ligurom przez pretora Kwintusa Fabiusza odpowiedziano, że senat nie uwierzy nikomu innemu jak tylko konsulom".

Należy jednak zaznaczyć, że w przypadku, gdy bezokolicznik reprezentuje leksem, dla którego gramatyczna kategoria strony ma charakter selektywny (niefleksyjny, klasyfikujący), wartość passivum determinuje diatezę nienacechowaną (czynną):

Cuius rei tantae tamque difficilis facultatem consecutum esse me non profiteor. (Cic., Nat. $1,12)$

„Nie twierdzę, że ją osiągnạłem zdolność uprawiania tej tak wielkiej i tak trudnej sztuki”.

Może również funkcjonalny odpowiednik orzeczenia sygnalizować nacechowaną diatezę niepodmiotową, z czym wiąże się nieotwieranie miejsca dla funkcjonalnego odpowiednika podmiotu ( $w$ akuzatiwie):

Gallis parci quam maxime iubet. (Liv. 21, 45)

"Rozkazuje, by Gallów jak najbardziej oszczędzano".

Funkcjonalny odpowiednik orzeczenia może być stanowiony nie tylko przez samą formę bezokolicznikową. Tak, jak orzeczenie może mieć strukturę złożoną i składać się np. z czasownikowego łącznika i rzeczownikowego orzecznika (np. Cicero orator fuit - „Cyceron był mówcą"), tak również funkcjonalny odpowiednik orzeczenia może mieć strukturę złożoną, składając się z bezokolicznikowego funkcjonalnego odpowiednika łącznika oraz funkcjonalnego odpowiednika orzecznika stanowionego przez:

a. formę rzeczownikową:

Consul $[\ldots]$ se M. Valerium Messalam [...] dictatorem dicturum esse aiebat. (Liv. 27, 5) „Konsul twierdzil, że on zamianuje dyktatorem Marka Waleriusza Messalę".

b. formę przymiotnikową:

Omnibus $[\ldots]$ expedit salvam esse rem publicam. (Cic., Phil. 13, 16)

„Jest $w$ interesie wszystkich, żeby państwo bylo bezpieczne".

c. formę imiesłowową:

Scis amicitias sancte colendas esse. (Sen., Lucil. 94, 26)

„Wiesz, że związki przyjaźni powinny być nabożnie szanowane”.

d. inny bezokolicznik:

(Clodius) dictitabat palam consulatum Miloni eripi non posse. (Cic., Mil. 26)

„(Klodiusz) nieustannie powtarzal wobec wszystkich, że konsulat nie może być odebrany Milonowi". 
Struktura morfologiczna funkcjonalnego odpowiednika orzeczenia może być jeszcze bardziej złożona, obejmując:

a. dwa bezokoliczniki i formę rzeczownikową:

Censebat $[\ldots]$ regem $[\ldots]$ unum imperatorem videri debere. (Liv. 35,42$)$

„Uważał, że król powinien być postrzegany jako jedyny wódz".

b. dwa bezokoliczniki i formę przymiotnikową / imiesłowową:

Quid aliud respondeatis, quam vos triumphantis videri velle? (Liv. 45, 38)

"Cóż innego odpowiedzielibyście, jak (10), że wy chcecie być oglądani jako tryumfujący?"

c. trzy bezokoliczniki:

Conantur ostendere multa posse videri esse, quae omnino nulla sint. (Cic., Lucull. 47)

„Usiłują wykazać, że liczne rzeczy, które w ogóle nie istnieją, mogą uchodzić za istniejące”.

Poza tym pozycja funkcjonalnego odpowiednika orzecznika wypełniana może być przez kataforyczny zaimek, który eksplikowany jest przez rozszerzające zdanie podrzędne funkcjonalnie orzecznikowe:

a. spójnikowe:

(Ad te) pertinet esse te talem, ut tuas laudes obscuratura nulla umquam sit oblivio. (Cic., Marcell. 30)

„(Od ciebie) zależy, byś ty był takim, żeby twoich zasług nigdy nic przysłoniło żadne zapomnienie".

b. względne:

Talem te esse oportet, qui te ab impiorum civium societate seiungas. (Cic., Fam. 10, 6, 3)

„Trzeba, abyś tỵ był takim, który trzyma się z dala od związków z nieprawymi ludźmi”.

Z kolei funkcjonalny odpowiednik podmiotu, oprócz form rzeczownikowych i zaimkowych, stanowiony może być także przez:

a. substantywizowane formy przymiotnikowe:

Possum igitur [...] suscensere dicenti non omnis bonos esse beatos? (Cic., Tusc. 5, 25)

„Czyż mogę zatem oburzać się na kogoś mówiącego, że nie wszyscy dobrzy są szczęśliwi?”

b. bezokolicznik:

Caesar $[\ldots]$ exspectare $[. .$.$] dum hostium copiae augerentur equitatusque reverteretur,$ summae dementiae esse iudicabat. (Caes., Gall. 4, 13)

„Cezar uważal, że czekanie, aż wzrosną siły nieprzyjaciół i powróci (ich) konnica, byłoby największym szaleństwem".

Hieronymus $[\ldots]$ censet summum bonum esse sine ulla molestia vivere. (Cic., Fin. 2, 16) 
„Hieronim uważa, że najwyższym dobrem jest życie bez żadnych przykrości”.

Caesari nuntiatur Helvetiis esse in animo [...] iter in Santonum fines facere. (Caes., Gall. $1,10)$

„Cezarowi doniesiono, ze jest zamiarem Helwetów dokonanie przemarszu do kraju Santonów".

Praesidibus [...] rescripsit boni pastoris esse tondere pecus, non deglubere. (Suet., Tib. 32)

„Zarządcom (prowincji) odpisal, że dobremu pasterzowi przystoi strzyc owce, a nie obdzierać (je) ze skóry".

Spoliavit [...] virtutem suo decore imbecillamque reddidit, quod negavit in ea sola positum esse beate vivere. (Cic., Acad. 1, 33)

„Odarł cnotę z jej blasku i osłabil ją, ponieważ zaprzeczył temu, że tylko na niej samej opiera się szczęśliwe życie".

Oprócz tego miejsce funkcjonalnego odpowiednika podmiotu może być wypełniane przez zdanie podrzędne funkcjonalnie podmiotowe:

a. spójnikowe:

Doce posse fieri, ut qui diu vixit, parum vixerit. (Sen., Lucil. 49, 10)

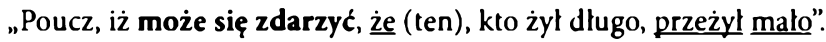

(Philodamus) negavit moris esse Graecorum, $\underline{\text { t }}$ in convivio virorum accumberent $\underline{\text { mulie- }}$ res. (Cic., Verr. 2, 1, 66)

„(Filodamus) stwierdzil, że nie jest wlaściwe dla obyczaju greckiego, aby podczas uczty dla mężczyzn zajmowaly miejsce przy stole (także) kobiety".

In consilio $[\ldots]$ dixerat $[\ldots]$ fore, uti exercitus Caesaris pelleretur. (Caes., Civ. 3, 86)

„Podczas narady wojennej powiedział, że stanie się tak, że wojsko Cezara zostanie rozpędzone".

Magno sibi usui fore arbitrabatur, si modo insulam adisset. (Caes., Gall. 4, 20)

„Uważal, że będzie dla niego wielkim pożytkiem (już samo to), jeśli tylko dotartby do wyspy".

b. względne:

Placet Stoicis, quae in terris gignantur ad usum hominum omnia creari. (Cic., Off. 1, 22) „Stoicy wyznają pogląd, iż (to), co rodzi się na ziemi, wszystko jest tworzone na użytek ludzi".

In his oratoribus illud animadvertendum est, posse esse summos, qui inter $\underline{\text { se }} \underline{\text { sint }} \underline{\text { dissimi- }}$ les. (Cic., Brut. 204)

„W odniesieniu do tych mówców należy zwrócić uwagę na to, że mogą być najwybitniejszymi (tacy), którzy sa do siebie (zupełnie) niepodobni".

Negat $[\ldots]$ ius esse, qui miles non sit, cum hoste pugnare. (Cic., Off. 1, 37)

„Twierdzi, że nie jest rzeczą sluszną, by (ten), kto nie jest żołnierzem, walczył z wrogiem”. 
Miejsce funkcjonalnego odpowiednika podmiotu może też być wypełniane przez równoważnik zdania podrzędnego funkcjonalnie podmiotowego, a więc przez kolejną strukturę typu accusativus cum infinitivo:

Publice maximam putant esse laudem quam latissime a suis finibus vacare agros. (Caes., Gall. 4, 3)

„Uważają, że w wymiarze publicznym największą chwalą jest (to), by na jak największą odleglość od ich granic pola zioneły pustka".

Id $[\ldots]$ putare quemquam hominem [...] summae adrogantiae censet esse. (Cic., Nat. deor. 3, 26)

„Sądzi, że to, iż jakikolwiek człowiek miałby tak myśleć, byłoby niesłychanym zuchwalstwem".

Videtis nefas esse dictu miseram fuisse talem senectutem. (Cic., Sen. 13)

„Widzicie, że nie godzi się powiedzieć (dosł. czymś niegodnym do powiedzenia byłoby to), iż taka starość byla nieszczęśliwa".

W przypadku, gdy desygnat funkcjonalnego odpowiednika podmiotu identyfikowalny jest kontekstowo, pozycja funkcjonalnego odpowiednika podmiotu może pozostać niewypełniona:

Hostis ante adesse potest, quam quisquam [eum] venturum esse suspicari queat. (Cic., Rep. 2, 6)

„Wróg może nadejść wcześniej, niż ktokolwiek mógłhy podejrzwać, że [on] nadejdzie”.

Pozycja ta może pozostać niewypełniona również w przypadku desygnatu o charakterze uogólnionym, jak $\mathrm{w}$ przywołanym niżej równoważniku eksplikatywnego zdania przydawkowego:

Magna etiam illa laus et admirabilis videri solet, tulisse casus sapienter adversos, non fractum esse fortuna, retinuisse in rebus asperis dignitatem. (Cic., De orat. 2, 346)

„Zwykle również i ta pochwała uchodzi za wielką i wspaniałą, że mianowicie ktoś roztropnie zniósł przeciwności losu, nie załamal się nieszczęściami, zachowal godność w trudnych sytuacjach".

Bezpośrednimi nadrzędnikami równoważników zdań podrzędnych typu accusativus cum infinitivo nie zawsze są orzeczenia zdań nadrzędnych; mogą nimi być również inne składniki tych zdań lub składniki równoważników zdaniowych zależnych od tych zdań, stanowione przez nieosobowe formy czasownikowe, np. przez:

a. pasywny bezokolicznik pełniący w zdaniu nadrzędnym funkcję dopełnienia, otwierający miejsce dla równoważnika zdania podmiotowego:

Turpe [...] sibi existimabat [...] ab reliquis copiis adversariorum suorum ex fuga collectis se cruentam adeptum (esse) existimari victoriam. (Ps.-Ceas., Bell. Afr. 31)

„Uważał za rzecz haniebną dla siebie (to), by sądzono, iż osiągnąl on krwawe zwycięstwo nad pozbieranymi z ucieczki resztkami wojsk jego przeciwników". 
b. pasywny imiesłów będący funkcjonalnym odpowiednikiem orzeczenia $\mathrm{w}$ równoważniku zdania typu ablativus absolutus, otwierający miejsce dla równoważnika zdania podmiotowego:

Oram Asiae legens pervenit in Lyciam, Patarisque cognito vivere Ptolomaeum navigandi quidem in Aegyptum omissum consilium est. (Liv. 33, 41)

„Płynąc wzdłuż wybrzeża Azji dotarł do Licji i gdy w Patarach dowiedzial się, że Ptolemeusz żyje, zarzucony (przez niego) zostal plan poplynięcia do Egiptu".

Simul nuntiato regem Artaxian Armeniis a Germanico datum (esse), decrevere patres, ut Germanicus atque Drusus ovantes urbem introirent. (Tac., Ann. 64)

„Skoro tylko zostało doniesione, że na króla zostal Armeńczykom dany przez Germanika Artaksjasz, senatorowie uchwalili, żeby Germanik i Druzus wsród owacji wkroczyli do miasta".

c. aktywny imiesłów będący funkcjonalnym odpowiednikiem orzeczenia w równoważniku zdania typu ablativus absolutus, otwierający miejsce dla równoważnika zdania dopełnieniowego:

Postero [...] die iam militibus castra urbemque se oppugnaturos (esse) frementibus $n i$ copia pugnae fiat, utrimque acies inter bina castra in medium campi procedunt. (Liv. $4,18)$

„Następnego dnia, gdy żołnierze już wolali, że oni uderzą na obóz i miasto, jeśli nie będą mieli możliwości stoczenia bitwy, $\mathbf{z}$ jednej i drugiej strony wystąpily na środek pola między oboma obozami gotowe do walki oddziały".

Mogą nimi być także formy przymiotnikowe, stanowiące np. orzecznik w zdaniu nadrzędnym:

Ambarii [...] Caesarem certiorem faciunt sese [...] non facile ab oppidis vim hostium prohibere. (Caes., Gall. 1, 11)

"Ambarrowie Cezara powiadamiają (dosł. czynią pewnym (tego)), że oni z trudem odpierają od miast ataki wrogów".

Non sumus ignari multos studiose contra esse dicturos. (Cic., Tusc. 2, 3)

„Nie jesteśmy nieświadomi (tego), że wielu usilnie zaprzeczy”.

Nadrzędnikami tymi mogą być również formy rzeczownikowe, w związku z czym struktury typu accusativus cum infinitivo mogą być równoważnikami nie tylko zdań dopełnieniowych czy podmiotowych, ale także przydawkowych, zwykle o charakterze eksplikatywnym:

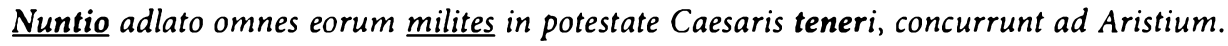
(Caes., Gall. 7, 43)

„Po tym, gdy nadeszla wiadomość, iż wszyscy ich żołnierze znajdują się w rękach Cezara, pospieszyli do Arystiusza".

Illa dubitatio erat, singulaene cohortes an universi ad stipendium petendum irent. Inclinavit sententia $[\ldots]$ universos ire. (Liv. 28, 25) 
„Ta wątpliwość się pojawiła, czy po odbiór żołdu mają się udać poszczególne kohorty, czy wszyscy razcm. Przważyla opinia, żeby wszyscy razem poszli".

Ex Sicilia litterae allatae sunt ab T. Otacilio propraetore, regnum Hieronis classe Punica vastari. (Liv. 22, 56)

„Z Sycylii nadszedł list od propretora Tytusa Otacyliusza, że mianowicie królesstwo Hierona pustoszone jest przez fotę punicka".

Spes tamen una est, aliquando populum Romanum maiorum similem fore. (Cic., Fam. $12,22,2)$

„Jedna jesı tylko nadzieja, że kiedyś naród rzymski stanie się podobny do przodków”.

Est [...] illa Platonis vera [...] vox, omnem doctrinam harum ingenuarum et humanarum artium uno quodam societatis vinculo contineri. (Cic., De orat. 3, 21)

„Isınieje owa pełna prawdy wypowiedź Platona, że wszystkie nauki dotyczące owych ludzkich sztuk i umiejętności, zlączone są jakby jednym węzłem powinowactwa".

eksplikatywny równoważnik zdania przydawkowego, apozycyjny w stosunku do przydawkowego zdania względnego:

His ego litteris lectis in eadem opinione fui, qua reliqui omnes, te cum omnibus copiis ad Corfinium esse venturum. (Cic., Att. 8, 11d, 3)

„Po przeczytaniu tego listu miałem takie samo przekonanie, jakie (mieli) wszyscy inni, że mianowicie ły ze wszystkimi oddziałami przybędziesz pod Korfinium".

eksplikatywny równoważnik zdania przydawkowego ze zdaniem podrzędnym (funkcjonalnie podmiotowym), wypełniającym pozycję funkcjonalnego odpowiednika podmiotu:

Crassus, cum [...] omnium voces audirentur exspectari diutius non oportere quin ad castra iretur, cohortatus suos [...] ad hostium castra contendit. (Caes., Gall. 3, 24)

„Krassus, gdy zewsząd słychać było glosy, iż nie powinno być już dlużej wyczekiwane (to), by ruszyć na obóz, dodawszy swoim otuchy uderzyl na nieprzyjacielski obóz".

eksplikatywny równoważnik zdania przydawkowego $z$ diatezą niepodmiotową:

Nuntium ad consulem remittunt perventum ad hostem esse. (Liv. 44, 3)

„Wysyłają do konsula wiadomość, że doszli (dosł.: doszło się) do nieprzyjaciela”.

Accusativus cum infinitivo może także stanowić eksplikatywne rozszerzenie kataforycznego zaimka o funkcji okolicznikowej (w podanym niżej przykładzie zaimek ten sam również jest składnikiem (nadrzędnego) równoważnika zdaniowego o postaci accusativus cum infinitivo):

Tale itaque aliquid et in hoc esse suspicor, quod prima specie pulchrum atque magnificum est, nec iniuriam nec contumeliam accepturum esse sapientem. (Sen., Dial. 2, 3, 2)

„Podejrzewam więc, że coś takiego (tj. złudnego) jest również w tym, co na pierwszy rzut oka jest piękne i wspaniałe, że mianowicie mędrzec (nigdy) nie dozna krzywdy ani zniewagi". 
Wreszcie nadrzędnikiem struktury typu accusativus cum infinitivo może być funkcjonalny odpowiednik orzeczenia $w$ nadrzędnej strukturze tego samego typu, w tym i taki, który determinuje diatezę niepodmiotową i otwiera miejsce dla równoważnika zdania podrzędnego dopełnieniowego:

Laetandum esse ausus es scribere Trebonium dedisse poenas? (Cic., Phil. 13, 22)

„Poważyleś się pisać, że należy się cieszyć, iż Treboniusz poniósł karę?”

Mea interesse puto te istic esse. (Cic., Att. 11, 7, 5)

„Sądzę, że jest w woim interesie (to), żebyś ţ̣ tam byl (gdzie jesteś)".

Specyficzną odmianę stanowią równoważniki zdania podmiotowego, które zależne są od nadrzędnego orzeczenia będącego wykładnikiem wyłącznie nacechowanej modalności epistemicznej:

Dicitur eo tempore matrem Pausaniae vixisse. (Nep., Paus. 5)

„Podobno w tym czasie żyla (jeszcze) matka Pauzaniasza”.

Stosunkowo rzadko równoważniki zdań podrzędnych typu accusativus cum infinitivo mają charakter rozszerzający:

Caesari cum id nuntiatum esset eos per provinciam nostram iter facere conari, maturat ab urbe proficisci. (Caes., Gall. 1, 7)

„Gdy Cezarowi doniesiono o tym, że chcą oni dokonać przemarszu przez naszą prowincję, przyśpieszył wyjazd z Rzymu".

Illud cognosces profecto, mihi te neque cariorem neque iucundiorem esse quemquam. (Cic., Fam. 2, 3, 2)

„Poznasz to niezawodnie, że (mianowicie) nikt nie jest mi droższy ani milszy od ciebie”.

$\underline{I d}[\ldots]$ putare quemquam hominem, nihil homine esse melius, summae adrogantiae censet esse. (Cic., Nat. 3, 26)

„Sądzi, że to, iż jakikolwiek człowiek miałby tak myśleć, a mianowicie że nie ma (na świecie) nic doskonalszego od człowieka, byłoby niestychanym zuchwalstwem".

\subsubsection{Ablativus absolutus}

Struktura składniowa znana jako ablativus absolutus jest równoważnikiem zdania okolicznikowego. Jej człony konstytutywne to funkcjonalny odpowiednik podmiotu, stanowiony przez wyrażoną $w$ ablatiwie formę imienną (zwykle rzeczownikową lub zaimkową), oraz funkcjonalny odpowiednik orzeczenia, stanowiony najczęściej przez formę imiesłowową w ablatiwie (zwykle czasu praesens lub perfectum). Oba te składniki pozostają względem siebie w składniowym związku kongruencji atrybutywnej, a więc $w$ związku zgody pod względem wartości gramatycznej kategorii liczby, rodzaju i przypadka, w którym to związku członem nadrzędnym (akomodującym) jest funkcjonalny odpowiednik podmiotu. Wyrażane przez formę imiesłowową wartości gramatycznej kategorii czasu mają charakter 
czasu względnego (uprzedniość, równoczesność, rzadko następczość), zrealacjonowanego w stosunku do czasu (bezwzględnego), na który wskazuje wartość gramatycznej kategorii czasu osobowej formy czasownikowej (współ)konstytuującej orzeczenie zdania nadrzędnego. Kategoria strony formy imiesłowowej determinuje diatezę równoważnika, a więc identyfikuje status desygnatu funkcjonalnego odpowiednika podmiotu jako argumentu predykatu wyrażanego przez imiesłów. Chociaż struktura tego równoważnika jest na ogół mniej rozbudowana niż struktura równoważnika typu accusativus cum infinitivo, obu jego konstytutywnym składnikom, tj. funkcjonalnemu odpowiednikowi podmiotu i funkcjonalnemu odpowiednikowi orzeczenia, mogą towarzyszyć dodatkowe (nieobligatoryjne) składniki mające status członów syntaktycznych (przydawki, dopełnienia, okolicznika). Z uwagi na to, że równoważnik ten pod względem semantycznym nie reprezentuje propozycjonalnej treści argumentowej (stanowiąc fakultatywny adjunkt), a wprowadzany jest $w$ strukturę zdania nadrzędnego asyndetycznie, relacja semantyczna, w jakiej jego treść pozostaje $w$ stosunku do treści zdania nadrzędnego, determinowana jest wyłącznie kontekstowo. Tradycyjnie wskazuje się na struktury typu ablativus absolutus, stanowiące równoważniki zdań podrzędnych:

a. czasu:

Q. Titurius et $L$. Cotta legati [...] aedificiis incensis [...] ad Caesarem se receperunt. (Caes., Gall. 4, 38)

„Legaci Kwintus Tyturiusz i Lucjusz Kotta, po tym gdy budynki zostały spalone, powrócili do Cezara".

b. przyczyny:

Inter bonos viros ac deos amicitia est conciliante virtute. (Sen., Dial. 1, 1, 5)

„Między dobrymi ludźmi i bogami istnieje przyjaźń, ponieważ lączy (ich) cnota”.

c. przyzwolenia:

Noviodonum $[\ldots]$ paucis defendentibus expugnare non potuit. (Ceas., Gall. 2, 12)

"Nie mógl zdobyć miasta Nowiodonum, chociaż bronilo (je) niewielu".

d. warunku:

Facile me paterer $[\ldots]$ illo ipso acerrimo iudice quaerente [...] pro Sex. Roscio dicere. (Cic., S. Rosc. 85)

„Łatwo zgodziłbym się przemawiać w obronie Sekstusa Roscjusza, jeśli badałby (sprawę) ów bardzo surowy sędzia".

Bardzo rzadko funkcjonalny odpowiednik orzeczenia stanowiony jest przez participium futuri activi:

Carthaginienses [...], quia metus et periculum cessandi non dabat tempus prima luce oppugnaturis hostibus castra, $[\ldots]$ augent vallum, munimento sese $[. .$.$] defensuri. (Liv.$ $28,15)$ 
„Kartagińczycy, ponieważ strach i niebezpieczeństwo nie dawały (im) czasu na ociąganie się w stytuacji, gdy o świcie nieprzyjaciele mogli zaatakować obóz, powiększają wal obronny, zamierzając bronić się zza szańców".

Quia ex tam propinquis stativis parum tuta frumentatio erat, dispersos milites per agros equitibus extemplo invasuris, [...] castra ad Ottolobum [...] movit. (Liv. 31, 36)

„Ponieważ $z$ uwagi na bliskość kwater (nieprzyjaciół) zaopatrywanie się w żywność nie było wystarczająco bezpieczne, jako że rozproszonych po polach żołnierzy mogla znienacka zaatakować konnica, przeniósł obóz pod miejscowość Ottolobos".

Pozycję funkcjonalnego odpowiednika orzeczenia wypełniać może także forma rzeczownikowa lub przymiotnikowa ( $w$ ablatiwie), która odpowiada wówczas orzecznikowi orzeczenia złożonego; tym samym stanowi ona funkcjonalny odpowiednik orzecznika:

Bellum Gallicum [...] C. Caesare imperatore gestum est. (Cic., Prov. 32)

„Wojna $z$ Gallami stoczona została pod dowództwem Gajusza Cezara (dosł.: gdy Gajusz Cezar był dowódcą)".

Relinquebatur una per Sequanos via, qua Sequanis invitis propter angustias ire non poterant. (Caes., Gall. 1, 9)

„Pozostawala jedna droga przez kraj Sekwanów, klórą - ze względu na jej ciasnotę - nie mogli iść, gdyby Sekwanowie byli temu niechętni (= wbrew woli Sekwanów)".

Z kolei pozycję funkcjonalnego odpowiednika podmiotu wypełniać może również zdanie podrzędne (funkcjonalnie podmiotowe):

a. asyndetyczne (pytajne zależne):

Sed tu [...] nuntiato quid adveneris susceptoque quod offeretur [...] canis saevitiam offula reliqua redime. (Apul., Met. 6, 19)

„Ty zaś, gdy już zostanie (przez ciebie) zakomunikowane, po co przychodzisz i gdy zostanie przyjęte (to), co będzie ci dawane, ułagodź wściekłość psa pozostałym kawałkiem jedzenia".

b. względne:

Sed tu $[\ldots]$ nuntiato quid adveneris susceptoque quod offeretur $[\ldots]$ canis saevitiam offula reliqua redime. (Apul., Met. 6, 19)

„Ty zaś, gdy już zostanie (przez ciebie) zakomunikowane, po co przychodzisz i gdy zostanie

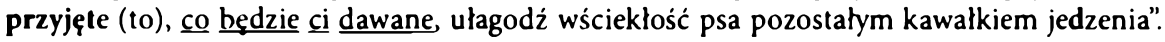

Może ją wypełnić także równoważnik zdania (funkcjonalnie podmiotowego) typu accusativus cum infinitivo:

Oram Asiae legens pervenit in Lyciam, Patarisque cognito vivere Ptolomaeum navigandi quidem in Aegyptum omissum consilium est. (Liv. 33, 41)

„Płynąc wzdłuż wybrzeża Azji dotarl do Licji i gdy w Patarach zostało (przez niego) odkryte, że Ptolemeusz żyje, zarzucony zostal plan popłynięcia do Egiptu". 
W ramach równoważnika zdania podrzędnego typu ablativus absolutus funkcjonalny odpowiednik orzeczenia związany może być $z$ dwoma funkcjonalnymi odpowiednikami podmiotu, połączonymi szeregowo:

$M$. Valerius consul [...] provincia exercituque mandato $L$. Cincio praetori $[\ldots]$ senatum extemplo habuit. (Liv. 27, 5)

„Konsul Marek Waleriusz, po tym gdy zarzad prowincji i wojsko powierzone zostaly pretorowi Lucjuszowi Cyncjuszowi, bezzwlocznie zwołal posiedzenie senatu".

Funkcjonalny odpowiednik orzeczenia może też być związany z rzeczownikową przydawką apozycyjną, którą określony jest funkcjonalny odpowiednik podmiotu:

Dictatore habente comitia Caesare consules creantur Iulius Caesar et P. Servilius. (Caes., Civ. 3, 1)

„Gdy Cezar jako dyktator przewodniczyl komicjom, konsulami zostali wybrani Juliusz Cezar i Publiusz Serwiliusz".

Ablativus absolutus stanowić może równoważnik zdania podrzędnego zależny od innego równoważnika zdania podrzędnego, tj. od równoważnika o postaci accusativus cum infinitivo; tym samym jego składniowym nadrzędnikiem będzie bezokolicznikowy funkcjonalny odpowiednik orzeczenia:

Carthaginienses [...] ad moenia urbis Romae nullo prohibente se pervenisse in gloria ponebant. (Liv. 26, 37)

„Kartagińczycy poczytywali sobie za chwalebne to, że podeszli pod mury Rzymu w sytuacji, gdy nikt (ich) nie bronil (= bez niczyjego oporu)".

Może też być zależny od innego równoważnika typu ablativus absolutus; w podanym niżej przykładzie zależne są od niego dwa współrzędne względem siebie równoważniki:

Caesar [...] quartae cohortis omnibus centurionibus occisis signiferoque interfecto signo amisso $[\ldots]$ rem esse in angusto vidit. (Caes., Gall. 2, 25)

„Cezar, gdy po zabiciu wszystkich centurionów czwartej kohorty i zgladzeniu (jej) chorążego utracony zostal sztandar, spostrzegl. że rzecz znalazła się w krytycznym położeniu".

Dwa równoważniki zdaniowe typu ablativus absolutus mogą też być zhierarchizowane względem siebie posiadając ten sam funkcjonalny odpowiednik podmiotu, raz tylko wyrażony powierzchniowo; w podanym niżej przykładzie równoważnik podrzędny względem drugiego markowany jest koncesywnym spójnikiem quamquam:

M. Aemilio C. Valerio Potito consulibus bellum Aequi parabant, Volscis, quamquam non publico consilio capessentibus arma, voluntariis mercede secutis militiam. (Liv. 4, 53)

„Za konsulatu Marka Emiliusza i Gajusza Waleriusza Potitusa do wojny szykowali się Ekwowie, podczas gdy Wolskowie, chociaż oficjalnie nie chwycili za broń, podjęli służbę wojskową jako najemni ochotnicy". 


\subsubsection{Wybrana literatura}

Aliffi (1997), Álvarez Huerta (1996), Baños (2011), Bertocchi (2001b, 2002), Bertocchi, Maraldi $(2005,2011)$, Bodelot $(1987,2003,2005)$, Bolkestein (1976a, 1976b, 1981b, 1989a, 198b, 1991, 1996b, 1998), Bortolussi (2005), Cabrillana (2011b), Cabrillana Leal (2002), Calboli (1994b, 1995-1996), Coleman (1983), Cuzzolin (1994, 1995), Elerick (1985), Escriva (2005), i Font (1995), Grassi (1962, 1966), Heberlein (2011), Lavency (1981, 1998, 2005), Longrée (1995), Maraldi (2001a, 2001b, 2002), Mellet (1994), Moralejo (1996), Orlandini (1990, 1994, 1996), Panchón (2005), Pasoli (1960), Pepicello (1977), Pompei (2011), Rosén (1989), Suárez Martínez (2001), Tarriño (2011), Tariverdieva (2002), Torrego (2009), Traina (1959), Vester $(1989,1994)$, Vonlaufen (1974), Zorzi (1955) 



\section{Bibliografia}

$\mathrm{GL}=$ Grammatici Latini ex recensione H. Keili, t. 1-8, Lipsiae (Teubner) 1855-1880.

Abbate L., 1995, Lapprocio fonologico nella didattica delle lingue classiche e moderne, "Atti della Accademia Peloritana dei Pericolanti, Classe di Lettere, Filosofia e Belle Arti" 71, s. 97-111.

Adams J. N., 1976, A Typological Approach to Latin Word Order, „Indogermanische Forschungen" 81, s. 70-100.

Adams J. N., Jense M., Swain S. (red.), 2002, Bilingualism in Ancient Society. Language Contact and the Written Text, Oxford.

Adams J. N., 2003a, Bilingualism and the Latin Language, Cambridge.

Adams J. N., 2003b, Petronius and New Non-Literary Latin, [w:] Herman J., Rosén H. (2003), s. 11-23.

Adams J. N., 2003c, 'Romanitas' and the Latin Language, „Classical Quarterly" 53 (1), s. $184-205$.

Ahern T., 1987, Tense Usage in Latin, Amherst.

Aliffi M. L., 1997, Paratassi e concessione: il costrutto latino "licet" e il congiuntivo, "Annali dell'Istituto Universitario Orientale di Napoli, Sezione linguistica" 19, s. 229-259.

Allen W. S., 1965, Vox Latina. A Guide to the Pronunciation of Classical Latin, Cambridge.

Allen W. S., 1973, Accent and Rhytm. Prosodic Features of Latin and Greek: A Study in Theory and Reconstruction, Cambridge.

Álvarez Huerta O., 1996, Relativo de unión y estilo indirecto en latin, [w:] Rosén H. (1996a), s. $567-575$.

Álvarez Huerta O., 2002, Algunas consideraciones sobre el modo subjuntivo en Plauto, [w:] Calboli G. (2002a), s. 1-24.

Álvarez Huerta O., 2005, ¿Accusativus pendens en Latín?, [w:] Calboli G. (2005a), s. 433-442. Amata B. (a cura di), 1986, Cultura e lingue classiche. Il convegno di aggiornamento e di didattica (t. 1), Roma.

Andreoni Fontecedro E., 1986, Il modello Tesnière-Sabatini e la sua applicazione al latino, "Atene e Roma" 31, s. 49-60.

Andreoni Fontecedro E., 1988, Progetto sequenziale per l'insegnamento della morfologia e della sintassi latina nel biennio secondo il modello Tesnière-Sabatini, „Aufidus” 5, s. 83-99.

Arias Abellán C., 1996, La sustantivación del adjectivo latino: el caso de los adjectivos derivados, [w:] Rosén H. (1996a), s. 231-240.

Arias Abellán C., 2001, Análisis de la modalidad en los adjetivos latinos deverbativos, „Habis” 32, s. 677-684.

Arias Abellán C., 2003, Los adjectivos en -ax en la obra de Petronio, [w:] Herman J., Rosén H. (2003), s. 25-35. 
Asensio De La Cru P., 2002, „Superare aliquem aliqua re" el comparativo de exceso en Latín, [w:] Espinilla E., Quetglas P. J., Torrego M. E. (2002), s. 11-37.

Babič M., 2005, Word Length and Clitics in Latin, [w:] Calboli G. (2005a), s. 443-451.

Bakkum G., 1994, The Second-declension Nominative Plural in -eis, -es, -is, and the First-declension Nominative in -as, [w:] Heman J. (1994), s. 19-39.

Baldi Ph., 1983, Speech Perception and Grammatical Rules in Latin, [w:] Pinkster H. (1983a), s. 11-26.

Baldi Ph., 1994, Some Thoughts on Latin Rhotacism, „General Linguistics” 34 (3-4), s. 209 $-216$.

Baldi Ph., 2002, The Foundations of Latin, Berlin - New York.

Baldi Ph., Cuzzolin P. (red.), 2009, New Perspectives on Historical Latin Syntax. Vol. 1: Syntax of the Sentence, Berlin - New York.

Baldi Ph., Cuzzolin P. (red.), 2010a, New Perspectives on Historical Latin Syntax. Vol. 2: Constituent Syntax: Adverbial Phrases, Adverbs, Mood, Tense, Berlin - New York.

Baldi Ph., Cuzzolin P. (red.), 2010b, New Perspectives on Historical Latin Syntax. Vol. 3: Constituent Syntax: Quantification, Numerals, Possession, Anaphora, Berlin - New York.

Baldi Ph., Cuzzolin P. (red.), 2011, New Perspectives on Historical Latin Syntax. Vol. 4: Complex Sentences, Grammaticalization, Typology, Berlin - New York.

Baldi Ph., Nuti A., 2010, Possession, [w:] Baldi Ph., Cuzzolin P. (2010b), s. 239-387.

Bammesberger A., Heberlein F. (red.), 1995, Akten des VIII Internationalen Kolloquiums zur lateinischen Linguistik (Proceedings of the Eight International Colloquium on Latin Linguistics), Heidelberg.

Baños J. M., 2011, Causal Clauses, [w:] Baldi Ph., Cuzzolin P. (2011), s. 195-234.

Barański W., 1997, O tacińskich terminach gramatycznych (artykut dyskusyjny), „Języki Obce w Szkole" 2, s. 171-172.

Bartonèk A., 1995, Das lateinisches Vocalsystem, [w:] Bammesberger A., Heberlein F. (1995), s. 117-124.

Bartoněk A., 1996, Literacy in Archaic Latium, [w:] Rosén H. (1996a), s. 19-26.

Bassols de Climent M., 1992, Sintaxis Latina (wyd. 10), Madrit.

Bauer B., 1993, The Development of Latin Absolute Constructions: From Stative to Transitive Constructions, "General Linguistics” 33, s. 64-83.

Bauer B., 2003, The Adverbial Formation in „-mente" in Vulgar and Late Latin: a Problem in Grammaticalization, [w:] Solin H., Leiwo M., Halla-aho H. (2003), s. 438-457.

Bauer B., 2009, Word Order, [w:] Baldi Ph., Cuzzolin P. (2009), s. 241-316.

Bednarczuk L., 2001, Wyrazy funkcyjne a morfemy gramatyczne, „Prace Filologiczne" 46, s. $59-67$.

Bednarski M., 1981, Lacina potoczna, Wrocław.

Bednarski M., 1983, Kategoria przechodniości - nieprzechodniości czasownika w języku lacińskim, „Eos” 71, s. 43-56.

Bednarski M., 1992, Gerundium i gerundivum w świetle badań, „Eos” 80, s. 301-312.

Bednarski M., 1995a, Gerund or Gerundive: Which was first?, [w:] Smoczyński W. (red.), Analecta Indoeuropaea Cracoviensia I. Safarewicz Memoriae Dicata, Kraków, s. 89-98.

Bednarski M., 1995b, Problem wymowy jezzyka lacińskiego, „Filomata” 427, s. 171-181.

Beltrán J. A., 1999, Introducción a la morfología latina, Zaragoza.

Benedetti M., 1996, Dittonghi e geminazione consonantica in latino: un caso di „deriva“, „Studi e saggi linguistici" 36, s. 11-93.

Bergh B., 1975, On Passive Imperatives in Latin, Uppsala. 
Bergh B., 1990, De imperativis Latinis passivis, [w:] Teodorsson S.-T. (red.), Greek and Latin Studies in Memory of Cajus Fabricius, Goeteborg, s. 165-170, Studia Graeca et latina Gothoburgensia 54.

Bernardi Perini G., 1970, Laccento latino. Cenni teorici e norme pratiche, Bologna (wyd. 3; 1. wyd. 1964).

Bernardi Perini G., 1983, Le „riforme“ ortografiche latine di età repubblicana, „Annali dell'Istituto Universitario Orientale di Napoli, Sezione Linguistica" 5, s. 141-169.

Bertocchi A., Casadio C., 1980, Conditions on Anaphora: An Analysis of Reflexive in Latin, [w:] Calboli G. (1980), s. 1-46.

Bertocchi A., Casadio C., 1983, Anaphoric Relations, Pronouns and Latin Complementation, [w:] Pinkster H. (1983a), s. 27-39.

Bertocchi A., 1985, Subject Ellipsis and Case Agreement, [w:] Touratier Ch. (1985), s. 25-39.

Bertocchi A., 1986, Anaphor and Tense in Latin, [w:] Calboli G. (1986), s. 63-86.

Bertocchi A., 1989, The Role of Antecedents of Latin Anaphors, [w:] Calboli G. (1989), s. 441-461.

Bertocchi A., Maraldi M., (1990), Nominalization and Possessives in Latin, [w:] Calboli G. (1990a), s. 69-127.

Bertocchi A., 1994, Occurences of is as Grammaticalizations of the Speaker, [w:] Calboli G. (1994a), s. 1-27.

Bertocchi A., 1995, Some Semantic and Pragmatic Properties of „paene”, [w:] Bammesberger A., Heberlein F. (1995), s. 457-472.

Bertocchi A., 1996, Some Properties of „ipse”, [w:] Rosén H. (1996a), s. 539-552.

Bertocchi A., Orlandini A. M., 1996, Quelques aspects de la comparaison in latin, „Indogermanische Forschungen" 101, s. 195-232.

Bertocchi A., 2000, „Ipse” as an Intensifier, [w:] Calboli G. (2000), s. 15-30.

Bertocchi A., Maraldi M., Orlandini A. M., (red.), 2001, Papers on Grammar 7. Argumentation in Latin, Bologna.

Bertocchi A., 2001 a, The Scalar Interpretation of the Restrictive Adverb "modo", [w:] Bertocchi

A., Maraldi M., Orlandini A. M. (2001), s. 87-111.

Bertocchi A., 2001b, The Relationship between Simple si Conditionals and Restrictive si modo Conditionala, [w:] Moussy C. (2001a), s. 227-244.

Bertocchi A., 2002, The Expression of Exclusiveness by „nisi”, [w:] Calboli G. (2002a), s. 25-42. Bertocchi A., Maraldi M., 2003, Some Concessive Expressions in the Passage from Classical to Late Latin, [w:] Solin H., Leiwo M., Halla-aho H. (2003), s. 459-477.

Bertocchi A., Maraldi M., 2005, Indefinite Pronouns in Conditional Clauses, [w:] Calboli G. (2005a), s. 453-466.

Bertocchi A., Maraldi M., Orlandini A., 2010, Quantification, [w:] Baldi Ph., Cuzzolin P. (2010b), s. 19-173.

Bertocchi A., Maraldi M., 2011, Conditionals and Concessives, [w:] Baldi Ph., Cuzzolin P. (2011), s. 93-193.

Bertoli E.,1979, Problemi di fonologia latina, Verona 1979.

Binder V., 2000, Sprachkontakt und Diglossie. Lateinische Wörter im Griechischen als Quellen für die lateinische Sprachgeschichte und das Vulgärlatein, Hamburg.

Biville F., 1996, Le statut linguistique des interjections en latin, [w:] Rosén H. (1996a), s. 209-220. Biville F., 2003, „Familia vero - babae babae!...” (Satyricon 37,9) Exclamations et interjections chez Pétrone, [w:] Herman J., Rosén H., (2003), 37-57.

Bodelot C., 1987, L'interrogation indirecte en latin. Syntaxe - Valeur illocutoire - Formes, Paris. 
Bodelot C., 1996, Is, hic, ille, iste coréférentiels d'une proposition complétive: étude distributionnelle, [w:] Rosén H. (1996a), s. 525-537.

Bodelot C., 2003, Grammaire fondamentale du latin (red. G. Serbat): Les propositions completives en latin, Louvain-Paris.

Bodelot C., 2005, Interférences fonctionnelles entre relatives, complétives et circonstancielles, [w:] Calboli G. (2005a), s. 467-477.

Bolkestein A. M., 1976a, A.c.I- and ut-clauses with „verba dicendi" in Latin, "Glotta" 54, s. 263-291.

Bolkestein A. M., 1976b, The Relation between Form and Meaning of Latin Subordinate Clauses Governed by „verba dicendi”, „Mnemosyne” 29, s. 155-175 i 268-300.

Bolkestein A. M., 1976c, rec. Happ H. (1976), „Kratylos” 21, s. 137-146.

Bolkestein A. M., 1980, Problems in the Description of Modal Verbs: an Investigation of Latin, Assen.

Bolkestein A. M. (et al.), 1981 a, Predication and Expression in Functional Grammar, London.

Bolkestein A. M., 1981b, Embedded Predications, Displacement and Pseudo-argument Formation in Latin, [w:] Bolkestein A. M. (1981a), s. 63-112.

Bolkestein A. M. (et al.), 1985a, Syntax and Pragmatics in Functional Grammar, Dordrecht. Bolkestein A. M., 1985b, Discourse and Case-marking: Three-place Predicates in Latin, [w:] Touratier Ch. (1985), s. 191-225.

Bolkestein A. M., 1987, Discourse Functions of Predications: The Background/Foreground Distinction and Tense and Voice in Latin Main and Subordinate Clauses, [w:] Nuyts J., de Schutter G. (1987), s. 163-178.

Bolkestein A. M., 1989a, Parameters in the Expression of Embedded Predications in Latin, [w:] Calboli G. (1989), s. 4-35.

Bolkestei A. M., 1989b, Latin Sentential Complements from a Functional Grammar Perspective, "Cahiers Inst. de Linguistique Univ. Cathol. Louvain" 15, s. 41-52.

Bolkestein A. M., 1991, Causally Related Predications and the Choice between Parataxis and Hypotaxis in Latin, [w:] Coleman R. (1991), s. 427-451.

Bolkestein A. M., 1993, Functional Grammar and Latin Linguistics, „Lalies (actes des sessions de linguistique et de littérature)" 12, s. 75-115.

Bolkestein A. M., van de Grift M., 1994, Participant Tracking in Latin Discourse, [w:] Heman J. (1994), s. 283-302.

Bolkestein A. M., 1996a, Free but not Arbitrary: „emotive” Word Order in Latin?, [w:] Risselada R., De Jong J. R., Bolkestein A. M. (1996), s. 7-23.

Bolkestein A. M., 1996b, Is "qui" "et is"? On the So-called Free Relative Connection in Latin, [w:] Rosén H. (1996a), s. 553-566.

Bolkestein A. M., 1998, Between Brackets: (Some Properties of) Parenthetical Clauses in Latin. An Investigation of the Language of Cicero's Letters, [w:] Risselada R. (1998a), s. 3-17.

Bolkestein A. M. (red.), 2002a, Theory and Description in Latin Linguistics: Selected Papers from the XI-th International Colloquium on Latin linguistics, Amsterdam.

Bolkestein A. M., 2002b, Linguistic Reflection of Discourse Structure in Latin, [w:] Bolkestein A. M. (2002a), s. 13-24.

Bologna M. P., 1982, A proposito di equivalenza morfosintattica in latino e del rapporto sintassi-semantica, „Studi e Saggi Linguistici” 22, s. 29-47.

Bonelli G., 1979, La frase latina „sintetica”, „Rivista di Studi Classici” 27, s. 28-65.

Bonelli G., 1981, Struttura del significato e ordine frasale in latino, Torino.

Bonelli G., 1983, Dativo direzionale e significato delle funzioni sintattiche, „Latomus” 42 , s. 863-868. 
Bonfante G., 1983, La lingua latina parlata nelletà imperiale, „Aufstieg und Niedergang der römischen Welt" II, 29.1, s. 413-452.

Bonfante G., 1998, The Origin of the Romance Languages. Stages in the Development of Latin, Heidelberg.

Bonfante G., 2002, Lo pseudo dittongo "ae”, „Athenaeum" 90 (1), s. 231.

Bortolussi B., 2005, Subordination seconde du relatif. Contraintes d'emploi, [w:] Calboli G. (2005a), s. 479-492.

Borzák I., 2003, „Capax imperii” mit einem Ausblick auf Petron, [w:] Herman J., Rosén H. (2003), s. 59-66.

Brosman P. W. Jr., 2001, The Latin Feminine o- Stems, „Indogermanische Forschungen” 106, s. 204-215.

Brown H. P., Joseph B. D., Wallace R. E., 2009, Questions and Answers, [w:] Baldi Ph., Cuzzolin P. (2009), s. 489-530.

Bubenik V., 1999, An Introduction to the Study of Morphology, München.

Buck C. D., 1933, Comparative Grammar of Greek and Latin, Chicago.

Buzássyová L., 2005, The Latin Third Declension in the Scope of Natural Morphology, [w:] Calboli G. (2005a), s. 15-24.

Bybee J. L., 1985, Morphology. A Study of the Relation between Meaning and Form, Amsterdam-Philadelphia.

Cabrillana C., 1996, Multifunctional Analysis of Word Order, [w:] Rosén H. (1996a) s. 377-388.

Cabrillana C., 2001, Locative Structures in Constructions with „sum”, [w:] Moussy C. (2001a), s. $275-290$.

Cabrillana C, 2002, Semantic and Syntactic Characterization of the "genetive + esse" Construction, [w:] Calboli G. (2002a), s. 43-68.

Cabrillana C., 2005, Inserción sintáctica y Función Semántica en construcciones de Dativos no "posesivos" + sum, [w:] Calboli G. (2005a), s. 493-506.

Cabrillana C., 2011 a, Adverbial Subordination: Introductory Overview, [w:] Baldi Ph., Cuzzolin P. (2011), s. 11-18.

Cabrillana C., 2011 b, Purpose and Result Clauses, [w:] Baldi Ph., Cuzzolin P. (2011), s. 19-92.

Cabrillana Leal C., Caracterización sintáctica y semántica de las oraciones comparativas condicionales en Latín, [w:] Espinilla E., Quetglas P. J., Torrego M. E. (2002), s. 63-80.

Calboli G., 1962a, Studi grammaticali, Bologna.

Calboli G., 1962b, Sulla costruzione impersonale "dicitur eo tempore matrem Pausaniae vixisse" (Nep. 4.5.3), [w:] Calboli G. (1962a), s. 3-115.

Calboli G., 1962c, Infinito iussivo latino, [w:] Calboli G. (1962a), s. 117-126.

Calboli G., 1962d, Participio in -turus e infinito futuro attivo, [w:] Calboli G. (1962a), s. 127-138.

Calboli G., 1968, Sintassi latina e linguistica moderna, „Lingua e Stile” 3, s. 307-317.

Calboli G., (red.), 1980, Papers on Grammar 1, Bologna.

Calboli G., 1983a, The Development of Latin (Cases and Infinitive), [w:] Pinkster H. (1983a), s. 41-57.

Calboli G., 1983b, Problemi di grammatica latina, „Aufstieg und Niedergang der römischen Welt" II, 29, s. 3-177.

Calboli G. (red.), 1986, Papers on Grammar 2, Bologna.

Calboli G. (red.), 1989a, Subordination and Other Topics in Latin (Proceedings of the Third Colloquium on Latin Linguistics, Bologna 1-5 April 1985), Amsterdam.

Calboli G., 1989b, Subordination and Opacity, [w:] Calboli G. (1989b), s. 37-64.

Calboli G. (red.), 1990a, Papers on Grammar 3, Bologna. 
Calboli G., 1990b, The Expansion of One Latin NP into Two Clauses: From Indo-European to Romance, [w:] Calboli G. (1990a), s. 129-145.

Calboli G., 1990c, Das lateinische Passiv und seine Beziehung zur nominalen Quantifikation, "Indogermanische Forschungen" 95, s. 104-160.

Calboli G., 1990d, rec. Rish E. (1984), „Indogemanische Forschungen” 95, s. 274-281.

Calboli G. (red.), 1994a, Papers on Grammar 4, Bologna.

Calboli G., 1994b, Subordination and Coordination: Constructions in between, [w:] Heman J. (1994), s. 167-177.

Calboli G. 1995-1996, The Consecutive Clause in Latin, "Studi Orientali e Linguistici" 6, s. $137-155$.

Calboli G., 1996, The Accusative as a Default Case in Latin, [w:] Rosén H. (1996a), s. 423-436.

Calboli G. (red.), 2000, Papers on Grammar 5, Bologna.

Calboli G. (red.), 2002a, Papers on Grammar 8, Roma.

Calboli G., 2002b, Moods and Tenses in Declarative Clauses: At the Origin of the Acl Construction, [w:] Calboli G. (2002a), s. 69-89.

Calboli G. (red.), 2005a, Papers on Grammar 9 (1-2): Latina Lingua! Nemo te lacrimis decoret neque funera fletu faxit. Cur? Volitas viva per ora virum. Proceedings of the Twelfth International Colloquium on Latin Linguistics (Bologna 9-14 June 2003), Roma.

Calboli G., 2005b, The Accusative as a "default" Case in Latin Subordinate Clauses, "Indogermanische Forschungen" 110, s. 235-266.

Calboli G., 2009, Latin Syntax and Greek, [w:] Baldi Ph., Cuzzolin P. (2009), s. 65-193.

Campanile E., 1961, Elementi dialettali nella fonetica e nella morfologia del latino, „Studi e Saggi Linguistici" 1, s. 1-21.

Campanile E., 1973, Sulla quantità della vocale che precede - $m$ in latino, "L'Italia dialettale" 36, s. 1-6.

Casadio C., Orlandini A., 1991, On the Interpretation of Generic Statements in Latin, [w:] Coleman R. (1991), s. 349-364.

Casadio C., 1994, The Semantics of Partitive Constructions. The Definite vs. Indefinite Contrast in Italian and Latin, [w:] Calboli G. (1994a), s. 65-84.

Cecchetto C., Oniga R., 2002, Consequences of the Analysis of Latin Infinitival Clauses for the Theory of Case and Control, „Lingue e Linguaggio” 1 (1), s. 151-189.

Cennamo M., 2001, On the Reorganization of Voice Distinctions and Grammatical Relations in Late Latin, [w:] Moussy C. (2001a), s. 51-65.

Clackson J., 2011, A Companion to the Latin Language, Wiley-Blackwell.

Coleman R., 1975, Greek Influence on Latin Syntax, „Transactions of the Philological Society”, s. $101-156$.

Coleman R., 1983, The Structure of Latin Complex Sentences, [w:] Pinkster H. (1983a), s. 73-94 .

Coleman R., 1985a, The Latin Future Passive Infinitive, „Glotta” 63, s. 208-212.

Coleman R., 1985b, The Indo-European Origins and Latin Development of the Accusative with Infinitive Construction, [w:] Touratier Ch. (1985), s. 307-342.

Coleman R., 1989, The Rise and Fall of Absolute Constructions: A Latin Case History, [w:] Calboli G. (1989a), s. 353-374.

Coleman R. (red.), 1991, New Studies in Latin Linguistics. Selected Papers from the $4^{\text {th }}$ International Colloquium on Latin Linguistics, Amsterdam-Philadelphia 1991.

Coleman R., 1996, Conditional Clauses in the Twelve Tables, [w:] Rosén H. (1996a), s. 403-421. Cooper F. T., 1895 (1975), Word Formation in the Roman Sermo Plebeius, New York. 
Cracas Th. L., 1979, Quattro modelli linguistici per la comprensione della frase latina, [w:] Proverbio G. (1979a), s. 31-44.

Cristofani M., 1978, Rapporto sulla diffusione della scrittura nell'Italia antica, „Scrittura e civiltà" 2, s. 5-33.

Cser A., 1999, Diphthongs in the Syllable Structure of Latin, „Glotta” 75, s. 172-193.

Cupaiuolo F., 1993, Bibliografia della lingua latina 1949-1991 (Studi Latini 11), Napoli.

Cuzzolin P., 1994, On Sentential Complementation after Verba Affectuum, [w:] Heman J. (1994), s. 201-210.

Cuzzolin P., 1995, Some Considerations on the Verba Accidendi, [w:] Bammesberger A., Heberlein F. (1995), s. 222-232.

Cuzzolin P., Haverling G., 2009, Syntax, sociolinguistics, and literary genres, [w:] Baldi Ph., Cuzzolin P. (2009), s. 19-64.

Cuzzolin P., 2011, Comparative and Superlative, [w:] Baldi Ph., Cuzzolin P. (2011), s. 549 -659 .

Cygan J., 1986, Prawo Lachmanna a teoretyczna fonologia, „Eos” 74, s. 121-127.

Cygan J., 1996, Uwagi o akcencie lacińskim, greckim i polskim, „Classica Wratislaviensia" 20, s. $179-185$.

Daheim J., Blänsdorf J., 2003, Petron und die Inschriften, [w:] Herman J., Rosén H. (2003), s. 96-1-7.

Dall'Olio G., 1959, Punti controversi di sintassi latina, Bologna.

De Carvalho P., 2005, Morphosyntaxe de la „voix” verbale en latin: le pseudo-,réfléchi pronominal", [w:] Calboli G. (2005a), s. 521-532.

De Dardel R., 1983, Esquisse structurale des subordonnants conjonctionnels en roman commun, Genéve.

De Jong Jan R., 1983, Word Order within Latin Noun Phrases, [w:] Pinkster H. (1983a), s. $131-141$.

De Jong Jan R., 1989, The Position of the Latin Ssubject, [w:] Calboli G. (1989a), s. 521-540.

De Jong Jan R., 1996, The Borderline between Deixis and Anaphora in Latin, [w:] Rosén H. (1996a), s. 499-509.

De Jong Jan R., 1998, Deictic and (Pseudo)anaphoric Functions of the Pronoun „iste”, [w:] Risselada R. (1998a), s. 19-35.

De La Villa J., 1996, Lexical Parameters of Prepositional Phrases in Latin, [w:] Rosén H. (1996a), s. 259-272.

De La Villa J., 2010, Numerals, [w:] Baldi Ph., Cuzzolin P. (2010b), s. 175-238.

Della Casa A., 1974, Lalfabeto e la pronuncia del latino, [w:] Introduzione allo studio della cultura classica, t. 2, Milano, s. 363-380.

Della Casa A., 1975, Il latino e gli strutturalismi, „Maia” 27, s. 53-60.

Dell'Era A., 1968, Appunti sulla paraipotassi latina, „Rivista di Cultura Classica e Medievale” 10, s. 193-218.

Del Vecchio T., 2002, Deixis and Anaphora in the Prologue of the "Captivi", [w:] Calboli G. (2002a), s. 91-100.

Denooz J., 2005, L'interjection dans un corpus d'auteurs latins, [w:] Calboli G. (2005a), s. 843-852.

Devine A. M., Stephens L. D., 1977, Two Studies in Latin Phonology (I. The Latin Labiovelars, II. The Latin Consonant Clusters), Saratoga.

Devine A. M., Stephens L. D., 2006, Latin Word Order: Structured Meaning an Information, Oxford. 
Dickey E., 2000a, „O egregie grammatice”: The Vocative Problems of Latin Words Ending in -ius, "Classical Quarterly" 50 (2), s. 548-562.

Dickey E., 2000b, "O dee ree PIE": The Vocative Problems of Latin Words Endings in -eus, „Glotta" 76, s. 32-49.

Dönnges U., Happ H., 1977, Dependenz-Grammatik und Latein-Unterricht, Göttingen.

Dressler W., 1979, Come descrivere la sintassi dei casi in latino?, [w:] Proverbio G. (1979a), 168-185.

Dressler W., 2002, Latin Inflection Classes, [w:] Bolkestein A. M. (2002a), s. 91-110.

Drinka B., 1991, Lachmann's Law: A Phonological Solution, „Indogermanische Forschungen” 96, s. 52-74.

Eklund S., 1984-1986, Alleged Anteriority in the Latin Present Participle, [w:] Kronholm T., Riad E. (red.), On the Dignity of Man. Oriental and Classical Studies in Honour of Frithiof Rundgren (= Orientalia Suecana 33-35), s. 97-105.

Elerick Ch., 1985, Latin Relative Clauses of Purpose: Lexical, Syntactic and Stylistic Determinants, [w:] Touratier Ch. (1985), s. 289-305.

Elerick Ch., 1989, Gapping, Preemptive Markedness, and Word Order in Latin, [w:] Calboli G. (1989a), s. 559-571.

Elerick Ch., 1990, Latin as an SDOV Language: The Evidence from Cicero, [w:] Calboli G. (1990a), s. 1-17.

Elerick Ch., 1994a, How Latin Word Order Works, [w:] Calboli G. (1994a), s. 99-117.

Elerick Ch., 1994b, Phenotypic Linearization in Latin, Word Order Universals, and Language Change, [w:] Heman J. (1994), s. 67-73.

Escriva J.-P., 2005, Corrélatifs, relatifs et conjonctions en latin: rupture ou continuité, de la corrélation à subordination?, [w:] Calboli G. (2005a), s. 533-541.

Espinilla E., Quetglas P. J., Torrego M. E. (red.), 2002, La comparación en Latín, Barcelona.

Favarin S., 1979, Per un vocabolario valenziale dei verbi latini, „Rivista di studi classici” 27, s. $454-470$.

Favarin S., 2000, La "grammatica della dipendenza" applicata alle lingue classiche, [w:] Proverbio G. (2000), s. 39-51.

Favarin S., Mancino E., 1981, Proposta di un nuovo strumento didattico: il Dizionario valenziale latino, „Orientamenti Pedagogici” 28 (4), s. 636-653.

Fink R. O., 1969, A Long Vowel before Final $m$ in Latin?, "American Journal of Philology" 90, s. 444-452.

Firbas J., 1964, On Defining the Theme in Functional Sentence Analysis, „Travaux Linguistiques de Prague" 1, s. 267-280.

Fögen Th., 2003, Forms of Language Awareness in Antiquity and Their Significance for Latin Linguistics: Some Theoretical Remarks, [w:] Solin H., Leiwo M., Halla-aho H. (2003), s. 29-45.

i Font X. G., 1995, Loració complexa llatina. Aproximació a una tipologia, „Faventia” 16 (1), s. 21-37.

Foubert F., 2005, Infinitif de narration et présent historique dans les „Res Gestae Alexandri Macedonis" de Julius Valerius, [w:] Calboli G. (2005a), s. 543-546.

Franceschi T., 1976, Sullevoluzione del vocalismo dal latino repubblicano al neolatino, [w:] Scritti in onore di Giuliano Bonfante, t. 1, Brescia, s. 257-279.

Fruyt M., 1991, Complex Lexical Units in Latin, [w:] Coleman R. (1991), s. 75-91.

Fruyt M., 2002, Constraints and Productivity in Latin Nominal Compounding, „Transactions of the Philological Society (Oxford)" 100 (3), s. 259-287. 
Fruyt M., 2004, Some Cases of Grammaticalisation in Latin: Subordinating Conjunctions, Concessivity and Modal Lexemes, „Classica et Mediaevalia” 55, s. 301-321.

Fruyt M., 2011, Grammaticalization in Latin, [w:] Baldi Ph., Cuzzolin P. (2011), s. 661-864.

Garcia-Hernández B., 1980, El desarrollo de la expresión analítica en latin vulgar. Planteamiento general, „Revista Española de Lingüística” 10 (2), s. 307-330.

Garcia-Hernández B., 1994, From Lexemics to Syntax: The Double Accusative with "doceo" and the Dative with "sum", [w:] Heman J. (1994), s. 379-392.

Garcia-Hernández B., 1996, Aspecto verbal y grado de transitividad, [w:] Rosén H. (1996a), s. 273-285.

García Jurado F., 2003, Introducción a la semántica latina: de la semántica tradicional al cognitivismo, Madrid.

Giannecchini G., 1985-1986, Su alcuni costrutti quasi-soggettivi in latino, „Annali della Facoltà di Lettere e Filosofia dell'Università degli Studi di Perugia" 23 (nuova serie 9), s. 44-65 .

Giannini S., 1994, Categorie e strutture naturali. I metaplasmi di diatesi nel latino tardo, „Indogermanische Forschungen" 99, s. 190-216.

Giannini S., Marotta G., 1989, Fra grammatica e pragmatica: la geminazione consonantica in latino, Pisa.

Gianollo C., 2005, Middle Voice in Latin and the Phaenomenon of Split Intransitivity, [w:] Calboli G. (2005a), s. 97-109.

Giomini R., 1986, Sintassi arcaica e sistemazione sintattica delletà classica, [w:] Amata B. (1986), s. 19-34.

Giordano Rampioni A., 1988, Manuale per l'insegnamento del latino nella scuola del 2000, Bologna.

Giuisti A., 1934, Dellaccento latino, Milano.

González Luis F., 1999, La caracterización morfológica del género flexional (animado/inanimado) en latin, „Fortunatae” 11, s. 161-192.

González Luis F., 2000-2001, Oscilaciones de género y de flexión en la latinización de préstamos griegos de la declinación atemática, „Fortunatae” 12, s. 85-124.

González Luis F., 2002, La quinta declinación yel género gramatical, „Fortunatae” 13, s. 131-148.

Górska M., 1999, Gramatyka zależności a nauczanie składni tacińskiej, „Roczniki Humanistyczne KUL" 47 (3), s. 105-122.

Górska M., 2004, Walencja lacinskich rzeczowników odczasownikowych i odprzymiotnikowych na podstawie "Mów" Cycerona, wraz ze slownikiem walencyjnym, Lublin.

Grassi C., 1962, A proposito della cosiddetta regola dell'anterioritá in latino, „Atene e Roma” 7, s. 220-224.

Grassi C., 1966, Problemi di sintassi latina. Consecutio temporum e aspetto nel verbo latino, Firenze.

Greenough J. B., Kittredge G. L., Howard A. A., D'Ooge B. L. (red.), 1903 (1983), Allen and Greenough's New Latin Grammar for Schools and Colleges, Founded on Comparative Grammar, New York.

Grzegorczykowa R., Laskowski R., Wróbel H. (red.), 1984 (1998, 1999), Gramatyka wspótczesnego języka polskiego. Morfologia, Warszawa.

Grzegorczykowa R., 1998, Wyklady z polskiej skladni, Warszawa.

Hammond M., 1976, Latin: A Historical and Linguistic Handbook, Harvard.

Hamp E. P., 1959, Final -s in Latin, „Classical Philology” 54, s. 165-172.

Happ H.,1976, Grundfragen einer Dependenz-Grammatik des Lateinischen, Göttingen. 
Happ H., 1979, Possibilità di una grammatica della dependenza del latino, [w:] Proverbio G. (1979a), s. 186-214.

Harris M., 1979, Alcuni problemi circa una grammatica dei casi del latino e del protoromanzo, [w:] Proverbio G. (1979a), s. 262-280.

Harrison S. J., 2003, Some Problems in the Text of Petronius, [w:] Herman J., Rosén H. (2003), s. $127-137$.

Hartleb-Kropidło B., 1999, Lacińskie formacje adwerbialne na -iter od przymiotników I i II deklinacji, „Meander” 5, s. 465-474.

Häusler S., 2000, Parenthesen im Lateinischen am Beispiel der Pliniusbriefe, "Glotta" 76, s. $202-231$.

Haverling G., 1994, On the sco-Suffix, on Prefixes and on the Development of the Latin Verbal System, [w:] Heman J. (1994), s. 41-53.

Haverling G., 1995, Some More Remarks on sco-Verbs, Prefixes and Semantic Functions, [w:] Bammesberger A., Heberlein F. (1995), s. 401-414.

Haverling G., 1996, On sco-Verbs, on Prefixes and on Semantic Functions, [w:] Rosén H. (1996a), s. 169-180.

Haverling G., 2002, On the Semantic Functions of the Latin Perfect, [w:] Bolkestein A. M., (2002a), s. 153-167.

Haverling G., 2004, On Linguistic Development and School Tradition. Direct and Indirect Evidence of the Development of Late Latin, "Classica et Mediaevalia" 55, s. 323-347.

Haverling G., 2005, On Tense, Viewpoint and Actionality in Vulgar and Literary Late Latin, [w:] Calboli G. (2005a), s. 281-291.

Haverling G, 2010, Actionality, Tense and Viewpoint, [w:] Baldi Ph., Cuzzolin P. (2010a), s. 277-523.

Heberlein F., 1995, Über prädikative Adjektive, [w:] Bammesberger A., Heberlein F. (1995), s. 354-371.

Heberlein F., 2011, Temporal Clauses, [w:] Baldi Ph., Cuzzolin P. (2011), s. 235-371.

Hejtmanová M., 2003, Hedging in Vulgar Latin Texts, [w:] Solin H., Leiwo M., Halla-aho H. (2003), s. 541-553.

Helttula A., 1973, Some New Evidence of the Late Latin Accusative Absolute, [w:] Classica et Mediaevalia F. Blatt dedicata, Copenhagen, s. 342-348.

Herman J., 1991, On the Grammatical Subject in Late Latin, [w:] Coleman R. (1991), s. 415-425. Herman J. (red.), 1994, Linguistic Studies on Latin. Selected Papers from the $6^{\text {th }}$ International Colloquium on Latin Linguistics, Budapest, 23-27 March 1991, Amsterdam-Philadelphia. Herman J., 1995, A propos du si interrogatif: évolutions achevées et évolutions bloquées, [w:] Bammesberger A., Heberlein F. (1995), s. 296-307.

Herman J., 2000, Vulgar Latin (tłum. R. Wright), University Park (oryg.: Le latin vulgaire, Paris 1967).

Herman J., 2003, Notes syntaxiques sur la langue de Trimalcion et de ses invités, [w:] Herman J., Rosén H., (2003), s. 139-146.

Herman J., Rosén H., 2003, Petroniana. Gedenkschrift für Hubert Petersmann, Heidelberg. Hernández Cabrera, T., La comparación con "quam" como criterio de caracterización funcional, [w:] Espinilla E., Quetglas P. J., Torrego M. E. (2002), s. 105-127.

Heslin Th. P., 1987, Prefixation in Latin, „Lingua” 72, s. 133-154.

Hilton J., 1997-1998, The Role of Discourse and Lexical Meaning in the Grammaticalisation of Temporal Particles in Latin, "Glotta" 74, s. 198-210.

Hoffmann M. E., 1989, Litotes Expressions in Latin, [w:] Calboli G. (1989a), s. 589-610. 
Hoffmann R., 1995, Funktionsverbgefüge im Lateinischen, [w:] Bammesberger A., Heberlein F. (1995), s. 200-212.

Hoffmann R., 2005, Functional Verb Constructions of the Type adferre + accusative: Synchronic and Diachronic Observations, [w:] Calboli G. (2005a), s. 547-559.

Hofmann J. B., 1985 (1980), La lingua d'uso latina (introduzione, traduzione italiana e note a cura di L. Ricottilli), Bologna, (wyd. 2.; oryg.: Lateinische Umgangssprache, wyd. 3. Hedelberg 1951).

Huitink L., 2005, Saying NO to Iam, [w:] Calboli G. (2005a), s. 561-570.

Janson T., 1971, The Latin Third Declension, "Glotta" 49, s. 111-142.

Janson T., 1976, Placement of Enclitics in Latin and the Relation between Syntax and Phonology, [w:] Karlsson F. (red.), Papers from the Third Scandinavian Conference on Linguistics, Hanasaari, October 1-3, 1976, Turku, s. 237-244.

Janson T., 1977, Latin Vowel Reduction and the Reality of Phonological Rules, „Studia Linguistica" 31, s. 1-17.

Janson T., 1979, Mechanisms of Language Change in Latin, Uppsala.

Joffre M.-D., 1995, Le verbe latin: voix et diathese, Louvain - Paris.

Jones F., 1995, Grammatical Ambiguity in Latin, „Mnemosyne” 48 (4), s. 438-459.

Jones F. M. A., 2000, Reference in Latin, „Mnemosyne” 53 (1), s. 12-29.

Joseph B., 1979, Lachmann's Law Once Again, „Linguistic Inquiry” 10, s. 363-365.

Juret A, C., 1926, Systeme de la syntaxe latine, Paris.

Kaczmarkowski M., 1985, Nominalne grupy syntaktyczne laciny okresu klasycznego, Lublin.

Karlsen E., 2005, Quasi and tamquam - Some Developments in Imperial Latin, [w:] Calboli G.

(2005a), s. 293-302.

Kelly D. H., 1967, Distinctive Feature Analysis in Latin Phonology, „American Journal of Philology", s. 67-77 (= K. Strunk, Probleme der lateinischen Grammatik, Darmstadt 1973, s. $32-58)$.

Kelly D. H., 1968, Transformations in the Latin Nominal Phrase, "Classical Philology" 63, s. 46-52.

Kelly D. H., 1979, Trasformazioni nel sintagma nominale latino, [w:] Proverbio G. (1979a), s. $248-261$.

Keyser P., 1988, The Origin of the Latin Numerals 1 to 1000, „American Journal of Archaeology" 92, s. 529-546.

Kircher-Durand Ch., 1991, Syntax, Morphology and Semantics in the Structuring of the Latin Lexicon, as Illustrated in the -lis Derivatives, [w:] Coleman R. (1991), s. 111-127.

Kircher-Durand Ch., 1996, Ladjectif en latin: aspects flexionnels, syntaxiques, énonciatifs et lexicaux, [w:] Rosén H. (1996a), s. 221-229.

Kircher-Durand Ch., 2002, Grammaire fondamentale du latin (red. G. Serbat): Création lexicale: la formation des noms par dérivation suffixale, Louvain - Paris.

Kiss S., 2005, Anaphore et coordination dans les textes latins tardifs, [w:] Calboli G. (2005a), s 571-576.

Klausenburger J., 1976, (De)morphologization in Latin, „Lingua” 40, s. 305-320.

Klasenburger J., 1979, Is Lachmann' Law a Rule?, „Linguistic Inquiry” 10, s. 362-363.

Klausenburger J., 2000, Grammaticalization. Studies in Latin and Romance Morphosyntax, Amsterdam.

Kristophson J., 1997, Sul trattamento di materiale linguistico straniero in lingua greca, [w:] Banfi E. (red.), Atti del secondo incontro internazionale di linguistica greca, Trento, s. 383-392. 
Kroon C., 1994, Discourse Connectives and Discourse Type: The Case of Latin at, [w:] Heman J. (1994), s. 303-317.

Kroon C., Rose P., 1996, Atrociter Corruptus? The Use of 'narrative' Tenses in Ammianus Marcelinus' "Res Gestae”, [w:] Risselada R., De Jong J. R., Bolkestein A. M. (1996), s. 71-89. Kroon C., 1998, Discourse Particles, Tense, and the Structure of Latin Narrative Texts, Risselada R. (1998a), s. 37-61.

Kroon C., 2005, The Relationship between Grammar and Discourse: Evidence from the Latin Particle quidem, [w:] Calboli G. (2005a), s. 577-590.

Kroon C., Risselada R., 1998, The discourse functions of iam, [w:] Garcia-Hernández B. (red.), Estudios de lingüistica latina, Madrid, s. 429-445.

Kroon C., Risselada R., 2002, Phasality, Polarity, Focality: A Feature Analysis of the Latin Particle iam, „Belgian Journal of Linguistics” 16, s. 65-78.

Kurylowicz J., 1968, A Remark on Lachmann's Law, "Harvard Studies in Classical Philology” 72, s. 295-299.

Lagerqvist H., 2004, Virtualisation by Change of Temporal Reference: The Example of Latin and Old French Conditional Clauses, „Classica et Mediaevalia” 55, s. 349-359.

Lambertz Th., 1995, Zur syntaktischen Kategorie der Verbalabstrakta auf-tu-im Lateinischen, [w:] Bammesberger A., Heberlein F. (1995), s. 337-353.

Langslow D. R., 1991, The Formation of Latin Technical Vocabulary with Special Reference to Medicine, [w:] Coleman R. (1991), s. 187-200.

Langslow D. R., 2000, Latin Discourse Particles, "Medical Latin” and "Classical Latin”, "Mnemosyne" 53 (3), s. 537-560.

Lavency M., 1979, Sulla sintassi dei casi nel latino classico, [w:] Proverbio G. (1979a), s. 151-167. Lavency M., 1981, La proposition relative du latin classique, „L'Antiquité Classique” 50, s. $445-468$.

Lavency M., Longrée D. (red.), 1989, Actes du Ve Colloque de Linguistique latine, Louvain-la-Neuve/Borzée 1989, Louvain-la-Neuve.

Lavency M., 1991, The Three Modifiers of the Latin NP, [w:] Coleman R. (1991), s. 269-280. Lavency M., 1998, Grammaire fondamentale du latin (red. G. Serbat): La proposition relative, Louvain - Paris.

Lavency M., 2005, Il congiuntivo nella proposizione relativa nominalizzata (Cic. Verr. II), [w:] Calboli G. (2005a), s. 591-595.

Lazzeroni R., 1997-1999, I neutri latini in -s: mutamento morfologico e riorganizzazione dei paradigmi, „Studi e Saggi Linguistici” 37, s. 63-71.

Lehmann Ch., 1973, Latein mit abstrakten Strukturen, München.

Lehmann Ch, 1983, Latin Preverbs and Cases, [w:] Pinkster H. (1983a), 145-161.

Lehmann Ch., 1985, Latin Case Relations in Typological Perspective, [w:] Touratier Ch. (1985), s. $81-104$.

Lehmann Ch., 2002, Latin Valency in Typological Perspective, [w:] Bolkestein A. M. (2002a), s. 183-203.

Lehmann Ch., 2005, Latin Syllable Structure in Typological Perspective, [w:] Calboli G. (2005a), s. $127-147$.

Lenoble M., 2005, Prédication et construction passive impersonnelle à l'infinitif, [w:] Calboli G. (2005a), s. 597-607.

Leumann M., 1963, 1977, Lateinische Laut- und Formenlehre, München.

Lindner Th., 2002, Lateinische Komposita. Morphologische, historische und lexikalische Studien, Innsbruck. 
Löfstedt E., 1959, Late Latin, Oslo.

Longrée D., 1995 „Relatives en rallonge" ou "relatifs de liason": l'exemple de Tacite, [w:] Bammesberger A., Heberlein F. (1995), s. 268-281.

Luraghi S., 1989, The Relationship between Prepositions and Cases within Latin Prepositional Phrases, [w:] Calboli G. (1989a), s. 253-271.

Luraghi S., 1997, Omission of the Direct Object in Latin, „Indogermanische Forschungen” 102, s. 239-257.

Luraghi S., 2001, The Discourse Function of cum with the Subjunctive in Narrative Texts, [w:] Moussy C. (2001a), s. 409-426.

Luraghi S., 2005, Prepositions in Cause Expressions, [w:] Calboli G. (2005a), s. 609-619.

Luraghi S., 2010, Adverbial Phrases, [w:] Baldi Ph., Cuzzolin P. (2010a), s. 19-107.

Magni E., 2005, Modality's Semantic Maps. An Investigation of Some Latin Modal Forms, [w:]

Calboli G (2005a), s. 325-336.

Magni E., 2010, Mood and Modality, [w:] Baldi Ph., Cuzzolin P. (2010a), s. 193-275.

Maltby R., 2003, Evidence for Late and Colloquial Latin in the Commentaries of Porphyrio,

Donatus and Servius, [w:] Solin H., Leiwo M., Halla-aho H. (2003), s. 265-276.

Mańczak W., 1968, Iambenkürzung im Lateinischen, „Glotta” 46, s. 137-143.

Mańczak W., 1995, Origine de l'imparfait latin en -bam, „Eos” 83, s. 109-113.

Maraldi M., 1980, The Complement Structure of Perception Verbs in Latin, [w:] Calboli G. (1980), s. 47-79.

Maraldi M, 1983, New Approaches to Accusative Subjects: Case Theory vs. Raising, [w:] Pinkster H. (1983a), s. 167-176.

Maraldi M., 1985, Null Subjects: Some Implications for Latin Syntax, [w:] Touratier Ch. (1985), s. 41-53.

Maraldi M., 1986, The Proleptic Accusative: Problems of Structural Analysis, [w:] Calboli G. (1986), s. 87-105.

Maraldi M., 1994, Some Remarks on the Historical Development of the Ablative of the Gerund in Latin, [w:] Calboli G. (1994a), s. 141-164.

Maraldi M., 1996, The Single Infinitive as a Control Structure, [w:] Rosén H. (1996a), s. 437$-449$.

Maraldi M., 2000, Some Remarks on Latin Free-choice Indefinites, [w:] Calboli G. (2000), s. $109-124$.

Maraldi M., 2001a, Concession and Argumentation in Latin, [w:] Bertocchi A., Maraldi M., Orlandini A. (2001), s: 113-132.

Maraldi M., 200lb, Forms of Concession in Latin, [w:] Moussy C. (2001a), s. 427-445.

Maraldi M., 2002, Textual Concessives in Latin, [w:] Calboli G. (2002a), s. 123-140.

Maraldi M., Bertocchi A., 2003, Some Concessive Expressions in the Passage from Classical to Late Latin, [w:] Solin H., Leiwo M., Halla-aho H. (2003), s. 459-477.

Marchese M. P., 1979, Nota sulla morfologia di parricidas/parricida, „Archivio Glottologico Italiano" 64, s. 106-111.

Marini E., 2000, Criteri di individuazione di una costruzione a verbo supporto: due esempi latini (opem ferre e morem gerere), "Studi e Saggi Linguistici” 38, s. 365-395.

Marotta G., 1982, Il problema delle labiovelari latine nel confronto di due teorie fonologiche, "Annali della Scuola Normale Superiore di Pisa", seria 3, t. 12, 3, s. 1189-1207.

Marouzeau J., 1955, La prononciation du latin, Paris (wyd. 4).

Martín Puente C., 2001, Quamquam correctivum: sintaxis y pragmática, [w:] Moussy C. (2001a), s. 447-457. 
Martín Puente C., Santos Guzmán P., 2003, El marco predicativo de „verto” y el complemento direccional, „Revista Española de Lingüística” 33 (2), s. 409-427.

Matthews P. H., 1972, Inflectional Morphology. A Theorethical Study Based on Aspects of Latin Verb Conjugation, Cambridge.

Matthews P. H., 1979, Il latino: le parti del discorso, [w:] Proverbio G. (1979a), s. 45-78.

Maurel J.-P., 2002, „Si...”, „Pallas” 59, s. 225-233.

Maurer Th. H. Jr., 1959, Gramática do Latim Vulgar, Rio De Janeiro.

Mayer R. G., 2001, „Not” again?, „Glotta” 77, s. 65-74.

Meiser G., 1998, Historische Laut- und Formenlehre der lateinischen Sprache, Darmstadt.

Mellado Rodríguez, J., 2002, Estructuras sintácticas "relativas" de la comparación en latin, [w:] Espinilla E., Quetglas P. J., Torrego M. E. (2002), s. 129-147.

Mellet S., Joffre M.-D., Serbat G., 1994, Grammaire fondamentale du latin (red. G. Serbat): Le signifié du verbe, Louvain-Paris.

Mellet S., 1994, Le subjonctif dans les subordonnées en cum en latin classique, [w:] Heman J. (1994), s. 227-239.

Mellet S., 1995, Pour un nouveau regard sur dum, [w:] Bammesberger A., Heberlein F. (1995), s. 308-321.

Menge H., 2000, Lehrbuch der lateinischen Syntax und Semantik, Völlig neu bearbeited von Thorsten Burkard und Markus Schauer, Darmstadt.

Mensink J. A. H., 1994, The Semantic Value of Restrictive Participle Clauses in Latin, [w:] Heman J. (1994), s. 241-257.

Milanese G. (red.), 2004, A ciascuno il suo latino. La didattica delle lingue classiche dalla scuola di base all'università (Atti del convegno Palazzo Bonin-Logare, Vicenza 1-2 ottobre 2001, Progetto Pallante), Lecce.

Molinelli P., 1986, Lordine delle parole in latino: studi recenti, „Lingua e Stile” 21, s. 485-498. Molinelli P., 1989, Double Negation from Latin to Italian, [w:] Calboli G. (1989a), s. 611-633. Molinelli P., 2000, Sequence of Tenses and Mood Selection in Late Latin, [w:] Calboli G. (2000), s. $125-150$.

Molinelli P., 2001, Absolute Structures in Late Latin, [w:] Moussy C. (2001a), s. 473-484.

Moralejo J.-L., 1996, Subjuntivo oblicuo y subordinación, [w:] Rosén H. (1996a), s. 287-296. Morani M., 1985-1986, Un problema di grammatica latina: l'accusativo plurale dei temi in "- $i-$ ", "Atti del Sodalizio Glottologico Milanese" 27, s. 8-19.

Morani M., 2000, Introduzione alla linguistica latina, München.

Moreno H. A., 1996, The Ablative Absolute in Late Latin, [w:] Rosén H. (1996a), s. 471-482. Moussy C. (red.), 2001 a, De lingua Latina novae quaestiones: actes $d u X^{e}$ colloque international de linguistique latine, Louvain - Paris.

Moussy C., 2001b, Nequeo, queo, non queo: l'expression de la modalité, [w:] Moussy C. (2001a), s. $485-496$.

Moussy C., 2002, „Opus est” et „usus est”: semantique, syntaxe, pragmatique, [w:] Calboli G. (2002a), s. 141-158.

Murru F., 1977, Il latino e la "Grammatica dei casi”: Un Excursus ed alcune proposte in relazione al problema della subordinazione, "Indogermanische Forschungen” 82, s. 142-154.

Murru F., 1979, La "grammatica dei casi" el'insegnamento del latino, [w:] Proverbio G. (1979a), s. 281-309 (= Proverbio G. (2000), s. 23-37).

Murru F., 1985, Il latino tra didattica e didassi, „Studi italiani di linguistica teorica e applicata” 14 , s. 467-481.

Nagórko A., 1996, Zarys gramatyki polskiej, Warszawa. 
Nagórko A., 2010, Podręczna gramatyka języka polskiego, Warszawa.

Nuti A., 2005, A Few Remarks on the habeo + object + passive perfect participle Construction in Archaic Latin, with Special Reference to Lexical Semantics and the Reanalysis Process, [w:] Calboli G. (2005a), s. 393-404.

Nuyts J., de Schutter G. (red.), 1987, Getting One's Words into Line. On Word Order and Functional Grammar, Dordrecht.

Oniga R., 1988, I composti nominali latini. Una morfologia generativa (Testi e manuali 29), Bologna.

Oniga R., 1991, Grammatica generativa e insegnamento del latino, „Aufidus” 14, s. 83-110.

Oniga R., 1992, Compounding in Latin, „Rivista di Linguistica” 4 (1), s. 97-116.

Oniga R., 1994, Morfologia, sintassi e semantica nella composizione nominale latina, "Aufidus” 23, s. 81-98.

Oniga R., 1996, Per una teoria della diatesi in latino, „Bollettino di Studi Latini” 26 (1), s. 235-250.

Oniga R., 2002, La formazione delle parole per composizione in latino, „Paideia” 57, s. 340-361 .

Oniga R., 2004, Il latino. Breve introduzione linguistica, Milano.

Önnerfors A., 2002, Über den Dativus possessivus mit esse bzw. über habere mit Akkusativobjekt in den Büchern 7-11 der „Naturalis historia" des Plinius, [w:] Defosse P. (red.), Collection Latomus vol. 267, Hommages à Carl Deroux: II - Prose et linguistique, Médicine, Bruxelles, s. 336-346.

Orlandini A. M., 1990, Les enonces generiques et la consecutio temporum, [w:] Calboli G. (1990a), s. 195-203.

Orlandini A. M., 1994, De l'oratio obliqua comme papier de tournesol; une analyse pragmatique d'un phénomène du discours indirect en latin: le changement des modes, „Indogermanische Forschungen" 99, s. 168-189.

Orlandini A. M. 1995, 1, 2, 3 videor: analyse d'un prédicat polysémique, [w:] Bammesberger A., Heberlein F. (1995), s. 415-427.

Orlandini A. M., Bertocchi A., 1996, Quelques aspects de la comparaison in latin, „Indogermanische Forschungen" 101, s. 195-232.

Orlandini A. M., 2000, Les pronoms indéfinis et la négation, [w:] Calboli G. (2000), s. 151-178.

Orlandini A. M., 2001, Grammaire fondamentale du latin (sous la dir. de G. Serbat): Négation et artgumentation en latin, Louvain - Paris.

Orlandini A. M., 2002, Pour une pragmatique des propositions circonstancielles en "sans que" en latin, [w:] Calboli G. (2002a), s. 159-184.

Orlandini A. M., 2005, Vers la construction de mondes possibles en latin: la non-actualisation, [w:] Calboli G. (2005a), s. 621-629.

Palmer L. R., 1954, The Latin Language, London.

Panchón F., 2005, Las completivas de ut con verba accedendi, [w:] Calboli G. (2005a), s. 631-639.

Panfilov E., 1977, Le basi delle sillabe fonologiche nel latino classico, „Archivio Glottologico Italiano" 62 (1-2), s. 83-97.

Panhuis D. G. J., 1978, The Latin Ablative: A Study in Syntax and Semantics, „Classical Journal" 73, s. 223-235.

Panhuis D. G. J., 1982, The Communicative Perspective in the Sentence: A Study of Latin Word Order, Amsterdam - Philadelphia.

Panhuis D. G. J., 1984a, Is Latin an SOV Language? A Diachronic Perspective, „Indogermenische Forschungen" 89, s. 140-159. 
Panhuis Dirk G. J., 1984b, Topic Shift and Other Discourse Functions of Passives in Latin Narratives, „Glotta” 62, s. 232-240.

Pasoli E., 1956, Di alcune questioni di sintassi latina, „Athenaeum” 34, s. 284-324.

Pasoli E., 1960, Lattrazione modale e le interrogative del discorso indiretto, „Athenaeum” 38, s. $230-252$.

Pepicello W. J., 1977, Relativization and purpose in Latin, „Indogermanische Forschungen” 82, s. 136-141.

Pieroni S., 2000, Agents in Latin Impersonal Passives, „Mnemosyne 53 (3), s. 288-301.

Pieroni S., 2001a, Voice Shifts in Late Latin: The Case of "facere potest" - "it is possible to do (something)", „Indogermanische Forschungen” 106, s. 216-228.

Pieroni S., 2001b, Subject Properties, Zero-anaphoras and Semantic Roles, [w:] Moussy C. (2001a), s. 539-552.

Pieroni S., 2002, „First Subject” and Clause Structure: A Morphosyntactic Hypothesis on the Control of Reflexives, [w:] Bolkestein A. M. (2002a), s. 273-287.

Pieroni S., 2010, Deixis and Anaphora, [w:] Baldi Ph., Cuzzolin P. (2010b), s. 389-501.

Pinkster H., 1969, A B \& C-coordination in Latin, „Mnemosyne” 22, s. 258-267.

Pinkster H. (red.), 1983a, Latin Linguistics and Linguistic Theory. Proceedings of the $1^{\text {st Interna- }}$ tional Colloquium on Latin Linguistics. Amsterdam, April 1981, Amsterdam - Philadelphia. Pinkster H., 1983b, Praedicativum (Quantifying Adjectives and Adjectives Denoting Physical or Mental State), [w:] Pinkster H. (1983a), s. 199-214.

Pinkster H., 1983c, Tempus, Aspect and Aktionsart in Latin (Recent Trends 1961-1981), „Aufstieg und Niedergang der römischen Welt" II, 29.1, s. 270-320.

Pinkster H., 1985a, Latin Cases and Valency Grammar: Some Problems, [w:] Touratier Ch. (1985), s. 163-189.

Pinkster H., 1985b, The Discourse Function of the Passive, [w:] Bolkestein A. M. (1985a), s. $107-118$.

Pinkster H., 1985c, The Development of Future Tense Auxiliares in Latin, „Glotta” 63, s. 186-208.

Pinkster H., 1989, Some Methodological Remarks on Research on Future Tense Auxiliaries in Latin, [w:] Calboli G. (1989a), s. 311-326.

Pinkster H., 1990, Latin Syntax and Semantics, London - New York.

Pinkster H., 1992, The Latin Impersonal Passive, „Mnemosyne” 45, s. 159-177.

Pinkster H., 1998, Is the Latin Present Tense the Unmarked, Neutral Tense in the System?, [w:] Risselada R. (1998a), s. 63-83.

Pocetti P., Polo D., Santini C., 1999, Una storia della lingua latina: formazione, usi, communicazione, Roma.

Poirier M., 1995, Dum (jusqu'au moment où) = dum non (tant que ... ne ... pas). Ce paradoxe se vérifie-t-il?, [w:] Bammesberger A., Heberlein F. (1995), s. 322-336.

Pompei A., 2002, Riflessivi indiretti in latino e logoforicità, „Studi Italiani di Linguistica Teorica e Applicata" 31 (3), s. 407-446.

Pompei A., 2011, Relative Clauses, [w:] Baldi Ph., Cuzzolin P. (2011), s. 427-547.

Porzio Gernia M. L., 1973, Lo statuto fonologico del fonema /s/ in latino, „Rendiconti dell'Accademia Nazionale dei Lincei", s. 829-840.

Porzio Gernia M. L., 1974, Vicende storiche e strutturali dellaspirazione latina, „Archivio Glottologico Italiano" 59, s. 56-102.

Porzio Gernia M. L., 1976, Tendenze strutturali della sillaba latina in etá arcaica e classica, [w:] Devoto, G., Pagliaro, A., Pisani V. (red.), Scritti in onore di Giuliano Bonfante, t. 2, Brescia, s. 757-779. 
Porzio Gernia M. L., 1986, Latin Declension: A Theoretical and Methodological Approach, [w:] Calboli G. (1986), s. 1-18.

Proverbio G. (red.), 1979a, La sfida linguistica. Lingue classiche e modelli grammaticali, Torino. Proverbio G., 1979b, Lingue classiche e modelli grammaticali, [w:] Proverbio G. (1979a), s. 7-30.

Proverbio G., 1981, Lingue classiche alla prova. Note storiche e teoriche per una didattica, Bologna.

Proverbio G., Lamacchia R., Fedeli P., Santoro A., 1982, La didattica del latino. Da un convegno di studi, Foggia.

Proverbio G., 1998, Sintassi e semantica nel sistema dei casi latini, [w:] Rapallo U., Garbugino G. (1998), s. 123-128.

Proverbio G. (red.), 2000, Cum docent discunt. Per una didattica delle lingue classiche, Bologna. Pulgram E., 1974, Prosodics of Vowel and Syllable in Greek and Latin, „Indogermanische Forschungen" 79, s. 78-91.

Pulgram E., 1975, Latin-Romance Phonology: Prosodics and Metrics (Ars grammatica 4), München.

Pultrová L., 2006, The Vocalism of Latin Medial Syllables, Praha.

Pultrová L., Urbanová D., Malá M., Subrt J., 2006, Archaická Latina, Praha.

Ramat P., 1994, On Latin Absolute Constructions, [w:] Heman J. (1994), s. 259-268.

Rapallo U., Garbugino G. (red.), 1998, Grammatica e lessico delle lingue „morte”, t. 2, Torino. Rapallo U., 1998, Gli „agrammatismi” del latino, [w:] Rapallo U., Garbugino G. (1998), s. 129-147.

Reggio G., 2002, The Hypothetical Period in Alfenus Varus' Digesta, [w:] Calboli G. (2002a), s. $185-207$.

Remmelink H. W., 2002, Inferring Implicit First-argument Participants of Passive Ablative $A b$ solutes in Ammianus Marcellinus. A Discourse-processing Account, [w:] Bolkestein A. M. (2002a), s. 301-315.

Ricca D., 2010, Adverbs, [w:] Baldi Ph., Cuzzolin P. (2010a), s. 109-191.

Risch E., 1984, Gerundivum und Gerundium. Gebrauch im klassischen und älteren Latein. Entstehung und Vorgeschichte, Berlin.

Risselada R., 1984, Coordination and Juxtaposition of Adjectives in the Latin NP., "Glotta" 72, s. 202-231.

Risselada R., 1991, Passive, Perspective and Textual Cohesion, [w:] Coleman R. (1991), s. 401-414.

Risselada R., 1993, Imperatives and Other Directive Expressions in Latin. A Study in the Pragmatics of a Dead Language, Amsterdam.

Risselada R., 1994, Modo and sane, or What to Do with Particles in Latin Directives, [w:] Heman J. (1994), s. 319-343.

Risselada R., 1996, And Now for Something Completely Different? Temporal Discourse Markers: Latin nunc and English now, [w:] Risselada R., De Jong J. R., Bolkestein A. M. (1996), s. $105-125$.

Risselada R. (red.), 1998a, Latin in Use. Amsterdam Studies in the Pragmatics of Latin, Amsterdam.

Risselada R., 1998b, Tandem and postremo: Two of a Kind?, [w:] Risselada R. (1998a), s. 85$-116$.

Risselada R., De Jong J. R., Bolkestein A. M. (red.), 1996, On Latin. Linguistic and Literary Studies in Honour of Harm Pinkster, Amsterdam. 
Robino O., 2000, Il problema della transitivita verbale: indagine sullorigine del concetto e proposte didattiche, [w:] Proverbio G. (2000), 137-149.

Roca Alamá M. J., 2003, De nuevo sobre quod completivo en latín clásico, „Fortunatae" 14, s. 209-222.

Romagno D., 2003, Azionalità e transitività: il caso dei preverbi latini, „Archivio Glottologico Italiano" 88 (2), s. 156-170.

Romero M. I., 1996, The Partitive Reading of "summus mons", [w:] Rosén H. (1996a), s. 361-376.

Ros H., 2001, Binding Theory and Valency Grammar in Latin, "Glotta” 77, s. 244-261.

Rosén Haiim B., 1980, On Some Grammatical Uses and Functional Values of the Subjunctive,

[w:] Rosén, Hannah and Haiim B., 1980, On Moods and Tenses of the Latin Verb: Two Essays Dedicated to H. J. Polotsky on the Occasion of His Seventy-fifth Birthday, München, s. 5-26.

Rosén H., 1981, Studies in the Syntax of the Verbal Noun in Early Latin, München.

Rosén H., 1983, The Mechanisms of Latin Nominalization and Conceptualization in Historical

View, „Aufstieg und Niedergang der römischen Welt” II, 29.1, s. 178-211.

Rosén H., 1986, One Instance of the Partitive Subject in Literary Latin (Plin. Ep. 10.96.10 again), „Glotta" 64, s. 83-90.

Rosén H., 1989, General Subordinators and Sentence Complements, [w:] Calboli G. (1989a), s. 197-217.

Rosén H., 1991, Grammatical-converting and Semantically Mutating Word-formation in the Latin Lexicon, [w:] Coleman R. (1991), s. 93-110.

Rosén H., 1994, The Definite Article in the Making, Nominal Constituent Order, and Related Phenomena, [w:] Heman J. (1994), s. 129-150.

Rosén H., 1995, The Latin Infinitivus Historicus Revisited, „Mnemosyne 48” (5), s. 536-564.

Rosén H. (red.), 1996a, Aspects of Latin. Papers from the Seventh International Colloquium on Latin Linguistics (Jerusalem 1993), Innsbruck.

Rosén H., 1996b, „Eam vitam vivere quae est sola vita nominanda”. Reflections on Cognate Complements, [w:] Risselada R., De Jong J. R., Bolkestein A. M. (1996), s. 127-149.

Rosén H., 1999, Latine loqui. Trends and Directions in the Crystallization of Clasical Latin, München.

Rosén H., 2000a, Grammaticalization in Latin? Two Case Studies, „Glotta” 76 (1-2), s. 94-112. Rosén H., 2000b, On Pro-nouns, Pro-verbs and Pro-sentences in Latin, [w:] Calboli G. (2000), s. $178-197$.

Rosén H., 2002, Equating and Comparing: Remarks on Apposition, Adjective Gradation, and Equation Sentences in Latin, [w:] Calboli G. (2002a), s. 209-228.

Rosén H., 2003, Immo - its Atypical Use in Petronius, [w:] Herman J., Rosén H. (2003), s. $169-181$.

Rosén H., 2009, Coherence, Sentence Modification, and Sentence-part Modification - The Contribution of Particles, [w:] Baldi Ph., Cuzzolin P. (2009), s. 317-441.

Ross D. P., 1996, Anaphors and Antecedents in Narrative Text, [w:] Rosén H. (1996a), s. 511-523. Rubenbauer H., Hofmann J. B. (neubearbeited von R. Heine), 1975, Lateinische Grammatik, Bamberg.

Rubio G., 1983, Institutión a la sintaxis estructural del latin, Barcelona.

Rubio G., 2009, Semitic Influence in the History of Latin Syntax, [w:] Baldi Ph., Cuzzolin P. (2009), s. 195-239.

Safarewicz J., 1932, Le rhotacisme latin, Wilno. 
Safarewicz J. 1937, Tendencje rozwojowe języka łacińskiego, „Eos” 38, s. 325-339.

Safarewicz J., Otrębski J. 1937, Gramatyka historyczna języka lacińskiego, część I, Wilno.

Safarewicz J., 1950, Gramatyka historyczna języka lacińskiego, część II (Skladnia), Warszawa.

Safarewicz J., 1953, Zarys gramatyki historycznej języka lacińskiego (fonetyka historyczna i fleksja), Warszawa.

Safarewicz J., 1962, Oznaczania aspiracji w inskrypcjach rzymskich I wieku n.e., „Eos” 52, s. 337-349.

Safarewicz J., 1966, Charakterystyka fonologiczna laciny klasycznej, „Eos” 56, s. 100-107.

Safarewicz J., 1986, Zarys historii języka lacińskiego, Wrocław.

Salanitro G., 2003, Avviamento allo studio della lingua e della letteratura latina, Catania.

Saloni Z., Swidziński M., 1998, Składnia wspótczesnego jezyka polskiego, wyd. 4, Warszawa.

Samolewicz Z., Sołtysik T., 2000, Składnia lacińska, (wydanie poprawione), Bydgoszcz.

Scherer A., 1975, Handbuch der lateinischen Syntax, Heidelberg.

Schoof S., 2005, The Reflexive NP In A+I-And AcI-Constructions, [w:] Calboli G. (2005a),

s. 709-717.

Serbat G., 1975, Les structures du Latin, Paris.

Serbat G., 1996, Grammaire fondamentale du latin: Lemploi des cas en latin. 1, Nominatif, vocatif, accusatif, génitif, datif, Louvain - Paris.

Shalev D., 2001, A Pattern of Agent Expression in Non Active and Non Personal Expressions in Latin, [w:] Moussy C. (2001a), s. 583-596.

Siewierska A., 1984, The Passive. A Comparative Linguistic Analysis, London.

Smith G., 1996, Futur et subjonctif, [w:] Rosén H. (1996a), s. 297-305.

Solin H., Leiwo M., Halla-aho H. (red.), 2003, Latin vulgaire - latin tardif: Actes du VI' colloque international sur le latin vulgaire et tardif (Helsinki 2000), Hildesheim - Zurich.

Sommer F., 1914, Handbuch der lateinischen Laut- und Formenlehre, Heidelberg.

Sommer F., Pfister R., 1977, Handbuch der lateinischen Laut- und Formenlehre, I, Heidelberg. Somers M. H., 1994, Theme and Topic. The Relation between Discourse and Constituent Fronting in Latin, [w:] Heman J. (1994), s. 151-163.

Spence N. C. W., 1965, Quantity and Quality in the Vowel-System of Vulgar Latin, „Word” 21, s. $1-18$.

Spevak O., 2000, La distribution des morphèmes concessifs en latin tardif, "Glotta" 76, s. $113-131$.

Spevak O., 2004, Verb-Subject Order in Latin: The Case of Existential and Locative Sentences, „Classica et Mediaevalia” 55, s. 381-396.

Spevak O., 2005, A propos de „verbum primo loco”: essai de synthèse, [w:] Calboli G. (2005a), s. 731-740.

Spigariol S., 1990, The Discontinuity of NP in the Latin Sentence: An Attempt of Interpretation, [w:] Calboli G. (1990a), s. 57-68.

Stefański W., 1992, On the Origin of the Latin Superlative Suffix-issimus, „Eos” 80, s. 51.

Steinthal H., 1979, Sull'uso di una grammatica generativo-trasformazionale nell'insegnamento del latino, [w:] Proverbio G. (1979a), s. 215-247.

Stempel R., 1994, Das lateinische Gerundium und Gerundivum in historischer und typologischer Perspektive, „Glotta” 72, s. 235-251.

Stephens L. D., Devine A. M., 1977, Two Studies in Latin Phonology (I. The Latin Labiovelars, II. The Latin Consonant Clusters), Saratoga (California).

Stephens L., 1978, Universals of Consonant Clusters and Latin GN-, „Indogermanische Forschungen" 83 , s. 290-300. 
Stephens L., 1979, Once again Lachmann's Law, „Linguistic Inquiry” 10, s. 365-369.

Stephens L., 1980, Latin gn-. Further Considerations, „Indogermanische Forschungen” 85, s. $165-175$.

Stephens L., 1986, The Shortening of Final -o in Classical Latin: A Study in Multiple Conditioning and Lexical Diffusion of Sound Change, "Indogermanische Forschungen" 91, s. 236-258.

Stephens L., 1991, On the Modal Semantics of the Latin Construction fore/futurum (esse) ut(i), "Indogermanische Forschungen" 96, s. 75-95.

Stephens L. D., Devine A. M., 2006, Latin Word Order: Structured Meaning an Information, Oxford.

Stok F., 1997, Appendix Probi IV, Napoli.

Stolz F., Schmalz J. H., Leumann M., Hofmann J. B., 1928, Lateinische Grammatik, München. Strzelecki W., 1938, De Velii Longi auctoribus quaestiones, „Eos” 39, s. 11-27.

Strzelecki W., 1947, Czterej reformatorzy ortografii lacinskiej, „Meander” 2, s. 512-524.

Strzelecki W., 1949, De Ps.-Capri „Orthogapia”, „Eos” Suppl. 21, Wratislava.

Strzelecki W., 1950, Quaestionum orthographicarum specimen, „Eos” 44, s. 89-111.

Strzelecki W., 1958, Die lateinischen Buchstabennamen und ihre Geschichte, "Das Altertum” 4, s. 24-32.

Stumpf P., 1976, System und Gebrauch. Zu den lateinischen Demonstrativ-Pronomina, „Indogermanische Forschungen" 81, s. 100-135.

Sturtevant E. H., 1940, The Pronunciation of Greek and Latin, Philadelphia (wyd. 2; 1. wyd. Chicago 1920).

Suárez Martínez P. M., 2001, Quelques problèmes concernant la consecutio temporum en latin, „Les Études Classiques” 69 (3), s. 251-268.

Suárez Martínez P. M., 2005, Constructions „apersonnelles” en latin, [w:] Calboli G. (2005a), s. 741-748.

Tarriño E., 2011, Comparative Clauses, [w:] Baldi Ph., Cuzzolin P. (2011), s. 373-426.

Tariverdieva M. A., 2002, I periodi ipotetici in latino e in italiano: forma e contenuto, „Studi Italiani di Linguistica Teorica e Applicata" 31 (2), s. 215-225.

Tesarová-Nováková D., 1984, Der Begriff des Agens und das Passiv im Lateinischen, "Listy Filologické" 107, s. 5-10.

Tondo L., 1975, Testimonianze dell'evoluzione della pronunzia latina nelle leggende monetali di età imperiale, „Epigraphica” 37, s. 188-197.

Topolińska Z. (red.), 1984, Gramatyka wspólczesnego jezyka polskiego. Składnia, Warszawa.

Torrego M. E., 1986, The System of Substantive Clauses as Complement in Classical Latin, "Glotta" 64, s. 66-83.

Torrego M. E., 1991, The Genitive with Verbal Nouns in Latin: A Functional Analysis, [w:] Coleman R. (1991), s. 281-293.

Torrego M. E., 1994, The Syntax of adhuc with Verbal Predicates, [w:] Heman J. (1994), s. $345-355$.

Torrego M. E., 2005, Grammar and Pragmatics: The Textual Uses of repente and subito, [w:] Calboli G. (2005a), s. 763-773.

Torrego M. E., 2009, Coordination, [w:] Baldi Ph., Cuzzolin P. (2009), s. 443-487.

Touratier Ch., 1979, Saggio di analisi sintattica, [w:] Proverbio G. (1979a), s. 90-150.

Touratier Ch. (red.), 1985, Syntaxe et latin. Actes du Ilème Congrès International de Linguistique Latine, Aix-en-Provence, 28-31 mars 1983, Aix-en-Provence. 
Traglia A., 1986, Problemi di grammatica latina (fonetica, accento, pronuncia, aspetto verbale), [w:] Amata B. (1986), s. 9-18.

Traina A., 1957, Lalfabeto e la pronuncia del latino, Bologna.

Traina A., 1959, Due questioni di sintassi latina: l'attrazione modale e le interrogative nel discorso indiretto, „Athenaeum” 37, s. 258-278.

Traina A., Bertotti T., 1965-1969, Sintassi normativa della lingua latina, t. 1-3, Bologna.

Traina A., Bertotti T., 1970-1971, Sintassi latina (per i Licei Scientifici e gli Istituti Magistrali), t. 1-2, Bologna.

Traina A., Bernardi Perini G., 1971-1972, Propedeutica al latino universitario, Bologna.

Traina A., Pasqualini L., 1985, Morfologia latina (terza edizione interamente riveduta e corretta), Bologna (wyd. 1, 1970).

Väänänen V., 1963, Introduction au latin vulgaire, Paris.

Vester E., 1977, On the So-called „participium coniunctum”, „Mnemosyne” 30, s. 243-285.

Vester E., 1985, Agentless Passive Constructions, [w:] Touratier Ch. (1985), s. 227-239.

Vester E., 1989, Relative Clauses: A Description of the Indicative-subjunctive Opposition, [w:]

Calboli G. (1989a), s. 327-350.

Vester E., 1991, Reflections on the Gerund and Gerundive, [w:] Coleman R. (1991), s. 295-309.

Vester E., 1994, The Internal Structure of Adverbial ut-Clauses, [w:] Heman J. (1994), s. 269-279.

Vincent N., Bentley D., 2001, The Demise of the Latin Future Periphrasis in -urus + esse, [w:] Moussy C. (2001a), s. 143-155.

Viparelli V., 2003, Lo studio del latino tra grammatica e stilistica, „Bollettino di Studi Latini” 33 (1), s. 175-194.

Visconti G. G., 2001, Spigolature di sintassi latina, „Atti della Accademia Pontaniana” 50, s. $149-190$.

Vonlaufen J., 1974, Studien über die Stellung und Gebrauch des lateinischen Relativsatzes, unter besonderer Berücksichtigung von Lukrez, Fribourg.

Ward R. L., 1962, Evidence for the Pronunciation of Latin, "Classical World” 55, s. 161-164, 273-275.

Warner R., 1980 (1982), Word Order in Old Latin: Copulative Clauses, „Orbis” 29, s. 251-263. Watkins C., 1970, A Further Remark on Lachmann's Law, „Harvard Studies in Classical Philology" 74, s. 55-65.

Wharton D., 1995, Attributive Prepositional Phrases in Latin Prose, [w:] Bammesberger A., Heberlein F. (1995), s. 165-175.

Wielewski M., 1964, Krótka gramatyka języka łacińskiego, Warszawa.

Wikarjak J., 1978, Gramatyka opisowa języka tacińskiego, Warszawa.

Wolanin H., 1999, Aulus Gellius and Vulgar Latin, [w:] Petersmann H., Kettemann R. (red.), Latin vulgaire - latin tardif. Actes du V Colloque international sur le latin vulgaire et tardif, Heidelberg 5-8 septembre 1997, Heidelberg, s. 497-503.

Wolanin H., 2001, Kategoria strony w klasycznej łacinie z punktu widzenia fleksji funkcjonalnej, „Biuletyn Polskiego Towarzystwa Językoznawczego” 57, s. 107-126.

Wolanin H., 2002, Szczególny przypadek interferencji: gramatyczny status lacińskich liczebników mille $i$ milia, „Biuletyn Glottodydaktyczny UJ” 8, s. 49-56.

Wolanin H., 2011, Syntactic Status of the NcI Construction in Latin, „Classica Cracoviensia” 14, s. 381-388.

Woodcock E. C., 1959, A New Latin Syntax, London.

Wright R., 2003, A Sociophilological Study of Late Latin, Turnhout. 
Wróbel H. (red.), 1995, Gramatyka wspótczesnego języka polskiego. Fonetyka i fonologia, Warszawa.

Wróbel H., 2001, Gramatyka języka polskiego, Kraków.

Zamboni A., 2003, Evoluzione e rinnovamento nel lessico del latino volgare: tendenze strutturali e derive interne, [w:] Solin H., Leiwo M., Halla-aho H. (2003), s. 419-435.

Zawadzki R. K., 2003, Praktyczna skladnia łacinska, Częstochowa.

Zirin R. A., 1970, The Phonological Basis of Latin Prosody, The Hague - Paris.

Zorzi E., 1955, Coordinazione e subordinazione nella sintassi latina, „Aevum” 29, s. 105-118. 


\section{Skróty}

\section{CYTOWANE TEKSTY ŹRÓDŁOWE:}

\begin{tabular}{|c|c|}
\hline Acc., Praetext. & $=$ Accius, Fabulae praetextae \\
\hline App., $I b$. & $=$ Appianus, Iberica \\
\hline App., Ill. & $=$ Appianus, Illyrica \\
\hline App. Vergil.: Copa & $=$ Appendix Vergiliana \\
\hline Apul., Apol. & $=$ Apuleius, De magia (apologia) \\
\hline Apul., Flor. & $=$ Apuleius, Florida \\
\hline Apul. Met. & $=$ Apuleius, Metamorphoses \\
\hline Caes., Civ. & $=$ Caesar, Commentarii de bello civili \\
\hline Caes., Gall. & $=$ Caesar, Commentarii de bello Gallico \\
\hline Cap., Orthogr. & $=$ Flavius Caper, De orthographia (GL VII, 92-107) \\
\hline Cap., Verb. dub.. & $=$ Flavius Caper, De verbis dubiis (GL VII, 107-112) \\
\hline Cato, Agr. & $=$ Cato, De agri cultura \\
\hline Cato, Or. & $=$ Cato, Orationes \\
\hline Catull. & $=$ Catullus, Carmina \\
\hline Cels., Med. & $=$ Celsus, De medicina \\
\hline Cic., Acad. & $=$ Cicero, Academica \\
\hline Cic., ad Brut. & $=$ Cicero, Epistulae ad Brutum \\
\hline Cic., Arch. & $=$ Cicero, Pro Archia poeta \\
\hline Cic. Att. & $=$ Cicero, Epistulae ad Atticum \\
\hline Cic., Balb. & $=$ Cicero, Pro L. Balbo \\
\hline Cic., Brut. & $=$ Cicero, Brutus \\
\hline Cic. Caecin. & $=$ Cicero, Pro Caecina \\
\hline Cic. Cael. & $=$ Cicero, Pro Caelio \\
\hline Cic., Catil. & $=$ Cicero, In Catilinam \\
\hline Cic., Cluent. & $=$ Cicero, Pro Cluentio \\
\hline Cic., Dom. & $=$ Cicero, De domo sua \\
\hline Cic., De fato & $=$ Cicero, De fato \\
\hline Cic., Deiot. & $=$ Cicero, Pro rege Deiotaro \\
\hline Cic., De orat. & $=$ Cicero, De oratore \\
\hline Cic., Div. & $=$ Cicero, De divinatione \\
\hline Cic., Fam. & $=$ Cicero, Epistulae ad familiares \\
\hline Cic., Fin. & $=$ Cicero, De finibus bonorum et malorum \\
\hline Cic., Flacc. & $=$ Cicero, Pro Flacco \\
\hline Cic., Font. & $=$ Cicero, Pro M. Fonteio \\
\hline Cic., Har. Resp. & $=$ Cicero, De haruspicum responso \\
\hline
\end{tabular}


Cic., Inv.

Cic., Lael.

Cic., Leg.

Cic., Leg. Agr.

Cic., Lucull.

Cic., Lig.

Cic., Manil.

Cic., Marcell.

Cic., Mil.

Cic., Mur.

Cic., Nat.

Cic., Off.

Cic., Orat.

Cic., Parad.

Cic., Part.

Cic., Phil.

Cic., Pis.

Cic., Planc.

Cic., $P$. red. in sen.

Cic., P. red. ad Quir.

Cic., Prov.

Cic., Q. fr.

Cic., Q. Rosc.

Cic., Quinct.

Cic., Rab. Perd.

Cic., Rab. Post.

Cic., Rep.

Cic., Scaur.

Cic., Sen.

Cic., Sest.

Cic., S. Rosc.

Cic., Sull.

Cic., Top.

Cic., Tusc.

Cic., Vatin.

Cic., Verr.

Curt., Hist. Al. Magn.

Enn., Ann.

Enn., Trag.

Flor., Epit.

Frontin., Strat.

Gell., Noc. Att.

GL

Hirt., Gall. 8

Hor., Ars

Hor., Carm.
$=$ Cicero, De inventione

= Cicero, Laelius de amicitia

$=$ Cicero, De legibus

= Cicero, De lege agraria

= Cicero, Lucullus sive Academicorum priorum liber 2

= Cicero, Pro Ligario

= Cicero, Pro lege Manilia

= Cicero, Pro Marcello

= Cicero, Pro Milone

= Cicero, Pro Murena

= Cicero, De natura deorum

= Cicero, De officiis

$=$ Cicero, Orator

= Cicero, Paradoxa Stoicorum

= Cicero, Partitiones oratoriae

= Cicero, Philippicae

= Cicero, In L. Pisonem

= Cicero, Pro Cn. Plancio

$=$ Cicero, Oratio post reditum in senatu

= Cicero, Oratio post reditum ad Quirites

= Cicero, De provinciis consularibus

= Cicero, Epistulae ad Quintum fratrem

= Cicero, Pro Q. Roscio comoedo

= Cicero, Pro Quinctio

= Cicero, Pro C. Rabirio perduellionis reo

= Cicero, Pro C. Rabirio Postumo

= Cicero, De re publica

= Cicero, Pro Scauro

= Cicero, Cato Maior de senectute

= Cicero, Pro Sestio

= Cicero, Pro Sex. Roscio Amerino

= Cicero, Pro Sulla

= Cicero, Topica

= Cicero, Tusculanae disputationes

$=$ Cicero, In P. Vatinium testem interrogatio

$=$ Cicero, In Verrem

= Curtius, Historiae Alexandri Magni

$=$ Ennius, Annales

$=$ Ennius, Tragoediae

= Florus, Epitoma de Tito Livio

= Frontinus, Strategemata

$=$ Gellius, Noctes Atticae

= Grammatici Latini ex recensione H. Keili, t. I-VIII Lipsiae (Teubner) $1855-1880$

$=$ Hirtius, $C$. Iulii Caesaris commentarii de bello Gallico lib. 8

= Horatius, Ars poetica

= Horatius, Carmina 
Hor., Epist.

Hor., Epod.

Hor., Serm.

Iuv., Sat.

Liv.

Long., Orthogr.

Lucan., Bell. Civ.

Lucilius

Lucretius

Mart. Cap., Nupt.

Mart., Epigr.

Maur. Litt.

Naev., Trag.

Nep., Ages.

Nep., Alc.

Nep., Arist.

Nep., Att.

Nep., Cato

Nep., Cim.

Nep., Con.

Nep., Dat.

Nep., Di.

Nep., Epam.

Nep., Eum.

Nep., Ham.

Nep., Hann.

Nep., Iph.

Nep., Lys.

Nep., Milt.

Nep., Paus.

Nep., Pel.

Nep., Phoc.

Nep., Pr.

Nep., Reg.

Nep., Them.

Nep., Thras.

Nep., Timol.

Nep., Timoth.

Ov., Ars

Ov., Ib.

Ov., Fasti

Ov., Met.

Ov., Pont.

Ov., Rem.

Ov., Trist.

Persius

Petron., Sat.
$=$ Horatius, Epistulae

$=$ Horatius, Epodes

$=$ Horatius, Saturae (Sermones)

= Juvenalis, Saturae

$=$ Titus Livius, $A b$ urbe condita

$=$ Velius Longus, De orthographia (GL VII, 46-81)

$=$ Lucanus, Bellum civile

$=$ Gaius Lucilius, Saturae

$=$ Titus Lucretius Carus, De rerum natura

= Martianus Felix Capella, De nuptiis Philologiae et Mercurii

$=$ Martialis, Epigrammaton libri XIV

= Terentianus Maurus, De litteris, de syllabis, de metris (GL VI, 328-413)

$=$ Gnaeus Naevius, Tragoediae

$=$ Nepos, Agesilaus

$=$ Nepos, Alcibiades

$=$ Nepos, Aristides

$=$ Nepos, Atticus

$=$ Nepos, Cato

$=$ Nepos, Cimon

$=$ Nepos, Conon

$=$ Nepos, Datames

$=$ Nepos, Dion

$=$ Nepos, Epaminondas

$=$ Nepos, Eumenes

$=$ Nepos, Hamilcar

$=$ Nepos, Hannibal

$=$ Nepos, Iphicrates

$=$ Nepos, Lysander

$=$ Nepos, Miltiades

$=$ Nepos, Pausanias

$=$ Nepos, Pelopidas

$=$ Nepos, Phocion

$=$ Nepos, Praefatio

$=$ Nepos, De regibus

$=$ Nepos, Themistocles

$=$ Nepos, Thrasybulus

$=$ Nepos, Timoleon

$=$ Nepos, Timotheus

= Ovidius, Ars amatoria

$=$ Ovidius, Ibis

$=$ Ovidius, Fasti

= Ovidius, Metamorphoses

$=$ Ovidius, Epistulae ex Ponto

= Ovidius, Remedia amoris

$=$ Ovidius, Tristia

= Aulus Persius Flaccus, Saturae

$=$ Petronius, Satyricon 


\begin{tabular}{|c|c|c|}
\hline Pl., Amph. & & Plautus, Amphitruo \\
\hline Pl., Aul. & $=$ & Plautus, Aulularia \\
\hline Pl., Asin. & $=$ & Plautus, Asinaria \\
\hline Pl., Bacch. & $=$ & Plautus, Bacchides \\
\hline Pl., Capt. & $=$ & Plautus, Captivi \\
\hline Pl., Cas. & $=$ & Plautus, Casina \\
\hline Pl., Cist. & $=$ & Plautus, Cistellaria \\
\hline Pl., Curc. & $=$ & Plautus, Curculio \\
\hline Pl., Epid. & $=$ & Plautus, Epidicus \\
\hline Pl., Men. & $=$ & Plautus, Menaechmi \\
\hline $\mathrm{Pl}$, Merc. & $=$ & Plautus, Mercator \\
\hline Pl., Mil. & $=$ & Plautus, Miles gloriosus \\
\hline Pl., Most. & $=$ & Plautus, Mostellaria \\
\hline Pl., Pers. & $=$ & Plautus, Persa \\
\hline Pl., Poen. & $=$ & Plautus, Poenulus \\
\hline Pl., Pseud. & $=$ & Plautus, Pseudolus \\
\hline $\mathrm{Pl} .$, Rud. & $=$ & Plautus, Rudens \\
\hline Pl., Stich. & $=$ & Plautus, Stichus \\
\hline Pl., Trin. & $=$ & Plautus, Trinumnus \\
\hline Pl., Truc. & $=$ & Plautus, Truculentus \\
\hline Pl., Vid. & $=$ & Plautus, Vidularia \\
\hline Plin., Epist. & $=$ & Plinius, Epistulae \\
\hline Plin., Nat. hist. & $=$ & Plinius, Naturalis historia \\
\hline Prisc., Inst. gram. & $=$ & $\begin{array}{l}\text { Priscianus, Institutionum grammaticarum libri XVIII (GL II, } \\
\text { fasc. 1-2) }\end{array}$ \\
\hline Prop., Eleg. & $=$ & Propertius, Elegiae \\
\hline Ps.-Caes., Bell. Afr. & $=$ & Pseudo-Caesar, Bellum Africum \\
\hline Ps.-Caes., Bell. Alex. & $=$ & Pseudo-Caesar, Bellum Alexandrinum \\
\hline Publ. Syr., Sent. & $=$ & Publilius Syrus, Sententiae \\
\hline Quint., Inst. & $=$ & Quintilianus, Institutio oratoria \\
\hline Quint., Decl. Min. & $=$ & Quintilianus, Declamationes minores \\
\hline Rhet. Her. & $=$ & Rhetorica ad Herennium \\
\hline Sall., Cat. & $=$ & Sallustius, De coniuratione Catilinae \\
\hline Sall., Iug. & $=$ & Sallustius, De bello Iugurthino \\
\hline Scaur., Orthogr. & $=$ & Quintus Terentius Scaurus, De orthographia (GL VII, 11-35) \\
\hline Scip. Afr. Min., Orat. & $=$ & Publius Cornelius Scipio Aemilianus Africanus Minor, Orationes \\
\hline Sen., Benef. & $=$ & Seneca, De beneficiis \\
\hline Sen., Clem. & & Seneca, De clementia \\
\hline Sen., Controv. & $=$ & Seneca, Controversiae \\
\hline Sen., Dial. & $=$ & Seneca, Dialogi \\
\hline Sen., Lucil. & & Seneca, Epistulae morales ad Lucilium \\
\hline Sen., Nat. & & Seneca, Naturales quaestiones \\
\hline Sen., Phaedr. & & Seneca, Phaedra \\
\hline Sen., Suas. & & Seneca, Suasoriae \\
\hline Sen., Thy. & $=$ & Seneca, Thyestes \\
\hline Serv., Aen. & $=$ & Servius, In Vergilii Aeneidos Libros \\
\hline Serv., Donat. & $=$ & Servius, Commentarius in 'Artem' Donati \\
\hline Serv., Georg. & $=$ & Servius, In Vergilii Georgicon Libros \\
\hline
\end{tabular}


Stat., Silv.

Stat., Theb.

Suet., Aug.

Suet., Cal.

Suet., Claud.

Suet., Gramm.

Suet., Iul.

Suet., Ner.

Suet., Oth.

Suet., Tib.

Suet., Tit.

Suet., Vit.

Tac., Agr.

Tac., Ann.

Tac., Dial.

Tac., Germ.

Tac., Hist.

Ter., Adelph.

Ter., Andr.

Ter., Eun.

Ter., Heaut.

Ter., Hec.

Ter., Phorm.

Tib.

Val. Max.,

Varro, Ling.

Varro, Rust.

Vell. Pat., Hist. Rom.

Verg., Aen.

Verg., Ecl.

Verg., Georg.
$=$ Statius, Silvae

$=$ Statius, Thebais

= Suetonius, Divus Augustus

$=$ Suetonius, Caligula

$=$ Suetonius, Claudius

= Suetonius, De grammaticis

$=$ Suetonius, Divus Iulius

$=$ Suetonius, Nero

$=$ Suetonius, Otho

$=$ Suetonius, Tiberius

$=$ Suetonius, Divus Titus

$=$ Suetonius, Vitellius

= Tacitus, De vita et moribus Iulii Agricolae

$=$ Tacitus, Annales

= Tacitus, Dialogus de oratoribus

= Tacitus, De origine et situ Germanorum

$=$ Tacitus, Historiae

$=$ Terentius, Adelphoe

$=$ Terentius, Andria

= Terentius, Eunuchus

$=$ Terentius, Heautontimorumenos

$=$ Terentius, Hecyra

$=$ Terentius, Phormio

$=$ Tibullus, Elegiae

= Valerius Maximus, Facta et dicta memorabilia

= Varro, De lingua Latina

= Varro, Res rusticae

= Velleius Paterculus, Historia Romana

$=$ Vergilius, Aeneis

$=$ Vergilius, Eclogae

$=$ Vergilius, Georgica

\section{JĘZYKI:}

$\begin{array}{ll}\text { ang. } & =\text { angielski } \\ \text { franc. } & =\text { francuski } \\ \text { goc. } & =\text { gocki } \\ \text { gr. } & =\text { grecki } \\ \text { hiszp. } & =\text { hiszpański } \\ \text { lac. } & =\text { laciński } \\ \text { niem. } & =\text { niemiecki } \\ \text { osk. } & =\text { oskijski } \\ \text { pol. } & =\text { polski } \\ \text { sard. } & =\text { sardyński } \\ \text { skr. } & =\text { sanskryt } \\ \text { wł. } & =\text { włoski }\end{array}$




\section{INNE:}

$$
\begin{aligned}
& \text { abl. = ablativus } \\
& \text { abl.abs. = ablativus absolutus } \\
& \text { acc. = accusativus } \\
& \text { a.c.i. = accusativus cum infinitivo } \\
& \text { act. = activum } \\
& \text { arch. = archaiczny, archaizm } \\
& \mathrm{C}=\text { consonans } \\
& \text { con. }=\text { coniunctivus } \\
& \text { dat. = dativus } \\
& \text { elipt. = eliptycznie/eliptyczny } \\
& \text { fem. = femininum } \\
& \text { frgm. }=\text { fragment } \\
& \text { fut. } \quad=\text { futurum } \\
& \text { gen. }=\text { genetivus } \\
& \text { ger. }=\text { gerundium } \\
& \text { gl. }=\text { glajd } \\
& \text { imper. }=\text { imperativus } \\
& \text { impf. }=\text { imperfectum } \\
& \text { ind. } \quad=\text { indicativus } \\
& \text { inf. }=\text { infinitivus } \\
& \text { inskr. = inskrypcja/inskrypcyjny } \\
& \text { klas. }=\text { klasyczny } \\
& \text { masc. = masculinum } \\
& \text { nast. } \quad=\text { następ (sylaby) } \\
& \text { neutr. }=\text { neutrum } \\
& \text { nom. = nominativus } \\
& \text { obs. } \quad=\text { obstruent } \\
& \text { ośr. = ośrodek (sylaby) } \\
& \text { pass. = passivum } \\
& \text { part. }=\text { participium } \\
& \text { perf. }=\text { perfectum } \\
& \text { pl. } \quad=\text { pluralis } \\
& \text { plpf. = plusquamperfectum } \\
& \text { praes. }=\text { praesens } \\
& \text { proverb. }=\text { proverbium (przystowie) } \\
& \text { sam. = samogloska } \\
& \text { scil. }=\text { scilicet } \\
& \text { son. = sonant } \\
& \text { sup. = supinum } \\
& \text { sg. } \quad=\text { singularis } \\
& V \quad=\text { vocalis } \\
& \text { voc. }=\text { vocativus } \\
& \text { zest. }=\text { zestęp (sylaby) }
\end{aligned}
$$





Hubert Wolanin - kierownik Zakładu Języka Greckiego i Łacińskiego w Instytucie Filologii Klasycznej Uniwersytetu Jagiellońskiego. W 1994 r. obronił pracę doktorską pt. Stowotwórstwo w mysli jezykoznawczej starożytnej Grecji. Od Homera do Dionizjusza Traka, w 2005 r. habilitował się na podstawie pracy Fleksja w gramatyce starożtnej Grecji. Przedmiotem jego badań są dzieje językoznawstwa w starożytności grecko-rzymskiej oraz metodologia opisu języków klasycznych. Jest autorem licznych artykułów w czasopismach naukowych i współautorem Stownika tacinsko-polskiego pod redakcją Józefa Korpantego oraz polskiego przekładu Digestów Justyniańskicb pod redakcją Tomasza Palmirskiego.

Opracowanie niniejsze stanowi próbę zastosowania metodologii $\mathrm{i}$ aparatury pojęciowo-terminologicznej współczesnego językoznawstwa strukturalistycznego do stworzenia pełnego synchronicznego opisu systemu fonologicznego, morfologicznego i syntaktycznego klasycznej łaciny. Materiał badawczy i egzemplifikacyjny został zaczerpnięty z korpusu tekstów autorów klasycznych pochodzących z okresu od II w. przed Chr. do IV w. po Chr.

W pracy przedstawiona została m.in. problematyka łacińskiej prozodii, segmentacji tekstu na poziomie fonologicznym, morfologicznym i składniowym, typologii łacińskich fonemów, morfemów i wyrazów, klasyfikacji funkcjonalnej leksemów oraz struktury morfologicznej wyrazów. Podręcznik zawiera również pełną paradygmatykę fleksyjną, charakterystykę funkcjonalną wszystkich klas leksemów (części mowy), opis struktury syntaktycznej zdania, a także systematykę zdań złożonych. Jest to pierwszy na polskim rynku wykład całości gramatyki opisowej starożytnej łaciny sporządzony na poziomie akademickim $\mathrm{i}$ ujęty w ramy modelu spełniającego standardy nowoczesnej lingwistyki strukturalno-funkcjonalnej. Dołączony na końcu obszerny wykaz literatury przedmiotu ułatwi pogłębienie wiedzy w wybranej dziedzinie lub podjęcie własnych studiów $w$ interesującym Czytelnika zakresie.

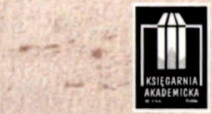

